\title{
Fabiana Richard
}

Organizadora

\section{Ciências da Saúde: Teoria e Prática}

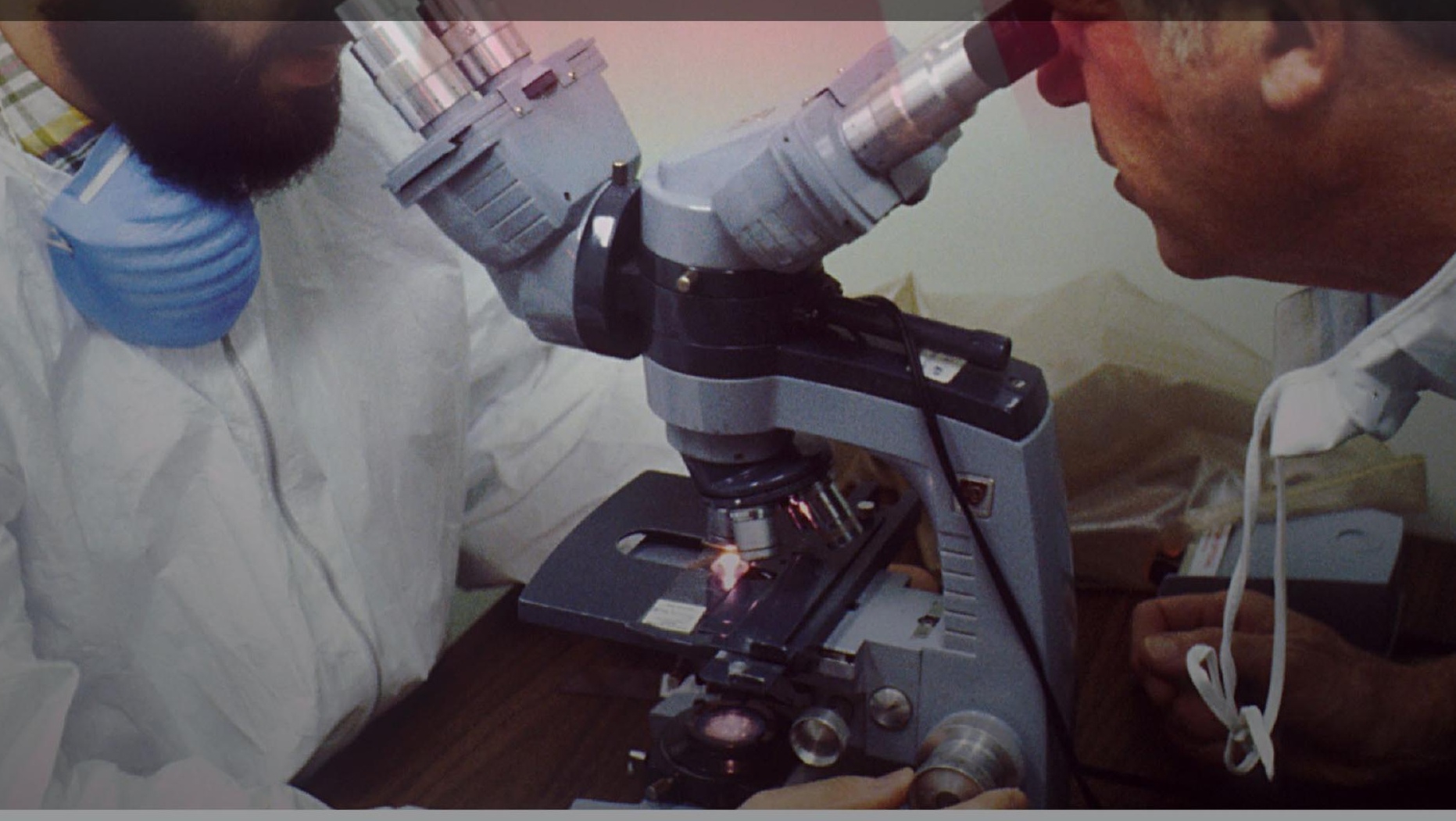

UNIEDUSUL EDITORA

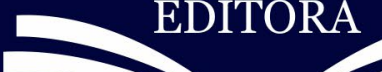


FABIANA RICHARD

Organizadora

\section{CIÊNCIAS DA SAÚDE: TEORIA E PRÁTICA}


Copyright da Uniedusul Editora

Editor Chefe: Prof ${ }^{\mathrm{o}}$ Me. Welington Junior Jorge

Diagramação e Edição de Arte: André Oliveira Vaz

Revisão: $\mathrm{O} / \mathrm{s}$ autor/es

\section{Conselho Editorial}

Adriana Mello

Alexandre António Timbane

Aline Rodrigues Alves Rocha

Angelo Ferreira Monteiro

Carlos Antonio dos Santos

Cecilio Argolo Junior

Cleverson Gonçalves dos Santos

Delton Aparecido Felipe

Fábio Oliveira Vaz

Gilmara Belmiro da Silva

Izaque Pereira de Souza

José Antonio

Kelly Jackelini Jorge

Lucas Araujo Chagas

Marcio Antonio Jorge da Silva

Ricardo Jorge Silveira Gomes

Sandra Cristiane Rigatto

Thiago Coelho Silveira

Wilton Flávio Camoleze Augusto

Yohans De Oliveira Esteves

Dados Internacionais de Catalogação na Publicação (CIP) (eDOC BRASIL, Belo Horizonte/MG)

C569 Ciências da saúde [recurso eletrônico] : teoria e prática /

Organizadora Fabiana Richard. - Maringá, PR: Uniedusul, 2020.

Formato: PDF

Requisitos de sistema: Adobe Acrobat Reader

Modo de acesso: World Wide Web

Inclui bibliografia

ISBN 978-65-80277-44-5

1. Ciências da saúde - Pesquisa - Brasil. 2. Saúde - Brasil. I.Richard, Fabiana.

CDD 362.1

Elaborado por Maurício Amormino Júnior - CRB6/2422

O conteúdo dos artigos e seus dados em sua forma, correção e confiabilidade são de responsabilidade exclusiva dos autores.

Permitido fazer download da obra e o compartilhamento desde que sejam atribuídos créditos aos autores, mas sem de nenhuma forma ou utilizá-la para fins comerciais. 


\section{SUMÁRIO}

\section{CAPÍTULO 1}

ASSISTÊNCIA DO ENFERMEIRO AO PACIENTE COM TRAUMATISMO CRANIOENCEFÁLICO LEANDRO SILVA PIMENTEL

FRANCIS POLLIANA MACEDO FREITAS

JOÃO SOBRAL MELO

LEONARDO DA SILVA ALMEIDA

RELIELTON MACIEL ARRUDA

NATHALIA MENDES AVELINO

ELLEN PRISCILA NUNES GADELHA

CYNTHIA COELHO FERREIRA

KENY MADURO DA SILVA

RODRIGO MONTEIRO ROQUE

DOI 10.29327/513494-1

CAPÍTULO 2 27

ATENDIMENTO DE SAÚDE À POPULAÇÃO GARIMPEIRA DA REGIÃO DO RIO TAPAJÓS: RELATO DE EXPERIÊNCIA

THALYTA MARIANY RÊGO LOPES UENO

DANIELE MELO SARDINHA

HERBERTO UENO SEELIG DE SOUZA

ANA MARIA REVORÊDO DA SILVA VENTURA

KARLA VALÉRIA BATISTA LIMA

DOI 10.29327/513494-2

CAPÍTULO 3 36

COMPLICAÇÕES DA INSUFICIÊNCIA RENAL CRÔNICA DE PACIENTES NA UTI: UM ESTUDO DE REVISÃO

SIDNEI DE SOUSA CRUZ

ELIZABETH GOMES DA CRUZ

CONCEIÇÃO NEVES MONTEIRO

RAISSA PANTOJA LEÃO

NAINE DOS SANTOS LINHARES

ANA CLAUDIA GARCIA MARQUES

ANDRÉA DIAS REIS

LEANDRO SILVA PIMENTEL

DOI 10.29327/513494-3

\section{CAPÍTULO 4} .44

O PROCESSO DE TRABALHO DO ENFERMEIRO NA TRANSFUSÃO DE SANGUE EM TERAPIA INTENSIVA

KELLY ADRIANI DOS SANTOS BAETA

THAIS DOS SANTOS PINHEIRO DA SILVA

MARIANA SOUZA DE LIMA

STEPHANY SIQUEIRA BRAGA

JOSÉ CARLOS CORREA REGO FILHO

RUHAN DA CONCEIÇÃO SACRAMENTO

BEATRIZ DUARTE DE OLIVEIRA

DOI 10.29327/513494-4 
DIAGNÓSTICO SITUACIONAL DA FARMÁCIA BÁSICA E ESPECIALIZADA DE UM CENTRO DE SAÚDE ESCOLA EM BELÉM DO PARÁ

STEPHANY SIQUEIRA BRAGA

IVANETE MIRANDA CASTRO DE OLIVEIRA

MATTHEUS LUCAS NEVES DE CARVALHO

BIANCA LEÃO PIMENTEL

THALIA BARARUÁ MACHADO

SANDRA MARIA FERREIRA DE ALENCAR

LISIANY CARNEIRO DE SANTANA MOREIRA

KELLY ADRIANI DOS SANTOS BAETA

DOI 10.29327/513494-5

CAPÍTULO 6 64

RELEVÂNCIA CLINICA DA UTILIZAÇÃO DE EXTRATOS DE UNCARIA TOMENTOSA COMO USO MEDICINAL: REVISÃO NARRATIVA

JESSIKA MUNIRA GONÇALVES DE SOUSA

JESSICA DA SILVA CAMPOS

Ms. ALAN DUMONT CLEMENTE

Dra. CARLA AFONSO DA SILVA

DOI 10.29327/513494-6

CAPÍTULO 7 74

APLICAÇÕES FARMACOLÓGICAS DAS SUBSTÂNCIAS PRODUZIDAS PELAS PLANTAS E FITOTERÁPICOS VENDIDOS COM E SEM PRESCRIÇÃO MÉDICA

DOUGLAS BORGES DE AGUIAR

JOVECY MATIAS DA CRUZ

PATRICK MICKAEL SOARES GOMES

BRUNO MARTINS DE JESUS

WILLIAN FERNANDES DE OLIVEIRA

ENILDO IZIDORO RIBEIRO

TARIK DE SOUZA

JULIANA SANTANA DE CURCIO

DOI 10.29327/513494-7

CAPÍTULO 8 .83

CONTRIBUIÇÃO DA ENFERMAGEM NA ASSISTÊNCIA A PACIENTES ACOMETIDOS POR ACIDENTE VASCULAR CEREBRAL ISQUÊMICO INTERNADOS NA UNIDADE DE TERAPIA INTENSIVA

NOÉLIA CUNHA LAURIDO

ANA GREICY DA SILVA CRUZ

ANA CAROLINA MOREIRA ARAÚJO

JUCILENE CARVALHO DE SOUZA

LEANDRO SILVA PIMENTEL

DOI 10.29327/513494-8

\section{CAPÍTULO 9}

FATORES RELACIONADOS AO REGANHO DE PESO APÓS A CIRURGIA BARIÁTRICA

LUCIANA PEREIRA DA COSTA

SIMONE APARECIDA FERNANDES DA SILVA

EDER FERREIRA DE ARRUDA

FRANCIELY GOMES GONÇALVES

ADRIANA MARINHO PEREIRA DAPONT

MATEUS RODRIGUES LIMA

RODRIGO DAMINELLO RAIMUNDO

NATÁLIA DA SILVA FREITAS MARQUES

DOI 10.29327/513494-9 
O CÂNCER DE MAMA E O RASTREAMENTO MAMOGRÁFICO

DANIEL ALVARENGA FERNANDES

FELIPE AGUERA OLIVERA

FAIANE RODRIGUES DE SÁ

CAIO AFFONSO NETO

CAMILA DA SILVA AMORIM

ADRIANA MARINHO PEREIRA DAPONT

MATEUS RODRIGUES LIMA

NATÁLIA DA SILVA FREITAS MARQUES

SAMARA MARIA MESSIAS DA SILVA

DOI 10.29327/513494-10

CAPít ULO 11. 126

RISCOS DE QUEDAS EM IDOSOS RESIDENTES EM INSTITUIÇÕES DE LONGA PERMANÊNCIA FRANCIELY GOMES GONÇALVES

NATÁLIA DA SILVA FREITAS MARQUES

MÁRCIA REGINA MELO CONDE

PATRICIA MERLY MARTINELLI

FRANCISCO DE ASSIS MOTA DE SOUZA

BRUNA COSTA RODRIGUES

GABRIEL ZORELLO LAPORTA

DOI 10.29327/513494-11

CAPÍTULO 12 132

PREVALÊNCIA DE SINAIS E SINTOMAS DE DISBIOSE INTESTINAL EM ESTUDANTES DO CURSO DE MEDICINA DE UMA INSTITUIÇÃO DE ENSINO SUPERIOR PRIVADA EM MINEIROS $-\mathrm{GO}$

GÉSSICA HELEN DE MELO

ANDRESSA CAITANO RIBEIRO

NÁRGELLA SILVA CARNEIRO

GILBERTO DE MELO JUNIOR

JANE SOUSA NAVES

VANESSA ALVES DE ARAÚJO

RENATO MILHOMEM DE OLIVEIRA FILHO

DOI 10.29327/513494-12

CAPÍTULO 13 143

PLANEJAMENTO DA ATENÇÃO HOSPITALAR NO SUS PARA O PERÍODO 2016 A 2019: PRIORIDADES E LACUNAS NACIONAIS E ESTADUAIS

FANNY ALMEIDA WU

THADEU BORGES SOUZA SANTOS

SILVANA LIMA VIEIRA

JOSEANE APARECIDA DUARTE

JULIETE SALES MARTINS

LILIAN BARBOSA ROSADO

LAÍSE REZENDE DE ANDRADE

ISABELA CARDOSO DE MATOS PINTO

DOI 10.29327/513494-13 
CAPÍTULO 14

OBESIDADE NA GRAVIDEZ E COMPLICAÇÕES ASSOCIADAS: REVISÃO INTEGRATIVA

CRISTIANE COSTA MORAIS DE OLIVEIRA

MARIA DO SOCORRO MARQUES SOARES

CLICE PIMENTEL CUNHA DE SOUSA

GIVALDO DE JESUS PINHEIRO LOPES

LUZINETE PONTES BRANDÃO

FRANCO CELSO DA SILVA GOMES

JOELMARA FURTADOS DOS SANTOS PEREIRA

GERUSINETE RODRIGUES BASTOS DOS SANTOS

JOSIEDNA ABREU PINHEIRO

KARLA CONCEIÇÃO COSTA OLIVEIRA

CELIJANE DO NASCIMENTO ALVES

FRANCISCA BRUNA ARRUDA ARAGÃO

DOI 10.29327/513494-14

CAPÍTULO 15 170

CUIDADOS DE ENFERMAGEM NO FERIMENTO POR ARMA DE FOGO COM TRAUMATISMO CEREBRAL DIFUSO: ESTUDO DE CASO

TATIANA FABÍOLA DA SILVA LIMA

MARCOS MIRANDA RODRIGUES

VIRGÍNIA MERCÊS LARA PESSOA OLIVEIRA

CINTHYA LORENA BEZERRA SARMANHO

WEBER MARCOS

JAQUELINE CARDOSO MARCENA

GABRIEL FAZZI COSTA

SARA DE OLIVEIRA SILVA

DOI 10.29327/513494-15

CAPÍTULO 16 178

USO DA CANNABIS COMO PRÁTICA INTEGRATIVA E COMPLEMENTAR DE SAÚDE NO CONTROLE DA DOR ONCOLÓGICA: REVISÃO SISTEMÁTICA

RENATA CARNEIRO CARVALHO

LUCIMAR FRANCISCA DE ARAÚJO

JAQUELINE CORREIA PONTES

JESSICA DA SILVA CAMPOS

JÚLIO CÉSAR COELHO DO NASCIMENTO

DOI 10.29327/513494-16

CAPÍTULO 17

ATIVIDADE BIOLÓGICA E FARMACOLÓGICA DE Sonchus oleraceus

IDELVÂNIA DOS ANJOS NONATO

GABRIEL DOMINGOS CARVALHO

CAMILO AMARO DE CARVALHO

MARLENE ISABEL VARGAS VILORIA

JOAQUIN HERNAN PATARROYO SALCEDO

DOI 10.29327/513494-17

CAPÍTULO 18

A IMPORTÂNCIA DOS APLICATIVOS DE DISPOSITIVOS MÓVEIS PARA A ONCOLOGIA JEREMIAS BEZERRA SOBRINHO

DOI 10.29327/513494-18

CAPÍTULO 19

PERFIL DO SISTEMA IMUNE ESTIMULADO PELO ZIKA VÍRUS

NATHÁLIA PEREIRA ALVES

RENATA DELLALIBERA-JOVILIANO

DOI 10.29327/513494-19 
EPIDEMIOLOGIA DA OCORRÊNCIA DA NEOPLASIA MALIGNA DA PRÓSTATA DURANTE A ÚLTIMA DÉCADA NO BRASIL

ANTONIO PAULO REIS DE AMORIM LISBOA

ANA CLÁUDIA DA SILVA FERNANDES DUARTE

ANA KELLY DA SILVA FERNANDES DUARTE

DAVI WESLEY RAMOS DO NASCIMENTO

FLÁVIA DANIELLE SOUZA DE VASCONCELOS

MATHEUS DOS SANTOS DO NASCIMENTO CARVALHO

CAMILA MARIA BEDER RIBEIRO GIRISH PANJWANI

DOI 10.29327/513494-20

CAPÍTULO 21 .231

EPIDEMIOLOGIA DAS INTERNAÇÕES POR LINFOMA DE HODGKIN DURANTE A ÚLTIMA DÉCADA NO BRASIL

MATHEUS DOS SANTOS DO NASCIMENTO CARVALHO

CAMILA MARIA BEDER RIBEIRO GIRISH PANJWANI

ANA CLÁUDIA DA SILVA FERNANDES DUARTE

ANA KELLY DA SILVA FERNANDES DUARTE

ANTONIO PAULO REIS DE AMORIM LISBOA

DAVI WESLEY RAMOS DO NASCIMENTO

FLAVIA DANIELLE SOUZA DE VASCONCELOS

RAFAEL RAGAZZI DE MORAES

DOI 10.29327/513494-21

CAPÍTULO 22 240

EPIDEMIOLOGIA DAS INTERNAÇÕES POR NEOPLASIA MALIGNA DE ESÔFAGO DURANTE A ÚLTIMA DÉCADA NO BRASIL

ZION CARVALHO DA SILVA

ANA CLÁUDIA DA SILVA FERNANDES DUARTE

JOSÉ JOÃO FELIPE COSTA DE OLIVEIRA

GABRIEL JOSÉ TORRES DA SILVA

RENATA LINS WANDERLEY

EMANNUELA BERNARDO DA SILVA

AMANDA ARAÚJO SOUZA

CAMILA MARIA BEDER RIBEIRO GIRISH PANJWANI

DOI 10.29327/513494-22

CAPÍTULO 23

EPIDEMIOLOGIA DAS INTERNAÇÕES POR NEOPLASIA MALIGNA DE FÍGADO E DAS VIAS BILIARES INTRA-HEPÁTICAS DURANTE A ÚLTIMA DÉCADA NO BRASIL

AMANDA ARAÚJO SOUZA

ROBÉRIO SILVA MELO

ANA CLÁUDIA DA SILVA FERNANDES DUARTE

EMANNUELA BERNARDO DA SILVA

GABRIEL JOSÉ TORRES DA SILVA

JOSÉ JOÃO FELIPE COSTA DE OLIVEIRA

RENATA LINS WANDERLEY

ZION CARVALHO DA SILVA

DOI 10.29327/513494-23 
EPIDEMIOLOGIA DOS CASOS CONFIRMADOS DE TUBERCULOSE NO BRASIL DURANTE A ÚLTIMA DÉCADA

GABRIEL JOSÉ TORRES DA SILVA

ANA CLÁUDIA DA SILVA FERNANDES DUARTE

JOSÉ JOÃO FELIPE COSTA DE OLIVEIRA

ZION CARVALHO DA SILVA

RENATA LINS WANDERLEY

EMANNUELA BERNARDO DA SILVA

AMANDA ARAÚJO SOUZA

THIAGO JOSÉ MATOS ROCHA

DOI 10.29327/513494-24

CAPÍTULO 25

265

COVID-19: INTERAÇÕES DO MINISTÉRIO DA SAÚDE COM OS USUÁRIOS DO INSTAGRAM SILVIA CRISTIANNE NAVA LOPES

ELAYNNE VIEIRA DA COSTA

ROSANE DE FÁTIMA ANTUNES OBREGON

VICTOR HUGO TORRES CRUZ

DOI 10.29327/513494-25

CAPÍTULO 26 .275

A RELAÇÃO ENTRE O ALEITAMENTO MATERNO E O DESENVOLVIMENTO DO SISTEMA ESTOMATOGNÁTICO

MILAYDE SERRA BRAGA

EMILY CARLA PRESTES CAVALCANTE

DOI 10.29327/513494-26

\section{CAPÍTULO 27}

PARACOCCIDIOIDOMICOSE: ANALISE GERAL

INAIÁ PALMIRO BENTO FRANCISCO

ANA CRISTINA SOUZA MELGAÇO

JULIA VERISSIMO E SILVA

RAPHAELA SUANO DE FARIA

THALITA GRAZIELLY SANTOS

DOI 10.29327/513494-27

CAPÍTULO 28

EXIBIÇÃO DOS LAÇOS CONSCIENTIZADORES DA SAÚDE UTILIZANDO SISTEMAS EMBARCADOS E LEDS RGB

PAULO PEREIRA DE ALBUQUERQUE JUNIOR

RENAN CORREAA BASONI

CÉSAR AUGUSTO VICTOR

FABIANO CARNEIRO RIBEIRO

FRANCISCO ALDINEI PEREIRA ARAGÃO

DOI 10.29327/513494-28 
CAPÍTULO 29 .309

PERFIL EPIDEMIOLÓGICO DAS OCORRÊNCIAS DE SARAMPO NO BRASIL DURANTE OS ÚLTIMOS 5 ANOS

RENATA LINS WANDERLEY

AMANDA ARAÚJO SOUZA

ANA CLÁUDIA DA SILVA FERNANDES DUARTE

GABRIEL JOSÉ TORRES DA SILVA

JOSÉ JOÃO FELIPE COSTA DE OLIVEIRA

LUCIANA MARIA DE MEDEIROS PACHECO

VITORIA CRUZ TORRES

ZION CARVALHO DA SILVA

DOI 10.29327/513494-29

CAPÍTULO 30 .319

PERFIL SOCIODEMOGRÁFICO DOS RESIDENTES DE UMA INSTITUIÇÃO DE LONGA PERMANÊNCIA

FRANCISCA SOUZA SANTOS DIAS

CLARA CYNTHIA MELO E LIMA

PATRÍCIA DE SOUSA FERNANDES QUEIROZ

HÉRIKA MARIA SILVEIRA RUAS

VIVIANE MAIA SANTOS

DOI 10.29327/513494-30

CAPÍTULO 31 325

RESÍDUOS DE PÓLVORA COMO DETERMINANTES DE DISTÂNCIA DO TIRO EM PERICIA DA MEDICINA LEGAL

CRISTIANO HAYOSHI CHOJI

FERNANDO ANTÔNIO MOURÃO VALEJO

RODRIGO SALA FERRO

JOSÉ OTAVIO DE FELICE JUNIOR

LUÍS ANTÔNIO GILBERTI PANUCCI

RAPHAEL ADILSON BERNARDES

TELMA DE CARVALHO PENAZZI

MAYÉLI PEREIRA DOMINGOS

DOI 10.29327/513494-31

CAPÍTULO 32 337

TUBERCULOSE PULMONAR: OS RISCOS DA INTERRUPÇÃO DO TRATAMENTO PARA O INDIVÍDUO E PARA A SAÚDE PÚBLICA

FRANCISCA SOUZA SANTOS DIAS

CLARA CYNTHIA MELO E LIMA

PATRÍCIA DE SOUSA FERNANDES QUEIROZ

HÉRIKA MARIA SILVEIRA RUAS

VIVIANE MAIA SANTOS

DOI 10.29327/513494-32

CAPÍTULO 33 .345

SOFTWARE CHECK-LIST PARA CIRURGIA SEGURA

FLÁVIO FRAGA VILELA

RODRIGO NEVES OTTOBONI DIAS

JOSÉ DIAS DA SILVA NETO

LUIZ ANTONIO DA SILVA

DIEGO DOBSCHA DA CRUZ PIEDADE

DOI 10.29327/513494-33 
A IMPORTÂNCIA DO CONHECIMENTO DOS ACADÊMICOS DE ENFERMAGEM SOBRE RCP: UM ESTUDO DE REVISÃO

CAROLAINE DA SILVA HIGGINS

CAIO CESAR ANDRADE DE ARIMATHÉA

KELLY CRISTINA FREITAS DA SILVA DOS SANTOS

SANDRA CONCEIÇÃO RIBEIRO CHÍCHARO

ADRIANA LOUREIRO DA CUNHA

DOI 10.29327/513494-34

CAPÍTULO 35 .359

ATUAÇÃO DA ENFERMAGEM NA PARADA CARDIORRESPIRATÓRIA E NA REANIMAÇÃO CARDIOPULMONAR: UMA REVISÃO INTEGRATIVA

JÚLYA DE ARAUJO SILVA MONTEIRO

MARISTELA MOURA BERLITZ

BEATRIZ GERBASSI COSTA AGUIAR

CÁSSIO BAPTISTA PINTO

TAMIRES ZÊBA GUIMARÃES

PATRÍCIA APARECIDA TAVARES MENDES

DANIELA DE OLIVEIRA MATIAS

DOI 10.29327/513494-35

CAPÍTULO 36 .369

TRANSTORNO ESQUIZOAFETIVO: VÁRIAS FACES DE UMA SÍNDROME

ALIALDO DANTAS DAMASCENA

JOSÉ CARLOS MORAIS DE OLIVEIRA

DOI 10.29327/513494-36

CAPÍTULO 37 374

VALIDAÇÃO DA CURVA DE CALIBRAÇÃO (LINEARIDADE E HOMOCEDASTICIDADE) DO $\alpha$-PINENO POR CROMATOGRAFIA EM FASE GASOSA COM DETECÇÃO POR IONIZAÇÃO EM CHAMA (CG-DIC) NO ÓLEO ESSENCIAL DE SCHINUS TEREBENTHIFOLIUS RADDI

GLEICE CAROLINA SANTOS CRUZ

FRANCIELLE DAIANE LOPES LUNA

RAFAELLA CRUZ DE AZEVEDO SILVA

ADÉLIA MARA BELEM LIMA

MARCELO RAUL ROMERO TAPPIN

GLAUCIO DIRÉ FELICIANO

ALAIDE DE SÁ BARRETO

DOI 10.29327/513494-37

CAPÍTULO 38

CONVULSÕES E SUAS CONSEQUÊNCIAS QUANDO TRATADAS TARDIAMENTE: ESTADO

DO MAL EPILÉPTICO NA PEDIATRIA

CATHARINE VITÓRIA DOS SANTOS SIQUEIRA

CECÍLIA CÂNDIDA GRAÇA MOTA DAMASCENO

ANA LUIZA TINOCO ABUNAHMAN

BEATRIZ CRIVELLI ALVARENGA

DEBORAH BRAGA DA CUNHA

GIOVANNA CHALOM

KELLY FIGUEIREDO BARBOSA

ANDRÉA PEREIRA COLPAS

DOI 10.29327/513494-38 
CAPÍTULO 39

ESTUDOS DA RELAÇÃO QUANTITATIVA ESTRUTURA ATIVIDADE TRIDIMENSIONAL (QSAR3D) COM INIBIDORES OXADIAZOL DA ENZIMA EthR POTENCIALIZADORES DA ATIVIDADE ANTI-TUBERCULOSE DA ETIONAMIDA

SAMER VALENTE DA SILVA

MIKAELA VIVIAN PEREIRA ANDRADE

LOURDES OLIVEIRA GOMES

SOLANGE MARIA VINAGRE CORRÊA

RICARDO MORAIS DE MIRANDA

DOI 10.29327/513494-39

CAPÍTULO 40 410

FATORES DE RISCO ASSOCIADOS À RUPTURA UTERINA EM PACIENTES PRIMIGESTAS: UMA REVISÃO INTEGRATIVA

THAYNARA MELO DOS ANJOS

DINÁRIO AUGUSTO LEMOS NETO

ALINE TENÓRIO LINS CARNAÚBA

ISABELA MACÊDO DE ARAUJO

MARIANA MENDONÇA DE ARAÚJO TAVARES

MATHEUS DE ANDRADE AMARAL

YANCKA LERNER HORA ROCHA

DOI 10.29327/513494-40

CAPÍTULO 41 420

SÍNDROME DE HERLYN-WERNER-WUNDERLICH: UMA ENTIDADE RARA A SER CONHECIDA NATHALIA BRAGA PEREIRA

MARINA RODRIGUES CHAVES

ÁLLAN COSTA SOUZA

MARIA FERNANDA DIAS BASÍLIO

LAÉRCIO FONSECA COSTA

LUÇANDRA RAMOS ESPÍRITO SANTO

DOI 10.29327/513494-41

CAPÍTULO 42 424

TRAUMA HEPÁTICO: TRATAMENTO CIRÚRGICO VERSUS CONSERVADOR NO MANEJO DA AFECÇÃO

LAIRANE BRIDI LOSS

CAROLAINY FROHLICH LOSS

LUCAS MELHADO VIEIRA

ALLANA FREDERICH PINTO

LUCIANO AZEVEDO DUARTE

DOI 10.29327/513494-42

CAPÍTULO 43 433

TROMBOEMBOLISMO VENOSO ASSOCIADO À INFECÇÃO POR SARS-COV-2

BRUNO RODRIGUES PEREIRA

GABRIEL PIRES CALZAVARA

GUILHERME DE OLIVEIRA CINTRA FARIAS

JOÃO PEDRO BRANT ROCHA

LUCAS NUNES BANDEIRA DE MELO

LUIZ FRANCISCO DE MELLO

PAULA MOREIRA SENA

PEDRO HENRIQUE COELHO PINTO

DOI 10.29327/513494-43 
A INCIDÊNCIA DOS RISCOS CARDIOVASCULARES E SUA RELAÇÃO COM OS FATORES DE RISCOS

FERNANDO AUGUSTO DE CASTRO RIBEIRO

OSORINO RODRIGUES DOS SANTOS NETO

CAROLINE BARROS FARIAS GOMES

QUEREN HAPUQUE ALMEIDA GONÇALVES MUNIZ

ÂNGELO RICARDO BALDUINO

DOI 10.29327/513494-44

CAPÍTULO 45 454

UMA REVISÃO INTEGRATIVA SOBRE TAMPONAMENTO CARDÍACO EM NEONATOS DEVIDO AO CATETERISMO VENOSO UMBILICAL JOSÉ RODRIGUES DOS SANTOS NETO MAYSA REGINA DE ASSIS LIMA VITOR HUGO LEOCADIO DE OLIVEIRA FRANCISCO JOSÉ DE ARAGÃO EDIVANIO GONÇALVES DA SILVA SANTOS GIOVANNI BADY CASSEB DOI 10.29327/513494-45

CAPÍTULO 46 463

AVANÇOS NA ATENÇÃO BÁSICA ATRAVÉS DA IMPLEMENTAÇÃO DO E-SUS: UM RELATO DE EXPERIÊNCIA CAMILA BARBOSA CARVALHO DE AMORIM ANA CAROLINA DA SILVA OLIVEIRA RAFAELA ANDRADE DOS SANTOS PIMENTEL EDVÂNIA JOSÉ DA SILVA LEILA KARINA DE AMORIM PONTES RAIANA FERNANDA DA SILVA SANTOS DOI 10.29327/513494-46

CAPÍTULO 47 470

O ESTADO NUTRICIONAL E OS PRINCIPAIS FATORES DE RISCO PARA O DESENVOLVIMENTO DE DOENÇAS CRÔNICAS NÃO TRANSMISSIIVEIS (DCNTs) ENTRE ESTUDANTES LEIDIAN COELHO DE FREITAS BRUNO LIMA FREITAS CÉLIA DA SILVA NUNES DEUSANETE PINTO MACHADO MARIA DA PAZ DEMES GONÇALVES GRAZIELLA NUNES DE OLIVEIRA PAULA GRAZIELA PRATES COSTA DENISE SILVA OLIVEIRA DOI 10.29327/513494-47

CAPÍTULO 48 477

ENCEFALOPATIA EM PACIENTES IDOSOS ACOMETIDOS PELA COVID-19: UMA REVISÃO INTEGRATIVA PAULO VICTOR MOREIRA BRITO RENÊ LUIS MOURA ANTUNES OÍGRES LEÃO SCHAUN DE ARAÚJO GESSITANIA ROCHA PIRES PEREIRA GRASIELY FACCIN BORGES RONALDO DE TOLEDO 
ASSISTÊNCIA ÀS GESTANTES SURDAS NA SALA DE PARTO

JOSEFA MARIA DAS GRAÇAS GOMES DA SILVA

VITÓRIA MARIA FALCÃO DE LIMA SALSA

DOI 10.29327/513494-49

CAPÍTULO 50 .496

PERFIL FUNCIONAL DA BEXIGA EM PACIENTES COM DOENÇA DE PARKINSON

SÂNZIA DA SILVA VIRGINIO MELGÃO

DOI 10.29327/513494-50

CAPÍTULO 51

AVALIAÇÃO ANATOMOPATOLÓGICA DE NÓDULOS DA TIREOIDE DIAGNOSTICADOS EM PACIENTES DA CIDADE DE MARINGÁ-PR

VITOR ZANATA ADACHESKI

JOÃO VITOR SCALON ESTÉRCIO RIZZO

IORRAN NOCETI SILVESTRI

MARIA CLARA ICERI

EDILSON NOBUYOSHI KANESHIMA

PAOLA DA COSTA SOUZA

TÂNIA CRISTINA ALEXANDRINO BECKER

ALICE MARIA DE SOUZA KANESHIMA

DOI 10.29327/513494-51

CAPÍTULO 52

DO DEFUNTO VELADO À PEÇA ANATÔMICA DISSECADA: EMBALSAMAMENTO, TANATOPRAXIA E RITOS FÚNEBRES NA ERA MODERNA

EDUARDO MANGOLIM BRANDANI DA SILVA

CHRISTIAN FAUSTO MORAES DOS SANTOS

10.29327/513494-52

CAPÍTULO 53 528

CARACTERIZAÇÃO E DIAGNÓSTICO DE TUMORES RELACIONADOS AO CÂNCER COLORRETAL (CCR) NA CIDADE DE MARINGÁ- PR

IORRAN NOCETI SILVESTRI

MARIA CLARA ICERI

VITOR ZANATA ADACHESKI

JOÃO VITOR SCALON ESTÉRCIO RIZZO

EDILSON NOBUYOSHIKANESHIMA

PAOLA DA COSTA SOUZA

TÂNIA CRISTINA ALEXANDRINO BECKER

ALICE MARIA DE SOUZA KANESHIMA

DOI 10.29327/513494-53

CAPÍTULO 54 .538

EFEITOS DA ELETROESTIMULAÇÃO NERVOSA TRANSCUTÂNEA NA REDUÇÃO DO QUADRO ÁLGICO EM UNIVERSITÁRIAS PORTADORAS DE DISMENORREIA

ELIZABETH BEZERRA GOMES DA SILVA

MARIANNE COTRIM PEREIRA

SILVANA MARIA MACÊDO UCHÔA

MARINA DE LIMA NEVES BARROS

ÉRICA PATRÍCIA BORBA LIRA UCHÔA

VALÉRIA CONCEIÇÃO PASSOS DE CARVALHO

DOI 10.29327/513494-54 
CONTROLE DE QUALIDADE DE MEDICAMENTOS QUE CONTÊM O PRINCÍPIO ATIVO NAPROXENO

BÁRBARA ALEXSSANDRA SCARABELOT RODRIGUEZ

FERNANDO AUGUSTO DE FREITAS

DOI 10.29327/513494-55

CAPÍTULO 56 557

DIFICULDADES NA COLETA DE GASOMETRIA ARTERIAL DE PACIENTES OBESOS EM UMA UNIDADE DE PRONTO ATENDIMENTO: RELATO DE EXPERIÊNCIA

TATIANA FABÍOLA DA SILVA LIMA

WEBER MARCOS

VIRGÍNIA MERCÊS LARA PESSOA OLIVEIRA

MARCOS MIRANDA RODRIGUES

INÁCIO LIMA DO NASCIMENTO

RENATA FORO LIMA CARDOSO

IRANY ALMEIDA SILVA DOS SANTOS

GESSICA DA SILVA FARIAS VIANA

DOI 10.29327/513494-56

CAPÍTULO 57 564

FATORES QUE AFETAM A SAÚDE MENTAL DE ESTUDANTES UNIVERSITÁRIOS INDIGENAS: REVISÃO INTEGRATIVA DA LITERATURA

TATIANA FABÍOLA DA SILVA LIMA

MÁRCIO EVERTON MENDES FERNANDES

SHIRLEY AVIZ DE MIRANDA

ANA GRACINDA IGNÁCIO DA SILVA

MARCELO VALENTE DE SOUZA

MARIA RUTE DE SOUZA ARAUJO

CINTHYA LORENA BEZERRA SARMANHO

SUSIANE MARTINS SILVA

DOI 10.29327/513494-57

CAPÍTULO 58 578

INFLUÊNCIA DA TÉCNICA DE IMPOSTAÇÃO DE MÃOS (REIKI) SOBRE O PROCESSO DE CICATRIZAÇÃO DE CAMUNDONGOS COM ÚLCERA CUTÂNEA

GLORIA EDELMA MEGA

MARINA CORREAA ANDREOLLA

MARIA VERONICA DAVILA PASTOR

MARLUCE CORREA

MÁRCIA MARIA DE SOUZA

DOI 10.29327/513494-58

\section{CAPÍTULO 59}

DETECÇÃO DA PRODUÇÃO DE CARBAPENEMASES ENTRE ENTEROBACTERALES OBTIDAS DE PACIENTES DE UM HOSPITAL UNIVERSITÁRIO NO RIO DE JANEIRO

PAULO DE ALVARENGA CORDEIRO TERRA

KEREN VIEIRA DE ALCÂNTARA

DOUGLAS GUEDES FERREIRA

NATÁLIA ARRUDA COSTA CAMACHO REBELLO

CLÁUDIA REZENDE VIEIRA DE MENDONÇA-SOUZA

THIAGO PAVONI GOMES CHAGAS

DOI 10.29327/513494-59 
EDUCAÇÃO EM SAÚDE BUCAL PARA GESTANTES PARTICIPANTES DE FISIOTERAPIA AQUÁTICA NO CENTRO DE REABILITAÇÃO DA UNIOESTE

ANA LUÍZA GARCIA PROCÓPIO

ANDRÉ LUIZ MARÇAL TERRERI

DHIENARA SGARBOSA TOMIN

HELENARA SALVATI BERTOLOSSI MOREIRA

LUANA ASSUNÇÃO DELGADO

MARIA GORETI WEIAND BERTOLDO

DOI 10.29327/513494-60

CAPÍTULO 61

TABAGISMO E CIGARROS ELETRÔNICOS: SAÚDE BUCAL E SISTÊMICA

JULIANA THEBERGE DOS SANTO DE OLIVEIRA

TAMMY MARTINS DE OLIVEIRA

MARIA CYNÉSIA MEDEIROS DE BARROS

DOI 10.29327/513494-61

CAPÍTULO 62 .627

CÂNCER DE MAMA ACESSÓRIA: REVISÃO DE LITERATURA

EDUARDO FRANCO CORREIA CRUZ FILHO

ANNA JULIE MEDEIROS CABRAL

CAMILA ARAÚJO NOVAIS LIMA

FRANÇUELDA PEREIRA DA NÓBREGA MARQUES

GABRIEL LUCENA DE CARVALHO SOARES

SAMUEL ESTRELA DE ABRANTES

ANA SUZY DE GOIS MELO CRUZ

BRUNO ARAÚJO NOVAIS LIMA

DOI 10.29327/513494-62

CAPÍTULO 63

636

TRATAMENTO ODONTOLÓGICO DE PACIENTES COM COAGULOPATIA HEREDITÁRIA:

HEMOFILIA E DOENÇA DE VON WILLEBRAND

RAFAEL BEZERRA DOS SANTOS

JADNA SILVA FRANCO

JEFFERSON ALVES FREITAS

DAIANE PORTELA DE CARVALHO FERREIRA

FABÍOLA SANTOS LIMA DE OLIVEIRA

MARIA DO AMPARO VELOSO MAGALHÃES

DOI 10.29327/513494-63

CAPÍTULO 64 646

LASERTERAPIA NO TRATAMENTO DA HIPERSENSIBILIDADE DENTINÁRIA: REVISÃO DE LITERATURA

ANA ROBERTA NEGROMONTE DA SILVA

MARIA EDUARDA DE MORAIS CAVALCANTI

MARINA MARIA FERREIRA FALCÃO

MÁRCIA DE ALMEIDA DURÃO

DOI 10.29327/513494-64

CAPÍTULO 65 655

ANGINA DE LUDWIG: COMPLICAÇÃO INFECCIOSA DA REGIÃO DE CABEÇA E PESCOÇO JADNA SILVA FRANCO

RAFAEL BEZERRA DOS SANTOS

DAIANE PORTELA DE CARVALHO FERREIRA

CAIO CARVALHO MOURA FÉ

MAURA PIMENTEL COSTA CRONEMBERGER

LARA BEATRIZ DA PAZ COSTA

CELBE PATRÍCIA PORFÍRIO FRANCO

DOI 10.29327/513494-65 


\section{ASSISTÊNCIA DO ENFERMEIRO AO PACIENTE COM TRAUMATISMO CRANIOENCEFÁLICO}

LEANDRO SILVA PIMENTEL

Enfermagem da Faculdade Estácio do Amazonas, AM, Brasil

FRANCIS POLLIANA MACEDO FREITAS

Faculdade Estácio Amazonas, Amazonas, AM, Brasil

JOÃO SOBRAL MELO

Faculdade Estácio Amazonas, Amazonas, AM, Brasil

LEONARDO DA SILVA ALMEIDA

Faculdade Estácio Amazonas, Amazonas, AM, Brasil

RELIELTON MACIEL ARRUDA

Faculdade Estácio Amazonas, Amazonas, AM, Brasil

NATHALIA MENDES AVELINO

Faculdade Metropolitana de Fortaleza-FAMETRO, CE, Brasil

ELLEN PRISCILA NUNES GADELHA Faculdade Estácio Amazonas, Amazonas, AM, Brasil

CYNTHIA COELHO FERREIRA

Faculdade Estácio Amazonas, Amazonas, AM, Brasil

KENY MADURO DA SILVA

Faculdade Estácio Amazonas, Amazonas, AM, Brasil

\section{RODRIGO MONTEIRO ROQUE}

Faculdade Estácio do Amazonas

RESUMO: Este artigo apresenta as atribuições do enfermeiro na assistência de enfermagem ao paciente com traumatismo cranioencefálico (TCE). O trauma é uma das principais causas de morbimortalidade tanto no Brasil como no mundo, e a principal causa de morte em pessoas entre 1 a 44 anos, dentre esta se destaca o TCE. Este estudo objetiva-se em apresentar as complicações mais comuns em pacientes com TCE, concentrando as atenções na assistência do enfermeiro, visando a evolução do quadro clinico do cliente. A pesquisa fora realizada através do estudo bibliográfico em artigos, revistas e livros relacionados ao TCE dos anos de 2010 à 2018, desta forma o estudo far-se-á estruturado nos seguintes teóricos Gaudêncio (2013); Fernandes (2018); Arruda (2015); Almeida (2018); Mendes (2018); Brunner (2015). Constatou-se por meio deste estudo à importância e autonomia do enfermeiro na assistência e reabilitação de pacientes vítima de TCE, o hábil e padronizado atendimento visando evitar complicações no quadro clinico e evolução do mesmo. Indenticou-se o impacto do trauma tanto em morbimortalidade, quanto em custos com a reabilitação de pacientes vitima de TCE, para tanto, pretende-se que através dos resultados colhidos por meio deste estudo, obtenha-se impacto positivo de informações e alerta ao TCE, visto que é um problema de saúde que atinge não só a vítima, mas também, seus familiares.

Palavras chave: Traumatismo craniano. Enfermeiro. Assistência.

ABSTRACT: This article presents the duties of the nurse in nursing assistance to the patient with traumatic brain injury (TBI). Trauma is one of the main causes of morbidity and mortality in Brazil and in the world, and the main cause of death in people between 1 and 44 years of age, among which is TBI. This study aims at presenting the most common complications in patients with TBI, focusing the attention on the assistance of the nurse, aiming at the evolution of the clinical picture of the client. The research had been conducted through the bibliographic study in ar- 
ticles, journals and books related to TBI from 2010 to 2018, thus the study will be structured in the following theoreticians Gaudêncio (2013); Fernandes (2018); Arruda (2015); Almeida (2018); Mendes (2018); Brunner (2015). This study showed the importance and autonomy of the nurse in the care and rehabilitation of patients suffering from TBI, the skillful and standardized care in order to avoid complications in the clinical picture and its evolution. The impact of trauma in morbidity and mortality as well as in costs with rehabilitation of TBI patients was identified. Therefore, it is intended that through the results obtained through this study, a positive impact of information and alert to TBI is obtained, since it is a health problem that affects not only the victim, but also their relatives.

Key words: Head trauma. Nurse. Assistance.

\section{INTRODUÇÃO}

O trauma é uma das principais causas de morbimortalidade tanto no Brasil como no mundo, e a principal causa de morte em pessoas entre 1 e 44 anos. Dentre esta se destaca o Traumatismo Cranioencefálico (TCE), em termos de gravidade e, sobretudo como causa de morte e incapacidade. (GAUDÊNCIO, Talita Guerra; LEÃO, G. de M. A, 2013)

A esse respeito, é preciso considerar que:

[...] dentre as causas principais de lesão cerebral por traumatismo estão os acidentes automobilísticos, ciclísticos e motociclísticos; lesões físicas por quedas, agressões por arma de fogo e por arma branca, acidentes esportivos e atropelamentos. [...] as lesões traumáticas relacionadas aos acidentes de trânsito constituem a maior causa de morte entre 10 e 29 anos de idade no Brasil. Na faixa etária entre 5 e 9 anos, representa $40 \%$ das mortes e $18 \%$ entre 1 e 4 anos, sendo o trauma de crânio a principal causa de mortalidade e sequelas nessas faixas etárias. (Santos AM0R dos, et al. p. 3961).

No Brasil o TCE é a principal causa de mortalidade em crianças acima de 5 anos e constitui $50 \%$ das mortes na adolescência. Configurando-se como um problema de saúde pública no Brasil de alta importância, apesar de que não há um consenso quanto à incidência nos dados colhidos pelo ministério da saúde. (Santos AM0R dos, Sousa MEC, Lima LO et al., 2016)

Segundo SANTOS et al. (2013), os tipos de lesões cranioencefálico incluem concussão, contusão, fraturas de crânio, hematoma epidural ou subdural, hemorragia subaracnóidea e herniação. $\mathrm{O}$ TCE pode ser qualquer agressão de ordem traumática que acarrete lesão anatômica ou comprometimento funcional dessas estruturas, mesmo que nada se choque contra o crânio do paciente no acidente. (SANTOS, et al., 2013)

A atribuição do enfermeiro exige uma grande importância no cuidado a essas vítimas, por tratar-se de variados graus de complexidade de atendimento, é fundamental que o enfermeiro esteja apto para obter uma breve coleta de dados e da história do paciente, bem como realizar o exame físico, preocupando-se com o bem estar e manutenção vital do cliente. É crucial que este profissional em momento oportuno use sua capacidade de liderança, habilidades assistenciais e a fundamentação de ensino para lidar com a situação. (Vieira, Santiago, Silva, Cestari, Penaforte, Barbosa, 2016) 
A assistência do enfermeiro (a) a pacientes vítimas de TCE, é de suma importância que o mesmo esteja atento para possíveis intercorrências, tais quais podem dificultar a recuperação do cliente. A monitorização dos sinais vitais é um fator predominante nos cuidados do enfermeiro (a), além de manter o paciente sob vigilância rigorosa e restrita ao leito. (RUY, Erika; ROSA, Maria, 2016)

O estudo de Damliang et al (2014) revela que no estudo que o pacote de cuidados de enfermagem ao paciente com TCE (durante a emergência) é baseado em evidências e focado em sete elementos principais: (DAMLIANG, 2014 apud MENDES OLIVEIRA, Leilyanne de Araújo et al., 2018 p. 43)

De acordo com o estudo de Mendes Oliveira:

1. estabelecer uma via aérea segura juntamente com a proteção da coluna,

2. manter a adequação da oxigenação e ventilação,

3. manter a circulação e o equilíbrio dos fluidos,

4. avaliação de Escala de Coma de Glasgow e tamanho e reatividade da pupila,

5. mantêm fluxo venoso cerebral,

6. administração de dor, agitação e irritabilidade, e

7. agilizar para realização de tomografia computadorizada urgente. (MENDES OLIVEIRA, Leilyanne de Araújo et al. p. 43).

Um dos componentes básicos da atenção à saúde é a assistência de enfermagem que abrange todas as etapas do ciclo vital, incluindo uma variada gama de atividades e incumbências partindo da mais básica a mais complexa que variam conforme o grau de complexidade do paciente a ser assistido e as condições da instituição (FERNANDES, Ronald Teixeira Peçanha, 2018).

A SAE (Sistematização da assistência em enfermagem) garante uma ampla autonomia para o enfermeiro, um respaldo seguro e significativo através do registro de diagnósticos e intervenções, que permite a continuidade/complementaridade multiprofissional, além de estabelecer uma aproximação enfermeiro - paciente enfermeiro - equipe multiprofissional. Sendo ainda inegável um conjunto de conhecimentos e habilidades que preparem o enfermeiro a um atendimento humanizado. (NASCIMENTO, 2008 apud MENDES OLIVEIRA, Leilyanne de Araújo et al., 2018 p. 37)

O objetivo deste artigo foi apresentar as complicações mais comuns em pacientes com traumatismo crânioencefálico concentrando as atenções na assistência do enfermeiro. Os objetivos específicos foram: apresentar as principais etiologias relacionadas ao TCE; Apresentar as fases de reabilitação do paciente vítima de TCE e especificar as atribuições do enfermeiro na UTI, visando a evolução do quadro clínico do paciente. 


\section{METODOLOGIA}

Trata-se de um estudo bibliográfico retrospectivo baseado em artigos acadêmicos, revistas de enfermagem e em livros, dos anos de 2010 a 2018, com os temas direcionados com traumatismos cranianos, perfil epidemiológico de traumas: TCE, assistência de enfermagem, a coleta de dados foi realizada no período de fevereiro e primeira quinzena de março, como critérios adotados para inserção foram adotados artigos publicados em português disponíveis na sua totalidade indexados nas bases de dados scielo e revistas de enfermagem, assim como em livros e manuais da área de saúde publicados como Manual de enfermagem médico-cirúrgica, Brunner \& Suddarth, 2015 e o do ministério da saúde, Diretrizes de atenção à reabilitação da pessoa com TCE, e o livro didático da faculdade Estácio, Ensino Clínico em alta complexidade. No total foram pesquisados 16 artigos e dois livros e um manual da área da saúde, no qual onde depois de uma leitura aprofundada foram selecionados 9 artigos, e trechos dos livros já citados para a elaboração do projeto. Quadro 1.

Quadro 1: Livros utilizados para a elaboração do artigo (2019).

\begin{tabular}{|c|c|c|c|}
\hline $\mathbf{N}^{\mathbf{0}}$ & Livro & Páginas & Ano \\
\hline 1 & Manual de Enfermagem Médico-Cirúrgico 13º Edição & $1072-1083$ & 2015 \\
\hline 2 & Ensino clínico em alta complexidade & $108-111$ & 2018 \\
\hline 3 & $\begin{array}{c}\text { Diretrizes de atenção à reabilitação da pessoa com traumatismo } \\
\text { cranioencefálico }\end{array}$ & $09-12$ & 2015 \\
\hline
\end{tabular}

Fonte: próprios autores.

Quadro 2: Artigos utilizados para elaboração (2019)

\begin{tabular}{|c|c|c|c|c|}
\hline $\mathbf{N}^{0}$ & Autor & Titulo & Revista & Ano \\
\hline 1 & $\begin{array}{l}\text { Santos, Sousa, Lima, } \\
\text { Ribeiro, Madeira, } \\
\text { Oliveira }\end{array}$ & $\begin{array}{l}\text { Perfil epidemiológico do trauma } \\
\text { cranioencefálico }\end{array}$ & Rev enferm UFPE on line & 2016 \\
\hline 2 & Ruy, Rosa & $\begin{array}{l}\text { Perfil epidemiológico de pacientes com } \\
\text { traumatismo crânio encefálico. }\end{array}$ & $\begin{array}{c}\text { Arquivos Catarinenses de } \\
\text { Medicina Vol. 40, no. 3, } \\
\text { de 2011 } \\
\end{array}$ & 2011 \\
\hline 3 & Gaudêncio, Leão & $\begin{array}{c}\text { A Epidemiologia do Traumatismo } \\
\text { Crânio- Encefálico: Um Levantamento } \\
\text { Bibliográfico no Brasil }\end{array}$ & $\begin{array}{l}\text { Rev Neurociências } \\
\text { 2013;21(3):427-434 }\end{array}$ & 2013 \\
\hline 4 & $\begin{array}{l}\text { Oliveira, Soares, } \\
\text { Noleto, Fontinele, } \\
\text { Galvão, Souza }\end{array}$ & $\begin{array}{c}\text { ASSISTÊNCIA DE ENFERMAGEM } \\
\text { EM PACIENTES VÍTIMAS DE } \\
\text { TRAUMATISMO CRÂNIO } \\
\text { ENCEFÁLICO: REVISÃO } \\
\text { INTEGRATIVA } \\
\end{array}$ & $\begin{array}{l}\text { Rev. UNINGÁ, Maringá, } \\
\text { v. } 55, \text { n. } 2\end{array}$ & 2018 \\
\hline 5 & $\begin{array}{l}\text { Vieira, Santiago, } \\
\text { Silva, Cestari, } \\
\text { Penaforte, Barbosa }\end{array}$ & $\begin{array}{c}\text { Intervenções de enfermagem } \\
\text { ao paciente com traumatismo } \\
\text { crânioencefálico: Revisão Integrativa }\end{array}$ & $\begin{array}{l}\text { I mostra do internato em } \\
\text { enfermagem / II SIEPS }\end{array}$ & 2016 \\
\hline 6 & ALMEIDA & $\begin{array}{l}\text { Atuação do Enfermeiro no Atendimento } \\
\text { ao Paciente com Traumatismo } \\
\text { Crânioencefálico: Revisão Bibliográfica }\end{array}$ & $\begin{array}{c}\text { Revista Científica } \\
\text { Multidisciplinar Núcleo } \\
\text { do Conhecimento }\end{array}$ & 2018 \\
\hline 7 & SOARES, Mirelle & $\begin{array}{l}\text { Sistematização da assistência de } \\
\text { enfermagem: facilidades e desafios do } \\
\text { enfermeiro na gerência da assistência }\end{array}$ & $\begin{array}{c}\text { Escola Anna Nery } \\
\text { Revista de Enfermagem }\end{array}$ & 2015 \\
\hline
\end{tabular}




\begin{tabular}{|c|c|c|c|c|}
\hline 8 & $\begin{array}{c}\text { SANTOS, } \\
\text { F; CASAGRANDA, } \\
\text { L.P; LANGE, C.; } \\
\text { FARIAS, J.C.; } \\
\text { PEREIRA, P.M.; } \\
\text { JARDIM, V.RM., et al }\end{array}$ & $\begin{array}{c}\text { Traumatismo cranioencefálico: causas } \\
\text { e perfil das vítimas atendidas no } \\
\text { pronto socorro de Pelotas/Rio Grande } \\
\text { do Sul, Brasil }\end{array}$ & Rev Min Enferm & 2013 \\
\hline 9 & $\begin{array}{l}\text { Arruda BP, Akamatsu } \\
\text { PYF, Xavier AP, Costa } \\
\text { RCV, Oliveira-Alonso } \\
\text { GS, Madaleno IMP }\end{array}$ & $\begin{array}{c}\text { Traumatismo crânio encefálico e suas } \\
\text { implicações cognitivas e na qualidade } \\
\text { de vida }\end{array}$ & Revista USP & 2015 \\
\hline
\end{tabular}

Fonte: próprios autores.

\section{RESULTADOS E DISCUSSÃO}

O TCE é um problema de saúde pública que necessita de atenção especial, pois afeta diretamente a qualidade de vida da faixa etária ativa da população, além de proporcionar gastos altíssimos para o governo tanto em cuidados como também na retirada dessas vítimas do mercado de trabalho sendo assim forçando o governo a aposentá-los precocemente (Rev enferm UFPE on line., Recife, 10(11):3960-8, nov., 2016).

Sabemos que o TCE poderá ocorrer mesmo que nada se choque diretamente no crânio da vítima, porém o mais comum é o que ocorre através de traumas. Brunner \& Suddarth [2015, p. 1072, 1073] cita o seguinte no Manual de enfermagem médico-cirúrgica:

O traumatismo crânioencefálico pode provocar condições que variam desde uma concussão leve até o coma e a morte; a forma mais grave é conhecida como lesão cerebral traumática (LCT). As causas mais comuns de LCT consistem em quedas $(35,2 \%)$, acidentes com veículos motorizados $(17,3 \%)$, colisão de objetos $(16,5 \%)$ e assaltos $(10 \%)$. Os grupos que correm maior risco de LCT são indivíduos com idade entre 15 e 19 anos, com maior incidência nos homens em qualquer grupo etário. (Brunner \& Suddarth, Manual de enfermagem médicocirúrgica, p. 1072, 1073).

Em relação ao TCE o DATASUS TabWin (www.datasus.gov.br), traz os seguintes dados, no Brasil, em 2011, foram realizadas 547.468 internações devido a causas externas variadas e destas resultaram 12.800 óbitos. Quadro 3.

Quadro 3 - Registros de ocorrências no SUS por causa externas.

\begin{tabular}{|l|l|l|l|}
\hline Ano 2011 & Internações & Óbitos & Taxa de Mortalidade \\
\hline Pedestre & 37.577 & 1.739 & $4,63 \%$ \\
\hline Ciclista & 9.291 & 203 & $4,63 \%$ \\
\hline Motociclista & 77.171 & 1.766 & $2,229 \%$ \\
\hline Ocupantes de triciclo motorizado & 423 & 16 & $3,78 \%$ \\
\hline Ocupantes de automóvel & 17.053 & 1.812 & $23,79 \%$ \\
\hline Acidentes de transporte aquático & 1.242 & 36 & $2,90 \%$ \\
\hline Acidentes de transporte aéreo & 110 & 2 & $1,82 \%$ \\
\hline Quedas & 373.354 & 7.226 & $1,94 \%$ \\
\hline Total & 515.211 & 12.800 & $2,34 \%$ \\
\hline
\end{tabular}


Dentro da unidade hospitalar é necessário que a equipe de enfermagem esteja preparada, necessita de conhecimento científico atualizado, capacidade de lidar com pressão do momento, com o estresse, precisam tomar decisões corretas e imediatas, além de ter experiência profissional e saber trabalhar em equipe (PEREIRA et al., 2011).

Em um estudo realizado com 93 pacientes da unidade de terapia intensiva (UTI) do Hospital São José de criciúma nos anos de 2008 e 2009, apresentou as intercorrências mais comuns durante a permanência na UTI foram Pneumonia, Sepses e Insuficiência renal aguda (IRA), a condição clinica mais encontrada: hemorragia cerebral, contusão cerebral, edema cerebral, fratura óssea e pneumoencéfalo.

As lesões relacionadas ao TCE se subdividem em duas: lesão primária é aquela lesão inicial ao encéfalo, resultado de um evento traumático. $E$ as lesões secundárias que são aquelas que evoluem durante as horas e dias após a lesão inicial, resultante do aporte ineficaz de nutrientes e oxigênio às células, encaixam-se nessa categoria: hemorragia intracraniana, edema cerebral, elevação da pressão intracraniana, lesão cerebral hipóxia e infecção (Brunner \& Suddarth, 2015).

É dever do enfermeiro avaliar o seu paciente de forma holística devendo priorizar a sua atenção na procura de lesões secundárias ao trauma, ou seja, aquelas que advém depois de um período de tempo de ocorrido o trauma (TCE). Essas lesões estão bastante associadas e quando não diagnosticadas e tratadas no início, levam a altos níveis de morbimortalidade.

Nas lesões secundarias é suma importância o apoio da equipe de enfermagem, principalmente o enfermeiro (a) que estará monitorando o seu paciente para verificar possíveis intercorrências as quais foram citadas acima. Um meio de avaliação ou monitoramento do paciente que o enfermeiro (a) pode utilizar é a escala de coma de Glasgow (ECG), que classifica a gravidade do TCE, conforme o valor do score pode classifica-lo como TCE leve, TCE moderado ou TCE grave. (Ministério da saúde, 2015). Quadro 4. 
Quadro 4. - ESCALA DE COMA DE GLASGOW.

\begin{tabular}{|c|c|c|}
\hline \multicolumn{2}{|c|}{ VARIÁVEIS } & \multirow{2}{*}{$\frac{\text { ESCORE }}{4}$} \\
\hline Abertura ocular & Espontânea & \\
\hline & À voz & 3 \\
\hline & À dor & 2 \\
\hline & Nenhuma & 1 \\
\hline \multirow[t]{5}{*}{ Resposta Verbal } & Orientada & 5 \\
\hline & Confusa & 4 \\
\hline & Palavras inapropriadas & 3 \\
\hline & Palavras incompreensivas & 2 \\
\hline & Nenhuma & 1 \\
\hline \multirow[t]{6}{*}{ Resposta motora } & Obedece a comandos & 6 \\
\hline & Localiza dor & 5 \\
\hline & Movimento de retirada & 4 \\
\hline & Flexão anormal & 3 \\
\hline & Extensão anormal & 2 \\
\hline & Nenhuma & 1 \\
\hline TOTAL MÁXIMO & TOTAL MÍNIMO & INTUBAÇÃO \\
\hline 15 & 3 & 8 \\
\hline
\end{tabular}

O Ministério da saúde elaborou e disponibilizou no ano de 2015, as Diretrizes de atenção à reabilitação da pessoa com TCE, onde no qual é descrito as cinco fases do processo de reabilitação de pessoas que tiveram um TCE. (CHESNUT, et al. 1999 a; CHESNUT, et al., 1999b).

A esse respeito, é preciso considerar que:

1. Fase pré-trauma: fase anterior ao trauma;

2. Fase aguda: desde o primeiro atendimento da equipe de resgate (ex.: Samu) até o CTI/UTI (diagnóstico/triagem/tratamento);

3. Fase intensiva: do CTI/UTI até a alta hospitalar (diagnóstico/tratamento);

4. Fase de recuperação: educação e treinamento (avaliação de habilidades e alterações, programa de reabilitação);

5. Fase ambulatorial: estabelecimento de uma nova vida; ajustamento pessoal (habilidades, alterações, personalidade etc.), ajustamento social (família, amigos, trabalho, relacionamentos etc.) e qualidade de vida (produtividade, realização pessoal, emprego etc.). (Ministério da saúde, 2015).

O enfermeiro intensivista ou o de urgência e emergência, estará dando suporte integral nas fases 2 e 3. Mas isso não impede de o mesmo auxiliar nas fases seguintes, preparando o paciente e a família para a readaptação e a reabilitação do convalescente. 
As atribuições do enfermeiro dentro de uma unidade de terapia intensiva (UTI) são variadas dentre eles podemos destacar os seguintes: Auxiliar e orientar no cuidado para banho e higiene oral; encaminhar para banho de aspersão em cadeira; Aplicar conforto em proeminências ósseas com coxins; restringir dietas laxativas e oferecer dieta rica em fibras; realizar massagem abdominal no sentido horário com óleo de girassol; realizar curativo em inserção de cateter periférico e em lesões com SF 0,9\% uma vez ao dia e se necessário; realizar curativo em incisão cirúrgica com SF 0,9\%, mantendo-o ocluso; oferecer outros meios para comunicação como papel, caneta e imagens ilustrativas, quadros, lousas. (Rev. UNINGÁ, Maringá, v. 55, n. 2, p. 33-46, abr./jun. 2018).

Dentro de uma UTI, podem ocorrer possíveis complicações potenciais que podem ser: Diminuição da perfusão cerebral, Edema e herniação cerebrais, Comprometimento da oxigenação e da ventilação, Comprometimento do equilíbrio hidreletrolítico e nutricional, Risco de convulsões pós-traumáticas. As metas a serem alcançadas com esse paciente será a manutenção de uma via respiratória desobstruída, Pressão de Perfusão Cerebral adequada, equilíbrio hidreletrolítico, estado nutricional adequado, prevenção de lesão secundária, manutenção da temperatura corporal normal, manutenção da integridade da pele, melhora da capacidade de enfrentamento, prevenção da privação do sono, enfrentamento familiar eficaz, maior conhecimento sobre o processo de reabilitação e ausência de complicações (Brunner \& Suddarth, 2015).

O Manual de enfermagem médico-cirúrgica (2015) traz as seguintes sugestões de intervenções:

- Monitorar o Nível de Consciência (NC) utilizando a ECG a intervalos regulares. Um escore de 3 é menos responsivo, enquanto um escore de 15 é mais responsivo. Uma leitura da ECG entre 3 e 8 geralmente é considerada como indicativa de traumatismo cranioencefálico grave

- Monitorar os sinais vitais a intervalos frequentes para avaliar o estado intracraniano

- Monitorar à procura de sinais de elevação da PIC, incluindo diminuição da frequência cardíaca (bradicardia), elevação da pressão arterial sistólica e alargamento da pressão do pulso (reflexo de Cushing)

- Manter a temperatura abaixo de $38^{\circ} \mathrm{C}$. A taquicardia e a hipotensão arterial podem indicar existência de sangramento em outra parte do corpo. (Brunner \& Suddarth, 2015, p. 1083).

Vale lembrar que uma rápida elevação na temperatura é desfavorável a um paciente com TCE, pois a hipertermia aumenta as demandas metabólicas do cérebro e também pode ser uma indicação de uma lesão no tronco encefálico (Brunner \& Suddarth, 2015). 


\section{CONCLUSÃO}

Este estudo contribuiu para identificar o impacto do trauma tanto em mobilidade, quanto em custos financeiros e reabilitação social.

O estudo epidemiológico destaca a gravidade e aumento do problema no Brasil, principalmente por atingir uma faixa etária jovem, com probabilidades de sequelas por toda a vida, decorrente do TCE.

Foi possível observar através desse estudo a importância e autonomia do enfermeiro na assistência e reabilitação de pacientes vítimas de trauma, o rápido e hábil atendimento, como forma de evitar complicações, tanto na coleta de informações, quanto no monitoramento e SAE, onde o enfermeiro se respalda através do registro do diagnóstico e intervenções, somando assim com os demais profissionais para que haja um atendimento multiprofissional e humanizado ao paciente vítima de trauma.

Com isso, pretende se que através de seus resultados se obtenha um impacto positivo em informações e alerta ao TCE que também é um problema de saúde pública que afeta diretamente na qualidade de vida não só da vítima, mas também de seus familiares.

\section{REFERÊNCIAS}

ALMEIDA, Letícia de Carvalho Ferreira; BRASILEIRO, Marislei Espíndula. Atuação do Enfermeiro no Atendimento ao Paciente com Traumatismo Crânioencefálico: Revisão Bibliográfica. Revista Científica Multidisciplinar Núcleo do Conhecimento. Ano 03, Ed. 05, Vol. 02, pp. 139-148, Maio de 2018. ISSN:2448-0959

Arruda BP, Akamatsu PYF, Xavier AP, Costa RCV, Oliveira-Alonso GS, Madaleno IMP. Traumatismo crânio encefálico e suas implicações cognitivas e na qualidade de vida. São Paulo. 2015.

Brasil. Ministério da Saúde. Secretaria de Atenção à Saúde. Diretrizes de atenção à reabilitação da pessoa com traumatismo cranioencefálico / Ministério da Saúde. Secretaria de Atenção à Saúde. Departamento de Ações Programáticas Estratégicas. - Brasília : Ministério da Saúde, 2015.

Brunner \& Suddarth, Manual de enfermagem médico-cirúrgica/revisão técnica Sonia Regina de Souza; tradução Patricia Lydie Voeux. - 13. ed. Rio de Janeiro: Guanabara Koogan, 2015.

FERNANDES, Ronald Teixeira Peçanha. Ensino clínico em alta complexidade / Ronald Teixeira Peçanha Fernandes. Rio de Janeiro: SESES, 2018.

GAUDÊNCIO, Talita; LEÃO, Gustavo. A Epidemiologia do Traumatismo Cranioencefálico: Um Levantamento Bibliográfico no Brasil. Rev Neurocienc 2013;21(3):427-434 Disponível em: <http://www.revistaneurociencias.com.br/edicoes/2013/RN2103/revisao/814revisao.pdf > Acesso em: 04 de março de 2019

MENDES OLIVEIRA, Leilyanne de Araújo et al. Assistência de enfermagem em pacientes vítimas de traumatismo crânio encefálico: revisão integrativa. REVISTA UNINGÁ, [S.1.], v. 55, n. 2, p. 33-46, jun. 2018. ISSN 2318-0579. Disponível em: <http://revista.uninga.br/index.php/uninga/article/view/2090>. Acesso em: 19 mar. 2019. 
RUY, Erika; ROSA, Maria. Perfil epidemiológico de pacientes com traumatismo crânio encefálico. Rev. enfermagem UFPE on line. Recife, 10(11):3960-8, nov., 2016

Santos AM0R dos, Sousa MEC, Lima LO et al. Perfil epidemiológico do trauma cranioencefálico. Rev. enferm UFPE on line. Recife, 10(11): 3960-8, nov. 2016. Disponível em: <https://periodicos.ufpe.br/revistas/ revistaenfermagem/article/download/11478/13326> Acesso em: 07 de março de 2019

SANTOS, F; CASAGRANDA, L.P; LANGE, C.; FARIAS, J.C.; PEREIRA, P.M.; JARDIM, V.RM., et al. Traumatismo cranioencefálico: causas e perfil das vítimas atendidas no pronto socorro de Pelotas/Rio Grande do Sul, Brasil. Rev Min Enferm., v.4, n.17, p.882-7, 2013.

SOARES, Mirelle. Sistematização da assistência de enfermagem: facilidades e desafios do enfermeiro na gerência da assistência. Escola Anna Nery Revista de Enfermagem 19(1) Jan-Mar 2015. Disponível em: <http:// www.scielo.br/pdf/ean/v19n1/1414-8145-ean-19-01-0047.pdf> Acesso em: 07 de março de 2019.

VIEIRA, R.S; SANTIAGO R.P; SILVA, M.E.S; CESTARI, V.R.F; PENAFORTE, K.L;BARBOSA, I.V. INTERVENÇÕES DE ENFERMAGEM AO PACIENTE COM TRAUMATISMO CRÂNIO ENCEFÁLICO: REVISÃO INTEGRATIVA. I mostra do internato em enfermagem. II SIEPS, Fortaleza. 2016. Disponível em: $<$ http:// www.uece.br/eventos/seminarioppcclisenfermaio/anais/trabalhos_completos/256-39114-08052016-161703. docx.> Acesso em: 14/03/2019 


\section{ATENDIMENTO DE SAÚDE À POPULAÇÃO GARIMPEIRA DA REGIÃO DO RIO TAPAJÓS: RELATO DE EXPERIÊNCIA}

THALYTA MARIANY RÊGO LOPES

UENO

Universidade do Estado do Pará, Programa de Pós - Graduação em Biologia Parasitária da Amazônia.

Belém - Pará

DANIELE MELO SARDINHA

Instituto Evandro Chagas, Programa de PósGraduação Epidemiologia e Vigilância em Saúde.

Ananindeua - Pará

HERBERTO UENO SEELIG DE SOUZA Universidade Federal Rural da Amazônia, Programa de Pós-Graduação em Ciências Florestais. Belém -

Pará

ANA MARIA REVORÊDO DA SILVA VENTURA

Instituto Evandro Chagas, médica e pesquisadora. Ananindeua - Pará

KARLA VALÉRIA BATISTA LIMA Instituto Evandro Chagas, Pesquisador em Saúde Pública. Ananindeua - Pará

RESUMO: a região do Tapajós tem como uma das principais atividades econômicas a extração mineral, sobretudo do ouro. A população que sobrevive do garimpo, vive em condições degradantes, o que influência diretamente na qualidade de vida e de saúde. Objetivo: relatar a experiência vivenciada pela enfermeira e discente do programa de doutorado de Biologia Parasitária da Amazônia durante o atendimento da população garimpeira no período de coleta de dados na região. Percurso Metodológico: trata-se de estudo descritivo, do tipo relato de experiência, realizado entre os meses de fevereiro a dezem- bro de 2019 com pessoas advindas da região dos garimpos do Tapajós. Foram atendidos um total de 908 indivíduos que procuram o setor de endemias na cidade de Itaituba - Pará. Atividades de educação em saúde foram efetuadas de forma individualizada após a realização do teste da gota espessa e do teste rápido para sífilis. Resultado: a maioria das pessoas atendidas apresentava quadro sugestivo para malária, eram do sexo masculino e desenvolviam atividades de garimpagem na região. Informaram que durante o exercício da atividade laboral estão sujeitos a várias injúrias, a condições de vida e de saúde precárias. Relataram escassos serviços de saúde disponíveis nessas regiões. Quase 100\% já apresentaram malária em algum momento da vida, poucos procuram o serviço de saúde para realização de exames complementares ou testes rápidos para infecções sexualmente transmissíveis. Os casos recebidos foram majoritariamente das regiões dos garimpos do Amano, do Rio Bom Jardim e do Tocantins. Considerações: a possibilidade da realização do teste rápido de sífilis no setor de endemias foi vista como uma ação importante para a saúde daquela população. Foi observado que as orientações realizadas sobre prevenção e promoção a saúde foram aceitas pelos indivíduos, haja vista que a minoria procura outros setores da saúde para realização de consultas ou de exames.

PALAVRAS-CHAVE: Mineração. Garimpo. Vulnerabilidade-em-saúde. Condições-de-vida. Enfermagem.

ABSTRACT: the Tapajós region has mineral extraction as its main economic activity, especially gold. The population that survives from mining, 
lives in degrading conditions, which directly influences the quality of life and health. Objective: to report the experience of the nurse and student of the doctoral program in Parasitic Biology in the Amazon during the care of the gold mining population during the period of data collection in the region. Methodological Path: it is a descriptive study, of the type of experience report, carried out between the months of February to December 2019 with people from the region of the Garajim do Tapajós region. A total of 908 individuals who attended the endemic sector in the city of Itaituba - Pará were attended to. Health education activities were carried out individually after the thick drop test and the rapid syphilis test. Result: most of the people assisted had a suggestive picture for malaria, were male and developed mining activities in the region. They informed that during the exercise of the work activity they are subject to various injuries, to precarious living and health conditions. They reported scarce health services available in these regions. Almost 100\% have had malaria at some point in their lives, few seek the health service to carry out additional tests or rapid tests for sexually transmitted infections. The cases received were mostly from the Amano, Rio Bom Jardim and Tocantins mining regions. Considerations: the possibility of performing the rapid syphilis test in the endemic sector was seen as an important action for the health of that population. It was observed that the guidelines given on prevention and health promotion were accepted by individuals, given that the minority seeks other sectors of health to carry out consultations or tests.

KEYWORDS: Mining. Panning. Vulnerability-in-health. Life conditions. Nursing.

\section{INTRODUÇÃO}

O Estado do Pará é um dos principais produtores de mineiro do Brasil. O setor de mineração é considerado motor de crescimento econômico, haja vista que $88 \%$ das exportações do Estado corresponde às Indústrias de Mineração e Transformação Mineral. Em 2019, cerca 2,7 toneladas de ouro foram exportadas, o que perfaz um total de 104 milhões de dólares (SIMINERAL, 2019). Segundo o Instituto Chico Mendes de Conservação da Biodiversidade (ICMBIO, 2012), no Estado do Pará, desde a década de 50 a atividade garimpeira na região de Itaituba, é a principal fonte de renda da maioria da população, em 2012, representava aproximadamente $60 \%$ do produto interno bruto (PIB) do município, e no mesmo ano existiam na região cerca de três mil garimpos entre clandestinos e licenciados.

Áreas de garimpos são consideradas propensas para diversos agravos. Na região Amazônica, áreas de alta incidência de malária são também locais de atividade de garimpagem de ouro, isso ocorre em virtude das condições hidrográficas, clima e temperatura que favorecem a presença e a sobrevivência do vetor - mosquito do gênero Anopheles - infectado pelo Plasmodium, agente etiológico da malária, o qual vai interagir com o homem (BRASIL, 2010; TAIUL, 2015). Além da malária, Joanoni Neto e Santos (2018) asseguram que áreas de garimpos atraem outros serviços, como pequenos estabelecimentos comerciais, bares e casa de prostituição. Nesse ambiente, o uso exagerado de bebidas alcoólicas, drogas e a prostituição são frequentes, essas são condições que constituem comprovados fatores de risco para infecções sexualmente transmissíveis (IST) (ABDISSA et al, 2014; TEDESCO, 2015; CHAPONDA et al, 2016).

Em 2019, foram registrados no Brasil 153.988 casos de malária, dos quais 32.612 casos foram no Pará. Nesse Estado, Itaituba foi quarto município com maior incidência pelo agravo, sendo responsável por cerca de 11,2\% (3.650) do total de ocorrência de malária (BRASIL, 2020). A malária é 
uma doença infecciosa, que acomete milhões de pessoas nas zonas tropicais e subtropicais do globo. É um dos mais sérios problemas de saúde pública, presente em 91 países/territórios e com aproximadamente 216 milhões de casos registrados em todo mundo (WHO, 2017). Para o controle da malária, a Organização Mundial de Saúde (OMS) (2017) recomenda ações voltadas para o indivíduo doente, visando à oferta de diagnóstico precoce e tratamento correto e imediato.

Itaituba, por sua intensa atividade de mineração de ouro no vale do rio Tapajós, apresenta como prática comum alta mobilidade populacional entre os vários garimpos aí localizados. Nos baixões e nas currutelas estabelece-se um fluxo constante de pessoas que apresentam os mais diversos relacionamentos favoráveis para transmissão de IST (TEDESCO, 2015). Por ano, a OMS (2016) estima 357 milhões de novos casos de IST curáveis entre pessoas de 15 a 49 anos, dos quais 64 milhões na Região das Américas, com aproximadamente 20 milhões de indivíduos com sífilis.

A sífilis adquirida, uma das formas de classificação desse agravo, apresentou um aumento de $81,2 \%$ no norte do Brasil (BRASIL, 2016a). Dos 9.890 casos de sífilis adquirida da região Norte, 26,5\% (2.625) foram notificados no Estado do Pará, situando-o como o $2^{\circ}$ em casuística dessa região (BRASIL, 2019). A sífilis é uma doença infectocontagiosa sistêmica, causada pela espiroqueta Treponema pallidum, que acomete a espécie humana há muitos anos. A transmissão ocorre por via sexual e vertical, ocasionando, respectivamente, a sífilis adquirida e a congênita. A forma adquirida da sífilis subdivide-se em precoce e tardia, dependendo do tempo de infecção e do grau de infectividade (BRASIL, 2016b). O controle da sífilis constitui um dos focos de estratégia global do setor de saúde para as IST (2016-2021), com recomendações específicas para populações socioeconomicamente mais vulneráveis (OMS, 2016).

Diante do exposto, o objetivo desse estudo consiste em: relatar a experiência vivenciada pela enfermeira e discente do programa de doutorado de Biologia Parasitária da Amazônia no atendimento da população garimpeira durante o período de coleta de dados na região.

\section{PERCURSO METODOLÓGICO}

Trata-se de um relato de experiência que emergem do atendimento à população garimpeira durante a coleta de dados desenvolvida na pesquisa de doutorado "Aspectos epidemiológicos, moleculares e dinâmica espaço temporal da coinfecção malária e sífilis em uma região de garimpo da Amazônia brasileira", do curso de pós-graduação em Biologia Parasitária da Amazônia da Universidade do Estado do Pará em parceira com o Instituto Evandro Chagas. A atividade proposta pela pesquisa constituiu-se no atendimento aos pacientes com quadro sugestivo de malária oriundos da região garimpeira com o intuito de coletar de dados epidemiológicos e socio-comportamentais desses indivíduos. Além da realização do exame da gota espessa e do teste rápido para sífilis. Outrossim, a pesquisadora atuava nas orientações que abordavam prevenção, promoção e recuperação da saúde.

Para execução da atividade, o projeto de doutorado foi encaminhado para o Comitê de Ética e Pesquisa (CEP) da Universidade do Estado do Pará (UEPA), sendo aprovado no mês de agosto de 2018, com parecer número 2.852.618. Concomitantemente, foi solicitado a anuência da Secretaria 
Municipal de Saúde da cidade de Itaituba no Estado do Pará e do setor de endemias, referência no diagnóstico e no tratamento da malária. Esse agravo é o principal retratado entre a população que vive nas regiões de garimpo dessa área. Ainda foi solicitado da Secretária de Saúde do Estado Pará (SESPA) a disponibilização de kits de teste rápido para sífilis. Ao mesmo tempo, para a realização da atividade, a pesquisadora esteve em algumas áreas de garimpo da cidade de Itaituba/PA, realizando um diagnóstico situacional, tal fato possibilitou o reconhecimento da comunidade e das vulnerabilidades da população adstrita.

Utilizou-se para subsidiar a atividade os dados do relatório gerado a partir da visita técnica do diagnóstico situacional, os relatos da população que vive na área de garimpo e revisão bibliográfica sobre o tema. Após essa etapa, identificou-se os problemas que deveriam ser abordados durante orientações em saúde, a saber: malária, infecções sexualmente transmissíveis, prática sexuais seguras e prevenção de problemas por uso de drogas e álcool.

Assim, a pesquisadora dirigiu-se até o setor de endemias em Itaituba/PA, local de estudo, e em reuniões com chefe do setor definiram o espaço que seria utilizado pela pesquisadora e a equipe que iria acompanhar. Diante disso, todo o processo foi planejado no ano de 2018 e executado em 2019. Participaram 908 indivíduos, todos realizaram o exame da gota espessa, o teste rápido de sífilis e foram atendidos de forma individual. Os casos positivos para malária eram tratados no próprio local e a esses indivíduos eram disponibilizados os medicamentos de acordo com a espécie de plasmodium identificado por meio do exame da gota espessa. Os casos positivos no teste rápido para sífilis, receberam orientações sobre a infecção, foram esclarecidas dúvidas e posteriormente foram encaminhados para a Unidade Básica de Saúde (UBS) mais próxima do domicílio para continuidade de exames e de tratamento.

Por se tratar de uma pesquisa com seres humanos, houve a aplicação do Termo de Consentimento Livre e Esclarecido (TCLE) e do Termo Assentimento Informado Livre e Esclarecido (TALE). No mais, os indivíduos foram informados do objetivo, dos riscos e dos benefícios da pesquisa. Foi respeitado o que é preconizado pela Resolução 466/1212 do Conselho Nacional de Ética em Pesquisa (CONEP).

\section{RESULTADOS E DISCUSSÃO}

Participaram do atendimento 908 indivíduos, a maioria dos participantes era proveniente da cidade de Itaituba - Pará, com idade entre 19 - 59 anos, do sexo masculino, autodeclarados pardos, em união estável, com ensino fundamental incompleto, garimpeiros e com renda familiar variando entre 1 a 5 mil reais. A maior parte deles já apresentou malária ao longo da vida.

No Estado do Pará, a cidade de Itaituba está inserida na chamada Província Auríferas do Tapajós, com quase meio de século de atividade na garimpagem de ouro. Foi a maior área de mineração de ouro da América Latina entre as décadas de 1980 a 1990. Atualmente, ainda tem o garimpo como uma das principais atividades econômicas (BAIA-JÚNIOR, 2014; LOPES et al, 2019). De acordo 
com dados de Informação de Sistema de Vigilância Epidemiológica (SIVEP-malária) em 2019 foram registrados 3.650 casos de malária no munícipio e o município apresenta Índice Parasitário Anual (IPA) de 36,1 classificado com médio (10,0 a 49,9/1.000 hab.) (RISPA, 2008).

A região Amazônia é considerada endêmica para transmissão da malária. A ocorrência de casos desse agravo está relacionada a vários fatores, entre eles as atividades de extrativismo dos recursos naturais, como a garimpagem (MACIEL; OLIVEIRA, 2014). Ademais, de acordo com o estudo de Lopes et al (2019) realizado no município de Itaituba- Pará, a prevalência dos casos de malária registrados são em homens (71,9\%), com faixa etária predominante entre 20 a 39 anos $(55,8 \%)$, $76,6 \%$ auto se declaram pardos, $45,5 \%$ estudaram o ensino fundamental de forma incompleta e 53,3\% trabalham com garimpo. Yang et al (2017) e Dawaki et al (2016) descrevem em seus estudos a prevalência de homens, com faixa etária produtiva e que desenvolviam atividades de extrativismo de recursos naturais, capazes de potencializar a transmissão da doença.

Os garimpeiros da região do Tapajós residem em baixões (lugares próximos da extração de ouro e de outros minerais) que ficam nas proximidades de currutelas ou vilarejos de garimpo (local onde há pequenos comércios, bares, casas de prostituição e alguns serviços de saúde). Nas currutelas a prostituição é uma prática expressiva. Nos baixões, os garimpeiros ocupam moradias feitas de lona e madeira, conhecidos como barracões. A região apresenta um alto fluxo migratório, pois os garimpeiros se deslocam de um garimpo para outro quando há maior disponibilidade de extração de minerais.

De acordo com a pesquisa de Joanoni Neto e Santos (2018) a existência da currutela é diretamente proporcional a "força" do garimpo na região. A prostituição e o uso de álcool e de drogas é frequente nesses locais. Ademais, para os garimpeiros, os baixões e as currutelas são ponto de passagem e sua permanência está condicionada ao sucesso imediato na busca do minério.

Em sua maioria, utilizam a água do rio e/ou de poços amazônicos para cozinhar, beber e banhar. Alimentam-se, em geral, de comidas enlatadas, frutas e algumas vezes de carne de caça, as refeições ocorrem cerca de 3 vezes por dia. Muitos não utilizam repelentes ou mosquiteiros. Trabalham em média de 8 a 12 horas por dia. A maioria é fumante, etilista e já utilizou pelo menos por uma vez algum tipo de droga ilícitas, dentre elas, maconha, cocaína aspirada e crack.

No estudo de Nascimento et al (2019) foi evidenciado que os garimpeiros trabalham cerca de 10 a 12 horas por dia, alimentam-se cerca de 3 a 4 vezes por dia e costumam comer frutas e legumes, ingerem com frequência algum tipo de bebida alcoólica, no entanto, não referem uso de tabaco e nem drogas ilícitas. Além disso, o estudo retratou que todos possuem vida sexual ativa.

De acordo com Brasil (2000), garimpeiros, profissionais do sexo e usuários de drogas lícitas e ilícitas são considerados grupos vulneráveis para infecção e transmissão de ISTs. Nessa pesquisa, todos os indivíduos possuíam vida sexual ativa, seja com parceiro fixo, parceiro eventual ou ambos. Muitos referiram está em união estável, porém mantinham vida sexual paralela com profissionais do sexo. Em geral, não usam preservativo com os parceiros fixos e mencionam utilizá-lo apenas com as prostitutas. Do total de participantes, $474(52,8 \%)$ informaram já terem realizado teste rápido para o vírus da imunodeficiência humana (HIV) e 104 (11,2\%) apresentaram resultado reagente no teste rápido de sífilis. Ademais, $96(10,6 \%)$ indivíduos relataram terem tido algum tipo de infecção sexual- 
mente transmissíveis nos últimos 12 meses, no entanto, não sabem informar qual a infecção. Desses, 66 (69\%) não trataram e/ou apenas se automedicaram.

Corroborando Joanoni Neto e Santos (2018) descrevem em sua pesquisa a abundância de prostitutas, bebidas e jogatinas em áreas de garimpo. Ademais, apontam o garimpo como um ambiente predominantemente masculino, e a forma de suprir a escassez da figura feminina é a existência das casas de prostituição. Além disso, Brasil (2011) descreve a presença e o tráfico de drogas em regiões de garimpo devido a constante expansão associada à mobilidade populacional. Ainda descreve a cidade de Itaituba (PA) com um dos municípios na região Norte com casos notificados de HIV na categoria de exposição referente ao uso de drogas injetáveis. De mesmo modo, a pesquisa de Barros et al (2018) realizada com uma população de rua na região Centro Oeste do Brasil, apontou que 10,2\% dos testes rápidos para sífilis foram reativos, 97,7\% utilizaram algum tipo de substância psicoativa ao longo da vida, 33,9\% relataram histórico de ISTs.

A maioria dos casos positivos de malária e testes reagentes para sífilis foram das regiões de garimpo do Amana (Porquinho, Cara Preta, Pistas AB, CVA, Nova, Formoso, Garimpinho, Cachoeira do São Pedro), do Rio Jardim (Batalha, Comunidade Mandioca, Mineração Bom Jardim e Porto do Edson) e o garimpo do Tocantins. De acordo com os relatos dos garimpeiros nessas regiões não há serviço de saúde, a automedicação e a compra de medicamentos de forma ilegal são uma prática comum. O setor de endemias do munícipio verificando o expressivo número de casos de malária advindos dessas regiões encaminhou expedições para realizarem o diagnóstico e o tratamento de forma precoce, além da distribuição de mosquiteiros impregnados. De acordo com os dados do SIVEP - malária (2019) os casos registrados de malária nesses garimpos foram: região da Amana (1.152), região do rio Bom Jardim (138) e o Tocantins (202), tais dados corroboram com achados encontrados.

Todos os pacientes receberam orientações de forma individualizada sobre malária, infecções sexualmente transmissíveis, práticas sexuais seguras, prevenção e tratamento sobre a dependência de álcool e de outras drogas. A maioria do público atendido foi receptivo com as informações fornecidas, muitos aproveitaram o momento para sanar dúvidas e ainda agradeceram a oferta do teste rápido para sífilis no setor de endemias, haja vista que muitos deles não realiza nem um tipo de consulta ou exames complementar. Brasil (2018) assegura que a probabilidade de infecções por ISTs não está relacionada apenas ao comportamento ou as escolhas pessoais, acredita-se que uma pessoa que não consegue acessar informações, seja pelo seu baixo grau de instrução ou seja porque se encontra em uma situação de exclusão social também está mais vulnerável. Da mesma forma, uma pessoa que não consegue acessar os serviços de saúde, seja porque eles inexistem ou são muito distantes, seja porque não acolhem ou não respondem às suas necessidades, ou porque criam barreiras para o atendimento, poderá estar mais vulnerável a ser infectada e mais propensa a transmitir a infecção.

Ademais, Brasil (2014) ressalta a prática educativa em saúde como um objetivo de cuidar de forma individual ou coletiva visando à melhoria da qualidade de vida e de saúde da comunidade assistida. Além do mais, conforme as diretrizes estabelecidas pela carta de Otawa, a educação e a saúde são práticas sociais inseparáveis e interdependentes que devem se manter articuladas, haja vista que são consideradas elementos fundamentais no processo de trabalho dos profissionais de saúde. Roecker et al (2012) consideram o momento do atendimento ao usuário como um espaço de educação em 
saúde. Asseguram que o desenvolvimento de um cuidado baseado em ações de educação em saúde, alicerçado nos princípios da promoção à saúde, podem melhorar os indicadores de saúde, o acesso aos serviços e a qualidade de vida da população.

\section{CONSIDERAÇÕES FINAIS}

As regiões de garimpo ainda são áreas vulneráveis a presença de diversos agravos de saúde. O homem adentra a floresta com intuito de retira dela recursos naturais a fim de garantir sua sobrevivência e isso permite com que ele fique exposto as várias doenças, entre elas a malária. $\mathrm{O}$ ouro atrai entre outras coisas, a prostituição, o consumo de álcool e de drogas e o aumento de violência nessa área. $\mathrm{O}$ ambiente das curretelas é favorável a infecção e transmissão de infecções sexual transmissíveis, haja vista que o maior entretenimento do garimpeiro é frequentar casas noturnas, manter relações sexuais com profissionais do sexo, ingerir bebidas alcoólicas e outras drogas.

A vida e a saúde do garimpeiro ainda são precárias nessa região. Por ser um município com grande extensão territorial, muitos garimpos estão localizados a vários quilômetros dos serviços de saúde. Tal fato, permite com essa população adquira medicamentos de forma ilegal, pratique a auto medicação e até mesmo não trate a enfermidade. Orientações sobre prevenção, promoção e recuperação à saúde desses indivíduos constitui uma estratégia para aumentar a qualidade de vida e de saúde dessa população. O momento do atendimento em saúde configura-se com um espaço importante a fim de orientar essa população para realização de outras consultas e outros exames complementares.

\section{REFERÊNCIAS}

ABDISSA, H. G.; LEMU, Y. K.; NIGUSSIE, D. T. HIV preventive behavior and associated factors mong mining workers in Sali traditional gold mining site bench maji zone, Southwest Ethiopia:a cross sectional study. BMC Public Health, v. 14, n. 1003, 2014.

BAIA JÚNIOR, P.C. Entre o ouro e a Biodiversidade: Garimpos e Unidades de Conservação na região de Itaituba, Pará, Brasil. Tese (Doutorado do Programa de Desenvolvimento Sustentável do Trópico Úmido, do Núcleo de Altos Estudos Amazônicos (NAEA)) - Belém. Universidade Federal do Pará, 2014, 212p.

BARROS, et al. C. V. de L. Bio-behavioral survey of syphilis in homeless men in Central Brazil: a cross-sectional study. Cad. Saúde Pública, v. 34, n. 6, 2018.

BRASIL. Ministério da Saúde. Coordenação Nacional de DST e Aids. Treinamento para o manejo de casos de doenças sexualmente transmissíveis: modulo 1, 2 e 3. Brasília (DF): Ministério da Saúde, 2000.

BRASIL. Ministério da Saúde. Secretaria de Vigilância em Saúde. Departamento de Vigilância Epidemiológica. Guia de Vigilância Epidemiológica: caderno 10 malária. $7^{\mathrm{a}}$ ed. Brasília (DF): Ministério da Saúde, 2010.

BRASIL. Ministério da Saúde. Secretaria de Vigilância em Saúde. Departamento de DST, Aids e Hepatites Virais. Pesquisa de conhecimento, atitudes e práticas na população brasileira. Secretaria de Vigilância em Saúde. 
Departamento de DST, Aids e Hepatites Virais. - Brasília: Ministério da Saúde, 2011.

BRASIL. Ministério da Saúde. Gabinete do Ministro. Portaria No 2.446, de 11 de novembro de 2014. 2014.

BRASIL. Ministério da Saúde. Secretária de Vigilância em Saúde. Boletim Epidemiológico: Sífilis. v. 47, n. 3, 2016a.

BRASIL. Ministério da Saúde. Secretária de Vigilância em Saúde. Departamento de Vigilância, Prevenção e Controle das Doenças Sexualmente Transmissíveis, Aids e Hepatites Virais. Manual Técnico para Diagnóstico da Sífilis. Brasil: Ministério da Saúde, $2016 b$.

BRASIL. Ministério da Saúde. Secretaria de Vigilância em Saúde. Departamento de Vigilância, Prevenção e Controle das Infecções Sexualmente Transmissíveis, do HIV/Aids e das Hepatites Virais. Agenda Estratégica para Ampliação do Acesso e Cuidado Integral das Populações-Chave em HIV, Hepatites Virais e outras Infecções Sexualmente Transmissíveis. Brasília: Ministério da Saúde, 2018. 36 p.

BRASIL. Ministério da Saúde. Secretária de Vigilância em Saúde. Boletim Epidemiológico: Sífilis. v. 01, n. esp., 2019.

BRASIL. Ministério da Saúde. Sistema de Informação de Vigilância Epidemiológica - Malária, SIVEP. Relatório: Boletim Epidemiológico 2019. Disponível em: $<$ http://200.214.130.44/sivep_malaria/relatorio/ rel_resumo_estado_infeccao.asp?cd_uf_relatorio $=14 \& t x \_u f$ relatorio=PA\&tx_opcao_agravo=MALARIA\&opcao_agravo $=$ B54\%20\&dt_inicial $=01 / 01 / 2019 \& d t$ final $=31 / 12 / 2019 \&$ niv_relatorio $=$ ESTADO\&frm_relatorio $=2 \&$ frm_aglomerado $=\&$ frm_aglomerado_t $=\mathrm{N} \% \mathrm{E} 3 \mathrm{o} \% 20$ categorizar $\% 20$ (dados $\% 20$ gerais) $>$. Acesso: 12.02.2019.

CHAPONDA, E. B. et al. Malarial Infection and Curable Sexually Transmitted and Reproductive Tract Infections among Pregnant Women in a Rural District of Zambia. Am. J. Trop. Med. Hyg., v.95, n. 5, p. 1069-1076. 2016.

DAWAKI, S.et al. Is Nigeria winning the battle against malaria? Prevalence, risk factors and KAP assessment among Hausa communities in Kano State. Malar J., v.15, n.351. 2016.

ICMBIO - INSTITUTO CHICO MENDES DE CONSERVAÇÃO DA BIODIVERSIDADE. Coordenação Regional - CR 3. Floresta Nacional Itaituba II. Itaituba, 2012. Disponível em: <http://www.icmbio.gov.br/ portal/images/stories/servicos/Relat $\% \mathrm{C} 3 \% \mathrm{~B} 3$ rio $\% 20$ Garimpos $\% 20 \mathrm{e} \% 20 \mathrm{Hidrel} \% \mathrm{C} 3 \% \mathrm{~A} 9$ tricas.pdf $>$. Acessado em: 01.02.2019

JOANONI NETO, V.; SANTOS, J.C. dos. Práticas de violências na fronteira: estudo sobre os garimpos de diamante em Juína, MT (1987-1994). História: Debates e Tendências, v.18, n.2, p. 214 -228, maio/ago.2018.

LOPES, T. M.R. et al. Situação epidemiológica da malária em uma região de Garimpo, na região da Amazônia brasileira, no período de 2011 a 2015. REAS/EJCH, v.supl., n.25, jul.2019. Disponível em: $<$ https://acervomais.com.br/index.php/saude/article/view/759 >. Acesso em: 01.02.2019.

MACIEL, G.B.M.L.; OLIVEIRA, E. C. Perfil entomológico e epidemiológico da malária em região garimpeira no norte do Mato Grosso, 2011. Epidemiol. Serv. Saúde, v. 23, n.2, p. 355-360, abr/jun.2014.

NASCIMENTO, V.F. et al. Vulnerabilidades en salud de garimpeiros de una región amazónica. Revista Enfermería Actual, Edición Semestral, n.37, jul/dez.2019.

OMS. Organização Mundial de Saúde. Report on global sexually transmitted infection surveillance 2015. Disponível em: < https://apps.who.int/iris/bitstream/handle/10665/249553/9789241565301-eng.pdf;jsessioni$\mathrm{d}=67$ A533D99E30DB61674718FE7D0C6EA4?sequence=1>. Acesso em:20.12.2018.

RISPA. Rede Interagencial de Informação para a Saúde Indicadores básicos para a saúde no Brasil: conceitos e aplicações / Rede Interagencial de Informação para a Saúde - Ripsa. - 2. ed. - Brasília: Organização Pan-Americana da Saúde, 2008.

ROECKER, S., BUDÓ, M.L.D., MARCON, S.S. The educational work of nurses in the family health strategy: 
difficulties and perspectives on change. Rev Esc Enferm, v.46, n.3, p. 638- 643. 2012.

SIMINERAL. Sindicato das Indústrias Minerais do Estado do Pará. $8^{a}$ Anuário do Pará. 2019. Disponível em:< http://simineral.org.br/pdf/anuarios/8-desktop_pt-br.pdf>. Acesso em: 11.02.2019.

TAUIL, P. L. Epidemiologia. In: Tratado de Infectologia. FOCACCIA, R. São Paulo: Editora Atheneu, p.1894 $-99,2015$.

TEDESCO, L. da L. No trecho dos garimpos: Mobilidade, gênero e modos de viver na garimpagem de ouro amazônica. Amsterdam, 2015.

WHO - WORLD HEALTH ORGANIZATION. GLOBAL MALARIA PROGRAMME. World Malaria Report 2017. 2017. Dísponível em: < https://reliefweb.int/sites/reliefweb.int/files/resources/WMR-2017-slide-deck-briefings.pdf $>$. Acesso em: 02/03/2018.

YANG, D.; XU, C.; WANG, J.; ZHAO, Y. Spatiotemporal endemic characteristics and risk factor analysis of malaria in Yunnam Province, China. BMC Public Health. 17: 66, 2017. Disponível em: < https://www.ncbi. nlm.nih.gov/pmc/articles/PMC5225622/> Acesso em: 15/04/2019. 


\section{COMPLICAÇÕES DA INSUFICIÊNCIA RENAL CRÔNICA DE PACIENTES NA UTI: UM ESTUDO DE REVISÃO}

SIDNEI DE SOUSA CRUZ

Faculdade Estácio do Amazonas, Amazonas, AM

ELIZABETH GOMES DA CRUZ

Faculdade Estácio do Amazonas, Amazonas, AM

CONCEIÇÃO NEVES MONTEIRO

Faculdade Estácio do Amazonas, Amazonas, AM

RAISSA PANTOJA LEÃO

Faculdade Estácio do Amazonas, Amazonas, AM

NAINE DOS SANTOS LINHARES

Universidade CEUMA, São Luís, MA

ANA CLAUDIA GARCIA MARQUES

Universidade Federal do Maranhão, São Luís, MA

ANDRÉA DIAS REIS

Universidade Estadual Paulista Júlio de Mesquita Filho, Presidente Prudente, SP

LEANDRO SILVA PIMENTEL

Faculdade Estácio do Amazonas, Amazonas, AM

RESUMO: Objetivos. Descrever as complicações da insuficiência renal crônica (IRC) de pacientes internados na unidade terapia intensiva. Detectar as causas que ocasionam a IRC e Identificar as principais complicações da insuficiência renal crônica. Metodologia: Trata-se de uma revisão descritiva, exploratória, por meio de levantamentos bibliográficos, cujo objetivo foi discutir a doença renal, as complicações frequentes durante a hemodiálise, e o estudo constituiu artigos que abordavam a doença renal e a hemodiálise, publicados em a literatura nacional no período de 2010 a 2018, indexada na Biblioteca Virtual de Campo, Google Acadêmico, livros, revistas. Resulta- dos: Os autores corroboram no tratamento desse assunto, pois descrevem que a insuficiência renal crônica é mais rápida, mais rápida e mais tratável, quanto maior o diagnóstico, maior o tempo de cura e as complicações do paciente. Conclusão: Os principais desfechos em pacientes com doença renal crônica são complicações (anemia, acidose metabólica, desnutrição e metabolismo alterado de cálcio e fósforo) devido à perda funcional renal, morte (principalmente causas cardiovasculares) e perda da função renal.

PALAVRA-CHAVE: Insuficiência renal crônica; Função renal; Unidade de Terapia Intensiva; Anemia; Metabolismo.

ABSTRACT: Objectives: To describe the complications of chronic renal failure (CRF) of patients hospitalized in the intensive care unit. Detect the causes that cause CRF and Identify the main complications of chronic renal failure. Methodology: This is a descriptive, exploratory, through bibliographic surveys, whose objective was to discuss renal disease, the frequent complications during hemodialysis, and the study constituted articles that addressed renal disease and to hemodialysis, published in the national literature in the period from 2010 to 2018, indexed in the Field Virtual Library, Google Scholar, books, magazines. Results: The authors corroborate in the treatment of this subject, since they describe that chronic renal failure is faster, faster and more treatable, the greater the diagnosis, the longer the cure time and the complications of the patient. Conclusion: The main outcomes in patients with chronic kidney disease are complications (anemia, metabolic acidosis, malnutrition and altered 
calcium and phosphorus metabolism) due to renal functional loss, death (mainly cardiovascular causes) and loss of renal function.

KEYWORDS: Chronic renal insufficiency; Renal function; Intensive Care Unit; Anemia; Metabolism.

\section{INTRODUÇÃO}

As Unidades de Terapia Intensiva (UTIs) são unidades hospitalares destinadas ao atendimento de pacientes graves ou de risco, que dispõem de assistência e de enfermagem ininterruptamente, com equipamentos específicos próprios, recursos humanos especializados, e que têm acesso a outras tecnologias destinadas ao diagnóstico e terapêutica, como a doença renal crônica (DRC) (SANTOS; MARINO, 2013).

A doença renal crônica é progressiva, debilitante e irreversível, acomete milhões de pessoas de todos os grupos raciais e étnicos, apresenta elevada incidência, altas taxas de morbimortalidade e é um problema de saúde pública mundial. Essa doença caracteriza-se por anormalidades estruturais do rim que podem levar à redução da função renal, diagnosticada por uma filtração glomerular menor que $60 \mathrm{~mL} / \mathrm{min} / 1,73 \mathrm{~m}$ durante três meses ou mais (MARQUES et al, 2016).

Quando um paciente apresenta lesão renal sustentada o suficiente para exigir terapia de substituição renal em uma base permanente ou perda progressiva e irreversível da função dos rins, onde o paciente não consegue mais manutenção da função renal, consequentemente é definido como insuficiência renal (IRC) ou DRT (Romão Junior, 2004).

A Nefropatia Diabética (ND) é a principal causa de Insuficiência Renal Crônica em pacientes iniciando tratamento em Hemodiálise (HD), nos países desenvolvidos, representando quase 50\% dos novos casos 1,2 e grande responsável pelo crescente número de pacientes nos países em desenvolvimento. Dados europeus e norte-americanos mostram que sua incidência tem aumentado, progressivamente, ao longo dos anos (GODINHO; DOMINGOS 2016).

Segundo Smeltzer et al (2005), uma falha na função renal pode ocorrer pela qualidade e intensidade de estímulos agressivos aos rins, o que provoca perdas da unidade funcional desse órgão, o néfron. As causas mais comuns atualmente dessa falha renal são o diabetes de longa duração, a hipertensão arterial (HA) e a glomerulonefrite crônica.

A incidência da Insuficiência Renal Crônica (IRC) varia de acordo com as condições clínicas dos pacientes, sendo maior em unidades de terapia intensiva (UTI - 20 a 40\%) e menor em unidades onde o cuidado é intermediário ( 1 a 7\%). Em estudo multicêntrico, mostraram que 5,7\% dos pacientes internados em UTI evoluem com IRA e necessidade dialítica (PONCE et al 2011).

Diagnóstico de admissão na UTI, necessidade de ventilação mecânica, necessidade de diálise, uso de drogas vasoativas e desfecho (alta hospitalar ou óbito). Os critérios diagnósticos para sepse grave e choque séptico foram definidos de acordo com a American College of Chest Physicians/Society of Critical Care Medicine (ACCP/SCCM) Consensus Conference de 1992.10. O diagnóstico de 
insuficiência renal aguda foi definido como aumento da creatinina sérica maior que $50 \%$ dos níveis basais (OKAMOTO et al 2012).

A hemodiálise é um tipo de tratamento substitutivo da função renal, realizado por uma máquina, para remover líquidos e produtos do metabolismo do corpo quando os rins são incapazes de fazê-lo (SOARES; ZEHETMEYER; RABUSKE, 2007). A prescrição do tratamento físico pode ser realizada concomitante ao tratamento hospitalar convencional, dois meses de treinamento físico realizado em média três sessões semanais, com duração de uma hora por sessão obteve benefícios na qualidade de vida e capacidade física de pacientes com doença renal crônica (PERES et al 2009).

A doença renal em estágio terminal (DRET) pode ser causada por várias doenças sistêmicas, tais como: diabetes mellitus, hipertensão, glomerulonefrite crônica, pielonefrite, obstrução do trato urinário, lesões hereditárias, como a doença do rim policístico, distúrbios vasculares, infecções, medicamentos ou agentes tóxicos (PIVATTO; ABREU, 2010).

Os rins são órgãos fundamentais para a manutenção da homeostase do corpo humano. Assim, não é surpresa constatarmos que, diminuição progressiva da função renal, implique em comprometimento de essencialmente todos os outros órgãos. A função renal é avaliada pela filtração glomerular (FG) e a sua diminuição é observada na Doença Renal Crônica (DRC), associada a perda das funções regulatórias, excretórias e endócrinas do rim (BASTOS et al, 2010).

A presença de pequenas quantidades de albumina na urina representa o estágio inicial da nefropatia diabética (microalbuminúria ou nefropatia incipiente). O estágio avançado caracteriza a nefropatia clínica (macroalbuminúria ou proteinúria) e a fase terminal é a insuficiência renal. Indivíduos com ND apresentam outras condições crônicas associadas, como retinopatia diabética, doença macrovascular e hipertensão arterial sistêmica. (TSCHIEDEL, 2014).

A hemodiálise consiste na depuração artificial do sangue realizada por uma máquina. $\mathrm{O}$ tratamento consiste, em média, de três sessões semanais de quatro horas cada dependendo das necessidades individuais (CRAVO et al, 2011). A hemodiálise é a escolha de Terapia de Substituição Renal Contínua (CRRT) mais utilizada $(89,4 \%$ ) até que um transplante renal seja feito, porém, a adaptação ou a adesão do cliente, mesmo que não confortável, acaba por acontecer devido à necessidade (JORGE et al, 2016).

A Insuficiência Renal Aguda (IRA) ainda é uma doença de difícil definição. Devido às várias causas e diferentes mecanismos de lesão renal envolvendo velocidade de progressão e prognóstico ainda mais variáveis, esta doença, que determina em torno de $30 \%$ das internações em unidades de terapia intensiva, representa um importante problema de saúde pública (LOPES et al, 2014).

A hemodiálise, necessita de um tratamento especializado, com profissionais preparados e que tenham conhecimentos teóricos e práticos suficientes para realizarem uma ótima assistência de forma humanizada nesses pacientes (SANTANA et al, 2013).

O objetivo deste artigo é descrever as complicações da insuficiência renal crônica (IRC) de pacientes internados na unidade terapia intensiva. Temos os seguintes objetivos específicos: Detectar as causas que ocasionam a IRC e Identificar as principais complicações da insuficiência renal crônica. 


\section{MATERIAIS E MÉTODOS}

Trata-se de uma pesquisa descritiva, exploratória, do tipo revisão narrativa por meio de levantamentos bibliográficos, cujo objetivo foi discorrer sobre a doença renal, as complicações frequentes durante o tratamento hemodialítico, sendo o estudo constituído por artigos que abordavam a doença renal e hemodiálise, publicados na literatura nacional no período de 2010 a 2018, indexados no Google Acadêmico, livros, revistas, o estudo foi realizado no período entre fevereiro a abril de 2019.

Para Dalfovo et al (2008), este método caracteriza-se pelo emprego da quantificação, tanto nas modalidades de coleta de informações, quanto no tratamento dessas através de técnicas estatísticas, desde as mais simples até as mais complexas. No tratamento das informações, utilizando-se técnicas estatísticas, objetivando resultados que evitem possíveis distorções de análise e interpretação, possibilitando uma maior margem de segurança.

Para Souza et al (2010) "a pesquisa bibliográfica é uma das melhores formas de iniciar um estudo, buscando-se semelhanças e diferenças entre os artigos levantados nos documentos de referência".

\section{RESULTADOS E DISCUSSÃO}

De acordo com os estudos realizados foram selecionados dez artigos onde abordavam de forma geral as características dos pacientes com nefropatia na UTI, com publicações nos anos de 2010, 2011, 2014, e 2016 (Quadro 1). 
Quadro 1. Artigos relacionados às características do paciente com nefropatia de acordo com os autores, título, ano, tipo de pesquisa e principais resultados.

\begin{tabular}{|c|c|c|c|c|}
\hline Autores & Título & Ano & $\begin{array}{c}\text { Tipo de } \\
\text { pesquisa }\end{array}$ & Principais resultados \\
\hline BASTOS et al & $\begin{array}{l}\text { Doença renal } \\
\text { crônica: } \\
\text { frequente e } \\
\text { grave, mas } \\
\text { também } \\
\text { prevenível e } \\
\text { tratável. }\end{array}$ & 2010 & $\begin{array}{l}\text { Revisão } \\
\text { bibliográfica }\end{array}$ & $\begin{array}{l}\text { Estudos recentes indicam que estes } \\
\text { desfechos indesejados podem ser } \\
\text { prevenidos ou retardados se a DRC } \\
\text { for diagnosticada precocemente e } \\
\text { as medidas nefro e cardioprotetoras } \\
\text { implementadas o mais rápido possível. } \\
\text { O atual estadiamento da doença e uma } \\
\text { descrição dessas medidas preventivas são } \\
\text { apresentados na presente revisão. }\end{array}$ \\
\hline CRAVO, et al. & $\begin{array}{l}\text { Perfil } \\
\text { epidemiológico } \\
\text { dos pacientes } \\
\text { em hemodiálise } \\
\text { de um hospital } \\
\text { universitário. }\end{array}$ & 2011 & $\begin{array}{l}\text { Natureza } \\
\text { descritiva e do } \\
\text { tipo ecológico }\end{array}$ & $\begin{array}{l}\text { Predominou o sexo masculino, com } \\
58,6 \% \text {, e a faixa etária entre } 30 \text { e } \\
39 \text { anos, correspondendo a } 31 \% \text {; } \\
62 \% \text { tinham cor branca, } 34,5 \% \text { eram } \\
\text { tabagistas, } 17,2 \% \text { eram etilistas e } 20,7 \% \text {, } \\
\text { obesos. }\end{array}$ \\
\hline $\begin{array}{l}\text { GODINHO; } \\
\text { DOMINGOS }\end{array}$ & $\begin{array}{l}\text { Perfil Clínico- } \\
\text { Epidemiológico } \\
\text { dos pacientes } \\
\text { com nefropatia } \\
\text { diabética em } \\
\text { hemodiálise, em } \\
\text { Ipatinga-MG. }\end{array}$ & 2016. & $\begin{array}{l}\text { Estudo } \\
\text { descritivo, } \\
\text { transversal e } \\
\text { quantitativo }\end{array}$ & $\begin{array}{l}\text { A amostra foi constituída por } \\
86 \text { indivíduos diabéticos com } \\
\text { insuficiência renal } \\
\text { crônica, em hemodiálise, dos quais } 50 \\
(58,1 \%) \text { eram homens, } 23(26,7 \%) \text { acima } \\
\text { de } 60 \text { anos, } 73(84,9 \%) \text { aposentados, } \\
57(66,3 \%) \text { diabéticos e hipertensos, } \\
64(77,1 \%) \text { apresentaram hipotensão } \\
\text { durante sessão de hemodiálise. }\end{array}$ \\
\hline JORGE et al & $\begin{array}{l}\text { Pacientes com } \\
\text { doenças renais } \\
\text { atendidos na } \\
\text { emergência de } \\
\text { um hospital } \\
\text { escola. }\end{array}$ & 2016 & $\begin{array}{l}\text { Estudo } \\
\text { transversal }\end{array}$ & $\begin{array}{l}\text { Houve predominância do sexo } \\
\text { feminino, brancos, de oito a } 11 \text { anos } \\
\text { de escolaridade, que trabalham em } \\
\text { outras profissões, casados, tendo como } \\
\text { patologia renal a cólica nefrética não } \\
\text { especificada e alta médica após consulta } \\
\text { e/ou internação. }\end{array}$ \\
\hline LOPES, et al & $\begin{array}{l}\text { Insuficiência } \\
\text { renal aguda em } \\
\text { uma unidade de } \\
\text { terapia intensiva } \\
\text { no norte do } \\
\text { Brasil. }\end{array}$ & 2014 & $\begin{array}{l}\text { Estudo } \\
\text { retrospectivo, } \\
\text { descritivo e } \\
\text { analítico }\end{array}$ & $\begin{array}{l}\text { A IRA neonatal na UTI neonatal } \\
\text { da FSCMPA esteve em } 3,76 \% \text { dos } \\
\text { pacientes. Dos } \\
\text { pacientes estudados, } 8(53,3 \%) \text { eram } \\
\text { do sexo feminino e } 7(46,7 \%) \text { do } \\
\text { sexo masculino. Neonatos com até } 07 \\
\text { dias de vida que desenvolveram IRA } \\
\text { representaram } 13(86,7 \%) \text { casos. A } \\
\text { assistência pré-natal foi observada em } 12 \\
\text { (80\%) casos. } \\
\text { Quanto ao diagnóstico, em } 53 \% \text { dos } \\
\text { casos foram realizados em até } 7 \text { dias } \\
\text { e em } 47 \% \text { após } 7 \text { dias. Condições } \\
\text { associadas: elevada prematuridade }(80 \%) \\
\text { e baixo peso (53,3\%) neonatos, com } \\
\text { mortalidade em } 87,5 \% \text {. }\end{array}$ \\
\hline
\end{tabular}


Na quadro 2, discorre as causas mais distintas da insuficiência renal crônica, sendo uma patologia de difícil definição envolvendo diferentes mecanismos de lesão renal.

Quadro 2: Causas da Insuficiência renal crônica

- Diabetes Mellitus;

- Hipertensão;

- Glomerulonefrite crônica;

- Pielonefrite;

- Obstrução do trato urinário;

- Lesões hereditárias;

- Doença do rim policístico;

- Distúrbios vasculares;

- Infecções;

- Medicamentos;

- Agentes tóxicos.

No quadro 3, os autores relatam as complicações da Insuficiência renal crônica que estão associadas com a hemodiálise.

Quadro 3: Efeitos adversos da Insuficiência renal crônica

- Hipotensão arterial;

- Síndrome do desequilíbrio da diálise;

- Reação pirogênica e bacteremia;

- Náuseas e vômitos;

- Hipertensão arterial;

- Cefaleia;

- Arritmia cardíaca;

- Precordialgia;

- Hemorragias;

- Convulsões;

- Lombalgia;

- Câimbras;

- Hipoxemia;

- Reações alérgicas;

- Prurido. 
As competências do profissional assistencial da unidade de terapia intensiva no sistema hospitalar se dão a partir da tomada de decisão como suporte para estratégias e ações que visam alcançar um objetivo definido. Os autores se corroboram em tratar desse assunto, pois descrevem que a insuficiência renal crônica quando mais rápida for diagnóstica, mais rápido e tratável, mais quanto mais longo o diagnóstico o tempo de cura se torna longo e gerando complicações para o paciente. O profissional de saúde deve compreender as complexas dimensões que envolvem o cuidado, produzindo assistência de forma imediata, na qual evita possíveis complicações.

\section{CONCLUSÃO}

No Brasil, a incidência e a prevalência de falência de função renal estão aumentando; o prognóstico muitas vezes ruim e os custos do tratamento da doença são altíssimos. Independentemente da etiologia da doença de base, os principais desfechos em pacientes com doença renal crônica são as suas complicações (anemia, acidose metabólica, desnutrição e alteração do metabolismo de cálcio e fósforo), decorrentes da perda funcional renal, óbito (principalmente, por causas cardiovasculares) e perda de função renal.

Estudos recentes indicam que estes desfechos indesejados podem ser prevenidos ou retardados se a doença for diagnosticada precocemente e as medidas nefro e cardioprotetoras implementadas o mais rápido possível.

Foi possível através desse estudo, observar as principais complicações da doença renal crônica que são acometidas em pacientes internados na UTI. Foi possível identificar as causas da doença renal crônica.

\section{REFERÊNCIAS}

BASTOS, Marcus Gomes; et al. Doença renal crônica: frequente e grave, mas também prevenível e tratável. Rev Assoc Med Bras, v. 56, n. 2, p. 248-256, 2010.

CRAVO, Carla Danielle Lopes; et al. Perfil epidemiológico dos pacientes em hemodiálise de um hospital universitário. Cienc Cuid Saude, v. 10, n. 1, p. 110-115, 2011.

DALFOVO, Michael Samir; et al. Métodos quantitativos e qualitativos: um resgate teórico. Revista Interdisciplinar Científica Aplicada, v.2, n.4, p. 1- 13, 2008.

GODINHO, Matheus de Navarro Guimarães; DOMINGOS, Eberaldo Severiano. Perfil Clínico-Epidemiológico dos pacientes com nefropatia diabética em hemodiálise, em Ipatinga-MG. Revista Ciência e Saúde, p. 46-53, 2016.

JORGE, Samaris Cristina; et al. Pacientes com doenças renais atendidos na emergência de um hospital escola. Rev enferm UFPE on line, v. 10, n. 10, p. 3814-3818, 2016.

LOPES, Cássia de Barros; et al. Insuficiência renal aguda em uma unidade de terapia intensiva no norte do Brasil. Revista paraense de medicina, v. 28, n. 1, p. 41-47, 2014. 
MARQUES, Veronius da Rosa; et al. Avaliação da intensidade da dor de pacientes renais crônicos em tratamento hemodialítico. Rev. Dor, v.17, n. 2, p. 96-100, 2016.

OKAMOTO, Thábata Yaedu; et al. Insuficiência renal aguda em pacientes com sepse grave:fatores prognósticos. SCIENTIA MEDICA (Porto Alegre), v. 22, n. 3, p. 138-114, 2012.

PERES, Celeide Pinto Aguiar; et al. Efeitos de um programa de exercícios físicos em pacientes com doença renal crônica terminal em hemodiálise. J Bras Nefrol., v. 31, n. 2, p.105-113, 2009.

PONCE, Daniela; et al. Injúria renal aguda em unidade de terapia intensiva: Estudo prospectivo sobre a incidência, fatores de risco e mortalidade. Rev Bras Ter Intensiva, v. 23, n. 3, p. 321-326, 2011.

PIVATTO, Daiane Roberta; ABREU, Isabella Schroeder. Princípais causas de hospitalização de pacientes em hemodiálise no município de Guarapuava, Paraná, Brasil. Rev Gaúcha Enferm., v. 31, n. 3, p. 515-520, 2010.

ROMÃO JUNIOR, João Egidio . Doença Renal Crônica: Definição, Epidemiologia e Classificação. Jornal Brasileiro de Nefrologia, v. 26, n. 3, supl. 1, 2004.

SANTANA, Suellen Silva; et al. Assistência de enfermagem prestada aos pacientes em tratamento Hemodialítico nas unidades de Nefrologia. Revista Científica do ITPAC, v. 6, n. 3, p. 2013.

SANTOS, Eliandro de Souza; MARINHO, Carina Martins da Silva. Principais causas de insuficiência renal aguda em unidades de terapia intensiva: intervenção de enfermagem. Revista de Enfermagem Referência, III Série, n. 9, p. 181-189, 2013.

SMELTZER SC, Bare BG. Brunner \& Suddarth: tratado de enfermagem médico-cirúrgica. 10a. ed. Rio de Janeiro: Guanabara Koogan; v. 2. 2005.

SOARES, A.; ZEHETMEYER, M.; RABUSKE M. Atuação da fisioterapia durante a hemodiálise visando à qualidade de vida do paciente renal crônico. Revista de Saúde da UCPEL, v. 1, n. 1, p. 7-12, 2007.

SOUZA, Marcela Tavares de; et al. Revisão integrativa: o que é e como fazer. Einstein. v. 8, n. 1, p. 102-106, 2010. Disponível em: <http://www.scielo.br/pdf/eins/v8n1/ pt_1679-4508-eins-8-1-0102>. Acesso em 27 de Fev. de 2019.

TSCHIEDEL, Balduino. Complicações crônicas do diabetes. J. Bras. Med., v. 102, n. 5, 2014. 
KELLY ADRIANI DOS SANTOS BAETA Centro Universitário do Estado do Pará (CESUPA)

THAIS DOS SANTOS PINHEIRO DA SILVA

Centro Universitário do Estado do Pará (CESUPA)

MARIANA SOUZA DE LIMA

Universidade Federal do Pará (UFPA)

STEPHANY SIQUEIRA BRAGA

Universidade do Estado do Pará (UEPA)

JOSÉ CARLOS CORREA REGO FILHO Centro Universitário do Estado do Pará (CESUPA)

RUHAN DA CONCEIÇÃO SACRAMENTO Universidade do Estado do Pará (UEPA)

BEATRIZ DUARTE DE OLIVEIRA

Universidade do Estado do Pará (UEPA)

RESUMO: O sangue, os seus componentes e os seus derivados são utilizados como suporte para tratamento de inúmeras doenças e no apoio de transplantes, quimioterapia e cirurgias, tornando-se, assim, produtos essenciais e insubstituíveis. No que diz respeito à transfusão sanguínea na unidade de terapia intensiva (UTI), várias são as causas que podem levar o paciente internado a precisar de transfusão de sangue, uma das causas é a hemostasia, na qual, o paciente pode sofrer quadros de hemorragias agudas, a outra causa são as anemias agudas, onde o paciente sofre uma dificuldade em transportar oxigênio, sofrendo uma queda no valor da hemoglobina. Sob esse aspecto, o Conselho Federal de Enfermagem 306/2006, traz uma abordagem da atuação e competências do Enfermeiro na hemoterapia, dentre as atribui- ções do enfermeiro, está o de promover a saúde e segurança do paciente, minimizando os riscos desde os doadores até os receptores dos hemocomponentes, realizando supervisões e avaliando os procedimentos de hemoterapia. Diante do exposto, objetiva-se, de forma narrativa, destacar o processo de trabalho do profissional Enfermeiro na transfusão de sangue, especificamente, em terapia intensiva. Foi possível abordar o sistema hematológico, apresentando os componentes do sangue e seus hemoderivados, a sua relação com os outros sistemas do corpo humano, as reações adversas, bem como o posicionamento ético quanto a hemotransfusão e a inserção do profissional enfermeiro sob respaldo legal. A prática hemoterápica é multiprofissional, tendo a necessidade cada vez mais de profissionais qualificados, capacitados e responsáveis, logo, a inserção do profissional enfermeiro, é salutar para contribuir positivamente neste processo e assegurar a qualidade e segurança do paciente nas etapas da hemotransfusão.

PALAVRA-CHAVE: Enfermagem; Hemoterapia; Terapia Intensiva.

ABSTRACT: The blood, its components and its derivatives are used as a support for the treatment of numerous diseases and in support of transplants, chemotherapy and surgeries, thus becoming essential and irreplaceable products. With regard to blood transfusion in the intensive care unit (ICU), there are several causes that may lead the hospitalized patient to need blood transfusion, one of the causes is hemostasis, in which the patient may suffer from hemorrhages acute, the other cause is acute anemia, where the patient 
has a difficulty in transporting oxygen, suffering a drop in the hemoglobin value. In this regard, the Federal Nursing Council 306/2006, brings an approach to the role and competencies of the nurse in hemotherapy, among the nurse's duties, is to promote the health and safety of the patient, minimizing the risks from donors to the recipients of blood components, performing supervision and evaluating hemotherapy procedures. Given the above, the objective is, in a narrative way, to highlight the work process of the nurse professional in blood transfusion, specifically, in intensive care. It was possible to approach the hematological system, presenting blood components and their blood products, their relationship with other systems of the human body, adverse reactions, as well as the ethical position regarding blood transfusion and the insertion of the nurse professional under legal support. The hemotherapeutic practice is multiprofessional, with the need for increasingly qualified, trained and responsible professionals, therefore, the insertion of the professional nurse, is healthy to contribute positively in this process and ensure the quality and safety of the patient in the stages of blood transfusion.

KEYWORDS: Nursing; Hemotherapy; Intensive care.

\section{INTRODUÇÃO}

A Hemoterapia no Brasil surgiu no ano de 1879, com o médico José Vieira Marcondes, onde em sua tese de doutorado da Faculdade de Medicina do Rio de Janeiro, relatou suas vivências empíricas sobre transfusão de sangue, fazendo o questionamento de qual seria a melhor forma de transfusão: entre animais e seres humanos ou a realizada entre dois seres humanos. Porém o relato mais relevante veio de Salvador, quando o médico Garcez Fróes realizou a primeira transfusão de sangue utilizando o aparelho de Agote, por ele idealizado, transfundido $129 \mathrm{ml}$ de sangue de um doador para uma receptora com metrorragia grave (JUNQUEIRA; ROSENBLIT; HAMERSCHLAK, 2005).

Atualmente, a hemoterapia no país é regulamentada por portaria e resolução sobre coleta, processamento, transfusão de sangue e seus derivados, bem como sobre os requisitos de boas práticas para serviços de hemoterapia que desenvolvam atividades relacionadas ao ciclo produtivo do sangue e para serviços de saúde que realizem procedimentos transfusionais (BRASIL, 2014).

O sangue, os seus componentes e os seus derivados são utilizados como suporte para tratamento de inúmeras doenças e no apoio de transplantes, quimioterapia e cirurgias, tornando-se, assim, produtos essenciais e insubstituíveis (TAVARES et al., 2015).

No que diz respeito à transfusão sanguínea na unidade de terapia intensiva (UTI), várias são as causas que podem levar o paciente internado precisar de transfusão de sangue, uma das causas são: a hemostasia, na qual, o paciente pode sofrer quadros de hemorragias agudas e a outra causa são as anemias agudas, onde o paciente sofre uma dificuldade em transportar oxigênio, sofrendo uma queda no valor da hemoglobina (AMARAL, 2015).

Em pacientes críticos como um dos problemas mais frequentes, encontra-se a anemia, sendo necessário transfusão de concentrado de hemácias (CHA). Essa técnica é comumente utilizada para o seu tratamento nos Centros de Tratamento Intensivo (CTI). A etiologia da anemia em pacientes críticos é multifatorial. Entre as diversas causas, hemorragias decorrentes de procedimentos cirúrgi- 
cos, trauma e sangramentos gastrointestinais, ainda são as mais significativas (COSTA FILHO, et al., 2009).

Os benefícios e riscos das transfusões têm direcionado as decisões clínicas para a introdução e aprimoramento das evidências científicas na prática transfusional. Mesmo que novos tratamentos à saúde estejam surgindo e apresentando progressos significativos, ainda não se encontrou um substituto com fins terapêuticos, como o sangue humano. A prática transfusional é um processo complexo que necessita de uma equipe de profissionais de saúde para realizá-la com segurança. Pois, cada profissional não depende apenas de conhecimentos e habilidades, mas precisa dos conhecimentos e habilidades de toda a equipe e da eficiência do sistema (SOUZA, 2012).

Algumas das recomendações, é que a transfusão sanguínea deve ser administrada pelos profissionais médicos ou enfermeiros da equipe, a qual, tenha qualificação devida para o procedimento. $\mathrm{O}$ enfermeiro tem participação fundamental na assistência da hemotransfusão, pois, ele possui conhecimento e competência para a administração, para indicar a quem necessite da terapêutica tranfusional e realizar a checagem dos dados, com intuito de prevenir erros. Além disso, o paciente internado que necessite da hemotransfusão permanece sob os cuidados da equipe de enfermagem (CHEREM, et al., 2018).

O COFEN (Conselho Federal de Enfermagem) 306/2006, traz uma abordagem da atuação e competências do Enfermeiro na hemoterapia, dentre as atribuições do enfermeiro, está o de promover a saúde e segurança do paciente, minimizando o risco desde os doadores até os receptores dos hemocomponentes e, acima de tudo, realizar supervisão e avaliar os procedimentos de hemoterapia.

Assim, é importante a capacitação e realização de boas práticas ao cuidado com pacientes em terapia intensiva pela enfermagem, visto que o enfermeiro participa do processo da hemotransfusão, assim como, assiste à reação do receptor do sangue com intuito de prestar uma assistência de qualidade, evitar riscos e possíveis causas de reações transfusionais que podem ocorrer no momento do procedimento ou no período após 24 horas da transfusão (AMARAL, et al., 2015).

Diante do exposto, objetiva-se, de forma narrativa, destacar o processo de trabalho do profissional Enfermeiro na transfusão de sangue, especificamente, em terapia intensiva.

\section{SISTEMA HEMATOLÓGICO}

O sistema hematológico é o conjunto de estruturas representadas pelo sangue e o local onde este é produzido, abrangendo também a medula óssea e o Sistema Retículo Endotelial (SRE). Os órgãos que compõe o sistema sanguíneo são locais onde se originam a maior parte das células do sangue, são eles: medula óssea, timo, baço e linfonodos (NETTO, et al., 2011).

A medula óssea vermelha é formada por um tecido gelatinoso que preenche a parte interna da cavidade dos ossos, é onde acontece a produção da maioria das células do sangue, os eritrócitos, leucócitos e trombócitos (NETTO, et al., 2011). 
O timo é uma pequena glândula que tem por função a produção dos linfócitos $\mathrm{T}$, de grande importância na resposta imunitária. São constituídos por dois lobos intimamente ligado por tecido conjuntivo, as principais células do timo são os linfócitos (timócitos), as células reticulares e uma pequena quantidade de macrófagos. Sua função protetora na fase adulta permanece para manter a saúde (FAUSTO, et al., 2004).

Os linfonodos são pequenas estruturas ovais e podem chegar a medir de 0,1 a $2,5 \mathrm{~cm}$ de largura, eles estão organizados em córtex (região periférica) e medula (região central). Está situado na região cortical os folículos linfoides e a parte central germinativa, encontrando-se os linfócitos-B. Na região cortical extra folicular, paracortical e na região medular, situasse os linfócitos-T (CHAMMAS, et al., 2004). O hilo localiza-se em uma pequena chanfradura no córtex, por onde passam os vasos (artérias e veias) do linfonodo e vasos linfáticos e aferentes, os vasos linfáticos aferentes drenam para o córtex do linfonodo, na qual a linfa que corresponde ao liquido intersticial que circula por muitos canais linfáticos, fazendo com que a linfa fique exposta a ação dos macrófagos e linfócitos $\mathrm{T}$ e $\mathrm{B}$ (RODRIGUES, 2003).

O baço é um órgão com sua consistência mole, com bastante vascularização, apresenta uma coloração púrpura e com uma relativa mobilidade, apresenta uma variação no seu tamanho, forma e peso, ele está localizado no hipocôndrio esquerdo, na região sub-frênica com relação com as costelas IX, X e XI. Ele apresenta várias funções no corpo que são de suma importância, dentre elas são: a função hematopoiéticas ainda na vida fetal e na fase adulta nas condições patológicas, apresenta a função imunológica, na qual produz a tuftisina e opsonimasque que estão relacionadas com a ativação dos leucócitos; o baço apresenta também a função de armazenar as células do sangue no seu parênquima, ocorrendo a liberação na corrente sanguínea de acordo com a necessidade do corpo, apresenta a função de hemocatarese e pôr fim a função de regulação lipídica (AGUIAR, et al., 2008).

O sangue é considerado o fluido que contacta com todos os sistemas do corpo humano, sendo necessário para a manutenção dos mesmos, através de sua função principal que é o transporte, regulação e proteção. Sendo uma das funções do sangue o transporte, o mesmo conduz O2, CO2, metabólitos, guia e excreta as células para os rins. O sangue ajuda na manutenção da homeostase, auxilia na regulação da temperatura do corpo, proteção dos tecidos contra substancias tóxicas e estranhas que entram em contato com o organismo, previne a perda excessiva de líquidos através do mecanismo de coagulação (MESCHER, 2013).

A principal função das hemácias é transportar oxigênio dos pulmões para o tecido e do tecido para os pulmões, elas são anucleadas, apresentam o formato bicôncavo e não possui organelas. As hemácias são numerosas no corpo humano, apresentando diferenciações quando comparado ao sexo, em um adulto homem a quantidade se aproxima 5.200.000 milímetros e nas mulheres adultas 4.800.000 milímetros, pode- se considerar que a altitude modifica o quantitativo de hemácias. A vida média das hemácias é de 100 a 120 dias, quando chegam a este período, as membranas das hemácias tornam-se fracas sendo removida pelo baço. A hemoglobina também tem um funcionamento no organismo como um sistema tampão adicional, participando da manutenção do equilíbrio ácido básico (SOUZA; ELIAS, 2006; OLIVEIRA, 2015). 
Os glóbulos brancos ou leucócitos se constituem em um grupo com maior heterogeneidade de células, tanto morfológico como fisiológico, considera-se que a existência no sangue periférico 6.000 a 8.000 leucócitos por milímetro de sangue. São eles: neutrófilos, eosinófilos, basófilos monócitos e linfócitos (SOUZA; ELIAS, 2006).

Os neutrófilos, eosinófilos e basófilos são leucócitos polimorfonucleares, pois sua forma estrutural apresentam núcleos com dois ou mais lobos. O tempo de vida dos leucócitos é de pouca duração, ou seja, indica vida curta, eles só realizarão sua função quando requisitada, posteriormente a serem acionadas na medula óssea para circulação sanguínea, permanecem de seis a oito horas circulando no sangue e após tem uma durabilidade de dois a três dias nos tecidos, ainda pode-se afirmar que quando os tecidos apresentam algum tipo de infecção em percurso, os leucócitos em circulação possui uma durabilidade menor no sangue, pois agem diretamente na área infectada, onde ingerem os organismos invasores e em seguida são destruídos (SOUZA; ELIAS, 2006).

Os leucócitos e células teciduais que tem por origem os leucócitos, atuam como importante papel de duas formas, a primeira é através da destruição efetiva dos agentes que invadem o organismo realizando o processo de fagocitose e também pela segunda que é formação de anticorpos e linfócitos que estão sensibilizados e, por fim, destrói o agente invasor. Embora o organismo possa estar exposto a microrganismos, principalmente na cavidade oral, epiderme, vias respiratórias, trato gastrointestinal, mucosa dos olhos e vias urinarias, estas células, em conjunto, impossibilitam doenças de se instalarem no organismo (RENA, et al., 2001).

As plaquetas são fragmentos citoplasmáticos de células gigantes anucleadas e estão presentes no sangue e são formadas na medula óssea, sua estrutura é complexa e discoide, a sua estrutura interna são organizadas em quatro zonas sendo, a zona periférica, zona sol-gel, zona de organelas e por fim sistema de membrana. Está presente no organismo humano, $70 \%$ plaquetas na circulação e $30 \%$ no baço, possui uma permanência na corrente sanguínea de dez dias em média, após, saem da circulação pelas SRE do baço e do fígado (CASTRO, et al., 2006; SOUZA; ELIAS, 2006).

Sua função está envolvida em diversos processos, como a iniciação e amplificação a inflamação, interage com as células do sistema imunológico, participa também da progressão tumoral, angiogênese e metástase. Portanto, pode-se afirmar que as plaquetas têm uma total participação em processos inflamatórios que podem ter influência na resposta imune, também participam da desordem de plaquetas autoimunes e, não menos importante, estão relacionadas a presença de auto-anticorpos após transfusões sanguíneas (OLIVEIRA, et al., 2013).

A parte líquida do sangue, sem células, é constituída como plasma sanguíneo, sendo o maior componente do sangue, sua composição é a maior parte água e substâncias diluídas. As seguintes substâncias, são: proteínas, hidratos de carbono, lipídios, eletrólitos, pigmentos, vitaminas e hormônios. O plasma permite o livre intercâmbio dos componentes com o líquido intersticial, isso acontece através dos poros existente na membrana capilar. As proteínas do plasma são três tipos: albumina, fibrinogênio e globulinas (SOUZA; ELIAS, 2006). 


\section{REAÇÕES ADVERSAS NA TRANSFUSÃO SANGUÍNEA}

Como muitos tratamentos terapêuticos, a transfusão sanguínea possui o potencial de ocasionar reações adversas e até mesmo desfechos clínicos fatais; para que isso não ocorra, é importante a constante elaboração e implementação de estratégias que objetivem reduzir o uso inapropriado do sangue e seus componentes (SOUZA, 2012).

A transfusão sanguínea é um procedimento irreversível que resulta em benefícios e riscos potenciais ao receptor, dentre esses riscos há a reação adversa a transfusão, que é toda e qualquer intercorrência que ocorre em consequência da hemotransfusão, durante ou após a sua administração. O diagnóstico preciso de uma reação, dá subsídios ao profissional que realiza a transfusão, para que se utilize estratégias apropriadas para prevenção de novos episódios (OLIVEIRA, 2012).

No Brasil, observa-se um aumento no número de notificações no uso de sangue e na ocorrência de Eventos Adversos relacionados à hemotransfusão a partir de 2007, este aumento é justificado pela implantação do Sistema de Notificação da Vigilância Sanitária (NOTIVISA), o que representou um avanço para a Hemovigilância (OLIVEIRA; XAVIER; SANTOS JUNIOR, 2013).

As reações adversas da transfusão sanguínea ou os incidentes transfusionais, são considerados como agravos que ocorrem durante ou após a transfusão sanguínea, podendo ser classificado como imediatos ou tardios, a partir do tempo decorrido entre a transfusão e a ocorrência do incidente (OLIVEIRA, 2012).

Os eventos adversos à transfusão podem ser classificados em não imunológicos, como por exemplo, pela transmissão de doenças, sobrecarga circulatória, reações alérgicas, reações metabólicas, e outros riscos referente a imunologia, principalmente relacionado a hemólise por destruição de hemácias devido à formação de complexo antígeno-anticorpo (OLIVEIRA, 2012).

As ações gerais preconizadas para a enfermagem, diante de uma reação transfusional, são: interromper imediatamente a transfusão, verificar os sinais vitais e estado clínico do paciente, manter o acesso venoso com solução fisiológica, averiguar os dados de identificação da etiqueta do hemocomponente, correlacionando com os dados do paciente, comunicar imediatamente ao médico e notificar o banco de sangue (SOUZA, 2012).

O Sistema Nacional de Hemovigilância, criado em 2011, define comunicação como a transmissão de informação sobre a ocorrência de eventos adversos relacionados aos produtos de interesse sanitário e aos procedimentos técnicos e terapêuticos em doadores e receptores de sangue e componentes. A notificação do evento adverso na hemotransfusão é primordial para que se previna outros eventos adversos, assim, as normas brasileiras tornam obrigatórias a notificação de todas as reações transfusionais ao SNVS (BRASIL, 2015).

As reações transfusionais de correlação confirmada, provável, possível, improvável e inconclusiva, devem ser notificadas, já a correlação descartada só será notificada se anteriormente a mesma 
reação foi notificada com outa categoria de correlação e, se após a investigação teve sua correlação alterada para ser descartada (BRASIL, 2015).

De acordo com a literatura, grande parte das reações adversas são provocadas por concentrado de hemácias, e os principais sintomas apresentados, referentes às reações imediatas, são: febre, dispneia e urticária (SOUZA, 2012). Ainda, Callera e colaboradores (2004) encontraram uma taxa de 5,5 reações aos hemocomponentes em cada 1000 bolsas transfundidas, enquanto no estudo de Meza e colaboradores (2013), foram encontradas 11,5 reações a cada 1000 transfusões.

\section{QUESTÕES ÉTICAS RELACIONADAS À HEMOTRANSFUSÃO}

$\mathrm{Na}$ área das ciências da saúde e da vida, a ética aplicada a vida, em um contexto social, é considerada um conjunto de valores. Por meio de conhecimentos teóricos, o profissional da saúde, através da bioética, junto a equipe, toma decisões em prol do paciente, considerando sua cultura, valores e crenças e seguindo o preceito ético profissional (LARA; PENDLOSKI, 2013).

Em seu exercício profissional, a equipe de saúde deve considerar que sua formação fará com que atenda e valorize as necessidades religiosas/espirituais dos usuários, visto que, esta ação visa a consecução da integralidade do cuidado, proporcionado bem-estar e cura aos que buscam por cuidado. A dedicação do profissional da saúde e o respeito quanto a sua crença, cultura e outros, transmite conforto, tranquilidade e qualidade ao cuidado do cliente, pois é importante que o mesmo não se limite apenas na preservação da vida do paciente, mas também numa assistência que atenda todas suas necessidades (LARA; PENDLOSKI, 2013).

O Código de Ética de Enfermagem, no artigo 25, aborda como finalidade para o profissional da enfermagem, o respeito, a solidariedade, na diversidade de opinião e posição ideológica, ou seja, promover a saúde a partir dos preceitos éticos e legais, garantindo o direito da própria pessoa (COFEN, 2017).

Quando se trata de religião, em especifico as Testemunhas de Jeová, todos adeptos da religião concordam com a proibição da hemoterapia, mesmo quando há risco de morte. Para as testemunhas, a transfusão de sangue não é um tema apenas religioso, mas também uma questão de saúde. Atualmente, são várias as pesquisas científicas que relatam os inúmeros riscos por trás das transfusões (LARA; PENDLOSKI, 2013).

Cabe ao profissional de saúde conhecer seus amparos legais, para realização da hemotransfusão, assim como ter respeito e ser ético nas tomadas de decisões para realização do procedimento. Decidir que esta terapêutica transfusional deve ser realizada, cabe ao paciente ou ao responsável legal, quando este está impossibilitado de tomar qualquer decisão. Assim como a equipe de saúde deve esclarecer sobre a necessidade do paciente em aceitar o sangue e que a rejeição em receber o mesmo trará riscos à saúde e risco de morte ao cliente (COFEN, 2006). 


\section{HEMOTRANFUSÃO NA TERAPIA INTENSIVA}

$\mathrm{Na}$ terapia intensiva é comum a admissão de pacientes com quadro de anemia. Ela surge, podendo se agravar ao longo do tempo de internação. Assim a prática de transfusão de concentrado de hemácias $(\mathrm{CH})$ é uma terapêutica frequente em pacientes críticos, o plasma e o concentrado de plaquetas também são utilizados com frequência. Com essa terapia, espera-se um resultado satisfatório na oxigenação dos tecidos, na melhora no quadro da doença e na prevenção de uma possível disfunção orgânica (VOLPATO, et al., 2009).

Quando se associa o tempo de internação na UTI e a transfusão, quanto maior o tempo em uma unidade de terapia intensiva, maior é a incidência de uma hemotransfusão. Entre os critérios para indicar uma hemoterapia, ainda é variável, podendo ser influenciada por diversos fatores, no entanto, observou-se que a maior variabilidade na indicação clínica ocorre em pacientes em terapia intensiva (VOLPATO, et al., 2009).

A qualidade e a segurança do paciente na hemotransfusão necessitam da integração de recursos humanos e alguns aspectos importantes, tais como a conferência dos sinais vitais, antes, durante e após a transfusão sanguínea, a checagem na administração, conferência da bolsa de sangue e monitoramento na ocorrência de reações adversas. O acompanhamento e registro dos sinais vitais é um indicativo importante para equipe multiprofissional, pois é critério de avaliação para garantir a segurança dos pacientes transfundidos (GURGEL, et al., 2019).

\section{TRANSFUSÃO SANGUÍNEA E A ENFERMAGEM}

Atualmente a resolução COFEN 306/2006, fixa as atribuições e as competências dos profissionais de enfermagem na hemoterapia, na qual participa da equipe multiprofissional, em que garanta de forma integral a assistência desde o doador, receptor e familiar. As suas competências, são: planejar, executar, coordenar, supervisionar e avaliar o procedimento hemoterápico, assistir de maneira integral os receptores da hemotransfusão, de forma que o profissional só poderá exercer seu papel na hemoterapia se for devidamente capacitado a exercer ações especificas, como o manuseio do sangue e a hemotransfusão, pelo fato da complexidade e riscos durante a hemotransfusão.

As instituições que realizam transfusão de sangue devem seguir as seguintes normas, nos prontuários dos pacientes devem constar os registros relacionados à transfusão, como a data, hora em que iniciou a hemotransfusão e término, sinais vitais no início e no término (temperatura, frequência respiratória, pressão arterial e pulso), origem e identificação das bolsas dos hemocomponentes, identificação do profissional responsável e registro de reação transfusional. Deve haver o acompanhamento nos primeiros dez minutos da transfusão pelo profissional de saúde qualificado, e o monitoramento dos pacientes durante o ato transfusional (BRASIL, 2014). 
O enfermeiro com competência na hemoterapia deve ter conhecimento dos tópicos e conteúdos para acompanhar um paciente submetido à transfusão de sangue. São eles (MATTIA; ANDRADE, 2016):

1. Identificação do paciente: Identificar o nome completo do paciente, nome da genitora, idade, data de nascimento, leito, unidade de internação, tipo sanguíneo, dados transfusionais: transfusão prévia, reação transfusional, informar se necessita de preparo para a transfusão, resultado da pesquisa de anticorpos irregulares, identificação de anticorpos irregulares, fenotipagem eritrocitária, quando realizada, teste de compatibilidade, resultado de exames laboratoriais.

2. Pré-Transfusão: Número da bolsa de hemocomponente que será utilizado, tipo de hemocomponente, verificação da dupla checagem, sinais vitais, registrar data e hora de início da transfusão, via de acesso que ocorrerá a administração, local do acesso, dispositivo utilizado (único, compartilhado), orientação do paciente ou responsável sobre o procedimento e campo para observações.

3. Transfusão: Monitorização dos sinais vitais.

4. Pós-Transfusão: Continuar a monitorização dos sinais vitais, anotar hora de término da transfusão, remoção do acesso, campo para observações.

5. Observações complementares: observar a quantidade de hemocomponentes, reações transfucionais: realizar orientações e recomendações transfusionais.

Portanto a assistência de enfermagem de qualidade somente poderá ser alcançada com um padrão ótimo de assistência e cuidado, se o enfermeiro desenvolver sua função em cada etapa da transfusão exercendo um papel fundamental na segurança transfusional. Pois, além de administrar as transfusões, devem ter o conhecimento das suas indicações, providenciar a checagem de dados importantes na prevenção de erros, realizar a orientação aos pacientes sobre a transfusão, detectar, comunicar e atuar no atendimento das reações transfusionais e documentar todo o processo (FERREIRA, et al., 2007; MATTIA; ANDRADE, 2016).

\section{CONSIDERAÇÕES FINAIS}

A assistência prestada pelo enfermeiro aos pacientes em terapia intensiva no período pré, trans e pós-transfusional é de extrema relevância para evitar a ocorrência de iatrogenias e reações adversas, de modo que esta prática seja manejada com qualidade e sem intercorrências. A realização de boas práticas de cuidados, é essencial para a tomada de decisões do enfermeiro, uma vez que este planeja e organiza as ações que serão realizadas ao paciente que está em uma terapia intensiva e será submetido a uma transfusão sanguínea, e que necessita de avaliações constantes. 
Tendo em vista poucos profissionais da enfermagem atuando na hemotransfusão e com dificuldades em realizar procedimentos durante este processo, é importante que haja investimento em capacitação permanente e atualização constante destes profissionais. A prática hemoterápica é multiprofissional, tendo a necessidade cada vez mais de profissionais qualificados, capacitados e responsáveis, logo, a inserção do profissional enfermeiro, é salutar para contribuir positivamente neste processo e assegurar a qualidade e segurança do paciente nas etapas da hemotransfusão.

\section{REFERÊNCIAS}

AGUIAR, G. L. N.; BARRETO, J. H. P. M.; MORAIS, L. R.; SILVA FILHO, L. R. Estudo da segmentação arterial do baço. Revista do Colégio Brasileiro de Cirurgiões. Rio de janeiro, v. 35, n. 5, p. 311-314, 2008.

AMARAL, F. S. Enfermeiro e a prática da hemoterapia: Jogos como estratégia de ensino. 2015. f. 76. Dissertação (Mestrado Profissional em Ensino de Ciências da Saúde e do Meio Ambiente) - Fundação Oswaldo Aranha Centro universitário de Volta Redonda. Volta Redonda, 2015.

BRASIL. Resolução RDC n ${ }^{\circ}$ 34, de 11 de junho de 2014. Dispõe sobre as boas praticas no ciclo do sangue. Órgão emissor: ANVISA- Agencia nacional de Vigilância Sanitária.

BRASIL, Ministério da Saúde. Marco conceitual e operacional de hemovigilância: Guia para Hemovigilância no Brasil. Agência Nacional de Vigilância Sanitária. Brasília, 2015.

CALlERA, F.; SILVA, A. C. O.; MOURA, A. F.; MELO, D. B.; MELO C. M. T. P. Descriptions of acute transfusion reactions in a Brazilian Transfusion Service. Revista Brasileira de Hematologia e Hemoterapia. v. 26, n. 2, p. $78-83.2004$.

CASTRO, H. C.; FERREIRA, B. L. A.; NAGASHIMA, T.; SCHUELER, A.; RUEFF, C.; CAMISASCA, D.; MOREIRA, G.; SCOVINO, G.; BORGES, L.; LEAL, M.; FILGUEIRA, M.; PASCHOAL, P.; BERNANRDO, M.; BOURGHUINHO, S.; RODRIGUES, C. R.; SANTOS, D. O. Plaquetas: ainda um alvo terapêutico. J. Bras. Patol. Med. Lab. Rio de Janeiro, v. 42, n. 5, p. 321-332. Out., 2006.

CONSELHO FEDERAL DE ENFERMAGEM. Resolução COFEN n. 306, de 25 de abril de 2006. Dispõe sobre as competências e atribuições do Enfermeiro na área de Hemoterapia. Diário Oficial da União, Brasília (DF); 2006 Abr 25.

CONSELHO FEDERAL DE ENFERMAGEM. Resolução COFEN n. 564, de 6 de dezembro de 2017. Dispõe sobre código de ética dos profissionais de enfermagem. Diário Oficial da União, Brasília (DF); 2017 Dez 6.

COSTA FILHO, R. C.; GUTIERREZ, F.; FERNANDES, H.; MENDES, C.; LOBO, S. Transfusão de hemácias em terapia intensiva: controvérsias entre evidências. Revista Brasileira de Terapia Intensiva, v. 21, $\mathrm{n}$. 3, p. 315-23, 2009.

CHAMMAS, M. C.; LUNDBERG, J. S.; JULIANO, A. G.; SAITO, O. C.; MARCELINO, A. S. Z.; CERRI, G. G. Linfonodos cervicais: um dilema para o ultra-sonografista. Revista Radiologia Brasileira. v. 37, n. 5, p. 357-364, 2004.

CHEREM, E. O.; ALVES, V. H.; RODRIGUES, D. P.; PIMENTA, P. C. O.; SOUZA, F. D. L.; GUERRA, J. V. V. Processo de terapia transfusional em unidade de terapia intensiva neonatal: o conhecimento do enfermeiro. Texto \& Contexto Enfermagem. v. 27, n. 1, 2018.

FAUSTO, C. S. C. V. CHAMMAS, M. C.; SAITO, O. C.; GARCIA, M. R. T.; JULIANO, A. G. SIMÕES, C. A.; CERRI, G. G. Timo: caracterização ultra-sonográfica. Revista Radiologia Brasileira. v. 37, n. 3,p. 207210, 2004. 
FERREIRA, O.; MARTINEZ, E. Z.; MOTA, C. A.; SILVA, A. M. Avaliação do conhecimento sobre hemoterapia e segurança transfusional de profissionais de enfermagem. Revista Brasileira de Hematologia e Hemoterapia. v. 29, n. 2, p. 160-167, 2007.

GURGEL, A. P.; MELO, V. S.; LEITÃO, J. S.; STUDART, R. M. B.; BONFIM, I. M.; BARBOSA, I. V. Paciente crítico: segurança em terapia Transfusional mediante lista de verificações. Revista Brasileira de Ciências de Saúde. v. 23, n. 4, p. 525-534, 2019.

JUNQUEIRA, P.C.; ROSENBLIT, J.; HAMERSCHLAK, N. História da hemoterapia no Brasil. Revista Brasileira de Hematologia e Hemoterapia. v. 27, n. 3, p. 201-207, 2005.

LARA, G. F.; PENDLOSKI, J. Os enfermeiros diante do dilema ético: Transfusão de Sangue em Testemunhas de Jeová. Paraná. Revista Uningá Review, v. 16, n. 1, p.70-77, 2013.

MATTIA, D.; ANDRADE, S. R. Cuidados de enfermagem na transfusão de sangue: um instrumento para monitorização do paciente. Florianópolis. Texto \& Contexto Enfermagem, v. 25, n. 2, jun. 2016.

MESCHER. A. L. Junqueira's Basic Histology Texte e Atlas. 13 ed. Bloomington: McGraw Hill, 2013.

MEZA, B. P.; LOHRKE, B.; WILKINSON, R.; PITMAN, J. P.; SHIRAISHI, R. W.; BOCK, N.; LOWRANCE, D. W.; KUEHNERT, M. J.; MATARANYIKA, M.; BASAVARAJU, S. V. Estimation of the prevalence and rate of acute transfusion reactions occurring in Windhoek. Namibia. Blood Transfus 2013.

NETTO, A. U.; BARROS, L. G.; ELOY, Y. L. Hematologia. MED resumos, 2011.

OLIVEIRA, E. G. R. Epidemiologia das Reações Transfusionais Imediatas no Hospital Amaral Carvalho de Jaú. Faculdade de Medicina de Botucatu. São Paulo, 2012.

OLIVEIRA, I.; GIRÃO, M. J. B. C.; SAMPAIO, M. U.; OLIVA, M. L. V.; ANDRADE, S. S. Plaquetas: Papéis tradicionais e não tradicionais na hemostasia, na inflamação e no câncer. ABCS Health Sciences. São Paulo, v. 38, n. 3, p. 153-161, 2013.

OLIVEIRA, J. R.; XAVIER, R. M. F.; SANTOS JUNIOR, A. F. Eventos adversos notificados ao Sistema Nacional de Notificações para a Vigilância Sanitária (NOTIVISA): Brasil, estudo descritivo no período 2006 a 2011. Epidemiol. Serv. Saúde, Brasília, v. 22, n. 4, p. 671-678, out-dez 2013.

OLIVEIRA, L. P. Tecido sanguíneo e hematopoiético. LAAN. 2015.

RENA, C. L.; VADIGAL, F. M.; BARRA, A. A.; SCHEIB, E. J. S.; TOLÊDO, L. O.; DORNELAS, M. C.; RENA, R. L. Estudo revisional sobre a morfologia e as funções dos leucócitos. Revista Medica Oficial do Hospital Universitário da Universidade Federal de Juiz de Fora. Juiz de Fora, v. 27, n. 1, p. 337-334, jan./ dez. 2001.

RODRIGUES. C. F. S. Anatomia aplicada do sistema linfático. 5 ed. Rio de Janeiro: Angiologia e cirurgia vascular: guia ilustrado, 2003.

SOUZA, M. H. L.; ELIAS, D. O. Fundamentos da circulação extracorpórea. 2 ed. Rio de Janeiro: Centro Editorial Alfa Rio, 2006.

SOUZA, G. F. Instrumento de boas práticas de enfermagem em hemoterapia na unidade de terapia intensiva: Uma Construção Coletiva. Universidade Federal de Santa Catarina. Florianópolis, 2012.

TAVARES, J. L.; BARICHELLO, E.; MATTIA, A. L.; BARBOSA, M. H. Fatores associados ao conhecimento da equipe de enfermagem de um hospital de ensino sobre hemotransfusão. Rev. Latino-Am. Enfermagem. Minas Gerais, v. 23, n.4, p. 595-602, jul-agos 2015.

VOLPATO, S. E.; FERREIRA, J. S.; FERREIRA, V. L. P. C.; FERREIRA, D. C. Transfusão de concentrado de hemácias na unidade de terapia intensiva. São Paulo. Revista Brasileira de Terapia Intensiva. v. 21, n. 4, 2009. 


\section{DIAGNÓSTICO SITUACIONAL DA FARMÁCIA BÁSICA E ESPECIALIZADA DE UM CENTRO DE SAÚDE ESCOLA EM BELÉM DO PARÁ}

STEPHANY SIQUEIRA BRAGA Universidade do Estado do Pará (UEPA)

\section{IVANETE MIRANDA CASTRO DE} OLIVEIRA

Universidade do Estado do Pará (UEPA)

MATTHEUS LUCAS NEVES DE

CARVALHO

Universidade do Estado do Pará (UEPA)

BIANCA LEÃO PIMENTEL

Universidade do Estado do Pará (UEPA)

THALIA BARARUÁ MACHADO

Universidade do Estado do Pará (UEPA)

SANDRA MARIA FERREIRA DE ALENCAR

Universidade do Estado do Pará (UEPA)

LISIANY CARNEIRO DE SANTANA MOREIRA

Universidade Federal do Pará (UFPA)

KELLY ADRIANI DOS SANTOS BAETA

Centro Universitário do Estado do Pará (CESUPA)

RESUMO: A estruturação da Assistência Farmacêutica tem sido grande tema de discussão, principalmente no seu processo de gerenciamento, seja por questões de recursos financeiros ou pela necessidade de estratégias gerenciais, com vistas ao seu aperfeiçoamento, de modo que haja interação entre os serviços e a população, além da aquisição de medicamentos para a distribuição, fomentando o acesso, o uso racional dos medicamentos, e sobretudo, a inserção efetiva da assis- tência farmacêutica como ação de saúde e parte integrante do sistema de saúde. Com foco na assistência farmacêutica, o presente trabalho consiste na elaboração de Diagnóstico Situacional da Farmácia Básica e Especializada do Centro Escola de Saúde do Marco, como proposta de atividade prática do Componente Curricular: Gestão e Gerenciamento dos Serviços de Saúde. Trata-se de um estudo descritivo com abordagem qualitativa do tipo relato de experiência, sobre a elaboração do Diagnóstico Situacional dos serviços: Farmácia Básica e Farmácia Especializada de um Centro de Saúde Escola localizado em Belém/ PA. Ao analisar a organização e o funcionamento da farmácia básica e da farmácia especializada, à luz do referencial teórico, foram identificados alguns problemas de carácter gerencial, tais como: falta e vencimento de medicamentos, profissionais que desconhecem o fluxo do seu processo de trabalho, bem como pacientes sem medicamentos devido o preenchimento incorreto da ficha de solicitação. Com o estudo, foi possível compreender que as questões gerenciais são os meios necessários para a qualidade da assistência à saúde, quando há falhas no processo de gerenciamento nos serviços de saúde, consequentemente haverá problemas na assistência ao usuário, que saíra da unidade insatisfeito e com pouca ou até mesmo sem resolutividade nas demandas por ele apresentadas.

PALAVRA-CHAVE: Gestão em Saúde; Assistência Farmacêutica; Diagnóstico Situacional.

ABSTRACT: The structuring of Pharmaceutical Assistance has been a major topic of discussion, especially in its management process, whether due to financial resources or the needs of management strategies, with a view to its improvement, so that there is interaction between services and 
the population, in addition to the purchase of medicines for distribution, promotion or access, rational use of medicines and, above all, an effective insertion of pharmaceutical assistance as a health action and an integral part of the health system. With a focus on pharmaceutical assistance, the present work consists of the elaboration of a diagnosis of the Basic and Specialized Pharmacy of the Health Center of the Marco School, as a practical activity proposal of the Curricular Component: Management and Management of Health Services. This is a study descriptive with qualitative approach, type of experience report, on the preparation of the Situational diagnosis of the services: Basic Pharmacy and Specialized Pharmacy of the Centro de Saúde Escola located in Belém / PA. When analyzing the organization and functioning of the basic pharmacy and specialized pharmacy, in light of the theoretical framework, some managerial problems were used, such as: lack and expiration of medications, professionals who are unaware or the flow of the work process, as well as patients without medication due or incorrectly filled out with the request form. With the study, it was possible to understand that managerial issues are the necessary means for the quality of health care, when there are failures in the health service management process, consequently, there are still problems in care for the user, who leave unsatisfied units and with little or even no resolution in the demands caused by it.

KEYWORDS: Health Management; Pharmaceutical care; Situational Diagnosis.

\section{INTRODUÇÃO}

A Assistência Farmacêutica (AF) como política pública de saúde no Brasil se iniciou na década de 70, com a implantação da Central de Medicamentos, a qual viabilizava o fornecimento de medicamentos à população mais carente, sem condições financeiras para adquiri-los (BERMUDEZ, et al., 2018). Com a institucionalização do Sistema Único de Saúde (SUS) na carta constitucional de 1988 e com a Lei Orgânica da Saúde (nº 8080/90), foi estabelecido a saúde como direito de todos e dever do Estado e, inclusive, atribuiu ao setor saúde a competência em realizar ações de assistência farmacêutica, respectivamente. Dessa forma a $\mathrm{AF}$, está presente em todos os níveis de atenção à saúde (BRASIL, 1988; BRASIL, 1990).

A estruturação da AF tem sido grande tema de discussão, principalmente no seu processo de gerenciamento, seja por questões de recursos financeiros ou pela necessidade de estratégias gerenciais, com vistas ao seu aperfeiçoamento, de modo que haja interação entre os serviços e a população, além da aquisição de medicamentos para a distribuição, fomentando o acesso, o uso racional dos medicamentos, e sobretudo, a inserção efetiva da assistência farmacêutica como ação de saúde e parte integrante do sistema de saúde (BERMUDEZ, et al., 2018).

Como arcabouço político para estruturar a AF, destacam-se a Política Nacional de Medicamentos (PNM) e a Política Nacional de Assistência Farmacêutica (PNAF). A PNM, tem como objetivo garantir a segurança, eficácia e qualidade dos medicamentos, o uso racional destes e o acesso da população aos medicamentos considerados essenciais e dispostos na Relação Nacional de Medicamentos Essenciais (Rename). A PNAF é definida como um conjunto de ações relacionadas com o medicamento, com intuito de apoiar assistência à saúde demandada pela população. Assim, verifica-se que ambas não podem ser desvinculadas (BRASIL, 2002).

Para consolidação da assistência farmacêutica, é necessário um gerenciamento efetivo, quando ausente, poderá acarretar grandes desperdícios, principalmente financeiro, considerando que o 
mesmo é advindo de recurso público. A qualidade no gerenciamento da AF, parte do planejamento, organização, da estruturação das ações desenvolvidas, execução e controle, vislumbrando alcançar bons resultados utilizando eficientemente os recursos (GERLACK, 2017).

Diante do exposto, o Diagnóstico Situacional, mostra-se como um instrumento de grande valia no processo de gerenciamento, principalmente na etapa de planejamento, uma vez que proporciona a investigação dos problemas de uma determinada realidade, para posteriormente planejar e programar ações relacionadas as problemáticas encontradas (BAULI; MATSUDA, 2009).

Com foco na assistência farmacêutica, o presente trabalho consiste na elaboração de Diagnóstico Situacional da Farmácia Básica e Especializada do Centro Escola de Saúde do Marco, como proposta de atividade prática do Componente Curricular: Gestão e Gerenciamento dos Serviços de Saúde.

\section{METODOLOGIA}

Trata-se de um estudo descritivo com abordagem qualitativa do tipo relato de experiência, sobre a elaboração do Diagnóstico Situacional dos serviços: Farmácia Básica e Farmácia Especializada de um Centro Escola localizado em Belém/PA. O diagnóstico situacional realizado, tem como objetivo gerar subsídios para a construção de ações de reestruturação do setor para que o mesmo alcance os padrões de qualidade estabelecidos e para a melhoria do processo de trabalho nestes setores.

O estudo foi realizado por acadêmicos pertencentes ao $8^{\circ}$ semestre, do Curso de Graduação em Enfermagem da Universidade Estadual do Pará (UEPA), durante as aulas práticas do componente curricular Gestão e Gerenciamento, no mês de maio de 2019.

O desenvolvimento deste estudo se deu a partir de uma reunião no dia 22 de maio de 2019 , onde foram levantados e estabelecidos os pontos chaves sobre as problemáticas encontradas no serviço. Para o prosseguimento do estudo, houve uma conversa com os responsáveis pelo setor da farmácia básica e farmácia especializada nos dias 17, 21 e 23 de maio.

Durante estes dias pôde-se identificar alguns nós críticos relacionado ao serviço, quais as causas dessas problemáticas, os efeitos destes problemas para o usuário do serviço e quais as possíveis medidas de solução. Esses tópicos foram tabulados e discutidos conforme o que propõe o processo para a construção do Diagnóstico Situacional.

\section{RESULTADOS E DISCUSSÃO}

Ao analisar a organização e o funcionamento da farmácia básica e da farmácia especializada, à luz do referencial teórico, foram identificados alguns problemas de carácter gerencial de acordo com as tabelas (Tabela 1 e Tabela 2). 
TABELA 1 - Diagnóstico situacional da farmácia básica

\begin{tabular}{|c|l|}
\hline PROBLEMAS & $\begin{array}{l}\text { a) Medicamentos vencidos; b) Medicamentos entregues (pelos fornecedores) próximo } \\
\text { ao prazo de validade; c) Falta de Medicamentos; d) A farmacêutica da unidade desco- } \\
\text { nhece o fluxo de processos de trabalho; e) Sistema de informação manual. }\end{array}$ \\
\hline CAUSAS & $\begin{array}{l}\text { a) Falta de planejamento; b) Falta de controle do almoxarifado no momento do rece- } \\
\text { bimento dos medicamentos e falta de supervisão, falta de treinamento para os funcio- } \\
\text { nários; c) A farmácia atende as pessoas provenientes de outras unidades, demora no } \\
\text { processo de licitação e planejamento não eficiente; d) Falta de interação com os demais } \\
\text { serviços e a gerência, falta de capacitação (educação permanente) e falta de comunica- } \\
\text { ção; e) O não funcionamento do sistema de informação }\end{array}$ \\
\hline EFEITOS & $\begin{array}{l}\text { a) Prejuízo para o paciente e desperdício de recursos públicos; b) Usuário fica sem o } \\
\text { tratamento adequado, desperdício de recursos públicos e agravo nas condições dos } \\
\text { pacientes; c) Usuário fica sem assistência farmacêutica; d) Retardo no processo de } \\
\text { aquisição de medicamentos; e) Deficiência na assistência farmacêutica aos pacientes. }\end{array}$ \\
\hline SOLUÇÕES & $\begin{array}{l}\text { a) Estabelecer um planejamento adequado para a aquisição dos medicamentos } \\
\text { e estudo da demanda de pacientes; b) Estabelecer um processo efetivo de supervisão } \\
\text { no almoxarifado e estabelecer um controle efetivo e rigoroso no recebimento das me- } \\
\text { dicações; c) Reserva técnica para suprir as necessidades dos clientes de outros bairros e } \\
\text { realizar estudo relacionado a demanda recebida pela unidade; d) Estabelecer interação } \\
\text { do profissional com o serviço e realizar um cronograma de capacitação dos profissio- } \\
\text { nais; e) Instalar um sistema de informações e capacitar os funcionários para a utiliza- } \\
\text { ção do sistema de informação }\end{array}$ \\
\hline
\end{tabular}

TABELA 2 - Diagnóstico situacional da farmácia especializada

\begin{tabular}{|c|l|}
\hline PROBLEMAS & $\begin{array}{l}\text { a) Medicamentos em não conformidade; b) Pacientes sem medicamentos devido o } \\
\text { preenchimento incorreto da ficha de solicitação; c) Acondicionamento inadequado } \\
\text { dos medicamentos; d) Farmacêutico desconhece o fluxo de trabalho da farmácia. }\end{array}$ \\
\hline CAUSAS & $\begin{array}{l}\text { a) Falta de supervisão na farmácia e falta de conferência no recebimento dos medica- } \\
\text { mentos; b) Falta de sensibilização dos profissionais que realizam a solicitação e falta } \\
\text { de comunicação entre a farmácia especializada e os profissionais que preenchem a } \\
\text { solicitação; c) Indisponibilidade de uma câmara fria; d) Falta de capacitação. }\end{array}$ \\
\hline EFEITOS & $\begin{array}{l}\text { a) Prejuízo para o paciente e agravamento dos casos do paciente; b) Agravamento da } \\
\text { situação do paciente, geração de estresse para o paciente e prejuízos sociais; c) Desper- } \\
\text { dício de verbas, perda dos princípios ativos dos medicamentos, prejuízo no tratamento; } \\
\text { d) Prejuízo no repasse de informações e na operacionalização do trabalho. }\end{array}$ \\
\hline SOLUÇÕES & $\begin{array}{l}\text { a) Maior controle na hora do recebimento dos materiais; b) Trabalho de sensibilização } \\
\text { com os profissionais que realizam as solicitações e estabelecer uma comunicação efeti- } \\
\text { va entre os profissionais da farmácia com os profissionais solicitantes; c) Aquisição de } \\
\text { uma câmara fria; d) Estabelecer um programa de capacitação dos profissionais. }\end{array}$ \\
\hline
\end{tabular}

O planejamento estratégico é uma técnica administrativa que, por meio da avaliação do ambiente de uma organização, identifica as oportunidades e ameaças buscando elencar os pontos fortes 
e fracos para o cumprimento da missão estabelecida. Desta forma consegue-se aproveitar melhor as oportunidades e reduzir os riscos. Sendo assim, a realização de um diagnóstico situacional capaz de identificar os pontos fortes e fracos pode garantir uma assistência farmacêutica de qualidade, entendendo o planejamento estratégico como uma ferramenta importante para a gestão da saúde. O enfrentamento de nós críticos, aliado às ambiências interna e externa favoráveis, culminam em resultados positivos aos usuários do serviço (BAULI; MATSUDA, 2009).

O Planejamento e o controle da produção podem ser utilizados para a análise da gestão da produção e, em específico, para a previsão da demanda. É o elo principal entre a disponibilidade de estoques e a redução de custos. Aplicar as ferramentas de gestão da demanda em uma farmácia, tem grande importância, não apenas pelo impacto financeiro que a organização pode obter, como também pela redução dos riscos de perdas de fármacos de uso contínuo por pacientes devido ao vencimento de sua validade ou por conta de aquisição em excesso (ABREU; MACHADO, 2016).

No ato do recebimento de medicamentos, cada entrada deve ser examinada quanto a sua documentação e fisicamente inspecionada para se verificar suas condições, rotulagem, tipo e quantidade. Se for o caso de recebimento de um produto com mais de um lote de fabricação, ele deve ser subdividido em quantos lotes forem necessários e estocados dessa forma. Os lotes que forem submetidos a amostragem ou os julgados passíveis de análise, devem ser conservados em quarentena até decisão do Controle de Qualidade (NETO, 2005).

Gestão da Assistência Farmacêutica deve estar estreitamente vinculada às ofertas de serviços e à cobertura assistencial dos programas de saúde, no Centro do Marco não há um controle efetivo no recebimento dos medicamentos ocasionando desperdício dos recursos públicos com medicações recebidas na unidade de saúde próximo ao vencimento do prazo de validade. O monitoramento e a avaliação dos processos são fundamentais para aprimorar a gestão e intervir nos problemas. (COELHO; PINHEIRO; MARGARINOS-TORRES,2014).

A falta de um programa de capacitação de profissionais com relação aos instrumentos organizacionais do serviço, tais como, o fluxograma do processo de trabalho das ações de assistência farmacêutica possibilita falhas no desenvolvimento do trabalho e consequentemente fragiliza a assistência ao usuário (BRASIL, 2010).

O estoque de Segurança é a quantidade de cada item que deve ser mantida como reserva para garantir a continuidade do atendimento em caso de ocorrência não prevista como: elevação brusca no consumo e atraso no suprimento. O estoque de segurança evita ruptura do atendimento. Sendo assim, este estoque visa garantir que haja medicamentos na farmácia básica, mesmo com a alta procura de fármacos pela população. Logo, o desafio do gestor de estoque é saber quando e quanto ressuprir de cada material e quanto devem manter em estoque de segurança (BRASIL, 2002).

Alguns medicamentos, para manterem suas efetividades de uso, requerem condições ótimas de estocagem, especialmente no que se refere a temperatura. Os medicamentos termolábeis necessitam de estocagem sob rigoroso controle de temperatura e, a Câmara fria para medicamentos é o equipamento apropriado para esta feita, inclusive constam recomendações expressas do seu uso, seja no Manual de Rede de Frio da Funasa, bem como Manual de Boas Práticas para Estocagem de Me- 
dicamentos do Ministério da Saúde. Por conta da sensibilidade aos fatores ambientais, o armazenamento dos fármacos termolábis requer uma Câmara fria para medicamentos extremamente confiável, dotada de um equipamento de frio competente, inclusive os acessórios especializados para asseverar o correto armazenamento. Tal resolução se aplica locais que realizam as atividades de distribuição, armazenagem ou transporte de medicamentos (ÁLVARES, et al., 2017; BRASIL, 2001).

Linhas de pesquisas apontam que a complexidade da prática farmacêutica, em relação ao que o serviço de dispensação pode oferecer, especificamente no que diz respeito à provisão de serviços orientados aos usuários, pode estar limitada pelas condições de trabalho, como tempo, infraestrutura e a gestão dos serviços, provocando erros de dispensação importantes e impactantes para a saúde dos usuários. Logo, a dispensação deve considerar o acesso como um atributo; o acolhimento, vínculo e responsabilização, a gestão, o planejamento e a clínica farmacêutica como seus componentes; e o uso racional de medicamentos como um propósito. Sendo assim, tal abordagem pressupõe a integração das ações de gestão e clínica, a integração multiprofissional do serviço com o sistema de saúde, e a responsabilização pelo acesso do usuário como atributo inerente à dispensação do medicamento (LEITE et al., 2017).

A informação é fundamental para o processo de democratização da Saúde e o aprimoramento de sua gestão. Apoiar os estados, municípios e o distrito federal na informatização das atividades do Sistema Único de Saúde (SUS) é essencial para a descentralização das atividades de saúde e viabilização do controle social sobre a utilização dos recursos disponíveis. Neste cenário destaca-se a importância dos sistemas informatizados no apoio às decisões que possibilitam transformar dados primários em fatos e formas significativas, gerando informações executivas e inteligentes. Este estudo demostra que a informatização pode gerar uma maior agilidade no controle da solicitação, recebimento, armazenamento, estoque e dispensação de medicamentos, minimizando assim possíveis falhas neste processo (ABREU; MACHADO, 2016).

Realizar cronograma de capacitação profissional é uma ferramenta utilizada com intuito de promover novos conhecimentos, novas habilidades e treinar no sentido mais profundo ensinando a pensar, a criar, e aprender. Treinar é promover mudanças para que esses profissionais adquiram conhecimentos e habilidades para desempenharem seus cargos dentro das organizações (CHIAVENATO,2014).

Capacitar os funcionários para utilização do sistema de informação tem como objetivo a importância da qualificação profissional, nos programas informatizados que facilite com que esse profissional possa melhorar as habilidades e destrezas para a execução e a operação de tarefas, manejar equipamentos, maquinas e ferramentas. Proporcionando um ponto de vista para interpretação de eventos ou fenômenos, tendo visibilidade e significados antes invisíveis. Visto que a informação é um meio necessário para extrair e construir conhecimentos (DUTRA, 2009).

O processo de capacitação profissional é importante para que o funcionário aperfeiçoe suas habilidades básicas, específicas e de gestão. E, torne-se desta forma compreendedor do seu processo de trabalho, para, desta maneira melhorar aspectos como apresentação pessoal, comunicação, relacionamentos interpessoais, e sua capacidade de se auto gerir, participa das tomadas de decisões junto a 
gestão do serviço, bem como aprimorar o seu processo de desenvolvimento no trabalho (MOURÃO, 2009).

Outra ferramenta essencial no ambiente de trabalho é a comunicação efetiva principal responsável por transmitir mensagens claras, com o objetivo de aprimorar a rotina de trabalho, desta forma, proporcionando o compartilhamento de idéias, soluções e estratégias com clareza e de forma objetiva. A comunicação incorporada no processo de trabalho representa a organização do serviço, uma boa comunicação entre os serviços evita que informações sejam repassadas de forma inadequada ao usuário, ou seja, é dever do emissor assegurar que sua mensagem será compreendida de forma clara e objetiva pelo receptor, para que haja fluidez no serviço (NOGUEIRA; RODRIGUES, 2015).

O profissional precisa estar a par de suas atribuições para assistir o usuário de forma integral, sendo necessário que seja preenchido corretamente as solicitações, exames, laudos, receitas, atentando para os dados corretos, afim de evitar prejuízos para o usuário, bem como o agravamento do seu estado clínico. Nesse sentido, sensibilizar os profissionais da importância do preenchimento adequado de documentos deve ser uma tarefa rotineira juntamente com a equipe multiprofissional, evitando transtornos de qualquer aspecto para o usuário (ABREU; MACHADO, 2016).

\section{CONSIDERAÇÕES FINAIS}

A gestão e o gerenciamento são a base para a organização e funcionamento dos serviços de saúde, deles são provenientes planejamentos estratégicos necessários para a qualidade e para o aperfeiçoamento da assistência. Diante de um diagnóstico situacional, é possível realizar planos de ações com intuito de minimizar os eventos indesejáveis de um determinado estabelecimento e fortalecer a estrutura organofuncional para o seu bom estado de manutenção.

Nesse estudo, foi possível realizar o diagnóstico situacional de um Centro de Saúde Escola nos setores farmacêuticos, o que culminou na compreensão de que as questões gerenciais são os meios necessários para a qualidade da assistência à saúde, quando há falhas no processo de gerenciamento nos serviços de saúde, consequentemente haverá problemas na assistência ao usuário, que saíra da unidade insatisfeito e com pouca ou até mesmo sem resolutividade nas demandas por ele apresentadas.

Os problemas elencados, evidenciam uma realidade de muitos serviços de saúde no país, que apesar de demandarem de soluções simples, são fundamentais para subsidiar uma assistência efetiva, eficiente e fidedigna as necessidades do usuário.

Dessa forma, é importante compreender a gestão e o gerenciamento como parte integrante das ações de saúde, as quais devem estruturar-se prioritariamente para atender as necessidades do usuário. Logo, se há o distanciamento da gestão dos serviços que são ofertados, falta de interação dos profissionais com a gestão e o desconhecimento dos profissionais da unidade sobre o próprio serviço que por ele são ofertados, provavelmente haverá deficiência na prestação dos serviços, bem como na assistência à saúde da população. 
Consolidar tais práticas na unidade, estabelecendo articulação entre a gestão e os profissionais com foco no usuário, é estar comprometido em ofertar serviços com qualidade, tendo em vista os princípios regidos pelo SUS, de modo que uma boa assistência é reflexo de uma boa gestão.

\section{REFERÊNCIAS}

ABREU, C. R. C.; MACHADO, F. B. Planejamento estratégico situacional na farmácia de uma UBS de um município do entorno sul do Distrito Federal. Boletim Informativo Geum, v. 7, n. 3, p. 7-15, jul./set. 2016.

ÁLVARES, J. et al. Pesquisa Nacional sobre Acesso, Utilização e Promoção do Uso Racional de Medicamentos: métodos. Revista de Saúde Pública, 2017.

AZEREDO, T. B. Política Nacional de Medicamentos no Brasil: da estrutura normativa à reflexão dos agentes sobre o processo de implementação [tese]. Rio de Janeiro: Escola Nacional de Saúde Pública Sergio Arouca; 2012.

BAULI, J. D.; MATSUDA, L. M. Diagnóstico situacional do serviço de enfermagem de hospital de ensino sob a ótica dos profissionais de nível médio. Revista de Administração em Saúde, v. 11, n. 43. Abr-Jun, 2009.

BERMUDEZ, J. A. Z. et al. Assistência Farmacêutica nos 30 anos do SUS na perspectiva da integralidade. Revista Ciência \& Saúde Coletiva, v. 23, n. 6, p. 1937-1951, 2018.

BRASIL. Constituição (1988). Constituição da República Federativa do Brasil. Brasília, DF: Senado Federal: Centro Gráfico, 1988.

BRASIL. Lei $n^{\circ}$ 8.080, de 19 de setembro de 1990. Lei Orgânica da Saúde. Dispõe sobre as condições para a promoção, proteção e recuperação da saúde, a organização e o funcionamento dos serviços correspondentes e dá outras providências. Brasília, set. 1990.

BRASIL. Ministério da Saúde. Fundação Nacional de Saúde. Manual de Rede de Frio - elaboração de Cristina Maria Vieira da Rocha et al. 3. ed. - Brasília: Ministério da Saúde: Fundação Nacional de Saúde; 2001. 80p. il.

BRASIL. Ministério da Saúde. Secretaria de Políticas de Saúde. Departamento de Atenção Básica. Gerência Técnica de Assistência Farmacêutica. Assistência Farmacêutica: instruções técnicas para a sua organização / Ministério da Saúde, Secretaria de Políticas de Saúde. Departamento de Atenção Básica. Gerência Técnica de Assistência Farmacêutica. Brasília: Ministério da Saúde, 2002.

BRASIL. CONSELHO FEDERAL DE FARMÁCIA (CFF). A assistência farmacêutica no SUS. Brasília, DF: CFF, 2010

BRASIL. Fundação Oswaldo Cruz (FIOCRUZ). Utilização de medicamentos. In: OSÓRIO-DE-CASTRO, C. G. S. et al. Assistência farmacêutica: gestão e prática para profissionais da saúde. Rio de Janeiro: Fiocruz, 2014. p. 119-134.

COELHO, H. L. L.; PINHEIRO, R. M.; MAGARINOS-TORRES, R. Promoção do Uso Racional de Medicamentos. In: OSÓRIO-DE-CASTRO, C. G. S. et al. Assistência farmacêutica: gestão e prática para profissionais da saúde. Rio de Janeiro: Fiocruz, p. 283-294, 2014.

CHIAVENATO, I. Gestão de pessoas: o novo papel dos recursos humanos nas organizações. 4. ed. São Paulo: Manole, 2014

DUTRA, J. S. Gestão de pessoas: modelo, processos, tendências e perspectiva. São Paulo: Atlas, 2009. 
GERLACK, L. F. et al. Gestão da assistência farmacêutica na atenção primária no Brasil. Revista de Saúde Pública, v. 51, n. 2, 2017.

LEITE, S. N. et al. Medicine dispensing service in primary health care of SUS. Revista de Saúde Pública, v. 51, n. 2, p.1-10, 2017.

MOURÃO, L. Oportunidades de Qualificação Profissional no Brasil: Reflexões a eflexões a partir de um Panorama Quantitativo partir de um Panorama Quantitativo. Revista de Administração Contemporânea, v. 13, n. 1, p. 136-153, 2009.

NETO, J. F. M. Farmácia hospitalar e suas interfaces com a saúde. 1. ed. São Paulo: Rx Editora e Publicidade Ltda, 2005. 237 p. ISBN 85-88682-04-4.

NOGUEIRA, J. W. S.; RODRIGUES, M. C. S. Comunicação efetiva no trabalho em equipe em saúde: desafio para a segurança do paciente. Revista Cogitare Enfermagem, v. 20, n. 3, p. 636-640, 2015. 


\section{RELEVÂNCIA CLINICA DA UTILIZAÇÃO DE EXTRATOS DE UNCARIA TOMENTOSA COMO USO MEDICINAL: REVISÃO NARRATIVA}

JESSIKA MUNIRA GONÇALVES DE SOUSA

Programa de Pós-Graduação Assistência e Avaliação em Saúde (PPGAAS), Universidade Federal de Goiás (UFG).

JESSICA DA SILVA CAMPOS

Programa de Pós-Graduação Assistência e Avaliação em Saúde (PPGAAS), Universidade Federal de Goiás (UFG).

Ms. ALAN DUMONT CLEMENTE Professor oficial do Instituto Federal de Goiás.

Dra. CARLA AFONSO DA SILVA Professora Associada IV do Instituto de Patologia Tropical e Saúde Pública (IPTSP), Universidade Federal de Goiás (UFG).

RESUMO: Introdução: Uncaria tomentosa ( $U$. tomentosa) é uma planta medicinal nativa da bacia amazônica e membro da família Rubiaceae. O povo Inca já usufruía desta planta para tratar diversas doenças, devido à grande variedade de substâncias bioativas presente neste vegetal. Os metabólitos secundários de $U$. tomentosa têm despertado o interesse dos pesquisadores, instigando a novas pesquisas sobre a utilização etnofarmacológica desta planta, como possível tratamento para doenças como câncer, infecções virais e inflamações. Visando a padronização no desenvolvimento e produção de extratos, bem como na escolha das partes da planta a serem utilizadas, com ênfase no mecanismo de ação dos marcadores químicos presentes. Objetivo: levantar evidências acerca da relevância clínica quanto ao uso medicinal dos extratos de $U$. tomentosa. Materiais e Métodos: Trata-se de um estudo descritivo, com abordagem qualitativa, do tipo revisão Narrativa. A busca foi realizada em Janeiro de 2020. Resultados: A análise dos estudos revelaram que esta espécie é popularmente utilizada no tratamento de câncer, doenças infecciosas e inflamações em geral. Estudos que realizaram testes farmacológicos in vitro e in vivo confirmaram seu potencial anti-inflamatório, antioxidante, imunomodulador por vias distintas, bem como seu efeito significativo no tratamento do câncer. Observou-se que os alcalóides indólicos e oxindólicos do tipo pentacíclicos (POA) são seus principais marcadores químicos, além de ser os mais presentes nos extratos utilizados. Conclusão: Portanto, conclui-se que é de grande importância a escolha da parte da planta e da descrição do extrato de $U$. tomentosa a ser utilizado, pois isso definirá quais metabólitos estarão presentes, e com isso suas atividades farmacológicas, o que resultará em um tratamento mais eficaz. Além disto, deve-se destacar a necessidade de padronização das preparações com plantas medicinais, visando sua reprodutibilidade, o que é de extrema importância na busca por resultados mais eficazes.

PALAVRA-CHAVE: Uncaria tomentosa, Unha de Gato, Tratamento.

ABSTRACT: Introduction: Uncaria tomentosa (U. tomentosa) is a medicinal plant native to the Amazon basin and a member of the Rubiaceae family. The Inca people already used this plant to treat several diseases, due to the wide variety of bioactive substances present in this plant. The secondary metabolites of $U$. tomentosa have aroused the interest of researchers, prompting 
further research on the ethnopharmacological use of this plant, as a possible treatment for diseases such as cancer, viral infections and inflammations. Aiming to standardize the development and production of extracts, as well as the choice of parts of the plant to be used, with emphasis on the mechanism of action of the chemical markers present. Objective: to raise evidence about the clinical relevance regarding the medicinal use of $U$. tomentosa extracts. Materials and Methods: This is a descriptive study, with a qualitative approach, of the Narrative review type. The search was carried out in January 2020. Results: Analysis of studies revealed that this species is popularly used in the treatment of cancer, infectious diseases and inflammation in general. Studies that carried out pharmacological tests in vitro and in vivo confirmed its anti-inflammatory, antioxidant, immunomodulatory potential by different routes, as well as its significant effect in the treatment of cancer. It was observed that indolic and oxindolic alkaloids of the pentacyclic type (POA) are its main chemical markers, in addition to being the most present in the extracts used. Conclusion: Therefore, it is concluded that it is of great importance to choose the part of the plant and the description of the extract of U. tomentosa to be used, as this will define which metabolites will be present, and with this their pharmacological activities, which will result in more effective treatment. In addition, the need to standardize preparations with medicinal plants should be highlighted, aiming at their reproducibility, which is extremely important in the search for more effective results.

KEYWORDS: Uncaria tomentosa, Cat's Claw, Treatment.

\section{INTRODUÇÃO}

O gênero Uncaria, membro da família Rubiaceae, possui entre 50 a 60 espécies distribuídas em regiões tropicais do mundo, como Sudeste Asiático, África, América Central e do Sul (HEITZMAN et al. 2005; HONÓRIO et al. 2016). Dentre as espécies de Uncaria existem aquelas que apresentam maior potencial terapêutico, tais como U. formosana, U. sinensis, U. macrophylla, U. rhynchophylla, $U$. guianensis e $U$. tomentosa, sendo que as duas últimas são as mais estudadas e apresentam maior valor comercial agregado em todo mundo (HONÓRIO; BERTONI; PEREIRA 2016).

A planta $U$. tomentosa é conhecida popularmente como "unha-de-gato" e está distribuída em países da América Central e do Sul como Brasil, Bolívia, Colômbia, Costa Rica, Equador, Guiana, Guiana Francesa, Honduras, Nicarágua, Panamá, Peru e Venezuela. No Brasil, é nativa dos estados do Acre, Amapá, Amazonas e Pará (HONÓRIO; BERTONI; PEREIRA, 2016; HONORIO et al., 2017; AZEVEDO et al., 2018).

Possui flores amarelas, espinhos pontiagudos e pequenos, de consistência lenhosa, que lembram garras. Os espinhos são responsáveis pelo crescimento da planta, pois facilita sua aderência aos troncos e ramos de árvores, fazendo com que alcance entre 10 a $30 \mathrm{~m}$ de altura quando adulta, sendo descrita como uma trepadeira gigante (HONÓRIO; BERTONI; PEREIRA, 2016; AZEVEDO et al., 2018).

Os extratos ou preparações de U. tomentosa são obtidos a partir de folhas, cascas, caules e raiz, que podem ser utilizados inteiros, cortados, moídos ou em pó. As preparações são descritas como decocto, extrato bruto, alcoólico, hidroalcoólico, aquoso e extrato seco, a depender da forma de preparação (HONÓRIO; BERTONI; PEREIRA, 2016; NAVARRO-HOYOS et al., 2017; AZEVEDO 
et al., 2018). Algumas destas preparações são utilizadas por indígenas da Amazônia há gerações para tratar diversas doenças como câncer, artrite reumatoide e infecções virais (PEÑALOZA et al., 2015; AZEVEDO et al., 2019). Preparações essas descritas de forma diferente por cada autor de acordo com sua finalidade de utilização da planta para o tratamento de cada doença, pois o método de preparação e obtenção do extrato a ser utilizado no tratamento das doenças determinam quais os metabólitos ou conjunto de metabólitos presentes no mesmo, que por sua vez determinam quais desequilíbrios fisiológicos tratar.

Devido ao poder medicinal atribuído às plantas do gênero Uncaria, trabalhos científicos têm sido desenvolvidos com o objetivo de descobrir novos compostos bioativos para fabricação de medicamentos fitoterápicos, sendo estes estudos fundamentados em relatórios etnobotânicos sobre a utilização de suas propriedades farmacológicas (KAISER et al., 2016).

Desse modo, o objetivo do presente estudo foi levantar evidências acerca da relevância clínica quanto ao uso medicinal dos extratos de $U$. tomentosa.

\section{MATERIAIS E MÉTODOS}

Trata-se de um estudo descritivo, com abordagem qualitativa, do tipo revisão narrativa, que proporciona uma análise ampla sobre um determinado conteúdo (SOUZA et al., 2010). Este método é relevante por possibilitar a atualização sobre determinada temática e elucidar novas ideias, de acordo com o que está sendo descrito na literatura cientifica (ROTHER, 2007).

Para operacionalizar a revisão, inicialmente foi definido o objetivo do estudo e posteriormente elaborada a seguinte questão de pesquisa: Qual é a relevância clínica quanto ao uso medicinal dos extratos de Uncaria tomentosa?

A busca dessas evidências foi realizada em janeiro de 2020, na base eletrônica de dados do Pubmed. A estratégia de busca foi elaborada utilizando-se vocabulários controlados, consultados na plataforma da Medical Subject Headings (MeSH), e vocabulários não controlados, no qual foram interligados pelos operadores booleanos " $A N D$ " e "OR". Os principais termos utilizados foram Uncaria tomentosa, Unha de Gato e Tratamento.

Foram incluídos estudos que respondessem a problemática levantada, sendo excluídos teses de dissertação, cartas editoriais, livros, relatos de experiência e estudos que não correspondessem ao objetivo proposto. Não houveram restrições quanto ao idioma e ano das publicações.

Portanto, foi realizada a triagem dos estudos de acordo com os critérios de inclusão e exclusão. Posteriormente, os estudos selecionados foram analisados criteriosamente para levantar as evidências encontradas. Por fim, os dados foram sumarizados em uma planilha no Excel, categorizados e discutidos. 


\section{RESULTADOS E DISCUSSÃO}

Foram localizadas 100 estudos, que após serem submetidos ao processo de triagem, resultaram em oito referências. Estes atenderam aos critérios de inclusão do estudo e foram caracterizados no quadro abaixo (Quadro 1).

Quadro 1: Caracterização dos estudos analisados acerca da relevância clínica quanto ao uso medicinal de extratos da planta Uncaria tomentosa, segundo autores, ano, periódico, desenho do estudo, extrato e objetivo.

\begin{tabular}{|c|c|c|c|c|}
\hline $\mathbf{N}^{\circ}$ & $\begin{array}{l}\text { Autor/ } \\
\text { Ano }\end{array}$ & $\begin{array}{c}\text { Desenho do } \\
\text { Estudo }\end{array}$ & $\begin{array}{l}\text { Extração/ Local } \\
\text { da coleta }\end{array}$ & Objetivo \\
\hline 01 & $\begin{array}{l}\text { Kaiser, } \\
\text { s. et al. } \\
2016 .\end{array}$ & $\begin{array}{c}\text { Estudo Expe- } \\
\text { rimental }\end{array}$ & $\begin{array}{l}\text { Extrato Bruto da } \\
\text { casca do caule e } \\
\quad \text { folhas/ } \\
\text { Amazônia Perua- } \\
\quad \text { na. }\end{array}$ & $\begin{array}{l}\text { Avaliou a influência de três quimiotipos de "unha- } \\
\text {-de-gato" na genotoxicidade e citotoxicidade contra } \\
\text { modelos de linhagem celular humana maligna e não } \\
\text { maligna. }\end{array}$ \\
\hline 02 & $\begin{array}{l}\text { Domin- } \\
\text { gues, A.et } \\
\text { al. } 2011\end{array}$ & $\begin{array}{l}\text { Estudo E } \\
\text { riment }\end{array}$ & $\begin{array}{c}\text { Extrato hidroal- } \\
\text { coólico da casca } \\
\text { do caule/ Cruzeiro } \\
\text { do Sul, Acre, Bra- } \\
\text { sil. }\end{array}$ & $\begin{array}{l}\text { Investigou o potencial imunomodulador do extrato } \\
\text { aquoso de Uncaria tomentosa na progressão do dia- } \\
\text { betes imunomediado por vias distintas. }\end{array}$ \\
\hline 03 & $\begin{array}{l}\text { Azevedo, } \\
\text { B. C. et } \\
\text { al. } 2019\end{array}$ & $\begin{array}{r}\text { Estud } \\
\text { rim }\end{array}$ & $\begin{array}{l}\text { Extrato aquoso de } \\
\text { folhas/ Fazenda } \\
\text { São João, Pará, } \\
\text { Brasil. }\end{array}$ & $\begin{array}{l}\text { Avaliou o potencial efeito antioxidante de um extrato } \\
\text { aquoso de folhas de } U \text {. tomentosa e seus principais } \\
\text { alcalóides mitraphyilina e isomitraphylline }\end{array}$ \\
\hline 04 & $\begin{array}{l}\text { Elgaw- } \\
\text { ish et al. } \\
2018\end{array}$ & $\begin{array}{l}\text { Est } \\
\text { per }\end{array}$ & $\begin{array}{l}\text { Extrato aquoso, } \\
\text { não deixa claro as } \\
\text { partes da planta } \\
\text { que utilizou/ Bio- } \\
\text { tanica em Nova } \\
\text { Zelândia. }\end{array}$ & $\begin{array}{l}\text { Investigou o efeito da administração oral de fipronil } \\
\text { (FPN) na função hepática, peroxidação lipídica e al- } \\
\text { gumas alterações nos biomarcadores do estresse oxi- } \\
\text { dativo em ratos machos adultos, bem como explorou } \\
\text { o efeito profilático do extrato de Uncaria tomentosa } \\
\text { como antioxidante e anti-inflamatório contra lesão } \\
\text { hepática subcrônica e estresse oxidativo induzidos } \\
\text { por FPN através da expressão de NF-kB após } 6 \text { se- } \\
\text { manas de exposição. }\end{array}$ \\
\hline 05 & $\begin{array}{l}\text { Araujo, } \\
\text { L. C. C. } \\
\text { et al., } \\
2018\end{array}$ & $\begin{array}{r}\text { Estud } \\
\text { rim }\end{array}$ & $\begin{array}{l}\text { Extrato bruto, } \\
\text { não deixa claro as } \\
\text { partes da planta } \\
\text { que utilizou/ Não } \\
\text { deixa claro. }\end{array}$ & $\begin{array}{l}\text { Investigou o efeito do extrato bruto de Uncaria to- } \\
\text { mentosa sobre a doença hepática gordurosa não al- } \\
\text { coólica (DHGNA), em dois modelos de obesidade: } \\
\text { dieta hiperlipídica (DHG) e obesos geneticamente. }\end{array}$ \\
\hline 06 & $\begin{array}{l}\text { Ciani, } \\
\text { F. et al., } \\
2018\end{array}$ & $\begin{array}{r}\text { Estudo } \\
\text { rime }\end{array}$ & $\begin{array}{l}\text { Extrato aquoso } \\
\text { da casca do caule, } \\
\text { não deixa claro as } \\
\text { partes da planta } \\
\text { que utilizou/ Não } \\
\text { deixa claro. }\end{array}$ & $\begin{array}{l}\text { Analisou os efeitos biológicos do extrato aquoso de } \\
\text { U. tomentosa em queratinócitos humanos imortaliza- } \\
\text { dos e em células de carcinoma escamoso, a fim de } \\
\text { fornecer evidência molecular, apoiando seu uso tera- } \\
\text { pêutico contra esse tipo de câncer. }\end{array}$ \\
\hline 07 & $\begin{array}{l}\text { Castilhos, } \\
\text { L. G. et } \\
\text { al. } 2015\end{array}$ & $\begin{array}{c}\text { Estudo Expe- } \\
\text { rimental }\end{array}$ & $\begin{array}{l}\text { Extrato seco da } \\
\text { raiz/ Londrina, } \\
\text { Paraná, Brasil. }\end{array}$ & $\begin{array}{l}\text { Investigou os efeitos de } U \text {. tomentosa na atividade } \\
\text { das enzimas E-NTPDase e E-ADA em linfócitos de } \\
\text { ratos com artrite induzida por Adjuvante Completo } \\
\text { de Freund (CFA). }\end{array}$ \\
\hline 08 & $\begin{array}{l}\text { Santos, } \\
\text { K. F. et } \\
\text { al., } 2016\end{array}$ & $\begin{array}{l}\text { Estudo Expe- } \\
\text { rimental }\end{array}$ & $\begin{array}{llr}\text { Extrato } & \text { seco } & \text { da } \\
\text { casca } & \text { moída } & / \\
\text { Parque } & \text { planta } & \text { no } \\
\text { Peru. } & & \end{array}$ & $\begin{array}{l}\text { Avaliou o extrato hidroalcoólico de } U \text {. tomento- } \\
\text { sa quanto a sua capacidade de influenciar o sis- } \\
\text { tema purinérgico em células do câncer de mama, } \\
\text { MDAMB-231. }\end{array}$ \\
\hline
\end{tabular}


Os estudos elucidados foram analisados na integra de forma criteriosa e as evidências encontradas, foram expostas logo abaixo (quadro 2).

Quadro 2: Principais achados evidenciados nos estudos analisados acerca da relevância clínica quanto ao uso medicinal do extrato da planta Uncaria tomentosa.

\begin{tabular}{|c|l|}
\hline Autor & \multicolumn{1}{|c|}{ Evidências } \\
\hline Kaiser, S. et al. & $\begin{array}{l}\text { Os três quimiótipos de "unha-de-gato" mostraram atividade citotóxica em relação às } \\
\text { linhagens malignas. Ao contrário, não demonstrou reação citotóxica contra células da } \\
\text { linhagem não maligna (leucócitos). Conclui-se que os quimiotipos de U. tomentosa } \\
\text { apresentam seletividade diferente contra células malignas humanas, de modo que pa- } \\
\text { rece ser muito importante para a atividade antitumoral, pois influenciam a seletividade } \\
\text { citotóxica contra células malignas. }\end{array}$ \\
\hline $\begin{array}{c}\text { Domingues, A. } \\
\text { et al. }\end{array}$ & $\begin{array}{l}\text { O extrato hidroalcoólico de } \text { U. tomentosa foi capaz de impedir a evolução completa do } \\
\text { diabetes e a sua incidência; Todas as doses testadas foram capazes de diminuir níveis } \\
\text { glicêmicos; Resultados indicaram que o extrato foi eficaz para impedir a progressão do } \\
\text { diabetes imunomediado por vias distintas. }\end{array}$ \\
\hline Azevedo, B. C. & $\begin{array}{l}\text { O extrato Aquoso das folhas de U. tomentosa apresentou uma capacidade antioxidante } \\
\text { em Caenorhabditis elegans, independente do seu conteúdo de alcalóides, enquanto o } \\
\text { fator de transcrição SKN-1 é necessário para a resistência ao estress oxidativos mediado } \\
\text { por este extrato. }\end{array}$ \\
\hline $\begin{array}{c}\text { Elgawish, R. A. } \\
\text { et al., }\end{array}$ & $\begin{array}{l}\text { O extrato aquoso U. tomentosa combateu o estresse oxidativo e o dano ao fígado indu- } \\
\text { zido pelos efeitos do fipronil (FPN). }\end{array}$ \\
\hline
\end{tabular}

\begin{tabular}{|c|l|}
\hline $\begin{array}{c}\text { Araujo, L. C. C. } \\
\text { et al., }\end{array}$ & $\begin{array}{l}\text { O extrato bruto de U. tomentosa reverteu a forma grave e maligna da doença hepática } \\
\text { gordurosa (DHGNA) relacionada a obesidade para uma condição de esteatose hepática } \\
\text { benigna; Reduziu significativamente a esteatose hepática e inflamação; Melhorou ho- } \\
\text { meostase da glicose. }\end{array}$ \\
\hline Ciani, F. et al. & $\begin{array}{l}\text { O extrato aquoso da casca do caule de } U \text {. tomentosa se mostrou potencialmente eficaz } \\
\text { no tratamento de lesões cutâneas cancerígenas. }\end{array}$ \\
\hline $\begin{array}{c}\text { Castilhos, L. G. } \\
\text { et al. }\end{array}$ & $\begin{array}{l}\text { O extrato seco da raiz de } U \text {. tomentosa mostrou a possibilidade de sua utilização como } \\
\text { adjuvante no tratamento da artrite induzida; Impedindo o aumento da atividade da E-N- } \\
\text { TPDase nos linfócitos em ratos com artrite induzida. }\end{array}$ \\
\hline Santos, K. F. et al., & $\begin{array}{l}\text { O extrato hidroalcólico da casca moída de } U \text {. tomentosa demonstrou uma participação } \\
\text { significativa na regulação da progressão do câncer de mama MDA-MB-231 através da } \\
\text { via purinérgica; O tratamento com o extrato de } U \text {. tomentosa sozinho ou combinado } \\
\text { com quimioterapia favoreceu a ação da doxorrubicina; Este extrato pode ser respon- } \\
\text { sável por reduzir os níveis de adenosina no meio extracelular, o que poderia contribuir } \\
\text { para a redução da progressão do tumor. }\end{array}$ \\
\hline
\end{tabular}

No meio ambiente a planta medicinal $U$. tomentosa ocorre em três quimotipos diferentes, caracterizados na classe dos alcalóides indólicos e oxindólicos do tipo pentacíclicos (POA) ou tetracíclicos (TOA). A atividade farmacológica desta planta tem sido atribuída em maior parte ao conteúdo 
do tipo alcalóides oxindólicos pentacíclicos em vez dos tetracíclicos (SANTOS et al., 2016; KAISER et al., 2016; PEÑALOZA et al., 2015).

Atualmente há uma atenção significativa para estudos sobre utilização clínica de extratos de plantas medicinais com forte índice de resultados positivos no tratamento de doenças, com base em relatos e pesquisas de cunho etnobotânico como no tratamento de câncer, infecções virais e inflamações como artrite reumatóide e diabetes imunomediado. (CASTILHOS et al., 2015; CIANI et al., 2018; DOMINGUES et al., 2011; ELGAWISH; SOLIMAN, 2018; SANTOS et al., 2016)

Nos trabalho realizado por Kaiser et al., (2016) observou-se a relevância do uso dos diversos extratos de $U$. tomentosa na clínica e que frações purificadas de alcalóides oxindólicos do extrato bruto liofilizado, de folhas e da casca do caule de U. tomentosa, no qual demonstraram uma boa atuação contra a linhagem de células do câncer de bexiga e glioblastoma humano. Não se observou nenhuma alteração na citologia nem na genética de linhagens de leucócitos humanos, sendo assim descrito como eficaz no tratamento do câncer de bexiga e glioblastoma humano.

O mesmo relato foi observado no trabalho de Ciani et al. (2018), que analisou os efeitos do extrato aquoso da casca do caule de $U$. tomentosa sobre os queratinócitos humanos imortalizados e em células do carcinoma escamoso. Foi demonstrado uma grande eficácia do extrato no tratamento de lesões cutâneas cancerígenas. O estudo citou uma grande quantidade de sacarídeos e metabólitos de baixa massa molecular presentes neste extrato, que ainda serão posteriormente identificados, a fim de confirmar a natureza das classes dos compostos, além de identificar aqueles que são eficazes contra este tipo de câncer.

O estudo realizado por Santos et al. (2016) também avalia a utilização de um extrato de $U$. tomentosa. Este estudo avaliou a capacidade do extrato hidroalcoólico de $U$. tomentosa quanto à capacidade de influenciar o sistema purinérgico, envolvido na progressão tumoral, em células do câncer de mama MDAMB-231, por meio da atividade e expressão de ectonucleotídeos (NTPDase-CD39; ecto-5'-nucleotidase- CD73) e receptores purinérgicos P2X7 e A1. O trabalho concluiu que o extrato hidroalcoólico de $U$. tomentosa talvez contribua para evitar progressão de tumor, por inibir a atividade da enzima ecto-5' -nucleotidase, reduzindo assim a conversão de AMP em adenosina, sendo adenosina um agente proliferativo do tumor. Este extrato alterou a expressão dos receptores purinérgicos, não sendo esclarecido o mecanismo de ação sobre o receptor A1, sendo observado uma diminuição significativa do receptor P2X7 que reduz a chance de invasão tumoral e metástase. Outro resultado do tratamento com este extrato que vale ser destacado, é a inibição de CD73 que medeia a imunossupressão da atividade terapêutica da doxorrubicina in vivo, quimioterápico mais utilizado no tratamento do câncer de mama, sugerindo uma atividade sinérgica na quimioterapia com doxorribicina, contribuindo para um tratamento bem-sucedido com esse quimioterápico. Com tudo os autores concluíram que $U$. tomentosa e doxorrubicina combinadas podem ter um efeito promissor sobre o sistema purinérgico.

Castilhos et al. (2015) discorre sobre o potencial imunomodulador do extrato seco da raiz de $U$. tomentosa, identificando a mitrafilina como o alcalóide predominante neste extrato, como adjuvante no tratamento de artrite induzida por Adjuvante Completo de Freund (CFA) em linfócitos de 
roedores. Como a ação inflamatória está intimamente associada ao processo imunológico, os benefícios desta planta para o sistema imunológico, como na sinalização purinérgica presente nos linfócitos, também podem ser expressos como uma ação anti-inflamatória. De acordo com Santos et al. (2016), existe uma relação direta entre os componentes desta planta e os nucleotídeos de purina. O trabalho apoia a hipótese de que o aumento da atividade da E-NTPDase verificado em ratos artríticos pode ser uma tentativa de manter os níveis basais de ATP e ADP no meio extracelular, uma vez que a indução da artrite causa dano tecidual e, consequentemente, grande quantidades de ATP são liberados no meio. Além disso, o autor destaca a possibilidade de usar o extrato seco da raiz de U. tomentosa como adjuvante no tratamento da artrite.

Araújo et al. (2018), demonstrou em seu estudo o potencial anti-inflamatório de U. tomentosa, no qual investigou o efeito do extrato bruto da planta sobre a doença hepática gordurosa não alcoólica (DHGNA) em dois modelos de camundongos, dieta hiperlipídica e ratos geneticamente obesos. O tratamento com este extrato reduziu os níveis de glicemia em jejum e a sensibilidade à insulina, ao reduzir a fosforilação sérica da tirosina IRS-1 induzida por insulina.

É importante salientar que o extrato também diminuiu significativamente a esteatose hepática, por reverter o padrão NASH, sua forma mais agressiva, considerada uma doença progressiva que pode evoluir para cirrose hepática e carcinoma hepatocelular para o fenótipo NAFLD, que é a forma benigna da esteatose hepática. Os resultados indicaram que $U$. tomentosa melhorou a homeostase da glicose ao reverter NASH para uma condição de esteatose hepática benigna e estes efeitos foram associados a atenuação da inflamação do fígado em camundongos obesos, sugerindo que o extrato bruto de $U$. tomentosa possa ser considerado uma intervenção terapêutica para aumentar a sensibilidade hepática à insulina e na reversão de NASH em um fenótipo menos prejudicial. Os autores, no entanto, não deixam claro de qual parte da planta foi preparado o extrato (ARAUJO et al., 2018).

Assim como os trabalhos descritos por Azevedo et al., (2019) e Elgawish et al. (2018) que utilizaram extrato aquoso de folhas e $10 \%$ de extrato aquoso de $U$. tomentosa, respectivamente, identificando a presença de alcalóides oxindólicos em ambos estudos.

Elgawish et al. (2018) relataram, além do efeito antioxidante, o efeito anti-inflamatório do extrato aquoso de $U$. tomentosa, contendo $1,5 \%$ de alcalóides oxindólicos, contra lesão hepática subcrônica induzida por fipronil por meio da expressão de NF-kB, TNF- $\alpha$ e IL-6. Os resultados deste estudo demostraram ação profilática do extrato aquoso de $U$. tomentosa ao agir sobre a função hepática, peroxidação lipídica e sobre os biomarcadores hepáticos de stress oxidativos em ratos, porém o papel exato de $U$. tomentosa no bloqueio de ativação de NF-kB e na redução da produção de citocinas, bem como o alívio da inflamação hepática e necrose ainda precisavam ser investigadas.

Já Azevedo et al. (2019) descrevem a capacidade antioxidante do extrato aquoso de folhas de U. tomentosa, rico em alcalóides oxindólicos, ao reduzir os níveis de ERO em um modelo in vivo de vermes Caenorhabditis elegans, o que sugere que esse efeito é independente do conteúdo de alcalóides presente no extrato. $\mathrm{O}$ fator de transcrição SKN-1 mostrou-se necessário para a resistência ao stress mediado pelo extrato aquoso de $U$. tomentosa observados no efeito antioxidante. 
Pode-se observar também, nos resultados descritos por Domingues et al. (2011) sobre o potencial imunomodulador do extrato hidroalcoólico da casca do caule de U. tomentosa, em impedir a progressão do diabetes imunomediado por vias distintas. De acordo com o autor, houve melhora do quadro clínico do paciente devido ao aumento significativo do número de células T CD4 ${ }^{+}$e CD8 ${ }^{+}$, semelhantes aos observados em animais saudáveis. Observou-se também, aumento do número de $\mathrm{CD}^{+}, \mathrm{CD} 25^{+}, \mathrm{Foxp}^{+}$e células T reguladoras. Além disso, o extrato modulou a produção de Th1 e Th2, com níveis aumentados de IL-4 e IL-5.

Diante do exposto, nota-se a importância da escolha da parte da planta e da descrição do extrato de $U$. tomentosa a ser utilizado, pois isso definirá quais metabólitos estarão presentes, e com isso suas atividades farmacológicas, o que resultará em um tratamento mais eficaz. Além disto, deve-se destacar a necessidade de padronização das preparações com plantas medicinais, visando sua reprodutibilidade, o que é de extrema importância na busca por resultados mais eficazes, principalmente quando se trata de pesquisas sobre o potencial farmacológico de plantas medicinais.

\section{CONSIDERAÇÕES FINAIS}

As diversas preparações de $U$. tomentosa se mostram ricas em metabólitos secundários, descritos como seus marcadores químicos. Os bioativos são responsáveis pelas ações farmacológicas da planta e são descritos como sendo alcalóides indólicos e oxindólicos pentacíclicos (POA) e tetracíclicos (TOA), triterpenos derivados do ácido quinóvico, polifenóis, flavonoides e proantocianidinas.

Devido às suas características químicas, genéticas e botânicas, os extratos ou preparações obtidas de $U$. tomentosa demonstraram regular a plasticidade de algumas células do sistema imune, interferindo na resposta inflamatória com potencial imunomodulador, anti-inflamatório e antioxidante.

Portanto, sugere-se uma padronização metodológica quanto ao preparo do extrato da planta, bem como as partes a serem utilizadas e estudos com ênfase no mecanismo de ação dos marcadores químicos, para utilização da planta de forma racional e eficaz no tratamento de doenças.

\section{REFERÊNCIAS}

ARAUJO, L. C. C. et al. Uncaria tomentosa improves insulin sensitivity and inflammation in experimental NAFLD. n. June, p. 1-14, 2018.

AZEVEDO, B. C. et al. Aqueous extracts from Uncaria tomentosa (Willd. ex Schult.) DC. reduce bronchial hyperresponsiveness and inflammation in a murine model of asthma. Journal of Ethnopharmacology, v. 218, n. September 2017, p. 76-89, 2018.

AZEVEDO, B. C. et al. Antioxidant Activity of an Aqueous Leaf Extract from. Molecules, v.24, p. 3299, 2019. DOI: $10.3390 /$ molecules 24183299 . 
CIANI, F. et al. Anti-proliferative and pro-apoptotic e ff ects of Uncaria tomentosa aqueous extract in squamous carcinoma cells. Journal of Ethnopharmacology, v. 211, n. June 2017, p. 285-294, 2018.

CASTILHOS, L. G. et al. Effect of Uncaria tomentosa extract on purinergic enzyme activities in lymphocytes of rats submitted to experimental adjuvant arthritis model. BMC Complementary and Alternative Medicine, p. 1-11, 2015.

ALKALOIDS, I. M. et al. Antioxidant Activity of an Aqueous Leaf Extract from. [s.d.].

ARAUJO, L. C. C. et al. Uncaria tomentosa improves insulin sensitivity and inflammation in experimental NAFLD. n. June, p. 1-14, 2018.

CASTILHOS, L. G. et al. Effect of Uncaria tomentosa extract on purinergic enzyme activities in lymphocytes of rats submitted to experimental adjuvant arthritis model. BMC Complementary and Alternative Medicine, p. 1-11, 2015.

CIANI, F. et al. Anti-proliferative and pro-apoptotic e ff ects of Uncaria tomentosa aqueous extract in squamous carcinoma cells. Journal of Ethnopharmacology, v. 211, n. June 2017, p. 285-294, 2018.

DOMINGUES, A. et al. Prevention of experimental diabetes by Uncaria tomentosa extract : Th2 polarization, regulatory T cell preservation or both ? Journal of Ethnopharmacology, v. 137, n. 1, p. 635-642, 2011.

ELGAWISH, R. A.; SOLIMAN, M. T. A. Hepatoprotective activity of Uncaria tomentosa extract against sub-chronic exposure to fipronil in male rats. n. Eisenstein 2015, 2018.

FREITAS, K. et al. Uncaria tomentosa extract alters the catabolism of adenine nucleotides and expression of ecto-5 ' -nucleotidase / CD73 and P2X7 and A1 receptors in the MDA-MB-231 cell line. Journal of Ethnopharmacology, v. 194, p. 108-116, 2016.

KAISER, S. et al. Genotoxicity and cytotoxicity of oxindole alkaloids from Uncaria tomentosa ( cat' s claw ): Chemotype relevance. v. 189, p. 90-98, 2016.

PEÑALOZA, E. M. C. et al. Chemical composition variability in the Uncaria tomentosa (cat's claw) wild population. Quimica Nova, v. 38, n. 3, p. 378-386, 2015.

ALKALOIDS, I. M. et al. Antioxidant Activity of an Aqueous Leaf Extract from. [s.d.].

ARAUJO, L. C. C. et al. Uncaria tomentosa improves insulin sensitivity and inflammation in experimental NAFLD. n. June, p. 1-14, 2018.

CASTILHOS, L. G. et al. Effect of Uncaria tomentosa extract on purinergic enzyme activities in lymphocytes of rats submitted to experimental adjuvant arthritis model. BMC Complementary and Alternative Medicine, p. 1-11, 2015.

CIANI, F. et al. Anti-proliferative and pro-apoptotic e ff ects of Uncaria tomentosa aqueous extract in squamous carcinoma cells. Journal of Ethnopharmacology, v. 211, n. June 2017, p. 285-294, 2018.

DOMINGUES, A. et al. Prevention of experimental diabetes by Uncaria tomentosa extract : Th2 polarization, regulatory T cell preservation or both ? Journal of Ethnopharmacology, v. 137, n. 1, p. 635-642, 2011.

ELGAWISH, R. A.; SOLIMAN, M. T. A. Hepatoprotective activity of Uncaria tomentosa extract against sub-chronic exposure to fipronil in male rats. n. Eisenstein 2015, 2018.

FREITAS, K. et al. Uncaria tomentosa extract alters the catabolism of adenine nucleotides and expression of ecto-5' -nucleotidase / CD73 and P2X7 and A1 receptors in the MDA-MB-231 cell line. Journal of Ethnopharmacology, v. 194, p. 108-116, 2016.

KAISER, S. et al. Genotoxicity and cytotoxicity of oxindole alkaloids from Uncaria tomentosa ( cat' s claw ): Chemotype relevance. v. 189, p. 90-98, 2016. 
PEÑALOZA, E. M. C. et al. Chemical composition variability in the Uncaria tomentosa (cat's claw) wild population. Quimica Nova, v. 38, n. 3, p. 378-386, 2015.

ALKALOIDS, I. M. et al. Antioxidant Activity of an Aqueous Leaf Extract from. [s.d.].

ARAUJO, L. C. C. et al. Uncaria tomentosa improves insulin sensitivity and inflammation in experimental NAFLD. n. June, p. 1-14, 2018.

CASTILHOS, L. G. et al. Effect of Uncaria tomentosa extract on purinergic enzyme activities in lymphocytes of rats submitted to experimental adjuvant arthritis model. BMC Complementary and Alternative Medicine, p. 1-11, 2015.

CIANI, F. et al. Anti-proliferative and pro-apoptotic e ff ects of Uncaria tomentosa aqueous extract in squamous carcinoma cells. Journal of Ethnopharmacology, v. 211, n. June 2017, p. 285-294, 2018.

DOMINGUES, A. et al. Prevention of experimental diabetes by Uncaria tomentosa extract: Th2 polarization, regulatory T cell preservation or both ? Journal of Ethnopharmacology, v. 137, n. 1, p. 635-642, 2011.

ELGAWISH, R. A.; SOLIMAN, M. T. A. Hepatoprotective activity of Uncaria tomentosa extract against sub-chronic exposure to fipronil in male rats. n. Eisenstein 2015, 2018.

FREITAS, K. et al. Uncaria tomentosa extract alters the catabolism of adenine nucleotides and expression of ecto-5 ' -nucleotidase / CD73 and P2X7 and A1 receptors in the MDA-MB-231 cell line. Journal of Ethnopharmacology, v. 194, p. 108-116, 2016.

KAISER, S. et al. Genotoxicity and cytotoxicity of oxindole alkaloids from Uncaria tomentosa ( cat 's claw ): Chemotype relevance. v. 189, p. 90-98, 2016.

PEÑALOZA, E. M. C. et al. Chemical composition variability in the Uncaria tomentosa (cat's claw) wild population. Quimica Nova, v. 38, n. 3, p. 378-386, 2015. 


\section{APLICAÇÕES FARMACOLÓGICAS DAS SUBSTÂNCIAS PRODUZIDAS PELAS PLANTAS E FITOTERÁPICOS VENDIDOS COM E SEM PRESCRIÇÃO MÉDICA}

DOUGLAS BORGES DE AGUIAR Faculdades FAN Padrão - Modalidade de Ensino Progressivo

JOVECY MATIAS DA CRUZ Faculdades FAN Padrão - Modalidade de Ensino Progressivo

PATRICK MICKAEL SOARES GOMES Faculdades FAN Padrão - Modalidade de Ensino Progressivo

BRUNO MARTINS DE JESUS Faculdades FAN Padrão - Modalidade de Ensino Progressivo

WILLIAN FERNANDES DE OLIVEIRA Faculdades FAN Padrão - Modalidade de Ensino Progressivo

\section{ENILDO IZIDORO RIBEIRO}

Faculdades FAN Padrão - Modalidade de

Ensino Progressivo

TARIK DE SOUZA

Faculdades FAN Padrão - Modalidade de

Ensino Progressivo

JULIANA SANTANA DE CURCIO Doutora em Patologia Molecular - Universidade de Brasília (UnB). Docente das Faculdades FAN

Padrão - Modalidade de Ensino Progressivo

RESUMO: O presente estudo objetivou apresentar como são feito as aplicações farmacológica dos medicamentos que contém substâncias de origem vegetal, explicar as normas da Resolução da Diretoria Colegiada (RDC) para venda de um fitoterápico, citar exemplos de remédios fitoterápicos, e como é feito a venda dessas substâncias naturais com e sem prescrição médica, nas drogarias convencionais. Para responder o objetivo, optou-se pela revisão narrativa que é fundamental na aquisição e atualização de conhecimento sobre uma temática específica, evidenciando novas ideias conforme os registros apresentados na literatura. Os resultados demostraram que os requisitos para a liberação de um medicamento fitoterápico são os mesmos dos medicamentos sintetizados. Observou-se também que ainda é muito pouco os estudos científicos voltados para essa importante descoberta que são, os fitoterápicos para avaliar não só sua eficácia mas também sua toxicidade, também para a notificação de novas drogas vegetais. Apesar de avanço na regulamentação dos fitoterápicos, ainda há muitas questões que merece atenção.

Palavras-chave: Medicamentos. Fitoterápico. Medicamentos Sintéticos. Plantas. Prescrição Médica.

ABSTRACT: The present study aims to present how pharmacological applications of medicines containing substances of plant origin are made, explain how the rules of the Collegiate Board Resolution (RDC) for the sale of a herbal medicine, quote samples of herbal medicines, and how they are sold. natural substances with and without medical prescription, in associated drugs. To answer the objective, choose the narrative review that is fundamental in the acquisition and updating of knowledge on a specific theme, evidencing new ideas according to the records published in the 
literature. The results demonstrated that the requirements for the release of a herbal medicine are the same as those of synthesized medicines. Also note that there are still very few scientific studies focused on this important discovery, which are herbal medicines to assess not only their effectiveness, but also their toxicity, also for the notification of new drugs. Despite advancing in the adaptation of herbal medicines, there are still many issues that deserve attention.

Keywords: Medicines. Phytotherapic. Synthetic Drugs. Plants. Recipe.

\section{INTRODUÇÃO}

Este estudo é recorte dos conteúdos discutidos na disciplina de farmacobotânica do curso de farmácia ministrada na modalidade ensino progressivo. Este método consiste em desenvolver as habilidades e competências dos alunos no que se refere a prática profissional.

Na disciplina de farmacobotânica debatemos sobre a utilização da fitoterapia para tratamento no Brasil por ser considerada uma alternativa terapêutica econômica, conforme descreve Carvalho et al., (2002).

O uso de plantas como medida alternativa possibilita o combate ou prevenção de doenças e se constitui como uma estratégia importante para a melhoria da saúde e da qualidade de vida da população (SANTOS et al., 2011).

Dentro as inúmeras possibilidades, a utilização dos extratos vegetais vem sendo uma opção muito comum em tratamentos de doenças utilizadas pelo homem desde a antiguidade, a utilização destas tem contribuído em resultados significativos para os tratamentos terapêuticos de várias doenças (IBIAPINA et al, 2014).

De acordo com a legislação sanitária brasileira, o fitoterápico é o medicamento obtido exclusivamente das matérias-primas ativas vegetais. Segundo a Agência de Vigilância Sanitária (ANVISA) as plantas medicinais são aquelas capazes de aliviar ou curar enfermidades e têm tradição de uso como remédio em uma população ou comunidade (BRASIL, 2016).

Os estudos dos metabólitos das plantas se desenvolveram rapidamente nas últimas décadas. Os princípios ativos compostos pelas plantas são conhecidos por cumprirem um papel importante na adaptação das plantas aos seus ambientes e também representam uma fonte importante de substâncias farmacologicamente ativas. O desenvolvimento de novos fármacos é um longo e dispendioso processo, que pode levar de dez a quinze anos de pesquisa e de desenvolvimento para ser concluído (MONTANARI, 2001).

Portanto, esse trabalho tem objetivo de elucidar como são feito as aplicações farmacológica dos medicamentos que contém substâncias de origem vegetal, explicar as normas da Resolução da Diretoria Colegiada (RDC) para venda de um fitoterápico, citar exemplos de remédios fitoterápicos, e como é feito a venda dessas substâncias naturais com e sem prescrição médica, nas drogarias convencionais. 
Para explicar como são feito as aplicações farmacológica dos medicamentos que contém substâncias de origem vegetal, sustentamos teoricamente nos manuais da Anvisa e para detalhar a atuação no tratamento nos guias dos medicamentos fornecidos pelos próprios fabricantes.

\section{MATERIAIS E MÉTODOS}

Para responder o objetivo proposto optou-se pelo estudo qualitativo de revisão narrativa, adequado para discutir o estado da arte de um determinado assunto. Trata-se de uma análise ampla da literatura, sem definir uma metodologia replicável conforme proposto por Vosgerau e Romanowsk (2014).

Embora não apresente rigor metodológico, as revisões narrativas são fundamentais na aquisição e atualização de conhecimento sobre uma temática específica, evidenciando novas ideias conforme os registros apresentados na literatura (ROTHER, 2007).

A busca dos artigos ocorreu em pares, em junho de 2020, de forma on-line nas bases de dados eletrônicas: Biblioteca Virtual em Saúde (BVS) e Google Scholar.

Em relação à seleção de estudos encontrados na busca eletrônica, os pesquisadores avaliaram de forma independente, por meio de leitura dos títulos e resumos. Em seguida foi realizada uma triagem para selecionar os estudos de acordo com os critérios de elegibilidade. Foram incluídos: artigos publicados na língua portuguesa e qualquer ano de publicação em que o texto se relacionou as aplicações farmacológicas das substâncias produzidas pelas plantas e fitoterápicos vendidos com e sem prescrição médica.

Por fim, os dados apresentados foram submetidos a análise de conteúdo. Posteriormente, os resultados foram discutidos com o suporte de outros estudos provenientes dos manuais da Agência Nacional de Vigilância Sanitária (ANVISA) e as recomendações do Ministério da Saúde (MS).

\section{RESULTADOS E DISCUSSÕES}

O uso de plantas medicinais como medicamentos, já é uma tradição entre a população brasileira. Principalmente em povoados mais afastados onde existe pouco acesso aos profissionais da saúde, os benefícios dos vegetais se espalham de geração em geração e auxiliam no tratamento de diversas doenças. É comum dizer para as pessoas nervosas tomarem suco de maracujá, pois age como calmante, ou para quem está com certa dor estomacal, que o boldo é um excelente remédio, nos tempos atuais com a evolução de vários estudos, outras centenas de plantas aliadas com o avanço da medicina foram criados como medicamentos fitoterápicos (BRASIL, 2020). 
Segundo a Anvisa, podemos afirma que medicamentos derivados e produzidos a partir de plantas são considerados medicinais, os fitoterápicos passam pelos mesmos controle e estudos clínicos que outros medicamentos tradicionais, o que é importante para definir a eficácia e segurança para o uso humano. Há diferença as entre os medicamentos fitoterápicos e sintéticos. A principal delas é que os sintéticos são produzidos por um processo de síntese, em que moléculas químicas são unificadas a fim de chegar na fórmula desejada. Já fitoterápicos são medicamentos fabricados a partir de plantas medicinais têm como base apenas o extrato do vegetal, que contém milhares de substâncias naturais (BRASIL, 2020).

A ligação do farmacêutico com fitoterapia sempre foi muito forte, desde o começo da profissão. Hoje nos dias atuais tem sido mais comum a participação do farmacêutico, nas áreas de manipulação, dispensação de produtos fitoterápicos. Alguns anos atrás, só quem podia prescrever medicamentos fitoterápicos era médico ou veterinário, após a criação da PNPIC que é política nacional de práticas integrativas e complementares, outros conselhos profissionais conseguiram regulamentar a prescrição da fitoterápica (CARVALHO, 2020)

A Resolução do Conselho Federal de Farmácia (CFF) No . 546, de 21 de julho de 2011, o farmacêutico que comprovar habilitação em fitoterapia poderá, sempre que solicitado pelo usuário ou paciente, dispensar um fitoterápico ou planta medicinal, desde que o mesmo seja isento de prescrição médica (CARVALHO, 2020).

Alguns medicamentos fitoterápicos, só podem ser vendidos com recomendação médica, esses medicamentos são diferenciados, uns contém tarja e outros não. Os medicamentos de tarja vermelha, são de venda sob prescrição, ou seja, tem que ser recomendado por um profissional capacitado. No caso das tarjas vermelhas em que vem com um texto falando, venda sob prescrição médica, pode ser vendido sem retenção de receita, a pessoa pode comprar livremente, mais sempre deve usar o remédio somente com a orientação médica, pois esses medicamentos podem provocar sérios efeitos colaterais. Os fitoterápicos sem tarja são de venda livre são conhecidos como MIP, que são para tratar sintomas e males menores e podem ser vendido sem prescrição médica, devido a sua segurança e eficácia (MOREIRA, 2020).

Alguns medicamentos fitoterápicos que necessita de prescrição médica, são valeriana, ginkgo biloba, hedera helix, motore entre outros. A valeriana também conhecida como erva dos gatos, é uma planta medicinal muito antiga, ela é usada no combate da insônia é ansiolítica. O Ginkgo biloba (figura 1) é um medicamento fitoterápico para o tratamento microvarizes, labirintite, deficiência de oxigênio e substância nutritivas, e para o tratamento de toda isquemia seja cerebral ou periférica. Hedera helix é indicado para o tratamento broncopulmonares, inflamatórias agudas e crônicas, associadas a aumento de secreção. Já o motore é um medicamento fitoterápico destinado ao tratamento da osteoartrite, e artrite reumática e tem ação anti-inflamatória, o motore tem princípio ativo a curcumina, agente do corante amarelo característico da raiz do açafrão da terra de Curcuma longa (BIERNATH, 2017). 


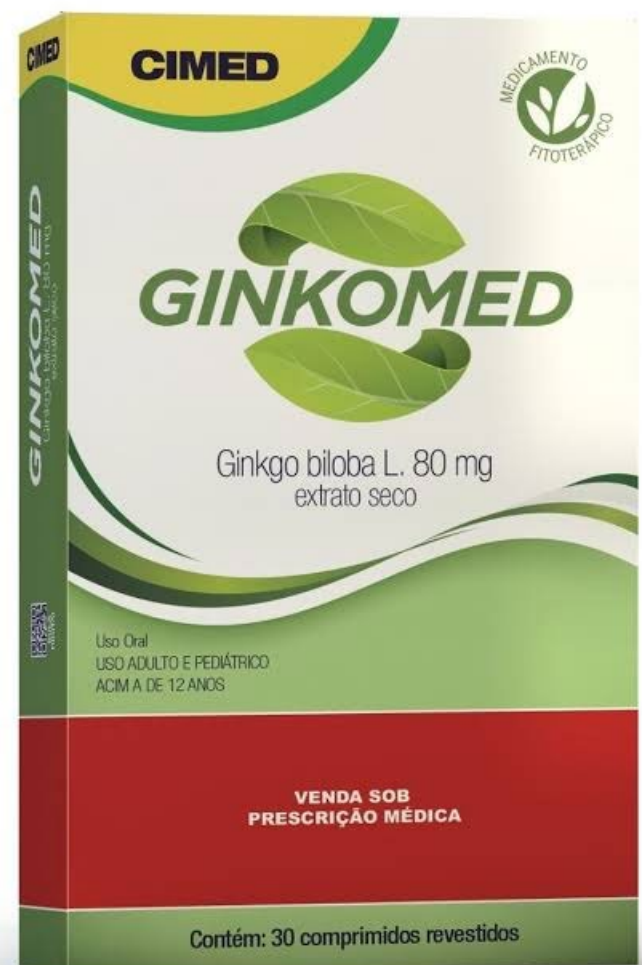

Fonte: Farmacobotânica.

Figura 2 Curcuma longa.

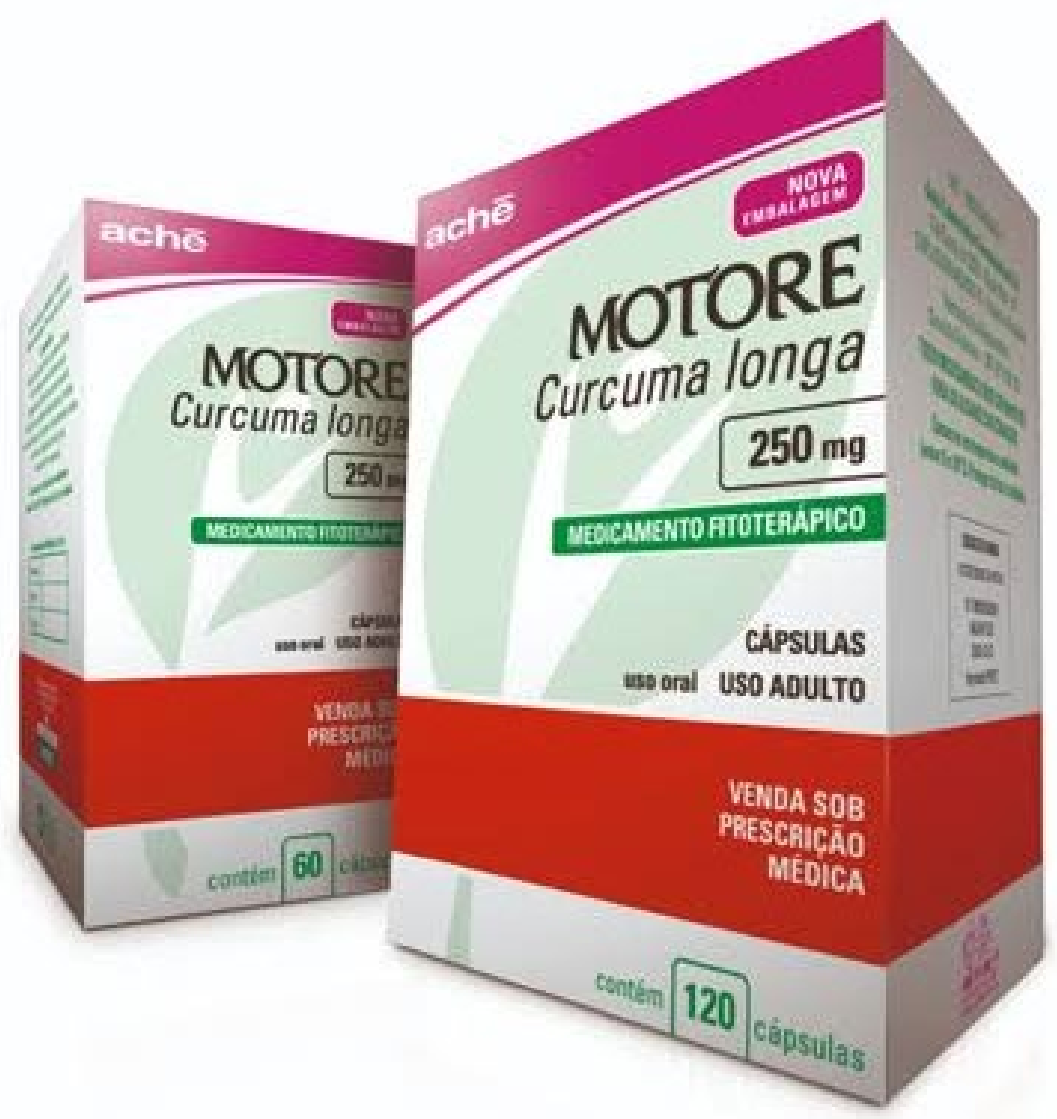

Fonte: Farmacobotânica. 
Os fitoterápicos já está em uso a muito tempo pela humanidade, tendo influência nas práticas religiosas, medicina e folclore e lendas. Os chineses a 5.000 A.C, já usavam plantas para cura de doenças. Como qualquer medicamento os fitoterápicos devem ter garantia de qualidade efeitos terapêutica comprovada composição comprovada e segurança no seu uso o sistema sanitário deve fiscalizar esses medicamentos para evitar riscos à saúde da população, pois tais medicamentos podem ter eventos adversos e desvios de qualidade ocasionando problemas à saúde do usuário (VELLOSO; PEGLOW, 2003).

Alguns medicamentos que podem ser vendido sem prescrição médica, tais como, seakalm, guaco, alho, castanha da índia, entre outros. Seakalm é um medicamento fitoterápico a base de Passiflora incarnata, é um sedativo leve, tem ação contra a ansiedade. O Guaco (Figura 3) é uma planta medicinal, também conhecida por ervas de serpentes, ou ervas de cobra, muito utilizado em problemas respiratório devido seu efeito broncodilatador. Alho ajuda a combater bronquite, asma, sintomas de gripe e resfriado, colesterol alto, hipertensão e aterosclerose, lesões nas paredes dos vasos sanguíneos. A castanha da índia, (figura 4) Aesculus hippocastanum é utilizada para o tratamento de insuficiência venosa, varizes, dor nas pernas e hemorroida (BIERNATH, 2017).

Figura 3. Guaco

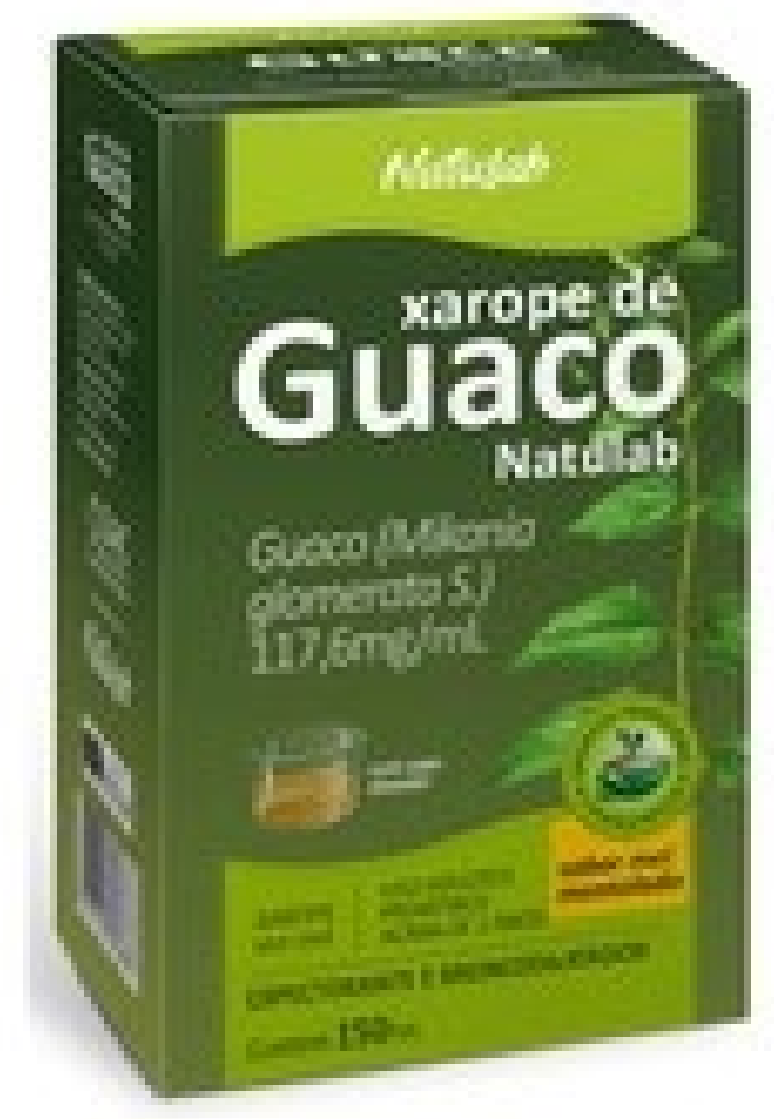

Fonte: Farmacobotânica 


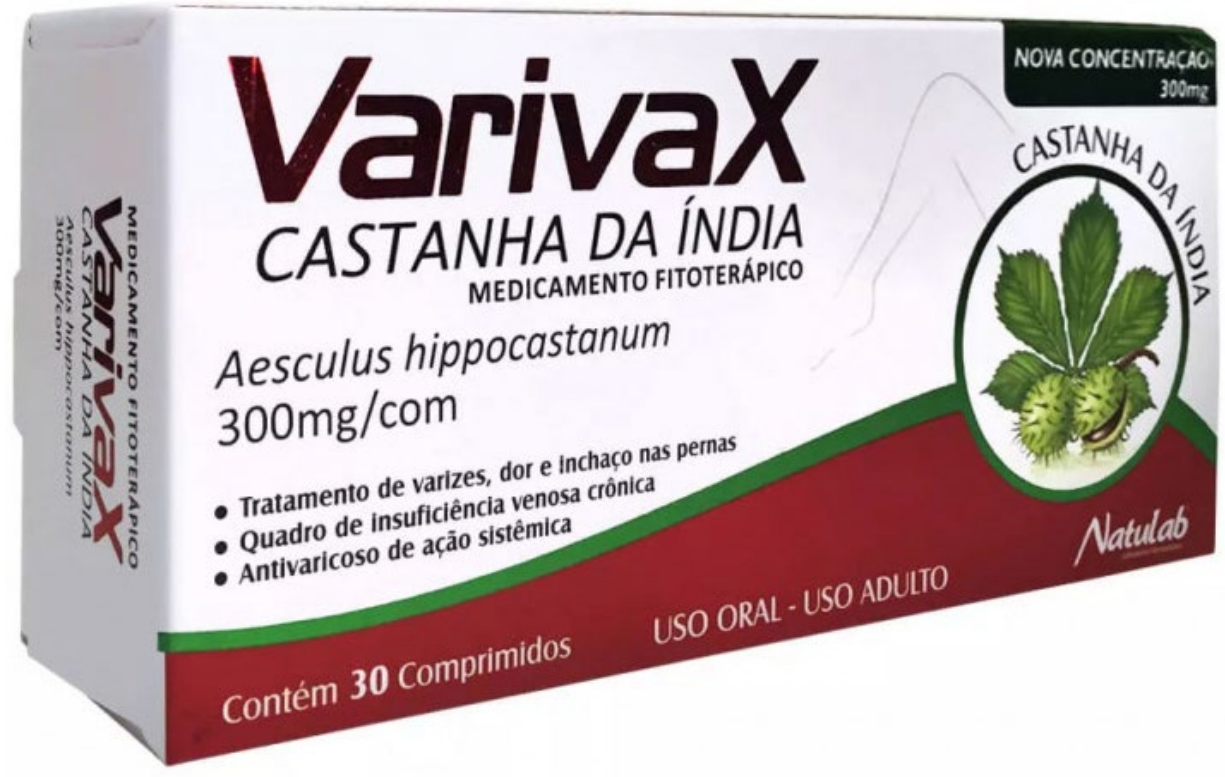

Fonte: Farmacobotânica.

Segundo a Fiocruz (2007), para que ocorra a permissão de produção e venda dos produtos fitoterápicos, existem requisitos na norma que devem ser cumpridos para que então tenha o seu registro aceito. Estes requisitos são divididos em requisitos tecnológicos, que está relacionado à produção e ao controle de qualidade, e os requisitos terapêuticos, sendo eles relacionados à segurança e eficácia do uso do medicamento. Para que ocorra então o registro de um medicamento fitoterápico, primeiramente deverão ser apresentados os estudos científicos que comprovem que a segurança do produto acabado aborda toxicologia pré clínica e clínica, estabelecendo também a relação dose atividade, indicações terapêuticas e reações adversas, contraindicações e restrições de uso.

É determinado pela norma que todos os estudos devem ser realizados seguindo as normas de pesquisa em saúde do Conselho Nacional de Saúde. As novas exigências terapêuticas que foram feitas trouxeram um problema, sendo ele que boa parte dos medicamentos fitoterápicos no mercado não cumpria então as exigências que eram feitas. E então para que isso fosse solucionado, foi determinado levando em conta que haveria um prazo de cinco anos de validade do registrado determinado na Lei $\mathrm{n}^{\circ}$ 6.360, que os produtos que já tivessem sido registrados teriam o prazo igual para apresentar os resultados de segurança que eram requeridos na norma, entretanto isso gerou problemas, que levaram a adicionar avisos nos rótulos dos produtos, para que então quem comprasse o mesmo tivesse total conhecimento do que estaria levando pra casa, e caso fosse constatado que houvesse toxicidade no produto durante aquele período, ele seria retirado do mercado de forma imediata (FIOCRUZ, 2007).

Os hormônios vegetais, também conhecidos como fitormônios, são substâncias orgânicas produzidas pelas plantas e desempenham funções fundamentais no seu crescimento e desenvolvimento de cada parte da planta. Esses hormônios está presente em pequenas quantidades, por todas as partes da planta, e são produzidos pela própria planta. Essas substâncias desempenha funções super importante na vida das plantas desde o amadurecimento da semente, o nascimento de uma nova planta, 
crescimento, de ambas as partes dessas plantas, lembrando que para cada parte da planta existe um tipo específico de hormônio. Ou seja, essas substâncias são responsáveis pelas funções fisiológicas da planta (ALBUQUERQUE; VIEIRA, 1998).

Os hormônios são divididos em cinco principais grupos, auxinas, citocininas, giberelinas, o etileno e o ácido Abscísico. Auxinas agem no desenvolvimento do caule e das raízes, em caso de baixa quantidade de auxinas, as raízes podem até, desenvolver, mas o caule não se desenvolve. Ao contrário da alta concentração de auxinas que podem promover o crescimento do caule, mas deixando as raízes pouco desenvolvidas. As citocininas agem na diferenciação e divisão das células vegetais, também no desenvolvimento das raízes e das gemas laterais, além de controlar o envelhecimento da planta. As Giberelinas são produzidas nos meristemas, nas folhas novas e nos frutos, sua principal função é estimular o alongamento e a divisão da célula vegetal, age também na produção de flores, desenvolvimento das folhas e germinação das sementes. Etileno substância produzida em diversas partes da planta, sua função é controlar o amadurecimento dos frutos e no processo de renovação das folhas. Ácido Abscísico, hormônio fabricado pelas folhas, caule e ápice radicular das plantas, atua no desenvolvimento do caule, além de inibir a germinação de sementes. Caso aconteça um estresse hídrico,falta de água, este hormônio realiza vários processos na planta fazendo com que esta planta possa diminuir a perda de água, e mantendo assim a hidratação necessária para sobreviver (LEÃO, P; POSSIDIO, 2000).

\section{CONSIDERAÇÕES FINAIS}

Concluímos neste trabalho, que na atualidade de hoje os requisitos para a liberação de um medicamento fitoterápico, são adotada as mesmas legislações que regem sobre a liberação e fiscalização dos medicamentos sintetizados. Infelizmente, no Brasil mesmo com legislação específica desde a década de sessenta, a quantidade de estudos científicos e registros de fitoterápicos ainda é muito pequena, quando comparado com alguns países, porém com o avanço das políticas públicas no setor, esperamos por um crescimento significativo já que atualmente este tipo de medicamento se encontra em alta aceitação pela população, superando até mesmo a aceitação dos medicamentos sintéticos.

A Anvisa tem promovido nos últimos anos principalmente a partir de 2006, uma reformulação nas leis que rege sobre os fitoterápicos, cumprindo seu papel obedecendo às regras impostas pelas políticas públicas, a partir daí notou se um avanço em relação à situação anterior foram publicadas normas, as quais foram revisadas, como a RDC 14/1020, sobre o registro de medicamentos fitoterápicos; ainda é muito pouco os estudos científicos voltados para essa importante descoberta que são, os fitoterápicos para avaliar não só sua eficácia mas também sua toxicidade, também para a notificação de novas drogas vegetais. Apesar de ter havido um certo avanço na regulamentação do fitoterápicos, ainda há muitas questões que merece toda atenção e aperfeiçoamento. 


\section{REFERÊNCIAS}

ALBUQUERQUE, LA.S.; VIEIRA, S.M.N.S. Efeito da cianamida hidrogenada na brotação da videira cv. Itália na região semi-árida do Vale do São Francisco. In: Congresso Brasileiro de Fruticultura, 9., 1987, Campinas, SP. Anais. Campinas: SBF, 1988, v.2, p.739-744.

BIERNATH, A. 28 plantas medicinais. Disponível em: <https://www.google.com/amp/s/saude.abril.com.br/ medicina/plantas-medicinas-poderes-as-contraindicacoes/amp/>. Acesso em 20 de junho 2020.

BRASIL, Miniistério da Saúde. Relação De Nacional De Plantas Medicinais De Interesse Do Sus (RENISUS) disponível em http://portalsaude.saude.gov.br/index.php/o-ministerio/principal/leia-mais-oministerio/465-sctie-raiz/daf-raiz/ceaf-sctie/fitoterapicos-cgafb/11-fitoterapicos/12552- plantas-de-interesse-ao-sus. Acesso em junho de 2020 .

BRASIL. Medicamento fitoterápico, o que é e quando optar por ele. Disponível em: $<$ https://www.drogarialiviero.com.br/blog/medicamento-fitoterapico/>. Acessado em 22 de junho 2020 ás 17:00.

CARVALHO, C E et al.. Atividade Antimicrobiana in vitro de Extratos Hidroalcoólicos de Psidium guajava L. sobre Bactérias Gram-Negativas. Acta Farmacéutica Bonaerense, Recife-Pernambuco, v. 21, p. 255-258, 2002.

CARVALHO, M. Prescrição de fitoterapia. Disponível em: <https://siteantigo.portaleducacao.com.br/conteudo/artigos/medicina-alternativa/prescricao-de-fitoterapicos/10234>. Acesso em 20 junho de junho.

FIOCRUZ, 2007. REVISTA FITOS. Rio de Janeiro: Laboratório de Química de Produtos Naturais e Plataforma de Métodos Analíticos, FarManguinhos, FIOCRUZ, v 3, n 1, março 2007.

IBIAPINA, Waléria Viana et al. Inserção da Fitoterapia na Atenção Primária aos Usuários do Sus. Revista Ciência Saúde Nova Esperança, Nova Esperança, v.12, p. 58-68, 2014.

Leão, P.C.S.; Possidio, E.L. 2000. Implantação do pomar e manejo da cultura. In: Leão, P.C.S.; Soares, J.M(eds.). A viticultura no semi-arido brasileiro. Petrolina: Embrapa Semi-Arido, p.93-128.

MOREIRA, D. Tarjas de medicamentos. Disponível em: <https://www.infoescola.com/medicina/tarjas-dos-medicamentos/\#: : text=Tarja\%20vermelha\&text=Em\%20ambos\%20os\%20casos\%20os,de\%20 $\mathrm{se} \% 20$ evitar\%20riscos\%20maiores $>$. Acesso em 21 de junho.

Rother ET. Revisão sistemática X revisão narrativa. Acta paul. Enferm 2007; 20(2):v-vi.

SANTOS, R.L.et al. Análise sobre a fitoterapia como prática integrativa no Sistema Único de Saúde. Revista brasileira plantas medicinais, v. 13, p. 486- 491, 2011. 
NOÉLIA CUNHA LAURIDO

Enfermagem da Faculdade Estácio do

Amazonas, Manaus, AM, Brasil.

ANA GREICY DA SILVA CRUZ

Enfermagem da Faculdade Estácio do Amazonas, Manaus, AM, Brasil.

ANA CAROLINA MOREIRA ARAÚJO

Enfermagem da Faculdade Estácio do Amazonas, Manaus, AM, Brasil.

JUCILENE CARVALHO DE SOUZA

Enfermagem da Faculdade Estácio do Amazonas, Manaus, AM, Brasil.

LEANDRO SILVA PIMENTEL Doutor em Infectologia e doenças tropicais. Enfermagem da Faculdade Estácio do Amazonas, Manaus, AM, Brasil.

RESUMO: Doenças cerebrovasculares, como o acidente vascular cerebral - AVC, é a segunda que mais mata no mundo. Apresentam altos índices de vítimas entre homens e mulheres, leva ao óbito e provoca inúmeras incapacidades aos que sobrevivem. Objetivo: analisar as contribuições da Enfermagem que atuam, na Unidade de Terapia Intensiva. Metodologia: Revisão de literaturas, baseadas em livros e artigos científicos. Resultados: constatado nos artigos, que as contribuições de Enfermagem se dão grandemente com as reabilitações, que começam a beira leito e que essas são efetivas, certifica-se também que os profissionais de saúde seguem critérios rígidos de atendimento ao paciente com acidente vascular cerebral. Conclusão: Este estudo deixou clara que a Enfermagem contribui enormemente para a estabilidade do quadro e minimiza as possíveis sequelas.

Palavras-chave: Acidente Vascular Cerebral, Unidade de Terapia Intensiva, Enfermagem.

ABSTRACT: Cerebrovascular diseases, such as stroke, is the second most killing in the world. They have high rates of victims among men and women, lead to death and cause numerous disabilities to those who survive. Objective: to analyze the contributions of nursing nursing that work in the Intensive Care Unit. Methodology: Literature review, based on books and scientific articles. Results: found in the articles, that nursing contributions are very much related to rehabilitation, that they begin at the bedside and that these are effective, it is also certified that health professionals follow strict criteria for stroke patient. Conclusion: This study made it clear that the Sick contributes enormously to the stability of the condition and minimizes the possible sequelae.

Keywords: Stroke, Intensive Care Unit, Nursing; 


\section{INTRODUÇÃO}

Estima-se que até 2030 o Acidente Vascular Cerebral - AVC continue sendo a segunda maior causa de morte no mundo, com óbitos em torno de 12,2 \%[...]. Esses dados são bastantes preocupantes, uma vez que representam índices elevados por ano de 6,7 milhões de óbitos em 2012. (OMS, 2014).

No Brasil, as estimativas também estão altas, sendo o Acidente Vascular Cerebral (AVC) a causa da maioria das mortes, assumindo o primeiro lugar, e só perdendo para o infarto agudo do miocárdio (SAÚDE,2016).

“A ocorrência de um acidente isquêmico cerebral é consequente a uma redução crítica do debito sanguíneo, devido a à oclusão parcial ou total de uma artéria cerebral.”(CAMBIER; MASSON; DEHEN, 2005, p.202). Essa patologia atinge vasos arteriais de forma a escassear suprimento sanguíneo e dependendo de seu grau de acometimento pode ocorrer de maneira completa ou não.

Estudos afirmam que há formas diferentes de acidente vascular cerebral (AVC). Sendo classificados em hemorrágico e isquêmico, o último objeto desse estudo. $\mathrm{O}$ isquêmico apresenta subclassificações como, trombótico, embólico, transitório e progressivo. (PIRES; SATARLING,2002).

As causas bem conhecidas de AVC isquêmico estão relacionadas a pressão arterial sistêmica descontrolada, placas de gordura nos vasos sanguíneos, que muitas vezes o indivíduo desconhece essa lesão, e o que ela pode provocar. Os altos níveis de açúcar e gordura no sangue, também são bem significativos para desencadear uma isquemia vascular cerebral. Todos os fatores já citados associados ou não ao tabagismo e a falta de atividade física. ( PIRES; STARLING 2002).

Os mecanismos pelos quais o AVC isquêmico se dá são as lesões trombóticas, aquelas oriundas da coagulação do sangue, em que as plaquetas se agregam. E as embólicas, que dizem respeito a um trombo que se soltou e que viaja pela circulação, podendo ocluir um vaso. Já os lacunares é um infarto de pequeno tamanho ou uma arteríola perfurante (HIGA; ATALLAH, 2004).

Como toda doença apresenta uma sintomatologia, as do AVC são hemiparesia contralateral à lesão, é uma paralisia parcial que afeta um lado do corpo. A diplopia, que faz o indivíduo perceber a visão dupla, vertigem, tonteira, queda espontânea são sugestivos de isquemia (PIRES; STARLING, 2010).

O acidente cerebral vascular, geralmente deixam sequelas incapacitantes que prejudicam não só as atividades de trabalho, mas às sociais também. Depois da ocorrência de um AVC o indivíduo atingido perde sua independência, devido ter sido atingido em alguma área importante que o limita, passando a dependência de alguém. Tal circunstância é provável que prejudique todo o cotidiano do sequelado e de seus familiares que terão que mudar toda a dinâmica de suas vidas(CANUTO;NOGUEIRA;ARAÚJO,2016).

Considera-se alguns fatores de risco para o desencadeamento do AVC, como as características genética, a raça negra, histórico familiar de problemas cardiovasculares e o envelhecimento. A aten- 
ção deve ser maior quando se tratar desses indivíduos. Daí a importância da realização de consultas médicas sempre que possível ou mais frequentemente (BRASIL, 2015).

A prevenção do AVC pode ser primária ou secundária. A primária diz respeito as medidas de detecção e correção dos riscos, voltados ao indivíduo que tem um certo grau de risco, mas que não sofreu nenhum evento de isquemia cerebral. Já a secundária são os cuidados dedicados a uma pessoa que já foi acometida pelo AVC isquêmico. O paciente que já passou por essa lesão uma vez, as chances de ter um outro evento é de nove vezes. Por isso, é prudente que haja uma intervenção farmacológica e, eventualmente, na cirurgia ou neurologia intervencionista (NETO; TAKAYANAGUI, 2013)

O manual de rotina de atenção ao AVC, apresenta protocolo, escalas e orientações aos profissionais de saúde, no manejo clínico ao paciente acometido por AVC [...]. Permitindo qualificação dos trabalhadores da atenção básica ao hospital de alta complexidade[...] e melhoria da atenção ao AVC no SUS (BRASIL, 2013).

A Unidade de Terapia Intensiva-UTI, é uma estrutura no hospital que recebe pessoas em estado crítico, um ambiente com trabalhos ou monitoração de pacientes de forma contínua. "A Unidade de Terapia Intensiva (UTI) é caracterizada como um ambiente de internação para pacientes em estado crítico de saúde e que necessitam de atenção especializada e monitorada.” (BRASIL,2005).

\begin{abstract}
A Unidade de Terapia Intensiva (UTI) é um setor hospitalar bastante complexo pelo perfil crítico de seus pacientes. São pessoas que têm quadros clínicos graves, que precisam de cuidados intensivos e que devem ser monitoradas 24 horas. Dessa forma, a equipe multidisciplinar deve trabalhar concomitantemente para atender as tais necessidades (OLIVEIRA et al., 2017).
\end{abstract}

A Enfermagem junto a outras equipes multidisciplinares devem estar prontas para compartilhar conhecimento e juntas colocarem em prática todas as estratégias de assistência ao paciente crítico para surtir os melhores resultados possíveis. Por isso a enfermagem precisa ter habilidade na identificação do problema e agir com rapidez devido o quadro desses pacientes que já são graves e de grande instabilidade (FERREIRA; et al., 2016).

Desta forma, lança-se os conhecimentos sistemáticos da Enfermagem como meio para atingir os objetivos que se buscam dentro de uma unidade de terapia intensiva.

A utilização do Processo de Enfermagem, como método de organizar abordagem clínica da profissão em UTI, favorece a identificação das condições apresentadas pelos pacientes que requerem intervenção de enfermagem e tomada de decisões terapêuticas mais adequadas para atingir resultados pelos quais a enfermagem é responsável (DIAGNÓSTICO DE ENFERMAGEM NANDA I, 2012).

Em busca de atender a essas demandas, as pesquisas em Enfermagem voltadas para o adoecimento por AVC têm-se evidenciado entre as temáticas estudadas pela profissão, com vista à melhoria da qualidade do cuidado prestado a essa clientela. Nesse sentido, o exercício do cuidado pleno requer do Enfermeiro subsídios teóricos, práticos e de procedimentos terapêuticos, além dos destinados a atender as necessidades de saúde do paciente e família (MANIVA; et al., 2013). 
O paciente crítico atingido por AVC requer cuidados intensivos em algum momento do período de hospitalização, [talvez em todos os momentos, já que foi hospitalizado] sobretudo na emergência (ALEGRIA,M.A.; et al., 2002) .

A reabilitação é uma das inúmeras funções da enfermagem, que busca a independência para a realização do autocuidado, sendo o segundo entendido como um conjunto de ações desenvolvidas pelo indivíduo e pela família para atender as necessidades da vida diária, que é aprendido e aperfeiçoado ao longo da vida (OREM D.E., 1995).

Quando há o acometimento do acidente vascular cerebral é provável que as vítimas sofram alguma sequela, entre elas o movimento fica prejudicado, restrição de movimentação devido ter atingido a musculatura e articulação (RYERSON,2004).

Dessa forma, a Enfermagem atua ativamente na reabilitação dos movimentos, aplicando atividades que dão maior movimento e amplitude de movimento, associado a alongamento para pacientes afetados por AVC. O exercício é realizado por profissionais, mas que também pode ser feito pelos pacientes, assim que eles aprendam (PERLINI; FARO, 2005).

\footnotetext{
Além da reabilitação motora, um estudo aponta que a reabilitação funcional ajuda os pacientes a integrar as atividades recém-aprendidas da vida diária e habilidades técnicas para executar tais atividades, auxiliando os pacientes a encontrar novas formas de realizá-las para garantir a segurança (SUMMER, 2009).
}

A reabilitação funcional traz um nova forma de elaborar atividades que dão segurança ao paciente, a partir dos novos conhecimentos, são técnicas que ajudarão no cotidiano dessa nova realidade.

O papel do Enfermeiro quanto a reabilitação neurológia, abrange orientações ao paciente de forma a recuperar não só a saúde física, mas a espiritual, que tão logo recuperada, a auto estima se eleva, assim será mais rápida a busca pela independência que algum momento se perdeu (SMELTZER, 2005).

O déficit neurológico é um dos agravos que o AVC isquêmico provoca e o Enfermeiro tem um papel grandioso na busca pela recuperação. "Durante e após a fase aguda, as prescrições de Enfermagem concentram-se nas pessoas como um todo"(BRUNNER;SUDDARTH,2014,p.1908).

Entre os acometimentos de um AVC, existe o déficit do campo visual, em que a Enfermagem instrui o paciente na compensação do dano causado; no motor, o auxílio vem do estímulo a realização de atividades que possam ampliar os movimentos do lado lesionado.

Já no verbal o paciente é encorajado a repetir os sons do alfabeto. E no cognitivo, é feito uma orientação de espaço e tempo.

$\mathrm{Na}$ experiência sensorial afetada, ocorre a instrução de que houve alterações e passa a aguçar a área afetada. Entretanto, o comprometimento emocional, deve-se envolver a família, pois é possível que episódios de explosões possam acontecer e os familiares devem ter ciência da origem patológica dessas explosões (BRUNNER; SUDDARTH,2014). 
Suporte emocional promovido pela enfermagem tem objetivo de estabelecer relação de confiança com paciente e familiares, na busca de envolver todos para juntos enfrentar o tratamento e buscar as adaptações necessárias (MARITE,1997).

\section{METODOLOGIA}

Este estudo é uma pesquisa de finalidade básica estratégica, com objetivo descritivo, e abordagem qualitativa e executado por meio de levantamento bibliográfico.

A pesquisa básica estratégica visa aquisição de novos conhecimentos direcionados a amplas áreas com vistas à solução de reconhecidos problemas práticos” (GIL, 2010, p.27).

No tocante ao objetivo, avista-se que foi realizado um levantamento bibliográfico, com finalidade de descrever o conhecimento mais atual já existente entre os registros a respeito da contribuição de enfermagem na assistência a pacientes acometidos por acidente vascular cerebral isquêmico, internados na unidade de terapia intensiva, assunto de investigação desta pesquisa.

Deste modo, é possível afirmar que a primeira parte do trabalho se adequa na pesquisa descritiva que "trata-se do estudo e da descrição das características, propriedades ou relações existentes na comunidade, grupo ou realidade pesquisada." (CERVO et al,2007, p.62).

Para mais, a pesquisa foi desenvolvida, a partir da questão norteadora de observar a contribuição assistencial do Enfermeiro a paciente vítima de acidente vascular cerebral que foram internados na Unidade de Terapia Intensiva.

A pesquisa traz uma abordagem qualitativa, diz que "na pesquisa qualitativa o pesquisador procura reduzir a distância entre a teoria e os dados, entre o contexto e a ação, usando a lógica da análise fenomenológica, isto é, da compreensão dos fenômenos pela sua descrição e interpretação [...].’(TEIXEIRA,2012, p. 137),

De início, buscou-se a base teórica sobre contribuição da Enfermagem na assistência a pacientes acometidos por acidente vascular cerebral isquêmico, internados na unidade de terapia intensiva.

Para compor a revisão de literatura proposta foram realizados, a busca de literaturas, fichamentos em livros específicas e artigos científicos contemporâneos, avaliação dos dados, análise e apresentação.

Foram estabelecidos critérios de inclusão para a revisão: artigos disponíveis eletronicamente; artigos disponíveis nos idiomas português e espanhol; artigos que abordam a atuação de Enfermagem nas Unidades de Terapia Intensiva junto ao paciente com Acidente Vascular Cerebral, e foram excluídos aqueles que não atenderam a temática. As intervenções de Enfermagem foram escolhidas por categoria de assistência na reabilitação motora, funcional, neurológica e afetiva. 
Busca realizada entre os meses de fevereiro a abril de 2020 por meio dos sites da Scielo, Ministério da Saúde, Organização Mundial da Saúde e periódicos em Bibliotecas Públicas da Universidade Federal do Amazonas.

\section{RESULTADOS ESPERADOS}

Com base nos critérios de inclusão e exclusão descritos na metodologia a revisão de literatura, o estudo de reabilitação elegeu cinco artigos que tratam do assunto.

O quadro a seguir destaca cinco tipos de assistência de Enfermagem ao paciente acometido por Acidente Vascular Cerebral, onde traz título, autor, ano de publicação, objetivo, tipo de estudo.

\begin{tabular}{|c|c|c|c|c|c|}
\hline Fonte & Título & Autor/Ano & Objetivo & Tipo de estudo & Resultados \\
\hline $\begin{array}{l}\text { Tratado de Enfer- } \\
\text { magem Médico- } \\
\text {-Cirúrgica }\end{array}$ & $\begin{array}{l}\text { Manifestação } \\
\text { e Implica- } \\
\text { ções de En- } \\
\text { fermagem ao } \\
\text { paciente com } \\
\text { défic neuroló- } \\
\text { gico/AVC }\end{array}$ & $\begin{array}{l}\text { Brunner \& } \\
\text { S u d d a r - } \\
\text { th, } 2014\end{array}$ & $\begin{array}{l}\text { Analisar a função } \\
\text { do Enfermeiro } \\
\text { junto ao paciente } \\
\text { isquêmico }\end{array}$ & $\begin{array}{l}\text { Análise Temá- } \\
\text { tica }\end{array}$ & $\begin{array}{l}\text { Implicações de Enfermagem e } \\
\text { Aplicações à instrução do pa- } \\
\text { ciente com AVC. }\end{array}$ \\
\hline Orem DE. & $\begin{array}{l}\text { Nursing con- } \\
\text { cepts of pra- } \\
\text { tice }\end{array}$ & $\begin{array}{l}\text { M e n e s e s } \\
\text { L.S.T.; et } \\
\text { al,1995 }\end{array}$ & $\begin{array}{l}\text { Analisar os be- } \\
\text { nefícios } \\
\text { reabilitação mo- } \\
\text { tora propõe ao } \\
\text { paciente com } \\
\text { AVC }\end{array}$ & $\begin{array}{l}\text { Pesquisa Bi- } \\
\text { bliográfica }\end{array}$ & $\begin{array}{l}\text { Propõe o retorno das funções } \\
\text { perdidas por meio da reabili- } \\
\text { tação. }\end{array}$ \\
\hline $\begin{array}{l}\text { Comprehensive } \\
\text { overview of nurs- } \\
\text { ing and interdisci- } \\
\text { plinary care of to } \\
\text { the acute ischemic } \\
\text { stroke patient. }\end{array}$ & $\begin{array}{l}\text { Reabilitação } \\
\text { Funcional. }\end{array}$ & $\begin{array}{l}\text { Summers, } \\
\text { D. et al, } \\
2009\end{array}$ & $\begin{array}{l}\text { Mostra a ligação } \\
\text { que se faz entre } \\
\text { novos conheci- } \\
\text { mentos e ativi- } \\
\text { dades práticas } \\
\text { diárias. }\end{array}$ & $\begin{array}{l}\text { Pesquisa Bi- } \\
\text { bliográfica }\end{array}$ & $\begin{array}{l}\text { Reabilitação funcional faz a } \\
\text { interação do cognitivo com o } \\
\text { motor. }\end{array}$ \\
\hline $\begin{array}{l}\text { Tratado de Enfer- } \\
\text { magem médico-ci- } \\
\text { rúrgica }\end{array}$ & $\begin{array}{l}\text { Reabilitação } \\
\text { neurológica }\end{array}$ & $\begin{array}{l}\text { Smeltzer, } \\
2005 .\end{array}$ & $\begin{array}{l}\text { Mostrar que a } \\
\text { reabilitação neu- } \\
\text { rológica propõe } \\
\text { melhoras, a par- } \\
\text { tir dos métodos } \\
\text { aplicados }\end{array}$ & $\begin{array}{l}\text { Pesquisa Bi- } \\
\text { bliográficas }\end{array}$ & $\begin{array}{l}\text { Quando há compromisso do } \\
\text { paciente, é possível uma boa } \\
\text { recuperação }\end{array}$ \\
\hline $\begin{array}{l}\text { The role of nursing } \\
\text { in the rehabilitation } \\
\text { of acute strokem } \\
\text { patients: toward a } \\
\text { unified theoretical } \\
\text { perspective. Adv } \\
\text { Nurs19(4):55-64 }\end{array}$ & $\begin{array}{l}\text { Reabilitação } \\
\text { emocional. }\end{array}$ & $\begin{array}{l}\text { M a r i - } \\
\text { te, } 1997\end{array}$ & $\begin{array}{l}\text { Mostrar que a } \\
\text { reabilitação emo- } \\
\text { cional traz segu- } \\
\text { rança para o pa- } \\
\text { ciente. }\end{array}$ & $\begin{array}{l}\text { Pesquisa Bi- } \\
\text { bliográfica }\end{array}$ & $\begin{array}{l}\text { É vantajoso quando o paciente } \\
\text { tem apoio dos familiares. }\end{array}$ \\
\hline $\begin{array}{l}\text { Ministério da Saú- } \\
\text { de }\end{array}$ & $\begin{array}{l}\text { Diretrizes de } \\
\text { Atenção à } \\
\text { Reabilitação } \\
\text { da Pessoa } \\
\text { com Acidente } \\
\text { Vascular Ce- } \\
\text { rebral }\end{array}$ & $\begin{array}{l}\text { Secretaria } \\
\text { de Atenção } \\
\text { à Saúde } \\
\text { Departa- } \\
\text { mento de } \\
\text { Ações Pro- } \\
\text { gramáticas } \\
\text { Estratégi- } \\
\text { cas/ } 2013\end{array}$ & $\begin{array}{l}\text { Recomenda-se } \\
\text { que a reabilitação } \\
\text { da pessoa com } \\
\text { AVC aconteça de } \\
\text { forma precoce. }\end{array}$ & $\begin{array}{l}\text { Pesquisa Bi- } \\
\text { bliográfica }\end{array}$ & $\begin{array}{l}\text { Espera-se que a abordagem } \\
\text { dos aspectos relacionados à } \\
\text { reabilitação da pessoa com } \\
\text { AVC sirva de subsídio para } \\
\text { ações da equipe multidiscipli- } \\
\text { nar e que tenha como resulta- } \\
\text { do final a manutenção da saú- } \\
\text { de física e mental, bem como } \\
\text { o desenvolvimento de sua au- } \\
\text { tonomia e inclusão social. }\end{array}$ \\
\hline
\end{tabular}




\section{DISCUSSÃO}

Este trabalho foi inspirado em uma das aulas de Alta Complexidade, cujo nome é auto sugestivo para o desenvolvimento da investigação em Acidente Vascular Cerebral AVC.

A coleta ocorreu em biblioteca e sites voltados para estudos científicos. De início, buscou saber como se dá a atuação da Enfermagem, nas Unidade de Terapia Intensiva, junto a pacientes isquêmicos.

Precipuamente, buscou-se conhecer as definições e como se desencadeia o AVC. Seguidamente, procurou-se descrever a Assistência de Enfermagem na Unidade de Terapia Intensiva voltada a pacientes com acidente vascular cerebral. E por último avaliar a contribuição da assistência de Enfermagem frente ao paciente internado na Unidade de Terapia Intensiva em decorrência de Acidente Vascular Cerebral.

A análise dos dados rastreados sobre a atuação da Enfermagem na Unidade de Terapia Intensiva, junto ao paciente acometido por Acidente Vascular Cerebral AVC, patologia que decorre da redução de débito sanguíneo, levando a incapacidade diversas e que dependendo da região afetada pode acometer diversas funções importantes.

As funções eleitas nesse estudo foram: implicações ao déficit motor, funcional neurológico e emocional e práticas da Enfermagem.

Percebeu-se, que a atuação de Enfermagem é importante e se dá desde o início da entrada do paciente com AVC na unidade hospitalar e que a reabilitação é um dos maiores apoios dados pela Enfermagem e equipe multidisciplinar.

O Enfermeiro deve está pronto para receber o paciente crítico e ser capaz de reconhecer os sinais apresentados pela patologia de acordo com literaturas clássicas que abordam Acidente Vascular Cerebral.

Sabe-se que o tempo é um fator preponderante para diagnosticar de pronto o AVC e iniciar um tratamento adequado.

Já do conhecimento da Enfermagem os mecanismos do AVC, é rigor para essa equipe, dá início assim que possível, a manejos de reabilitação para que as lesões não tragam ou não alcancem prejuízos maiores.

Daí, a preocupação em traçar umas estratégias, ainda em ambiente hospitalar, de reabilitação, o direcionamento dessa reabilitação vai depender da área atingida.

O Acidente Vascular Cerebral (AVC) acontece quando vasos que levam sangue ao cérebro entopem ou se rompem, provocando a paralisia da área cerebral que ficou sem circulação sanguínea. É uma doença que acomete mais os homens e é uma das principais causas de morte, incapacitação e internações em todo o mundo. 
Quanto mais rápido for o diagnóstico e o tratamento do AVC, maiores serão as chances de recuperação completa. Desta forma, torna-se primordial ficar atento aos sinais e sintomas e procurar atendimento médico imediato.

Sintomas do AVC: Fraqueza, Confusão Mental, Alteração da fala, Alteração da visão

Dor de cabeça súbita, intensa, sem causa aparente. Alteração do equilíbrio, coordenação, tontura ou alteração no andar.

O tratamento do Avc Isquêmico é a busca pelo médico seja feita o mais rápido possível. $\mathrm{Na}$ maioria das emergências hoje tem um medicamento chamado alteplase, que deve ser aplicado em até quatro horas e meia após o início dos sintomas.

O AVC hemorrágico ocorre quando há rompimento de um vaso cerebral, provocando hemorragia. Esta hemorragia pode acontecer dentro do tecido cerebral ou na superfície entre o cérebro e a meninge. É responsável por $15 \%$ de todos os casos de AVC, mas pode causar a morte com mais frequência do que o AVC isquêmico.

Principais fatores de risco para desenvolver um AVC; Colesterol alto; Sobrepeso; Obesidade; Tabagismo; Uso excessivo de álcool; Idade avançada; Sedentarismo;

Uso de drogas ilícitas; O diagnóstico do AVC é feito por meio de exames de imagem, que permitem identificar a área do cérebro afetada e o tipo do derrame cerebral.

O estudo menciona a reabilitação neurológica, pois o AVC tende a causar déficits graves, onde ocorre o prejuízo da visão, do cognitivo, da fala, entre outros danos. Ciente disso, a Enfermagem planeja e define metas, quanto a atividade escolhida para aquela sequela.

Outro tipo de reabilitação é o motor, que a Enfermagem dá início ainda em ambiente hospitalar. Aplicar atividades voltadas ao alongamento dos músculos afetados e articulações, busca movimentar e ampliar esses movimentos. Na expectativa da redução da perda de movimento.

Já a reabilitação funcional está relacionada a métodos que ensinam o paciente a relacionar os novos conhecimentos com atividades práticas que ele desenvolve diariamente. Percebe-se que essa modalidade envolve condição de pensar e movimento.

Nessa sequência, vem a reabilitação emocional, essa o Enfermeiro busca a família para participar do tratamento. Pois, o paciente precisará perceber que tem apoio em casa e que pode contar com a compreensão dos seus cuidadores. Essa reabilitação vai esclarecer familiares das complicações e instruir o paciente na comunicação.

Acredita-se que tais estratégias de reabilitação surtam efeitos significativos para recuperação dos pacientes, pois as literaturas reiteram esses métodos e nenhuma levantou qualquer dúvida.

As reabilitações são um dos principais fatores que mais contribuem com o acometido por isquemia. E esse manejo é uma atribuição da Enfermagem, que o planeja e observa o momento oportuno para iniciar, minimizando ou até mesmo corrigindo sequelas. 
Constata-se que a atuação da Enfermagem frente ao paciente com AVC tem crescido e colhido frutos positivos quanto a minimização das sequelas. Sendo que esse profissional segue protocolos estabelecidos para esse público.

O Acidente Vascular Cerebral é uma patologia em que põe os profissionais em um jogo de tempo. E tudo dependerá de uma velocidade na identificação, nos primeiros socorros e continuidade na fase aguda. Paciente que são atendidos a tempo tem grandes chances da redução dos prejuízos. Porém, se identificado tardiamente é provável que haja grandes acometimentos.

Assim, na unidade hospitalar, segue-se protocolos de atendimento voltado para pessoas que sofreram uma isquemia. E o procedimento da Enfermagem se estabelece dentro desses parâmetros.

As dificuldades enfrentadas nesse estudo estão na raridade de informações voltadas ao paciente isquêmicos, na Unidade de Terapia Intensiva, sob os cuidados da Enfermagem.

\section{REABILITAÇÃO AVCS ISQUÊMICO}

AVC isquêmico: Ocorre quando há obstrução de um vaso sanguíneo, bloqueando o seu fluxo para as células cerebrais. No caso de um Acidente Isquêmico Transitório (AIT), este pode ser preditor de um novo evento.

\section{REABILITAÇÃO:}

Recomenda-se que a reabilitação da pessoa com AVC aconteça de forma precoce e em toda a sua integralidade. A pessoa com alterações decorrentes de um AVC pode apresentar diversas limitações em consequência do evento, e a recuperação é diferente em cada caso. O tratamento médico imediato, associado à reabilitação adequada, pode minimizar as incapacidades, evitar sequelas e proporcionar ao indivíduo o retorno o mais breve possível às suas atividades e participação na comunidade.

Serão apresentadas, a seguir, algumas diretrizes voltadas à abordagem multiprofissional, baseadas nas possíveis condições e complicações advindas de, pelo menos, um evento do AVC. Estas diretrizes podem, de acordo com a apresentação clínica e funcional identificada pela avaliação multiprofissional do indivíduo, ser realizadas no ambiente hospitalar ou ambulatorial.

Condições relacionadas ao AVC

1.Déficit sensório-motor

\subsection{Disfagia:}

Condições da deglutição do paciente pós-AVC e a conduta sugerida aos profissionais na atenção hospitalar e ambulatorial:

INTERVENÇÃO: Auxiliar a introdução do alimento à boca, facilitando a captura de todo o alimento e o fechamento dos lábios, quando o paciente não puder fazer sozinho; • Evitar ofertar 
alimentos antes que o anterior seja totalmente deglutido; • Estimulação sensorial intra e extraoral; Exercício miofuncional de lábios, língua, bucinadores e mastigatórios; • Adequar consistência e volume alimentar; • Manobra de deglutição com esforço; • Manobra de queixo para baixo; • Adequar utensílios para a introdução do alimento; • Aumentar a pressão intraoral; • Treino de mastigação

Tosse e engasgo: • adequar consistência e volume alimentar; • Exercício miofuncional para maximizar a ação da musculatura suprahióidea e esfinctérica da laringe; • Manobras: ○ Deglutição com esforço; ○ Queixo para baixo; ○ Rotação de cabeça associada com deglutição e tosse; ○ Exercitador e incentivador respiratório; ○ Masako; ○ Mendelsohn; ○ Supraglótica.

Para pacientes que fazem uso de traqueostomia: • Uso de válvula de fala; • observar se há saída de conteúdo alimentar pelo traqueostoma; • adequar consistência e volume alimentar.

Retorno do alimento para o nariz: • adequar consistência e volume alimentar; $\bullet$ Manobra de deglutição com esforço; • Exercício miofuncional de esfíncter velofaríngeo.

Sensação de alimento parado na garganta: • Alternar com alimentos de menor consistência alimentar, desde que ambas sejam seguras à deglutição; • Adequar consistência e volume alimentar; - Exercício miofuncional de lábios, língua, bucinadores e de elevação laríngea; • Uso de Biofeedback; • Aumentar a pressão intraoral; • Manobras: ○ Deglutição com esforço; ○ Queixo para baixo; ○ Deglutição múltipla; ○ Rotação de cabeça associada com deglutição e tosse; ○ Exercitador e incentivador respiratório; ○ Masako; ○ Mendelsohn.

É recomendada a introdução de via alternativa de alimentação para pacientes pós-AVC com quadros graves de disfagia, em risco nutricional e de complicações pulmonares. O objetivo da reabilitação será retomar a dieta via oral com manutenção do estado nutricional, buscando evitar as complicações pulmonares e, principalmente, o risco de pneumonia aspirativa.

\subsubsection{Paralisia facial}

A paralisia facial é uma manifestação frequentemente observada no pós-AVC. Caracteriza-se pela diminuição dos movimentos faciais na hemiface acometida, podendo resultar nas alterações da mímica facial, das funções de deglutição e fonação, com consequente impacto estético e funcional.

Central (Supranuclear): • Estratégias passivas, no caso de associação com alterações de compreensão (linguagem ou cognição); • Uso de massagem indutora, durante ação motora automática.

Nuclear: Fase flácida $\bullet$ compressa fria: na hemiface e no músculo desejado; • batidas com as pontas dos dedos; • Exercícios miofuncionais isométricos, com associação de massagem (manual, lenta e profunda) indutora no sentido do movimento; • Uso de feedback visual; • Realização de exercícios com ativação cortical.

Nuclear: Fase de recuperação de movimentos: • Exercícios miofuncionais isotônicos; • Realização de contração com contrarresistência; • Uso de feedback visual; • Conscientização; • Realização de exercícios com ativação cortical. 
Sequelas: Contraturas e sincinesias: • Liberação do movimento: estratégias de relaxamento e alongamento, associadas à dissociação; • Exercícios miofuncionais isotônicos; • Exercícios miofuncionais isotônicos com dissociação de movimentos; • Uso de calor úmido; • Estimulação do controle voluntário; • Uso de feedback: eletromiografia, espelho, terapeuta

\subsubsection{Fraqueza muscular}

A fraqueza muscular representa um dos maiores contribuintes para a incapacidade após AVC. É importante que, em qualquer nível de atenção, os exercícios sejam delineados de forma que uma atividade muscular mínima resulte em movimento do membro. Evidências de estratégias de fortalecimento muscular incluem:

- Exercícios de fortalecimento muscular progressivo;

- Eletroestimulação associada ao treino de tarefas funcionais.

10.1.1.4. Déficits de sensibilidade

Déficits de sensibilidade envolvem as modalidades perceptivas e proprioceptivas. Dor, tato e sensação térmica podem estar alterados. conclusão 29 Intervenções destinadas ao manejo dos déficits sensoriais podem envolver:

- Tocar o membro superior do ombro até a mão;

- Favorecer a discriminação de objetos com a mão afetada;

- Estimular o reconhecimento da posição de partes do corpo no espaço, sem auxílio da visão;

- Identificar diferentes movimentos e suas direções no espaço, sem auxílio da visão;

- Identificar desenhos com a ponta dos dedos, com os olhos fechados;

- Estimular sensibilidade da face com diferentes texturas e temperaturas.

- Identificar e integrar os objetos do cotidiano pelas suas propriedades sensoriais. Por exemplo: olfato, visão, tato, paladar, audição; ensinar estratégias compensatórias ao déficit de sensibilidade: o Usar a visão para identificar situações de risco; o Ajustar a abertura da mão para pegar objetos com diferentes funções; o Discriminar objetos pelas suas texturas ou peso diferenciados; o Discriminar pesos diferenciados nos objetos; o Proporcionar a descarga de peso corporal no hemicorpo afetado; o Discriminar sabores e odores.

10.1.1.6 Limitação de atividades motoras e funcionais

A desordem motora envolve tanto a manutenção postural quanto as transferências. Algumas estratégias/manobras para o ganho funcional nas atividades motoras estão descritas

Dificuldade em manter-se sentado: Prática de exercícios de alcance de objetos (em todas as direções) além do comprimento do braço, com supervisão ou assistência de outra pessoa, se necessário; • Adequação da postura sentada para favorecer o alinhamento corporal. 
Dificuldade em passar de sentado para de pé: Posicionamento dos pés atrás da linha dos joelhos; • Altura do assento deve ser elevada quanto menor o grau de força muscular dos membros inferiores; • O movimento deve iniciar com o tronco em posição vertical; • Oscilar o tronco superior à frente, empurrar os pés para baixo e levantar-se; • Solicitar aumento da velocidade do movimento (caso esteja muito lento); • Solicitar direcionamento do olhar ao nível da linha do horizonte; • Solicitar que o paciente segure o membro superior plégico pelo punho, a fim de reduzir o peso do braço durante a troca de postura.

Dificuldade de manter-se na posição ortostática: Exercícios que envolvam a distribuição de peso nos membros inferiores com deslocamentos do centro de massa corporal: • Movimentos da cabeça para cima e para os lados; • Movimentos de rotação de tronco (girar para olhar sobre os ombros); • Alcance de objetos à frente, lateralmente, posteriormente, acima e abaixo. Progressão da dificuldade das tarefas: • Mudar a base de suporte (pés juntos, um pé à frente do outro, um pé no degrau); • Aumentar o peso e a distância dos objetos; • Aumentar o tamanho dos objetos, para que se possa utilizar ambas as mãos para o alcance; • Aumentar a demanda de velocidade.

Dificuldade para deambular: Prática específica e repetitiva da marcha ou de seus componentes. Além do treino convencional, podem ser utilizados: • Pista de visual; • Marcha assistida; $\bullet$ Biofeedback; • Suporte de peso corporal; • Órteses de tornozelo-pé para deformidades do pé e/ou dispositivos de auxílio, quando necessário.

\subsubsection{Comunicação:}

As lesões cerebrais decorrentes do AVC, dependendo da área de comprometimento, podem gerar sequelas relativas à linguagem oral e escrita (afasias), distúrbios auditivos, planejamento (apraxia oral e verbal) e execução da fonoarticulação (disartrias/disartrofonias), visto que o Sistema Nervoso Central se apresenta como um sistema funcional complexo, hierarquicamente organizado e de funcionamento integrado. Todos estes eventos, isolados ou em conjunto, podem trazer ao paciente uma dificuldade em comunicar-se, que pode implicar em isolamento social que, por sua vez, pode desencadear ou agravar quadros depressivos.

10.1.3.1 Afasia As afasias são distúrbios que afetam os aspectos de conteúdo, forma e uso da linguagem oral e escrita, em relação à sua expressão e/ ou compreensão, como consequência de uma lesão cerebral; envolve os processos centrais de significação, seleção de palavras e formulação de mensagens. Este distúrbio é observado na expressão de símbolos por meio da comunicação oral, escrita (dislexias e agrafias adquiridas) ou gestual, tratando-se de uma dificuldade do paciente em lidar com elementos linguísticos.

Expressiva: Garantir estimulação auditiva e visual, dentro de um contexto adequado; • Combinar estímulos auditivos e visuais com significação atribuída; • Controlar extensão do estímulo; • Comunicação por meio de palavra-chave, com sequência narrativa; • Usar o gesto e a escrita como auxiliares à expressividade; • Estimular respostas do paciente, garantindo a integração de aferência, processamento e eferência; • Métodos terapêuticos: o Terapia melódica; o Comunicação alternativa, com recomendação para atividades funcionais. 
Compreensiva: Estimular os componentes de duração, intensidade e frequência dos sons verbais e não verbais; • Tarefas de designação de objetos e figuras; • Identificar temática central; Associar o estímulo apresentado a vivências anteriores e ao contexto; • Exercícios de associação do significado, com recursos visuais, auditivos, gestuais e contextuais; • Utilizar os efeitos de preditividade, de previsão pragmática, de expectativa, de redundância e de ênfase adequada ao significado da mensagem.

\subsubsection{Distúrbios do humor:}

A mudança do estado de humor e a labilidade emocional do indivíduo após AVC é comum e geralmente de instalação tardia, sendo está uma situação que a equipe de reabilitação comumente se depara. Também conhecido como transtorno da expressão emocional involuntária, esta condição, embora não tão rara, não tem ainda sua fisiopatologia claramente estabelecida, estando envolvido o lobo frontal e sistema límbico e comumente associado a quadro depressivo. É caracterizada por crises de choro e/ou riso incontrolável e estereotipa- 44 das, sem relação direta com fator causal, podendo, inclusive, ocorrer de forma dissociada ao estado de humor do sujeito acometido, que pode reconhecer esse comportamento como inadequado, o que aumenta ainda mais a sua ansiedade e contribui para o seu isolamento.

BENEFÍCIOS ESPERADOS: Espera-se que a abordagem dos aspectos relacionados à reabilitação da pessoa com AVC sirva de subsídio para ações da equipe multidisciplinar e que tenha como resultado final a manutenção da saúde física e mental, bem como o desenvolvimento de sua autonomia e inclusão social.

\section{CONSIDERAÇÕES FINAIS}

O trabalho teve como ideia inicial, pesquisar as contribuições da Enfermagem na assistência a pacientes acometidos por acidente vascular cerebral isquêmico - AVC, internados na unidade de terapia intensiva - UTI.

Acreditou-se na relevância desse trabalho pelo fato de perceber as sequelas originadas dessa patologia e buscou-se investigar sua relação com a assistência oferecida dentro dos hospitais.

Desse modo, constata-se que a pesquisa tem relevância grandiosa. Tendo em vista que é notório as sequelas que ficam após um AVC, consequência dos eventos que não são assistidos rapidamente e adequadamente. E que são importantes as contribuições da Enfermagem a evitar ou pelos menos minimizar tais lesões.

Pesquisa Nacional de Saúde [...] avaliou a prevalência de AVC no Brasil e calculou o número absoluto estimado de pessoas acometidas pela doença de 2.231 .000 , e 568.000 de incapacidades decorrentes desta[...]. A prevalência pontual de1,6\% em homens e 1,4\% em mulheres, e a de incapacidade 29,5\% em homens e de 21,5\% em mulheres [...] (BENSENOR et al., 2013). 
Além do mais, as doenças cerebrovasculares ocupam o segundo lugar entre as que mais matam, em ordem mundial, perdendo apenas para as cardiovasculares. As pesquisas indicam que esta posição tende a se manter até o ano de 2030 (BRASIL,2013.)

Porém, um prognóstico favorável depende muito do tempo de atendimento e de uma avalição exata dos profissionais. Tudo isso, será vital para a sobrevida do paciente (BRASIL, 2013).

O trabalho tem como objetivo geral de pesquisa conhecer as contribuições da Enfermagem na assistência a pacientes acometidos por acidente vascular cerebral isquêmico. Percebe-se, nesse momento, que a meta, em saber se as contribuições da Enfermagem são efetivas, foi atingida. Haja vista que todas as literaturas analisadas reafirmam as contribuições da Enfermagem como estratégias eficazes na redução de sequelas.

Os passos eleitos para se chegar a satisfação da pesquisa, foram os seguintes: explicar o desencadeante do Acidente Vascular Cerebral; descrever a assistência de Enfermagem na Unidade de Terapia Intensiva voltada a pacientes com acidente vascular cerebral; Avaliar a contribuição da assistência de Enfermagem frente ao paciente internado na Unidade de Terapia Intensiva em decorrência de Acidente Vascular Cerebral. Todos foram exaustivamente investigados, analisados e satisfatoriamente atingidos.

Diante desses objetivos, estabeleceu-se como questão norteadora o seguinte questionamento: Qual a contribuição de enfermagem ao paciente com AVC na UTI. Dessa forma, percebeu-se que tal questão teve resposta favorável e crucial para minimizar danos isquêmicos, utilizando atividade de reabilitação, e com isso alcança-se bons resultados para a continuidade de uma vida menos penosa.

A pesquisa partiu da seguinte pergunta de pesquisa: Qual o fator fundamental que ainda é motivo de tantas sequelas isquêmicas?

O fator chave nas sequelas de AVC isquêmico tem relação com o tempo de chegada nos Hospitais e identificação rápida da patologia. Entretanto, assim que dão entrada nas Unidades Hospitalares, todos os cuidados são realizados, pois existe protocolo de atendimento voltado ao paciente com AVC.

Este estudo, desenvolveu-se a partir de uma pesquisa de finalidade básica estratégica, com objetivo descritivo, e abordagem qualitativa e executado por meio de levantamento bibliográfico. Teve como limitações o tempo restrito e escassez de documentos que aborde a assistência de enfermagem a pacientes com Acidente Vascular Cerebral, em Unidade de Terapia Intensiva.

Recomenda-se a continuidade do trabalho, com disposição de um tempo maior para a busca de mais documentos. 


\section{REFERÊNCIA BIBLIOGRÁFICA:}

ALEGRIA; M.A. et al. Medidas generales y cuidados intensivos del AVC agudo. Rev Invest Clín. 2002;54(3):262-5.

BENSENOR, Isabela M. et al. Prevalência de acidente vascular cerebral e de incapacidade associada no Brasil: Pesquisa Nacional de Saúde - 2013. Arquivos de Neuro-Psiquiatria, São Paulo, v. 73, n. 9, p. 746750, set. 2015. Disponível em: < http://bvsms.saude.gov.br/edicoes-2016/is-n-1/2213-acidente-vascular-cerebral>Acesso: 07 fev. 2020.

BRASIL. Ministério da Saúde .Departamento de Atenção Especializada . Manual de rotinas para atenção

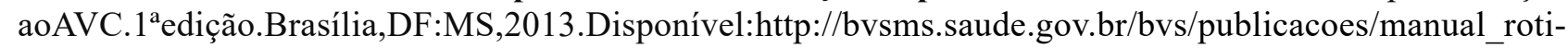
nas_para_atencao_avc.pdf. Acesso: 23 fev. 2020

BRASIL. Ministério da Saúde. Gabinete do Ministro. Portaria n 551/GM, de 13 de abril de 2005. Requisitos Comuns para Unidades de Terapia Intensiva de Adultos do Mercosul. In: Brasil. Ministério da Saúde [Internet]. Brasília; 2005[cited 2014 Dec 22]; Available from: Disponível em: http://dtr2001.saude.gov.br/sas/ PORTARIAS/Port2005/GM/GM-551.htm.Acesso 27 fev. 2020

BRASIL. Ministério da Saúde. Informações de saúde TABNET- Estatísticas vitais. Datasus. [internet]. [Citado em 2016 nov 22]. Disponível em: http://tabnet.datasus.gov.br.Acesso 23 de março

BRASIL. Ministério da Saúde. Manual de rotinas para atenção ao AVC .Brasília,2013.Disponível em: $<$ http://www.redebrasilavc.org.br/para-profissionais-de-saude/manual-de-rotinas/...> Acesso:07 fev. 2020.

BRASIL. Ministério da Saúde. Secretaria de Atenção à Saúde Departamento de Ações Programáticas Estratégicas Diretrizes de Atenção à Reabilitação da Pessoa com AcidenteVascularCerebral.Brasília,2013. Disponívelem: $<$ http://bvsms.saude.gov.br/bvs/publicacoes/diretrizes_atencao_reabilitacao_acidente_vascular_cerebral.pdf $>$ Acesso: 07 fev. 2020.

BRASIL. Ministério da Saúde. Acidente Vascular Cerebral. Brasília-DF, 2015.Disponível em:http://bvsms. saude.gov.br/dicas-em-saude/2188-avc-acidente-vascular-cerebral. Acesso 8 de fev. 2020.

BRASIL. Ministério da Saúde. Gabinete do Ministro. Portaria n 551/GM, de 13 de abril de 2005. Requisitos Comuns para Unidades de Terapia Intensiva de Adultos do Mercosul. In: Brasil. Ministério da Saúde [Internet]. Brasília; 2005[cited 2014 Dec 22]. Disponível em: http://dtr2001. saude.gov.br/sas/PORTARIAS/ Port2005/GM/GM-551.htm.Acesso em:11mar. 2020

BRUNNER;SUDDART.Tratado de Enfermagem Medico-Cirúrgica.12.ed.Rio de Janeiro: Guanabara Koogan,2014.

CANUTO; NOGUEIRA; ARAÚJO. Qualidade de vida relacionada à saúde de pessoas após acidente vascular cerebral.Enferm. 2016; 29(3):245-52. 245. Disponível em: http://www.scielo.br/pdf/ape/ v29n3/19820194ape29030245.pdf.Acesso em8 de fev. 2020.

CAMBIER;MASSON;DEHEN. Neurologia .Sistema Nervoso. $11^{\circ}$ Edição.Rio de Janeiro:Guanabara Koogan, 2005.

FERREIRA; A. M. et al. Diagnóstico de enfermagem em terapia intensiva: mapeamento cruzado e Taxonomia da NANDA-I.Revista Brasileira de Enfermagem.São Paulo-SP, 2015. Disponível em: http://www. scielo.br/pdf/reben/v69n2/0034-7167-reben-69-02-0307.pdf. Acesso 22 fev 2020.

HERDMAN;TH. Diagnósticos de enfermagem da NANDA Internacional: definições e classificação 20122014. 2 ed. Porto Alegre: Artmed; 2013

HIGA; ATALLA. Guias de medicina ambulatorial e hospitalar- UNIFESP.Escola paulista de medicina.1.ed. São Paulo;Manole Ltda,2004. 
MANIVA; SJCF, et al. Vivendo o acidente vascular encefálico agudo: significados da doença para pessoas hospitalizadas. Rev Esc Enfermagem. USP [Internet]. 2013[cited 2015 Apr 22];47(2):362-8. Available from: http://www.scielo.br/pdf/reeusp/v47n2/en_13.pdf.

MARITE; $\mathrm{k}$. The role of nursing in the rehabilitation of acute strokem patients: toward a unified theoretical perspective.Adv Nurs Sci. 1997; 19(4):55-64

MELTZER; SC, et al. Tratado de Enfermagem médico-cirúrgica. 10.ed. Rio de Janeiro: Guanabara Koogan; 2005.

NETO; TAKAYANAGUI.Tratado de neurologia da academia brasileira de neurologia. $1^{\circ}$ Edição. Rio de Janeiro: Elsevier,2013.

OLIVEIRA, E. M, et al. Ambiente das práticas de enfermagem e satisfação profissional em unidades críticas. Revista Brasileira de Enfermagem. v.70, n.1, p. 1-8, Brasília, 2017.

OREM DE. Nursing concepts of pratice. 5th ed. Saint Louis: Mosby; 1995.

PERLINI ; FARO. Cuidar da pessoa incapacitada por acidente vascular cerebral no domicílio: $O$ fazer do cuidador familiar. Rev Esc Enfrem USP 2005; 39(2): 154-63.

PIRES; STARLING.Manual de Urgência em Pronto Socorro. 7.ed.Rio de Janeiro,2002.

PIRES; STARLING. Manual de urgência em pronto socorro. 9.ed. Rio de Janeiro: Guanabara Koogan, 2010.

RYERSON,SD.Hemiplegia. In: Umphred DA, organizador. Reabilitação neurológica. 4a ed. Barueri: Manole; 2004. p.782- 830. 7. Anderson TP. Reab

SOCIEDADE BENEFICENTE ISRAELITA BRASILEIRA. Acidente Vascular Cerebral Isquêmico. Disponível em: https://www.einstein.br/doencas-sintomas/avc/avc-isquemico. Acesso: 8 de fev. 2020.

SUMMER, D; et al. Comprehensive overview of nursing and interdisciplinary care of to the acute ischemic stroke patient. Stroke. 2009;40(8):2911-44.

WORLD HEALTH ORGANIZATION. Health statistics and information systems - Projections of mortality and causes of death, 2015 and 2030. [Internet]. Geneva; 2013. [Cited in 2016 Nov 22]. Available from: http:// www.who.int/healthinfo/global_burden_disease/projections/em.

WORLD HEALTH ORGANIZATION. The top 10 causes of death. [Internet] Geneva; 2014. [Cited in 2016 Nov 22]. Available from: http://www.who. int/mediacentre/factsheets/fs310/em.

CARTILHA MINISTERIO DA SAÚDE.2015. https://bvsms.saude.gov.br/bvs/publicacoes/diretrizes_atencao_reabilitacao_acidente_vascular_cerebral.pdf Diretrizes de Atenção à Reabilitação da Pessoa com Acidente Vascular Cerebral 


\section{FATORES RELACIONADOS AO REGANHO DE PESO APÓS A CIRURGIA BARIÁTRICA}

LUCIANA PEREIRA DA COSTA ${ }^{1}$

SIMONE APARECIDA FERNANDES DA

SILVA $^{1}$

EDER FERREIRA DE ARRUDA ${ }^{1,3}$

FRANCIELY GOMES GONÇALVES ${ }^{1,2,3}$

ADRIANA MARINHO PEREIRA DAPONT $^{1,3}$

MATEUS RODRIGUES LIMA ${ }^{1}$

RODRIGO DAMINELLO RAIMUNDO ${ }^{2}$

NATÁLIA DA SILVA FREITAS

MARQUES ${ }^{1,2,3}$

RESUMO: Introdução: A obesidade é considerada uma epidemia global, caracterizada pelo excesso de gordura no organismo. Uma das opções terapêuticas é através da Cirurgia bariátrica (CB), entretanto pacientes que são submetidos à mesma costumam acreditar que ela será a cura para obesidade, no entanto é necessária uma mudança comportamental para que haja perda de peso acentuada. Objetivo: Descrever os fatores relacionados ao reganho de peso após a cirurgia bariátrica. Método: Para atender ao objetivo estabelecido, será realizado um levantamento das produções científicas referentes ao tema com o cruzamento dos descritores "Bariatric Surgery" and "Weight Gain" nos buscadores BVS e PUBMED. Os artigos identificados serão examinados quanto aos critérios de inclusão: artigos científicos publicados em revista, gratuitos, nos idiomas português e inglês, de todos os delineamentos (exceto revisão, metanálise, estudos de caso, manuais e cartas ao editor) e publicados nos últimos 10 anos. Serão excluídos do estudo, artigos com informações insuficientes, indisponíveis e que não atendiam à proposta da pesquisa. Resultados: O reganho de peso está muito presente no PO de CB, em especial no primeiro ano após a cirurgia, sendo os fatores de risco à este reganho a urgência alimentar inicial, diminuição de bem-estar, preocupação com o comportamento aditivo, atividade laboral executada, não adesão à reeducação alimentar, manutenção de estilo de vida inadequado e ainda alteração do volume gástrico residual após a cirurgia. Mediante o aumento do peso corporal após a $\mathrm{CB}$, o uso de Liraglutido tem surtido efeito na redução do peso, entretanto alguns pacientes apresentaram náusea, ou desistiram pelo custo inviável do medicamento. Conclusão: A exposição à um procedimento invasivo como a CB pode ser em vão quando os pacientes apresentam urgência alimentar inicial, diminuição de bem-estar, preocupação com o comportamento aditivo, atividade laboral executada, não adesão à reeducação alimentar, manutenção de estilo de vida inadequado e ainda alteração do volume gástrico residual após a cirurgia.

\footnotetext{
1 Laboratório de Práticas de Pesquisa Científica. Centro Universitário Uninorte, Rio Branco, AC, Brasil.

2 Laboratório de Delineamento de Estudos e Escrita Científica. Centro Universitário FMABC, Santo André, SP, Brasil.

3 Laboratório Multidisciplinar de Estudos e Escrita Cientifica em Ciências da Saúde. Universidade Federal do Acre, Rio Branco, AC, Brasil. Centro Universitário Uninorte, Rio Branco, Acre, Brasil.
} 
PALAVRA-CHAVE: Cirurgia bariátrica. Reganho de peso. Fisioterapia.

\begin{abstract}
Introduction: Obesity is considered a global epidemic, characterized by excess fat in the body. One of the therapeutic options is through bariatric surgery (CB), however patients who undergo it usually believe that it will be the cure for obesity, however a behavioral change is necessary for severe weight loss. Objective: To describe the factors related to weight regain after bariatric surgery. Method: To meet the established objective, a survey of the scientific productions related to the theme will be performed with the crossing of the descriptors "Bariatric Surgery" and "Weight Gain" in the search engines VHL and PUBMED. The articles identified will be examined for inclusion criteria: free scientific articles published in Portuguese and English, from all the designs (except review, meta-analysis, case studies, manuals and letters to the editor) and published in the last 10 years. Will be excluded from the study, articles with insufficient information, unavailable and that did not meet the research proposal. Results: Weight regain is very present in the OP of CB, especially in the first year after surgery, and the risk factors for this regimen are the initial food urgency, decreased welfare, concern with addictive behavior, work activity. performed, non-adherence to dietary reeducation, maintenance of inadequate lifestyle and alteration of residual gastric volume after surgery. Due to the increase in body weight after $\mathrm{CB}$, the use of Liraglutide has had an effect on weight reduction, however some patients presented nausea, or gave up for the unfeasible cost of the drug. Conclusion: Exposure to an invasive procedure such as $\mathrm{CB}$ can be in vain when patients present with initial food urgency, decreased well-being, concern about addictive behavior, performed work activity, non-adherence to food reeducation, maintenance of lifestyle. inadequate and residual gastric volume alteration after surgery.
\end{abstract}

KEYWORDS: Bariatric surgery. Weight regain. Physiotherapy.

\title{
INTRODUÇÃO
}

A obesidade é o acúmulo de gordura corporal em excesso, afetando a saúde e o bem-estar do indivíduo. Médicos do mundo inteiro tem se mobilizado para prevenir e tratar essa doença (PÉREZ et al., 2017).

Estima-se que 600 milhões de pessoas no mundo são acometidas pela obesidade. Sendo que $5 \%$ dessa população se encontra no Brasil, responsável pelo gasto de $10 \%$ da saúde pública (GOSLAN et al., 2018)

Em 1991 o Instituto de Saúde Norte Americana estabeleceu os primeiros critérios para indicação de tratamento cirúrgico para obesidade. Com o passar dos anos foram acrescentadas novas indicações. As indicações formais atuais são: idade média entre 18 e 65 anos, IMC $>40 \mathrm{~kg} / \mathrm{m}^{2}$ ou 35 $\mathrm{kg} / \mathrm{m}^{2}$ com comorbidades graves associadas a obesidade (PÉREZ et al., 2017).

As comorbidades mais comuns são: hipertensão, diabetes, artropatias, apneia, dislipidemia e tabagismo, e a quantidade destas é um fator relevante nas complicações no pós-operatório (KELLES et al., 2015). 
Pacientes que são submetidos à cirurgia bariátrica $(\mathrm{CB})$ costumam acreditar que ela será a cura para obesidade, no entanto é necessária uma mudança comportamental para que haja perda de peso acentuada. $\mathrm{O}$ número de pacientes que recuperam peso chega a ser bem acentuado de $7 \%$ a $50 \%$ sendo que entre 20 a 25\% do peso é recuperado em dez anos (ABREU et al., 2015).

Entretanto tal procedimento pode gerar algumas complicações como: mudanças no parâmetro comportamental, sentimental/cognitivo, levando o paciente a desenvolver compulsão alimentar periódica (PRAZERES et al., 2017).

Diante do exposto, esse artigo tem como propósito estudar artigos que abordem os fatores relacionados ao reganho de peso após a CB.

\section{MATERIAIS E MÉTODO}

Este artigo trata-se de um estudo de revisão sistemática sobre os fatores relacionados ao ganho de peso após a $\mathrm{CB}$.

Para atender ao objetivo estabelecido, foi realizado um levantamento das produções científicas referentes ao tema com o cruzamento dos descritores "Bariatric Surgery" and "Weight Gain" nos buscadores BVS (bases de dados: MEDLINE, LILACS, IBECS e Index Psicologia) e PUBMED (base de dados: MEDLINE). Os buscadores foram configurados para localizar as referências que apresentavam os descritores supramencionados entre o título, resumo e assunto. Esse método foi adotado para viabilizar um alcance de resultados mais precisos do que os que poderiam ser encontrados caso não houvesse tais especificações. Optou-se pelo emprego dos descritores mencionados levando-se em consideração que são reconhecidos pelas bases de dados pesquisadas e utilizados de forma corrente na literatura científica especializada, mais especificamente cadastrada nos Descritores em Ciências da Saúde (DECS).

Os artigos identificados foram examinados quanto aos critérios de inclusão: artigos científicos publicados em revista, gratuitos, nos idiomas português e inglês, de todos os delineamentos (exceto revisão, metanálise, estudos de caso, manuais e cartas ao editor) e publicados nos últimos 10 anos. Foram excluídos do estudo, artigos de outras bases de dados, realizados em animais, informações insuficientes, indisponíveis e que não atendiam à proposta da pesquisa.

O detalhamento das informações dos artigos foi realizado após a leitura rigorosa de duas pesquisadoras, através de planilhas onde se incluíram os dados: autor, ano, objetivo, amostra, sexo, idade, tipo de cirurgia e fatores relacionados ao reganho de peso.

Para garantir uma melhor estruturação e organização dos resultados e posteriormente o artigo, foram utilizados o checklist PRISMA e o Fluxograma de seleção de citação de revisão de literatura propostas por Moher e colaboradores (2009). 
A busca inicial oriunda dos 01 cruzamentos em 02 buscadores resultou em 912 artigos, porém apenas 08 estudos corresponderam aos critérios de inclusão. $\mathrm{O}$ desenrolar da busca até os resultados estão apresentados nas Figuras 1 e 2.

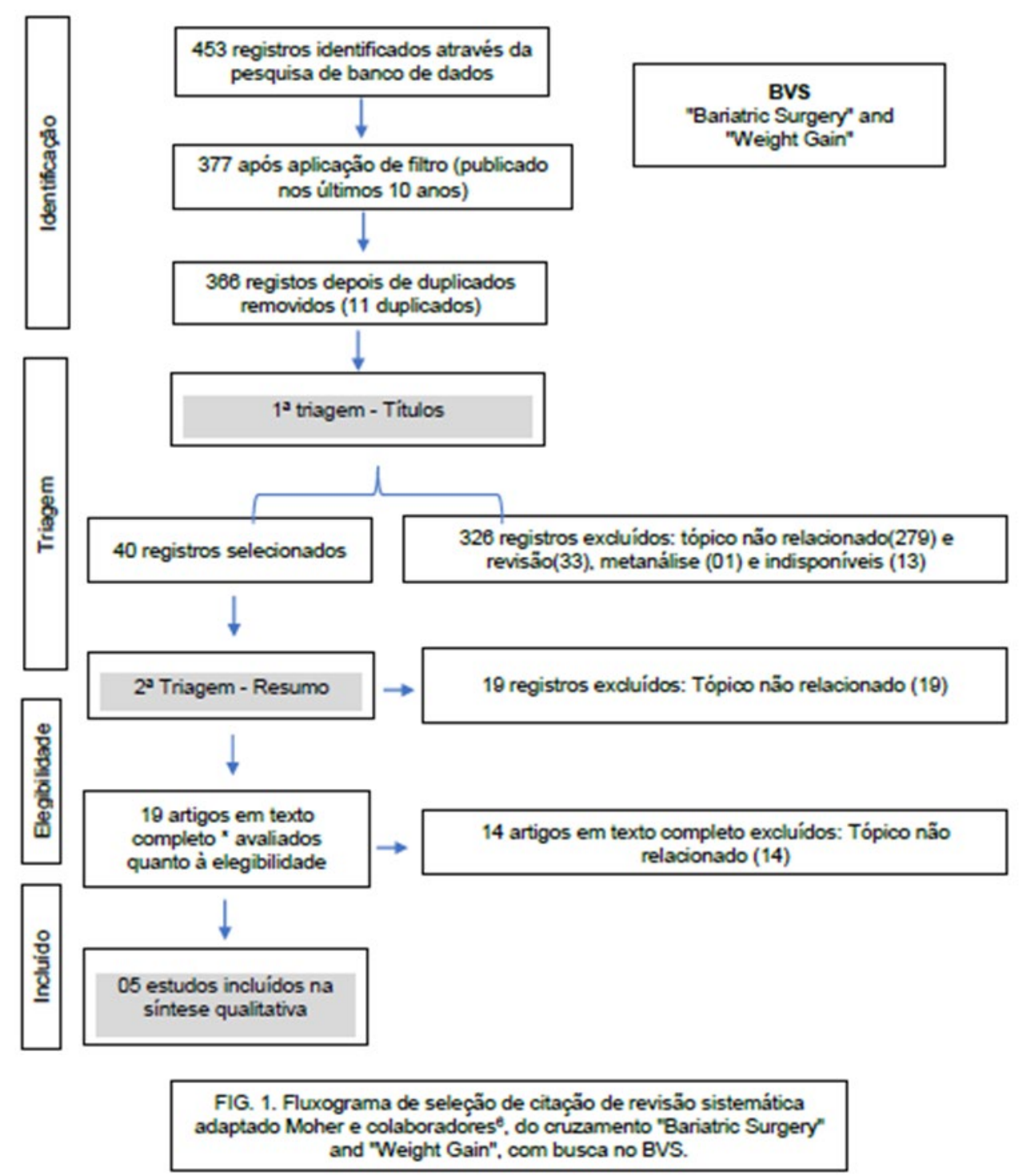




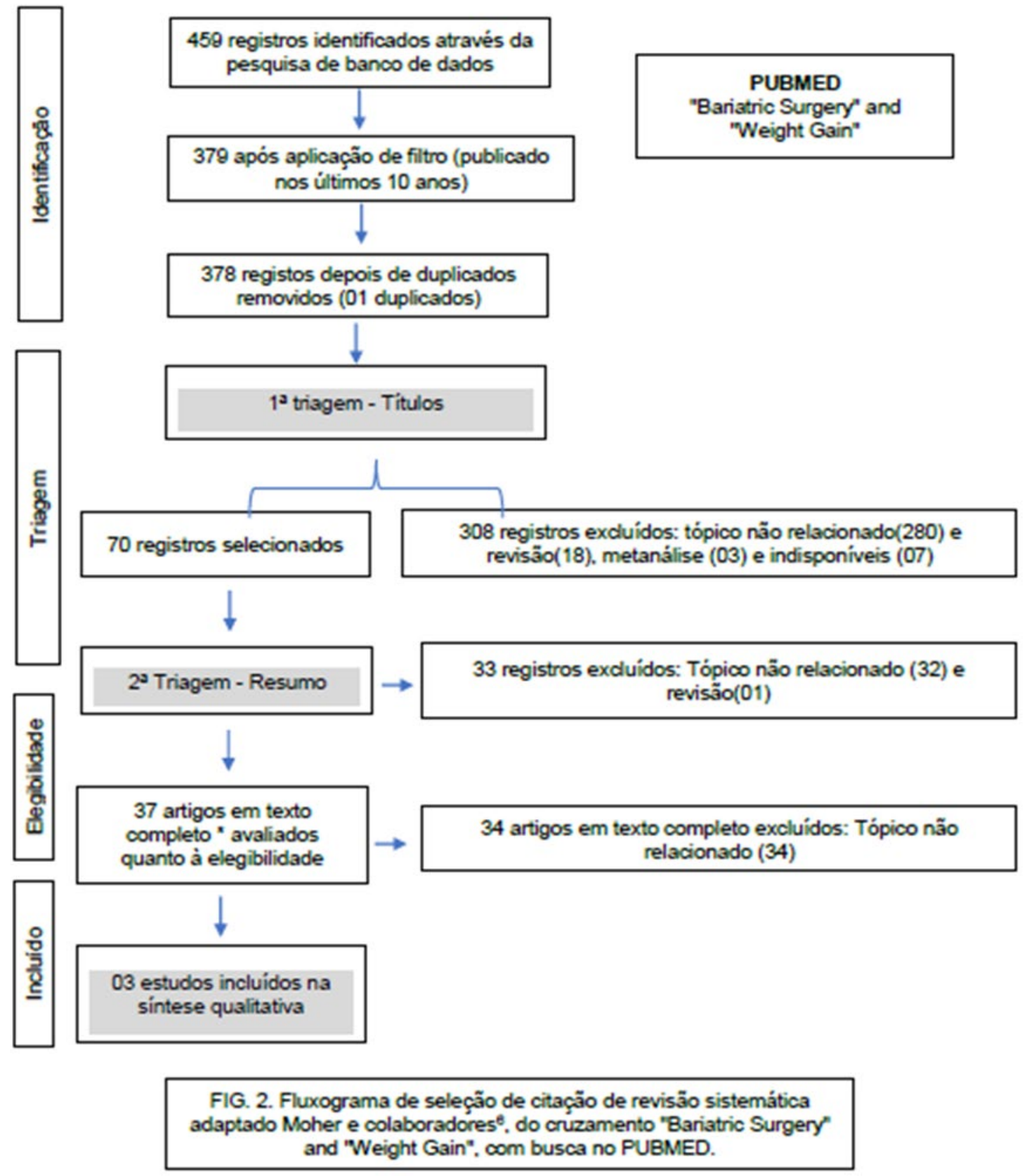




\section{RESULTADOS E DISCUSSÃO}

Esse artigo revisou os estudos que abordavam os fatores relacionados ao reganho de peso após a CB, e estão apresentadas na Tabela 1.

Tabela 1 - Caracterização dos estudos selecionados por autor, amostragem, parâmetros mensurados e resultados.

\begin{tabular}{llll}
\hline Autores/Ano & Amostragem & Objetivo & Implicações \\
\hline ODOM et al., 2010. & $\begin{array}{l}\text { 1.117 pacientes adultos, de } \\
\text { ambos os sexos, faixa etá- } \\
\text { ria de } 52 \text { a } 98 \text { anos. }\end{array}$ & $\begin{array}{l}\text { Identificar preditores que } \\
\text { possam levar pacientes a }\end{array}$ & Os preditores de recuperação \\
obesidade extrema após o & -operatóriva de cirurgia bariátrica \\
& Bypass gástrico de Roux. & incluem indicadores de urgência \\
& & & $\begin{array}{l}\text { alimentar inicial, diminuição do } \\
\text { bem-estar e preocupações com o } \\
\text { comportamento aditivo. }\end{array}$
\end{tabular}

KING et al.,

2018.
1.406 pacientes adultos, de ambos os sexos, mediana de idade de 47 anos.
Descrever o ganho de
peso após atingir o peso do nadir, após a cirurgia de derivação gástrica em $\mathrm{Y}$ de Roux e comparar medidas de recuperação de peso para associação com desfechos.
A taxa de reganho de peso foi maior durante o primeiro ano após atingir o peso, mas o reganho de peso continuou a aumentar durante o seguimento (variação de mediana de 9,5\% do peso máximo perdido [2575 percentil, $4,7 \%-17,2 \%$ ] para $26,8 \%$ do peso máximo perdido [percentil 25-75, 16,7\% -41 . $5 \%$ ] 1 a 5 anos após atingir o peso do nadir).

BASTOS et al., 2013.

64 pacientes, ambos os se- Identificar os determixos, com idade de 41,76 \pm 7,93 anos e média de pós-operatório de 53,4 $\pm 18,4$ rurgia pós-bariátrica. meses.
O peso significativo recuperado ocorreu em $18(28,1 \%)$ casos. O pós-operatório médio de $66 \pm$ 8,3 meses e as atividades laborais relacionadas à alimentação apresentaram significância estatística $(\mathrm{p}=000$ e $\mathrm{p}=0,003)$ para o peso recuperado.

O tempo médio de pós-operatório de $66 \pm 8,3$ meses e a atividade laboral relacionada à alimentação apresentaram significância estatística ( $\mathrm{p}=000$ e $\mathrm{p}=0,003)$ para o reganho ponderal. 
Tabela 1 - Caracterização dos estudos selecionados por autor, amostragem, parâmetros mensurados e resultados.

\begin{tabular}{|c|c|c|c|}
\hline Autores/Ano & Amostragem & Objetivo & Implicações \\
\hline RODRIGUES, 2014. & $\begin{array}{l}1 \text { paciente, sexo feminino, } \\
\text { idade } 20 \text { anos. }\end{array}$ & $\begin{array}{l}\text { Aplicar uma intervenção } \\
\text { comportamental para } \\
\text { adequação do apoio so- } \\
\text { cial em cuidador de pa- } \\
\text { ciente com reganho de }\end{array}$ & $\begin{array}{l}\text { O reganho de peso está direta- } \\
\text { mente relacionado com a não } \\
\text { adesão à dieta e não modifica- } \\
\text { ção de estilo de vida em longo } \\
\text { prazo. }\end{array}$ \\
\hline
\end{tabular}

peso pós-CB

Verificar os efeitos da intervenção mediante a avaliação da percepção do paciente sobre a disponibilidade e satisfação com o apoio social e do peso corporal, antes (linha de base), imediatamente após (momento 2) e um mês depois da intervenção (momento 3).

ALVAREZ et al.,2016.
40 pacientes submetidos a GE (32 mulheres, 8 homens; idade 42,9 $\pm 10,7$ anos; índice de massa corporal pré-operatório de 35 $\left.\pm 2,8 \mathrm{~kg} / \mathrm{m}^{2}\right)$.
Investigar fatores que $\mathrm{O}$ fator mais importante assoestão relacionados com ciado à recuperação de peso em o peso recuperado no longo prazo após MG foi o volongo prazo após manga lume gástrico residual. Estudos gastrectomia (MG). prospectivos adicionais com maior número de pacientes são necessários para confirmar nossos resultados.

PAJECKI et al., 2013.

Os autores realizaram uma Avaliar os resultados do análise retrospectiva de 15 operados pacientes que tinham excesso de peso perda $<50 \%$ após dois anos de follow-up ou recuperou peso, mais de $15 \%$ do mínimo atingido peso. Foram incluídos apenas os pacientes que tinham a "anatomia cirúrgica" esperada, avaliada por radiografia contrastada e endoscopia. A média de idade foi de 47,2 $\pm 12,5$ anos.

CARVALHO JUNIOR et Oito mulheres, que recupeal., 2014. um grupo de pacientes $\pm 12,1 \mathrm{~kg}$. O peso médio foi sigsubmetidos a tratamento nificativamente reduzido após cirúrgico de obesidade o tratamento com liraglutido mórbida com perda insa- $(100,9 \pm 18,3 \mathrm{~kg}$ vs. $\mathrm{Kg} 93,5 \pm$ tisfatória de peso ou recu- $17,4, \mathrm{p}<0,0001)$. Seis pacientes peração de mais de $15 \%$ tiveram náusea e dois interromdo peso mínimo atingido. peram a terapia devido ao custo da medicação.

O objetivo deste estudo foi avaliar o significado emocional, para as mulheres, de recuperar $o$ peso após o MBS.
Foram identificadas quatro categorias: 1) recuperação de peso: derrota e falha; 2) ausência de arrependimento e certeza de sucesso; 3 ) experiência de abandono; e 4) perda da autoestima: risco de isolamento social 
Diante dos estudos analisados observou-se relatos importantes de reganho de peso após a CB(ODOM et al., 2010; KING et al., 2018; BASTOS et al., 2013; RODRIGUES, 2014; ALVAREZ et al.,2016; PAJECKI et al., 2013; CARVALHO JUNIOR et al., 2014), sendo que o maior ganho de peso acontece no primeiro ano após a cirurgia (KING et al., 2018).

Este reganho de peso pode ocorrer naqueles pacientes em que não houve acompanhamento junto a um profissional nutricionista, antes de iniciar o procedimento cirúrgico. Este acompanhamento é bastante vantajoso, quando se trata de manutenção de peso pós intervenção, visto que, esses pacientes quando acompanhados desde a fase pré-operatória apresentam uma melhor adesão ao tratamento, isto é, aderem com mais eficiência as recomendações quanto a educação alimentar. Isto posto, entende-se que as dificuldades na reeducação alimentar podem influenciar em recidiva de aumento do peso corporal (BARDAL; CECCATTO; MEZZOMO, 2016; SOARES et al., 2017).

Em outro estudo, é dito que, erros técnicos durante a operação, em especial aqueles métodos que possui ação puramente restritiva, é outro fator relacionado ao aumento ponderal, assim como, a seletividade nutricional inadequada, sendo esta, motivada ou não, por distúrbios psiquiátricos (PAJECKI, et al., 2013).

Diferente do encontrado nesta revisão, Bardal, Ceccatto e Mezzomo (2016) estimam que pelo menos metade dos pacientes que passam pelo procedimento cirúrgico, recuperam o peso anterior à intervenção, após cinco anos do tratamento.

Já no estudo de Soares e colaboradores (2017) o reganho de peso tende a ocorrer no segundo ano após a realização do tratamento, e este reganho ocorre pelo fato de aderirem à práticas inadequadas, que na maioria das vezes são estimuladas por crenças alimentares. Contudo, não deixa dúvidas que a partir do sexto mês pós-cirúrgico já começa a haver uma adaptação da quantidade de alimento ingerido, o que incita o indivíduo a colocar em prática hábitos alimentares indevidos, que certamente, é um fator de risco importante para reganho ponderal.

Estão relacionados a este reganho a urgência alimentar inicial, diminuição de bem-estar, preocupação com o comportamento aditivo (ODOM et al., 2010), atividade laboral executada, não adesão à reeducação alimentar, manutenção de estilo de vida inadequado e ainda alteração do volume gástrico residual após a cirurgia (BASTOS et al., 2013; RODRIGUES, 2014; ALVAREZ et al.,2016; PAJECKI et al., 2013).

A falta de cuidados com os alimentos e o sedentarismo são os grandes fatores que contribuem para a diminuição do bem-estar dos pacientes após a CB. Nesse estágio em que o órgão digestivo é relativamente reduzido, não muda somente a vontade de comer, o organismo também se transforma passando por mudanças que se elevam além da perda de peso, exigindo do organismo um ajuste completo de estilo de vida após a intervenção cirúrgica (SILVA; HELENO, 2012).

A displicência em relação ao estilo de vida associada à menor absorção de vitaminas e minerais resulta em efeitos imediatos e de longo prazo que podem levar a graves problemas ósseos, fisiológicos e até neurológicos. Portanto é importante que o paciente desenvolva hábitos de vida mais saudáveis, para que esses efeitos se tornem menos nocivos (SILVA; HELENO, 2012). 
Já o comportamento aditivo, tido como fator de risco para reganho ponderal, é definido como compulsão e obsessão, que é designado à uma condição psicopatológica que atinge a população de forma geral, independentemente de idade e sexo. É visto que, o reganho de peso está diretamente associado a esses episódios, pois boa parte dos pacientes apresenta compulsão alimentar prévia e a maioria das vezes continua com esse comportamento após o tratamento cirúrgico, o que se torna um preditivo importantíssimo para a recidiva de peso (MACHADO et al., 2016).

Em relação às atividades laborais observam-se que pacientes que exercem atividade laboral relacionada à alimentação, passaram a apresentar aumento de peso no pós-operatório, quando comparado com pacientes de outras profissões ${ }^{9}$. Outro fator relacionado às atividades laborais, é que em indivíduos que abandonaram as mesmas, aparecia reações de estresse à ociosidade, aumentando o comportamento aditivo, gerando reganho de peso (BIRCK, 2017).

A adesão de padrões ou hábitos não saudáveis pode acontecer ainda em virtude de condições psiquiátricas como, por exemplo, a compulsão alimentar, fator muito frequente nessa população. E deixa claro que apesar do tratamento cirúrgico ser capaz de minimizar esse quadro compulsivo, há possibilidades de o paciente permanecer no mesmo estilo de vida que costumava ter antes do tratamento (SOARES et al., 2017).

Machado e colaboradores (2016) corroboram com os dados de Soares e colaboradores, ao reafirmar que a maior dificuldade de adesão a um bom estilo de vida está intimamente relacionada a fatores psíquicos e emocionais. Entretanto, ainda pode haver outros fatores externos, como os que se refere ao meio social em que esse indivíduo pertence.

Manter um estilo de vida saudável não é uma tarefa fácil, uma vez que depende de fatores extrínsecos e intrínsecos, como retratados anteriormente. O principal objetivo da gastroplastia é a cura da obesidade, porém outros problemas como, transtornos psíquicos e emocionais tendem a continuar após o ato cirúrgico, um quadro bastante referido com difícil controle, devido a isso, utiliza o alimento como fuga dos problemas relacionados ao seu estado emocional (KORTCHMAR et al., 2018).

Outro ponto abordado e relacionado ao reganho de peso após a CB é a alteração do volume gástrico residual, que pode gerar um aumento da velocidade de esvaziamento gástrico, pela diminuição da complacência secundária ao menor volume e ausência do piloro (LE ROUX et al., 2016).

Mediante o aumento do peso corporal após a CB, clinicamente os profissionais tem adotado o medicamento Liraglutido na tentativa de diminuir a massa corpórea. Tal tratamento medicamentoso tem surtido efeito na redução do peso, entretanto alguns pacientes apresentaram náusea, ou desistiram pelo custo inviável do medicamento (PAJECKI et al., 2013).

O Liraglutido é uma substância que foi desenvolvida especialmente para tratar pacientes diabéticos, sobretudo, a diabetes mellitus tipo II. Seu mecanismo de ação é por meio de estímulos que acontece nas células betas pancreáticas, células responsáveis por produzir insulina. Esse princípio ativo simula a mesma ação do hormônio GLP-1. Esta substância promove a sensação de saciedade, como resultado, o indivíduo tende a ingerir porções menores de alimento, isso deve-se à sua ação 
diretamente no hipotálamo, região responsável por essas sensações, e o retardo do esvaziamento gástrico, o que resulta em perda de peso (MORANTE; GALENDE, 2016).

Entretanto tal substância gera no organismo do paciente náuseas, vômitos e hiperamilasemia (PAJECKI et al., 2013). Além dos efeitos colaterais citados, este princípio ativo ainda pode causar doenças inflamatórias intestinais, gastroparesia diabética, pancreatite, bócio, neoplasia tireoidiana e disfunções renais (MORANTE; GALENDE, 2016).

Além dos diversos efeitos colaterais, tal substância é ofertada no mercado brasileiro com alto custo, que equivale à um gasto de 250 dólares por mês (PAJECKI et al., 2013).

\section{CONCLUSÕES}

A exposição à um procedimento invasivo como a $\mathrm{CB}$ pode ser em vão quando os pacientes apresentam urgência alimentar inicial, diminuição de bem-estar, preocupação com o comportamento aditivo, atividade laboral executada, não adesão à reeducação alimentar, manutenção de estilo de vida inadequado e ainda alteração do volume gástrico residual após a cirurgia.

Assim sendo, a CB é um meio de alcançar o objetivo de reduzir o peso, devendo ser associado não apenas por uma assistência multiprofissional, mas também exige empenho e determinação do paciente, através da manutenção de uma novo estilo de vida para obter a composição corporal ideal, acompanhada de uma boa qualidade de vida, e diminuição da morbimortalidade à qual estavam anteriormente expostos.

\section{REFERÊNCIAS}

ABREU, R. et al. Apoio Social e reganho de peso pós-cirurgia bariátrica: estudo de caso sobre intervenção com cuidador. Revista Temas em Psicologia, v. 23, n. 4, p. 7-13, 2015.

ABREU-RODRIGUES, M. Apoio social e reganho de peso pós cirurgia bariátrica: efeitos de intervenção comportamental com cuidadores. 2014. 82 f. Tese (Doutorado em Processos de Desenvolvimento Humano e Saúde) - Psicologia da Saúde, Universidade de Brasília. Brasília, 2014.

ALVEREZ, V. et al. Mechanisms of long-term weinht regain in patients undergoing sleeve gastrectomy. Journal of Nutrition, v. 32, n. 3, p. 303-308, 2016.

BARDAL, A. G.; CECCATTO, V.; MEZZOMO, T. G. Fatores de risco para recidiva de peso no pós-operatório tardio de cirurgia bariátrica. Revista Scientia Medica, v. 26, n. 4, p. 1-7, 2016.

BASTOS, E. C. L. et al. Fatores determinantes do reganho ponderal no pós-operatório de cirurgia bariátrica/ Determinants of weight regain after bariatric surgery, Arquivos Brasileiros de Cirurgia Digestiva, v. 26, sup. 1, p. 26-32, 2013. 
BIRCK, M. D. "Comer para preencher": uma compreensão psicológica do reganho de peso após a cirurgia bariátrica. 2017. 160 f. Tese (Doutorado em Psicologia Clínica e Cultura) Psicologia Clínica, Universidade de Brasília. Brasília 2017.

CARVALHO JÚNIOR, A. et al. Reganho de peso em mulheres após cirurgia metabólica e bariátrica: estudo qualitativo no Brasil. Trends in Psychiatry and Psychotherapy, v. 36, n. 3, p. 140-146, 2014.

GOSLAN, J.C et al. Profilaxia da trombose venosa profunda em cirurgia bariátrica: estudo comparativo com doses diferentes de heparina de baixo peso molecular. Jornal Vascular Brasileiro v. 17, n. 1, p. 7-8, 2018.

KELLES, S. M. B. et al. Perfil de pacientes submetidos à cirurgia bariátrica, assistidos pelo Sistema Único de Saúde do Brasil: revisão sistemática. Cad Saúde Pública v.31, n. 8, p. 12-18, 2015.

KING, W. C.; HINERMAN, A. S.; BELLE, S. H. Comparison of the performance of common measures of weight regain after bariatric surgery for association with clinical outcomes. American Medical Association, v. 320, n. 15 , p. $1561-1569,2018$.

KORTCHMAR, E. et al. Reganho de peso após a cirurgia bariátrica: um enfoque da fenomenologia social. Revista Acta Paulista de Enfermagem, v. 31, n. 4, p. 417-422, 2018.

LE ROUX et al. Mecanismo subjacente a perda de peso e complicações do desvio gástrico em Y de Roux. Federação Internacional para a Cirurgia da Obesidade e Distúrbios Metabólicos, v. 26, n. 2, p. 410-421, 2016.

MACHADO, C. E. et al. Compulsão alimentar antes e após a cirurgia bariátrica. Arquivos Brasileiros de Cirurgia Digestiva, v. 21, n. 4, p. 185-191, 2008.

MOHER, D. et al. Preferred Reporting Items for Systematic Reviews and MetaAnalyses: The PRISMA Statement. PLOS Medicine. The PRISMA Group 2009.

MORANTE, Y. M.; GALENDE, S. B. Mecanismo de Ação da Liraglutida em Pacientes Acometidos por Diabetes Mellitus tipo II. Revista Uningá, v. 25, n. 1, p. 74-78, 2016.

ODOM, J. et al. Behavioral Predictors of weight regain after bariatric surgery. Obesity Surgery, v. 20, n. 3, p. 349-356,2010.

PAJECKI, D. et al. Tratamento de Curto Prazo Com Liraglutide no Reganho de Peso Após a Cirurgia Bariátrica. Revista do Colégio Brasileiro de Cirurgiões, v. 40, n. 3, p. 191-195, 2013.

PAJECKI. et al. Tratamento de curto prazo com liraglutide no reganho de peso após cirurgia bariátrica. Revista do Colégio Brasileiro de Cirurgiões, v. 40, n. 3, p. 191-195, 2013.

PÉREZ, L. D. S et al. Obesidade Mórbida. Revista Acta Médica v. 38, v. 8, p. 34-39, 2017.

PRAZERES, I. S. et al. Prevalência da compulsão alimentar periódica de desenvolvimento de obesidade grave. Revista Sociedade Brasileira de Clínica Médica, v. 15, n. 2, p. 27-32, 2017.

SILVA, E. C.; HELENO, M. G. V. Qualidade de Vida e Bem-Estar Subjetivo de Estudantes Universitário. Revista Psicologia e Saúde, v. 4, n. 1, p. 69-79, 2012.

SOARES, J. M. et al. Práticas Alimentares de Pacientes Em Pós-Operatório de Cirurgia Bariatrica: Revisao Integrativa. Biblioteca Virtual em Saúde, v. 32, n. 3, p. 32-33, 2017. 


\section{O CÂNCER DE MAMA E O RASTREAMENTO MAMOGRÁFICO}

DANIEL ALVARENGA FERNANDES ${ }^{1}$

FELIPE AGUERA OLIVERA ${ }^{2}$

FAIANE RODRIGUES DE SÁ ${ }^{3}$

CAIO AFFONSO NETO ${ }^{3}$

CAMILA DA SILVA AMORIM ${ }^{4}$

ADRIANA MARINHO PEREIRA DAPONT ${ }^{4,5,7}$

MATEUS RODRIGUES LIMA ${ }^{5}$

NATÁLIA DA SILVA FREITAS

MARQUES ${ }^{5,6,7}$

SAMARA MARIA MESSIAS DA SILVA ${ }^{4}$

RESUMO: O câncer de mama (CA mama) é um grave problema de saúde pública, destacando-se como o câncer de maior incidência e de maior mortalidade em mulheres em todo o mundo, inclusive no Brasil. Embora tenham sido identificados alguns fatores ambientais e comportamentais associados a um risco aumentado de desenvolver o CA mama, a compreensão acerca da etiologia da doença ainda não mostra evidências conclusivas que justifiquem a recomendação de estratégias específicas de prevenção primária. Entretanto, a prevenção secundária (detecção precoce) do CA mama é factível, destacando-se a mamografia como método de rastreamento, uma vez que apresenta capacidade de detectar lesões clinicamente inaparentes, sendo considerada por este motivo o método mais sensível para detectar precocemente o CA mama. Na busca de uma linguagem única entre os diversos centros de estudos e da uniformização de ações que tornem o rastreamento do CA mama mais eficaz na redução de sua morbimortalidade, o Colégio Americano de Radiologia (American College of Radiology - ACR) elaborou um conjunto de recomendações para a padronização de laudos de MMG que ficou conhecido pela sigla BI-RADS ${ }^{\circledR}$. Neste cenário, o nosso propósito consiste em revisar a literatura acerca do câncer de mama e da detecção através da mamografia. Para isso, será realizada uma revisão de literatura de abordagem qualitativa de natureza exploratório-descritiva. As múltiplas condições e direcionamentos para melhoria do controle do CA mama devem ser continuamente estimuladas, contribuindo assim com informações que possam vir a ser utilizadas como subsídios às políticas

1 Departamento de Radiologia, Faculdade de Ciências Médicas da Universidade Estadual de Campinas- FCM/ UNICAMP, Campinas, SP, Brasil.

2 Faculdade de Medicina de Botucatu, Universidade Estadual Paulista, UNESP, Botucatu- SP, Brasil.

3 Secretaria de Estado de Saúde de Rondônia, RO, Brasil.

$4 \quad$ Secretaria de Estado de Saúde do Acre, Rio Branco- AC, Brasil.

5 Laboratório de Práticas de Pesquisa Científica. Centro Universitário Uninorte, Rio Branco, AC, Brasil.

6 Laboratório de Delineamento de Estudos e Escrita Científica. Centro Universitário FMABC, Santo André, SP, Brasil.

7 Laboratório Multidisciplinar de Estudos e Escrita Cientifica em Ciências da Saúde. Universidade Federal do Acre, Rio Branco, AC, Brasil. Centro Universitário Uninorte, Rio Branco, Acre, Brasil. 
públicas de saúde para intervir, modificar e implementar a assistência preventiva, diagnóstica e terapêutica desta neoplasia.

PALAVRA-CHAVE: Câncer de mama; mamografia; diagnóstico por imagem.

\begin{abstract}
The breast cancer (breast CA) is a grave public health issue, being the cancer with the major incidence and mortality in women worldwide, including in Brazil. Although there have been identified some environment factors and associated behaviors to a high risk on developing the breast cancer, the comprehension about the etiology of the disease can't show yet the conclusive evidences which justify the recommendations of specific strategies on primary prevention. However, the secondary prevention (precocious detection) of the breast cancer is feasible, highlighting the mammography as a screening method, once it presents the capacity to detect lesions clinically unapparent, being considered, for this reason, the most sensitive method to detect precociously the breast cancer. In the search of an unique language among several study centers and the uniformization of the actions that become the breast cancer screening more effective in the decrease of its morbimortality, the American College of Radiology (ACR) drew up a group of recommendations to the stardardization of clinical report of MMG that have become known as BI-RADS ${ }^{\circledR}$. In this scenario, our purpose consists in reviewing the literature about breast cancer and its detection through mammography. To this end, it will be performed a literature review of qualitative approach of exploratory-described nature. The multiple conditions and directions to the improvement of breast cancer control must be constantly stimulated, thus contributing with reports that may become useful as subsides to the public politics of health intervening, modifying and implementing the preventive, diagnostic and therapeutic assistance of this neoplasia.
\end{abstract}

KEYWORDS: Breast cancer; mammography; diagnostic by image.

\title{
1. INTRODUÇÃO
}

O câncer de mama (CA mama) é um grave problema de saúde pública, destacando-se como o câncer de maior incidência e de maior mortalidade em mulheres em todo o mundo, inclusive no Brasil (WORLD HEALTH ORGANIZATION, 2007; BRASIL, 2007; BRASIL, 2008). No Estado do Acre, este câncer divide a primeira posição de neoplasia mais incidente com o câncer de colo de útero (BRASIL, 2008) e corresponde à segunda neoplasia de maior mortalidade entre as mulheres (ACRE, 2006). Além de sua elevada incidência e mortalidade, atinge mulheres em fase reprodutiva, levando a limitações estéticas e funcionais com importantes repercussões físicas e psíquicas, interferindo em sua auto-imagem e sexualidade (ARÁN, 1996; BERGAMASCO et al., 2001; ALONSO, 2002). Destaca-se ainda seu alto custo de tratamento quando detectado em fases mais avançadas (PAULINELLI et al., 2004).

Embora tenham sido identificados alguns fatores ambientais e comportamentais associados a um risco aumentado de desenvolver o CA mama, a compreensão acerca da etiologia da doença ainda não mostra evidências conclusivas que justifiquem a recomendação de estratégias específicas de prevenção primária (LAMAS et al., 2000; PASQUALETTE, 2001; BRASIL, 2004), fazendo com que 
o Ministério da Saúde indique que alguns destes fatores de risco, tais como obesidade e tabagismo, sejam alvo de ações visando a promoção de saúde da população em geral (BRASIL, 2004).

Entretanto, a prevenção secundária (detecção precoce) do CA mama é factível, destacando-se a mamografia como método de rastreamento, uma vez que apresenta capacidade de detectar lesões clinicamente inaparentes a partir de apenas 0,1 cm (GRUBE et al., 2005), sendo considerada por este motivo o método mais sensível para detectar precocemente o CA mama, em um estadio em que o índice de cura tem alcançado até 95\% (GODINHO et al., 2002; TABAR et al., 2003). Além desse fato, sabe-se que o rastreio mamográfico reduz a mortalidade em 30 a 50\% dos casos, estando comprovada sua eficácia nesse screening (HALBE, 2000; PASQUALETTE, 2001; GRUBE et al., 2005; PIATO, 2006).

Em países como Estados Unidos, Canadá, Reino Unido, Holanda, Dinamarca e Noruega, têmse observado aumento na incidência de CA mama a cada ano, mas a mortalidade vem diminuindo graças à detecção precoce pela mamografia (MMG), em especial após instituição do sistema BI-RADS ${ }^{\circledR}$ (Breast Imaging Reporting and Data System) e pelo tratamento adequado dos casos (FLETCHER, 2003; BRASIL, 2004). Por outro lado, em países como o Brasil, o aumento da incidência tem sido acompanhado pelo aumento da mortalidade (BRASIL, 2004). Embora esse quadro possa refletir também uma melhora do diagnóstico e do registro nas declarações de óbito, a principal causa apontada no Brasil refere-se ao fato de que as medidas de rastreamento e controle da doença ainda são muito deficientes (LOPES, 1995; KLIGERMAN, 2002; ABREU, 2002; PINHO et al., 2007).

$\mathrm{Na}$ busca de uma linguagem única entre os diversos centros de estudos e da uniformização de ações que tornem o rastreamento do CA mama mais eficaz na redução de sua morbimortalidade, o Colégio Americano de Radiologia (American College of Radiology - ACR) elaborou, em 1992, um conjunto de recomendações para a padronização de laudos de MMG que ficou conhecido pela sigla BI-RADS ${ }^{\circledR}$. O objetivo da sistematização é padronizar a nomenclatura de laudos, que devem possuir conclusão diagnóstica e propor conduta, ressaltando que a mamografia deve ser sempre precedida pelo exame físico e comparada com exames anteriores (AMÂNCIO et al., 2002).

No Brasil, em abril de 1998, ocorreu a I Reunião de Consenso para a padronização dos laudos mamográficos, que contou com a participação do Colégio Brasileiro de Radiologia (CBR), da Sociedade Brasileira de Mastologia (SBM) e da Federação Brasileira de Ginecologia e Obstetrícia (FEBRASGO), com o intuito de adaptar esse sistema de laudo, que é americano, às características das mulheres brasileiras. Nesta reunião, adotou-se como padrão de laudos um sistema baseado no léxico BI-RADS ${ }^{\circledR}$, também se postulando como obrigatório uma recomendação para a conduta clínica. $\mathrm{O}$ Brasil adotou a nomenclatura BI-RADS ${ }^{\circledR}$ pelos claros benefícios demonstrados pela literatura (GELLER et al., 2006; MILANI et al., 2007; KESTELMAN et al., 2007).

A demanda de realização de ações de variados níveis de atenção se faz presente na busca da diminuição da mortalidade da neoplasia mais comum entre as mulheres brasileiras (NOVAES et al., 2003). Neste cenário, o nosso propósito consiste em revisar a literatura acerca do câncer de mama e da detecção através da mamografia. Para isso, será realizada uma revisão de literatura de abordagem qualitativa de natureza exploratório-descritiva. Para a coleta de dados foram utilizadas as bases de 
dados Scientific Eletronic Library Online (SciELO), Literatura Latino-Americana e do Caribe em Ciências da Saúde (Lilacs) e National Library of Medicine National Institutes of Health dos EUA (PubMed).

\section{REVISÃO DE LITERATURA}

\subsection{FATORES DE RISCO}

Dentre os fatores de risco relacionados ao CA mama destacam-se (MENKE et al., 2007):

Epidemiologia clínica: Os fatores com associações confirmadas são: sexo feminino, idade ( $4^{\mathrm{a}}-6^{\mathrm{a}}$ décadas), história familiar, índice de massa corpórea elevado, nuliparidade, uso de terapia de reposição hormonal (TRH), uso de álcool, menopausa tardia, menarca precoce, exposição à radiação ionizante na infância, idade no primeiro recém nascido a termo superior a 30 anos ou inferior a 20 anos. Outros fatores de risco incluem: sedentarismo, fumo, cafeína, gorduras, açúcar, estresse (MENKE et al., 2007).

Genéticos: Os genes BRCA 1 e BRCA 2, localizados nos cromossomos 17q e 13q, respectivamente, são genes supressores tumorais, ou seja, quando ativados impedem a proliferação celular (STRUWEWNG, J. P. et al., 1997; HALBE, 2000). Dentre os testes genéticos, destaca-se que mulheres com mutação do gene BRCA 1 apresentam 60\% de chance de desenvolver carcinoma de mama, enquanto que em mulheres com mutação em BRCA 2 esta chance alcança 85 \% (MENKE et al., 2007).

Tipos histológicos: Com relação ao risco histológico, é obtido pelo acompanhamento, a longo prazo, dos casos de patologia benigna submetidos a biópsia e expressos em risco relativo (Tabela I).

Tabela I - Risco Relativo para Câncer Baseado na Histologia

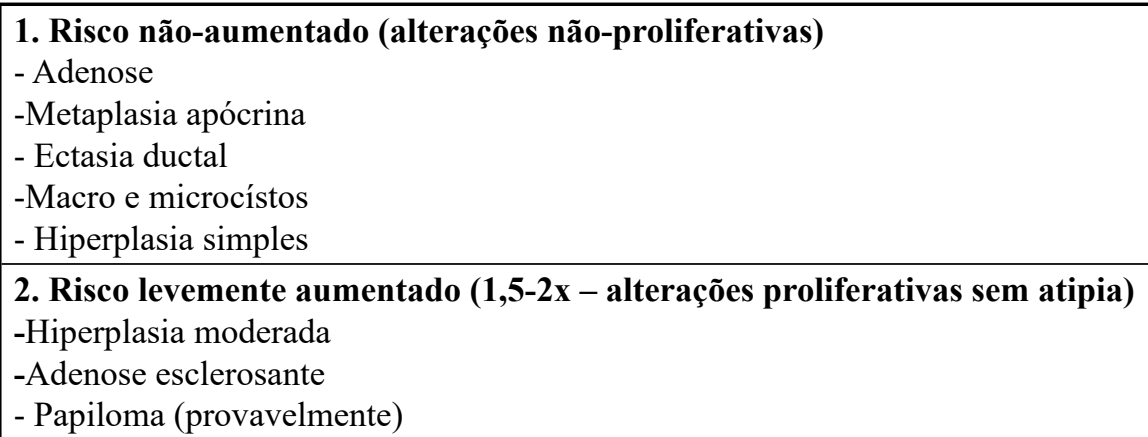

3. Risco moderadamente aumentado $(5 x-$ com atipia $)$

- Hiperplasia ductal atípica

- Hiperplasia lobular atípica

4. Alto risco (10x - carcinoma in situ)

- Carcinoma lobular in situ

- Carcinoma ductal in situ 
A anotação acima, em termos de risco relativo (RR), duplica quando há história de câncer de mama na família. (MENKE et al, 2007).

Ellery (2004) aborda não só os fatores de risco já consagrados pela literatura médica, trazendo novos dados epidemiológicos e estudos na área da psico-oncologia que discutem a influência dos aspectos subjetivos no processo de adoecimento. Destaca ainda que os fatores de risco tradicionalmente descritos na literatura baseiam- se no Modelo Biomédico e isoladamente são insuficientes para explicar a complexa e sistêmica etiologia do CA mama, necessitando-se uma abordagem integral e holística do ser humano e do processo de adoecimento para sua real compreensão. Corrobora tal afirmação o fato que cerca $25 \%$ dos casos de CA mama ocorre em mulheres que não apresentam nenhum dos fatores de risco conhecidos (MALZYNER et al., 2000).

Embora muito se conheça sobre epidemiologia do CA mama (GRUBE et al., 2005; MENKE et al., 2007), a compreensão acerca da etiologia da doença ainda é insuficiente para indicação de estratégias específicas por meio de programas de prevenção primária (LAMAS et al., 2000; BRASIL, 2004), sendo as recomendações do Ministério da Saúde em relação à alguns destes fatores de risco, como obesidade e tabagismo, que sejam alvo de ações visando a promoção de saúde da população em geral (BRASIL, 2004). Desta maneira, esforços relacionados ao controle da doença estão dirigidos à detecção precoce ou prevenção secundária.

\subsection{DETECÇÃO PRECOCE}

\subsubsection{Auto-exame das mamas (AEM)}

O AEM consiste em incentivar a mulher a examinar suas próprias mamas de modo sistemático e metódico, a fim de que ela descubra nódulos mais precocemente. Isto se baseia na constatação prática de que, cerca de 70\% dos tumores são detectados pela própria paciente (MENKE et al., 2007). Para as mulheres que se encontram na menacme preconiza-se sua realização após a menstruação, uma vez que na segunda metade do ciclo menstrual está presente algum grau de edema mamário (PIATO et al., 2006). Mulheres que possuem mamas muito volumosas e aquelas com parênquima mamário muito denso devem ser orientadas quanto à limitação da prática do AEM, já que nestas os resultados são pouco capazes de detectar o CA mama em estágios iniciais (PIATO et al., 2006).

Até o ano de 2003 o INCA considerava que as formas mais eficazes de detecção precoce do CA mama eram o AEM, Exame Clínico das Mamas (ECM) e MMG (BRASIL, 2001). A partir do Consenso para o Controle do Câncer de mama (2004), houve mudança substancial no enfoque ao AEM. O INCA, neste consenso, aponta diversos pontos negativos em relação ao AEM: aumento do número de biópsias de lesões benignas, ilusória sensação de segurança nos falsamente negativos, impacto psicológico negativo nos falsamente positivos, baixa taxa de aderência, além de já sabidamente não contribuir para a redução da mortalidade (BRASIL, 2004; ELLERY, 2004). 
Ainda assim, sua prática vem sendo recomendada especialmente para mulheres que não têm acesso a exames mamográficos, constituindo- se procedimento auxiliar na detecção precoce desta neoplasia (PIATO, 2006). Autores como Ellery (2004) e Menke (2007) defendem a idéia de que o AEM possa fazer um rebaixamento no estágio do CA mama, aumentando o número de cirurgias conservadoras pela descoberta de lesões menores e evitando a mutilação da mulher pala mastectomia, além de ser oportunidade para a prevenção e promoção de saúde. Esse fato tem importância em um país como o Brasil, aonde cerca de $50 \%$ dos casos de neoplasia mamária vêm à consulta em estágios avançados (MENKE et al., 2007).

\subsubsection{Exame clínico das mamas (ECM)}

As técnicas do ECM variam bastante em seus detalhes, entretanto, todas elas preconizam a inspeção estática e dinâmica, a palpação dos linfonodos, axilares e supraclaviculares, e das mamas (BRASIL, 2006; MENKE et al., 2007).

Sabe-se que 5\% dos cânceres da mama são detectados por ECM em pacientes com MMG negativa, benigna ou provavelmente benigna. O ECM também se constitui boa oportunidade a ser utilizada pelo profissional de saúde para educar a população feminina sobre o CA mama, seus sintomas, fatores de risco, detecção precoce e sobre a composição e variabilidade da mama normal (BRASIL, 2006).

O tempo de duplicação tumoral é em média estimado entre 90 e 120 dias, podendo ser muito variável, na dependência da agressividade tumoral e da imunocompetência do hospedeiro (PINOTTI et al., 2004). Quando um nódulo torna-se detectável clinicamente, ou seja, a partir de 1-2 cm, estima-se que existam 1 bilhão de células produzidas a partir de uma célula primitiva, após cerca de 30 divisões mitóticas, estando, portanto, em crescimento há aproximadamente 10 anos (PIATO et al., 2006).

\subsubsection{Mamografia (MMG)}

\subsubsection{Redução da mortalidade}

Diferente da detecção clínica, que detecta o nódulo somente quando o mesmo adquire cerca de 1 a $2 \mathrm{~cm}$, na prevenção secundária (detecção precoce) o nódulo pode ser detectado quando ainda clinicamente inaparente, a partir de apenas 0,1 cm, através da MMG, (GRUBE et al., 2005), sendo esta considerada, por este motivo, o método mais sensível para detectar precocemente o CA mama (TABAR et al., 1995; GODINHO et al., 2002).

O rastreamento mamográfico reduz a mortalidade por CA mama em 30-50\%, dados comprovados por estudos prospectivos, controlados e randômicos (HALBE, 2000; PASQUALETTE, 2001; GRUBE et al., 2005; PIATO et al., 2006). 
Em metanálise publicada por Humphrey et al. (2002), que analisou nove importantes ensaios clínicos nos quais foi avaliada a eficácia da $\mathrm{MMG}$ em promover a redução da mortalidade por CA mama, comparou-se um grupo de mulheres submetidas ao rastreamento com outro grupo submetido a apenas ao exame clínico (Quadro I). Estes estudos, iniciados entre 1963 e 1982, incluíram mulheres de 39 a 74 anos de idade, com intervalos entre os exames que variaram de 12 a 34 meses e mostraram que a MMG de rotina reduz a mortalidade por CA mama em 20\% a 39\% entre mulheres com 50 anos ou mais. A sensibilidade do exame mamográfico anual em detectar o CA mama variou entre 71 e $96 \%$, enquanto para o exame bienal esta variou entre 53 a 86\%, conforme a faixa etária; já a especificidade esteve entre 94 e $97 \%$ e o valor preditivo positivo variou de 2 a $22 \%$ para resultados anormais que exigiram avaliação adicional e de 12 a $78 \%$ para resultados anormais que exigiram biópsia (HUMPHREY et al., 2002).

Quadro I - Ensaios Clínicos que Avaliaram a Eficácia da Mamografia como Rastreamento para câncer de mama

\begin{tabular}{|c|c|c|c|c|c|c|c|c|}
\hline & HIP & CNBSS1 & CNBSS2 & Edimburgo & Gothenburgo & Estocolmo & Malmõ & $\begin{array}{l}\text { Kopparburge } \\
\text { Ostergotland }\end{array}$ \\
\hline $\begin{array}{l}\text { Ano de } \\
\text { início }\end{array}$ & 1963 & 1980 & 1980 & 1978 & 1982 & 1981 & $1976-78$ & 1977 \\
\hline Referência & $\begin{array}{l}\text { Shapiro } \\
\text { et al., } \\
1988\end{array}$ & $\begin{array}{l}\text { Miler et } \\
\text { al., 1992, } \\
2002\end{array}$ & $\begin{array}{l}\text { Miler et } \\
\text { al., 1992, } \\
2002\end{array}$ & $\begin{array}{l}\text { Alexander et } \\
\text { al., } 1999\end{array}$ & $\begin{array}{l}\text { Bjurstam et } \\
\text { al., } 1997\end{array}$ & $\begin{array}{l}\text { Frisell et } \\
\text { al., } 1997\end{array}$ & $\begin{array}{l}\text { Anderson } \\
\text { et al., } 1997\end{array}$ & $\begin{array}{l}\text { Tabar et al., } \\
1995\end{array}$ \\
\hline $\begin{array}{c}\text { Idade } \\
\text { para inclusão }\end{array}$ & $40-64$ & $40-49$ & $50-59$ & $45-64$ & $39-59$ & $40-64$ & $45-70$ & $40-74$ \\
\hline $\begin{array}{c}\text { Intervalo en- } \\
\text { tre exames }\end{array}$ & $12 \mathrm{~m}$ & $12 \mathrm{~m}$ & $12 \mathrm{~m}$ & $24 \mathrm{~m}$ & $18 \mathrm{~m}$ & $24-28 \mathrm{~m}$ & $18-24 \mathrm{~m}$ & $24-33 \mathrm{~m}$ \\
\hline $\begin{array}{l}\mathrm{N}^{0} \text { de parti- } \\
\text { cip: Grupo- } \\
\text { estudo e }\end{array}$ & 30.239 & 25.214 & 19.711 & 28.628 & 20.724 & 40.318 & 21.088 & 77.080 \\
\hline $\begin{array}{l}\text { Grupo- con- } \\
\text { trole }\end{array}$ & 30.256 & 25.216 & 19.694 & 26.015 & 28.809 & 19.943 & 21.195 & 22.985 \\
\hline ECM & SIM & SIM & SIM & SIM & NÃO & $\mathrm{NÃO}$ & NÃO & NÃO \\
\hline $\begin{array}{c}\text { Tempo de } \\
\text { seguimento } \\
\text { até } 2002\end{array}$ & $18 \mathrm{a}$ & $13 \mathrm{a}$ & $13 \mathrm{a}$ & $14 \mathrm{a}$ & $12 \mathrm{a}$ & $11 \mathrm{a}$ & $11-13$ a & $20 \mathrm{a}$ \\
\hline $\begin{array}{l}\text { Risco relati- } \\
\text { vo de mor- } \\
\text { talidade Ca } \\
\text { mama } \\
\text { (IC- } 95 \%)\end{array}$ & 0,79 & $\begin{array}{l}0,97 \\
0,74-1,27\end{array}$ & $\begin{array}{l}1,02 \\
0,78-1,33\end{array}$ & $\begin{array}{l}0,79 \\
0,6-1,02\end{array}$ & $\begin{array}{l}0,76 \\
0,56-1,04\end{array}$ & $\begin{array}{l}0,91 \\
0,65-1,27\end{array}$ & $\begin{array}{l}0,82 \\
0,67-1,00\end{array}$ & $\begin{array}{l}0,68 \\
0,69-0,80\end{array}$ \\
\hline $\begin{array}{c}\mathrm{N}^{0} \text { de MMG } \\
\text { necessárias } \\
\text { para salvar } \\
\text { uma vida }\end{array}$ & 883 & --- & --- & 980 & 1.139 & 3.468 & 584 & 553 \\
\hline
\end{tabular}

Adaptado de HUMPHREY et al., 2002. 


\subsubsection{Técnicas da Mamografia (MMG)}

Para garantir o bom desempenho da MMG, a imagem obtida deve ter alta qualidade e, para tanto, são necessários: equipamento adequado, técnica radiológica correta, conhecimento, prática e dedicação dos profissionais envolvidos (BRASIL, 2007). O selo concedido pelo CBR constitui-se um meio seguro da garantia de qualidade de um serviço radiológico, e a obtenção desse selo deveria ser estimulada por todos (PIATO et al., 2006).

O exame mamográfico de rotina é realizado com duas incidências em cada mama: craniocaudal (CC) e médio-lateral-oblíqua (MLO), como mostra a figura I. Na incidência MLO, é importante sempre visualizar-se a musculatura peitoral até, pelo menos, metade da mama para que tenhamos certeza que o tecido mamário não deixou de ser avaliado (MENKE, 2007). Esta incidência inclui as estruturas profundas dos quadrantes superior externo e a porção axilar do parênquima, a cauda de Spence (PASQUALETTE, 2001). Na incidência CC, também deve-se incluir todo o corpo da glândula com a gordura retromamária medial e lateral (MENKE, 2007). O exame deve ser sempre comparativo entre os dois lados e com os anteriores (BRASIL, 2007).

Figura I. Incidências mamográficas de rotina: craniocaudal (CC) e médio-lateral-oblíquo (MLO)
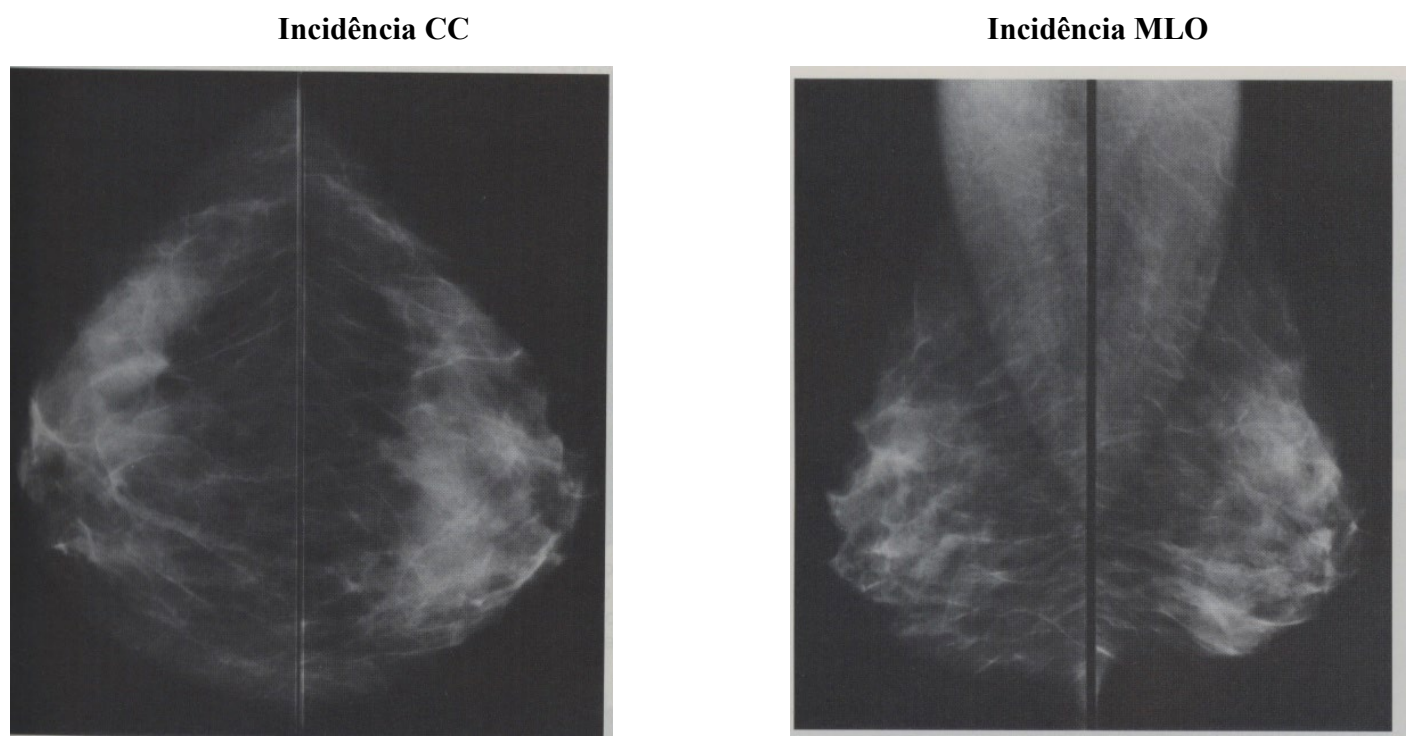

Fonte: Brasil, 2007.

Por vezes, para confirmar anormalidades sugestivas de câncer observadas nas incidências de rotina, são necessárias incidências complementares (PASQUALETTE, 2001; PINOTTI et al., 2004; MENKE, 2007). A radiação de cada exame mamográfico com duas incidências de cada lado é calculada em menos de 2,5 mGy (miligray, a unidade de medida de absorção de radiação), sendo estimado que o risco de CA mama aumente em mulheres que recebam pelo menos $250 \mathrm{mGy}$ e, principalmente, na adolescência. Desta maneira, o risco de carcinogênese induzido pelo exame mamográfico é desprezível (MCLELLAND R. et al., 1991; METTLER F.A., 1996;). 


\subsubsection{Indicações da Mamografia (MMG)}

As indicações de MMG podem ser divididas em 2 grupos: (PINOTTI et al., 2004; BRASIL, 2007).

O grupo das mulheres sintomáticas apresentam alterações clinicamente suspeitas de malignidade, principalmente:

A.1. Nódulos palpáveis: Se o nódulo for um novo achado no exame clínico, a MMG deve ser sempre realizada, independente da data do exame anterior. Se o nódulo palpável não tiver expressão na MMG, a complementação com USG é obrigatória.

A.2. Espessamentos: Enquanto os nódulos são descritos como achados palpatórios tridimensionais, os espessamentos (adensamentos) são perceptíveis em apenas duas dimensões. Todas as alterações do exame físico são mais suspeitas quando assimétricas e solitárias (MENKE et al., 2007). A indicação de MMG segue os mesmos parâmetros descritos para o nódulo (BRASIL, 2007).

A.3. Derrame papilar significante: A secreção das mamas fora do ciclo gravídico puerperal deve ser analisada criteriosamente: Presença de derrame papilar espontâneo, unilateral, de aspecto cristalino tipo "água de rocha" ou serossanguinolento são suspeitos de doença maligna (BRASIL, 2007).

A.4. Mastalgia: Na mama dolorosa, a indicação de MMG não difere da rotina de screening, pois não se observa que a dor seja um sintoma comum no quadro clínico do CA mama, não implicando em maior risco para esta neoplasia (PINOTTI et al., 2004; BRASIL,2007).

Já o grupo de mulheres assintomáticas como screening de CA mama a aceitação do rastreio mamográfico levou uma série de associações e entidades médicas a publicar recomendações a respeito da periodicidade da MMG. Todas elas são praticamente concordantes quanto à MMG basal de 35 a 39 anos (PASQUALETTE, 2001), entretanto há discretas variações neste sentido, a saber:

Segundo a I Reunião de Consenso entre a SBM, o CBR e a FEBRASGO, realizada em 1998, cuja recomendação de periodicidade da MMG foi a mesma que a levada em consideração por Cançado (2007), recomenda-se:

- MMG anual ou bianual entre os 40 e 50 anos;

- MMG anual em mulheres com mais de 50 anos de idade;

Freitas (2006) recomenda que após a MMG de base, as mulheres de risco a repitam anualmente, e as demais, de dois em dois anos, até a idade de 50 anos, entrando após no regime anual.

Menke (2007), baseando-se em diretrizes internacionais e no Projeto Diretrizes do Conselho Federal de Medicina e AMB, recomenda o rastreamento anual a partir dos 40 anos de idade (MENKE, 2007).

Segundo o Ministério da Saúde/ INCA (BRASIL, 2007) recomenda-se: 
- ECM a partir dos 40 anos.

- $\quad$ MMG para mulheres entre 50 e 69, com intervalo máximo de 2 anos entre os exames.

- ECM e MMG anual, a partir dos 35 anos, para mulheres de grupos de risco. São definidos como grupos de risco elevado para o desenvolvimento de CA mama (BRASIL, 2006):

* Mulheres com história familiar de pelo menos um parente de primeiro grau (mãe, irmã ou filha) com este diagnóstico, abaixo dos 50 anos de idade, ou com diagnóstico de CA mama bilateral ou câncer de ovário, em qualquer faixa etária.

* Mulheres com história familiar de CA mama masculino.

* Mulheres com diagnóstico histopatológico de lesão mamária proliferativa com atipia ou neoplasia lobular in situ.

Neste documento do Ministério da Saúde (BRASIL, 2007) explicita-se que também há na literatura a recomendação de realizar a MMG de rotina nas mulheres assintomáticas a partir dos 40 anos, e que, embora aparentemente conflitante, a recomendação do Ministério da Saúde não invalida a recomendação da literatura para as mulheres que têm acesso ao exame (BRASIL, 2007).

Entretanto, recentemente, em abril de 2008, a lei N ${ }^{\circ} 11.664$, que efetiva as ações de saúde e assegura a prevenção, a detecção, o tratamento e o seguimento dos cânceres de mama e colo uterino, no âmbito do SUS, foi atualizada, trazendo importantes mudanças no que diz respeito à saúde da mulher brasileira: a diminuição na idade e no tempo da realização do exame mamográfico. A partir desta, recomenda-se que mulheres de 40 anos deverão realizar MMG anualmente no Brasil (BRASIL, 2008).

Contribuíram na recomendação da redução do intervalo entre os exames nas pacientes da faixa etária entre 40 e 49 anos para anualmente estudos como o de Tábar et al., em 1995, realizado em dois municípios suecos, onde analisando-se a taxa de crescimento tumoral em mulheres nas diversas faixas etárias, foi observado que o tempo de permanência média (fase pré-clínica) nas mulheres de 40-49 anos era de 1,7 anos e entre 50 e 59 anos era de 3,3 anos (TÁBAR et al., 1995), tendo a observação de que o crescimento do tumor se dá de maneira mais rápida na faixa etária entre 40-49 anos, contribuído para a recomendação de redução do intervalo entre os exames nesta faixa etária para anualmente (TÁBAR et al., 1995).

Já a Sociedade Americana do Câncer (American Cancer Society - ACS) recomenda para as mulheres assintomáticas (SMITH, 2006):

- 40 anos- ideal para exame clínico e MMG iniciais.

- 40 a 49- ECM anual e MMG anual ou bianual.

- acima de 50 anos- ECM e MMG anuais.

Não há uma recomendação padronizada sobre em qual idade se deve parar o rastreamento mamográfico, devendo ser levada em consideração a condição clínica de cada mulher, sua expectativa de vida e a avaliação do custo-efetividade do exame mamográfico (GRUBE, 2005). 
Destaca-se ainda quanto às indicações de MMG que no seguimento pós quadrantectomia recomenda-se que o primeiro exame seja realizado seis meses depois da cirurgia e a seguir, anualmente, na pesquisa de recidivas locais. Para o controle da mama oposta, sua indicação se faz com freqüência anual (PINOTTI et al., 2004; MENKE, 2007).

Duas outras indicações absolutas do exame para as mulheres assintomáticas são: avaliação pré-operatória para cirurgias plásticas de mama e avaliação basal antes do início da TRH no climatério (PINOTTI et al., 2004).

\subsubsection{Classificação BI-RADS ${ }^{\circledR}$}

Buscando cada vez mais a integração entre as especialidades médicas, mastologistas, radiologistas, patologistas e clínicos, e tentando uniformizar ações que tornem o rastreamento do CA mama mais eficaz na redução da morbimortalidade associada a este câncer, o ACR elaborou, em 1992, um conjunto de recomendações para a padronização de laudos de MMG que ficou conhecido pela sigla BI-RADS ${ }^{\circledR}$. Estas medidas visaram, sobretudo, aumentar a confiabilidade na interpretação das imagens e na transmissão das informações, facilitar o acompanhamento das pacientes, melhorar o diálogo entre diferentes especialidades médicas, criar uma ferramenta para auditoria dos serviços de MMG e permitir a formação de um banco de dados para elaboração de estudos epidemiológicos (AMÂNCIO H., 2002).

Nas três primeiras edições do BI-RADS ${ }^{\circledR}(1993,1995,1998)$, a MMG era classificada em seis categorias: Categoria 0 - achados que necessitam de avaliação adicional; Categoria 1 - sem achados; Categoria 2 - achados benignos; Categoria 3 - achados provavelmente benignos; Categoria 4 - achados suspeitos; Categoria 5 - achados altamente suspeitos (AMERICAN COLLEGE OF RADIOLOGY, 2003; BRASIL, 2007).

Em abril de 1998 ocorreu no Brasil a I Reunião de Consenso para a padronização dos laudos mamográficos, que contou com a participação do CBR, SBM e a FEBRASGO, com o intuito de obter-se adaptação às características das mulheres brasileiras. Nesta reunião, adotou-se como padrão de laudos um sistema baseado no léxico BI-RADS ${ }^{\circledR}$, também se postulando como obrigatório ao laudo uma recomendação para a conduta clínica. O Brasil adotou a nomenclatura BI-RADS ${ }^{\circledR}$ pelos claros benefícios demonstrados pela literatura (MILANI et al., 2007; KESTELMAN et al., 2007).

Em 2003, como fruto de esforços para aperfeiçoar o método, membros de vários comitês do Colégio Americano de Radiologia e com a cooperação do INCA, do Centro de Controle e Prevenção de Doenças, da FDA, da Sociedade Médica Americana e do Colégio Americano de Patologia, foi publicada a quarta edição do BI-RADS ${ }^{\circledR}$, que incluiu também uma classificação para os exames de USG e ressonância magnética para exame de mama (Quadro II). Nesta quarta edição do BI-RADS ${ }^{\circledR}$, foi criada a Categoria 6, para lesões já com diagnóstico de câncer, e a Categoria 4 foi subdividida em A, B, C, de acordo com baixa, média e alta suspeição (porém não clássica para malignidade), respectivamente, divisão esta que é opcional (AMERICAN COLLEGE OF RADIOLOGY, 2003; BRASIL, 2007). 


\begin{tabular}{|l|l|l|l|}
\hline Categoria & Interpretação & Risco de Câncer & Recomendação de Conduta \\
\hline 0 & Inconclusivo & & $\begin{array}{l}\text { Exame adicional (ultra-sonografia, mag- } \\
\text { nificação ou compressão localizada) }\end{array}$ \\
\hline 1 & Benigno & $0,05 \%$ & Controle anual a partir dos 40 anos \\
\hline 2 & Benigno & $0,05 \% /$ & Controle anual a partir dos 40 anos \\
\hline $3(\mathrm{~A}, \mathrm{~B}, \mathrm{C})$ & Provavelmente benigno & Até $2 \%$ & $\begin{array}{l}\text { Repetir em seis meses (eventualmente } \\
\text { biópsia) }\end{array}$ \\
\hline 5 & Suspeito & $\begin{array}{l}>20 \%, \text { sendo: } \\
\text { A- 5\% } \\
\text { B-25\% } \\
\text { C-70\% }\end{array}$ & Biópsia \\
\hline 6 & $\begin{array}{l}\text { Altamente Suspeito-(Provavelmente } \\
\text { maligno) }\end{array}$ & $>75 \%$ a $\leq 95 \%$ & Biópsia \\
\hline & $\begin{array}{l}\text { Lesão já biopsiada e } \\
\text { magnosticada como maligna, retirada ou tratada }\end{array}$ & $100 \%$ & \\
\hline
\end{tabular}

Breast Imaging Reporting and Data System: BI-RADS ${ }^{\circledR} .4$ th edition/copyright 1992, 1993, 1995, 1998, 2003 (AMERICAN COLLEGE OF RADIOLOGY, 2003).

Para alterações na categoria BI-RADS ${ }^{\circledR} 4$ a recomendação de conduta tem variado em diferentes serviços. De acordo com a I Reunião de Consenso brasileira para padronização dos laudos mamográficos a categoria $\mathrm{BI}-\mathrm{RADS}^{\circledR} 4$ deve ser submetida a estudo cito ou histológico, não havendo ainda a subdivisão em 4A, B e C quando desta reunião (FREITAS et al., 2006; CAMARGO JÚNIOR et al., 2007). Apenas na quarta edição do BI-RADS ${ }^{\circledR}$, em virtude de um Valor Preditivo Positivo (VPP) bastante variável (entre 3 e 94\%) nesta categoria, é que propôs-se a subdivisão opcional, cuja proposta visa a possibilidade de melhoria na qualidade de auditorias, auxiliar o médico assistente e o patologista na correlação do resultado da biópsia com o achado mamográfico e orientar decisões de condutas posteriormente à realização de biópsia, uma vez que na categoria BI-RADS ${ }^{\circledR} 4 \mathrm{~A}$ seria aceitável um resultado histopatológico benigno, entretanto categoria BI-RADS 4C com histopatológico benigno deve-se continuar a investigação diagnóstica (AMERICAN COLLEGE OF RADIOLOGY, 2003; CAMARGO JÚNIOR et al., 2007).

Desta forma, a subdivisão da categoria BI-RADS ${ }^{\circledR} 4$ não teve o objetivo de contra-indicar a investigação histopatológica de alterações incluídas nesta categoria (AMERICAN COLLEGE OF RADIOLOGY, 2003). Porém pelo fato de estar envolvido risco de malignidade muito heterogêneo na categoria, muitos serviços já trabalham com recomendações variadas nas subclassificações: 4A ou 4 Leve (recomendação de apenas acompanhamento e não biópsia), B e C (com recomendação de biópsia) (CAMARGO JÚNIOR, 2007).

Na categoria 5 , cerca de $80 \%$ das lesões são malignas, não havendo controvérsia quanto à indicação de estudo cito ou histológico (AMERICAN COLLEGE OF RADIOLOGY, 2003; CAMARGO JÚNIOR, 2007). 
Em sua quinta edição, a classificação BI-RADS ${ }^{\circledR}$ teve como um de seus enfoques principais uniformizar os termos entre mamografia, ultrassonografia e ressonância magnética. Nesta edição algumas lesões foram reclassificadas, devido a um maior valor preditivo positivo dos achados em estudos realizados em todo o mundo com a classificação. Cita-se, por exemplo, quando há mais de três nódulos sólidos com características provavelmente benignas (como: ovalados, circunscritos, homogêneos e paralelos à pele), sendo dois em uma mama e um na outra, já podem ser caracterizados como benignos (BI-RADS ${ }^{2} 2$ ), ficando a classificação BI-RADS ${ }^{\circledR} 3$ para casos que não preencham esses critérios. Achados ultrassonográficos de casos com múltiplos "cistos espessos" e "agrupamentos de microcistos", já podem ser considerados como benignos (BI-RADS ${ }^{\circ} 2$ ), ficando reservada a categoria BI-RADS $® 3$ para os casos isolados. Alteração também ocorreu na abordagem dos linfonodos axilares, que anteriormente não eram incluídos na avaliação da mama; entretanto nesta atualização se os mesmos apresentam características suspeitas e não há uma doença de base conhecida, devem ser classificados como BI-RADS® 4 (AMERICAN COLLEGE OF RADIOLOGY, 2013).

Um estudo multicêntrico realizado pelo Breast Cancer Suveillance Consortium comparou a concordância das categorias mamográficas finais e de recomendação de condutas para exames mamográficos em mulheres sintomáticas ou não, antes e após as regras estabelecidas pelo programa de controle da qualidade de MMG norte-americano, Mammography Quality Standards Act (MQSA), que preconiza o uso da classificação BI-RADS ${ }^{\circledR}$. Neste estudo, foi demonstrado que de 1996 a 2001 ocorreu melhora na concordância dos laudos mamográficos, possivelmente relacionada às publicações do BI-RADS ${ }^{\circledR}$ (quarta edição não incluída nessa análise), às regras para controle de qualidade e ao uso de sistemas de laudos informatizados (GELLER et al., 2006).

\section{CONSIDERAÇÕES FINAIS}

Indubitavelmente, o controle do CA mama é uma prioridade da política de saúde do Brasil, tendo sido incluído como uma das metas do Pacto pela Saúde (BRASIL, 2006), no qual se busca o fortalecimento, a integração e a resolutividade do SUS, por meio de estratégias de co-responsabilização dos gestores federal, estadual e municipal (BRASIL, 2007). As múltiplas condições e direcionamentos para melhoria do controle do CA mama devem ser continuamente estimuladas, incluindo a educação e/ou informação da população; aprimoramento da qualidade dos serviços e dos recursos humanos, dentre outros, contribuindo assim com informações que possam vir a ser utilizadas como subsídios às políticas públicas de saúde para intervir, modificar e implementar a assistência preventiva, diagnóstica e terapêutica desta neoplasia. 


\section{REFERÊNCIAS}

ABREU, Evaldo de; KOIFMAN, Sérgio. Fatores prognósticos no câncer da mama feminina. Rev Bras Cancerol. Rio de Janeiro, 2002. Disponível em: <http://bases.bireme.br/cgi-bin/wxislind.exe/iah/online/?IsisScript $=$ iah/iah. $x i s \& s r c=$ google \&base $=$ LILACS\&lang $=$ p\&nextAction $=$ lnk\&exprSearch $=314017$ \&indexSearch=ID $>$. Acesso em: 05 fev. 2008.

ALONSO, Elena Peréz. Relato de uma Prática em Centro de Diagnóstico Mamário - Considerações sobre Intervenções Psicanalíticas com as Usuárias e Membros da Equipe. São Paulo, 2002. Disponível em: $<$ http://www.scielo.br/scielo.php?script=sci_arttext\&pid=S0100-39842002000500017\&lng=\&nrm=iso $>$. Acesso em: 26 jan. 2008.

AMÂNCIO H.; JÚNIOR C. O laudo mamográfico e a recomendação de conduta. Rev. bras. mastol. 2002.

AMERICAN COLLEGE OF RADIOLOGY. Breast imaging reporting and data system (BI-RADS $\left.{ }^{\circledR}\right) .4^{\mathrm{a}}$ ed. para mamografia Reston, Va. American College of Radiology; 2003.

AMERICAN COLLEGE OF RADIOLOGY. Breast imaging reporting and data system (BI-RADS ${ }^{\circledR}$ ). $5^{\mathrm{a}}$ ed. American College of Radiology; 2013.

ARÁN, M.R.; et al. Representações de Pacientes Mastectomizadas sobre Doença e Mutilação e seu Impacto no Diagnóstico Precoce do Câncer de Mama. J Bras Psiq, 1996.

BERGAMASCO, R. B.; ANGELO, M. O sofrimento de descobrir-se com câncer de mama: como o diagnóstico é experenciado pela mulher. Rev Bras Cancerol. 2001.

BRASIL. Conhecendo o Viva Mulher: Programa nacional de controle do Câncer do Colo do útero e de Mama. Rio de Janeiro: INCA, 2001.

BRASIL. Controle do câncer de mama. Documento de consenso. Instituto Nacional do Câncer e Coordenação de prevenção e Vigilância. Brasília> INCA/CONPREV, 2004.

BRASIL. Estimativa da incidência e mortalidade por câncer no Brasil. Rio de Janeiro: 2008.

BRASIL. Falando sobre doenças da mama. Brasília: 2007.

BRASIL. Mamografia: da prática ao controle. Rio de Janeiro: INCA, 2007.

BRASIL. Política Nacional de Atenção Integral à Saúde da Mulher - Princípios e Diretrizes. Secretaria de Atenção à Saúde/ Departamento de Ações Programáticas e Estratégicas. Brasília, 2004.

BRASIL. Secretaria de Atenção à Saúde. Instituto Nacional de Câncer. Coordenação de Prevenção e Vigilância. Controle do Câncer de Mama: documento de consenso. Rio de Janeiro: INCA; 2006.

CAMARGO JUNIOR, Hélio Sebastião Amâncio de et al. Biópsia de fragmento em nódulos mamários suspeitos com até 10 mm. Rev. Bras. Ginecol. Obstet. Rio de Janeiro, v. 29, n. 6, 2007. Disponível em: <http://www. scielo.br/scielo.php?script=sci_arttext\&pid=S0100-72032007000600007\&lng=pt\&nrm=iso $>$. Acesso em: 26 jan. 2008.

CANÇADO,V. A.; GOMES, A. L. R. R.; OLIVEIRA, T. C. F. Propedêutica em Mastologia in Ginecologia e Obstetrícia: manual para concursos. Rio de Janeiro: Guanabara Koogan, 2007.

ELLERY, Ana Ecilda Lima. Aspectos psicossociais do auto- exame: implicações num outro olhar da prevenção do câncer de mama. 170 f. Dissertação (Mestrado em Saúde Pública). Universidade Federal do Ceará, Ceará, 2004. Disponível em: $<$ http://www.teses.ufc.br/tde_busca/arquivo.php?codArquivo=124>. Acesso em: 15 jan. 2008. 
FLETCHER, S. W., ELMORE, J.G. Mammographic Screening for Breast Cancer. Massachusetts Medical Society, 2003. Disponível em: <http://www.nejm.org>. Acesso em: 26 jan. 2008.

FREITAS, F. et al. Patologia Benigna da mama. In: Rotinas em Ginecologia. Porto Alegre: Artmed,2006.

GELLER B. M., Ichikawa LE, Buist DS et al. Improving the concordance of mammography assessment and managment recommendations. Radiology, 2006.

GODINHO, Eduardo Rodrigues; KOCH, Hilton Augusto. O perfil da mulher que se submete a mamografia em Goiânia: uma contribuição a "Bases para um programa de detecção precoce do câncer de mama". Radiol Bras. São Paulo, v. 35, n. 3, 2002. Disponível em: $<$ http://www.scielo.br/scielo.php?script=sci_arttext\&pi$\mathrm{d}=\mathrm{S} 0100-39842002000300004 \& \operatorname{lng}=\mathrm{pt} \& \mathrm{nrm}=\mathrm{iso}>$. Acesso em: 26 jan. 2008.

GRUBE, Baiba; GIULIANO, Armando. E. Câncer de Mama. In: Tratado de Ginecologia. $13^{\mathrm{a}}$ ed. Guanabara Koogan: Rio de Janeiro, 2005.

HALBE, Hans Wolfgang. Tratado de ginecologia. $3^{\text {a }}$ ed. São Paulo: Roca, 2000.

KESTELMAN, Fabíola Procaci et al. Breast Imaging Reporting and Data System - BI-RADS ${ }^{\circledR}$ : valor preditivo positivo das categorias 3, 4 e 5. Revisão sistemática da literatura. Radiol. Bras. São Paulo, 2007.

KLIGERMAN J. Fundamentos para uma política nacional de prevenção e controle do câncer. Rev. Bras. Canceroln. 2002.

LAMAS J. M.; PEREIRA M. G.; KOCH H. A. Avaliação dos resultados de exames mamográficos para detecção precoce de câncer de mama em mulheres assintomáticas, no Distrito Federal. Radiol. Bras. 2000.

LAMAS J. M.; PEREIRA M. G.; KOCH H. A. Avaliação dos resultados de exames mamográficos para detecção precoce de câncer de mama em mulheres assintomáticas, no Distrito Federal. Radiol. Bras. 2000.

LOPES E. R. et al. Câncer de mama: epidemiologia e grupos de risco. Rev. Bras. Cancerol. 1995.

MALZYNER, A.; CAPONERO, R.; DONATO, E. M. D.; A metamorfose de uma angústia: o tratamento do câncer de mama de Halsted ao BRC1. Gimenez, M.G.G. A mulher e o câncer. São Paulo: Livro Pleno, 2000.

MCLELLAND R. et al. The American College of Radiology Mammography Accreditation Program. Am J Roentgenal. 1991.

MENKE, Carlos H. et al. Rotinas em mastologia. $2^{\text {a }}$ ed. Porto alegre: Artmed, 2007.

METTLER, F. A.; UPTON, AC; KELSEY CA et al. Benefits versus risks from mammography. Cancer. 1996.

MILANI, Vivian et al. Presumed prevalence analysis on suspected and highly suspected breast cancer lesions in São Paulo using BIRADS ${ }^{\circledR}$ criteria. São Paulo Med. J., São Paulo, v. 125, n. 4, 2007. Disponível em: $<$ http://www.scielo.br/scielo.php?script=sci_arttext\&pid=S1516-31802007000400003\&lng=pt\&nrm=iso $>$. Acesso em: 26 jan. 2008.

NOVAES, Hillegonda Maria Dutilh; BRAGA, Patrícia Emilia; SCHOUT, Denise. Fatores associados à realização de exames preventivos para câncer nas mulheres brasileiras, PNAD 2003. Ciênc. saúde coletiva, Rio de Janeiro, v. 11, n. 4, 2006. Disponível em: $<$ http://www.scielosp.org/scielo.php?script=sci arttext\&pi$\mathrm{d}=\mathrm{S} 141381232006000400023 \& \operatorname{lng}=\mathrm{pt \& nrm}=\mathrm{iso}>$. Acesso em: 16 jan. 2008.

PASQUELETTE, Henrique Alberto Portela. Tratado de ginecologia - Vol 1. Rio de Janeiro: Revinter, 2001.

PAULINELLI, Régis Resende; MOREIRA, Marise Amaral Rebouças; FREITAS JÚNIOR, Ruffo de. A Importância do diagnóstico precoce do câncer de mama. Femina, São Paulo, 2004. Disponível em: $<$ http://bases. bireme.br/cgi-bin/wxislind.exe/iah/online/?IsisScript=iah/iah.xis\&src=google\&base=LILACS\&lang=p\&nextAction=lnk\&exprSearch=404416\&indexSearch=ID>. Acesso em: 20 jan. 2008.

PIATO, Sebastião; PIATO, José Roberto Moraes. Doenças da mama. Revinter: Rio de Janeiro, 2006. 
PINHO, Valéria Fernandes de Souza; COUTINHO, Evandro Silva Freire. Variáveis associadas ao câncer de mama em usuárias de unidades básicas de saúde. Caderno de Saúde Pública. Rio de Janeiro, 2007. Disponível em: $<$ http://bases.bireme.br/cgi-bin/wxislind.exe/iah/online/?IsisScript=iah/iah.xis\&src=google\&base=LILACS\&lang=p\&nextAction=lnk\&exprSearch=449109\&indexSearch=ID>. Acesso em: 14 fev. 2008.

PINOTTI, José Aristodemo; BARROS, Alfredo Carlos.D. Ginecologia Moderna- Condutas da clínica ginecológica da Faculdade de Medicina da USP. Ed. Revinter: Rio de Janeiro, 2004.

SMITH R. A., Cokkinides V., Eyre H.J. American Cancer Society Guidelines for the Early Detection of Cancer. Cancer J Clin. 2006.

STRUWEWNG J. P. et al. The risk of cancer associated with specific mutations of BRCA1 and BRCA2 among Ashkenazi Jews. N Engl J Med. 1997.

TABAR L.; DEAN, P. B. Mammography and breast cancer: the new era. Int. J. Gynecol. Obstet. 2003.

TABAR, L.; FAGERBERG G, CHEN HH et al. Efficacy of breast cancer screening by age: new results from the Swedish two-counstry trial. 1995.

WORLD HEALTH ORGANIZATION. Who Library Cataloguing- in- Publication Data. World Health Statistes. 2007. 


\section{RISCOS DE QUEDAS EM IDOSOS RESIDENTES EM INSTITUIÇÕES DE LONGA PERMANÊNCIA}

FRANCIELY GOMES GONÇALVES 1,2,3,4,5

NATÁLIA DA SILVA FREITAS MARQUES ${ }^{1,2,3}$

MÁRCIA REGINA MELO CONDE ${ }^{1}$

PATRICIA MERLY MARTINELLI ${ }^{1,2,3,6}$

FRANCISCO DE ASSIS MOTA DE SOUZA ${ }^{1}$

BRUNA COSTA RODRIGUES ${ }^{1}$

GABRIEL ZORELLO LAPORTA ${ }^{4}$
12 meses. Método: trata-se de pesquisa de campo quantitativa e descritiva. Resultados: participaram do estudo 11 idosos, 9 do sexo masculino e 2 do sexo feminino, com idade entre 71 a 93 anos, os quais foram submetidos ao Mini Exame do Estado Mental (MEEM), Escala de Tinetti e Teste de Romberg. A maioria dos idosos apresentaram baixo resultado no MEEM, índice de Tinetti e alteração nos testes de Romberg. Conclusão: os idosos institucionalizados apresentaram altas frequências de risco de quedas, sobretudo os idosos longevos, situação que demonstra a importância da avaliação para implementação de ações que visem prevenir os riscos de quedas nessa população.

Palavras chaves: Idosos; Equilíbrio; Quedas.

RESUMO: Introdução: a transição demográfica assevera aumento importante da população idosa, cenário decorrente à diminuição das taxas de mortalidade e natalidade da população geral. $\mathrm{O}$ avançar da idade aumenta os riscos de quedas principalmente em idosos residentes em Instituições de Longa Permanência (ILPI). Objetivo: identificar os riscos de quedas em idosos residentes em Instituição de Longa Permanência, através da escala de Tinetti e teste de Romberg e a quantidade de episódios de quedas nos últimos
ABSTRACT: Introduction: the demographic transition asserts a significant increase in the elderly population, because of a decrease in mortality and birth rates in the whole population. Advancing age increases the risk of falls, especially among elderly people living in long-term care facilities (ILPI). Objective: to identify the risks of falls in elderly residents in a Long-Term Care Institution, using the Tinetti scale and Romberg

1 Laboratório de Práticas de Pesquisa Científica. Centro Universitário Uninorte, Rio Branco, AC, Brasil.

2 Laboratório de Delineamento de Estudos e Escrita Científica. Centro Universitário FMABC, Santo André, SP, Brasil.

3 Laboratório Multidisciplinar de Estudos e Escrita Cientifica em Ciências da Saúde. Universidade Federal do Acre, Rio Branco, AC, Brasil. Centro Universitário Uninorte, Rio Branco, Acre, Brasil.

4 Setor de Pós-graduação, Pesquisa e Inovação, Centro Universitário Saúde ABC (FMABC), Fundação ABC, Santo André, SP, Brasil.

5 Serviço Estadual de Dermatologia do Acre, Programa Estadual de Controle da Hanseníase (SESACRE), Rio Branco, AC, Brasil.

6 Centro Universitário UniDomBosco, Curitiba, PR, Brasil. 
test and the number of episodes of falls in the last 12 months. Method: this is a quantitative and descriptive field research. Results: 11 elderly people participated in the study, 9 males and 2 females, aged 71 to 93 years, who underwent the Mini Mental State Examination (MEEM), Tinetti Scale and Romberg's Test. Most of the elderly people presented low results in the MEEM, Tinetti index and changes in the Romberg tests. Conclusão: idosos institucionalizados apresentaram altas frequências de risco de quedas, principalmente idosos longevos, situação que demonstra a importância da avaliação para a implementação de ações voltadas à prevenção de riscos de quedas nessa população.

Keywords: Elderly ; Balance; Falls.

\section{INTRODUÇÃO}

Observa-se mundialmente, um contingente cada vez maior de pessoas idosas. Cenário que está relacionado a diversos fatores, dentre eles, a redução das taxas de mortalidade e natalidade, ocasionando importantes alterações na estrutura etária da população ${ }^{1}$.

O envelhecimento é considerado processo esperado, irreversível, não patológico, com ritmo individual, que pode comprometer os sistemas corporais e neurológicos, com efeitos desfavoráveis aos fatores ambientais, econômicos, culturais e sociais. Os danos oriundos ao processo de envelhecimento podem aumentar o risco de quedas, e como resultado, maior probabilidade de incapacidade funcional, aumento da morbidade e mortalidade. Os idosos residentes em ILPI, apresentam maior predisposição a quedas, em consequência da maior fragilidade, que correspondem ao menor grau de força muscular, resistência e equilíbrio, em comparação aos idosos da comunidade. A queda relaciona se a fatores de riscos intrínsecos, oriundos das alterações orgânicas do indivíduo durante o processo de envelhecimento, que podem refletir na diminuição do equilíbrio e alterações da marcha. Os fatores extrínsecos, por sua vez, estão relacionados as alterações no ambiente de convívio do idoso, dentre elas, tapetes, pisos irregulares, má iluminação, calçados inadequados ${ }^{2-5}$.

A alteração de equilíbrio, resultante do declínio fisiológico que engloba sistema vestibular, visual, força muscular, comando central, periférico e neuromuscular, representa importante evento impulsionador de quedas em idosos, com riscos de limitação das atividades de vida diária, autonomia, isolamento, medo de quedas, depressão e até a morte $2,4,6$.

As alterações na marcha, também contribuem para o evento quedas, e ocorrem principalmente pela incapacidade do sistema nervoso central de analisar e processar dados enviados a partir da visão, propriocepção e vestibular, gerando assim uma instabilidade na posição bípede ${ }^{2}$. As alterações são mais evidentes durante a marcha tendo elevação da base de sustentação no duplo apoio, diminuição do comprimento dos passos e velocidade ${ }^{4}$.

Dessa forma, o objetivo do estudo foi identificar fatores de exposição aos riscos de quedas em idosos residentes em Instituições de Longa Permanência, através da escala de Tinetti e teste de Romberg e a quantidade de episódios de quedas nos últimos 12 meses. 


\section{MÉTODO}

Trata-se de uma pesquisa de abordagem quantitativa, realizada em agosto de 2018, na Instituição de Longa Permanência em Idosos, Lar de Vicentino Raimunda Odília, localizada no município de Rio Branco/Ac. Participaram do estudo 11 idosos de ambos os sexos. A coleta aconteceu em dois dias, sendo que no primeiro dia foi explicado o estudo, após compreenderem e concordarem em participar da pesquisa, os idosos assinaram o Termo de Consentimento Livre e Esclarecido, em seguida, preenchido os formulários, para coleta do nome, idade, sexo, cor, escolaridade, questionário para identificar quantas quedas apresentaram nos últimos 12 meses e o Mini Exame do Estado Mental (MEEM). No segundo dia foi realizado a avaliação da marcha e do equilíbrio através da escala de Tinetti e teste de Romberg, com objetivo identificar fatores de exposição aos riscos de quedas em idosos residentes em Instituições de Longa Permanência, através da escala de Tinetti e teste de Romberg e a quantidade de episódios de quedas nos últimos 12 meses.

O Mini Exame do Estado Mental (MEEM) visa avaliar o estado mental de uma forma padronizada simplificada e rápida no contexto clínico. O exame é composto por duas partes a primeira avalia orientação, memória e atenção, totalizando 21 pontos, e a segunda avalia a capacidade de nomeação, de obediência a um comando verbal e escrito, de redação livre de uma sentença e de cópia de um desenho complexo (polígonos), perfazendo nove pontos, totalizando um score de 30 pontos no qual uma pontuação de 23 a 24 é indicativo déficit cognitivo. Estudos citam que declínio cognitivo aumenta o risco de quedas ${ }^{7-8,12}$.

A escala de Tinetti é um exame muito utilizado para avaliar a marcha e o equilíbrio, o teste é formado por 16 itens, no qual 8 são para o equilíbrio e 7 para a marcha, com pontuação que varia de 0 a 1 ou de 0 a 2 de cada exercício, sendo que a contagem mais baixa indica habilidade física menor. O resultado do teste é somado o equilíbrio e a marcha totalizando 28 pontos. Pontuação menor que 19 indica risco elevado de quedas ${ }^{13}$.

O teste de Romberg, o idoso ficará em ortostatismo, descalço, com os pés paralelos, juntos, sobre o solo, braços estendidos ao longo do corpo e olhos fechados, por um minuto. A perda do equilíbrio é confirmada, mediante saída da posição inicial, caracterizando alteração do equilíbrio estático ${ }^{9}$.

Os dados foram tabulados em planilha Microsoft Excel 2010 e analisados. Foram excluídos do estudo os idosos com incapacidades neurológios, acamados e cadeirantes. A pesquisa foi aprovada pelo Comitê de Ética em Pesquisa da União Educacional do Norte, sob o parecer 2.761.478.

\section{RESULTADOS}

Em agosto de 2018, foi avaliado, o risco de quedas em 11 idosos institucionalizados, residentes no Lar Vicentino Raimunda Odília. A caracterização da amostra foi apresentada na Tabela 1, a seguir. 
Tabela 1 - Estatística descritiva, dos 11 idosos moradores no Lar Vicentino Raimunda Odília.

\begin{tabular}{llll}
\hline Características & & $\mathbf{N}$ & $\mathbf{\%}$ \\
\hline Idade (média) & Masculino & 79 & $81,82 \%$ \\
Sexo & 9 & $18,18 \%$ \\
Feminino & 2 & $18,18 \%$ \\
& Branco & 2 & $45,45 \%$ \\
& Pardo & 5 & $9,1 \%$ \\
& Moreno & 1 & $27,27 \%$ \\
\hline Escolaridade (anos) & Negro & 3 & \\
\hline
\end{tabular}

A média de idade dos idosos institucionalizados participantes da pesquisa foi de 79 anos, com predomínio do sexo masculino $(81,82 \%)$, com a cor parda $(45,45 \%)$ e com média de escolaridade de 3 anos.

$\mathrm{Na}$ Tabela 2, tem-se a modelação numérica dos testes: Mini Exame do Estado Mental, Índice de Tinetti, Teste de Romberg, risco e número de quedas nos últimos 12 meses.

Tabela 2 - Resultados dos testes da população estudada.

\begin{tabular}{cccccc}
\hline Idade & $\begin{array}{c}\text { Mini Exame } \\
\text { Estado Mental }\end{array}$ & $\begin{array}{c}\text { Índice de } \\
\text { Tinetti }\end{array}$ & Risco de queda & Teste Romberg & Quedas \\
\hline 81 & 19 & 21 & Moderado & Alterado & 2 \\
71 & 21 & 22 & Moderado & Alterado & 1 \\
77 & 24 & 19 & Elevado & Alterado & 2 \\
85 & 23 & 22 & Moderado & Normal & 0 \\
82 & 23 & 18 & Elevado & Alterado & 3 \\
77 & 16 & 19 & Elevado & Alterado & 3 \\
81 & 4 & 19 & Elevado & Alterado & 4 \\
83 & 14 & 20 & Moderado & Alterado & 2 \\
\hline 74 & 22 & 23 & Moderado & Normal & 0 \\
72 & 14 & 28 & Baixo & Normal & 0 \\
\hline 93 & 18 & 15 & Elevado & Alterado & 3 \\
\hline
\end{tabular}

Em acordo com a Tabela 2, 10 dos idosos institucionalizados apresentaram alterações no MEEM, Índice de Tinetti, Teste de Romberg, com riscos de quedas de moderado a elevado. Desses, a maioria são longevos (5), com idade igual ou superior a 80 anos e apresentaram mais episódios de quedas nos últimos 12 meses. 


\section{DISCUSSÃO}

O índice de quedas está mais evidenciado em pacientes institucionalizados e fragilizados. Os principais fatores que indicam tal evento são idade avançada, imobilidade, doenças crônicas, história prévia de quedas, déficits cognitivos e presença de ambiente físico inadequado. De acordo com dados do ministério da saúde $30 \%$ da população idosa que reside em comunidades sofrem múltiplas quedas a cada ano. Porém em idosos institucionalizados esse risco é triplicado, e 39,8\% das quedas, são em idosos com idade entre 80 a 89 anos. Esses idosos possuem características peculiares como sedentarismo, perda da autonomia, abandono familiar, fatores esses que contribuem com o aumento de morbidades e comorbidades ${ }^{10}$.

Estudos identificaram altos percentuais de quedas em idosos institucionalizados e a maior parte dos que caem sofrem recorrência de quedas. Idosos que vivem em ILPI, apresentam maior percentual de risco de quedas (40\%) em comparação com os idosos moradores da comunidade (30\%), evidências semelhantes a esse estudo, que demonstra alto risco de quedas, e mais de um episódio de quedas nos últimos 12 meses, em idosos que vivem em ILPI ${ }^{11}$.

A literatura cita que o risco de quedas aumenta em paciente com déficit cognitivo e escore do MEEM inferior a 30 pontos. Cenário consequente à desorientação visual e espacial, relacionado a má percepção em seus respectivos ambientes. Um estudo realizado nos Estados Unidos em 2017, revelou que o declínio cognitivo aumenta o risco de quedas. Portanto o MEEM é um instrumento muito importante na avaliação do estado mental desses idosos e que sua menor pontuação está relacionada com o nível de escolaridade, sendo diretamente proporcional. Panorama compatível com os achados desse estudo, uma vez que os idosos com menor resultado do MEEM, também apresentaram mais episódios de quedas nos últimos 12 meses, associada a baixa escolaridade ${ }^{12}$.

Teste de Tinetti é um exame muito utilizado para avaliar a marcha, equilíbrio, e risco de quedas. Os achados desse estudo apresentam baixo resultado no teste, o que representa maior risco de quedas. A literatura descreve que idosos submetidos a um programa de exercícios obtiveram melhora significativa na pontuação do teste de Tinetti, comparado aos idosos que não fizeram nenhuma atividade física ${ }^{13}$.

Com o envelhecimento o sistema visual, somatossensorial e vestibular são alterados. Para que o equilíbrio ocorra de forma correta é necessária à manutenção do centro de gravidade sobre a base de sustentação, no entanto com o envelhecimento essa capacidade é diminuída levando a uma instabilidade e podendo ocorrer quedas. Os idosos desse estudo com alteração no teste de equilíbrio apresentaram mais episódio de quedas ${ }^{14}$.

Nosso estudo demonstra que os longevos com idades superiores a 80 anos-apresentaram mais episódios de quedas no último ano, relacionando se com a literatura que ressalta, que com o avançar da idade as quedas tornam se recorrentes, podendo causar complicações leves ou graves. Os longevos, com idades acima de 80 anos estão 14 vezes mais propensos a sofrem quedas que idosos com menor idade ${ }^{15}$. 


\section{CONCLUSÃO}

Os idosos moradores em ILPI, submetidos a avaliação com o MEEM, Índice de Tinneti e Teste de Romberg apresentaram baixos resultados compatíveis com elevado risco e recorrência de quedas nos últimos 12 meses, principalmente entre os longevos. Ressalta-se a importância da oferta de programas de intervenção que envolvam exercícios físicos com objetivo de prevenir quedas, considerando idosos ativos apresentam menor risco das mesmas.

\section{REFERÊNCIA}

1. Alves JED. A transição demográfica e a janela de oportunidade. São Paulo: Instituto Fernand Braudel de Economia Mundial. 2008

2. Fechine B, Trompieri N. O processo de envelhecimento: As principais alterações que acontecem com o idoso com o passar dos anos. Revista Científica Internacional, v. 1, n. 7, p. 106-194, 2012.

3. Pinho, TA et al. Avaliação do risco de quedas em idosos atendidos em Unidade Básica de Saúde. Revista Escola Enfermagem USP. v. 46, n.2 p. 320-7, 2012.

4. Mallmann D G, Hammerschmidt KS, Santos SS. Instrumento de avaliação de quedas para idosos (IAQI): enfermeiro analisando vulnerabilidade e fragilidade. Revista Brasileira Geriátrica Gerontol, v.15 n.3, p.517$527,2012$.

5. Silva, MI. Avaliação do risco de quedas- Contributos para a implementação da supervisão clinicas em enfermagem. 2015. 189f. Dissertação de Mestrado, Escola Superior de Enfermagem do Porto, 2015.

6. Bardin L. Análise de Conteúdo. Lisboa, Portugal; Edições 70, LDA, 2009.

7. Melo DM, Barbosa AJG. O uso do Mini-Exame do Estado Mental em pesquisas com idosos no Brasil: uma revisão sistemática. Ciência \& Saúde Coletiva, v.20,n.12, 2015.

8. Christofoletti G, Oliani MM, Gobbi LTB, Gobbi S, Stella F. Risco de quedas em idosos com doença de Parkinson e demência de Alzheimer: um estudo transversal. Rev. bras. fisioter., v. 10, n. 4, 2006.

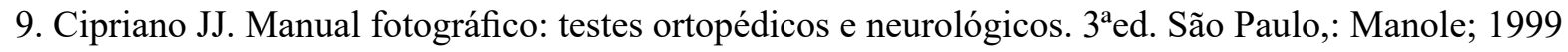

10. Gomes EC et al. Fatores associados ao risco de quedas em idosos institucionalizados: uma revisão integrativa. Ciência \& Saúde Coletiva, v.19,n.8, 2014.

11. Ferreira LMBM et al. Quedas recorrentes e fatores de risco em idosos institucionalizados. Ciência \& Saúde Coletiva, v.24,n.1, 2019.

12. Smith AA et al. Avaliação do risco de quedas em idosos residentes em domicílio. Rev. Latino-Am. Enfermagem, v.25, 2017.

13. Silva A et al. Equilíbrio, Coordenação e Agilidade de Idosos Submetidos à Prática de Exercícios Físicos Resistidos. Rev Bras Med Esporte, vol. 14, n. 2, 2008.

14. Gnoato K, Godoy KJ, Dorst LM. Distúrbio do equilíbrio em idoso. EFDeportes.com, Revista Digital. v.16, n.157, 2011.

15. Ferreti F, Lunardi D, Bruschi L. Causas e consequências de quedas de idosos em domicílio. Fisioter. Mov, v. 26, n. 4, 2013. 


\section{PREVALÊNCIA DE SINAIS E SINTOMAS DE DISBIOSE INTESTINAL EM ESTUDANTES DO CURSO DE MEDICINA DE UMA INSTITUIÇÃO DE ENSINO SUPERIOR PRIVADA EM MINEIROS - GO}

GÉSSICA HELEN DE MELO Faculdade Morgana Potrich - FAMP

ANDRESSA CAITANO RIBEIRO Faculdade Morgana Potrich - FAMP

NÁRGELLA SILVA CARNEIRO Faculdade Morgana Potrich - FAMP

GILBERTO DE MELO JUNIOR Instituto Federal de Goiás - IFG

JANE SOUSA NAVES

Universidade Federal de Goiás - UFG

VANESSA ALVES DE ARAÚJO

Universidade Federal de Goiás - UFG analisar os fatores de risco associados, através do Questionário de Hábitos de Vida. É um estudo descritivo, transversal, de caráter quantitativo. Os dados foram coletados através dos questionários aplicados em 190 acadêmicos da instituição. Observou-se a taxa de 30\% de hipersensibilidade alimentar, sendo 73,68\% mulheres. Os sintomas mais frequentes foram arrotos e gases $(71,58 \%)$, diarreia (67,37\%), distensão abdominal $(62,64 \%)$, dor gástrica $(58,95 \%)$ e azia $(56,85 \%)$. Os fatores de risco mais prevalentes foram o consumo de alimentos embutidos $(93,15 \%)$, de alto teor de índice glicêmico $(96,3 \%)$, e carboidratos simples $(95,25 \%)$. Além do etilismo $(77,71 \%)$ e do uso de medicamentos, como anti-inflamatórios $(69,23 \%)$ e antibióticos (56,83\%). Desse modo, evidencia-se a necessidade de mudanças dietéticas e alterações de alguns hábitos de vida, tendo em vista uma melhor qualidade de vida e prevenção da disbiose intestinal.

PALAVRA-CHAVE: Disbiose; Sintomas; Intestino.

ABSTRACT: This survey aims to investigate the prevalence of signs and symptoms about intestinal dysbiosis among medical students in a private higher education institution in Mineiros-GO through the Metabolic Screening Questionnaire. Regarding this, it sought to analyze the associated risk factors through the Life Habits Questionnaire. This study is all about a descriptive, cross-sectional, quantitative study. Data were collected through questionnaires applied to 190 academics from the institution. There was a $30 \%$ rate of food hypersensitivity, with $73.68 \%$ women. The most frequent symptoms were belching and 
gas $(71.58 \%)$, diarrhea $(67.37 \%)$, abdominal distension $(62.64 \%)$, gastric pain $(58.95 \%)$ and heartburn $(56.85 \%)$. The most prevalent risk factors were the consumption of embedded foods $(93.15 \%)$, high glycemic index (96.3\%) and simple carbohydrates $(95.25 \%)$, including alcoholism $(77.71 \%)$ and the use of medications such as anti-inflammatory drugs $(69.23 \%)$ and antibiotics $(56.83 \%)$. There is a need for dietary changes and changes in some lifestyle habits, in view of a better quality of life and prevention of intestinal dysbiosis.

KEYWORDS: Dysbiosis; Symptoms; Intestine.

\section{INTRODUÇÃO}

Atualmente, pode-se observar um crescente perfil de afecções alérgicas, autoimunes e Doenças Crônicas Não Transmissíveis (DCNT), que vêm sendo provocadas por mudanças tanto no estilo de vida quanto nos hábitos da sociedade. Em décadas passadas, notava-se um perfil de doenças mais relacionadas às doenças infecciosas do que nos dias atuais (MAIA et al., 2018).

O sistema gastrintestinal é o segundo maior sistema do corpo humano, tendo como funções secreção e absorção de substratos necessários ao organismo. No intestino, encontram-se mais de 1000 tipos diferentes de bactérias e aproximadamente 100 trilhões de micro-organismos de transição e nativos, número equivalente a 10 vezes o número de células de um adulto (BONFANTE, 2012).

A microbiota intestinal é composta pelo equilíbrio dos microrganismos que colonizam o sistema gastrintestinal e nela residem. Alterações nesse ecossistema caracterizam a disbiose, que pode ser definida como estado de alteração da qualidade e/ou quantidade da microbiota intestinal, sua ação metabólica e local de distribuição, aumentando o número de bactérias patogênicas (FAGUNDES, 2010).

Dentre os fatores que podem ser citados para essas alterações, estão: a utilização indevida de antibióticos, que matam tanto bactérias patogênicas quanto as residentes; uso elevado de laxantes; consumo exagerado de alimentos industrializados, disfunções hepatopancreáticas e estresse. Idade, tempo de trânsito colônico e estado imunológico do indivíduo são fatores que também influenciam na disbiose (ALMEIDA, 2009).

A dieta do homem é uma das principais causas de disbiose, uma vez que a alimentação é o principal fator na alteração da microbiota intestinal. A mudança dos hábitos alimentares do brasileiro acompanha uma queda nutricional e aumento do excesso de peso, propiciando o surgimento de doenças crônicas não transmissíveis (ALMEIDA, 2009; BRASIL, 2017; ARAUJO, 2011).

Medidas dietéticas e hábitos de vida são fatores fundamentais para a diminuição do surgimento da disbiose. O uso de probióticos, prebióticos e simbióticos funcionam como meio de prevenção e tratamento das alterações da microbiota intestinal (MAIA et al., 2018).

Devido à alta carga horária de estudos, os estudantes do curso de Medicina acabam se envolvendo em uma rotina estressante, na qual negligenciam os hábitos de vida saudáveis em detrimento 
dos compromissos acadêmicos. Desse modo, optar por alimentos industrializados e até mesmo pular refeições se torna constante no cotidiano dos alunos. Essa alimentação desregrada contribui para a alteração da microbiota gastrintestinal.

Sendo assim, o objetivo dessa pesquisa foi identificar a prevalência dos sinais e sintomas envolvidos no desenvolvimento da disbiose intestinal em estudantes do curso de Medicina de uma Instituição de Ensino Superior Privada em Mineiros - GO.

\section{MATERIAIS E MÉTODOS}

Este estudo trata-se de uma pesquisa de natureza quantitativa, descritiva e do tipo transversal. A pesquisa foi desenvolvida em uma Instituição de Ensino Superior Privada de Mineiros - GO, no período de outubro de 2019.

Foram incluídos na pesquisa acadêmicos do curso de Medicina, de ambos os sexos e que possuam mais de 18 anos. O curso foi escolhido pela disponibilidade dos elementos da pesquisa. Entre os excluídos da pesquisa estão: aqueles que não preencheram completamente o questionário, se recusaram a participar da pesquisa e os que apresentaram idade inferior a 18 anos. Os alunos foram escolhidos ao acaso, independente do semestre. A amostra está composta por 190 acadêmicos e os dados somente foram coletados após a autorização da Instituição, do Comitê de Ética em Pesquisa e do consentimento do acadêmico, assinando o Termo de Consentimento Livre e Esclarecido.

A coleta de dados foi feita a partir do mês de outubro de 2019, após aprovação do Comitê de Ética em Pesquisa. Através da aplicação de dois questionários autoaplicáveis, compostos por questões objetivas que foram preenchidas de forma subjetiva, com informações do que ocorreu com o organismo nos últimos 30 dias, nas últimas semanas e nas últimas 48 horas. O Questionário de Rastreamento Metabólico (QRM) foi dividido em 14 blocos referentes aos sinais e sintomas relacionados a hipersensibilidades alimentares e/ou ambientais, sendo validado pelo Instituto Brasileiro de Nutrição Funcional. O Quadro 1 ilustra o QRM apresentado aos voluntários para responderem.

Quadro 1 - Questionário de Rastreamento Metabólico.

\begin{tabular}{|l|l|l|}
\hline & & TOTAL \\
\hline \multirow{4}{*}{ CABEÇA } & Dor de cabeça & \\
\cline { 2 - 3 } & Sensação de desmaio & \\
\cline { 2 - 3 } & Tonturas & \\
\cline { 2 - 3 } & Insônia & \\
\hline \multirow{4}{*}{ OLHOS } & Lacrimejantes ou coçando & \\
\cline { 2 - 3 } & Inchados, vermelhos ou com cílios colando & \\
\cline { 2 - 3 } & Bolsas ou Olheiras abaixo dos olhos & \\
\cline { 2 - 3 } & Visão borrada ou em túnel (não inclui miopia ou astigmatismo) & \\
\hline
\end{tabular}




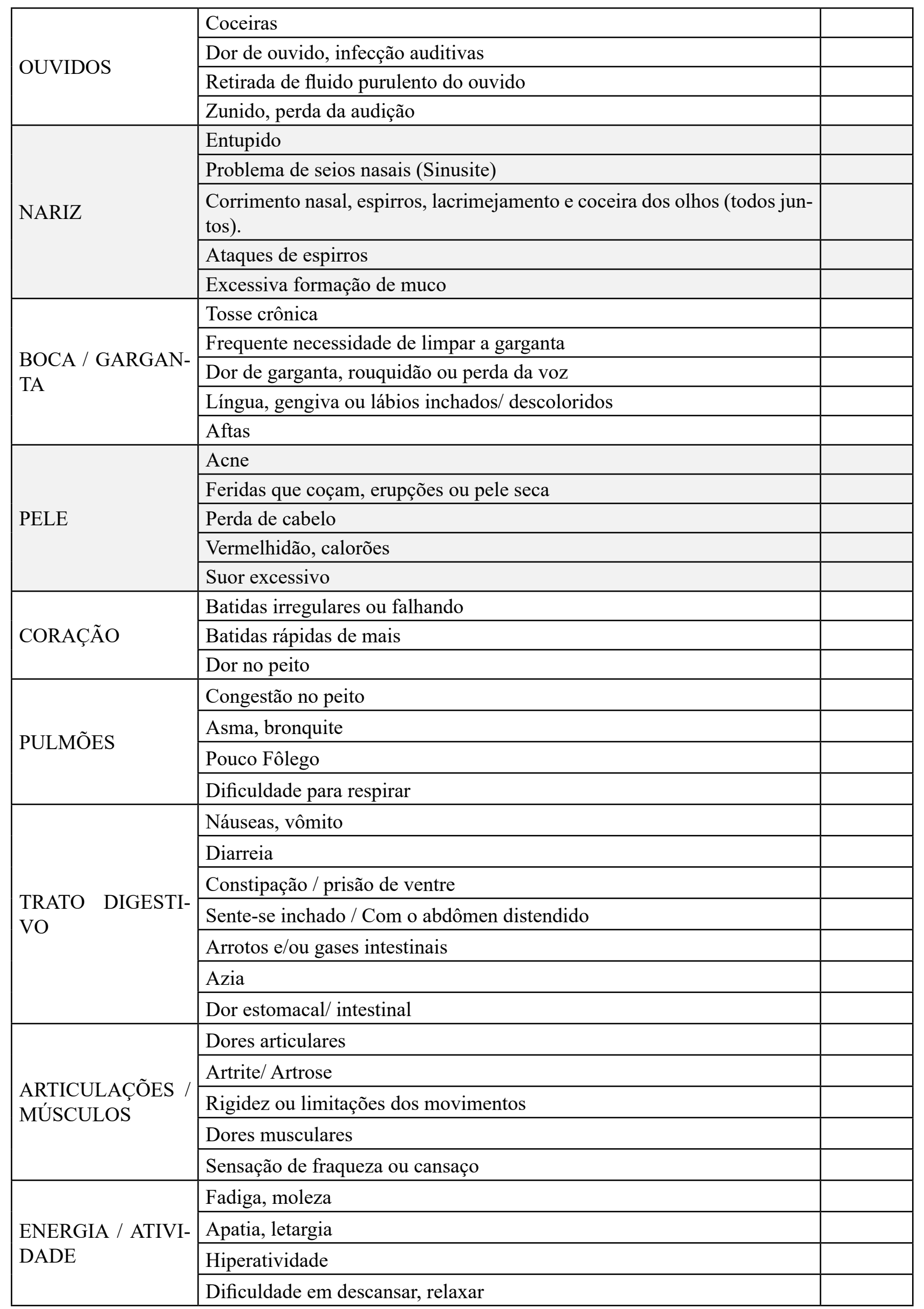




\begin{tabular}{|c|c|}
\hline \multirow{8}{*}{ MENTE } & Memória ruim \\
\hline & Confusão mental, compreensão ruim \\
\hline & Concentração ruim \\
\hline & Fraca coordenação motora \\
\hline & Dificuldade em tomar decisões \\
\hline & Fala com repetições de sons ou palavras, com várias pausas involuntárias \\
\hline & Pronuncia palavras de forma indistinta, confusa \\
\hline & Problemas de aprendizagem \\
\hline \multirow{4}{*}{ EMOÇÕES } & Mudanças de humor/ mal humor matinal \\
\hline & Ansiedade, medo, nervosismo \\
\hline & Raiva, irritabilidade, agressividade \\
\hline & Depressão \\
\hline \multirow{4}{*}{ OUTROS } & Frequentemente doente \\
\hline & Frequente ou urgente vontade de urinar \\
\hline & Coceira genital ou corrimento \\
\hline & Edema / Inchaço - Pés/ Pernas/ Mãos \\
\hline
\end{tabular}

O Questionário de Hábitos de Vida aborda fatores de risco associados às alterações na microbiota intestinal. O Quadro 2 ilustra tal questionário.

Quadro 2-Questionário de Hábitos de Vida.

\begin{tabular}{|l|l|l|l|}
\hline \multicolumn{1}{|c|}{ HÁBITOS } & NUNCA & ÀS VEZES & SEMPRE \\
\hline Prática de exercícios físicos & & & \\
\hline Ingestão de alimentos embutidos & & & \\
\hline $\begin{array}{l}\text { Ingestão de carboidratos simples (como fa- } \\
\text { rinha branca e bolos industrializados) }\end{array}$ & & & \\
\hline $\begin{array}{l}\text { Ingestão de alimentos com elevado teor de } \\
\text { índice glicêmico }\end{array}$ & & & \\
\hline Ingestão de bebida alcoólica & & & \\
\hline Tabagismo & & & \\
\hline Uso de anti-inflamatórios & & & \\
\hline Uso de antibióticos & & & \\
\hline Uso de laxantes & & & \\
\hline
\end{tabular}


A Disbiose Intestinal foi avaliada através da pontuação dada pelo participante aos sintomas que estão relacionados no QRM: náuseas/vômitos, diarreia, constipação/ prisão de ventre, inchaço/ abdômen distendido, gases intestinais/ eructações, azia, dor estomacal/ intestinal, que constituem a seção voltada ao trato gastrointestinal.

A pontuação foi registrada conforme uma escala de pontos baseada na frequência e na gravidade dos sintomas, sendo: " 0 " quando nunca ou quase nunca apresentou o sintoma; "1" quando ocasionalmente teve, mas o efeito não foi severo; " 2 " quando ocasionalmente teve o sintoma e o efeito foi severo; " 3 " quando frequentemente teve, mas o efeito não foi severo e "4" quando frequentemente teve e o efeito foi severo.

Assim, para a análise dos dados, sempre que houver pontuação de "10" ou mais pontos em uma seção do QRM, é indicativo da existência de hipersensibilidade alimentar. Os dados foram tabulados e analisados estatisticamente em forma de gráficos e tabelas utilizando o Microsoft Office Excel versão 2019.

\section{RESULTADOS E DISCUSSÕES}

A pesquisa seguiu os preceitos éticos conforme consta na Resolução n ${ }^{\circ}$ 466/2012 do Conselho Nacional de Saúde (CNS) que envolve pesquisas com seres humanos. O projeto com o Certificado de Apresentação de Apreciação Ética (CAAE): 18062219.2.0000.5428, foi aprovado pelo Comitê de Ética em Pesquisa, conforme o parecer número: 3.630.668. A participação foi voluntária, assinando o Termo de Consentimento e esclarecidos de todos os riscos e benefícios dos participantes.

Fizeram parte deste estudo 190 alunos do curso de Medicina, sendo 112 (58,95\%) do sexo feminino e 78 (41,05\%) do sexo masculino. A indicação de hipersensibilidade alimentar apresentada por pontuações iguais ou superiores a 10 pontos na seção específica do trato gastrintestinal foi notada em 57 (30\%) acadêmicos, dentre essas 73,68\% mulheres e 26,31\% homens. As pontuações dos sintomas analisados na população estudada foram especificadas na Tabela 1.

Tabela 1 - Sintomas Gastrintestinais.

\begin{tabular}{|c|c|c|c|c|c|}
\hline $\begin{array}{l}\text { Frequência } \\
\text { Sintomas }\end{array}$ & 0* & $1 *$ & $2 *$ & $3 *$ & $4 *$ \\
\hline Náuseas e vômitos & $51,57 \%$ & $31,57 \%$ & $7,89 \%$ & $6,31 \%$ & $2,63 \%$ \\
\hline Diarreia & $32,63 \%$ & $43,68 \%$ & $7,89 \%$ & $10 \%$ & $5,78 \%$ \\
\hline Constipação & $56,31 \%$ & $29,47 \%$ & $4,21 \%$ & $4,73 \%$ & $5,26 \%$ \\
\hline Distensão Abdominal & $37,36 \%$ & $35,26 \%$ & $4,73 \%$ & $17,89 \%$ & $4,73 \%$ \\
\hline Arrotos e gases & $28,42 \%$ & $38,42 \%$ & $8,94 \%$ & $20 \%$ & $4,21 \%$ \\
\hline Azia & $43,15 \%$ & $30 \%$ & $8,94 \%$ & $11,05 \%$ & $6,84 \%$ \\
\hline Dor gástrica & $41,05 \%$ & $31,57 \%$ & $9,47 \%$ & $10 \%$ & $7,89 \%$ \\
\hline
\end{tabular}


*Legenda:

0 - Nunca ou quase nunca teve o sintoma 1 - Ocasionalmente teve, efeito não foi severo

2 - Ocasionalmente teve, efeito foi severo 3 - Frequentemente teve, efeito não foi severo

4 - Frequentemente teve, efeito foi severo.

Em relação aos fatores de risco, como pode ser observado no gráficos 1 e 2, entre os 190 acadêmicos, foi evidenciado que 19 (10\%) alunos são sedentários, 149 (78,42\%) são etilistas sociais, 32 $(16,84 \%)$ tabagistas, 177 (93,15\%) consomem alimentos embutidos, 181 (95,26\%) ingerem carboidratos simples, 183 (96,31\%) consomem alimentos com alto teor de índice glicêmico, 126 (66,31\%) fazem uso de anti-inflamatórios, 17 (8,94\%) tiveram contato com laxantes e 108 (56,84\%) utilizam antibióticos de forma esporádica ou frequente.

Os Gráficos 1 e 2 apresentam os resultados das respostas dos voluntários em relação aos questionários do Quadro 1 e 2.

Gráfico 1 - Hábitos de vida dos acadêmicos de medicina de uma instituição de ensino superior privada em Mineiros-GO.

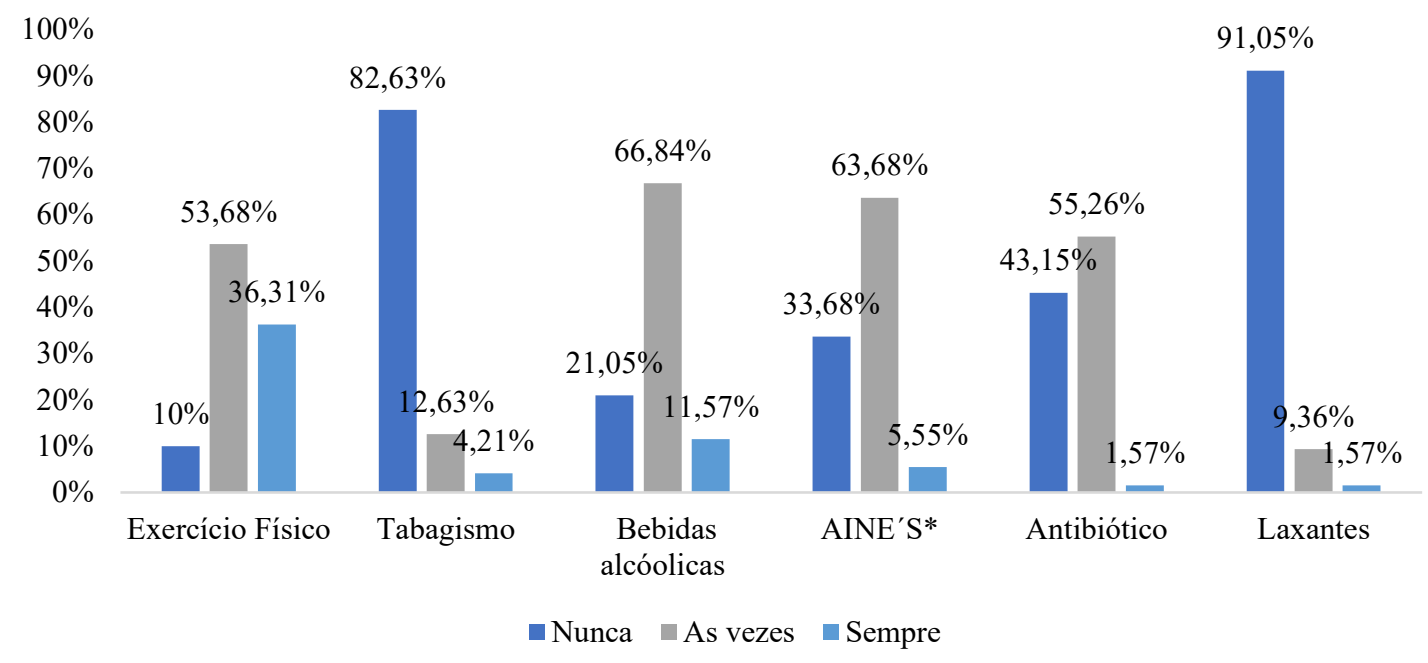

*AINES: Anti-inflamatórios não esteroidais

Gráfico 2 - Hábitos alimentares dos acadêmicos de medicina de uma instituição de ensino superior privada em Mineiros-GO.

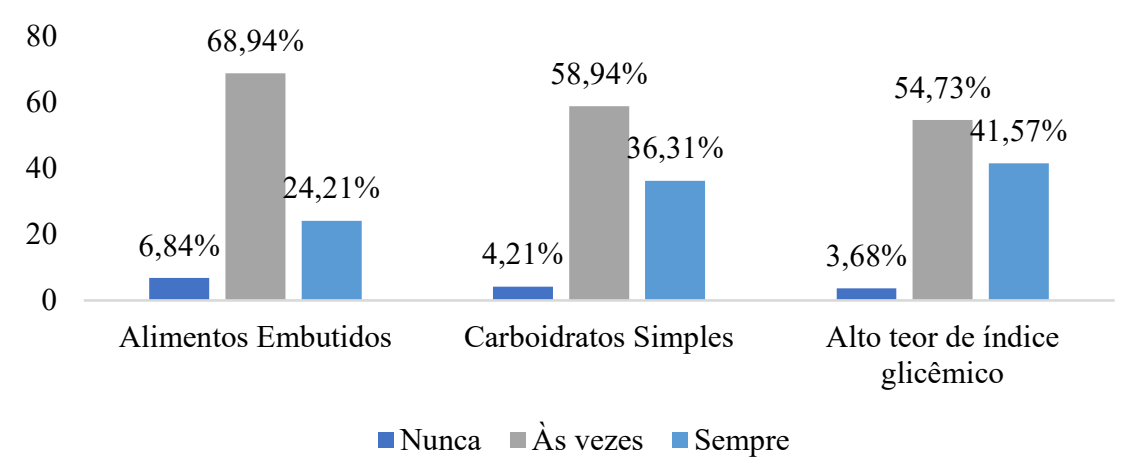


No estudo de Feitosa et al. (2010) acerca dos hábitos alimentares de estudantes de uma universidade pública no Nordeste, foi relatado que 51,1\% dos universitários apresentavam consumo de frituras, embutidos ou doces adequados. Na presente pesquisa, observou- se um consumo de alimentos embutidos de $68,94 \%$ esporadicamente e $24,21 \%$, frequentemente. Dentre os pesquisados, $58,94 \%$ às vezes ingerem carboidratos simples e 36,31\% mais de 3 vezes na semana. Apenas 3,68\% nunca consomem alimentos com alto teor de índice glicêmico, enquanto $41,57 \%$ sempre ingerem. A má alimentação entre os acadêmicos pode ser justificada pela falta de tempo. Num estudo entre estudantes de medicina de uma Universidade em Alagoas, 62\% afirmaram não realizar refeições adequadas durante o período das aulas, principalmente o almoço (43\%) (LESSA E MOTENEGRO, 2008).

Os alimentos refinados sofrem processos que reduzem seus valores nutricionais, devendo ser consumidos com moderação, já que sua alta ingestão interfere na fisiologia normal do organismo como, por exemplo, em condições normais as bactérias intestinais atuam na formação de vitamina $\mathrm{K}$ e do complexo B, já com consumo abusivo de carboidratos simples, ocorre a fermentação e produção do álcool no intestino. Além disso, contribuem no desenvolvimento de doenças diverticulares, apendicites, constipação intestinal e câncer de colo (YÉPEZ, 2004).

Em se tratando do estilo de vida, o percentual de etilistas foi alto, totalizando 77,71\%, incluindo aqueles que bebem esporadicamente. A taxa de 64,4\% encontrada entre acadêmicos de medicina de uma Universidade no Maranhão também foi considerada elevada (BARBOSA, 2013). Já se tratando do tabagismo, o número de estudantes que nunca fumaram é prevalente com $82,63 \%$, o que se assemelha à baixa prevalência de fumantes entre alunos de Medicina de uma Universidade no Rio de Janeiro, de 14\% (SILVA JUNIOR, 2006).

Numa pesquisa realizada em 04 cursos de Medicina existentes na cidade de Fortaleza, foi verificado que aproximadamente 70\% dos estudantes são sedentários (MAIA, 2014), o que mostra um resultado positivo da presente pesquisa, já que apenas $10 \%$ não praticam nenhuma atividade esportiva ou física.

O exercício, principalmente o de baixa intensidade, tem efeito protetor sobre o trato gastrintestinal (LIRA et al., 2008). Em relação ao tabagismo, a fumaça do tabaco contém centenas de substâncias químicas. Acredita-se que a nicotina presente atue como imunossupressora nos macrófagos, o que significa que algumas bactérias maléficas não conseguem sair do intestino (STEINWURZ, 2014). A ingestão de álcool irrita a mucosa do trato gastrintestinal, podendo levar a sintomas como náusea, vômito, diarreia e sangramento (STEINWURZ, 2014).

Em relação ao uso de medicamentos, 63,68\% afirmaram que às vezes fazem uso de anti-inflamatórios e 33,68\% nunca o fazem. Já 55,26\% esporadicamente fazem uso de antibióticos e 1,57\%, sempre. Num estudo realizado entre estudantes de Medicina de Universidade da Paraíba, 65,75\% ingeriram essa classe no ano da pesquisa e 66,54\% tomaram antibióticos (DE OLIVEIRA ROCHA, 2011). Em se tratando do consumo de laxantes, $91,05 \%$ relataram que nunca fazem uso e entre os que fazem $80 \%$ são mulheres. Em pesquisa feita entre acadêmicas do curso de Nutrição em Porto Alegre, $55 \%$ afirmaram usar ou já terem usado algum tipo de laxante (BILLODRE, 2013). 
No que se refere à presença de náuseas e vômitos, 48,43\% dos acadêmicos apresentaram esses sintomas. Assemelhando-se ao estudo entre profissionais de Enfermagem de uma instituição em Curitiba, em que estiveram presentes em 43,52\% da população analisada (GALDINO, 2016). Na atual pesquisa, se tratando de diarreia, $67,37 \%$ a apresentaram. Enquanto em outro estudo, em que foi utilizado o mesmo questionário com acadêmicos de Nutrição de uma instituição de Fortaleza, 73,63\% não tiveram esse sintoma (DE MELO e DE OLIVEIRA, 2018).

A prevalência de constipação intestinal entre os acadêmicos foi de 43,69\%, resultado próximo ao da pesquisa feita com universitários de uma instituição particular de Goiânia, que foi de $40 \%$ (JAIME et al., 2009). De acordo com os questionários, 62,64\% apresentam ou já tiveram distensão abdominal, que é um dos sintomas característicos para diagnóstico de síndrome do intestino irritável.

As eructações foram apresentadas por $71,58 \%$ dos alunos; resultado que se assemelha ao de um estudo entre acadêmicos de nutrição de uma universidade em Florianópolis, que foi de 82,82\% de prevalência de arrotos entre os sintomas presentes (FERREIRA, 2018). Dentre os sintomas dispépticos, a azia esteve presente em $56,85 \%$ da população analisada. Já em estudo com adultos de Belo Horizonte, a queimação no estômago esteve presente em 10,6\% (USNAYO et al., 2017).

Com relação à dor gástrica, a prevalência foi de 58,95\%. Já em estudo com pacientes de uma clínica em Teresina, foi de $100 \%$, sendo essa considerada sintoma marcante para disbiose intestinal (LOPES et al., 2017).

Sintomas como gases, cólicas, diarreias e constipação frequentes são indicativos de disbiose intestinal e devem ser investigados. A disbiose apresenta um agravante quando relacionada às disfunções do TGI, tais como aumento da permeabilidade intestinal, constipação intestinal, acarretando no aparecimento de patologias devido ao não funcionamento das funções da microbiota (JARDIM, 2018).

\section{CONCLUSÃO}

Em suma, este trabalho identificou a prevalência de sintomas que predispõem a Disbiose intestinal, sendo esses, arrotos, gases, diarreia, distensão abdominal, dor gástrica e azia, acarretando em presença de $30 \%$ de hipersensibilidade alimentar dentre os alunos participantes da pesquisa. Foi notado que os principais fatores de risco presentes entre os acadêmicos estão associados aos maus hábitos alimentares, além do consumo de bebidas alcóolicas e do uso de anti-inflamatórios e antibióticos. Desse modo, percebe-se a necessidade de mudanças dietéticas e algumas alterações nos hábitos de vida, vislumbrando uma qualidade de vida a curto e a longo prazo e a prevenção do desenvolvimento da Disbiose Intestinal. 


\section{APROVAÇÃO CÔMITE DE ÉTICA}

O projeto com o Certificado de Apresentação de Apreciação Ética (CAAE): 18062219.2.0000.5428, foi aprovado pelo Comitê de Ética em Pesquisa, conforme o parecer número: 3.630 .668 .

\section{REFERÊNCIAS}

ALMEIDA, Luciana Barros et al. Disbiose intestinal. Revista Brasileira de Nutrição Clínica, v. 24, n. 1, p. $58-65,2009$.

ARAÚJO, E. M. Q. Disbiose intestinal. Pujol, APP Nutrição Aplicada à Estética. Rio de Janeiro. Editora Rubio, p. 139-153, 2011.

BARBOSA, Felipe Lacerda et al. Uso de álcool entre estudantes de medicina da Universidade Federal do Maranhão. Revista brasileira de educação médica, v. 37, n. 1, p. 89-95, 2013.

BILLODRE, Bibiana Nor; GOMEZ, Rosane; CALETTI, Greice. Prevalência e motivação de uso de laxantes entre universitárias do curso de nutrição do Centro Universitário Metodista de Porto Alegre/RS. Ciência em Movimento, v. 15, n. 30, p. 35-43, 2013.

BONFANTE, V. Disbiose Intestinal: a estreita relação entre o intestino e a saúde. Revista Essentia Pharma. Florianópolis-SC. $2^{\mathbf{a}}$ edição, 2012.

BRASIL, Vigitel. Saúde Suplementar: vigilância de fatores de risco e proteção para doenças crônicas por inquérito telefônico [recurso eletrônico] / Ministério da Saúde, Agência Nacional de Saúde Suplementar. Brasília: Ministério da Saúde, p. 170, 2017.

DE MELO, Bárbara Rebeca Cordeiro; DE OLIVEIRA, Raquel Sombra Basílio. Prevalência de disbiose intestinal e sua relação com doenças crônicas não transmissíveis em estudantes de uma instituição de ensino superior de Fortaleza-CE. RBONE-Revista Brasileira De Obesidade, Nutrição E Emagrecimento, v. 12, n. 74, p. 767-775, 2018.

DE OLIVEIRA ROCHA, Aline Maria et al. Perfil da utilização de medicamentos por estudantes de medicina da Universidade Federal de Campina Grande (UFCG). Revista Saúde \& Ciência Online, v. 2, n. 1, p. 75-87, 2011.

FAGUNDES, G. E. Prevalência de sinais e sintomas de Disbiose Intestinal em estudantes do curso de Nutrição da Universidade do Extremo Sul Catarinense. TCC em Nutrição. Universidade do Extremo Sul Catarinense. Criciúma, 2010.

FEITOSA, Eline Prado Santos et al. Hábitos alimentares de estudantes de uma universidade pública no Nordeste, Brasil. Alim Nutr, v. 21, n. 2, p. 225-30, 2010.

FERREIRA, Eliz Garcia. Disbiose intestinal em estudantes do curso de nutrição de uma universidade da grande Florianópolis. Nutrição-Pedra Branca, 2018.

GALDINO, Janaina Juk et al. Questionário de rastreamento metabólico voltado a disbiose intestinal em profissionais de enfermagem. RBONE-Revista Brasileira de Obesidade, Nutrição e Emagrecimento, v. 10, n. 57, p. 117-122, 2016.

JAIME, Raquel Peixoto et al. Prevalência e fatores de risco da constipação intestinal em universitários de uma instituição particular de Goiânia, GO* Prevalence and risk factors of constipation in students of a private institution of Goiânia, GO. 2009. 
JARDIM, A.T.; RANGEL JUNIOR, C.L.A.; FONTOURA, C.C.; ARAGÃO, F.B.A.; Salvador, E.P. Prevalência de hipersensibilidade e disbiose intestinal em policiais militares. $\mathbf{1 2}^{\circ}$ Congresso Nacional dos estudantes de saúde, Porto Seguro, 2018.

LESSA, Simone Schwartz; MONTENEGRO, Arthur Cabús. Avaliação da prevalência de sobrepeso, do perfil nutricional e do nível de atividade física nos estudantes de medicina da Universidade de Ciências da Saúde de Alagoas-UNCISAL. Rev. Soc. Bras. Clín. Méd, p. 90-93, 2008.

LIRA, Claudio Andre Barbosa de et al. Efeitos do exercício físico sobre o trato gastrintestinal. Revista Brasileira de Medicina do Esporte, v. 14, n. 1, p. 64-67, 2008.

LOPES, C.L.R.; SANTOS, G.M.; COELHO, F.O.A.M. A prevalência de sinais e sintomas de disbiose intestinal em pacientes de uma clínica em Teresina- PI. C\&D- Revista Eletrônica da FAINOR, Vitória da Conquista, v. 10, n. 3, p. 280-292, set./dez., 2017.

MAIA, D. de A.C.; VASCONCELOS, J.A.; FILHO, J.O.V.; Acadêmicos de medicina e a prática de atividade física. Coleção de Pesquisa em Educação Física, Várzea Paulista, v. 13, n. 1, p. 15-22, 2014.

MAIA, Priscilla Lima; DE CERQUEIRA FIORIO, Bárbara; DA SILVA, Francisco Regis. A influência da microbiota intestinal na prevenção do câncer de cólon. Arquivos Catarinenses de Medicina, v. 47, n. 1, p. 182-197, 2018.

SILVA JUNIOR, C. T. et al. Prevalência de tabagismo entre estudantes de graduação em medicina da Universidade Federal Fluminense. Pulmão RJ, v. 15, n. 1, p. 11-15, 2006.

STEINWURZ, F. O fumo/ nicotina e a Doença Inflamatória Intestinal (DII). Revista da Associação Brasileira de Colite Ulcerativa e Doença de Chron, [s. l.], ano IV, n. 57, p.10-15, 2014.

STEINWURZ, F. Os efeitos da ingestão de bebidas alcoólicas na DII. Revista da Associação Brasileira de Colite Ulcerativa e Doença de Chron, [s. l.], ano IV, n. 57, p.16-17, 2014.

USNAYO, Katherine Maria; PALACIOS, Pierre; PISCOYA, Alejandro. Prevalência de sintomas dispépticos e de pirose em uma população de adultos em Belo Horizonte, Brasil. Arquivos de Gastroenterologia, v. 54, n. 3, p. 267-267, 2017.

YÉPEZ, J.A. Carboidratos: usinas de energia. A natureza da cura. Rio de Janeiro, cap.9, 2004. 


\section{PLANEJAMENTO DA ATENÇÃO HOSPITALAR NO SUS PARA O PERÍODO 2016 A 2019: PRIORIDADES E LACUNAS NACIONAIS E ESTADUAIS}

FANNY ALMEIDA WU

Universidade do Estado da Bahia - UNEB

THADEU BORGES SOUZA SANTOS

Universidade do Estado da Bahia - UNEB

SILVANA LIMA VIEIRA

Universidade do Estado da Bahia - UNEB

JOSEANE APARECIDA DUARTE Universidade do Estado da Bahia - UNEB

JULIETE SALES MARTINS

Universidade do Estado da Bahia - UNEB

LILIAN BARBOSA ROSADO

Universidade Federal da Bahia - UFBA

LAIISE REZENDE DE ANDRADE Universidade Federal da Bahia - UFBA

ISABELA CARDOSO DE MATOS PINTO Universidade Federal da Bahia - UFBA

RESUMO: Este capítulo descreverá prioridades nacionais e estaduais para atenção hospitalar, estabelecidas nos instrumentos de planejamento para o período de 2016 a 2019. Através da análise qualitativa dos Planos de Saúde Nacional (01), Distrito Federal (01) e Estaduais (26), foram reconhecidos oito eixos de recomendações nacionais, a saber: ampliação e qualificação do acesso; ampliação de leitos terapia intensiva; formação e qualificação de profissionais; regulação, controle e avalição assistencial; atenção à saúde materna; transplantes de órgãos; atenção à situação de violência sexual; e ressarcimento ao SUS.
As principais estratégias apontadas atenderam a tais eixos, merecendo destacar que as prioridades contemplaram qualificação do acesso, ampliação da oferta de leitos com maior complexidade assistencial, desospitalização da atenção psiquiátrica, qualificação dos gestores para regulação, controle e execução financeira, enfrentamento às formas de precarização do trabalho, fortalecimento das residência multiprofissional e das estruturas institucionais da gestão do trabalho e da educação, institucionalização dos complexos reguladores, melhoria da atenção ao parto e nascimento e otimização da captação e transplantes de órgãos. A principal desarticulação entre as agendas nacional e estaduais foi relacionada ao ressarcimento dos planos de saúde ao SUS, pois nenhum estado estabeleceu estratégias. Conclui-se que o planejamento governamental para atenção hospitalar no SUS, no período de 2016 a 2019, teve parcial alinhamento entre os níveis nacional e estadual, e percebe-se alinhamento com as atuais políticas públicas de saúde.

PALAVRA-CHAVE: Planejamento em Saúde; Hospitais; Sistema Único de Saúde

ABSTRACT: This chapter will describe national and state priorities for hospital care, established in the planning instruments for the period from 2016 to 2019. Through the qualitative analysis of the National (01), Federal District (01) and State (26) Health Plans, they were recognized eight axes of national recommendations, namely: expansion and qualification of access; expansion of intensive care beds; training and qualification of professionals; regulation, control and evaluation of assistance; attention to maternal health; organ 
transplants; attention to the situation of sexual violence; and reimbursement to SUS. The main strategies pointed out met these axes, and it is worth noting that the priorities included qualifying access, expanding the offer of beds with greater care complexity, de-hospitalization of psychiatric care, qualifying managers for regulation, control and financial execution, facing the precarious ways work, strengthening professional residencies and institutional structures for managing work and education, institutionalizing complex regulators, improving care for childbirth and birth and optimizing organ procurement and transplantation. The main disarticulation between national and state agendas was related to the reimbursement of health plans to SUS, as no state has established strategies. It is concluded that the government planning for hospital care in SUS, in the period from 2016 to 2019, had partial alignment between the national and state levels, and it is perceived alignment with the current public health policies.

KEYWORDS: Health Planning; Hospitals; Unified Health Systems

\section{INTRODUÇÃO}

O planejamento se originou da administração a partir da modernização provocada pela Revolução Industrial do Século XIX e trouxe para saúde a possibilidade de reflexão correlacionada aos princípios dos enfoques prescritivos (teoria científica e das relações humanas), explicativos (behaviorismo, estruturalismo e sistêmico) e prescritivo-explicativo (desenvolvimento organizacional) (MOTTA, 1976). Com vistas ao planejamento e previsão das ações governamentais, o planejamento foi primeiramente adotado nos Planos Quinquenais do estado soviético, a partir de 1928 (VILLELA, 1964).

Na América Latina, em meados da década de 70, o economista chileno Carlos Matus deu origem a um instrumento de planejamento em um contexto democrático em que atores sociais estratégicos compartilhavam o poder e que ainda hoje é utilizado em variadas áreas, sendo muito aplicado na saúde. O Planejamento Estratégico Situacional é estruturado em 4 momentos: explicativo (identificação de problemas), normativo (elaborações de operações), estratégico (análise da viabilidade das operações propostas) e tático-operacional (monitoramento e avaliação das ações na prática) (TEIXEIRA, 2010).

Há diversos conceitos e enfoques metodológicos desenvolvidos no setor da saúde para o planejamento, a saber, o método CENDES-OPS (cunho normativo, de diagnóstico de saúde, descrição de problemas e indicadores) (OPS, 1965) e CPPS (formulação de políticas) (OPS, CPPS,1975). Na área do planejamento em saúde, houve contribuições significativas de Mário Testa com o pensamento estratégico e o Postulado da Coerência (TESTA, 1992) e Carlos Matus abordando o enfoque situacional com o Triângulo do Governo (MATUS, 1997) (TEIXEIRA, 2010).

No Brasil, o planejamento alcançou maior visibilidade a partir da década de 1980, com a criação do SUS quando se iniciou sua institucionalização como instrumento de gestão em saúde, contemplando prioridades e iniciativas de fortalecimento de políticas públicas, dando possibilidade a estudos de monitoramento a avaliação da gestão em saúde (MONTEIRO, 2005; PINTO et al, 2019). Vale destacar que no decorrer do processo de redemocratização do país no início dos anos 1980 trou- 
xe-se à tona bases teórico-metodológicas de sustentação da área de Políticas, Planejamento e Gestão (PPG) no campo da Saúde Coletiva (JESUS et. al, 2011).

Desde início dos anos 1980, a atenção hospitalar tem sido preocupação dos gestores públicos devido crise do sistema médico-previdenciário. Mesmo passados 30 anos do SUS, existem grandes desafios à Política, Planejamento e Gestão na Saúde (PPGS) (PAIM, 2018) e a crise hospitalar se caracterizou pelos vazios assistenciais, alta demanda de financiamento, de pessoal especializado, além da necessidade de melhorar na acessibilidade e gerenciamento (SOLLA; CHIORO, 2012; BRAGA NETO et al, 2012).

$\mathrm{Na}$ área de PPGS, a atenção hospitalar especificamente tem abarcado problemáticas correlacionadas ao déficit assistencial, baixa fidedignidade do sistema de informação do seu financiamento, descentralização da responsabilidade gestora (para via da municipalização e modelos de gestão indireta), entraves para efetivação da atenção com orientação às redes e regionalização e vinculada a coordenação do acesso regulado governamentalmente (SANTOS et al., 2019),

Correlacionado aos instrumentos de planejamento em saúde, a problemática acerca da atenção hospitalar que chama atenção são as prioridades estabelecidas na agenda governamental para os períodos de gestão. Assim, os Planos de Saúde, que de acordo com a Lei nº 8.080, Art. 36, Parágrafo $1^{\circ}$, determinam as atividades e programações no Sistema Único de Saúde (SUS) e fundamentam o financiamento que será previsto através de outros três instrumentos de gestão: o Plano Plurianual PPA, a Lei de Diretrizes Orçamentárias - LDO e a Lei Orçamentária Anual - LOA (BRASIL, 1990).

Assim, o Plano Nacional de Saúde (PNS) consiste num instrumento que possui atribuição de orientar iniciativas de gestão, cujo União preconiza ações pautadas na promoção, equidade, melhoria das condições de saúde, propondo reflexão através da análise situacional, que possibilita identificar as necessidades de saúde da população e a priorização de problemas de saúde e gestão regional (BRASIL, 2016).

O Plano Nacional de Saúde (PNS) e o Plano Estadual de Saúde (PES) são elaborados a cada quatro anos, sendo importante ressaltar que a estruturação desses planos deve considerar as diretrizes definidas pelos Conselhos e Conferências Estaduais e Nacional de Saúde. Para tanto é necessária a análise e aprovação dos instrumentos pelos respectivos Conselhos de Saúde, que considerarão sua correlação com o Plano Plurianual (PPA) (BRASIL, 2016).

A partir do projeto intitulado "Contemporâneas complexidades associadas à capacidade de gestão e implementação da atenção hospitalar”, aprovado como Projeto para o SUS (PPSUS) da Fundação de Apoio à Pesquisa a Bahia (FAPESB). Assim, este capítulo descreverá prioridades nacionais e estaduais para atenção hospitalar, estabelecidas nos instrumentos de planejamento para o período de 2016 a 2019. 
Como parte do projeto PPSUS Bahia, aprovado pelo Comitê de Ética na Pesquisa com CAAE $n^{\circ}$ 41872715.2.0000.5030, caracterizado como de caráter qualitativo, documental (MINAYO, 2010) e do tipo estudo de caso (GIL, 2009), este capítulo analisou o planejamento em saúde para o SUS no período 2016 a 2019.

Seu processo metodológico consistiu na busca de documentos oficiais de planejamento do Ministério da Saúde (MS) e Secretarias Estaduais de Saúde (SES) dos 26 estados brasileiros e do Distrito Federal, totalizando inclusão de 28 planos de saúde. O processo de busca documental foi realizado através do Sistema de Apoio à construção do Relatório de Gestão do SUS (SARGSUS) e constituído o banco de dados com suas versões eletrônicas. Eles foram submetidos ao plano de tratamento que consistiu na leitura completa e profunda em duas etapas, permitindo o reconhecimento de prioridades para atenção hospitalar e convergências entre os níveis de gestão nacional e estadual.

A partir do plano de análise, foi constituída planilha em Microsoft Excel para tabulação dos fragmentos textuais que correspondem as diretrizes, metas e ações apresentadas nos respectivos planos de saúde do período de gestão 2016-2019. As unidades de conteúdo reconhecidas nos instrumentos de planejamento dos estados foram agrupadas. Cada um destes fragmentos foi identificado pela sigla da Secretaria Estadual de Saúde (SES) e seguida da abreviação da Unidade Federada.

Assim, a matriz completa conteve 198 unidades de conteúdo (UC). Suas similaridades permitiram agrupamento em oito eixos de recomendações do PNS, sendo eles e suas respectivas quantidades absolutas de unidade de conteúdo: a. Ampliação e qualificação do acesso (27), b. Ampliação de leitos UTI (39), c. Formação e qualificação de profissionais (25), d. Regulação, controle e avalição assistencial (34), e. Atenção à saúde materna (32), f. Transplantes de órgãos (35), g. Atenção à situação de violência sexual (6), h. Ressarcimento ao SUS (0).

Assim, foi possível realizar análise de conteúdo de todo os documentos incluídos (MINAYO, 2010). Os resultados estão apresentados em dois subtópicos. O primeiro citará os estados que contemplaram cada uma das recomendações nacionais. E no segundo subtópico, serão descritas as principais estratégias apontadas pelos estados para cada um dos eixos do PNS 2016 a 2019.

\section{RESULTADOS}

\section{Recomendação do PNS e alinhamento estaduais}

O PNS 2016-2019 estabeleceu quatorze estratégias para atenção hospitalar no SUS, organizadas nos oito eixos de recomendações. Elas foram tomadas como estruturantes para reconhecimento dos possíveis alinhamentos entre as prioridades estabelecidas pelos estados nos seus respectivos instrumentos de planejamento em saúde. Assim, estruturou-se a Figura 1, que ilustra quais estados con- 
templaram as estratégias e, consequentemente, eixos de recomendações nacionais. E em seguida, a descrição de quais estratégias foram apontadas nos PES, para cada uma das quatorze recomendações nacionais, estruturadas em 8 eixos.

De acordo com a Figura 1, os 26 (vinte e seis) estados e Distrito Federal contemplaram em seus respectivos Planos de Saúde a recomendação do Plano Nacional de Saúde - PNS, representado pelo Eixo A, que visa a ampliação e qualificação do acesso ao serviço de saúde, com ênfase na humanização, equidade e necessidades de saúde, aprimorando as políticas de atenção básica e especializada, ambulatorial e hospitalar.

Ao analisar o Eixo B, referente à recomendação de ampliação do número de leitos SUS de UTI, 16 (dezesseis) estados alinharam-se ao PNS, entretanto, para recomendação específica de novos leitos de UTI Adulto, Pediátrico, Neonatal, Unidade Coronariana (UCO), UCI Convencional e Canguru no SUS, 13 (treze) Unidades Federativas a contemplaram, estando de fora apenas o estado de Minas Gerais.

A indicação de ampliação de leitos de saúde mental em hospitais gerais foi contemplada por 10 (dez) estados, apenas a região centro-oeste não se alinhou a esta recomendação. Portanto, o Eixo B teve média de 13,66 estados que expressaram como ações estratégicas as recomendações do PNS, representando $50,59 \%$ dos estados brasileiros.

Figura 1. Distribuição das Unidades Federadas por estratégicas e eixos de recomendações para atenção hospitalar, 2016 a 2019

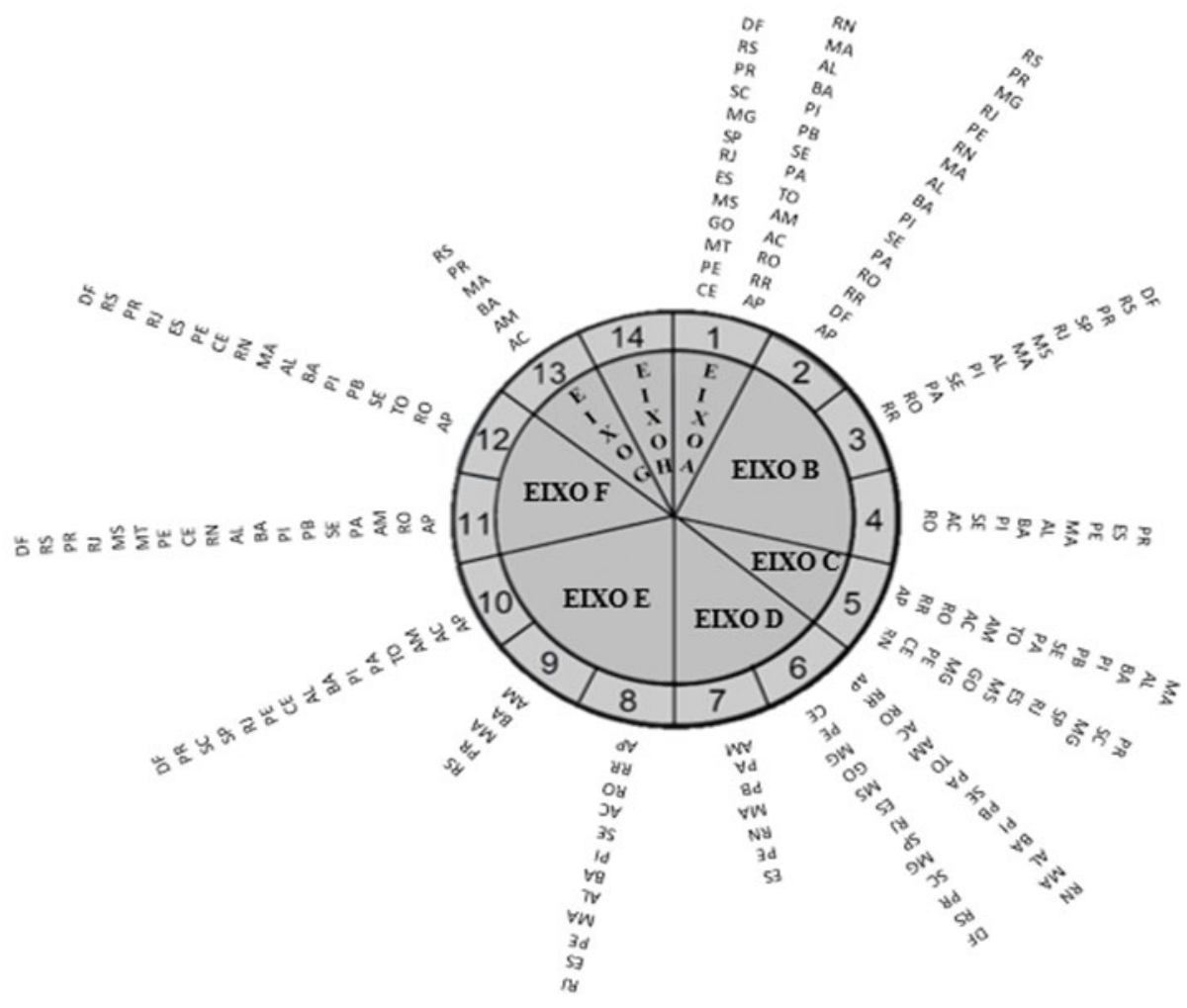




\section{Legenda:}

\section{Eixo A: Ampliação e qualificação do acesso}

1. Ampliar e qualificar o acesso aos serviços de saúde, em tempo adequado, com ênfase na humanização, equidade e no atendimento das necessidades de saúde, aprimorando a política de atenção básica e especializada, ambulatorial e hospitalar;

\section{Eixo B: Ampliação de leitos UTI}

2. Ampliar do número de leitos SUS de UTI;

3. Ampliar em 5.994 o número de leitos, sendo 4.080 novos leitos de UTI Adulto, Pediátrico, Neonatal e Unidade Coronariana (UCO) e 1.914 leitos de UCI Convencional e Canguru no SUS, em todas as regiões do País;

4. Apoiar a implantação de 502 leitos de saúde mental em hospitais gerais;

\section{Eixo C: Formação e qualificação de profissionais}

5. Induzir a formação e qualificação de recursos humanos especializados;

\section{Eixo D: Regulação, controle e avalição assistencial}

6. Induzir a implantação de mecanismos de regulação, controle e avalição da assistência prestada aos pacientes graves ou potencialmente graves no SUS;

7. Aumentar de 20 para 160 as Centrais de Regulação que recebem incentivo federal de custeio para a melhoria do acesso aos serviços ambulatoriais especializados e hospitalares;

\section{Eixo E: Atenção à saúde materna}

8. Adequar a ambiência de 120 maternidades (reforma e aquisição de equipamentos) para a atenção humanizada ao parto e nascimento;

9. Implantar 60 novos Centros de Parto Normal - CPN;

10. Estimular a adesão ao Plano Nascer Saudável e a novos modelos assistenciais, visando a redução anual de parto cesariano nos serviços ofertados pela saúde suplementar;

\section{Eixo F: Transplantes de órgãos}

11. Aumentar em 4\% ao ano o Índice de Transplantes de Órgãos Sólidos por milhão da população (pmp), passando de 37,95 pmp para 46,18 pmp;

12. Aumentar em $4 \%$ ao ano o Índice de Doadores Efetivos de Órgãos por milhão da população (pmp), passando de 13,36 pmp para $16,25 \mathrm{pmp}$;

\section{Eixo G: Atenção à situação de violência sexual}

13. Implantar 80 serviços de referência para atenção integral às pessoas em situação de violência sexual em hospitais de referência do SUS, para a realização do registro de informações e da coleta de vestígios;

\section{Eixo H: Ressarcimento ao SUS}

14. Aumentar, anualmente, o ressarcimento dos planos de saúde ao SUS em decorrência das internações hospitalares e atendimentos ambulatoriais especializados.

O Eixo C, composto pela recomendação de formação e qualificação de recursos humanos especializados teve expresso em 92,59\% dos estados, verifica-se que apenas o Rio Grande do Sul e Distrito Federal não a contemplaram, contabilizando 25 (vinte e cinco) estados alinhados. O Eixo D, é composto por recomendações de implantação de mecanismos de regulação, controle e avalição, atendida pelas 27 (vinte e sete) Unidades Federativas (UF), e no que se refere à ampliação do número de Centrais de Regulação, apenas 7 (sete) estados expressaram esta recomendação, ou seja, esse eixo teve suas recomendações expressadas em forma de ações estratégicas em $62,96 \%$ dos PE.

As recomendações acerca da saúde materno-infantil compuseram o Eixo E, e são referentes a: adequação da ambiência de maternidades, que foi contemplada por 12 (doze) estados, a implantação de Centros de Parto Normal - CPN, priorizada apenas por 5 (cinco) estados e a estimulação do Pla- 
no Nascer Saudável, priorizada por 15 (quinze) estados, sendo assim, este eixo foi contemplado por $39,48 \%$ dos PE. No Eixo F, expresso em 62,96\% dos PE, a recomendação que dispõe sobre aumento do Índice de Transplantes de Órgãos Sólidos por milhão da população (pmp) e aumento do Índice de Doadores Efetivos de Órgãos pmp foi priorizada respectivamente em 18 (dezoito) UF e 17 (dezessete) UF.

Em relação ao Eixo G, referente à diretriz do PNS, sobre a implantação de serviços de referência para atenção integral às pessoas em situação de violência sexual em hospitais de referência do SUS, apenas 6 (seis) estados a priorizaram, representando a região Norte, Nordeste e Sul, portanto, esse eixo foi atendido pelo menor percentual de estados, com 18,52\%. Por outro lado, nenhuma das 27 (vinte e sete) Unidades Federativas contemplou a recomendação de aumentar, anualmente, o ressarcimento dos planos de saúde ao SUS em decorrência das internações hospitalares e atendimentos ambulatoriais especializados.

Analisando todos os estados brasileiros e o DF, o eixo A apresentou 100\% das recomendações do PNS para a atenção hospitalar em formato de ações estratégica dos PE, o eixo B uma média de $50,61 \%$, o eixo C $88,88 \%$, o eixo D a média de $61,11 \%$, o eixo $\mathrm{E}$ em média de $39,50 \%$, o eixo $\mathrm{F}$ média de $62,96 \%$, o eixo G $18,51 \%$ e o eixo $\mathrm{H} 0 \%$.

Ao analisar por regiões brasileiras, as ações estratégicas do PE alinhadas as recomendações do PNS, temos o Nordeste com o maior percentual de 65,08\%, seguido pela região Sul com 52,38\%, região Sudeste com $46,83 \%$, Norte com $45,53 \%$, e o menor percentual é da região Centro-Oeste, com apenas 35,71\%. Cabe ressaltar que os estados com menor percentual foram Amazonas e Goiás (com apenas 3 recomendações expressas em forma de ações estratégicas) e os estados com maior percentual foram Pernambuco, Maranhão e Bahia com 78,57\% (11 ações estratégicas).

Comparativamente, apresentam-se também as estratégias definidas pelos estados em seus respectivos Planos de Saúde, de modo que foi possível reconhecer a conformação das agendas estratégicas para atenção hospitalar no Brasil.

\section{Principais estratégias apontadas pelos estados para cada um dos eixos de recomendações, segundo PNS 2016 a 2019.}

A primeira recomendação do PNS 2016-2019, disposta no eixo A, apontou para ampliação e qualificação do acesso aos serviços hospitalares, enfatizando a humanização, equidade e atendimento das necessidades de saúde regionais. Além disso, há que se destacar a importância dada a política de atenção especializada, ambulatorial e hospitalar.

Como estratégias estaduais, houve a intenção de melhorar unidades hospitalares em seu desempenho, resolutividade e qualidade, considerando as diversidades sanitárias das regiões; reestruturar unidades hospitalares próprias, quanto a organização, integração, recursos humanos e tecnológicos para melhoria do desempenho; pactuar e monitorar a Política Nacional da Urgência e Emergência a partir de indicadores; ampliar e qualificar assistência nas referências da alta complexidade. 
Também foram colocadas como prioridades nos Planos: Aperfeiçoar acesso regionalizado às ações de MAC; ampliar utilização das policlínicas; qualificar serviços aos princípios da humanização; ampliar serviços da Rede de Atenção às Urgências e monitorar as portas de acesso a essa rede; fortalecer regulação sistêmica e promover garantias à segurança do paciente; favorecer acesso a atenção especializada, a partir da ampliação e descentralização da oferta de serviços e qualificar rede hospitalar; fortalecer resolubilidade, acessibilidade e humanização da atenção hospitalar e instituir estratégias de monitoramento do desempenho dos hospitais.

A segunda, terceira e quarta recomendação (eixo B) do PNS versam sobre a readequação do quantitativo de leitos SUS, priorizando a ampliação do número de leitos; novos leitos de UTI adulto, pediátrico, neonatal e coronarianos; e também ao apoio a implantação de leitos de saúde mental em hospitais gerais.

Os estados ainda planejaram habilitar e qualificar leitos novos e já existentes através da rede de urgência e emergência, implantando leitos de UTI com reestruturação do perfil dos hospitais regionais, para enfrentar a insuficiência de leitos de UTI. Também foram estratégias a disponibilização de leitos de retaguarda para urgências e emergências, de forma regulada, o fortalecimento da atenção especializada com novos hospitais adstritos regionalmente, com vistas às demandas da pactuação intermunicipal e à superação da incapacidade de atenção cirúrgica, com destaque especial para necessidade de implantação de núcleos de segurança do paciente.

Quanto as prioridades para atenção hospitalar associadas a leitos de saúde mental, os PES contemplaram habilitação de leitos para tal, sendo que a ampliação se destinava a qualificação dos CAPS e fortalecimento da Política Nacional de Saúde Mental e necessidades regionais. Foram previstas reduções de leitos em hospitais psiquiátricos, a fim de reconduzir o modelo de atenção através da implantação de leitos de saúde mental nos hospitais regionais e gerais, com readequação do número de leitos de psiquiatria. Assim, explicitaram as estratégias para processos de desinstitucionalização e desospitalização de pacientes psiquiátricos e residências terapêuticas, fortalecendo política de atenção psicossocial e reinserção social, bandeiras da luta antimanicomial no Brasil.

Apontou-se também na priorização de leitos voltados para constituição de rede de atenção psiquiátrica extra-hospitalar, como retaguarda às crises, principalmente destinados a implantação de CAPS III e adequação de leitos nos hospitais gerais.

Destaca-se ainda que a formação e qualificação de recursos humanos especializados em saúde foi apontada como quinta recomendação nacional (eixo C) à atenção hospitalar no SUS.

Os estados propuseram nos PES a formação de apoiadores da Política Nacional de Humanização (PNH), capacitações em temas de hemoterapia e hematologia, Programa Sentinela e qualificação de gestores sobre regulação, controle, avaliação e auditoria, ouvidoria no SUS e fluxo de execução financeira.

Além disso foram citadas como prioridades no combate a precarização de trabalho, fortalecimento dos programas de residência multiprofissional, consolidação da saúde do trabalhador, fortale- 
cimento das estruturas institucionais da gestão do trabalho e da educação em saúde, valorização da saúde física e mental dos servidores.

A regulação, controle e avaliação assistencial definiu a sexta e sétima recomendações do PNS, compondo o eixo D, que apontou para implantação de mecanismos que os efetivem principalmente quanto a atenção a pacientes graves ou potencialmente graves no SUS; e ampliação das Centrais de Regulação de Leitos e melhoria do acesso aos serviços ambulatoriais especializados e hospitalares.

Referente aos mecanismos de regulação, controle e avalição da assistência prestada aos pacientes graves no SUS, os estados estabeleceram como prioridades a implementação de ações de controle e avaliação ambulatorial e hospitalar e complexos reguladores, aumentar número de centrais de regulação para consultas e exames de MAC, implementação complexos reguladores nas regiões de saúde, assim como entre o sistema público e suplementar, implantar ouvidoria do SUS em unidades hospitalares para articulação com ouvidoria estadual.

Nos PSE nordestinos, destacam-se a necessidade de fortalecer a regulação da demanda de leitos UTI; implantar Núcleos Internos de Regulações nos Grandes Hospitais, Regionais e Metropolitanos e Centrais Macrorregionais de Regulação do SAMU, ampliando e modernizando serviços de regulação no SUS, com vistas a constituição de uma rede interfederativa de serviços que levem a melhoria da eficiência dos serviços de Urgência e Emergência; implementar regulação de redes assistenciais prioritárias (Oncologia, Materno-Infantil e Urgência-Emergência); além de implantar os Núcleos de Regulação Ambulatorial nas Regiões de Saúde, hospitalares, da regulação de urgência, regulação nas redes de atenção à saúde do SUS e qualificação das ações regulatórias (ampliação de funcionários efetivos, protocolo de acesso, consentimento das famílias para transferência de pacientes, habilitação e incentivo de custeio das Centrais de Regulação em funcionamento pelo MS).

Quanto ao eixo E, o PNS abordou a oitava, nona e décima recomendação sobre a ambiência e qualificação de maternidades, reforma e aquisição de equipamentos para melhoria da atenção humanizada ao parto e nascimento; implantação de novos Centros de Parto Normal (CPN); e estímulo a adesão ao Plano Nascer Saudável e redução anual de parto cesáreos.

Nos Planos dos Estados e DF as prioridades que envolveram esta recomendação foram: acompanhar implementação da Rede Cegonha; desenvolver convênios da atenção obstétrica e neonatal humanizada com apoio à redução da mortalidade materna e ampliar o acesso triagem auditiva neonatal; reduzir parto cesariano e ampliar acesso a consultas de pré-natal; habilitar Centros de Parto Normal, ambiência de maternidades e qualificar assistência as gestantes de alto risco nas regiões de saúde; estimular novos modelos assistenciais que reduzam o parto cesariano e envolvam boas práticas de atenção ao parto e nascimento, urgência e emergência Obstétrica.

Também foram assumidas como prioridades nos Planos fortalecer e reestruturar Rede Materno Infantil estimulando o Plano Nascer Saudável; qualificar profissionais de saúde para fortalecer atenção humanizada ao parto e nascimento e reformar leitos com vistas aos novos modelos assistências de redução do parto cesariano e capaz de atender ao alto risco ao neonato. 
A décima primeira e décima segunda recomendação nacional constituem o eixo $\mathrm{F}$, que versa sobre a estimulação ao aumento no índice de transplantes; e índice de doadores efetivos de órgãos por milhão da população.

Assim, os estados priorizaram ampliar e apoiar o índice de transplantes e doação de órgãos garantindo celeridade na realização de apoio diagnóstico para transplante, implementando serviço de captação e distribuição de órgãos e tecidos, aumentar o quantitativo de transplante renal, reforma e adequação da central de transplantes, investir no número de notificação e doações de órgãos e tecidos, qualificar os serviços quanto a doação de órgãos e ampliar número de doadores de órgãos, o acesso dos pacientes inscritos em lista de espera para transplante renal, captação de córnea. Também ampliar o quantitativo de Comissão Intra Hospitalar de Doação de Órgãos Tecidos, o número de transplante de órgãos nos estados, diminuindo o tempo do processo de doação e tornar os estados independentes de outros para realização de transplantes.

Implantar e implementar os bancos de células e tecidos previstos para o Centro de Tecidos Biológicos e fortalecer busca ativa de potenciais doadores nas UTI.

A décima terceira recomendação (eixo $G$ ) se refere a implantação de serviços de referência para atenção integral às pessoas em situação de violência sexual, tendo hospitais de referência no SUS, de modo que o PNS estabeleceu a realização do registro de informações e da coleta de vestígios.

Os estados contemplaram esta recomendação priorizando fortalecer a atenção integral às pessoas em situação de violência sexual; ampliar número de serviços de notificação contínua da violência doméstica, sexual e outras; qualificar servidores efetivos das maternidades e delegacias especializadas para o acolhimento das mulheres, adolescentes e crianças vítimas de abuso sexual e outras situações de risco. No que se refere a promover ações preventivas elegeu o apoio e monitoramento das unidades de saúde na atenção às pessoas em situação de violência sexual. Incluiu ainda a prioridade de monitorar taxa de notificação de violência sexual nos hospitais de referência para atendimento às pessoas vítimas; ampliar o número de serviços especializados para atenção integral às pessoas em situação de violência sexual, viabilizar a estruturação dos serviços favorecendo o protocolo de atendimento integral a essas pessoas.

E a décima quarta recomendação (eixo $\mathrm{H}$ ), conforme prioridades postas no PNS, diz respeito ao ressarcimento dos planos de saúde ao SUS, previsto pelo Art. 32 da Lei $n^{\circ}$ 9.656/1998, que deve ser aumentado anualmente. Todavia, nenhum dos estados estabeleceram estratégias para tal prioridade.

Assim, a partir dos instrumentos de planejamento em saúde, foi possível reconhecer quais foram as principais prioridades para atenção hospitalar nos âmbitos nacional e estaduais no SUS para o período 2016 a 2019, bem como o que houve de alinhamento de estratégias nessas distintas esferas de gestão e unidades da federação. 


\section{DISCUSSÃO}

Sobre a ampliação e qualificação do acesso a serviço de saúde, o PNS dá ênfase aos princípios do SUS e aprimora as principais políticas públicas de saúde. As políticas públicas são conjuntos de programações realizadas no âmbito nacional, estadual ou municipal acerca de uma temática, visando assegurar um direito a determinado serviço em consonância com o Sistema Único de Saúde - SUS (SARRETA, 2009).

O acesso aos serviços de saúde vem crescendo ao longo dos 30 anos do SUS, possivelmente relacionado ao aumento da procura da atenção preventiva. Segundo Viacava (2018) esse processo é marcado por desafios como a desigualdade, evidenciada através da análise que demonstra que pessoas com menor escolaridade apresentam maiores percentuais de internação hospitalar em comparação àquelas com mais anos de estudo.

Além disso, o subfinanciamento possui papel importante no desafio a ampliação e qualificação do acesso e oferta de serviços, dificultando a incorporação de tecnologias, contratação e qualificação de profissionais e democratização dos serviços. Outro desafio mais recente, que agrava ainda mais a situação de subfinanciamento, é a Emenda Constitucional 95/2016 que restringe os gastos públicos nos 20 anos seguintes (VIACAVA, 2018).

Referente ao planejamento de ampliação de leitos UTI do SUS, é evidente a necessidade de expansão no acesso aos serviços e aumento da cobertura e atenção à saúde no eixo hospitalar. Segundo Medeiros (2018), a região sudeste apresenta maior quantitativo de leitos de UTI, mas a proporção de leitos de UTI por habitantes ainda é abaixo de 3, conforme recomendação ideal do MS. A pior situação nacional está na região Norte, onde a oferta tem os piores indicadores do Brasil. Outra questão peculiar é a má distribuição de leitos pelos territórios, sendo assim a oferta de serviços de saúde de forma regionalizada é um desafio para o sistema de saúde brasileiro, devido à expansão territorial do país e a grande diversidade geopolítica de cada território.

Houve aumento dos hospitais de pequeno porte distribuídos pelo país, e por outro lado, há concentração de equipamentos de média e alta complexidade ainda concentrados nos grandes centros urbanos (ALBUQUERQUE et al, 2017). É persistente a falta de articulação da Atenção Hospitalar com o restante da Rede de Atenção à Saúde, sobretudo relacionando com a APS como ordenadora do cuidado, superando a lógica puramente hospitalocêntrica e de oposição à APS. Os desafios da Atenção Hospitalar no SUS, perpassam por questões financeiras, políticas, organizacionais, assistenciais, sociais e de ensino e pesquisa, portanto, implementar de forma efetiva a PNHOSP (2013) ainda consistem em um problema para o SUS (VIANA, et.al., 2018).

Em meados de 1980, juntamente a fundamentação do SUS no processo de redemocratização do país, fomentava-se a Política Nacional de Saúde Mental, pautando a baixa qualidade e violação dos direitos humanos do sistema psiquiátrico brasileiro (ALMEIDA, 2019). Em 2001, foi aprovada a Lei da Reforma Psiquiátrica que dispôs sobre proteção e direitos das pessoas portadoras de transtornos mentais e redirecionamento do modelo assistencial em saúde mental. Este marco histórico 
representou uma vitória, possibilitando defesa da redução dos leitos em hospitais psiquiátricos e, simultaneamente, crescimento gradual dos Centros de Atenção Psicossociais (CAPS) e residências terapêuticas, em substituição aos hospitais psiquiátricos (ALMEIDA, 2019).

Segundo a Nota Técnica sobre a Portaria no 148 de 31 de janeiro de 2012, os leitos de Saúde Mental em Hospitais Gerais são componentes da Rede de Atenção Psicossocial (RAPS), que visam superar o modelo dos hospitais psiquiátricos, a fim de promover a garantia do acesso dos usuários à tecnologia hospitalar, e manejo adequado as intercorrências clínicas.

Correlacionado a formação e qualificação de profissionais, em 2004, a publicação da Política Nacional de Educação Permanente em Saúde (PNEPS) representou um marco importante para o fortalecimento da educação na área da saúde, aliada a criação da Secretaria de Gestão do Trabalho e da Educação na Saúde (SGTES) no Ministério da Saúde (BATISTA, 2011).

A PNEPS foi proposta pelo MS como estratégia para contribuir para formação e desenvolvimento dos profissionais de saúde, através de constantes processos educativos de atualização, considerando as diferentes realidades de trabalho e atuando na mudança do predomínio de práticas assistenciais tradicionais. Isto a fim de expandir as estratégias educativas, a relação interpessoal e humanização da assistência (BRASIL, 2004).

Segundo Flores (2016), a presença da educação permanente no âmbito da assistência hospitalar fomenta a transformação das práticas, dinamiza os processos de trabalho e capacidade de gestão, proporciona abertura da escuta, do compartilhamento de saberes e divisão do poder, tomando direção contrária a formação tecnicista e a modelos tradicionais de saúde. Essa perspectiva de fortalecimento da educação permanente está aliada ao mecanismo de transformação da formação e qualificação em saúde, não simplesmente técnica, mas correlacionada com mudanças nas relações, processos, atos de saúde e pessoas (JAEGER E CECCIM, 2004).

Sobre a regulação, controle e avalição assistencial, é importante diferenciar três níveis de regulação do Estado. A regulação sobre sistemas de saúde visa a definição de normas, monitoramento, controle e avaliação dos serviços de saúde; quando sobre a atenção a saúde, volta-se para os prestadores de serviços de saúde atuando na contratação, controle, avaliação e auditoria; e relacionando com a regulação assistencial, ocupa-se da oferta assistencial disponível partindo do princípio da equidade e integralidade e organizando as centrais de regulação por temas/áreas (VILARINS, 2012).

A regulação assistencial busca organizar e gerenciar a oferta de serviços de saúde e dos fluxos assistenciais no âmbito do SUS. Entretanto, esse processo se depara com diversos desafios, entre eles, a escassez de recursos para atendimento, caracterizado pela carência de leitos no setor público e falta de recursos de especialidade mais complexa, restringindo o acesso a média e alta complexidade; a dificuldade de utilização de fluxos para o acesso representada pela baixa cobertura e resolutividade da atenção primária, tida como porta de entrada ao acesso, resultando na queima de etapas do fluxo assistencial e em longas filas no âmbito hospitalar; e a rede de relações pessoais determinando o acesso, motivada pela responsabilização pessoal ao acesso dos usuários e compromisso com as necessidades da população, resultando na adoção de caminhos alternativos aos mecanismos formais para obtenção 
de vagas e serviços, prática que evidencia a incapacidade dos mecanismos pactuados atuais de regulação assistencial (GAWRYSZEWSKI, 2012).

O processo de descentralização e regionalização dos serviços de saúde vem avançando desde a criação do SUS, através das Normas Operacionais Básicas (NOBs), Normas Operacionais de Assistência à Saúde (NOAS) e estruturação de novos instrumentos de gestão como a Programação Pactuada Integrada (PPI) e o Plano Diretor de Regionalização (PDR). Apesar disso, a regionalização ainda precisa superar desafios como a dificuldade na regulação de fluxos de acesso regionais e em sua incorporação no cotidiano da assistência nos diferentes níveis de atenção à saúde (BARBOSA, 2016). Ademais, a insuficiente disponibilidade de recursos financeiros, físicos e humanos, falhas no planejamento, na integração dos serviços e coordenação do cuidado dificultam a consolidação da regionalização (MELLO, 2017).

Quanto a atenção materno-infantil, a partir da $8^{\text {a }}$. Conferência Nacional de Saúde, a tentativa de reorganização do modelo assistencial através do Programa de Saúde da Família provocou mudanças no paradigma da saúde materno-infantil, iniciando melhorias da mortalidade neonatal, maior acesso à consulta pré-natal e ao parto hospitalar nos anos 1990 e 2000. A Política Nacional de Humanização do Pré-Natal e Nascimento (PNHPN) implementado no ano de 2000, objetivou reduzir as taxas de mobi-mortalidade materna, perinatal e neonatal no país e simbolizou avanço na melhoria da assistência à saúde materna no país (SANTOS NETO, 2008).

Em 2004, o MS elaborou a Política Nacional de Atenção Integral à Saúde da Mulher (PNAISM), abordando pautas como a clínica ginecológica, pré-natal, parto e puerpério, climatério, planejamento familiar, DST, câncer de colo de útero e de mama, fundamentados nos princípios e diretrizes do SUS e contemplando a saúde de diferentes grupos de mulheres (negras, indígenas, trabalhadoras rurais, entre outras), além de abordar a vulnerabilidade social através de temas como direitos sexuais e reprodutivos e violência doméstica e sexual (DA SILVA, 2016).

Um ano após a elaboração da PNAISM, o MS publicou a Política Nacional de Atenção Obstétrica e Neonatal, em 2005, estabelecendo diretrizes e princípios importantes. Entre as recomendações desta política pública, destaca-se o direito a presença de acompanhante durante o trabalho de parto e pós-parto imediato (Lei $\mathrm{n}^{\circ} 11.108 / 05$ ); atenção especial as gestantes adolescentes, negras, indígenas e de mulheres vivendo com HIV; e rede de atenção organizada com serviço de referência e contrarreferência, considerando a vinculação de unidades de atenção ao pré-natal com maternidades e hospitais (BRASIL, 2005).

E com a criação da Rede Cegonha em 2011, provocou-se o objetivo de reduzir a mortalidade materna e infantil, estruturar e melhorar o planejamento reprodutivo e pré-natal, consolidar a atenção humanizada durante a gravidez, parto/nascimento e puerpério através da implementação de um novo modelo de atenção à saúde da mulher e criança, além de organizar a Rede de Atenção à Saúde Materna e Infantil (LEAL, 2019).

Um dos fomentos deste novo modelo de atenção à saúde materno-infantil é a diminuição das taxas de cirurgias cesarianas (MASCARELLO, 2016). Para isso, foi criado em 2015, no âmbito da 
saúde suplementar, o programa Parto Adequado, uma parceria entre o Ministério da Saúde e ANS, destinado a reduzir as cesarianas sem indicação (LEAL, 2018).

Mesmo diante os avanços e elaboração de diversas políticas públicas e programas no contexto da saúde materna e infantil, ainda há muito para ser desenvolvido, como a implementação das políticas públicas; redução da mortalidade materna; fortalecimento, melhoria e ampliação da cobertura do pré-natal; elevação da qualidade e humanização do parto; redução do parto cesariano; combate a violência obstétrica; melhoria da atenção a saúde no período do puerpério; e fortalecimento de novos modelos assistenciais (LEAL, 2018).

Correlacionado a transplante de órgãos, sabe-se que no Brasil, foi realizado em 1964 o primeiro transplante de rim e, até 2012, mais de 75.600 transplantes de órgãos sólidos foram realizados (MENDES, 2012). No ano de 2018, 96\% dos transplantes foram financiados pelo SUS, colocando o Brasil como referência mundial em transplantes (SOARES, 2020).

Quanto aos desafios no âmbito da captação de órgãos e transplantes, podemos destacar baixas taxas de notificação de potenciais doadores, recusa dos familiares, demora no diagnóstico de morte encefálica e falta de conhecimento sobre doação de órgãos (SOARES, 2020). Aliado a falta de conhecimento e recusa dos familiares está a influência da mídia sensacionalista sobre tráfico órgãos, a não compreensão do diagnóstico de morte encefálica e crença de reversão do quadro e a não aceitação da manipulação do corpo (MORAIS, 2012).

Para superar os desafios existentes e incentivar a captação de órgãos podemos destacar a estratégia de educação para profissionais e estudantes da área da saúde, diante da influência que os profissionais de saúde exercem na divulgação da informação sobre doação de órgãos, atuando em campanhas de esclarecimento dentro das próprias instituições de saúde que visem incentivar a discussão sobre doação de órgãos e transplantes entre familiares (MORAIS, 2012).

Quanto a atenção à situação de violência sexual, incluindo a violência contra a mulher, representa um problema de saúde pública, uma vez que as vítimas chegam aos serviços de saúde do SUS. Através de uma releitura histórica sobre a atenção a violência sexual no Brasil, podemos destacar o avanço ao longo das décadas avaliando que em meados do século XX, homicídios cometidos por parceiros eram justificados como legitima defesa da honra, entretanto, marcos de progresso são percebidos através da Carta Magna que declarou em 1988 a igualdade de gêneros; o Estatuto da Criança e Adolescente (1990) que trata da garantia de serviços especiais de prevenção e atendimento médico e psicossocial às vítimas de negligência, maus-tratos, exploração, abuso, crueldade e opressão; a obrigatoriedade da notificação compulsória de violência contra a mulher no âmbito do SUS, estabelecida pela Lei 10.778, de 2003; os progressos continuam e em 2013 foi publicada a Lei 12.845 que estabeleceu o atendimento obrigatório integral de pessoas em situação de violência sexual, de forma que todos os hospitais integrantes da rede do SUS devem oferecer às vítimas de violência sexual atendimento emergencial, integral e multidisciplinar (PINTO, 2017).

Contudo, em 2019, houve retrocesso em relação à proposta do projeto de lei, que sinalizada a obrigatoriedade dos hospitais públicos e privados em notificar casos suspeitos de violência doméstica à polícia, que segundo o atual presidente Jair Bolsonaro, justificou seu veto integral, devido à con- 
trariedade do interesse público. Vale ressaltar que essa medida pode intensificar a subnotificação dos casos e deixar as vítimas suspeitas e confirmadas de violência em estado de vulnerabilidade.

E relacionado ao ressarcimento ao SUS, no Brasil, o acesso a saúde é disponível através do Sistema Único de Saúde, e de forma suplementar pela rede privada com desembolso direto e/ou pelos planos de saúde. Por meio do Art. 32 da Lei 9.656/1998, regulamenta-se normas da Agência Nacional de Saúde Suplementar (ANS), determinando que as Operadoras de Plano de Saúde (OPS) realizem o ressarcimento ao SUS, quando seus beneficiários utilizem a Rede Pública para procedimentos já cobertos pelo plano contratado, sendo o ressarcimento ao SUS componente legal das obrigações das Operadoras de Saúde (COSTA, 2018; BRASIL, 1998).

Este procedimento consiste inicialmente pelo atendimento do usuário no SUS, que posteriormente é identificado pelo ANS, por meio de cruzamento dos sistemas de informação do SUS com o Sistema de Informação de Beneficiários da ANS, caso haja identificação de que o serviço prestado possui cobertura contratual, é encaminhada por meio de processo, passível de recorrer e de impugnação, que em última instância administrativa, é encaminhada para a operadora do plano de saúde, a cobrança integral ou parcial, que terá o prazo de até 15 dias para realizar o pagamento ou parcelamento da despesa. Os valores recolhidos são repassados pela ANS para o Fundo Nacional de Saúde do SUS (BRASIL, 2014).

\section{CONSIDERAÇÕES FINAIS}

A guisa das considerações finais sobre o planejamento governamental para atenção hospitalar no SUS no período de 2016 a 2019, percebemos que o alinhamento entre PES e PNS foram parciais, sendo melhor articulado nos estados da região sul e menos nos da região centro-oeste do Brasil.

Dentre as principais prioridades, destacaram-se a qualificação do acesso baseado nas necessidades loco-regionais e ampliação da oferta de leitos com maior complexidade assistencial; desinstitucionalização e desospitalizando da atenção psiquiátrica; qualificação dos gestores para regulação, controle, avaliação e auditoria e fluxo de execução financeira no SUS; fomento a ações de enfrentamentos à precarização de trabalho e fortalecimento das residência multiprofissional e das estruturas institucionais da gestão do trabalho e da educação; ampliação das Centrais de Regulação do acesso aos serviços ambulatoriais especializados e hospitalares.

Aos pacientes, foram estabelecidas prioridades de controle e avaliação ambulatorial e hospitalar e complexos reguladores para os usuários em condições graves, qualificação de maternidades e melhoria da atenção ao parto e nascimento, aumento da captação e índice de transplantes, fortalecimento da atenção integral na situação de violência. E, com maior desarticulação com a agenda nacional, não houve priorização do ressarcimento dos planos de saúde ao SUS pelos estados brasileiros.

Mesmo sendo reconhecido que o alinhamento entre PES e PNS foi parcial todas as regiões, atenta-se que foi melhor articulado nos estados da região sul e menos nos da região centro-oeste do 
Brasil. E cabe pontuar que as Secretarias Estaduais de Saúde têm autonomia na definição de suas prioridades frente as diretrizes apontadas pelo Ministério da Saúde.

O fundamental é que gestores de todas as esferas de gestão entendem e pratiquem o planejamento em saúde como instrumento relevante e estratégico no processo de institucionalização do SUS, principalmente por ele permitir guiar implementação de ações e acompanhamento da sua efetivação.

\section{REFERÊNCIAS}

ALBUQUERQUE, Mariana Vercesi et. al. Desigualdades regionais na saúde: mudanças observadas no Brasil de 2000 a 2016. Ciência \& Saúde Coletiva, 22(4):1055-1064, 2017.

ALMEIDA, José Miguel Caldas de Política de saúde mental no Brasil: o que está em jogo nas mudanças em curso. Cadernos de Saúde Pública, v. 35, n. 11, 2019.

BARBOSA, Dayse Vieira Santos. BARBOSA, Nelson Bezerra. NAJBERG, Estela. Regulação em Saúde: desafios à governança do SUS. Cad. Saúde Colet., 2016, Rio de Janeiro, 24 (1): 49-54.

BATISTA, Karina Barros Calife; GONCALVES, Otília Simões Janeiro. Formação dos profissionais de saúde para o SUS: significado e cuidado. Saúde soc., São Paulo, v. 20, n. 4, p. 884-899, Dec. 2011.

BRASIL. Lei $\mathrm{n}^{\circ}$ 9.656, de 3 de junho de 1998. Dispõe sobre os planos e seguros privados de assistência à saúde. Diário Oficial, Brasília, DF, 03 jun.1998.

BRASIL. Nota Técnica sobre a Portaria nº 148. Diário Oficial, Brasília, DF, 31 de janeiro de 2012.

BRASIL. Portaria GM/MS no 198/04, de 13 de fevereiro de 2004. Institui a Política Nacional de Educação Permanente em Saúde como estratégia do Sistema Único de Saúde para a formação e o desenvolvimento de trabalhadores para o setor e dá outras providências. Diário Oficial. Brasília, DF, 2004.

BRASIL. Portaria No $\mathrm{N}^{\circ}$ 1.067, de 4 de julho de 2005. Institui a Política Nacional de Atenção Obstétrica e Neonatal, e dá outras providências. Diário Oficial. Brasília, DF, 2005..

BRASIL. Reforma Psiquiátrica e política de Saúde Mental no Brasil - Conferência Regional de Reforma dos Serviços de Saúde Mental: 15 anos depois de Caracas. Ministério da Saúde. Brasília, 2005.

BRASIL. Resolução Normativa - RN n ${ }^{0} 388$, de 25 de novembro de 2015. Dispõe sobre os procedimentos adotados pela Agência Nacional de Saúde Suplementar - ANS para a estruturação e realização de suas ações fiscalizatórias. Diário Oficial. Brasília, DF. Nov.2015.

COSTA, Jéssica Caeiro de Souza. Os impactos econômico-financeiros do ressarcimento ao SUS para as operadoras de planos de saúde. Agência Nacional de Saúde Suplementar (ANS). Belo Horizonte, 2018.

DA SILVA, Thayná Champe; Bisognin, Priscila; Prates, Lisie Alende; Wilhelm, Laís Antunes; de Bortoli, Cleunir de Fatima Candido; Ressel, Lúcia Beatriz. As boas práticas de atenção ao parto e nascimento sob a ótica de enfermeiros. Biblioteca Lascasas, 2016; 12(1).

FLORES, Giovana Ely; OLIVEIRA, Dora Lúcia Leidens de; ZOCCHE, Denise Antunes de Azambuja. Educação permanente no contexto hospitalar: a experiência que ressignifica o cuidado em enfermagem. Trab. educ. saúde, Rio de Janeiro, v. 14, n. 2, p. 487-504, ago. 2016.

GIL, Antonio Carlos. Como elaborar projetos de pesquisa. 4. ed. São Paulo: Atlas, 2008. 
JAEGER, M. L.; CECCIM, R. B. Política de Educação e Desenvolvimento para o SUS: caminhos para a Educação Permanente em Saúde. Brasília: Ministério da Saúde, 2004.

JESUS, WLA., et al. Planejamento em saúde no Brasil: configurações e tendências no sistema e nos serviços de saúde. In: JESUS, WLA., and ASSIS, MMA., orgs. Desafios do planejamento na construção do SUS. Salvador: EDUFBA, 2011, pp. 61-77.

LEAL, Maria do Carmo et al. Avanços na assistência ao parto no Brasil: resultados preliminares de dois estudos avaliativos. Cad. Saúde Pública, Rio de Janeiro, v. 35, n. 7.

LEAL, Maria do Carmo. Parto e nascimento no Brasil: um cenário em processo de mudança. Cadernos de Saúde Pública. 2018, v. 34, n. 5.

MACHADO, Ralph. Bolsonaro veta obrigatoriedade de notificação de indícios de violência contra a mulher. Agência Câmara de Notícias. Brasília, DF. 10 out. 2019.

MATTOS, Ruben Araujo de. Princípios do Sistema Único de Saúde (SUS) e a humanização das práticas de saúde. Interface (Botucatu), Botucatu, v. 13, supl. 1, p. 771-780, $2009 .$.

MEDEIROS, R.S. Insuficiência de leitos de UTI: crise do capital e mercantilização da saúde. Argum., Vitória, v. 10, n. 1, p. 229-240, jan./abr. 2018.

MELLO, Guilherme Arantes et al. O processo de regionalização do SUS: revisão sistemática. Ciênc. saúde coletiva, Rio de Janeiro, v. 22, n. 4, p. 1291-1310, 2017.

MENDES, Karina Dal Sasso, et al. Transplante de órgãos e tecidos: responsabilidades do enfermeiro. Texto Contexto Enferm, Florianópolis, 2012 Out-Dez; 21(4): 945-53.

MONTERO, Alfred P. Brazilian politics: reforming a democratic state in a changing world. Cambridge, UK: Polity Press, 2005.

MORAIS, Taise Ribeiro; MORAIS, Maricelma Ribeiro. Doação de órgãos: é preciso educar para avançar. Saúde debate, Rio de Janeiro, v. 36, n. 95, p. 633-639, dez. 2012.

MOTTA, F.C.P. Teoria Geral da Administração: uma introdução. SP: Livraria Pioneira; 1976.

PINTO, I.C. de M. et al. Gestão do Sistema Único de Saúde. IN: PAIM, JS. SUS. Tudo que você precisa saber. São Paulo: Ateneu, 2019, p.151-172.

PINTO, Lucielma Salmito Soares et al. Políticas públicas de proteção à mulher: avaliação do atendimento em saúde de vítimas de violência sexual. Ciência \& Saúde Coletiva. 2017, v. 22, n.5.

SANTOS NETO, Edson Theodoro dos et al. Políticas de saúde materna no Brasil: os nexos com indicadores de saúde materno-infantil. Saude soc., São Paulo, v. 17, n. 2, p. 107-119, 2008.

SANTOS, T. B. S. et al..Gestão hospitalar no sistema único de saúde: Problemáticas de estudos em política, planejamento e gestão em saúde. Cien Saude Col, 2019 (prelo).

SARRETA, FO. Educação permanente em saúde para os trabalhadores do SUS. São Paulo: Editora UNESP; São Paulo: Cultura Acadêmica, 2009. 132 p. ISBN 978-85-7983-009-9.

SOARES, Letícia Santana da Silva et al. Transplantes de órgãos sólidos no Brasil: estudo descritivo sobre desigualdades na distribuição e acesso no território brasileiro, 2001-2017. Epidemiol. Serv. Saúde. 2020, vol.29, n.1, e2018512. Acesso em: 31 jul. 2020.

TEIXEIRA, Carmen Fontes, organizadora. Planejamento em Saúde - Conceitos, Métodos e Experiências. Salvador: EDUFBA; 2010. p. 17.

VIACAVA, Francisco et al. SUS: oferta, acesso e utilização de serviços de saúde nos últimos 30 anos. Ciência \& Saúde Coletiva. 2018, v. 23, n. 6. Acesso em: 07 de agosto de 2020. 
VIANA, Ana Luiza D’Ávila; BOUSQUAT, Aylene; MELO, Guilherme Arantes; NEGRI FILHO, Armando de; MEDINA, Maria Guadalupe. Regionalização e Redes de Saúde. Ciência \& Saúde Coletiva, [S.L.], v. 23, n. 6, p. 1791-1798, jun. 2018.

VILARINS, Geisa Cristina Modesto; SHIMIZU, Helena Eri; GUTIERREZ, Maria Margarita Urdaneta. A regulação em saúde: aspectos conceituais e operacionais. Saúde debate, Rio de Janeiro, v. 36, n. 95, p. 640-647, Dec. 2012.

VILLELA, A. Os métodos de planejamento na URSS. Revista Brasileira de Economia, v.18, n.4, p.7-11, 1964. Acesso em: 31 de julho de 2020. 


\section{OBESIDADE NA GRAVIDEZ E COMPLICAÇÕES ASSOCIADAS: REVISÃO INTEGRATIVA}

\section{CRISTIANE COSTA MORAIS DE} OLIVEIRA

Faculdade Gianna Beretta, São Luís, MA, Brasil

MARIA DO SOCORRO MARQUES

SOARES

Universidade Federal do Maranhão- UFMA,

São Luís, MA, Brasil

CLICE PIMENTEL CUNHA DE SOUSA

Universidade Federal do Maranhão- UFMA,

São Luís, MA, Brasil

GIVALDO DE JESUS PINHEIRO LOPES

Faculdade Supremo Redentor- FACSUR,

Pinheiro, MA, Brasil

LUZINETE PONTES BRANDÃO

Faculdade Supremo Redentor- FACSUR, Pinheiro, MA, Brasil

FRANCO CELSO DA SILVA GOMES

Universidade Federal do Maranhão- UFMA, São Luís, MA, Brasil

JOELMARA FURTADOS DOS SANTOS

PEREIRA

Universidade Federal do Maranhão- UFMA, São Luís, MA, Brasil

\section{GERUSINETE RODRIGUES BASTOS DOS}

SANTOS

Universidade Federal do Maranhão- UFMA, São Luís, MA, Brasil

JOSIEDNA ABREU PINHEIRO

Hospital Regional da Baixada Maranhense Dr. Jackson Lago, Pinheiro, MA, Brasil
KARLA CONCEIÇÃO COSTA OLIVEIRA

Universidade Federal do Maranhão- UFMA,

São Luís, MA, Brasil

CELIJANE DO NASCIMENTO ALVES

Unidade de Saúde da Família Jardim Silvia,

Francisco Morato, SP, Brasil

FRANCISCA BRUNA ARRUDA ARAGÃO

Escola de Enfermagem de Ribeirão Preto EERP, Universidade de São Paulo - USP,

Ribeirão Preto, SP, Brasil

RESUMO: A obesidade vem crescendo nas últimas décadas e já se transformou, em países desenvolvidos, em um importante problema de saúde pública e pela Organização Mundial de Saúde (OMS) uma epidemia global, atingindo todas as faixas etárias, especialmente gestantes. Diante do exposto este estudo objetivou apresentar as principais complicações referente a associação entre gestação e obesidade. Trata-se de uma revisão de literatura, do tipo integrativa. Foi realizado busca nas bases de dados da Pubmed, Scielo e Bireme, de artigos no período de 2009 a 2019, através dos descritores: obesidade, gestação e complicações. As principais patologias neonatais encontradas foram: diabetes gestacional e DHEG. As publicações ressaltam que a principal complicação materna é a doença hipertensiva específica da gestação e a complicação neonatal é a prematuridade. Diante do exposto, é necessário que ocorra uma prestação mais adequada do acompanhamento pré-natal e assistência ao trabalho de parto, parto, puerpério e ao recém-nascido, podendo, assim, reduzir os efeitos deletérios da idade extrema materna sobre a mulher e o recém-nascido.

Palavras-chave: Obesidade. Gestação. Complicações. 


\begin{abstract}
Obesity has been growing in recent decades and in developed countries has already become a major public health problem and the World Health Organization (WHO) has a global epidemic, reaching all age groups, especially pregnant women. Given the above, this study aimed to present the main complications regarding the association between pregnancy and obesity. This is an integrative literature review. We searched the Pubmed, Scielo and Bireme databases for articles from 2009 to 2019, through the descriptors: obesity, pregnancy and complications. The main neonatal pathologies found were: gestational diabetes and DHEG. The publications point out that the main maternal complication is pregnancy-specific hypertensive disease and the neonatal complication is prematurity. Given the above, it is necessary that a more adequate provision of prenatal care and assistance to labor, delivery, puerperium and the newborn occur, thus reducing the deleterious effects of extreme maternal age on women and children. newborn.
\end{abstract}

Keywords: Obesity. Gestation. Complications.

\title{
1 INTRODUÇÃO
}

A gravidez é um momento sublime para toda mulher, consiste em uma situação fisiopatológica, que envolve um tempo a partir da fertilização, implantação uterina, e finando com a parição. Nada mais é, do que uma ação transformadora das estruturas corporais que envolvem todo processo de gestação, onde o útero inicialmente se expande ocasionando aumento gradativo das curvas ósseas, especialmente, as lombares e complexos ósseos do quadril (CARDOSO et al., 2016).

Relativamente todas as transformações ocorridas durante a gravidez tornam-se numerosas, e devem ser minunciosamente observadas e consequentemente relatadas para que se inicie um ciclo de atividade física com a parturiente. As estruturas corporais mudam, e o abdômen é o primeiro a ser transformado; o útero passa a requerer sustentação e desloca-se, passando a ocupar uma posiçãocentral, resultando em uma rotação pélvica, progredindo para uma lordose lombar. A estabilidade ocorrerá por meio de um trabalho maior da musculatura e ligamentos da coluna vertebral. À proporção que o abdômen fica distendido, mas transformações posturais passam a ocorrer (SANTOS et al., 2011).

É o período que traz mais desconforto para mulher é o inicial, quando há ânsia de vômito, dores mamárias, a preocupação com possível aborto, com cólicas e aumento de secreção vaginal. Já o segundo trimestre, caracteriza-se pelo aumento do útero, há uma melhora do mal-estar e saída do colostro pela papila mamária. O terceiro é marcado pelas primeiras contrações, pré-trabalho de parto, dores pélvicas, aumento de secreção, com aumento de ansiedade e preocupação quanto ao bebê que está prestes a vir (CARDOSO et al., 2016).

A melhora da saúde materna é reconhecidamente um investimento não somente na saúde da gestante e seu filho, mas também na saúde da mulher a longo prazo, pois complicações advindas na gestação podem se associar com morbidades futuras, como hipertensão arterial, diabetes e obesidade. Com relação a obesidade, a literatura afirma que associado com a gravidez aumentam as complicações maternas e fetais (ABREU et al., 2019).

Portanto, as mulheres ao logo de sua gestação passam por uma sequência de transformações orgânicas e corporais que mudam todo seu cotidiano, e dentre estas mudanças estão o sono excessivo, 
cansaço, indisposição, inchaços causados pelo período gestacional, aspectos que levam a gestante ao ganho de peso. Tendo em vista que a gestação juntamente com as inúmeras transformações pode levar a obesidade, justifica-se o desenvolvimento desta temática. Nesse contexto, este estudo objetivou apresentar as principais complicações referente a associação entre gestação e obesidade.

\section{METODOLOGIA}

Trata-se de uma revisão de literatura, do tipo integrativa. Segundo Souza, Silva e Carvalho (2010) “a revisão integrativa é uma abordagem metodológica referente às revisões, permitindo a inclusão de estudos experimentais e não-experimentais para uma compreensão completa do fenômeno analisado".

O primeiro momento do estudo foi a formulação de uma pergunta para subsidiar a busca eletrônica em bases de dados, nesse sentido indagou-se: “Quais são as principais complicações referente a obesidade gestacional?".

Após o desenvolvimento da pergunta, foi realizado uma busca nas bases de dados da Lilacs, Scielo e Bireme, utilizando-se os seguintes descritores: gestação, obesidade e complicações, combinados entre si com a utilização dos operadores booleanos AND e OR.

Para a coleta de dados dos artigos, foi elaborado instrumento baseado em protocolo de revisão, composto dos seguintes itens: autor (ano), tipo de estudo, amostra, peso e complicações maternas.

A busca foi iniciada pela BIREME com o descritor gestação. Devido à grande abrangência de publicações disponíveis, foi necessário fazer cruzamento entre os termos usando o operador lógico booleano and. Utilizando os termos gestação and obesidade and complicações. No LILACS foram usados os mesmos descritores, contudo operador booleano or: Já na plataforma do SCIELO, foram utilizados os descritores, gestação e obesidade, com o operador booleano and.

Foram excluídos estudos em línguas diferentes das escolhidas primariamente, as cartas ao editor, editoriais, estudos que não apresentassem relação com a temática estudada. Para facilitar a exclusão, foram utilizados os seguintes filtros: "Dates - Last 5 years"; "Text options - Links To Free Full Text"; e "Languages - English and Portuguese and Espanhol", abstracts e resumos, para então contemplação dos textos completos.

Após a busca inicial e verificação dos títulos e obtenção dos resumos, foi selecionado os trabalhos pertinentes de acordo com os critérios de inclusão e de não inclusão. Estudos quantitativos e qualitativos que analisavam idade gestacional e patologias neonatais, foram incluídos na realização da revisão integrativa, que estavam na língua portuguesa e inglesa publicados no período de janeiro de 2009 e a agosto de 2019. 


\section{RESULTADOS}

Uma primeira etapa de seleção dos trabalhos foi utilizada a estratégia de busca encontrou, no LILACS 123 artigos, no qual foram selecionados 73 artigos após realizada a análise dos títulos e dos resumos. Com critérios de exclusão e artigos repetidos, forma selecionados somente 8 publicações. No banco de dados do BIREME, encontrou-se 491 artigos, após a realização do filtro no banco de dados, encontrou-se 111 artigos após a análise dos títulos e dos resumos, contudo foram incluídos 10 trabalhos para leitura na integra, após aplicação critérios de exclusão.

Na plataforma do SCIELO, inicialmente não foram encontrados nenhum artigo, entretanto, no segundo cruzamento foram encontrados 10 artigos, pelo título e breve leitura do resumo, foram selecionados 5 artigos, após a leitura na integra dos artigos, foram selecionados somente 2 publicações. Na figura 1, demonstra a seleção dos artigos.

Figura 1 - Seleção de artigos

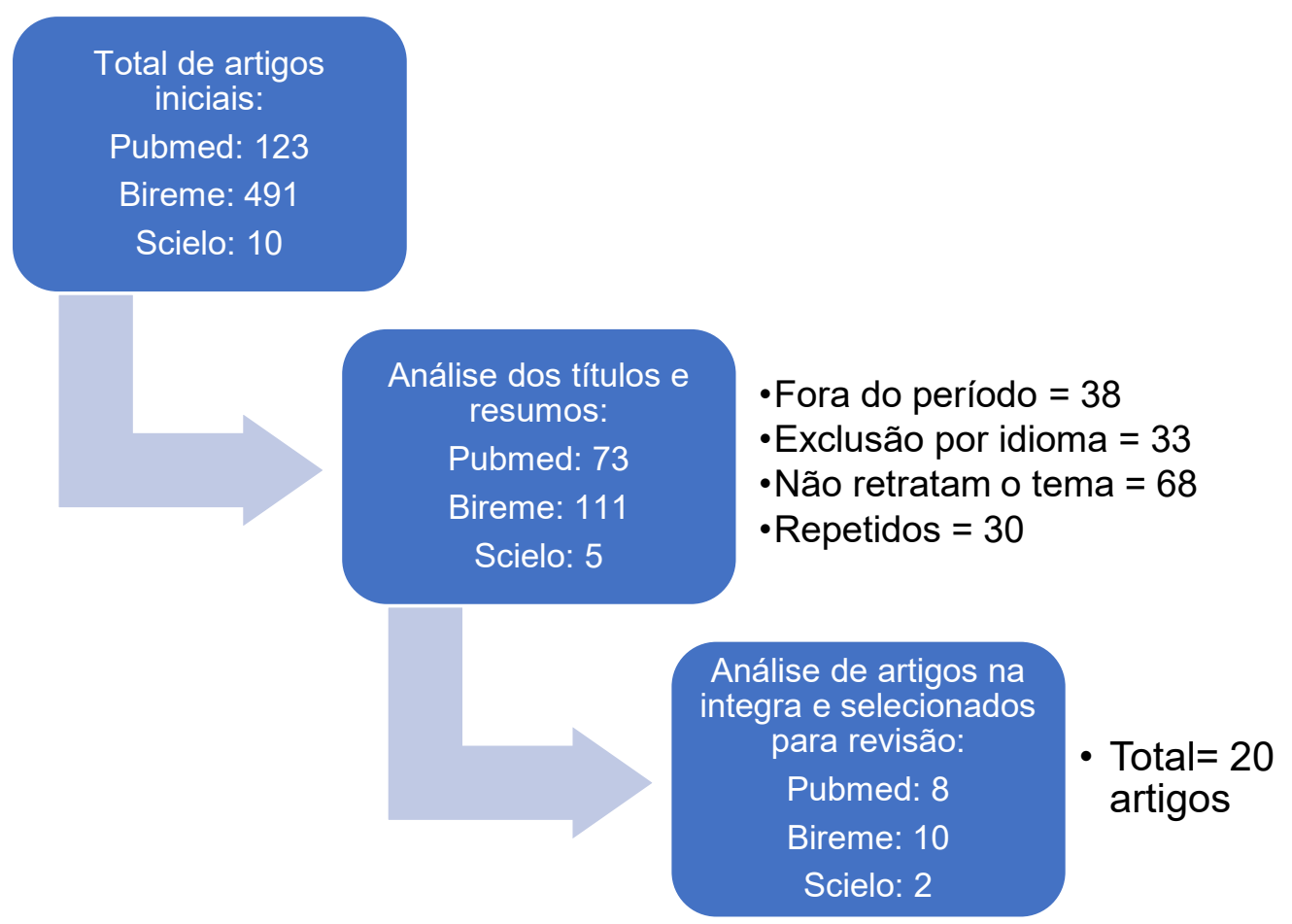

Fonte: Autora do estudo (2019).

Portanto o corpus da pesquisa correspondeu a 20 produções, lidas na íntegra. Assim, das 20 publicações lidas na íntegra, foram selecionadas 12 , que se enquadraram melhor na temática estudada. A organização dos dados foi feita por meio de uma ficha documental com a seguinte informação: ano de publicação; tipo de estudo; complicações associadas a obesidade gestacional. Portanto, os 12 artigos selecionados para a discussão, demonstraram potencial para participar da revisão integrativa, como demonstra o quadro 1. 
Quadro 1 - Artigos sobre a temática

\begin{tabular}{|c|c|c|c|c|}
\hline Autor (ano) & Tipo de estudo & Amostra & Peso & Complicações \\
\hline $\begin{array}{l}\text { Abreu et al. } \\
\text { (2019) }\end{array}$ & Estudo longitudinal & 57 gestantes & $\begin{array}{c}19,2 \% \text { estavam } \\
\text { com sobrepeso e } \\
14 \% \text { obesas }\end{array}$ & $\begin{array}{c}38,6 \% \text { com dislipi- } \\
\text { demia }\end{array}$ \\
\hline $\begin{array}{c}\text { Bozatski; } \\
\text { Pinto; Lava- } \\
\text { do (2019) }\end{array}$ & $\begin{array}{l}\text { análise retrospecti- } \\
\text { va, descritiva, quan- } \\
\text { titativa e transversal }\end{array}$ & 328 gestantes & $64,8 \%$ obesas & $\begin{array}{c}\text { Todas com diabetes } \\
\text { gestacional }\end{array}$ \\
\hline $\begin{array}{l}\text { Zuccolotto et } \\
\text { al. (2019) }\end{array}$ & Estudo transversal & $\begin{array}{l}785 \text { gestantes } \\
\text { investigadas }\end{array}$ & $\begin{array}{c}33,2 \% \text { foram } \\
\text { classificadas } \\
\text { com sobrepeso e } \\
23,8 \% \text { com obe- } \\
\text { sidade }\end{array}$ & $\begin{array}{l}17,7 \% \text { apresentaram } \\
\text { diabetes gestacional }\end{array}$ \\
\hline $\begin{array}{l}\text { Antunes et } \\
\text { al. (2018) }\end{array}$ & Estudo transversal & 217 gestantes & $\begin{array}{c}49,3 \% \text { estavam } \\
\text { com excesso de } \\
\text { peso }\end{array}$ & $\begin{array}{l}\text { 24\% eram hiperten- } \\
\text { sas; } 10,1 \% \text { diabé- } \\
\text { ticas; } 17 \% \text { tiveram } \\
\text { trabalho de parto } \\
\text { prematuro (TPP) }\end{array}$ \\
\hline $\begin{array}{l}\text { Vidal et al. } \\
\text { (2018) }\end{array}$ & $\begin{array}{l}\text { Estudo quantitativo, } \\
\text { retrospectivo, analí- } \\
\text { tico, transversal }\end{array}$ & $\begin{array}{l}730 \text { prontuá- } \\
\text { rios de gestan- } \\
\text { tes }\end{array}$ & $\begin{array}{c}34,1 \% \text { com obe- } \\
\text { sidade }\end{array}$ & $\begin{array}{c}14,2 \% \text { com diabetes } \\
\text { gestacional }\end{array}$ \\
\hline $\begin{array}{l}\text { Müssnich et } \\
\text { al. (2018) }\end{array}$ & $\begin{array}{c}\text { Pesquisa transversal } \\
\text { e quantitativa }\end{array}$ & $\begin{array}{l}96 \text { prontuários } \\
\text { de gestantes }\end{array}$ & $\begin{array}{c}87,5 \% \text { com obe- } \\
\text { sidade }\end{array}$ & 100\% hip \\
\hline $\begin{array}{l}\text { Rufino et al. } \\
\text { (2018) }\end{array}$ & $\begin{array}{l}\text { Estudo de caráter } \\
\text { exploratório, quan- } \\
\text { titativo, descritivo, } \\
\text { retrospectivo, com } \\
\text { análise documental }\end{array}$ & 116 gestantes & $\begin{array}{c}34,1 \% \text { que es- } \\
\text { tavam com so- } \\
\text { brepeso e } 15,4 \% \\
\text { obesas }\end{array}$ & tensa \\
\hline $\begin{array}{l}\text { Monteiro et } \\
\text { al. (2017) }\end{array}$ & Estudo transversal & $88 \mathrm{~g}$ & $19,3^{\circ}$ & ensas \\
\hline $\begin{array}{c}\text { Costa et. al. } \\
(2016)\end{array}$ & Estudo transversal & $\begin{array}{c}61 \text { prontuários } \\
\text { de gestante }\end{array}$ & $18 \%$ obesas & $24,6 \%$ hipertensas \\
\hline $\begin{array}{c}\text { Rodrigues } \\
\text { e Brandão } \\
\text { (2011) }\end{array}$ & Estudo Transversal & $\begin{array}{l}315 \text { prontuá- } \\
\text { rios de gestan- } \\
\text { tes }\end{array}$ & $100 \%$ obesas & $\begin{array}{c}\text { hipertensão em } \\
45,4 \% \text {, diabetes em } \\
16,5 \% \text {, trombose } \\
\text { venosa profunda em } \\
0,6 \% \text { e dislipidemia } \\
\text { em } 0,3 \% \text {. }\end{array}$ \\
\hline $\begin{array}{c}\text { Seabra et al. } \\
(2011)\end{array}$ & Estudo transversal & 433 mulheres & $24,5 \%$ obesas & $100 \%$ hipertensas \\
\hline $\begin{array}{c}\text { Santos et al. } \\
(2011)\end{array}$ & Estudo Transversal & 36 gestantes & $33,3 \%$ obesas & Hipertensas \\
\hline
\end{tabular}

Fonte: Lilacs e Scielo (2019). 


\section{DISCUSSÃO}

Com relação a diabetes gestacional (DMG), estudos (BOZATSKI; PINTO; LAVADO, 2019; ZUCCOLOTTO et al., 2019; VIDAL et al., 2018) indicam a prevalência de diabetes mellitus durante a gestação é equivalente à sua prevalência em mulheres em idade reprodutiva. O DMG gestacional se desenvolve no $2^{\circ}$ ou $3^{\circ}$ trimestre de gestação devido a hormônios secretados pela placenta, depois da gravidez pode desaparecer os sintomas, mas pode ocorrer também depois de algum tempo, o desenvolvimento de DM tipo 2.

A DMG tem prevalência entre 3 a 25\% das gestações, sendo que $90 \%$ das gestantes, principalmente as obesas, possui mais risco para a doença. Nas gestações complicadas pelo diabetes, a hiperglicemia materna é seguida por morbidades designadas "fetopatia diabética", sendo associadas a um maior número de perda fetal (ZUCCOLOTTO et al., 2019). Portanto, o comprometimento fetal decorre da hiperglicemia materna e transmissão facilitada ao feto, favorecendo o crescimento fetal exagerado e, entre outras complicações como: a macrossomia, o crescimento da cesareana, os traumas de canal de parto e a ocorrência de resultados neonatais adversos. Entre os mais comuns, destacam-se: hipoglicemia, hiperbilirrubinemia, hipocalcemia, policitemia e distúrbios respiratórios. Já com relação às malformações congênitas esta sujeita a presença de hiperglicemia materna no começo da gravidez e da qualidade de seu controle, sendo mais frequente no diabetes prévio à gestação (VIDAL et al., 2018).

A dislipidemia também é citada na literatura que a dislipidemia associado a obesidade é um fator de risco que aumenta a probabilidade de mortalidade e morbidade após a gestação. Cita-se também o tromboembolismo venoso (TVE) na gestação, sendo que a obesidade é uma das principais causas, visto que essa associação, gestação e obesidade, aumenta 14,9 vezes de risco para o desenvolvimento de TVE (ABREU et al., 2019; RODRIGUES, BRANDÃO, 2011).

Ressalta-se ainda que as modificações alterações fisiológicas da gravidez juntamente com a obesidade fazem essa paciente com reservas fisiológicas limitadas e geralmente está paciente recorre a cesariana como tipo de parto (RODRIGUES, BRANDÃO, 2011). Estudos indicam outra complicação o parto prematuro, visto que o nascimento de prematuros representa um grande desafio para os serviços de saúde pública, por tratar-se de um determinante de morbimortalidade neonatal. No mundo, atualmente, a prematuridade representa a principal causa de mortalidade neonatal com um percentual de 75\%. Embora, os prematuros não apresentem comprometimento neurológico durante o período neonatal, contudo, os mesmos possuem um maior risco de atraso no desenvolvimento motor em relação aos recém-nascidos (RNs) a termo (ANTUNES et al., 2018; RUFINO et al., 2018).

Entre outras complicações maternas associadas a obesidades, destaca-se as DHEG, resultando em aproximadamente 60 mil óbitos maternos a cada ano. No Brasil, a pré-eclâmpsia representa a terceira causa de morte materna, sendo responsável por cerca de 35\% dos óbitos, com uma taxa de 140 a 160 mortes maternas por cada 100.000 nascidos vivos (MONTEIRO et al., 2017). 
O agravamento da DHEG tem a complicações como: a pré-eclâmpsia leve que há um aumento exagerado e subitâneo do peso (500 gramas por semana), PA maior que 160x110mmHg, proteinúria maior que $2 \mathrm{~g} / 24 \mathrm{~h}$, com ou sem edema; a pré-eclâmpsia grave caracteriza-se quando um ou mais sintomas são encontrados mais PA maior ou igual a 160x110mmHg; a eclampsia que se caracteriza pelo agravamentos dos sinais e sintomas da pré-eclâmpsia e pela presença da crise convulsiva; na Síndrome HELLP apresenta $\mathrm{H}$ - hemólise (fragmentação das células vermelhas do sangue na circulação), EL - níveis elevados de enzimas hepáticas, e LP - diminuição do número de plaquetas (MÜSSNICH et al., 2018).

Nesse contexto, a DHEG apresenta potencialmente os piores prognósticos materno-fetal; deste modo, conceptos de mães hipertensas têm maiores riscos de prematuridade, ocorrência de partos de fetos pequenos para idade gestacional (PIG), necessidade de UTIN, necessidade de suporte ventilatório e maior incidência da mortalidade perinatal (SANTOS et al., 2011; SEABRA et al., 2011).

As síndromes hipertensivas gestacionais são doenças possíveis de se prevenir em quase todas as circunstâncias, por isso, a captação precoce da gestante e a realização de um pré-natal adequado é de suma relevância. Pois, nesse período a gestante sendo bem orientada, adquire informações necessárias que lhe dê condições de aprender e reconhecer as alterações que ocorrem em seu organismo, para que assim, possa ser feito o diagnóstico da doença antes que evolua para pré-eclâmpsia, causando outras complicações para a mãe e o bebê (MÜSSNICH et al., 2018; COSTA et al., 2016).

A literatura demonstra que, quando as gestantes recebem orientação sobre nutrição e atividade física, ocorre melhora do seu estado de saúde, ou seja, a alteração de seu hábito de vida está relacionada ao conhecimento sobre a temática Vale ressaltar que no período gestacional ocorre variação das necessidades, dependendo do peso pré-gestacional, do ganho de peso durante a gestação, do estágio da gravidez e do nível de atividade física (SANTOS et al., 2011; SEABRA et al., 2011).

Diante do exposto, as intervenções educacionais que podem ajudar as equipes de ESF, a promover um estilo de vida mais saudável para esse público e justificam-se pela necessidade de propor novas estratégias de tratamento para problemas de saúde das gestantes, promovendo uma recuperação mais rápida ou o controle de peso de forma segura, eficaz e com menos despesas para o tratamento (ZUCCOLOTTO et al., 2019; SANTOS et al., 2011; SEABRA et al., 2011).

Nesse contexto, mostra-se a importância de um programa educacional para esse público, no qual a prática de atividade física é fator benéfico para a gestante, além de aquisição de hábitos de vida mais saudáveis. Ressalta-se também que a indicação da prática de atividade física na gravidez, inclusive para as gestantes obesas, é considerada um exercício seguro, contudo devendo ser conhecida e orientada por toda equipe de profissionais da saúde multidisciplinar. Logo, intervenções nesse público, são necessárias, pois a gravidez é uma fase em que a mulher passa por diversas mudanças fisiológicas, e com essa a intervenção decorre a iniciação de um estilo de vida ativo para pessoas previamente sedentárias que é de suma importância (ABREU et al., 2019; COSTA et al., 2016). 


\section{CONSIDERAÇÕES FINAIS}

O ganho de peso excessivo na gestação tornaram-se importantes problemas no Brasil, ampliando a relevância de estudos sobre atividades físicas de mulheres em idade reprodutiva e de gestantes. A melhora da saúde materna é reconhecidamente um investimento não somente na saúde da gestante e seu filho, mas também na saúde da mulher a longo prazo, pois complicações advindas na gestação podem se associar com morbidades futuras, como hipertensão arterial, diabetes e obesidade. Nesse sentido, a prática de exercício físico e uma boa alimentação são formas de melhorar a qualidade de vida e a saúde materna, além de ajudar no controle do ganho peso gestacional e no retorno ao peso no puerpério.

Além disso, o profissional de enfermagem deve conhecer a situação da parturiente com obesidade, para poder atendê-la de forma humanizada. A adesão do cuidado humano a parturição faz com que ocorra a sensibilização do parto e nascimento como um evento único e precioso tanto para a mulher como para os profissionais de enfermagem, ao resgatar a visão e a prática de assistência integralizada do ser humano. A competência da Enfermeira Obstétrica não se constrói apenas no seu saber técnico, mas em todo um conjunto de saberes, que devem surgir na prática. Portanto, é de extrema relevância que os cursos de formação de Enfermeiras Obstétricas estimem em seus currículos o caráter multidimensional da competência profissional, ressaltando a necessidade da busca constante do seu desenvolvimento.

\section{REFERÊNCIAS}

ABREU, Rosiane FS et al. Associação de preditores de doença cardiovascular em gestantes: um estudo longitudinal. Revista da Faculdade de Medicina de Teresópolis, v. 3, n. 1, 2019.

ANTUNES, Louriene et al. Caracterização clínica e nutricional de gestantes de alto risco assistidas no hospital universitário de Maceió-Alagoas. Gep News, v. 1, n. 1, p. 14-19, 2018.

BOZATSKI, Barbara Louise; PINTO, Maria Fernanda; LAVADO, Mylene Martins. Perfil epidemiológico de gestantes diabéticas no município de Itajaí, SC. Arquivos Catarinenses de Medicina, v. 48, n. 2, p. 34-55, 2019.

CARDOSO, Mirian Domingos et al. Percepção de gestantes sobre a organização do serviço/assistência em um pré-natal de baixo risco de Recife. Revista de Pesquisa: Cuidado é Fundamental Online, v. 8, n. 4, p. 5017-5024, 2016.

COSTA, Lediana et al. Perfil epidemiológico de gestantes de alto risco. Cogitare Enfermagem, v. 21, n. 2, 2016.

MARCHESINI, Simone Dallegrave. Acompanhamento psicológico tardio em pacientes submetidos à cirurgia bariátrica. ABCD arq. bras. cir. dig, v. 23, n. 2, p. 108-113, 2010.

MEDEIROS, Patricia Flores; GUARESCHI, Neuza Maria. Políticas públicas de saúde da mulher: a integralidade em questão. Estudos Feministas, p. 31-48, 2009. 
MONTEIRO, Anna Louise Stellfeld et al. Avaliação epidemiológica de gestantes hipertensas crônicas da maternidade HC-UFPR. Revista Médica da UFPR, v. 4, n. 1, p. 17-22, 2017.

MÜSSNICH, Daniela et al. Perfil Sociodemográfico e Consumo Alimentar de Gestantes Hipertensas. Nutrición clínica y dietética hospitalaria, v. 38, n. 1, p. 175-181, 2018.

OLIVEIRA, Virgínia Junqueira; MADEIRA, Anézia Moreira Faria; PENNA, Cláudia Maria. Vivenciando a gravidez de alto risco entre a luz e a escuridão. Revista da Rede de Enfermagem do Nordeste, v. 12, n. 1, p. 49-56, 2011.

RODRIGUES, Flávia Romano et al. Anestesia regional para cesariana em gestantes obesas: estudo retrospectivo. Revista Brasileira de Anestesiologia, 2011.

RUFINO, Marcela Portela Rezende et al. Avaliação do estado nutricional e do ganho de peso das gestantes atendidas em um Centro de Saúde da Família do interior norte do estado do Ceará/Brasil. Revista Interdisciplinar, v. 11, n. 4, p. 11-20, 2018.

SANTOS, Elaine Valdna Oliveira dos et al. Estado Nutricional Pré-Gestacionale Gestacional: uma Análise de GestantesInternas em um Hospital Público. Rev. bras. ciênc. saúde, v. 15, n. 4, p. 439-446, 2011.

SEABRA, Gisele et al. Sobrepeso e obesidade pré-gestacionais: prevalência e desfechos associados à gestação. Rev. bras. ginecol. obstet, p. 348-353, 2011.

SILVA, Raimunda Magalhães da et al. Cartografia do cuidado na saúde da gestante. Ciência \& Saúde Coletiva, v. 17, p. 635-642, 2012.

SOUZA, Marcela Tavares de; SILVA, Michelly Dias da; CARVALHO, Rachel de. Revisão integrativa: o que é e como fazer?. Revista Einstein.; n. 8(1 Pt 1), p:102-6, 2010.

VIDAL, Juliana et al. Diabetes gestacional e estado nutricional de mulheres acompanhadas no pré-natal de um hospital universitário de alta complexidade - Niterói - RJ -Brasil. Convención Internacional de Salud, Cuba Salud, 2018.

ZUCCOLOTTO, Daniela Cristina Candelas et al. Padrões alimentares de gestantes, excesso de peso materno e diabetes gestacional. Revista de Saúde Pública, v. 53, 2019. 


\section{CUIDADOS DE ENFERMAGEM NO FERIMENTO POR ARMA DE FOGO COM TRAUMATISMO CEREBRAL DIFUSO: ESTUDO DE CASO}

TATIANA FABÍOLA DA SILVA LIMA

Centro Universitário Metropolitano da Amazônia (UNIFAMAZ)

MARCOS MIRANDA RODRIGUES

Centro Universitário Metropolitano da Amazônia (UNIFAMAZ)

VIRGÍNIA MERCÊS LARA PESSOA OLIVEIRA

Centro Universitário Metropolitano da Amazônia (UNIFAMAZ)

CINTHYA LORENA BEZERRA SARMANHO

Centro Universitário Metropolitano da Amazônia (UNIFAMAZ)

WEBER MARCOS

Centro Universitário Metropolitano da Amazônia (UNIFAMAZ)

\section{JAQUELINE CARDOSO MARCENA}

Centro Universitário Metropolitano da Amazônia (UNIFAMAZ)

GABRIEL FAZZI COSTA

Centro Universitário Metropolitano da

Amazônia (UNIFAMAZ)

SARA DE OLIVEIRA SILVA

Centro Universitário Metropolitano da

Amazônia (UNIFAMAZ)
RESUMO: Os traumas representam agravos complexos e graves, quando envolvem o crânio podem afetar funções motoras, cognitivas e nível de consciência. Os traumas comuns nessa região são o Traumatismo Cerebral. O objetivo deste estudo é relatar um caso clínico de paciente vítima de ferimento por arma de fogo, bem como propor e apresentar intervenções de enfermagem aos problemas identificados e diagnosticados, no intuito de proporcionar a melhora do quadro clínico do paciente. Foi realizado na clinica médica de um hospital referência em urgência e emergência do estado do Pará por acadêmicos de enfermagem, a partir da sistematização da assistência de enfermagem. Os diagnósticos de enfermagem que emergiram foram relacionados a condição biológica e psicossocial. Elaborou-se as intervenções de enfermagem para cada diagnóstico. Evidenciamos a melhora considerável da dislalia, plegia e paresia, dentro de um período de 8 dias. De acordo com o plano de cuidados elaborados, foram dadas as devidas orientações, ao paciente e a acompanhante, quanto aos cuidados com higiene oral, alimentação, ingesta hídrica e encorajamento a dar continuidade ao tratamento de sua patologia, no CAPS.

PALAVRAS-CHAVE: Cuidados de Enfermagem. Traumatismo Craniano. Diagnóstico de Enfermagem.

ABSTRACT: Traumas represent complex and serious aggravations, when they involve the skull they can affect motor functions, cognitive and level of consciousness. The common traumas in this region are Brain Trauma. The objective of this study is to report a clinical case of a patient 
victim of gunshot wound, as well as to propose and present nursing interventions to the identified and diagnosed problems, in order to provide the improvement of the patient's clinical picture. It was performed in the medical clinic of a reference hospital in urgency and emergency of the state of Pará by nursing academics, from the systematization of nursing care. The emerging nursing diagnoses were related to biological and psychosocial condition. Nursing interventions were prepared for each diagnosis. We showed considerable improvement in dyslalia, plegia and paresis, within a period of 8 days. In accordance with the plan of care elaborated, the patient and the companion were given the proper orientations, as for the cares with oral hygiene, feeding, water ingestion and encouragement to give continuity to the treatment of its pathology, in CAPS.

KEY WORDS: Nursing Care. Cranial Trauma. Nursing Diagnosis.

\section{INTRODUÇÃO}

As lesões primárias são aquelas que ocorrem no momento do trauma. No paciente com ferimentos por projétil de arma de fogo ou arma branca que penetram o crânio, a lesão primária ocorre em virtude do trauma direto ao parênquima encefálico. Quando não ocorre contato com o conteúdo intracraniano, as lesões primárias podem resultar da movimentação cerebral associada à energia cinética do acidente. As lesões secundárias decorrem de agressões que se iniciam após o momento do acidente, resultantes da interação de fatores intra e extracerebrais, que se somam para inviabilizar a sobrevivência de células encefálicas poupadas pelo trauma inicial. Hipotensão arterial, hipoglicemia, hipercarbia, hipóxia respiratória, hipóxia anêmica e distúrbios hidroeletrolíticos são os principais fatores de lesão secundária. Posteriormente, são somados outros distúrbios metabólicos e infecciosos sistêmicos (ANDRADE et al., 2009).

A lesão difusa refere-se a um processo de dano axonal generalizado, secundário aos mecanismos de rotação, aceleração e desaceleração da cabeça, bem como a propagação da força através do cérebro após um trauma agudo ou repetitivo. Devido a lesão, há proteólise, desgaste dos pequenos vasos sanguíneos, acumulação de remanescentes de mielina e agregação de proteína beta-amilóide e proteína TAU cronicamente. $\mathrm{O}$ dano induzido diminui a plasticidade axonal e evita a recuperação em sua forma original. As áreas mais afetadas são o tronco encefálico, a substância branca do córtex cerebral e o corpo caloso. Dependendo da gravidade e extensão da lesão, pode manifestar-se agudo com confusão ou perda imediata de consciência e em casos mais graves, persistir ao coma ou disfunção cognitiva (ROJAS-GALLEGO et al., 2018).

A Lesão Difusa correlaciona-se com sintomas cognitivos e comportamentais, pois afeta principalmente os lobos frontais do encéfalo, que são altamente suscetíveis a essas alterações. São comuns disfunções cognitivas, mentais e psicomotoras que podem causar incapacidades e deficiências em curto longo prazo como a disfasia, dificuldade na execução de tarefas, que requerem atenção e planejamento, agressividade e irritabilidade. Estudos também apontam que o prejuízo de memória é o mais comum, acrescido de distúrbios emocionais e comportamentais (CURVELO et al., 2014).

Efeitos posteriores à lesão cerebral estendem-se para uma fase subaguda e crônica do trauma desencadeando complicações para vários sistemas do corpo. As contraturas ou encurtamentos da 
pele, tendões, ligamentos, músculos ou cápsula articular podem resultar do período de imobilização do paciente, ocasionando fatores de risco representados pela espasticidade muscular, mau alinhamento e o posicionamento impróprio. Em alguns casos observa-se a presença do padrão hemiplégico e ou hemiparético, que são caracterizados pela abolição da função de um hemicorpo (hemiplegia) e diminuição da função de um hemicorpo (hemiparesia), com alterações de marcha e mobilidade funcional de membro superior e de membro inferior (BRASIL, 2013).

As sequelas sensório-motoras do trauma podem prejudicar a comunicação do indivíduo, afetando sua capacidade de produzir a fala de maneira inteligível. Isso ocorre quando o trauma compromete o hemisfério esquerdo, pois nele localiza-se áreas especializadas: Área de Broca (B), o córtex responsável pela motricidade da fala e a área de Wernicke $(\mathrm{W})$, córtex responsável pela compreensão verbal provocando um distúrbio neuromotor denominado disartria. Esse distúrbio é caracterizado por lentidão, fraqueza e/ou incoordenação da musculatura relacionada a esta função e tem como principal manifestação a redução da inteligibilidade da fala, que limita a atividade comunicativa do falante e sua participação social (RODRIGUES et al., 2008; SILVA et al., 2017).

Da mesma forma, prejuízos na integração perceptual, as agnosias, caracterizadas como desordens de reconhecimentos, podem fazer parte de um conjunto de alterações associadas ao TC, apesar da função sensorial intacta (visão, audição e tato). A perda da capacidade de reconhecer pode incluir objetos, pessoas, sons, cores e formas. Uma pessoa com agnosia pode ter visão normal e não ter capacidade de reconhecer objetos cotidianos (agnosia visual), pessoas familiares ou mesmo sua própria imagem no espelho (prosopagnosia), ser incapaz de lembrar informações sobre os objetos (agnosia perceptiva), de reconhecer sons (agnosia auditiva), de reconhecer os objetos com o tato (agnosia tátil), entre outras, isto resulta da degeneração, em geral, nos lobos parietais ou em suas conexões, ou menor frequência, no córtex pré-motor ou corpo caloso e lobo frontal (BRASIL, 2013; SILVA et al., 2018).

Nesse contexto, pacientes vítimas deste agravo, necessitam de cuidados complexos, dependendo da gravidade, devem ser realizados em terapia intensiva. Uma equipe multiprofissional capacitada atua, com o objetivo de prevenir complicações, manter a estabilidade hemodinâmica e reestabelecer as funções afetadas. Nesta perspectiva, a equipe de enfermagem (Enfermeiro e Técnico), são fundamentais nesse processo, pois desempenham cuidados essenciais, e utilizam instrumentos para a aplicabilidade do cuidado baseado em ciência, com a Sistematização da Assistência de Enfermagem (SAE). A SAE é composta por cinco etapas: Anamnese e Exame físico (identificar os problemas); Diagnósticos de Enfermagem (auxílio da taxonomia NANDA); Planejamento e Resultados Esperados; Implementação; Avaliação. Essas etapas são realizadas respectivamente, e garantem a assistência sistematizada e baseado em evidências científica, pois são sustentadas pelas teorias de enfermagem (COSTA et al., 2020; SARDINHA et al., 2019, 2020).

Este estudo tem como objetivo relatar um caso clínico de paciente vítima de ferimento por arma de fogo, bem como propor e apresentar intervenções de enfermagem aos problemas identificados e diagnosticados, no intuito de proporcionar a melhora do quadro clínico do paciente. 


\section{METODOLOGIA}

O presente estudo clínico foi realizado na Clínica Cirúrgica, de um hospital referência em urgência e emergência no estado do Pará, por acadêmicos decimo semestre do curso bacharelado em enfermagem, no módulo de estagio curricular Urgência e Emergência. Paciente do sexo masculino, 47 anos, vítima de Ferimento por Arma de Fogo (FAF) em região craniana e torácica, no momento em que trabalhava. Após o ocorrido, paciente foi levado por familiares à Unidade de Pronto Atendimento (UPA) onde foram prestados os atendimentos assistenciais iniciais. Após avaliação do quadro clínico, foi referenciado para o hospital através do Serviço de Atendimento Móvel (SAMU).

Paciente recebeu diagnóstico inicial de Traumatismo Cerebral Difuso e evoluiu ao quadro de dislalia, plegia em membro superior direito (MSD) e paresia em membro inferior direito (MID). É portador de Transtorno Afetivo Bipolar (CID 10 - F 31.7) no qual se tratou por um ano no CAPS II, mas abandonou o tratamento após sentir-se melhor. Atualmente não aceita a doença, segundo acompanhante. Nega HAS e DM, é tabagista há 34 anos, nega etilismo e não pratica atividades físicas.

O método seguiu-se as etapas da SAE, Anamnese e Exame físico (identificar os problemas); Diagnósticos de Enfermagem (auxílio da taxonomia NANDA); Planejamento e Resultados Esperados; Implementação; Avaliação. Os resultados foram apresentados em um quadro, com os problemas, diagnósticos de enfermagem, resultados esperados e intervenções de enfermagem.

\section{RESULTADOS}

Paciente, 47 anos, vítima de ferimento por arma de fogo, enquanto trabalhava, em região craniana $\mathrm{E}$ torácica nas regiões mamária $\mathrm{D}$ e inframamária $\mathrm{E}$, foi levado por familiares à UPA, onde foram prestados os cuidados iniciais. No momento do atendimento, encontrava-se consciente, orientado em tempo e espaço, deambulando com auxílio, sinais vitais estáveis, lesões não hemorrágicas. Foi transferido da UPA de e levado pelo SAMU para o Hospital referência, onde foi admitido. No momento encontrava-se estável hemodinamicamente, confortável em ar ambiente, com perda da capacidade de fala e paresia de membro superior esquerdo. Com diagnóstico inicial de Traumatismo cerebral Difuso. Admitido na clínica cirúrgica, proveniente da unidade de terapia intensiva 2, após cirurgia de correção de fratura de afundamento frontal e correção de fístula liquórica + crânioplastia. Portador de transtorno mental compatível com CID 10 F 31.7, apresentando limitações nas áreas de convívio social. 


\begin{tabular}{|c|c|c|c|c|}
\hline $\begin{array}{l}\text { PROBLEMA } \\
\text { IDENTIFICA- } \\
\text { DO }\end{array}$ & $\begin{array}{l}\text { PADRÃO DE } \\
\text { NECESSIDA- } \\
\text { DE HUMANA } \\
\text { AFETADA }\end{array}$ & $\begin{array}{c}\text { DIAGNÓSTI- } \\
\text { CO } \\
\text { DE } \\
\text { ENFERMA- } \\
\text { GEM }\end{array}$ & $\begin{array}{l}\text { RESULTADO } \\
\text { ESPERADO }\end{array}$ & $\begin{array}{c}\text { PRESCRIÇÃO } \\
\text { DE } \\
\text { ENFERMAGEM }\end{array}$ \\
\hline $\begin{array}{l}\text { Plegia em mão } \\
\text { direita e paresia } \\
\text { em membro in- } \\
\text { ferior direito. }\end{array}$ & $\begin{array}{l}\text { Atividade/ Re- } \\
\text { pouso }\end{array}$ & $\begin{array}{l}\text { Mobilidade fí- } \\
\text { sica prejudicada } \\
\text { caracterizada } \\
\text { pela alteração de } \\
\text { marcha e perda } \\
\text { de força dos mo- } \\
\text { vimentos finos, } \\
\text { relacionado ao } \\
\text { prejuízo neuro- } \\
\text { lógico causado } \\
\text { pelo traumatis- } \\
\text { mo cerebral. }\end{array}$ & $\begin{array}{l}\text { Espera-se que } \\
\text { melhore movi- } \\
\text { mentos e tenha } \\
\text { disposição } \\
\text { para participar } \\
\text { das atividades } \\
\text { de acordo com } \\
\text { suas necessida- } \\
\text { des em } 8 \text { dias; } \\
\text { Que compreen- } \\
\text { da a situação, } \\
\text { o regime te- } \\
\text { rapêutico e as } \\
\text { medidas de } \\
\text { segurança para } \\
\text { seu caso em } \\
\text { até } 24 \mathrm{~h} .\end{array}$ & $\begin{array}{l}\text {-Ajudar paciente na deambulação } \\
\text { em intervalos regulares } \\
\text { às } 9 \mathrm{~h} \text {; } \\
\text {-Auxiliar o paciente a sentar-se } \\
\text { a beira da cama para facilitar os } \\
\text { ajustes posturais: } \\
\text { M T N; } \\
\text {-Encorajar e informar ao paciente } \\
\text { quanto a importância da deambu- } \\
\text { lação independente, dentro dos li- } \\
\text { mites seguros; } \\
\text { às } 9 \mathrm{~h}\end{array}$ \\
\hline $\begin{array}{c}\text { Sono e repouso } \\
\text { prejudicados }\end{array}$ & $\begin{array}{l}\text { Atividade/ Re- } \\
\text { pouso }\end{array}$ & $\begin{array}{l}\text { Padrão de sono } \\
\text { prejudicado, } \\
\text { caracterizado } \\
\text { pelo relato, rela- } \\
\text { cionado a dor. }\end{array}$ & $\begin{array}{c}\text { Espera-se que } \\
\text { haja melhora } \\
\text { do padrão de } \\
\text { sono, e que se } \\
\text { sinta melhor e } \\
\text { mais descansa- } \\
\text { do em até 24h. } \\
\text { Espera-se que } \\
\text { não tenha dor } \\
\text { após serem } \\
\text { aplicadas as } \\
\text { medidas de } \\
\text { controle sobre } \\
\text { esta em até } \\
24 \mathrm{~h} .\end{array}$ & $\begin{array}{l}\text {-Proporcionar ambiente calmo e } \\
\text { seguro } \\
\qquad \text { M T N; } \\
\text {-Monitorar padrão de sono e quan- } \\
\text { tidades de horas dormidas; } \\
\text { ATENÇÃO; } \\
\text {-Oferecer informações ao pacien- } \\
\text { te e acompanhante sobre a dor, as } \\
\text { causas, tempo de duração quando } \\
\text { necessário. } \\
\text { ATENÇÃO }\end{array}$ \\
\hline $\begin{array}{c}\text { Evacuações au- } \\
\text { sentes }\end{array}$ & $\begin{array}{c}\text { Eliminação e } \\
\text { troca }\end{array}$ & $\begin{array}{l}\text { Constipação, ca- } \\
\text { racterizado por } \\
\text { abdômen disten- } \\
\text { dido, relaciona- } \\
\text { do a motilidade } \\
\text { gastrointestinal } \\
\text { diminuída. }\end{array}$ & $\begin{array}{c}\text { Espera-se } \\
\text { que paciente } \\
\text { evacue em até } \\
48 \mathrm{~h} ; \\
\text { Espera-se que } \\
\text { abdômen vol- } \\
\text { te ao estado } \\
\text { normal em até } \\
48 \mathrm{~h} .\end{array}$ & $\begin{array}{l}\text {-Incentivar o aumento da ingesta } \\
\text { hídrica; } \\
\qquad \text { M T N; } \\
\text {-Estimular a deambulação; } \\
\text { Às 9h } \\
\text {-Monitorar as eliminações intesti- } \\
\text { nais, frequência, consistência, cor } \\
\text { e formato e ruídos hidroaéreos; } \\
\text { ATENÇÃO } \\
\text {-Proporcionar privacidade. } \\
\text { M T N }\end{array}$ \\
\hline
\end{tabular}




\begin{tabular}{|c|c|c|c|c|}
\hline $\begin{array}{l}\text { Acesso venoso } \\
\text { periférico e feri- } \\
\text { da operatória }\end{array}$ & $\begin{array}{l}\text { Segurança/ Pro- } \\
\text { teção }\end{array}$ & $\begin{array}{c}\text { Risco de infec- } \\
\text { ção relacionado } \\
\text { à procedimentos } \\
\text { invasivos, evi- } \\
\text { denciado por } \\
\text { AVP e cirurgia }\end{array}$ & $\begin{array}{c}\text { Espera-se } \\
\text { que paciente } \\
\text { não apresente } \\
\text { infecções no } \\
\text { acesso venoso } \\
\text { periférico e na } \\
\text { ferida opera- } \\
\text { tória durante } \\
\text { período de in- } \\
\text { ternação. }\end{array}$ & $\begin{array}{l}\text { - Avaliar o estado nutricional } \\
\text { ATENÇÃO; } \\
\text { - Avaliar locais de inserção de ca- } \\
\text { teteres quanto a presença de hipe- } \\
\text { remia; Às 9h; } \\
\text {-Monitorar temperatura } \\
6 \mathrm{~h} 14 \mathrm{~h} 22 \mathrm{~h} ; \\
\text {-Utilizar técnicas assépticas apro- } \\
\text { priadas a cada curativo. } \\
\text { ATENÇAO }\end{array}$ \\
\hline $\begin{array}{l}\text { Algias no leito } \\
\text { da ferida opera- } \\
\text { tória }\end{array}$ & $\begin{array}{l}\text { Segurança/ Pro- } \\
\text { teção }\end{array}$ & $\begin{array}{c}\text { Dor por ferida } \\
\text { cirúrgica, carac- } \\
\text { terizado por re- } \\
\text { lato do paciente. }\end{array}$ & $\begin{array}{l}\text { Espera-se que } \\
\text { não tenha dor } \\
\text { após serem } \\
\text { aplicadas as } \\
\text { medidas de } \\
\text { controle sobre } \\
\text { esta durante } \\
\text { período de in- } \\
\text { ternação }\end{array}$ & $\begin{array}{l}\text {-Avaliar a dor quanto a localiza- } \\
\text { ção, frequência e duração } \\
\text { M T N; } \\
\text {-Avaliar a eficácia das medidas de } \\
\text { controle da dor } \\
\text { M T N; } \\
\text {-Avaliar ferida operatória quanto a } \\
\text { sinais de infecção. } \\
\text { Âs 9h; } \\
\text {-Monitorar a dor após administra- } \\
\text { ção de medicamentos. } \\
\text { ATENÇÃO }\end{array}$ \\
\hline $\begin{array}{l}\text { Dentição incom- } \\
\text { pleta }\end{array}$ & $\begin{array}{c}\text { Segurança/ Pro- } \\
\text { teção }\end{array}$ & $\begin{array}{c}\text { Dentição pre- } \\
\text { judicada ca- } \\
\text { racterizada por } \\
\text { ausência de } \\
\text { dentes molares } \\
\text { superiores e } \\
\text { manchas suges- } \\
\text { tivas de cárie, } \\
\text { relacionado a } \\
\text { higiene bucal } \\
\text { inadequada }\end{array}$ & $\begin{array}{c}\text { Espera-se } \\
\text { que paciente } \\
\text { compreenda a } \\
\text { importância da } \\
\text { manutenção da } \\
\text { higiene; em até } \\
\text { 24h; } \\
\text { Que apresente } \\
\text { higiene oral } \\
\text { satisfatória } \\
\text { durante todo } \\
\text { período de in- } \\
\text { ternação; } \\
\text { Que aceite au- } \\
\text { xílio durante a } \\
\text { escovação, en- } \\
\text { quanto neces- } \\
\text { sário, durante } \\
\text { todo período } \\
\text { de internação. }\end{array}$ & $\begin{array}{l}\text {-Orientar quanto à necessidade de } \\
\text { uma rotina diária de cuidado oral } \\
\text { M T N; } \\
\text {-Orientar quanto à importância de } \\
\text { solicitar auxílio durante a escova- } \\
\text { ção dos dentes, respeitando as li- } \\
\text { mitações de autocuidado. } \\
\text { M T N; } \\
\text {-Orientar o paciente quanto à ne- } \\
\text { cessidade de consultar um dentis- } \\
\text { ta. } \\
\text { ATENÇÃO }\end{array}$ \\
\hline
\end{tabular}




\begin{tabular}{|c|c|c|c|c|}
\hline Dislalia & $\begin{array}{l}\text { Percepção/ Cog- } \\
\text { nição }\end{array}$ & $\begin{array}{l}\text { Comunicação } \\
\text { verbal prejudi- } \\
\text { cada, caracteri- } \\
\text { zada pela difi- } \\
\text { culdade de falar, } \\
\text { relacionado ao } \\
\text { prejuízo neuro- } \\
\text { lógico causado } \\
\text { pelo trauma. }\end{array}$ & $\begin{array}{l}\text { Espera-se que } \\
\text { paciente obte- } \\
\text { nha melhora na } \\
\text { comunicação } \\
\text { em até } 8 \text { dias. }\end{array}$ & $\begin{array}{l}\text {-Proporcionar mecanismos de co- } \\
\text { municação quando apropriado. } \\
\qquad \text { M T N; } \\
\text {-Solicitar a assistência da família } \\
\text { na compreensão da fala do pacien- } \\
\text { te, conforme apropriado. } \\
\text { ATENÇÃO } \\
\text {-Encorajar o paciente a repetir a } \\
\text { palavra, se possível. } \\
\text { M T N; } \\
\text {-Oferecer lembretes/ sugestões } \\
\text { verbais. Permitir que o paciente } \\
\text { ouça frequentemente a linguagem } \\
\text { falada. } \\
\text { M T N }\end{array}$ \\
\hline $\begin{array}{l}\text { Medo de não } \\
\text { poder voltar a } \\
\text { trabalhar }\end{array}$ & $\begin{array}{c}\text { Enfrentamento/ } \\
\text { Tolerância ao } \\
\text { estresse }\end{array}$ & $\begin{array}{l}\text { Risco de senti- } \\
\text { mento de impo- } \\
\text { tência, relacio- } \\
\text { nado ao medo } \\
\text { de não poder } \\
\text { realizar ativida- } \\
\text { des anteriores. }\end{array}$ & $\begin{array}{l}\text { Espera-se que } \\
\text { expresse senti- } \\
\text { mento de con- } \\
\text { trole sobre sua } \\
\text { situação atual } \\
\text { e o desfecho } \\
\text { futuro durante } \\
\text { todo período } \\
\text { de internação; } \\
\text { Que possa } \\
\text { identificar as } \\
\text { áreas sobre as } \\
\text { quais pode ter } \\
\text { controle em até } \\
24 \mathrm{~h} ; \\
\text { Reconheça a } \\
\text { realidade de } \\
\text { que algumas } \\
\text { áreas estão } \\
\text { fora do seu } \\
\text { controle em até } \\
48 \mathrm{~h} .\end{array}$ & $\begin{array}{l}\text {-Observar sentimentos de tristeza, } \\
\text { irritabilidade, medo, ansiedade e } \\
\text { solidão, buscando subsídios para } \\
\text { compreender o estado emocio- } \\
\text { nal do paciente e possibilitar-lhe } \\
\text { apoio. } \\
\text { M T N } \\
\text {-Procurar proporcionar uma me- } \\
\text { lhor qualidade de vida fornecendo } \\
\text { condições de um sono tranquilo, } \\
\text { aliviando sua dor, controlando o } \\
\text { fluxo de visitas. } \\
\text { ATENÇÃO; } \\
\text {-Esclarecer paciente quanto a ci- } \\
\text { rurgia, diagnóstico, tratamento e } \\
\text { prognóstico. } \\
\text { ATENÇÃO; } \\
\text {-Usar medidas alternativas para } \\
\text { alívio, como: construção de ima- } \\
\text { gem e relaxamento. } \\
\text { Às 9h }\end{array}$ \\
\hline
\end{tabular}

(JOHN WILEY \& SONS, 2014; JOHNSON et al., 2007).

\section{CONCLUSÃO}

No decorrer do acompanhamento ao paciente podemos pontuar diversas progressões benéficas ao estado de saúde deste. Na primeira abordagem, tínhamos um quadro hemodinamicamente estável, porém com alterações neurológicas importantes na fala, movimentos e cognição. Ao término deste acompanhamento efetuado pelos discentes, evidenciamos a melhora considerável da dislalia, plegia e paresia, dentro de um período de 8 dias. 
De acordo com o plano de cuidados elaborados, foram dadas as devidas orientações, ao paciente e a acompanhante, quanto aos cuidados com higiene oral, alimentação, ingesta hídrica e encorajamento a dar continuidade ao tratamento de sua patologia, no CAPS.

Paciente ainda segue internado, com previsão de alta ainda não definida pela equipe, porém lhes foi informado como devem proceder após receber alta: Solicitar encaminhamento para serviço de fisioterapia, odontologia presente dentro da Rede de Atenção Primária à Saúde (APS), ofertado pelo Núcleo de Apoio a Saúde da Família (NASF), ao serviço psicossocial, presente na atenção primária, secundária e terciaria e mais especificamente o Centro de Atenção Psicossocial (CAPS).

Para se garantir a integralidade do cuidado é necessário um conjunto articulado e contínuo das ações e serviços preventivos e curativos, individuais e coletivos exigidos para cada caso em todos os níveis de complexidade do sistema e, através da SAE, garantimos a integralidade do cuidado.

\section{REFERÊNCIAS}

ANDRADE, A. F. DE et al. Mecanismos de lesão cerebral no traumatismo cranioencefálico. Revista da Associação Médica Brasileira, v. 55, n. 1, p. 75-81, 2009.

BRASIL, M. DA S. Diretrizes de atenção à reabilitação da pessoa com traumatismo cranioencefálico. Brasília: Secretaria de Atenção à Saúde. Departamento de Ações Programáticas Estratégicas, 2013.

COSTA, G. F. et al. Nursing Care for Patients Submitted to Coronary Transluminal Angioplasty: An Integrative Review. Cardiology and Angiology: An International Journal, v. 9, n. 1, p. 18-26, 9 jan. 2020.

CURVELO, E. et al. Communication Disorders Following Traumatic Brain Injury. In: Traumatic Brain Injury. [s.l.] InTech, 2014.

JOHN WILEY \& SONS, L. Diagnosticos de enfermagem NANDA 2015-2017. 10o ed. [s.1: s.n.].

JOHNSON, M. et al. LIGAÇÕES NANDA NIC-NOC. 3o ed. [s.1: s.n.].

RODRIGUES, T. P. et al. Bases fisiopatológicas do traumatismo crânio- encefálico e insuficiência hipofisária pós-traumática. Biosaúde, v. 10, n. 2, p. 129-146, 2008.

ROJAS-GALLEGO, I. C. et al. Fisiopatologia do dano cerebral e traumatismo encéfalo craniano. Ces Medicina, v. 32, n. 1, p. 31-40, 2018.

SARDINHA, D. M. et al. Nursing Care in Severe Traumatic Brain Injury. International Journal of Advanced Engineering Research and Science, v. 6, n. 12, p. 432-438, 2019.

SARDINHA, D. M. et al. Nursing Diagnoses in Heart Failure: Integrative Review. Cardiology and Angiology: An International Journal, p. 1-9, 8 jan. 2020.

SILVA, J. A. DA et al. Traumatismo Cranio Encefálico No Município De Fortaleza. Enferm. Foco, v. 8, n. 1, p. 22-26, 2017.

SILVA, P. F. et al. Caracterização das vítimas de traumatismo encefálico que evoluíram para morte encefálica. Rev Cuidarte, v. 6, n. 2, p. 1029-1040, 2018. 


\section{USO DA CANNABIS COMO PRÁTICA INTEGRATIVA E COMPLEMENTAR DE SAÚDE NO CONTROLE DA DOR ONCOLÓGICA: REVISÃO SISTEMÁTICA}

RENATA CARNEIRO CARVALHO Faculdade Noroeste (FAN), Goiânia-GO, Brasil.

LUCIMAR FRANCISCA DE ARAÚJO Faculdade Noroeste (FAN), Goiânia-GO, Brasil.

JAQUELINE CORREIA PONTES

Núcleo de Estudo da Helicobacter pylori (NEHP), Universidade Federal de Goiás - UFG, Goiânia, GO, Brasil.

JESSICA DA SILVA CAMPOS Programa de Pós-Graduação em Assistência e Avaliação em Saúde, Faculdade de Farmácia, Universidade Federal de Goiás - UFG

\section{JÚLIO CÉSAR COELHO DO} NASCIMENTO

Programa de Pós-Graduação em Assistência e Avaliação em Saúde, Faculdade de Farmácia, Universidade Federal de Goiás - UFG.

RESUMO: Os pacientes oncológicos podem apresentar dores em grau moderado ao severo, sendo os opioides preconizados como a abordagem de primeira linha para tratamento. Outros analgésicos prescritos incluem anti-inflamatórios não esteroides, acetaminofeno e antidepressivos, no entanto, Infelizmente o conjunto dessas intervenções não vem sendo suficiente para controlar a dor oncológica. Diante disso, o objetivo deste estudo foi levantar evidências acerca do uso da Cannabis como prática integrativa e complementar de saúde para o controle da dor oncológica. Trata-se de uma revisão sistemática da literatura, realizada em Fevereiro de 2020, sendo revisada em agosto deste mesmo ano. A busca foi processada nas bases de dados da Cochrane, PubMed e a Biblioteca Virtual em Saúde (BVS). Os estudos incluídos na revisão apresentaram forte qualidade metodológica e baixo risco de viés. Através da análise dos dados, observou-se que não houve evidências consistentes para afirmar eficácia do uso da Cannabis como medida alternativa no tratamento da dor oncológica. No entanto, percebeu-se um resultado favorável quanto à qualidade de vida dos pacientes oncológicos e também não foi identificado nenhum abuso ou uso indevido da Cannabis nos estudos. Portanto, conclui-se, que são necessários mais estudos sobre a farmacocinética da Cannabis ou Canabinóides e seu mecanismo de ação, para que sejam inseridos no arsenal terapêutico no tratamento da dor oncológica.

PALAVRAS-CHAVE: Dor, Cannabis, Dor do Câncer, Cuidados Paliativos, Canabinóides

ABSTRACT: Cancer patients can present moderate to severe pain, opioids being recommended as a first-line approach to treatment. Other analgesics prescribed include non-steroidal anti-inflammatory drugs, acetaminophen and antidepressants, however, unfortunately, the set of these techniques has not been sufficient to control cancer pain. Therefore, the objective of this study was evidence about the use of Cannabis as an integrative and complementary health practice for the control of cancer pain. This is a systematic review of the literature, carried out in February 2020, being reviewed in August of the same year. The search was processed in the databases of Cochrane, PubMed and the Virtual Health Library 
(VHL). The studies included in the independent review had strong methodological quality and low risk of bias. Through data analysis, it was observed that there was no consistent evidence for the efficacy of using Cannabis as an alternative measure in the treatment of cancer pain. However, a favorable result was improvised regarding the quality of life of cancer patients and no abuse or misuse of Cannabis was also identified in the studies. Therefore, it is concluded that there are more studies on the pharmacokinetics of Cannabis or Cannabinoids and their mechanism of action, so that they are inserted in the therapeutic arsenal in the treatment of cancer pain.

KEYWORDS: Pain, Cannabis, Cancer Pain, palliative care, cannabinoids

\section{INTRODUÇÃO}

O câncer se tornou a principal causa de mortes nas últimas décadas. No ano de 2018 ocorreram 18 milhões de casos de câncer com 9,6 milhões de óbitos no mundo. No mesmo ano, havia 18,1 milhões de pessoas diagnosticadas com essa doença e estima-se que em 2040 o quantitativo possa alcançar 29,4 milhões, ou seja, haverá um aumento de mais de $60 \%$ de novos casos no mundo (INTERNATIONAL AGENCY FOR RESEARCH ON CANCER, 2018).

De acordo com Couceiro et al. (2018), durante o enfrentamento do câncer os pacientes apresentam dor em grau moderado a severa. Mesmo sendo este um dos sintomas mais comuns relatados por pacientes oncológicos, infelizmente ele ainda continua sendo controlada de forma inadequada (NEUFELD; ELNAHAL; ALVAREZ, 2016).

Para tratamento da dor, os opioides são preconizados como a abordagem de primeira linha; além destes outros analgésicos são prescritos, dentre os quais sel incluem os anti-inflamatórios não esteróides, acetaminofeno e antidepressivos. Ainda que haja disponibilidade de opioides e outros analgésicos, o conjunto dessas intervenções tem se relevado insuficientes no tratamento da dor oncológica (National Comprehensive Cancer Network, 2018),

No ano de 2016, uma pesquisa realizada nos Estados Unidos, relacionou comumente ao aumento de prescrição de opioides um número quadriplicado de mortes nos últimos 15 anos. Um em cada 32 pacientes medicado com pelo menos 200 miligramas equivalente de morfina por dia, morreram ao realizarem tratamento pra dor crônica (DOWELL; HAEGERICH; CHOU, 2016).

Nesse contexto, o uso exacerbado de medicamentos opioides apresenta-se como uma crise de saúde pública crescente no mundo. A prescrição para tratamento em situação de dor crônica vem levantando discussões em relação ao potencial abuso dessa medicação. Com proporções epidêmicas, os opioides foram responsáveis por $76 \%$ das mortes em todo o mundo no ano de 2015 no mundo, como mostrou o relatório mundial sobre drogas apresentado no ano de 2018 pela United Nations Office On Drugs and crime (UNODC, 2018).

Com o progresso dos estudos, estão surgindo outros recursos terapêuticos a serem utilizados no tratamento da dor, sendo um destes recursos a Cannabis (VANDOLAH; BAUER; MAUCK, 2019). A Cannabis tem se mostrado muito promissora na medicina integrativa como uma opção de 
tratamento para pacientes com histórico clinico de dor, visto que, registro para essa finalidade de uso e outras recomendações terapêuticas foi evidenciado há milênios por diversas populações do mundo (VANDOLAH; BAUER; MAUCK, 2019).

Diante dos elevados índices de morbimortalidade, cada nova possibilidade terapêutica traz uma perspectiva de melhora na qualidade de vida desses pacientes (FIGUEIREDO et al, 2018).

No entanto, apesar da Cannabis ter seu uso medicinal datado de vários anos atrás, estudos capazes de determinar sua eficácia, bem como seu potencial efeito no tratamento da dor em pacientes oncológicos ainda são muito limitados na literatura científica (CARLINI; GARRETT; CARTER, 2017). Diante disso, o objetivo deste estudo foi levantar evidências cientificas acerca do uso da Cannabis como prática integrativa e complementar de saúde para o controle da dor oncológica.

\section{MATERIAIS E MÉTODOS}

Trata-se de uma revisão sistemática da literatura que consiste em responder uma pergunta específica de forma objetiva e imparcial. Para isso utiliza métodos sistemáticos e definidos a priori na identificação e seleção dos estudos, extração dos dados e análise dos resultados (MARTíNEZ-SILVEIRA, 2015).

De modo geral, esse método de pesquisa é composto por oito etapas, sendo: 1) Elaboração da pergunta de pesquisa; 2) Definição dos critérios de inclusão e exclusão; 3) seleção das bases de dados; 4) Seleção dos estudos; 5) Avaliação da qualidade metodológica dos estudos; 6) Extração dos dados; 7) Análise e síntese dos estudos relevantes; 8) Apresentação e interpretação dos resultados, incluindo ferramentas que possibilita avaliar nível de evidencias. (JBI, 2020)

Portanto, para direcionar o estudo inicialmente foi elaborada uma questão norteadora, estruturada de acordo com os acrônimos PICOS conforme demonstrado na tabela 1. Os acrônimos PICOS são os mais utilizados, pois sua estrutura permite que os estudos de revisão sistemática tenham foco direcionado na investigação, de forma mais eficaz. O acrônimo delimita o âmbito da pesquisa, bem como determina a população de estudo para quais as evidencas elucidadas possam ser aplicadas (.GUPTA et al., 2018).

Tabela 1: Elaboração da pergunta norteadora do estudo.

\begin{tabular}{|c|c|l|}
\hline Pergunta: & \multicolumn{2}{|l|}{$\begin{array}{l}\text { O uso da Cannabis como prática integrativa e complementar de saúde em pacientes oncológicos, } \\
\text { tem-se mostrado eficaz no controle da dor? }\end{array}$} \\
\hline P & População & Pacientes Oncológicos com dor desde moderada à severa \\
\hline I & Intervenção & $\begin{array}{l}\text { Uso da Cannabis ou Canabinóides como prática integrativa e complemen- } \\
\text { tar de saúde }\end{array}$ \\
\hline C & Controle & Não se aplica \\
\hline O & Desfecho & Controle da dor \\
\hline S & Desenho do Estudo & Ensaios Clínicos Randomizados \\
\hline
\end{tabular}

Fonte: Elaborados pelos autores. 


\subsection{Protocolo e Registro}

O presente artigo é um recorte de um projeto de pesquisa maior, intitulado "The use of cannabis as an alternative measure for the control of cancer pain: systematic review" cadastrado na plataforma International prospective register of systematic reviews (PROSPERO) sob $\mathrm{n}^{\mathrm{o}}$ do registro CRD42020172479. Esse protocolo de revisão visa estudar a eficácia clínica da Cannabis Sativa como alternativa de tratamento para o controle da dor oncológica, disponibilizado no link https://www.crd. york.ac.uk/prospero/display_record.php?ID=CRD42020172479

\section{2 Critérios de Elegibilidade}

Foram considerados elegíveis apenas os estudos disponíveis na íntegra feitos a partir de ensaios clínicos randomizados que avaliaram o uso da Cannabis na prática integrativa em pacientes com dor oncológica e que foram publicados nos últimos cinco canos. Não houve restrição de idioma.

\subsection{Fontes de informações e estratégias de busca}

A busca dos artigos foi realizada nas seguintes bases de dados eletrônicas: National Library of Medicine (PubMed), Biblioteca Virtual em Saúde (BVS) e Cochrane library. As referências alcançadas foram importadas para o software Mendeley ${ }^{\circledR}$ para checagem de duplicatas e posteriormente importadas para um aplicativo na Web para auxiliar na triagem dos estudos.

A estratégia de busca aplicada no PubMed foi a seguinte: ((patients AND oncological OR neoplasms) OR (patients AND "palliative care" OR "palliative treatment”) OR (tumors OR "palliative treatment" OR cancer) AND (cannabinoids OR cannabis OR cannabinol OR cannabidiol OR marijuana OR “cannabis sativa”) AND ("cancer pain” OR “oncological pain” OR "pain tumors" OR aches AND Therapeutics OR Treatment OR Treatments)). Essa estratégia foi adaptada para as outras bases de dados.

As pesquisas foram realizadas a partir de fevereiro de 2020, sendo a ultima busca realizada em agosto de 2020. Adicionalmente, as listas de referências bibliográficas dos estudos relevantes foram consultadas, com intuito de identificar aqueles potencialmente elegíveis.

\subsection{Seleção dos estudos e extração dos dados}

De acordo com os critérios de elegibilidade, as autoras (RCC e LFA) realizaram a seleção dos estudos de maneira independente a partir de duas fases (I e II): A fase I consistiu na leitura dos títulos e resumos e a fase II, leitura na íntegra dos artigos. As discordâncias foram resolvidas por consenso e quando não alcançado, um terceiro revisor (JCC) foi consultado para arbitrar.

A extração dos dados foi realizada por um único pesquisador (RCC), porém verificada por outro revisor (LFA). Foi elaborada uma planilha no Microsoft Excel, contendo as seguintes informa- 
ções: Titulo do Artigo, Autores, Ano de publicação, Objetivo do estudo, População/amostra, Relato e Intensidade da dor, Terapia aplicada e Principais conclusões. Os artigos que não apresentaram todas as informações ou que não estivesse totalmente claro tiveram os autores contatados pelo menos duas vezes.

\section{5 Avaliação da qualidade metodológica dos estudos incluídos}

A qualidade dos estudos foi avaliada por dois revisores independentes (RCC e LFA). Foi aplicada uma ferramenta de avaliação crítica recomendada pelo Instituto Joanna Briggs, especifica para ensaios clínicos randomizados. Essa ferramenta é constituída por treze questões, no qual foram respondidas com "Y" (yes), "N" (No - Não), "U” (Unclear - Pouco claro), "Not" (Not applicable- não aplicável) (TUFANARU et al., 2020). Todos os estudos foram avaliados qualitativamente e os resultados foram expressos pela frequência de cada classificação dos itens de avaliação.

\section{6 Síntese dos dados}

Para análise dos dados optou-se por uma síntese narrativa do tipo descritiva combinada com análise qualitativa das evidências encontradas. A sumarização dos achados foi apresentada na forma de quadros e tabelas para melhor visualização das evidências. O resultado da seleção dos estudos foi exposto por meio do fluxograma PRISMA (MOHER et al., 2009). 


\section{RESULTADOS}

\section{1 Seleção dos estudos}

Foi identificado um total de 137 referências, sendo excluídas três duplicadas, resultando em 134 estudos. Após serem submetidos à fase $\mathrm{I}$, os estudos foram reduzidos para um total de 11 artigos. Na fase II, destes 11, apenas 2 atenderam aos critérios de elegibilidade e incluídos na revisão (Figura 1).

Figura 1. Diagrama de Fluxo PRISMA que expõe com detalhes os resultados da seleção dos artigos.
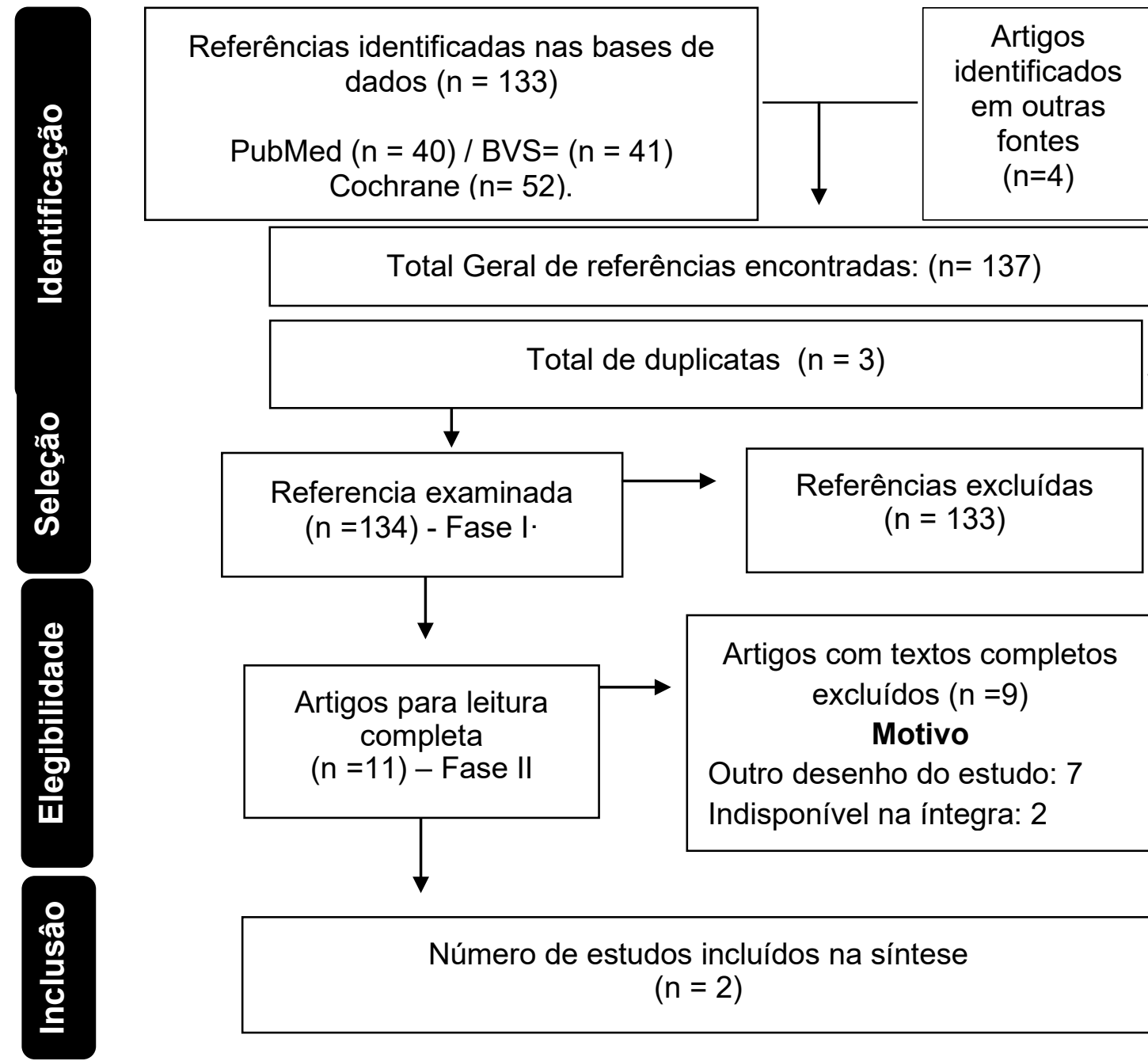

Total Geral de referências encontradas: $(n=137)$

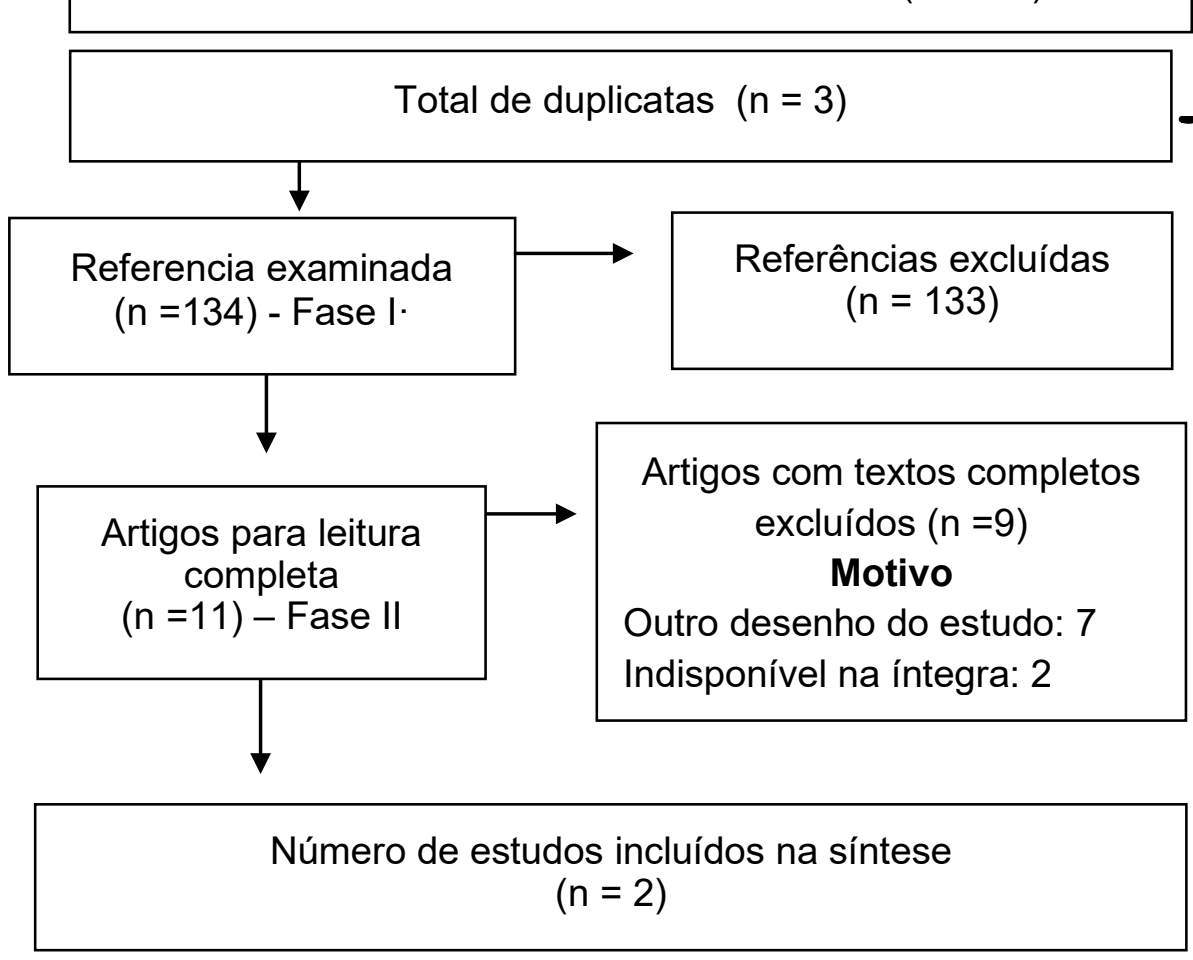

Fonte: (MOHER et al., 2009, adaptado)

\section{2 Característica dos estudos}

Os estudos apresentaram os mesmo critérios de elegibilidade, ambos era fase III. Na pesquisa de Lichtman et al. (2018), foram incluidos total de 779 pacientes, enquanto que no estudo de Fallon et al. (2017), foram elegiveis total de 399 pacientes com dor oncologica. Mais detalhes no quadro 1. 
Quadro 1. Caracterização dos estudos analisados acerca do uso da Cannabis como prática integrativa e complementar de saúde para o controle da dor oncológica, segundo, autor, ano, titulo dos estudos, objetivo do estudo, população, desenho do estudo e evidencias.

\begin{tabular}{|c|c|c|c|c|c|}
\hline $\begin{array}{l}\text { Autor/ } \\
\text { Ano }\end{array}$ & Titulo do estudo & $\begin{array}{c}\text { Objetivo do es- } \\
\text { tudo }\end{array}$ & $\begin{array}{c}\text { População/ } \\
\text { amostra }\end{array}$ & $\begin{array}{c}\text { Desenho do } \\
\text { estudo }\end{array}$ & Evidências \\
\hline $\begin{array}{l}\text { FALLON } \\
\text { et al., } \\
2017\end{array}$ & $\begin{array}{l}\text { Sativex oromucosal } \\
\text { spray as adjunctive } \\
\text { therapy in advanced } \\
\text { cancer patients with } \\
\text { chronic pain unalle- } \\
\text { viated by optimized } \\
\text { opioid therapy: two } \\
\text { double-blind, ran- } \\
\text { domized, placebo- } \\
\text {-controlled phase } 3 \\
\text { studies }\end{array}$ & $\begin{array}{c}\text { Avaliar a eficá- } \\
\text { cia analgésica do } \\
\text { Sativex }\left(\Delta^{9} \text {-te- }\right. \\
\text { trahidrocanabinol } \\
\text { canabidiol) em } \\
\text { pacientes com cân- } \\
\text { cer avançado com } \\
\text { dor crônica não } \\
\text { aliviada por terapia } \\
\text { opioide otimizada. }\end{array}$ & $\begin{array}{l}\text { Pacientes com } \\
\text { diagnóstico de } \\
\text { câncer em es- } \\
\text { tado terminal, } \\
\geq 18 \text { anos de } \\
\text { idade e com } \\
\text { histórico clíni- } \\
\text { co de dor não } \\
\text { aliviado pela } \\
\text { terapia com } \\
\text { opioide. }\end{array}$ & $\begin{array}{l}\text { Ensaios } \\
\text { clínicos ran- } \\
\text { domizados } \\
\text { controlado } \\
\text { por placebo }\end{array}$ & $\begin{array}{l}\text { O Sativex não } \\
\text { demonstrou } \\
\text { superioridade } \\
\text { em relação } \\
\text { ao placebo } \\
\text { na redução } \\
\text { dos escores } \\
\text { de escala } \\
\text { numérica que } \\
\text { avalia a dor. }\end{array}$ \\
\hline $\begin{array}{l}\text { LICHT- } \\
\text { MAN et } \\
\text { al., } 2018\end{array}$ & $\begin{array}{l}\text { Results of a Double- } \\
\text {-Blind, Randomized, } \\
\text { Placebo-Controlled } \\
\text { Study of Nabiximols } \\
\text { Oromucosal Spray } \\
\text { as an Adjunctive } \\
\text { Therapy in Advanced } \\
\text { Cancer Patients with } \\
\text { Chronic Uncontrolled } \\
\text { Pain. }\end{array}$ & $\begin{array}{c}\text { Avaliar Nabiximóis } \\
\text { extrato de Canna- } \\
\text { bis sativa contendo } \\
\text { dois Canabinóides } \\
\text { potencialmente te- } \\
\text { rapêuticos ( } \Delta 9 \text {-te- } \\
\text { trahidrocanabinol } \\
\text { e Canabidiol), } \\
\text { em pacientes com } \\
\text { câncer avançado } \\
\text { com dor crônica } \\
\text { não aliviada por } \\
\text { opioide otimizada } \\
\text { terapia. }\end{array}$ & $\begin{array}{l}\text { Pacientes que } \\
\text { tinham câncer } \\
\text { avançado, } \geq 18 \\
\text { anos de idade } \\
\text { e diagnóstico } \\
\text { clínico de dor } \\
\text { relacionada } \\
\text { ao câncer não } \\
\text { aliviado pela } \\
\text { terapia com } \\
\text { opioide. }\end{array}$ & $\begin{array}{l}\text { Ensaios } \\
\text { clínicos ran- } \\
\text { domizados } \\
\text { controlado } \\
\text { por placebo }\end{array}$ & $\begin{array}{l}\text { Os nabiximóis } \\
\text { podem ter utili- } \\
\text { dade em pacien- } \\
\text { tes com câncer } \\
\text { avançado que } \\
\text { recebem uma } \\
\text { dose menor de } \\
\text { opióides, como } \\
\text { em indivíduos } \\
\text { com intolerância } \\
\text { precoce à terapia } \\
\text { com opióides }\end{array}$ \\
\hline
\end{tabular}

Fonte: Elaborada pelos autores

\section{3 Resultados da avaliação da qualidade metodológica dos estudos}

A avaliação critica da qualidade metodológica dos estudos incluído na revisão evidenciou homogeneidade. Os artigos avaliados apresentaram baixo risco viés, pois todos os parâmetros avaliados foram unanimemente cumpridos como evidenciado logo abaixo (Quadro 2). 
Quadro 2. Qualidade metodológica dos estudos incluídos na revisão avaliados de acordo com a lista de verificação de avaliação crítica do Instituto Joanna Briggs para ensaios clínicos randomizados.

\begin{tabular}{|c|c|c|c|c|c|c|c|c|c|c|c|c|c|}
\hline \multirow[b]{2}{*}{ Autores } & \multicolumn{13}{|c|}{ Question } \\
\hline & 1 & 2 & 3 & 4 & 5 & 6 & 7 & 8 & 9 & 10 & 11 & 12 & 13 \\
\hline (FALLON et al., 2017) & $\mathbf{Y}$ & $\mathbf{Y}$ & $\mathbf{Y}$ & $\mathbf{Y}$ & $\mathbf{Y}$ & $\mathbf{Y}$ & $\mathbf{Y}$ & $\mathbf{Y}$ & $\mathbf{Y}$ & $\mathbf{Y}$ & $\mathbf{Y}$ & $\mathbf{Y}$ & $\mathbf{Y}$ \\
\hline $\begin{array}{l}\text { (LICHTMAN et al., } \\
\text { 2018) }\end{array}$ & $\mathbf{Y}$ & $\mathbf{Y}$ & $\mathbf{Y}$ & $\mathbf{Y}$ & $\mathbf{Y}$ & $\mathbf{Y}$ & $\mathbf{Y}$ & $\mathbf{Y}$ & $\mathbf{Y}$ & $\mathbf{Y}$ & $\mathbf{Y}$ & $\mathbf{Y}$ & $\mathbf{Y}$ \\
\hline$\%$ & 100 & 100 & 100 & 100 & 100 & 100 & 100 & 100 & 100 & 100 & 100 & 100 & 100 \\
\hline \multicolumn{14}{|c|}{$\mathbf{Y}=$ Yes $($ Sim $), \mathbf{N}=\mathbf{N O}($ Não), Not $=$ Not Applicable $($ Não aplicável $)$} \\
\hline Question 1 & \multicolumn{13}{|c|}{ Was true randomization used for assignment of participants to treatment groups? } \\
\hline Question 2 & \multicolumn{13}{|c|}{ Was allocation to treatment groups concealed? } \\
\hline Question 3 & \multicolumn{13}{|c|}{ Were treatment groups similar at the baseline? } \\
\hline Question 4 & \multicolumn{13}{|c|}{ Were participants blind to treatment assignment? } \\
\hline Question 5 & \multicolumn{13}{|c|}{ Were those delivering treatment blind to treatment assignment? } \\
\hline Question 6 & \multicolumn{13}{|c|}{ Were outcomes assessors blind to treatment assignment? } \\
\hline Question 7 & \multicolumn{13}{|c|}{ Were treatment groups treated identically other than the intervention of interest? } \\
\hline Question 8 & \multicolumn{13}{|c|}{$\begin{array}{l}\text { Was follow up complete and if not, were differences between groups in terms of their fol- } \\
\text { low up adequately described and analyzed? }\end{array}$} \\
\hline Question 9 & \multicolumn{13}{|c|}{ Were participants analyzed in the groups to which they were randomized? } \\
\hline Question 10 & \multicolumn{13}{|c|}{ Were outcomes measured in the same way for treatment groups? } \\
\hline Question 11 & \multicolumn{13}{|c|}{ Were outcomes measured in a reliable way? } \\
\hline Question 12 & \multicolumn{13}{|c|}{ Was appropriate statistical analysis used? } \\
\hline Question 13 & \multicolumn{13}{|c|}{$\begin{array}{l}\text { Was the trial design appropriate, and any deviations from the standard RCT design (individ- } \\
\text { ual randomization, parallel groups) accounted for in the conduct and analysis of the trial? }\end{array}$} \\
\hline
\end{tabular}

Fonte: (JBI Critical Appraisal Checklist For Randomized Controlled Trials, adaptado)

\section{4 Síntese dos resultados}

Os resultados apresentados no quadro 3 são referente a amostra final dos participantes que iniciaram o tratamento e permaneceram até o final. O motivo de diminuição da amostra em ambos os estudos foram descritos como: eventos adversos; retirada do consentimento e mortes. Todos os casos de mortes não tiveram relação com o uso dos medicamentos e sim com resultado da progressão da doença instalada. 
Quadro 3. Descrição dos estudos incluídos na revisão quanto à duração da amostra, terapia aplicada, critérios de elegibilidade, pacientes que se retiraram e completaram o estudo.

\begin{tabular}{|c|c|c|c|c|c|c|}
\hline & \multicolumn{4}{|c|}{ FALLON et al., 2017} & \multicolumn{2}{|c|}{ LICHTMAN et al., 2018} \\
\hline \multirow{2}{*}{$\begin{array}{c}\text { Duração da } \\
\text { amostra }\end{array}$} & \multicolumn{2}{|c|}{ Estudo 1} & \multicolumn{2}{|c|}{ Estudo 2} & & \\
\hline & \multicolumn{2}{|c|}{5 semanas } & \multicolumn{2}{|c|}{5 semanas } & \multicolumn{2}{|c|}{5 semanas } \\
\hline Terapia & Sativex & Placebo & Sativex & Placebo & Nabiximóis & Placebo \\
\hline $\begin{array}{l}\text { Preencheram os } \\
\text { critérios de ele- } \\
\text { gibilidade }\end{array}$ & 200 & 197 & 103 & 103 & 199 & 198 \\
\hline $\begin{array}{l}\text { Retiraram-se do } \\
\text { estudo }\end{array}$ & $64(32,0 \%)$ & $41(20,6 \%)$ & $\begin{array}{c}25 \\
(24,3 \%)\end{array}$ & $\begin{array}{c}15 \\
(14,6 \%)\end{array}$ & $\begin{array}{c}58 \\
(29,1 \%)\end{array}$ & $\begin{array}{c}48 \\
(24,2 \%)\end{array}$ \\
\hline \multirow[t]{2}{*}{$\begin{array}{c}\text { Completaram o } \\
\text { estudo }\end{array}$} & $136(68,0 \%)$ & $\begin{array}{c}158 \\
(79,4 \%) \\
\end{array}$ & 78 & 88 & 141 & 150 \\
\hline & \multicolumn{2}{|c|}{$\begin{array}{l}\text { Dos } 397 \text { pacientes que } \\
\text { preencherem os critérios } \\
\text { de elegibilidade, } 279 \text { fo- } \\
\text { ram recrutados na Europa } \\
\text { e } 120 \text { nos Estados Unidos. }\end{array}$} & \multicolumn{2}{|c|}{$\begin{array}{l}\text { Entre os } 406 \text { pacientes } \\
\text { inscritos no estudo, } \\
388 \text { foram recrutados } \\
\text { na Europa e } 18 \text { em } \\
\text { Taiwan. }\end{array}$} & \multicolumn{2}{|c|}{$\begin{array}{l}\text { Dos } 397 \text { pacientes rando- } \\
\text { mizados neste estudo, } 129 \\
(32,5 \%) \text { foram recrutados } \\
\text { nos EUA e } 268(67,5 \%) \text { no } \\
\text { restante do mundo. }\end{array}$} \\
\hline
\end{tabular}

Fonte: Elaborada pelos autores

Em relação à segurança e tolerabilidade, foram realizados testes laboratoriais clínicos e avaliações dos sinais vitais durante os períodos de triagem e tratamento. A dosagem média de pulverizações administradas por dia durante primeira semana e as quatro semanas restantes ao curso do tratamento estão apresentadas no quadro 4.

Quadro 4: Descrição dos medicamentos utilizados no controle da dor oncológica, de acordo com o número médio de pulverizações administradas conforme relatados nos estudos.

\begin{tabular}{|c|c|c|c|c|c|c|}
\hline \multirow{2}{*}{} & \multicolumn{3}{|c|}{ FALLON et al., 2017 } & \multicolumn{2}{c|}{ LICHTMAN et al., 2018} \\
\cline { 2 - 7 } & \multicolumn{2}{|c|}{ Estudo 1 } & \multicolumn{2}{c|}{ Estudo 2 } & \\
\cline { 2 - 7 } & Sativex & Placebo & Sativex & Placebo & Nabiximóis & Placebo \\
\hline Primeira semana & 3,7 & 3,7 & 3,6 & 6,3 & 3,7 & 3,8 \\
\hline Semanas seguintes & 6,3 & 7,4 & 6,5 & 6,5 & 7,3 & 6,4 \\
\hline
\end{tabular}

Fonte: Elaborada pelos autores

Ademais, foi observado que o perfil de segurança foi consistente em todos os pacientes com câncer em estágio avançado, não identificando problemas de segurança em relação à terapia proposta. Os eventos comuns em todos os grupos de tratamento estavam relacionados com progressão do câncer (Quadro 5). 
Quadro 5: Descrição dos eventos adversos emergentes do tratamento nos estudos incluídos na revisão.

\begin{tabular}{|c|c|c|c|c|c|c|}
\hline \multirow{2}{*}{} & \multicolumn{3}{|c|}{ FALLON et al., 2017 } & \multicolumn{2}{c|}{ LICHTMAN et al., 2018 } \\
\cline { 2 - 7 } & \multicolumn{2}{|c|}{ Estudo 1 } & \multicolumn{2}{c|}{ Estudo 2 } & \\
\hline \multirow{2}{*}{$\begin{array}{c}\text { Relataram evento ad- } \\
\text { verso }\end{array}$} & Sativex & Placebo & Sativex & Placebo & Nabiximóis & Placebo \\
\cline { 2 - 7 } & $68 \%$ & $64 \%$ & $72 \%$ & $62 \%$ & $72,4 \%$ & $65,7 \%$ \\
\hline
\end{tabular}

Fonte: Elaborada pelos autores

O estudo de Lichtnan et al (2018), relatou que 5\% dos pacientes oncológicos que foram submetidos à terapia com Nabiximóis apresentaram algum evento adverso emergentes do tratamento. Os pesquisadores acreditam que dentre os diversos eventos, a tontura e a náuseas podem estar potencialmente associado ao tratamento. A mesma porcentagem foi atribuída ao estudo de Fallon et al. (2017) e os eventos adversos foram semelhantes, acrescentando neste a "sonolência".

Nas buscas por melhores evidências, os estudos analisados nesta revisão foram classificados segundo o nível de evidência e grau de recomendação. Para obter essa informação, utilizou a classificação de Oxford Centre for Evidence-Based Medicine (PHILLIPs et al., 2005) (Quadro 6).

Quadro 6. Nível de evidência e grau de recomendação dos estudos de acordo com a classificação de Oxford Center for Evidence-Based Medicine.

\begin{tabular}{|c|c|c|}
\hline Estudos analisados & Grau de recomendação & Nível de evidência \\
\hline FALLON et al., 2017 & \multirow{2}{*}{ A } & $1 \mathrm{~B}$ \\
\cline { 1 - 1 } & LICHTMAN et al., 2018 & $1 \mathrm{~B}$ \\
\hline
\end{tabular}

Fonte: Elaborado pelos autores.

Os artigos incluídos na revisão apresentam forte nível de evidência e grau de recomendação "A" para resposta da questão de pesquisa levantada.

\section{DISCUSSÃO}

De acordo com Petzke et al., (2019), os estudos recentes apontaram que os medicamentos à base de Cannabis estão sendo aprovados para o controle da dor como parte de um tratamento multidisciplinar e de preferência como medicação adjuvante mesmo diante das incertezas e controvérsias sobre o papel e o uso apropriado desses medicamentos. O mesmo autor reforça citando um estudo realizado pela European Pain Federation (EFIC) em 2018, no qual concluiu que o uso de Cannabis medicinal no tratamento da dor crônica apresenta evidências insuficientes ao ponto de assegurar sua eficácia.

A pesquisa sobre a Cannabis evidenciou que o delta-9-tetrahidrocanabinol (THC) é uma substância que atua em múltiplos sistemas de receptores endógenos e pode aumentar o efeito analgésico 
dos opioides, porém, o único medicamento aprovado em 2007 no Canadá utilizado para o alívio de dores provenientes de doenças malignas, é uma mistura entre THC e canabidiol (CBD), chamado de Nabiximols, e com o nome comercial de sativex ${ }^{\circledR}$. Os estudos vêm tentando demonstrar a modulagem do CBD (que não possui implicações psicoativas e tem efeitos anti-inflamatórios e mediados pela inibição da síntese de prostaglandina - o efeito analgésico) (SOUZA et al., 2019).

Colaborando com Lichtman et al., (2018) os resultados finais apresentados de Fallon et al. (2017) para a terapia proposta de Nabiximóis adjuvantes (Sativex ${ }^{\circledR}$ ) não foi superior ao placebo no desfecho de eficácia para tratamento da dor oncológica, houve um resultado favorável em questionários de avalição da qualidade de vida relatados pelos pacientes e nenhuma evidência de abuso ou uso indevido foi identificada.

Em relação ao desfecho primário e secundário de todos os estudos multicêntricos envolvidos nesta pesquisa, não foi evidenciado melhora percentual nos escores de avaliação da dor. Porém as análises post hoc identificaram efeito estatisticamente favorável em ambos os estudos para Sativex® em pacientes dos EUA, fato que levantou a hipótese que fatores externos não selecionados a priori podem ter sido responsáveis para os diferentes resultados entre estes pacientes e os demais no resto do mundo LICHTMAN et al., (2018).

A prova de eficácia de uma intervenção terapêutica em oncologia consegue-se através de ensaios clínicos rigorosamente administrados. A triagem do desfecho além de basear-se na apreciação de eficácia terapêutica, é analisada a toxicidade relativa do tratamento experimental na sobrevivência esperada após progressão da doença e também na existência de fármacos alternativos já estudados com indicações idênticas (ROEVER, 2016).

\section{CONSIDERAÇÕES FINAIS}

Apesar da escassez de pesquisas de ensaio padronizado e controlado para avaliar os efeitos da Cannabis no controle da dor de pacientes oncológico, existem evidências aceitáveis para apoiar o seu uso como terapia adjuvante, pois os ensaios clínicos disponíveis na literatura demonstraram segurança em relação ao uso a curto e longo prazo, no entanto, ainda não há evidências consistentes capaz de fundamentar a eficácia da Cannabis com terapêutica alternativa no controle da dor.

Apesar de ter sido evidenciada melhora da qualidade de vida destes pacientes, os tratamentos clínicos disponíveis atualmente são insuficientes para evidenciar o objetivo primário, que se refere a eficácia da Cannabis no controle da dor oncológica, isso se deve em parte, à falta de conhecimento sobre a posologia para indicações específicas, bem como a escassez de novos medicamentos à base da Cannabis e seus Canabinóides no mercado farmacêutico.

Para que os Canabinóides sejam inseridos no arsenal terapêutico no tratamento da dor oncológicas são necessários amplos estudos sobre a farmacocinética dos Canabinóides e seu mecanismo de ação. 


\section{REFERÊNCIAS}

CARLINI, B. H.; GARRETT, S. B.; CARTER, G. T. Medicinal Cannabis: A Survey Among Health Care Providers in Washington State. The American journal of hospice \& palliative care, v. 34, n. 1, p. 85-91, Feb. 2017.

COUCEIRO, T. C. DE M. et al. Prevalence of neuropathic pain in patients with cancer. BrJP, v. 1, p. 231-235, 2018.

DOWELL, D.; HAEGERICH, T.M.; CHOU, R. CDC Guideline for Prescribing Opioids for Chronic Pain — United States, 2016. DOI: http://dx.doi.org/10.15585/mmwr.rr6501e1external icon. Acesso em 25 de 08.

FALLON, M. T. et al. Sativex oromucosal spray as adjunctive therapy in advanced cancer patients with chronic pain unalleviated by optimized opioid therapy: two double-blind, randomized, placebo-controlled phase 3 studies. British Journal of Pain, v. 11, n. 3, p. 119-133, 1 Aug. 2017.

FIGUEIREDO, J. F.; SOUZA, V.M.; COELHO, H.V.; SOUZA, R.S. Qualidade de Vida de Pacientes Oncológicos em Cuidados Paliativos. Revista de Enfermagem do Centro Oeste Mineiro, v.8, p. 2638, 2018. Doi: http://dx.doi.org/10.19175/recom.v8i0.2638.

GUPTA, S. et al. Systematic Review of the Literature : Best Practices. Academic Radiology, p. 1-10, 2018.

INTERNATIONALAGENCY FOR RESEARCH ON CANCER. IARC Global Cancer Observatory (GCO). 2020. Disponível em: https://www.iarc.fr/cards_page/iarc-research/. Acesso em: 25 de fev. 2020

JBI. JBI Manual for Evidence Synthesis. n. July, 2020.

LICHTMAN, A. H. et al. Results of a Double-Blind, Randomized, Placebo-Controlled Study of Nabiximols Oromucosal Spray as an Adjunctive Therapy in Advanced Cancer Patients with Chronic Uncontrolled Pain. J Pain Symptom Manage, v. 55, n. 2, p. 179- 188.e1, 1 Feb. 2018.

MARTHA SILVIA MARTÍNEZ-SILVEIRA (2015) https://www.arca.fiocruz.br/bitstream/icict/12432/1/martha_silveira_icict_dout_2015.pdf

MOHER, D. et al. Preferred reporting items for systematic reviews and meta-analyses: The PRISMA statement. PLoS Medicine, v. 6, n. 7, 2009.

NEUFELD, N. J.; ELNAHAL, S. M.; ALVAREZ, R. H. Cancer pain : a review of epidemiology, clinical quality and value impact. Future Oncology, 2016.

PETZKE, F. et al. Ein Positionspapier zu medizinischem Cannabis und cannabisbasierten Medikamenten in der Schmerzmedizin. TT - [Position paper on medical cannabis and cannabis-based medicines in pain medicine]. Schmerz, v. 33, n. 5, p. 449-465, 2019.

PHILLIPS B, BALL C, SACKETT D, BADENOCH D, Straus S, Haynes B, et al. Levels of Evidence and Grades of Recommendation. Oxford Centre for Evidence-Based Medicine-Centre for Evidence - Based Medicine Website - http://www.cebm.net/,2005

ROEVER, L. Endpoints in Clinical Trials: Advantages and Limitations. Evidence Based Medicine and Practice, v. 1, p. e111, 22 Feb. 2016.

SOUZA, A. F. DE et al. Cannabis sativa. Brazilian Journal of Natural Sciences, v. 2, n. 1 SE-Artigos de Revisão, 11 Jan. 2019.

TUFANARU C, MUNN Z, AROMATARIS E, CAMPBELL J, HOPP L. CHAPTER: Systematic reviews of effectiveness. In: Aromataris E, Munn Z (Editors). JBI Manual for Evidence Synthesis. JBI, 2020. Available from https://synthesismanual.jbi.global. 
THE NCCN CLINICAL PRACTICE GUIDELINES IN ONCOLOGY (NCCN Guidelines $®$ ) Adult Cancer Pain (Version 1.2018). 2018 National Comprehensive Cancer Network, Inc. Available at: NCCN.org. https://www.nccn.org/professionals/physician_gls/pdf/palliative_core.pdf. Acesso em: 25 de 08. 2020

VANDOLAH, H. J.; BAUER, B. A.; MAUCK, K. F. Clinicians' Guide to Cannabidiol and Hemp OilsMayo Clinic. ProceedingsElsevier Ltd, , 1 set. 2019. Disponível em: <https://pubmed.ncbi.nlm.nih.gov/31447137/>. Acesso em: 5 set. 2020.

WORLDDRUG REPORT2018 - ANALYSIS OF DRUG MARKETS A. Opioids - https://www.unodc.org/ wdr2018/prelaunch/WDR18_Booklet_3_Opioids.pdf. Acesso em 26 de fev. 2020 


\section{ATIVIDADE BIOLÓGICA E FARMACOLÓGICA DE Sonchus oleraceus}

IDELVÂNIA DOS ANJOS NONATO

Professora do Centro Universitário UNA Contagem/MG,

GABRIEL DOMINGOS CARVALHO

Professor do Instituto Federal do Espírito Santo Ifes Campus Piúma

CAMILO AMARO DE CARVALHO

Professor da Universidade Federal de Viçosa - UFV

Campus Viçosa

MARLENE ISABEL VARGAS VILORIA

Professora da Universidade Federal de Viçosa - UFV

Campus Viçosa

JOAQUIN HERNAN PATARROYO

SALCEDO

Professor da Universidade Federal de Viçosa - UFV

Campus Viçosa

RESUMO: O uso de produtos medicinais a base de plantas é uma prática comum na terapêutica, desde épocas remotas. Dessa forma, são essenciais os estudos sobre caracterização dos compostos químicos presentes nas plantas e suas atividades biológicas e farmacológicas. Neste capítulo será apresentado uma revisão sobre a atividade biológica e farmacológica de Sonchus oleraceus, que é uma planta com ação medicinal, muito presente na dieta de algumas pessoas, por ser rica em nutrientes. Ela é eficiente em tratamentos de doenças gastrointestinais, tem propriedades laxativas e auxilia nos processos inflamatórios, dores de cabeça, hepatopatias, além de ter ação antibacteriana e cicatrizante, devia as altas concentrações de antioxidantes.

PALAVRA-CHAVE: fitoterápicos, plantas medicinais, serralha.

ABSTRACT: The use of herbal medicinal products is a common practice in therapy since remote times. Thus, studies are essential for the characterization of chemical compounds present in plants and their biological and pharmacological activities. In this chapter a review will be presented with focus on the biological and pharmacological activity of Sonchus oleraceus, which is a plant with medicinal action, very present in the diet of some people, as it is rich in nutrients. This plant is effective in treating of gastrointestinal diseases, has laxative properties and helps in inflammatory processes, headaches, liver diseases, in addition to having antibacterial and healing action, due to the high concentrations of antioxidants.

KEYWORDS: herbal medicines, medicinal plants, sow thistle.

\section{INTRODUÇÃO}

Plantas medicinais são todas aquelas que possuem princípios ativos e são conhecidas pelo seu aspecto cultural entre as populações, apresen- 
tando ação terapêutica com capacidade de prevenir, aliviar ou curar enfermidades. O uso destas plantas no Brasil iniciou-se com as culturas indígena e africana e, nas últimas décadas, a fitoterapia tem sido utilizada na medicina sendo seus efeitos comprovados cientificamente. Há um interesse evidente em se conhecer as funções químicas e biológicas dos princípios ativos responsáveis pelas ações farmacológicas das plantas medicinais (Rodrigues e Carvalho, 2001).

Diante da necessidade de validar a eficácia de novos fármacos para o tratamento ou prevenção de diversas enfermidades, deve-se levar em conta a quantidade de produtos naturais disponíveis no Brasil, as quais possuem múltiplas funções biológicas (Simões et al., 2010).

O crescimento de pesquisas farmacológicas de compostos naturais oriundos de plantas vem se intensificando ao longo dos anos para a terapêutica de várias doenças, além de proporcionar parâmetros para os estudos teóricos da fisiologia e farmacologia (Nascimento, 2014). Um dos fatores mais importantes, é que o âmbito da pesquisa médico-farmacológica clínica sempre corresponde à aplicação em carácter experimental de determinados compostos, os quais se quer foram estudados em animais e em humanos, a fim de proteger os pacientes de alguns efeitos adversos quanto a ineficiência do medicamento usado. Essa conduta requer acompanhamento permanente e supervisionado (Souza et al., 2013).

As plantas medicinais ao serem processadas para obtenção de um medicamento têm-se como produto um medicamento fitoterápico. Ao longo da história, a utilização de produtos medicinais a base de plantas sempre foi uma prática comum na terapêutica popular, no entanto, o mercado de fitoterápicos decaiu com o desenvolvimento dos medicamentos sintéticos, principalmente em movimentos históricos como os pós-guerras. Contudo, nas últimas décadas tem ocorrido um crescimento marcante de tratamento alternativo aos medicamentos sintéticos (Carvalho et al., 2007).

O Ministério da Saúde tem sinalizado interesse na busca por tratamentos à base de plantas medicinais e medicamentos fitoterápicos para serem utilizados pelo Sistema Único de Saúde (SUS) (Brasil, 2014), demonstrando ser uma alternativa na redução dos gastos públicos com medicamentos, e aliado a uma comprovação científica da eficácia e do baixo custo operacional, além do acesso as plantas no Brasil serem de grande facilidade (Lorenzi e Matos, 2002).

Contudo, ressalta-se que planta medicinal não é um fitoterápico. Fitoterápico é um medicamento vegetal que passa pelos preceitos éticos ditados pela Organização Médica Mundial e pelos requisitos legais definidos pela legislação, que no caso Brasil é representado pela ANVISA - Agência Nacional de Vigilância Sanitária (Brasil, 2004).

A espécie, Sonchus oleraceus L. é frequente em várias regiões agrícolas e, muitas vezes, se encontra infestando lavouras, sendo conhecida popularmente como serralha. Na medicina humana é utilizada por meio de infusão ou decocção, em tratamento da dor estomacal, hepatite, infecções, inflamação, dores de cabeça, reumatismo e dor de dente, e de modo geral em afecções do trato gastrintestinal (Vilela, 2010).

Estudos confirmam a ação cicatrizante de $S$. oleraceus e sugerem que esse efeito está relacionado com sua alta concentração de flavonoides (antocianinas), estes metabólitos são conhecidos por 
atuar como mediadores da inflamação, estimulando a produção de citocinas inflamatórias e fator de necrose tumoral (Li et al., 2017). Na natureza, estes compostos, possuem a peculiaridade de dar cor a várias espécies vegetais (Nonato et al., 2014).

A caracterização fitoquímica dos compostos presentes do extrato de $S$. oleraceus, aliado a biocompatibilidade em estudos in vitro pode auxiliar na compreensão dos seus efeitos farmacológicos ou validar efeitos já existentes em pesquisas anteriores. Essas informações são importantes para nortear o estabelecimento de doses e indicações mais seguras e efetivas dessa espécie.

Sendo assim, esta revisão abordará a atividade biológica e farmacológica de S. oleraceus abordando as suas potencialidades terapêuticas.

\section{REVISÃO DE LITERATURA}

\subsection{Família Asteracea}

A família Asteraceae foi descrita há mais de 200 anos, no ano de 1972 foi denominada de Compositae, mais tarde em 1822 outros estudiosos, propôs uma nova terminologia como Asteracea como família, sendo distribuída em todo mundo exceto na Antártida (Katinas et al., 2007).

Segundo Anderberg et al. (2007) o primeiro registro fóssil de Asteraceae se mostrava solto, e era constituído de grãos de pólen. Funk et al. (2005) ressaltam que a família Asteraceae poderia ter surgido há 50 milhões de anos no sudeste da América do Sul, diversificando na mesma área de extensão, colonizando a partir de então o resto do mundo.

A família Asteracea compreende espécies de plantas cosmopolitas, sendo facilmente encontradas em regiões tropicais, subtropicais e de clima temperados com exceção da Antártida (Lorenzi e Matos, 2002). Elas podem ser encontradas em vegetações abertas como áreas de campos e savanas, e regiões de grandes altitudes (Anderberg et al., 2007).

Esta família pertence à classe das angiospermas, sendo considerada como uma das maiores famílias entre as plantas floríferas, possuindo aproximadamente entre 1600-1700 gêneros e 24.000 espécies corretamente identificadas. No entanto, há uma evidente existência de cerca de 23.00032.000 famílias (Pruski e Sancho, 2004). No Brasil, ocorrem cerca de 300 gêneros e 2000 espécies (Funk et al., 2009; Souza, 2013).

Uma variedade de espécies de uso popular em vários campos compõe a família Asteraceae, principalmente na alimentação como alface (Lactuca sativa L.) e chicória (Cichorium endívia L.), na obtenção de produtos, como girassol (óleo) (Helianthus annus L.), camomila (chá) (Matricaria recutita L.) e carqueja (Baccharis trimera Less.) muitas outras mostram além de potencial nutricional, servem de uma natural interação com insetos como as abelhas no fornecimento do pólen e néctar para apicultura (Vitto e Petenatti, 2009). 
Essas plantas fazem parte de um grupo monofilético representado em sua maioria por plantas herbáceas, subarbustos e arbustos (Judd et al., 2009). Suas flores são caracterizadas como sendo monocíclicas ou dicíclicas, actinomorfas ou zigomorfas, com pétalas conatas que formam coroa tubular (Roque e Bautista, 2008). São de aparência pequena, agregada e envolvidas brácteas involucrais, além de possuírem uma corola hipertrofiada, o que facilita a atração para o processo de polinização (Souza e Lorenzi, 2008).

As espécies da família Asteracea são caracterizadas por terem estruturas secretoras nas folhas, como tricomas, que secretam alguns óleos essenciais (Fonseca et al., 2006; Del-Vechio-Vieira et al., 2008). Outras produzem um decoto leitoso com atividade biológica em tratar afecções, além de serem fontes de produtos naturais com grande potencial farmacológico (Lorenzi e Matos, 2002; Lima et al., 2009).

\subsection{Gênero Sonchus}

Pertence à família Asteracea, os espécimes do gênero Sonchus são caracterizados por terem o sabor amargo e serem benéficas ao trato gastrointestinal, principalmente a mucosa estomacal. Diversas espécies compõem esse gênero e são conhecidas por possuírem características semelhantes entre si (Lima, 2009).

Essas espécies podem ser encontradas durante todo o ano, e são caracterizadas como glabras, lactescentes, eretas e seu caule se apresenta num tamanho entre 20 e $150 \mathrm{~cm}$ de altura. De forma geral, suas folhas têm formato variável e ao mesmo tempo simples, com rosulado basilares ou inseridas ao longo da haste da planta, podendo ser observadas amplexicaules, inteiras ou profundamente dentadas, pinatipartidas ou pinatilobadas. Inflorescência terminal racemosa e capítulos com flores hermafroditas de corola ligulada e amarela, também são conhecidas como ervas daninhas (Aranha et al., 1982; Jorge e Ferro, 1989).

O gênero Sonchus é composto em por aproximadamente 60 espécies e subespécies distribuídas mundialmente, dentre elas podendo-se destacar: S. acaulis, S. arvensis, S. asper, S. bornmuelleri, $S$. gandogeri, S. canariensis, S. ustulatus, S. frutcosus, S. hierrensis, S. brachyotus, S. oleraceus, S. palmensis, S. tenerrimus, S. maritimus, S. pinnatifidus, S. congestus (Figura 1) e S. oleraceus (Figura 2) (McCarren e Scott, 2013). 


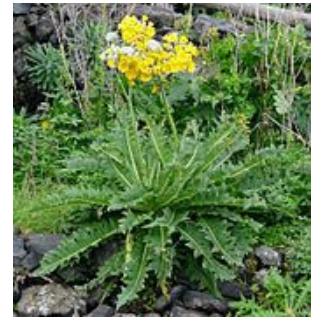

a) $S$. acaulis

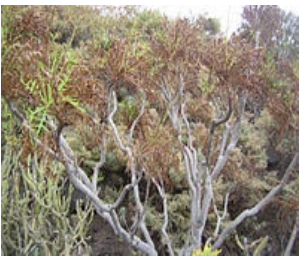

e) $S$. gandogeri

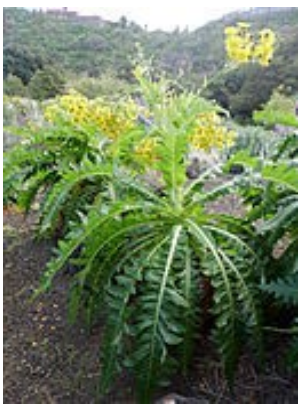

i) S. hierrensis

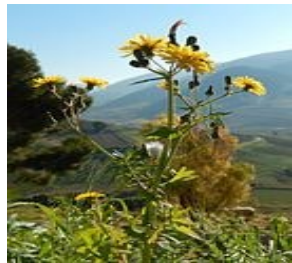

n) S. tenerrimus

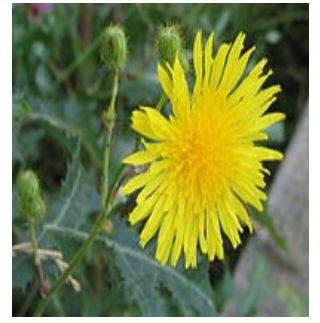

b) $S$. arvensis $L$

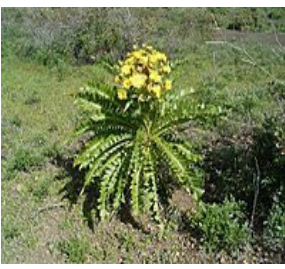

f) S. canariensis

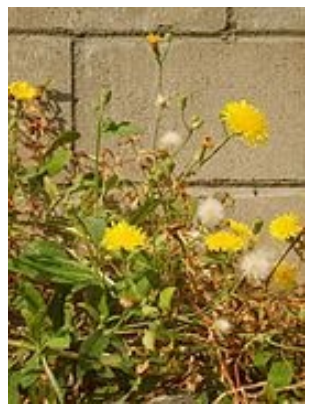

j) S. brachyotus

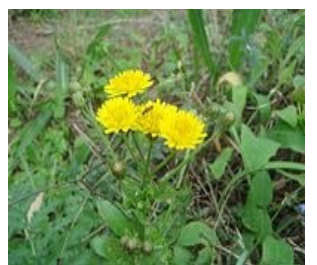

o) S. maritimus

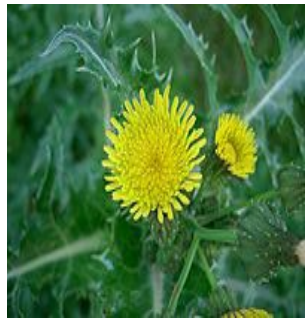

c) $S$. asper $L$

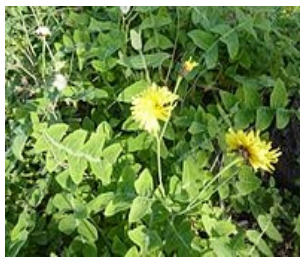

g) S. ustulatus

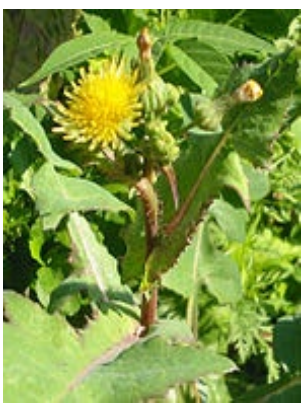

I) S. oleraceus

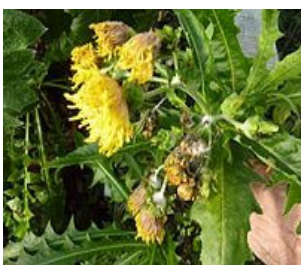

p) S. pinnatifidus

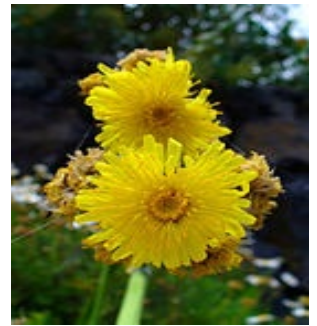

d) S. bommuelleri

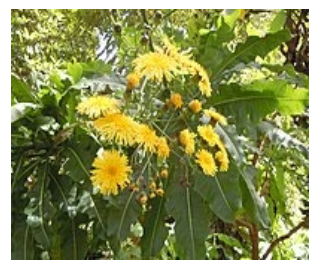

h) S. fruticosus

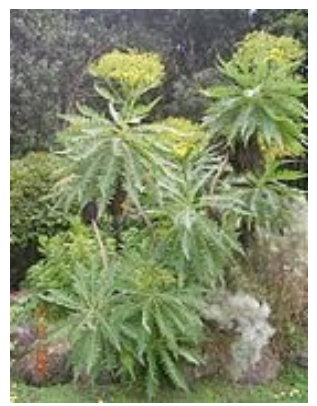

m) S. palmensis

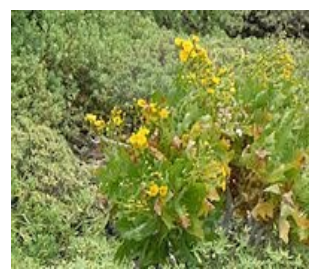

q) S. congestus

Figura 1. Espécies do gênero Sonchus: 1a. S. acaulis; 1b. S. arvensis; 1c. S. asper; 1d. S. bornmuelleri; 1e. S. gandogeri; 1f. S. canariensis; 1g. S. congestus; 1h. S. frutcosus; 1i. S. hierrensis; 1j. S. brachyotus; 11. S. oleraceus; 1m. S. palmensis; 1n. S. tenerrimus; 10. S. maritimus; 1p. S. pinnatifidus; 1q. S. ustulatus. Fonte: Wikimedia, 2019.

Jorge e Ferro (1989) descrevem as espécies mais comuns dentro do gênero (Tabela 1), caracterizando de forma morfológica e química a espécie $S$. oleraceus $L$ e ressaltam a importância de se caracterizar quimicamente o gênero como um todo. 
Tabela 1. Caracterização morfológica de três espécies do gênero Sonchus.

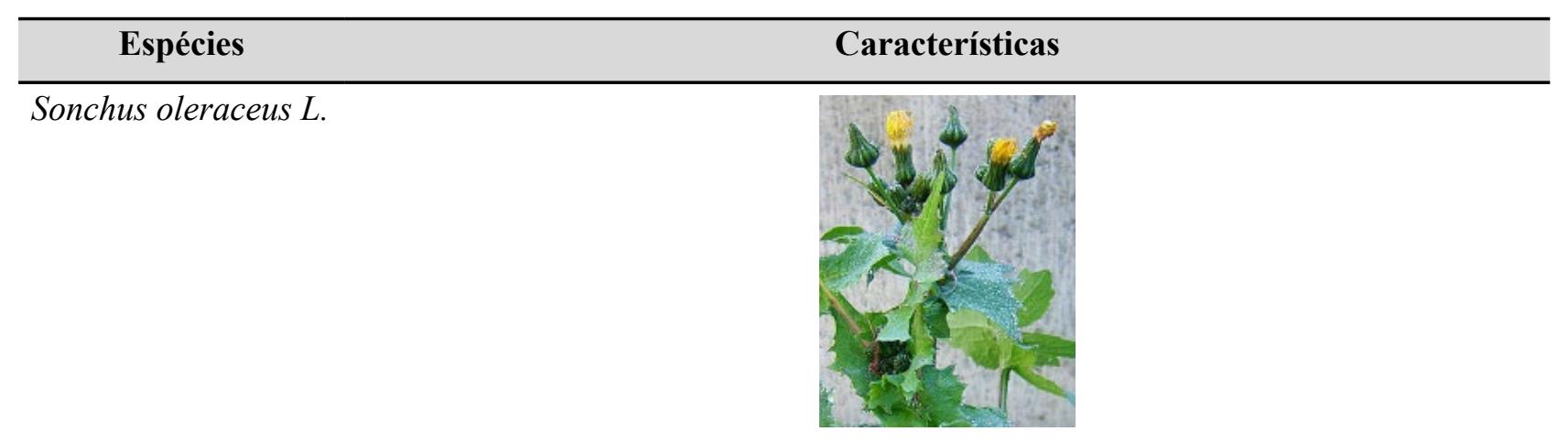

Erva glaba, lactescentes, eretas, folhas auriculadas e amplexicantes, flor amarelas.

Sonchus asper $L$.

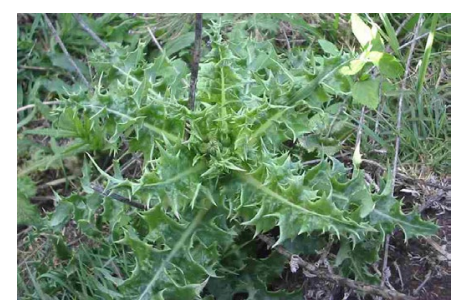

Semelhantes a $S$. oleraceus $L$ (serralha espinhenta). Apresenta sinônimos científicos: S. oleraceus L. var; asper L, S. spinosus lam, S. fallaz wall. Possui folhas com bordas desdentadas semelhantes a espinhos e caule sem ramificações.

Sonchus arvensis L.

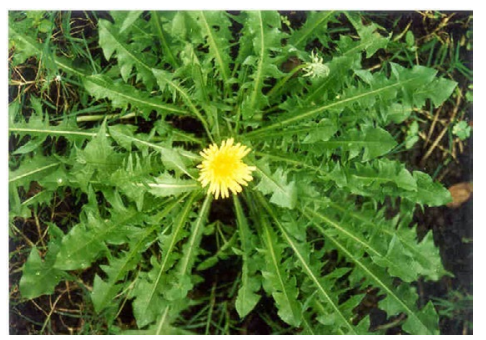

O caule apresenta glândulas em seu ápice; longos pendulados e as folha não são auriculadas

Fonte: Adaptado de Jorge e Ferro (1989).

\subsection{Sonchus oleraceus}

Sonchus oleraceus L. (Figura 2) faz parte do grupo das ervas cosmopolitas, sendo encontrada em todo mundo, com destaque ao Norte da África, Europa, Canadá, Ásia e Brasil, fazendo parte da alimentação de muitas pessoas (Hutchinson et al., 1984; Akepic, 2010). Está espécie também é conhecida na América do Norte, América do Sul, Ásia, África, Austrália e Nova Zelândia (Hyatt, 2006; McCarren e Scott, 2013). Também há registros dela no Pacífico Marítimo e em regiões ecogeográfica do interior-boreal do Alasca (Hultén, 1968; Akepic, 2010). 


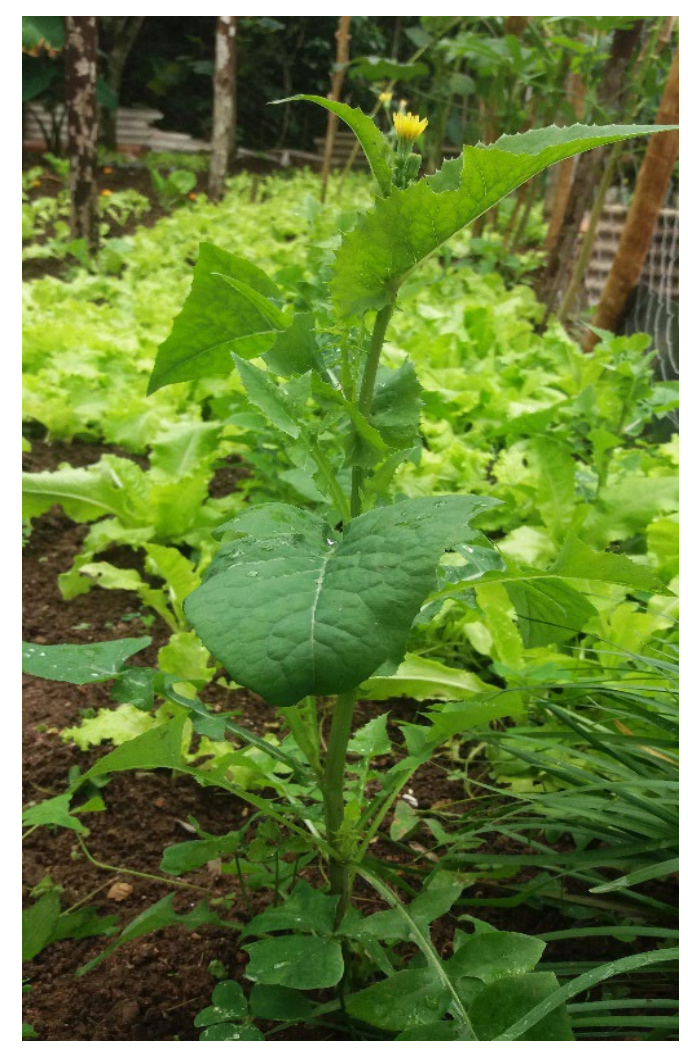

Figura 2. Sonchus oleraceus L., folha e flores características dessa espécie. Fonte: Arquivo pessoal dos autores, 2019.

Esta espécie pode ser encontrada no Brasil nas regiões Sul e Sudeste durante todo ano (Figura 3), com um pico maior de produção durante o inverno, principalmente nos campos agrícolas, hortas e lavouras de café (Gomaa e Abd Elgawad, 2012). Em outros países como Egito é observada rotineiramente em pomares (Abd Elgawad, 2014).

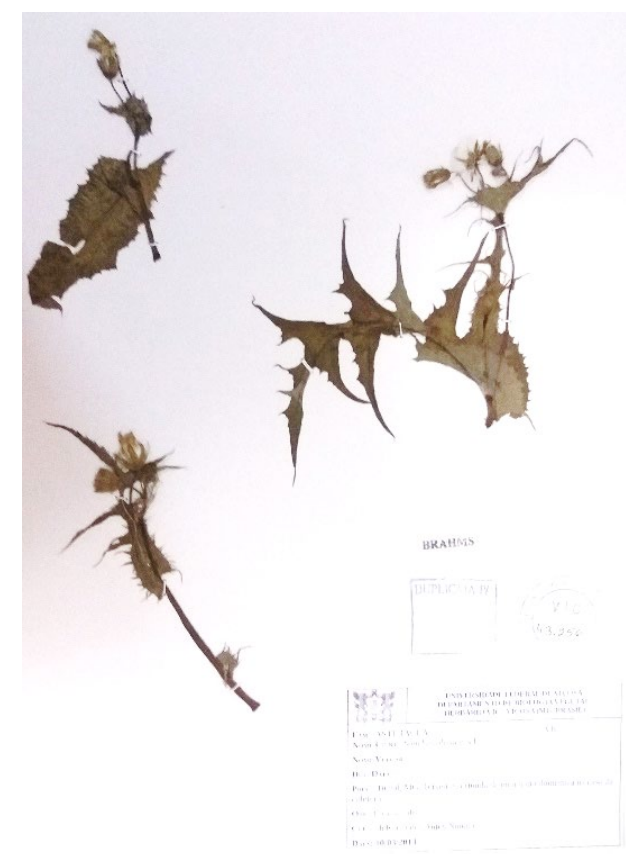

Figura 3. Exsicata de Sonchus oleraceus, depositada no Herbário do Departamento de Biologia Vegetal da Universidade Federal de Viçosa sob registro de $n^{\circ}$ 43.256. Fonte: Arquivo pessoal dos autores, 2019. 
Esta planta é conhecida também como serralha (Lima, 2009), chicória-brava, serralha-lisa, serralheira ou ciúmo. Suas sementes, assim como o pólen de suas flores, são dispersadas com o vento, podendo ficar no solo por até oito anos em média (Fraga e Tasende, 2003).

Estudos sugerem que o decoto leitoso das folhas é considerado antidiarreico e é usado como base tópica numa tentativa de curar doenças da pele (Lima et al., 2009).

No Brasil a S. oleraceus faz parte da dieta de grande parte da população rural, apresentando grande valor nutricional. Ela é fonte de proteínas, vitaminas, minerais e aminoácidos essenciais e auxilia a evitar o processo de desnutrição em populações carentes, uma vez que é barata e fácil de ser encontrada, além de proporcionar complemento econômico na renda dos produtores de vegetais e hortaliças, no âmbito da agricultura familiar (Vilela et al., 2009; Vilela et al., 2010; Juhaimi et al., 2017).

Além do benefício nutricional, esta planta é tradicionalmente utilizada na medicina popular brasileira, por meio de infusão ou decocção, nos tratamentos de afecções estomacais, hepatites, processos inflamatórios, dores de cabeça e dente, reumatismos, doenças cardiovasculares. Em alguns países também é usada como laxante, depurativa, facilitadora da função hepática e para melhorar absorção intestinal (Vendruscolo, 2005; Agra, 2007; Vilela, 2010). Também, tem sido utilizada como diurética, reversor de casos de anemia e em tratamentos para o controle do vitiligo (Fraga e Tasende, 2003; Lima et al., 2009).

Alguns estudos também demonstram que $S$. oleraceus possui atividade antibacteriana e contem elevadas quantidades de antioxidantes tais como compostos fenólicos e flavonóides, compostas estes investigados principalmente como forma de proteção contra o envelhecimento celular, reduzindo as concentrações de radicais livres (Zong et al., 2015). Outros possíves componentes como taraxasterol, apigenina 7-glicuronídeo e luteolina 7-glicosídeo, além de alcalóides também foram detectados nessa espécie (Vilela et al., 2009; Mawalagedera et al., 2016).

Também já foram descritas as atividades cicatrizantes em feridas tratadas com estratos de $S$. oleraceus (Nonato et al., 2015; Nonato et al., 2018). Prichoa (2011) identificou a ação cicatrizante por meio de estudos feitos com extrato hidroalcóolico de Sonchus oleraceus a 10\% na reparação de feridas em ratos. Semelhante a esse resultado, Nonato (2014) mostrou eficácia com extrato hidroalcóolico de $S$. oleraceus $L$. a 15\% também na reparação de feridas experimentais em ratos. Esse efeito sugere que ação antioxidante e cicatrizante pode estar relacionada com a alta concentração de flavonoides (antocianinas), estes metabólitos são conhecidos por atuarem como mediadores da inflamação, estimulando a produção de citocinas inflamatórias e fator de necrose tumoral (Lima et al., 2009; Wang et al., 2017).

Os flavonoides classificados como polifenóis, presentes em $S$. oleraceus são responsáveis pela pigmentação de uma vasta variedade de espécies de plantas. Além de contribuir diretamente no crescimento dessas plantas, atribuindo função de resistência a patógenos, predadores e algumas pragas, eles também atuam como antioxidantes e anticancerígenos, como relatado em alguns estudos (Ross, 2002; Alvarenga et al., 2011; Huyan et al., 2016). 
Estudos feitos com plantas do mediterrâneo como Sonchus oleraceus, Cichorium intybus, Papaver rhoeas, quando comparada a atividade antioxidante de $S$. oleraceus com a dessas plantas, $S$. oleraceus mostrou-se rica em polifenóis (Schaffer et al., 2005), além de apresentar um alto teor de vitamina A, por ter em sua composição óleos essenciais, resinas, esteroides, sais minerais e algumas classes de glicídios (Muradian, 2000).

Em estudos realizados com plantas de outras espécies mostram que substâncias tidas como puras, como os triterpenos pentacíclicos; por exemplo, ácido betulínico, lupeol, tem sua separação considerada muito difícil. Em contrapartida substâncias tidas como misturas ( $\alpha$-amirina, $\beta$-amirina), e os esteróides encontradas (estigmasterol e $\beta$-sitosterol) na forma livre e glicosilada, são mais fáceis de separarem (Silva; Oliveira e Silva, 2010) (Tabela 2).

Os principais compostos identificados em $S$. oleraceus foram alcalóides, cumarinas, saponinas, sendo o de maior destaque os flavonóides (Tabela 3 e 4) (Nonato, 2015; Nonato et al., 2018). O teor de polifenóis totais e flavonóides encontrados no extrato de S. oleraceus está descrito na Tabela 3 (Nonato, 2019). Os flavonóides atuam como oxidantes, estabilizando moléculas de oxigênio reativas, dimunuindo a produção de radicais livres (Martínez-Florez, 2002). Alguns deles sugerem possuir ação anti-inflamatória, estimulando a produção de citocinas e fator de necrose tumoral (Lima et al., 2009), atuando como cicatrizante, estimulando a proliferação de fibroblastos e a produção de colágeno (Ribeiro, 2012).

Plantas do gênero Sonchus são produtos de estudos científicos em busca de seus efeitos biológicos. Vilela et al., 2009, estudou o efeito ansiolítico de $S$. oleraceus em camundongos nas doses de 30, 100 e 300mg como dose crônica e $5 \mathrm{~g} / \mathrm{kg}$ como dose aguda mostrando positivas nesse efeito. Todavia, estudos sobre citotoxicidade foram testadas apenas em Artemia salina (Lima et al., 2009). Sendo necessário a realização de ensaios toxicológicos para se obter dados científicos referentes à segurança ou toxicidade das plantas desse gênero (Assemi, 2001). Estudos utilizando extratos de $S$. oleraceus não demonstraram intoxicação sistêmica em protocolos de doses agudas e crônicas em ratos da linhagem Wistars (Nonato, 2019). 
Tabela 2: Atividades biológicas dos compostos encontrados no extrato de $S$. oleraceus $L$.

\section{Padrão Atividade Composto}

Ácido Antioxidante, antimicrobiano, antibacteriano, neuroprotetor, antidiabético, cicatrizan-

te, anticolinesterase, inibe o crescimento de insetos, anti-inflamatório, antiasmático,

Arjúnico cardioprotetor, antifúngico, antiplaquetário, antitumoral (GHOSH et al., 2013)

Ácido Maslínico Anti HIV, inibe crescimento de insetos, antifúngico, antidiabético, gastroprotetor, reduz níveis de lipídeos no sangue e potencial agente antiproliferativo (CHENG et al., 2011; SÁNCHEZ-GONZÁLEZ et al., 2013; SÁNCHEZ-ÁVILA et al., 2009; MARTÍN et al., 2007)

Ácido Betulínico Antiviral, age contra o crescimento de parasitas, antibacteriano, anti-inflamatório, antitumoral, antioxidante e hepatoprotetor (PAI et al., 2011; MORE et al., 2012; DONFACK et al., 2010)

Lupeol Protetor a danos na membrana age contra o crescimento de protozoários, anti-inflamatório, antitumoral, cardioprotetor, antimicrobiano, hepatoprotetor, antiartritíco, antimutagenico, antioxidante e age contra malária, antidiabético, protetor da pele, nefroprotetor (MARTELANC et al., 2007; KUMARI et al., 2012; SALEEM et al., 2008); SIDDIQUE et al., 2011)

及-amirina Gastroprotetor, antipruriginoso, hepatoprotetor, anti-inflamatório e analgésico (MARTELANC et al., 2007; DIAS et. al., 2011; BACKHOUSE et al., 2008b)

a-amirina Gastroprotetor, antipruriginoso, hepatoprotetor, anti-inflamatório, antiartrite analgésico e antimicrobiano (MARTELANC et al., 2007; DIAS et. al., 2011; BACKHOUSE et al., 2008b; MORE et al., 2012)

Estigmasterol Antitumoral, redutor de colesterol e gastroprotetor (LEE et al., 2012; QUíLEZ et al., 2010)

Sitosterol Antitumoral, redutor de colesterol e gastroprotetor (LEE et al., 2012; CHAUHAN et al., 2013; QUíLEZ et al., 2010)

*HPLC-UV. (+) resultado positivo

Tabela 3. Compostos presentes no extrato hidroalcoólico de S. oleraceus

\begin{tabular}{cc}
\hline TESTES & Presença no extrato \\
\hline Tanino & + \\
Flavonóides & + \\
Saponina & + \\
Cumarina & + \\
Antracênicos & + \\
Alcalóides & + \\
Heterosídeos Cardiotônicos & + \\
\hline
\end{tabular}

Fonte: Nonato, 2015. 
Tabela 4. Teor de polifenóis e flavonóides totais em $\mathrm{mg} / \mathrm{g}$ de extrato de $S$. oleraceus $L$. e os respectivos desvios padrões.

\begin{tabular}{ccccc}
\hline Amostra & Polifenóis & Desvio Padrão & Flavonóides & Desvio Padrão \\
\hline S. oleraceus L. & 22,82 & 0,86 & 7,77 & 0,29 \\
\hline
\end{tabular}

Fonte: Nonato, 2019.

\section{CONSIDERAÇÕES}

O extrato de $S$. oleraceus L. é rico em compostos fenólicos: ácido arjúnico, ácido maslínico, ácido betulínico, lupeol, $\beta$-amirina, $\alpha$-amirina, estgmasterol e sitosterol, polifenóis e flavonóides.

Apesar das atividades biológicas de $S$. oleraceus. serem bem descritas, estudos sobre as atividades farmacológicas e toxicológicas ainda são pouco explorados. Com bases em resultados científicos na literatura existente sobre $S$. oleraceus L., as perspectivas sobre as formulações oriundas de uma base natural do extrato de S. oleraceus L., podem gerar um produtos farmacológicos capazes de promover qualidade de vida a pacientes com lesões ulcerativas persistentes, por ter ação antioxidante, cicatrização e atividade de proliferação de fibroblastos, e além disso mostra reações adversas sistêmicas inexistentes, visto que trata de um extrato natural de plantas isentas de toxicidade.

\section{REFERÊNCIAS}

Abd El-Gawad, A. M. Ecology and allelopathic control of Brassica tournefortii in reclaimed areas of the Nile Delta, Egypt. Turkish Journal of Botany, v.38, p.347-357, 2014.

Anderberg, A. A.; Baldwin, B. G.; Bayer, R. G.; Breitwieser, J.; Jeffrey, C.; Dillon, M. O.; Eldenas, P.; Funk, V.; Garcia-Jacas, N.; Hind, D. J. N.; Karis, P. O.; Lack, H. W.; Nesom, G.; Nordenstam, B.; Oberprieler, C. H.; Panero, J. L.; Puttock, C.; Robinson, H.; Stuessy, T. F.; Susanna, A.; Urtubey, E.; Vogt, R.; Ward, J.; Watson, L. E. Compositae. In: Kubitski, K. (Ed.). The families and genera of vascular plants. Berlin: Springer, p. 61-588, 2007.

Agra, M. F.; Baracho, G. S.; Nutrit, K.; Basílio, I. J. L. D.; Coelho, V. P. M. Medicinal and poisonous diversity of the flora of "Cariri Paraibano", Brazilian Journal of Ethnopharmacology, v.111, p.383-395, 2007.

Alvarenga, T. C.; Neto, H. F. S.; Ogassavara, F. O.; Arantes, F. C.; Marques, M. O.; Frigieri, M. C. Polifenoloxidase: uma enzima intrigante. Ciência \& Tecnologia: FATEC, v.3, n.1, p.83-93, 2011.

Akepic (Alaska Exotic Plant Information Clearinghouse). Data base. 2010. Disponível em: http://accs.uaa. alaska.edu/. Acessado em 15.01.2020.

Aranha, C.; Bacchi, O.; Leitão Filho, H. In: Plantas invasoras de culturas.. Instituto Campineiro de Ensino Agrícola, v.2, p.412-413. 1982.

Assemi, M. Herbs Affecting the Central Nervous System: Gingko, Kava, St. John's Wort, and Valerian. Clinical Obstetrics and Ginecology, v.44, n.4, p.824-835, 2001.

Brasil. Agência Nacional de Vigilância Sanitária (ANVISA) 2004. Resolução RE nº90, de 16 de março de 2004. Determina a publicação do "Guia para a Realização de Estudos de Toxicidade Pré-Clínica de Fitoterápicos". 
Carvalho, A. C. B.; Nunes, D. S. G.; Baratelli, T. G.; Shuqair, N. S. M. S. A. Q.; Netto, E. M. Aspectos da legislação no controle dos medicamentos fitoterápicos. T\&C Amazônia, ano V, n.11, p.26-32, 2007.

Fonseca, M. C. M.; Meira, R. M. S. A.; Casali, V. W. D. Anatomia dos órgãos vegetativos e histolocalização de compostos fenólicos e lipídicos em Porophyllum ruderale (Asteraceae). Planta Daninha., v.24, n.4, p.707$713,2006$.

Fraga, M. I.; Tasende, M. G. Mechanisms of resistanceto simazine in Sonchus oleraceus. Weed Research, v.43, n.5, p.333-340, 2003.

Funk, V. A.; Bayer, R. J.; Keeley, S.; Chan, R.; Watson, L.; Gemeinholzer, B.; Schilling, E.; Panero, J. L.; Baldwin, B. G.; Garciajacas, N.; Susanna, A.; Jansen, R. K. Everywhere but Antarctica: using a supertree to understand the diversity and distribution of the Compositae. Biologiske Skrinfter, v.55, p.343-374, 2005.

Funk, V. A.; Afonso, S.; Tod, A.; Bayer, R. (eds.). Systematics, Evolution and Biogeographics of Compositae. Vienna: IAPT. 965 p., 2009.

Gomaa, N. H.; Abdelgawad, H. R. Phytotoxic effects of Echinochloa colona (L.) Link. (Poaceae) extracts on the germination and seedling growth of weeds. Spanish Journal of Agricultural Research, v.10, n.2, p.492$501,2012$.

Hyatt, P. Sonchus oleraceus L. In: Flora of North America Editorial Committee, eds. 1993. Flora of North America North of Mexico. New York and Oxford., v.19, p.275, 2006.

Hultén, E. 1968. Flora of Alaska and Neighboring Territories. Stanford University Press, Stanford, CA. $1008 \mathrm{p}$.

Huyan, T.; Li, Q.; Wang, Y. L.; Li, J.; Zhang, Y. J.; Liu, Y. X.; Shahid, R. M.; Yang, H.; Li, H. Q. Anti-tumor effect of hot aqueous extracts from Sonchus oleraceus (L.) L. and Juniperus sabina LTwo traditional medicinal plants in China. Journal of Ethnopharmacology, v.185, p.289-299, 2016.

Hutchinson, I.; Colosi, J.; LEWIN, R. A. The Biology of Canadian Weeds. 63. Sonchus asper (L.) Hill and S. oleraceus L. Canadian Journal of Plant Science, v.64, n.3, p.731-744 p, 1984.

Jorge, L. I. F.; Ferro, V. O. Identificação de Sonchus oleraceus L. (Serralha) principais características estruturais e químicas. Revista Brasileira de Farmacognesia, v.2, p.3-4, 1998.

Judd, W. S.; Campell, C. S.; Kellog, E. A.; Stevens, P. F. Sistemática Vegetal: um enfoque filogenético. Artmed. Porto Alegre, p.1-612, 2009.

Juhaimi, F. A.; Ghafoor, K.; Ahmed, I. A. M.; Babiker, E. E.; Özcan, M. M. Comparative study of mineral and oxidative status of Sonchus oleraceus, Moringa oleifera and Moringa peregrina leaves. Journal of Food Measurement and Caracterization, v.11, n.4, p.1745-1751, 2017.

Li, Q.; Dong, D. D.; Huang, Q. P.; Li, J.; Du, Y. Y.; Li, B.; Li, H. Q.; Huyan, T. The anti-inflammatory effect of Sonchus oleraceus aqueous extract on lipopolysaccharide stimulated RAW 264.7 cells and mice. Pharmaceutical Biology., v.55, n.1, p.799-809, 2017.

Lima, J. M.; Silva, C. A.; Rosa, M. B.; Santos, J. B.; Oliveira, T. G.; Silva, M. B. Prospecção fitoquímica de Sonchus oleraceus e sua toxicidade sobre o microcrustáceo Artemia salina (phytochemical prospecting of Sonchus oleraceus and its toxicity to Artemia salina). Planta daninha, v.27, n.1, p.7-11, 2009.

Lorenzi, H.; Matos, F. J. A. Plantas medicinais no Brasil: nativas e exóticas. Nova Odessa: Instituto Plantarum, 2002. $544 \mathrm{p}$.

Souza, V. C..; Lorenzi, H. Botânica sistemática: guia ilustrado para identificação das famílias de Fanerógamas nativas e exóticas no Brasil, baseado em APG II. 2. ed. Nova Odessa: Instituto Plantarum, 2008. 703 p.

Katinas, L. D. G.; Gutiérrez, M. A.; Grossi, Y. J. V. C. Panorama de la familia Asteraceae (Compositae) en la República Argentina. Boletín de la Sociedad Argentina de Botánica, v.42, p.113-129, 2007. 
Martínez-Flórez, S.; González-Gallego, J.; Culebras, J. M.; Tuñón, J. Los flavonoides: propiedades y acciones antioxidantes. Nutricion Hospitalaria, v.17, n.6, p.271-278, 2002.

Mawalagedera, S. M.; Ou, Z. Q.; McDowell, A.; Gould, K. S. Effects of boiling and in vitro gastrointestinal digestion on the antioxidant activity of Sonchus oleraceus leaves. Food e Function., v.7, n.3, p.1515-1522, 2016.

McCarren, K. L.; Scott, J. Host range and potential distribution of Aceria thalgi (Acari: Eriophyidae): a biological control agent for Sonchus species. Australian Journal of Entomology, v. 52, p. 393-402, 2013.

Nonato, I. A. Efeito cicatrizante de formulações contendo o extrato de Sonchus oleraceus. Dissertação de Mestrado (Patologia Animal). Departamento de Veterinária - Univ, Federal de Viçosa. 47f. 2015.

Nonato, I. A. Toxicidade pré-clínica de formulações contendo extrato de Sonchus oleraceus L. em Rattus novergicus albinus linhagem wistar. Tese de Doutorado (Patologia Animal). Departamento de Veterinária Univ, Federal de Viçosa. 54f. 2019.

Nonato, I. A.; Carvalho, G. D.; Carvalho, C. A.; Vargas Viloria, M. I. Experimental wound healing under the effect of Sonchus oleraceus extract. In: IV Congresso Luso-Brasileiro de Patologia Experimental, UFPE, Recife, 2014.

Nonato, I. A.; Viloria, M. I. V.; Carvalho, G. D.; Valente, F. L.; Salcedo, J. H. P.; Rosa, M. B.; Caralho, C. A. Healing effects of formulations with extract of Sonchus oleraceus. Acta Scientiae Veterinariae, v.46, n.1, p.1-7, 2018.

Muradian, L. B. A.; Vanderlinde, D. W.; Sasaki, R. Provitamin A activity of raw and cooked Brazilian leaves. Ciência e Tecnologia de Alimentos., v.20, n.2, p. 151-153, 2000.

Nascimento, T. G. A.; Lucena, T. L.; Nóbrega, C. C. D.; Pereira, L. R. A. B.; Alustau, M. C. Importância da química de produtos naturais e sintéticos no desenvolvimento de novos medicamentos. In: I Congresso Nacional de Ciências e da Saúde - Avanços, interfaces e práticas interativas. Cajazeiras/PB. 2014.

Prichoa, F. C.; Roman, S. S.; Manfredidni, V. Tissue injuries of wistar rats treated with hydroalcoholic extract of Sonchus oleraceus L. Brazilian Journal of Pharmaceutical Sciences, v.47, n.3, p.605-613, 2011.

Ribeiro, A. F. C. Avaliação das atividades anti-inflamatórias, antiangiogênica e antitumoral de extratos da Arrabidaea chica (Humb. \& Ponpl) B. Verlot. Tese de Doutorado (Ciência Animal) Universidade Federal de Minas Gerais. 92 f. 2012.

Rodrigues, V. E. G.; Carvalho, D. A. Levantamento etnobotânico de plantas medicinais no domínio do cerrado na região do alto Rio Grande - Minas Gerais. Ciência Agrotécnica, v.25, n.1, p.102-123, 2001.

Roque, N.; Bautista, H. Asteracea. Caracterização e morfologia floral. Universidade Federal da Bahia. Editora UFBA, p.1-73, 2008.

Ross, J. A.; Kasum, C. M. Dietary Flavonoids: Bioavailability, metabolic effects, and safety. Annu. Revista de Nutrição, v.22, p.19-34, 2002.

Schaffer, S.; Schmitt-Schillig, S.; Müller, W. W. E.; Eckert, G. P. Antioxidant properties of mediterranean food plant extracts: geographical differences. Journal of Physiology and Pharmacology, v.56, p.115-124, 2005.

Silva, F.O.; Oliveira, I.R.O.; Silva, M.G.V. Constituintes químicos das folhas de Senna spectabilis (DC) Irwin \& Barneby var. excelsa (Schrad.) Irwin \& Barneby. Química Nova, v.33, n.9, p.1874-1876, 2010.

Simões, C. M. O.; Schenkel, E. P.; Gosmann, G.; Mello, J. C. P.; Mentz, L. A.; Petrovick. P. R. (Orgs). Farmacognosia: da planta ao medicamento. 6 ed. Porto Alegre: Editora da UFRGS: Florianópolis: Editora da UFSC, 2010. 1104p.

Souza, J. P.; Santos, V. L. P.; Franco, C. R. C.; Bortolozo, E. A. F. Q.; Farago, P. V.; Matzenbacher, N. I.; Budel, J. M. Baccharis rufescens Spreng. var. tenuifolia (DC.) Baker: contribuição ao estudo farmacognóstico. 
Revista Brasileira de Plantas Medicinais, v.15, n.4, p.566-574, 2013.

Vendruscolo, G. S.; Rates, S. M. K.; Mentz, L. A. Dados químicos e farmacológicos sobre as plantas utilizadas como medicinais pela comunidade do bairro Ponta Grossa, Porto Alegre, Rio Grande do Sul. Revista Brasileira de Farmacognesia, v. 15, n.4, p.361-372, 2005.

Vilela, F. C.; Padilha, M. M.; Silva, L. C.; Silva, G. A.; Paiva, A. G. Evaluation of the antinociceptive activity of extracts of Sonchus oleraceus L. in mice. Journal of Ethnopharmacology, v.124, p.306-310, 2009.

Vilela, F. C.; Bitencourt, A. D.; Cabral, L. D. M.; Franqui, L. S.; Soncini, R.; Paiva, A. G. Anti-inflammatory and antipyretic effects of Sonchus oleraceus in rats. Journal of Ethnopharmacology, v.1 27, p.737-741, 2010.

Vitto, L. A.; Petenatti, E. M. Asteráceas de importancia económica y ambiental. Primera parte. Sinopsis morfológica y taxonómica, importancia ecológica y plantas de interés industrial. Multequina, v.18, p.87-115, 2009.

Zong-Quan, O.; Rades, T.; McDowell, A. Anti-ageing effects of Sonchus oleraceus L. (pūhā) Leaf extracts on $\mathrm{H}_{2} \mathrm{O}_{2}$-induced cell senescence. Molecules, v.20, p.4548-4564, 2015.

Wang, N.; Yi, W. J.; Tan, L.; Zhang, J. H.; Xu, J.; Chen, Y.; Zhang, R. Apigenin attenuates streptozotocin-induced pancreatic $\beta$ cell damage by its protective effects on cellular antioxidant defense. In vitro Cellular \& Developmental Biology-Animal., v.1, n.10, p.210-221, 2017.

Wikimedia Commons Contributors. Sonchus. Wikimedia Commons, the free media repository. Disponível em: https://commons.wikimedia.org/wiki/Sonchus. Acessado em 15 de fevereiro de 2019. 


\section{A IMPORTÂNCIA DOS APLICATIVOS DE DISPOSITIVOS MÓVEIS PARA A ONCOLOGIA}

JEREMIAS BEZERRA SOBRINHO

Universidade Federal do Rio Grande do Norte

oportunidades para o desenvolvimento de ferramentas que promovam melhorias nas atividades do cotidiano.

Entre várias tecnologias diferentes que RESUMO: Foi estimado para o Brasil, no período 2020-2022, a ocorrência de 625 mil casos novos de câncer para cada ano. Com essa problemática em foco, o autor analisou o crescimento do mercado de aplicativos no Brasil e buscou dados qualitativos e quantitativos através de artigos e estudos publicados com o intuito de demonstrar a função que um aplicativo móvel pode ter na busca da cura da doença como também na elevação do bem-estar dos pacientes envolvidos.

Palavras-chave: Aplicativos; Câncer; Oncologia; Tratamento; Tecnologia.

\section{INTRODUÇÃO}

Devido a um relatório divulgado pelo Instituto Nacional de Câncer José Alencar Gomes da Silva (INCA), onde foi estimado para o Brasil, no período 2020-2022, a ocorrência de 625 mil casos novos de câncer para cada ano e em 2018, foram 17 milhões no mundo (Instituto Nacional de Câncer José Alencar Gomes da Silva, 2020). Foi percebido que alguma ação deve ser tomada para que o impacto dessa doença seja minimizado na sociedade brasileira. Para tentar resolver esse problema, foi pensando em utilizar a tecnologia como solução, pois ela é um grande horizonte de

existem no mundo, os aplicativos móveis foram escolhidos pois, após a transição da tecnologia analógica para a digital, houve uma maior disseminação da internet, em função do surgimento do $3 \mathrm{G}$ e do Wi-Fi, assim fazendo com que o celular torna-se uma tecnologia de rápido crescimento (Moura, 2009). Tudo isso permitiu que os aplicativos se espalhassem rapidamente por boa parte da sociedade, tanto que no Brasil, existem 226,3 milhões de celular ativos, segundo a Anatel (Agência Nacional de Telecomunicações), sendo que $64,2 \%$ da população no país está conectada a internet de algum modo e dentro dessa porcentagem, 92,1\% das famílias brasileiras usam o smartphone como principal meio de acesso à internet (Instituto Brasileiro de Geografia e Estatística, 2016).

Contudo, é necessário verificar se a união entre a tecnologia e a saúde é realmente positiva para a sociedade em geral e se o cenário econômico mundial e brasileiro está apto a aceitar essa fusão, assim visualizaremos se existe uma possibilidade prática do uso dos aplicativos móveis na melhoria do tratamento do câncer. 


\section{MATERIAL E MÉTODOS}

O presente trabalho explorou a função que um aplicativo pode ter no avanço tanto das atividades de busca da cura da doença como também na elevação do bem-estar dos pacientes envolvidos. Buscou-se dados qualitativos e quantitativos através de artigos e estudos publicados que evidenciam o uso da tecnologia de aplicativos em 2020, no Brasil e em outros países, dando destaque no setor da saúde. Desta feita, a pesquisa realizada justificada pelos dados apresentados, mostrou a importância de relacionar os 600 mil novos casos de câncer que surgirão durante os próximos anos com o crescimento do mercado de aplicativos no Brasil, gerando a possibilidade prática do uso dos aplicativos móveis na melhoria do tratamento do câncer.

\section{RESULTADOS E DISCUSSÃO}

A medicina e tecnologia são áreas do conhecimento que seguem de mãos dadas ao longo dos anos, gerando avanços importantes e imprescindíveis em prol da saúde humana (De Oliveira e Alencar, 2017). Além disso, temos que os aplicativos celulares otimizam os tratamentos e ajudam a compreender fatores determinantes que promovem a saúde do paciente e facilitam a busca pela cura da doença (Barra et al., 2017). Essas afirmações nunca estiveram tão fortes quanto hoje em dia, em virtude da popularização de aplicativos na área de saúde e é por isso que, esse assunto precisa ser discutido.

O ritmo acelerado da rotina que vigora atualmente vem fazendo com que as pessoas tenham menos tempo de cuidar de si mesmo, é tanto que a Organização Mundial de Saúde (OMS) relatou que um em cada dois brasileiros não se exercita o suficiente. Isso favorece o uso de apps de saúde como uma alternativa prática para tal (Organização Mundial de Saúde, 2018). Alguns deles servem como uma agenda que criam e organizam dietas personalizadas e indicam uma série de exercícios a serem realizados. Há também lembretes de medicações que um paciente deve tomar, facilitando assim, o seu tratamento. E ainda existem funções de gerar gráficos e tabelas exibindo resultados em comparação a semanas ou meses passados. Sendo uma boa forma do usuário conseguir monitorar a própria saúde.

Quando há a necessidade de um especialista, existem aplicativos que facilitam a comunicação entre pacientes e profissionais de saúde, tornando mais prático marcar uma consulta presencial e até mesmo virtual ou, simplesmente tirar alguma dúvida e esclarecer um "alarme falso".

Porém, a quantidade de aplicativos disponíveis é escassa. E conforme dados de um artigo de investigação, as doenças oncológicas ficam em segundo lugar no Brasil quando se trata de causa de morte. Isso é causado, dentre outros fatores, pela atuação incorreta dos profissionais, pela complexidade clínica e por problemas estruturais (Peiter et al., 2016). 
É nesse contexto que se percebe a necessidade de criar um aplicativo para smartphones que tenha como objetivo a gestão do cuidado do paciente com alguma doença oncológica, de modo a ajudá-lo de todas as formas cabíveis.

O aplicativo pode possuir várias funções que irá facilitar a vida dos doentes. Podemos citar a comunicação entre o paciente e o profissional de saúde, onde o usuário poderá marcar uma consulta online ou até mesmo ser monitorado em casa, aumentando assim seu conforto e diminuindo a quantidade de pessoas em filas de hospitais. O próprio paciente terá condições de acompanhar a sua saúde através de tabelas geradas diariamente, facilitando a percepção de quando ele precisará ver o seu médico presencialmente para uma consulta mais detalhada.

Ele também poderá ser utilizado como um guia para pessoas que acabaram de descobrir que apresentam algum tipo de câncer. Ele mostrará o que deve ser feito e o método mais eficaz para tomar as medicações de acordo com o perfil de doença do enfermo. O médico responsável conseguirá acompanhar o andamento do tratamento, pois, receberá no seu aplicativo, um relatório notificando se o indivíduo seguiu as etapas recomendadas por ele e pela aplicação corretamente, ou seja, um feedback.

Dentro do mundo das enfermidades estudadas e combatidas, temos o câncer, que se aplica a um universo de 100 doenças. E o avanço tecnológico não deixou de fora o domínio oncológico. Diariamente vemos novos procedimentos, estudos, drogas e técnicas inovadoras que contribuem com o diagnóstico precoce, o combate mais eficaz, o processo de tratamento menos conturbado e, consequentemente, a cura mais frequente, promovendo uma melhor qualidade de vida para os pacientes da oncologia.

Um aplicativo, corretamente direcionado, que permita ao paciente mais esclarecimento, controle e auxílio no tratamento, contribui vigorosamente para o seu fortalecimento psicológico, fator determinante para o caminho até a cura.

Pode ser um instrumento da técnica cognitiva-comportamental, levando o paciente a aprender novas atitudes, reordenar pensamentos diante dos percalços enfrentados, realizar atividades diversas e, ainda, promover interações interpessoais, com o intuito de compartilhar experiências, controlando sintomas como ansiedade, depressão, estresse, dor, medo etc. Essa técnica traz ao paciente a capacidade de aprender ou reaprender comportamentos mais saudáveis, aumentando seu bem-estar e qualidade de vida durante o processo de tratamento.

O método cognitivo-comportamental é aplicado de várias formas, desde uma orientação profissional, seja por médicos, psicólogos, enfermeiros, e terapeutas ocupacionais, seja por intervenções autônomas, como um aplicativo de celular que traz consigo a programação das atividades nos mais diversos caracteres, desde algo lúdico até o contato com outros profissionais e a aproximação social com o meio.

Outro benefício da tecnologia aliada à saúde é para os profissionais do setor, que verificam uma melhoria no atendimento e tratamento dos pacientes, através de instrumentos que auxiliam no desenvolvimento dessas atividades e desempenham o controle do tratamento e evolução dos pacientes submetidos a seus cuidados diários. 
Nos permitimos ligar, todos esses fatores, a um progresso na psicoterapia dos pacientes que sofrem de câncer, haja vista, sua contribuição na recuperação, manutenção e fortalecimento não só da parte orgânica do paciente, mas também da parte psíquica, importante em qualquer manifestação debilitante.

A automação, nesse sentido de uso é, portanto, um meio de aproximação das pessoas e promoção do bem-estar. Evidenciando a multidisciplinaridade do uso tecnológico e de suas inovações no auxílio aos profissionais de saúde atuantes e, primordialmente, na contribuição para o progresso do paciente oncológico.

Agora que está evidente a importância dos aplicativos móveis na oncologia, é necessário analisar o cenário econômico mundial e o brasileiro. Podemos conferir uma rápida aceitação de apps pelo mundo que ocasionou um surgimento de um novo mercado voltado para aplicativos móveis. Segundo uma pesquisa feita pelo App Annie, revelou que no quarto trimestre de 2017 houve um recorde de downloads de apps, 19 bilhões da Google Play Store e 8 bilhões da App Store. Ainda no mesmo ano, o gasto com aplicativos pagos chegou a US\$ 17 bilhões, crescendo 20\% em relação ao ano anterior. Já em 2018, o relatório consta que o mercado de aplicativos para celular movimentou US\$ 82,2 bilhões, em comparação, 2021 deve movimentar US\$ 139 bilhões (App Annie Market Forecast 2016-2021, 2017).

Agora, em relação ao funcionamento do mercado do ponto de vista dos consumidores, a BigData Corp. criou dois gráficos onde alguns sites foram analisados. Aqui temos uma comparação entre a preferência dos brasileiros sobre apps pagos ou gratuitos (os dois gráficos foram adaptados pelo autor):

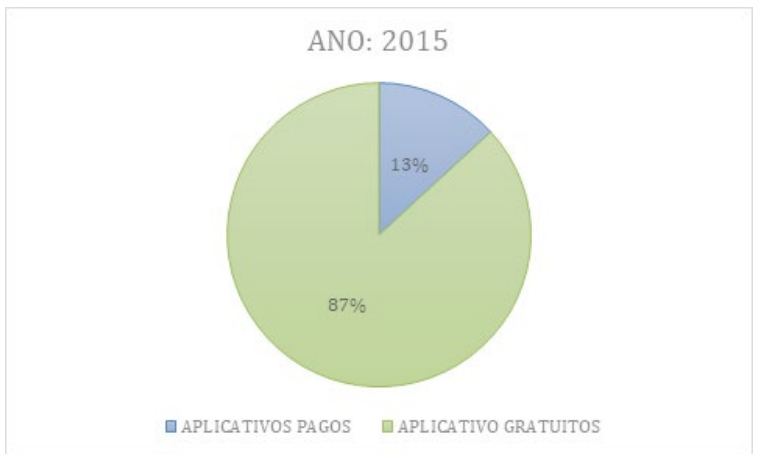

Figura 1. Preferência dos brasileiros entre aplicativos pagos ou gratuitos em 2015.

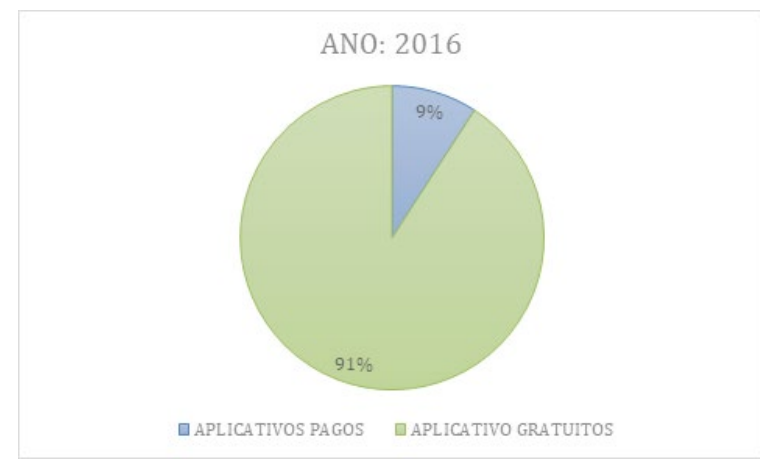

Figura 2. Preferência dos brasileiros entre aplicativos pagos ou gratuitos em 2016. 
Com isso, é perceptível que pode ser mais vantajoso para um produtor de aplicativos lucrar de outras formas com a sua criação do que colocando ele pago, além de que uma boa parte da sociedade não está disposta a pagar grandes valores em um aplicativo (Da Silva e Santos, 2014). Um exemplo de como lucrar com um aplicativo gratuito é com o uso de propagandas que gerem uma certa renda depois de assistida ou acessada. É necessário lembrar, que devido as mudanças econômicas que ocorrem constantemente, é preciso sempre comparar os pagos com os gratuitos e assim conseguir se atualizar em relação ao futuro da tecnologia no país.

Em relação ao que o país pode esperar da tecnologia nos próximos anos, o diretor internacional do Google Play, Mark Bennett em 2016, relatou que o Brasil possui um mercado muito grande se o compararmos proporcionalmente com o resto do mundo e que está sendo impulsionado um investimento para crescer cada vez mais no país, já que ele é um fenômeno em produção, monetização e geração de produtos.

Bennett realmente estava correto, pois nesse país, em janeiro de 2017, foi constado 312 mil empregos em relação à economia de aplicativos (Mandel e Long, 2017). O gráfico a seguir dividi o total de empregos gerados nesse período por estado:

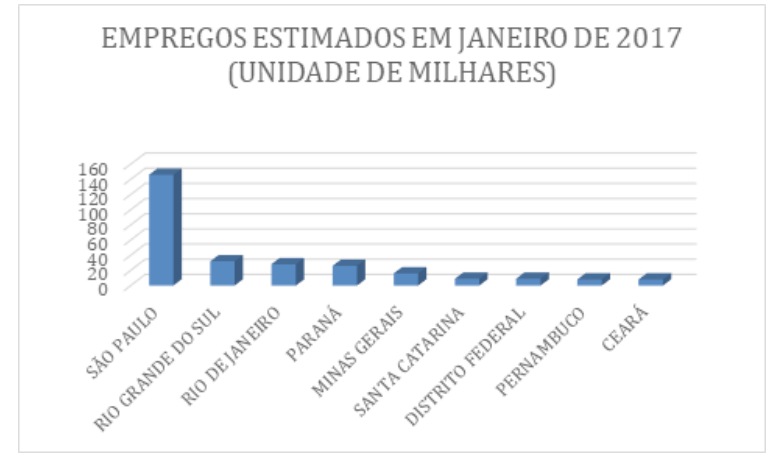

Figura 3. Empregos na economia de aplicativos em janeiro de 2017 por estado.

Com todas as informações referidas, podemos analisar o mercado de aplicativos médicos e de como eles são capazes de afetar o país. A produção nacional de apps na área da saúde é tanto endógena (onde uma empresa brasileira consegue fazer sucesso pelo mundo inteiro), quanto exógena (na qual um estabelecimento estrangeiro se consolida na sociedade do país), em que há uma competição perfeita, ou seja, existem várias firmas trabalhando com o mesmo produto, nesse caso, com apps.

Analisando o primeiro caso, a porção endógena, podemos mencionar a empresa "whizHealth", primeira a ser totalmente digital em saúde na América Latina, gerando 8 bilhões de reais por ano além de ter acesso a mais de 1500 instituições hospitalares e mais de 250 profissionais.

Acerca da exógena temos o grupo UnitedHealthcare. Ela é responsável por oferecer seus serviços em mais de 130 países. No seu site, a organização liberou alguns dados referentes aos benefícios que tem proporcionado à sociedade brasileira, como: 
1) 178 mil casos de bem-estar concluídos com sucesso; 2) 195 vagas esperando para serem preenchidas; 3) Mais de 80 milhões de contas médicas analisadas; 4) 1,1 milhões de aconselhamentos de saúde por telefone; 5) Mais de 470 mil chamadas para pacientes com doenças crônicas.

No Brasil, um dos seus serviços é a corporação Optum, uma empresa de serviços de saúde e inovação que afirma em sua página "Nós estamos ajudando a fazer com que o sistema de saúde funcione melhor para todos.". A Optum foi responsável pela criação do aplicativo "myLivewell”, onde é possível contatar profissionais que oferecem apoio individualizado ou até mesmo informações e recursos valiosos relativos à área da saúde.

Com todos esses fatos relatados, podemos afirmar que o mercado de aplicativos móveis no mundo e no Brasil movimenta bastante dinheiro todos os anos e que a combinação da tecnologia com a área da saúde é uma união positiva para a sociedade.

\section{CONCLUSÃO}

Ao longo dos anos, os smartphones passaram por um grande processo de evolução, fazendo com que suas atribuições, sobretudo os aplicativos, transformassem os hábitos de vida das pessoas

Graças à sua popularidade e aceitação pelo mundo, novos desenvolvedores têm surgido, provocando o crescimento da sua produção. Dessa forma, uma nova Revolução Industrial está ocorrendo, o que afeta todos os setores da sociedade. Devido a isso, o antigo modelo de saúde é totalmente diferente do atual.

O avanço, embora seja substancialmente positivo, traz consigo novos problemas como a falta de tempo para acompanhar as necessidades e tarefas diárias a serem efetuadas, o que prejudica a atenção e cuidado necessários ao bem-estar e à saúde, contribuindo para o surgimento ou agravo de doenças.

Infelizmente, nem todas essas doenças podem ser solucionadas através da prática de atividades físicas e uma dieta equilibrada, como é caso do câncer. Doenças mais complexas, como as oncológicas estão crescendo de forma alarmante não só no Brasil, como em todo o mundo e, necessitam de maior atenção e tratamentos específicos, por isso, torna-se mais difícil auxiliar as pessoas portadoras da enfermidade. Além disso, o mercado de aplicativos está em ascensão nos últimos anos, o que torna mais viável inserir uma aplicação relacionada à gestão de cuidados em oncologia, além de que há uma grande quantidade de pessoas que necessitam de ajuda no tratamento oncológico.

Assim, manifesta-se a ideia de usar a tecnologia a favor da saúde, através de um aplicativo de smartphone para dar suporte aos pacientes, visto que seu objetivo é facilitar e ajudar a vida do ser humano. Assim, a tecnologia poderá continuar causando uma nova evolução nesse setor que busca uma melhor forma de comunicação entre pacientes e médicos. Os aplicativos não só estão melhorando a vida das pessoas, mas também, estão mudando toda a realidade da saúde no país e no mundo. 


\section{AGRADECIMENTOS}

Agradeço à Escola de Ciências e Tecnologia (ECT) da Universidade Federal do Rio Grande do Norte (UFRN) pelo apoio e cooperação. Além disso, gratifico o Conselho Nacional de Desenvolvimento Científico e Tecnológico (CNPq) pelo apoio financeiro.

\section{REFERÊNCIAS}

APP ANNIE., App Annie Market Forecast 2016-2021. 2017.

BARRA, Daniela Couto Carvalho; PAIM, Sibele Maria Schuantes; SASSO, Grace Teresinha Marcon Dal; COLLA, Gabriela Winter. Métodos para Desenvolvimento de Aplicativos Móveis em Saúde: Revisão Integrativa da Literatura. Texto \& Contexto - Enfermagem, v. 26, n.p, 2017.

DA SILVA, Marcelo Moro; SANTOS, Marilde Terezinha Prado. Os Paradigmas de Desenvolvimento de Aplicativos para Aparelhos Celulares. Revista T.I.S. - Tecnologias, Infraestrutura e Software, v. 3, p. 162-170, 2014.

DE OLIVEIRA, Ana Rachel Fonseca; ALENCAR, Maria Simone de Menezes. O uso de aplicativos de saúde para dispositivos móveis como fontes de informação e educação em saúde. Revista Digital Biblioteconomia e Ciência da Informação, v. 15, n.p, 2017.

INSTITUTO BRASILEIRO DE GEOGRAFIA E ESTATÍSTICA. Pesquisa Nacional por Amostra de Domicílios Contínua. 2016.

INSTITUTO NACIONAL DE CÂNCER JOSÉ ALENCAR GOMES DA SILVA. Estimativa 2020. Incidência do Câncer no Brasil. 2019

MANDEL, Michael; Long, Eliiot. A Economia de Aplicativos no Brasil. Progressive Policy Institute, s.v, n.p, 2017.

MOURA, Adelina. Geração móvel: um ambiente de aprendizagem suportado por tecnologias móveis para a "Geração Polegar". In: Actas da VI Conferência Internacional de TIC na Educação - Desafios 2009, s.v, p. 50-78, 2009.

ORGANIZAÇÃO MUNDIAL DE SAÚDE. Global Action Plan on Physical Activity 2018-2030. 2018.

PEITER, Caroline Cechinel; CAMINHA, Maria Eduarda Pereira; LANZONI, Gabriela Marcellino de Melo; ERDMANN, Alacoque Lorenzini. Gestão do cuidado de enfermagem ao paciente oncológico num hospital geral: uma Teoria Fundamental nos Dados. Revista Referência - Enfermagem, s.v, p. 61-69,2016. 


\section{PERFIL DO SISTEMA IMUNE ESTIMULADO PELO ZIKA VÍRUS}

NATHÁLIA PEREIRA ALVES

Universidade do Estado de Minas Gerais

RENATA DELLALIBERA-JOVILIANO

Universidade de Ribeirão Preto

Universidade Estadual de Minas Gerais

RESUMO: A manutenção do sistema imune permite a homeostase do organismo através de um arranjo de células, tecidos e moléculas capazes de mediarem as respostas inflamatórias presentes nos processos de saúde-doença. Dentre o espectro de patologias que podem afetá-lo, têm-se as arboviroses, que são doenças causadas por arbovírus, a incluir o Zika vírus. No Brasil e também em nível mundial estudos vêm correlacionando a interação do sistema imune com as diferentes arboviroses. Particularmente neste estudo, objetivamos avaliar o perfil do sistema imune mediante ao estímulo do Zika vírus através de uma contextualização. Como instrumento de metodologia analisamos publicações atuais em bases catalogadas do Scielo, Pubmed e Periódico CAPES, que versavam a respeito da interação do sistema de defesa diante de estímulos do Zika vírus e a resposta cruzada com vírus da Dengue catalogadas nos últimos anos. Resultados mostram que a participação de mediadores inflamatórios (citocinas), interferons, proteínas virais, receptores, células NK, macrófagos e monócitos desempenham papel importante na imunidade inata e adaptativa frente ao estímulo do Zika vírus, corroborando assim para o aumento da resposta inflamatória. Além disso, a reação cruzada entre os vírus da Dengue e Zika promovem efeitos protetores nos indivíduos expostos previamente ao vírus da dengue que entram em contato com o Zika vírus, resultando na proteção de anticorpos neutralizantes. Contudo, o aprimoramento dependente de anticorpo pode estar presente nos indivíduos imune ao Zika vírus que se infectaram com o vírus da dengue, ou seja, a pré imunização pelo Zika vírus pode aumentar a viremia pelo vírus da Dengue e severidade da doença. Sumarizando, conclui-se que o Zika vírus modula o sistema imune através da participação celular e de mediadores inflamatórios.

PALAVRA-CHAVE: Ziika vírus; Dengue; Sistema imune; Reação cruzada; Mediadores inflamatórios.

ABSTRACT: The maintenance of the immune system allows homeostasis of the organism through an arrangement of cells, tissues and molecules capable of mediating the inflammatory responses present in health-disease processes. Among the spectrum of pathologies that can affect it, there are arboviruses, which are diseases caused by arboviruses, including the Zika virus. In Brazil and also worldwide, studies have been correlating the interaction of the immune system with different arboviruses. Particularly in this study, we aim to assess the profile of the immune system by stimulating the Zika Virus through contextualization. As a methodology tool, we analyzed current publications based on Scielo, Pubmed and Periódico CAPES catalogs, which dealt with the interaction of the defense system in the face of Zika virus stimuli and the cross-response with Dengue viruses cataloged in recent years. Results show that the participation of inflammatory mediators (cytokines), interferons, viral proteins, receptors, NK cells, macrophages and monocytes play an important role in innate 
and adaptive immunity to the Zika virus stimulation, thus corroborating the increase in the inflammatory response. In addition, the cross reaction between the Dengue and Zika viruses promotes protective effects in individuals previously exposed to the dengue virus that come into contact with the Zika virus, resulting in the protection of neutralizing antibodies. However, antibody-dependent enhancement may be present in individuals immune to the Zika virus that became infected with the dengue virus, that is, pre-immunization with the Zika virus can increase Dengue virus viremia and disease severity. In summary, it is concluded that the Zika virus modulates the immune system through cellular participation and inflammatory mediators.

KEYWORDS: Zika; Dengue; Imune system; Cross reaction; Inflammatory mediators.

\section{INTRODUÇÃO}

O sistema imune é ativado devido a capacidade do organismo de combater as doenças causadas por diferentes micro-organismos ou provocadas por seus produtos e ainda, sendo estimuladas por componentes do ambiente ou fatores endógenos. Este sistema de defesa consiste em uma organização envolvendo moléculas, células, tecidos e órgãos, os quais são responsáveis por mediar a resistência às infecções que o indivíduo está exposto, modulam estímulos do ambiente ou respondem a fatores endógenos, a fim de manter a homeostase do organismo frente aos estímulos recebidos. Dessa maneira, quando os antígenos microbiológicos atacam um indivíduo, geram resposta imune que promovem defesa através do vários mecanismos de imunidade (HUSE, 2017; SATTLER, 2017; NGUYEN e SOULIKA, 2019).

O sistema imunológico apresenta perfil de respostas que permitem ser ativados na presença de um antígeno. Assim, é dividido em resposta imune inata e resposta imune adquirida ou natural e adaptativa, respectivamente. A imunidade inata abrange a resposta natural do organismo para eliminar ou bloquear a entrada de microorganismos, sendo composta por barreiras física e química; incluem a participação de células sem especificidade como células fagocitárias, células dendríticas, natural killer/NK, mastócitos, eosinófilos, basófilos; além disso também ativam proteínas solúveis do sistema complemente (C3a, C4a, C5a, proteínas opsonizantes e formadora do complexo ao ataque as membranas/MAC, entre outras) e ativam diferentes mediadores inflamatórios (HUSE, 2017). Em contrapartida, a imunidade adaptativa, consiste em uma resposta celular específica e com memória imunológica dos quais envolvem os linfócitos T e B (NICHOLSON, 2016).

Através da especificidade no reconhecimento de antígenos mediada pelos receptores dos linfócitos B e $\mathrm{T}$, os organismos podem estabeler novas formas de interação com o ambiente. A imunidade celular é mediada pelos linfócitos T, que são maturados no timo, onde através da seleção positiva e negativa clones diferenciados passam a ser produzidos incluindo os subtipos de linfócitos TCD4+ (produtor e secretor importante de citocinas) e TCD8+ (potencialmente citotóxico) (NATOLI e OSTUNI, 2019). Já os linfócitos B produzidos e maturados na medula óssea, são constituintes da resposta imune humoral, sendo responsáveis pela produção e liberação de imunoglobulinas, conhecidas como anticorpos, principalmente quando diferenciado em plasmócitos (BESEDOVSKY et al., 2019). Dessa maneira, tanto a imunidade celular quanto a humoral participam da inflamação, a qual contem- 
pla respostas complexas, organizadas e dinâmicas para a defesa contra lesões e estímulos antigênicos (ABDULKHALEQ et al., 2018).

Por meio desse cenário de respostas imunológicas ocorre uma modulação no processo saúde-doença do organismo. Há um amplo espectro de doenças que podem afetá-lo, tais como as arboviroses, que são doenças virais causadas por arbovírus, incluindo os flavivírus, uma família viral que abrange o Zika vírus (ZIKV), o vírus da dengue (DENV), o vírus da febre amarela e o vírus do Nilo Ocidental (MAUCORANT et al., 2019).

Primeiramente o ZIKV foi descrito em 1947, em macaco Rhesus da floresta do Zika em Uganda, nesse período haviam poucos estudos pois acreditava-se numa doença viral leve e com distribuição geográfica limitada. Entre os anos de 2013-2014 houve o registro de surto de ZIKV, atingindo as ilhas do Pacífico Sul, países do continente americano incluindo América do Sul, atingindo número expressivo com mais de 1,5 milhão de infectados. O ZIKV constitui-se por um vírus envelopado de cadeia de RNA simples (não segmentado), pertence a família Flaviviridae e gênero flavivírus. A transmissão desta arbovirose ocorre principalmente, pela picada do mosquito Aedes aegypti e em alguns casos pode ocorrer via contato sexual (PAQUIN-PROULX et al., 2018). O quadro clínico do paciente infectado com ZIKV é diverso, podendo apresentar quadros assintomáticos ( $80 \%$ dos casos) até mesmo febre leve (conhecida como febre do zika), erupção cutânea maculopapular, mal-estar, mialgia e cefaleia, contudo, também pode se manifestar com malformações congênitas graves no feto, na síndrome de Guillain-Barré e distúrbios do desenvolvimento, tendo em vista a capacidade do ZIKV infectar progenitores de células neurais (HASTINGS et al., 2019). Dessa maneira, nota-se que o ZIKV pode trazer consequências importantes para a saúde pública, as quais foram verificadas no ano de 2015 através do aumento substancial de casos de microcefalia no nordeste brasileiro e que ainda perpetuam nos dias atuais. Isto pode ser verificado através da incidência de 1,1 casos de ZIKV em cada 100.000 habitantes no Brasil, dados que foram notificados pelo Ministério da Saúde no ano de 2019 (NGONO e SHRESTA, 2018; HASTINGS et al., 2019; BRASIL, 2019).

Assim como o ZIKV, o DENV pertence à família Flaviridae, só contêm RNA (filamento único de ácido ribonucléico revestido por uma capa de proteína icosaédrica - capsídio) e é transmitido pela picada do mosquito Aedes aegypti. Os estudos apontam para a existência de quatro tipos de vírus da dengue incluindo DEN-1, DEN-2, DEN-3 e DEN-4. A manifestação clínica do indivíduo infectado por DENV pode se limitar desde à quadros leves com manifestação apenas de mialgia e febre, e até mesmo apresentar sinais de alarme ou evoluir para a síndrome do choque da dengue (NGONO e SHRESTA, 2018; PAQUIN-PROULX et al., 2018).

Tanto o ZIKV quanto o DENV se estabeleceram em regiões tropicais e subtropicais, além disso, compartilham semelhanças antigênicas, trazendo assim um alerta epidemiológico visto que pesquisadores observaram o aumento de casos de zika e dengue em regiões coincidentes (PEREZ-GUZMAN et al., 2019). Ademais, atualmente vivencia-se processos de urbanização, globalização, migração e de mudanças climáticas, os quais contribuíram para a disseminação de arboviroses, tendo em vista que o vetor Aedes aegypti se reproduz em ambientes urbanos. Prova cabal disso foi a epidemia de arboviroses no verão de 2015/2016, que representou uma das maiores emergências de saúde pública na história do Brasil envolvendo DENV e ZIKV (LUM et al., 2018; BRASIL, 2019). 
Diante do perfil das arboviroses apresentadas e os mecanismos das respostas imune, propõe-se nesta revisão analisar a interação entre o sistema imunológico mediante aos estímulos do ZIKV, correlacionando com os principais componentes envolvidos na resposta inflamatória.

\section{MATERIAL E MÉTODOS}

Para a elaboração deste conteúdo revisional, foram avaliadas publicações atualizadas e registradas no período entre 2016 e 2020, sendo catalogadas em revistas indexadas na base de estudos Scielo, Pubmed e Periódicos da CAPES. Dessa seleção foram excluídos os artigos que versavam pouco sobre a conjuntura da interação entre o sistema imune e o ZIKV. Assim, 23 artigos foram selecionados para este estudo sendo classificados de acordo com a temática: a modulação do sistema imune pelo ZIKV, os estímulos do ZIKV gerando resposta inflamatória e reatividade cruzada entre ZIKV e DENV.

Utilizamos os unitermos "health", “disease", “inflammatory mediators”, “inflammation”, “cytokines", "immune system", "neutralizing antibodies", "antibody dependent enhancement" os quais foram combinados com os unitermos "Zika virus" e "arboviroses".

\section{RESULTADOS E DISCUSSÃO}

\section{A modulação do sistema imune pelo ZIKV}

O ZIKV é um vírus de RNA de fita simples, possui capsídeo e envelope viral, seu genoma é composto por três proteínas estruturais no terminal $\mathrm{N}$ (cápside $\mathrm{C}$, pré membrana prM, envelope $\mathrm{E}$ ) e sete não estruturais no terminal C (NS1, NS2A, NS2B, NS3, NS4A, NS4B, NS5). Faz-se necessário compreender que a proteína NS5 está envolvida com a replicação do genoma, sendo dessa maneira crucial na infecção pelo ZIKV. Apesar de o ZIKV possuir um histórico marcado por surtos e problemas na saúde pública mundial, infelismente pouco são os conhecimentos acerca da biologia deste flavivírus e a resposta do hospedeiro à esta infecção (NGONO e SHRESTA, 2018).

A caracterização precisa dos receptores de entrada para ZIKV é incerta, mas a maioria dos estudos apontam que após a picada do vetor Aedes aegypyi infectado, o ZIKV é depositado no espaço extracelular da derme do hospedeiro, e posteriormente infectam as células dendríticas, como os monócitos. Os monócitos são uma das células iniciais à interagirem com o vírus no sistema circulatório, eles são componentes da imunidade inata, com função de eliminar microorganismos e interagir com demais células imunes, a fim de desencadear resposta inflamatória. Após o processo de diapedese sofrido pelos monócitos, os mesmos dão origem aos macrófagos (LUM et al., 2018; ABDULKHALEQ et al., 2018). 
Macrófagos apresentam infecção mais significativa por ZIKV do que monócitos. E as vias ativadas nestes macrófagos infectados compreendem a sinalização por interferon, vias patogênicas da esclerose múltipla e vias de comunicação cruzada entre macrófagos e células NK, sendo a resposta do interferon a mais expressa e significativa, caracterizando portanto, a fase aguda da infecção (LUM et al., 2018). Diante do papel da sinalização por interferon, Kumar et al. (2016) mostram que a infecção pelo ZIKV prejudica a indução de interferon tipo I sendo várias proteínas virais capazes de afetar esses processos. A degradação do STAT-2 mediada por vírus atua para reduzir a sinalização mediada por interferon tipo I e tipo III. Além disso, o NS5 do ZIKV se liga ao STAT-2, e sua expressão está correlacionada com a degradação do STAT-2 pelo proteassoma. Deste modo, é possível compreender como o ZIKV bloqueia os sistemas de defesa celular para infectar e se reproduzir no organismo.

\section{Os estímulos do ZIKV gerando resposta inflamatória}

$\mathrm{Na}$ fase aguda da infecção por ZIKV ocorre a produção de interferon tipo 1, após a identificação do flavivírus por receptores de reconhecimento de padrões celulares (receptores tipo Toll, tipo RIG-I, tipo NOD (NLRs)). Uma família de genes interferon- $\alpha$ codifica o interferon tipo 1, e este influencia processos celulares, afetando diretamente fases do ciclo de vida viral e consequentemente a replicação do ZIKV. O interferon tipo 1 atua como mediador central da resposta antiviral do hospedeiro, assim, os flavivírus desenvolveram mecanismos a fim de inibir vias que favoreçam a produção do interferon tipo 1, como por exemplo, o ZIKV pode impedir a sinalização de interferon por meio de processos mediados pela proteína viral NS5 (MAUCORANT et al., 2019; WANG et al., 2018).

A fim de detectar e lisar células infectadas por vírus, as células NK, consideradas efetoras de vida curta, realizam papéis antivirais e reguladores através de sinais inibitórios e ativadores. Pesquisas mostram que amostras de sangue de pacientes infectados por ZIKV durante a fase aguda da doença apresentaram células NK ativadas, principalmente ativadas por monócitos CD14+, isso foi observado através de estudos com células mononucleares do sangue periférico (PBMCs) sem monócitos $\mathrm{CD} 14+$, que ao serem estimuladas apresentaram redução significativa da atividade das células NK quando comparado com PBMCs contendo monócitos CD14+ (MAUCORANT et al., 2019; LUM et al., 2018).

Nesses processos inflamatórios citados durante uma infecção por ZIKV, também há ação de citocinas, que são proteínas mediadoras importantes nas atividades das células, afinal envolvem secreções de interleucina (IL)-1 $\beta$, IL-8, fator de necrose tumoral alfa, IL-6, e IL-12, regulando assim a atividade imunológica do indivíduo (ABDULKHALEQ et al., 2018).

Dentre os receptores de reconhecimento de padrões celulares envolvidos na identificação dos flavivírus tem-se os receptores do tipo NOD (NLRs). Os NLRs estão envolvidos na formação de inflamassomas, caracterizados por conjuntos de moléculas envolvidas na resposta imune inata. Os inflamassomas são formados pela proteína adaptadora (com domínio de recrutamento de caspase (ASC), molécula sensor citoplasmática (proteína 3 com domínios NACHT, LRR, PYD (NLRP3) e proteína efetiva (pró-caspase-1). Desse modo, a NLRP3 e ASC clivam a pró-caspase 1, gerando 
sua ativação e secreção de IL-1 $\beta$, mediador pró-inflamatório crucial para resposta imune adaptativa (WANG et al., 2018).

Diante da importância do inflamassoma, Wang et al. (2018) mostraram que a infecção pelo ZIKV facilita esta montagem do inflamassoma e assim ativa a secreção de IL-1 $\beta$. A proteína não estrutural NS5 presente no genoma do ZIKV interage com a NLRP3, e forma uma estrutura entre a NS5, NLRP3 e ASC, formando o complexo do inflamassoma NLRP3, descobriu-se portanto, um novo mecanismo pelo qual a infecção pelo ZIKV facilita a maturação da IL-1 $\beta$.

Apesar da resposta gerada pelo reconhecimento do ZIKV através dos receptores celulares, estudos mostraram a capacidade da saliva do Aedes aegypti em também alterar o ambiente imunológico local. Inicialmente,foi identificado uma molécula chamada fator estimulador de neutrófilos (NeSt1) na saliva do vetor da DENV e ZIKV, a qual é responsável por estimular neutrófilos no local da picada do mosquito e recrutar macrófagos suscetíveis, gerando então um aumento na replicação viral precoce e consequentemente acentuando a patogênese do ZIKV e predispondo acometimentos mais graves (HASTINGS et al., 2019).

Também há contribuição das células T invariantes associadas à mucosa (MAIT) na resposta gerada ao ZIKV. Estudos demontraram que tais células T são ativadas na infecção aguda pelo DENV e ZIKV. Quando infectadas por ZIKV, as células MAIT produziram interferon- $\gamma$, o mesmo ocorreu na infecção por DENV, evidenciando portanto a participação das respostas celulares MAIT nas infecções por flavivírus (PAQUIN-PROULX et al., 2018).

Demais estudos sugerem a participação das respostas das células T e B durante infecção por ZIKV. Em modelos experimentais de camundongos com depleção de células TCD8+, TCD4+ e B expostos ao ZIKV resultou em infecção dos animais, demonstrando o papel protetor das células em estudo na infecção pelo vírus (LUCAS et al., 2018). Além disso, avaliações de pacientes com infecções confirmadas por ZIKV evidenciaram forte ativação de células TCD8+ e moderada ativação de células TCD4+ (LAI et al., 2018), e demais estudos mostraram que as respostas das células TCD8+ ao ZIKV não necessitam da ajuda das células TCD4+ (NGONO et al, 2019). De forma mais precisa, nas células T provocadas pela infecção por DENV, as proteínas NS3, NS4B e NS5 são os alvos das células TCD8+, e as proteínas C e E os alvos das células TCD4+, entretanto, quanto ao ZIKV, pesquisas com modelos animais ainda estão sendo realizadas (NGONO e SHRESTA, 2018).

\section{Reatividade cruzada entre o ZIKV e DENV}

Partindo das semelhanças antigênicas entre o DENV e o ZIKV, iniciou-se estudos que investigaram a presença de reatividade cruzada entre estes flavivírus. A reação cruzada é definida como a capacidade do sítio de combinação do anticorpo de interagir com mais de um antígeno (DELGADO et al., 2018).

Em pesquisas envolvendo PBMCs de pacientes imunes ao DENV, observou-se respostas mais fortes de células T contra peptídeos encontrados nos DENV e ZIKV, com um maior nível de anticorpos neutralizantes ao ZIKV, quando expostos ao ZIKV, do que em pacientes ingênuos ao DENV. 
Isso mostra que indivíduos imunes ao DENV previamente, apresentaram melhores respostas contra o ZIKV, constatou-se então a presença de reação cruzada entre anticorpos anti-DENV com o ZIKV, a qual resultou em efeitos protetores devido a neutralização (DELGADO et al., 2018; ANDRADE et al., 2019).

Em contrapartida, quanto aos pacientes imunes ao ZIKV e ao DENV, verificou-se a presença de anticorpos neutralizantes apenas contra o ZIKV, não contra o DENV, sugerindo portanto que a infecção prévia ao ZIKV não melhora a resposta imunológica ao DENV, contudo, pesquisas ainda precisam ser realizadas para melhor investigar essa relação (PÉREZ-GUZMÁN et al., 2019).

Essa reação cruzada está diretamente relacionada com o reconhecimento de epítopos compartilhados entre DENV e ZIKV, sendo a proteína NS5 o alvo com maior número de epítopos em comum, dominando assim, a reposta de células T cruzadas conta o ZIKV (DELGADO el at., 2018).

Diante deste panorama de reação cruzada entre os flavivírus, surgiram mais estudos. Na neutralização cruzada foi estabelecido que anticorpos contra o DENV neutralizam o ZIKV, gerando efeito protetor. Entretanto, quando há baixo número de anticorpos neutralizantes surge uma infecção aumentada caracterizada pelo aprimoramento dependente de anticorpo (ADE), apoiado por alguns estudos e em investigação por outros (VALIANT e MATTAPALLIL, 2018). O ADE já é bem estabelecido entre os quatro sorotipos do DENV, e sugere que uma exposição prévia à um dos sorotipos determina maior gravidade quando exposto a outro sorotipo, como por exemplo a febre hemorrágica da dengue. Quanto ao papel do ADE no ZIKV, alguns estudos já mostraram que a infecção pelo ZIKV induziu o ADE de DENV, acentuando a viremia por DENV e severidade da doença,mas ainda há controvérsias, e necessita-se de maiores pesquisas (VALIANT e MATTAPALLIL, 2018; MARTÍN-ACEBES et al., 2018).

\section{CONCLUSÃO}

As pesquisas envolvendo a comunicação entre o sistema imune e a infecção pelo ZIKV demostraram o papel dos receptores de genoma viral, padrões moleculares e monócitos na infecção do hospedeiro. Na fase aguda, têm-se que interferons, citocinas, interleucinas e células NK desempenham papel significativo como mediadores da imunidade inata e ativação da imunidade adaptativa.

Além disso, esta contextualização sugere que pode existir reação cruzada entre o DENV e o ZIKV, devido a semelhança antigêntica entre estes flavivírus, culminando assim na proteção de articorpos neutralizantes ou no ADE. Estudos futuros podem contribuir para melhor compreender o resultado dessa reatividade cruzada. 


\section{REFERÊNCIAS}

ABDULKHALEQ, L.A.A.; ASSI, M.A.; ABDULLAH, R.; ZAMRI-SAAD, M.; TAUFIQ-YAP, H.; HEZMEE, M.N.M. The crucial roles of inflamatory mediators in inflammation: A review. Vest World, v.5, p.627$635,2018$.

ANDRADE, P.; GIMBLET-OCHIENG, C.; MODIRIAN, F. et al. Impact of pre-existing dengue immunity on human antibody and memory B cell responses to Zika. Nature communications, v.10, p. 938, 2019.

BESEDOVSKY, L.; LANGE, T.; HAACK, M. The sleep-immune crosstalk in health and disease. Physiol Rev., v.3, p. 1325-1380, 2019.

BRASIL. Monitoramento dos casos de arboviroses urbanas transmitidas pelo Aedes (dengue, chikungunya e Zika) até a Semana Epidemiológica 12 de 2019 e Levantamento Rápido de Índices para Aedes aegypti (LIRAa). Secretaria de Vigilância em Saúde, v. 50, p. 1-18, 2019.

DELGADO, F.G.; TORRES, K.I.; CASTELLANOS, J.E. et al. Improved immune responses against Zika virus after sequencial Dengue and Zika virus infection in humans. Viruses, v.9, 2018.

HASTINGS, A.K.; URAKI, R.; GAITSCH, H. et al. Aedes aegypti NeSt1 preotein enhances zika virus pathogenesis by activating neutrophils. J Virol., v. 13, 2019.

KUMAR, A.; HOU, S.; AIRO, A.M. et al. Zika virus inhibits type-I interferon production and downstream signaling. EMBO Rep., v.7, n.12, p. 1766-1775, 2016.

HUSE M. Mechanical forces in the immune system. Nat Rev Immunol., v.17, n.11, p.679-690, 2017.

LAI, L.; ROUPHAEL, N.; XU, Y. et al. Innate, T-, and B-cell responses in acute human zika patients. Clinical Infectious Diseases, v.1, p.1-10, 2018.

LUCAS, C.G.O.; KITOKO, J.Z.; FERREIRA, F.M. et al. Critical role of CD4+ T cells and IFN $\gamma$ signaling in antibody-mediated resistance to Zika virus infection. Nat Commun., v.1, p.3136, 2018.

LUM, F.M.; LEE, D.; CHUA, T.K. et al. Zika virus infection preferentially counterbalances human peripheral monocyte and/or NK cell activity. mSphere, v.2, 2018.

MARTÍN-ACEBES, M.A.; SAIZ, J.C.; OYA, N.J. Antibody-dependent enhancement and zika : real threat or phantom menace?. Frontiers in cellular and infection microbiology, v.8, p. 44, 2018.

MAUCORANT, C.; PETITDEMANGE, C.; YSSEL, H.; VIEILLARD, V. Control of acute arboviral infection by natural killer cells. Viruses, v.2, p. 131, 2019.

NATOLI, G.; OSTUNI, R. Adaptation and memory in immune responses. Nat Immunol., v.20, n.7, p.783792, 2019.

NGONO, A.E.; SHRESTA, S. Immune Response to Dengue and Zika. Annu Rev Immunol., v. 36, p. 279308, 2018.

NGONO, A.E.; YOUNG, M.P.; BUNZ, M. et al. CD4+T cells promote humoral immunity and viral control during Zika virus infection. PLoS Pathogens, v.1, p.1-29, 2019.

NGUYEN, A.V.; SOULIKA, A.M. The Dynamics of the Skin's Immune System. Int J Mol Sci., v.20(8), p $1811,2019$.

NICHOLSON, L.B. The immune system. Essays Biochem., v.60(3), p. 275-301, 2016.

PAQUIN-PROULX, D.; AVELINO-SILVA, V.I.; SANTOS, B.A.N. et al. MAIT cells are activated in acute Dengue virus infection and after in vitro Zika virus infection. PloS Negl Trop Dis., v.1, p. 164, 2018. 
PÉREZ-GUZMÁN, E.X.; PANTOJA, P.; SERRANO-COLLAZO, C. Time elapsed between Zika and Dengue virus infections affects antibody and T cell responses. Nat Commun., v.1, p. 4316, 2019.

SATTLER, S. The Role of the Immune System Beyond the Fight Against Infection. Adv Exp Med Biol., v.1003, p. 3-14, 2017.

VALIANT, W.G.; MATTAPALLIL, J.J. A simple flow cytometry based assay to determine in vitro antibody dependent enhancement of Dengue virus using Zika virus convalescent serum. Journal of Visualized Experiments, v.134, 2018.

WANG, W.; WU, D.; LUO, Z. et al. Zika virus infection induces host inflammatory responses by facilitating NLRP3 inflammasome assembly and interleukin-1 $\beta$ secretion. Nature Communications, v.9, p. 480, 2018. 


\section{EPIDEMIOLOGIA DA OCORRÊNCIA DA NEOPLASIA MALIGNA DA PRÓSTATA DURANTE A ÚLTIMA DÉCADA NO BRASIL}

ANTONIO PAULO REIS DE AMORIM

LISBOA

Universidade Estadual de Ciências da Saúde de Alagoas

ANA CLÁUDIA DA SILVA FERNANDES

DUARTE

Universidade Estadual de Ciências da Saúde de Alagoas

ANA KELLY DA SILVA FERNANDES DUARTE

DAVI WESLEY RAMOS DO NASCIMENTO

Universidade Estadual de Ciências da Saúde de Alagoas

FLÁVIA DANIELLE SOUZA DE VASCONCELOS

Universidade Estadual de Ciências da Saúde de Alagoas

MATHEUS DOS SANTOS DO NASCIMENTO CARVALHO

Universidade Estadual de Ciências da Saúde de Alagoas

CAMILA MARIA BEDER RIBEIRO GIRISH PANJWANI

Universidade Estadual de Ciências da Saúde de Alagoas

RESUMO: O câncer de próstata $(\mathrm{CP})$ emergiu como um problema de alto impacto na saúde pública do Brasil. Apesar dos avanços de diagnóstico, como o exame digital retal (EDR) e a detecção do antígeno prostático no sangue (PSA), essa doença ainda se configura entre as principais causas de morte no mundo. O perfil desses casos são homens a partir dos 50 anos, com casos familiares próximos, cuja incidência reflete os fatores de envelhecimento da população, associado a uma vida cada vez mais sedentária e artificializada. Nesse estudo, objetivou-se a exploração dos dados epidemiológicos secundários mediante acesso do Sistema de Informações Hospitalares do SUS (SIH), da plataforma DataSUS, buscando casos de neoplasia maligna da próstata no Brasil no período entre 2010 e 2019 dos sistemas público e privado de saúde. Analisou-se as variantes: internação, caráter de atendimento, região do país, raça/etnia, faixa etária e óbitos. Dos resultados observados, o CP apresentou incidência crescente na década observada (janeiro de 2010 a dezembro de 2019), com maior incidência em 2019. Também se percebeu o predomínio das internações eletivas em detrimento da urgência. A região mais afetada foi a Sudeste, dada a grande densidade populacional. Destaca-se, ainda, o acometimento majoritário da população branca; predominantemente a partir da $6^{\mathrm{a}}$ década de vida; além de se verificar um número crescente de óbitos, inclusive entre os mais velhos, para os casos mais graves, em regiões menos assistidas, como o caso do Norte. Diante da metodologia empregada, tais estatísticas reafirmam que o número de CP ainda é elevado no Brasil e espera-se que os dados dessa pesquisa contribuam com a amplificação de dados epidemiológicos, bem como ajudar na construção de perspectivas futuras e estratégias, na forma de políticas públicas, para prevenção, diagnóstico e tratamento.

PALAVRAS-CHAVE: Neoplasia Maligna da Próstata. Saúde do Homem. Epidemiologia no Brasil. 
ABSTRACT: Prostate cancer (PC) has emerged as a problem of high impact on public health in Brazil. Despite advances in diagnosis, such as digital rectal examination (EDR) and the detection of prostate antigen in the blood (PSA), this disease is still among the main causes of death in the world. The profile of the cases are men from 50 years old, with close family cases, whose incidence reflects the aging factors of the population, associated with an increasingly sedentary and artificialized life. In this study, the objective was to explore secondary epidemiological data through access to the SUS Hospital Information System (SIH), from the DataSUS platform, looking for cases of malignant neoplasm of prostate in Brazil between 2010 and 2019 from the public and private health systems. Variants were analyzed: hospitalization, service character, region of the country, race / ethnicity, age group and deaths. From the observed results, the CP increased in the observed decade (January 2010 to December 2019), with a higher incidence in 2019. Also, the predominance of elective hospitalizations to the detriment of the urgency. The most affected region was the Southeast, given the high population density. The majority of the white population is also affected; predominantly from the 6th decade of life; in addition to an increasing number of deaths, including among the oldest, for the most severe cases, in less assisted areas, such as the North. In view of the methodology employed, such statistics reaffirm that the number of PC is still high in Brazil and it is expected that the data from this research will contribute to the amplification of epidemiological data, as well as help in the construction of future perspectives and strategy, in the form of public policy for prevention, diagnosis and treatment.

KEYWORDS: Malignant Neoplasm of Prostate. Men’s Health. Brazilian Epidemiology.

\section{INTRODUÇÃO}

O câncer configura-se como um importante problema de saúde no mundo, cuja ocorrência se constitui como uma das principais causas de morte antes dos 70 anos (Abreu et al, 2016; INCA, 2019). Segundo Bray et al. (2018), os motivos para tamanho crescimento e índice dessa patologia são complexos, mas refletem fatores como o envelhecimento da população, o desenvolvimento socioeconômico, como também alterações na prevalência dos fatores de risco para o câncer.

Nesse contexto, o câncer de próstata (CP) emergiu como um grande problema na saúde do homem em escala mundial, com valores de risco que chegam a 33,1/100 mil (Bray et al., 2018; INCA, 2019). No Brasil, a estimativa para os casos no triênio de 2020-2022 é de 65.840 por ano, um valor que se destaca na primeira posição das patologias em todas as regiões do país (INCA, 2019).

O perfil típico para essa doença são homens acima dos 50 anos, com acometimento crescente de acordo com o passar dos anos; pode haver variações de caráter prematuro, como nos exemplos de antecedentes familiares positivos em grau próximo. Além disso, costuma-se ocorrer com maior frequência na população negra (1,6 vezes mais comum que na população branca); raramente entre asiáticos, porém, os costumes e hábitos de vida principalmente os ocidentalizados se sobressaem em relação a esses fatores (Kumar et al., 2010; INCA, 2011).

Etiologicamente, apesar dos avanços em técnicas de detecção, reconhece-se que ainda não se tem o domínio sobre a causa dessa patologia, há apenas suspeitas relacionadas aos fatores de riscos associados (Kumar et al., 2010). Com isso, tornou-se imprescindível o investimento em técnicas de 
prevenção e diagnóstico, representadas pelos exames do toque retal (exame digital retal ou EDR) e buscas pelo antígeno prostático específico no sangue, o PSA (Friestino et al., 2014).

Quanto à incidência anatômica, diferentemente das outras hiperplasias que costumam a atingir da zona de transição, esse tipo de câncer inicia-se majoritariamente (70\% dos casos) na zona periférica prostática, em localização posterior e proximal a região retal (palpável no EDR). Dentre as regiões de desdobramento, o tecido periprostático, vesículas seminais e bexiga urinária são as primeiras a serem atingidas em caráter local. Já nas metástases iniciais, são acometidos os linfonodos regionais, seguindo para a via de disseminação hematogênica para os ossos e vísceras (Kumar et al., 2010).

De acordo com Filippi (2018), a definição do estadiamento do câncer prostático é um fator preditivo na definição do tratamento e prognóstico do paciente. Com a sua classificação não é diferente. Para esta, o sistema de Gleason tem sido o mais utilizado, o qual constitui um critério de estratificação graduado nos níveis de I a V, segundo os arranjos morfológicos da histologia. Para aquela, utiliza-se o sistema TNM, que usa como base os achados anatômicos (Kumar et al., 2010; Heidenreich et al., 2012). Diante dessas identificações é que serão escolhidas as melhores opções de tratamento, sendo as principais: manipulação hormonal, radioterapia e prostatectomia radical (Heidenreich et al., 2012).

Diante da relevância e do impacto não só na saúde do homem, mas também, em todas as estratégias de saúde pública, o presente estudo objetiva analisar a epidemiologia relacionada à ocorrência de neoplasia maligna da próstata durante a última década no Brasil e contribuir positivamente com as perspectivas futuras nas estratégias de prevenção, diagnóstico e tratamento.

\section{MATERIAL E MÉTODOS}

Foi desenvolvido um estudo exploratório com dados secundários, obtidos pelo Sistema de Informações Hospitalares do SUS (SIH) do DataSUS, no endereço eletrônico (http://tabnet.datasus.gov. br), que foi acessado em 14/07/2020, sobre a epidemiologia das internações de pacientes portadores de neoplasia maligna da próstata no Brasil em estabelecimentos públicos e privados durante o período de 2010 a 2019. Ao obter os dados, foram analisadas as seguintes variantes: internação, caráter de atendimento, regiões do país, raça/etnia, faixa etária e óbitos.

\section{RESULTADOS E DISCUSSÃO}

Diante do estudo dos dados, verificou-se que durante os últimos 10 anos (janeiro de 2010 a dezembro de 2019), no Brasil, ocorreram 281.950 internações por neoplasia da próstata. A tabela 1 mostra como esse total é distribuído entre os anos analisados. 
Tabela 1. Internações por CP em conformidade com

\begin{tabular}{lc} 
O ano de processamento. & Casos \\
\hline 2010 & 21.644 \\
2011 & 23.586 \\
2012 & 25.314 \\
2013 & 26.238 \\
2014 & 27.331 \\
2015 & 29.564 \\
2016 & 29.658 \\
2017 & 31.649 \\
2018 & 32.271 \\
2019 & 34.695 \\
\hline
\end{tabular}

Fonte: Dados do DataSUS (2020) compilados na pesquisa.

Conforme a análise dos dados presentes na tabela 1, nota-se uma progressão de casos de câncer de próstata com o passar dos anos, na qual se observa uma maior incidência no ano de 2019. Percebe-se ainda que ocorreu um aumento de 7,0\% entre os anos de 2018 e 2019 . A elevação no registro de internações pode ocorrer mediante a ampliação do acesso à exames diagnósticos, assim como, pelo aumento de novos métodos diagnósticos. Essa tendência mostra uma consonância com os achados mundiais, já que, somente em 2018, foram notificados ao GLOBOCAN 1.276.106 novos casos de CP (Bray et al., 2018), configurando-se nesse ano como a $5^{\mathrm{a}}$ maior causa de morte no cenário mundial.

\begin{tabular}{lcc}
\multicolumn{3}{l}{ Tabela } \\
o caráter de atendimento e ano de processamento. \\
\hline Ano & Eletivo & Urgência \\
\hline 2010 & 13.146 & 8.498 \\
2011 & 14.286 & 9.300 \\
2012 & 14.856 & 10.458 \\
2013 & 15.254 & 10.984 \\
2014 & 15.640 & 11.691 \\
2015 & 16.988 & 12.576 \\
2016 & 16.922 & 12.736 \\
2017 & 17.207 & 14.442 \\
2018 & 18.194 & 14.077 \\
2019 & 19.922 & 14.773 \\
\hline Total & 162.415 & 119.535 \\
\hline
\end{tabular}

Fonte: Dados do DataSUS (2020) compilados na pesquisa.

Averiguando-se o caráter de atendimento das internações, é possível verificar o elevado número de casos eletivos, ou seja, aqueles não precisam de atendimento de emergência. Assim, do total de atendimentos hospitalares, 57,6\% sucederam em procedimentos eletivos. Portanto, pode-se inferir que a maioria dos eventos possui diagnóstico precoce. Esses números parecem discordar de uma tendência vista na realidade, uma vez que fatores como a desinformação, crença religiosa, descrédito quanto ao prognóstico do câncer e a falta de acesso básico à saúde podem afastar a procura e, por conseguinte, o diagnóstico de forma prévia, permitindo que o diagnóstico na maioria dos casos seja feito quando o CP já se encontra avançado, na forma disseminada (VIEIRA; ARAÚJO; VARGAS, 2012). 
Além disso, 2019 se destaca com um maior número de casos, apresentando um aumento de 8,7\% se comparado à 2018, seguindo o cenário mundial no tocante ao crescimento dos casos (Bray et al., 2018).

\begin{tabular}{|c|c|c|}
\hline Região & Casos & $\%$ \\
\hline Norte & 7.706 & $2,7 \%$ \\
\hline Nordeste & 63.515 & $22,5 \%$ \\
\hline Sudeste & 148.696 & $52,7 \%$ \\
\hline Sul & 45.067 & $16 \%$ \\
\hline Centro-Oeste & 16.966 & $6,1 \%$ \\
\hline
\end{tabular}

Fonte: Dados do DataSUS (2020) compilados na pesquisa.

Ao verificar as regiões do país associada à ocorrência do CP durante a última década, presente na tabela 3, observa-se o destaque da região Sudeste que concentra o maior número de casos, taxa de $52,7 \%$, seguida pela região Nordeste com $22,5 \%$. A região Sudeste se destaca com maior número de casos por tratar da região mais populosa do país, assim como a região Nordeste, configurada como a segunda região mais populosa do Brasil. De acordo com Santos (2018), essa realidade reflete os índices socioeconômicos regionais, na forma de acesso à saúde, hábitos de vida, expectativa de vida, bem como a renda, o que gera um cenário de peculiaridades entre a ocorrência de câncer nas 5 regiões do Brasil.

Tabela 4. Internações por $\mathrm{CP}$ em conformidade com a

\begin{tabular}{lcc|c} 
raça/etnia. & \multicolumn{2}{c}{$\%$} \\
\hline Raça/etnia & Casos & \multicolumn{2}{c}{$\%$} \\
\hline Branca & 108.151 & $38,5 \%$ & $7,5 \%$ \\
Preta & 21.079 & $34,8 \%$ \\
Parda & 98.054 & $1,2 \%$ \\
Amarela & 3.445 & $0,02 \%$ \\
Indigina & 68 & $17,98 \%$ \\
Sem informação & 51.153 &
\end{tabular}

Fonte: Dados do DataSUS (2020) compilados na pesquisa.

Em relação à raça/etnia, presente na tabela 4, verifica-se o elevado número de homens brancos como principais afetados, com taxa de 38,5\%. Seguido dos pardos, que também se destacam com $34,8 \%$, ocupando a segunda posição de etnia mais afetada. Essa não é a realidade referida na literatura, a qual traz o homem de etnia preta como o mais acometido pela doença, com cerca de 1,6 vezes mais que a população branca (Kumar et al., 2010; Rawla, 2019). Essa disparidade parece refletir o cenário de desigualdade ao acesso à saúde no brasil, sendo, portanto, mais acessível à população branca, com maior acesso aos serviços de detecção. 
Tabela 5. Internações por $\mathrm{CP}$ em conformidade com a

\begin{tabular}{lcc} 
faixa etária. & & \\
\hline Idade & Casos & $\%$ \\
\hline $0-9$ & 230 & $0,08 \%$ \\
$10-19$ & 146 & $0,05 \%$ \\
$20-29$ & 167 & $0,06 \%$ \\
$30-39$ & 313 & $0,1 \%$ \\
$40-49$ & 4.676 & $1,6 \%$ \\
$50-59$ & 40.494 & $14,4 \%$ \\
$60-69$ & 108.163 & $38,4 \%$ \\
$70-79$ & 89.728 & $31,8 \%$ \\
80 ou mais & 38.033 & $13,57 \%$ \\
\hline
\end{tabular}

Fonte: Dados do DataSUS (2020) compilados na pesquisa.

Quanto à faixa etária, dados expostos na tabela 5, é possível perceber uma concentração de casos na faixa etária entre 60 e 69 anos que possuem um total de 38,4\% dos doentes. Contudo, observa-se uma quantidade semelhante na faixa etária entre 70 e 79 anos, com 31,8\% das internações. De maneira genérica, esses resultados revelam os indivíduos idosos como os mais afetados por essa patologia, uma realidade que coincide com os dados mundiais, os quais revelam um acometimento majoritário de homens a partir da sexta década de vida, de forma progressiva (Kumar et al., 2010; INCA, 2011; Rawla, 2019).

No tocante aos óbitos, constata-se que ocorreram 25.435 mortes por $\mathrm{CP}$, mostrando uma mortalidade de $9,5 \%$, observada nesse período.

\begin{tabular}{lc} 
Tabela 6. Óbitos por CP em conformidade com o ano \\
de processamento. \\
\hline Ano & Casos \\
\hline 2010 & 1.776 \\
2011 & 2.016 \\
2012 & 2.096 \\
2013 & 2.321 \\
2014 & 2.505 \\
2015 & 2.672 \\
2016 & 2.762 \\
2017 & 3.012 \\
2018 & 3.096 \\
2019 & 3.036 \\
\hline Total & 25.435 \\
\hline
\end{tabular}

Fonte: Dados do DataSUS (2020) compilados na pesquisa.

$\mathrm{Na}$ análise dos dados expostos na tabela 6, percebe-se que os óbitos por CP sofrem um discreto crescimento gradativo durante os últimos 10 anos analisados, tendência essa que continua a refletir a escala crescente de casos a nível mundial (Bray et al., 2018). Todavia, em 2019 observa-se uma redução de $1,9 \%$ as mortes quando comparado com 2018, fator esse que pode ser fruto de uma inconsistência no levantamento de dados pelos órgãos responsáveis, ou indicar o início de uma melhora nas estratégias de tratamento adotadas em solo brasileiro. 
Tabela 7. Óbitos por neoplasia maligna de próstata em conformidade com a faixa etária.

\begin{tabular}{lcc}
\hline Idade & Casos & $\%$ \\
\hline $0-9$ & 12 & 0,05 \\
\hline $10-19$ & 6 & 0,025 \\
$20-29$ & 15 & $0,06 \%$ \\
\hline $30-39$ & 24 & $0,09 \%$ \\
\hline $40-49$ & 186 & $0,7 \%$ \\
\hline $50-59$ & 1.781 & $7 \%$ \\
\hline $60-69$ & 6.080 & $23,9 \%$ \\
\hline $70-79$ & 9.625 & $37,9 \%$ \\
\hline 80 ou mais & 7.706 & $30,275 \%$ \\
\hline
\end{tabular}

Fonte: Dados do DataSUS (2020) compilados na pesquisa.

Ao associar as variáveis óbitos e faixa etária, presentes na tabela 8 , infere-se que os indivíduos entre 70 e 79 anos portadores de câncer de próstata evoluem para óbito com maior frequência do que os demais, com uma taxa de 37,9\%. Ademais, nota-se uma quantidade de casos semelhantes presentes na faixa etária com 80 ou acima de 80 anos, com 30,275\% dos afetados, e aqueles entre 60 e 69 anos, com $23,9 \%$. De modo geral, esses dados revelam que essa doença atinge e mata com maior frequência os idosos (Rawla, 2019).

\begin{tabular}{lll}
$\begin{array}{l}\text { Tabela 8. Obitos de acordo com } \\
\text { atendimento e ano de processamento. }\end{array}$ \\
\hline Ano & Eletivo & Urgência \\
\hline 2010 & 354 & 1.430 \\
2011 & 372 & 1.612 \\
2012 & 344 & 1.742 \\
2013 & 394 & 1.927 \\
2014 & 364 & 2.116 \\
2015 & 429 & 2.241 \\
2016 & 488 & 2.284 \\
2017 & 527 & 2.490 \\
2018 & 535 & 2.520 \\
2019 & 534 & 2.732 \\
\hline Total & 4.341 & 21.094 \\
\hline
\end{tabular}

Fonte: Dados do DataSUS (2020) compilados na pesquisa.

Ao verificar-se o caráter de atendimento dos casos que evoluíram para óbito de acordo com o ano de processamento, presente na tabela 8, percebe-se a permanência de casos graves que cursam com a morte. Além disso, nota-se que essas taxas permanecem relativamente constantes e elevadas durante todo o período analisado, fatores que revelam que a procura tardia pelo tratamento dessa neoplasia maligna, outrora relatado por Vieira, Araújo e Vargas (2012), revela-se como um fator diretamente incisivo para um mau prognóstico. 
Tabela 9. Óbitos de acordo com a raça/etnia.

\begin{tabular}{lcc}
\hline Raça/etnia & Óbitos & $\%$ \\
\hline Branca & 10.156 & $40 \%$ \\
Preta & 1.829 & $7,2 \%$ \\
Parcla & 8.023 & $31,5 \%$ \\
Amarela & 295 & $1,1 \%$ \\
Indigena & 6 & $0,1 \%$ \\
Sem informação & 5.126 & $20,1 \%$ \\
\hline
\end{tabular}

Fonte: Dados do DataSUS (2020) compilados na pesquisa.

Relacionando-se a raça/etnia e os óbitos, observada na tabela 9, percebe-se o elevado número de homens brancos que são acometidas pela doença também constitui a elevada parcela que mais evolui para óbitos durante o período analisado, com um total de $40 \%$ dos casos que cursaram com a morte.

\begin{tabular}{lc}
$\begin{array}{l}\text { Tabela 10. Internações por } \mathrm{CP} \text { conforme a região e } \\
\text { taxa de óbitos. }\end{array}$ & Taxa de óbitos \\
\hline Região & $13,22 \%$ \\
\hline Norte & $8,06 \%$ \\
Nordeste & $8,80 \%$ \\
Sudeste & $9,88 \%$ \\
Sul & $10,35 \%$ \\
Centro-Oeste
\end{tabular}

Fonte: Dados do DataSUS (2020) compilados na pesquisa.

Dos óbitos distribuídos pelas regiões do Brasil associadas à ocorrência do câncer de próstata durante a última década, presente na tabela 10 , verifica-se o destaque da região Norte que concentra o maior número de óbitos, com taxa de $13,22 \%$, e da região Centro-Oeste, com total de 10,45\% dos casos. Assim, observa-se que mesmo que o maior número de casos seja registrado nas regiões Sudeste e Nordeste, presente na tabela 3, a maior taxa de óbitos ocorre no Norte do país e na região Centro-Oeste que são as áreas menos povoadas do Brasil. Dessa forma, pode-se inferir que a mortalidade pode estar fortemente relacionada às características socioeconômicas dessas localidades conforme o abordado por Santos (2018) e Rawla (2019), cujas discussões trazem, a esse contexto, o peso dos fatores socioeconômicos na ocorrência da neoplasia maligna da próstata.

\section{CONCLUSÃO}

Podemos concluir com o presente estudo que o câncer de próstata (CP), adenocarcinoma prostático, ainda pode ser referido como uma problemática que interfere na saúde do homem brasileiro, ainda que os avanços nas técnicas de detecção não possibilitaram um domínio sobre a causa dessa patologia, apenas hipóteses relacionadas aos fatores de riscos associados.

Com essa ferramenta, constatou-se que durante os últimos 10 anos no Brasil, ocorreram 281.950 internações por neoplasia da próstata, observando-se uma progressão de casos de CP, uma 
maior incidência em 2019 e períodos de crescimento destacáveis (como entre 2018 e 2019). Sendo assim, tais estatísticas reafirmam que o número de internações por CP ainda é elevado no Brasil, o que mostra a importância de realização de busca ativa dessas lesões para que se alcance uma abordagem rápida e eficaz nos casos de $\mathrm{CP}$.

Dos perfis dessas internações, apontou-se uma maioria delas como eletivas, destacando o diagnóstico cada vez mais precoce dos casos. Além disso, verificou-se a prevalência da região Sudeste, seguida pelo Nordeste, as duas regiões mais populosas do país. Em sua maioria, foram homens brancos e pardos, dados que não concordaram do exposto na literatura; e acomete os pacientes majoritariamente a partir dos 60 anos, o que confirmou o peso da senilidade na patologia da doença.

Destacou-se, ainda, o número de óbitos, constatando-se que ocorreram 25.435 mortes por CP, mostrando uma mortalidade de $9,5 \%$, cujos números acompanharam o aumento gradativo do número de casos nesse período, abrindo uma exceção para a redução de 1,9\% de 2019 em comparação com o ano anterior. Ao associar os óbitos e faixa etária, percebeu-se que os indivíduos entre 70 e 79 anos portadores de câncer de próstata evoluem para óbito com maior frequência do que os demais, com uma taxa de 37,9\%. Ademais, notou-se uma quantidade de casos semelhantes presentes em indivíduos com 80 ou acima de 80 anos, 30,275\% dos afetados, e aqueles entre 60 e 69 anos, com 23,9\%. De modo geral, esses dados revelam das pessoas afetadas por esse tipo de neoplasia maligna, os idosos formam o grupo mais suscetível à morte do que os demais.

Considerando-se os óbitos distribuídos pelas regiões do Brasil associadas à ocorrência de $\mathrm{CP}$, observou-se que mesmo com o maior número de casos registrados nas regiões Sudeste e Nordeste, as maiores taxas de óbito ocorre no Norte e no Centro-Oeste país, que são as áreas menos povoadas do Brasil. Dessa forma, pode-se inferir que a mortalidade pode estar fortemente às características socioeconômicas dessas localidades.

Portanto, espera-se que esse trabalho possibilite a contribuição no cenário dos estudos epidemiológicos, com a abordagem não somente numérica, mas ostensivamente aplicada nas em políticas públicas de prevenção, diagnóstico e tratamento.

\section{REFERÊNCIAS}

Abreu, D. M. X. et al. O Impacto da Correção dos Dados na Mortalidade Prematura por Câncer de Próstata, Brasil, 1996-2011. Revista Brasileira de Cancerologia, v.62 n.2, p. 147-154, 2016.

Brasil. Ministério da Saúde. Banco de dados do Sistema Único de Saúde - DATASUS, Sistemas de Informações Hospitalares (SIH). Disponível em: $<$ http://tabnet.datasus.gov.br/cgi/tabcgi.exe?sih/cnv/niuf.def $>$. Acesso em: 27 jun. 2020.

Bray, F. et al. Global cancer statistics 2018: GLOBOCAN estimates of incidence and mortality worldwide for 36 cancers in 185 countries. ACS Journals, v. 68, p. 394-424, 2018.

Filippi, Renée Zon. Patologia do câncer de próstata - Quais as informações críticas para o manejo do paciente? In: IX Congresso Internacional de Uro-Oncologia. São Paulo, 2018. 
Friestino, J. K. O. et al. Mortalidade por Câncer de Próstata no Brasil: contexto histórico e perspectivas. Revista Baiana de Saúde Pública, v. 37, p. 688-701, 2018.

Heidenreich, A. et al. Therapies used in prostate cancer patients by European urologists: data on indication with a focus on expectations, perceived barriers and guideline compliance related to the use of bisphosphonates. Karger, Basel, v. 89(1), p. 30 - 38.

INCA. Instituto Nacional do Câncer. Coordenação de Prevenção e Vigilância. Estimativa 2020: incidência de câncer no Brasil. Rio de Janeiro, RJ, 2019.

Kumar, V. et al. Robbins e Cotran Patologia Bases Patológicas das Doenças. Elsevier Editora Ltda, Rio de Janeiro, RJ, 2010.

Ministério da Saúde, Instituto Nacional do Câncer. ABC do Câncer: Abordagens Básicas para o Controle do Câncer. INCA. Rio de Janeiro, 2011.

RAWLA, P. Epidemiology of Prostate Cancer. World Jounal of Oncology, Ontario, v.10(2), p. 63 - 89.

SANTOS, M. DE O. Estimativa 2018: Incidência de Câncer no Brasil. Revista Brasileira de Cancerologia, v. 64, n. 1, p. 119-120, 30 mar. 2018. 


\section{EPIDEMIOLOGIA DAS INTERNAÇÕES POR LINFOMA DE HODGKIN DURANTE A ÚLTIMA DÉCADA NO BRASIL}

MATHEUS DOS SANTOS DO

NASCIMENTO CARVALHO

Universidade Estadual de Ciências da Saúde de

Alagoas

CAMILA MARIA BEDER RIBEIRO GIRISH PANJWANI

Universidade Estadual de Ciências da Saúde de Alagoas

ANA CLÁUDIA DA SILVA FERNANDES DUARTE

Universidade Estadual de Ciências da Saúde de Alagoas

ANA KELLY DA SILVA FERNANDES

DUARTE

Universidade Estadual de Ciências da Saúde de Alagoas

ANTONIO PAULO REIS DE AMORIM

LISBOA

Universidade Estadual de Ciências da Saúde de Alagoas

DAVI WESLEY RAMOS DO NASCIMENTO

Universidade Estadual de Ciências da Saúde de Alagoas

FLAVIA DANIELLE SOUZA DE VASCONCELOS

Universidade Estadual de Ciências da Saúde de Alagoas

RAFAEL RAGAZZI DE MORAES

Universidade Estadual de Ciências da Saúde de

Alagoas
RESUMO: O linfoma de Hodgkin é das neoplasias mais comuns em jovens e adultos, marcada pelas células de Reed-Sternberg, originadas de mutações de células $\mathrm{B}$ e com diversas causas como infecção por Epstein-Barr vírus e estado de imunossupressão. Destaca-se por apresentar diversos tipos de acordo com a imunofenotipagem das células $\mathrm{RS}$ e da análise histológica. Caracteriza-se por apresentar linfonodos aumentados e que a depender da evolução da doença, pode partir dos linfonodos para outras regiões linfáticas, como baço e medula óssea. Sua ação constitui em interagir com células do sistema imune através de citocinas liberadas por células RS, o que gera os filtrados linfocitários. A perspectiva é que acometa mais de 2000 pessoas no triênio 2020-2022. Na análise dos dados do Datasus, constata-se na última década 42.681 internações por tal linfoma, sendo 2019 o ano com maior número de internações e com aumento de $9,75 \%$ entre 2018 e 2019 . Foi perceptível que mais da metades dos casos desse linfoma foram de caráter de urgência. Nesse período de tempo analisado, houve uma mortalidade de $4,7 \%$, embora tenha ocorrido uma redução da mortalidade nos últimos 4 anos. Ademais, quanto ao gênero, mais de $50 \%$ das internações foram de pessoas masculinas, e quanto à etnia, a branca foi a mais afetada, de modo a ser quase a metade dos pacientes $(45,11 \%)$. A idade em que mais prevaleceram os casos foi entre 20 e 29 anos, mas as maiores taxas de óbito foram na faixa de 50 a 59 anos. Por fim, a região Sudeste apresentou o maior número de internações (49,1\% dos casos), embora a região Norte tenha sido a que apresentou maior taxa de óbitos $(7,33 \%)$.

PALAVRA-CHAVE: Linfoma de Hodgkin; Células RS; Neoplasia; Epidemiologia. 


\begin{abstract}
Hodgkin's lymphoma is one of the most common neoplasms in young people and adults, marked by Reed-Sternberg cells, originated from B-cell mutations and with several causes such as Epstein-Barr virus infection and immunosuppression conditions. It is known for presenting different types according to the immunophenotyping of RS cells and histological analysis. It is characterized by presenting enlarged lymph nodes and depending on the evolution of the disease, may spread from the lymph nodes to other lymphatic regions, such as the spleen and bone marrow. Its action constitutes interaction with cells of the immune system through cytokines released by RS cells, which generates lymphocyte filtrates. The perspective is that it affects more than 2,000 people in the 2020-2022 period. In the analysis of Datasus data, 42,681 hospitalizations for such lymphoma have been observed in the last decade, and 2019 was the year with the highest number of hospitalizations, beside that, there was an increase of $9.75 \%$ of cases between 2018 and 2019. It was noticeable that more than half of the cases of this lymphoma were urgent. During this period of time analyzed, there was a mortality of $4.7 \%$, although there was a reduction in mortality in the last 4 years. In addition, regarding gender, more than $50 \%$ of hospitalizations were male, and regarding ethnicity, the most affected, in order to be almost half of the patients (45.11\%). The age at which cases most prevalent was between 20 and 29 years old, but the highest death rates were in the range of 50 to 59 years. Finally, the Southeast region has the highest number of hospitalizations (49.1\% of cases), although the North region was the one with the highest rate of deaths $(7.33 \%)$.
\end{abstract}

KEYWORDS: Hodgkin's lymphoma; RS cells; Neoplasia; Epidemiology.

\title{
1. INTRODUÇÃO
}

O linfoma de Hodgkin é uma neoplasia caracterizada pela formação de uma massa tumoral que envolve os tecidos linfóides. É uma das formas mais comuns de neoplasias com melhores prognósticos se comparada a outras formas de câncer (MONTEIRO et al., 2016).

Essa doença se diferencia dos outros linfomas não Hodgkin por possuir aspectos peculiares. Dentre eles, há a localização do linfoma que possui preferência pelos grupos axiais de gânglios linfáticos, como os da cervical e mediastinal; sua disseminação é ordenada e padronizada, de modo que sua propagação começa em um linfonodo e segue para tecidos linfoides anatomicamente contíguos e, em condições de pior prognóstico, ocorre o acometimento do baço, fígado, e por fim da medula óssea e outros tecidos (KUMAR; ABBAS; ASTER, 2016).

Como principais sinais e sintomas verifica-se os linfonodos aumentados, principalmente nas regiões cervical, axilar ou inguinal, seguido de febre, suor noturno, perda de peso, baço e fígado aumentados, bem como anergia cutânea (SHANBHAG; AMBINDER, 2017).

As causas desse tipo de neoplasia ainda são desconhecidas, porém, presume-se que fatores como história familiar, doenças autoimunes, estado de imunossupressão do paciente, como ao receber algum órgão transplantado, exposição à radiação e, sobretudo, contato com alguma doença infecciosa, como o Epstein-Barr vírus, são prováveis causas (MONTEIRO et al., 2016).

Sabe-se ainda que o linfoma de Hodgkin se divide em 2 grupos: a clássica, formada por 4 subgrupos, e a predominância linfocitária. A diferença entre esses 2 grandes grupos se baseia em análises imunofenotípicas de suas típicas células mutantes RS (células de Reed-Sternberg), já que é 
constatado que tais células possuem origem de células B do centro germinativo que sofreram mutações envolvendo a ativação de fatores de transcrição NF-kB (KNOWLES, 2001).

As células RS costumam atuar produzindo citocinas e quimiocinas que atraem as células linfocitárias do distema imune para o local do tumor. Tais células de defesa interagem com determinados receptores da célula RS, como o CD-30 o que favorece ainda mais seu crescimento. Outra ação da célula típica do linfoma de Hodgkin é estimular a produção de linfócitos reguladores e suprimir a supressão de linfócitos TH1 e citotóxicos, o que provoca uma imunodeficiência. (VARDHANA; YOUNES, 2016)

O linfoma de Hodgkin clássico pode ser dividido em 4 tipos. O primeiro, denominado esclerose nodular, é caracterizado por células RS lacunares e pela formação de fibras colágenas que separam a massa tumoral em nódulos, além disso, esse tipo também é o mais comum de linfoma de Hodgkin (TOWNSEND; LINCH, 2012). Outro tipo é a celularidade mista, formada por células RS mononucleares e possui uma grande relação com o Epstein-Barr vírus. O terceiro tipo é composto por infiltrados ricos em linfócitos. Por fim, há a depleção linfocitária, na qual há a abundância das células RS e suas variações, além de ser a forma que apresenta o pior prognóstico comparado aos demais (KUMAR; ABBAS; ASTER, 2016).

Os métodos de tratamento disponíveis se baseiam nas aplicações de radioterapia e quimioterapia com esquema de ciclos de ABVD, por exemplo (SPECTOR, 2009). Tais procedimentos, apesar de elevadas taxas de sucesso, ainda encaram certos problemas devido à ausência de um padrão de tratamento para todas as idades, bem como pelo fato de tais tratamentos serem capazes de gerar danos secundários aos pacientes, como os casos de formação de tumores secundários pós-tratamento (KUMAR; ABBAS; ASTER, 2016).

Mesmo por se tratar de uma neoplasia com bons prognósticos, caso diagnosticada precocemente, o linfoma de Hodgkin ainda é uma doença que merece atenção, haja vista que essa patologia apresentou 79.990 novos casos e 26.167 mortes no mundo inteiro, apenas em 2018. Outrossim, houve um crescimento nos números de casos globais, de maneira que em 1990, houve 72.937 casos, enquanto em 2017, houve 101.133. A incidência mostrou uma distribuição bimodal com valores de pico em pacientes com idades entre 20 e 39 anos e pacientes com 60 anos ou mais (ZHOU et al., 2019).

Enquanto, no Brasil, há estimativas de para cada ano do triênio 2020-2022, um número de 1.590 casos em homens e de 1.050 em mulheres. Esses valores correspondem a um risco estimado de 1,52 casos novos a cada 100 mil homens e de 0,95 a cada 100 mil mulheres (INCA, 2019). Além disso, por ser uma doença que varia sua incidência e seu subtipo entre os países desenvolvidos e em desenvolvimento, essa patologia apresenta uma grande variação de incidência no que se refere à idade, estado de saúde, gênero, etnicidade e localização geográfica dos pacientes (SALATI et al., 2014).

Para cada uma dessas variáveis há um índice de risco diferente, como, por exemplo, o caso dos pacientes imunossuprimidos, como HIV, em que o linfoma de Hodgkin não tem um bom prognóstio. Outro fator influenciado pela variação do paciente é a aplicação de métodos diferentes de tratamento a depender da idade, como idosos ao receberem determinados níveis de radiação na radioterapia (SPECTOR, 2009). 
Por todo o exposto, é perceptível que, apesar de ser uma neoplasia controlada, o linfoma de Hodgkin é frequente e deve ser monitorado, o que exige estudos epidemiológicos dos casos de internação na última década, a fim de orientar os profissionais de saúde para o conhecimento dos pacientes acometidos por tal linfoma e garantir melhores métodos de prevenção e tratamento.

\section{MATERIAL E MÉTODOS}

Sucedeu-se um estudo exploratório com dados secundários, obtidos pelo Sistema de Informações Hospitalares do SUS (SIH) do DataSUS, sobre a epidemiologia das internações por linfoma de Hodgkin em estabelecimentos públicos e privados durante o período de 2010 a 2019. Ao obter os dados, foram analisadas as seguintes variantes: internação, caráter de atendimento, regiões do país, sexo, raça/etnia, faixa etária e número de óbitos.

\section{RESULTADOS E DISCUSSÃO}

Mediante a análise dos dados, verificou-se que durante a última década (janeiro de 2010 a dezembro de 2019), no Brasil, ocorreram 42.681 internações por doença de Hodgkin. A tabela 1 expõe como esse total se distribui durante o período analisado.

\begin{tabular}{lc}
$\begin{array}{l}\text { Tabela 1. Internações } \\
\text { processamento. }\end{array}$ & conforme \\
\hline Ano & Casos \\
\hline 2010 & 3.169 \\
2011 & 3.594 \\
2012 & 4.047 \\
2013 & 4.207 \\
2014 & 4.140 \\
2015 & 3.910 \\
2016 & 4.343 \\
2017 & 4.756 \\
2018 & 4.988 \\
2019 & 5.527 \\
\hline
\end{tabular}

Através da análise dos dados presentes na tabela 1 acima, observa-se um aumento progressivo com o passar dos anos do número de internações por doença de Hodgkin, no qual observa-se uma maior incidência no ano de 2019. Pode-se notar, ainda que ocorreu um aumento de 9,75\% entre os anos de 2018 e 2019. Esse elevado registro de internações pode ser explicada pela ampliação do acesso à exames diagnósticos, bem como, pelo aumento de pacientes identificados em estágios avançados da doença, nos quais necessitam de imediata intervenção médica. 


\begin{tabular}{llc}
\hline Ano & Eletivo & Urgência \\
\hline 2010 & 1.283 & 1.886 \\
2011 & 1.459 & 2.135 \\
2012 & 1.646 & 2.401 \\
2013 & 1.744 & 2.463 \\
2014 & 1.719 & 2.421 \\
2015 & 1.640 & 2.270 \\
2016 & 1.801 & 2.542 \\
2017 & 1.866 & 2.890 \\
2018 & 2.067 & 2.921 \\
2019 & 2.470 & 3.057 \\
\hline Total & 17.695 & 24.986 \\
\hline
\end{tabular}

Verificando-se o caráter de atendimento das internações, confirma-se não apenas o crescimento da quantidade de casos graves, mas também de casos de pacientes que precisam de atendimento de urgência. Dessa forma, infere-se, de modo geral, que do total de atendimentos hospitalares $58,6 \%$ das ocorrências foram de urgência. Além disso, 2019 se sobressai com o maior número de casos registrados, com um aumento de 4,5\% em relação à 2018 .

Tabela 3. Internações conforme a região e o ano de processamento.

\begin{tabular}{lcc}
\hline Região & Casos & $\%$ \\
\hline Norte & 1.610 & $3,78 \%$ \\
Nordeste & 9.759 & $22,9 \%$ \\
Sudeste & 20.959 & $49,1 \%$ \\
Sul & 7.574 & $17,7 \%$ \\
Centro-Oeste & 2.779 & $6,52 \%$ \\
\hline
\end{tabular}

Atentando-se para regiões do país associada à ocorrência do linfoma de Hodgkin durante a última década, presente na tabela 3, verifica-se o destaque da região Sudeste concentrando o maior número de casos, taxa de 49,1\%. Seguida pela região Nordeste com 22,9\%. A região Sudeste se destaca com maior número de casos por ser a região mais populosa do país, assim como a região Nordeste, configurada como a segunda região mais populosa do Brasil.

Tabela 4. Sexo dos individuos com doença de Hodgkin.

\begin{tabular}{lcc}
\hline Sexo & Casos & Percentual \\
\hline Feminino & 18.998 & $44,5 \% \%$ \\
Masculino & 23.683 & $55,5 \%$ \\
\hline
\end{tabular}

Quanto às informações relacionadas ao sexo dos pacientes, presentes na tabela 4 , observa-se a prevalência de casos no sexo masculino, assim como verificado na literatura. 


\begin{tabular}{lcc}
\hline Raça/etnia & Casos & $\%$ \\
\hline Branca & 19.260 & $45,1 \%$ \\
Preta & 1.511 & $3,6 \%$ \\
Parda & 13.553 & $31,75 \%$ \\
Amarela & 473 & $1,1 \%$ \\
Indigena & 27 & $0,05 \%$ \\
Sem informação & 7.857 & $18,4 \%$ \\
\hline
\end{tabular}

Quanto a relação dessa doença com a raça/etnia, presente na tabela 5, nota-se o elevado número de indivíduos brancos como principais afetadas, com taxa de 45,1\% dos casos. Além disso, verifica-se os pardos como segundos mais afetada, com taxa de $31,75 \%$ do total.

Tabela 6. Casos de doença de Hodgkin conforme a faixa etária.

\begin{tabular}{lcc}
\hline Idade & Casos & $\%$ \\
\hline $0-9$ & 2.570 & $6,0 \%$ \\
$10-19$ & 9.598 & $22,5 \%$ \\
$20-29$ & 10.692 & $25,05 \%$ \\
$30-39$ & 7.260 & $17,0 \%$ \\
$40-49$ & 4.102 & $9,6 \%$ \\
$50-59$ & 3.730 & $8,7 \%$ \\
$60-69$ & 2.862 & $6,7 \%$ \\
$70-79$ & 1.450 & $3,4 \%$ \\
80 ou mais & 417 & $1,05 \%$ \\
\hline
\end{tabular}

Atentando-se para os dados da tabela 6, é possível notar uma concentração de casos nas faixa etárias entre 20 e 29 anos que possuem um total de $25,05 \%$ dos doentes. Contudo, verifica-se uma quantidade de casos semelhantes presentes na faixa etária entre 10 e 19 anos, com 22,5\% dos afetados. De forma genérica, esses dados mostram uma ocorrência dessa doença em indivíduos pré-adolescentes, adolescentes e jovens adultos.

Em relação aos óbitos, verifica-se que ocorreram 2.009 mortes por neoplasia de Hodgkin. A mortalidade observada nesse período é de $4,7 \%$. 


\begin{tabular}{lc}
\hline Ano & Casos \\
\hline 2010 & 188 \\
2011 & 178 \\
2012 & 232 \\
2013 & 199 \\
2014 & 201 \\
2015 & 200 \\
2016 & 235 \\
2017 & 191 \\
2018 & 187 \\
2019 & 198 \\
\hline Total & 2.009 \\
\hline
\end{tabular}

Pautando-se nos dados expostos na tabela 7, observa-se que a quantidade de óbitos por neoplasia de Hodgkin sofrem alterações de crescimento e decrescimento durante os últimos 10 anos analisados. Todavia, quando verifica-se os últimos 4 anos, observa-se uma redução do número de mortes, é possível perceber um decrescimento de 15,7\% se comparar os anos de 2016, ano que registra o maior número de casos, com o ano de 2019, último ano analisado.

\begin{tabular}{|c|c|c|}
\hline Idade & Casos & $\%$ \\
\hline $0-9$ & 42 & $2,1 \%$ \\
\hline $10-19$ & 140 & $7 \%$ \\
\hline $20-29$ & 312 & $15,5 \%$ \\
\hline $30-39$ & 320 & $16 \%$ \\
\hline $40-49$ & 247 & $12,3 \%$ \\
\hline $50-59$ & 323 & $16,1 \%$ \\
\hline $60-69$ & 299 & $15 \%$ \\
\hline $70-79$ & 237 & $11,8 \%$ \\
\hline 80 ou mais & 89 & $4,2 \%$ \\
\hline
\end{tabular}

Associado-se as variáveis óbitos e faixa etária, contidos na tabela 8 , infere-se que os indivíduos entre 50 e 59 anos portadores da doença de Hodgkin evoluem para óbito com maior frequência do que os demais, com uma taxa de 16,1\%. Além disso, observa-se uma quantidade de casos semelhantes presentes na faixa etária entre 30 e 39 anos, com 16\% dos afetados, e as pessoas entre 20 e 29 anos, com 15,5\%. De modo geral, esses dados mostram que mesmo que essa doença atinja pré-adolescentes, adolescentes e jovens adultos, os indivíduos que mais morrem são as pessoas de meia idade, adultos e jovens, respectivamente. 
Tabela 9. Internações conforme a região e taxa de óbitos.

\begin{tabular}{lc}
\hline Região & Taxa de óbitos \\
\hline Norte & $7,33 \%$ \\
Nordeste & $4,85 \%$ \\
Sudeste & $4,58 \%$ \\
Sul & $4,44 \%$ \\
Centro-Oeste & $4,43 \%$ \\
\hline
\end{tabular}

Considerando-se os óbitos distribuídos pelas regiões do Brasil associadas à ocorrência do linfoma de Hodgkin durante a última década, presente na tabela 9, observa-se o destaque da região Norte concentrando o maior número de óbitos, com taxa de 7,33\%. Dessa maneira, verifica-se mesmo que o maior número de casos seja registrado nas regiões Sudeste e Nordeste, a maior taxa de óbitos ocorre no Norte do país, quarta área mais populosa do país, o que pode estar fortemente associado às características socioeconômicas da localidade.

\section{CONCLUSÃO}

Por todo o exposto, é perceptível que, apesar de ser uma neoplasia controlada, o linfoma de Hodgkin é frequente e deve ser monitorado, o que exige estudos epidemiológicos dos casos de internação na última década, a fim de orientar os profissionais de saúde para o conhecimento dos pacientes acometidos por tal linfoma e garantir melhores métodos de prevenção e tratamento. Sendo assim, tais estatísticas reafirmam que o número de internações por LH ainda é elevado no Brasil, o que mostra a importância de realização de estudos de perfil epidemiológico para a elaboração de campanhas focadas para a população mais acometida por essa enfermidade.

\section{REFERÊNCIAS}

INSTITUTO NACIONAL DE CÂNCER JOSÉ ALENCAR GOMES DA SILVA. Coordenação de Prevenção e Vigilância. Estimativa 2020: Incidência de câncer no Brasil. Rio de Janeiro, 2019.

KNOWLES, Daniel. Neoplastic Hematopathology. 2.ed. Philadelphia: Lippincott Williams \& Wilkins, 2001.

KUMAR, Vinay; ABBAS, Abul K.; ASTER, Jon C. Robbins \& Cotran - Patologia: Bases Patológicas Das Doenças. 9.ed. Rio de Janeiro: Elsevier Editora Ltda., 2016.

MONTEIRO, Talita Antonia Furtado et al . Linfoma de Hodgkin: aspectos epidemiológicos e subtipos diagnosticados em um hospital de referência no Estado do Pará, Brasil. Rev Pan-Amaz Saude, Ananindeua, v. 7, n. 1, p. 27-31, mar. 2016 .

SALATI, Massimiliano et al. Epidemiological Overview of Hodgkin Lymphoma across the Mediterranean Basin. Mediterr J Hematol Infect Dis., v. 6, n. 1, jul. 2014. 
SHANBHAG, Satish; AMBINDER, Richard. Hodgkin Lymphoma: a review and update on recent progress. CA Cancer J Clin., v. 68, n. 2, p. 116-132, dec. 2017.

SPECTOR, Nelson. Linfoma de Hodgkin: aspectos atuais. Rev. Bras. Hematol. Hemoter., São Paulo, v. 31, supl. 2, p. 3-6, aug. 2009.

TOWNSEND, WILLIAM; LINCH, David. Hodgkin's lymphoma in adults. The Lancet, v. 380, p. 836-847, set. 2012.

VARDHANA, Santosha; YOUNES, Anas. The immune microenvironment in Hodgkin lymphoma: T cells, B cells and immune checkpoints. Haematologica, v. 101, n. 7, p. 794-802, jul. 2016.

ZHOU, Linghui et al. Global, regional, and national burden of Hodgkin lymphoma from 1990 to 2017: estimates from the 2017 Global Burden of Disease study. J Hematol Oncol, v. 12, out. 2019 


\section{EPIDEMIOLOGIA DAS INTERNAÇÕES POR NEOPLASIA MALIGNA DE ESÔFAGO DURANTE A ÚLTIMA DÉCADA NO BRASIL}

ZION CARVALHO DA SILVA Universidade Estadual de Ciências da Saúde de Alagoas

\section{ANA CLÁUDIA DA SILVA FERNANDES}

DUARTE

Universidade Estadual de Ciências da Saúde de Alagoas

JOSÉ JOÃO FELIPE COSTA DE OLIVEIRA

Universidade Estadual de Ciências da Saúde de Alagoas

GABRIEL JOSÉ TORRES DA SILVA Universidade Estadual de Ciências da Saúde de Alagoas

RENATA LINS WANDERLEY

Universidade Estadual de Ciências da Saúde de Alagoas

EMANNUELA BERNARDO DA SILVA Universidade Estadual de Ciências da Saúde de Alagoas

AMANDA ARAÚJO SOUZA Universidade Estadual de Ciências da Saúde de Alagoas

CAMILA MARIA BEDER RIBEIRO GIRISH PANJWANI

Universidade Estadual de Ciências da Saúde de Alagoas

RESUMO: O câncer de esôfago (CE) é um tipo agressivo de neoplasia maligna. Ele difere histologicamente entre carcinoma epidermoide es- camoso (CEE) e adenocarcinoma (AC). É relativamente incomum, porém por ser uma doença de difícil diagnóstico costuma apresentar um alto grau de letalidade. No Brasil as neoplasias esofágicas atingem duas vezes mais o sexo masculino em relação ao sexo feminino. Dessa forma, o trabalho objetivou analisar a frequência de internações no país derivadas de CE. Realizou-se um estudo exploratório, em que os dados foram extraídos do Sistema de Informações Hospitalares do SUS. Com base na análise desses dados, constatou-se que na última década (Janeiro de 2010 até dezembro de 2019) houve um aumento discreto nas internações por CE. Por meio do estudo, também foi possível identificar um aumento de internações sobretudo em caráter de urgência. Esses dois últimos fatos sendo explicados tanto pela identificação tardia, quanto pela ampliação do acesso aos exames diagnósticos. A região brasileira mais afetada é a Sudeste, fato esse explicado pelo maior número absoluto da população nesse território. Destacou-se também a região Sul, com o segundo maior número de casos. A correlação com esse fato se dá pelo fator de risco que envolve a ingestão de bebidas quentes, tanto por aspectos culturais, como por condições climáticas que favorecem esse tipo de prática. Além disso, os dados também revelaram que os indivíduos mais suscetíveis ao óbito, decorrente de CE, são os de idade mais avançada. Sendo assim, tais estatísticas reafirmam a importância de um abordagem rápida e eficaz em se tratando de neoplasias que atingem o esôfago.

PALAVRA-CHAVE: Epidemiologia; Câncer de esôfago; Hospitalização; Mortalidade. 
ABSTRACT: Esophageal cancer (EC) is an aggressive type of malignant neoplasm. It differs histologically between squamous cell carcinoma (ESCC) and adenocarcinoma (AC). It is relatively uncommon, but because it is a disease that is difficult to diagnose, it usually has a high degree of lethality. In Brazil, esophageal neoplasms affect twice as many men as compared to women. Thus, the work aimed to analyze the frequency of hospitalizations in the country derived from EC. An exploratory study was carried out, in which the data were extracted from the SUS Hospital Information System. Based on the analysis of these data, it was found that in the last decade (January 2010 to December 2019) there was a slight increase in hospitalizations for EC. Through the study, it was also possible to identify an increase in hospitalizations, especially on an urgent basis. These last two facts are explained by both the late identification and the expansion of access to diagnostic tests. The most affected Brazilian region is the Southeast, a fact explained by the greater absolute number of the population in this territory. The South region also stood out, with the second highest number of cases. The correlation with this fact is due to the risk factor that involves the consumption of hot drinks, both for cultural aspects, as well as for climatic conditions that favor this type of practice. In addition, the data also revealed that the individuals most susceptible to death, due to EC, are those of older age. Thus, such statistics reaffirm the importance of a fast and effective approach when dealing with neoplasms that reach the esophagus.

KEYWORDS: Epidemiology; Esophageal cancer; Hospitalization; Mortality.

\section{INTRODUÇÃO}

O câncer de esôfago (CE) é um tipo de neoplasia maligna agressiva e relativamente incomum, mas extremamente letal devido a sua dificuldade diagnóstica (Queiroga e Pernambuco, 2006). No Brasil, ocupa o sexto lugar na frequência entre os homens e o $15^{\circ}$ entre as mulheres, exceto o câncer de pele não melanoma. Nos homens a incidência é aproximadamente duas vezes maior do que em mulheres (INCA,2020). Além disso, é crescente o número de casos de CE no Brasil.

Histologicamente, o CE pode ser classificado em dois subtipos: o carcinoma epidermoide escamoso (CEE) - Responsável por cerca de 96\% dos casos - e o adenocarcinoma (AC) o qual está em crescente aumento e está mais relacionado a porção distal do esôfago (Brasil, 2018).

Em se tratando da etiologia, o CEE apresenta uma diversidade de fatores de risco. Alguns deles são: idade, histórico familiar, associação genética e causas extrínsecas. Entre essas últimas, estão a ingestão de bebidas muito quentes -- chimarrão, chás, café, em temperaturas de $65^{\circ} \mathrm{C}$ ou mais --, etilismo em qualquer nível, tabagismo - isoladamente responsável por $25 \%$ dos casos de CE --, uso de nitrosaminas e aflotoxinas, infecções locais por fungos e deficiência de riboflavina e vitamina A. Ademais, alguns fatores ocupacionais como exposição em longo prazo à poeira de sílica, metais e hidrocarbonetos aromáticos têm sido estudados como fatores de risco nesse tipo de câncer (Monteiro et al., 2009; INCA, 2020).

Já a fisiopatologia do AC esofágico, está vinculada ao aumento das taxas de obesidade nos países ocidentais, além do crescente casos da doença do refluxo gastroesofágico (DRGE). A DRGE é responsável direta por causar AC de esôfago, ou quando em associação ao Esôfago de Barrett (EB) uma lesão pré-maligna. Nas últimas três décadas o aumento da indigência de EB está correlacionada 
ao aumento de AC no mesmo período. Além disso, nos Estados Unidos, a incidência de AC nos homens é 8 vezes mais comum no sexo masculino em comparação ao sexo feminino. Já em relação a raça, os brancos apresentam 5 vezes mais chances de apresentar o AC. (Mohamed, e al., 2018; Domper et al., 2015).

A dificuldade do diagnóstico consiste no fato de que no início da doença o principal sintoma, a disfagia, não se manifesta até que o tumor tenha crescido de modo a causar obstrução do lúmen esofágico. Assim, instintivamente, os pacientes ajustam a dificuldade de deglutição ao trocar paulatinamente sua dieta de alimentos sólidos para líquidos, surgindo a perda de peso sem causa aparente. Com a progressão do aumento do tumor, dor e salivação excessivas são vistas. Alguns outros sintomas aos quais os médicos devem atentar são um desconforto retroesternal, sensação de corpo estranho no esôfago próxima, dor epigástrica, náuseas e perda sanguínea (Queiroga e Pernambuco, 2006; Monteiro et al., 2009; INCA, 2020).

Logo, este estudo objetivou analisar a frequência de internações, no Brasil, de casos de CE ao longo da última década por meio de análise epidemiológica, para elucidar os seus desdobramentos em âmbito nacional e, assim, trazer benefícios para os gestores, profissionais e usuários da saúde pública e privada do país.

\section{MATERIAL E MÉTODOS}

Foi realizado um estudo exploratório com dados secundários, cujos dados foram obtidos por meia da consulta à base de dados do Sistema de Informações Hospitalares do SUS (SIH/SUS) fornecidos pelo Departamento de Informática do Sistema Único de Saúde (DataSUS), no endereço eletrônico (http://tabnet.datasus.gov.br) que foi acessado 04/08/2020, sobre a epidemiologia das internações por neoplasia maligna de esôfago em estabelecimentos públicos e privados durante o período de 2010 a 2019.

Ao obter os dados, foram analisadas as seguintes variantes: internação, caráter de atendimento, regiões do país, raça/etnia, faixa etária e número de óbitos.

\section{RESULTADOS E DISCUSSÃO}

Diante da análise dos dados, verificou-se que durante a última década (janeiro de 2010 a dezembro de 2019), no Brasil, ocorreram 171.069 internações por neoplasia de esôfago. A tabela 1 abaixo mostra como esse total é distribuído entre os anos analisados. 
Tabela 1. Internações de acordo com o ano de processamento.

\begin{tabular}{ll}
\hline Ano & Casos \\
\hline 2010 & 15.187 \\
2011 & 15.343 \\
2012 & 16.467 \\
2013 & 17.003 \\
2014 & 17.393 \\
2015 & 17.555 \\
2016 & 17.371 \\
2017 & 17.912 \\
2018 & 18.024 \\
2019 & 18.814 \\
\hline
\end{tabular}

Fonte: DATA SUS (2020).

Por meio da análise dos dados presentes na tabela acima, observa-se um aumento discreto do número de internações por CE, no qual registra maior incidência no ano de 2019. Essa alta quantidade de internações pode ser explicada tanto pela ampliação do acesso aos exames diagnósticos, com também, pelo aumento de pacientes identificados em estágios avançados da doença, nos quais geralmente necessitam de intervenção médica imediata.

Tabela 2. Internações de acordo com o caráter de atendimento e ano de processamento.

\begin{tabular}{lll}
\hline Ano & Eletivo & Urgência \\
\hline 2010 & 4.345 & 10.842 \\
2011 & 4.390 & 10.953 \\
2012 & 4.606 & 11.861 \\
2013 & 4.754 & 12.249 \\
2014 & 4.560 & 12.833 \\
2015 & 4.694 & 12.861 \\
2016 & 4.393 & 12.978 \\
2017 & 4.712 & 13.200 \\
2018 & 4.661 & 13.363 \\
2019 & 4.858 & 13.956 \\
\hline Total & 45.973 & 125.096 \\
\hline
\end{tabular}

Fonte: DATA SUS (2020).

Ao verificar o caráter de atendimento das internações confirma-se não apenas o crescimento da quantidade de casos graves, mas também de pacientes que precisam de atendimento de urgência. Dessa maneira, constata-se, de modo geral, que do total de atendimentos hospitalares $73,12 \%$ das ocorrências foram de urgência. Além disso, o ano de 2019, o maior número de casos com um aumento de $4,3 \%$ em relação à 2018 . 
Tabela 3. Internações de acordo com a região (2010-2019).

\begin{tabular}{ll}
\hline Região & Casos \\
\hline Norte & 3.607 \\
Nordeste & 27.767 \\
Sudeste & 85.674 \\
Sul & 45.033 \\
Centro-Oeste & 8.988 \\
\hline
\end{tabular}

Fonte: DATA SUS (2020).

Examinando as regiões do país associada à ocorrência do CE durante a última década, presente na tabela 3, observa-se o destaque da região Sudeste concentrando o maior número de casos, com taxa de $50,0 \%$ do total. Seguida pela região Sudeste com $26,32 \%$. A região Sudeste se sobressai com maior número de casos por ser a região mais populosa do país. Já o surgimento do Sul como a segunda região mais frequente de casos pode ser explicada mediante a associação de fatores, dos quais a causa extrínseca, como a alta ingestão de bebidas muito quentes em temperaturas acima de $65^{\circ} \mathrm{C}$, como chimarrão, chás e café. Sendo o estado do Rio Grande do Sul o que apresenta o maior número de casos no país.

Tabela 4. Internações de acordo com a raça/etnia (2010-2019).

\begin{tabular}{lll}
\hline Raça/etnia & Casos & $\%$ \\
\hline Branca & 69.469 & $40,6 \%$ \\
Preta & 12.190 & $7,12 \%$ \\
Parda & 59.336 & $34,7 \%$ \\
Amarela & 1.505 & $0,9 \%$ \\
Indígena & 47 & $0,03 \%$ \\
Sem informação & 28.522 & $16,65 \%$ \\
\hline
\end{tabular}

Fonte: DATA SUS (2020).

Em relação à raça/etnia, observada na tabela 4, percebe-se o elevado número indivíduos brancos como principais afetadas, com taxa de $40,6 \%$ dos casos. Além disso, verifica-se os pardos ocupando o segundo lugar de etnia mais afetada com taxa de $34,7 \%$ do total.

Tabela 5. Casos de CE de acordo com a faixa etária. (2010-2019)

\begin{tabular}{lll}
\hline Idade & Casos & Percentual \\
\hline $0-9$ & 755 & $0,44 \%$ \\
$10-19$ & 530 & $0,31 \%$ \\
$20-29$ & 1.175 & $0,7 \%$ \\
$30-39$ & 3.497 & $2,04 \%$ \\
$40-49$ & 20.220 & $11,8 \%$ \\
$50-59$ & 52.168 & $30,5 \%$ \\
$60-69$ & 52.431 & $30,7 \%$ \\
$70-79$ & 30.187 & $17,6 \%$ \\
80 ou mais & 10.106 & $5,91 \%$ \\
\hline
\end{tabular}

Fonte: DATA SUS (2020). 
Observando as tabela 5, percebe-se uma concentração do número de casos nas faixa etárias entre 60 e 69 anos que possuem um total de 30,7\% dos doentes. Todavia, nota-se uma quantidade de casos semelhantes presentes na faixa etária entre 50 e 59 anos, com 30,5\%. De modo geral, esses dados revelam a ocorrência dessa doença em indivíduos de meia idade e idosos.

Quanto aos óbitos, observa-se que ocorreram 27.539 mortes por CE. A mortalidade verificada nesse período é de $16,1 \%$.

Tabela 6. Óbitos por CE de acordo com o ano de processamento.

\begin{tabular}{ll}
\hline Ano & Casos \\
\hline 2010 & 2.390 \\
2011 & 2.447 \\
2012 & 2.583 \\
2013 & 2.748 \\
2014 & 2.768 \\
2015 & 2.966 \\
2016 & 2.867 \\
2017 & 2.853 \\
2018 & 2.941 \\
2019 & 2.976 \\
\hline Total & 27.539 \\
\hline
\end{tabular}

Fonte: DATA SUS (2020).

Baseado nos dados exposto na tabela 6, observa-se que a quantidade de óbitos por CE permanece relativamente constante durante os últimos 10 anos analisados. Contudo, quando verificado o crescimento de mortes tomando como base os anos de 2010 e 2019, é possível perceber um crescimento de $19,7 \%$ das ocorrências por esse tipo de neoplasia maligna. Além disso, nota-se o destaque de 2019 como o ano de maior incidência de CE, todavia, com crescimento pouco relevante de 1,2\% se comparado com 2018.

Tabela 7. Óbitos por CE de acordo com a faixa etária (2010-2019).

\begin{tabular}{lll}
\hline Idade & Casos & Percentual \\
\hline $0-9$ & 68 & $0,25 \%$ \\
$10-19$ & 20 & $0,07 \%$ \\
$20-29$ & 105 & $0,4 \%$ \\
$30-39$ & 388 & $1,4 \%$ \\
$40-49$ & 2.788 & $10,12 \%$ \\
$50-59$ & 7.711 & $28,0 \%$ \\
$60-69$ & 8.374 & $30,5 \%$ \\
$70-79$ & 5.567 & $20,2 \%$ \\
80 ou mais & 2.518 & $9,06 \%$ \\
\hline
\end{tabular}

Fonte: DATA SUS (2020). 
Correlacionando as variáveis óbitos e faixa etária, contidos na tabela 7 , depreende-se que os indivíduos entre 60 e 69 anos portadores do CE evoluem para óbito com maior frequência que os demais, com uma taxa de 30,5\%. De modo geral, esses dados revelam das pessoas afetadas por esse tipo de neoplasia maligna, os idosos formam o grupo mais suscetível à morte do que os demais.

\section{CONCLUSÃO}

De modo geral, esses dados revelam que das pessoas afetadas por esse tipo de neoplasia maligna, os idosos formam o grupo mais suscetível à morte do que os demais. Com destaque, ainda, para a região Sul do país, a qual revelou o grande impacto dos fatores ambientais e culturais nessa patologia, Sendo assim, tais estatísticas reafirmam que o número de internações por CE ainda é elevado no Brasil, o que mostra a importância da realização de busca ativa dessas lesões para que se alcance uma abordagem rápida e eficaz nos casos de CE.

\section{REFERÊNCIAS}

Brasil. Ministério da Saúde. Secretaria de Vigilância em Saúde. Departamento de Vigilância em Saúde Ambiental e Saúde do Trabalhador. Atlas do Câncer Relacionado ao Trabalho no Brasil/ Ministério da Saúde, Secretaria de Vigilância em Saúde, Departamento de Vigilância em Saúde Ambiental e Saúde do Trabalhador. - Brasília: Ministério da Saúde, 202 p.: il. 2018.

Câncer de esôfago. INCA, 2020. Disponível em: <https://www.inca.gov.br/tipos-de-cancer/cancer-de-esofago> Acesso em: 25 de jun. de 2020.

SALEM, Mohamed. E. et al. Comparative molecular analyses of esophageal squamous cellcarcinoma, esophageal adenocarcinoma, ad gastricadenocarcinoma. The oncologist, 23:1319-1327, 2018

Domper Arnal MJ, Ferrández Arenas \&, Lanas Arbeloa \&. Esophageal cancer: Risk factors, screening and endoscopic treatment in Western and Eastern countries. World J Gastroenterol; 21(26): 7933-7943, 2015.

MONTEIRO, Nonato. M. L. et al. Câncer de esôfago: perfil das manifestações clínicas, histologia, localização e comportamento metastático em pacientes submetidos a tratamento oncológico em um centro de referência em Minas Gerais. Revista brasileira de cancerologia, 55(1), 27-32, 2009.

QUEIROGA, Ricardo. C., PERNAMBUCO A.P. Câncer de esôfago: epidemiologia, diagnóstico e tratamento. Revista Brasileira de Cancerologia, 52(2), 173-178, 2006. 


\section{EPIDEMIOLOGIA DAS INTERNAÇÕES POR NEOPLASIA MALIGNA DE FÍGADO E DAS VIAS BILIARES INTRA-HEPÁTICAS DURANTE A ÚLTIMA DÉCADA NO BRASIL}

AMANDA ARAÚJO SOUZA Universidade Estadual de Ciências da Saúde de Alagoas

\section{ROBÉRIO SILVA MELO}

Docente - Universidade Estadual de Ciências da Saúde de Alagoas

ANA CLÁUDIA DA SILVA FERNANDES DUARTE

Universidade Estadual de Ciências da Saúde de Alagoas

EMANNUELA BERNARDO DA SILVA

Universidade Estadual de Ciências da Saúde de Alagoas

GABRIEL JOSÉ TORRES DA SILVA Universidade Estadual de Ciências da Saúde de Alagoas

\section{JOSÉ JOÃO FELIPE COSTA DE}

OLIVEIRA

Universidade Estadual de Ciências da Saúde de Alagoas

RENATA LINS WANDERLEY Universidade Estadual de Ciências da Saúde de Alagoas

ZION CARVALHO DA SILVA Universidade Estadual de Ciências da Saúde de Alagoas

RESUMO: Na última década, o cenário brasileiro das internações por neoplasias hepáticas e dos ductos biliares (NHDB) demonstra contribuição significativa no entendimento da epidemiologia desses cânceres. Conforme o INCA, as NHDB ocupam a sexta posição em homens e a oitava em mulheres como causa de óbito, sendo a segunda maior etiologia de morte por câncer no mundo e a sétima mais incidente. Assim, objetiva-se analisar a epidemiologia das internações por neoplasia de fígado e das vias biliares intra-hepáticas durante a última década no Brasil, a sua tendência temporal e características sociodemográficas implicadas. Trata-se de um estudo epidemiológico retrospectivo, descritivo do tipo transversal sobre o número de internações por neoplasia de fígado e vias biliares intra-hepáticas em hospitais públicos nos últimos dez anos no país. Os dados foram obtidos no Departamento de Informática do SUS (DATASUS). No Brasil, de janeiro de 2010 a dezembro de 2019, verificou-se 81.875 internações por essas neoplasias com aumento de $52,8 \%$ nos registros. Houve aumento dos casos graves e de internações (62,9\% do total) e aumento de $47,1 \%$ dos casos de urgência em relação a 2010. O Sudeste concentrou maior número de casos $(49,1 \%)$ seguido pelo Sul $(23,1 \%)$. O sexo masculino representou $56,1 \%$ do total. Pessoas brancas foram mais afetadas (48,2\%), seguida de pardos, $28 \%$. A faixa etária de 60 e 69 anos correspondeu a $30 \%$ dos doentes e $24,2 \%$ pacientes tinham de 50 e 59 anos. Houve 19.140 óbitos pelos cânceres citados, com mortalidade de $23,4 \%$. O crescimento no número de óbitos foi de $51,4 \%$. O Sudeste concentra mais óbitos $(48,2 \%)$, seguido pelo Sul, com $22,6 \%$. O estudo revelou importantes informações epidemiológicas que poderão ser utilizadas para planejamento e execução de estratégias de controle e prevenção direcionadas ao rastreio dessas neoplasias.

PALAVRAS-CHAVE: neoplasias hepáticas; neoplasias dos ductos biliares; internações; óbitos 
ABSTRACT: In the last decade, the Brazilian scenario of hospitalizations for liver cancer and bile ducts (NHDB) demonstrates a significant contribution to the understanding of the epidemiology of these cancers. According to the INCA, NHDB ranks sixth in men and eighth in women as the cause of death, being the second largest etiology of cancer death in the world and the seventh most incident. Thus, the objective is to analyze the epidemiology of hospitalizations for liver cancer and intrahepatic bile ducts during the last decade in Brazil, its temporal tendency and the sociodemographic characteristics involved. This is a retrospective, descriptive, cross-sectional epidemiological study on the number of hospitalizations for liver cancer and intrahepatic bile ducts in public hospitals in the last ten years in the country. Data were obtained from the SUS Computer Department (DATASUS). In Brazil, from January 2010 to December 2019, there were 81,875 hospitalizations for these neoplasms with an increase of $52.8 \%$ in the records. There was an increase in severe cases and hospitalizations $(62.9 \%$ of the total) and an increase of $47.1 \%$ in emergency cases compared to 2010 . The Southeast concentrated the largest number of cases $(49.1 \%)$ followed by the South $(23,1 \%)$. The male sex represented $56.1 \%$ of the total. White people were more affected (48.2\%), followed by browns, $28 \%$. The age group of 60 and 69 years old corresponded to $30 \%$ of the patients and $24.2 \%$ patients were between 50 and 59 years old. There were 19,140 deaths from the aforementioned cancers, with a mortality rate of $23.4 \%$. The increase in the number of deaths was $51.4 \%$. The Southeast concentrates more deaths $(48.2 \%)$, followed by the South, with $22.6 \%$. The study revealed important epidemiological information that can be used for planning and executing control and prevention strategies aimed at screening for these neoplasms.

KEYWORDS: liver neoplasms; bile duct neoplasms; hospitalizations; deaths

\section{INTRODUÇÃO}

Tendo em vista o panorama brasileiro da última década, nota-se a expressividade do número de internações por neoplasia de fígado e de vias biliares, sobretudo em países em desenvolvimento como o Brasil. Consoante ao Instituto Nacional do Câncer (INCA), o câncer de fígado e das vias biliares ocupa, como causa de óbito por câncer, a sexta posição em homens e a oitava posição em mulheres. Ademais, a neoplasia de fígado e vias biliares intra-hepáticas é denotada como a sétima mais incidente e a segunda maior etiologia de morte por câncer na população mundial (Santos et al, 2020).Outrossim, os agravos em saúde referentes a neoplasias são de notificação compulsória, desde que foi incorporado à Lei 12.732, de 2012, a qual dispõe sobre o primeiro tratamento dos pacientes diagnosticados com neoplasia, sendo garantida a terapêutica em até sessenta dias do diagnóstico no Sistema Único de Saúde (SUS).

Acerca das neoplasias hepáticas mais frequentes, destaca-se o carcinoma hepatocelular, o qual corresponde de $70 \%$ a $85 \%$ das neoplasias primárias de fígado. Em seguida, tem-se o colangiocarcinoma representando em torno de 10 a $15 \%$ e 5\% correspondem a tumores mais raros, a citar angiossarcoma primário e linfoma hepático primário (Santos et al, 2019). Já o câncer de vias biliares figura como uma afecção pouco comum, no entanto tem alta letalidade. Nos últimos dez anos, houve crescimento de sua incidência vinculado ao aperfeiçoamento de exames de imagem para a detecção da doença, o que possibilitou a realização dos diagnósticos (Soto et al, 2016). Integram os tumores malignos do trato biliar: câncer de vesícula biliar, colangiocarcinoma intra-hepático e extra-hepático, proximal e distal, e CA da papila do duodeno- ampola de Vater (Riechelmann et al., 2016). 
Em consonância à Sociedade Americana do Câncer, como fatores de risco para neoplasia de vesícula biliar e ductos biliares extra-hepáticos, têm-se: sexo feminino, litíase da vesícula biliar vinculada, colecistite aguda e doenças parasitárias biliares. Já o câncer hepático, por sua vez, associa-se a patologias como cirrose hepática, hepatite $\mathrm{B}$ e C, hemocromatose; estilo de vida, a citar, alcoolismo, pressão alta, assim como exposição a esteroides androgênicos, mais comuns na adolescência. Apesar disso, deve ser considerada a variabilidade da prevalência desses fatores em cada localidade, no Brasil, por exemplo, existem diferenças quanto à endemicidade de doenças, como as hepatites virais.

Conforme o International Agency For Research On Cancer, dentre as causas ligadas ao estágio de câncer estão: aflatoxinas, etilismo, contraceptivos estrogênio-progesterona (associam-se a lesões pré-malignas, a saber, adenomas de fígado, os quais são precursores de câncer), infecção viral (hepatite B e C), tabagismo (em pacientes fumantes e em sua filiação), doenças metabólicas (esteatose) e diabetes. Condições preveníveis e ligadas a condições socioeconômicas e médico-sanitárias, fazendo-se importante a detecção precoce de fatores predisponentes e precipitantes dessas neoplasias malignas.

O INCA expõe que o diagnóstico é feito, principalmente, por exames de imagem, sendo complementares à história clínica, a citar: tomografia computadorizada (TC) e ressonância nuclear magnética (RNM). A ultrassonografia mais colangiotomografia e colangiografia por RNM também podem ser usadas, mas ainda a laparoscopia e biópsia pela capacidade de identificar lesões típicas de câncer. A depender do estadiamento dos tumores e sua evolução, é recomendado o tratamento cirúrgico, o transplante, no câncer hepático, ou, se realizado tardiamente, os cuidados paliativos tornam-se mandatórios.

Na perspectiva de Amorim, Merchán-Hamann (2013), a tendência de mortalidade por câncer hepático e de vias biliares cresceu gradativamente nos últimos trinta anos no país. O sexo masculino foi o mais acometido com acréscimo no coeficiente médio de mortalidade e no aumento linear a cada ano, além do que a faixa de idade predominante é de 50 anos ou mais. Essa circunstância reflete o maior número de internações registradas e indica que os fatores de risco não estão sendo bem controlados, além de que há ainda, no Brasil, desigualdade de assistência aos serviços de saúde entre as suas cinco regiões.

Este trabalho objetiva analisar a epidemiologia das internações por neoplasia de fígado e das vias biliares durante a última década no Brasil, elucidar a tendência temporal dessas neoplasias no país, bem como descrever características do perfil dos pacientes internados e entender os impactos gerados ao sistema público de saúde.

\section{MATERIAL E MÉTODOS}

Trata-se de um estudo epidemiológico descritivo, quantitativo e retrospectivo do tipo transversal acerca do número de internações por neoplasia de fígado e vias biliares em hospitais públicos durante a última década no Brasil. Para isso, foram utilizados artigos de base de dados Scielo, Pubmed e Lilacs e os dados epidemiológicos foram obtidos do Sistema de Informações Hospitalares do SUS (DATASUS). 
Assim, foi feita a filtragem das informações em planilha de Excel e foi feita uma análise descritiva das variáveis: internações, sexo, faixa etária, cor/etnia, caráter de atendimento e óbitos por regiões.

\section{RESULTADOS E DISCUSSÃO}

A partir da análise dos dados, verificou-se que durante a última década (janeiro de 2010 a dezembro de 2019), no Brasil, ocorreram 81.875 internações por câncer de fígado e das vias biliares. A tabela 1 expõe como esse total se distribui durante o período analisado.

Tabela 1 - Internações por CA de fígado e das vias biliares conforme o ano de processamento.

\begin{tabular}{cc}
\hline Ano & Casos \\
2010 & 4.948 \\
2011 & 5.862 \\
2012 & 6.863 \\
2013 & 7.901 \\
2014 & 8.074 \\
2015 & 8.809 \\
2016 & 9.119 \\
2017 & 9.738 \\
2018 & 10.069 \\
2019 & 10.492 \\
\hline
\end{tabular}

Fonte: Dados extraídos do DATASUS, 2020.

Através da análise dos dados, tabela 1, observa-se um aumento progressivo com o passar dos anos dos casos de internações por CA de fígado e das vias biliares, no qual nota-se uma maior incidência em 2019. Além disso, pode-se verificar que ocorreu um aumento de 52,8\% entre os anos de 2010 a 2019. Esse elevado registro de internações pode estar relacionado à ampliação do acesso a exames diagnósticos.

Tabela 2 - Internações por CA de fígado e das vias biliares conforme o caráter de atendimento e ano de processamento.

\begin{tabular}{c|c|c|}
\hline Ano & Eletivo & Urgência \\
\hline 2010 & 1.807 & 3.141 \\
2011 & 2.263 & 3.599 \\
2012 & 2.548 & 4.315 \\
2013 & 2.916 & 4.985 \\
2014 & 3.106 & 4.968 \\
2015 & 3.262 & 5.547 \\
2016 & 3.377 & 5.742 \\
2017 & 3.603 & 6.135 \\
2018 & 3.632 & 6.437 \\
2019 & 3.831 & 6.661 \\
Total & 30.345 & 51.530 \\
\hline
\end{tabular}

Fonte: Dados extraídos do DATASUS, 2020. 
Verificando-se o caráter de atendimento das internações confirmar-se o crescimento dos casos graves e de pacientes que precisam de atendimento de urgência. Dessa forma, nota-se, de modo geral, que do total de atendimentos $62,9 \%$ das ocorrências foram de urgência. Além disso, 2019 se destaca com o maior número de casos registrados, com um aumento de 47,1\% dos casos de urgência em relação a 2010, o que pode sugerir a ausência de rastreio e diagnóstico em estágio inicial ou dificuldade de acesso ao atendimento médico.

Tabela 3 - Internações por CA de fígado e das vias biliares conforme a região para a última década.

\begin{tabular}{lcc}
\multicolumn{1}{c}{ Região } & Casos & \% \\
Norte & 2.803 & $3,4 \%$ \\
Nordeste & 15.711 & $19,2 \%$ \\
Sudeste & 40.210 & $49,1 \%$ \\
Sul & 18.922 & $23,1 \%$ \\
Centro-Oeste & 4.229 & $5,2 \%$ \\
Todas as regiões & 81.875 & $100 \%$ \\
\hline
\end{tabular}

Fonte: Dados extraídos do DATASUS, 2020.

Analisando as regiões do país associadas às ocorrências do câncer de fígado e vias biliares, presentes na tabela 3, verifica-se o destaque da região sudeste concentrando o maior número de casos, taxa de 49,1\%. Seguida pela região sul com 23,1\%. Regiões que se destacam em centros de referência oncológicos e que detêm parcela de desenvolvimento econômico expressivo no país comparadas a outras regiões.

Tabela 4 - Sexo dos indivíduos com CA de fígado e das vias biliares para os últimos dez anos.

\begin{tabular}{ccc} 
Sexo & Casos & $\%$ \\
Feminino & 35.933 & $43,9 \%$ \\
Masculino & 45.942 & $56,1 \%$ \\
\hline
\end{tabular}

Fonte: Dados extraídos do DATASUS, 2020.

Quanto às informações relacionadas ao sexo dos pacientes, tabela 4, nota-se a prevalência de casos no sexo masculino que concentra um total de $56,1 \%$ dos casos. Isso pode ser entendido pela exposição maior, muitas vezes, de homens a fatores de risco para o CA hepático e o de ducto biliar, como a hepatite alcóolica e a infecção por hepatites virais.

Tabela 5 - Internações por CA de fígado e das vias biliares conforme a raça/etnia na última década.

\begin{tabular}{lcc} 
Raça/etnia & Casos & $\%$ \\
Branca & 39.494 & $48,2 \%$ \\
Preta & 3.240 & $4 \%$ \\
Parda & 22.863 & $28 \%$ \\
Amarela & 967 & $1,2 \%$ \\
Indígena & 37 & $0,04 \%$ \\
Sem informação & 15.274 & $18,56 \%$ \\
\hline
\end{tabular}

Fonte: Dados extraídos do DATASUS, 2020. 
Quanto à raça/etnia, presente na tabela 5, nota-se o elevado número de indivíduos brancos como principais afetados, com taxa de $48,2 \%$ dos casos. Além disso, verifica-se os pardos, em segundo lugar, como mais afetados, com taxa de $28 \%$.

Tabela 6 - Casos de CA de fígado e das vias biliares conforme a faixa etária para a última década.

\begin{tabular}{l|c|c}
\hline Idade & Casos & $\%$ \\
$0-9$ & 3.150 & $3,8 \%$ \\
$10-19$ & 1.216 & $1,5 \%$ \\
$20-29$ & 1.571 & $1,9 \%$ \\
$30-39$ & 3.394 & $4,1 \%$ \\
$40-49$ & 7.914 & $9,7 \%$ \\
$50-59$ & 19.859 & $24,2 \%$ \\
$60-69$ & 24.579 & $30 \%$ \\
$70-79$ & 15.147 & $18,5 \%$ \\
80 ou mais & 5.045 & $6,3 \%$ \\
\hline
\end{tabular}

Fonte: Dados extraídos do DATASUS, 2020.

Atentando-se para os dados da tabela 6, nota-se uma concentração de casos nas faixas etárias entre 60 e 69 anos que possuem um total de 30\% dos doentes. Contudo, verifica-se uma quantidade semelhante de casos presentes na faixa etária entre 50 e 59 anos, com $24,2 \%$ dos afetados. De forma genérica, esses dados mostram uma ocorrência dessa doença em indivíduos de idosos e de meia idade, respectivamente.

Em relação aos óbitos, verifica-se que ocorreram 19.140 mortes por câncer de fígado e de vias biliares. Além disso, a mortalidade observada no período estudado é de 23,4\%.

Tabela 7 - Óbitos por CA de fígado e das vias biliares conforme o ano de processamento.

\begin{tabular}{cc} 
Ano & Casos \\
\hline 2010 & 1.222 \\
2011 & 1.354 \\
2012 & 1.562 \\
2013 & 1.763 \\
2014 & 1.879 \\
2015 & 2.135 \\
2016 & 2.071 \\
2017 & 2.213 \\
2018 & 2.428 \\
2019 & 2.513 \\
Total & 19.140 \\
\hline
\end{tabular}

Fonte: Dados extraídos do DATASUS, 2020.

Observando-se nos dados expostos na tabela 7, nota-se que os óbitos por câncer de fígado e das vias biliares cresceram gradativamente durante os últimos 10 anos analisados, em que se verifica um aumento de $51,4 \%$ entre os anos de 2010 e 2019. Isso pode estar relacionado a melhores condições de acesso aos serviços de saúde, os quais podem estar diagnosticando mais casos e estabelecendo mais terapêuticas com maior possibilidade de sobrevida para os acometidos. 
Tabela 8 - Óbitos por CA de fígado e das vias biliares conforme a faixa etária nos últimos dez anos.

\begin{tabular}{lcc}
\hline Idade & Casos & $\%$ \\
\hline $0-9$ & 125 & $0,6 \%$ \\
$10-19$ & 82 & $0,4 \%$ \\
$20-29$ & 191 & $1 \%$ \\
$30-39$ & 514 & $2,7 \%$ \\
$40-49$ & 1.575 & $8,2 \%$ \\
$50-59$ & 4.406 & $23 \%$ \\
$60-69$ & 5.866 & $30,6 \%$ \\
$70-79$ & 4.368 & $22,8 \%$ \\
80 ou mais & 2.013 & $10,7 \%$ \\
\hline
\end{tabular}

Fonte: Dados extraídos do DATASUS, 2020.

Relacionando-se os óbitos e a faixa etária, contidos na tabela 8, nota-se que os indivíduos entre 60 e 69 anos portadores da neoplasia maligna hepática e das vias biliares evoluem para óbito com maior frequência do que os demais, com uma taxa de 30,6\%. Além disso, observa-se uma quantidade de casos semelhantes presentes na faixa etária entre 50 e 59 anos, com 23\%, e as pessoas entre 70 e 79 anos, com 22,8\%. De modo geral, esses dados mostram que essa doença atinge pessoas idosas e de meia idade, todavia os indivíduos que mais morrem são os idosos.

Tabela 9 - Sexo dos indivíduos com CE que evoluíram para óbito na última década.

\begin{tabular}{ccc} 
Sexo & Casos & $\%$ \\
Feminino & 8.421 & $46 \%$ \\
Masculino & 10.719 & $54 \%$ \\
\hline
\end{tabular}

Fonte: Dados extraídos do DATASUS, 2020.

Em relação aos óbitos associados ao sexo dos pacientes, tabela 9, observa-se a prevalência no sexo masculino, tanto de casos quanto de óbitos, dos quais correspondem a $54 \%$ dos eventos fatais.

Tabela 10 - Óbitos de acordo com o caráter de atendimento e ano de processamento.

\begin{tabular}{ccc} 
Ano & Eletivo & Urgência \\
\hline 2010 & 259 & 963 \\
2011 & 252 & 1.102 \\
2012 & 225 & 1.337 \\
2013 & 235 & 1.528 \\
2014 & 281 & 1.598 \\
2015 & 373 & 1.762 \\
2016 & 331 & 1.740 \\
2017 & 354 & 1.859 \\
2018 & 376 & 2.052 \\
2019 & 375 & 2.138 \\
Total & 3.061 & 16.079 \\
\hline
\end{tabular}

Fonte: Dados extraídos do DATASUS, 2020. 
Ao verificar o caráter de atendimento dos casos que evoluíram para óbito de acordo com o ano de processamento, tabela 10, percebe-se a permanência de casos graves que cursam com a morte. Além disso verifica-se a o aumento progressivo, o que torna essa patologia com taxas constantemente elevadas durante o passar dos anos no período do estudo.

Tabela 11 - Óbitos de acordo com a raça/etnia para a última década.

\begin{tabular}{lcc} 
Raça/etnia & Óbitos & $\%$ \\
Branca & 8.460 & $44,2 \%$ \\
Preta & 817 & $4,3 \%$ \\
Parda & 5.495 & $28,7 \%$ \\
Amarela & 233 & $1,2 \%$ \\
Indígena & 10 & $0,05 \%$ \\
Sem informação & 4.125 & $21,55 \%$ \\
\hline
\end{tabular}

Fonte: Dados extraídos do DATASUS, 2020.

Associando-se as variáveis raça/etnia e os óbitos, observada na tabela 11, percebe-se o elevado número de indivíduos brancos acometidos por doença neoplásica, assim como também constitui uma elevada parcela que mais evolui para óbitos durante o período analisado, com um total de 44,2\% dos casos que cursaram com morte.

Tabela 12 - Internações por CA de fígado e das vias biliares conforme a região e taxa de óbitos nos últimos dez anos.

\begin{tabular}{|l|c|}
\hline Norte & $4,6 \%$ \\
\hline Nordeste & $18,5 \%$ \\
\hline Sudeste & $48,2 \%$ \\
\hline Sul & $22,6 \%$ \\
\hline Centro-Oeste & $6,1 \%$ \\
\hline
\end{tabular}

Fonte: Dados extraídos do DATASUS, 2020.

Ao relacionar os óbitos distribuídos pelas regiões do Brasil associados à ocorrência dessa doença, presente na tabela 12, observa-se o destaque da região sudeste, concentrando o maior número de óbitos, com taxa de 48,2\%; seguida pela região sul, com 22,6\%. Dessa maneira, verifica-se que o maior número de casos foi registrado nas regiões sudeste e sul e a maior taxa de óbitos também ocorre nessas duas regiões, respectivamente. Conquanto deve ser dada atenção à diferença de padrão de notificações da ocorrência dessas patologias para as cinco regiões do país, com maior taxa de óbitos em locais de maior desenvolvimento socioeconômico e redes de assistência à saúde com estruturas superiores, que podem diagnosticar mais casos.

\section{CONCLUSÃO}

Por meio da análise promovida por esse estudo, pode-se verificar que a distribuição das internações por neoplasia maligna de fígado e de vias biliares possui um crescimento gradual durante 
o período em que foi estudado, podendo estar associado à ampliação de casos em estágio tardio da doença, o que se confirma mediante a verificação do caráter de admissão, no qual 62,9\% dos atendimentos registrados foram de urgência. Além disso, é possível definir um perfil, no qual os indivíduos mais atingidos são homens brancos da região Sudeste entre 60 e 69 anos que se destacam nesse tipo de neoplasia maligna. Isso pode ser explicado pela maior longevidade da população brasileira ao longo do período estudado, além de que grandes centros de diagnóstico são encontrados nessa região, o que faz com que pacientes de outras regiões também possam buscá-la para a realização do tratamento. Há de se considerar também a subnotificação e a falta de diagnóstico em áreas com menor aporte de recursos técnicos e humanos para o diagnóstico adequado.

O estudo realizou uma análise do número de internações por neoplasia de fígado e das vias biliares intra-hepáticas a partir de variáveis que auxiliam no entendimento do número crescente de registros no país. Faz-se importante sanar as diferenças existentes nas regiões brasileiras quanto às causas preveníveis, sensibilizar o corpo civil com menores condições socioeconômicas sobre doenças e fatores predisponentes a essas neoplasias, além de melhorar as condições sócio-sanitárias dos indivíduos mais vulneráveis a hepatopatias e doenças das vias biliares. Ainda se faz importante o registro adequado de informações, a exemplo do DATASUS, evitando subnotificações.

Assim, faz-se importante maior atenção à assistência dos pacientes acometidos para um diagnóstico preciso e precoce e tratamento adequado, a fim de evitar complicações e óbitos consequentes a esses cânceres. Desse modo, as informações epidemiológicas geradas pelo estudo poderão ser utilizadas para planejamento e execução de estratégias de controle e prevenção direcionadas ao rastreio dessas neoplasias. Isso por intermédio de uma gestão adequada e equânime entre as regiões de recursos públicos para o enfrentamento dessas doenças e o planejamento de estratégias de políticas em saúde, em especial nas regiões mais expostas.

\section{REFERÊNCIAS}

AMORIM, Thiago Rodrigues de; MERCHAN-HAMANN, Edgar. Mortalidade por neoplasia maligna do fígado e vias biliares intra-hepáticas no Brasil, 1980-2010. Cad. Saúde Pública, Rio de Janeiro, v. 29, n. 7, p. 14271436, July 2013 .

ALONSO SOTO, Jordi et al. Caracterização de pacientes com tumores do ducto biliar utilizando colangiopancreatografia endoscópica retrógrada. Rev cubana med, Cidade de Havana, v. 55, n. 2 P. 141-149, jun. 2016.

CAVALCANTE DOS SANTOS, F. A.; GOMES DE MORAIS FERNANDES, F. C.; DE OLIVEIRA SANTOS, E. G.; MARTINIANO MEDEIROS, N. B.; BEZERRA DE SOUZA, D. L.; RIBEIRO BARBOSA, I. Mortalidade por Câncer de Fígado e Vias Biliares no Brasil: Tendências e Projeções até 2030. Revista Brasileira de Cancerologia, v. 65, n. 4, p. e-01435, 27 jan. 2020.

JUSTO, Iago et al. Análise retrospectiva em pacientes com câncer de vesícula biliar: tratamento cirúrgico e sobrevida dependendo do estágio do tumor. Rev. esp. doente escavação. Madri, v. 110, n. 8, p. 485-492, agosto de 2018.

RIECHELMANN, Rachel et al . GUIDELINE FOR THE MANAGEMENT OF BILE DUCT CANCERS BY THE BRAZILIAN GASTROINTESTINAL TUMOR GROUP. Arq. Gastroenterol., São Paulo, v. 53, n. 1, p. 5-9, Mar. 2016. 


\section{EPIDEMIOLOGIA DOS CASOS CONFIRMADOS DE TUBERCULOSE NO BRASIL DURANTE A ÚLTIMA DÉCADA}

GABRIEL JOSÉ TORRES DA SILVA

Universidade Estadual de Ciências da Saúde de Alagoas

ANA CLÁUDIA DA SILVA FERNANDES

DUARTE

Universidade Estadual de Ciências da Saúde de Alagoas

JOSÉ JOÃO FELIPE COSTA DE OLIVEIRA

Universidade Estadual de Ciências da Saúde de Alagoas

ZION CARVALHO DA SILVA

Universidade Estadual de Ciências da Saúde de Alagoas

RENATA LINS WANDERLEY

Universidade Estadual de Ciências da Saúde de Alagoas

EMANNUELA BERNARDO DA SILVA Universidade Estadual de Ciências da Saúde de Alagoas

AMANDA ARAÚJO SOUZA

Universidade Estadual de Ciências da Saúde de Alagoas

THIAGO JOSÉ MATOS ROCHA Docente- Universidade Estadual de Ciências da Saúde de Alagoas

RESUMO: a Tuberculose (TB) é uma doença infecciosa que afeta múltiplos órgãos, é causada por bacilos do complexo Mycobacterium tuberculosis e foi a doença infecciosa que mais causou óbitos no mundo em 2017. A TB possui coinfec- ção importante com o Vírus da Imunodeficiência Humana (HIV), causador da Síndrome da Imunodeficiência Adquirida (AIDS), e representa um problema de saúde pública no Brasil, sendo condição de notificação compulsória, o que motivou a realização do estudo. O trabalho objetivou descrever aspectos sociais, epidemiológicos e demográficos dos casos notificados de TB no Brasil na última década. Foi realizado um estudo observacional, retrospectivo, de caráter quantitativo que analisou os casos de TB no período de janeiro de 2010 a dezembro de 2019, através de dados epidemiológicos e sociodemográficos secundários obtidos pelo Sistema de Informações Hospitalares do SUS. Foram analisadas as variáveis: casos confirmados por ano, tipo de entrada, forma clínica da doença, presença de AIDS ou coinfecção por HIV, realização de baciloscopia no $6^{\circ}$ mês de tratamento, sexo, etnia, faixa etária e região do país. Através dessa análise, verificouse notificação crescente da TB até o ano de 2018, totalizando 877.929 casos, sendo em sua maioria $(81,2 \%)$ novos casos. Além disso, houve maior notificação de tuberculose em indivíduos do sexo masculino (68,5\%), da cor parda $(45,9 \%)$, entre 20 e 39 anos (45,6\%), das regiões Sudeste $(45,13 \%)$ e Nordeste $(26,8 \%)$. A forma clínica mais comum $(99,4 \%)$ foi Ignorada/Branca, provavelmente por se tratar da forma pulmonar, enquanto a maior porcentagem $(33,4 \%)$ das baciloscopias foi Ignorada/Branca, por provável cura clínica. Em relação à testagem dos indivíduos para HIV, mostrou-se negativa na maioria desses $(63,5 \%)$, porém a não realização em uma população significativa (21,5\%), merece destaque, já a presença de AIDS ocorreu em 10,1\% dos casos confirmados. Tais estatísticas reafirmam a importância crescente da TB em saúde pública no Brasil. 
PALAVRA-CHAVE: Epidemiologia; Tuberculose; Saúde Pública; Morbidade.

\begin{abstract}
The Tuberculosis (TB) is an infectious disease that affect multiples organs, is caused by bacillus of the Mycobacterium tuberculosis complex and was the infectious disease which registered the most number of deaths in the year of 2017. The TB is commonly related to the infection by the Virus of Human Immunodeficiency (HIV), that is the most common cause for Acquired Immunodeficiency Syndrome (AIDS), and represent a public health problem in Brazil, being a compulsory notification disease, what motivated the research. The study aimed to describe social, demographic and epidemiologic aspects of the confirmed cases of TB at the past decade. It was an observational, retrospective and quantitative research, that analyzed the period between January of the year 2010 and December of the year 2019 using the secondary epidemiological and sociodemographic data from de Sistema de Informações Hospitalares of the Sistema Único de Saúde. The analyzed variants were: confirmed cases by year, type of entry, clinical presentation, presence of AIDS or coinfection by HIV, realization of bacilloscopy at the $6^{\text {th }}$ month of treatment, sex, ethnicity, age range and region of country. The analysis showed growing TB notification until 2018, totalizing 887,929 cases, being the most of them $(81.2 \%)$ new cases. Also, there was bigger notification on male $(68.5 \%)$, with " pardo" skin (45.9\%), between 20 and 39 years $(45.6 \%)$ at the regions Southeast $(45.13 \%)$ and Northeast (26.8\%). The prevalent clinical form was Ignored/Blank (99.4\%), probably because were pulmonary, and most of the bacilloscopys (33.4\%) were (Ignored/Blank), probably due to clinical cure. About the HIV testing, it was negative to the most part (63.5\%), but the non-testing at a great proportion $(21.5 \%)$, needs attention, and the AIDS presence was notified in $10.1 \%$ of the confirmed cases. Those statistics reinforce the growing importance of the TB at public health in Brazil.
\end{abstract}

KEYWORDS: Epidemiology; Tuberculosis; Public Health; Morbidity.

\title{
INTRODUÇÃO
}

A tuberculose (TB) foi a doença infecciosa responsável pelo maior número de óbitos no mundo no ano de 2017, quando foram notificados 1,3 milhão de óbitos, enquanto no ano de 2016 foram notificados 4.426 óbitos no Brasil (Silva et al., 2020). A doença pode afetar múltiplos órgãos, principalmente no trato respiratório inferior, e é causada por bacilos do complexo Mycobacterium tuberculosis, em especial a bactéria M. tuberculosis, que é transmitida através de aerossóis presentes na tosse, fala ou espirros de pacientes contaminados, sobretudo aqueles que apresentam baciloscopia positiva (Brasil, 2019).

A TB é reconhecida desde o século XIX, apresentando grande recrudescimento após o início dos anos 1980, concomitante à emergência do vírus HIV em países desenvolvidos e à urbanização desenfreada, ampliação da miséria e desestruturação dos serviços de saúde em países subdesenvolvidos (Brasil, 2019).

A doença apresenta íntima relação com as desigualdades socioeconômica na saúde. Em um estudo de distribuição espacial dos casos de TB realizado entre 2006 e 2011 na cidade de Itaboraí, no Rio de Janeiro, evidenciou o maior número de casos em regiões com infraestrutura de saúde e habitação precárias ou em regiões pobres de áreas com melhor infraestrutura sanitária (Pedro, et al.,2017). Além disso, de acordo com Brasil (2019), o risco de contração da doença é 56 vezes maior do que a média em indivíduos em situação de rua. 
Em relação ao sexo e à faixa etária, um estudo epidemiológico realizado na cidade de Vitória, entre os anos de 2008 e 2013, demonstrou maior prevalência da infecção por M. tuberculosis em homens adultos. $\mathrm{O}$ estudo sugere que isso se deva tanto a fatores sociais, como a maior exposição social, além da prevalência de etilismo e tabagismo (os quais também favorecem o desenvolvimento da doença a partir da infecção), quanto a fatores biológicos, uma vez que estudos experimentais em animais demonstraram efeito protetor do estrógeno (hormônio produzido por mulheres após a puberdade) contra micobactérias (Fernandes et al., 2018).

Contudo, na infância, observou-se prevalência de infecção pelo bacilo no sexo feminino, o que tanto se explica pela produção de estrógeno, bastante reduzida em pré-puberes, quanto pela menor exposição de meninos à comunidade, durante a infância (Fernandes et al., 2018).

Já em relação às coinfecções, no Brasil, o risco de adoecimento por TB é 28 vezes maior em portadores do vírus HIV (Brasil, 2019). Mundialmente, a coinfecção Tuberculose-HIV é a mais frequente, ocorrendo em virtude das graves depleção de células T-CD4 observados em portadores do HIV, em especial nos que a condição não é tratada (Esmail, et al. 2018).

No Brasil, a tuberculose também é cerca de 28 vezes mais incidente em populações privadas de liberdade e 3 vezes em populações indígenas (Brasil, 2019). A proporção estimada dos casos notificados no país no ano de 2017 é de $87 \%$, estando a subnotificação concentrada nas regiões localizadas principalmente no Nordeste e Sudeste, em estados como o Rio Grande do Sul, Minas Gerais e Bahia (Silva et al. 2020).

Além disso, com a presença de 4.528 casos de tuberculose drogarresistente (TBDR) registrados no Brasil entre 2013 e 2017, dos quais 7,3\% apresentaram desfecho clínico desfavorável com morte e 19,6\% apresentaram abandono ao tratamento, há receio na esfera da saúde pública quanto ao surgimento de bacilos multirresistentes, os quais podem se mostrar como ameaças à saúde global (Tourinho, et al. 2020).

Desse modo, considerando a elevada incidência da doença no Brasil, bem como suas repercussões na esfera da saúde pública e a existência de poucos trabalhos com escopo abrangente para acompanhar a evolução epidemiológica da tuberculose, este trabalho propõe formulação do perfil dos pacientes diagnosticados com a doença da última década. Na qual, tem por objetivo evidenciar o comportamento dessa patologia haja vista sua elevada capacidade de transmissão.

\section{MATERIAL E MÉTODOS}

Realizou-se um estudo observacional e retrospectivo com dados secundários, obtidos pelo Sistema de Informações Hospitalares do SUS (SIH) do DataSUS, sobre a epidemiologia dos casos confirmados de pacientes portadores de tuberculose no Brasil em estabelecimentos públicos e privados durante o período de 2010 a 2019 . Ao obter os dados, foram analisadas quantitativamente as seguintes variantes: casos confirmados por ano, tipo de entrada no sistema de saúde, área do corpo 
acometida, presença de aids ou HIV, realização de baciloscopia no $6^{\circ}$ mês de tratamento, sexo, raça/ etnia, faixa etária e regiões do país.

\section{RESULTADOS E DISCUSSÃO}

Por intermédio da análise dos dados, verificou-se que durante o período de análise, no Brasil, ocorreram 877.929 casos confirmados de tuberculose. A tabela 1 abaixo mostra como esse total é distribuídos durante os últimos 10 anos.

Tabela 1. Casos confirmados de tuberculose no Brasil, de acordo com o ano de notificação, no período de 2010 a 2019.

\begin{tabular}{ll}
\hline Ano & Casos \\
\hline 2010 & 85.381 \\
2011 & 87.813 \\
2012 & 86.183 \\
2013 & 86.208 \\
2014 & 85.213 \\
2015 & 85.492 \\
2016 & 86.004 \\
2017 & 90.305 \\
2018 & 94.274 \\
2019 & 91.056 \\
\hline
\end{tabular}

Mediante a análise dos dados contidos na tabela 1, depreende-se que ocorreu uma redução na incidência de casos entre os anos de 2013 e 2014 que voltaram a crescer em 2015 atingindo seu valor máximo em 2018 e regredindo em 2019. De modo geral, há uma lenta ascensão da tuberculose que, no entanto, em 2019 registrou uma diminuição de 3,4\% em relação ao ano anterior.

Tabela 2. Casos confirmados de tuberculose no Brasil, segundo tipo de entrada no sistema de saúde, no período de 2010 a 2019.

\begin{tabular}{lll}
\hline Tipo de entrada & Quantidade & $\%$ \\
\hline Ignorado/Branco & 28 & $0,06 \%$ \\
Caso novo & 712.873 & $81,2 \%$ \\
Recidiva & 62.654 & $7,1 \%$ \\
Reingresso após abandono & 67.840 & $7,7 \%$ \\
Não sabe & 2.981 & $0,34 \%$ \\
Transferência & 28.067 & $3,2 \%$ \\
Após óbito & 3.486 & $0,4 \%$ \\
\hline
\end{tabular}

Ao verificar a distribuição do total de casos confirmados de TB pelo tipo de entrada no sistema de saúde, presente na tabela 2, é possível notar que $81,2 \%$ refere-se à novos casos registrados. Além disso, 7,7\% desse total corresponde à pacientes que abandonaram o tratamento e posteriormente procuraram ajuda médica. Ademais, é notável a taxa de 7,1\% dos eventos de recidiva da doença. Assim, contata-se, de maneira geral, o alarmante crescimento de novos casos de TB na última década, assim como, o elevado número de reingresso após o abandono do tratamento e eventos de recidiva. 
Tabela 3. Casos confirmados e área do corpo afetada pela tuberculose no Brasil, no período de 2010 a 2019.

\begin{tabular}{lll}
\hline Área do corpo & Quantidade & $\%$ \\
\hline Ignorado/Branco & 872.634 & $99,4 \%$ \\
Pleura & 1.968 & $0,2 \%$ \\
Gânglios periféricos & 1.372 & $0,15 \%$ \\
Sis. Genitourinário & 129 & $0,01 \%$ \\
Ossos & 265 & $0,03 \%$ \\
Olhos & 63 & $0,007 \%$ \\
Miliar (disseminada) & 534 & $0,06 \%$ \\
Meningoencefálica & 348 & $0,03 \%$ \\
Cutânea & 132 & $0,01 \%$ \\
Laringe & 206 & $0,02 \%$ \\
Outras & 278 & $0,03 \%$ \\
\hline
\end{tabular}

Quanto às áreas do corpo humano que foram afetadas, nota-se que 99,4\% dos casos não possuiu um órgão ou estrutura acometida informada no registro, o que pode ter ocorrido por se tratar de uma forma pulmonar da doença. Já em relação às frequência de tuberculose extra pulmonar, pode-se inferir que as formas de tuberculose pleural e ganglionar periférica foram a que mais se apresentaram durante o período analisado.

Tabela 4. Presença de HIV nos casos confirmados de tuberculose no Brasil, no período de 2010 a 2019.

\begin{tabular}{lll}
\hline HIV & Casos & Percentual \\
\hline Ignorado/Branco & 2.801 & $0,3 \%$ \\
Positivo & 96.842 & $11 \%$ \\
Negativo & 557.563 & $63,5 \%$ \\
Teste em andamento & 32.287 & $3,7 \%$ \\
Não realizado & 188.436 & $21,5 \%$ \\
\hline
\end{tabular}

Tabela 5. Presença de AIDS nos casos confirmados de tuberculose no Brasil, no período de 2010 a 2019.

\begin{tabular}{lll}
\hline HIV & Casos & Percentual \\
\hline Ignorado/Branco & 126.778 & $12,7 \%$ \\
Sim & 88.895 & $10,1 \%$ \\
Não & 662.256 & $77,2 \%$ \\
\hline
\end{tabular}

Analisando os dados presentes nas tabelas 4 e 5, é possível compreender que do total de casos confirmados de TB, $11 \%$ é portador de HIV e 10,1\% possui aids. Além disso, verifica-se que $63,5 \%$ não possui HIV/Aids. Ainda é possível verificar que 21,5\% dos pacientes não realizaram o teste de HIV, dado preocupante haja vista a repercussão de casos não tratados.

Tabela 6. Realização de baciloscopia no $6^{\circ}$ mês de tratamento da tuberculose no Brasil, no período de 2010 a 2019.

\begin{tabular}{lll}
\hline Baciloscopia & Casos & Percentual \\
\hline Ignorado/Branco & 293.117 & $33,4 \%$ \\
Positivo & 3.907 & $0,4 \%$ \\
Negativo & 214.516 & $24,5 \%$ \\
Não realizado & 308.482 & $31,0 \%$ \\
Não se aplica & 57.907 & $10,7 \%$ \\
\hline
\end{tabular}


Ao verificar a realização da baciloscopia durante o $6^{\circ}$ mês de tratamento, dados presentes na tabela 6 , observa-se que o exame foi ignorado em 33,4\% dos casos. Ainda, nota-se que em $31 \%$ dos pacientes esse teste não foi realizado e em $10,7 \%$ dos eventos não foi necessário indicando a possível cura clínica dos indivíduos.

Tabela 7. Sexo dos indivíduos com tuberculose no Brasil, no período de 2010 a 2019.

\begin{tabular}{lll}
\hline Sexo & Casos & Percentual \\
\hline Ignorado/Branco & 59 & $0,007 \%$ \\
Feminino & 275.372 & $31,4 \%$ \\
Masculino & 602.498 & $68,593 \%$ \\
\hline
\end{tabular}

Quanto as informações sobre o sexo dos pacientes, presentes na tabela 7, nota-se a prevalência de casos no sexo masculino. Tal diferença pode ser entendida devido às diferenças na exposição social, associação a fatores de risco comportamentais e produção reduzida de estrógeno pelo sexo masculino.

Tabela 8. Casos de tuberculose de acordo com a faixa etária no Brasil, no período de 2010 a 2019.

\begin{tabular}{lll}
\hline Idade & Casos & Percentual \\
\hline $0-14$ & 25.550 & $3 \%$ \\
$15-24$ & 150.643 & $17,15 \%$ \\
$25-34$ & 207.826 & $23,7 \%$ \\
$35-44$ & 171.919 & $19,6 \%$ \\
$44-54$ & 143.242 & $16,3 \%$ \\
$55-64$ & 99.116 & $11,3 \%$ \\
65 ou mais & 79.165 & $9,95 \%$ \\
\hline
\end{tabular}

Tabela 9. Casos de tuberculose de acordo com a faixa etária no Brasil, no período de 2010 a 2019.

\begin{tabular}{lll}
\hline Idade & Casos & Percentual \\
\hline $0-4$ & 9.747 & $1,1 \%$ \\
$5-9$ & 5.335 & $0,6 \%$ \\
$10-14$ & 10.468 & $1,3 \%$ \\
$15-19$ & 49.145 & $5,6 \%$ \\
$20-39$ & 400.029 & $45,6 \%$ \\
$40-59$ & 281.435 & $32,0 \%$ \\
60 ou mais & 121.215 & $13,8 \%$ \\
\hline
\end{tabular}

Observando as tabelas 8 e 9, percebe-se uma concentração do número de casos nas faixa etárias entre 25 e 34 anos que possuem um total de 23,7\% dos doentes. Ao verificar a tabela 9 , nota-se o acúmulo de pacientes pertencentes à faixa etária entre 20 e 39 anos com um total de 45,6\% dos casos. Esses dados revelam a ocorrência de infectados pela TB pertencentes aos indivíduos jovens e adultos. 
Tabela 10. Casos de tuberculose de acordo com a raça/etnia no Brasil, no período de 2010 a 2019.

\begin{tabular}{lll}
\hline Raça/etnia & Casos & Percentual \\
\hline Ignorado & 69.097 & $6,9 \%$ \\
Branca & 275.702 & $31,4 \%$ \\
Preta & 114.775 & $13,1 \%$ \\
Parda & 402.422 & $45,9 \%$ \\
Amarela & 6.684 & $0,8 \%$ \\
Indígena & 9.249 & $1,9 \%$ \\
\hline
\end{tabular}

Quanto à raça/etnia, observada na tabela 10, percebe-se um elevado número de indivíduos pardos como os principais afetados, com taxa de 45,9\% do total. Os brancos também se destacam com $31,4 \%$, ocupando o segundo lugar de etnia mais afetada.

Tabela 11. Casos de tuberculose de acordo com a região do país, no período de 2010 a 2019.

\begin{tabular}{lll}
\hline Região & Casos & $\%$ \\
\hline Norte & 93.729 & $10,7 \%$ \\
Nordeste & 235.016 & $26,8 \%$ \\
Sudeste & 396.249 & $45,13 \%$ \\
Sul & 111.218 & $12,67 \%$ \\
Centro-Oeste & 41.717 & $4,7 \%$ \\
\hline
\end{tabular}

Investigando as regiões do país associada à ocorrência da TB durante a última década, presente na tabela 11, observa-se o destaque da região Sudeste concentrando 45,13\% do total. Em segundo lugar encontra-se a região Nordeste com $26,8 \%$ dos casos. Naturalmente, o Sudeste detém o maior número de eventos por ser a região mais populosa do país. Já o nordeste, se destaca pelas suas características socioeconômicas e quantidade de habitantes (segunda localidade mais populosa do Brasil), o que explica sua posição como segunda região mais afetada.

Quando comparada a estatísticas globais, nota-se semelhança com o perfil epidemiológico da TB apresentado pelas notificações de casos brasileiros, uma vez que há também prevalência em indivíduos do sexo masculino (65\%), na faixa etária adulta (90\%), com os casos de coinfecção por HIV registrando uma porcentagem de $10 \%$ do total estimado, embora, ao contrário das estatísticas globais, tenha apresentado tendência de elevação no número de casos (Glaziou, et al. 2018). Tais informações denotam necessidade de adoção e reforço de medidas multissetoriais para monitoração e intervenção, a nível nacional e internacional, com o fito de exiguição da doença (Kuruvilla, et al. 2016). Assim, o fortalecimento do Plano Nacional pelo Fim da Tuberculose como Problema de Saúde Pública, proposto pelo Ministério da Saúde em 2017, mostra-se um esforço nacional a ser realizado (Ministério da Saúde, 2017).

Nessa perspectiva, há necessidade de aplicação de investimentos na pesquisa de melhores e mais curtos tratamentos farmacológicos, bem como no desenvolvimento de vacinas mais eficazes (Furin, et al. 2019). Além disso, há necessidade de abordagem da TB em uma perspectiva social, que explora a descentralização do sistema de saúde de forma a valorizar as características epidemiológicas e sociodemográficas locorregionais. (Matteelli, et al. 2018). Adicionalmente, fazem-se necessárias capacitações aos profissionais da saúde e atualização dos dados epidemiológicos de cada território, de modo a reavaliar e aprimorar as intervenções realizadas (Kritski, et al, 2018). 


\section{CONCLUSÃO}

A pesquisa concluiu que os portadores de TB no período analisado, em sua maioria, foram relacionados aos casos na região Sudeste, havendo tendência de crescimento até o ano de 2018. A doença foi mais frequente no sexo masculino e na raça/etnia parda, com destaque para a faixa etária de 20 a 39 anos. Tendo a área do corpo afetada branca/ignorada, presumivelmente pelo acometimento pulmonar. Além disso, houve presença de coinfecção com HIV, bem como presença de AIDS estatisticamente relevante, destacando-se a insuficiente testagem para HIV. Com relação à baciloscopia, houve reduzida testagem após o sexto mês, provavelmente evidenciando a cura clínica.

A partir da análise desses dados, reforça-se a necessidade da testagem para HIV após a suspeita clínica ou confirmação diagnóstica da TB. Além disso, a adoção de medidas de reforço ao já existente programa de controle da TB, que incluem a capacitação dos profissionais da saúde, fomento a estudos para terapias e profilaxias mais eficazes, bem como estímulo a estudos locais e regionais de caracterização epidemiológica, são necessárias para que as estatísticas da condição no país possam adentrar em curva decrescente.

\section{REFERÊNCIAS}

BRASIL. Manual de Recomendações para o Controle da Tuberculose no Brasil, 2.ed. PO 700, Brasília, 2019.

ESMAIL, H.; RIOU, C.; BRUYN, E.; LAI, R.P.-J.; HARLEY, Y.X.R.; MEINTIES, G.; WILKINSON, K.A.; WILKINSON, R.J. The Immune Response to Mycobacterium tuberculosis in HIV-1-Coinfected Persons. Annual Review of Immunology, vol.36, 603-638, 2018.

FERNANDES, P.; MA, Y.; GAEDDERT, M.; TSACOGIANIS, T.; MARQUES-RODRIGUES, P.; FREGONA, G.; LOOMANS, A.; JONES-LÓPES, E.C.; DIETZE, R.; ELLNER, J.J.; WHITE, L.F. HOCHBERG, N.S. Sex and age differences in Mycobacterium tuberculosis infection in Brazil. Epidemiology and infection, vol. 146, 1503-1510, 2018.

FURIN, J.; COX, H.; PAI, M. Tuberculosis. The Lancet, vol. 393, ed. 10181, 1642-1656, 2019.

GLAZIOU, P.; FLOYD, K.; RAVIGLIONE, M.C. Global Epidemiology of Tuberculosis. Seminars in Respiratory and Critical Care Medicine, vol. 39, 271-285, 2018.

KRITSKI, A.; ANDRADE, K.B.; GALLIEZ, R.M.; MACIEL, E.L.N; CORDEIRO-SANTOS, M.; MIRANDA, S.S.; VILLA, T.S.; NETTO, A.R.; ARAKAKI-SANCHÉZ, D.; CRODA, J. Tuberculosis: renewed challenge in Brazil. Revista da Sociedade Brasileira de Medicina Tropical, vol. 51, ed. 1, 2-6, 2018.

KURUVILLA, S.; BRUSTEO, F.; KUO, T.; MISHRA, C.K. The global strategy for women's, children's and adolescents' health (2016-2030): a road-map based on evidence and country experience. 2016. Disponível em: http://cdrwww.who.int/entity/bulletin/volumes/ 94/5/16-170431.pdf. Acesso em: 20 set. 2020.

MATTEELLI, A.; RENDON, A.; TIBERI, S.; AL-ABRI, S.; VONIATIS, C.; CARVALHO, A.C.C.; CENTIS, R.; D'AMBROSIO, L.; VISCA, D.; SPANEVELLO, A.; MIGLIORI, G.B. Tuberculosis elimination: where are we now? European Respiratory Review, ed. 27, 180035, 2018. 
MINISTÉRIO DA SAÚDE. Secretaria de Vigilância em Saúde. Departamento de Vigilância das Doenças Transmissíveis. Sistema de Informação de Agravos de Notificação: Casos confirmados de Tuberculose desde 2001 por região de notificação. Brasília; 2020. Disponível em: http://tabnet.datasus.gov.br/cgi/tabcgi.exe?sinannet/cnv/tubercbr.def. Acesso em: 20 set. 2020.

MINISTÉRIO DA SAÚDE. Secretaria de Vigilância em Saúde. Departamento de Vigilância das Doenças Transmissíveis. Brasil Livre da Tuberculose: Plano Nacional pelo Fim da Tuberculose como Problema de Saúde Pública.

PEDRO, A.S.; GIBSON, G.; SANTOS, J.P.C.; TOLEDO, M.L.; SABROZA, P.C.; OLIVEIRA, R.M. Tuberculosis as a marker of inequities in the context of socio-spatial transformation. Rev. Saúde Pública, vol.51, Epub, 2017.

SILVA, G.D.M.; DUARTE E.C.; CRUZ, O.G.; GARCIA, P.L. Identificação de microrregiões com subnotificação de casos de tuberculose no Brasil, 2012 a 2014. Epidemiol. Serv. Saúde, vol.29 no.1, Epub, 2020.

TOURINHO, B.D.; OLIVEIRA, P.B.; SILVA, G.D.M.; ROCHA, M.S.; PENNA, E.Q.A.A.; PÉRCIO, J. Avaliação do Sistema de Vigilância da Tuberculose Drogarresistente, Brasil, 2013-2017. Epidemiol. Serv. Saúde, vol.29 no.1, Epub, 2020. 


\section{COVID-19: INTERAÇÕES DO MINISTÉRIO DA SAÚDE COM OS USUÁRIOS DO INSTAGRAM}

SILVIA CRISTIANNE NAVA LOPES

Universidade Federal do Maranhão, São Luís,

Brasil

ELAYNNE VIEIRA DA COSTA

Universidade Federal do Maranhão, São Luís,

Brasil

Acadêmica do Curso Interdisciplinar em Ciência e Tecnologia

ROSANE DE FÁTIMA ANTUNES

OBREGON

Universidade Federal do Maranhão, São Luís,

Brasil

VICTOR HUGO TORRES CRUZ

Universidade Federal do Maranhão, São Luís,

Brasil

Acadêmico do Curso Interdisciplinar em Ciência

e Tecnologia

RESUMO: este estudo pretende analisar as interações virtuais entre a sociedade e o Ministério da Saúde sobre as ações de controle da Covid-19. Trata-se de uma pesquisa bibliográfica e documental, além da análise do material empírico coletado no perfil do Ministério da Saúde no Instagram. Conclui-se que a maioria das interações foram propostas pelos usuários por meio de críticas, questionamentos e elogios. Assim, o Instagram representa um espaço de participação social.

Palavras-chave: Saúde Digital; Mídia Social; Covid-19.
ABSTRACT: This study intends to analyze the virtual interactions between society and the Ministry of Health on the control actions of Covid-19. This is a bibliographical and documentary research, in addition to the analysis of the empirical material collected in the profile of the Ministry of Health on Instagram. It is concluded that the majority of interactions were proposed by users through criticism, questioning and praise. Thus, Instagram represents a space for social participation.

Keywords: Digital Health; Social media; Covid-19.

\section{INTRODUÇÃO}

Marco na evolução tecnológica e comunicacional, em meados da primeira década dos anos 2000, o advento da $W e b$, rede que conecta computadores em todo mundo, trouxe uma nova concepção de uso da Internet. Nesse contexto, intensificou o modo de interagir através de uma comunicação multidirecional. No desdobramento dessa nova abordagem do ambiente virtual, houve o surgimento dos Sites de Redes Sociais (SRS), que permitem aos usuários manter vínculos de relacionamentos. Por conseguinte, possibilita a troca de mensagens públicas e privadas, postagens de fotos e de vídeos, etc. O Facebook, 
Instagram, Twitter e Linkedin são os exemplos de ferramentas mais populares mundialmente (Sousa e Bruck, 2018).

O crescimento e popularização dessas novas formas de comunicação, impactou de forma significativa no comportamento humano e, inclusive, no campo do discurso institucional. Nessa linha, as diferentes organizações precisaram se reinventar e criar formas inovadoras para estabelecer relações com a sociedade. É válido ressaltar, por exemplo, na disseminação de informações sobre doenças, nos tratamentos ou em novas definições para a realização de intervenções no âmbito da saúde pública (Carvalho, 2015).

De acordo com dados do Instituto Brasileiro de Geografia e Estatística (IBGE), o Brasil fechou o ano de 2017 com 126,3 milhões de pessoas conectadas à Internet, o equivalente a 69,8\% da população com 10 anos de idade ou mais. Segundo a pesquisa, o celular se configurou como o principal aparelho para acessar a Internet com 98,7\% dos internautas, à frente de computadores (52,3\%), tablets (15,5\%) e televisões (11,3\%) (Silveira, 2018).

O Instagram é um site de compartilhamento de fotos e vídeos, lançado no ano de 2010, por Kevin Systrom e Mike Krieger. É amplamente utilizado para fins sociais e comerciais que, num pequeno espaço de tempo, tornou-se o maior site de compartilhamento de dados, obtendo a marca de 150 milhões de usuários ativos mensais. Com a crescente quantidade de usuários e o sucesso, o Instagram foi vendido, em 2012, para a empresa Facebook, pelo valor de 1 bilhão de dólares. Acredita-se que o conteúdo fotográfico chama mais atenção do que as mensagens de textos postadas, mas o site apresenta um enorme potencial, uma vez que é possível integrá-lo com outras redes sociais como Facebook e o Twitter, aumentando a sua visibilidade e acessibilidade na Internet (Instagram, 2020).

De acordo com dados publicizados em dezembro de 2019 no SocialBakers, site referência em estatísticas nas redes sociais que destaca as tendências sobre engajamento e publicidade, o Instagram é a rede social mais engajada que apresenta maior índice de usuários que o Facebook. Para o desenvolvimento do estudo do SocialBakers, foram utilizados dados de mais de 10 bilhões de conteúdos em redes sociais gerados por mais de 17 milhões de perfis.

Nesse alinhamento, o presente estudo visa analisar o perfil oficial do Ministério da Saúde no Instagram (@minsaude).Tal proposição torna-se relevante, pois além de compartilhar diversas informações sobre a Covid-19, o MS quando comparado com outros órgãos regulatórios de saúde oficiais brasileiros, é a que reúne o maior número de usuários ativos. Ao visualizar o perfil (@minsaude) no Instagram é possível verificar o registro de aproximadamente 2,2 milhões de seguidores.

\section{CONTEXTO COVID-19}

Com a eclosão de um novo vírus letal, o Novo Coronavírus, em escala mundial e, consequentemente, a imposição de uma série de regras de isolamento social, quarentena e/ou Lockdown 
à população brasileira, a participação social no ambiente virtual, através das redes sociais cresceu exponencialmente.

De acordo com o Ministério da Saúde (MS), o Novo Coronavírus, também denominado de Síndrome Coronariana Aguda 2 da Síndrome Respiratória Aguda (SARS-CoV-2) é uma nova cepa de Coronavírus, que não foi previamente identificada em humanos e causador da doença Covid-19. A transmissão ocorre de uma pessoa doente para outra, por contato próximo, por meio do toque ou aperto de mão, além de gotículas de saliva, espirro, tosse e contato com objetos ou superfícies contaminadas como celulares, mesas, maçanetas, entre outras. O tempo médio entre o período de incubação e a manifestação da doença é de 02 a 14 dias (Brasil, 2020a).

Dentre os sintomas mais comuns da Covid-19, destacam-se a febre alta persistente e tosse ou dificuldade para respirar, entre outros sintomas gripais. Esta doença é mais frequente na população idosa, com comorbidades, tais como hipertensão arterial, diabetes mellitus e cardiopatias. Mas, também pode se manifestar na população jovem. Alguns pacientes não apresentam sintomas, são assintomáticos. Outros poderão desenvolver a forma mais grave da doença e necessitar de suporte avançado para manutenção da vida. Na forma mais grave, o risco de morte é eminente (Brasil, 2020a).

Em janeiro de 2020, a Organização Mundial da Saúde (OMS) declarou o surto da Covid-19 como uma emergência de saúde pública de interesse internacional e, em março de 2020, com a disseminação do Novo Coronavírus em diferentes países, foi declarada a pandemia (Brasil, 2020b).

É importante destacar que, desde o registro do primeiro caso confirmado na cidade de Wuhan (China) no final de 2019, até o dia 30 de junho de 2020, já foram contabilizados um total de 10.538.577 casos confirmados e 512.689 óbitos por Covid-19 no mundo. O Brasil ocupa o $2^{\circ}$ lugar no ranking mundial com 1.402.041 casos confirmados e 59.594 óbitos, permanecendo acima de países como a China, Itália, Espanha, Rússia e a Índia (Johns Hopk, 2020). No Maranhão, foram contabilizados 80.451 casos confirmados e 2.048 de óbitos (Ses-MA, 2020).

Nesse momento ímpar de crise sanitária, a pandemia pela Covid-19 apresenta uma complexa rede de aspectos, relacionadas à estrutura e regulação do sistema público de saúde, o SUS, no qual se impõe a necessidade de manutenção de regras de etiqueta respiratória e medidas de isolamento social, gerando insegurança, angústia e medos na população diante da possibilidade de contágio/infecção e de morte provocados pelo "inimigo invisível”, o Novo Coronavírus. Assim, emerge o papel relevante dos sites de redes sociais, possibilitando que um maior número de pessoas tenha acesso as informações sobre medidas protetivas e sobre o que está sendo discutido pelos órgãos oficiais de regulação em saúde no Brasil.

Nesse contexto, o objetivo do presente estudo foi analisar as interações entre o Ministério da Saúde e seus usuários do perfil oficial do Ministério da Saúde no Instagram sobre a pandemia da Covid-19. 


\section{MATERIAL E MÉTODOS}

Trata-se de uma pesquisa exploratória, de abordagem qualitativa acerca das interações realizadas entre o Ministério da Saúde (MS) e os seus usuários sobre a Covid-19 no Instagram. Foi adotado o Estudo das Representações Sociais como tipologia qualitativa.

Para Jovchelovitch (2015), o Estudo das Representações Sociais tem como premissa as palavras, sentimentos e condutas que se institucionalizam, sendo analisadas a partir da compreensão das estruturas e comportamentos sociais. Sua mediação é a linguagem, tomada como forma de conhecimento e de interação social, fruto da vivência das contradições que permeiam o dia a dia de grupos sociais.

O Cenário de Estudo foi o perfil oficial do Ministério da Saúde no Instagram (@minsaude). Os sujeitos de pesquisa foram: o Estado, representado pelo próprio Ministério da Saúde e a sociedade brasileira contemporânea, representada pelos usuários do perfil do Ministério da Saúde no Instagram.

A amostra se caracterizou como do tipo Casos Múltiplos, obtida de acordo com os critérios usados em investigações qualitativas, buscando abranger, a partir de uma escolha intencional, as diferentes experiências e condições.

De acordo com Minayo (2001), a pesquisa qualitativa não se baseia no critério numérico para garantir a sua representatividade. A amostra adequada é a que possibilita abranger a totalidade do problema investigado em suas múltiplas dimensões.

Assim o fechamento da amostra qualitativa seguiu o critério de Saturação de Sentidos, que é determinado pela repetição das falas e/ou discursos. Fontanella et al. (2008) afirmam que a Saturação de Sentidos representa uma ferramenta conceitual utilizada para estabelecer ou fechar o tamanho final de uma amostra de estudo, interrompendo a captação de novos componentes, quando os dados obtidos passam a apresentar uma certa redundância ou repetição.

Com relação aos instrumentos de pesquisa, foram utilizados documentos oficiais do Ministério da Saúde sobre a Covid 19, tais como manuais, protocolos e boletins epidemiológicos de saúde publicizados na Internet, na forma de texto, hipertexto e hipermídia. Além disso, foram selecionados artigos em sites de busca, tais como: Biblioteca Virtual em Saúde (BVS), Scielo (Scientific Electronic Library On Line) e Google Acadêmico com os seguintes descritores: saúde digital, mídia social e Covid-19. A pesquisa foi complementada e atualizada por autores e títulos considerados relevantes.

Ainda no que concerne aos instrumentos de pesquisa, destaca-se que a Internet pode se configurar como objeto de pesquisa (aquilo que se estuda), bem como o local da pesquisa (ambiente ou cenário onde a pesquisa é realizada) e, ainda, como um instrumento de pesquisa, ou seja, a ferramenta para coleta de dados sobre um determinado tema (Fragoso et al., 2011). Nesse sentido, a coleta de dados do presente estudo foi realizada através da observação estruturada do perfil oficial do Ministério da Saúde no Instagram, buscando informações sobre a Covid-19 publicizadas, no período de janeiro a março de 2020 . 
A partir da coleta dos dados, realizou-se um mapeamento das principais interações do Ministério da Saúde e seus usuários no Instagram. Foram mapeadas as informações mais relevantes sobre medidas preventivas de controle da Covid-19 publicizadas pelo Ministério da Saúde; as principais dúvidas dos usuários sobre a Covid-19; as denúncias e críticas dos usuários direcionadas as ações de controle da Covid-19 desenvolvidas pelo Ministério da Saúde; as principais sugestões dos usuários para melhoria das ações de controle da Covid-19 no país e; os elogios à atuação do Ministério da Saúde contra a Covid-19.

Com relação ao processo de análise dos dados coletados, este foi desenvolvido em três fases propostas por Bardin (2011), quais sejam: Pré-análise, Exploração do Material e Interpretação. Na primeira fase, foi realizada a leitura, organização do material e definição das categorias analíticas. $\mathrm{Na}$ segunda fase, os núcleos de sentidos atribuídos pelos usuários, foram classificados por categorias analíticas, já definidas na etapa anterior. Finalmente, na terceira fase foi realizada a análise e articulações destes dados com os referenciais teóricos da pesquisa.

Com relação aos aspectos éticos, destaca-se que a proposta da pesquisa se dispôs a trabalhar apenas com dados de domínio público, além de pesquisa bibliográfica e documental de materiais publicizados na Internet (de acesso público). Neste caso, de acordo com a Resolução 510/2016, do Conselho Nacional de Saúde (CNS), não necessitou de aprovação por parte de Comitê de Ética em Pesquisa (CEP).

\section{RESULTADOS E DISCUSSÃO}

Ao lançar a sua conta no Instagram, o Ministério da Saúde destaca que se trata da de uma conta oficial de relacionamento com os usuários, para atendimento à população e divulgação de campanhas, agendas, programas e ações do Ministério da Saúde, ampliando a sua interação com os usuários das redes sociais.

Assim, compreende-se que o Ministério qualifica a conta no Instagram como um espaço de socialização e de conversação, propício para interagir com a população. É importante destacar a percepção que o Ministério da Saúde tem do Instagram para desvelar as estratégias que vem utilizando para se posicionar nesse ambiente e quais resultados espera alcançar ao dialogar com a sociedade sobre as políticas públicas de saúde.

O propósito da pesquisa foi analisar essas interações, tendo como foco os tipos de debates que elas suscitam em torno da pandemia da Covid-19 e a necessidade de realização de uma campanha educativa sobre a adoção de medidas preventivas. Para isso, foi possível mapear as interações, a partir do discurso dos sujeitos de pesquisa (usuários e Ministério da Saúde) e das relações (conexões) construídas entre si no ambiente virutal.

O volume de informações produzidas no perfil do Ministério da Saúde do Instagram, no período de janeiro de 2020, quando a Organização Mundial da Saúde (OMS) declarou o surto da 
Covid-19 como uma Emergência de Saúde Pública de Interesse Internacional, até março de 2020, quando a OMS declarou a Pandemia de Covid-19 foi de 153 postagens pelo Ministério da Saúde.

Durante o processo de mapeamento das interações, foi identificada uma publicação do Ministério da Saúde, postada no Instagram, no dia 29 de janeiro de 2020, advertindo a sociedade brasileira de que havia uma notícia falsa, fake News. Tal notícia era referente ao chá de erva-doce, que continha substâncias similares ao medicamento Tamiflu (Fosfato de Oseltamivir), medicamento utilizado na época para tratamento de pacientes com Covid-19 na Tailândia. Foi a partir deste incidente, que o Ministério da Saúde passou a realizar postagens mais frequentes contra o compartilhamento de notícias falsas contra a Covid-19:

\footnotetext{
"Nenhum tipo de chá pode ser usado para substituir um tratamento adequado contra a gripe, muito menos contra o Coronavirus. Também é falso que o chá de erva-doce tem a mesma substância do medicamento Tamiflu (Fostato de Oseltamivir). Não confiem e nem compartilhem mensagens deste tipo. Podem ter consequências graves [...] Se você receber alguma mensagem sobre o Novocoronavírus, procure o canal SAÚDE SEM FAKE NEWS do Ministério da Saúde ANTES DE REPASSÁ-LA aos seus amigos e familiares" (Fonte: Ministério da Saúde, 2020).
}

Figura 1: Fake news.

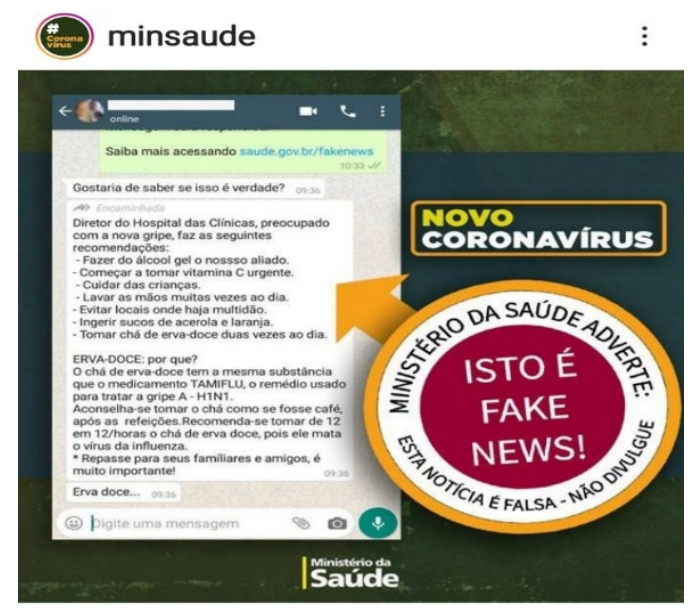

Fonte: Ministério da Saúde, 2020.

Vale ressaltar que a maioria das postagens do Ministério da Saúde relacionadas as ações de prevenção e controle da pandemia da Covid-19 foram direcionadas para a sociedade em geral, priorizando como público-alvo, os idosos, os pacientes portadores de doenças crônicas, como o Diabetes Mellitus e as doenças cardiovasculares, as gestantes e pacientes sintomáticos respiratórios recém-chegados no Brasil, provenientes de países com casos confirmados da Covid-19.

As crianças, segundo o Ministério da Saúde seriam, na maioria assintomáticas e raramente poderão desenvolver a forma grave da doença. Foram excluídos os pacientes portadores de doenças imunodeprimidas (autoimunes) e os pacientes portadores do Vírus da Imunodeficiência Humana (HIV), demonstrando que a concepção do Ministério ao desenhar as medidas preventivas, no período de janeiro a março de 2020 foi vertical, focalizada, seletiva e não-universal, o que pode ter contribuído para o crescimento exponencial da pandemia da Covid-19 no país, logo após o período do Carnaval. Isso ficou evidente no discurso (texto, imagem e vídeos) utilizado, conforme é possível verificar: 
Figura 2: Grupo de Risco no perfil @minsaude

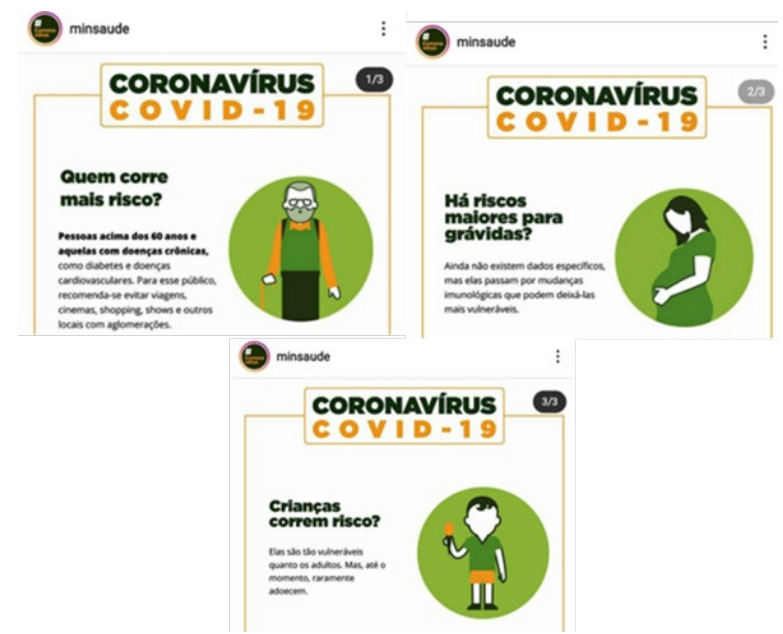

Fonte: Ministério da Saúde, 2020.

Adicionalmente, a pesquisa apontou que a iniciativa do Ministério da Saúde, no seu perfil no Instagram, se limitou a realizar postagens acerca das ações pontuais de controle da Covid-19 e informações acerca das principais medidas preventivas adotadas no período de janeiro a março de 2020. No entanto, constatou-se que as perguntas postadas pelos usuários, não havia uma iniciativa do Ministério da Saúde em respondê-las integralmente e, quando respondiam, continham poucas informações, conforme exemplo a seguir:

Figura 3: Postagens no perfil@minsaude.

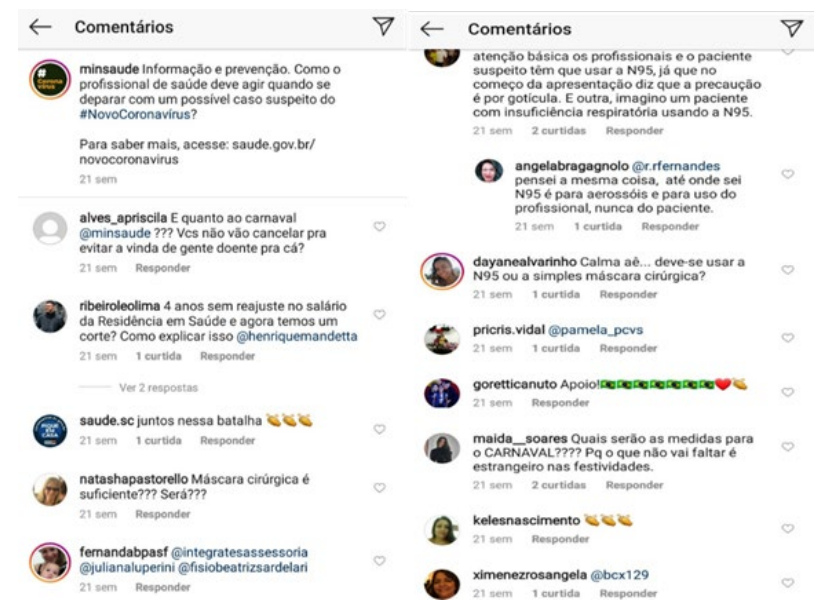

Fonte: Ministério da Saúde, 2019.

A partir do mapeamento das interações no Instagram, foi possível identificar como o Ministério da Saúde assentava as postagens e o que os usuários argumentavam. Essa lógica discursiva Essa lógica discursiva (Jovchelovitch, 2015; Fontanella et al., 2008) pode ser observada no quadro a seguir: 


\begin{tabular}{|c|c|}
\hline Discurso dos Usuários & Discurso do Ministério da Saúde \\
\hline $\begin{array}{l}\text { Ações de Controle da Covid-19: Fechem os aeroportos. } \\
\text { Controlem os voos vindos de fora. } \\
\text { Não deixem as nossas fronteiras abertas. } \\
\text { Cancelem o carnaval. } \\
\text { Cuidem dos brasileiros. } \\
\text { Pelo amor de Deus, tenham atitude. }\end{array}$ & $\begin{array}{l}\text { O SUS está preparado para desenvolver todas as ações para proteger a } \\
\text { saúde dos brasileiros. } \\
\text { Será realizado o monitoramento de portos, aeroportos em relação aos ris- } \\
\text { cos para a saúde e ao trânsito de bens, pessoas e mercadorias. }\end{array}$ \\
\hline $\begin{array}{l}\text { Medidas Preventivas: } \\
\text { Deveria proibir os vôos de locais onde há casos confirmados dessa doen- } \\
\text { ça; } \\
\text { Que tenhamos águas nas torneiras, em primeiro lugar; } \\
\text { Cancelar o carnaval. } \\
\text { Proibir aglomerações. } \\
\text { É para andar de máscara? } \\
\text { A máscara de tecido também protege? } \\
\text { Devemos usar a máscara N95? }\end{array}$ & $\begin{array}{l}\text { Lavar as mãos com água e sabão; } \\
\text { Usar lenço descartável para higiene nasal; } \\
\text { Cobrir o nariz e a boca ao espirrar e tossir; } \\
\text { Evite tocar os olhos, nariz e a boca; } \\
\text { Não compartilhe objetos de uso pessoal; } \\
\text { Evite contato com pessoas com sintomas respiratórios/gripadas; } \\
\text { Os sintomáticos devem usar máscaras. }\end{array}$ \\
\hline $\begin{array}{l}\text { Sobre o Carnaval: } \\
\text { Como o Brasil vai se preparar para o Carnaval? } \\
\text { Cancelem o carnval. } \\
\text { Boa sorte para nós nesse carnaval. Já que vai acontecer de qualquer jeito } \\
\text { né? } \\
\text { O carnaval vai ser contagiante, kkkk. } \\
\text { Cancelem o carnaval, tenham bom senso, já tem muita gente morta lá } \\
\text { fora. } \\
\text { Alerta máximo? Isso já resolve tudo né? } \\
\text { Cancelem o carnaval, mais cautela com o povo brasileiro. } \\
\text { Depois do carnaval os casos vão aparecer. } \\
\text { Eu ficarei em casa. } \\
\text { O vírus já está em } 13 \text { países e você pode ter o vírus e não apresentar } \\
\text { sintomas. }\end{array}$ & $\begin{array}{l}\text { O Carnaval é uma festa cultural e não será cancelada. O Ministério da } \\
\text { Saúde irá trabalhar com o máximo de alerta em aeroportos e portos. No } \\
\text { momento, não há comprovação de que o Novo Coronavírus esteja circu- } \\
\text { lando Brasil. }\end{array}$ \\
\hline $\begin{array}{l}\text { Repatriamento de brasileiros da China: } \\
\text { E quem vigia os chineses no Brasil? } \\
\text { Precisa proibir a entrada de chineses no Brasil. } \\
\text { Não vamos ter estrutura para receber esse povo. Os brasileiros estão cor- } \\
\text { rendo um sério risco com a decisão de repatriar os brasileiros da China. } \\
\text { Deixem os brasileiros lá na China, é um meio de não trazer mais gente } \\
\text { doente para o Brasil. } \\
\text { O Brasil é um país acolhedor, Em meio ao caos, somos capazes de aco- } \\
\text { lher de braços abertos o nosso povo. Sejam bem vindos. } \\
\text { Parabéns pelo incentivo. } \\
\text { Trazê-los é uma questão de humanidade } \\
\text { Proíbam a entrada de qualquer pessoa vinda de áreas de risco. }\end{array}$ & $\begin{array}{l}\text { Como vai funcionar a operação de Regresso ao Brasil: São duas aero- } \\
\text { naves. Que vão chegar e pousar na base. Não haverá circulação em am- } \\
\text { biente civil. Os repatriados ficarão } 18 \text { dias isolados e em monitoramento } \\
\text { médico. } \\
\text { Atenção: evitem viagens para a China. }\end{array}$ \\
\hline $\begin{array}{l}\text { Caso Suspeito: } \\
\text { Quem define caso suspeito? } \\
\text { O SUS não está preparado para nada. } \\
\text { Será? } \\
\text { Como? Se não existe exame, nem medicamentos e nem vacina contra } \\
\text { ele? } \\
\text { Já pensaram em qualificação profissional para identificação? }\end{array}$ & $\begin{array}{l}\text { O SUS está em alerta para detectar os casos suspeitos de \#Coronavírus } \\
\text { e agir. } \\
\text { O Ministério da Saúde está pronto para realizar o diagnóstico. } \\
\text { Definição de Caso suspeito: febre e pelo menos um sintoma respiratório, } \\
\text { como tosse e dificuldade de respirar e histórico de viagem para áreas de } \\
\text { transmissão local do Coronavírus. }\end{array}$ \\
\hline $\begin{array}{l}\text { Disseminação do vírus: } \\
\text { As fronteiras ainda estão abertas? Que tipo de exigência ou averiguação } \\
\text { se faz para entrada no país? } \\
\text { Encomenda que vem da China pode transmitir o vírus? } \\
\text { Estou aguardando uma encomenda da China. Alguma recomendação? } \\
\text { Tenham mais rigidez nos aeroportos, por favor! }\end{array}$ & $\begin{array}{l}\text { Não há caso de contaminação com Coronavírus da China. } \\
\text { Não há chance de uma pessoa receber uma encomenda contaminada da } \\
\text { Chin com o Coronavírus. }\end{array}$ \\
\hline
\end{tabular}

Fonte: os autores.

O quadro acima nos dá uma visão geral dos argumentos utilizados pelos usuários e Ministério da Saúde. Dessa forma, é possível constatar que houve pouca intervenção do Ministério da Saúde no sentido de se estabelecer uma conversação mais efetiva com os seus usuários. A análise dos dados permite-nos afirmar que a maioria das interações são provenientes dos usuários no sentido de solicitar esclarecimentos sobre as ações de controle contra o Novo Coronavírus, propostas pelo Ministério da Saúde. Por conseguinte, observa-se interações de insatisfação e críticas dos usuários com as ações 
do Ministério de Saúde. Nesse sentido, infere-se que apesar das limitações, o perfil do Ministério da Saúde no Instagram representa um espaço de socialização, no qual as pessoas estabelecem um contato direto com o Estado.

A tensão está presente em grande parte das interações, na qual os usuários criticam e/ou tentam desqualificar as postagens do Ministério da Saúde. Nesse entendimento, o discurso do senso comum dos usuários denota fragilização às ações do Ministério da Saúde, que na maioria das vezes, adota uma postura de evitar o confronto, se limitando a fornecer informações mais gerais acerca das medidas preventivas e ações de controle da Covid-19 no país.

Diante do exposto, as redes sociais da Internet configuram-se como espaços de interação e sociabilização situados nas fronteiras, cada vez mais frágeis, entre o público e o privado. Neste caso concreto a interação propicia uma aproximação entre o Estado e o cidadão, estabelecendo relações, em que o cidadão busca informação e cobra o governo acerca das ações mais enérgicas de controle da Covid-19. É claro que essas interações não estão na mesma esfera de decisão da participação social legitimada pelos instrumentos legais. A finalidade das interações nas redes sociais é de gerar o debate sobre as políticas de saúde.

\section{CONCLUSÃO}

Neste estudo foi possível analisar a participação dos cidadãos nas redes sociais da Internet, tomando como referência os debates sobre as ações de controle do Ministério da Saúde contra a Covid-19. Fica evidente na pesquisa a participação do Estado, através do seu órgão regulatório oficial, o Ministério da Saúde. Nesse sentido, ferramentas como a referenciada neste escopo, ratifica que a presença dos perfis de instituições públicas nas mídias sociais, têm possibilitado uma aproximação entre os cidadãos e o Estado. Por conseguinte, lançado consolida bases para a democratização da administração pública, em conformidade com os princípios do Sistema Único de Saúde, o SUS.

Finalmente, constata-se que ancorada no objetivo principal da pesquisa, foi possível reunir um substrato significativo para analisar as interações entre o Ministério da Saúde e seus usuários na rede social Instagram. A análise dos dados demostrou que a maioria das interações foram propostas pelos usuários com o propósito de questionar e criticar as estratégias verticais, seletivas e não-universal das ações contra a Covid-19.

No que diz respeito às políticas públicas de saúde, as interações nas redes sociais na Internet não possuem o poder decisório dos espaços tradicionais e constitucionalmente legitimados e institucionalizados de participação social. Entretanto, se configuram como um novo ambiente que possibilita outras formas de participação social. São espaços de interação, às vezes permeados por tensão entre os campos sociais, no qual a população se posiciona e disputa o poder de questionar e de criticar as políticas públicas de saúde. Por outro lado, a presença do Ministério da Saúde na rede social viabiliza um ambiente propício para realização de debates, no qual os cidadãos podem interagir com o Estado e mobilizar outras pessoas para maior engajamento no âmbito da saúde pública. 


\section{REFERÊNCIAS}

Bardin, L. Análise de conteúdo. Lisboa: Edições 70, 2011.

Brasil, Ministério da Saúde. O que é coronavírus? 2020a. Disponível em: https://coronavirus.saude.gov.br/ sobre-a-doenca\#transmissao. Acesso em: 22 jun. 2020.

Brasil, Ministério da Saúde. Painel coronavírus? 2020b. Disponível em: https://covid.saude.gov.br/. Acesso em: 22 jun. 2020.

Carvalho, M.C. Comunicação e saúde: interações do ministério da saúde com os usuários das redes sociais na internet. Dissertação (Mestrado em Políticas Públicas) da Universidade Federal do Maranhão, 2015. 129 f. Disponível em: http://tedebc.ufma.br:8080/jspui/handle/tede/794. Acesso em 22 jun. 2020.

Fontanella, B.J.B., Ricas, J., Turato, E. R. Amostragem por saturação em pesquisas qualitativas em saúde: contribuições teóricas. Cadernos de Saúde Pública. v.24, n.1, p.17-27, 2008.

Fragoso, S.; Recuero, R.; Amaral, A. Métodos de pesquisa para internet. Porto Alegre: Sulinas, 2011.

Silveira, D. Brasil ganha 10 milhões de internautas em 1 ano, aponta IBGE. Portal Globo.com, Brasília, 20 dez. 2018. Disponível em: https://g1.globo.com/economia/tecnologia/noticia/2018/12/20/numero-de-internautascresce-em-cerca-de-10-milhoes-em-um-ano-no-brasil-aponta-ibge.ghtml. Acesso em: 22 jun. 2020.

Instagram, Os segredos do instagram: como usar o instagram para alcançar sucesso na vida e nos negócios [ONLINE]. Disponível em: https://pt.slideshare.net/DigitalCoaching/os-segredos-do-instagram. Acesso em: 22 jun. 2020.

Johns Hopk. University and Medicine. Coronavirus covid-19 global cases by the center for systems science and engineering. Johns Hopk, 30 jun. 2020. Disponível em: https://coronavirus.jhu.edu/map.html. Acesso em 30 jun. 2020.

Jovchelovitch, S. The anthropological, narrative, dialogical and subjective paradigmatic approaches to social representations. Roma: European Comission, Research Executive Agency, 2015.

Minayo, M.C.S. Pesquisa social: teoria, método e criatividade. Petrópolis: Vozes, 2001.

Ses-MA, Secretaria de Estado da Saúde do Maranhão. Boletim epidemiológico com distribuição de casos de covid-19 notificados no Maranhão. 2020. Disponível em: http://www.saude.ma.gov.br/wp-content/ uploads/2020/06/BOLETIM-30-06.pdf. Acesso em: 30 jun. 2020.

Socialbakers, Tendências mais importantes das mídias sociais a serem lembradas em 2019 [ONLINE]. Disponível em: https://www.socialbakers.com/social-media-content/studies/most-important-social-media-trendsto-remember-in-2019. Acesso em: 22 jun. 2020.

Sousa, M.P.L; Bruck, M.S. Processos de comunicação das operadoras de saúde: apontamentos para utilização da internet para promoção da saúde no Brasil. Rev. Caderno de Comunicação Santa Maria. v.22, n.1, p.144$169,2018$. 


\section{A RELAÇÃO ENTRE O ALEITAMENTO MATERNO E O DESENVOLVIMENTO DO SISTEMA ESTOMATOGNÁTICO}

MILAYDE SERRA BRAGA

Universidade Nilton Lins (UNL)

\section{EMILY CARLA PRESTES CAVALCANTE}

Universidade Nilton Lins (UNL)

RESUMO: O aleitamento materno exclusivo é de extrema importância para o desenvolvimento infantil, especificamente para o sistema estomatognático, podendo evitar futuros problemas de maloclusões. Contudo, existem casos de crianças que não possuem acesso ao aleitamento materno exclusivo e isto contribui negativamente com o desenvolvimento mastigatório e craniofacial, além de problemas a longos prazos. Objetiva-se determinar de que maneira o leite materno influencia no desenvolvimento infantil e suas influências.

PALAVRA-CHAVE: Leite humano; Sistema estomatognático; Aleitamento materno.

\begin{abstract}
Exclusive breastfeeding is extremely important for infant development, specifically for the stomatognathic system, and may prevent future malocclusion problems. However, there are cases of children who do not have access to exclusive breastfeeding and this contributes negatively to the masticatory and craniofacial development, as well as long-term problems. The aim is to determine how breast milk influences infant development and its influences.
\end{abstract}

KEYWORDS: Human milk; Stomatognathic system; Breastfeeding.

\section{INTRODUÇÃO}

O aleitamento materno é um fator essencial para o crescimento e desenvolvimento do bebê, especificamente nos primeiros seis meses de vida (BOCCOLINI, CARVALHO e OLIVEIRA, 2015; MINISTÉRIO DA SAÚDE, 2015; BOCCOLINI et al., 2017). Além disso, auxilia na relação afetiva entre mãe e filho, mas também no processo imunológico e psicológico. Tudo se inicia na trigésima segunda semana de gestação, pois é o momento em que o feto passa a apresentar reflexos de sucção (CASSIMIRO et al., 2019). Após o nascimento, o aleitamento materno traz diversos benefícios para o desenvolvimento do sistema estomatognático da criança, pois devido a sucção que ocorre neste período, a língua e o lábio movimentam-se em conjunto permitindo que ocorra o processo de deglutição alinhado à respiração, podendo evitar futuros problemas de maloclusões.

O leite materno possui diversos nutrientes e uma variedade de vitaminas, minerais, proteínas, gorduras e carboidratos, além de ser rico em anticorpos necessários ao desenvolvimento do bebê (OLIVEIRA, CARIELLO e DINELLY, 2016). Boccolini et al. (2017) afirmam que somente o leite produzido pela mãe é suficiente para a correta nutrição do bebê até os 6 primeiros 
meses de vida. Os principais benefícios para a criança englobam um melhor desenvolvimento intelectual, a prevenção contra obesidade, doenças cardíacas, contagiosas e alérgicas, alívio de cólicas, permite também o estabelecimento do peso ideal devido a inúmeros nutrientes e vitaminas (CIAMPO e CIAMPO, 2018). Mas essas consequências não se restringem apenas ao bebê, pois a mãe que amamenta também possui seus benefícios, como a prevenção de câncer de útero e mama, o restabelecimento do peso, menor sangramento pós-parto, além de evitar a osteoporose e doenças cardiovasculares (ROCHA et al., 2018).

Mas umas das maiores influências do aleitamento materno se dá no processo de sucção praticado pelo bebê durante a amamentação, processo este que contribui com o desenvolvimento do sistema estomatognático (SILVA et al., 2019). Neste ato, com a correta posição da língua, o bebê pressiona o seio da mãe de forma que saia somente a quantidade de leite necessária a ser deglutida, auxiliando o desenvolvimento dos fonemas da fala e outros benefícios, como a formação da musculatura e dos ossos (ROCHA e GONÇALVES, 2019). Além disso, este processo possibilita o estímulo necessário para o desenvolvimento do sistema muscular, da ossatura bucal e da respiração nasal (CASSIMIRO et al., 2019).

Contudo, existem casos em que bebês não possuem acesso ao leite materno devido a inúmeros fatores. Isto contribui negativamente ao desenvolvimento mastigatório e consequentemente ao desenvolvimento craniofacial, impossibilitando a correta sucção e outros processos necessários ao desenvolvimento da criança, além de problemas a curtos, médios e longos prazos. Segundo Duarte (2019), a atuação do cirurgião-dentista é primordial no auxilio, orientação e incentivo à mulher gestante e às recém-mães em relação à prática do aleitamento, visto que se não for feito da forma correta podem haver consequências de maloclusões dentárias. Sendo assim, o objetivo deste estudo é determinar de que maneira o aleitamento materno influencia no desenvolvimento infantil, as consequências ao sistema estomatognático do bebê que não tem acesso a este método e, a partir disso, demonstrar a importância do aleitamento natural para a mãe e para o bebê.

\section{MATERIAL E MÉTODOS}

Realizou-se uma revisão bibliográfica de caráter descritivo e explicativo mediante pesquisa de informações pertinentes ao tema. A coleta de dados foi realizada nas bases de dados Scielo, PubMed e Lilacs entre os meses de março e julho de 2020. Foram relacionados diversos artigos da bibliografia atual e clássica, utilizando palavras-chave como leite humano, sistema estomatognático e aleitamento materno. Os resultados das pesquisas mostraram-se positivamente similares na relação do aleitamento materno exclusivo com o desenvolvimento infantil. 


\section{RESULTADOS E DISCUSSÃO}

Durante o período gestacional o feto passa por diversas fases de desenvolvimento, porém é na décima terceira semana de gestação que a sucção passa a ser notada (SILVA et al., 2019). Ainda nesse período, inicia-se a odontogênese, a formação da língua, dos lábios, dos músculos e da articulação temporomandibular (ATM) e desenvolve-se também o palato primário, que origina a pré-maxila, rebordo alveolar e parte interna do lábio superior (Tabela 1). Mas é somente na trigésima segunda semana de vida intrauterina que o feto passa apresentar reflexos de sucção (CASSIMIRO et al., 2019).

\begin{tabular}{|c|c|}
\hline Estrutura & Início do desenvolvimento intrauterino \\
\hline Mandíbula & $3^{\mathrm{a}}$ semana \\
\hline Maxila & $3^{\mathrm{a}}$ semana \\
\hline Língua & $4^{\mathrm{a}}$ semana \\
\hline Odontogênese & $6^{\mathrm{a}}$ semana \\
\hline Lábios & $6^{\mathrm{a}}$ semana \\
\hline ATM & $8^{\mathrm{a}}$ semana \\
\hline
\end{tabular}

Tabela 1: Desenvolvimento do Sistema Etomatognático durante a vida intrauterina

A odontologia atua desde a vida intrauterina de modo a prevenir riscos futuros, por isso o correto acompanhamento da vida do bebê no útero evita possíveis alterações no desenvolvimento infantil. No entanto, a literatura aponta que existe uma impossibilidade de diagnosticar problemas bucais nesta fase com os métodos de diagnósticos atuais (ROCHA e GONÇALVES, 2019).

Após esse período, o desenvolvimento continua após o nascimento a partir do processo da amamentação. A Organização Mundial da Saúde (OMS) e o Ministério da Saúde (MS) recomendam o aleitamento materno exclusivo até os seis primeiros meses de vida do bebê, podendo começar a receber alimentos complementares somente após este período e continuando a ingerir o leite materno até os dois anos de vida ou mais (BOCCOLINI et al., 2017; MINISTÉRIO DA SAÚDE, 2015). Esta recomendação parte do pressuposto de que o desenvolvimento dos lactentes, bem como o desenvolvimento craniofacial, depende das propriedades nutricionais e imunológicas que apenas o leite materno pode oferecer.

Inúmeros fatores apontam para a importância dos primeiros seis meses de vida do bebê, como o fortalecimento do vínculo mãe-filho devido o contato - o que traz a sensação de segurança para o bebê e de autoconfiança para a mãe -, o desenvolvimento cognitivo, a prevenção da diarreia (principalmente entre crianças de baixa renda) e da pneumonia, que são as principais causas de mortalidade infantil (SANTOS et al., 2016). Jama et al. (2020) afirmam que até o ano de 2020 apenas cerca de $40 \%$ das crianças obtiveram amamentação exclusiva, devendo aumentar para 50\% até 2025. Embora o aleitamento materno exclusivo tenha aumentado nas últimas décadas, ainda há um longo caminho para atingir os 100\% recomendados pelo Fundo das Nações Unidas para a Infância.

Além disso, o aleitamento materno auxilia no desenvolvimento de diversas funções do sistema estomatognático, como a face, fonação, respiração e deglutição. Estudos apontam que a amamentação traz menor risco de maloclusão dental, além de prevenir cerca de 820.000 mortes de crianças 
menores de cinco anos por ano no mundo e cerca de 20.000 mortes de mulheres por câncer de mama (SANTOS et al., 2017; BOCCOLINI et al., 2017). Por isso a importância de sempre promover o aleitamento materno exclusivo nas diversas esferas sociais como modo de incentivo às mulheres e seus familiares, dado o fato de seus inúmeros benefícios.

Segundo a OMS, evidências apontam que o aleitamento materno apresenta benefícios para a vida da mãe e do bebê, que podem ser a curtos e longos prazos. O MS (2015) destaca que, com relação à mãe, ocorre a involução uterina e sangramento reduzido, o retorno do peso e imagem corporal, prevenção da depressão pós-parto, câncer de mama, ovário e endométrio, endometriose, doença de Alzheimer e doenças sistêmicas, tais como diabetes mellitus, osteoporose e doenças cardiovasculares (CIAMPO e CIAMPO, 2018). Além disso, a OMS afirma que, para o bebê, entre os principais benefícios estão a redução da morbimortalidade infantil, aumento do número de anticorpos, ganho de peso, desnutrição, doenças respiratórias, diabetes mellitus, dermatite atópica, rinite alérgica, obesidade, melhores índices de desenvolvimento neuromotor e cognitivo, quociente intelectual e exercita a região perioral e intraoral (DUARTE, 2019; BRASIL, 2015).

Os inúmeros benefícios supracitados se devem às propriedades do leite materno, que se manifestam por meio dos componentes solúveis ( $\operatorname{IgA}$, $\operatorname{IgM}$, $\operatorname{IgC}$, $\operatorname{IgD}$, $\operatorname{IgE}$, lisozimas, lactobacilos e outras substâncias imunorreguladoras) e dos componentes celulares, como os macrófagos, linfócitos, granulócitos, neutrófilos e células epiteliais (WOLDEAMANUEL, 2020). Esses benefícios tornam-se muito relevantes em relação aos bebês, visto que possuem um sistema imunológico mais vulnerável. Estudos apontam que a sucção exercida pelo bebê também é um fator determinante para uma amamentação consistente, além de contribuir com o desenvolvimento do SE, como os músculos, lábios, língua, entre outros componentes da face (CASSIMIRO et al., 2019; MESQUISTA et al., 2016; EXAVERY et al., 2015).

O sistema estomatognático é um conjunto formado por estruturas bucais interligadas e relacionadas, como as articulações, músculos, ossos, lábios, língua, bochechas e dentes e realiza funções principais, tais como a deglutição, fonação, mastigação e respiração. O correto exercício do sistema estomatognático acarreta na estimulação e desenvolvimento craniofacial e isto se dá principalmente no processo de amamentação. Segundo Kebede et al. (2020), o leite humano contém todos os macronutrientes (carboidratos, proteínas e lipídios), micronutrientes (minerais e vitaminas) e componentes bioativos e imunológicos necessários para o correto desenvolvimento do sistema estomatognático, mas é no ato da sucção que ocorre o fortalecimento dos músculos e o desenvolvimento dos ossos, gerando harmonia facial.

Durante a amamentação do bebê, os músculos da mandíbula posicionam-se horizontalmente e realizam movimentos anteroposteriores, preparando assim os movimentos mastigatórios no futuro e possibilitando a cessação do retrognatismo mandibular, que é a desarmonia facial que envolve ossos e dentes da mandíbula e maxila (DUARTE, 2019; MEDEIROS e RODRIGUES, 2001; QUELUZ e GIMENEZ, 2000). Para isto, o bebê precisa aprender a retirar o leite adequadamente, abrindo a boca e fixando-a no mamilo e na aréola, momento em que o rebordo incisivo superior apoia-se na superfície superior do mamilo. Concomitantemente, a mandíbula realiza movimentos de protusão (movimentos dianteiros) e retrusão (movimentos de retração) e a língua ergue suas bordas laterais e ápice por meio 
de movimentos peristálticos, levando o leite até a faringe e esôfago, o que ativa o reflexo de deglutição (CASSIMIRO et al., 2019).

O bebê realiza um esforço físico intenso e isto propicia o estímulo do sistema muscular, da ossatura bucal e da respiração nasal. Os músculos que compreendem o aleitamento materno são os digástricos, gênio-hióideos e milo-hióideos, em destaque o pterigóideo lateral, pterigoideo medial, masseter e temporal. O desenvolvimento ósseo-mandibular ocorre devido ao exercício da sucção praticada pelo bebê no ato da amamentação, como o rebaixamento, a ântero-posteriorização e as elevações da mandíbula (MESSIAS et al., 2019). Isto faz com que os ossos e os músculos estejam devidamente preparados e tonificados para a chegada dos primeiros dentes e dos futuros movimentos mastigatórios. Um estudo realizado com 144 crianças entre três e cinco anos de idade mostrou que indivíduos amamentados por 1 ano apresentaram resultados de mastigação significantemente mais elevados (SILVA et al., 2016).

Pesquisas sobre o aleitamento materno demonstram que durante a amamentação o número de sucções varia entre cinco a trinta por minuto, processo que estimula o desenvolvimento do terço médio da face devido o sincronismo da respiração e do exercício muscular na amamentação, momento em que a cada duas ou três sucções a criança inspira, deglute e expira (JAMA et al., 2020). Isto mantém a correta relação entre as estruturas duras e moles do sistema estomatognático, o que possibilita a postura da língua e vedamento de lábios adequados. Além disso, ocorre o desenvolvimento dos órgãos fonoarticulatórios, permitindo futuramente a correta articulação dos sons das palavras (DUARTE, 2019).

No entanto, existem crianças em todo o mundo que possuem diversas consequências negativas no desenvolvimento craniofacial devido a falta de acesso ao aleitamento materno (KEBEDE et al., 2020). Sabe-se que o processo de urbanização na década de 70 levou as mulheres a terem responsabilidades fora de suas residências pela inserção no mercado de trabalho, o que trouxe consequências para o aleitamento materno exclusivo e para o bebê, que passou a obter outros tipos de alimentação. Isto se dá porque o seio da mãe não é estimulado, resultando na baixa produção de leite e no desmame precoce. Contudo, estudos apontam que outras questões, como a baixa escolaridade materna e a baixa frequência em consultas pré-natais, também podem influenciar na interrupção do aleitamento materno exclusivo e consequentemente no desenvolvimento do sistema estomatognático do bebê, visto que estes fatores dificultam o acesso a informações à mãe (CASSIMIRO et al., 2019).

Segundo Boccolini, Carvalho e Oliveira (2015) também há outros fatores que podem influenciar na interrupção da amamentação, como a cor da pele, situação conjugal, fatores socioeconômicos familiares, idade da mãe, local de residência (capital ou meio rural), entre outros. Além disso, podem ocorrer situações inesperadas nos primeiros seis meses de vida, como dificuldades do bebê na sucção do seio, fissuras nos mamilos, insuficiência de leite materno e mamilos planos ou invertidos. A autoconfiança da mãe e o incentivo e suporte familiar também são fatores que podem influenciar na interrupção do aleitamento materno exclusivo.

Outro determinante crucial é o uso de chupeta e mamadeira, que são objetos de fácil acesso, e podem fazer com que o bebê coloque o dedo na boca para satisfazer sua necessidade de sucção e obter 
o prazer do alimento nutritivo, levando ao incorreto selamento labial e acarretando negativamente no desenvolvimento do sistema estomatognático. Mas isso depende da intensidade, frequência e duração do hábito (tríade de Graber), pois a pressão que é feita no dedo juntamente com as contrações bucais e labiais podem ocasionar alterações ósseas, musculares, dentárias e oclusais (MESSIAS et al., 2019; KEBEDE et al., 2020). Este processo faz com que a criança crie hábitos deletérios que podem resultar em desequilíbrios psicológicos futuros.

Dessa forma, o aleitamento materno exclusivo pode prevenir alterações no sistema estomatognático, visto que o uso de meios artificiais pode resultar no desenvolvimento craniofacial incorreto. Dentre essas prevenções, estão a deformidade nas estruturas ósseas e dentárias, crescimento mandibular exagerado, alterações miofuncionais orofaciais, atresia de palato, atresia do arco superior, musculatura labial superior hipotônica, musculatura labial inferior hipertônica, interposição de língua e maloclusões, como mordida cruzada posterior, mordida aberta anterior e aumento de sobrassaliência (CASSIMIRO et al., 2019; DUARTE, 2019). É por isso que a amamentação natural possui diversas vantagens, em destaque o desenvolvimento craniofacial e psicológico, o estímulo das funções bucais e a oclusão dentária sem desvios. Isso mostra que o aleitamento materno exclusivo é um fator de extrema importância para o correto desenvolvimento infantil.

\section{CONCLUSÃO}

$\mathrm{O}$ aleitamento materno exclusivo mostra-se um determinante positivo frente o uso de meios artificiais, que pode resultar em um desenvolvimento infantil incorreto e em doenças a longo prazo. É por isso que a amamentação natural possui diversas vantagens, em destaque o desenvolvimento craniofacial e psicológico, o estímulo das funções bucais e a oclusão dentária sem desvios. Dessa forma, instruções como a importância e benefícios do aleitamento materno e, também, os manejos necessários para a prática correta, são essenciais durante o período gestacional e após o nascimento também. Entretanto, esses fatores ainda não são de conhecimento de todas as pessoas, por isso a importância da democratização de informações. É dever do profissional de saúde educar mulheres e famílias com relação à prática e aos benefícios do aleitamento materno exclusivo, mas para que isso ocorra são necessárias mais políticas públicas e projetos facilitadores para disseminação de informações tão necessárias e de direito de todos. 


\section{REFERÊNCIAS}

BOCCOLINI, C. S. et al. Tendência de indicadores do aleitamento materno no Brasil em três décadas. Revista de Saúde Pública, São Paulo, v. 51, n. 108, p. 1-9, 2017.

BOCCOLINI, C. S.; CARVALHO, M. L.; OLIVEIRA, M. I. C. Fatores associados ao aleitamento materno exclusivo nos primeiros seis meses de vida no Brasil: revisão sistemática. Revista de Saúde Pública, v. 49, n. 91, p. 1-16, dez. 2015.

BRASIL. Ministério da saúde. Saúde da criança: aleitamento materno e alimentação complementar. Editora MS, Brasília, 2015.

CASSIMIRO, I. G. V. et al. A importância da amamentação natural para o sistema estomatognático. Revista Uningá, v. 56, n. s5, p. 56-66, 2019.

CIAMPO, L. A.; CIAMPO, I. R. L. Aleitamento materno e seus benefícios para a saúde da mulher. Revista Brasileira de Ginecologia Obstetrícia, v. 40, n. 6, p. 354-359, 2018.

DUARTE, D. A. Benefícios da amamentação. Revista Eletrônica Acervo Enfermagem, v. 1, n. 1, p. 1-7, 2019.

EXAVERY, A. et al. Determinants of early initiation of breastfeeding in rural Tanzania. International Breastfeeding Journal, v. 10, n. 27, p. 1-9, 2015.

JAMA, A. et al. Exclusive breastfeeding for the first six months of life and its associated factors among children age 6-24 months in Burao District, Somaliland. International Breastfeeding Journal, n. 5, p. 1-8, 2020 .

KEBEDE, T. et al. Exclusive breastfeeding cessation and associated factors among employed mothers in Dukem town, Central Ethiopia. International Breastfeeding Journal, n. 6, p. 1-10, 2020.

MEDEIROS, E. B.; RODRIGUES, M. J. A importância da amamentação natural para o desenvolvimento do sistema estomatognático do bebê. Revista do Conselho Regional de Odontologia de Pernambuco, v. 4, n. 2, p. 79-83, 2001.

MESSIAS A. M. et al. Amamentação natural, artificial e maloclusão: há correlação?. Revista Odonto, v. 27, n. 53, p. 9-18, 2019.

MESQUITA A. L. et al. Atribuições de enfermeiros na orientação de lactantes acerca do aleitamento materno. Revista Científica Sena Aires, v. 5, n. 2, p. 158-170, 2016.

OLIVEIRA, F. L. A.; CARIELLO, M. P.; DINELLY, E. M. P. Influência da amamentação e do uso de chupetas no desenvolvimento do sistema estomatognático de bebês. In: ENCONTRO DE EXTENSÃO, DOCÊNCIA E INICIAÇÃO CIENTÍFICA, 12., 2017, Quixadá. Anais do EEDIC: Quixadá, 2017.

QUELUZ, D. P.; GIMENEZ, C. M. M. Aleitamento e hábitos deletérios relacionados a oclusão. Revista Paulista de Odontologia, v. 22, n. 6, p. 16-20, 2000.

NUNES, K. M.; SILVA, R. I.; SILVA, J. O. S. Cinema indígena: de objeto a sujeito da produção cinematográfica no Brasil. Polis, v. 13, n. 38, p. 1-26, 2014.

ROCHA, I. S. et al. Influência da autoconfiança materna sobre o aleitamento materno exclusivo aos seis meses de idade: uma revisão sistemática. Ciência e Saúde coletiva, v. 23, n. 11, p. 3609-3619, 2018.

ROCHA, M. D. L.; GONÇALVES, G. S. A. Hábitos de sucção não nutritiva em Odontopediatria. Cadernos de Odontologia do Unifeso, v. 1, n. 2, p 120-136, 2019.

SANTOS, A. A. et al. Aleitamento materno X aleitamento artificial. In: Semana de Pesquisa da Universidade Tiradentes, 18., 2016, Aracaju. Anais eletrônicos. Editora Universitária Tiradentes, 2016. p. 1-4. 
SANTOS, M. P. et al. Prevalência e fatores associados à interrupção precoce do aleitamento materno exclusivo: metanálise de estudos epidemiológicos brasileiros. Revista Brasileira de Saúde Materno Infantil, v. 17, n. 1, p 69-78, 2017.

SILVA, I. C. B. et al. Desenvolvimento do sistema estomatognático durante a vida intrauterina - revisão de literatura. Revista de Odontologia da Universidade Cidade São Paulo, v. 31, n. 1, p. 47-56, 2019.

SILVA, A. S. et al. Perfil mastigatório em crianças de três a cinco anos de idade. Revista CEFAC, v. 18, n. 3, p. 568-580, 2016.

WOLDEAMANUEL, B. T. Trends and factors associated to early initiation of breastfeeding, exclusive breastfeeding and duration of breastfeeding in Ethiopia: evidence from the Ethiopia Demographic and Health Survey 2016. International Breastfeeding Journal, v. 15, n. 3, p. 1-13, 2020.

WORLD HEALTH ORGANIZATION. Protecting, promoting and supporting breastfeeding in facilities providing maternity and newborn services. Genebra, 2017. 


\section{CAPÍTULO 27}

\section{PARACOCCIDIOIDOMICOSE: ANALISE GERAL}

INAIÁ PALMIRO BENTO FRANCISCO Graduanda do curso de Biomedicina - Universidade do Estado de Minas Gerais

ANA CRISTINA SOUZA MELGAÇO Graduanda do curso de Biomedicina - Universidade do Estado de Minas Gerais

JULIA VERISSIMO E SILVA Graduanda do curso de Biomedicina - Universidade do Estado de Minas Gerais

RAPHAELA SUANO DE FARIA Graduanda do curso de Biomedicina - Universidade do Estado de Minas Gerais

THALITA GRAZIELLY SANTOS

Professora do curso de biomedicina - Universidade do Estado de Minas Gerais

RESUMO: A paracoccidioidomicose (PCM) é uma fungimia oportunista causada pelo fungo Paracoccidioides brasiliensis. se apresenta com maior frequência nas Américas do Sul e Central, e é uma doença é intimamente ligada ao campo, sendo comum em plantadores de café da Colômbia, Venezuela e Brasil. Sua transmissão, ocorre por meio da inalação dos conídios ou através de cortes na pele ou nas mucosas. As infecções em geral, são crônicas e progressivas e o diagnóstico definitivo desta micose é obtido com a demonstração do agente etiológico em fluidos biológicos ou tecidos, principalmente por exame micológico direto e/ou histopatológico e a citologia esfoliativa. O tratamento deve compreender além das drogas antifúngicas, o emprego de medidas que melhorem as condições gerais do paciente, e acompanhamento posterior. É uma doença de alta taxa de mortalidade no Brasil e outras áreas subdesenvolvidas latinas, porém não é estudada mais profundamente e mesmo apresentando risco biológico para população, principalmente trabalhadores rurais e laboratórios de análise, não está incluída na lista de notificações compulsórias.

PALAVRAS-CHAVE: Paracoccidioidomicose; Doença oportunista; Fungimia; Micose.

ABSTRACT: Paracoccidioidomycosis (PCM) is an opportunistic fungimia caused by the fungus Paracoccidioides brasiliensis. it presents more frequently in South and Central America, and is a disease that is closely linked to the field, being common in coffee growers in Colombia, Venezuela and Brazil. Its transmission occurs through inhalation of the conidia or through cuts in the skin or mucous membranes. Infections in general are chronic and progressive and the definitive diagnosis of this mycosis is obtained by demonstrating the etiologic agent in biological fluids or tissues, mainly by direct mycological and / or histopathological examination and exfoliative cytology. The treatment must include, in addition to antifungal drugs, the use of measures that improve the general conditions of the patient, and subsequent follow-up. It is a disease with a high mortality rate in Brazil and other underdeveloped Latin areas, but it is not studied further and even presenting biological risk to the population, mainly rural workers and analysis laboratories, it is not included in the list of compulsory notifications.

KEYWORDS: Paracoccidioidomycosis; Opportunistic disease; Fungimia; Ringworm. 


\section{INTRODUÇÃO}

A paracoccidioidomicose (PCM) é uma fungimia causada pelo fungo Paracoccidioides brasiliensis. A PCM se apresenta com maior frequência nas Américas do Sul e Central, os casos diagnosticados são, majoritariamente, de homens na faixa etária de 30 a 50 anos, e é uma doença é intimamente ligada ao campo, sendo comum em plantadores de café da Colômbia, Venezuela e Brasil (REVANKAR,2017).

Por ser uma infecção oportunista, a paracoccidioidomicose (PCM) afeta muitos pacientes imunocomprometidos, mas não tem ligação direta com pessoas soropositivas para HIV sintomática (aids) ou não. Um estudo de mortalidade apresentado pelo II congresso em paracoccidioidomicose, mostrou uma taxa de 1,487 por milhão de habitantes no Brasil (ALMEIDA,2017).

Sua transmissão, majoritariamente, ocorre por meio da inalação dos conídios, que são esporos produzidos pelo fungo, após a contaminação eles se convertem em leveduras, os primeiros sinais e sintomas da doença irão conduzir o paciente ao médico dentista ou ao otorrinolaringologista por passar pela orofaringe causando lesões e posteriormente invadindo os pulmões (VIANNA,2012).

Pode também haver contaminação através de cortes na pele ou nas mucosas, mas é considerado extremamente raro. A maioria dos infectados por inalação desenvolvem infecção pulmonar assintomática, se manifestando como pneumonia aguda, que pode desaparecer espontaneamente, com isso podemos assumir que sua disseminação seja via linfo-hematogênica. As infecções em geral, são crônicas e progressivas (REVANKAR,2017).

O diagnóstico definitivo desta micose é obtido com a demonstração do agente etiológico em fluidos biológicos ou tecidos, principalmente por exame micológico direto e/ou histopatológico, como pode representar um risco biológico ao laboratório, este deve ser notificado sobre a suspeita diagnóstica (TOLLEDO, 2017).

Porém a citologia esfoliativa oral é um exame útil e válido na detecção da PCM, devido à simplicidade na sua execução, baixo custo operacional e por não apresentar efeitos indesejáveis, podendo ser utilizado como exame de rotina de ambulatório no diagnóstico de lesões orais suspeitas (TOLLEDO, 2017).

É de suma importância a adequada anamnese e exame físico dos pacientes, realizadas pelos diversos profissionais de saúde, sobretudo médico dentista e clínicos gerais, visando obter informações quanto à procedência dos doentes, por vezes oriundos de regiões endémicas, bem como perceber a existência de lesões localizadas e sistémicas (ELIAS, 2005).

O tratamento deve compreender além das drogas antifúngicas, o emprego de medidas que melhorem as condições gerais do paciente, e acompanhamento posterior. Os principais medicamentos utilizados são associações trimetropim com sulfametoxazol ou itraconazol e cetoconazol (derivados imidazólicos), entretanto o maior índice de utilização foi de sulfametoxasol-trimetropin (64,5\%) (TOLLEDO, 2017). 
O Itraconazol oral é considerado fármaco de escolha por apresentar baixo custo nas áreas endêmicas. A anfotericina B intravenosa é usada muitas vezes, em casos graves, também eliminando a infecção. Já as Sulfonamidas são amplamente utilizadas por serem baratas e suprimir o crescimento dos Paracoccidioides levando a melhora das lesões, mas não são curativas e precisam ser administradas por longos períodos, podendo chegar a 5 anos de tratamento (REVANKAR, 2017).

\section{OBJETIVO}

O trabalho foi realizado com o objetivo de se pesquisar sobre a paracoccidioidomicose e aprofundar o conhecimento nesse assunto, além de compreender como uma doença de alta taxa de mortalidade no Brasil e outras áreas subdesenvolvidas latinas, não é estudada mais profundamente e mesmo apresentando risco biológico para população, principalmente trabalhadores rurais e laboratórios de análise, não está incluída na lista de notificações compulsórias.

\section{METODOLOGIA}

A compilação dos dados foi realizada por meio de uma revisão sistemática da literatura, a partir do banco de dados PubMed e a plataforma scielo, utilizando-se artigos sobre o fungo Paracoccidioides brasiliensis e revisões sobre este tema desde o ano 2004.

\section{JUSTIFICATIVA}

Por se tratar de um assunto negligenciado pelo sistema de saúde e mais presente em zonas subdesenvolvidas e latinas, esse trabalho se torna extremamente importante para a difusão de conhecimento sobre o assunto e apresentar a realidade muitas vezes não enxergada.

\section{DESENVOLVIMENTO}

\section{O fungo}

O Paracoccidioides brasiliensis é um ascomiceto, membro da Ordem onygenales, família onygenaceae, dimórfico, sendo suas formas de micélio e levedura. A forma de micélio é a infectante, encontrada na natureza, produz colônias em temperatura de $25^{\circ} \mathrm{C}$, apresenta hifas septadas, finas e com clamidósporos. Já a forma de levedura é somente encontrada em tecido do hospedeiro e cresce 
a $37^{\circ} \mathrm{C}$. A morfologia transitória é determinada pela temperatura do ambiente estando relacionada à invasão do hospedeiro, sugerindo que o fungo perceba e responda via sinalização celular (SILVA, 2008).

\section{Enfermidade}

A paracoccidioidomicose é uma micose sistêmica causada pelo fungo dimórfico $P$. brasiliensis. A PCM é considerada um problema de saúde pública pois apresenta potencial incapacitante devido as sequelas que podem ser adquiridas e também por causar mortes prematuras. Ainda assim é uma doença sem notificação compulsória e sem dados precisos sobre sua incidência no Brasil (WANKE, 2009).

A região endêmica é especialmente a América Latina, podendo chegar até ao México. É a principal micose sistêmica no Brasil, $\mathbf{8 0 \%}$ dos casos, com maior incidência regiões sul, sudeste e centro-oeste. Estima- se que 10 milhões de pessoas, em média, possam ter se infectado, porém somente $2 \%$ vieram a desenvolveram sintomas, entretanto estes dados são imprecisos pois muitos casos são diagnosticados erroneamente (DERENGOWSKI, 2006; WANKE, 2009).

A enfermidade é normalmente adquirida pela inalação do agente, propagado no ar. Em regiões endêmicas, a infecção primária ocorre durante a infância apresentando se de forma aguda. Já no adulto é mais frequente a forma crônica na qual há disseminação multifocal, via hemolítica e linfática (WANKE, 2009).

Quanto ao sexo, acreditava-se que mulheres não contraíam a enfermidade, devido ao efeito inibidor do hormônio feminino b-estradiol, a transformação da forma de hifas do microrganismo para a forma patogênica de leveduras é atrapalhada pela ação do hormônio. No entanto, atualmente sabe-se que esse mecanismo não mais é aceito por consenso, haja vista a ocorrência de vários casos em mulheres. A complexa interação entre o sistema imune e os hormônios esteroides pode ajudar a entender as diferentes respostas imunes de homens e de mulheres, e auxiliar a explicar a grande diferença de casos de PCM entre os gêneros (FERREIRA, 2011; CAIXETA, 2017).

Epidemiologicamente, ainda se considera como perfil de pacientes paracoccidioidomicótico crônicos aqueles de meia-idade, sexo masculino, e trabalhador em zona rural (FERREIRA, 2011).

\section{Mecanismo de transmissão}

Quando na forma de micélio, o fungo produz conídios que se disseminam no ambiente. Ao serem inalados, atingem os pulmões onde realizam a transição para levedura, estabelecendo o início da infecção. Com o passar do tempo ela poderá acometer outros tecidos, disseminando se por via linfo-hematogênica (DERENGOWSKI, 2006). 


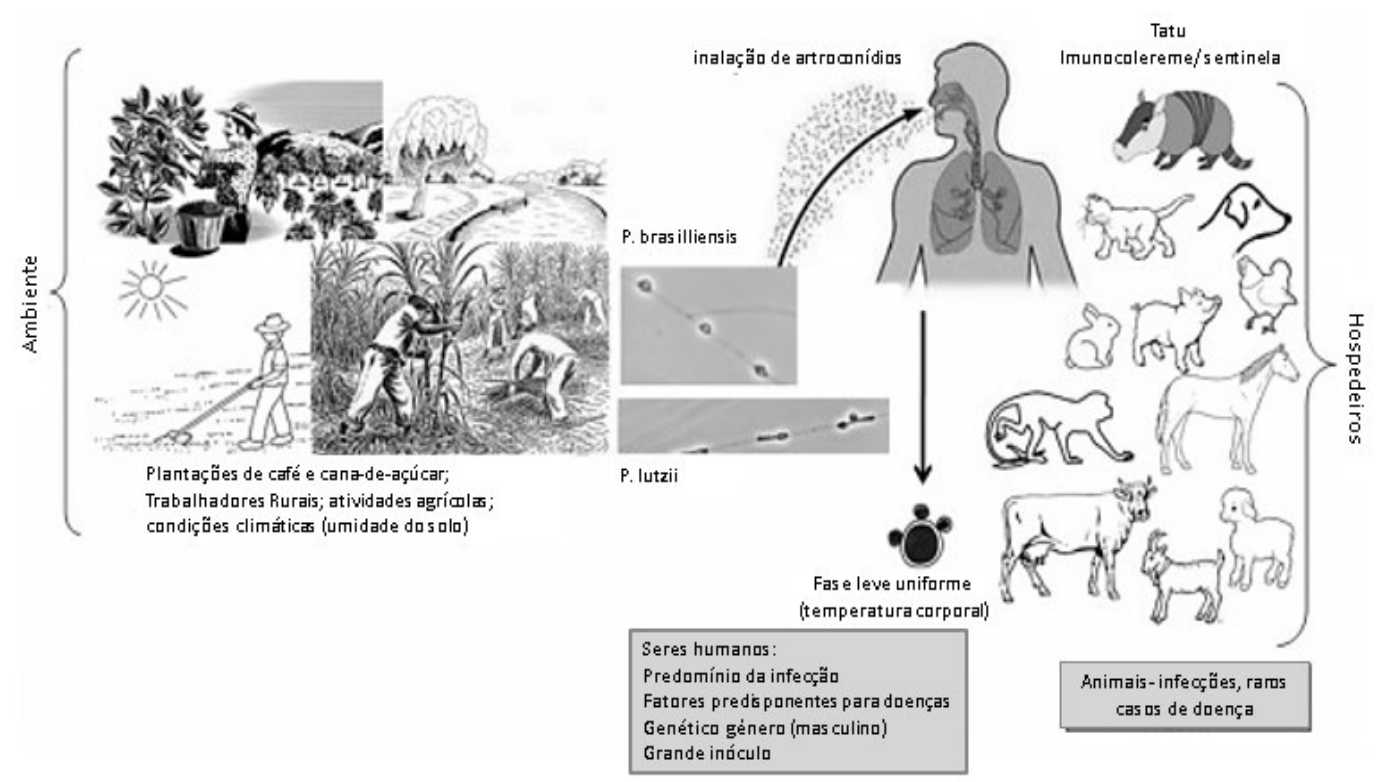

Figura 1: Propagação do fungo

Fonte: II Consenso bras. PCM, 2017

A capacidade dimórfica do patógeno é fundamental para seu estabelecimento no organismo por ser ativada pela temperatura relaciona, se muito à interação patógeno-hospedeiro, e dependendo da resposta imunológica do hospedeiro e da virulência fungo, poderá vir a ser latente, crônica ou ainda ser erradicada (SILVA,2008).

O homem e o tatu (Dasypus novemcinctus) são hospedeiros definitivos conhecidos, porém não há registro de transmissão entre espécies (II Consenso bras.PCM, 2017).

\section{Desenvolvimento no organismo}

O desenvolvimento da doença está associado a virulência do fungo e resistência ao hospedeiro. Já a resistência à infecção está relacionada a formação de um granuloma epitelioide, sua capacidade de desenvolver resposta imunológica celular efetiva e ao papel do interferon Gama, que é importante na ativação dos macrófagos para produção de óxido nítrico atuando como principal agente microbicida contra o P. brasiliensis, além de estimular macrófagos infectados a secretar fator de necrose tumoral necessário para persistência do granuloma (DERENGOWSKI, 2006).

A resposta imunológica celular em conjunto com a formação de lesão granulomatosa fornece uma resposta protetora máxima contra patógenos intracelulares, que é particularmente importante para o P. brasiliensis já que esse fungo pode se apresentar como um patógeno intracelular facultativo, sendo capaz de sobreviver e replicar no interior de células epiteliais e macrófagos humanos não ativado (DERENGOWSKI, 2006).

Após os mecanismos de fagocitose o fungo em questão é exposto a moléculas antimicrobianas no interior das células fagocíticas do hospedeiro, e a persistência dele nesse ambiente inóspito pode estar relacionada a diversos mecanismos que caracterizam a virulência do patógeno (evento altamente complexo), como resistência aos compostos antimicrobianos e adaptação aos metabólitos 
presentes no interior do fagossomo, porem pode-se haver outros pois seus fatores de virulência são pouco conhecidos, uma vez que não há sistema de transformação e ruptura gênica bem estabelecida para esse micro-organismo (DERENGOWSKI, 2006).

Algumas análises comparativas sugerem que há um desvio do metabolismo aeróbio para anaeróbio, juntamente com sua transição para levedura, o que poderia estar correlacionado a uma adaptação na interação com o hospedeiro. Quando ocorre dessa forma, se tem evolução crônica com diagnóstico tardio (DERENGOWSKI, 2006; WANKE, 2009).

\section{Sintomas}

A maioria dos indivíduos sadios que vivem em áreas endêmicas desenvolvem apenas infecção assintomática. No caso do indivíduo que desenvolve a doença, pela inalação ser a principal via de infecção os primeiros sinais apresentados são lesões bucais e irritação do trato respiratório (JHAM,2008).

Os sintomas clínicos são característicos por granulomas, lesões pulmonares, mucocutâneas e pseudotumores. A paracoccidioidomicose pode dar origem a duas formas que se diferenciam quanto as características clínicas, morfológicas e histopatológicas, sendo as formas aguda ou crônica (DERENGOWSKI, 2006).

A crônica é mais comum e aparece mais em adultos do sexo masculino, apresenta lesões restritas a alguns órgãos e pode progredir mais lentamente, sendo alguns dos sintomas fraqueza, emagrecimento, febre, tosse, dispneia. Quando causa infiltrado reticulonodular e hipertransparência distal bibasal pode acarretar sequelas pulmonares e subcutâneas e é considerado um caso mais grave, que na ausência de tratamento adequado pode vir a causar morte do indivíduo doente (DERENGOWSKI, 2006).

Já aguda representa 3-5\% dos casos e apesar de ter menor incidência está associada a alta taxa de mortalidade, tendo caráter bastante severo e acometendo crianças de ambos os sexos, adolescentes e adultos até 30-35 anos de idade, pois progride rapidamente para linfonodomegalias superficiais e profundas, com supuração de massa ganglionar, hepatoesplenomegalia e diversos outros sintomas que causa rápida deterioração do estado geral do paciente, tornando-se sistêmica (WANKE, 2009; DERENGOWSKI, 2006).

Quando a doença compromete outros sítios extrapulmonares, tais como a pele, a mucosa oral, da faringe e/ou da laringe e o ápice dos dentes, é considerada como forma multifocal, gerando sintomas de dor durante a mastigação, sialorreia e odinofagia. $\mathrm{O}$ indivíduo demora muito a procurar assistência médica, muitas vezes instalando-se um quadro de caquexia. A radiografia de tórax revela as mesmas lesões da forma unifocal (WANKE, 2009).

Outros locais envolvidos pela paracoccidioidomicose são as suprarrenais, o sistema nervoso central, os linfonodos cervicais e submandibulares, os intestinos, o sistema osteoarticular, o epidídimo, o fígado e o baço (WANKE, 2009). 


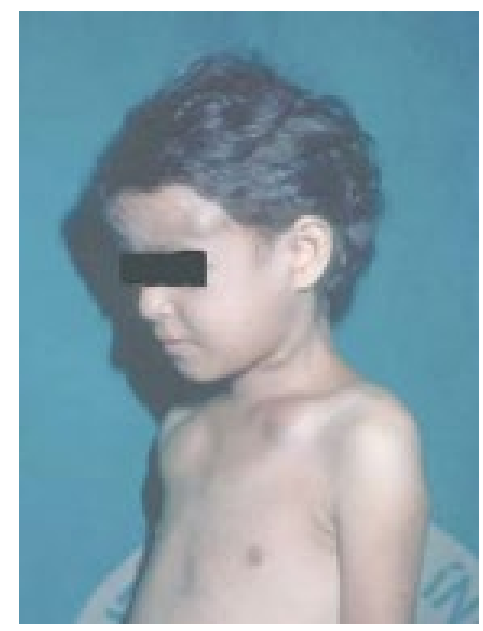

Figura 2: acometimento osteo-articular.

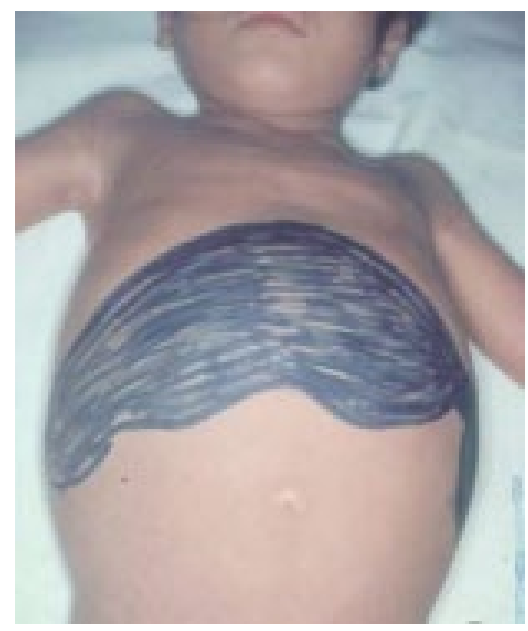

Figura 3:hepato-esplenomegalia.

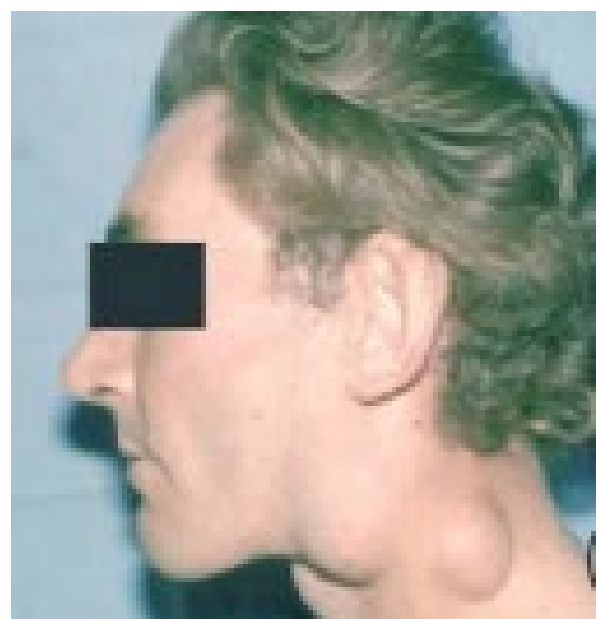

Figura 4: linfoadenomegalia

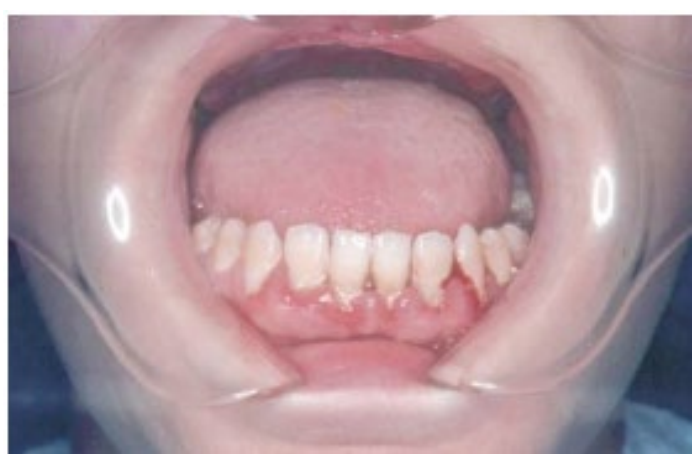

Figura 5: Gengivoestomatite

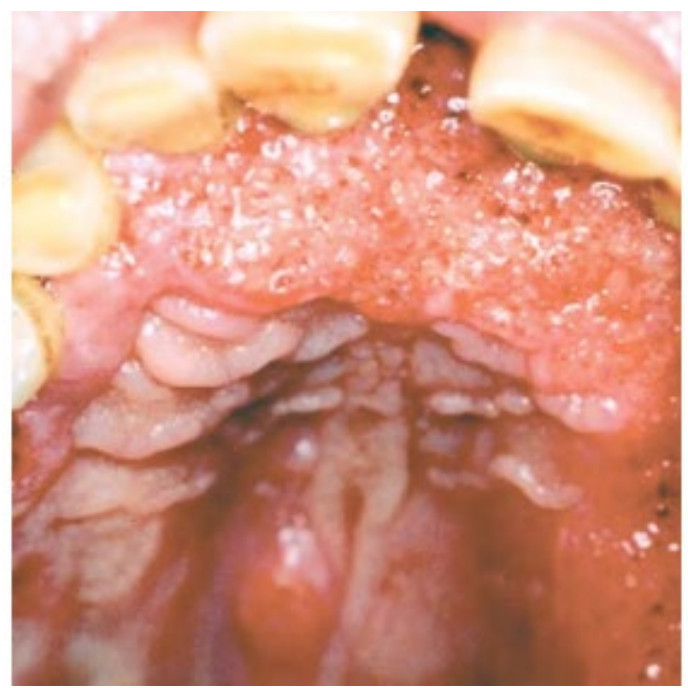

Figura 6: Estomatite moriforme

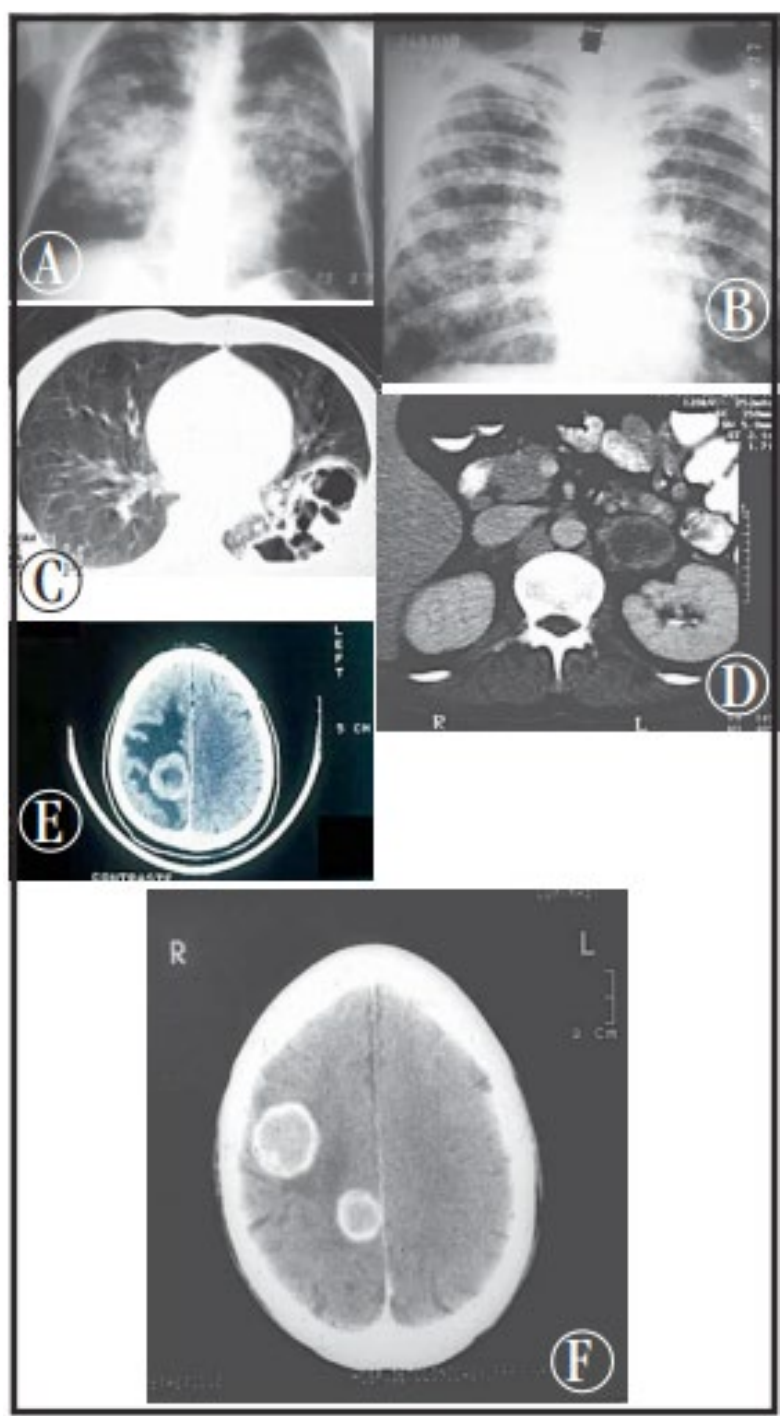

Figura 7: paracoccidioidomicose sistêmica

Fonte das figuras 2-7: Consenso em paracoccidioidomicose, 2006 


\section{Diagnostico}

Como os sintomas iniciais normalmente levam o paciente a visitar o médico dentista ou otorinolaragoligista por causas lesões bucais e no trato respiratório. A citologia esfoliativa da lesão consegue afirmar um diagnóstico precoce, porém não são comumente realizadas (JHAM,2008).

Em situação de suspeita os exames que devem ser realizados são inicialmente a anamnese dirigida, atentando para as formas clínicas e o grupo mais acometido por cada uma; radiografia simples de tórax que irá apresentar infiltrado reticulo nodular difuso; hemograma completo; exame de velocidade de hemossedimentação; provas de função hepática; ureia, creatinina, sódio e potássio. Diagnóstico definitivo é dado principalmente pelo achado do fungo em biópsia tecidual. Caso seja realizada uma tomografia de tórax de alta resolução pode se observar a presença de nódulos (VIANNA,2012 e ELIAS, 2005).

\section{Tratamento}

Os seguintes esquemas têm sido utilizados com bons resultados de acordo com médico pesquisador do serviço de micologia, Bodo Wanke.

Para infecção leve e moderada:

1) sulfametoxazol/trimetoprima, comprimidos de $80 / 400 \mathrm{mg}$ e de $160 / 800 \mathrm{mg}$. Com dose inicial de 3 comprimidos (80/400 mg) a cada $12 \mathrm{~h}$ por 21 dias, evoluindo para 2 comprimidos a cada $12 \mathrm{~h}$ por 21 dias e posteriormente passando para 1 comprimidos a cada $12 \mathrm{~h}$ por 2 anos. Em crianças: $8-10 \mathrm{mg} / \mathrm{kg} /$ dia de trimetoprima ou $40-50 \mathrm{mg} / \mathrm{kg} / \mathrm{dia}$ de sulfametoxazol a cada $12 \mathrm{~h}$.

2) Cetoconazol, cápsulas de $200 \mathrm{mg}$. Ingerir junto a refeição (almoço) começando com 400 $\mathrm{mg} /$ dia por 3 meses, seguido de $200 \mathrm{mg} /$ dia por 9 meses, pode causar efeitos colaterais: ginecomastia, diminuição da libido, hepatopatia, teratogênico.

3) Itraconazol, cápsulas de $100 \mathrm{mg}$. Fazer uso de $200 \mathrm{mg}$ /dia, durante as grandes refeições, por 6-9 meses. Pode desencadear distúrbios digestivos, teratogênico. Em crianças com menos de $30 \mathrm{~kg}$ de peso: $5-10 \mathrm{mg} / \mathrm{kg} / \mathrm{dia}$.

4) Fluconazol, cápsulas de $50 \mathrm{mg} ; 100 \mathrm{mg} ; 150 \mathrm{mg}$. Dose inicial de $400 \mathrm{mg} / \mathrm{dia}$, por 3-6 meses e manutenção com dose de 100 a 200 mg/dia por 6-12 meses. Em crianças: 3-6 mg/ $\mathrm{kg} / \mathrm{dia}$.

Para formas graves;

a) Anfotericina B, $50 \mathrm{mg} /$ frasco. Tratamento com $1 \mathrm{mg} / \mathrm{kg} / \mathrm{dia}$ (máximo de $2 \mathrm{~g} / \mathrm{dia}$ ) por 1 a 3 anos. Efeitos colaterais: retenção azotada, potássio, anemia, febre, calafrios e flebite.

b) Rifampicina, com dose de $600 \mathrm{mg} / \mathrm{dia}+$ anfotericina B, $25 \mathrm{mg} / \mathrm{kg} / \mathrm{dia}, 3 \times$ por semana.

Ao termino do tratamento devesse observar melhora clínica, radiológica e micológica. 


\section{CONCLUSÃO}

A PCM é uma doença comumente encontrado em Trabalhadores Rurais e com elevada mortalidade, além de deixar sequelas aos sobreviventes. $\mathrm{O}$ tratamento precoce é muito importante, pois pode evitar que ela atinja o sistema nervoso central, gerando sequelas incapacitantes (PEDROSO, 2009),

O trabalho ao abordar os aspectos gerais da paracoccidioidomicose e aprofundar o conhecimento nesse assunto, compreende a necessidade da notificação compulsória da doença, pois a mesma possui uma alta taxa de mortalidade, apresenta risco biológico para população, principalmente trabalhadores rurais e laboratórios de análise,

Um ganho veio com a divulgação da portaria $\mathrm{n}^{\mathrm{o}} 264$ de 17 de fevereiro de 2020 artigo primeiro, que aborda a inclusão da paracoccidioidomicose na lista Nacional de notificação compulsória de doenças agravos e eventos de saúde pública juntamente a outras, como doença de chagas crônica, criptococose e esporotricose humana, o que é muito importante para estudos posteriores sobre a evolução da doença, já que atualmente não existe muitos dados precisos do número de infectados.

\section{REFERÊNCIAS}

II consenso brasileiro em paracoccidioidomicose, 2017.Brazilians guidelines for the Clinical managemant of paracoccidioidomycosis. São Paulo-SP, Brasil. 2017.

ALMEIDA, S.M.; et all. Autopsy and biopsy study of Paracoccidioidomycosis and Neuroparacoccidioidomycosis with and without HIV coinfection. 2017.

CAIXETA, C.A. Expressão imuno-histoquimica do estrogeno e da progesterone em lesões bucais de Paracoccidioidomicose. Universidade Federal de Alfenas. 2017.

Consenso em paracoccidioidomicose Revista da Sociedade Brasileira de Medicina Tropical. São Paulo-SP, Brasil. 2006.

DERENGOWSKI, L.S.; PEREIRA, I.S. Análise da expressão gênica de potenciais fatores de virulência do fungo paracoccidioides brasiliensis submetidO a diferentes condições experimentais. Universidade de Brasília, instituto de ciências biológicas, departamento de biologia celular. 2006.

ELIAS JR, Jorge; et all. Central nervosa system paracoccidiomycosis: diagonais and treatment. Ribeirão Preto -SP, Brasil. 2005.

FERREIRA, A. C. S. Paracoccidioidomicose em paciente feminino. Faculdade de Odontologia, Universidade Estadual Paulista, Araçatuba, 2011.

JHAM, B.C.; et all. Importância do exame intrabuccal no diagnóstico diferencial da paracoccidioidomicose. Rev Bras Otorrinolaringol.74(6):946. 2008.

REVANKAR, S.G. Paracoccidioidomicose (Blastomicose sul-americana). Wayne State University School of Medicine. 2017. 
TOLLEDO, G.L.; et all. Blastomicose sul-americana apresentação de caso clinico tratado com Associação de sistêmico e tópico. São Paulo -SP, Brasil. 2011.

VIANNA, L.M.S.; et all. Cytological diagnosis of paracoccidiodomycosis: a reporta ir four cases. Brasília-GO, Brasil. 2012.

WANKE, B.; AIDÊ, M.A. Curso de atualização - micoses: Capítulo 6 - Paracoccidioidomicose. J. bras. pneumol. vol.35 no.12 São Paulo Dec. 2009.

Referencial sem citação utilizado para base do entendimento:

Minicurso micoses sistêmicas - Congresso online de infectologia. Realização: Liga Acadêmica de Doenças Parasitárias e Zoonoses e Liga Acadêmica de Infectologia. Universidade Federal de Mato Grosso. 2020. 


\section{EXIBIÇÃO DOS LAÇOS CONSCIENTIZADORES DA SAÚDE UTILIZANDO SISTEMAS EMBARCADOS E LEDS RGB}

PAULO PEREIRA DE ALBUQUERQUE JUNIOR

IFCE

RENAN CORREAA BASONI

IFC

CÉSAR AUGUSTO VICTOR

IFCE

FABIANO CARNEIRO RIBEIRO

IFCE

FRANCISCO ALDINEI PEREIRA

ARAGÃO

IFCE

RESUMO: Os laços conscientizadores da saúde são utilizados para mobilizar a população em campanhas de saúde e principalmente para o controle de doenças. Estes são mudados em cada período do ano, torna-se necessário a substituição de todo material utilizado para divulgação do símbolo anterior, acarretando mais custos para a divulgação do símbolo da saúde posterior e demanda por mão de obra para substituição dos materiais divulgadores, que podem ser cartazes, cartões etc. $\mathrm{O}$ trabalho proposto visa substituir esses cartazes por um painel que funcionará de forma automática exibindo os laços do Estado do Ceará por conta da não oficialização deles no Brasil. Dessa maneira, o trabalho propõe criar um protótipo de custo baixo para mostrar a cada mês estes componentes através do uso de LEDs RGB e Sistemas Embarcados. A proposta antes de ser feita, foi consultada em diversas empresas do município de Sobral (PAES, 2019), as pessoas gostaram da ideia e com base nisso o projeto foi alterado para ter aspectos mais chamativos em meios socias como hospitais, escolas, farmácias etc. O protótipo proposto teve êxito na exibição das cores dos laços do Estado do Ceará, tanto na parte da exibição destes, como no sistema de modificação dos horários que podem ser manipulados pelo usuário.

Palavras chaves: Laços Conscientizadores, LED RGB e Sistemas Embarcados.

\section{INTRODUÇÃO}

Os laços conscientizadores da saúde empregam na sociedade um grande papel de mobilização e conscientização, alertando sobre doenças como o câncer de mama, câncer de próstata, câncer ósseo e outros. O grande objetivo dos laços conscientizadores é fazer com que as pessoas se sensibilizem a realizarem a prevenção das doenças e também para conscientizar sobre determinadas síndromes citadas uma vez por ano em um determinado período, estabelecendo dessa maneira uma rotina.

Como os laços conscientizadores da saúde não são padronizados no Brasil, cada Estado do Brasil pode adotar seus próprios laços conscientizadores de acordo com a sua necessidade. Optou-se por considerar neste trabalho os laços conscientizadores da saúde do Estado do Ceará, estes podem ser visualizados através da Figura 1. 


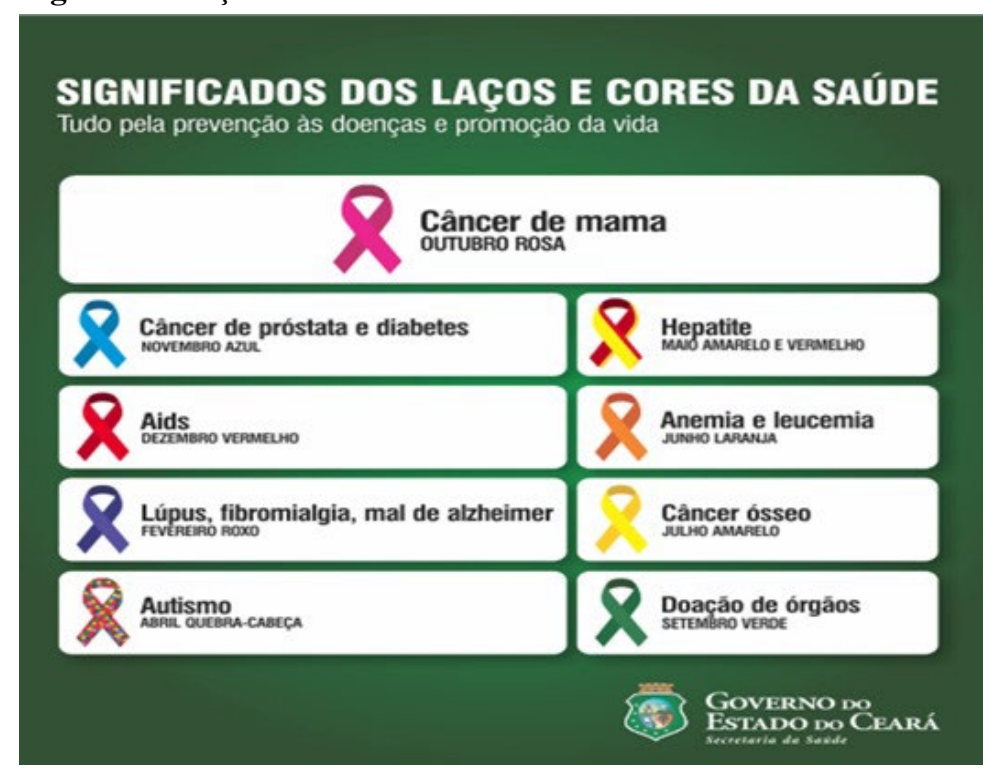

Fonte: Oliveira (2015).

Como os laços conscientizadores são mudados em cada período do ano, torna-se necessário a substituição de todo material utilizado para divulgação daquele anterior, acarretando mais custos para a divulgação deste posterior e demanda por mão de obra para substituição dos materiais divulgadores, que podem ser cartazes, cartões e outros. O projeto proposto visa diminuir o trabalho ocasionado pela substituição dos laços conscientizadores que hospitais, escolas e empresas empregam sempre que muda o mês, através do protótipo proposto, os estabelecimentos poderão utilizar para divulgá-los num painel de LEDs RGB.

A proposta deste trabalho, consiste no estudo de implementação de um protótipo utilizando LED RGB e Sistemas Embarcados que possam tornar automático a mudança dos laços conscientizadores. Um painel contendo os LEDs RGB seria alimentado pela rede elétrica e como os cartazes, poderia ser fixado na parede. Através do uso dos Sistemas Embarcados os laços conscientizadores poderiam ser trocados automaticamente sem a interferência humana, desta forma sempre seriam expostos durante todo o ano, aumentando assim visibilidade e a popularidade dos outros laços conscientizadores.

Como optou-se pela exibição dos laços conscientizadores da Figura 1, o protótipo proposto mostrará a cada mês o laço conscientizador correspondente aos adotados pela Secretaria de Saúde do Estado do Ceará para cada mês.

Tendo em vista que o custo para efetivação do protótipo do painel de LEDs pode ser relativamente alto, a proposta deste trabalho focou apenas em plataformas de software e hardware livres.

\section{SISTEMA EMBARCADO PROPOSTO}

De acordo com (NOERGAARD, 2005), conforme citado por Basoni (2015, p.19): 
Os sistemas embarcados estão presentes em grande parte dos dispositivos modernos como os computadores, tabletes e aparelhos celulares. Esses dispositivos fazem uso de tecnologias embarcadas para se comunicarem com outros equipamentos eletrônicos controlando suas funções e trocando informações na forma de dados.

É esse sistema embarcado que controla o funcionamento dos LEDs RGB no painel proposto por este trabalho.

Segundo (JÚNIOR,2010), "Os LEDs são componentes de estado sólido e, por este motivo, constituem as lâmpadas de estado sólido (SSL - Solid State Lighting).” Dessa maneira, o LED RGB é um componente de estado sólido que através das cores primárias, Red, Green e Blue produz todas as outras cores do espectro visível.

O funcionamento do diodo emissor de luz, o LED, é baseado em uma forma especial de eletroluminescência, produzida pela injeção de portadores em uma junção p-n. Quando uma junção p-n é polarizada no sentido direto, os buracos do lado $\boldsymbol{p}$ e os elétrons do lado $\boldsymbol{n}$ movem-se em sentidos opostos em direção à região de depleção. Os buracos injetados no lado $\boldsymbol{n}$ recombinam com elétrons que estão chegando à região de depleção, enquanto os elétrons injetados no lado $\boldsymbol{p}$ recombinam com buracos que lá se encontram. Desta forma, todos os elétrons e buracos que participam da corrente se recombinam nas imediações da região de depleção, numa camada de espessura $\boldsymbol{L} \boldsymbol{p}$ do lado $\boldsymbol{p}$ e $\boldsymbol{L} \boldsymbol{n}$ do lado $\boldsymbol{n}$ (KERN, 2004).

O LED RGB faz o uso da interação das cores primárias para produzir outras cores, dessa maneira, é possível produzir inúmeras outras cores através da combinação das cores primarias, esse processo é somativo, ou seja, juntando todas as cores com a mesma intensidade conseguimos produzir a cor branca. Em relação a intensidade e variação das cores, o sinal aplicado ao LED será proveniente de um PWM (Pulse Width Modulation) gerado pelo Atmega328p-pu, com a variação desses valores aplicados a cada cor, pode-se produzir todas as cores dos laços conscientizadores exibidos na Figura 1.

Após a realização dos estudos referentes ao funcionamento dos LEDs RBG, partiu-se para as primeiras simulações, possibilitando a interação com os LEDs RGB. Foi utilizado o software Proteus para realizar as simulações antes da montagem em bancada do circuito.

Na simulação as cores primárias, vermelho, amarelo e azul não foram tão afetadas, pois essas cores não precisam ser combinadas para serem geradas, ao contrário das cores que resultam de combinações, como por exemplo o verde. Inicialmente optou-se por simular e testar um LED RGB ligado a um Atmega328p-pu, após a obtenção de bons resultados na simulação, partiu-se para os testes em bancada, inicialmente foram testados com um LED de alto brilho, neste caso, as cores primarias se saíram bem, mas a cor amarela não saiu como o esperado, após inúmeros testes, resolveu-se testar com um LED de brilho difuso no lugar de um LED de alto brilho e os resultados superaram as expectativas, por este motivo, decidiu-se utilizar o LED RGB de brilho difuso, pois este combinou de modo mais satisfatório as cores combinadas.

A Figura 2 mostra um LED RGB de brilho difuso à esquerda e outro de alto brilho à direita. 


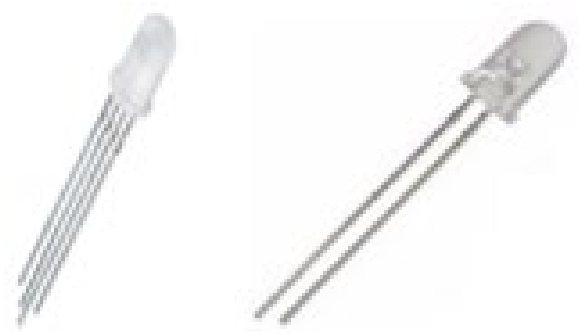

Fonte: AutocoreRobótica (2019).

Para que se pudesse acionar diferentes cores em um LED RGB foi necessário utilizar o sinal PWM nativo do microcontrolador Atmega328p-pu. No qual tem nativamente disponíveis 6 saídas PWM.

O PWM consiste em modulação por largura de pulso, pois se trata da comparação de dois sinais de tensão, um de baixa frequência (referência) e o outro de alta frequência (portadora), resultando em um sinal o com frequência fixa e largura de pulso variável (FERRORI,2018).

O microcontrolador Atmega328p-pu utilizado no protótipo proposto possui de fábrica 6 saídas PWM, mas para o desenvolvimento do protótipo era preciso mais do que seis saídas PWM, porque, como exibe a Figura 1, alguns laços conscientizadores possuem mais de uma cor, como é o caso do laço conscientizador do autismo, que necessita de 4 cores diferentes. Com 6 saídas de PWM só se pode reproduzir duas cores, uma vez que as conexões dos terminais do LED RGB devem ser distintas para cada cor, pensou-se em utilizar outro microcontrolador, com mais saídas nativas de PWM, mas isso provocaria mais custo para o protótipo. A solução encontrada foi, ao invés de usar as saídas nativas de PWM do Atmega328p-pu, resolveu-se emular 12 saídas de sinais PWM de baixa frequência para gerar todas as cores necessárias para o protótipo, utilizando as saídas digitais do microcontrolador.

Para SILVA (2013) a definição breve do que seria um microcontrolador e suas vantagens são:

Um microcontrolador é um componente eletrônico de constituição interna arrojada, o qual possui vários outros componentes interligados de forma a receber instruções, trabalhá-las e responder o processo. A sua utilização reduz o número de componentes externos do circuito, minimizando, assim, o custo do sistema, melhorando a confiabilidade e reduzindo o consumo de energia. Dessa forma, esse componente consegue efetuar com rapidez várias funções, operações lógicas e aritméticas, sob controle de um programa, que dita para a máquina a sequência das funções e operações a serem utilizadas.

O microcontrolador Atmega328p-pu, possui 3 timers, sendo 2 de 8 bits e um de 16 bits. Para gerar o sinal PWM utilizando as saídas digitais foi utilizado o Timer 1. Os temporizadores são importantes para diversas funcionalidades, dentre as mostradas a seguir uma das possibilidades usadas foi a de geração de sinais PWM para o projeto, as aplicações são: contagem de eventos externos, geração de sinais PWM, temporização, interrupção periódicas e Medidas de intervalos de pulsos.

Para ser gerado o sinal PWM utilizando as saídas digitais é necessário compreender as configurações de bits para implementar esse tipo de modulação. Inicialmente deve-se definir quais pinos 
serão utilizados e configurá-los como saída e para isso deve-se utilizar o registrador DDR (Data Direction Register) que é responsável por determinar se os pinos de um determinado PORT se comportarão como entrada (receberá tensão de $0 \mathrm{~V}$ ou $5 \mathrm{~V}$ ) ou saída (enviará tensão de $0 \mathrm{~V}$ ou $5 \mathrm{~V}$ ). Cada bit do registrador DDR (pequenas porções de memórias) controla o estado do respectivo pino. Por exemplo: o bit 1 em destaque do registrador DDRB (DDB1) controlará o estado lógico do pino PB1 como mostra a Figura 3.

Figura 3 - Registrador DDRB do microcontrolador Atmega328p.

\begin{tabular}{|c|c|c|c|c|c|c|c|c|}
\hline \multicolumn{7}{|c|}{ DDRB - The Port B Data Direction Register } & \multirow[b]{2}{*}{1} & \multirow[b]{2}{*}{0} \\
\hline Bit & 7 & 6 & 5 & 4 & 3 & 2 & & \\
\hline $0 \times 04(0 \times 24)$ & DDB7 & $\overline{\mathrm{DDB} 6}$ & DDB5 & $\overline{\mathrm{DDB} 4}$ & $\overline{\mathrm{DDB3}}$ & $\overline{\mathrm{DDB} 2}$ & $\overline{\mathrm{DDB1}}$ & $\overline{D D B 0}$ \\
\hline ReadWrite & RW & RW & RW & RWW & RWW & RWW & RWW & RWW \\
\hline Initial Value & 0 & 0 & 0 & 0 & 0 & 0 & 0 & 0 \\
\hline
\end{tabular}

Fonte: Microchip (2019).

Dois exemplos possíveis de configurações para o registrador DDRB, no que se refere individualmente ao PORTB, pode ser visualizada abaixo, sendo o primeiro a definição como saída do pino PB1 e o segundo a definição do pino PB1 como entrada.

- $\quad \operatorname{DDRB} \mid=(1<<$ DDB 1$)$;

- $\mathrm{DDRB} \&=\sim(1<<\mathrm{DDB} 1)$.

Para que se possa definir um pino como alto $(H I G H)$ tensão de $5 \mathrm{~V}$ ou baixo $(L O W)$ tensão de OV deve-se usar os registradores do tipo PORT. A Figura 4 mostra os registradores do tipo PORTB de 8 bits.

Figura 4 - Registrador PORTB do microcontrolador Atmega328p.

PORTB - The Port B Data Register

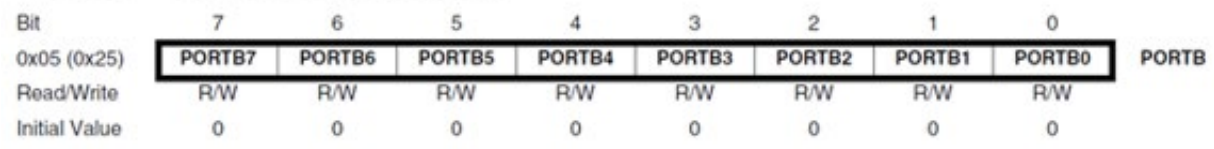

Fonte: Microchip (2019).

Dois exemplos possíveis de configurações para o registrador PORTB, no que se refere a cada saída individualmente do PORTB, pode ser visualizada abaixo, sendo o primeiro a definição como nível lógico alto do pino PB1 e o segundo a definição como nível lógico baixo do pino PB1.

- $\quad$ PORTB $\mid=(1<<$ PORTB 1$)$;

- $\quad$ PORTB $\&=\sim(1<<$ PORTB1). 
Para a geração dos PWMs de baixa frequência, no código proposto, foram utilizados 12 pinos digitais do Atmega328p-pu. Inicialmente foram realizadas as configurações dos 12 pinos como saída e com sinal em nível lógico baixo.

Após definir quais pinos seriam utilizados como geradores de PWM, o próximo passo foi fazer as configurações dos bits dos registradores relacionados ao funcionamento do Timer 1. Para a geração dos PWMs optou-se por utilizar o Timer 1, porque este é de 16 bits, tornando-se possível uma possibilidade maior para o tempo de contagem.

Para que se possa gerar os sinais PWMs utilizando as saídas digitais, deve-se configurar os registradores de um dos três timers para este fim. As primeiras configurações são em relação a inicialização do Timer 1.

Os registradores responsáveis pela configuração do Timer1 são o TCCR1A e o TCCR1B, para a aplicação teve que ser configurado o valor do registrador TCCR1A como zero para habilitar a interrupção por comparação. Dentre os modos de operação do Timer 1 se optou pelo uso do modo CTC (Clear Timer on Compare), neste modo ocorre constantemente a comparação dos incrementos do Timer 1 a cada vez que a interrupção acontece com o registrador OCR1A. Para configurar o modo CTC do Timer 1 é necessário configurar o bit WGM12=1 conforme mostra a Figura 5.

Figura 5 - Modo CTC aplicado ao Timer 1.

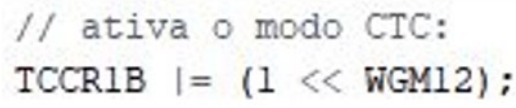

Fonte: Produção do próprio autor (2019).

Após o desenvolvimento das configurações mencionadas, deve-se selecionar com que frequência a interrupção do Timer ocorrerá, para isso é necessário fazer as configurações do Prescaler (Redutor de frequência para um fator determinado).

Para a aplicação proposta, decidiu-se utilizar um Prescaler de 1 para ser usado a frequência do cristal que é de $16 \mathrm{MHz}$, as configurações são mostradas na Figura 6.

Figura 6 - Valores para o Prescaler.

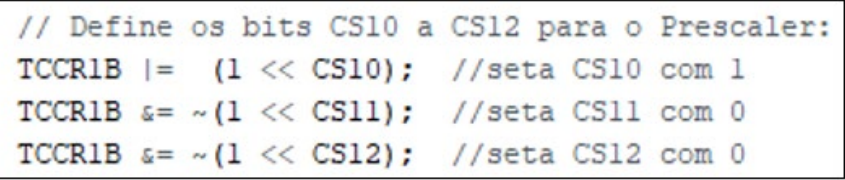

Fonte: Produção do próprio autor (2019).

Em relação a interrupção por comparação (CTC) implementada, também se faz necessário realizar a habilitação do bit OCIE1A permitindo assim o Atmega328p-pu passar os valores de comparação para a função de comparação ISR do registrador TIMSK1, conforme exibe a Figura 7. 
Figura 7 - Configuração da interrupção do Timer 1.

// interrupção do tipo comparação

\section{TIMSK1 $\mid=(1<<$ OCIE1A);}

Fonte: Produção do próprio autor (2019).

Para descobrir o tempo de estouro (tempo em que ocorre a interrupção) do Timer é necessário utilizar a Equação 1.

$$
\text { tempo_estouro }=O C R 1 A^{*}(\text { prescaler } / \text { oscilador })
$$

Para um OCRIA de 250, Prescaler de 1 e oscilador de $16 \mathrm{MHz}$, obtem-se um tempo de estouro de:

$$
\text { tempo_estouro }=250 *(1 / 16 \mathrm{MHz})=15,625 \mathrm{us}
$$

Dessa maneira, a interrupção por timer ocorrerá a cada 15, $625 \mu \mathrm{s}$.

A frequência dos sinais PWMs de baixa frequência projetados para a aplicação do prototipo proposto podem ser calculadas através da Equação 2.

$$
\text { frequência }=1 /(255 *(\text { OCR } 1 \text { A } / \text { oscilador })
$$

Para o OCR1A de 250 e um oscilador de $16 \mathrm{MHz}$ se obtem uma frequência de:

$$
\text { frequência }=1 /\left(255^{*}(250 / 16 \mathrm{MHz})=250 \mathrm{~Hz}\right.
$$

Para que ocorra a geração de PWM em cada um dos 12 pinos escolhidos, foi utilizada uma função que implementa a interrupção por rotina do Timer 1, a função é a ISR (Interrupt Service Routine). Como a interrupção do Timer 1 está ocorrendo a cada 15,625 $\mu$ s, pode-se gerar um PWM a cada 255 interrupções. A Figura 8 mostra como estão sendo gerados os PWMs, neste caso as variáveis PWM1,PWM2 e PWM3 assumem valores de 0 a 255.

Figura 8 - Geração do PWM através da função ISR.

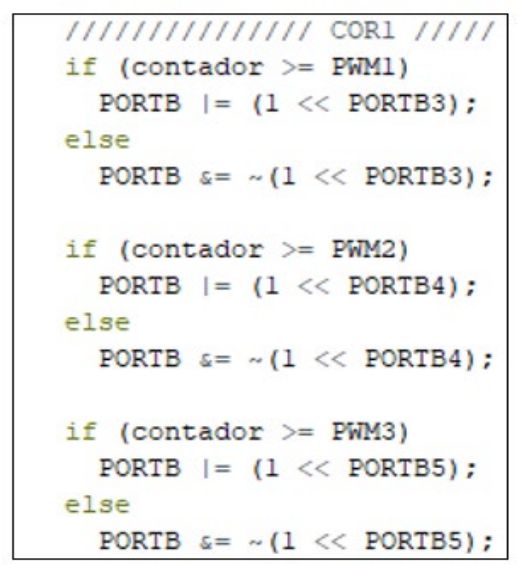

Fonte: Produção do próprio autor (2019). 
Como mencionado, foi necessário implementar 12 sinais distintos de PWM. Como cada LED RGB necessita de 3 sinais de PWM para gerar uma cor distinta, resolveu-se optar pelas nomenclaturas listadas na Tabela 1.

Tabela 1 - Descrição dos pinos utilizados para geração de quatro cores distintas.

\begin{tabular}{cccc}
\hline COR - 1 & COR - 2 & COR - 3 & COR - 4 \\
\hline R - PMW1 & R - PMW4 & R - PMW7 & R - PMW10 \\
G - PMW2 & G - PMW5 & G - PMW8 & G - PMW11 \\
B - PMW3 & B - PMW6 & B - PMW9 & B - PMW12 \\
\hline
\end{tabular}

Fonte: Produção do próprio autor (2019).

A Figura 9 ebibe a disposição de cada cor no Laço Conscientizador realizado com os LEDs RBG.

Figura 9 - Disposição das cores no Laço Conscientizador formado com LEDs RGB.

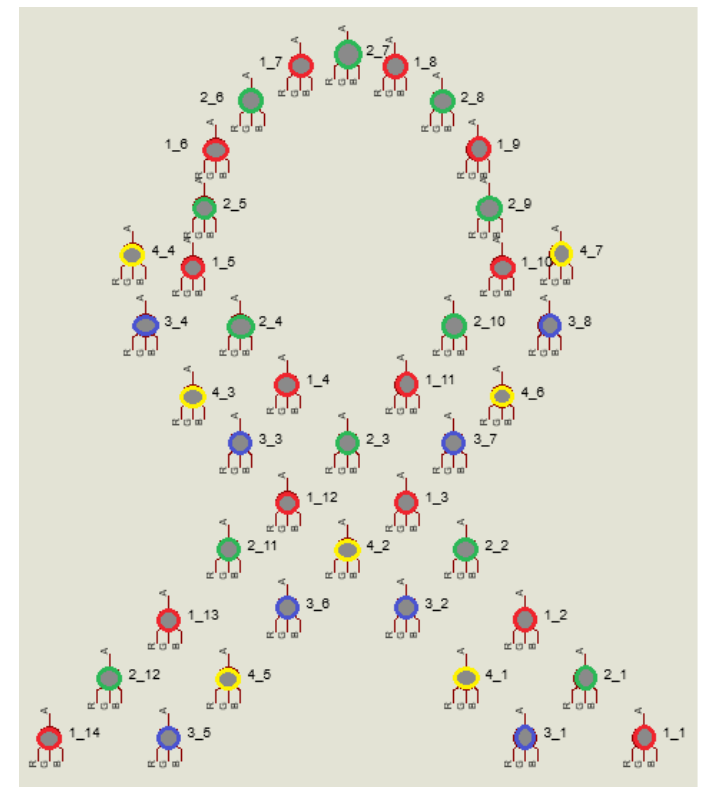

Fonte: Produção do próprio autor (2019).

Na Figura 9, a cor vermelha simboliza a Cor 1 (14 LEDs), a cor verde simboliza a Cor 2 (12 LEDs), a cor azul simboliza a Cor 3 (8 LEDs) e a cor amarela simboliza a Cor 4 (7 LEDs). Ficando evidente que 4 cores distintas podem ser reproduzidas no laço conscientizador proposto. Entretanto vale ressaltar que facilmente pode-se reproduzir uma mesma cor simultaneamente em todo o laço conscientizador, como é o caso do novembro azul.

A Tabela 2 exibe quais pinos do microcontrolador Atmega328p-pu foram utilizados para geração de cada uma das quatro cores distintas. 
Tabela 2 - Descrição dos pinos utilizados para geração de quatro cores distintas.

\begin{tabular}{cccc}
\hline COR - 1 & COR - 2 & COR - 3 & COR - 4 \\
\hline PB3 - PMW1 & PB0 - PMW4 & PD5 - PMW7 & PD2 - MW10 \\
PB4 - PMW2 & PB1 - PMW5 & PD6 - PMW8 & PD3 - MW11 \\
PB5 - PWM3 & PB2 - PWM6 & PD7 - PWM9 & PD4 - WM12 \\
\hline
\end{tabular}

Fonte: Produção do próprio autor (2019).

A cada vez que ocorrer a interrupção por Timer 1, a variável contador vai somando de 1 em 1 e conforme essa soma ocorre, também é realizada uma comparação com a variável PWM1, conforme exibido da Figura 8, podendo a variavel contador assumir valores entre 0 e 255, simulando dessa maneira um PWM.

Neste projeto também se optou pela exibição do horário atual. Com o intuito de não utilizar outro timer, utilizou-se a própria interrupção gerada pelo Timer 1, para tanto, foi utilizado uma variável chamada contador tempo, esta tem a função de ir somando de 1 em 1 a cada vez que a interrupção por Timer 1 acontece. Quando a variável contador_tempo atinge o valor de 64.000 vezes significa que se passou 1 segundo, após a variável é zerada e posteriormente o relógio no LCD é atualizado a partir da variável entrou. A Figura 10 exibe a manipulação da variável contador_tempo.

Figura 10 - Detalhe do funcionamento da variável contador_tempo.

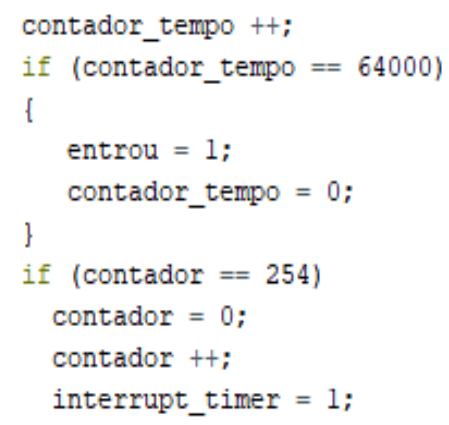

Fonte: Produção do próprio autor (2019).

O valor de 64.000 é encontrado a partir do valor que se deseja atualizar o relógio exibido pelo LCD, que no referido projeto é de um segundo, dessa maneira:

$$
64.000=1 / \text { tempo_de_int errupção }=1 / 15,625 \text { us }
$$

Visualizando a Figura 10, pode-se observar a variável contador_tempo. Esta variável fica incrementando a cada interrupção do Timer 1, quando esta atinge o valor 254 a mesma é zerada para iniciar uma nova contagem para a geração dos sinais PWMs.

A variável interrupt_timer é usada como flag para sinalizar que a interrupção aconteceu. Através desta variavel do tipo global se pode saber através do loop infinito que a interrupção por Timer 1 ocorreu. 
Após a obtenção dos 12 sinais distintos de PWM, partiu-se para a implementação do circuito físico. Inicialmente utilizou-se apenas um LED para testar as cores primárias e combinadas. Quando a maioria das cores foram testadas, decidiu-se energizar quatro LEDs simultaneamente.

Após a obtenção das cores primárias e secundárias utilizando quatro LED’s simultaneamente, decidiu-se adicionar ao projeto um relógio de tempo real (RTC). O RTC foi utilizado para ter um controle de tempo mais preciso, o modelo escolhido foi o RTC DS1307. O objetivo do DS1307 é marcar o tempo de acionamento de cada laço, a cada mês, o RTC mostrará a data e o horário para o usuário, para isso, foi adicionado no projeto um Display LCD 16X2 e dois botões para serem feitos os testes de cores dos laços e a mudança da data e hora no protótipo.

Com a obtenção de alguns resultados (manipulação das cores e do RTC), partiu-se para a confecção da placa de circuito impresso, para a confecção da placa de circuito impresso foi decidido optar pelo software Proteus, pela sua capacidade de simular circuitos e visualizar as placas projetadas em visão $3 \mathrm{D}$, permitindo assim uma melhor visualização de como ficaria o protótipo do circuito quando este fosse confeccionado na placa de circuito impresso.

Antes do projeto da placa de circuito impresso, se fez necessário realizar o dimensionamento dos componentes eletrônicos e listar seus repectivos preços.

Para o acionamento de diversos LEDs não se pode usar diretamente os pinos do Atmega aos LEDs, para isso foi necessário utilizar uma fonte externa, sendo acionada por um transistor, após a realização dos calculos de corrente, optou-se por escolher o transitor BD 139, este que permite drenar corrente de até $1 \mathrm{~A}$.

Como se utilizou o sinal PWM, é sabido que estes sinais ficam um tempo ligado e outro tempo desligado, a depender da razão ciclica, mesmo com essa caractiristica, deve-se considerar o pior caso, que é quando o pulso do PWM é alto, e neste momento o transistor deve operar no modo saturado como uma chave fechada, já no pulso baixo o transistor deve operar no modo corte como uma chave aberta. Para calcular os valores das resistências dos resistores se deve usar as seguintes equações no modo de saturação:

$$
\begin{aligned}
& I b_{\text {forçado }}=\left(I c_{\text {sat }} / \beta_{\min }\right) * \text { fator }_{\text {forçado }} \\
& R b=(V b b-V b e) / I b_{\text {forçado }} \\
& R c=\left(V c c-V l e d-V c e_{\text {sat }}\right) / I c_{\text {sat }}
\end{aligned}
$$

Sendo:

$\mathrm{I}_{\mathrm{C}_{\text {sat }}}$ - Corrente demandada pelos LEDs;

$\mathrm{V}_{\text {LED - Tensão sobre o LED; }}$

$\beta$ min - Ganho mínimo do transistor; 
$\beta$ - Ganho do transistor;

$\mathrm{V}_{\mathrm{CC}}$ - Tensão de alimentação do LED RGB;

$\mathrm{V}_{\mathrm{bb}}$ - Tensão de saída do microcontrolador;

$\mathrm{V}_{\mathrm{be}}$ - Queda de tensão na junção base-emissor do transistor;

$\mathrm{V}_{\text {CEsat - Tensão de saturação; }}$

$\mathrm{R}_{\mathrm{C}-\text { Resistência de coletor; }}$

$\mathrm{R}_{\mathrm{b}}$ - Resistência de base;

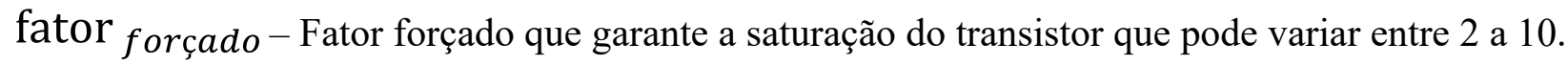

$\mathrm{I}_{\mathrm{B}_{\text {forçado }}}$ - Corrente de base para manter o transistor saturado.

Com o intuito de facilitar os cálculos, foi desenvolvido uma planilha no Excel, conforme os dados da Tabela 3 .

Tabela 3 - Parâmetros para cálculos dos resistores.

\begin{tabular}{lcc}
\hline \multicolumn{1}{c}{ Constantes } & Valor & Unidade \\
\hline Corrente que deve passar sobre cada LED RGB & 0,02 & A \\
Quantidade de LEDS para a COR1 & 14 & Adimensional \\
Quantidade de LEDS para a COR2 & 12 & Adimensional \\
Quantidade de LEDS para a COR3 & 8 & Adimensional \\
Quantidade de LEDS para a COR4 & 7 & Adimensional \\
Tensão VCC & 5 & V \\
Tensão VBB & 5 & V \\
Tensão VCEsat do BD139 & 0,5 & V \\
Tensão VBE & 0,7 & V \\
Beta mínimo BD139-10 & 63 & Adimensional \\
Fator forçado & 3 & Adimensional \\
Tensão R & 1,8 & V \\
Tensão G & 3,2 & V \\
Tensão B & 3,2 & V
\end{tabular}

Fonte: Produção do próprio autor (2019).

Utilizando os dados das Tabelas 1, 2 e 3, a divisão dos LEDs exibidas na Figura 9 e as Equações 3, 4 e 5 foi possível encontrar as resistências dos resistores utilizados no projeto proposto, conforme exibido na Tabela 4. 
Tabela 4 - Valores dos resistores utilizados no projeto proposto.

\begin{tabular}{clc}
\hline Cores & \multicolumn{1}{c}{ Resistor } & Valor \\
\hline Cor 1 (14 LEDs) & Resistor de Coletor do Terminal Red & $10,0 \Omega$ de $1,00 \mathrm{~W}$ \\
& Resistor de Coletor do Terminal Green & $4,7 \Omega$ de $0,50 \mathrm{~W}$ \\
& Resistor de Coletor do Terminal Blue & $4,7 \Omega$ de $0,50 \mathrm{~W}$ \\
& Resistor de Base & $330,0 \Omega$ de $0,0625 \mathrm{~W}$ \\
Cor 2 (12 LEDs) & Resistor de Coletor do Terminal Red & $12,0 \Omega$ de $1,00 \mathrm{~W}$ \\
& Resistor de Coletor do Terminal Green & $5,6 \Omega$ de $0,50 \mathrm{~W}$ \\
& Resistor de Coletor do Terminal Blue & $5,6 \Omega$ de $0,50 \mathrm{~W}$ \\
& Resistor de Base & $390,0 \Omega$ de $0,0625 \mathrm{~W}$ \\
Cor 3 (8 LEDs) & Resistor de Coletor do Terminal Red & $16,0 \Omega$ de $0,5 \mathrm{~W}$ \\
& Resistor de Coletor do Terminal Green & $8,2 \Omega$ de $0,25 \mathrm{~W}$ \\
& Resistor de Coletor do Terminal Blue & $8,2 \Omega$ de $0,25 \mathrm{~W}$ \\
& Resistor de Base & $560,0 \Omega$ de $0,0625 \mathrm{~W}$ \\
Cor 4 (7 LEDs) & Resistor de Coletor do Terminal Red & $20,0 \Omega$ de $0,50 \mathrm{~W}$ \\
& Resistor de Coletor do Terminal Green & $9,1 \Omega$ de $0,25 \mathrm{~W}$ \\
& Resistor de Coletor do Terminal Blue & $9,1 \Omega$ de $0,25 \mathrm{~W}$ \\
& Resistor de Base & $680,0 \Omega$ de $0,0625 \mathrm{~W}$ \\
\hline
\end{tabular}

Fonte: Produção do próprio autor (2019).

Com os componentes devidamente projetados, partiu-se para confecção da placa de circuito impresso. A Figura 12 mostra o modelo 3D da placa com vista superior do circuito impresso projetada no Proteus com a devida disposição dos componentes.

Figura 12 - Visão 3D da placa de circuito impresso projetada.

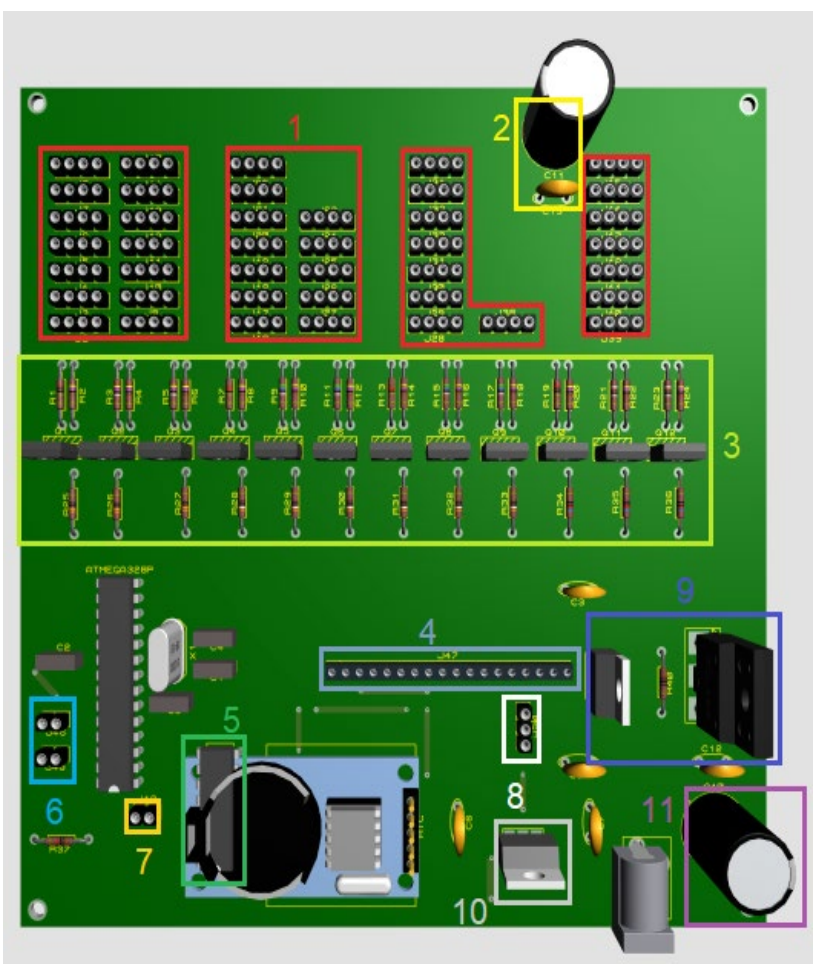

Fonte: Produção do próprio autor (2019). 
Tabela 5 - Informações dos blocos da Figura 12.

\begin{tabular}{|c|c|}
\hline Bloco & Explicação \\
\hline 1 & $\begin{array}{l}\text { Conectores disponíveis para os LEDs, da esquerda para a direita temos as ligações das } \\
\text { cores: COR1, COR } 2, \text { COR } 3 \text { e COR } 4 \text {. }\end{array}$ \\
\hline 2 & Capacitor cerâmico para altas frequências. \\
\hline 3 & $\begin{array}{l}\text { Circuito para o acionamento dos LEDs RGB, nesse circuito estão arranjados todos os } \\
\text { resistores, tanto os de potência como os de sinais e também os BDs que irão receber os } \\
\text { sinais PWMs do Atmega328 para serem amplificados. O capacitor eletrolítico de } 1000 \mu \mathrm{F} \\
\text { foi utilizado pra suprir os afundamentos de tensões devido a variação de corrente gerada } \\
\text { pela mudança dos laços conscientizadores. }\end{array}$ \\
\hline 4 & Conectores para os pinos do LCD. \\
\hline 5 & CI 74HC595 utilizado para reduzir a quantidade de pinos utilizados na ligação do LCD. \\
\hline 6 & $\begin{array}{l}\text { Conectores disponíveis para serem usados os dois botões, o botão de menu e o botão de } \\
\text { enter/avançar. }\end{array}$ \\
\hline 7 & Conectores disponíveis para o botão reset. \\
\hline 8 & Conectores disponíveis para o trimpot usado para possibilitar a variação do brilho do LCD. \\
\hline 9 & $\begin{array}{l}\text { Circuito de alimentação dos LEDs. Devido ao afundamento de tensão gerado pela mudança } \\
\text { dos laços conscientizadores, LCD estava mudando a intensidade de brilho, por este motivo } \\
\text { foi necessário utilizar um regulador de tensão em conjunto com um TIP36 para resolver } \\
\text { esse problema. }\end{array}$ \\
\hline 10 & Regulador 7805 para alimentação do LCD, RTC, Atmega328 e do CI 74HC595. \\
\hline 11 & $\begin{array}{l}\text { Capacitor eletrolítico de } 1000 \mu \mathrm{F} \text { pra suprir os afundamentos de tensões ocasionados pelas } \\
\text { variações dos laços conscientizadores. }\end{array}$ \\
\hline
\end{tabular}

Fonte: Produção do próprio autor (2019).

Após a obtenção do modelo final do circuito proposto, partiu-se para a confecção do painel do protótipo, como decidiu-se fazer o painel utilizando uma impressora $3 \mathrm{D}$, foi necessário projetá-lo através do software SolidEdge, o painel projetado pode ser visualizado através da Figura 13.

Figura 13 - Visão 3D do painel projetado.

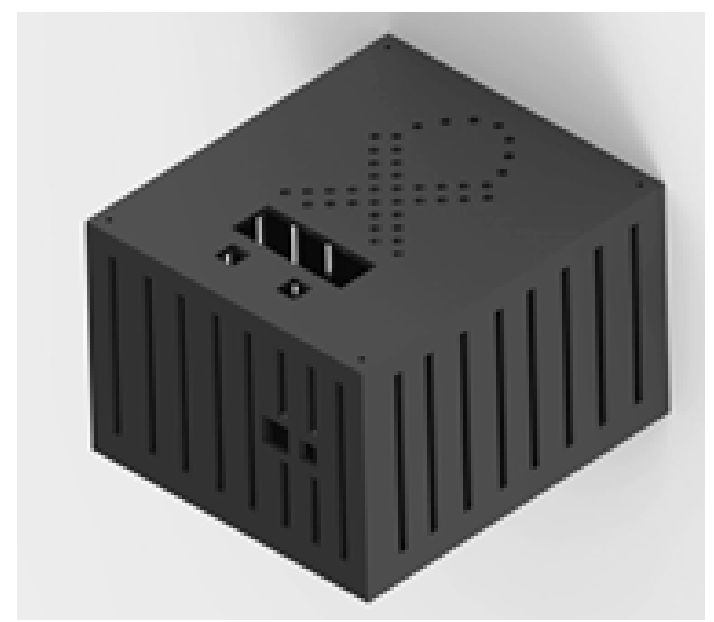

Fonte: Produção do próprio autor (2019). 


\section{RESULTADOS EXPERIMENTAIS}

Com a finalização da placa de circuito impresso e a finalização do painel, pode-se obter os resultados experimentais do protótipo dos laços conscientizadores, dessa maneira, foi possível obter os laços conscientizadores da secretaria de saúde do Ceará, conforme Figura 1. As Figuras 14, 15 e 16 mostram a vista superior do painel com o formato do laço conscientizador, um LCD 16x2 e dois botões, sendo um destes botões utilizados para a definição do menu e outro botão utilizado como enter/avançar.

A Figura 14 mostra dois laços conscientizadores, à esquerda o laço conscientizador rosa do mês de outubro, tendo como tema o câncer de mama e à direita o laço conscientizador azul do mês de novembro, tendo como tema o câncer de próstata e a diabetes.

Figura 14 - Laços conscientizadores rosa e azul.

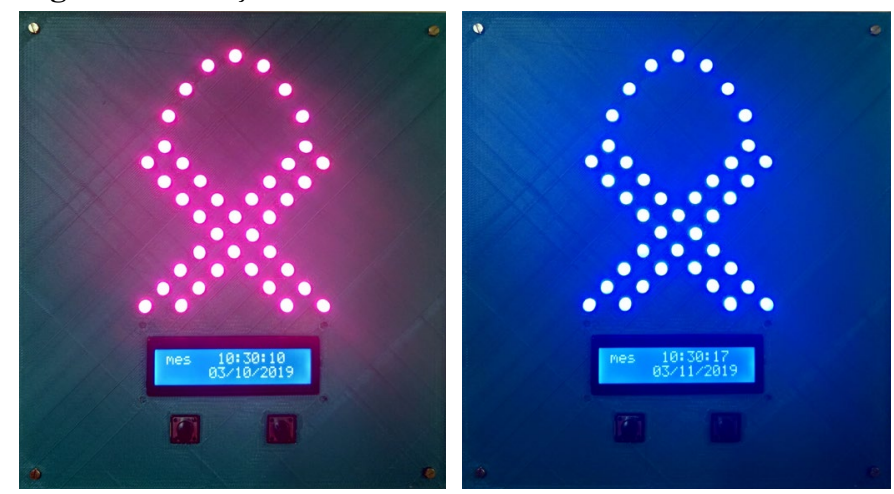

Fonte: Produção do próprio autor (2019).

A Figura 15 mostra dois laços conscientizadores, à esquerda o laço conscientizador quebra-cabeça do mês de abril, tendo como tema o Autismo e à direita o laço conscientizador laranja do mês de junho, tendo como tema a anemia e a leucemia.

Figura 15 - Laços conscientizadores quebra-cabeça e laranja.
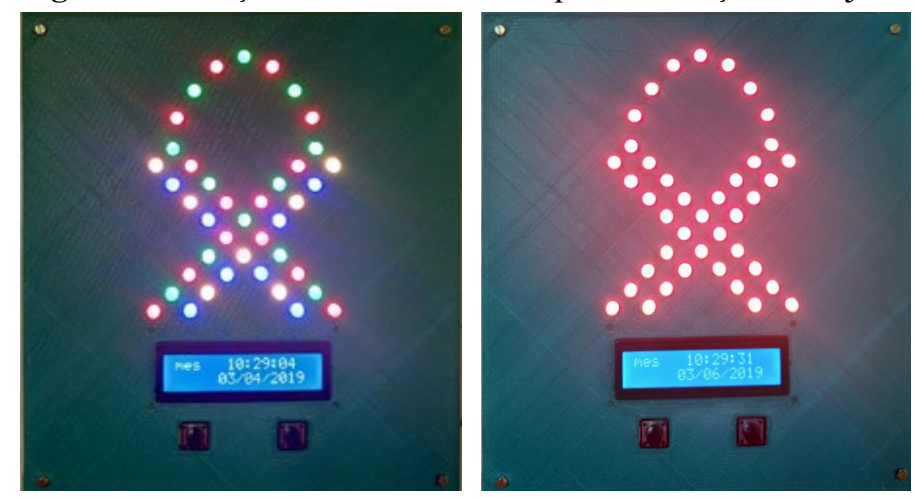

Fonte: Produção do próprio autor (2019). 
A Figura 16 mostra dois laços conscientizadores, à esquerda o laço conscientizador verde do mês de setembro, tendo como tema a doação de órgãos e à direita o laço conscientizador amarelo e vermelho do mês de maio, tendo como tema a hepatite.

Figura 16 - Laços conscientizadores verde e amarelo com vermelho.
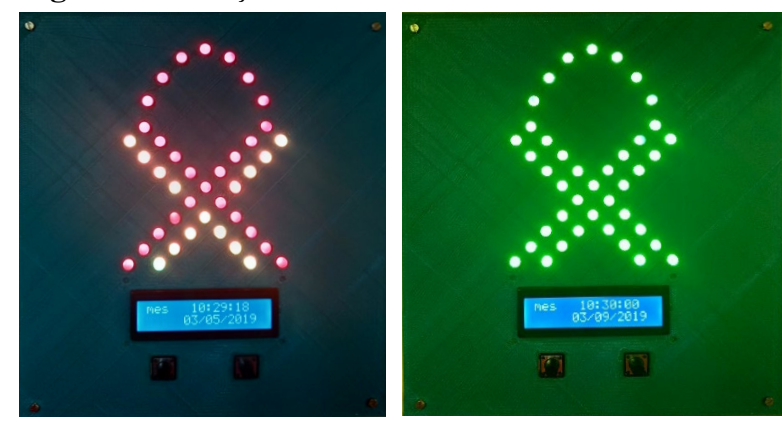

Fonte: Produção do próprio autor (2019).

\section{CONCLUSÃO}

Através dos resultados se pode constatar que o projeto se demonstrou adequado, pois o protótipo desenvolvido foi capaz de exibir os laços conscientizadores automaticamente a medida que cada mês mudava, tornando possível de maneira cômoda e eficaz demonstrar a conscientização da saúde com a imagem dos laços conscientizadores através da exibição e das trocas de cores efetivadas pelos LEDs RGB. Algumas dificuldades ocorreram ao longo do desenvolvimento deste projeto, uma delas foi a confecção da impressão 3D do painel, devido à dificuldade do acesso a uma impressora 3D e a aquisição de filamento, uma segunda dificuldade foi a geração de vários sinais PWM utilizando TIMER e saídas digitais. Todas as dificuldades foram superadas e desta forma foi possível concluir o projeto com êxito na sua função de representação dos laços conscientizadores da saúde. Dessa maneira, o trabalho foi capaz de mostrar por meio dos LEDs RGB interagindo com um Sistema Embarcado a consciência sobre a saúde por meio de componentes eletrônicos. Para trabalhos futuros, pode-se configurar o sistema embarcado para exibir as cores dos laços conscientizadores de qualquer Estado do Brasil.

\section{AGRADECIMENTOS}

Agradecemos ao IFCE (Projeto PIBIC 7.363) pelo auxílio financeiro que possibilitou a realização deste projeto e ao laboratório de Eletrônica 2 do IFCE Campus Sobral. 


\section{REFERÊNCIAS}

AUTOCORE. LED RGB. Autocore Robótica, 2019. Disponível em:

https://www.autocorerobotica.com.br/buscar?q=led+rgb. Acesso em: 20 de out.2019.

BASONI, Renan Corrêa. Sistema integrado para supervisão e controle de equipamentos eletroeletrônicos utilizando uma rede de comunicação sem fio de microcontroladores. Monografia (Graduação em Engenharia Elétrica) - Instituto Federal do Espírito Santo.Vitória,2015.

FERRORI, Felipe Martins. Inversor de tensão senoidal microcontrolado por arduino. Monografia ( Graduação em Engenharia de Controle e Automoção) - Escola de minas departamento de engenharia de controle e automoção, Universidade Federal de Ouro Preto. Ouro Preto,2018.

JÚNIOR, Edilson Mineiro Sá. Estudo de estruturas de reatores eletrônicos para leds de iluminação. Tese (Doutorado em Engenharia Elétrica) - Universidade Federal de Santa Catarina. Florianópolis, 2010.

KERN, S. Light-emitting diodes in automotive forward lighting applications: materials engineering solutions to fundamental challenges. (March 2004: Detroit, USA) Proceedings in SAE, Detroit, paper 0255, 2004.

OLIVEIRA, Selma, SÁ, Marcus. Cores da saúde: laços de fita alertam para controle de doenças. Governo do Estado do Ceará, 2015. Disponível em: https://www.saude.ce.gov.br/2015/10/02/cores-da-saude-lacos-de-fita-alertam-para-controle-de-doencas/. Acesso em: 14 de out.2019.

MICROCHIP. Datasheet ATmega328P. ATmega328P - 8-bit AVR Microcontrollers, 2019. Disponível em: http:/ww1.microchip.com/downloads/en/DeviceDoc/Atmel-7810-Automotive-Microcontrollers-ATmega328P_Datasheet.pdf. Acesso em: 22 de out.2019.

NORGAARD, Kari Marie. The Effects of Altered Diet on the Health of the Karuk People. Tese (Ph.D) Federal Energy Regulatory Comissioon Docket.California, 2005.

PAES. Vinicius de Carvalho (org.). Coletânea Brasileira de Engenharia de Produção 3. Itajubá: Stellata Editora, 2019. Disponível em: https://stellata.com.br/wp-content/uploads/2019/02/Coletânea-Brasileira-de-Engenharia-de-Produção-3.pdf Acesso em: 24 nov. 2019.

SILVA, F. L. et al. CONVERSOR DE FREQUÊNCIA CC-CA. E-xacta. Belo Horizonte - Minas Gerais, Mar. 2013. 


\section{PERFIL EPIDEMIOLÓGICO DAS OCORRÊNCIAS DE SARAMPO NO BRASIL DURANTE OS ÚLTIMOS 5 \\ ANOS}

RENATA LINS WANDERLEY

Universidade Estadual de Ciências da Saúde de Alagoas

AMANDA ARAÚJO SOUZA

Universidade Estadual de Ciências da Saúde de Alagoas

\section{ANA CLÁUDIA DA SILVA FERNANDES}

DUARTE

Universidade Estadual de Ciências da Saúde de Alagoas

GABRIEL JOSÉ TORRES DA SILVA

Universidade Estadual de Ciências da Saúde de

Alagoas

JOSÉ JOÃO FELIPE COSTA DE

OLIVEIRA

Universidade Estadual de Ciências da Saúde de

Alagoas

\section{LUCIANA MARIA DE MEDEIROS}

PACHECO

Universidade Estadual de Ciências da Saúde de

Alagoas

VITORIA CRUZ TORRES

Universidade Estadual de Ciências da Saúde de Alagoas

ZION CARVALHO DA SILVA

Universidade Estadual de Ciências da Saúde de Alagoas

RESUMO: O sarampo é uma doença exantemática aguda febril, causada por um vírus do gênero
Morbillivirus, transmissível e altamente contagiosa. Essa enfermidade é transmitida de pessoa para pessoa através de secreções nasofaríngeas, ocorrendo entre 4 dias antes e depois do aparecimento dos exantemas. Em 2016, a Organização Mundial da Saúde (OMS) anunciou a eliminação do sarampo no Brasil e nas Américas. Com essa erradicação, a doença tornou-se rara e, hoje, menos comum devido às campanhas de vacinação. No entanto, no ano de 2018, novos surtos aconteceram, e Roraima e Amazonas relataram casos confirmados. Os casos aumentaram substancialmente no início de 2019 a partir da entrada do vírus junto com turistas doentes e imigrantes suscetíveis. O objetivo central deste trabalho foi identificar as características epidemiológicas, incluindo regiões mais atingidas, sexo, etnia, faixa etária, caráter de atendimento e número de internações e óbitos dos casos confirmados para o sarampo no Brasil entre 2015 e 2019. Para isso, realizou-se um estudo exploratório com dados secundários, obtidos pelo Sistema de Informações Hospitalares do SUS (SIH) do DATASUS, sobre a epidemiologia das internações por sarampo em estabelecimentos públicos e privados durante o período de 2015 a 2019. Foi possível observar que todas as regiões brasileiras são afetadas, que não há preferência por gênero masculino ou feminino e que os menores de 1 ano permanecem sendo os mais atingidos. Além disso, o número de óbitos foi menor em comparação a outros períodos. Portanto, pesquisas ainda precisam ser realizadas para explicar o surto apresentado no país da melhor maneira, desde os motivos de recontaminação até as medidas de prevenção e manejo do sarampo.

PALAVRA-CHAVE: Epidemiologia; Morbillivirus; Sarampo. 
ABSTRACT: Measles is an acute febrile exanthematic disease, caused by a virus of the genus Morbillivirus, transmissible and highly contagious. This disease is transmitted from person to person through nasophageous secretions, ocurring between 4 days before and after the appearance of exantemas. In 2016, the World Health Organization (WHO) announced the elimination of measles in Brazil and the Americas. With this eradication, the disease has become rare and, today, less common due to vaccination campaigns. However, in 2018, new outbreaks occured, and Roraima and Amazonas reported confirmed cases. Cases increased substantially in early 2019 from the entry of the virus along with sick tourists and susceptible immigrants. The central objective of this study was to identify epidemiological characteristics, including the most affected regions, gender, ethnicity, age group, character of attendance, the number of hospitalizations and deaths of confirmed cases of measles in Brazil between 2015 and 2019. For this, an exploratory study was conducted with secondary data obtained by Hospital Information System (HIS) of DATASUS, about the epidemiology measles hospitalizations in public and private facilities during the period of 2015 to 2019. It was possible to observe that all brazilian regions are affected, that there is no preference for male or female gender and that children under 1 year remain the most affected. In addition, the number of deaths was lower compared to other periods. Therefore, research still needs to be conducted to explain the outbreak presented in the country in the best way, from the reasons for recontamination to the preventive measures and management of measles.

KEYWORDS: Epidemiology; Morbillivirus; Measles.

\section{INTRODUÇÃO}

O sarampo é uma doença exantemática aguda febril, causada pelo vírus da família Paramyxoviridae e do gênero Morbillivirus. Essa patologia é transmissível e extremamente contagiosa, com uma taxa de contaminação de mais de $90 \%$ para os expostos, no qual apenas um único paciente pode infectar outras 12 a 18 pessoas (Xavier et al., 2019).

Sua transmissão ocorre de pessoa para pessoa por meio de secreções nasofaríngeas e entre 4 dias antes e depois do aparecimento dos exantemas. No Brasil, a população atingida pelo vírus do sarampo quando sua circulação era maior, correspondia aos pré-escolares e escolares principalmente (Salomão, 2017).

A evolução clínica possui 3 fases: prodrômica, exantemática e de convalescença. Os sintomas da fase prodrômica são febre alta, coriza, conjuntivite e tosse produtiva, podendo também aparecer o Sinal de Koplik, o qual é identificado pela observação de lesões brancas com halo eritematoso na região da mucosa oral. Na segunda fase, aparecem os exantemas maculopapulares, com distribuição craniocaudal, iniciando em região retroauricular. Na terceira fase, as manchas começam a descamar, adquirindo uma característica furfurácea. $\mathrm{O}$ último sintoma a desaparecer é a tosse. Essa doença tem a capacidade de suprimir a resposta imune a outros patógenos, podendo causar agravos, tais como broncopneumonia, laringotraqueobronquite, otite média, diarreia e, mais raramente, panencefalite esclerosante subaguda após meses da infecção pelo vírus selvagem. Além disso, os indivíduos com imunidade debilitada possuem maior risco de óbito, como nos casos de HIV (vírus da imunodeficiência humana) positivo, leucemia e desnutrição. Grávidas também são um grupo importante a se con- 
siderar, visto que as complicações incluem aborto espontâneo, parto prematuro, baixo peso ao nascer e morte materna (Brasil, 2010).

O tratamento realizado é de suporte clínico e sintomatológico, sendo assim a vacinação torna-se importante como forma preventiva da enfermidade e como controle de surtos quando aplicada até 72 horas da exposição em indivíduos sem comprometimento da imunidade. Ademais, também pode ser utilizada a imunoglobulina em imunocomprometidos em até 6 dias quando expostos ao vírus. $\mathrm{O}$ percentual de eficácia vacinal pode chegar a 100\%, então, sua aplicação é útil contra a doença (Xavier et al., 2019).

No diagnóstico laboratorial, o teste mais realizado é o ELISA (ensaio de imunoabsorção enzimática), detectando os anticorpos específicos IgM e IgG, coletados na fase aguda após 4 dias de exantema e na fase de convalescência. No entanto, atualmente é importante realizar a detecção do vírus através do PCR (reação em cadeia de polimerase), com coleta nos primeiros dias de manifestação clínica, para identificar seu padrão genético a fim de saber se os casos são autóctones ou não e diferenciar o vírus selvagem e o vacinal. O PCR é um exame utilizado em circunstâncias específicas de maneira complementar, a fim de auxiliar a elucidação do caso, como nas seguintes ocasiões: sorologia reagente para doenças exantemáticas febris agudas; novas cadeias de transmissão; novos municípios com caso confirmado pela sorologia; história de vacina de tríplice viral ou tetraviral, conforme as datas de EAPV; município com reintrodução do vírus após 90 dias da data do exantema do último caso; óbito; história de viagem para locais com evidência de circulação do vírus do sarampo; contato com estrangeiro; e situações especiais definidas pela vigilância (Brasil, 2019).

Esse agente etiológico possui 8 classes diferentes de A ao $\mathrm{H}$, mostrando ser muito variado e distribuído de maneira diferente na população mundial. Dessa forma, é necessário entender a história do sarampo no Brasil, visto que mesmo com a diminuição dos casos no país, outros países ainda apresentam a doença (Salomão, 2017).

Na década de 60, a vacina chegou ao território brasileiro e o sarampo tornou-se uma doença de notificação compulsória no país. Em 1973, o Plano Nacional de Imunização (PNI) foi elaborado, contudo, até o início dos anos 90, aconteceram 9 epidemias. Em 1992, foi implementado o Plano Nacional de Eliminação do Sarampo, que apresentou estratégias de vacinação da população, manutenção da cobertura vacinal em 95\%, vigilância epidemiológica, capacitação do profissional de saúde e campanhas de divulgação para tentar extinguir a doença no Brasil. Desse modo, a campanha de vacinação atingiu um patamar impactante na diminuição dos casos notificados, com uma redução de 94,5\% (Domingues et al., 1997).

Também foi verificada a diminuição de óbitos nas crianças em razão da não infecção e, assim, não adquiriram as complicações da doença. Desde a década de 70, a faixa etária mais atingida permaneceu entre os menores de 1 ano de idade, seguido pela faixa de 1 a 4 anos e 5 a 14 anos. Dessa forma, outra campanha foi realizada em 1995, a Campanha Nacional de Vacinação de Seguimento contra o Sarampo. Porém, essa campanha não obteve tanto êxito na cobertura vacinal quando a de 1992, com a apresentação de dificuldades no fornecimento da vacina (Domingues et al., 1997). 
No ano de 1997, São Paulo elevou progressivamente o número de casos, possibilitando a transmissão para outros estados do país e outros países. Nesse mesmo ano, mais de $50 \%$ dos casos no país foram em adultos jovens entre 20 e 29 anos, os quais não participaram de uma campanha mais maciça durante a infância devido à falta de planos nacionais de saúde contra o sarampo (Domingues et al., 1997).

Em 1996 e 1997, a análise genômica foi realizada em amostras isoladas de vírus de São Paulo, Minas Gerais, Bahia e Rio de Janeiro. Os resultados indicaram que, no país, foi disseminado pelo menos três tipos de vírus em 1996 e 1997. Como não havia esse método de identificação antes do "Plano de Eliminação do Sarampo", não se pode dizer se o surto foi causado por importações de outros países ou se esses vírus são inerentes ao nosso país. Portanto, há importância da genotipagem em todos os estados onde são diagnosticados casos de sarampo (Domingues et al., 1997).

Em 2015, 214 casos foram confirmados nos estados do Ceará, Roraima e São Paulo, mas já em 2016 a Organização Mundial da Saúde (OMS) anunciou a eliminação do sarampo no Brasil e nas Américas. Com essa eliminação, a doença tornou-se rara e, hoje, menos comum devido às campanhas de vacinação. No entanto, no ano de 2018, novos surtos aconteceram, e Roraima e Amazonas relataram casos confirmados (Faria; Moura, 2020).

Os casos aumentaram substancialmente no início de 2019 a partir da entrada do vírus junto com turistas doentes e imigrantes suscetíveis. Constatou-se que a taxa inicial de vacinação na parte norte do país era muito baixa, abaixo de 95\%. Posteriormente, ele foi introduzido e espalhado para áreas mais densamente povoadas, como o sudeste, gerando maior impacto em São Paulo. Embora a cobertura da vacinação contra o sarampo em São Paulo seja de cerca de $90 \%$, ainda não é o suficiente para combater o surto (Medeiros, 2020).

Em outubro de 2019, o Brasil registrou 49.613 casos suspeitos de sarampo. Entre eles, 10.429 (21,0\%) foram casos confirmados, 8.235 (79,0\%) de acordo com padrões laboratoriais e $2.194(21,0 \%)$ de acordo com padrões clínicos de epidemiologia. A cobertura vacinal de mais de $95 \%$ é a maneira mais eficaz de manter as pessoas sem sarampo. Este método é chamado de "imunidade de rebanho" e pode impedir a propagação do vírus em qualquer circunstância (Brasil, 2019).

Existem poucos casos de sarampo hospitalizados e, até agora, a gravidade da doença foi menos grave do que a identificada nos anos anteriores. Com esses surtos mais atuais, foi percebido que indivíduos com imunização prévia foram infectados e sintomáticos, mesmo com as 2 doses da vacina, bem como com IgG positiva. Pacientes internados devem ser mantidos isolados para evitar maior contaminação e os profissionais da saúde também devem ser vacinados com 2 doses, mantendo seu cartão de imunização atualizado (Medeiros, 2020).

Teorias sobre a razão do novo surto são elaboradas e pode-se conjecturar que os níveis de anticorpos decaiam após a imunização, que a resposta imunológica contra o genótipo D8 não é tão eficiente ou que fatores genéticos estejam envolvidos. Contudo, questões sociais e políticas também são significativas para explicar o ocorrido, como as dificuldades apresentadas no sistema de saúde, os grupos antivacinas espalhados pelo mundo e o aumento da possibilidade de viagens entre países no atual mundo globalizado (Escalante, 2019). 
Conforme estudo realizado por Marieli et al. (2020), as informações falsas sobre a vacinação circulam em diversas redes sociais e, na rede social Facebook, a disseminação do Movimento Anti-vacina esteve presente com a aceitação de diversos indivíduos, mesmo com dados sem comprovação científica.

A presença do vírus no território brasileiro reforça a necessidade de vigilância epidemiológica ativa (de preferência dentro de 24 horas da notificação de casos suspeitos, investigação imediata, coleta e distribuição completa de amostras), esforços para prevenir e homogeneizar através da imunização, abrangendo crianças, adolescentes e adultos (Faria; Moura, 2020).

Os principais objetivos deste trabalho são identificar as características epidemiológicas (sexo, etnia, faixa etária, regiões mais atingidas) dos casos confirmados para o sarampo no Brasil a partir do ano de 2015 até 2019. É essencial que sejam identificados os perfis do surto para que novas medidas possam ser aplicadas como forma de promoção da saúde da população brasileira.

\section{MATERIAL E MÉTODOS}

Trata-se de um estudo epidemiológico descritivo, quantitativo e retrospectivo do tipo transversal. Assim, realizou-se um estudo exploratório com dados secundários, obtidos do Sistema de Informações Hospitalares do SUS (SIH) do DATASUS, sobre a epidemiologia das internações por sarampo em estabelecimentos públicos e privados durante o período de 2015 a 2019 . Ao obter os dados, foram analisadas as seguintes variantes: internação, caráter de atendimento, regiões do país, sexo, raça/etnia, faixa etária e número de óbitos.

\section{RESULTADOS E DISCUSSÃO}

Por meio da análise dos dados, verificou-se que durante os últimos cinco anos (janeiro de 2015 a dezembro de 2019), no Brasil, ocorreram 1.875 internações por sarampo. A tabela 1 expõe a distribuição dos casos durante o período analisado.

Tabela 1 - Internações por sarampo conforme o ano de processamento

\begin{tabular}{|c|c|}
\hline Ano & Casos \\
\hline 2015 & 55 \\
\hline 2016 & 33 \\
\hline 2017 & 63 \\
\hline 2018 & 891 \\
\hline 2019 & 833 \\
\hline
\end{tabular}

Fonte: Dados obtidos do DATASUS, 2020 
Através da análise dos dados, tabela 1, observa-se uma oscilação no aumento ou redução dos casos com o passar dos anos, no qual nota-se uma maior incidência em 2018, com aumento de aproximadamente 15 vezes a quantidade registrada em 2017. Além disso, pode-se verificar, que ocorreu um decrescimento de $6,5 \%$ entre os anos de 2018 e 2019, todavia, o número de casos permanece elevado e registrado como o segundo maior dos últimos 5 anos.

Tabela 2 - Internações por sarampo conforme o caráter de atendimento e ano de processamento

\begin{tabular}{|c|c|c|}
\hline Ano & Eletivo & Urgência \\
\hline 2015 & 1 & 54 \\
\hline 2016 & 4 & 29 \\
\hline 2017 & 16 & 47 \\
\hline 2018 & 89 & 802 \\
\hline 2019 & 22 & 811 \\
\hline Total & 132 & 1.743 \\
\hline
\end{tabular}

Fonte: Dados obtidos do DATASUS, 2020

Ao verificar o caráter de atendimento das internações confirma-se não apenas o crescimento dos casos graves, mas também dos que precisam de atendimento de urgência. Dessa forma, observa-se, de modo geral, que do total de atendimentos 92,96\% das ocorrências foram de urgência. Além disso, 2019 se sobressai com o maior número de casos de urgência, mesmo que tenha sido o ano em que ocorreu uma redução de casos, o que mostra a predominância desse tipo de ocorrência.

Tabela 3 - Internações por sarampo por região conforme número de casos e porcentagem

\begin{tabular}{|c|c|c|}
\hline Região & Casos & $\mathbf{\%}$ \\
\hline Norte & 854 & $45,5 \%$ \\
\hline Nordeste & 248 & $13,2 \%$ \\
\hline Sudeste & 701 & $37,4 \%$ \\
\hline Sul & 49 & $2,6 \%$ \\
\hline Centro-Oeste & 23 & $1,3 \%$ \\
\hline
\end{tabular}

Fonte: Dados obtidos do DATASUS, 2020

Atentando-se para as regiões do país associada à ocorrência do sarampo, tabela 3 , verifica-se o destaque da região norte concentrando o maior número de casos, taxa de $45,5 \%$, seguida pela região sudeste com $37,4 \%$.

Tabela 4 - Sexo dos indivíduos com sarampo

\begin{tabular}{|c|c|c|}
\hline Sexo & Casos & Percentual \\
\hline Feminino & 879 & $46,9 \%$ \\
\hline Masculino & 996 & $53,1 \%$ \\
\hline
\end{tabular}

Fonte: Dados obtidos do DATASUS, 2020 
Quanto às informações relacionadas ao sexo dos pacientes, tabela 4, nota-se a prevalência de casos no sexo masculino, com $53,1 \%$ do total.

Tabela 5 - Internações por sarampo conforme a raça/etnia

\begin{tabular}{|c|c|c|}
\hline Raça/etnia & Casos & \% \\
\hline Branca & 368 & $19,6 \%$ \\
\hline Preta & 31 & $1,7 \%$ \\
\hline Parda & 1.063 & $56,7 \%$ \\
\hline Amarela & 20 & $1,4 \%$ \\
\hline Indígena & 8 & $0,6 \%$ \\
\hline Sem informação & 385 & $20 \%$ \\
\hline
\end{tabular}

Fonte: Dados obtidos do DATASUS, 2020

Quanto à raça/etnia, tabela 5, nota-se o elevado número de indivíduos pardos como principais afetados, com taxa de 56,7\% dos casos. Além disso, verifica-se os brancos, em seguida, como mais afetados, com taxa de $19,6 \%$.

Tabela 6 - Casos de sarampo conforme a faixa etária

\begin{tabular}{|c|c|c|}
\hline Idade & Casos & \% \\
\hline Menor 1 ano & 723 & $38,5 \%$ \\
\hline $1-4$ & 490 & $26,1 \%$ \\
\hline $5-9$ & 142 & $7,5 \%$ \\
\hline $10-14$ & 80 & $4,2 \%$ \\
\hline $15-19$ & 102 & $5,4 \%$ \\
\hline $20-29$ & 190 & $10,1 \%$ \\
\hline $30-39$ & 75 & $4 \%$ \\
\hline $40-49$ & 30 & $1,6 \%$ \\
\hline 50 ou mais & 43 & $2,6 \%$ \\
\hline
\end{tabular}

Fonte: Dados obtidos do DATASUS, 2020

Analisando a tabela 6 , nota-se uma concentração de casos nas faixas etárias entre os menores de 1 ano que possuem um total de 38,5\% dos doentes. Contudo, verifica-se uma quantidade semelhante de casos presentes na faixa etária entre 1 e 4 anos, com 26,1\% dos afetados. De forma genérica, esses dados mostram uma ocorrência dessa doença em indivíduos recém-nascidos, bebês e crianças.

Em relação aos óbitos, verifica-se que ocorreram 5 mortes por sarampo. A mortalidade observada nesse período é de $0,3 \%$. 
Tabela 7 - Óbitos por sarampo conforme o ano de processamento

\begin{tabular}{|c|c|}
\hline Ano & Óbitos \\
\hline 2015 & 0 \\
\hline 2016 & 0 \\
\hline 2017 & 0 \\
\hline 2018 & 4 \\
\hline 2019 & 1 \\
\hline Total & 5 \\
\hline
\end{tabular}

Fonte: Dados obtidos do DATASUS, 2020

Pautando-se nos dados expostos na tabela 7, nota-se que os óbitos por sarampo foram estatisticamente pouco relevantes, com surgimento nos anos de explosão dos casos (2018-2019). Todavia, nota-se uma redução de mortes de 75\% entre os anos de 2018 e 2019.

Tabela 8 - Óbitos por sarampo conforme a faixa etária

\begin{tabular}{|c|c|}
\hline Idade & Óbitos \\
\hline Menor 1 ano & 1 \\
\hline $1-4$ & 1 \\
\hline $5-9$ & 0 \\
\hline $10-14$ & 0 \\
\hline $15-19$ & 1 \\
\hline $20-29$ & 1 \\
\hline $30-39$ & 0 \\
\hline $40-49$ & 0 \\
\hline 50 ou mais & 1 \\
\hline
\end{tabular}

Fonte: Dados obtidos do DATASUS, 2020

Associando-se os óbitos e a faixa etária, contidos na tabela 8, nota-se que os indivíduos menores de um ano, de 1 a 4 anos, entre 15 e 19 anos, de 20 a 29 anos e maiores de 50 anos portadores de sarampo possuíam a mesma taxa de óbitos durante os últimos 5 anos.

Tabela 9 - Taxa de óbitos por sarampo conforme a região

\begin{tabular}{|c|c|}
\hline Região & Taxa de óbitos \\
\hline Norte & 4 \\
\hline Nordeste & 1 \\
\hline Sudeste & 0 \\
\hline Sul & 0 \\
\hline Centro-Oeste & 0 \\
\hline
\end{tabular}

Fonte: Dados obtidos do DATASUS, 2020

Considerando-se os óbitos distribuídos pelas regiões do Brasil associadas à ocorrência do sarampo, presente na tabela 9 , observa-se o destaque da região Norte concentrando o maior número 
de óbitos, com taxa de $80 \%$, seguida pela região Nordeste, com $20 \%$. Dessa maneira, verifica-se que o norte do país possui o maior número de casos e de óbitos, e o sudeste, segunda região com mais casos, não apresenta óbitos registrados. Além disso, o Nordeste brasileiro surge com o segundo maior número de mortes e o terceiro com o maior número de casos.

\section{CONCLUSÃO}

Neste trabalho, foram discutidos os números de internação no Brasil entre 2015 e 2019, o que permitiu observar uma concordância com o aumento considerável de casos confirmados no país nos anos de 2018 e 2019. Além disso, mesmo com a declaração da OMS de eliminação do vírus nas Américas em 2016, no mesmo ano casos ainda eram confirmados, mas em quantidade baixa e tolerável, diferente da apresentada mais recentemente.

Também é perceptível que todas as regiões brasileiras são afetadas, porém Norte e Sudeste são as mais atingidas. No Norte, as taxas de vacinação são baixas, mas no Sudeste, mesmo sendo mais elevadas, ainda há contaminação. Desse modo, de um lado do país faltam campanhas vacinais e, do outros, há imigração estrangeira.

Observou-se que não há preferência por gênero masculino ou feminino, estando ambos suscetíveis, com uma porcentagem aproximada de 50\%.

Com a apresentação das faixas etárias, concluiu-se que os menores de 1 ano permanecem sendo os mais atingidos, no entanto, em adição a isso, todas as outras faixas etárias apresentaram casos confirmados. Porém, é importante ressaltar que mais de 50\% dos casos constituem a faixa entre menores de 1 ano e 4 anos, uma porcentagem bastante elevada ao analisar que a vacina deve ser administrada a partir de 12 meses e reforçada aos 15 meses (intervalo de 3 meses para $2^{\mathrm{a}}$ dose). Desse modo, provavelmente, a ausência da vacinação foi fator para esses números altos encontrados.

Um diferencial importante desse último surto foi a diminuição dos casos mais graves, reduzindo assim o número de óbitos decorrentes das complicações da doença.

Tendo em vista o exposto, compreende-se que pesquisas ainda precisam ser realizadas para explicar o surto apresentado no país da melhor maneira, desde os motivos de recontaminação até as medidas de prevenção e manejo do sarampo. 


\section{AGRADECIMENTOS}

À Liga Acadêmica de Diagnóstico por Imagem (LADI-UNCISAL), por proporcionar tal oportunidade em participar da construção desse trabalho com a ajuda da diretoria.

À professora, orientadora Luciana Maria de Medeiros Pacheco, pela disponibilidade e compromisso com o artigo, lapidando-o.

\section{REFERÊNCIAS}

BRASIL. Ministério da Saúde. Doenças infecciosas e parasitárias: guia de bolso. Brasília, 8 ed, 2010.

BRASIL. Ministério da Saúde. Plano de Contingência para Resposta às Emergências em Saúde Pública Sarampo. Brasília, 2016.

BRASIL. Ministério da Saúde. Boletim epidemiológico. Brasília, 2019.

BRASIL. Ministério da Saúde. Guia de vigilância em Saúde. Brasília, 3 ed, 2019.

DOMINGUES, Carla Magda Allan S. et al. A evolução do sarampo no Brasil e a situação atual. Inf. Epidemiol. Sus, Brasília, v. 6, n. 1, p. 7-19, mar. 1997.

ESCALANTE, Giovanni. El retorno del sarampión en las Américas. Rev. Méd. Urug., Montevideo, v. 35, n. 2, p. 1-3, jun. 2019.

FARIA, Shirley Cristiane Ramalho Bueno de; MOURA, Ana Débora Assis. Atuação de equipes da Estratégia Saúde da Família frente à epidemia de sarampo em Fortaleza, Ceará, Brasil. Epidemiol. Serv. Saúde, Brasília, v. 29, n. 3, 2020.

MARIELI, Vanessa Ferreira et al. Movimento antivacinação no Facebook®: uma análise crítica da disseminação de notícias falsas. Braz. J. of Develop., Curitiba, v. 6, n. 9, p.66669-66685, sep. 2020

MEDEIROS, Eduardo Alexandrino Servolo. Entendendo o ressurgimento e o controle do sarampo no Brasil. Acta paul. enferm., São Paulo, v. 33, 2020.

SALOMÃO, Reinaldo. Infectologia: Bases clínicas e tratamento. 1 ed. Rio de Janeiro: Guanabara Koogan, 2017.

SOCIEDADE BRASILEIRA DE PEDIATRIA. Atualização sobre o sarampo. n. 5, jul. 2018.

XAVIER, Analucia R. et al. Clinical, laboratorial diagnosis and prophylaxis of measles in Brazil. J. Bras. Patol. Med. Lab., Rio de Janeiro, v. 55, n. 4, p. 390-401, Aug. 2019. 


\section{PERFIL SOCIODEMOGRÁFICO DOS RESIDENTES DE UMA INSTITUIÇÃO DE LONGA PERMANÊNCIA}

FRANCISCA SOUZA SANTOS DIAS Instituto Federal do Norte de Minas Gerais

CLARA CYNTHIA MELO E LIMA Instituto Federal do Norte de Minas Gerais

PATRÍCIA DE SOUSA FERNANDES QUEIROZ Instituto Federal do Norte de Minas Gerais HÉRIKA MARIA SILVEIRA RUAS Instituto Federal do Norte de Minas Gerais

VIVIANE MAIA SANTOS Centro Universitário UNIFIPMOC
RESUMO: Com o aumento da população idosa, cresce a procura por Instituições de Longa Permanência para Idosos (ILPIs). Essa busca é elucidada em muitos casos, pelas dificuldades encontradas pelas famílias para o cuidado do idoso, sobretudo para aqueles que apresentam redução da capacidade funcional. Pois se tornam cada vez mais dependentes para realização de atividades cotidianas e requerem cuidados de maior complexidade e custo. Mesmo com um grande número de ILPIs no Brasil, existem poucos estudos verificando o perfil sócio-demográfico dos residentes. O estudo teve por verificar o perfil sócio-demográfico dos indivíduos que vivem em uma instituição de longa permanência localizada em Araçuaí, Minas Gerais. Trata-se de um estudo do tipo exploratório e descritivo, com abordagem quantitativa. A coleta de dados foi realizada no período de janeiro a fevereiro de 2020 . As informações descritivas do perfil do residente foram coletadas utilizando-se um formulário semiestruturado. Foram avaliados 35 indivíduos, sendo 21 homens $(60 \%)$ e 14 mulheres $(40 \%)$. A análise dos dados evidenciou que os residentes da instituição de longa permanência eram, em sua grande maioria, solteiros $(77,1 \%)$, não possuíam filhos $(54,3 \%)$, analfabetos $(82,9 \%)$ ou com baixa escolaridade $(17,1 \%)$ e não recebiam visitas $(77,1 \%)$. Os resultados encontrados nesse estudo acerca do perfil dos residentes de instituição de longa permanência estão de acordo com a literatura no que se refere ao estado civil, número de filhos e nível educacional. Conclui-se, portanto, que residem predominantemente nessa instituição de longa permanência, pessoas solteiras, que não possuem filhos, analfabetos ou de baixa escolaridade. Ressalta-se, ainda, que essas características encontradas, muitas vezes, são consideradas como fatores de risco para institucionalização.

PALAVRA-CHAVE: Envelhecimento; Institucionalização; Instituição de longa permanência para idosos.

ABSTRACT: With the increase in the elderly population, the demand for Long Term Care Institutions for the Elderly (ILPIs) grows. This search is elucidated in many cases, by the difficulties encountered by families in caring for the elderly, especially for those who have reduced functional capacity. Because they become increasingly dependent on daily activities and require more complex and costly care. Even with a large number of LTCFs in Brazil, there are few studies verifying the socio-demographic profile of residents. The study had to verify the socio-demographic profile of individuals who live in a long-term institution located in Araçuaí, Minas Gerais. This is an ex- 
ploratory and descriptive study, with a quantitative approach. Data collection was carried out from January to February 2020. The descriptive information of the resident's profile was collected using a semi-structured form. 35 individuals were evaluated, 21 men $(60 \%)$ and 14 women $(40 \%)$. The analysis of the data showed that the residents of the long-stay institution were, in the great majority, single (77.1\%), did not have children (54.3\%), illiterate $(82.9 \%)$ or with low education $(17.1 \%)$ and did not receive visits $(77.1 \%)$. The results found in this study about the profile of residents of a long-term institution are in accordance with the literature with regard to marital status, number of children and educational level. It is concluded, therefore, that single people, who do not have children, are illiterate or have low education, predominantly reside in this long-term institution. It is also noteworthy that these characteristics are often considered as risk factors for institutionalization.

KEYWORDS: Aging; Institutionalization; Homes for the Aged.

\section{INTRODUÇÃO}

O aumento da proporção de idosos é um fenômeno global, em que todos os países se encontram em algum estágio desse processo. Não sendo, um acontecimento repentino ou inesperado, mas pelo contrário, resulta das transformações demográficas ocorridas nas décadas pregressas. Assim como, não se trata de um fenômeno isolado, pois está profundamente associado a modificações demográficas, epidemiológicas e sociais que o Brasil vem sofrendo nas últimas décadas. Entretanto, é um fenômeno tão novo que só recentemente têm sido reconhecidas as demandas de uma sociedade envelhecida (CHAIMOWICZ, 2013).

De acordo com a Organização Mundial da Saúde (OMS), são consideradas idosas as pessoas com mais de 65 anos. Entretanto, essa definição é válida para a população de países desenvolvidos. Para os países em desenvolvimento, como o Brasil, a pessoa é considerada idosa a partir dos 60 anos (ZIMERMAN, 2007).

Diante das múltiplas modificações ocorridas com o envelhecer, considera-se que a definição de envelhecimento cronológico passa a ser de relevância muito menor que a do envelhecimento funcional, pois é quando as funções começam a ficar prejudicadas é que os problemas começam a surgir. Dessa forma, o conceito de envelhecimento está intimamente ligado à manutenção da autonomia (CARVALHO FILHO; PAPALÉU NETTO, 2000).

Segundo o Instituto Brasileiro de Geografia e Estatística (IBGE), no Brasil, desde a década de 1970, há uma diminuição das taxas de natalidade e de mortalidade. Podendo estar relacionado às mudanças culturais, como a inserção da mulher no mercado de trabalho e à melhora das condições higiênico-sanitárias (IBGE, 2009). Todavia, a mudança cultural também incluiu transformações na reestruturação da relação familiar, com a diminuição da responsabilidade pelos membros que dela fazem parte, principalmente com os idosos.

O processo de envelhecimento da população brasileira evidencia um problema de grande relevância, a ausência de políticas públicas e ações que visam à melhoria das condições de vida do novo 
perfil populacional. Além, da necessidade de reestruturação dos serviços especializados de maior complexidade e capacitação da equipe envolvida na assistência aos idosos (CHAIMOWICZ, 1997).

Com o aumento da população idosa, cresce a procura por Instituições de Longa Permanência para Idosos (ILPIs). Essa busca é elucidada em muitos casos, pelas dificuldades encontradas pelas famílias para o cuidado do idoso, sobretudo para aqueles que apresentam redução da capacidade funcional. Pois se tornam cada vez mais dependentes para realização de atividades cotidianas e requerem cuidados de maior complexidade e custo (PERLINI, LEITE, FURINI, 2007).

Mesmo com um grande número de ILPIs no Brasil, existem poucos estudos verificando o perfil sócio-demográfico dos residentes. Este fato dificulta a implementação de programas de assistência a esta população e, ainda, de capacitação e orientação dos profissionais envolvidos no seu cuidado. O presente capítulo tem por objetivo verificar o perfil sócio-demográfico dos indivíduos que residem em uma instituição de longa permanência localizada em Araçuaí, Minas Gerais. Para alcançar o objetivo proposto, os fatores sociodemográficos e econômicos foram obtidos através de questionário semiestruturado incluindo as variáveis: idade, sexo, escolaridade, situação conjugal, presença de filhos e recebimento de visitas.

Trata-se de um estudo transversal, descritivo, com abordagem quantitativa. A pesquisa foi realizada em uma instituição de longa permanência para idosos, localizada no Município de Araçuaí - MG.

A coleta de dados foi realizada no período de janeiro a fevereiro de 2020. Os participantes da pesquisa foram os residentes de uma instituição de longa permanecia que atenderam aos critérios de inclusão: idade igual ou superior a 18 anos, que aceitaram participar da pesquisa, que possuíam condições cognitivas para responder ao questionário ou a presença de um cuidador para tal.

Diante da necessidade de atender e garantir às exigências éticas e científicas fundamentais para a realização de estudos com seres humanos, o estudo foi encaminhado ao Comitê de Ética e Pesquisa (CEP) da Universidade Estadual de Montes Claros e aprovado sob o número do parecer: 3.812.628 e o consentimento dos participantes foi formalizado por meio da assinatura do Termo de Consentimento Livre e Esclarecido - TCLE.

Nessa abordagem, realizou-se a análise descritiva dos dados utilizando o programa estatístico Statistical Package for the Social Sciences (SPSS) versão 26.0, utilizando estatísticas descritivas básicas, como: frequência, média, mediana, desvio padrão e valor mínimo e máximo, com nível de significância estabelecido em $\alpha=0,05$.

\section{PERFIL DOS RESIDENTES DE UMA INSTITUIÇÃO DE LONGA PERMANÊNCIA}

A avaliação do perfil sócio-demográfico foi realizada com 35 indivíduos, sendo 21 homens (60\%) e 14 mulheres (40\%). Quanto à distribuição em faixas etárias, a maioria dos sujeitos tinha ida- 
de acima de 80 anos (41,7\%,), seguindo-se a faixa de 70 e 79 anos (37,5\%). A tabela 1 descreve os resultados encontrados em relação ao perfil sociodemográfico dos idosos.

Tabela 1. Perfil sócio-demográfico dos idosos institucionalizados. Araçuaí, 2020.

\begin{tabular}{lc}
\hline \multicolumn{1}{c}{ Variáveis } & $(\mathrm{n}) \%$ \\
\hline Sexo & \\
Feminino & $(14) 40 \%$ \\
Masculino & $(21) 60 \%$ \\
Estado civil & \\
Solteiros & $(27) 77,1 \%$ \\
Casados & $(2) 5,7 \%$ \\
Divorciados/Separados & $(1) 2,9 \%$ \\
Viúvos & $(5) 14,3 \%$ \\
Escolaridade & \\
Analfabeto & $(29) 82,9 \%$ \\
$\leq 4$ anos de estudo & $(6) 17,1 \%$ \\
$>4$ anos de estudo & $(0) 0,0 \%$ \\
Possui Filhos & \\
Sim & $(8) 22,9 \%$ \\
Não & $(27) 77,1 \%$ \\
Recebe visitas & \\
Sim & $(19) 54,3 \%$ \\
Não & $(16) 45,7 \%$ \\
\hline $\mathrm{n}=$ número de idosos; $\%=$ percentagem de idosos & \\
&
\end{tabular}

$\mathrm{n}=$ número de idosos; $\%=$ percentagem de idosos

A pesquisa identificou que $82,9 \%$ dos participantes eram analfabetos e $17,1 \%$ possuíam tempo inferior ou igual a quatro anos de estudo. A maioria dos residentes relatou ser solteira $(77,1 \% ; n=27)$ e não possuir filhos $(77,1 \%$; $=27)$. Um pouco mais da metade relatou receber visitas $(54,3 \%$; $n=19)$.

Ao considerar que, com o processo evolutivo de degeneração, o cuidado integral geralmente é destinado a terceiros, sendo esses muitas vezes os familiares, e esses frequentemente não conseguem manter a assistência adequada. Dessa forma, quando nenhum membro da família consegue manter um nível favorável de cuidado, a primeira alternativa tem sido a contratação de cuidadores profissionais e a outra é o encaminhamento para uma instituição, como asilos ou casas geriátricas (KARSCH, 2003).

$\mathrm{Na}$ instituição analisada residem 35 pessoas, com predominância do sexo masculino (60\%) entre os residentes, no entanto esse achado não é o frequentemente descrito na literatura, pois na maioria dos estudos analisados, o percentual de mulheres institucionalizadas é muito superior ao de 
homens (CARVALHO et al, 2011). Essa diferença nos estudos pode ser o reflexo da mudança da dinâmica familiar e da sociedade nos últimos anos, revelando mudanças no perfil dos institucionalizados.

Verificou-se que a maior parte dos residentes era solteira $(77,1 \%)$ semelhante ao estudo realizado em Passo Fundo-RS (GUEDES; SILVEIRA, 2004). Além disso, a maioria também não possuía filhos $(54,3 \%)$, resultado semelhante à pesquisa realizada em Belo Horizonte (MG) (ALENCAR et al., 2012). Destaca-se que esses fatores podem estar relacionados à institucionalização, devido à ausência de um familiar próximo para cuidar do idoso.

Em relação à escolaridade, identificou-se que a maioria dos idosos era analfabeta $(82,9 \%)$, seguida de baixa escolaridade (17,1\%). Tais achados se assemelham aos obtidos por Reis et al. (2020) em um estudo que realizaram com idosos institucioalizados, que identificou que $69 \%$ dos sujeitos eram analfabetos e $31 \%$ possuíam ensino fundamental incompleto.

De acordo com Alves-Silva et al. (2013), o baixo nível de escolaridade é amplamente verificado em pesquisas podendo ser justificado pela pouca valorização que os estudos tinham durante a infância desses idosos, não sendo prioridade, principalmente para as mulheres.

Verificou-se em estudo realizado em ILPI em Brasília- DF, que metade dos residentes recebia visitas de seus familiares (OLIVEIRA et al., 2013). Os achados desta pesquisa são corroborados por esse estudo, visto que $54,3 \%$ dos residentes recebiam visitas.

O grande número de idosos que recebem visitas demonstra que a família e/ou voluntários mantém relações de proximidade com o idoso, descaracterizando a questão do abandono do idoso na ILPI. Ressalta-se que as visitas são muito importantes, tendo em vista que contribui para que o mesmo apresente melhores condições de saúde, adaptação e participação nas atividades propostas (GUTHS et al., 2017)

\section{CONCLUSÃO}

Os resultados encontrados nesse estudo acerca do perfil dos residentes de instituição de longa permanência estão de acordo com a literatura no que se refere ao estado civil, número de filhos e nível educacional. Ao analisar os resultados desse estudo, conclui-se que residem predominantemente nessa instituição indivíduos do sexo masculino, solteiros, que não possuem filhos, analfabetos ou de baixa escolaridade. Ressalta-se, ainda, que essas características encontradas, muitas vezes, são consideradas como fatores de risco para institucionalização. 


\section{REFERENCIAS}

ALENCAR, M. A.; BRUCK, N. N. S.; PEREIRA, B. C., CÂMARA, T. M. M.; ALMEIDA, R S. Perfil dos idosos residentes em uma instituição de longa permanência. Revista Brasileira de Geriatria e Gerontologia. 2012;15(4):785-96.

ALVES-SILVA, Júnia Denise; SCORSOLINI-COMIN, Fabio; SANTOS, Manoel Antônio dos. Idosos em instituições de longa permanência: desenvolvimento, condições de vida e saúde. Psicol. Reflex. Crit., Porto Alegre, v. 26, n. 4, p. 820-830, Dec. 2013. Disponível em: https://doi.org/10.1590/S0102-79722013000400023.

CARVALHO FILHO ET, PAPALEO NETTO M. Geriatria: fundamentos, clínica e terapêutica. São Paulo: Atheneu, 2000.

CARVALHO, M. P.; LUCKOW, E. L. T; SIQUEIRA, F.V. Quedas e Fatores Associados em Idosos Institucionalizados no Município de Pelotas (RS, Brasil). Ciência e Saúde Coletiva. 2011; 16 (6): 2945-2952.

CHAIMOWICZ, F. Saúde do idoso. 2 ed. Belo Horizonte: NESCON UFMG:2013

CHAIMOWICZ, F. A saúde dos idosos brasileiros às vésperas do século XXI: problemas, projeções e alternativas. Rev Saúde Pública 1997;31(2):184-200.

GUEDES JM, SILVEIRA RC. Análise da capacidade funcional da população geriátrica institucionalizada na cidade de Passo Fundo-RS. Rev Bras Ciênc Envelhec Hum. 2004; 1:10-21.

GUTHS, Jucélia Fátima da Silva et al . Perfil sociodemográfico, aspectos familiares, percepção de saúde, capacidade funcional e depressão em idosos institucionalizados no Litoral Norte do Rio Grande do Sul, Brasil. Rev. bras. geriatr. gerontol., Rio de Janeiro, v. 20, n. 2, p. 175-185, Apr. 2017. Available from <http:// www.scielo.br/scielo.php?script=sci_arttext\&pid=S1809-98232017000200175\&lng=en\&nrm=iso $>$.

IBGE. Instituto Brasileiro de Geografia e Estatística [Internet]. Diretoria de Pesquisas. Coordenação de População e Indicadores Sociais. Rio de Janeiro; 2009.Disponível em: http://www.ibge.gov.br/home/estatistica/ população/indic_sociosaude/2009/indicsaude.pdf. Acesso: $23 \mathrm{fev} 2019$.

KARSCH, U.M. Idosos dependentes: famílias e cuidadores. Cad. Saúde Pública. Rio de Janeiro, 19(3):861-6, 2003.

OLIVEIRA, L. P. B. A. D.; MENEZES, R. M. P. D. Representações de fragilidade para idosos no contexto da estratégia saúde da família. Texto \& Contexto Enfermagem, Florianópolis, v. 20, n. 2, p. 301-309, 2011.

PERLINI, N. M. O. G., LEITE, M.T., FURINI, A.C. Em busca de uma instituição para a pessoa idosa morar: motivos apontados por familiares. Rev Esc Enferm USP 2007;41(2):229-36.

REIS, D.L. A. IGREJA, P.N., MOIA, M. Y. S. REIS, C. A. S. BORGES, R. C. S.; MEDEIROS, T.S.P.; KIETZER, K.S.; CALDATO, M. C. F. Avaliação multidimensional rápida aplicada em idosos de uma instituição de longa permanência em Tucuruí- PA. Braz. J. of Develop., Curitiba, v. 6, n. 3, p. 12018-12034, mar. 2020.

ZIMERMAN, G.I. Velhice. Aspectos biopsicossociais. Porto Alegre: Artes Médicas Sul; 2007. 


\section{RESÍDUOS DE PÓLVORA COMO DETERMINANTES DE DISTÂNCIA DO TIRO EM PERICIA DA MEDICINA LEGAL}

CRISTIANO HAYOSHI CHOJI UNOESTE / ACADEPOL / INSTITUTO MEDICO LEGAL SP

FERNANDO ANTÔNIO MOURÃO VALEJO UNOESTE / CREMESP / INSTITUTO MEDICO LEGAL SP

RODRIGO SALA FERRO UNOESTE / INSTITUTO MEDICO LEGAL SP JOSÉ OTAVIO DE FELICE JUNIOR ACADEPOL / INSTITUTO MEDICO LEGAL SP

LUÍS ANTÔNIO GILBERTI PANUCCI UNOESTE / INSTITUTO MEDICO LEGAL SP

RAPHAEL ADILSON BERNARDES INSTITUTO MEDICO LEGAL SP

TELMA DE CARVALHO PENAZZI INSTITUTO DE CRIMINALISTICA SP

\section{MAYÉLI PEREIRA DOMINGOS} UNOESTE

RESUMO: Descrever a importância da análise de resíduos proveniente da pólvora nas perícias médico-legais de partículas secundárias encontradas como determinantes da distância do tiro de arma de fogo, de acordo com a variação da distância da boca da arma em relação ao objeto analisado. Foram realizados testes com produção de residuogramas para descrição visual e física desses achados secundários constituídos por micro resíduos metálicos provenientes do projetil e partículas de pólvora parcialmente combusta.

PALAVRA-CHAVE: Arma de fogo, distância do tiro, resíduos do tiro, resíduos de pólvora.

ABSTRACT: Describe the importance of the analysis of residues from gunpowder in the medical-legal examinations of secondary particles found as determinants of the firing range of the firearm, according to the variation in the distance from the gun mouth in relation to the object analyzed. Tests were carried out with the production of residuograms for visual and physical description of these secondary findings, consisting of micro metallic residues from the projectile and partially combustion powder particles.

KEYWORDS: Firearm, firing distance, gunshot residues, gunpowder residues.

\section{INTRODUÇÃO}

Adequada descrição dos achados da pólvora provenientes do tiro de arma de fogo para a confecção de laudos médico legais, apresenta importância cientifica e legal, contribuindo de maneira importante a investigação criminal, bem como esclarecimento das características do ocor- 
rido após o tiro de arma de fogo, a fim de demonstrar achados médico legais para a determinação da distância que ocorreu o tiro.

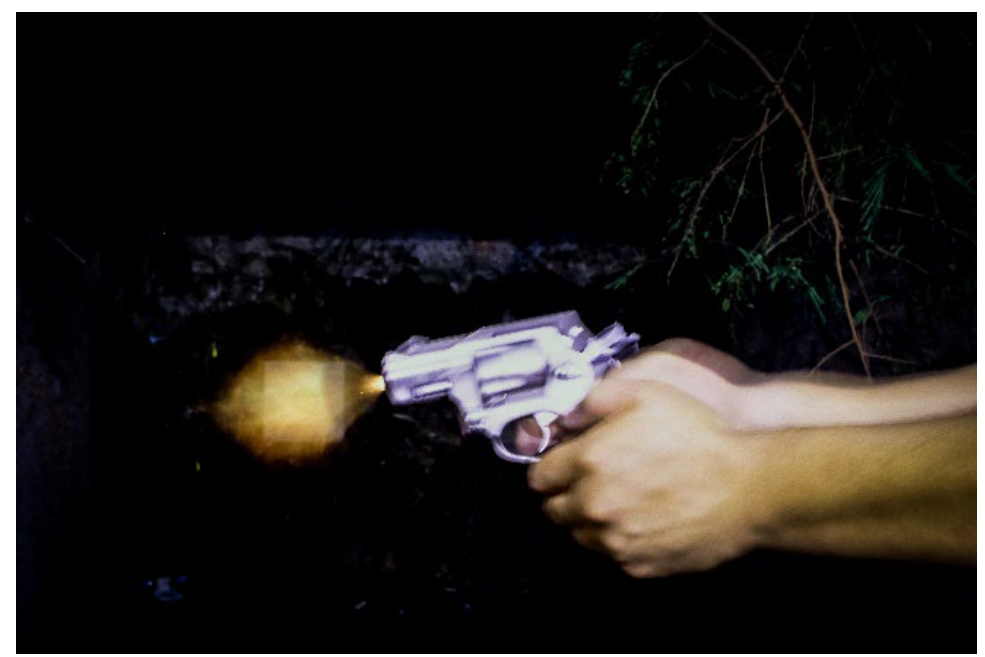

Figura 1 A queima total e parcial da pólvora proveniente do tiro, causa efeitos físicos que geram diversos achados nos residuogramas resultantes do tiro sobre papel branco.

Ocorrem diferentes posicionamentos para a classificação quanto ao aspecto de distância do tiro, em relação aos achados dos resíduos em relação a boca da arma de fogo, adotamos nesse presente trabalho a classificação de Tiro encostados, a curta distância e a finalmente tiro a distância (Tochetto, 2020).

O presenta trabalho se refere a descrição de achados provenientes da pólvora (e não ao projetil de arma de fogo). Durante testes de campo utilizando diversos tipos de armamento, com distancias variadas de tiro por sobre papel branco, foi notada a evolução de diversos aspectos dos residuogramas gerados (Choji, 2019).

Ocorre classicamente a descrição das zonas de esfumaçamento e também de tatuagem (verdadeira), sendo essas a motivação do trabalho, pois podem determinar de maneira aproximada a distância do evento relacionado ao tiro de arma de fogo no que se refere a distância do qual ocorreu o tiro em relação a arma e o alvo. A área de esfumaçamento sendo não aderida a pele, ou outro tecido, bem como proveniente de deposito superficial sem penetração de fuligem e fumaça proveniente da combustão da pólvora ou propelente.

A área de tatuagem se refere ao deposito forçado de partículas de pólvora incombusta ou parcialmente combusta, bem como partículas metílicas secundárias ao projetil que penetram no tecido, não sendo laváveis com água corrente como a área de esfumaçamento ou tatuagem falsa (França, 2012; Montanaro 1995; Galvão, 2008 ; Tochetto, 2020).

A presente analise se refere a evolução de achados decorrentes a partículas de pólvora nos residuogramas, que se mostra uma constante nos tiros a curta distância, sobremaneira causando surpresa pelo seu achado constante e proporcional desde o momento que o tiro deixa de ser encostado até se tornar a distância (também chamada de tiro a longa distância). 
Achados relativos a tamanho e densidade dos mesmos são importantes para a descrição correta da dinâmica que ocorreu anteriormente ao tiro, sendo determinantes aproximados de distância bem como ângulo do tiro (Haag, 2005).

Importante conceituar que cada evento analisado é único, devido a possibilidade de infinitas variáveis da situação no qual ocorreu o tiro. Sendo que a reconstituição especifica do caso seria a maneira de se aproximar da analise correto do evento. Porém o conhecimento de achados próximos se mostra muito importante, pois propicia a fundamentação técnica adequada para se estimar se os achados são ou não compatíveis com a dinâmica proposta.

Pólvoras modernas, são propelentes químicos complexos não mais constituídos apenas de mistura de minerais como incialmente se manufaturava a dita pólvora preta. Atualmente são constituídas de diversos componentes como Nitrocelulose e Nitroglicerina (Ditas de Base Simples ou Base Dupla, respectivamente). Esse trabalho se detém sobre a análise de residuogramas gerados por tiros que utilizaram munições carregados por pólvora de base simples ou de nitrocelulose, isso sendo evidenciado claramente pela declaração do fabricante na identificação de seus produtos bélicos (Tochetto, 2020).

\section{MATERIAL E MÉTODOS}

Foram produzidos 95 residuogramas resultantes de 95 disparos de arma de fogo nos distancia de 1 a $95 \mathrm{~cm}$ perpendiculares a direção de alvos de folha de papel cartolina branco quadrados nas dimensões $30 \mathrm{~cm}$ x $30 \mathrm{~cm}$ onde o mesmo sobre anteparo de madeira processada do tipo placa de fibra de média densidade.

Forma utilizados armamentos e munições nacionais, comumente envolvidos em pratica esportiva, bem como situações de defesa e uso policial devido sua maior credibilidade e fidelidade para realidade criminal, desta forma optado por a utilização de uma arma de fogo do tipo pistola da marca Taurus, modelo PT 100 AF-D. Utilizado munição para arma de fogo, sendo um de grande penetração, ogival/ponta plana modelo 40 S\&W ETPP 180 GR, da marca CBC. Descartado a hipótese de uso de armamentos e munições não convencionais, e não facilmente identificados como de interesse pericial para a medicina legal, pois poderiam interferir na conclusão e analise deste estudo.

Realizado os disparos em ambiente controlado de stand de um clube tiro situado em uma cidade do interior do Estado de São Paulo. Stand de tiro em tamanho oficial e espaço utilizado apenas por pessoas com certificado de registro autorizado pelo exército brasileiro, respeitando todas as normas de segurança, bem como aspectos legais relacionados a produtos controlados.

Disparos realizados por atiradores devidamente cadastros que possuem porte de arma de fogo perante a polícia federal deste pais.

Realizado 95 disparos feitos na distância da boca do cano da pistola e o alvo de papel, sendo o marco zero à $1 \mathrm{~cm}$ e o ultimo disparo à $95 \mathrm{~cm}$. Cada tiro realizado foi acrescentado $1 \mathrm{~cm}$ de distân- 
cia até a distância total de $95 \mathrm{~cm}$ e resultando 95 residuogramas. Subsequentemente aos tiros foram realizados o registro do efeito do disparo da pistola perante a folha de papel de cartolina através de imagem fotográfica e radiografia para posterior analise.

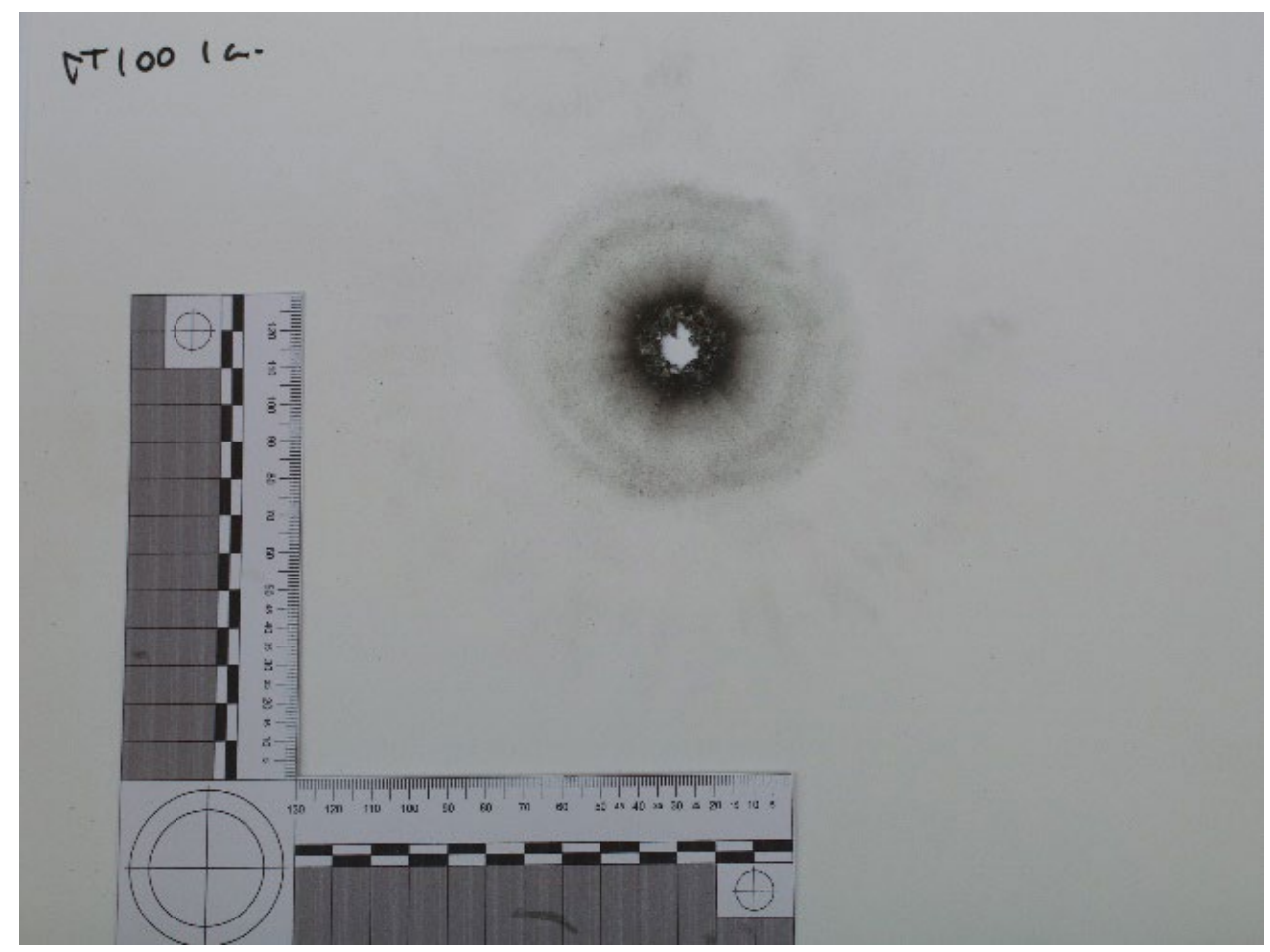

Figura 2 Residuogramas inicial com tiro a $1 \mathrm{~cm}$ de distância.

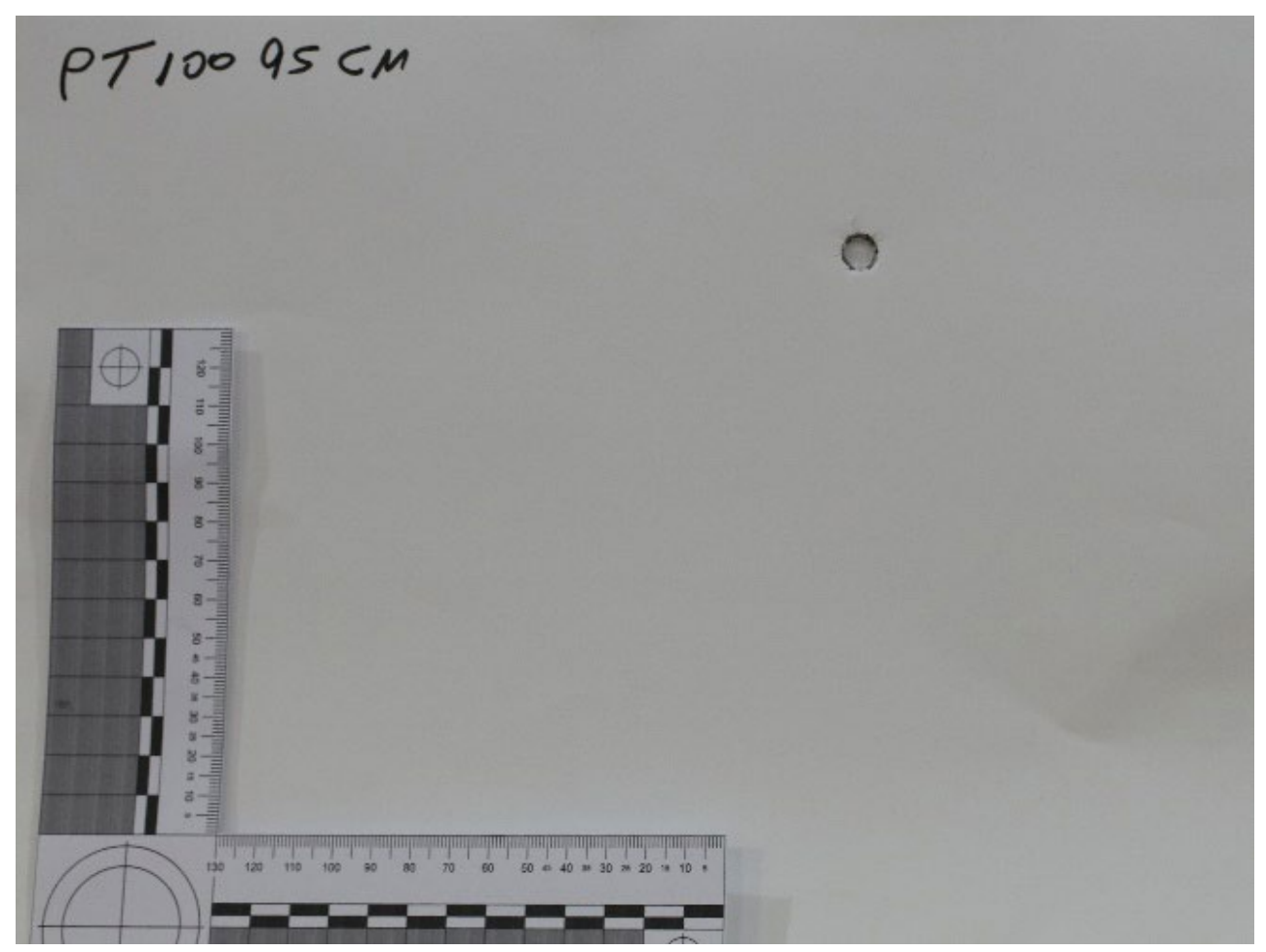

Figura 3 Residuogramas final, com tiro a $95 \mathrm{~cm}$ de distância da boca do cano. Onde não mais foram encontrados elementos secundários do tiro. Sendo assim classificado como tiro a distância. 


\section{RESULTADOS E DISCUSSÃO}

São encontrados na produção e análise dos residuogramas, todos os aspectos previamente descritos na literatura pericial e de medicina legal, com exceção dos correspondentes a reações vitais, uma vez que os disparos foram realizados em folhas de papel branco em anteparo de madeira para a geração de residuogramas.

Se mostrou uma constante desde o momento que não mais o cano da arma está encostado no alvo, até o momento que o tiro se mostra a distância (também chamado de longa distância) a presença de partículas de pólvora, da mais variada característica de combustão. Esse achado se contrapõe em muito à descrição clássica de achados relacionados a tatuagem verdadeira no que se supunha ser de partículas de metal secundárias ao projetil metálico junto com a pólvora.

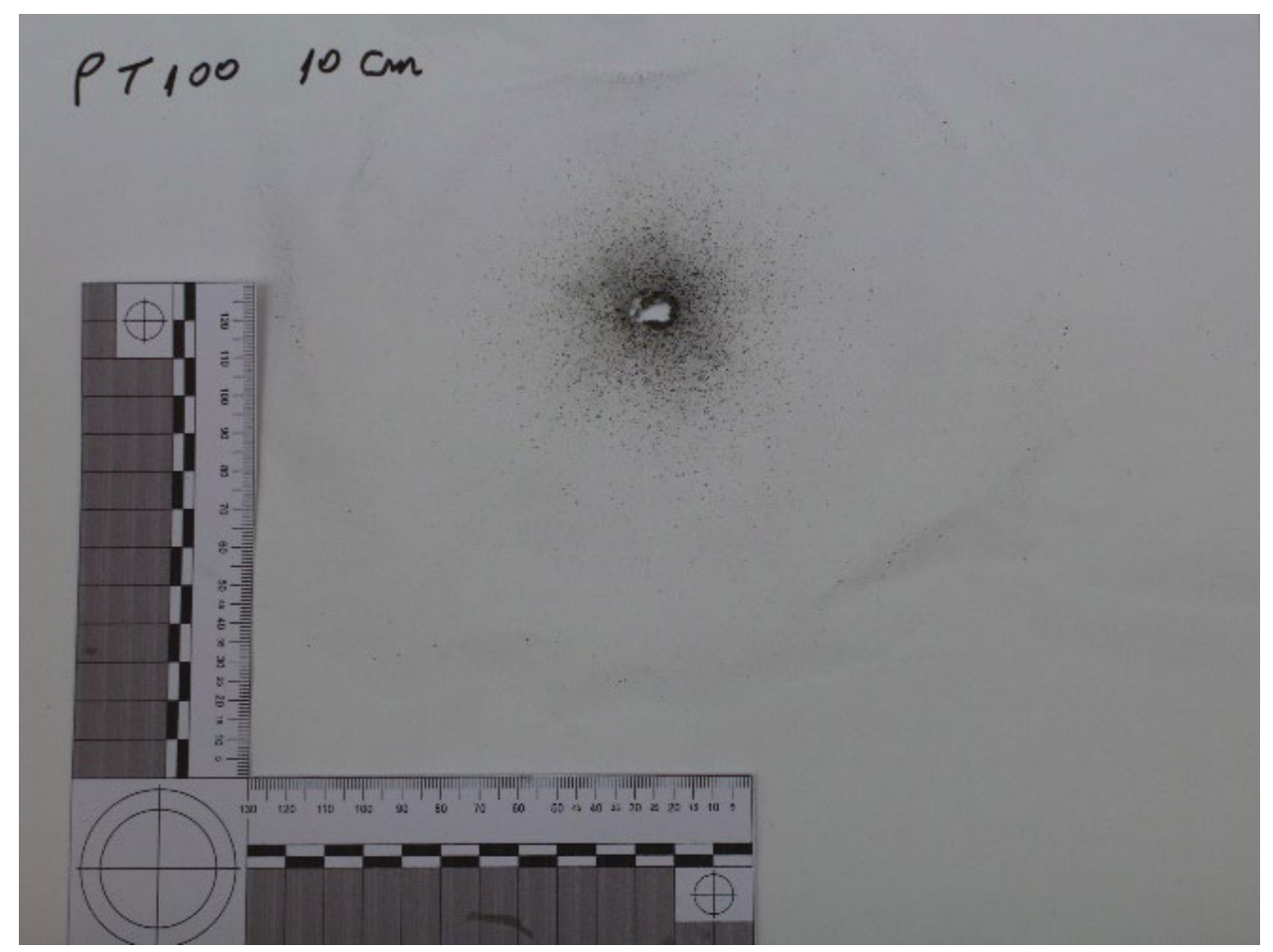

Figura 4. Residuogramas demonstrando o achado de todos os elementos secundários ao tiro a curta distância, excetuados os referentes a reação vital por se tratar de folha de papel branco.

Em momentos iniciais, a distâncias muito curtas, onde ocorre ainda o efeito térmico do tiro, as partículas de pólvora participam da formação da tatuagem verdadeira, devido a penetração superficial em tecido.

Conforme ocorre o aumento do distanciamento do cano e do alvo, começa a ser demonstrado achados das zonas de esfumaçamento, sendo que também participam da mesma, partículas de pólvora parcialmente incombusta, que não penetram no tecido, apenas se depositando sobre o mesmo. Novamente esse achado em muito se contrapondo ao achado de partículas de metal secundário. 


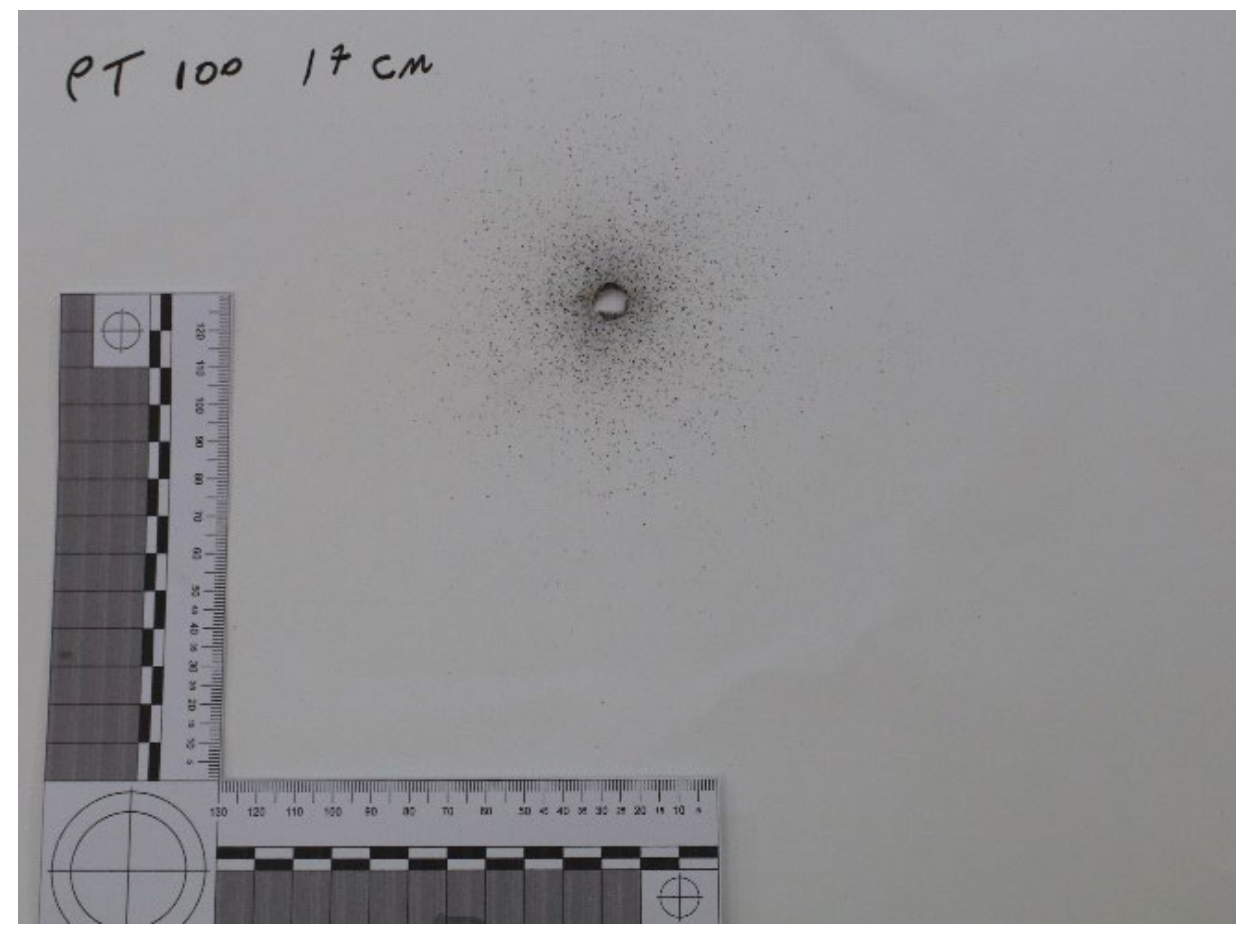

Figura 5. Residuogramas demonstrando o achado de elementos secundários ao tiro a curta distância, excetuados os referentes a reação vital por se tratar de folha de papel branco. Zona de falsa tatuagem.

Conforme a distância vai sendo aumentada, ocorre mudança do padrão do residuogramas gerado pelo tiro. Sendo dominante os achados relacionados a pólvora.

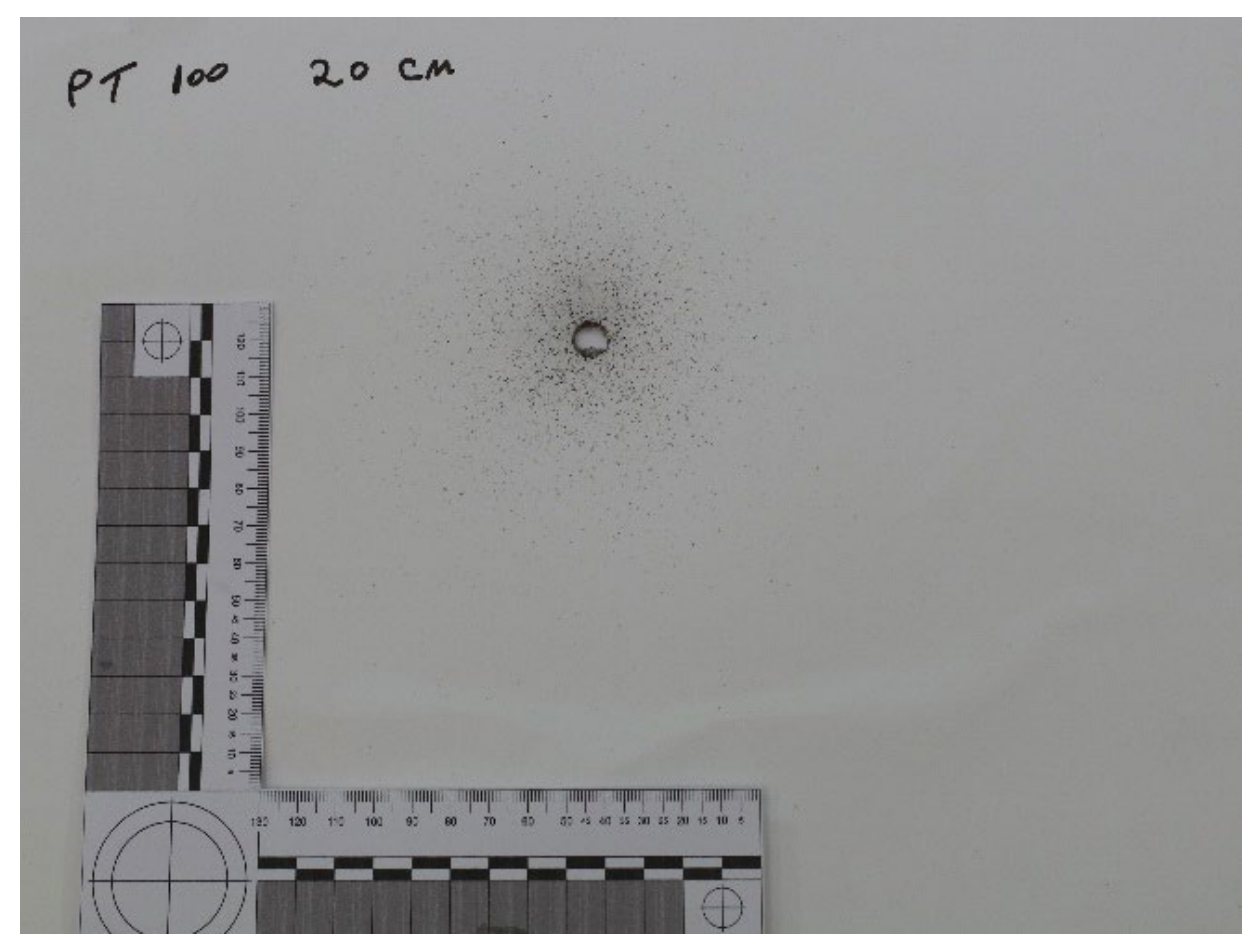

Figura 6. Residuogramas gerado a $20 \mathrm{~cm}$ da boca do cano da arma. 


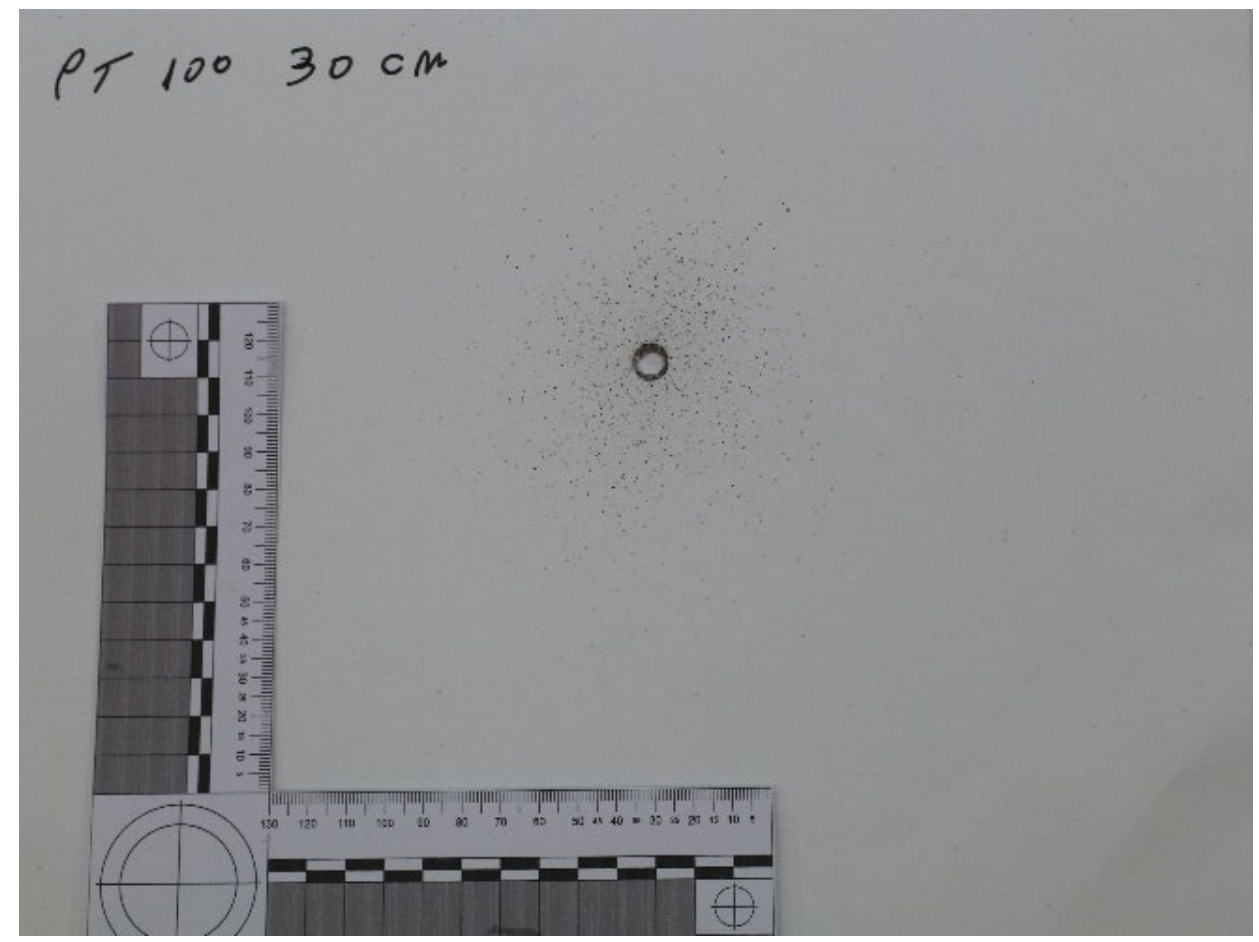

Figura 7. Residuogramas gerado a $30 \mathrm{~cm}$ da boca do cano da arma.

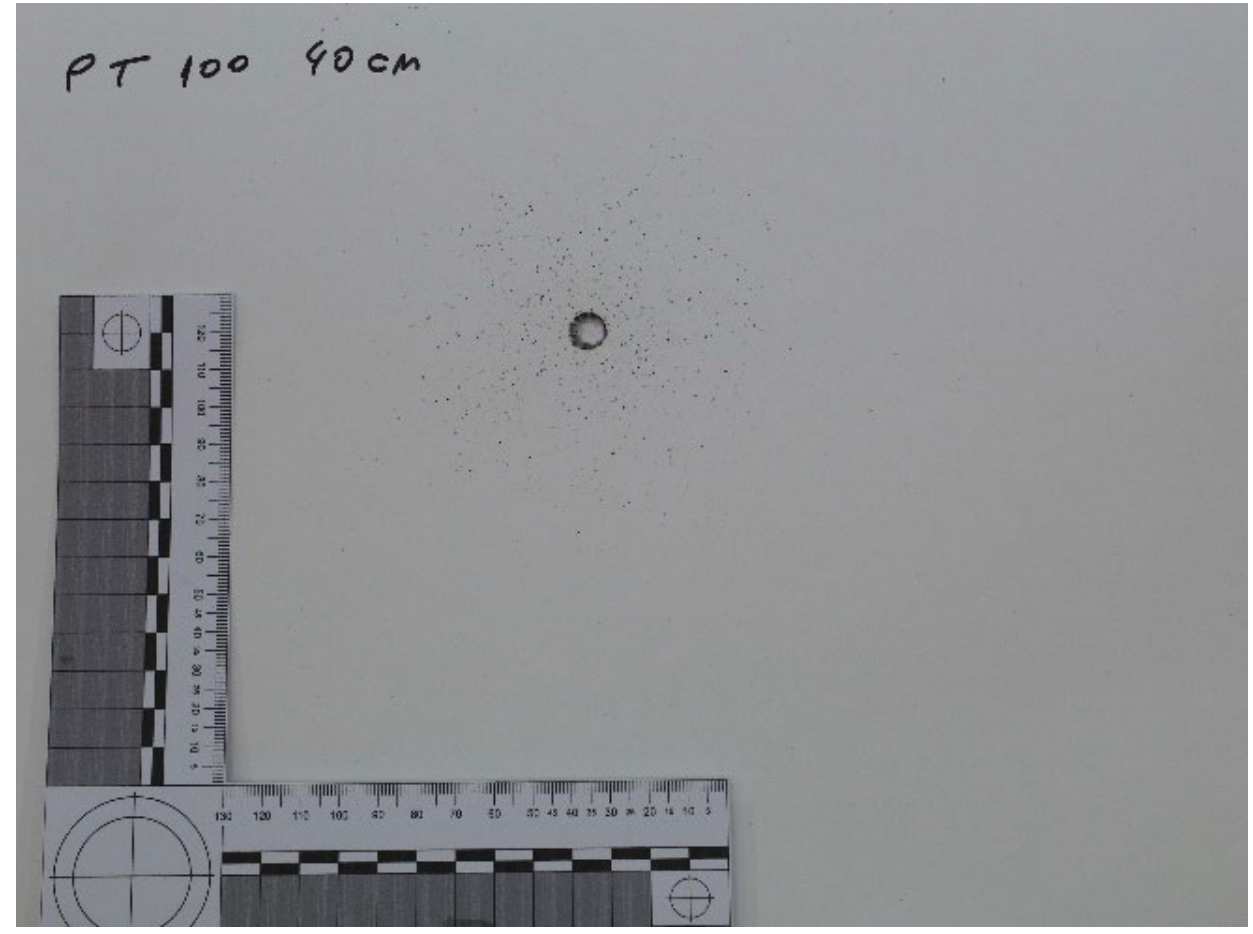

Figura 8. Residuogramas gerado a $40 \mathrm{~cm}$ da boca do cano da arma. Notar a progressiva redução de achados secundários referente a queima de pólvora. 


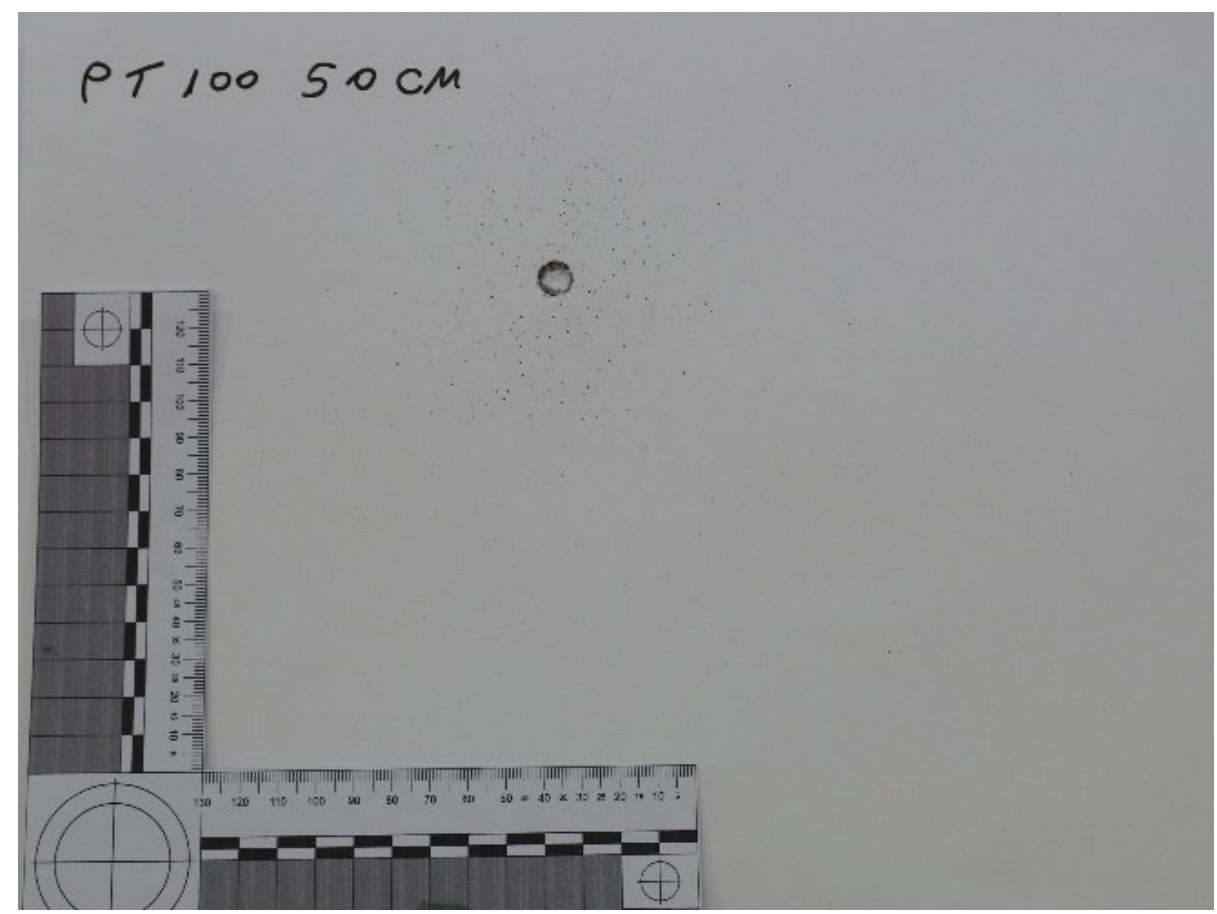

Figura 9. Residuogramas gerado a $50 \mathrm{~cm}$ da boca do cano da arma. Notar a progressiva redução de achados secundários referente a queima de pólvora, mas ainda mantendo padrão regular de dispersão dos achados.

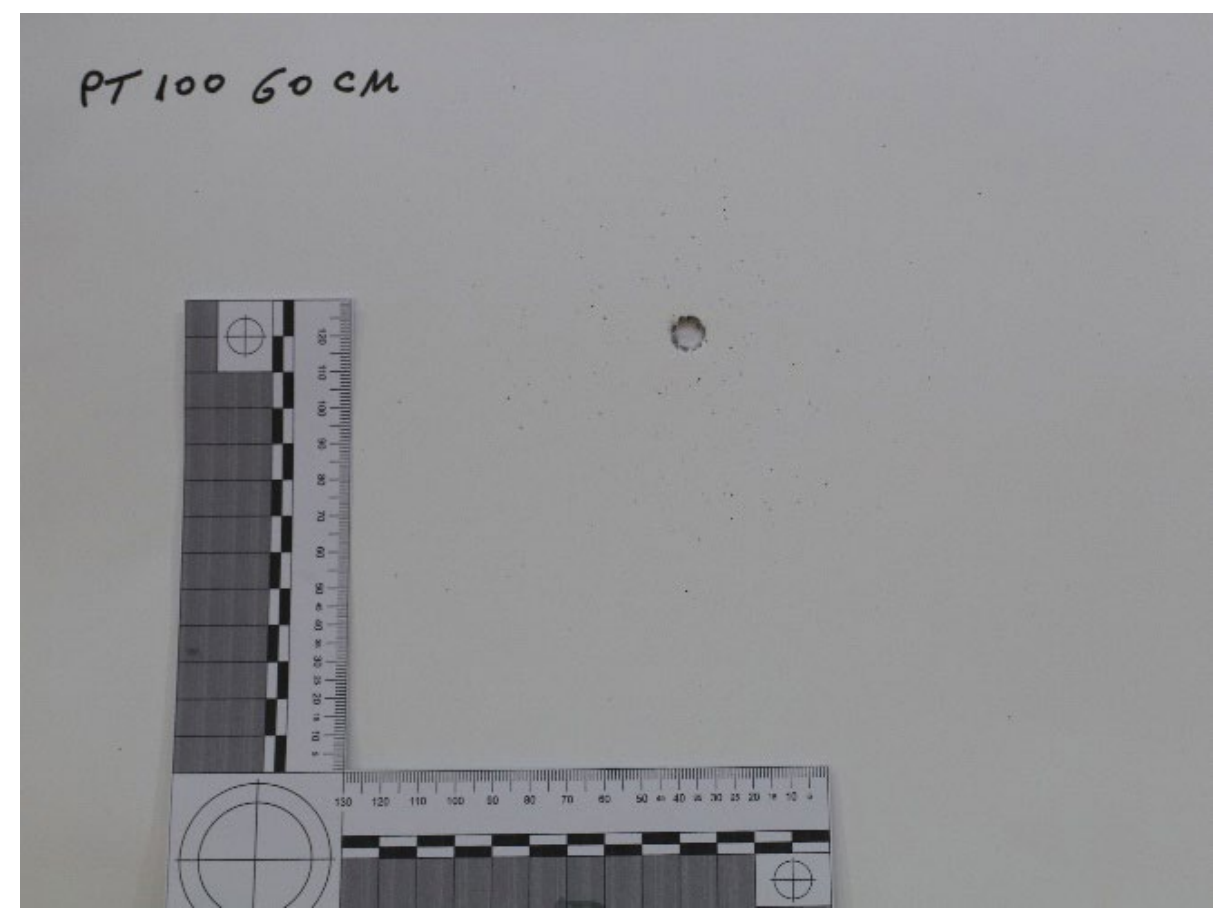

Figura 10. Residuogramas gerado a $60 \mathrm{~cm}$ da boca do cano da arma. Notar a progressiva redução de achados secundários referente a queima de pólvora, mas ainda mantendo padrão regular de dispersão dos achados. 


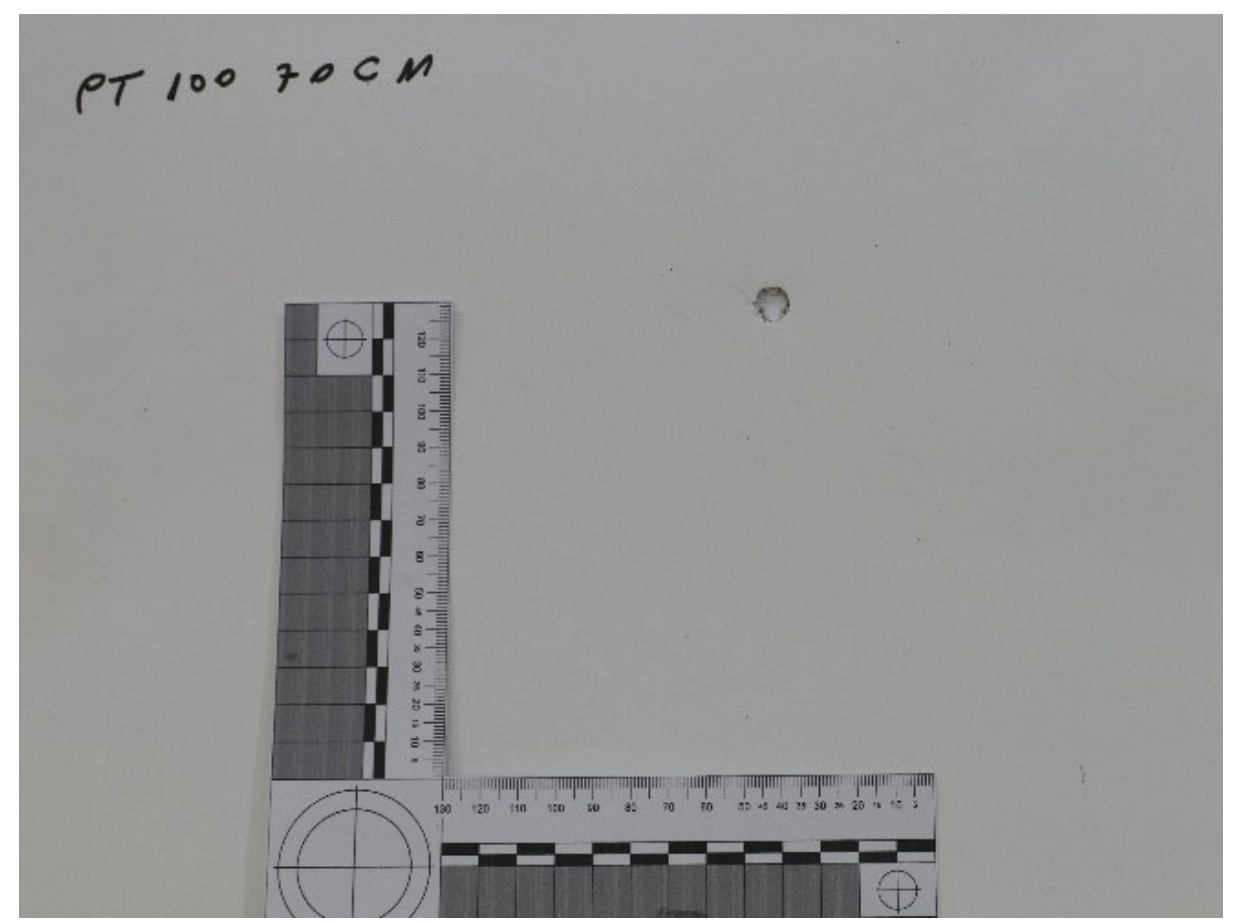

Figura 11. Residuogramas gerado a $70 \mathrm{~cm}$ da boca do cano da arma. Notar a progressiva redução de achados secundários bem como agora a distribuição dos achados secundários se torna errática. Notar que o alinhamento do armamento foi realizado com nível de bolha e estativa para se manter perpendicular ao alvo.

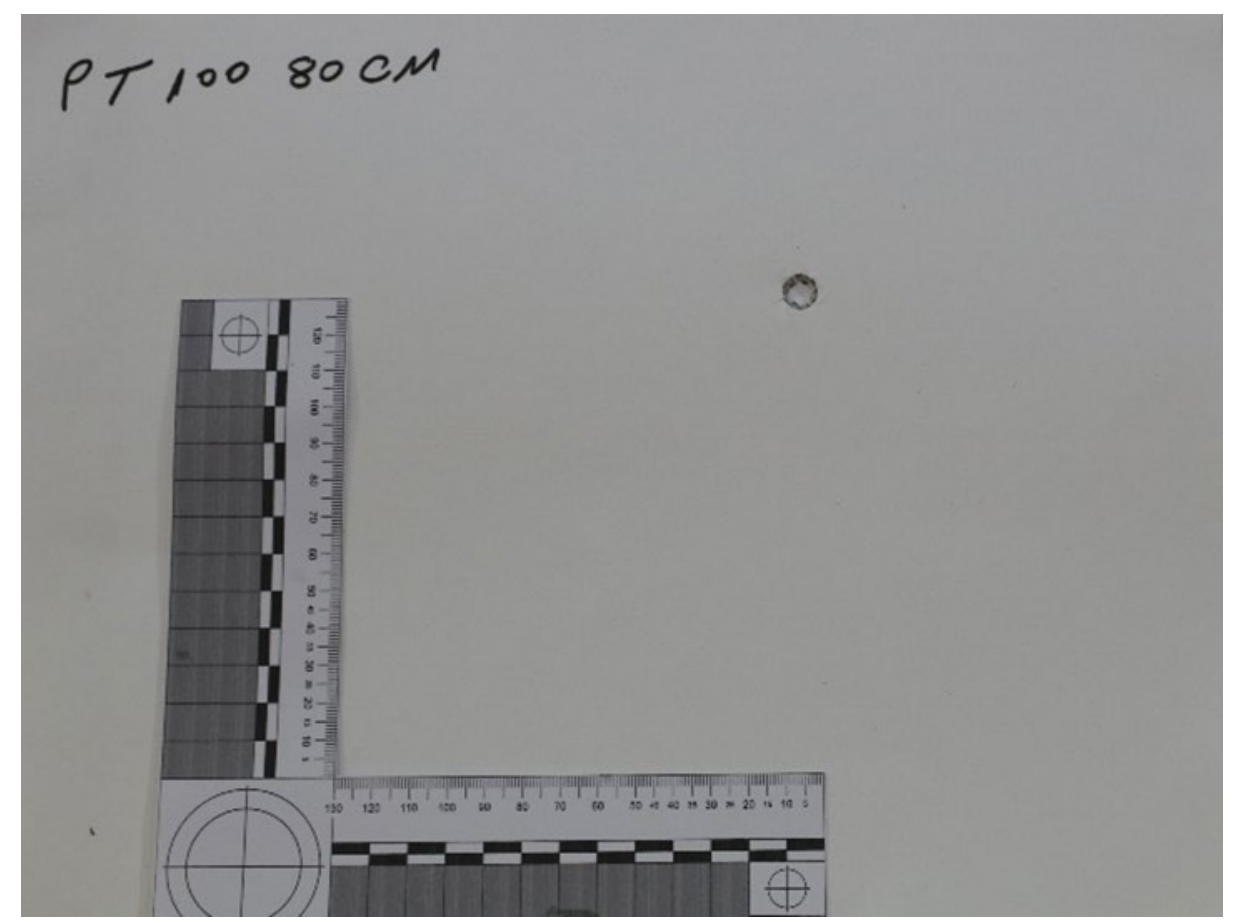

Figura 12. Residuogramas gerado a $80 \mathrm{~cm}$ da boca do cano da arma. Notar a progressiva redução de achados secundários bem como agora a distribuição dos achados secundários se torna errática e difusa sem seguir o padrão circular anterior.

Finalmente, a ausência dessas partículas de pólvora, elementos secundários do tiro, que por fim determinam a modificação da classificação de tiro a curta distância para tiro à distância. Ocorrendo seguidamente o mesmo como único elemento secundário presente que determina ainda a classificação como tiro a curta distância. 


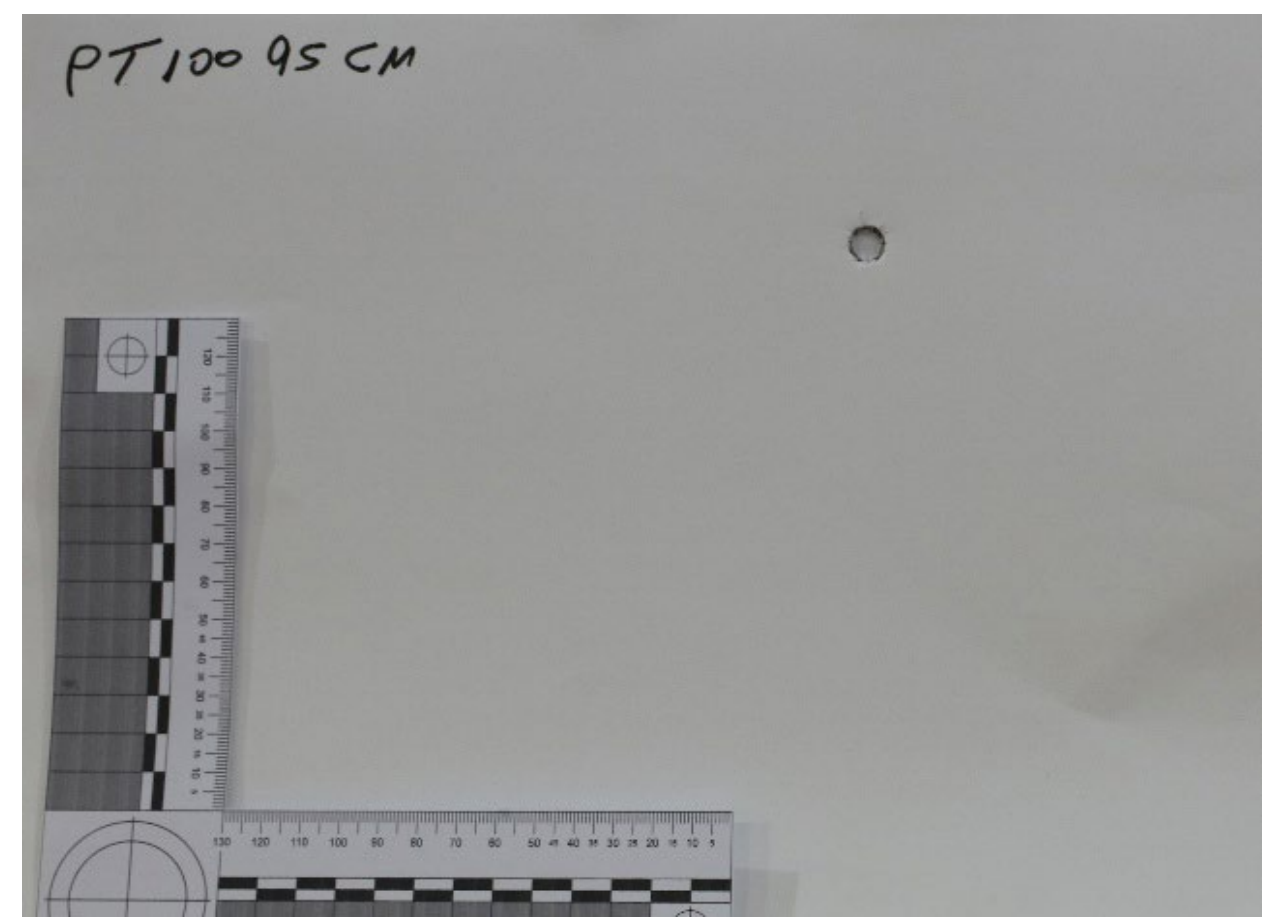

Figura 13. Residuogramas demonstrando o achado do tiro a distância. Onde não ocorrem achados de elementos secundários do tiro.

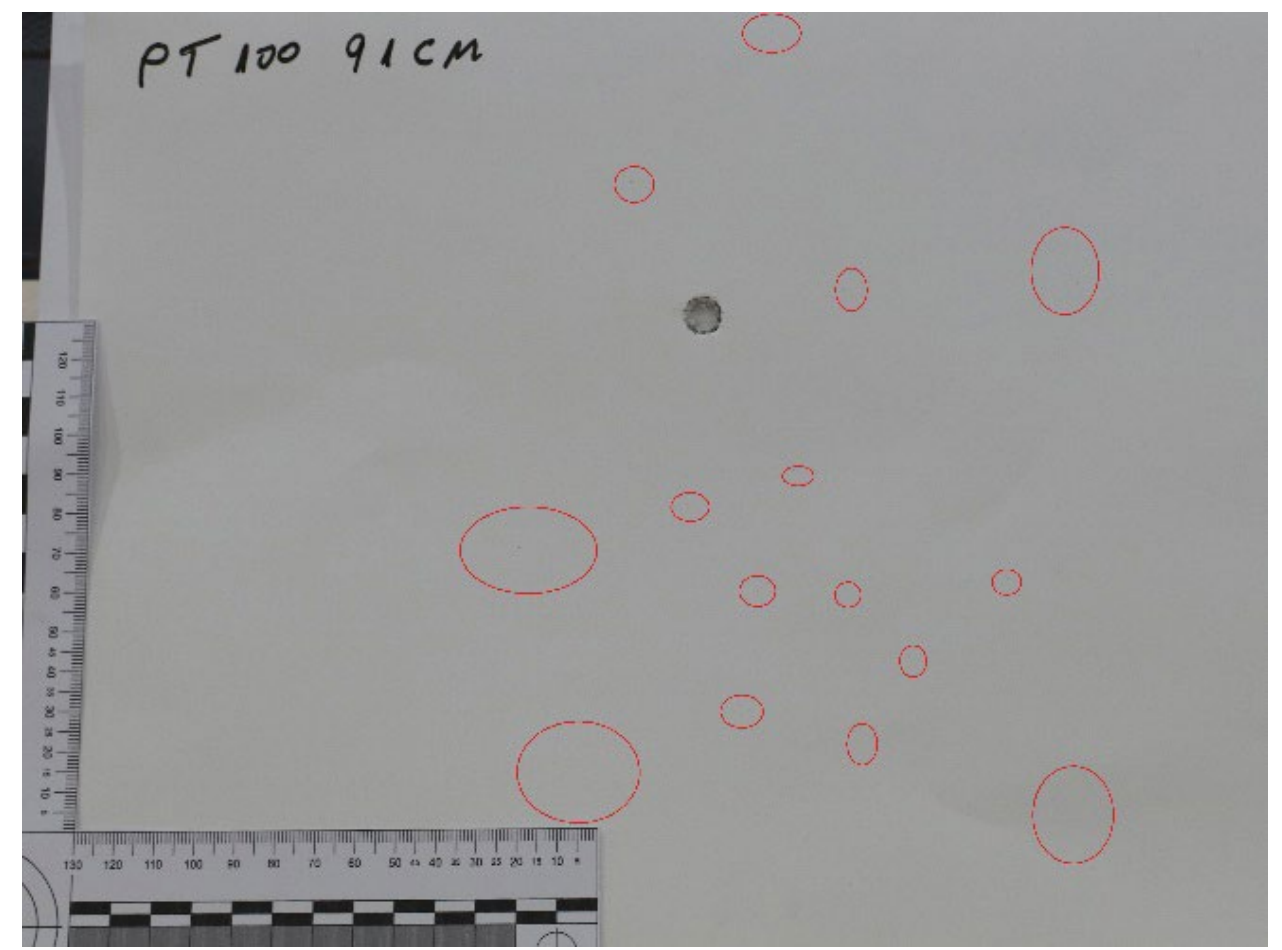

Figura 14. Residuogramas demonstrando o achado do tiro a curta distância. Podendo ainda ser assim classificado pelo achado de elementos secundários do tiro. Sendo essas partículas provenientes apenas de pólvora.

Por essa descrição de partícula secundária do tiro e proveniente da pólvora de base simples, analisando tiros provenientes de armas curtas (pistolas e revolveres de uso comum) ser constante e indicativa de elemento pericial para análise da distância do tiro de arma fogo, propomos a descrição da mesma como partícula de Bertoz - Choji, caso ainda não previamente descrita com essa função pericial para a Medicina Legal. 
Durante as análises agora no âmbito da criminalística dos residuogramas gerados, foi constatado fisicamente através do uso de radiografias, de que as partículas analisadas nos residuogramas não são decorrentes de fragmentos metálicos. Os micro_fragmentos metálicos também participam da formação da área de tatuagem verdadeira, mas de maneira menor e menos densa do que as partículas secundárias decorrentes da pólvora descrita na metodologia e resultados do trabalho (Bianco, 2019).

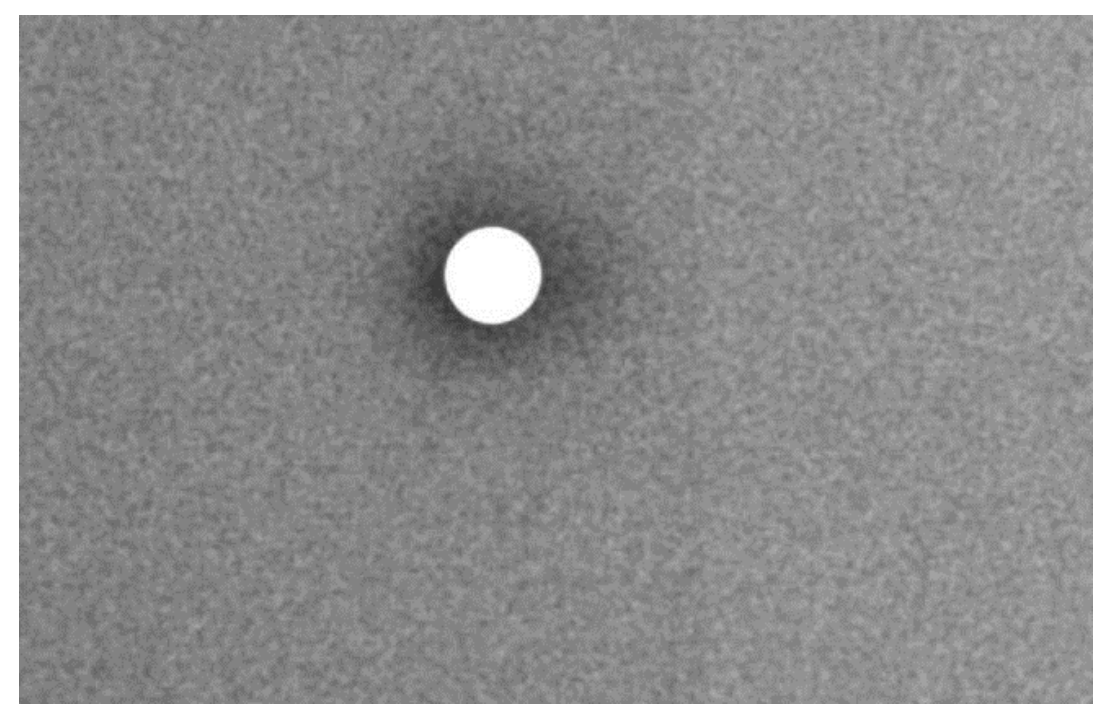

Figura 1. Radiografia do Residuogramas gerado demonstrando apenas duas partículas metálicas secundária.

\section{CONCLUSÃO}

A conclusão do trabalho se alinha com as descrições da literatura nacional e internacional sobre o tema. Tanto sob o aspecto de Medicina Legal quanto de Criminalística. Demonstrando a importância da adequada análise de resíduos de pólvora como elementos secundários do tiro apresentam para as determinações periciais a respeito da dinâmica que ocorre o fato estudado.

Se demonstra de maneira prática, que cada situação se mostra única, pois infinitas são as variáveis possíveis para cada tiro, bem como para cada alvo atingido. Porém, a criação de tabelas comparativas como essa proposta, pela análise do residuogramas gerado por tiros em ambientes parcialmente controlados, apresenta grande interesse e valor no sentido de dar rumo e parâmetro inicial para uma avaliação real.

Demonstrado principalmente que para a análise de tiros por armas curtas, que utilizam como propelente a pólvora de base simples. Os resíduos da mesma, após o tiro, é o mais importante achado de análise pericial dos elementos periciais da curta distância sendo também o determinante principal do encerramento de elementos secundários que já classifica o tiro a distância (ou longa distância). 


\section{AGRADECIMENTOS}

Unoeste - Universidade do Oeste Paulista, Delegacia Seccional de Presidente Prudente, Grupo de Operações Especiais - GOE Dracena SP, SPTC - Superintendência da Policia Técnico Cientifica do Estado de São Paulo, IML - Instituto Médico Legal do Estado de São Paulo, IC - Instituto de Criminalística SP , Taurus Armas, CBC - Companhia Brasileira de Cartuchos e Vida Radiologia Osvaldo Cruz - SP.

\section{REFERENCIAS}

BIANCO, F. V. D.; CHOJI, C. H.; BERTOZ, S. P. M.; PENAZZI, T. C.; ALVARENGA, T. S.; RANTIN, V. P. D.; MARANGONI, I. P.; BERNARDES, A. P.; TOMÉ, F.; NOBRE, I. P.; SOUSA, N. R.; VINHA, T. M. B. Analise das características do disparo de arma de fogo com RX convencional. In: ENCONTRO NACIONAL DE ENSINO, PESQUISA E EXTENSÃO - ENEPE. 2019, Presidente Prudente. Anais [...]. Presidente Prudente, SP: Unoeste, 2019. p. 1326. Disponível em: http://www.unoeste.br/Areas/Eventos/Content/documentos/EventosAnais/397/anais/Sa\%c3\%bade/Medicina.pdf. Acesso em: 14 fev. 2020.

BIANCO, F. V. D.; CHOJI, C. H.; BERTOZ, S. P. M.; PENAZZI, T. C.; ALVARENGA, T. S.; RANTIN, V. P. D.; MARANGONI, I. P.; BERNARDES, A. P.; TOMÉ, F.; NOBRE, I.P.; SOUSA, N. R.; VINHA, T. M. B.; CORREIA, G. C. M. Confirmação radiológica de características físicas de partículas do disparo de arma de fogo a média distância. In: ENCONTRO NACIONAL DE ENSINO, PESQUISA E EXTENSÃO - ENEPE. 2019, Presidente Prudente. Anais [...]. Presidente Prudente, SP: Unoeste, 2019. p. 1356. Disponível em: http://www. unoeste.br/Areas/Eventos/Content/documentos/EventosAnais/397/anais/Sa\%c3\%bade/Medicina.pdf. Acesso em: 14 fev. 2020.

CHOJI, C. H.; BERTOZ, S. P. M.; BIANCO, F. V. D.; PENAZZI, T. C.; ALVARENGA, T. S.; RANTIN, V. P. D.; MARANGONI, I. P.; BERNARDES, A. P.; TOMÉ, F.; NOBRE, I.P.; SOUSA, N. R.; VINHA, T. M. B.; CORREIA, G. C. M. Comparando achados de distância de disparo de arma de fogo para a medicina legal. In: ENCONTRO NACIONAL DE ENSINO, PESQUISA E EXTENSÃO - ENEPE. 2019, Presidente Prudente. Anais [...]. Presidente Prudente, SP: Unoeste, 2019. p. 1354. Disponível em: http://www.unoeste.br/Areas/Eventos/Content/ documentos/EventosAnais/397/anais/Sa\%c3\%bade/Medicina.pdf. Acesso em: 14 fev. 2020.

CHOJI, C. H.; BERTOZ, S. P. M.; BIANCO, F. V. D.; PENAZZI, T. C.; ALVARENGA, T. S.; RANTIN, V. P. D.; MARANGONI, I. P.; BERNARDES, A. P.; TOMÉ, F.; NOBRE, I.P.; SOUSA, N. R.; VINHA, T. M. B.; CORREIA, G. C. M. Comparações visuais de orifícios de entrada de disparo de projétil de armas de fogo em medicina legal. In: ENCONTRO NACIONAL DE ENSINO, PESQUISA E EXTENSÃO - ENEPE. 2019, Presidente Prudente. Anais [...]. Presidente Prudente, SP: Unoeste, 2019. p. 1355. Disponível em: http://www.unoeste.br/Areas/ Eventos/Content/documentos/EventosAnais/397/anais/Sa\%c3\%bade/Medicina.pdf. Acesso em: 14 fev. 2020.

FRANÇA, Genival Veloso de. Medicina legal. 9.ed. Rio de Janeiro: Guanabara Koogan, 2012.

GALVÃO, Luís Carlos Cavalcante. Medicina legal. São Paulo: Santos, 2008.

MONTANARO, Juarez Oscar de. Medicina legal para cursos e concursos. São Paulo: Gamatron, c1995.

Haag LC. Physical forms of contemporary small-arms propellants and their forensic value. Am J Forensic Med Pathol. 2005;26(1):5-10. doi:10.1097/01.paf.0000154117.60171.52

TOCCHETTO, Domingos, Balística Forense :aspectos técnicos e jurídicos / 10 Ed. Campinas, SP, Millennium, 2020.

TOCCHETTO, Domingos; WEINGAERTNER, João Alberto. Armas Taurus: uma garantia de segurança. 5. ed. Campinas: Millennium, 2013. 


\section{TUBERCULOSE PULMONAR: OS RISCOS DA INTERRUPÇÃO DO TRATAMENTO PARA O INDIVÍDUO E PARA A SAÚDE PÚBLICA}

FRANCISCA SOUZA SANTOS DIAS Instituto Federal do Norte de Minas Gerais

CLARA CYNTHIA MELO E LIMA Instituto Federal do Norte de Minas Gerais

\section{PATRÍCIA DE SOUSA FERNANDES \\ QUEIROZ}

Instituto Federal do Norte de Minas Gerais

HÉRIKA MARIA SILVEIRA RUAS

Instituto Federal do Norte de Minas Gerais

VIVIANE MAIA SANTOS

Centro Universitário UNIFIPMOC

RESUMO: A tuberculose é um importante problema de saúde pública no mundo, ultrapassando a área da saúde. Tendo em vista minimizar as consequências negativas da doença, sistemas públicos e privados de saúde buscam implementar estratégias de prevenção e tratamento da doença. Todavia mesmo com disponibilização gratuita da medicação, um dos problemas importantes da tuberculose são as altas porcentagens de interrupção do tratamento pelo paciente. $\mathrm{O}$ estudo teve por objetivo analisar os conhecimentos e práticas dos contatos dos portadores de tuberculose e dos profissionais de saúde em relação aos riscos à saúde pública decorrentes da interrupção do tratamento da tuberculose pulmonar. Trata-se de um estudo qualitativo, conduzido com seis profissionais da saúde e oito contatos de portadores de tuberculose, realizado no município de Araçuaí - MG. Para a coleta de dados, utilizou-se a entrevista semi-estruturada. Os dados foram ana- lisados com base na análise dos saberes e práticas dos participantes da pesquisa, identificando-se as unidades de registro. Por meio das entrevistas, observou-se que alguns pacientes apresentam dificuldades em aderir ao tratamento, tendo em vista que o mesmo é longo e apresenta eventos adversos. Sendo a tuberculose uma doença transmissível por via aérea, uma das consequências da interrupção do tratamento é a continuidade da cadeia de transmissão da doença, pois as pessoas com tuberculose que não aderem à terapêutica continuam doentes e permanecem como fonte de contágio, podendo apresentar riscos tanto para o indivíduo quanto para a população. Enquanto os contatos intradomiciliares não revelam receio em conviver com o portador de tuberculose, entre os profissionais e a vizinhança, o temor de contágio é constante, exigindo condutas diante desses casos.

PALAVRA-CHAVE: Risco; Tuberculose Pulmonar; Saúde Pública.

ABSTRACT: Tuberculosis is an important public health problem in the world, going beyond the health area. In order to minimize the negative consequences of the disease, public and private health systems seek to implement strategies for the prevention and treatment of the disease. However, even with the free availability of medication, one of the important problems of tuberculosis is the high percentage of interruption of treatment by the patient. The study aimed to analyze the knowledge and practices of contacts of people with tuberculosis and health professionals in relation to the risks to public health resulting from the interruption of treatment of pulmonary 
tuberculosis. This is a qualitative study, conducted with six health professionals and eight contacts of people with tuberculosis, carried out in the city of Araçuaí - MG. For data collection, semi-structured interviews were used. The data were analyzed based on the analysis of the knowledge and practices of the research participants, identifying the registration units. Through the interviews, it was observed that some patients have difficulties in adhering to the treatment, considering that it is long and has adverse events. Since tuberculosis is an airborne disease, one of the consequences of interrupting treatment is the continuity of the disease transmission chain, as people with tuberculosis who do not adhere to therapy remain ill and remain a source of contagion, which can present risks both for the individual and for the population. While household contacts do not reveal any fear of living with the tuberculosis patient, between professionals and the neighborhood, the fear of contagion is constant, requiring conduct in these cases.

KEYWORDS: Risk; Pulmonary Tuberculosis; Public health

\section{INTRODUÇÃO}

A tuberculose é um importante problema de saúde pública no mundo, ultrapassando a área da saúde. Tendo em vista minimizar as consequências negativas da doença, sistemas públicos e privados de saúde buscam implementar estratégias de prevenção e tratamento da tuberculose, de modo a garantir melhor qualidade de vida ao paciente e menos custos para a saúde (ARGENTINI et al., 2019).

Para a melhoria das condições relacionadas ao tratamento da tuberculose, a medicação é gratuita para o paciente, de uso diário e deve ser administrada de preferência em uma única tomada. Todavia mesmo com disponibilização gratuita da medicação, um dos problemas importantes da tuberculose são as altas porcentagens de interrupção do tratamento pelo paciente, encontrando-se no Brasil, taxas acima das consideradas aceitáveis pela Organização Mundial de Saúde (OMS), ou seja, inferior a 5,0\%. Em 2010, essa taxa média de abandono no país situou- se em 9,8\%, mas há diferenças regionais (BRASIL, 2012).

A irregularidade do tratamento leva à resistência medicamentosa e à recidiva da doença, impondo dificuldades ao processo de cura e aumentando o tempo e o custo do tratamento, com o retorno dos sinais e sintomas, situação em que o paciente pode ficar muito debilitado (MENDES e FENSTERSEIFER, 2004).

O portador de tuberculose que não prossegue com o tratamento permanece doente, podendo transmitir a doença aos seus contatos, representando um risco para sua saúde e para as pessoas que convivem com o mesmo. Evidenciando a importância da terapia para a diminuição da mortalidade e maior sobrevida destes pacientes (JÚNIOR et al., 2020).

Atualmente, pode-se dizer que viver, independente da maneira, acarreta na apropriação, voluntária ou não, de certos riscos individualizados ou coletivos. As pessoas enfrentam e compreendem seus riscos e os riscos alheios de formas diversas, que abrangem fatores que transcendem os saberes científicos que incorporam aspectos biológicos, psicológicos e socioculturais. No âmbito da saúde, a epidemiologia possibilita a quantificação da relevância da relação "exposição-doença" nos seres 
humanos e, dessa forma, a possibilidade de se modificar o risco através da intervenção. Portanto, o conceito de risco pode ser considerado como uma forma de entender e mensurar a probabilidade de ocorrência de agravos à saúde (CASTIEL, 2010).

Nesse sentido, justifica-se a realização deste estudo tendo em vista que quando o indivíduo recusa o tratamento de uma doença infecciosa, essa decisão acarreta riscos tanto para o nível individual quanto coletivo. Considerando que, ao associar o controle da doença à capacidade do indivíduo doente para autogerenciar as medidas terapêuticas prescritas, amplia-se a importância do comportamento pessoal na redução ou eliminação dos riscos envolvidos (ROSSETO, 2013).

O presente capítulo tem por objetivo analisar os conhecimentos e práticas dos contatos dos portadores de tuberculose e dos profissionais de saúde em relação aos riscos à saúde pública decorrentes da interrupção do tratamento da tuberculose pulmonar. Para alcançar o objetivo proposto, foram analisadas as entrevistas semi-estruturadas realizadas com seis profissionais que atuam na vigilância epidemiológica e na Estratégia Saúde da Família e oito contatos de pessoas que tiveram tuberculose no ano de 2013, no município de Araçuaí-MG.

Essa investigação foi encaminhada ao Comitê de Ética e aprovada sob o número do parecer: 842.608 e o consentimento dos participantes foi formalizado por meio da assinatura do Termo de Consentimento Livre e Esclarecido - TCLE. Nos discursos, os contatos das pessoas com tuberculose foram identificados no texto pela letra $\mathrm{C}$ seguida de um número sequencial de realização da entrevista (C1 a C8); e os profissionais de saúde foram identificados no texto segundo a profissão, sendo os enfermeiros identificados em EN01 e EN02, os técnicos em enfermagem por TE01 e TE02 e os agentes comunitários de saúde por ACS01 e ACS02.

Nessa abordagem, os discursos foram interpretados com base na análise dos saberes e práticas dos participantes da pesquisa, identificando-se as unidades de registro, fez-se a classificação que consistiu em compreender essas informações para relacionar as que tinham características comuns e agrupá-las de acordo com as questões presentes na informação.

\section{TUBERCULOSE PULMONAR: EXPERIÊNCIAS DO TRATAMENTO}

Alguns estudos evidenciam a tendência nas abordagens terapêuticas em tuberculose indicando que a maior carga de responsabilidade pela adesão e não adesão ao tratamento é efetivamente conferida ao usuário. Desse modo, a adesão ao tratamento da tuberculose torna-se um empreendimento individual, executado por pessoas conscientes do risco, enquanto que o abandono da terapêutica é considerado um ato de irresponsabilidade da pessoa doente.

Com isso fatores, grupos, comportamentos ou situações de risco são listados em discursos com a finalidade de prevenir ou controlar a doença, deixando sob a responsabilidade do indivíduo a adequada adoção de comportamentos protetores a sua saúde (ROSSETO, 2013). No entanto, esse modo de tratar as questões de saúde tem sido alvo de críticas. Essas críticas apoiam-se na generali- 
zação de previsões epidemiológicas baseadas em processos quantitativos, com grande precisão, mas que se distanciam, todavia, de outros aspectos fundamentais para pensar saúde, que como afirma Ayres (2002, p.15) são "a subjetividade, a significação, a interação e a dinamicidade”.

Os aspectos subjetivos são essenciais para a compreensão do processo de saúde, pois possibilitam o entendimento das distintas respostas individuais frente aos riscos aos quais os indivíduos estão expostos. Não somente as mensurações numéricas de forma isolada devem ser questionadas, mas também como as pessoas, de acordo com seu contexto social e cultural, poderão perceber os riscos para o desenvolvimento de uma doença (DATASUS, 2014).

Geralmente, é difícil o tratamento da tuberculose. A sintomatologia da doença já coloca o paciente em condições debilitadas e os medicamentos utilizados no tratamento acarretam sérios efeitos colaterais, interferindo diretamente no equilíbrio biopsicossocial dos pacientes, que se incomodam com o longo tempo do tratamento (SILVA e SILVA, 2016). Os depoimentos dos sujeitos do estudo revelam dificuldades como desconforto digestivo, náuseas, vômitos, fazendo com que estes abandonem o tratamento.

\footnotetext{
"Eu tomei quatrocentos comprimidos. Mas me pegou fazendo mal, tinha hora que eu não enxergava nada, uma náusea. Aí no dia que eu vomitei preto, se o menino não tivesse, eu tinha morrido. Aí agora eu cismei que eu não tomava mais os remédios. " C6
}

A doença desperta uma série de sentimentos durante o período que vai do diagnóstico, passando pelo tratamento até a cura. Normalmente são sentimentos diretamente relacionados às repercussões da enfermidade sobre as relações do indivíduo. Não referindo, apenas à vivência da doença, como um processo individual, mas do fato de que a enfermidade pode vir a determinar diversas rupturas (VENDRAMINI et al., 2002).

No entanto, observa-se que ainda persiste o preconceito em relação aos doentes, o que tende a dificultar ainda mais a experiência do adoecer (SILVA e SILVA, 2016). A análise dos depoimentos evidenciou que a tuberculose permanece impregnada de preconceito, o que pode ser visto pela própria forma como os participantes do estudo se remetem a doença: “doença ruim”, ou pelo afastamento de amigos ou devido às atitudes de vizinhos, entre outros. O sofrimento não se limita ao processo clínico, mas também pela vivência do estigma e rejeição.

Assim, os contatos que adquiriram tuberculose revelaram que mantêm o sigilo em relação a um diagnóstico positivo para tuberculose, assumindo deliberadamente a ocultação da condição de portador da doença, pelo temor de serem rejeitados.

Não. É bom ninguém ficar sabendo. C5

Ela arrumou essa tuberculose, mas não falou nada com ninguém não. Foi a enfermeira que veio e nós não sabíamos não. $\mathrm{C} 4$

Visando evitar a estigmatização do doente na comunidade, os profissionais de saúde relataram que mantêm o sigilo diante do diagnóstico de tuberculose. Somente em casos em que o paciente 
abandona o tratamento, as pessoas expostas ao risco são informadas sobre o caso. $\mathrm{O}$ termo "abandono de tratamento", segundo as normas técnicas, é compreendido como sendo a situação em que a pessoa com tuberculose, após ter iniciado o tratamento para essa doença deixa de comparecer à unidade por mais de 30 dias consecutivos, após a data prevista para seu retorno. Nos casos de tratamento supervisionado, o prazo de 30 dias conta a partir da última ingestão da droga (MINAS GERAIS, 2006).

A interrupção do tratamento centra-se no fato de que, o portador de tuberculose que não adere à terapêutica, continua doente, e permanece como fonte de contágio (MENDES e FENSTERSEIFER, 2004). Além disso, o abandono de tratamento de doença transmissível indica que a população está sob risco e pode representar ameaças à saúde. Nesse sentido, a interrupção do tratamento tem sido frequentemente descrito como importante fator que favorece o aparecimento de bacilos multirresistentes e maior obstáculo para o controle e eliminação da doença no campo da saúde pública (ROCHA e ADORNO, 2012). Essa problematização pode ser verificada na fala do profissional de saúde.

"O que acontece, quando a pessoa abandona o tratamento é muito risco para a população, entendeu? Porque pode está assim passando para outra pessoa, está espalhando.” TE01

Considerando todas essas implicações para a população em relação à recusa do tratamento, estratégias diferenciadas são adotadas, visto que os pacientes colocam em risco a saúde dos seus contatos e da sociedade pela transmissão desses bacilos, que poderão causar uma doença que pode ser incurável, até que novos medicamentos sejam disponibilizados (BRASIL, 2011).

\section{RECONHECENDO OS RISCOS DA TUBERCULOSE PARA O INDIVÍDUO E PARA A SAÚDE PÚBLICA}

A noção de risco tem sido central no campo da tuberculose, posição que emerge da tradicional implicação da saúde no comportamento individual. Neste sentido, a concepção de risco na tuberculose assume pelo menos três dimensões: os riscos para a pessoa doente, os riscos para a pessoa doente que interrompe o tratamento e os riscos que o doente representa para os indivíduos saudáveis.

A incorporação da noção de risco foi fruto de transformações sociais e tecnológicas. Trata-se de um termo recente e essencialmente moderno, refletindo a reorientação das relações das pessoas com eventos futuros. Antes implicando em fatalidade, agora o risco é ressignificado em controle possível (LUIZ e COHN, 2006).

Em circunstâncias que o paciente não prossegue com o tratamento, há um conflito entre o direito individual à liberdade da pessoa em recusar um tratamento, tendo em vista as dificuldades do paciente em aderir a um tratamento longo e com eventos adversos, e o direito coletivo à saúde pela população que reconhece que está exposta a riscos.

O portador de tuberculose ao ter a autonomia em escolher seguir ou não o tratamento corretamente e opta por não ingerir os medicamentos prescritos, indispensáveis para seu tratamento, com- 
promete a sua saúde, bem como a de terceiros. Os profissionais ressaltaram a importância de seguir o tratamento corretamente:

"O indivíduo que se propõe a tratar da tuberculose, ele primeiramente faz uma situação de relevância consigo mesmo e pensando ser uma doença de notificação compulsória, hoje a gente pretende que o paciente encare a situação como sendo dele, da familia e da sociedade." ENO2

Partindo do questionamento, para quem a tuberculose pode representar um risco, as entrevistas revelaram que para os contatos intradomiciliares, a tuberculose é uma doença que tem cura e não se sentiram ameaçados ao conviver com a pessoa com tuberculose.

\footnotetext{
Como ela era a única filha que morava próximo, então ela não tinha medo de adquirir, ela ficava em cima. $\mathrm{C} 1$

Tem não. Porque a tuberculose hoje em dia tem tratamento. O que não tem tratamento hoje é AIDS, Ave Maria, câncer. Tuberculose, não. A pessoa tomou o remédio acabou. C2
}

Não, até que eu não tinha medo de pegar. C4

No entanto, entre os profissionais e a vizinhança o risco de transmissão é percebido e o temor de contágio é constante. Essa situação demonstra a necessidade de um trabalho conjunto entre comunidade e o profissional de saúde, no que se refere às orientações sobre a disseminação da tuberculose.

Quando o paciente deu entrada no serviço ele tá vindo de uma unidade de atenção primária. Nós já tínhamos encaminhado ao serviço, BAAR positivo, tratar tuberculose. Então esse paciente já chega ao serviço e quem está trazendo é o profissional da portaria ou o agente, a gente já vê a distância que esse paciente fica dessa pessoa, dessa referência. EN02

Nesse contexto, é possível identificar um conflito entre o direito individual à liberdade da pessoa em recusar um tratamento, tendo em vista as dificuldades do paciente em aderir a um tratamento longo e com eventos adversos, e o direito coletivo à saúde pela população que reconhece que está exposta a riscos. Assim, são necessárias medidas para a garantia da saúde da população.

Com a Constituição de 1988 a saúde passa a ser um direito fundamental, com a prestação positiva do Estado no sentido de concretizá-la e ampliá-la a todos os cidadãos. Na saúde pública, prestação positiva do Estado, representa o instrumento técnico-político que irá intervir no processo saúde-doença, mediante o tratamento e a reabilitação do indivíduo doente, ou evitando seus riscos e danos por intermédio da prevenção e promoção da saúde (MATUMOTO; MISHIMA; PINTO, 2001).

O Estado, mais do que aplicador das leis, é produtor de congregação dos sujeitos sob sua jurisdição, não vislumbrando singularidades, mas os direitos que passam a envolvê-lo. A própria sociedade participa na indicação de práticas de governo para áreas que necessitem de vigilâncias da norma. A norma atua nos sujeitos de maneira fluida, capilar e fina. São pequenas produções cotidianas que vão sendo confirmadas pela família, pela escola e pelo trabalho, e operadas a partir de dispositivos normalizadores ou de um conjunto de forças diversificadas e finas (LOPES, 2012). 


\section{CONCLUSÃO}

Enquanto a recusa do tratamento para doenças não infecciosas implica em riscos apenas individuais, a recusa do tratamento da tuberculose traz consequências mais amplas, considerando que a tuberculose pulmonar é uma doença transmissível por via aérea e a pessoa quando não adere ao tratamento pode transmiti-la a seus contatos, colocando em risco a saúde do outro.

Uma das consequências da interrupção do tratamento da tuberculose pulmonar é a continuidade da cadeia de transmissão da doença, pois as pessoas com tuberculose que não aderem à terapêutica continuam doentes e permanecem como fonte de contágio. Além disso, a decisão de não prosseguir com o tratamento acarreta resistência medicamentosa e recidiva da doença, aumentando o tempo e o custo do tratamento. Tendo em vista as implicações decorrentes da recusa do tratamento, destaca-se o papel do Estado, em garantir que o indivíduo ou a coletividade fiquem o menos possível expostos ao perigo.

Nesta pesquisa foi evidenciado que os contatos intradomiciliares, não se sentiram ameaçados ao conviver com a pessoa com tuberculose, por considerarem que é uma doença que possui tratamento e cura. No entanto, entre os profissionais e a vizinhança o risco de transmissão é percebido e o temor de contágio é constante, exigindo condutas dos profissionais de saúde diante desses casos.

\section{REFERENCIAS}

ARGENTINI, G. ZUBER, J.F., MARTINS, J.C, ZANESCO, C. FADEL, C.B. A interdisciplinaridade no tratamento da tuberculose: ferramentas, desafios e perspectivas. Braz. J. of Develop., Curitiba, v. 5, n. 12, p. 33009-33024. 2019.

AYRES, J.R.C.M. Sobre o risco: para compreender a epidemiologia. São Paulo: Editora Hucitec; 1997.

BRASIL. Ministério da Saúde. Secretaria de Vigilância em Saúde. Manual de recomendações para o controle da tuberculose no Brasil. 1 ed. Brasília: Ministério da Saúde, 2011.

BRASIL. Ministério da Saúde. Secretaria de Vigilância em Saúde. Programa nacional de controle da tuberculose. Brasília: Ministério da Saúde; 2012.

CASTIEL, L.D; GUILAM, M.C.R; FERREIRA, M.S. Correndo o risco: uma introdução aos riscos em saúde. Rio de Janeiro: Editora Fiocruz, 2010.

DATASUS. Ministério da Saúde. [Internet]. Secretaria Executiva. Datasus. Informações de Saúde. Informações epidemiológicas e morbidade.

JUNIOR, A.C.V.,GUEDES, D.R.S., SOUZA, M.S., MACEDO, C.A., MEDEIROS, R.O, ALVES, H.B., NETO, H.D., SILVA, D. F. Avaliação do perfil epidemiológico da tuberculose e a sua coinfecção TB-HIV nos estados da Paraíba e Rio Grande do Norte. Braz. J. of Develop., Curitiba, v. 6, n. 1, p. 441-456. 2020.

LOPES, A.M.P. Saúde no processo de democratização brasileiro: promoção da saúde, biopolíticas e práticas de si na constituição de sujeitos da saúde. Tese (doutorado) - Universidade Federal de Santa Catarina. Programa de Pós-Graduação em Psicologia. 2012. 
LUIZ, O.C; COHN, A. Sociedade de risco e risco epidemiológico. Cad. Saúde Pública, Rio de Janeiro, 22(11):2339-2348, nov, 2006.

MATUMOTO, S; MISHIMA, S.M.; PINTO, I.C. Saúde Coletiva: um desafio para a enfermagem. Cad. Saúde Pública, Rio de Janeiro, 17(1):233-241, jan-fev, 2001.

MENDES, A.M; FENSTERSEIFER, L.M. Tuberculose: porque os pacientes abandonam o tratamento? Bol Pneum Sanitária. 2004 Abr; 12(1):7-38.

MINAS GERAIS. Secretaria de Estado de Saúde. Atenção à Saúde do Adulto: Tuberculose. Belo Horizonte, 2006. 144 p.

ROCHA, D.S; ADORNO, R.C.F. Abandono ou Descontinuidade do Tratamento da Tuberculose em Rio Branco, Acre. Saúde Soc. São Paulo, v.21, n.1, p.232-245, 2012.

ROSSETO, M. Reconhecendo-se como sujeito de riscos: a consciência dos possiveis danos da tuberculose. Dissertação (Mestrado). Universidade Federal do Rio Grande do Sul. Porto Alegre. 2013.

SILVA, E.A.; SILVA, G.A. O sentido de vivenciar a tuberculose: um estudo sobre representações sociais das pessoas em tratamento. Physis. 26 (4). 2016

VENDRAMINI, S.H.F; VILLA, T.C.S, PALHA, P.F; MONROE, A.A. Tratamento supervisionado no controle da tuberculose em uma unidade de saúde de ribeirão preto: a percepção do doente. Boletim de Pneumologia Sanitária - Vol. 10, Nº 1 - jan/jun - 2002. 


\section{SOFTWARE CHECK-LIST PARA CIRURGIA SEGURA}

FLÁVIO FRAGA VILELA Universidade do Vale do Sapucaí (UNIVÁS)

RODRIGO NEVES OTTOBONI DIAS Universidade do Vale do Sapucaí (UNIVÁS)

JOSÉ DIAS DA SILVA NETO Universidade do Vale do Sapucaí (UNIVÁS)

LUIZ ANTONIO DA SILVA

Universidade do Vale do Sapucaí (UNIVÁS)

DIEGO DOBSCHA DA CRUZ PIEDADE Universidade Federal de Ouro Preto (UFOP)

RESUMO: A segurança do paciente é uma nova disciplina na área da saúde que enfatiza o relato, análise e prevenção do erro médico. Em relação aos centros cirúrgicos (CC), a equipe necessita trabalhar conjuntamente, de forma eficaz, e utilizar o que tem de melhor no que se refere a conhecimentos e capacidades em prol do paciente para evitar tais eventos prejudiciais ao paciente. A partir da necessidade de incluir segurança do paciente como um dos alicerces de qualquer procedimento cirúrgico, principalmente relativa à cirurgia segura, o presente estudo justifica-se pela possibilidade de avaliação de instrumento computacional que implementa um controle específico no centro cirúrgico sob o ponto de vista de seus profissionais. $\mathrm{O}$ objetivo principal é utilizar um software no centro cirúrgico para promover a aplicação do check-list de cirurgia segura de forma ágil e simples. O método utilizado foi o quantitativo, não experimental, descritivo e transversal. O projeto técnico tratado pelo artigo se encontra em fase final de conclusão, disponível em um endereço eletrônico, e sua implantação no hospital somente ocorrerá após aprovação do sistema concebido pelo Comitê de Ética em Pesquisa (CEP). Estima-se que os ganhos para segurança do paciente serão bastante significativos.

PALAVRA-CHAVE: Software de Cirurgia Segura; Qualidade Assistencial; Segurança do Paciente.

ABSTRACT: Patient safety is a new discipline in healthcare that emphasizes the reporting, analysis and prevention of medical error. With regard to the surgical centers (CC), the team needs to work together, effectively, and use what is best in terms of knowledge and skills in favor of the patient to avoid such harmful events to the patient. From the need of including patient safety as one of the foundations of any surgical procedure, mainly related to safe surgery, the present study is justified by the possibility of evaluating a computational instrument that implements a specific control in the operating room from the point of view of its professionals. The main objective is to use this software in the operating room to promote the application of the safe surgery check list in an agile and simple way. The method used was quantitative, non-experimental, descriptive and transversal. The technical project covered by the article is in the final stages of completion, available at an electronic address, and its implementation in the hospital will only occur after approval of the system designed by the Research Ethics Committee (CEP). The gains for patient safety are estimated to be quite significant.

KEYWORDS: Safe Surgery Software; Assistance Quality; Patient safety. 


\section{INTRODUÇÃO}

O centro cirúrgico (CC) é uma unidade crítica para o alcance do principal objetivo do sistema hospitalar que é recuperar a saúde do paciente. Segundo Viacava (2004) existem três maneiras de garantir a sustentabilidade financeira de um sistema produtivo: cobrar mais, produzir/vender mais, e fazer o trabalho de forma mais eficiente. Contudo, dado o cenário de redução de custos, dificuldades de aumento dos repasses governamentais para o setor de saúde e também por saúde ser considerado um direito universal (não há possibilidade de cobrar no subsistema de saúde público); aparece como única alternativa de gestão buscar uma maior eficiência de modo a alavancar a qualidade e manter sustentável financeiramente o setor de saúde público brasileiro. O setor de saúde tem gradualmente se desenvolvido quanto a resultados e busca por maior eficiência. O presente projeto de software justifica-se pela possibilidade da avaliação e eficiência do CC aderindo a um instrumento computacional. Logo, o objetivo principal deste software é utilizar o check-list de cirurgia segura preconizado pela OMS com o acréscimo de métricas da gestão de operações com a função de tornar o ambiente mais sustentável e assertivo.

Vale ressaltar que estudos evidenciam que há inovação na prática assistencial, principalmente, relacionada à segurança do paciente quando a tecnologia é usada de forma facilitadora (Melo e Damasceno, 2012; Merritt, 2004).

O planejamento de cirurgias é algo extremamente importante e sua efetividade depende de um alinhamento coerente com subprocessos indiretos como o setor de suprimentos, gerenciamento de leitos, UTIs etc. Uma das informações mais relevantes no momento da elaboração dos mapas de cirurgias é a duração de cada procedimento cirúrgico. A abordagem convencional é estimar as durações das cirurgias embasado no relato dos médicos cirurgiões. Porém, este método não possui nenhum rigor quantitativo e estatístico. Esta falta de confiabilidade afeta a precisão na concepção do sequenciamento dos procedimentos médicos e as métricas adicionais supracitadas que são constituintes do software, tem o propósito de cobrir essas lacunas.

\section{REFERENCIAL TEÓRICO}

A preocupação com a qualidade nas organizações de saúde define-se através da busca por melhores práticas e otimização dos serviços, para assim atender a grande carga de atendimentos e maior qualidade nos procedimentos. Mensurar o desempenho torna-se de vital importância para melhoria dos processos de trabalho, reduzindo os custos operacionais e promovendo harmonização da inter-relação paciente, hospital e promoção da saúde. O objeto dessa medição incorpora a estrutura necessária ou utilizada, os processos, os resultados obtidos, as influências e repercussões promovidas no meio ambiente e os instrumentos utilizados são os indicadores (BITTAR, 2008). 
O período perioperatório é um momento crítico, pois o paciente será submetido a procedimento cirúrgico, expondo-se aos riscos e às suas diversas complicações, sendo necessária assistência de enfermagem e médica especializadas. As especificidades do período perioperatório foram muito discutidas ao longo do tempo; porém, a partir de 2002, também vêm preocupando a Organização Pan Americana da Saúde (OPAS) da Organização Mundial da Saúde (OMS), quando relacionadas à segurança do paciente, resultando na criação da Aliança Mundial para a Segurança do Paciente, em outubro de 2004 (OMS, 2009). Com isso, abre-se um precedente para estudos relacionando a gestão de sistemas de produção na área de saúde a fim de alavancar sua eficiência, reduzir os custos e melhorando assim seus resultados e qualidade na assistência médica prestada. A segurança do paciente é entendida como a redução, a um mínimo aceitável, do risco de dano desnecessário ao paciente, associado ao cuidado de saúde (WHO, 2009).

O evento "desafios globais" foi criado para a segurança do paciente, sendo que a segunda edição desse evento se refere aos fundamentos e práticas da segurança cirúrgica, considerada uma prioridade em saúde pública (BITTAR, 2008). Na Austrália, um estudo indicou que 47,6\% das complicações cirúrgicas poderiam ser evitadas (KABLE et al., 2002).

Os estudos sobre segurança do paciente relacionam-se as questões que envolvem a cultura de segurança, que é conhecida como o 'resultado das atitudes, percepções e competências, e dos padrões de comportamento e valores de grupos, que poderão determinar: compromisso, estilo e competência de uma organização de saúde, e de uma gestão de segurança (SEXTON et al., 2006). O Brasil, como país membro da OMS, aderiu a Aliança Mundial pela Segurança do Paciente e recomendou por meio da resolução ministerial RDC no 36 a implantação de estratégias para segurança do paciente e dentre estas, um protocolo para cirurgia segura nos estabelecimentos de saúde através da aplicação do check-list (BRASIL, 2013). Em relação aos centros cirúrgicos (CC), a equipe necessita trabalhar conjuntamente, de forma eficaz, e utilizar o que tem de melhor no tocante a conhecimentos e capacidades em prol do paciente para evitar danos (OMS, 2009).

Os programas integrados de saúde dos hospitais convivem diariamente com situações ocorridas em $\mathrm{CC}$, as quais podem determinar risco de incidentes e eventos adversos, gerando angústia e estresse nos profissionais e comprometendo a segurança do paciente. O estresse dos profissionais, muitas vezes, dificulta a comunicação na sala de operação (SO), aumentando o potencial para causar danos. Por outro lado, a inexperiência e a pouca familiaridade com os equipamentos, a má comunicação entre os membros da equipe, a pressa, a desatenção e a fadiga também contribuem para a ocorrência de eventos adversos (OMS, 2009).

Os indicadores não devem ser vistos como medida direta de qualidade, no entanto, podem ser considerados como medidas quantitativas, utilizadas para reavaliar, replanejar e reorganizar as atividades de um serviço, oferecendo subsídios para tomada de decisão na gestão da assistência (BITTAR, 2008). Além dos aspectos citados, as medidas para a segurança do paciente são incipientes, revelando a necessidade de que mudanças neste sentido sejam implementadas. Neste ínterim, a mudança cultural acerca da segurança do paciente é crucial para que sejam implantadas medidas eficientes de prevenção e redução dos riscos e eventos adversos (SILVA, 2009). 
Um relevante marco inicial, que demonstrou os benefícios do uso de uma lista de verificação para a segurança de pacientes cirúrgicos, foi um estudo realizado por especialistas da Organização Mundial da Saúde (OMS) em oito países (Canadá, Índia, Jordânia, Filipinas, Nova Zelândia, Tanzânia, Inglaterra e EUA). No total, 7.688 pacientes foram investigados, dos quais 3733 foram investigados antes da utilização da lista de controle e 3,955 depois de preencher o check-list, que mostrou uma redução de $36 \%$ em complicações cirúrgicas, $47 \%$ na mortalidade, $50 \%$ na taxa de infecção e $25 \%$ na necessidade de uma nova intervenção cirúrgica.

Concluiu-se que o uso do check-list praticamente dobrou a possibilidade de uso de padrões de cuidados seguros durante o tratamento cirúrgico dos pacientes (HAYNES et al., 2009). A construção de uma nova cultura demonstra-se necessária, para que os valores, crenças e normas daquilo que é importante em uma instituição sejam compreendidos, como também as atitudes e comportamentos relacionados à segurança do paciente sejam suportados, recompensados e esperados (SORRA et al, 2009). A prática assistencial associada à informática pode trazer contribuições que favorecem a continuidade do cuidado, por meio da tomada de decisão baseada nos sistemas de apoio e com a elaboração de indicadores de qualidade da assistência ao paciente a partir dos registros eletrônicos (SOUSA et al., 2012). Aliada à praticidade, a informática está intimamente relacionada aos diversos processos no trabalho do médico e enfermeiro, otimizando ações seja no âmbito assistencial, gerencial ou de ensino (HAYNES et al., 2009).

\section{MÉTODO DE PESQUISA}

O software do CC que está em fase final de desenvolvimento, foi a consequência de uma solução para um problema encontrado no CC. A referida solução fez parte da ação de uma pesquisa-ação. Segundo Coughlan \& Coughlan (2002) a pesquisa-ação é um termo genérico, que cobre muitas formas de pesquisa orientada para a ação, e indicam uma diversidade na teoria e na prática entre os pesquisadores usuários deste método. Complementando a definição anterior o autor Thiollent (2005) define a pesquisa-ação como um tipo de pesquisa social com base empírica que é concebida e realizada em estreita associação com uma ação ou com a resolução de um problema coletivo e no qual os pesquisadores e os participantes representativos da situação ou do problema estão envolvidos de modo cooperativo ou participativo.

\section{INTERFACE DO SOFTWARE}

A seguir serão apresentadas algumas imagens da interface do software citado no presente projeto técnico. A Figura 1 apresentada mostra a tela inicial para o usuário do CC fazer o login. Cada usuário (enfermeiro, médico etc) possui sua própria senha de acesso. Este acesso pode ser feito meio de um Desktop, Android ou IOS. 
Figura 1 - Tela de login do software CC.

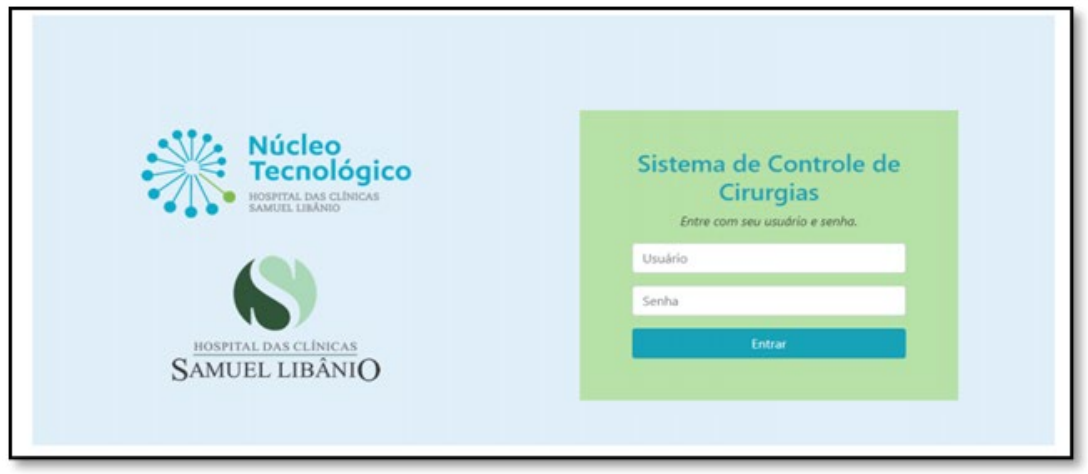

Fonte: Autores.

A Figura 2 permite ao usuário escolher qual ação efetivar. Tem-se neste caso a opção de entrar no protocolo de cirurgia segura e iniciar o check-list ou cadastrar o tipo de profissional de saúde na base de dados do sistema.

Figura 2 - Menu principal.

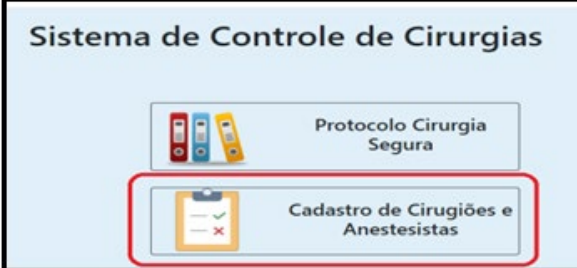

Fonte: Autores.

A Figura 3 apresenta algumas informações iniciais que devem ser inseridas no sistema. Será aberto uma tela para informar os dados do paciente (preencha todos os campos e clique em confirmar), caso o paciente já exista no sistema, os dados já virão preenchidos e será necessário apenas confirmá-los.

Figura 3 - Inserir CPF do paciente.

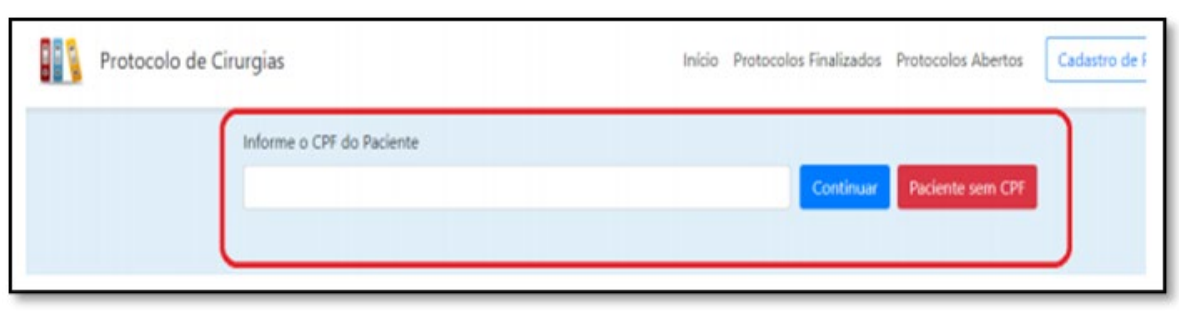

Fonte: Autores. 
Na Figura 4, é apresentado o formulário que deverá ser preenchido na internação do paciente antes do início da cirurgia. É importante salientar que o protocolo de cirurgia segura começa antes do processo de intervenção cirúrgica.

Figura 4 - Dados paciente na internação

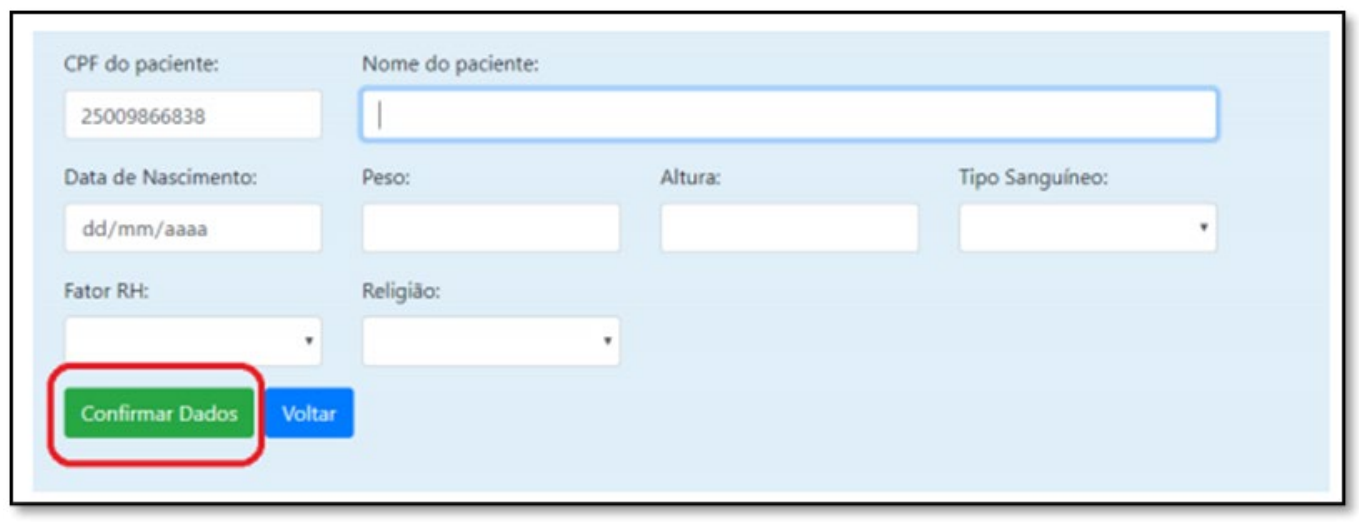

Fonte: Autores.

\section{CONCLUSÃO}

O presente projeto técnico apresentado está em fase final de conclusão e sua implantação no hospital se dará após aprovação do sistema concebido pelo Comitê de Ética em Pesquisa (CEP). As métricas adicionais que foram incorporadas são todas derivadas da informação de tempo que está dentro do check-list da cirurgia segura e é de preenchimento obrigatório. Com essas informações devidamente cadastradas é possível obter o tempo médio de cada procedimento cirúrgico e alguns down times, que são segundo Rother \& Shook (2007) atividades não agregadoras de valor. Por fim, gostaríamos de ressaltar que a aplicação de teste do software está disponível no seguinte endereço eletrônico: http://controlecirurgias.nucleotechcsl.com.br.

\section{AGRADECIMENTOS}

Os autores agradecem a Pró-Reitoria de Pesquisa e Pós-Graduação da Universidade do Vale do Sapucaí (UNIVÁS) pelo apoio e incentivo à pesquisa. Também agradecemos a direção executiva da Fundação do Vale do Sapucaí (FUVS) pelo suporte e patrocínio. 


\section{REFERÊNCIAS}

BITTAR, Olímpio J. Nogueira V. Indicadores de qualidade e quantidade em saúde. Rev. adm. saúde, p. 87-93, 2008.

BRASIL, Ministério da Saúde., Agência Nacional de Vigilância Sanitária. Resolução - RDC n. 36, de 25 de julho de 2013. Institui ações para a segurança do paciente em serviços de saúde e dá outras providências. Brasília (DF): Diário Oficial da União.2013 Jul.

COUGHLAN, Paul; COGHLAN, David. Action research for operations management. International journal of operations \& production management, 2002.

HAYNES et al. Grupo de Estudo Cirurgia Segura Salva Vidas. Uma lista de verificação de segurança cirúrgica para reduzir a morbimortalidade em uma população global. Engl J Med. 2009; 360 (5): 491-9. Disponível em: http://www.nejm.org/doi/full/10.1056/NEJMsa0810119\#t=article, DOI:10.1056/NEJMsa0810119

KABLE, A. K.; GIBBERD, R. W.; SPIGELMAN, A. D. Adverse events in surgical patients in Australia. International Journal for Quality in Health Care, v. 14, n. 4, p. 269-276, 2002.

MELO, Francisca Nellie de Paula; DAMASCENO, Marta Maria Coelho. A construção de um software educativo sobre ausculta dos sons respiratórios. Revista da Escola de Enfermagem da USP, v. 40, n. 4, p. 563-569, 2006, DOI:10.1590/S0080- 62342006000400016.

MERRITT, AC. National culture and work attitudes in commercial aviation: a cross-cultural investigation [tese]. Austin: The University of Texas; 1996.

Organização Mundial da Saúde - OMS. Segundo desafio global para a segurança do paciente: cirurgias seguras salvam vidas (orientações para cirurgia segura da OMS). Rio de Janeiro: Organização Pan-Americana da Saúde, Ministério da Saúde, Agência Nacional de Vigilância Sanitária; 2009.

ROTHER, Mike; SHOOK, John. Aprendendo a enxergar: mapeando o fluxo de valor para agregar valor e eliminar o desperdício: manual de trabalho de uma ferramenta enxuta. Lean Institute Brasil, 2007.

SEXTON, John B. et al. The Safety Attitudes Questionnaire: psychometric properties, benchmarking data, and emerging research. BMC health services research, v. 6, n. 1, p. 44, 2006, DOI: 10.1186/1472-6963-6-44.

SILVA, Lúcia de Fátima Neves da et al. Reorientação do gerenciamento de risco hospitalar do Instituto Nacional de Traumatologia e Ortopedia. 2009

SORRA et al. Hospital survey on patient safety culture. Agency for Healthcare Research and Quality AHRQ, 2009.

SOUSA, Paulino Artur Ferreira de; SASSO, Grace Teresinha Marcon Dal; BARRA, Daniela Couto Carvalho. Contribuições dos registros eletrônicos para a segurança do paciente em terapia intensiva: uma revisão integrativa. Texto contexto - enferm., Florianópolis , v. 21, n. 4, p. 971-979, Dec. 2012, Disponível em: http://www.scielo.br/scielo.php?pid=S0104-07072012000400030\&script=sci_arttext DOI:10.1590/S010407072012000400030.

THIOLLENT, Michel. Metodologia da pesquisa-açâo. 14ª edição, São Paulo: Cortez, 2005.

VIACAVA, Francisco et al. Uma metodologia de avaliação do desempenho do sistema de saúde brasileiro. Ciência \& Saúde Coletiva, v. 9, p. 711-724, 2004.

World Health Organization - WHO. The conceptual framework for the International Classification for Patient Safety. Version 1.1. Final Technical Report. WHO; 2009. Disponível em: www.who.int/en/ 


\section{A IMPORTÂNCIA DO CONHECIMENTO DOS ACADÊMICOS DE ENFERMAGEM SOBRE RCP: UM ESTUDO DE REVISÃO}

CAROLAINE DA SILVA HIGGINS Acadêmica de enfermagem da Universidade Castelo Branco

CAIO CESAR ANDRADE DE ARIMATHÉA Acadêmico de enfermagem da Universidade Castelo Branco

KELLY CRISTINA FREITAS DA SILVA DOS SANTOS

Mestre em Enfermagem e Tecnologias, Docente em Enfermagem da Universidade Castelo Branco, Enfermeira do Instituto Nacional de Cardiologia

\section{SANDRA CONCEIÇÃO RIBEIRO CHÍCHARO}

Doutoranda pela UFF, Docente em enfermagem da Universidade Castelo Branco e Universidade São José, Enfermeira do Hospital Federal Cardoso Fontes

ADRIANA LOUREIRO DA CUNHA Mestre em Enfermagem pela EEAN/UFRJ, Docente em Enfermagem da Universidade Castelo Branco, Enfermeira da SMS/RJ

RESUMO: As patologias de origem cardiovasculares compõem um agravo de escala global, sendo a principal causa de óbito na faixa etária de 30 anos. Portanto a identificação prematura das vítimas em parada cardiorrespiratória (PCR) é de suma importância para manutenção da vida, sendo esta realizada através de manobras de reanimação cardiopulmonar (RCP). Estudos demonstram o grande déficit de conteúdo teórico e prático de graduandos de enfermagem quanto a correta identificação do PCR e na realização da $\mathrm{RCP}$, o que pode acarretar danos futuros quanto profissionais. Objetivo: Discutir, na perspectiva da RCP, as implicações da falta de conhecimento pelos acadêmicos de enfermagem durante o momento de Parada Cardiorrespiratória. Metodologia: Estudo de revisão bibliográfica da literatura com ênfase no nível de conhecimento de graduandos de enfermagem frente situações de PCR.

Resultados: Foram encontrados dez artigos no total, sendo desses $80 \%$ de revista de enfermagem, oito artigos a nível acadêmico e apenas dois a nível profissional, 20\% são de revista de cardiologia. Discussão: Reitere-se a importância dos futuros profissionais na implementação efetiva das manobras de RCP em situações limítrofes à vida, como a PCR, de modo a propiciar aumento na sobrevida. Essa capacitação deve ser realizada no início do curso e aprimoradas nos anos subsequentes, por docente capacitado. Conclusão: Conclui-se, portanto, que há presença de défice de conhecimento entre os acadêmicos de enfermagem durante a formação acadêmica acerca de como intervir de forma precoce, segura, eficaz e resolutiva em situações de parada cardiorrespiratória. Onde se faz necessário a implementação de medidas como a aula de conteúdo de suporte básico e avançado de vida na grade curricular acadêmica bem como dinâmicas de simulação realística, visando uma capacitação plena desses acadêmicos, futuros profissionais enfermeiros, prestador de assistência privativa de enfermagem ao paciente crítico.

PALAVRA-CHAVE: Enfermagem, acadêmicos de enfermagem, reanimação cardiopulmonar, suporte básico de vida, suporte avançado de vida.

ABSTRACT: Cardiovascular pathologies make up a global problem, being the main cause of 
death in the age group of 30 years. Therefore, the premature identification of victims in cardiorespiratory arrest (CRP) is of paramount importance for maintaining life, which is performed through cardiopulmonary resuscitation (CPR) maneuvers. Studies demonstrate the great deficit of theoretical and practical content of nursing students regarding the correct identification of PCR and in the performance of CPR, which can cause future damage as professionals. Objective: To discuss, from the perspective of CPR, the implications of the lack of knowledge by nursing students during the time of cardiac arrest. Methodology: Study of literature review with emphasis on the level of knowledge of nursing students facing situations of PCR. Results: Ten articles were found in total, of which $80 \%$ were from a nursing journal, eight articles from an academic level and only two from a professional level, 20\% from a cardiology journal. Discussion: The importance of future professionals in the effective implementation of CPR maneuvers in situations bordering on life, such as CRP, is reiterated in order to increase survival. This training must be carried out at the beginning of the course and improved in subsequent years, by a trained teacher. Conclusion: It is concluded, therefore, that there is a lack of knowledge among nursing students during academic training on how to intervene in an early, safe, effective and resolving manner in situations of cardiorespiratory arrest. Where it is necessary to implement measures such as the class of basic and advanced life support content in the academic curriculum as well as realistic simulation dynamics, aiming at the full training of these academics, future professional nurses, private patient care provider critical.

KEYWORDS: Nursing, nursing students, cardiopulmonary resuscitation, basic life support, advanced life support.

\section{INTRODUÇÃO}

As patologias de origem cardiovasculares compõem um agravo de escala global, sendo a principal causa de óbito em indivíduos do sexo masculino e feminino na faixa etária de 30 anos, corroborando com cerca de $20 \%$ dos óbitos, totalizando 962.931 mortes em 2009. Sobretudo no ano de 2015 houve um aumento significativo de mortes por doenças cardiovasculares, estimando-se 17,7 milhões de óbitos, correspondendo a 31\% de mortalidade a nível mundial. No Brasil, estima-se que, anualmente, ocorre em torno de 200 mil casos de parada cardiorrespiratória, porém deste montante metade dos casos acontecem em ambiente intra-Hospitalar e metade Extra-hospitalar. (Nascimento et al., 2018, Citolino et al.,2015, Mansur et al.,2016).

A parada cardiorrespiratória (PCR) é caracterizada pela interrupção da motilidade cardíaca e respiratória, provocando alteração ou perda do nível de consciência, com ausência de sinais de circulação ou pulso, podendo resultar em danos cerebrais irreparáveis. Sendo então considerada como a principal causa de morte súbita a nível mundial. No Brasil estima-se que mais de 200 mil pessoas, ao ano, são vítimas de complicações cardíacas como arritmias cardíacas e infarto agudo do miocárdio (IAM) (Resende et al.,2019).

A PCR está incluída como uma das emergências que aumentam o índice de morbidade e mortalidade, o que se configura a necessidade de um atendimento ágil, eficiente e seguro, visando elevar o número de sobrevida entre indivíduos em situação emergencial (Freire et al., 2017).

Em casos de PCR, a cada sessenta segundos reduz-se em 10\% as chances de reversão e manutenção da vida e após passados dez minutos, sem realização de manobras adequadas de reanimação a 
reversão do quadro torna-se improvável. Entretanto com a realização de manobras eficazes, aumentam-se as chances de continuidade da vida e a diminuição ou a ausência de sequelas neurológicas. Tornando-se indispensável a correta identificação em casos de PCR e condução de uma assistência sistematizada e padronizada, visando a segurança e danos mínimos ao socorrido (Freire et al., 2017, Moraes et al.,2017, Resende et al.,2019).

Para reverter a PCR são indispensáveis as manobras de Reanimação Cardiopulmonar (RCP), a qual estabelece um conjunto de procedimentos visando manter a viabilidade da circulação do sangue arterial (oxigenado) para o cérebro e órgãos vitais, retendo dessa forma a manutenção transitória das funções sistêmicas até que o retorno da circulação sanguínea seja restabelecido espontaneamente (Costa et al., 2020, Galvão et al., 2020).

Tais condutas de suporte ao PCR são denominadas de suporte básico de vida (SBV) e suporte avançado de vida (SAV). Entende-se por SBV, conjunto de ações e manobras que visam a manutenção ou restauração das condições homeostáticas da circulação e respiração, sendo estas de livre realização por leigos previamente treinados. Ressalta-se que em ambientes intra-hospitalares, considerando o fato de promover cuidado direto ao paciente, os enfermeiros são geralmente os primeiros a identificar e agir em casos de PCR, por meio do SBV, conjuntamente com o time de resposta rápida (TRR) e/ou acionamento da equipe do setor, afim de que se inicie as manobras de SAV. Mediante os fatos, o profissional enfermeiro, deve possuir agilidade, habilidade teórica e prática, rápido raciocínio clínico e estabilidade emocional frente situações emergenciais, entretanto, segundo estudos, o índice de conhecimento teórico-prático por parte dos profissionais e estudantes da área da saúde, no que tange as ações de PCR/RCP são deficientes ou de má qualidade (Resende et al.,2019, Citolino et al.,2017, Brandão et al.,2020).

A pesquisa tem como objetivo mostrar as dificuldades, que os acadêmicos possuem para atuar em possíveis situações de parada cardiorrespiratória, afim de auxiliar os professores na intensificação desses conteúdos, para que eles possam direcionar o foco de ensino da matéria justamente nos pontos mais fracos apresentados pelos estudantes, e com isso melhorar a qualidade dos conteúdos que são ensinados, visando reduzir a deficiência dos mesmos em situações de ação imediata.

\section{METODOLOGIA}

Trata-se de uma revisão integrativa da literatura, pois permite a síntese de estudos publicados e possibilita conclusões de uma particular área de estudo, além de apontar lacunas do conhecimento que necessitam de novos estudos.

O levantamento bibliográfico foi realizado na base de dados Literatura Latino- -Americana e do Caribe em Ciências da Saúde (LILACS), Banco de Dados em Enfermagem (BDENF) e Scientific Electronic Library Online (SciELO), para isso foram selecionados aqueles que obedeciam aos seguintes critérios: artigos publicados a partir de 2015, artigos em português e que envolviam a relação entre enfermagem e o conhecimento sobre o suporte básico e avançado de vida. 
Foram utilizados os seguintes descritores: Enfermagem, acadêmicos de enfermagem, reanimação cardiopulmonar, suporte básico de vida, suporte avançado de vida.

\section{ANÁLISE E DISCUSSÃO DOS DADOS}

Inicialmente foram filtrados e selecionados um total de 21 artigos, sendo 10 da SCIELO, 6 da LILACS e 5 da BDENF. Sendo todos em língua portuguesa. Após realizar os critérios de exclusão foram selecionados 10 artigos para compor essa revisão.

Portanto, foram selecionados e incluídos nesta revisão dez artigos. Ao analisar as publicações, verificou-se que dentre os dez artigos, 8 foram publicados por enfermeiros e 2 por médicos, sendo $80 \%$ foram publicados por Enfermeiros/Acadêmicos de enfermagem e 20\% por profissionais médicos.

Este dado corrobora com as mudanças na área da educação em enfermagem no Brasil, a qual vem passando por transformações frente às exigências de seu papel na formação de recursos humanos com perfil adequado às necessidades de saúde da população e à legitimidade de seu papel na produção de conhecimentos inovadores e de utilidade para a sociedade.

Segue abaixo o quadro 1, que apresenta os artigos selecionados a partir da busca estabelecida na metodologia, de acordo com os critérios de seleção. Os artigos estão distribuídos entre os anos de 2015 a 2020, publicados em diferentes periódicos.

Quadro 1. Artigos que compõe corpus da pesquisa, por título, ano, objetivo, conclusão.

\begin{tabular}{|c|c|c|c|}
\hline Título & Ano & Objetivo & Conclusão \\
\hline $\begin{array}{l}\text { Autoconfiança, conhe- } \\
\text { cimento e habilidade } \\
\text { acerca da ressuscitação } \\
\text { cardiopulmonar de in- } \\
\text { ternos de enfermagem }\end{array}$ & 2020 & $\begin{array}{l}\text { Avaliar autoconfiança, conhe- } \\
\text { cimento e habilidade acerca da } \\
\text { ressuscitação cardiopulmonar de } \\
\text { internos de enfermagem. }\end{array}$ & $\begin{array}{l}\text { Foi evidenciado fragilidades no conhe- } \\
\text { cimento e habilidade, o que destaca a } \\
\text { relevância de novas metodologias para } \\
\text { intensificar e garantir a efetividade do } \\
\text { processo de ensino-aprendizagem. }\end{array}$ \\
\hline $\begin{array}{l}\text { Simulação no ensino } \\
\text { de emergência para } \\
\text { estudantes de enferma- } \\
\text { gem }\end{array}$ & 2020 & $\begin{array}{l}\text { Objetivou-se avaliar o conheci- } \\
\text { mento de estudantes de gradua- } \\
\text { ção em enfermagem recém-in- } \\
\text { gressos antes e após a realização } \\
\text { de um treinamento sobre Supor- } \\
\text { te Básico de Vida (SBV) utili- } \\
\text { zando simulação. }\end{array}$ & $\begin{array}{l}\text { Conclui-se que o uso da simulação evi- } \\
\text { denciou evolução positiva do conheci- } \\
\text { mento nos conteúdos sobre a profundida- } \\
\text { de da compressão torácica, sequência da } \\
\text { RCP e a relação compressão-ventilação } \\
\text { por minuto na RCP. }\end{array}$ \\
\hline $\begin{array}{l}\text { Liderança do enfer- } \\
\text { meiro nos serviços de } \\
\text { urgencia e emergencia: } \\
\text { revisão integrativa }\end{array}$ & 2019 & $\begin{array}{l}\text { Analisar as evidências científi- } \\
\text { cas acerca da liderança do enfer- } \\
\text { meiro nos serviços de urgência e } \\
\text { emergência. }\end{array}$ & $\begin{array}{l}\text { Verificou-se a necessidade de aprimora- } \\
\text { mento do enfermeiro na habilidade de } \\
\text { liderança. Sendo uma estratégia de suma } \\
\text { importância para desenvolvimento pro- } \\
\text { fissional, visto que esta é uma habilidade } \\
\text { requerida por muitas instituições. }\end{array}$ \\
\hline
\end{tabular}




\begin{tabular}{|c|c|c|c|}
\hline $\begin{array}{l}\text { Conhecimento de } \\
\text { acadêmicos da saúde } \\
\text { sobre ressuscitação } \\
\text { cardiopulmonar no su- } \\
\text { porte básico de vida }\end{array}$ & 2019 & $\begin{array}{l}\text { Avaliar o conhecimento dos aca- } \\
\text { dêmicos da escola da saúde de } \\
\text { uma universidade privada sobre } \\
\text { o atendimento de ressuscitação } \\
\text { cardiopulmonar no suporte bási- } \\
\text { co de vida. }\end{array}$ & $\begin{array}{l}\text { Foi possível identificar que apenas } \\
\text { os alunos de dois cursos obtiveram de- } \\
\text { sempenho significativo, tendo em vista } \\
\text { que esse é um conhecimento essencial } \\
\text { em suas profissões. }\end{array}$ \\
\hline $\begin{array}{l}\text { Conhecimento dos } \\
\text { acadêmicos de enfer- } \\
\text { magem sobre suporte } \\
\text { básico de vida }\end{array}$ & 2019 & \begin{tabular}{|l|} 
Avaliar o conhecimento sobre \\
suporte básico de vida com ênfa- \\
se em parada cardiorrespiratória \\
de graduandos de Enfermagem, \\
antes e após a disciplina Saúde \\
do Adulto em Enfermagem. \\
\end{tabular} & $\begin{array}{l}\text { os estudantes apresentam conhecimen- } \\
\text { tos insuficientes para atuar, de forma } \\
\text { resolutiva, em um atendimento de vítima } \\
\text { em parada cardiorrespiratória. }\end{array}$ \\
\hline $\begin{array}{l}\text { Epidemiologia das } \\
\text { Doenças Cardiovascu- } \\
\text { lares em Países de Lín- } \\
\text { gua Portuguesa: Dados } \\
\text { do "Global Burden of } \\
\text { Disease", 1990 a } 2016\end{array}$ & 2018 & $\begin{array}{l}\text { Descrever as tendências de mor- } \\
\text { bidade e mortalidade por doen- } \\
\text { ças cardiovasculares (DCV) nos } \\
\text { PLP, entre } 1990 \text { e } 2016 \text {, estrati- } \\
\text { ficadas por sexo, e sua associa- } \\
\text { ção com os respectivos índices } \\
\text { sociodemográficos (SDI). }\end{array}$ & $\begin{array}{l}\text { A colaboração entre os PLP poderá per- } \\
\text { mitir que experiências exitosas no com- } \\
\text { bate às DCV sejam compartilhadas entre } \\
\text { esses países. }\end{array}$ \\
\hline $\begin{array}{l}\text { Validação de questio- } \\
\text { nário para a avaliação } \\
\text { do conhecimento de } \\
\text { docentes e discentes } \\
\text { de enfermagem sobre o } \\
\text { suporte básico de vida } \\
\end{array}$ & 2017 & $\begin{array}{l}\text { validar o conteúdo de um ques- } \\
\text { tionário para a avaliação do } \\
\text { conhecimento de docentes e } \\
\text { discentes de Enfermagem rela- } \\
\text { cionados ao suporte básico de } \\
\text { vida. }\end{array}$ & $\begin{array}{l}\text { o instrumento pode ser considerado váli- } \\
\text { do em seu conteúdo, com todos os itens } \\
\text { considerados adequados, tanto separada- } \\
\text { mente, como de maneira global. }\end{array}$ \\
\hline $\begin{array}{l}\text { Conhecimento de aca- } \\
\text { dêmicos de enferma- } \\
\text { gem sobre a reanima- } \\
\text { ção }\end{array}$ & 2017 & $\begin{array}{l}\text { Este estudo teve como objetivo } \\
\text { avaliar o conhecimento teórico } \\
\text { dos acadêmicos do curso de en- } \\
\text { fermagem de uma } \\
\text { Universidade da Grande Floria- } \\
\text { nópolis/SC sobre reanimação } \\
\text { cardiopulmonar. }\end{array}$ & $\begin{array}{l}\text { Salienta-se a importância na formação } \\
\text { profissional tendo como um dos enfo- } \\
\text { ques a reanimação cardiopulmonar. Este } \\
\text { estudo poderá contribuir para discussões } \\
\text { acerca da intensificação na formação dos } \\
\text { acadêmicos de enfermagem nos conteú- } \\
\text { dos teóricos e práticos relacionados à } \\
\text { parada cardiorrespiratória e manobras de } \\
\text { reanimação cardiopulmonar. }\end{array}$ \\
\hline $\begin{array}{l}\text { Tendências da Taxa de } \\
\text { Mortalidade por Doen- } \\
\text { ças Cardiovasculares } \\
\text { no Brasil, 1980-2012 }\end{array}$ & 2016 & \begin{tabular}{|l|} 
Este analisar as tendências re- \\
centes na mortalidade por doen- \\
ça isquêmica do coração (DIC) \\
e doenças cerebrovasculares \\
(DCbV) na população brasileira.
\end{tabular} & $\begin{array}{l}\text { A tendência da mort } \\
\text { rou de cair no Brasil }\end{array}$ \\
\hline $\begin{array}{l}\text { Fatores que compro- } \\
\text { metem a qualidade da } \\
\text { ressuscitação cardio- } \\
\text { pulmonar em unidades } \\
\text { de internação: percep- } \\
\text { ção do enfermeiro. }\end{array}$ & 2015 & $\begin{array}{l}\text { Identificar, na percepção dos } \\
\text { enfermeiros, os fatores que in- } \\
\text { terferem na qualidade do ressus- } \\
\text { citação cardiopulmonar (RCP) } \\
\text { em unidades de internação de } \\
\text { adultos e investigar a influência } \\
\text { de turnos de trabalho e tempo de } \\
\text { experiência profissional na per- } \\
\text { cepção destes fatores. }\end{array}$ & $\begin{array}{l}\text { A identificação de fatores que afetam a } \\
\text { qualidade da RCP na percepção dos en- } \\
\text { fermeiros serve como parâmetro para } \\
\text { implementar melhorias e treinamento da } \\
\text { equipe que atua nas unidades de interna- } \\
\text { ção. }\end{array}$ \\
\hline
\end{tabular}

Fonte: Os autores, 2020.

Os eventos catastróficos decorrentes da falta de assistência que podem se originar a cerca da falta de conhecimento teórico e prático da temática suporte básico e avançado de vida, sejam eles de ocorrência extra ou intra-hospitalar podem ser fatais se não houver a identificação e intervenção precoce. Sendo, portanto, considerado um cenário onde faz se necessário uma rápida identificação do 
ambiente geral do acidente e estado clínico do acidentado, visando garantir o aumento das chances de sobrevida desse indivíduo. Dessa maneira o risco representado pelo défice de conhecimento dos acadêmicos de enfermagem torna-se alarmante tendo em vista que serão futuros profissionais atuantes de cuidados privativos ao paciente crítico.

Visando uma capacitação plena desses acadêmicos de enfermagem quanto as temáticas SBV E SAV, diversas pesquisas têm sido desenvolvidas visando reconhecer a lacuna de conhecimento e identificar os melhores métodos a serem desenvolvidos a fim de se garantir que quanto futuros profissionais estejam plenamente capacitados a intervir de maneira rápida, precoce e eficaz ao paciente critico.

De acordo com Galvão, 2019 as orientações corretas da AHA para as condutas imediatas a uma identificação de PCR em APH, o conhecimento e as habilidades técnicas a serem realizadas aumentam as chances de vida da vítima. Os estudos analisados demonstraram que os estudantes do curso de enfermagem tiveram um desempenho positivo com relação aos demais cursos da saúde sobre identificação de parada cardiorrespiratória e suporte básico de vida.

Moraes, 2017, Freire, 2017 e Citolino, 2015, abordam sobre a implementação de questionários para realizar um levantamento geral com relação ao nível de conhecimento de discentes de enfermagem sobre suporte básico/avançado a vida diante de situações de PCR, considerando que o sucesso do atendimento ao paciente depende do conhecimento cientifico e habilidade pratica afim de se promover uma conduta eficaz.

Costa, 2020 diz que a aparada cardiorrespiratória é considerada um problema mundial de saúde, sendo caracterizado como uma condição na qual requer intervenção imediata visando a sobrevida. Com isso foi proposto a realização de treinamentos de suporte básico e avançado de vida com base no défice de conhecimento dos acadêmicos de enfermagem sobre RCP/PCR. Os artigos analisados demonstraram um resultado positivo após a realização de implementação de treinamentos de SBV/SAV.

\section{CONCLUSÃO}

Os estudos apresentados neste trabalho demostram que há presença de deficiência no conhecimento entre acadêmicos de enfermagem/enfermeiros sobre a identificação e intervenção de forma segura e de qualidade perante uma clínica de Parada cardiorrespiratória.

Entretanto, evidenciou-se que a falta de vivência desde a academia até a atuação profissional perante a situação de risco eminente de PCR pode modificar o resultado da atuação, podendo ocasionar danos irreparáveis pela intervenção inadequada.

Concluiu-se, portanto, que de acordo com os dados analisados que o treinamento teórico-prático se torna a forma mais eficaz de intervenção ao défice de conhecimento sobre SBV/SAV na atuação efetiva na RCP aumentando as habilidades e segurança do profissional enfermeiro na intervenção. 
É importante ressaltar que eventos com simulação realística e demais tecnologias de inovação no ensino prático em saúde como simuladores com resposta de eficácia podem garantir não apenas os conhecimentos que são pertinentes à teórica, mas também as habilidades que provém da prática e são fundamentais ao futuro profissional.

\section{REFERÊNCIAS}

Citolino Filho CM, Santos ES, Silva RCG, Nogueira LS. Fatores que comprometem a qualidade da ressuscitação cardiopulmonar em unidades de internação: percepção do enfermeiro. Rev Esc Enferm USP · 2015

Costa, Christefany Régia Braz; Melo, Elizabete Santos; Reis, Renata Karina. Simulação no ensino de emergência. Revista Cuidarte. 2020; 11(2): e853.

Freire, G. V. et al. Liderança do enfermeiro nos serviços de urgencia e emergencia: revisão integrativa. Braz. J. Hea. Rev., Curitiba, v. 2, n. 2, p. 6, 2029-2041, mar./apr. 2019.

Freire ILS, Santos FR dos, Nascimento ACS do et al. VALIDAÇÃO DE QUESTIONÁRIO PARA A AVALIAÇÃO DO CONHECIMENTO DE DOCENTES E DISCENTES DE ENFERMAGEM SOBRE O SUPORTE BÁSICO DE VIDA. Rev enferm UFPE on line., Recife, 11(12):4953-60, dec., 2017

Galvão da Silva BT, Andrade ES, Paiva RM, Lucas da Silva HL, Santos WN, Lima Neto AV. Conhecimento de acadêmicos da saúde sobre ressuscitação cardiopulmonar no suporte básico de vida. Rev Fun Care Online. 2019.

LIMA, S. G. et al. Educação Permanente em SBV e SAVC: impacto no conhecimento dos profissionais de enfermagem. Arquivo Brasileiro de Cardiologia, São Paulo, v. 93, n. 6, p. 630-636, maio 2009.

Mansur et al. Mortalidade por doenças cardiovasculares no Brasil. Arq Bras Cardiol. 2016; [online].ahead print, PP.0-0

Moraes CL, Vasconcelos PC, Souza, EA, et al. Conhecimento de Acadêmicos de enfermagem sobre a reanimação cardiopulmonar. 2017;7:e1779.

Nascimento B. R. et al. Epidemiologia das Doenças Cardiovasculares em Países de Língua Portuguesa: Dados do "Global Burden of Disease", 1990 a 2016. Arq. Bras. Cardiol. vol.110 no.6 São Paulo June 2018

Brandão et at. Autoconfiança, conhecimento e habilidade acerca da ressuscitação cardiopulmonar de internos de enfermagem. Rev Cuidarte 2020.

Resende RT, Barbosa ACS, Luiz FS et al. CONHECIMENTO DOS ACADÊMICOS DE ENFERMAGEM SOBRE SUPORTE BÁSICO DE VIDA. Rev enferm UFPE on line., Recife, 13(5):1231-6, maio., 2019 


\section{ATUAÇÃO DA ENFERMAGEM NA PARADA CARDIORRESPIRATÓRIA E NA REANIMAÇÃO CARDIOPULMONAR: UMA REVISÃO INTEGRATIVA}

JÚLYA DE ARAUJO SILVA MONTEIRO

Universidade Federal do Estado do Rio de Janeiro

(UNIRIO)

MARISTELA MOURA BERLITZ

Universidade Federal do Estado do Rio de Janeiro

(UNIRIO)

BEATRIZ GERBASSI COSTA AGUIAR

Universidade Federal do Estado do Rio de Janeiro

(UNIRIO)

CÁSSIO BAPTISTA PINTO

Universidade Federal do Estado do Rio de Janeiro

(UNIRIO)

\section{GICÉLIA LOMBARDO PEREIRA}

Universidade Federal do Estado do Rio de Janeiro

(UNIRIO)

TAMIRES ZÊBA GUIMARÃES

Universidade Federal do Estado do Rio de Janeiro

(UNIRIO)

\section{PATRÍCIA APARECIDA TAVARES}

MENDES

Universidade Federal do Estado do Rio de Janeiro

(UNIRIO)

DANIELA DE OLIVEIRA MATIAS

Universidade Federal do Estado do Rio de Janeiro

(UNIRIO)

RESUMO: Introdução: A parada cardiorrespiratória é uma emergência cardiovascular de grande prevalência, morbidade e mortalidade, sendo necessária reanimação cardiopulmonar eficaz e eficiente. Objetivo: identificar na literatura científica a importância da enfermagem, e sua atuação na parada cardiorrespiratória e na reanimação cardiopulmonar. Método: Revisão integrativa de literatura, estudo exploratório, qualitativo, formado pelos descritores: "Equipe de Enfermagem", "Parada Cardíaca" e "Reanimação Cardiopulmonar", interligados pelo operador "and", utilizados na Biblioteca Virtual em Saúde Brasil (BVS), Scientific Electronic Library Online (SciELO), PubMed Central (PMC) e Google Acadêmico, tendo como critérios de inclusão: textos na íntegra, em português, publicados de 2016 a 2020 que estivessem de acordo com o tema desta pesquisa. Foram excluídos estudos com resultados parciais, em outro idioma, e que estavam fora do recorte temporal. Resultados/Discussão: Foram encontrados 2.462 artigos, após aplicados os critérios, restaram 859 artigos, sendo selecionados inicialmente 112 trabalhos. Após leitura foram pré-selecionados 92 estudos, e com auxílio do Mendley foram elencados 38 para análise, 3 da BVS, 0 da SciELO, 0 da PubMed e 35 do Google Acadêmico. A maioria dos estudos, foi publicada no ano de 2017 (10), com abordagem quantitativa (17) e realizados no cenário intra-hospitalar (17). Os temas abordados pelos artigos foram os seguintes: Atuação da enfermagem frente à PCR (10); Conhecimento da enfermagem sobre PCR/ RCP (19); Atualização e Capacitação da equipe de enfermagem (05); e Dificuldades enfrentadas pela equipe durante a PCR/RCP (04). Conclusão: Os profissionais de enfermagem, em geral, são os primeiros que identificam e iniciam as manobras de RCP, sendo de extrema importância a atuação desses profissionais na PCR. No entanto, nota-se a necessidade de atualização e capacitação dessa classe para garantir uma assistência de qualidade, seguindo as diretrizes e protocolos mais recentes.

PALAVRA-CHAVE: Equipe de Enfermagem; Parada Cardíaca; Reanimação Cardiopulmonar. 
ABSTRACT: Introduction: Cardiorespiratory arrest is a cardiovascular emergency of great prevalence, morbidity and mortality, requiring effective and efficient cardiopulmonary resuscitation. Objective: to identify in the scientific literature the importance of nursing, and its role in cardiopulmonary arrest and cardiopulmonary resuscitation. Method: Integrative literature review, exploratory, qualitative study, formed by the keywords: "Nursing Team", "Cardiac Arrest" and "Cardiopulmonary Resuscitation", linked by the "and" operator, used in the Virtual Health Library Brazil (VHL), Scientific Electronic Library Online (SciELO), PubMed Central (PMC) and Google Scholar, having as inclusion criteria: texts in full, in Portuguese, published from 2016 to 2020 that were in accordance with the theme of this research. Studies with partial results, in another language, and which were outside the time frame were excluded. Results / Discussion: 2,462 articles were found, after applying the criteria, 859 articles remained, with 112 papers initially selected. After reading, 92 studies were pre-selected, and with the help of Mendley, 38 were listed for analysis, 3 from VHL, 0 from SciELO, 0 from PubMed and 35 from Google Scholar. Most studies were published in 2017 (10), with a quantitative approach (17) and carried out in the in-hospital setting (17). The topics covered by the articles were as follows: Nursing performance in the face of PCR (10); Nursing knowledge about PCR / RCP (19); Updating and training of the nursing team (05); and Difficulties faced by the team during PCR / RCP (04). Conclusion: Nursing professionals, in general, are the first to identify and initiate CPR maneuvers, with the performance of these professionals in PCR being extremely important. However, there is a need to update and train this class to ensure quality care, following the most recent guidelines and protocols. (250 a 300 palavras, espaçamento simples e alinhamento justificado).

KEYWORDS: Nursing team; Cardiac Arrest; Cardiopulmonary resuscitation.

\section{INTRODUÇÃO}

A parada cardiorrespiratória (PCR) é uma emergência cardiovascular de grande prevalência, morbidade e mortalidade, sendo necessária reanimação cardiopulmonar (RCP) eficaz e eficiente, baseada em protocolos e algoritmos que permitam que essa reanimação e assistência sejam de qualidade. Entretanto, algumas barreiras interferem na construção desses protocolos que influenciam na assistência, como, por exemplo, a escassez de dados na literatura científica sobre a incidência da parada cardiorrespiratória no Brasil. Porém, em geral, sabe-se que o principal ritmo de PCR extra-hospitalar é a Fibrilação Ventricular (FV) e a Taquicardia Ventricular (TV), quase 80\% dos eventos; e no intra-hospitalar, o ritmo de PCR mais comum é Atividade Elétrica Sem Pulso (AESP) ou assistolia. (SBC, 2019)

Diversos avanços na área foram realizados, abrangendo, por exemplo, a legislação sobre acesso público à desfibrilação e obrigatoriedade de disponibilização de DEAs (desfibriladores externos automáticos); e treinamento em RCP (ressuscitação cardiopulmonar). Estima-se que ocorram cerca de 200.000 PCRs ao ano, no Brasil, sendo metade dos casos em ambiente hospitalar, e a outra metade em ambientes como residências, shopping centers, aeroportos, estádios, etc. As arritmias extra-hospitalares costumam apresentar um prognóstico melhor se comparadas às intra-hospitalares, um dos motivos se deve ao fato de que, frequentemente, as intra-hospitalares resultam de estados progressivos de desgaste e deteriorização da saúde. (SBC, 2013)

Para que ocorro êxito na ressuscitação cardiopulmonar (RCP) deve existir um algoritmo ou uma cadeia que siga uma ordem lógica, garantindo a organização e a fluidez do atendimento. No 
contexto intra-hospitalar alguns aspectos são essenciais para o sucesso na assistência à parada cardiorrespiratória, são eles: Reconhecimento de PCR; Treinamento e implementação; Feedback durante a PCR; Ênfase na RCP; Criação de sistemas de times de resposta rápida e sistemas de times de emergência médica; Melhoria nas estruturas e nos sistemas de saúde; Cumprimento dos elos da cadeia de sobrevivência; Cuidados pós-PCR. (SBC, 2019)

Mediante à gravidade e importância da PCR e da RCP, nota-se a necessidade do preparo técnico-científico dos profissionais de saúde ao se depararem com o evento, sendo o ponto de partida o conhecimento, através deve os protocolos serão entendidos e praticados corretamente, sendo esse conhecimento, a base para a tomada de decisão, podendo assegurar a qualidade dos procedimentos executados. Além disso, não se pode negar que as habilidades devem ser aperfeiçoadas pela equipe, principalmente pela equipe de enfermagem, que está diretamente relacionada à assistência. (SALAZAR; GASPAR; SANTOS, 2017)

Dessa maneira, o presente estudo tem como objetivo identificar na literatura científica a importância da enfermagem, e sua atuação na parada cardiorrespiratória e na reanimação cardiopulmonar.

\section{MÉTODO}

Trata-se de uma revisão integrativa de literatura, sendo um estudo exploratório com abordagem qualitativa, que abrangeu o período de 2016 a 2020 sendo utilizadas as diretrizes SQUIRE, ENTREQ e COREQ para conferir confiabilidade e qualidade ao artigo. Esta pesquisa é formada por seis etapas. 1) Identificação do tema e seleção da questão da pesquisa; 2) Estabelecimento de critérios de inclusão e exclusão; 3) Buscar na literatura, definições das informações a serem extraídas dos estudos selecionados e categorização do estudo; 4) Avaliação dos estudos incluídos na revisão integrativa. 5) Interpretação dos resultados e 6) Apresentação da síntese do conhecimento (MENDES; SILVEIRA; GALVÃO, 2008).

Na primeira etapa, identificou-se o tema, atuação da enfermagem na reanimação cardiopulmonar (RCP) e parada cardiopulmonar (PCR), e formulou-se a questão norteadora através da estratégia do acrônimo PICo ( $\mathrm{P}=$ população, $\mathrm{I}=$ interesse, $\mathrm{Co}=$ contexto), utilizado em pesquisas não-clínicas, sendo definido como: $\mathrm{P}=$ Enfermagem, $\mathrm{I}=$ Atuação da enfermagem, $\mathrm{Co}=$ Parada Cardiorrespiratória e Reanimação Cardiopulmonar. Assim, foi determinada a questão norteadora: "Qual é a atuação da enfermagem na parada cardiorrespiratória e na reanimação cardiopulmonar?”, com a hipótese: “A Enfermagem possui um papel de grande importância na assistência à PCR e na RCP nos serviços de saúde".

A segunda e terceira etapas ocorreram as buscas na literatura e seleção dos artigos. Para a busca nas bases foram utilizados os descritores de ciência da saúde (Decs/MESH): "Equipe de Enfermagem", "Parada Cardíaca" e "Reanimação Cardiopulmonar". Os descritores foram utilizados isoladamente e combinados através do operador booleano“AND”. A busca nas bases de dados ocorreu no período de abril de 2020 a julho de 2020. Utilizou-se as bibliotecas virtuais Scientific Electronic 
Library Online (SciELO), PubMed Central (PMC) e Google Acadêmico. Optou-se pelas bases de dados: Literatura Latino-Americana e do Caribe em Ciências da Saúde (LILACS), Base de Dados de Enfermagem (BDENF) e Medical Literature Analysis and Retrieval System on-line (MEDLINE), sendo estas acessadas através da Biblioteca Virtual em Saúde (BVS).

Os critérios de inclusão foram textos na íntegra, em português, publicados de 2016 a 2020 cuja abordagem estivesse de acordo com o tema desta pesquisa, tendo como público-alvo, adultos. Foram excluídos, portanto, estudos com resultados parciais, não relacionados ao público adulto, monografias, trabalhos de conclusão de curso, publicados outro idioma que não o português, e que não se enquadravam no recorte temporal delimitado. Para organização dos artigos, foi utilizado o gerenciador de artigos científicos Mendeley ${ }^{\circledR}$. A Figura 1 ilustra a seleção dos artigos.

Figura 1. Fluxograma de seleção dos estudos

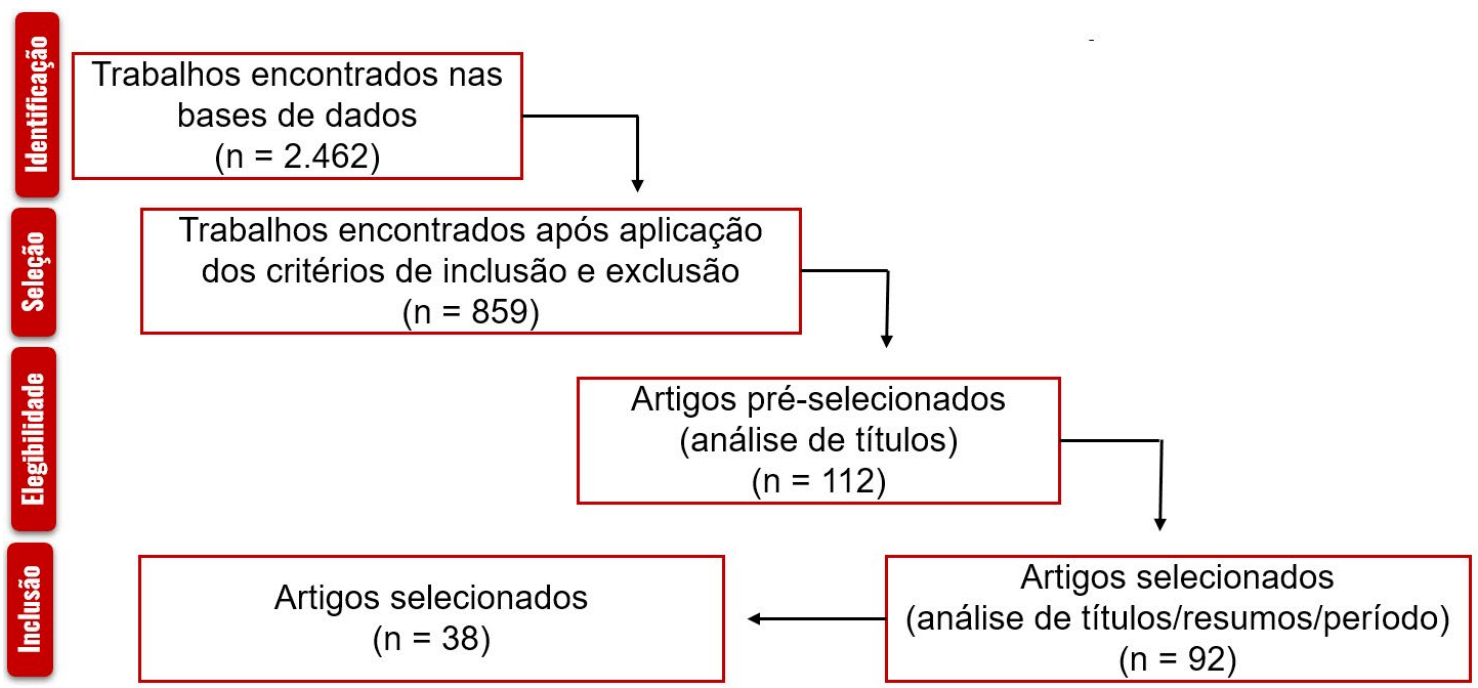

Autoria: Autoria Própria, 2020

$\mathrm{Na}$ terceira etapa também ocorreu a categorização dos estudos identificados que se relacionavam com o tema principal do estudo, atuação da enfermagem na RCP e PCR de forma indireta e direta, além de também estarem relacionados à pergunta norteadora. A categorização foi realizada de acordo com os temas dos artigos elencados, sendo encontradas 4 categorias para classificação dos estudos: 1) Atuação da enfermagem frente à PCR; 2) Conhecimento da enfermagem sobre PCR/RCP; 3) Atualização e Capacitação da equipe de enfermagem; 4) Dificuldades enfrentadas pela equipe durante a PCR/RCP

$\mathrm{Na}$ quarta etapa ocorreu a seleção da elegibilidade através da triagem e análise dos artigos, com leitura de título resumo, além da leitura do texto completo. Posteriormente, os dados extraídos dos artigos foram sintetizados em um quadro contendo categoria, artigos selecionados e características dos estudos. Após a catalogação do material, ocorreu uma análise mais profunda dos dados, de maneira crítica. 
A quinta e sexta etapas caracterizaram-se pela interpretação dos dados através de uma discussão dos resultados obtido, buscando comparar o conhecimento teórico e científico encontrados na literatura sobre o tema, para então, culminarem nas conclusões e implicações presentes nesta revisão integrativa. Para apresentação dos dados, optou-se pela análise descritiva dos dados colhidos e etapas realizadas.

Convém salientar que o estudo pode ter como limitações, o fato de considerar apenas as pesquisas com focadas no cuidado ao paciente adulto, além de ter um caráter mais generalista, não enfatizando a categoria de enfermagem (auxiliar de enfermagem, técnico de enfermagem ou enfermeiro), nem o cenário de pesquisa, englobando o ambiente intra-hospitalar, extra-hospitalar e buscas na literatura científica.

\section{RESULTADOS E DISCUSSÃO}

Foram encontrados 2.462 artigos, dos quais restaram 859 após serem aplicados os critérios de inclusão e exclusão. Posteriormente, foi realizada uma análise dos títulos sendo pré-selecionados 112 artigos, dos quais foram analisados novamente através não apenas dos títulos, mas também, resumos e ano de publicação, restando 92 artigos. Desses 92 artigos, foram selecionados para análise uma amostra de 38 estudos. No que se refere à base de dados, 3 artigos foram encontrados na BVS, 0 na Scielo, 0 no PubMed e 35 no Google Acadêmico.

De acordo com o ano de publicação, os artigos tiveram as seguintes distribuições: $13,16 \%$ $(n=05)$ em 2016; 26,31\% ( $n=10)$ em 2017; 23,68\% (n=9) em 2018; 18,42\% (n=07) em 2019 e 18,42\% $(n=07)$ em 2020. Quanto a abordagem empregada, 36,84\% $(n=14)$ dos estudos eram de caráter qualitativo, $18,42 \%(n=07)$ de caráter quanti-qualitativo e $44,73 \%(n=17)$ de caráter quantitativo.

Em relação ao cenário pesquisado, 44,74\% $(\mathrm{n}=17)$ dos estudos ocorreram no ambiente intra-hospitalar, 39,47\% (n=15) no ambiente extra-hospitalar (Unidades Básicas de Saúde, Unidades de Pronto Atendimento e Universidades); $15,79 \%(n=6)$ na busca da literatura científica.

Após leitura e análise dos artigos elencados, foram extraídas as principais informações e construído um quadro sinóptico que, mediante a grande amostra de 38 artigos, foi criado contendo categoria do estudo, de acordo com o tema principal; quantidade de artigos selecionados; e características dos estudos, conforme Quadro 1. 
Quadro 1: Categorização dos artigos elencados de acordo com o tema de pesquisa e principais aspectos

\begin{tabular}{|l|l|l|}
\hline Categoria do estudo & $\begin{array}{l}\text { Quantidade de artigos } \\
\text { selecionados }\end{array}$ & Características dos estudos \\
\hline $\begin{array}{l}\text { Atuação da enferma- } \\
\text { gem frente à PCR }\end{array}$ & 10 artigos & $\begin{array}{l}\text { Em geral, os estudos objetivavam identificar as atribui- } \\
\text { ços da enfermagem durante uma PCR/RCP, apontando } \\
\text { que é de extrema importância a atuação da equipe nes- } \\
\text { ses eventos. Salienta-se ainda, que situações de PCR/RCP } \\
\text { demandam muita tenção e tomada de decisão rápida e de } \\
\text { qualidade por parte da enfermagem, sendo necessário um } \\
\text { bom relacionamento multiprofissional e a constante capa- } \\
\text { citação e atualização dos profissionais da área. }\end{array}$ \\
\hline $\begin{array}{l}\text { Conhecimento da en- } \\
\text { fermagem sobre PCR/ } \\
\text { RCP }\end{array}$ & $\begin{array}{l}\text { Possuíam como objetivo comum identificar o grau de co- } \\
\text { nhecimento teórico da equipe de enfermagem quanto a } \\
\text { identificação de uma PCR e quanto a quais atitudes deve- } \\
\text { riam ser tomadas após essa identificação. A maioria dos } \\
\text { estudos utilizou formulários para avaliar os conhecimen- } \\
\text { tos dos profissionais, o que apontou um déficit quanto aos } \\
\text { conhecimentos na PCR e na RCP. }\end{array}$ \\
\hline $\begin{array}{l}\text { Atualização e Capaci- } \\
\text { tação da equipe de en- } \\
\text { fermagem }\end{array}$ & $\begin{array}{l}\text { De forma geral, os estudos buscavam propor instrumentos } \\
\text { que pudessem desenvolver competências dos profissionais } \\
\text { mediante uma PCR e uma RCP. A simulação realística e a } \\
\text { atuação da educação permanente foram as estratégias mais } \\
\text { estudadas pelas pesquisas. }\end{array}$ \\
\hline $\begin{array}{l}\text { Dificuldades enfrenta- } \\
\text { das pela equipe duran- } \\
\text { te a PCR/RCP }\end{array}$ & $\begin{array}{l}\text { Os estudos procuravam apontar e identificar fatores deter- } \\
\text { minantes que influenciam na assistência de enfermagem } \\
\text { ao paciente em PCR, necessitantes de RCP, sendo aponta- } \\
\text { dos o conhecimento dos profissionais, o processo de traba- } \\
\text { lho e o ambiente em que estão inseridos. }\end{array}$ \\
\hline
\end{tabular}

Fonte: Autoria própria, 2020

Sendo a parada cardiorrespiratória (PCR) um evento bastante frequente e com alto potencial para evolução a lesões muitas vezes irreversíveis ou a óbito, se não realizada uma ressuscitação cardiopulmonar (RCP) adequada (AGUIAR; ANDRADE, 2018). Assim, nota-se a importância de pesquisas e estudos voltados à temática, buscando aumentar sua visibilidade e proporcionando uma discussão quanto a atuação da equipe de enfermagem frente a PCR e à RCP. Dessa maneira, o presente estudo, categorizou os artigos selecionados em 4 partes para análise.

\section{Atuação da enfermagem frente à PCR}

A atuação da enfermagem na PCR é de extrema importância, principalmente, por serem, geralmente, os primeiros profissionais a identificarem uma parada cardiorrespiratória (PCR) e iniciarem as manobras de ressuscitação cardiopulmonar (RCP). Sendo assim, ressalta-se que a capacitação e o treinamento teórico-prático através de diretrizes e protocolos atualizados são primordiais na assistência, além do feedback entre profissionais, que pode garantir o sucesso no atendimento. (BRAGA, et.al. 2018; LIMA, INVENÇÃO; 2017) 
Vale também relembrar, que para uma atuação de qualidade, a enfermagem deve englobar a fundamentação teórica, a capacidade de liderança, o discernimento, a iniciativa, a habilidade de ensino, a maturidade e a estabilidade emocional, reconhecendo a evolução de um paciente a uma PCR e iniciando imediatamente a RCP, focando principalmente nas compressões torácicas e desfibrilação precoce. (SILVA, et.al. 2020; SANTOS, et. al. 2019)

\section{Conhecimento da enfermagem sobre PCR/RCP}

A maioria dos profissionais de enfermagem possuem conhecimentos básicos ou deficientes para uma atuação adequada diante uma parada cardiorrespiratória (PCR), e medidas de reanimação cardiopulmonar (RCP), sendo importante a identificação das carências quanto aos conhecimentos e a promoção de ações de capacitação sobre o tema. (SILVA, et. al. 2020; SOUSA, et.al. 2020) De acordo com os estudos, quanto maior o espaço de tempo entre as capacitações e/ou aperfeiçoamentos, maior o declínio de conhecimento dos profissionais sobre PCR e RCP. Além disso, fatores socioeconômicos e profissionais estão associados ao conhecimento da enfermagem. Sugere-se que ocorram treinamentos periódicos com menores intervalos para que ocorra aumento do grau de retenção de conhecimento da equipe de enfermagem. (LOPES, et.al. 2019)

Percebeu-se ainda, que os acadêmicos de enfermagem possuíam conhecimentos reduzidos e habilidades escassas sobre PCR e RCP, podendo comprometer a assistência prestada, culminando em um desfecho prejudicial ao paciente, contribuindo com o surgimento ou agravo de sequelas, ou então, levando ao óbito. Sendo assim, mostra-se a necessidade de aperfeiçoamento e maior ênfase a essa questão no curso de graduação, assim como, na vida cotidiana dos profissionais já formados, pois os protocolos e diretrizes são atualizados constantemente. (NOGUEIRA, et.al. 2018; MORAES, et.al. 2017)

\section{Atualização e Capacitação da equipe de enfermagem}

Como já mencionado, faz-se necessária a realização de capacitações periódicas, e treinamentos contínuos, vista a identificação de um déficit no conhecimento teórico-prático da equipe de enfermagem no atendimento à PCR e RCP, podendo causar implicações negativas à assistência. Para isso, duas estratégias se destacaram, o uso da simulação realística e a atuação da educação permanente. Observou-se também o impacto positivo da simulação realística no meio acadêmico, auxiliando na aquisição de conhecimento sobre a profundidade da compressão torácica, sequência da RCP e a relação compressão-ventilação por minuto na RCP. (SÉ, et.al. 2019; COSTA, et.al. 2020)

\section{Dificuldades enfrentadas pela equipe durante a PCR/RCP}

Algumas das dificuldades e alguns desafios aponteados pelos artigos elencados foram: conhecimento dos profissionais, o processo de trabalho e o ambiente em que estão inseridos. Dentre esses, mostra-se de maior carência e grande impacto o déficit de conhecimento quanto à assistência à PCR, 
o que aponta para um ponto chave: a qualificação profissional para um atendimento de qualidade, fazendo-se necessário a atuação da educação permanente para a equipe de enfermagem, bem como a criação de protocolos para padronizarem as ações da equipe visando o aumento da sobrevida e da qualidade de vida dos pacientes. (FERNANDES, et. al. 2016)

\section{CONCLUSÃO}

A presente revisão de literatura, possibilitou identificar na literatura científica, importância da enfermagem, e sua atuação na parada cardiorrespiratória e na reanimação cardiopulmonar. Os profissionais de enfermagem são, na grande maioria, os primeiros que identificam uma parada cardiopulmonar e iniciam as manobras de reanimação cardiopulmonar, sendo de extrema importância o reconhecimento adequado e a atuação desses profissionais. No entanto, nota-se a necessidade de atualização e capacitação dessa classe para garantir uma assistência segura e de qualidade, seguindo as diretrizes e protocolos mais recentes.

Através da revisão, foi possível observar que as pesquisas estão mais voltadas a aspectos relacionados aos conhecimentos da enfermagem sobre PCR/RCP; mas, que também abordam a atuação da profissão durante esses eventos; a necessidade de atualização e capacitação dos profissionais; e as dificuldades enfrentadas por essa classe no que se refere à temática. Nota-se que para uma atuação de qualidade por parte da enfermagem em PCR/RCP, esses 4 aspectos encontram-se interligados.

Espera-se que este estudo contribua com a produção científica na área da enfermagem, e busca fomentar discussões sobre a temática, visto sua importância. Além disso, cabe ressaltar que através desta pesquisa a profissão poderá se desenvolver ainda mais, encontrando suas fragilidades e usando-as para que sirvam como ponto de impulso para crescimento e valorização da categoria profissional, mostrando quão importante é a atuação do enfermeiro bem capacitado na PCR e na RCP. 


\section{REFERÊNCIAS}

AGUIAR, J.B.N.; ANDRADE, E.G.S. Conhecimento da equipe de enfermagem sobre o protocolo de ressuscitação cardiorrespiratória no setor de emergência. Goiás: Rev Inic Cient Ext. 1(4); 334-41, out/nov. 2018. Disponível em: $<$ https://revistasfacesa.senaaires.com.br/index.php/iniciacao-cientifica/article/view/111 >. Acesso em: 18 jun 2020.

BRAGA, R.M.N.; FONSECA, A.L.E.A.; RAMOS, D.C.L.; GONÇALVES, R.P.F.; DIAS, O. Atuação da equipe de enfermagem no atendimento à vítima de parada cardiorrespiratória no ambiente intra-hospitalar. São Caetano do Sul: Rev. Aten. Saúde. v. 16, n. 56, p. 101-107, abr./jun., 2018. Disponível em: <https://doi. org/10.13037/ras.vol16n56.4928>. Acesso em: 18 jun 2020.

COSTA, C.R.B.; MELO, E.S.; REIS, R.K. Simulação no ensino de emergência para estudantes de enfermagem. Revista Cuidarte. 11(2); mai/out, 2020. Disponível em: $<$ https://doi.org/10.15649/cuidarte.853 $>$. Acesso em: 19 jun 2020

FERNANDES, F.L.G.; SILVA, M.F.P.; PEREIRA, T.K.A.; BEZERRA, A.L.D.; TEMOTEO, R.C.A.; ROSA, V.C.S. Dificuldades encontradas pela enfermagem durante a assistência a vítima de parada cardiorrespiratória. Journal of Medicine and Health Promotion. 1(2):189-200; abr/jun, 2016. Disponível em: <http://jmhp.fiponline.edu.br/pdf/cliente=13-a354e0da0a9584dff4edcea8f9326482.pdf $>$. Acesso em: 20 jun 2020.

GUSKUMA, E.M.; LOPES, M.C.B.T.; PIACEZZI, L.H.V.; OKUNO, M.F.P.; BATISTA, R.E.A.; CAMPANHARO, C.R.V. Conhecimento da equipe de enfermagem sobre ressuscitação cardiopulmonar. Rev. Eletr. Enferm. [Internet]. 2019. Disponível em: <https://doi.org/10.5216/ree.v21.52253>. Acesso em: 19 jun 2020.

LIMA, A.R.; INVENÇÃO, A.S.S. Atuação do enfermeiro na parada cardiorrespiratória em uma unidade de pronto atendimento (UPA). São Paulo: Revista UNILUS Ensino e Pesquisa, v. 14, n. 36, p.272-279, jul./ set. 2017. Disponível em: <http://revista.unilus.edu.br/index.php/ruep/article/view/896/u2017v14n36e896>. Acesso em: 18 jun 2020

MENDES, K.D.S.; SILVEIRA, R.C.C.P.; GALVÃO, C.M.; Revisão integrativa: método de pesquisa para a incorporação de evidências na saúde e na enfermagem. Texto Contexto Enferm, Florianópolis, 17(4); 758-64, Out./Dez., 2008. Disponível em: <https://doi.org/10.1590/S0104-07072008000400018 >Acesso em: 18 jun 2020

MORAES, C.L.; VASCONCELOS, P.R.; SOUZA, E.A.; MARIA LIGIA DOS REIS BELLAGUARDA, M.L.R. Conhecimento de Acadêmicos de enfermagem sobre a reanimação cardiopulmonar. Minas Gerais: Revista de Enfermagem do Centro-Oeste Mineiro; 7(1779); 2017. Disponível em: <https://doi.org/10.19175/ recom.v7i0.1779>. Acesso em: 19 jun 2020.

NOGUEIRA, M.A.; RIBEIRO, A.L.C.V.; OLIVEIRA, C.C.R.B.; LOBO, F.F.; SOUSA, R.F.; MACIEL, D.O. Conhecimento de alunos de curso de graduação em enfermagem sobre reanimação cardiopulmonar. Rev Enferm UFPI; 7(2):11-7, Abr-Jun; 2019. Disponível em: <https://doi.org/10.26694/2238-7234.7211-17>. Acesso em: 19 jun 2020.

SALAZAR, E.R.S.; GASPAR, E.S.L., SANTOS, M.S. Diretrizes da American Heart Association para ressuscitação cardiopulmonar: conhecimento de socorristas. Rev baiana enferm. 2017;31(3):e20449. Disponível em: $<$ https://cienciasmedicasbiologicas.ufba.br/index.php/enfermagem/article/view/20449/15100> Acesso em: 18 jun 2020.

SANTOS, C.F.; COUTINHO, F.M.; SANTOS, H.F.; SOUZA, J.S.; SANTOS, J.B.; LIMA, L.S. Importância do enfermeiro frente a implementação do protocolo de RCP. São Paulo: Revista Recien. 9(28); 3-8, out/nov. 2019. Disponível em: <https://www.recien.com.br/index.php/Recien/article/view/310/pdf>. Acesso em: 18 jun 2020

SÉ, A.C.S.; REIS, A.L.; PAIVA, A.P.D.L.; PESTANA, L.C.; REIS, L.; GONÇALVES, R.C.S.; VIANNA, E.C.C. Atualização de trabalhadores de Enfermagem em suporte básico de vida. Rev enferm UFPE on line; 13(241981); 2019. Disponível em: <10.5205/1981-8963.2019.241981>. Acesso em: 19 jun 2020 
SILVA, D.W.R.; SENA, J.D.N.; MORAES, M.H.S.; SILVA, E.K.P.; MARIA, R.C.; PEDROSA, A.O.; CORREAA, A.A.; PORTO, G.A.C.; CHAVES, J.N.; LEYLA ADRIANO, L.G.O. Conhecimento teórico da enfermagem sobre parada cardiorrespiratória e ressuscitação cardiopulmonar. Revista Eletrônica Acervo Saúde. 12(6); 1-12, 2020. Disponível em: <https://doi.org/10.25248/reas.e2890.2020>. Acesso em: 19 jun 2020

SILVA, F.E.A.; LOPES, M.A.C.P.; MAFALDO, P.R.F.; SILVA, A.P.; NASCIMENTO, J.F.M.; AGUIAR, T.S.; ALMEIDA, K.A.B. Atuação do enfermeiro durante a parada cardiorrespiratória em pacientes críticos: revisão de literatura. Curitiba: Braz. J. Hea. Rev., v. 3, n. 2, p. 2783-2796 mar/abr. 2020. Disponível em: <10.34119/ bjhrv3n2-122>. Acesso em: 18 jun 2020.

SOCIEDADE BRASIELRIA DE CARDIOLOGIA. I Diretriz de Ressuscitação Cardiopulmonar e Cuidados Cardiovasculares de Emergência da Sociedade Brasileira de Cardiologia. Arq Bras Cardiol [Internet]. 2013. Revista da Sociedade Brasileira de Cardiologia. Vol. 101, No 2, Supl. 3, ISSN-0066-782X. Agosto 2013. Disponível em: $<$ http://publicacoes.cardiol.br/consenso/2013/Diretriz_Emergencia.pdf $>$. Acesso em:20 jun 2020.

SOCIEDADE BRASILEIRA DE CARDIOLOGIA. Atualização da Diretriz de Ressuscitação Cardiopulmonar e Cuidados Cardiovasculares de Emergência da Sociedade Brasileira de Cardiologia - 2019. [Internet] 2019. Disponível em: <http://publicacoes.cardiol.br/portal/abc/portugues/2019/v11303/pdf/11303025.pdf $>$. Acesso em: 20 jun 2020

SOUSA, P.R.C.; SILVA, V.A.; ALVES, B.P.; NUNES, P.T.C.M.; RODRIGUES, A.R.G.M. Conhecimento dos profissionais de enfermagem acerca da parada cardiorrespiratória e ressuscitação cardiopulmonar. Pombal, PB: Rev. Acta de Estudos Interdisciplinares; 02(01): 27-32, jan./dez. 2020. Disponível em: $<$ https://editoraverde. org/portal/revistas/index.php/aei/article/view/142>. Acesso em:19 jun 2020. 


\section{TRANSTORNO ESQUIZOAFETIVO: VÁRIAS FACES DE UMA SÍNDROME}

ALIALDO DANTAS DAMASCENA

Universidade Federal do Oeste da Bahia

JOSÉ CARLOS MORAIS DE OLIVEIRA

Universidade São Francisco na atenção especializada possibilitou um aprimoramento do diagnóstico de primeiro Transtorno psicótico a partir de critérios diagnósticos operacionais e instrumentos de avaliação padronizados (Del-Ben et al, 2010), reduzindo as chances de um diagnóstico inconclusivo que possa levar o paciente a um sofrimento crônico, juntamente com o círculo ao qual o mesmo está inserido, devido à ausência de intervenção eficaz.

RESUMO: O Transtorno Esquizoafetivo é uma entidade clínica variante dos Transtornos do humor e da esquizofrenia, caracterizada, no Código Internacional de Doenças - o CID-10, por sintomas afetivos e psicóticos simultâneos e igualmente proeminentes, apesar dos pacientes com Transtorno Esquizoafetivo e Esquizofrenia serem comumente incluídos nos mesmos estudos por falta de uma condição fisiopatológica das duas condições bem definida (Mathalon et al, 2010). Contudo, para além do Código Internacional de Doenças, desde sua terceira edição o Manual Diagnóstico e Estatístico de Transtornos Mentais - DSM - requer ao menos um período de duas semanas de delírios ou alucinações para o diagnóstico do Transtorno Esquizoafetivo, mesmo na ausência de sintomas afetivos destacados (Cheniaux et al, 2007). No Brasil, os serviços de emergências ainda se configuram como primeiro contato da maioria dos pacientes com algum sintoma psicótico e o sistema de saúde. Diante disso, a caracterização desse Transtorno ainda esbarra na dificuldade de diferenciação entre subtipos de esquizofrenia e Transtornos de humor, além da baixa estabilidade de diagnóstico elaborado em um único episódio de psicose e avaliação única, sem o provimento de informações por parte de acompanhantes, perdendo a observação da observação do quadro clínico. A agregação da psiquiatria e seus diversos serviços no setor de emergência e
PALAVRAS-CHAVE: Transtornos da Personalidade; Transtornos Psicóticos; Transtornos do Humor.

ABSTRACT: The Schizoaffective Disorder is a variant clinical entity of mood disorders and schizophrenia, characterized in the International Code of Diseases - ICD-10 by simultaneous and equally prominent affective and psychotic symptoms, although patients with Schizoaffective Disorder and Schizophrenia are commonly included in the same studies for lack of a well-defined pathophysiological condition of both conditions (Mathalon et al, 2010). However, in addition to the International Code of Diseases, since its third edition the Diagnostic and Statistical Manual of Mental Disorders - DSM - requires at least a twoweek period of delusions or hallucinations for the diagnosis of Schizoaffective Disorder, even in the absence of outstanding affective symptoms (Cheniaux et al, 2007). In Brazil, emergency services are still the first contact of most patients with some psychotic symptom and the health system. Therefore, the characterization of this disorder still encounters the difficulty of differentiating between subtypes of schizophrenia and mood disorders, besides the low diagnostic stability elaborated in a single episode of psychosis and 
unique evaluation, without the provision of information by the companions, losing the observation of the clinical picture. The aggregation of psychiatry and its various services in the emergency and specialized care sector has enabled an improvement in the diagnosis of the first psychotic disorder based on operational diagnostic criteria and standardized evaluation instruments (Del-Ben et al, 2010), reducing the chances of an inconclusive diagnosis that may lead the patient to chronic suffering, together with the circle in which he is inserted, due to the absence of effective intervention.

KEYWORDS: Personality Disorders; Psychotic Disorders; Mood Disorders.

\section{RELATO DE CASO}

Paciente JCM, masculino, 58 anos, aposentado por invalidez, natural de Fortaleza - CE e procedente de São Paulo - SP. Relata primeira crise em 1992, cursando com quadro maníaco, sintomas psicóticos e tentativa de suicídio. Iniciou tratamento psiquiátrico, seguido por instituições diversas, sendo acolhido pelo CAPS II em 2009, apresentando tristeza, irritabilidade, prejuízo do sono e relações familiares conflituosas. A partir daí, sucederam diversas internações hospitalares, juntamente com acompanhamento presencial compartilhado por equipes da Unidade Básica de Saúde (UBS) e CAPS II ao qual ele era vinculado. Em 2019, começou a apresentar recidiva dos sintomas, acompanhado de isolamento domiciliar, ausência de higiene e recusa alimentar, sensibilizado a retomar o acompanhamento presencial na UBS à qual equipe o acompanhava. Em 16 de abril de 2020, o CAPS II foi informado por familiar do paciente que o mesmo "havia ateado fogo à própria cabeça", sendo encaminhado ao hospital e recebendo cuidados até o dia da alta, 25 de abril de 2020. No mesmo dia, em visita domiciliar do CAPS II ao paciente, este relatou ter utilizado álcool em gel para higienizar a face e acendido um cigarro posteriormente, causando o acidente. Devido à necessidade, JCM foi referenciado ao serviço de acolhimento noturno no CAPS III, onde permaneceu por um período de duas semanas, com boa evolução e remissão sensível dos sintomas psicóticos, retornando ao acompanhamento pelo CAPS de origem. Atualmente, apresenta relativa estabilidade do quadro, com suas típicas alterações de pensamento e humor que causam prejuízos funcionais, fazendo uso de Olanzapina 10mg e Fluoxetina 20mg por dia.

\section{TRANSTORNO ESQUIZOAFETIVO: HISTÓRICO E RELAÇÕES}

O Transtorno Esquizoafetivo começou a ganhar definição na década de 70, quando Kraepelin, baseado em suas observações, distinguiu dois grupos principais de pacientes com quadro de psicose, classificando-os em "demência precoce" e "psicose maníaco-depressiva" a partir dos seus diferentes sintomas e cursos das doenças. Somente a partir da década de 90 o Transtorno Esquizoafetivo passou a ser encarado como uma entidade clínica única, sendo uma variante pertencente à esquizofrenia, aos Transtornos maiores de humor ou um espectro continuum entre ambas (Mathalon et al, 2010). 
A relação controversa entre o Transtorno Esquizoafetivo com a esquizofrenia e os Transtornos de humor fazem com que até hoje sua existência seja debatida, sem etiologia desconhecida, mas tendo como como suspeita de causa-base um desses Transtornos ou ambos (Coryell, 2008). De acordo com o Código Internacional de Doenças - CID-10 - o Transtorno Esquizoafetivo pode ser caracterizado por sintomas psicóticos e afetivos proeminentemente iguais e simultâneos. Já de acordo com o Manual Diagnóstico e Estatístico de Transtornos Mentais - DSM -, elaborado pela American Psychiatric Association, especificam, nas suas $3^{\mathrm{a}}$ e $4^{\mathrm{a}}$ edições (publicadas em 1987 e 1994, respectivamente) a presença concomitante de sintomas afetivos e psicóticos pelo paciente, além da presença de delírios ou alucinações por pelo menos duas semanas, na ausência de sintomas afetivos proeminentes (Cheniaux et al, 2007).

Vale ressaltar que os diagnósticos psiquiátricos se baseiam no princípio fundamental do julgamento clínico obtido a partir de anamnese psiquiátrica e exame físico mental do paciente, não existindo biomarcadores ou exames sorológicos para o diagnóstico dessas condições. Portanto, se torna imperioso o uso de critérios e instrumentos diagnósticos precisos desenvolvidos para este fim, tais como entrevistas e escalas, baseando, por fim, a precisão diagnóstica em critérios de confiabilidade e validade (Del-Ben et al, 2011).

\section{ALTERAÇÕES NEUROBIOLÓGICAS}

Em busca de elucidar as bases neurobiológicas do Transtorno Esquizoafetivo, alguns estudos adentraram o campo da neuroanatomia e neuroimagem desses pacientes, comparando-os com pacientes esquizofrênicos ou portadores de transtornos de humor. Amann e colaboradores (2015) identificaram uma redução disseminada de massa cinzenta no parênquima cerebral quando comparados aos

pacientes do grupo controle, enquanto os pacientes com transtorno bipolar não apresentavam essas alterações.

Madre et al (2016) identificaram resultados parecidos, a partir de buscas em bases de dados acerca de neuroimagem funcional e neuroimagem estrutural. Nesse estudo, a perda de volume de substância cinzenta - corpos celulares no parênquima cerebral - estava similarmente diminuída entre o transtorno Esquizoafetivo, aproximando-a por padrão da esquizofrenia do que dos aspectos fisiológicos do transtorno bipolar. Ao mesmo tempo, o estudo encontrou um melhor desempenho cognitivo nos pacientes que apresentavam apenas o transtorno afetivo bipolar, apesar dos aspectos de imagem isoladamente não constituírem fatores de diagnóstico conclusivo para transtornos psiquiátricos.

No âmbito cognitivo-comportamental, identificou-se que os pacientes com transtorno Esquizoafetivo e esquizofrenia são indistinguíveis em desempenho cognitivo geral e em estruturas cerebrais relacionadas a processamento social e comportamento e que a análise da neuroimagem estrutural não leva em conta o metabolismo regional entre diferentes regiões corticais, fluxo sanguíneo ou conectividade de dados pelo cérebro (Hartman et al, 2019). 


\section{CRITÉRIOS DIAGNÓSTICOS}

No mês de maio de 2013 foi editada a última revisão do DSM, alcançando a $5^{\text {a }}$ edição. A partir dessa nova atualização, foram revisados critérios de diagnóstico e tratamento para os transtornos mentais. Tendo em vista a proximidade e a distância concomitantes entre cada uma das patologias, destacamos os critérios diagnósticos da esquizofrenia e do transtorno Esquizoafetivo.

\section{1 - Esquizofrenia}

\begin{tabular}{|c|c|c|}
\hline \multicolumn{3}{|c|}{ Critérios diagnósticos de Esquizofrenia - DSM-V } \\
\hline & Critérios B & \\
\hline $\begin{array}{ll}\text { - } & \text { Delírios } \\
\text { - } & \text { Alucinações } \\
\text { - } & \text { Fala desorganizada } \\
\text { - } & \text { Comportamento desorganiza- } \\
\text { do ou catatônico } \\
\text { - } & \text { Sintomas negativos (expres- } \\
& \text { são emocional diminuída) }\end{array}$ & $\begin{array}{l}\text { Desde o início do quadro, uma } \\
\text { das áreas mais importantes do } \\
\text { funcionamento está compro- } \\
\text { metida. } \\
\square \text { Exemplo: trabalho, auto- } \\
\text { cuidado. }\end{array}$ & $\begin{array}{l}\text { - Sinais e sintomas devem per- } \\
\text { sistir por pelo menos } 6 \text { meses } \\
\text { O período de } 6 \text { meses deve in- } \\
\text { cluir pelo menos } 1 \text { mês de si- } \\
\text { nais ou sintomas dos critérios } \\
\text { A }\end{array}$ \\
\hline
\end{tabular}

Quadro 1 - Critérios diagnósticos para esquizofrenia de acordo com o DSM-V. Fonte: elaborada pelos autores.

\section{2 - Transtorno Esquizoafetivo}

\begin{tabular}{|c|c|c|}
\hline \multicolumn{3}{|c|}{ Critérios diagnósticos de Transtorno Esquizoafetivo - DSM-V } \\
\hline Critérios A & Critérios B & Critérios C \\
\hline $\begin{array}{l}\text { - Um período ininterrupto de } \\
\text { doença durante o qual há um } \\
\text { episódio depressivo maior ou } \\
\text { maníaco concomitante com o } \\
\text { Critério A da esquizofrenia. }\end{array}$ & $\begin{array}{l}\text { - Delírios ou alucinações por } \\
\text { duas semanas ou mais na au- } \\
\text { sência de episódio depressivo } \\
\text { maior ou maníaco durante a } \\
\text { duração da doença ao longo da } \\
\text { vida. }\end{array}$ & $\begin{array}{l}\text { - Os sintomas que satisfazem } \\
\text { os critérios para um episódio } \\
\text { de humor estão presentes na } \\
\text { maior parte da duração total } \\
\text { das fases ativa e residual da } \\
\text { doença. }\end{array}$ \\
\hline
\end{tabular}

Quadro 1 - Critérios diagnósticos para Transtorno Esquizoafetivo de acordo com o DSM-V. Fonte: elaborada pelos autores.

\section{AUTORES}

1. Alialdo Dantas Damascena - Acadêmico de Medicina. Universidade Federal do Oeste da Bahia.

2. Médico. Universidade São Francisco. Residência em Psiquiatria - Hospital Municipal do Campo Limpo. 


\section{REFERENCIAS}

AMANN, Benedikt L. et al. Brain structural changes in schizoaffective disorder compared to schizophrenia and bipolar disorder. Acta Psychiatrica Scandinavica, v. 133, n. 1, p. 23-33, 2016.

CHENIAUX, Elie et al. Does schizoaffective disorder really exist? A systematic review of the studies that compared schizoaffective disorder with schizophrenia or mood disorders. Journal of affective disorders, $\mathrm{v}$. 106, n. 3, p. 209-217, 2008.

CORYELL, William. Schizoaffective and Schizophreniform Disorders. In: HOSSEIN, Fatemi S. et al. The Medical Basis of psychiatry: third edition. Humana Press, 2008. p. 109-124.

DEL-BEN, Cristina Marta et al. Diagnóstico diferencial de primeiro episódio psicótico: importância da abordagem otimizada nas emergências psiquiátricas. Brazilian Journal of Psychiatry, v. 32, p. S78-S86, 2010.

FERREIRA, Jhennipher Tortola et al. Os Centros de Atenção Psicossocial (CAPS): uma instituição de referência no atendimento à saúde mental. Rev. Saberes, v. 4, n. 1, p. 72-86, 2016.

HARTMAN, Leah I.; HEINRICHS, R. Walter; MASHHADI, Farzaneh. The continuing story of schizophrenia and schizoaffective disorder: One condition or two? Schizophrenia Research: Cognition, v. 16, p. 36-42, 2019.

MADRE, Merce et al. Neuropsychological and neuroimaging underpinnings of schizoaffective disorder: a systematic review. Acta Psychiatrica Scandinavica, v. 134, n. 1, p. 16-30, 2016.

Manual diagnóstico e estatístico de transtornos mentais: DSM-5. 5. ed. Porto Alegre: Artmed, 2014.

MATHALON, Daniel H. et al. Neurophysiological distinction between schizophrenia and schizoaffective disorder. Frontiers in human neuroscience, v. 3, p. 70, 2010.

ROSA, Carlos Mendes; DE VILHENA, Junia. DO MANICÔMIO AO CAPS. DA CONTENÇÃO (IM) PIEDOSA À RESPONSABILIZAÇÃO. Barbarói, n. 37, p. 154-176, 2012.

TAVARES, Rosana Carneiro; SOUSA, Sônia M. Gomes. O usuário de CAPS: quem é esse sujeito?. Revista Psicologia e Saúde, 2009. 


\section{VALIDAÇÃO DA CURVA DE CALIBRAÇÃO (LINEARIDADE E HOMOCEDASTICIDADE) DO $\alpha$-PINENO POR CROMATOGRAFIA EM FASE GASOSA COM DETECÇÃO POR IONIZAÇÃO EM CHAMA (CG-DIC) NO ÓLEO ESSENCIAL DE SCHINUS TEREBENTHIFOLIUS RADDI}

\section{GLEICE CAROLINA SANTOS CRUZ} Mestre em Vigilância Sanitária. Fundação Oswaldo Cruz, Instituto Nacional de

Controle de Qualidade em Saúde - INCQS.

FRANCIELLE DAIANE LOPES LUNA Graduação em Matemática Bolsista FAPERJ Fundação Centro Universitário Estadual da Zona Oeste - UEZO

Laboratório de Análises Química e Biológica (LAQB)

\section{RAFAELLA CRUZ DE AZEVEDO SILVA} Mestre em Ciências

Fundação Oswaldo Cruz, Instituto de Tecnologia em Fármacos

Laboratório de Métodos Analíticos e Espectrometria de Massas (LACEM)

ADÉLIA MARA BELEM LIMA Mestre em Engenharia de Processos Químicos e Bioquímicos Universidade Federal do Rio de Janeiro Centro Nacional de Biologia Estrutural e Bioimagem - CENABIO, Unidade de Microscopia Avançada.

\section{MARCELO RAUL ROMERO TAPPIN}

Doutor em Ciências

Fundação Oswaldo Cruz, Instituto de Tecnologia em Fármacos

Laboratório de Métodos Analíticos e Espectrometria de Massas (LACEM)

\section{GLAUCIO DIRÉ FELICIANO}

Doutorado em Biologia (Biociências Nucleares) Fundação Centro Universitário Estadual da Zona Oeste - UEZO

Laboratório de Análises Química e Biológica (LAQB), Avenida Manuel Caldeira de
RESUMO: A espécie Schinus terebenthifolius Raddi. (Aroeira) é bastante conhecida por apresentar diversas atividades biológicas. Alguns autores descrevem que o $\alpha$ - pineno é o componente majoritário presente no óleo essencial dos frutos de $S$. terebenthifolius. Apesar da importância econômica e biológica do $\alpha$ - pineno verificamos na literatura a ausência de métodos analíticos que validem intralaboratorial, sob diferentes condições, em um intervalo de tempo justificado a função de calibração. Este trabalho teve como objetivo avaliação de linearidade e homocedasticidade através da preparação de três curvas de calibração em três dias distintos afim de verificar possíveis diferenças de comportamento linear do $\alpha$-pineno, do óleo essencial de $S$. terebenthifollius, com variação diária da análise, um dos requisitos mínimos para a validação de métodos analíticos. Verificamos que porcentagem do $\alpha$-pineno presente neste óleo essencial foi de $25,4 \%$ $\pm 0,7$. O teste de Levene indicou homogeneidade duvidosa dos dados do segundo dia e variâncias constantes no primeiro e terceiro dia de análise. A distribuição de probabilidade apresentou-se normal somente para o primeiro dia de avaliação. A regressão se mostrou significativa para os três dias de avaliação. Verificamos também que a li- 
nearidade foi comprovada na faixa de concentração avaliada, porém através do modelo linear obtido pelo MMQP. Concluímos que para cada dia de avaliação do óleo essencial deve-se preparar uma curva de calibração para quantificação do $\alpha$ - pineno, devido a significância estatística do intercepto em um dos três dias de avaliação.

Palavras chaves: Schinus terebenthifolius. Óleo essencial. CG/DIC, $\alpha$-pineno, validação.

\begin{abstract}
The species Schinus terebenthifolius Raddi. (Aroeira) is well known for presenting several biological activities. Some authors describe that $\alpha$-pinene is the major component present in the essential oil of $S$. terebenthifolius fruits. Despite the economic and biological importance of $\alpha$-pinene, we found in the literature the absence of analytical methods that validate intralaboratory, under different conditions, in a justified interval of time for the calibration function. This work aimed to evaluate linearity and homoscedasticity by preparing three calibration curves in three different days in order to verify possible differences in linear behavior of $\alpha$-pinene, of the essential oil of $S$. terebenthifollius, with daily variation of the analysis, a minimum requirements for the validation of analytical methods. We found that the percentage of $\alpha$-pinene present in this essential oil was $25.4 \%$ \pm 0.7 . Levene's test indicated doubtful homogeneity of data on the second day and constant variances on the first and third days of analysis. The probability distribution was normal only for the first day of assessment. The regression was significant for the three days of evaluation. We also verified that the linearity was proven in the evaluated concentration range, however through the linear model obtained by MMQP. We conclude that for each evaluation day of the essential oil, a calibration curve must be prepared to quantify $\alpha$-pinene, due to the statistical significance of the intercept on one of the three evaluation days.
\end{abstract}

Keywords: Schinus terebenthifolius, Essential oil, GC/FID, $\alpha$-pinene, validation.

\title{
INTRODUÇÃO
}

Os óleos essenciais e/ ou produtos derivados são empregados, industrialmente, como matérias-primas, insumos ou aditivos para as indústrias de alimentos, bebidas, farmacêutica, produtos de higiene e limpeza e cosmética (SEBRAE, 2020; IBGE, 2020 GOMES et al., 2013). Os óleos essenciais apresentam atividade antimicrobiana, antifúngica, antioxidante (CLEMENTE, 2006; DEGÁSPARI et al., 2005), uso veterinário (ARAUJO, 2010), propriedades sensoriais, entre outras (FRANZ, 2010; BIZZO et al., 2009).

As folhas e frutos da espécie Schinus terebenthifolius, por exemplo, é rica em óleos essenciais (GOMES et al., 2013; MATSUO, 2011; SILVA, 2010; SILVA et al., 2011; CLEMENTE, 2006; DEGÁSPARI et al., 2005; CHOWDHURY \& TRIPANI, 2001; SINGH et al., 1998;) e o preço destes é elevado (U\$800,00/L). Os óleos essenciais de Schinus terebenthifolius apresentam ação antioxidante, antiinflamatória, antibacteriana, cicatrizante, entre outras. Muitas destas atividades já foram comprovadas cientificamente (DEGÁSPARI et al., 2005). No entanto, apesar desta espécie apresentar uma grande dispersão no solo brasileiro, o custo do óleo ser elevado, poucas empresas no país o produzem. Isto se deve à falta de manutenção do padrão de qualidade dos óleos essenciais e baixos investimentos governamentais no setor, o que dificulta a sua comercialização (SEBRAE, 2020; BIALOSKORSKI NETO, 2009). 
Matsuo (2011) e Silva (2011) descrevem em seus respectivos trabalhos que o a- pineno é o componente majoritário presente no óleo essencial dos frutos de $S$. terebenthifolius. Já Dos Santos et al 2007 verificaram através da análise química mensal três exemplares (A, B e C) a presença de compostos químicos majoritários distintos ( $\underline{\mathrm{A}}$ o sabineno, o $\underline{\mathrm{B}}$ o $\alpha$-pineno e cariofileno e o $\underline{\mathrm{C}}, \alpha$-pineno e germacreno-D). Como todos esses exemplares se encontravam numa mesma região (Serra Gaúcha), a distâncias de cerca de 50m e são nativas espontâneas, os autores propuseram que os exemplares estudados pertenciam a dois quimiotipos (QT), são eles o: QT sabineno, representado pelo exemplar A e QT pineno germacreno-D, representado pelos exemplares B e C (DOS SANTOS et al., 2007).

Estudos demonstraram que o $\alpha$ - pineno apresenta efeito neuroprotetor em rato adultos machos Wistar com acidente vascular cerebral isquêmico através da atenuação da neuroinflamação e inibição da apoptose (KHOSHNAZAR, PARVARDEH \& BIGDELI, 2020), ação antiinflamatória por meio da supressão de proteínas quinases ativadas por mitogênio (MAPKs) e da via do fator nuclear kappa $B$ (NF-kB) em macrófagos peritoneais de camundongos (KIM et al., 2015), ação tripanomicida (SARTORELLI et al., 2012) e atividade antimicrobiana e neuroprotetora em neuroblastomas humanos, capaz de afetar o metabolismo energético de mitocôndrias isoladas através de pelo menos dois mecanismos, sendo eles o desacoplamento da fosforilação oxidativa ou inibição da cadeia transportadora de elétrons (COWAN, 1999; ABRAHIM et al., 2003; CHANG et al., 2007).

Apesar da importância econômica e biológica do alfa pineno verificamos na literatura a ausência de métodos analíticos que validem intralaboratorial a função de calibração, sob diferentes condições, em um intervalo de tempo justificado. Vale ressaltar que a validação por procedimentos interlaboratoriais é estabelecida por meio de estudos colaborativos. Contudo, esses estudos não são capazes de acompanhar a demanda por garantia de qualidade, a produção da fábrica e a velocidade dos avanços técnicos e científicos. Estas limitações das validações nterlaboratoriais por estudos colaborativos têm direcionado os laboratórios à adoção de procedimentos para validação intralaboratorial. Hoje a validação intralaboratorial é considerada apropriada para avaliar parâmetros de desempenho de um método (BRASIL, 2015; SOUZA et al., 2007). Além disso, a comunidade científica internacional reconhece a validação intralaboratorial como alternativa quando não se há disponibilidade de procedimento interlaboratorial ou quando os procedimentos não são aplicáveis (THOMPSON, ELLISON \& WOOD, 2002). Diante do exposto o presente trabalho objetiva a avaliação de linearidade e homocedasticidade através da preparação de três curvas de calibração em três dias distintos afim de verificar possíveis diferenças de comportamento linear do $\alpha$-pineno, presente no óleo essencial de $S$. terebenthifollius, com variação diária da análise, um dos requisitos mínimos para a validação de métodos analíticos (BRASIL, 2017; BRASIL, 2015) para a empresa Laszlo Ind. e Com. Ltda, localizada em Belo Horizonte, Minas Gerais, Brasil. 


\section{MATERIAL E MÉTODOS}

\section{1- Material vegetal}

O óleo essencial de Schinus terebenthifolius Raddi foi doado pela empresa Laszlo Ind. e Com. Ltda, localizada em Belo Horizonte, Minas Gerais. Parte do óleo essencial (10 mL; OE-1) foi acondicionado, hermeticamente, em frasco âmbar, enviado para o nosso Laboratório.

\section{2- Análise em CG-DIC e CG-EM}

As análises por cromatografia gasosa com Detector de Ionização em Chama e sistema de injeção automático (CG-DIC) e Cromatografia Gasosa acoplada a espectrômetro de massa (CG-EM) foram realizadas em triplicata na Plataforma de Métodos Analíticos (PMA) da Fundação Oswaldo Cruz - Farmanguinhos. Utilizou-se o CG-DIC da marca Schimadzu, modelo GC-6890 e coluna capilar de

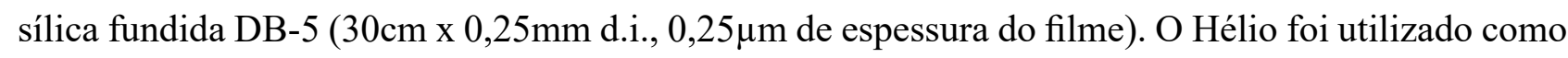
gás de arraste, com um fluxo de $1,0 \mathrm{~mL} / \mathrm{min}$. A temperatura do forno foi programada de $40^{\circ}(10 \mathrm{~min})$ a $260^{\circ}$ a $3^{\circ} \mathrm{C} / \mathrm{min}$. As temperaturas do injetor e do detector foram de $270^{\circ} \mathrm{C}$ e $280^{\circ} \mathrm{C}$, respectivamente. Utilizou- se um CG-EM da marca Schimadzu, modelo QP-5000- Quadrupole e EM operando com energia de ionização de 70 eV. Foi utilizada coluna capilar de sílica fundida DB-5 (30 mm x 0,25 mm d.i., $0,25 \mu \mathrm{M}$ de espessura do filme. O hélio foi utilizado como gás de arraste, com um fluxo de $1 \mathrm{~mL} /$ min com Split. As temperaturas do injetor e do detector foram de $270{ }^{\circ} \mathrm{C}$ e $280{ }^{\circ} \mathrm{C}$, respectivamente. As temperaturas do forno, do injetor e do detector foram as mesmas utilizadas no CG - DIC.

Os componentes foram identificados com base no índice de retenção (IR), determinados através da utilização de uma curva de calibração de uma série homóloga de $n$-alcanos $\left(\mathrm{C}_{7}-\mathrm{C}_{30}\right)$ injetados nas mesmas condições cromatográficas da amostra e nos modelos de fragmentação dos espectros de massas, sendo ambos comparados com dados da literatura (ADAMS, 2001).

A concentração dos constituintes foi calculada através da área integral de seus respectivos picos, relacionada com a área total de todos os constituintes da amostra, obtida pela análise em sistema de cromatografia em fase gasosa (VIEGAS \& BASSOLI, 2007).

\section{3- Avaliação da Linearidade e da homocedasticidade da Curva de Calibração}

A avaliação da linearidade foi conduzida, similarmente, aos procedimentos propostos por Souza e Junqueira (2005) exceto ao teste utilizado na normalidade da distribuição. Souza e Junqueira (2005) utilizou o teste de Ryan-Jonier ao invés do teste Shapiro-Wilk. O teste de Ryan-Jonier é similar ao potente teste de Shapiro-Wilk. Este último é um teste estatístico formal que abrange testes de hipóteses e propõe um teste de normalidade baseado na correlação linear entre as estatísticas observadas ordenadas e os valores esperados em uma distribuição normal, publicado em uma tabela de valores críticos. 
Para avaliação da linearidade do método foi feita analise em quadriplicata de cinco concentrações diferentes de $\alpha$ - pineno $(100,200,300,400$ e $500 \mu \mathrm{g} / \mathrm{mL})$. Foram preparadas três curvas de calibração em três dias distintos para verificação de possíveis diferenças de comportamento linear com variação do dia da análise (BRASIL, 2017; BRASIL, 2015, ICH Q2(R1), 2005; RIBANI et al., 2004; LEITE, 2002). A análise estatística dos dados foi efetuada através do software Statistica ${ }^{\circledR}$. As soluções padrão utilizadas na verificação foram preparadas a partir de uma solução mãe contendo padrão de $\alpha$ - pineno (Sigma Aldrich, Lote: 80796DJV) em concentração de 5000,00 mg/ mL. O padrão $\alpha$ - pineno e OE-1 foram pesados em balança analítica, Sartorius modelo CP225D, as soluções padrão foram preparadas em balões volumétricos $(5,10,25,50$ e $100 \mathrm{~mL})$ e pipetas volumétricas $(1$ a $5 \mathrm{~mL}$ ) calibrados. O solvente de diluição das soluções foi o diclorometano (Tedia, Lote: 912167R). As concentrações das soluções padrão para injeção foram de 100, 200, 300, 400 e $500 \mu \mathrm{g} / \mathrm{mL}$ de $\alpha$-pineno. O preparo das amostras para a quantificação foi realizado com uma diluição do OE-1 em diclorometano. A concentração da solução amostra para injeção foi de aproximadamente $10 \mathrm{mg} / \mathrm{mL}$.

\section{RESULTADOS E DISCUSSÃO}

A identificação dos constituintes presentes no óleo essencial de Schinus terebenthifolius Raddi $(1,5 \mathrm{~mL})$ foi efetuada através da comparação de seus espectros de massa com as bases de dados do sistema do equipamento do CG-EM. A figura 1 apresenta o Cromatograma dos íons totais do óleo essencial da espécie Schinus terebenthifolius. O perfil cromatográfico do óleo essencial apresentou maior composição de monoterpenos em relação aos sesquiterpenos e terpenos bicíclicos. O constituinte majoritário encontrado foi o $\alpha$-pineno (Figura 1, Tabela 1).

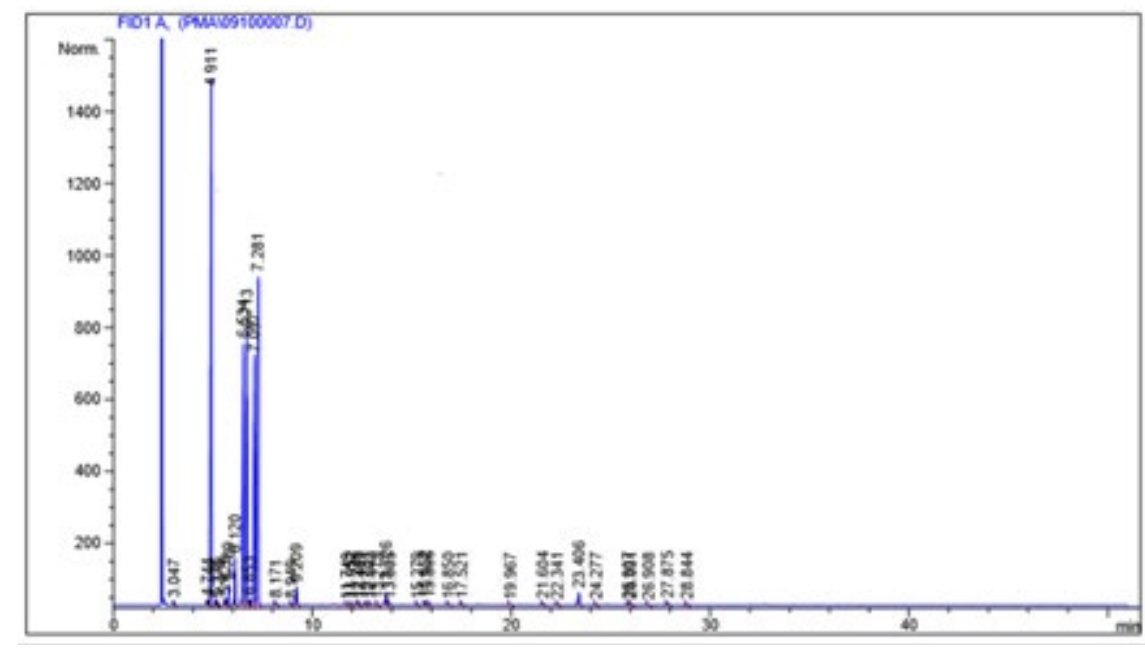

Figura 1. Cromatograma dos íons totais do óleo essencial de S. terebenthifolius 
Tabela 1. Composição do óleo essencial de Schinus terebenthifolius. O *IK corresponde ao Índice de Kovats da literatura e a \% aos valores normalizados das áreas.

\begin{tabular}{ccc}
\hline Substancias & $\mathbf{I K}_{\mathbf{1}}$ & $\mathbf{\%}$ \\
\hline$\alpha$ - pineno & 939 & 23.66876 \\
\hline canfeno & 953 & 2.20185 \\
\hline$\delta$-careno & 1011 & 15.69855 \\
\hline$\alpha$ - terpineno & 1018 & 14.81860 \\
\hline acetofenona & 1182 & 15.69865 \\
\hline Acetato de trans verbenila & 1292 & 20.08032 \\
\hline trans cariofileno & 1404 & 1.04626 \\
\hline & & Total $=$ \\
\hline
\end{tabular}

*(ADAMS, 2001)

Matsuo (2011) e Silva, (2011) descreveram em seus respectivos trabalhos que o a-pineno é o componente majoritário presente no óleo essencial de aroeira (S. terebenthifolius), juntamente, com o limoneno e o mirceno. Pawlowski et al. (2012) e Silva et al. (2010), demonstraram também a predominância dos monoterpenos nos óleos essenciais de aroeira destacando-se como constituinte majoritário o $\alpha$-pineno, com percentuais de $31,59 \%$ e $22,56 \%$, respectivamente.

Ribeiro (2015), Cole et al., (2014), Gehrke (2012) e Clemente (2006) identificaram o delta-careno como constituinte majoritário no óleo essencial dos frutos. No Brasil foram realizados um estudo, com 15 ecotipos de S. terebenthifolius. (GOMES et al., 2013). Os autores observaram que houve diferença significativa entre os indivíduos, com variação para o rendimento dos óleos essenciais e no constituinte majoritário. Eles observaram a formação de seis grupos, sendo dois deles formados por indivíduos com maior concentração de $\alpha$-pineno, $\alpha$-felandreno, o-cimeno, limoneno e $\beta$-felandreno (GOMES et al., 2013). A variação química observada para os componentes majoritários podem estar relacionadas à diferenças genotípicas, ontogênicas e ambientais (estação do ano, as condições geográficas, o período de colheita, a técnica de extração empregada entre outros), incluindo estresses bióticos e abióticos (MACIEL et al., 2002; SANGWAN et al., 2001). Já Dos Santos et al 2007 verificaram através da análise química mensal a presença de compostos químicos majoritários distintos nos três exemplares (A, B e C) estudados, são eles: $\underline{\mathrm{A}}$ o sabineno, $\underline{B}$ o $\alpha$-pineno e cariofileno e o $\underline{\mathrm{C}}$, $\alpha$-pineno e germacreno-D. A análise estatística mostrou que não houve variação da composição química do óleo essencial, para um mesmo exemplar, durante os meses de coleta. A análise estatística comprovou diferenças químicas entre os três exemplares estudados, quando comparados entre si em todos os meses avaliados (DOS SANTOS et al., 2007). Vale ressaltar que todos os acessos a esses exemplares se encontravam numa mesma região (Serra Gaúcha), a distâncias de cerca de 50m, portanto em condições ambientais e solo idênticos e são nativas espontâneas, consideradas como parte do grupo das pioneiras. Logo, os autores propuseram que os exemplares estudados pertenciam a dois quimiotipos (QT), são eles o: QT sabineno, representado pelo exemplar A e QT pineno germacreno-D, representado pelos exemplares B e C (DOS SANTOS et al., 2007). 
Neste trabalho observamos que a porcentagem do $\alpha$-pineno presente no OE- 1 foi $25,4 \% \pm$ 0,7. Essa composição química é compatível com os dados da literatura para constituintes voláteis de Schinus terebenthifolius (GOMES et al 2013; MATSUO, 2011; SILVA, 2011). Possivelmente, trata-se de um quimiotipo (DOS SANTOS et al., 2007) ou resultado das ações dos interferentes ambientais bióticos e abióticos (BARBOSA et al., 2010; SANGWAN et al., 2001; MACIEL et al. 2002).

A avaliação da função de calibração foi efetuada através da construção de três curvas de calibração com cinco níveis (Tabela 2 - 6), em quadruplicata com a injeção em três dias distintos. As concentrações foram 100, 200, 300, 400 e $500 \mu \mathrm{g} / \mathrm{mL}$ de $\alpha$-pineno. Toda a avaliação estatística encontra-se nas Tabelas 2 - 6. As figuras 2 -4 correspondem aos gráficos referentes às avaliações estatísticas.

Tabela 2. Avaliação estatística das curvas de calibração para $\alpha$-pineno (MMQO)

\begin{tabular}{|c|c|c|c|}
\hline \multirow[t]{2}{*}{ Testes } & $\begin{array}{l}\text { Curva } 1 \\
\text { PRIMEIRO DIA } \\
\quad(08 / 11)\end{array}$ & $\begin{array}{l}\text { Curva } 2 \\
\text { SEGUNDO DIA } \\
(12 / 11)\end{array}$ & $\begin{array}{l}\text { Curva } 3 \\
\text { TERCEIRO DIA } \\
\text { (14/11) }\end{array}$ \\
\hline & $\begin{array}{l}\text { Dados brutos re- } \\
\text { gressão linear or- } \\
\text { dinária }(k=5, n=4, \\
N=20)\end{array}$ & $\begin{array}{l}\text { Dados brutos re- } \\
\text { gressão linear or- } \\
\text { dinária }(k=5, n=4, \\
N=20)\end{array}$ & $\begin{array}{l}\text { Dados brutos re- } \\
\text { gressão linear or- } \\
\text { dinária }(k=5, n=4, \\
N=20)\end{array}$ \\
\hline $\begin{array}{l}\text { Avaliação de homogeneidade das variâncias - } \\
\text { Levene Test } \\
\mathrm{p} \leq 0,05 \text { - variâncias não constantes } \\
0,05<\mathrm{p} \leq 0,1 \text { - homogeneidade duvidosa } \mathrm{p}>0,1 \\
\text {-variâncias constantes }\end{array}$ & $\begin{array}{l}\mathrm{p}=0,396489 \mathrm{Va}- \\
\text { riâncias constantes }\end{array}$ & $\begin{array}{l}\mathrm{p}=0.050965 \text { Ho- } \\
\text { mogeneidade duvi- } \\
\text { dosa }\end{array}$ & $\begin{aligned} \mathrm{p}= & 0.279201 \text { Variân- } \\
& \text { cias constantes }\end{aligned}$ \\
\hline Equação da reta & $\begin{array}{l}\mathrm{b}_{0}=1.021803 \\
\mathrm{~b}_{1}=0.695474\end{array}$ & $\begin{array}{l}\mathrm{b}_{0}=2.279748 \\
\mathrm{~b}_{1}=0.682292\end{array}$ & $\begin{array}{l}b_{0}=2.577304 \\
b_{1}=0.692353\end{array}$ \\
\hline $\begin{array}{l}\text { Avaliação da significância do parâmetro } b_{0} \\
p \leq 0,05 \text { - intercepto estatisticamente significativo }\end{array}$ & $\begin{array}{c}\mathrm{p}=0.316254 \\
\text { Não significativo }\end{array}$ & $\begin{array}{c}\mathrm{p}=0.298641 \\
\text { Não Significativo }\end{array}$ & $\begin{array}{l}\mathrm{p}=0.111343 \\
\text { Não significativo }\end{array}$ \\
\hline $\begin{array}{l}\text { Avaliação da significância do parâmetro } b_{1} \\
p \leq 0,05 \text { - regressão estatisticamente significativa }\end{array}$ & $\begin{array}{l}\mathrm{p}<0,000001 \text { Esta- } \\
\text { tisticamente signifi- } \\
\text { cativo }\end{array}$ & $\begin{array}{l}\mathrm{p}<0,000001 \text { Esta- } \\
\text { tisticamente signifi- } \\
\text { cativo }\end{array}$ & $\begin{array}{l}\mathrm{p}<0,000001 \text { Esta- } \\
\text { tisticamente signifi- } \\
\text { cativo }\end{array}$ \\
\hline Erro padrão $b_{0}$ & 0.991202 & 2.130073 & 1.539260 \\
\hline Erro padrão $b_{1}$ & 0.002936 & 0.006279 & 0.004539 \\
\hline $\mathrm{R}^{2}$ & 0.99967937 & 0.99847775 & 0.99922684 \\
\hline $\mathrm{R}^{2}$ ajustado & 0.99966155 & 0.99839318 & 0.99918388 \\
\hline Erro padrão da estimativa & 1.8901 & 4.0619 & 2.9353 \\
\hline $\begin{array}{l}\text { Avaliação da distribuição dos resíduos (Teste de } \\
\text { normalidade) - Shapiro-Wilk’s } \mathrm{p} \leq 0,05 \text { - distri- } \\
\text { buição não normal dos resíduos }\end{array}$ & $\begin{array}{l}\mathrm{p}=0.16942 \text { Distri- } \\
\text { buição normal }\end{array}$ & $\begin{array}{l}\mathrm{p}=0.03334 \text { Distri- } \\
\text { buição não normal }\end{array}$ & $\begin{array}{l}\mathrm{p}=0.02860 \text { Distri- } \\
\text { buição não normal }\end{array}$ \\
\hline $\begin{array}{l}\text { Avaliação de outliers pelo teste de Grubbs } \\
(\alpha=0.05 ; \mathrm{k}=5, \mathrm{n}=4,1.46)\end{array}$ & Sem outliers & 2 outliers (1 e 17$)$ & 1 outlier (14) \\
\hline $\begin{array}{l}\text { Avaliação de autocorrelação dos resíduos Esta- } \\
\text { tística de Durbin-Watson - para } K=2 \text { e } \mathrm{N}=20 \\
\mathrm{~d}_{\mathrm{L}} \text { tab. }=1.201 \text { e } \mathrm{d}_{\mathrm{U}} \text { tab. }=1.411 \text { a } 5 \% \\
\text { Avaliação da autocorrelação positiva: } \\
\mathrm{d}<\mathrm{d}_{\mathrm{L}} \text { - resíduos positivamente autocorrelaciona- } \\
\text { dos } \\
\mathrm{d}_{\mathrm{L}} \leq \mathrm{d} \leq \mathrm{d}_{\mathrm{U}} \text { - teste inconclusivo } \\
\mathrm{d}>\mathrm{d}_{\mathrm{U}} \text { - resíduos não positivamente autocorrela- } \\
\text { cionados } \\
\text { Avaliação da autocorrelação negativa: } \\
(4-\mathrm{d})<\mathrm{d}_{\mathrm{L}}-\text { resíduos negativamente autocorrela- } \\
\text { cionados } \\
\mathrm{d}_{\mathrm{L}} \leq(4-\mathrm{d}) \leq \mathrm{d}_{\mathrm{U}} \text { - teste inconclusivo } \\
(4-\mathrm{d})>\mathrm{d}_{\mathrm{U}}-\mathrm{resíduos} \mathrm{não} \mathrm{negativamente} \mathrm{autocor-} \\
\text { relacionados }\end{array}$ & $\begin{array}{c}\mathrm{d}=2.376676 \text { Serial } \\
\text { corr. }=-0.194479 \\
\text { Resíduos não positi- } \\
\text { vamente ou negati- } \\
\text { vamente correlacio- } \\
\text { nados }\end{array}$ & $\begin{array}{c}\mathrm{d}=2.022469 \text { Serial } \\
\text { corr. }=-0.026061 \\
\text { Resíduos não positi- } \\
\text { vamente ou negati- } \\
\text { vamente correlacio- } \\
\text { nados }\end{array}$ & $\begin{array}{c}\mathrm{d}=1.947958 \\
\text { Serial corr. }= \\
0.019916 \\
\text { Resíduos não positi- } \\
\text { vamente ou negati- } \\
\text { vamente correlacio- } \\
\text { nados }\end{array}$ \\
\hline
\end{tabular}


Tabela 3. Avaliação estatística das curvas de calibração para $\alpha$-pineno com exclusão de outliers (MMQO).

\begin{tabular}{|c|c|c|}
\hline Testes & $\begin{array}{c}\text { Curva } 2 \\
\text { SEGUNDO DIA } \\
(12 / 11)\end{array}$ & $\begin{array}{c}\text { Curva } 3 \\
\text { TERCEIRO DIA } \\
(14 / 11)\end{array}$ \\
\hline & $\begin{array}{l}\text { Dados brutos regressão } \\
\text { linear ordinária }(k=5, n=4 \text {, } \\
N=18)\end{array}$ & $\begin{array}{l}\text { Dados brutos regressão linear } \\
\text { ordinária }(k=5, n=4, N=19)\end{array}$ \\
\hline $\begin{array}{l}\text { Avaliação de homogeneidade das variâncias - } \\
\text { Brown-Forsythe Test } \\
\mathrm{p} \leq 0,05 \text { - variâncias não constantes } \\
0,05<\mathrm{p} \leq 0,1 \text { - homogeneidade duvidosa } \mathrm{p}>0,1 \text {-va- } \\
\text { riâncias constantes }\end{array}$ & $\begin{array}{l}\qquad \mathrm{p}=0.058421 \\
\text { Homogeneidade duvidosa }\end{array}$ & $\begin{array}{l}\qquad \mathrm{p}=0.346426 \\
\text { Variâncias constantes }\end{array}$ \\
\hline Equação da reta & $\begin{array}{l}\mathrm{b}_{0}=1.673071 \\
\mathrm{~b}_{1}=0.686413\end{array}$ & $\begin{array}{l}\mathrm{b}_{0}=2.545819 \\
\mathrm{~b}_{1}=0.692661\end{array}$ \\
\hline $\begin{array}{l}\text { Avaliação da significância do parâmetro } \mathrm{b}_{0} \mathrm{p} \leq 0,05- \\
\text { intercepto estatisticamente significativo }\end{array}$ & $\begin{array}{l}\mathrm{p}=0.415947 \\
\text { Não Significativo }\end{array}$ & $\begin{array}{l}\mathrm{p}=0.125152 \\
\text { Não significativo }\end{array}$ \\
\hline $\begin{array}{l}\text { Avaliação da significância do parâmetro } b_{1} p \leq 0,05- \\
\text { regressão estatisticamente significativa }\end{array}$ & $\begin{array}{c}\qquad \mathrm{p}<0,000001 \\
\text { Estatisticamente significativo }\end{array}$ & $\begin{array}{l}\qquad \mathrm{p}<0,000001 \\
\text { Estatisticamente significativo }\end{array}$ \\
\hline Erro padrão $\mathrm{b}_{0}$ & 2.003390 & 1.578311 \\
\hline Erro padrão $b_{1}$ & 0.005966 & 0.004711 \\
\hline $\mathrm{R}^{2}$ & 0.99879262 & 0.99921416 \\
\hline $\mathrm{R}^{2}$ ajustado & 0.99871716 & 0.99916794 \\
\hline Erro padrão da estimativa & 3.4520 & 3.0060 \\
\hline $\begin{array}{l}\text { Avaliação da distribuição dos resíduos (Teste de } \\
\text { normalidade) - Shapiro-Wilk’s } p \leq 0,05 \text { - distribuição } \\
\text { não normal dos resíduos }\end{array}$ & $\begin{array}{l}\qquad \mathrm{p}=0.00888 \\
\text { Distribuição não normal }\end{array}$ & $\begin{array}{l}\qquad \mathrm{p}=0.02585 \\
\text { Distribuição não normal }\end{array}$ \\
\hline $\begin{array}{l}\text { Avaliação de autocorrelação dos resíduos Estatística } \\
\text { de Durbin-Watson - para } K=2 \text { e } N=20 \\
d_{L} \text { tab. }=1.201 \text { e } d_{U} \text { tab. }=1.411 \text { a } 5 \% \\
\text { Avaliação da autocorrelação positiva: } \\
d<d_{L} \text { resíduos positivamente autocorrelacionados } \\
d_{L} \leq d \leq d_{U} \text { - teste inconclusivo } \\
d>d_{U}-\text { resíduos não positivamente autocorrelacio- } \\
\text { nados } \\
\text { Avaliação da autocorrelação negativa: } \\
(4-d)<d_{L}-\text { resíduos negativamente autocorrelacio- } \\
\text { nados } \\
d_{L} \leq(4-d) \leq d_{U} \text { - teste inconclusivo } \\
(4-d)>d_{U}-\text { resíduos não negativamente autocorrela- } \\
\text { cionados }\end{array}$ & $\begin{array}{c}\mathrm{d}=1.794170 \\
\text { Serial corr. }=0.099834 \mathrm{Re}- \\
\text { síduos não positivamente ou } \\
\text { negativamente correlacio- } \\
\text { nados }\end{array}$ & $\begin{array}{l}\qquad \mathrm{d}=1.709506 \\
\text { Serial corr. }=0.140294 \\
\text { Resíduos não positivamente ou } \\
\text { negativamente correlacionados }\end{array}$ \\
\hline
\end{tabular}


Tabela 4. Avaliação estatística das curvas de calibração para $\alpha$-pineno (MMQP).

\begin{tabular}{|c|c|c|c|}
\hline Testes & $\begin{array}{c}\text { Curva } 1 \\
\text { PRIMEIRO DIA } \\
(08 / 11) \\
\end{array}$ & $\begin{array}{c}\text { Curva } 2 \\
\text { SEGUNDO DIA } \\
(12 / 11) \\
\end{array}$ & $\begin{array}{c}\text { Curva } 3 \\
\text { TERCEIRO DIA } \\
(14 / 11) \\
\end{array}$ \\
\hline & $\begin{array}{l}\text { Dados brutos re- } \\
\text { gressão linear pon- } \\
\text { derada }(k=5, n=4 \text {, } \\
N=20)\end{array}$ & $\begin{array}{l}\text { Dados brutos re- } \\
\text { gressão linear pon- } \\
\text { derada }(k=5, n=4, \\
N=20)\end{array}$ & $\begin{array}{l}\text { Dados brutos re- } \\
\text { gressão linear pon- } \\
\text { derada }(k=5, n=4, \\
N=20)\end{array}$ \\
\hline Equação da reta & $\begin{array}{l}\mathrm{b}_{0}=1.454900 \\
\mathrm{~b}_{1}=0.694056\end{array}$ & $\begin{array}{l}\mathrm{b}_{0}=2.249921 \\
\mathrm{~b}_{1}=0.682390\end{array}$ & $\begin{array}{l}\mathrm{b} 0=2.293002 \\
\mathrm{~b} 1=0.693280\end{array}$ \\
\hline $\begin{array}{l}\text { Avaliação da significância do parâmetro } b_{0} \\
p \leq 0,05 \text { - intercepto estatisticamente signifi- } \\
\text { cativo }\end{array}$ & $\begin{array}{l}\mathrm{p}=0.051846 \\
\text { Não significativo }\end{array}$ & $\begin{array}{l}\mathrm{p}=0.106812 \\
\text { Não Significativo }\end{array}$ & $\begin{array}{l}\mathrm{p}=0.039758 \text { Esta- } \\
\text { tisticamente signifi- } \\
\text { cativo }\end{array}$ \\
\hline $\begin{array}{l}\text { Avaliação da significância do parâmetro } b_{1} \\
p \leq 0,05 \text { - regressão estatisticamente significa- } \\
\text { tiva }\end{array}$ & $\begin{array}{l}\mathrm{p}<0,000001 \text { Esta- } \\
\text { tisticamente signifi- } \\
\text { cativo }\end{array}$ & $\begin{array}{l}\mathrm{p}<0,000001 \text { Esta- } \\
\text { tisticamente signifi- } \\
\text { cativo }\end{array}$ & $\begin{array}{l}\mathrm{p}<0,000001 \text { Esta- } \\
\text { tisticamente signifi- } \\
\text { cativo }\end{array}$ \\
\hline Erro padrão $\mathrm{b}_{0}$ & 0.698669 & 1.325385 & 1.034404 \\
\hline Erro padrão $b_{1}$ & 0.002678 & 0.005056 & 0.003947 \\
\hline $\mathrm{R}^{2}$ & 0.99973215 & 0.99901290 & 0.99941680 \\
\hline $\mathrm{R}^{2}$ ajustado & 0.99971727 & 0.99895807 & 0.99938440 \\
\hline Erro padrão da estimativa & 0.10876 & 0.20583 & 0.16067 \\
\hline $\begin{array}{l}\text { Avaliação de outliers da regressão (Resíduos } \\
\text { padronizados) }\end{array}$ & Sem outliers & Sem outliers & Sem outliers \\
\hline
\end{tabular}


Tabela 5. Avaliação estatística da curva global de calibração para o $\alpha$-pineno (MMQO).

\begin{tabular}{|c|c|}
\hline \multirow[t]{2}{*}{ Testes } & Curva global \\
\hline & $\begin{array}{c}\text { Dados brutos regressão linear ordiná- } \\
\text { ria }(k=5, n=12, N=60)\end{array}$ \\
\hline $\begin{array}{l}\text { Avaliação de homogeneidade das variâncias - Levene Test } \\
\mathrm{p} \leq 0,05 \text { - variâncias não constantes } \\
0,05<\mathrm{p} \leq 0,1-\text { homogeneidade duvidosa } \\
\mathrm{p}>0,1 \text { - variâncias constantes }\end{array}$ & $\begin{array}{l}\qquad \mathrm{p}=0.098468 \\
\text { Homogeneidade duvidosa }\end{array}$ \\
\hline Equação da reta & $\begin{array}{l}\mathrm{b}_{0}=1.968206 \\
\mathrm{~b}_{1}=0.690003\end{array}$ \\
\hline $\begin{array}{l}\text { Avaliação da significância do parâmetro } b_{0} \\
\mathrm{p} \leq 0,05 \text { - intercepto estatisticamente significativo }\end{array}$ & $\begin{array}{c}\mathrm{p}=0.063769 \\
\text { Não Significativo }\end{array}$ \\
\hline $\begin{array}{l}\text { Avaliação da significância do parâmetro } b_{1} \\
p \leq 0,05 \text { - regressão estatisticamente significativa }\end{array}$ & $\begin{array}{l}\qquad \mathrm{p}<0,000001 \\
\text { Estatisticamente significativo }\end{array}$ \\
\hline Erro padrão $\mathrm{b}_{0}$ & 1.041420 \\
\hline Erro padrão $b_{1}$ & 0.003075 \\
\hline $\mathrm{R}^{2}$ & 0.99884926 \\
\hline $\mathrm{R}^{2}$ ajustado & 0.99882942 \\
\hline Erro padrão da estimativa & 3.4397 \\
\hline $\begin{array}{l}\text { Avaliação da distribuição dos resíduos } \\
\text { (Teste de normalidade) - Shapiro-Wilk’s } \\
\text { p } \leq 0,05 \text { - distribuição não normal dos resíduos }\end{array}$ & $\begin{array}{l}\qquad \mathrm{p}=0.00004 \\
\text { Distribuição não normal }\end{array}$ \\
\hline Avaliação de outliers da regressão (resíduos padronizados) & 2 outliers $(41$ e 53$)$ \\
\hline $\begin{array}{l}\text { Avaliação de autocorrelação dos resíduos Estatística de Durbin-Watson - } \\
\text { para } K=2 \text { e } N=60 d_{L} \text { tab. }=1.549 \text { e } d_{U} \text { tab. }=1.616 \text { a } 5 \% \\
\text { Avaliação da autocorrelação positiva: } \\
d<d_{L} \text { resíduos positivamente autocorrelacionados } \\
d_{L} \leq d_{\leq} d_{U} \text { teste inconclusivo } \\
d>d_{U}-\text { resíduos não positivamente autocorrelacionados } \\
\text { Avaliação da autocorrelação negativa: } \\
(4-d)<d_{L}-\text { resíduos negativamente autocorrelacionados } \\
d_{L} \leq(4-d) \leq d_{U}-\text { teste inconclusivo } \\
(4-d)>d_{U}-\text { resíduos não negativamente autocorrelacionados }\end{array}$ & $\begin{array}{c}\mathrm{d}=2.117340 \\
\text { Serial corr. }=-0.065232 \\
\text { Resíduos não positivamente ou negativa- } \\
\text { mente correlacionados }\end{array}$ \\
\hline
\end{tabular}


Tabela 6. Avaliação estatística da curva global de calibração para $\alpha$-pineno (MMQP)

\begin{tabular}{|l|c|}
\hline \multicolumn{1}{|c|}{ Testes } & Curva global - MMQP \\
\cline { 2 - 2 } & Dados brutos \\
& regressão linear ponderada \\
& (k=5, n=12, N=58) \\
\hline Equação da reta & $\mathrm{b}_{0}=2.001998$ \\
& $\mathrm{~b}_{1}=0.689893$ \\
\hline Avaliação da significância do parâmetro $\mathrm{b}_{0}$ & $\mathrm{p}=0.004008$ \\
$\mathrm{p} \leq 0,05$ - intercepto estatisticamente significativo & Estatisticamente Significativo \\
\hline Avaliação da significância do parâmetro $\mathrm{b}_{1}$ & $\mathrm{p}<0,000001$ \\
$\mathrm{p} \leq 0,05$ - regressão estatisticamente significativa & Estatisticamente significativo \\
\hline Erro padrão $\mathrm{b}_{0}$ & 0.667993 \\
\hline Erro padrão $\mathrm{b}_{1}$ & 0.002552 \\
\hline $\mathrm{R}^{2}$ & 0.99920670 \\
\hline $\mathrm{R}^{2}$ ajustado & 0.99919303 \\
\hline Erro padrão da estimativa & 0.17983 \\
\hline Avaliação de outliers da regressão (Resíduos padronizados) & Sem outliers \\
\hline
\end{tabular}

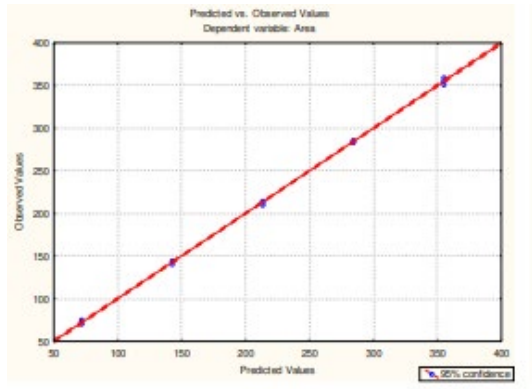

Valores previstos x observados para os dados da curva.

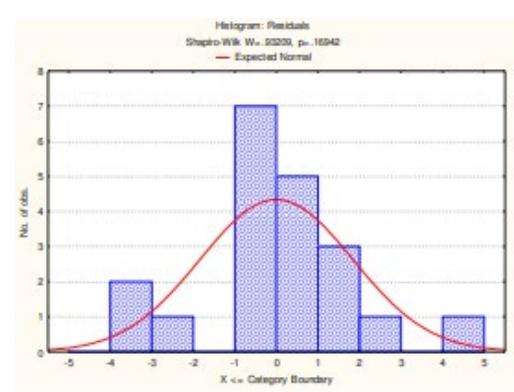

Gráfico de distribuição de probabilidade para os dados da curva

Figura 2. Gráficos das avaliações feitas no PRIMEIRO DIA

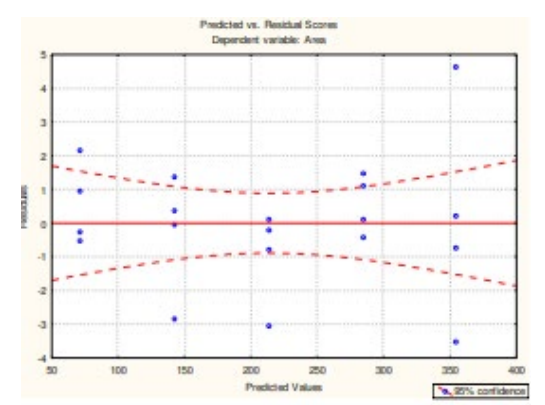

Valores previstos x resíduos para os dados da curva

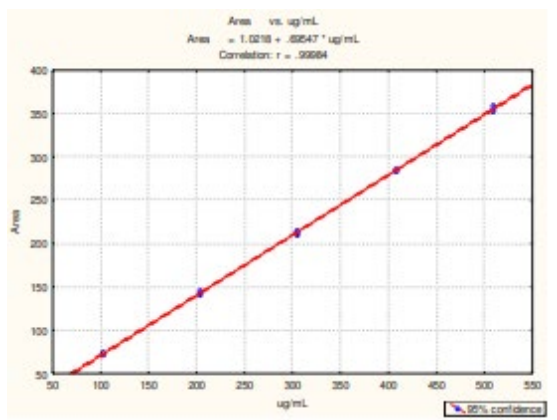

Função de calibração para os dados da curva 


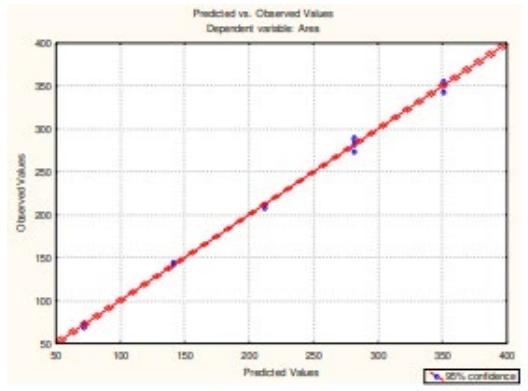

Valores previstos x observados para os dados da curva.

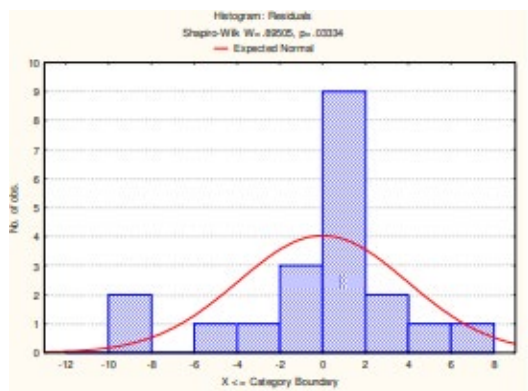

Gráfico de distribuição de probabilidade para os dados da curva

Figura 3. Gráficos das avaliações feitas no SEGUNDO DIA

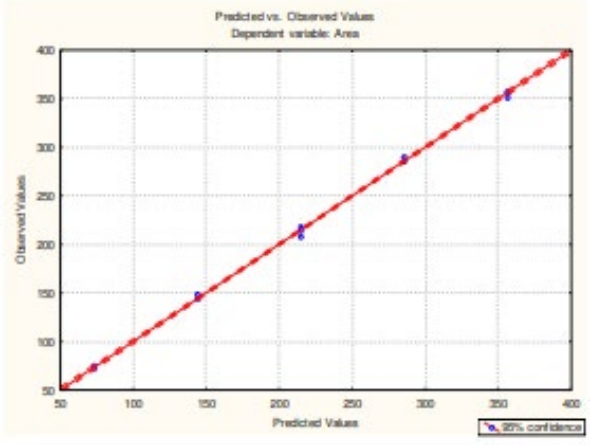

Valores previstos x observados para os dados da curva.

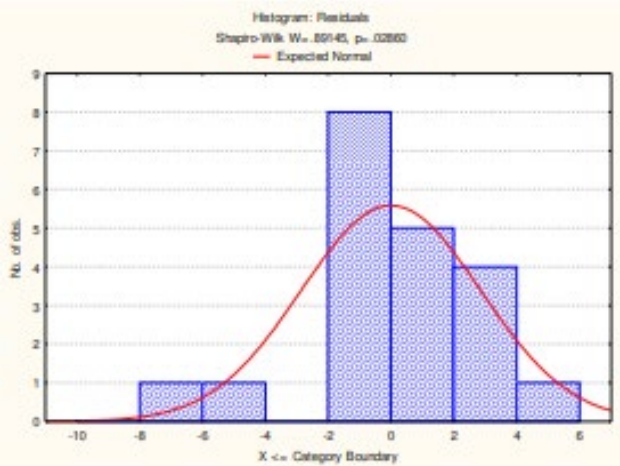

Gráfico de distribuição de probabilidade para os dados da curva

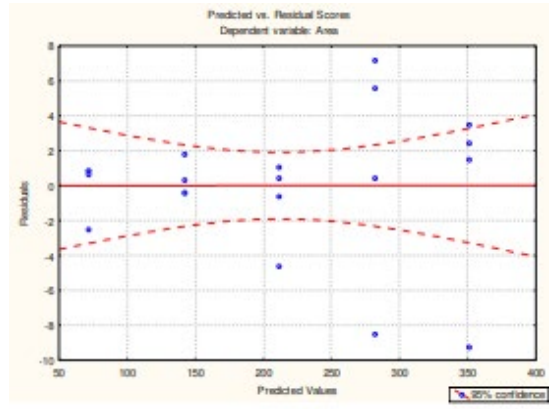

Valores previstos x resíduos para os dados da curva

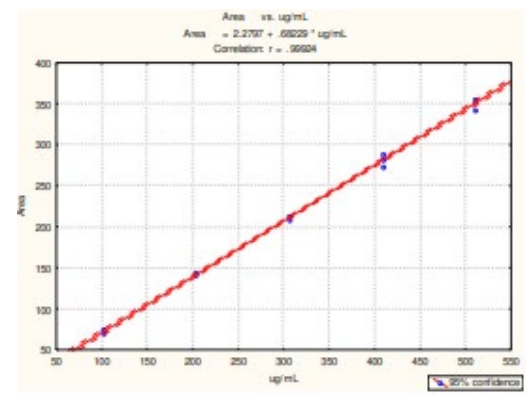

Função de calibração para os dados da curva

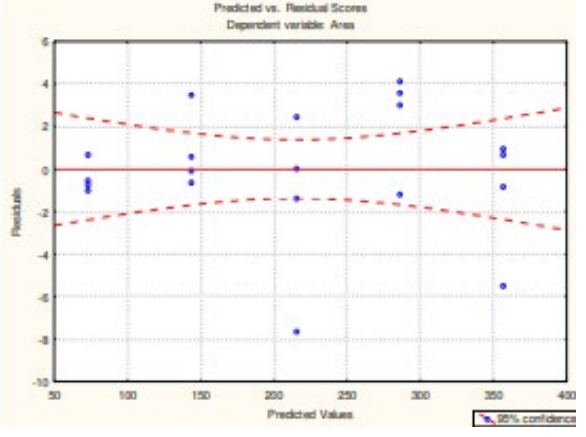

Valores previstos x resíduos para os dados da curva

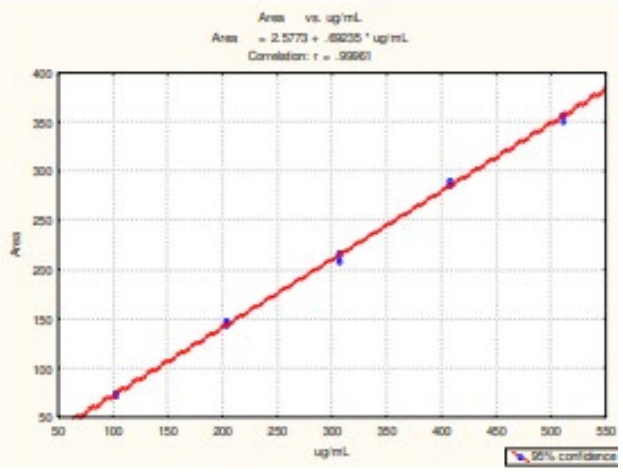

Função de calibração para os dados da curva

Figura 4. Gráficos das avaliações feitas no TERCEIRO DIA 
As análises estatísticas dos dados iniciaram-se pela avaliação da presença de valores aberrantes em cada conjunto de repetições em cada nível de concentração empregando-se a verificação de outliers através do teste de Grubbs a $\alpha=0.05$, supondo-se que os dados são provenientes de uma distribuição normal. Foram observados outliers em dois dias de preparação das curvas de calibração e estas observações foram retiradas do grupo de resultados.

Os testes utilizados para a avaliação da homogeneidade das variâncias foram os testes de Levene (teste paramétrico menos sensível à premissa de normalidade), aplicados aos dados brutos sem exclusão de observações (LEVENE, 1960) e o de Brown \& Forsythe, teste não paramétrico que corresponde a uma modificação do teste de Levene, aplicado nos casos de exclusão de resultados pela avaliação de outliers (BROWN \& FORSYTHE, 1974a, 1974b).

O teste de Levene indicou homogeneidade duvidosa dos dados do segundo dia e variâncias constantes no primeiro e terceiro dia. Entretanto, nos dois últimos dias, foram observados outliers que foram retirados e reavaliados pelo teste de Brown \& Forsythe (ALMEIDA et al., 2008), apresentando a mesma avaliação.

A distribuição de probabilidade dos resíduos da regressão foi avaliada nos três dias e apresentaram uma distribuição de probabilidade normal somente para o primeiro dia de avaliação, utilizando como critério o teste para verificação da normalidade de Shapiro-Wilk's (BUSSAB et al., 2003; ROYSTON, 1983).

Os desvios consideráveis da normalidade podem ser devidos à presença de dados aberrantes e à falta de ajuste do modelo. As opções para uma distribuição não normal é efetuar uma transformação de variáveis ( $\sqrt{ }, \log$, inverso, etc) ou usar o método dos mínimos quadrados generalizados. A autocorrelação dos resíduos foi avaliada pela estimativa $d$ de Durbin-Watson e os resíduos não apresentaram autocorrelação positiva ou negativa. Quando os resíduos estão autocorrelacionados a regressão linear ordinária não é adequada e pode-se tanto efetuar uma transformação de variáveis ( $\sqrt{ }, \log$, inverso, etc) quanto empregar-se o método dos mínimos quadrados generalizados (BUSSAB et al., 2003).

A avaliação da significância do intercepto foi adequada, pois se mostrou não significativo nos três dias. Se o intercepto é estatisticamente significativo, a hipótese de que ele seja igual a zero é rejeitada e a reta não passa pela origem. Isso equivale a dizer que existem evidências estatísticas a um nível de significância de 0,05 de que o verdadeiro intercepto não caia dentro dos limites do intervalo de confiança e que o sistema apresenta vício ou viés.

Entretanto, a regressão se mostrou significativa para os três dias de avaliação. Se o coeficiente angular é significativo, a hipótese de que ele seja igual a zero é rejeitada, ou seja, a regressão é significativa. Caso contrário, a não rejeição da hipótese nula decorre de duas possibilidades: a variável x não explica a variação de y ou a relação entre y e x não é linear (BUSSAB et al., 2003).

Como pode ser observado na Tabela 2, em dois dias houve uma violação das premissas para ajuste dos dados pelo Método dos Mínimos Quadrados Ordinários (MMQO), indicando que um ajuste mais adequado deve ser obtido pelo Método dos Mínimos Quadrados Ponderados (MMQP), o que de fato pôde ser constatado pelos menores erros padrão das estimativas, obtidos pelas equações ajustadas com ponderação. 
Na Tabela 6 observa-se também a violação das premissas quando avaliados os dados na equação global pelo MMQO. A RDC 166 (BRASIL, 2017) informa que a linearidade qualifica o procedimento analítico em obter resposta que seja diretamente proporcional a concentração do analito na amostra. Se o método for considerado linear, os resultados são proporcionais à concentração da amostra no intervalo determinado analisado. Diante do exposto verificamos que a linearidade foi comprovada na faixa de concentração avaliada por MMQP. A equação da reta global encontra-se na Tabela 6.

\section{CONCLUSÃO}

O perfil cromatográfico do óleo essencial de Schinus terebenthifollius Raddi apresentou maior composição de monoterpenos em relação aos sesquiterpenos e terpenos bicíclicos. O constituinte majoritário encontrado foi o $\alpha$-pineno. A porcentagem do $\alpha$-pineno presente no óleo essencial foi de $25,4 \% \pm 0,7$. Vale ressaltar que a literatura descreve, além do $\alpha$ - pineno, outros componentes monoterpenos majoritários. Possivelmente, os espécimes utilizados na obtenção do óleo essencial pela empresa Laszlo, consiste em um quimiotipo ou resultado das ações dos interferentes ambientais bióticos e abióticos. Esta variação química observada para os componentes majoritários que podem ocorrer em diferentes regiões, reforçam a importância de estudos com essa espécie em nível regional.

O teste de Levene indicou homogeneidade duvidosa dos dados do segundo dia e variâncias constantes no primeiro e terceiro dia. A distribuição de probabilidade apresentou-se normal somente para o primeiro dia de avaliação. A regressão se mostrou significativa para os três dias de avaliação. Verificamos também que a linearidade foi comprovada na faixa de concentração avaliada, porém através do modelo linear obtido pelo MMQP. Observamos que para cada dia de avaliação do óleo essencial deve-se preparar uma curva de calibração para quantificação do $\alpha$ - pineno, devido a significância estatística do intercepto em um dos três dias de avaliação. Como trata-se de uma validação preliminar ainda são necessários resultados que avaliem o efeito matriz, seletividade, repetitividade, precisão intermediária, recuperação e os limites de detecção e quantificação.

\section{AGRADECIMENTOS}

Os autores agradecem a empresa Laszlo Ind. e Com. pela doação do óleo essencial e a FAPERJ pelas bolsas concedidas. 


\section{REFERENCIAS BIBLIOGRÁFICAS}

ABRAHIM, D., FRANCISCHINI, A.C., PERGO, E.M., KELMER-BRACHT, A.M., ISHIIIWAMOTO, E.L. Effects of $\alpha$-pinene on the mitochondrial respiration of maize seedlings. Plant Physiology and Biochemistry, v. 41, p. 985-991, 2003.

ADAMS, R.P. Identification of Essential Oil Components by Gas Chromatography/ Quadrupole Mass Spectroscopy. USA: Allured Publishing Corporation, 2001.

ALMEIDA, A. de, ELIAN, S., NOBRE, J. Modificações e alternativas aos testes de Levene e de Brown e Forsythe para igualdade de variâncias e médias. Revista Colombiana de Estadística, v.31, n.2, p. 241-260, 2008.

ARAUJO, R.C. Óleos essenciais de plantas brasileiras como manipuladores de fermentação ruminal in vitro. 2010. 178 f. Tese (Doutorado em Ciência Animal e Pastagens). Escola Superior de Agricultura Luiz de Queiroz. Piracicaba, 2010. Versões impressas e eletrônica.

BARBOSA, L.C.A., DEMUNER, A.J., CLEMENTE, A.D., PAULA, V.F., ISMAILI, F.M.D. Seasonal variation in the composition of volatile oils from Schinus terebinthifolius Raddi. Química Nova, v. 30, n.8, p. 19591965, 2007.

BIALOSKORSKI NETO, S. Agronegócio cooperativo. In: BATALHA, M. O. (Coord.). Gestão agroindustrial. São Paulo: Atlas, 2009.

BIZZO, H. R.; HOVELL, A. M. C.; REZENDE, C. M. Óleos essenciais no Brasil: aspectos gerais, desenvolvimento e perspectivas. Química Nova, v. 32, n. 3, p. 588-594, 2009.

BRASIL, Ministério da Agricultura Pecuária e Abastecimento. Manual de garantia da qualidade analítica: áreas de identidade e qualidade de alimentos e de insumos / Ministério da Agricultura Pecuária e Abastecimento. Secretaria de Defesa Agropecuária. Brasília: MAPA/ACS, 2015.

BRASIL. Resolução de Diretoria Colegiada (RDC) no 166, de 24 de julho de 2017. Dispõe sobre a validação de métodos analíticos e dá outras providências. Diário Oficial da União, Brasília, DF, n. 141, 2017.

BROWN, M.B., FORSYTHE, A B. Robust Tests for the Equality of Variances. Journal of the American Statistical Association, v.69, p. 364-367, 1974a.

BROWN, M.B., FORSYTHE, A.B. The Small Sample Behavior of Some Statistics which Test the Equality of Several Means. Technometrics, v.16, p. 129-132, 1974b.

BUSSAB, W., MORETTIN, P.A. Estatística Básica, 5ª Edição, São Paulo: Editora Saraiva, 2003.

CHANG, H.J., KIM, H.J., CHUN, H.S. Quantitative structure-activity relationship (QSAR) for neuroprotective activity of terpenoids. Life Sciences, v. 80, p. 835-841, 2007.

CHOWDHURY, A.R.; TRIPANI, S. 2001. Essential oil from leaves of Schinus terebinthifolius Raddi. Ind. Perfumer, 45, 257-259.

CLEMENTE, A.D. Composição química e atividade biológica do óleo essencial da pimenta-rosa (Schinus terebinthifolius Raddi). 2006, 63 f. Tese (Tese de doutorado), Universidade Federal de Viçosa (UFV), Viçosa, 2006. Versões impressas e eletrônica.

COLE, E.R., DOS SANTOS, R.B., LACERDA JÚNIOR, V., MARTINS, J.D.L., GRECO, S.J., CUNHA NETO, A. Chemical composition of essential oil from ripe fruit of Schinus terebinthifolius Raddi and evaluation of its activity against wild strains of hospital origin. Brazilian Journal of Microbiology, v.45, n.3, p. 821828, 2014. 
COUTINHO, I.H.I.L.S.; TORRES, O.J.M.; MATIAS, J.E.F.; COELHO, J.C.U.; SAHLKE, JUNIOR, H.J.; AGULHAM, M.A.; BACHLE, E.; CAMARGO, P.A.M.; PIMENTEL, S.K.; FREITAS, A.C.T. Efeito do extrato hidroálcoólico de Aroeira (Schinus terebenthifolius raddi) na cicatrização de anas, tomosescolônicas. Estudo experimental em ratos. Acta Cirúrgica Brasileira, v. 21, n.3, 2006.

COWAN, M.M. Plant products as antimicrobial agents. Clinical Microbiology Review, v. 12, p. 564-582, 1999.

DEGÁSPARI, C.H., WASZCZYNSKYJ, N., PRADO, N.R.M. Atividade Antimicrobiana de Schinus terebenthifolius Raddi. Ciência e Agrotecnologia, v.29, n.3, p. 617-622, 2005.

DOS SANTOS, A.C.A., ROSSATO, M., AGOSTINI, F., DOS SANTOS, P.L.; SEREFINI, L.A.; MOYNA, P., DELLACASSA, E., Avaliação química mensal de três exemplares de Schinus terebinthifolius Raddi. Revista Brasileira de Biociências, v. 5, supl. 2, p. 1011-1013, 2007.

FRANZ, C.M. Essential oil research: past, present and future. Flavour Fragrance Journal, v. 25, p. 112-113, 2010.

GEHRKE, I.T.S. Estudo Químico e Biológico das espécies Schinus tentiscifolius, Schinus terebenthifolius, Schinus molle e Schinus polygamus (Anacardiaceae) do RS. 2012, $184 \mathrm{f}$. Tese (Tese de doutorado), Universidade Federal de Santa Maria (UFSM), Santa Maria, 2012, Versões impressas e eletrônica.

GOMES, L.J., SILVA-MANN, R., DE MATTOS, P.P., RABBANI, A.R.C. Pensando a biodiversidade: aroeira (Schinus terebinthifolius Raddi.). São Cristóvão: Editora UFS, 2013.

ICH Q2(R1), Validation of Analytical Procedures: Text and Methodology. Switzerland, November 2005. Disponível em: https://www.gmp-compliance.org/guidemgr/files/Q2(R1).pdf. Acesso: 28 de setembro de 2020.

INSTITUTO BRASILEIRO DE GEOGRAFIA E ESTATÍSTICA - IBGE/ SIDRA, Pesquisa Industrial Anual - Sistema IBGE de Recuperação de Dados Automática. 2020. Disponível em: https://sidra.ibge.gov.br/home/ pimpfbr/brasil. Acesso: 2 de outubro de 2020.

KHOSHNAZAR, M., PARVARDEH, S., BIGDELI, M.R. Alpha-pinene exerts neuroprotective effects via anti-inflammatory and anti-apoptotic mechanisms in a rat model of focal cerebral ischemia-reperfusion. Journal of Stroke and Cerebrovascular Diseases, v.29, n.8, p. 1049772020, 2020.

KIM, D.S., LEE, H.J., JEON, Y.-D., HAN, Y.H., KEE, J.Y., KIM, H.J., SHIN, H.J., KANG, J.W., LEE, B.S., KIM, S.H., KIM, S.J., PARK, S.H., CHOI, B.M., PARK, S.J., UM, J.Y. Alpha-Pinene Exhibits Anti-Inflammatory Activity Through the Suppression of MAPKs and the NF-kB Pathway in Mouse Peritoneal Macrophages. The American Journal of Chinese Medicine, v.43, n.04, p. 731-742, 2015.

LEITE, F. Validação em Análise Química, 4a ed., Campinas: Editora Átomo, 2002.

LEVENE, H. In Contributions to Probability and Statistics, OLKIN, I., GHURYE, S.G., HOEFFDING, W., MADOW, W.G., MANN, H.B. eds.; Stanford University Press: Stanford, 1960.

MACIEL, M.A.M., PINTO, A.C., VEIGA-JUNIOR, V.F. Plantas medicinais: a necessidade de estudos multidisciplinares. Química Nova, v. 25, n. 3, p. 429-438, 2002.

MATSUO, A.L., FIGUEIREDO, C.R., ARRUDA, D.C., PEREIRA, F.V., SCUTTI, J.A.B., MASSAOKA, M.H., TRAVASSOS, L.R., SARTORELLI, P., LAGO, J.H.G. Alpha-Pinene isolated from Schinus terebinthifolius Raddi (Anacardiaceae) induces apoptosis and confersanti metastatic protection in a melanoma model. Biochemical and Biophysical Research Communications, v. 411, n.2, p. 449-454, 2011.

PAWLOWSKI, U., KALTCHUK-SANTOS, E., ZINI, E.B., SOARES, G.L.G. Óleos essenciais de Schinus terebinthifolius e $S$. molle (Anacardiaceae): indutores mitodepressivos e aneugênicos em meristemas de raiz de cebola e alface. South African Journal of Botany, v,80, p. 96-103, 2012.

RIBANI, M., BOTTOLI, C.B.G., COLLINS, C.H.; JARDIM, I.C.S.F., MELO, L.F.C. Validação em Métodos Cromatográficos e Eletroforéticos. Química Nova, v.27, n.5, p. 771-780, 2004. 
ROYSTON, J. B. Some techniques for assessing multivariate based on the Shapiro-Wilk W. Applied Statistics, v.32, n.2, p. 121-133, 1983.

SANGWAN, N.S., FAROOQI, A.H.A., SHABIH, F., SANGWAN, R.S. Regulation of essential oil production in plants. Plant Growth Regulation, v.34, n.1, p. 3-21, 2001.

SARTORELLI, P.S., JEFFERSON, S., GUADAGNIN, R.C., LAGO, J.H.G., PINTO, É.G., TEMPONE, A.G., STEFANI, H.A., SOARES, M.G., SILVA, ADALBERTO, M. DA. Avaliação in vitro de tripanocida de derivados de pinano de óleos essenciais de frutas maduras de Schinus terebinthifolius Raddi (Anacardiaceae). Química Nova, v.35, n.4, p. 743-747, 2012.

SERVIÇO BRASILEIRO DE APOIO ÀS MICRO E PEQUENAS EMPRESAS- SEBRAE. Como montar uma fábrica de óleos essenciais. Brasil. Disponível em: https:/www.sebrae.com.br/sites/PortalSebrae/ideias/como-montar-uma-fabrica-de-oleos-naturais-e-essencias,c2387a51b9105410VgnVCM1000003b74010aRCRD . Acesso em: 28 de setembro de 2020.

SILVA, A.B., SILVA, T.; FRANCO, E.S.; RABELO, S.S.; LIMA, E.R.; MOTA, R.A.; CÂMARA, C.A.G.; PONTES-FILHO, N.T.; LIMA-FILHO, J.V. Antibacterial activity, chemical composition, and cytotoxicity of leaf's essential oil from Brazilian pepper tree (Schinus terebinthifolius, Raddi.). Brazilian Journal of Microbiology, v.41, n.1, p.158-163, 2010.

SILVA, M., PESSOTTI, B.M. de S., ZANINI, S.F., COLNAGO, G.L., NUNES, L.C., RODRIGUES, M.R.A., FERREIRA, L. Uso de óleo de aroeira-vermelha sobre o desempenho e a morfometria intestinal de frangos de corte. Ciência Rural, v.40, n.10, p. 2151-2156, 2010.

SILVA, M.A., PESSOTI, B.M. de S.; ZANINI, S.F.; COLNAGO, G.L.; NUNES, L.C., RODRIGUES, M.R.A., FERREIRA, L. Óleo essencial de aroeira-vermelha como aditivo na ração de frangos de corte. Ciência Rural, v.41, n.4, p. 676-681, 2011.

SINGH, A.K., SINGH, J., GUPTA, K.C., BROPHY, J.J. Essential oil of leaves and inflorescence of Schinus terebinthifolius: an exotic plant of India. Journal of Essential Oil Research, v.10, n.6, p. 697-699, 1998.

SOUZA, S.V.C., JUNQUEIRA, R.G. A procedure to assess linearity by ordinary least squares method. Analytica Chimica Acta, v.552, p. 25-35, 2005.

SOUZA, S.V.C., LIMA, J.A., TEODORO, J.C., JUNQUEIRA, R.G. Validação intralaboratorial de método quantitativo para determinação múltipla de resíduos de avermectinas em leite bovino por cromatografia líquida de alta eficiência com detecção de fluorescência. Food Science and Technology, v.27, n.4, p. 823-836, 2007.

THOMPSON, M., ELLISON, S.L.R., WOOD, R. Harmonized guidelines for a single-laboratory validation of methods of analysis. Pure Applied Chemistry, v.74, p. 835-855, 2002.

VIEGAS, M.C., BASSOLI, D.G. Utilização do Índice de Retenção Linear para Caracterização de Compostos Voláteis em Café Solúvel utilizando GC-MS e Coluna HP-INNOWAX. Química Nova, v.30, n.8, p. 20312034, 2007. 


\section{CONVULSÕES E SUAS CONSEQUÊNCIAS QUANDO TRATADAS TARDIAMENTE: ESTADO DO MAL EPILÉPTICO NA PEDIATRIA}

CATHARINE VITÓRIA DOS SANTOS SIQUEIRA

Fundação Técnico Educacional Souza Marques

CECÍLIA CÂNDIDA GRAÇA MOTA DAMASCENO

Fundação Técnico Educacional Souza Marques

ANA LUIZA TINOCO ABUNAHMAN Fundação Técnico Educacional Souza Marques

BEATRIZ CRIVELLI ALVARENGA Fundação Técnico Educacional Souza Marques

DEBORAH BRAGA DA CUNHA Fundação Técnico Educacional Souza Marques

GIOVANNA CHALOM

Fundação Técnico Educacional Souza Marques

KELLY FIGUEIREDO BARBOSA Fundação Técnico Educacional Souza Marques

ANDRÉA PEREIRA COLPAS

Fundação Técnico Educacional Souza Marques

RESUMO: INTRODUÇÃO: A crise epiléptica está entre uma das doenças mais graves e frequentes da infância. A maioria são breves, autolimitadas e cessam antes da chegada da criança ao serviço hospitalar. Entretanto, episódios com duração maior que 5 minutos podem levar a riscos de lesões cerebrais e necessitam de uma abordagem através de protocolos pré-estabelecidos com o objetivo de interrompê-las o mais rápido possível, além de determinar o diagnóstico etiológico. OBJETIVO: Esclarecer o conceito de crise convulsiva e estado mal epiléptico (EME) e a necessidade de conduta terapêutica adequada a fim de evitar a mesma e suas consequências e complicações. MÉTODO: Revisão de literatura, através das plataformas scielo, Pubmed e Scholar Google com artigos de 1999-2018. A busca foi realizada utilizando os descritores: "crise convulsiva", "emergências pediátricas", "epilepsia", "pediatria". RESULTADOS: Cerca de 9\% da população apresenta pelo menos uma crise epiléptica ao longo da vida. Diante de um quadro convulsivo epiléptico, é essencial o reconhecimento e manejo adequado da situação o mais precoce possível a fim de evitar o EME, que ocorre em $40 \%$ dos casos nos primeiros dois anos de vida. A anamnese e os exames clínicos e neurológicos são importantes para esclarecer a possível etiologia do quadro e, assim, nortear a conduta. Quando houver o EME, crises com mais do que 30 minutos sem a recuperação da consciência entre elas, é necessária uma intervenção com o objetivo de evitar danos neurológicos e os benzodiazepínicos intravenosos são padrão ouro. É essencial que a investigação diagnóstica ocorra simultaneamente ao manejo terapêutico e, posteriormente, ser aprofundada após a estabilização clínica do paciente. CONCLUSÃO: Dessa forma, quando a crise convulsiva é reconhecida e tratada tardiamente, os riscos de sequelas neurológicas e hemodinâmicas aumentam. Com isso, é fundamental que haja reconhecimento precoce e manejo adequado a fim de obter um prognóstico positivo.

PALAVRAS CHAVES: Estado do mal epiléptico; Convulsões; Tratamento tardio

ABSTRACT: INTRODUCTION: The epileptic 
seizure is one of the most serious and frequent diseases of childhood. Most are brief, self-limiting and cease before the child's arrival at the hospital. However, episodes lasting more than 5 minutes can lead to risk of injury and require an approach through pre-established protocols with the aim of interrupting them as soon as possible, in addition to determining the etiological diagnosis. OBJECTIVE: Clarify the concept of seizure crisis and status epilepticus (SE) and the need for adequate therapeutic conduct in order to avoid it and its consequences and complications. MATERIAL AND METHODS: Literature review, through scielo, Pubmed and Scholar Google platforms with articles from 1999-2018. The search was carried out using the descriptors: "seizure crisis", "pediatric emergencies", "epilepsy", “pediatrics". RESULTS: About 9\% of the population will experience at least one epileptic seizure in their lifetime. Faced with an epileptic seizure, it is essential to recognize and manage the situation as early as possible in order to avoid SE, which occurs in $40 \%$ of cases in the first two years of life. Anamnesis and clinical and neurological exams are important to clarify the possible etiology of the condition and, thus, guide the conduct. When there is SE, seizures lasting more than 30 minutes without regaining consciousness between them, an intervention is necessary in order to avoid neurological damage and intravenous benzodiazepines are the gold standard. It is essential that the diagnostic investigation occurs simultaneously with the therapeutic management and, subsequently, be deepened after the clinical stabilization of the patient. CONCLUSION: Thus, when the seizure is recognized and treated late, the risks of neurological and hemodynamic sequelae increase. Therewith, it is essential to have early recognition and adequate management in order to obtain a positive prognosis.

KEYWORDS: Status epilepticus; Seizure; Late treatment

\section{INTRODUÇÃO E OBJETIVO}

A crise epiléptica está entre uma das doenças mais graves e frequentes da infância e é um evento transitório, paroxístico e involuntário, sendo um sinal de anormalidade na função do cérebro, caracterizada por sinais e sintomas repentinos devido a alterações neuronais como descargas elétricas excessivas. Dentre as manifestações clínicas podem ser citados os distúrbios comportamentais, disfunção autonômica e sintomas sensitivos (Brito et al; 2017). Essas crises, podendo ser convulsivas ou não, são mais comuns do que se imagina e cerca de $9 \%$ da população apresentará pelo menos uma crise ao longo da vida (Carvalho, Valentina; 2002).

Segundo o que foi descrito por Liberalesso, Paulo, em seu estudo de 2002, as crises convulsivas são relatadas há mais de 5.000 anos e, antigamente, eram atribuídas a possessões demoníacas ou castigos divinos. No entanto, cientificamente e como descrito por Filho, Heber no mesmo ano, as convulsões são as crises epilépticas com manifestações motoras e, geralmente, são eventos assustadores para a família da criança e uma importante causa de emergência pediátrica. A maioria das convulsões são breves, autolimitadas e cessam antes da chegada da criança ao serviço de emergência, não necessitando de qualquer tratamento com anticonvulsivantes, apenas atenção na segurança do paciente no período de pós crise. O fato de ser uma alteração autolimitada junto com as informações escassas oriundas de pais angustiados com a situação gera a dificuldade de diagnóstico da crise convulsiva. Entretanto, grande parte dos episódios que apresentam duração maior que 5 minutos podem persistir por mais de 20-30 minutos, podendo levar a riscos de lesões e necessitando uma abordagem através de protocolos pré-estabelecidos com o objetivo de interrompê-las o mais rápido possível, 
além de determinar o diagnóstico etiológico, cujo tratamento é tão importante quanto o da própria crise (Liberalesso, Paulo; 2018). O protocolo de tratamento para crise epiléptica consiste em fazer o suporte de vida (abertura de vias aéreas, ventilação e compressão torácica), acesso venoso, dosagem de glicemia e a bioquímica do paciente (Carvalho, Valentina; 2002).

As crises com duração maior do que 30 minutos são consideradas o estado do mal epiléptico (EME) que é caracterizado por crises sequenciais sem a recuperação da consciência entre elas. O conceito temporal está relacionado ao aumento da mortalidade e lesões neurológicas. Além disso, há o EME refratário, que é quando a crise dura mais de 2 horas, e o EME super refratário, que consiste em uma crise convulsiva por mais de 24 horas. A etiologia do EME pode ser dividida em: forma sintomática aguda, que é decorrente de algum dano recente ao SNC, forma sintomática remota, que está relacionada a um dano mais antigo do sistema nervoso central, e forma criptogênica que é quando não é possível identificar a causa claramente. Dentre as principais causas de EME têm-se a causa febril e a suspensão abrupta de fármacos antiepilépticos. Além disso, alguns medicamentos como lidocaína, isoniazida, clozapina podem induzir as crises epilépticas prolongadas por mais de 30 minutos (Liberalesso, Paulo; 2018).

Sendo assim, o presente trabalho tem como objetivo esclarecer o conceito de uma crise convulsiva e do EME reforçando a necessidade de uma conduta terapêutica adequada a fim de evitar o mesmo. Além disso, apresentar as consequências e complicações de um quadro convulsivo sem tratamento na vida do infante.

\section{MATERIAL E MÉTODOS}

Este artigo consiste em uma revisão de literatura, sendo selecionados artigos científicos de 2010 a 2018, através da busca no banco de dados da SCIELO, PUBMED e Scholar google. Foram elencadas as publicações científicas que utilizaram os seguintes termos: "crise convulsiva", "emergências pediátricas", "epilepsia", "pediatria". Foram utilizados 12 artigos, sendo todos nacionais. Para a seleção das fontes foram considerados como critérios de inclusão bibliográficas artigos que abordassem as características clínicas, epidemiológicas e terapêuticas das crises convulsivas na infância, além das consequências do não tratamento objetivo e precoce e excluídas todas aquelas que não abordavam a faixa etária pediátrica.

\section{RESULTADOS}

Diante de um quadro convulsivo, é primordial o reconhecimento e manejo adequado o mais precocemente possível, a fim de evitar complicações neurológicas, como a evolução para o EME. Frente a uma criança apresentado um evento paroxístico, é importante elucidar se, realmente, trata-se de uma crise epiléptica, sendo essencial a exclusão de manifestações de caráter não epiléptico que 
podem ser confundidos com convulsões, como oxigenação cerebral diminuída, distúrbios metabólicos, distúrbios do sono, reação medicamentosa, distúrbios do movimento, refluxo gastresofágico e manifestações psicológicas (Brito et al; 2017).

As crises epilépticas podem ser febris, associadas a temperaturas superiores à $38^{\circ} \mathrm{c}$, com maior prevalência dos 3 meses a 5 anos de idade, geralmente autolimitadas e de curta duração (Filho, Heber; 2012) ou afebris, que possuem como causa importante as crises convulsivas epilépticas. Na investigação de um quadro convulsivo associado a um quadro febril podem ser consideradas possibilidades como infecções do sistema nervoso central ou podemos estar diante de uma criança epiléptica na qual a febre foi o fator responsável por ocasionar a crise (Brito et al; 2017). Estudos mostram que entre 2 e $5 \%$ das crianças podem apresentar ao menos uma crise febril até os 5 anos de idade (Machado et al; 2018). Segundo Mukherjee, em 21\% das crianças afetadas, a crise febril desenvolve-se uma hora após o início da febre, em 57\% em um intervalo de 1 a 24 horas e, em 22\%, acima de 24 horas. Dessa forma, tem-se que o período de maior risco para ocorrência da convulsão febril corresponde às primeiras 24 horas que o paciente apresenta febre. Machado e Cols demonstraram também em seu estudo que cerca de $40 \%$ das crianças que apresentam algum quadro febril em algum momento da vida, tendem a ter recorrência do quadro em algum momento. Se a crise convulsiva febril se tornar recorrente ou prolongada apresentando duração maior que 5 minutos é obrigatório a realização de investigação complementar a fim de esclarecer sua etiologia (Machado et al; 2018). Em outro estudo realizado na unidade de pediatria do hospital de Nossa Senhora da Conceição em Santa Catarina o qual foram analisados 259 prontuários, concluiu-se que de todos os pacientes que tiveram convulsão febril $34,4 \%$ foram internados com crises convulsivas. Além disso, a média de idade das crianças internadas com convulsões febris foi menor que a das crianças com convulsões não-febris. Ademais, segundo o mesmo estudo, o episódio febril teve como causas mais comuns a pneumonia e as infecções das vias aéreas superiores (Duarte, Cancelier; 2007).

As crises epilépticas podem ser: crises focais as quais são divididas em crises parciais simples, que vão possuir um início focal, podendo cursar com alterações no sistema oftalmológico e auditivo, alteração nos movimentos em apenas um lado do organismo, comprometimento da sensibilidade, mas sem afetar a consciência. Geralmente, os eventos cessam rapidamente, durando em torno de 10 a 20 segundos. Além disso, existem as crises parciais complexas, que também vão ter um início insidioso, porém, nessa situação há o comprometimento da percepção e possuem uma maior duração (1 a 2 minutos). As crises generalizadas são caracterizadas pela perda da consciência e amnésia do episódio. Podem ser tônico-clônico, ou seja, com presença de contrações musculares rítmicas e repetitivas divididas; apenas tônico onde não haverá a contração repetida e atônica na qual o indivíduo encontra-se com o corpo mole e acaba desmaiando. Existe, ainda, as crises desconhecidas a qual não é possível identificar a etiologia (Brito et al; 2017).

Dessa forma, durante a anamnese, deve-se procurar obter uma descrição detalhada do episódio paroxístico e dos períodos pré e pós ictal, tentando esclarecer os fatores que possam ter contribuído para o desencadeamento da crise. Aliado a uma boa anamnese, os exames clínicos e neurológicos auxiliam a fornecer pistas importantes sobre a possível etiologia do quadro convulsivo. É essencial que a investigação diagnóstica ocorra simultaneamente ao manejo terapêutico e, posteriormente, ser 
aprofundada após a estabilização clínica do paciente (Brito et al; 2017). No primeiro momento do atendimento poderão ser solicitados exames laboratoriais como dosagem da glicose, eletrólitos, gasometria arterial, creatinina, hemograma, plaquetas, punção lombar em caso de suspeita de infecção do sistema nervoso central. Além disso, posteriormente a estabilização do paciente com crise convulsiva pode ser realizado exames complementares como provas hepáticas, eletroencefalograma (EEG) além de exames de imagem como tomografia computadorizada de crânio ou ressonância nuclear magnética de encéfalo. No entanto, cabe destacar que cada caso deve ser conduzido individualmente de acordo com o quadro clínico apresentado por cada paciente (Guaragna et al).

As crises convulsivas epilépticas, em sua maioria, têm rápida resolução, sem necessidade de abordagem terapêutica emergencial. Entretanto, quando o quadro é persistente, além de causar grande aflição para os pais, podem precisar de intervenções medicamentosas para cessá-las imediatamente, principalmente, pelo risco de causar prejuízos neurológicos devido a um estado de mal epilético. O EME é caracterizado por uma crise prolongada ou crises recorrentes em que não há recuperação completa entre elas, de duração maior ou igual a 30 minutos. Semiologicamente, a convulsão apresenta manifestações motoras evidentes e no quadro não convulsivo esse evento está ausente ou são discretos. O EME enquadra-se em uma das mais importantes e recorrentes emergências pediátricas na prática clínico pediátrico, ou seja, os profissionais devem conhecer os protocolos a serem tomados diante de tal quadro clínico a fim de evitar maiores complicações. O conhecimento acerca de tal condição é essencial para a redução da mortalidade e de acometimentos neurológicos permanentes na vida do infante (Liberalesso, Paulo; 2018).

Segundo a Sociedade Brasileira de Pediatria, em 2018, dados recentes demonstram que o EME é a emergência neurológica mais frequente na pediatria, ocorrendo em $40 \%$ dos casos nos primeiros dois anos de vida. Um estudo europeu demonstrou que até $27 \%$ das crianças epilépticas com menos de 16 anos apresentaram pelo menos um episódio de EME e que o risco era maior nos primeiros anos após o diagnóstico da epilepsia. Demonstrou também que $12 \%$ dos pacientes que irão cursar com epilepsia durante a vida, terão como primeira manifestação este quadro, o que demonstra a importância no entendimento da abordagem precoce desta emergência. Com o desenvolvimento tecnológico dos métodos de neuroimagem, distúrbios do desenvolvimento cortical, que antes eram subdiagnosticados, o número de EME na infância vem aumentando. Nos casos de EME epiléptico durante o período neonatal, é importante ratificar a possibilidade de erros inatos no metabolismo (Liberalesso, Paulo; 2018).

Seguindo o pensamento de que qualquer crise epiléptica pode se prolongar e assumir um caráter duradouro e invariável, independentemente de ser um quadro convulsivo ou não, é possível crer que existem tantos tipos de EME quanto os tipos de crises epilépticas. O EME de ausência típica é a apresentação de um quadro clássico não convulsivo e a sua fisiopatologia está relacionada à uma exacerbação de eventos inibitórios por uma inibição neuronal síncrona. Neste caso, a abertura dos canais de cálcio do tipo T, devido ao ácido gama aminobutírico (GABA), gera a hiperpolarização e, posteriormente, uma despolarização neuronal cíclica. Dessa forma, a abertura desses canais provoca o influxo deste íon, ocasionando uma maior liberação de GABA e, sendo assim, tornando possível a realização de um novo ciclo inibitório. Ainda não é de conhecimento científico se este processo 
de inibição relacionado é passível de provocar lesões neuronais de forma permanente (Liberalesso, Paulo; 2018).

Já o mecanismo de ocorrência do EME convulsivo não é plenamente compreendido na literatura. Alguns estudos realizados em animais mostram que, além de alterações sistêmicas como aumento da concentração de gás carbônico na circulação sanguínea, aumento da temperatura corporal, diminuição da oxigenação e queda do fluxo sanguíneo, a atividade elétrica modificada e duradoura que acontece nesses quadros provoca lesões neurais permanentes e, na maior parte dos casos, atinge áreas do cérebro como o hipocampo, amígdala e núcleos talâmicos. A fisiopatologia dessa danificação está diretamente relacionada à excitotoxicidade gerada pelos receptores glutamatérgicos AMPA e NMDA, que ocasionam maior fluxo de cálcio para o interior do neurônio. Esse fluxo aumentado leva a produção de radicais livres, liberação de ácidos graxos, ativação intracelular de certas enzimas e alteração da função do sistema energético mitocondrial. Com essa lesão, o neurônio começa a liberar ainda mais neurotransmissores excitatórios, como glutamato, causando um feedback positivo e, consequentemente, fazendo com que tal evento ocorra de forma cíclica (Liberalesso, Paulo; 2018).

Em todos os casos, há uma falha no mecanismo de controle dos eventos excitatórios. Contudo, os motivos pelos quais alguns quadros tornam-se casos de EME refratários e outros super refratários ainda não é plenamente descrito. Recentemente, foi apresentado que a presença de receptores dispostos ao longo da membrana axonal de características dinâmicas e que sofrem de exteriorização e internalização durante o curso da crise podem estar relacionados à evolução do EME e determinar seu curso. Conforme há uma evolução temporal do EME, receptores sensíveis aos neurotransmissores inibitórios (GABA) são internalizados e receptores sensíveis aos neurotransmissores excitatórios (glutamato) são externalizados na membrana axonal, o que acaba por gerar o fenômeno ictal de forma contínua. Além disso, os fenômenos de falência do sistema mitocondrial, que geram necrosem celular e apoptose, e os fenômenos inflamatórios, capazes de alterar a permeabilidade da barreira hematoencefálica e, consequentemente, o fluxo local de potássio e a excitabilidade neuronal, também estão relacionados ao fenômeno ictal e morte neuronal que ocorrem durante o episódio de EME (Liberalesso, Paulo; 2018).

Desse modo, a história clínica é fundamental para o reconhecimento e diferenciação de eventos epilépticos e não-epilépticos, e para a determinação se haverá necessidade de alguma intervenção. O mal epiléptico é uma emergência clínica, devendo-se interromper a crise convulsiva o mais precocemente possível, com objetivo de evitar sua evolução negativa com danos neurológicos. A abordagem inicial de uma criança que chega com convulsão na emergência deve ser rápida e efetiva objetivando a manutenção de vias aéreas pérvias, realizar monitorização dos sinais vitais e saturação de $\mathrm{O} 2$, oxigenoterapia e em casos mais graves realização de intubação. (Brito et al; 2017). O tratamento medicamentoso inicial tem como objetivo, portanto, interromper o quadro convulsivo o mais precocemente possível reduzindo assim a chance de evolução para o EME. Os fármacos administrados são os benzodiazepínicos (Diazepam 0,3 a 0,5 mg/kg EV máximo $1 \mathrm{mg} / \mathrm{kg} / \mathrm{min}$ ou Diazepam 0,5 $\mathrm{mg} / \mathrm{kg}$ retal; Midazolam 0,2 mg/kg EV máximo $4 \mathrm{mg} / \mathrm{kg} / \mathrm{min}$, Fenitoína $20 \mathrm{mg} / \mathrm{kg}$ EV diluído 1:20 $\mathrm{SF} 0,9 \%, 1 \mathrm{mg} / \mathrm{kg} / \mathrm{min}$ ). Caso a crise não passe, em 10 minutos pode ser feito novamente o Diazepam $0,5 \mathrm{mg} / \mathrm{kg} \mathrm{EV}$ ou retal e, caso ainda persista por 20 minutos pode ser administrado Fenobarbital 20 
$\mathrm{mg} / \mathrm{kg} \mathrm{EV}$. Em casos de crise por mais de 3 o minutos pode ser feito o Midazolam $(0,2 \mathrm{mg} / \mathrm{Kg} \mathrm{EV})$ ou Midazolam contínuo ( $0,05 \mathrm{mg}$ a $0,4 \mathrm{mg} / \mathrm{Kg} / \mathrm{hora})$. Em crises convulsivas refratárias pode ser feito Tiopental 10 a 120 microgramas/Kg/min ou propofol 3 a $5 \mathrm{mg} / \mathrm{Kg} / \mathrm{hora}$. Em crianças maiores que 3 anos, e naquelas menores, avaliar possibilidade de piridoxina, sempre monitorando os sinais cardiológicos e respiratórios devido aos possíveis efeitos colaterais (Brito et al; 2017).

Além disso, deve ser solicitado exame de neuroimagem, monitorização EEG e mais exames laboratoriais (Filho, Heber; 2012). É necessário o conhecimento dos fatores de risco do paciente e da história natural antes da primeira convulsão sem causa aparente (traumatismo cranioencefálico ou febre por exemplo) para que as medidas profiláticas com drogas antiepilépticas possam ser realizadas (Carvalho, Valentina; 2002). Considerando manutenção do quadro convulsivo por mais de 2 horas, com ausência da resposta terapêutica, caracteriza-se a presença do EME refratário, devendo haver transferência da criança para uma unidade de terapia intensiva. Será preciso avaliar os efeitos neurológicos e possíveis sequelas através do eletroencefalograma contínuo, além de nova tentativa com infusão contínua de midazolam ou propofol. Em caso de persistência da refratariedade, é preciso considerar ventilação mecânica invasiva para fornecer infusões contínuas com tiopental ou anestesia geral, até que haja controle clínico e eletrográfico do EME. Os exames de imagem, neste caso, são fundamentais para detectar as anormalidades que podem estar causando a persistência das crises convulsivas, devendo ser o foco após a estabilização do paciente para avaliar as possíveis terapêuticas, que dependerá de cada quadro (Liberalesso, Paulo; 2018).

Diante de um quadro convulsivo torna-se essencial a orientação à família, devendo esta ser informada sobre os cuidados que devem ser tomados durante a crise, os riscos de recorrência e as consequências do não tratamento adequado e precoce. Deve-se também orientar os responsáveis sobre como proceder no momento exato da ocorrência da crise, deitando o paciente em decúbito lateral, virando sua cabeça para o lado evitando possíveis engasgos com saliva e/ou vômito, se possível pode ser oferecido alguma proteção para a cabeça. É importante orientar também que de maneira nenhuma deve se introduzir nenhum objeto na boca da criança para tentar de alguma forma puxar a língua que possa estar torcida, do mesmo modo que não se deve oferecer líquidos ou medicamentos pela via oral nesse momento. Além disso, é essencial mostrar a quem estiver próximo durante a crise, a importância de se observar atentamente as características da mesma, sua duração e que caso esta não cesse em até 5 minutos esta criança deve ser levada imediatamente a um serviço de pronto atendimento (Brito et al; 2017)

\section{CONCLUSÃO}

A crise epiléptica, por ter uma alta frequência de acometimento na infância e pelas evidências que demonstram que cerca de $12 \%$ dos pacientes terão como primeira manifestação a evolução para o EME, é fundamental que haja reconhecimento precoce e manejo adequado a fim de obter um melhor desfecho para o infante. Apesar de geralmente serem episódios autolimitados e breves, há um grande impacto emocional nos responsáveis e na vida da criança, com grande parcela de recorrência, tornan- 
do fundamental o fornecimento de informações e aconselhamento, tanto para utilização de medidas profiláticas, quanto para como devem proceder durante as crises, principalmente se elas passarem de 5 minutos, devendo ser encaminhadas a um hospital, pela grande possibilidade de evolução para o EME, ou seja, de se manter por mais de 30 minutos, sem a recuperação da consciência entre as crises. Com isso, quanto mais tempo o paciente passar em crise, maior a chance de danos neurais, reforçando a necessidade de reconhecimento da crise e intervenção com anticonvulsivantes, a fim de cessá-la. É possível ainda que devido a falha nos mecanismos de controle dos fenômenos excitatórios, muitos ainda desconhecidos, haja refratariedade ao EME, abrindo frente de necessidade de outros medicamentos caso haja falha dos benzodiazepínicos, como o tiopental e o propofol. Ademais, é essencial que seja realizado uma boa anamnese e exame físico, identificando os detalhes do episódio e dos períodos pré e pós-ictal, além de exames clínicos, neurológicos durante o manejo terapêutico, e de investigação complementar quando há estabilização do quadro, com o objetivo de identificar sua etiologia ou fator desencadeador.

\section{REFERÊNCIAS BIBLIOGRÁFICAS}

BEHRMAN, R. E.; KLIEGMAN, R. M.; JENSON, H. B; Crises Convulsivas na Infância; Tratado de pediatria Nelson. 20. ed. Rio de Janeiro: Elsevier, 2017. 2 v.

Brito et al; Convulsões; Rev. Ped. SOPERJ, v. 17, supl. 1, p. 56-62, dez. 2017

Carvalho, V.N \& Souza, A.M.M.H; Conduta no primeiro episódio de crise convulsiva; Jornal de Pediatria - Vol. 78, Supl.1, 2002 S15

Duarte, M.E \& Cancelier A.C.L; Prevalência de internações por convulsões febris em serviço de pediatria no sul do país: análise dos fatores associados. Arquivos Catarinenses de Medicina Vol. 36, no . 4, de 2007

Filho, H.S.M; Abordagem das Crises Epilépticas na Emergência Pediátrica; Revista de Pediatria SOPERJ - v. 13, no 2, p29-34 dez 2012

Guaragna et al; Manejo das crises convulsivas na emergência pediátrica; Disponível em: http://docs.bvsalud.org/ biblioref/2018/04/883018/40-crises-convulsivas.pdf. Acesso em 18 out. 2020

Liberalesso, P.B.N; Estado de mal epiléptico. Diagnóstico e tratamento; Residência Pediátrica 2018;8(supl 1):3539.DOI: 10.25060/residpediatr-2018.v8s1-06

Liberalesso, P.B.N; Manual de Diagnóstico e Tratamento das Epilepsias na Infância. 1a ed. Curitiba: UTP; 2010

Liberalesso P.B.N; Síndromes epilépticas na infância. Uma abordagem prática. Resid Pediatr. 2018;8(0 Supl.1):56-63 DOI: 10.25060/residpediatr-2018.v8s1-10)

Machado et al; Crise febril na Infância: Uma revisão dos principais conceitos; Residência Pediátrica 2018;8(supl 1):11-16;DOI: 10.25060/residpediatr-2018.v8s1-03

Maia, F.H.S; Abordagem das crises epilépticas na emergência pediátrica. Rev Ped SOPERJ. 2012;13(2):29-34

Protocolo Clínico e Diretrizes Terapêuticas para Epilepsia - 2019 Ministério da Saúde http://conitec.gov.br/images/ Consultas/Relatorios/2019/Relatorio_PCDT_Epilepsia_CP13_2019.pdf

Valdez, J.M; Estado de mal epiléptico en pediatría; Medicina (B. Aires). 2013;73 (supl. 1):77-82 


\section{ESTUDOS DA RELAÇÃO QUANTITATIVA ESTRUTURA ATIVIDADE TRIDIMENSIONAL (QSAR- 3D) COM INIBIDORES OXADIAZOL DA ENZIMA EthR POTENCIALIZADORES DA ATIVIDADE ANTI- TUBERCULOSE DA ETIONAMIDA}

SAMER VALENTE DA SILVA Instituto Federal do Pará - Campus Ananindeua

MIKAELA VIVIAN PEREIRA ANDRADE Instituto Federal do Pará - Campus Ananindeua

LOURDES OLIVEIRA GOMES

Instituto Federal do Pará - Campus Ananindeua

SOLANGE MARIA VINAGRE CORRÊA Instituto Federal do Pará - Campus Ananindeua

RICARDO MORAIS DE MIRANDA Instituto Federal do Pará - Campus Ananindeua

RESUMO: A tuberculose é causada pela bactéria Mycobacterium tuberculosis (MTB) sendo uma doença infeciosa que afeta os pulmões e com possibilidades de atingir outras partes do organismo. Ao longo das últimas décadas vários pesquisadores tentam viabilizar a pesquisa in silício partir de estudos computacionais que são divididos por etapas sendo uma delas o Estudo da Relação Quantitativa da Estrutura Atividade em sua dimensão tridimensional (QSAR-3D) e de drogas de segunda linha como a Etionamida e seus derivativos, que vem sendo utilizada desde 1956. Assim, este capítulo demonstra os passos e resultados a partir da utilização e a aplicação de ferramentas computacionais e conceitos de química computacional para construir modelos baseados em QSAR-3D, com o intuito de permitir o planejamento e simulação de novos inibidores bioativos contra a tuberculose. A pesquisa foi fundamentada a partir de trabalhos experimentais e softwares de modelagem e cálculos matemáticos que possibilitaram o desenvolvimento e a visualização dos melhores modelos baseados em conceitos de QSAR-3D.

\section{INTRODUÇÃO}

A tuberculose (TB) se apresenta como um problema de saúde global (JAVAD, et al., 2014), sendo a primeira doença infecciosa declarada pela Organização Mundial de Saúde (OMS) como uma emergência de saúde em âmbito mundial (SAXENA, SAMALA et al., 2015). Tal perspectiva explica a mortalidade entre milhões de pessoas a cada ano e se classifica como a segunda principal causa de morte no mundo entre as doenças infecciosas, após o vírus da imunodeficiência humana (HIV) (JAVAD, et al., 2014; COUTURIER et al., 2015).

Em 2014, a OMS informou que 1,3 milhões de pessoas morreram por causa da doença, e foram estimados 8,6 milhões de casos incidentes de TB em todo o mundo (JAVAD, et al., 2014; SAXENA, SAMALA et al., 2015). Quase um terço da população do mundo esta infectada com a bactéria gram-positiva, Mycobacterium tuberculosis (Mtb), o agente etiológico da doença conhecida como a tuberculose (TB). Dessas pessoas com infecção latente, 5-10\% podem apresentar sinais e sintomas da patologia. 
Na década de 1980, a redução da incidência global da doença deixa de ser observada nos estudos epidemiológicos, o que pode ser explicado pelo advento da AIDS, mais especificamente pela coinfecção entre tais patologias (HARRIES, 1990). Concomitantemente a esta situação, observa-se o desenvolvimento de cepas multidrogas resistentes (MDR-TB) e extensivamente resistentes (XDR-TB), mais do que nunca reforçou a necessidade de novas drogas (KOENIG, 2008).

Nesse sentido, a busca de moléculas alternativas contra esse alvo tem sido um dos esforços na atualidade. Novas estratégias têm sido exploradas para melhorar a eficácia de drogas já utilizadas no tratamento clínico da tuberculose. Deve-se ressaltar que a terapia medicamentosa vigente é constituída por um grande número de pró-fármacos que devem ser ativados metabolicamente para manifestar a sua atividade.

A Etionamida é uma droga de segunda linha que vem sendo utilizada para o tratamento da tuberculose desde o ano de 1956. Esta é um pró-fármaco inativo com estrutura análoga à isoniazida (InhA), porém sem resistência cruzada com a mesma, e necessita ser ativada pela enzima bacteriana EthA, uma monoxigenase contendo FAD, e é NADPH específica, atua nos bacilos intra e extracelulares (ARBEX et al., 2010).

Flipo et al. (2012), com o intuito de aprimorar o índice terapêutico de etionamida, desenvolveram um novo conceito baseado no uso de inibidores EthR que aumentam a bioativação do pró-fármaco (FLIPO et al., 2011), mostrados na Figura 1.

Figura 1. a) Estrutura cristalográfica contento proteína (EthR) e ligante obtida através do banco de dados de proteínas (3G1M); b) Região do sítio ativo, com inibidor EthR, obtida com o programa Chimera 1.9, indicando o resíduo Asn 179 da proteína como importante resíduo para a interação com o inibidor.

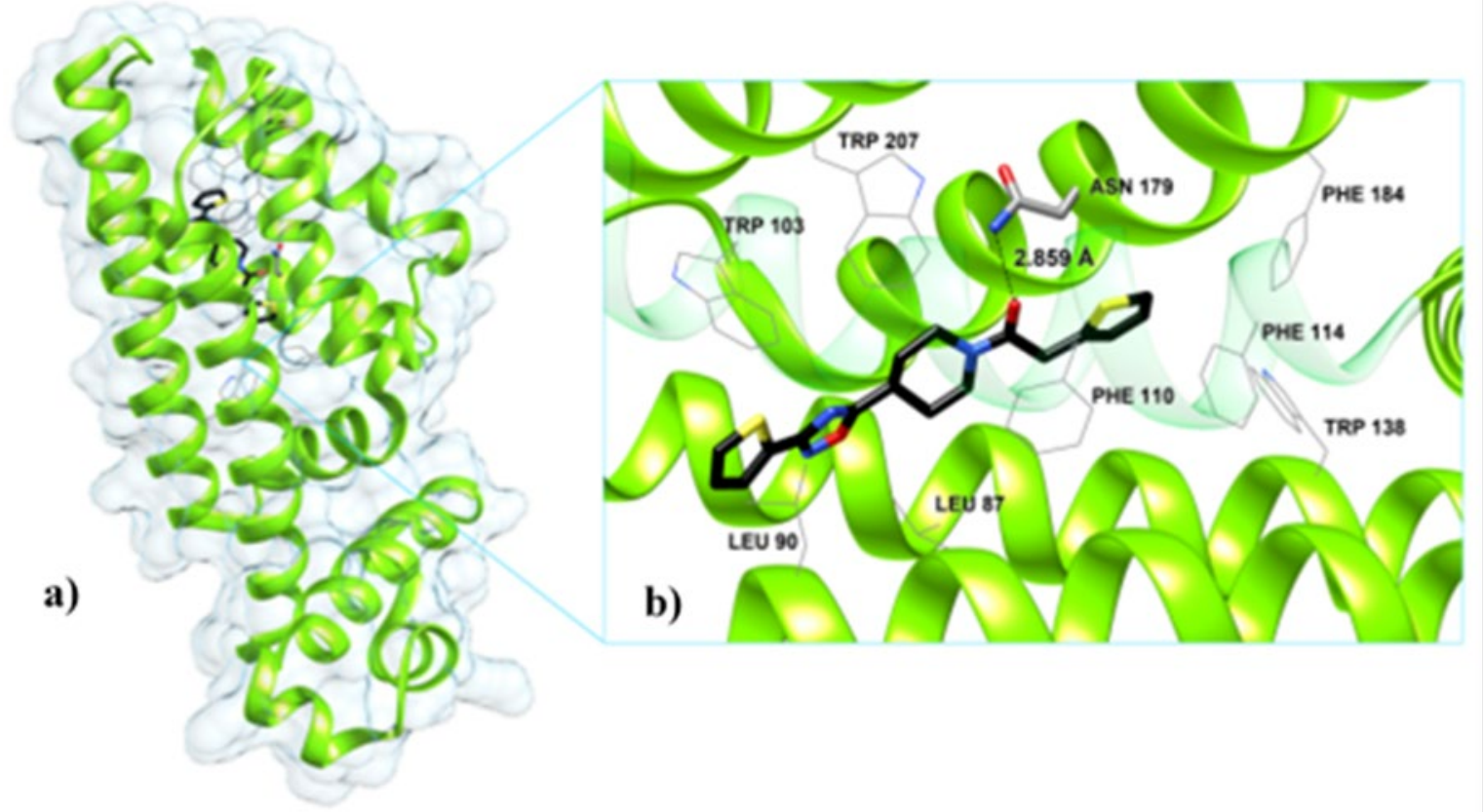

Fonte: Autoria Própria

Os compostos supracitados foram obtidos a partir de estudos realizados experimentalmente por FLIPO et al., (2011, 2012), onde projetou-se drogas capazes de inibir a função de ligação DNA- 
-EthR e as usou para aumentar a eficácia antimicobacteriana de etionamida, tanto in vitro como in vivo, proporcionando um sinergismo antibacteriano que permitir usar a etionamida como terapia de primeira linha.

Assim, este trabalho tem por objetivo realizar estudos químicos computacionais, baseados na relação quantitativa estrutura atividade QSAR-3D a fim de construir modelo que correlaciona a atividade biológica de inibidores 1,2,4-oxadiazol com as propriedades moleculares de campos estereoquímicos e eletrostático através do método de análise comparativa de campos moleculares (CoMFA), além de possibilitar a construção de novos inibidores determinando suas atividades biológicas para que permita o planejamento e a simulação de novos inibidores bioativos contra a tuberculose.

\section{DESENVOLVIMENTO}

A presente pesquisa teve como arbouço teórico os estudos experimentais desenvolvidos pelo grupo FLIPO et al., (2011, 2012), que investigou o caráter inibitório de compostos da classe do 1,2,4-oxadiazol contra tuberculose, capazes de potencializar o fármaco etionamida para ser usado como primeira linha, ao invés de segunda linha como está sendo usado no tratamento atual, permitindo maior eficácia e menor efeitos colaterais.

A primeira etapa foi a desenho das estruturas bidimensionais dos 39 inibidores, Tabela 1, derivados do 1,2,4-oxadiazol, com o programa ChemBioDraw12. Em seguida, construiu-se as estruturas tridimensional com o programa Avogadro a partir da estrutura cristalográfica de código 3G1M, retirada do Banco de Dados de Proteínas (Protein Data Bank).

Para finalizar a etapa de preparação das estruturas tridimensionais foram submetidas a cálculos quânticos com método baseado na teoria do funcional densidade (DFT), B3LYP/6- 31G**, neste caso foram otimizadas apenas as estruturas adicionadas na cadeia lateral da estrutura cristalográfica.

Todos os compostos apresentam suas atividades biológicas em termos de $E C_{50}$, que representa a concentração eficaz do ligante que permite a etionamida em $0.1 \mu \mathrm{g} / \mathrm{mL}$ (normal MIC/10) inibir 50\% do crescimento do $M$. tuberculosis em macrófagos. Os valores de $\mathrm{EC}_{50}(\mu \mathrm{M})$ foram convertidos para $p E C_{50}$ de acordo com a Fórmula 1 (SELVARAJ et al., 2011).

Fórmula 1. Equação de conversão da atividade $\mathrm{EC}_{50}$ para $p E C_{50}$

$$
p E C_{50}=-\log E C_{50} \cdot 10^{-6}
$$

Fonte: SELVARAJ et al., 2011

Para construção do modelo estatístico os compostos foram divididos em dois grupos e classificados como conjunto treinamento para validação interna, contendo $80 \%$ do número total de compos- 
tos, e conjunto teste para validação externa, contendo $20 \%$ do número total de compostos, conforme mostra a Gráfico 1. Para realizar a separação do conjunto treinamento e teste, os compostos foram divididos em 3 subgrupos de acordo com os valores de $p E C_{50}$, onde o subgrupo 1 contém os compostos com $p E C 50>5$ e $<5,9$, o subgrupo 2 contém os compostos com $p E C_{50}>6$ e $<6,9$ e o subgrupo 3 contém os compostos com $p E C_{50}$ igual a 7. Depois da separação, usou-se o programa Matlab para realizar a seleção aleatória dos compostos, considerando cada intervalo de $p E C_{50}$ e respeitando uma distribuição homogênea dos conjuntos de treinamento e teste.

Gráfico 1. Distribuição dos compostos em conjunto treinamento e conjunto teste de acordo com o intervalo de $p E C_{50^{\circ}}$

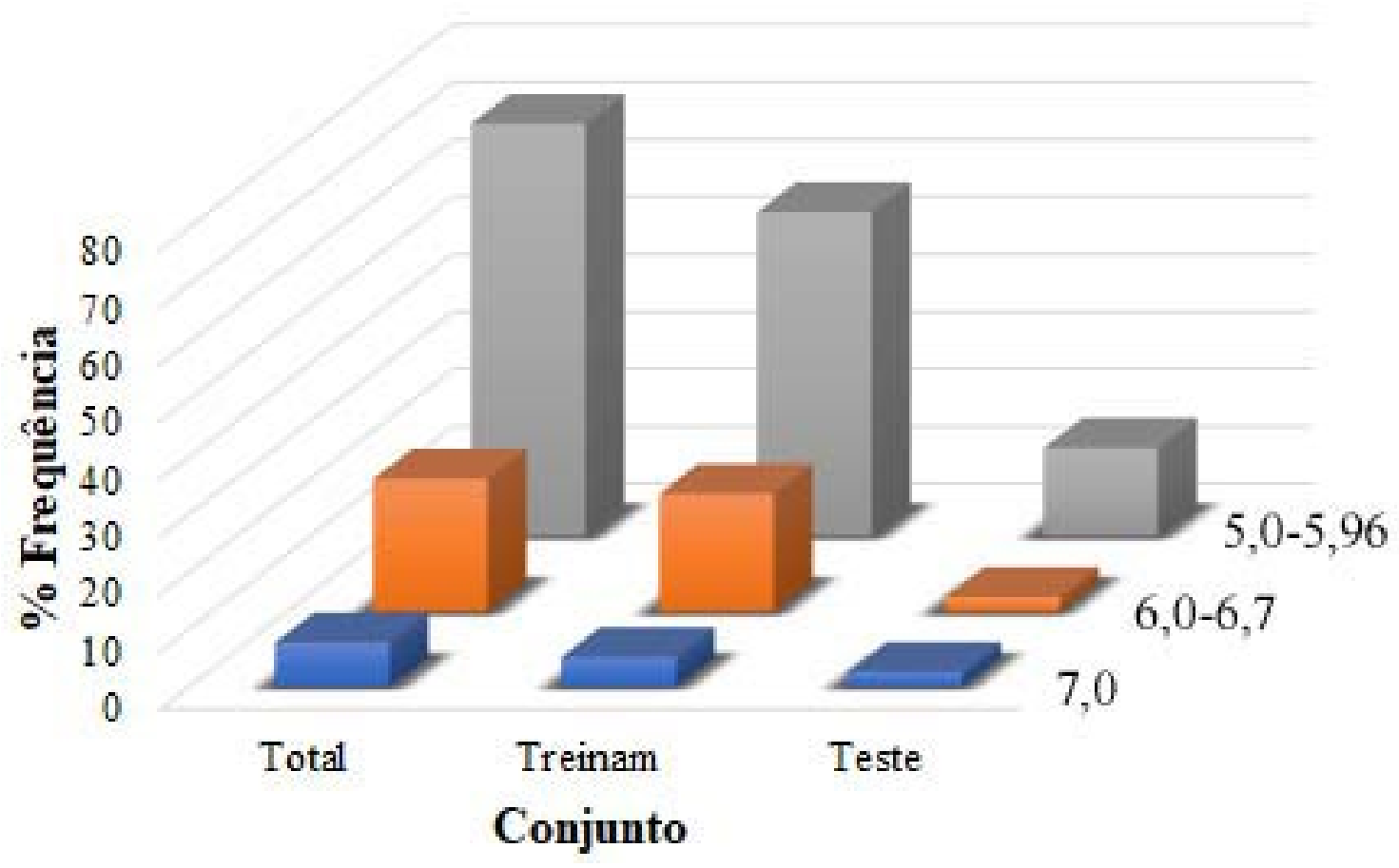

Fonte: Autoria Própria

Em seguida foram criados 5 modelos contendo 31 compostos no conjunto treinamento e 8 compostos no conjunto teste, os compostos foram preparados com adição de cargas PM3 e alinhados com base no grupo farmacóforo do ligante cristalográfico, Figura 2, com o programa SYBYL X 2.1. 
Figura 2. Alinhamento dos compostos dos 31 compostos do conjunto treinamento, usados na construção do modelo para validação interna.

Fonte: Autoria Própria

O método CoMFA foi usado para construir o modelo QSAR-3D, este método usa campos estérico (S) e eletrostáticos (E), que são calculados separadamente para cada molécula usando espaçamento de $2 \AA$ e átomo sonda com propriedade de van der Waals para carbono $\mathrm{sp}^{3}$ com carga de +1 (átomo sonda padrão do SYBYL), valores de energia de corte de $30 \mathrm{kcal} / \mathrm{mol}$ para campos tanto o estéricos e eletrostáticos. Os parâmetros de validação foram calculados e entre eles estão: coeficiente de determinação $\left(\mathrm{R}^{2}\right)$, coeficiente de correlação por validação cruzada $\left(\mathrm{Q}^{2}\right)$, erro padrão estimado (SEE) e teste de Fisher (F-test). Após a validação do conjunto de treinamento, aplicou-se a técnica de região de focagem com espaçamento da caixa $d$ variando $(0.5,1.0,1.5$ e $2 \AA)$ para cada peso $w(0.3,0.5,0.7$ e 1.0) do coeficiente de desvio padrão (stdev*coeff) da validação anterior.

Esse processo os aprimora, tornando-lhes mais eficientes, sobretudo melhorando os mapas de contornos dos campos (HONÓRIO, et a., 2007; ALMEIDA, et al., 2016). Após a conclusão desta etapa, validou-se os modelos CoMFA com focagem utilizando o conjunto de teste, aplicando a eles o coeficiente de correlação predito $\left(\mathrm{R}^{2}\right)$. Por fim, gerou-se os mapas de contornos dos campos de forma independente para o ligante mais ativo, esses campos foram gerados a partir dos modelos com e sem focagem. 
Tabela 1. Derivados da classe 1,2,4-oxadiazol, impulsionadores EthR da atividade da etionamida contra M.tuberculosis.

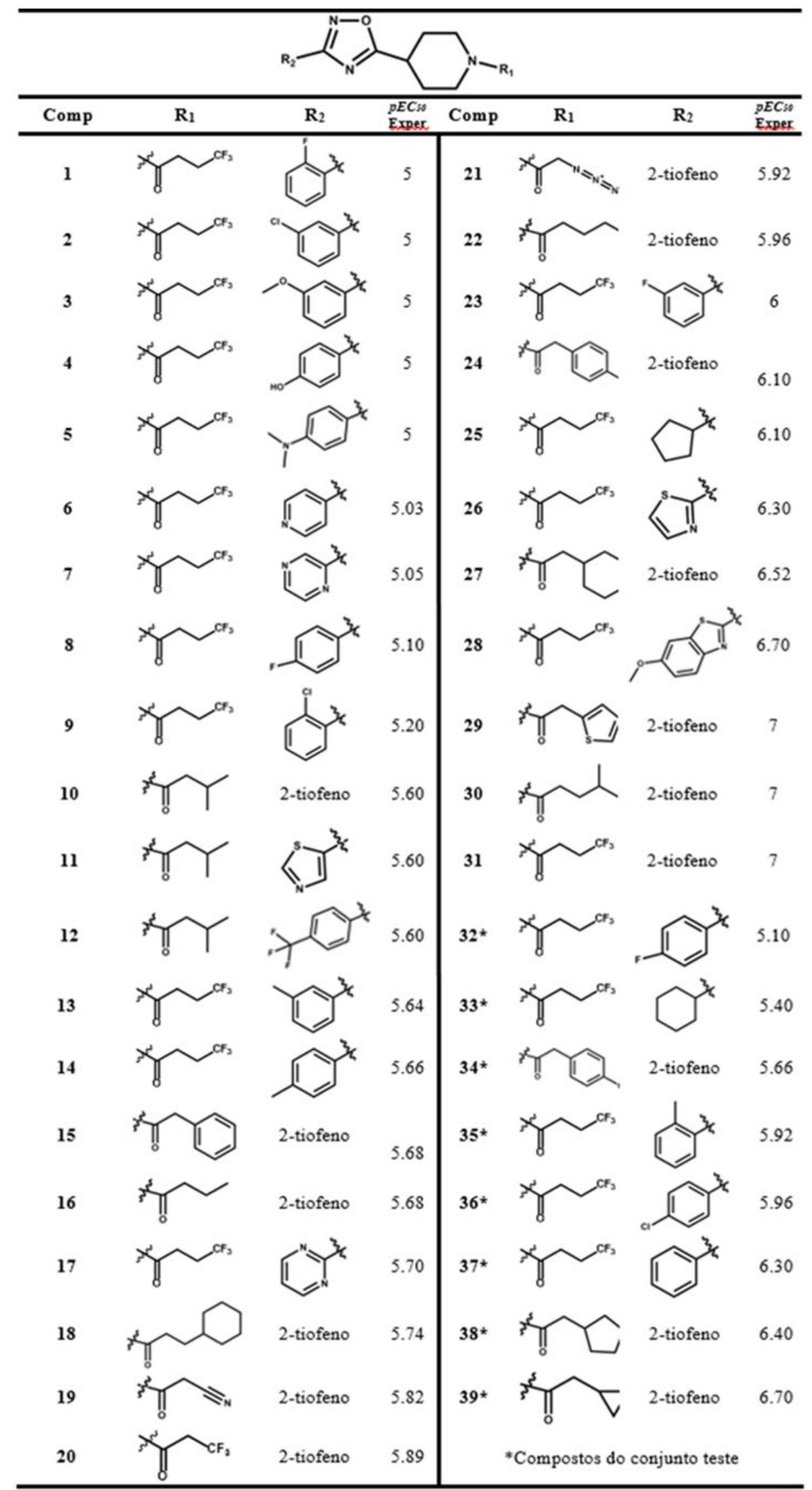

Fonte: Autoria Própria 
Os resultados estatísticos dos modelos CoMFA sem focagem e com focagem estão listados na Tabela 2, ressalta-se que entre todos os modelos de focagem testados o que apresentou melhor combinação de resultados de $\mathrm{R}^{2}$ e $\mathrm{Q}^{2}{ }_{\mathrm{LOO}}$ e contornos estéricos e eletrostáticos foi o $\mathrm{W}=0.3 \mathrm{com} \mathrm{d}=1.0$ Å. Os parâmetros de validação interna foram $\mathrm{Q}_{\mathrm{LOO}}^{2}=0,241$ para o modelo de sem focagem e $\mathrm{Q}^{2}{ }_{\mathrm{LOO}}$ $=0,538$ para o modelo com focagem, o valor de $\mathrm{R}^{2}$ foi igual a 0,929 e 0,967 , para os modelos sem e com focagem, respectivamente.

As contribuições dos campos estéricos e eletrostáticos obtidas pelo método CoMFA são de $26,3 \%$ e $73,7 \%$ para o modelo sem focagem e de $28,4 \%$ e $71,6 \%$ para o modelo com focagem. A aplicação desses modelos para prever a atividade do conjunto teste resultou em um $\mathrm{R}_{\text {pred }}^{2}$ igual a 0,802 e 0,845 para os modelos sem e com focagem, os parâmetros de validação estão acima dos critérios mínimos aceitáveis capazes de validar o modelo estatístico $\left(\mathrm{Q}^{2}>0,5\right.$ e $\left.\mathrm{R}^{2}>0,6\right)$, assim com a aplicação da técnica de região de focagem houve melhora significa nos parâmetros de validação do modelo.

Tabela 2. Parâmetros estatistísticos para os modelos CoMFA.

\begin{tabular}{|c|c|c|}
\hline \multirow[b]{2}{*}{$\begin{array}{l}\text { Parâmetros } \\
\text { de Validação }\end{array}$} & \multicolumn{2}{|c|}{ CoMFA } \\
\hline & Sem focogem & $\begin{array}{r}W=0.3 \\
d=1.0 \AA\end{array}$ \\
\hline $\mathrm{NC}$ & 5 & 5 \\
\hline $\mathrm{Q}_{\mathrm{LOO}}^{2}$ & 0,241 & 0,538 \\
\hline $\mathrm{R}^{2}$ & 0,929 & 0,967 \\
\hline SEE & 0,169 & 0,166 \\
\hline $\mathrm{F}_{\text {teste }}$ & 64977 & 144872 \\
\hline $\mathrm{R}_{\text {pred }}^{2}$ & 0,802 & 0,845 \\
\hline \multicolumn{3}{|c|}{ Fração de Contribuição dos Campos } \\
\hline Estérico & 0,263 & 0,284 \\
\hline Eletrostático & 0,737 & 0,716 \\
\hline
\end{tabular}

Fonte: Autoria Própria

A região de focagem foi ponderada pelos valores do coeficiente de desvio padrão (w) e espaçamento da grade (d). número ótimo de componentes $(\mathrm{NC})$; coeficiente de correlação cruzada após o procedimento LOO $\left(\mathrm{q}^{2}\right)$; coeficiente de correlação não cruzada $\left(\mathrm{R}^{2}\right)$; teste de Fisher $(\mathrm{F})$, um valor maior de F implica uma correlação mais significativa foi alcançada (SELASSIE 2003); estimativa do erro padrão (SEE); coeficiente de correlação para os compostos do conjunto teste $\left(\mathrm{R}_{\text {Pred }}^{2}\right)$.

$\mathrm{Na}$ Tabela 3 estão os resultados de predições das atividades biológicas, pode-se observar os valores de $\mathrm{pEC}_{50}$ experimental e predito obtido com o modelo $\mathrm{W}=0.3 \mathrm{com} \mathrm{d}=1.0 \AA$ para os conjuntos treinamento e teste, além dos valores residuais. A média dos valores residuais para os 31 compostos do conjunto treinamento é de 0,02 , enquanto que média para os 8 compostos do conjunto 
teste é de 0,05 , levando em consideração os 39 compostos do conjunto treinamento e teste a média dos desvios é de 0,011, indicando que existe boa similaridade entre os resultados experimentais e os obtidos teoricamente com a construção do modelo CoMFA.

Tabela 3. Valores $\mathrm{pEC}_{50}$ experimental, valores $\mathrm{pEC}_{50}$ preitos e residual para conjunto treinamento e conjunto teste.

\begin{tabular}{|c|c|c|c|c|c|c|c|}
\hline \multirow[b]{2}{*}{ Comp. } & \multirow[b]{2}{*}{$\begin{array}{l}p \mathbf{E C}_{50} \\
\text { (Exper.) }\end{array}$} & \multicolumn{2}{|c|}{ COMFA } & \multirow[b]{2}{*}{ Comp. } & \multirow[b]{2}{*}{$\begin{array}{l}p \mathbf{E C}_{50} \\
\text { (Exper.) }\end{array}$} & \multicolumn{2}{|c|}{ COMFA } \\
\hline & & $\begin{array}{c}p \mathbf{E C}_{\mathbf{5 0}} \\
(\mathrm{W}=0.3 \\
\mathrm{com} \mathrm{d}=1.0 \\
\AA)\end{array}$ & Res. $^{b}$ & & & $\begin{array}{c}p \mathbf{E C}_{\mathbf{5 0}} \\
(\mathrm{W}=0.3 \\
\mathrm{com} \mathrm{d}=1.0 \\
\AA)\end{array}$ & Res. $^{\mathrm{b}}$ \\
\hline 1 & 5 & 5,04 & $-0,04$ & 21 & 5,96 & 6,01 & $-0,05$ \\
\hline 2 & 5 & 5,13 & $-0,13$ & 22 & 6 & 5,84 & 0,16 \\
\hline 3 & 5 & 4,88 & 0,12 & 23 & 6,1 & 6,13 & $-0,03$ \\
\hline 4 & 5,03 & 5,15 & $-0,12$ & 24 & 6,1 & 5,89 & 0,21 \\
\hline 5 & 5,05 & 4,94 & 0,11 & 25 & 6,3 & 6,28 & 0,02 \\
\hline 6 & 5,1 & 5,1 & 0 & 26 & 6,4 & 6,41 & $-0,01$ \\
\hline 7 & 5,37 & 5,33 & 0,04 & 27 & 5,52 & 6,47 & $-0,95$ \\
\hline 8 & 5,4 & 5,62 & $-0,22$ & 28 & 6,7 & 6,58 & 0,12 \\
\hline 9 & 5,6 & 5,6 & 0 & 29 & 6,7 & 6,69 & 0,01 \\
\hline 10 & 5,6 & 5,42 & 0,18 & 30 & 7 & 6,87 & 0,13 \\
\hline 11 & 5,64 & 5,63 & 0,01 & 31 & 7 & 7,14 & $-0,14$ \\
\hline 12 & 5,66 & 5,73 & $-0,07$ & $32^{\mathrm{a}}$ & 5 & 4,88 & 0,12 \\
\hline 13 & 5,66 & 5,69 & $-0,03$ & $33^{\mathrm{a}}$ & 5 & 5,38 & $-0,38$ \\
\hline 14 & 5,68 & 5,8 & $-0,12$ & $34^{\mathrm{a}}$ & 5,2 & 5,17 & 0,03 \\
\hline 15 & 5,68 & 5,58 & 0,1 & $35^{\mathrm{a}}$ & 5,6 & 6,39 & $-0,79$ \\
\hline 16 & 5,7 & 5,76 & $-0,06$ & $36^{\mathrm{a}}$ & 5,82 & 6 & $-0,18$ \\
\hline 17 & 5,74 & 5,86 & $-0,12$ & $37^{\mathrm{a}}$ & 5,89 & 5,89 & 0 \\
\hline 18 & 5,89 & 5,82 & 0,07 & $38^{\mathrm{a}}$ & 6,3 & 5,41 & 0,89 \\
\hline 19 & 5,92 & 5,94 & $-0,02$ & $39^{\mathrm{a}}$ & 7 & 6,22 & 0,78 \\
\hline 20 & 5,96 & 6,03 & $-0,07$ & & & & \\
\hline
\end{tabular}

Fonte: Autoria Própria

Os diagramas de correlação entre os $\mathrm{pEC}_{50}$ experimental e os preditos CoMFA para todos os compostos está representado na Gráfico 2, os pontos azuis indicam os compostos do conjunto treinamento e foram usados para validação interna, enquanto os pontos vermelhos indicam os compostos do conjunto teste usados para validação externa. Considerando os 31 compostos do conjunto treinamento o coeficiente de correlação é 0,87 , entretanto quando se leva em consideração também os compostos do conjunto teste junto com o treinamento a correlação é de 0,74 . 
Gráfico 2 - $\mathrm{pEC}_{50}$ experimental versus predito para análise CoMFA com aplicação de região de focagem combinando $\mathrm{w}=0.3 \mathrm{com} \mathrm{d}=1.0 \AA$

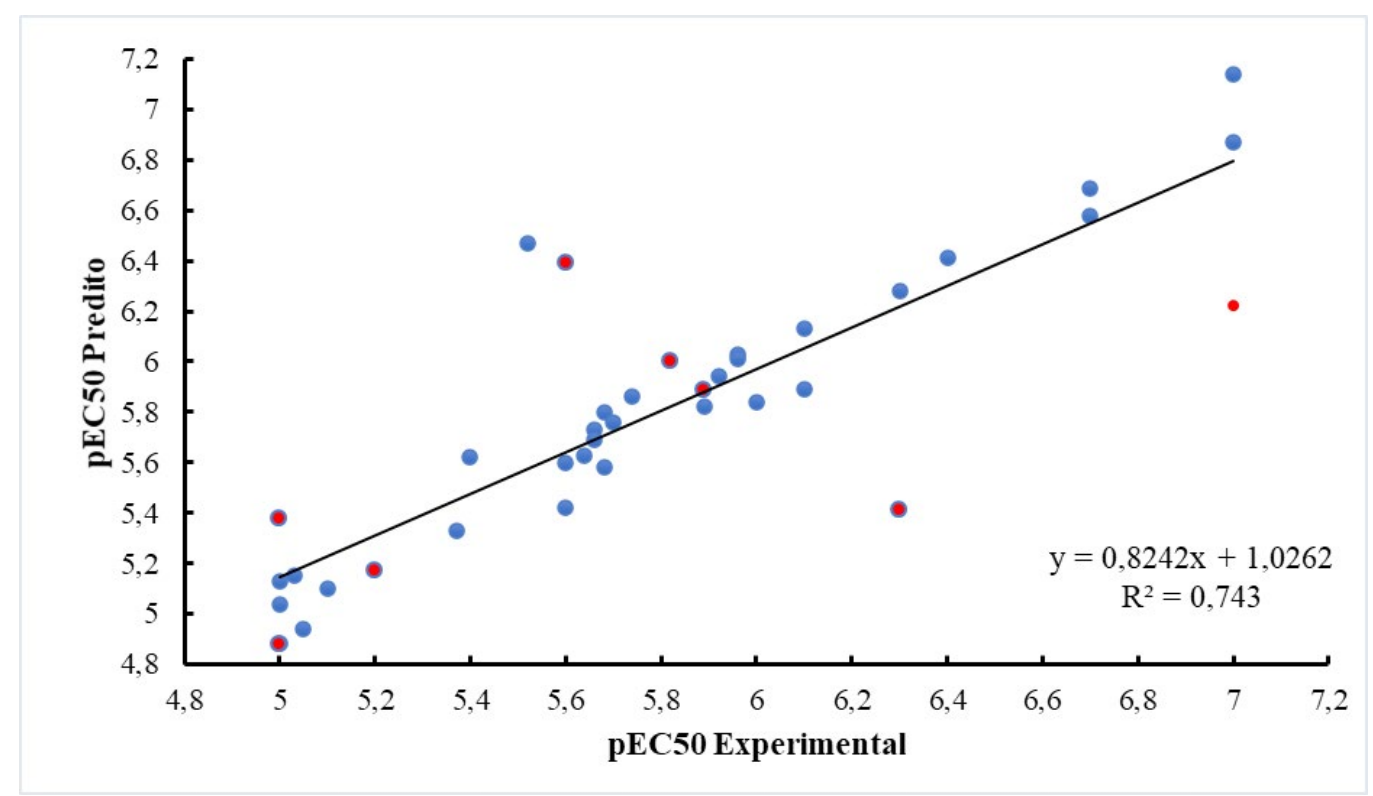

Fonte: Autoria Própria

Com aplicação da técnica de focagem ocorreu melhora tanto nos parâmetros de validação interna quanto interna. Além disso, os mapas de contorno mostraram-se mais refinados e eficientes, apontando pontos chaves para possíveis substituições de forma a melhorar o potencial das atividades. Os mapas de contorno COMFA para propriedades estéricas e eletrostáticas foram construídos usando desvio padrão e coeficiente (stdev*coeff), e gerados visualmente com poliedros em torno de pontos da rede. A Figura 4A e 4B ilustram os mapas de contorno estéricos e eletrostáticos do modelo CoMFA para a molécula 37.

Dessa forma, identifica-se que todos os contornos de CoMFA representaram $80 \%$ das contribuições para as regiões favoráveis e $20 \%$ das contribuições para as regiões desfavoráveis, exibido em verde e amarelo, a cor verde (estericamente favorável) e amarelo (estericamente desfavorável), enquanto o mapa de contorno eletrostático é exibido em azul e vermelho, da mesma forma o azul (carga eletropositiva favorável) e vermelho (carga eletronegativa favoráveis). Os contornos estereoquímicos favoráveis estão próximos dos substituintes R1 com grande volume e pouca representação no grupo R2.

Na Figura 3A, há contornos desfavoráveis estéricos, próximos do substituinte 2-tiofeno do grupo R1 e contorno mais bem distribuído localizado próximo ao grupo 2-tiofeno em R2, sugerindo que grupos volumosos nessas regiões diminuem a atividade. Na Figura 3B, o mapa de contorno eletrostático CoMFA é mostrado, contornos eletronegativos favoráveis (vermelhos) próximos ao grupo 2-tiofeno em R1 e R2, com maior representatividade em R2, sugerindo que a ocupação por um grupo eletronegativo nesta região é favorável para atividade inibidora na enzima EthR. Contornos eletropositivos favoráveis estão distribuídos próximos ao anel 2-tiofeno próximos ao substituinte R2, estas regiões azuis sugerem substituintes eletropositivos nessas regiões podem aumentar a atividade. 
Figure 3 - (a) Mapa de contorno para campo estérico do modelo CoMFA. (b) Mapa de contorno para campo eletrostático do modelo CoMFA.

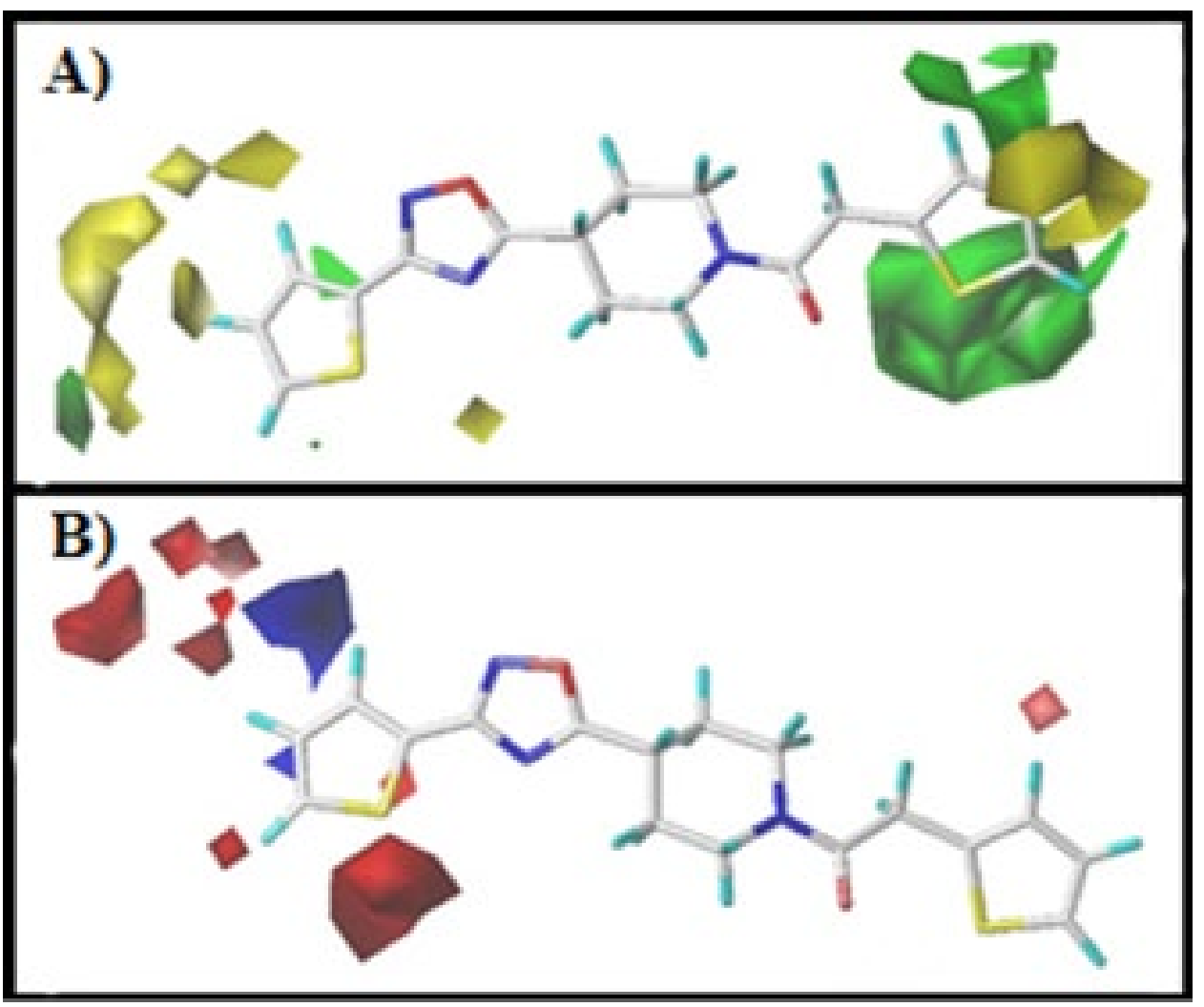

Fonte: Autoria Própria

\section{CONCLUSÃO}

Neste trabalho, realizou-se estudo de QSAR-3D, com inibidores EthR da classe 1,2,4-oxadiazol. O modelo QSAR-3D preditivo destes compostos foi obtido com parâmetros estatísticos satisfatórios, utilizando ferramentas COMFA. Os parâmetros de validação interna foram $\mathrm{Q}^{2}=0,538$ e $\mathrm{R}^{2}$ $=0,967$ estão acima dos critérios mínimos aceitáveis capazes de validar o modelo estatístico $\left(\mathrm{Q}^{2}>\right.$ 0,5 e $\mathrm{R}^{2}>0,6$ ). O modelo construído possuí boa capacidade preditiva, apresentando $\mathrm{R}_{\text {pred }}^{2}$ de 0.845 . Os mapas de contorno de CoMFA forneceram informações úteis para projetar novo inibidor com aumento das atividades de inibidores. Este estudo fornece informações úteis sobre as interações entre inibidores EthR e os requisitos necessários para ajustar as estruturas e assim obter novos compostos com características que possam melhorar o carater inibitório dessa classe.

\section{AGRADECIMENTOS}

Ao Curso Técnico em Informática do Instituto Federal de Educação, Ciência e Tecnologia do Pará, Campus Ananindeua. Ao meu orientador Professor Doutor Ricardo Moraes de Miranda e ao Laboratório de Modelagem e Simulação Computacional (LMSC). 


\section{REFERÊNCIAS}

ALMEIDA, M. O., TROSSINI, G. H. G., et at. In silico studies on the interaction between bioactive ligands and ALK5, a biological target related to the cancer treatment. Journal of Biomolecular Structure and Dynamics, v.34, n. 9, p. 2045-2053. 2016.

ARBEX, M. A., VARELLA, M.C. L., SIQUEIRA, H. R., MELLO, F. A. F.. Drogas antituberculose: Interações medicamentosas, efeitos adversos e utilização em situações especiais. Parte 2: Fármacos de segunda linha. J Bras Pneumol., v. 36, n. 5, p. 641-656. 2010.

COUTURIER, C.; et al. Nanomolar inhibitors of Mycobacterium tuberculosis glutamine synthetase 1: Synthesis, biological evaluation and X-ray crystallographic studies. Bioorganic \& Medicinal Chemistry Letters. v. 25, n. 7, p. $1455-1459.2015$.

FLIPO M., WILLAND, N., et al. Discovery of Novel N-Phenylphenoxyacetamide Derivatives as EthR Inhibitors and Ethionamide Boosters by Combining High-Throughput Screening and Synthesis. J. Med. Chem., v. 55, n. 1, p. 6391-6402. 2012.

FLIPO, M.; DESROSES, M.; LECAT-GUILLET, et al. Ethionamide boosters: synthesis, biological activity, and structure-activity relationships of a series of 1,2,4-oxadiazole EthR inhibitors. J. Med. Chem., v.54, n.1, p. 2994-3010. 2011.

HARRIES, A. D. Tuberculosis and human immunodeficiency vírus infection in developing countries. Lancet. v.335, n. 8686, p. 387-390. 1990.

HONÓRIO, K. M.; et al. 3D QSAR comparative molecular field analysis on nonsteroidal farnesoid X receptor activators. Journal of Molecular Graphics and Modelling, p. 921-927, 2007.

JAVAD, N. M., et al. Drug resistance pattern of Mycobacterium tuberculosis isolates from patients of five provinces of Iran. Asian Pacific Journal of Tropical Medicine. v. 7, n. 3, p. 193-196. 2014.

KOENIG, R. Drug-resistant tuberculosis: in South Africa, XDR TB and HIV prove a deadly combination. Science, v. 319, n. 5865, p. 894-897. 2008.

SAXENA S., SAMALA, G., et al. Development of 2-amino-5-phenylthiophene-3-carboxamide derivatives as novel inhibitors of Mycobacterium tuberculosis DNA GyrB domain. Bioorganic \& Medicinal Chemistry, v. 23, n.7, p. 1402-1412. 2015.

SELASSIE, C. D. History of Quantitative Structure-Activity Relationships. Burger's Medicinal Chemistry and Drug Discovery. Sixth Edition, v. 1: Drug Discovery. 2003.

SELVARAJ, C.; TRIPATHI, S. K.; K. K. REDDY, K. K.; SINGH, S. K. Tool development for Prediction of $p I C_{50}$ values from the $\mathrm{IC}_{50}$ values - A $p I C_{50}$ value calculator. Current Trends in Biotechnology and Pharmacy. v. 5, n. 2, p. 1104-1109. 2011. 


\section{FATORES DE RISCO ASSOCIADOS À RUPTURA UTERINA EM PACIENTES PRIMIGESTAS: UMA REVISÃO INTEGRATIVA}

THAYNARA MELO DOS ANJOS Centro Universitário CESMAC

DINÁRIO AUGUSTO LEMOS NETO Centro Universitário CESMAC

ALINE TENÓRIO LINS CARNAÚBA Centro Universitário CESMAC

ISABELA MACÊDO DE ARAUJO

Centro Universitário CESMAC

MARIANA MENDONÇA DE ARAÚJO

TAVARES

Centro Universitário CESMAC

MATHEUS DE ANDRADE AMARAL Centro Universitário CESMAC

YANCKA LERNER HORA ROCHA

Centro Universitário CESMAC

RESUMO: A ruptura uterina é uma emergência obstétrica de rara ocorrência, ocorre geralmente no terceiro trimestre da gestação e tem diferentes etiologias, como: curetagem uterina com perfuração, miomectomia, acretismo placentário, trauma abdominal, anomalias uterinas, hiperdistensão uterina, uso inapropriado de ocitocina, placenta percreta, trabalho de parto obstruído, indução de prostaglandina em gel, entrega instrumental, trabalho de parto normal administrado e até mesmo a implantação do embrião durante a fertilização in vitro. A ruptura é mais vista em mulheres multíparas, devido a presença de cicatrizes de partos cesáreos anteriores, no entanto, mulheres primi- gestas não podem descartar os riscos. A atuação nesse tipo de emergência deve ser rápida, pois o índice de morbimortalidade materno e fetal é alto. Sendo assim, tem-se como objetivo analisar os fatores de riscos que podem levar uma primigesta a ruptura uterina e os aspectos sociais que dificultam no momento da emergência. Trata-se de uma revisão integrativa, na base de dados Medline, por meio das estratégias de busca: "emergency AND uterine rupture, emergency AND rupture uterine AND first pregnancy". Foram utilizados filtros, como: artigos publicados nos últimos cinco anos e idioma (português e inglês). Foram incluídos artigos que abordassem a ruptura uterina como uma situação de emergência e excluídos artigos que discutem manejos cirúrgicos durante a ruptura uterina. De acordo com as buscas realizadas foram encontrados 490 artigos, dos quais 14 foram selecionados após leitura de títulos, resumos e textos completos. Os principais fatores que oferecem risco à ruptura são a idade materna e ausente/ineficaz pré-natal, o qual tem função de avaliar, identificar e orientar a mulher. Todavia, diversos determinantes sociais dificultam o acesso ao serviço médico de qualidade para que ocorra uma prevenção e intervenção rápida e eficaz.

PALAVRA-CHAVE: Ruptura uterina. Primigesta. Emergência.

ABSTRACT: Uterine rupture is a rare obstetric emergency, usually occurring in the third trimester of pregnancy. It has different etiologies, such as: uterine curettage with perforation, myomectomy, placental accretion, abdominal trauma, uterine anomalies, uterine hyperdistension, improper use of oxytocin, placenta percreta, obstructed 
labor, induction of prostaglandin gel, instrumental delivery, normal labor delivery and even embryo implantation during in vitro fertilization. This way, the rupture is more seen in multiparous women, due to the presence of scars from previous cesarean deliveries, however primigravid women cannot rule out the other risks. The action in this type of emergency should be fast, as the maternal and fetal morbidity and mortality rate is high. The analysis of the risk factors that can lead to a primigravida to uterine rupture and social aspects that make it difficult at the time of the emergency are listed as objectives. It is an integrative review, in the Medline database, through the search strategies: "emergency AND uterine rupture, emergency AND uterine rupture AND first pregnancy". Filters were used, such as: articles published in the last five years, language (Portuguese and English). Articles that addressed uterine rupture as an emergency situation were included by reading titles and abstracts; and articles that discuss surgical management during uterine rupture were excluded. According to the searches performed, a total of 490 articles were found, of which 14 were selected after reading titles, abstracts and full texts. The main factors that support the risk of rupture are maternal age and absent / ineffective prelabor care, which has the function of evaluating, identifying and guiding a woman. However, several social determinants make it difficult to access medical services for prevention and intervention to happen quickly and effectively.

KEYWORDS: Uterine rupture. Primigravidas. Emergency.

\section{INTRODUÇÃO}

A ruptura uterina é um acometimento que ocorre quando há perda da integridade do útero, pode ser completa, quando há rotura total e está relacionada diretamente com a emergência obstétrica, ou incompleta, quando o peritônio parietal permanece intacto e normalmente não está relacionada com um grau de complexidade maior, pode até passar despercebida em alguns casos. Essa patologia é de ocorrência rara, porém no âmbito da circunstância gestacional é uma das mais comuns e por isso deve-se sempre está atento à possibilidade, geralmente ocorre no segundo e terceiro trimestre de gravidez; no primeiro trimestre é raro de ocorrer, no entanto pode causar complicações graves devido a hemorragia (CHO et al., 2017).

De acordo com o Manual técnico de gestação de alto risco do Ministério da Saúde, $5^{a}$ edição, pode variar de $1-2 \%$ o risco de ruptura uterina em gestantes com presença de cicatriz uterina prévia decorrente de cesáreas anteriores, isto é, quanto maior o número de gestações maior a probabilidade da ocorrência, por outro lado quando se trata de paciente primigestas, sem a presença de cicatriz uterina prévia incide em $0,006 \%$ das pacientes (VERNEKAR; RAJIB, 2016).

É associado a esse evento uma alta taxa de morbimortalidade materna e fetal, com pior prognóstico em países em desenvolvimento, devido aos cuidados pré-natais e obstétricos. Muitos desses cuidados são precários e de baixa qualidades, uma vez que os exames de imagem, como a ultrassonografia, normalmente não são realizados periodicamente, diminuindo a chance de identificar malformações, cicatrizes cesarianas resultantes de gestações passada saudáveis ou não (VERNEKAR; RAJIB, 2016; CHO et al., 2017).

Em detrimento a essa questão social, o quadro clínico e a sintomatologia predominante da patologia é o abdome agudo com pneumoperitônio acompanhado de febre, dor abdominal severa, 
hipotensão, possível evolução para choque séptico e/ou hipovolêmico, frequência cardíaca fetal ausente, perda da contratilidade uterina, sangramento uterino e diminuição das contrações uterinas. No entanto, pode ocorrer de ser mimetizado pelos sintomas normais da gravidez como: náuseas, vômito e dor abdominal (POSTHUMUS; DONKER, 2017).

É também possível considerar o alto risco de hemorragia interna que pode ser causado pela ruptura uterina, bem como a relação de fatores que podem culminar em estresse materno e fetal com deterioração dos sinais vitais e ocasionar um choque. Nesse aspecto, no quesito de exames complementares (ultrassonografia) podem ser encontrados útero esvaziado e saco gestacional acima o útero, visto que há sangramento intrauterino e gás na região (PONTIS et al.,2016).

Diferentes etiologias podem ser observadas na ruptura, vista como: curetagem uterina com perfuração, miomectomia, acretismo placentário, trauma abdominal, anomalias uterinas, hiperdistensão uterina, uso inapropriado de ocitocina, placenta percreta, trabalho de parto obstruído, indução de gel de prostaglandina, entrega instrumental, trabalho de parto normal administrado e até mesmo a implantação do embrião durante a fertilização in vitro. Sendo assim, tem-se como objetivo analisar os fatores de risco em pacientes primigestas, uma vez que estas têm menos chances da ocorrência e por isso piores resultados na identificação e gestão são observados, bem como avaliar os impactos na vida das pessoas que passam por uma ruptura uterina (VERNEKAR; RAJIB, 2016).

\section{MÉTODOS/ PERCURSO METODOLÓGICO}

Trata-se de uma revisão integrativa. Para realização desta revisão foi estabelecida cinco fases: $1^{\mathrm{a}}$ ) elaboração da pergunta norteadora, $2^{\mathrm{a}}$ ) busca na literatura, $3^{\mathrm{a}}$ ) coleta de dados nos artigos, $4^{\mathrm{a}}$ ) análise crítica das variáveis estudadas e $5^{\mathrm{a}}$ ) discussão dos resultados.

Com o intuito de alcançar o objetivo desta revisão, a estratégia de busca foi direcionada mediante a seguinte pergunta norteadora: "Quais os fatores de risco de pacientes primigravidas que foram acometidas por ruptura uterina?"

A estratégia de busca foi realizada por meio do cruzamento dos Descritores em Ciências da Saúde (DeCS) e do Medical Subject Headings (Mesh), assim como para os termos livres. Visando identificar os artigos pertinentes com a questão proposta, foram elaboradas estratégias de busca: "emergency AND uterine rupture", "emergency AND rupture uterine AND first pregnancy".

O levantamento dos artigos foi realizado a partir de buscas eletrônicas na base de dados: Medline (via Pubmed). As buscas dos dados ocorreram entre 14 e 18 de outubro de 2020.

Os critérios de inclusão adotados foram: artigos que abordassem a ruptura uterina como uma situação de emergência através da leitura de títulos e resumos; e excluídos artigos que discutem manejos cirúrgicos durante a ruptura uterina. Foram usados filtros como: artigos publicados nos últimos cinco anos, na língua portuguesa e inglesa, bem como pesquisas feitas apenas em humanos. 
A partir da aplicação da estratégia de busca, a seleção dos artigos encontrados foi realizada em duas etapas. Na primeira etapa, foi realizada a leitura dos títulos e resumos nas diferentes bases eletrônicas de dados, sendo excluídos aqueles que claramente não se enquadram a qualquer um dos critérios de inclusão deste estudo. Na segunda etapa, após a leitura dos títulos e resumos, todos os estudos que se enquadraram nos critérios de inclusão e exclusão foram lidos na íntegra para seleção dos que fariam parte do escopo desta revisão.

Os títulos, resumos e artigos completos obtidos foram avaliados de forma independente por dois avaliadores que não estavam cegos para os autores ou para os títulos dos periódicos. As discordâncias foram decididas por consenso. Nos casos em que não houve consenso, um terceiro avaliador foi convocado para tomar a decisão final.

Os principais dados de cada artigo foram detalhadamente coletados e inseridos em um banco de dados no programa Microsoft Office Excel 2011, onde foram consideradas as seguintes.

\section{RESULTADOS E DISCUSSÃO}

De acordo com as buscas realizadas foram encontrados 490 artigos, dos quais 41 títulos foram considerados relevantes, pois associavam-se diretamente com o tema, após a leitura completa do resumo, foram excluídos 22. A partir disso, foi realizada a leitura completa do texto e foram selecionados 14 para compor este trabalho. O fluxograma a seguir (Figura 1) apresenta uma síntese do processo de obtenção dos artigos selecionados para revisão integrativa.

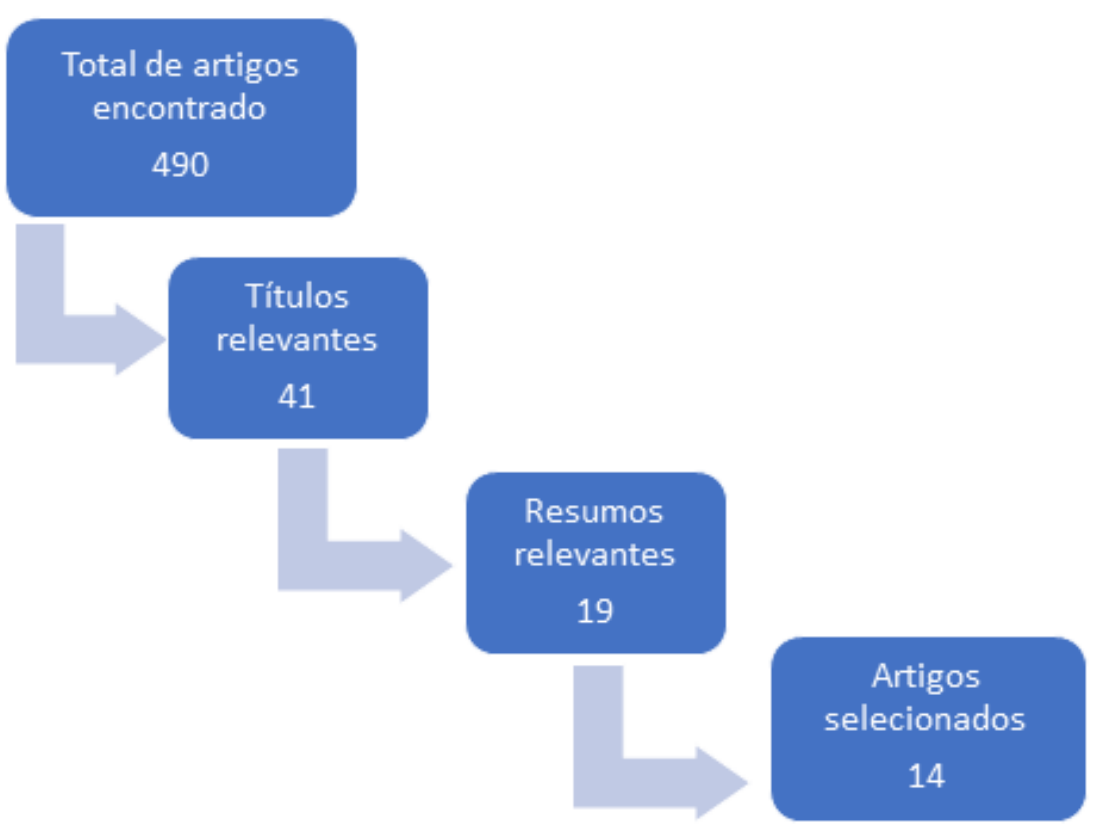

Figura 1. Fluxograma da estratégia de seleção de artigos.

Para a análise dos resultados foi criado um quadro (quadro 1) que aborda os autores, título, objetivo e resultados de cada artigo selecionado para construção do estudo. 
Quadro 1. Apresentação da síntese de artigos incluídos na revisão integrativa.

\begin{tabular}{|c|c|c|c|}
\hline Auto & Ano/País & Objetivo & Resultados \\
\hline $\begin{array}{l}\text { Shu-Han You, Yao-Lung Chang, } \\
\text { Chih-Feng Yen/ } \\
\text { Rupture of the scarred and uns- } \\
\text { carred gravid uterus: Outco- } \\
\text { mes and risk factors analysis }\end{array}$ & 2018/ Taiwan & $\begin{array}{l}\text { Estudar os resultados mater- } \\
\text { nos e fetais e avaliar os fa- } \\
\text { tores de risco em pacientes } \\
\text { com ruptura no segmento } \\
\text { inferior ou sem cicatriz do } \\
\text { segmento inferior, ou útero } \\
\text { grávido sem cicatrizes. }\end{array}$ & $\begin{array}{l}\text { Útero sem cicatrizes sem fator de } \\
\text { risco identificável rompido em } \\
\text { gestação significativamente pos- } \\
\text { te-rior associada a pesos fetais ao } \\
\text { nascimento mais elevados do que } \\
\text { os do útero com cicatrizes, ambos } \\
\text { os quais produziram morbidade }\end{array}$ \\
\hline $\begin{array}{l}\text { Manisha Vernekar, Roy Rajib/ } \\
\text { Unscarred Uterine Rupture: A } \\
\text { Retrospective Analysis }\end{array}$ & 201 & $\begin{array}{l}\text { Analisar a frequência, os } \\
\text { fatores predisponentes e os } \\
\text { resultados maternos e fetais } \\
\text { da ruptura uterina }\end{array}$ & $\begin{array}{l}\text { Nossa análise compreendeu } 13 \text { ca- } \\
\text { sos. Ruptura uterina ocorreu a ter- } \\
\text { mo em dez casos. A ruptura ocorreu } \\
\text { devido a trabalho de parto mal ad- } \\
\text { ministrado, uso de ocitocina, parto } \\
\text { instrumental, parto obstruído, indu- } \\
\text { ção por gel de prostaglandina e pla- } \\
\text { centa percreta. }\end{array}$ \\
\hline $\begin{array}{l}\text { Lotte Posthumus, Marielle } \\
\text { Eveline Donker } \\
\text { Uterine rupture in a primigra- } \\
\text { vid patient, an uncommon but } \\
\text { severe obstetrical event: a case } \\
\text { report }\end{array}$ & 20 & $\begin{array}{l}\text { Relato de caso: } \\
\text { Uma emergência foi reali- } \\
\text { zada e uma ruptura uterina } \\
\text { foi identificada como causa } \\
\text { do evento. }\end{array}$ & $\begin{array}{l}\text { Devido à rara incidência e apresen- } \\
\text { tação inespecífica, ruptura do útero } \\
\text { em nosso caso não foi o diagnóstico } \\
\text { principal. Não está claro se a apre- } \\
\text { sentação aguda foi devida apenas à } \\
\text { ruptura do útero, ou se esse desco- } \\
\text { lamento ocorreu antes da ruptura, } \\
\text { tornando-se uma possível causa do } \\
\text { evento. }\end{array}$ \\
\hline $\begin{array}{l}\text { Eloge Ilunga-Mbaya, Olivier } \\
\text { Nyakio, Raha Maroyi, Patrick } \\
\text { Bigabwa, Moise Kiminyi, Si- } \\
\text { las Hamisi, Dénis Mukwege, } \\
\text { Dieudonné Sengeyi Mushenge- } \\
\text { zi Amani } \\
\text { Spontaneous open book uterine } \\
\text { rupture at } 15 \text { weeks' gestation } \\
\text { in a pauciparous woman with } \\
\text { scarred uterus: a case study }\end{array}$ & 202 & $\begin{array}{l}\text { Relato de caso sobre ruptu- } \\
\text { ra uterina numa gestação de } \\
15 \text { semanas em uma mulher } \\
\text { primigesta detentora de ci- } \\
\text { catriz uterina. }\end{array}$ & $\begin{array}{l}\text { Este estudo evidencia que ruptura } \\
\text { uterina deve ser levada em consi- } \\
\text { deração quando relacionar com pa- } \\
\text { cientes que possuem cicatriz uterina } \\
\text { e apresentam dor abdominal asso- } \\
\text { ciada a sinais de hemoperitônio, } \\
\text { independente se sua gravidez for a } \\
\text { termo ou nos primeiros dois trimes- } \\
\text { tres e independentemente da idade } \\
\text { (pacientes jovens) e paridade. }\end{array}$ \\
\hline $\begin{array}{l}\text { Wen-Xi Tan, Xue-Jiao Lv, Rui- } \\
\text {-Qi Yang, Ben-Zheng Zhao, } \\
\text { Jun-Yu Chen, Shan Wu, Yan- } \\
\text {-Hui Zhao, Man-Hua Cui } \\
\text { Spontaneous rupture of an uns- } \\
\text { carred uterus with an intact } \\
\text { amniotic sac extrusion and fe- } \\
\text { tal leg entrapment at } 28 \text { gesta- } \\
\text { tional weeks: a case report }\end{array}$ & 2020/China & $\begin{array}{l}\text { Relato de caso de mulher } \\
\text { primigesta de } 27 \text { anos foi } \\
\text { encaminhada ao serviço, } \\
\text { devido à dor abdominal per- } \\
\text { pétua, com } 28 \text { semanas e } \\
\text { cinco dias de gestação. }\end{array}$ & $\begin{array}{l}\text { Uma ultrassonografia abdominal } \\
\text { sugeriu um defeito no corno uteri- } \\
\text { no esquerdo. Uma laparotomia de } \\
\text { emergência foi subsequentemente } \\
\text { realizada e revelou uma extrusão do } \\
\text { saco amniótico intacta e compres- } \\
\text { são da perna fetal. }\end{array}$ \\
\hline
\end{tabular}




\begin{tabular}{|c|c|c|c|}
\hline $\begin{array}{l}\text { Fariha Farooq, Rashid Siraj, Si- } \\
\text { btain Raza, Nadia Saif } \\
\text { Spontaneous Uterine Rup-ture } \\
\text { Due to Placenta Percreta in a } \\
\text { 17-Week Twin Pregnancy }\end{array}$ & 2016/Paquistão & $\begin{array}{l}\text { Relato de caso de paciente } \\
\text { de } 27 \text { anos na quarta gesta- } \\
\text { ção, com duas cesáreas de } \\
\text { segmento inferior anterior, } \\
\text { apresentou-se na } 17^{\text {a }} \text { sema- } \\
\text { na de gravidez gemelar com } \\
\text { dor abdominal aguda. }\end{array}$ & $\begin{array}{l}\text { A histopatologia da amostra do úte- } \\
\text { ro confirmou que a placenta percre- } \\
\text { ta foi a causa da ruptura uterina. }\end{array}$ \\
\hline $\begin{array}{l}\text { Kanika Batra, Harsha S } \\
\text { Gaikwad, Isha Gutgutia, Shashi } \\
\text { Prateek, Bindu Bajaj } \\
\text { Determinants of rupture of the } \\
\text { unscarred uterus and the re- } \\
\text { lated feto-maternal outcome: } \\
\text { current scenario in a low-inco- } \\
\text { me country }\end{array}$ & 2015/ Índia & $\begin{array}{l}\text { Avalia determinantes e re- } \\
\text { sultado do feto e da mãe } \\
\text { com rupturas uterinas sem } \\
\text { cicatriz prévia em país de } \\
\text { baixa renda. }\end{array}$ & $\begin{array}{l}\text { Houve } 141 \text { rupturas em } 43.886 \text { par- } \\
\text { tos. Destas, } 18 \text { ocorreram em útero } \\
\text { presumido sem cicatriz. As etio- } \\
\text { logias foram: obstrução, anomalia } \\
\text { uterina, administração ocitócica, } \\
\text { partos instrumentais e diversos. A } \\
\text { histerectomia foi realizada. }\end{array}$ \\
\hline $\begin{array}{l}\text { Mehmet B Senturk, Yusuf } \\
\text { Cakmak, Hakan Guraslan, Ke- } \\
\text { ziban Dogan } \\
\text { Emergency peripartum hyste- } \\
\text { rectomy: 2-year experiences in } \\
\text { non-tertiary center }\end{array}$ & 2015/ Turquia & $\begin{array}{l}\text { Avaliar os fatores de risco, } \\
\text { indicações e desfechos ma- } \\
\text { terno-fetais para histerecto- } \\
\text { mia periparto de emergên- } \\
\text { cia. }\end{array}$ & $\begin{array}{l}\text { Houve correlação entre histerec- } \\
\text { tomia periparto e atonia uterina ou } \\
\text { ruptura uterina. As taxas de encami- } \\
\text { nhamento de pacientes com parto } \\
\text { domiciliar foram significativamente } \\
\text { maiores do que aquelas de pacien- } \\
\text { tes que deram à luz no hospital, mas } \\
\text { nenhuma diferença significativa foi } \\
\text { observada nos resultados neonatais. }\end{array}$ \\
\hline $\begin{array}{l}\text { Baojing Zhao, Yanling Wang, } \\
\text { Ying Zhang } \\
\text { Uterine rupture in patients with } \\
\text { a history of laparoscopy or hys- } \\
\text { teroscopy procedu-res: Three } \\
\text { case reports }\end{array}$ & 2019/Eua & $\begin{array}{l}\text { Relato de três casos de rup- } \\
\text { tura uterina. Os casos um e } \\
\text { dois foram diagnosticados } \\
\text { durante a cirurgia. O caso } \\
\text { três foi diagnosticado por } \\
\text { uma ultrassonografia abdo- } \\
\text { minal de urgência antes da } \\
\text { cirurgia. }\end{array}$ & $\begin{array}{l}\text { Em conclusão, deve-se enfatizar } \\
\text { que gestantes com história de reti- } \\
\text { rada laparoscópica de gravidez ec- } \\
\text { tópica ou histeroscopia devem ser } \\
\text { submetidas a cuidados especiais. } \\
\text { Além disso, precisamos gerenciar } \\
\text { pacientes com histórico de tais ci- } \\
\text { rurgias em clínicas obstétricas de } \\
\text { alto risco. }\end{array}$ \\
\hline $\begin{array}{l}\text { A Pontis, C Prasciolu, P Litta, } \\
\text { S Angioni } \\
\text { Uterine rupture in pregnancy: } \\
\text { two case reports and review of } \\
\text { literature }\end{array}$ & 2016/ Itália & $\begin{array}{l}\text { Relato de dois casos de rup- } \\
\text { tura uterina total espontânea } \\
\text { durante a gravidez. O pri- } \\
\text { meiro caso tinha um históri- } \\
\text { co de dilatação e curetagem } \\
\text { para aborto; o segundo caso } \\
\text { tinha história pregressa de } \\
\text { dilatação e curetagem,sal- } \\
\text { pingectomialaparoscópica } \\
\text { monolateral para gravidez } \\
\text { ectópica. }\end{array}$ & $\begin{array}{l}\text { Esses casos mostram que deve ha- } \\
\text { ver um alto índice de suspeita de } \\
\text { ruptura uterina em uma mulher grá- } \\
\text { vida com histórico de curetagem, } \\
\text { possível presença de cicatriz uteri- } \\
\text { na, história pregressa de salpingec- } \\
\text { tomia com ou sem ressecção da cór- } \\
\text { nea. Aconselhamento apropriado e } \\
\text { acompanhamento rigoroso podem } \\
\text { ajudar a evitar tal catástrofe obsté- } \\
\text { trica. }\end{array}$ \\
\hline
\end{tabular}




\begin{tabular}{|c|c|c|c|}
\hline $\begin{array}{l}\text { Mahreen Rasool, Imrana Mas- } \\
\text { roor, Shafia Shakoor, Shama } \\
\text { Munim } \\
\text { Spontaneous uterine rupture at } \\
28 \text { weeks: A case report }\end{array}$ & 2016/ Karachi & $\begin{array}{l}\text { Relato de caso de uma mul- } \\
\text { tigravida com } 28 \text { semanas } \\
\text { de gestação, história de } \\
\text { cistos hepáticos, cesárea e } \\
\text { curetagem, apresentou dor } \\
\text { abdominal aguda e sensibi- } \\
\text { lidade dolorosa; ultrassono- } \\
\text { grafia revelou placenta per- } \\
\text { creta. A tomografia mostrou } \\
\text { hemoperitônio }\end{array}$ & $\begin{array}{l}\text { Foi relatado um caso de diagnóstico } \\
\text { de defeito uterino no início da gra- } \\
\text { videz diagnosticado por ultrassom } \\
\text { que foi reparado e a gravidez conti- } \\
\text { nuou até } 32 \text { semanas. }\end{array}$ \\
\hline $\begin{array}{l}\text { Hila Hochler, Tamar Wainsto- } \\
\text { ck, Michal Lipschuetz, Eyal } \\
\text { Sheiner, Yossef Ezra, Simcha } \\
\text { Yagel, Asnat Walfisch } \\
\text { Grandmultiparity, maternal } \\
\text { age, and the risk for uterine } \\
\text { rupture-A multicenter cohort } \\
\text { study }\end{array}$ & $\begin{array}{c}\text { 2019/ Escandi- } \\
\text { návia }\end{array}$ & $\begin{array}{l}\text { Determinar se a multipari- } \\
\text { dade (paridade } \geq 6 \text { ) repre- } \\
\text { senta um risco de ruptura } \\
\text { uterina em mulheres sem } \\
\text { cesariana anterior. }\end{array}$ & $\begin{array}{l}\text { Um total de } 388.784 \text { partos de mu- } \\
\text { lheres multíparas com útero sem ci- } \\
\text { catrizes foram registrados durante o } \\
\text { período do estudo. No entanto, em } \\
\text { um modelo multivariável que con- } \\
\text { trola a idade materna, a associação } \\
\text { entre grande multiparidade e rup- } \\
\text { tura uterina, a idade materna surgiu } \\
\text { como um preditor independente de } \\
\text { ruptura uterina. }\end{array}$ \\
\hline $\begin{array}{l}\text { Yan Sun, Jing Huang, Hong- } \\
\text {-Fang Kong } \\
\text { Spontaneous rupture of uns- } \\
\text { carred uterus in the third } \\
\text { trimester after in vitro fertiliza- } \\
\text { tion-embryo transfer because } \\
\text { of bilateral salpingectomy: A } \\
\text { case report }\end{array}$ & 201 & $\begin{array}{l}\text { Relato de caso de uma mu- } \\
\text { lher de } 24 \text { anos com história } \\
\text { de FIV-ET e salpingectomia } \\
\text { bilateral foi admitida em } \\
\text { hospital com dor abdominal } \\
\text { aguda inexplicável durante } \\
\text { o terceiro trimestre de gra- } \\
\text { vides. }\end{array}$ & $\begin{array}{l}\text { Dois bebês nasceram sem intercor- } \\
\text { rências. As avaliações de acompa- } \\
\text { nhamento da mãe e do bebê no } 42^{\circ} \\
\text { dia pós-parto produziram resultados } \\
\text { normais. O bebê do sexo masculino } \\
\text { foi diagnosticado com hidronefrose } \\
\text { esquerda. }\end{array}$ \\
\hline $\begin{array}{l}\text { Moon Kyoung Cho, Hyun } \\
\text { Kyung Ryu, Chul Hong Kim } \\
\text { Placenta Percreta-Induced } \\
\text { Uterine Rupture at 7th Week of } \\
\text { Pregnancy After In Vitro Ferti- } \\
\text { lization in a Primigravida Wo- } \\
\text { man: Case Report }\end{array}$ & $2017 /($ & $\begin{array}{l}\text { Relato de caso de ruptura } \\
\text { uterina espontânea induzida } \\
\text { pela placenta percreta na } 7^{\mathrm{a}} \\
\text { semana de gravidez após a } \\
\text { fertilização in vitro em uma } \\
\text { mulher primigesta. }\end{array}$ & $\begin{array}{l}\text { O tecido placentário penetrando } \\
\text { através da serosa uterina e com o } \\
\text { exame histopatológico confirmou } \\
\text { o diagnóstico de placenta percreta. } \\
\text { Foi encontrado um hemoperitônio. } \\
\text { Deve suspeitar de ruptura uterina } \\
\text { em mulheres grávidas com dor ab- } \\
\text { dominal mesmo no primeiro trimes- } \\
\text { tre de gravidez. }\end{array}$ \\
\hline
\end{tabular}

Conforme a leitura dos artigos selecionados, observou-se que as pacientes que sofrem ruptura uterina são detentoras de útero sem cicatrizes e primigesta representa um caso especial por ter um direcionamento diferenciado quando se avalia o histórico clínico prévio e percebe que os riscos pressupostos acabam não se correlacionando com sua clínica rara. É possível associar alguns fatores determinantes que incidem na progressão da gravidez presente e em uma possível gestação futura como a multiparidade, utilização não correta da ocitocina, um acometimento de hiperdistensão uterina por uma gravidez de gêmeos, procedimentos obstétricos como curetagem e em pacientes com histórico de histeroscopia e perfuração do útero. Devido a isso, o prognóstico mais grave e de emergência que 
é identificado é o choque, posterior sangramento interno, condições extremamente relevantes para a manutenção da vida da gestante e do feto (PONTIS et al.,2016).

A premissa de um útero com histórico cicatricial pode ser considerado um fator de predisponente de uma possível ruptura uterina em uma gestação em curso. A consequência do processo de ruptura é séria e incomum interfere na saúde da gestante e do feto o que se configura em uma emergência obstétrica que deve ser tratada imediatamente. Para Pontis (2016), a ruptura do útero durante o trabalho de parto também está associada à cessação da dor do parto, recessão das partes corporais fetais apresentadas, lacerações cervicais e defeito uterino palpável na vagina, em alguns casos é possível evidenciar sofrimento fetal antes do início do sangramento ou dor abdominal.

Podem ser considerados os fatores precursores responsáveis por ocasionar uma ruptura uterina, os casos que apresentavam história prévia de cesariana, curetagem uterina, extração manual de placenta e multiparidade e placenta percreta (CHO et al., 2017).

Entretanto, os casos que relacionam-se com os possíveis fatores de risco representam um nicho que precisa ser analisado com cautela, pois além de raro acometimento é uma condição extremamente danosa à saúde da paciente, o que requer tratamento imediato e faz-se necessário gerenciar pacientes com o histórico de tais cirurgias em cuidados especializados de alto risco (ZHAO et al., 2019).

Dentre os métodos diagnósticos essenciais pode ser destacado a tomografia computadorizada, o ultrassom e a ressonância magnética. A tomografia computadorizada acaba não sendo o método diagnóstico de primeira escolha para exames de imagem de mulheres grávidas com dor abdominal devido a complicações da radiação, porém pode ser considerado o melhor para visualizar a cavidade abdominal. Normalmente é escolhido a ultrassonografia por ser livre de radiação e bastante eficaz para examinar a paciente, todavia, sua precisão é frequentemente afetada por baixa resolução e gás na cavidade abdominal (ZHAO et al., 2019).

São tidos como fatores de risco para a ruptura uterina àquelas que não estão em sua primeira gravidez ou estão, como é o caso de primigestas, a idade materna, o uso inadequado de ocitócicos, prostaglandinas, obstruções, desproporção céfalo pélvica, útero bicorno, implantação inadequada da placenta, traumas, manobras obstétricas e vulnerabilidade social. Uma vez que são situações extremamente comuns de ocorrer no dia a dia, portanto, deve-se dar mais atenção, dado que a ruptura do útero é um evento não tão comum e quando é chegado ao diagnóstico da patologia o binômio mãe e feto já foram expostos a situações danosas que podem não ter reversão (BATRA et al., 2015).

\subsection{IDADE MATERNA}

Para as primigestas dentre os graus de risco para uma possível ruptura uterina está a idade materna, isto é, mulheres acima de 35 anos tendem a ter uma deterioração das células do miométrio, visto que todas as células musculares sofrem (HOCHLER et al., 2019). 


\subsection{USO INADEQUADO DE OCITÓCITOS}

Dentre os estudos vistos, um dos principais fatores de risco para o desprendimento das camadas uterinas é o uso inadvertido de ocitócitos que são utilizados para induzir/facilitar o trabalho de parto. Altas doses não nomeadas de ocitocina são administradas por via intravenosa ou intramuscular por profissionais não capacitados, que por vezes nem se quer avalia as contrações uterinas e os batimentos fetal. E assim, gera toxicidade e aumento da atividade contrátil do útero que progride para rompimento das camadas uterinas. (BATRA et al., 2015).

\subsection{VULNERABILIDADE SOCIAL}

A vulnerabilidade social pode ser o principal fator de risco para a ruptura uterina quando se trata de países em desenvolvimento, devido a falta de assistência adequada. Sabe-se que o pré-natal é imprescindível para o acompanhamento da gestação e prevenção de intercorrências como é o caso da emergência em questão. Ao realizar uma avaliação de qualidade é possível, por exemplo, identificar anormalidade da pelve e orientar a conduta a ser realizada em situações de traumas. Além disso, é importante destacar que em situações de vulnerabilidade social o número de partos domiciliares é maior e o acesso aos serviços ofertados também são menores (BATRA et al., 2015).

\section{CONSIDERAÇÕES FINAIS}

Por fim, percebe-se que a ruptura uterina é uma das emergências obstétricas que além de rara pode ser considerada uma das que mais pode provocar o óbito e com rápida evolução devido ao alto grau de hemorragia abdominal observado. Com isso, é possível perceber que essa consequência é causada pela evolução de um quadro clínico severo, o qual quando não diagnosticado corretamente para início do tratamento adequado pode trazer resultados catastróficos. A partir disso, os fatores de risco mais relevantes responsáveis por ocasionar a ruptura uterina em pacientes primigestas são: a idade avançada e a ausente/má avaliação do pré-natal que pode estar associada a uma dificuldade maior de auxílio em questão de sistema de saúde pouco acessível à população ou a falta de atenção médica na população em situação de vulnerabilidade social.

\section{REFERÊNCIAS}

BATRA, Kanika et al. Determinants of rupture of the unscarred uterus and the related feto-maternal outcome: current scenario in a low-income country. Tropical Doctor, v. 46, n. 2, p. 69-73, 2016. Disponível em: <https://pubmed.ncbi.nlm.nih.gov/26275978/>.

CHO, Moon Kyoung; RYU, Hyun Kyung; KIM, Chul Hong. Placenta percreta-induced uterine rupture at 7th week of pregnancy after in vitro fertilization in a primigravida woman: case report. The Journal of Emergency Medicine, v. 53, n. 1, p. 126-129, 2017.Disponível em: <https://pubmed.ncbi.nlm.nih.gov/28258880/>. 
FAROOQ, Fariha et al. Spontaneous Uterine Rupture Due to Placenta Percreta in a 17-Week Twin Pregnancy. J Coll Physicians Surg Pak, v. 26, n. 11, p. 121-123, 2016. Disponível em: < https://pubmed.ncbi.nlm.nih. gov/28666503/>.

GURASLAN, H; DOGAN, K SENTURK, M.B; CAKMAK, Y. Emergency peripartum hysterectomy: 2-year experiences in non-tertiary center. Archives of Gynecology and Obstetrics, v. 292, p. 1019-1025. 2015.Disponível em: <https://pubmed.ncbi.nlm.nih.gov/25929233/>.

HOCHLER, Hila et al. Grandmultiparity, maternal age, and the risk for uterine rupture-A multicenter cohort study. Acta Obstetricia et Gynecologica Scandinavica, v. 99, n. 2, p. 267-273, 2020.Disponível em: <https:// pubmed.ncbi.nlm.nih.gov/31505021/>.

ILUNGA-MBAYA, Eloge et al. Spontaneous open book uterine rupture at 15 weeks' gestation in a pauciparous woman with scarred uterus: a case study. The Pan African Medical Journal, v. 36, p. 44-44, 2020. Disponivel em: <https://pubmed.ncbi.nlm.nih.gov/32774620/>.

MASROOR, I; RASOOL, M; SHAKOOR, S; MUNIM, S. Spontaneous uterine rupture at 28 weeks: A case report. JPMA: Journal of Pakistan Medical Association, v. 66, n. 7, p. 898-900. 2016. Disponível em: < https://pubmed.ncbi.nlm.nih.gov/27427145/>.

PONTIS, Alessandro et al. Uterine rupture in pregnancy: two case reports and review of literature. Clin Exp Obstet Gynecol, v. 43, n. 2, p. 304-309, 2016. Disponínel em: <https://pubmed.ncbi.nlm.nih.gov/27132437/>.

POSTHUMUS, Lotte; DONKER, Marielle Eveline. Uterine rupture in a primigravid patient, an uncommon but severe obstetrical event: a case report. Journal of medical case reports, v. 11, n. 1, p. 1-4, 2017. Disponível em: <https://www.ncbi.nlm.nih.gov/pmc/articles/PMC5718063/>.

SUN, Yan; HUANG, Jing; KONG, Hong-Fang. Spontaneous rupture of unscarred uterus in the third trimester after in vitro fertilization-embryo transfer because of bilateral salpingectomy: A case report. Medicine, v. 98, n. 48, 2019. Disponível em: <https://www.ncbi.nlm.nih.gov/pmc/articles/PMC6890355/>.

TAN, Wen-Xi et al. Spontaneous rupture of an unscarred uterus with an intact amniotic sac extrusion and fetal leg entrapment at 28 gestational weeks: a case report. Gland Surgery, v. 9, n. 2, p. 459, 2020. Disponível em: $<$ https://www.ncbi.nlm.nih.gov/pmc/articles/PMC7225479/>.

VERNEKAR, Manisha; RAJIB, Roy. Unscarred uterine rupture: a retrospective analysis. The Journal of Obstetrics and Gynecology of India, v. 66, n. 1, p. 51-54, 2016. Disponível em: <https://pubmed.ncbi.nlm. nih.gov/27651577/>.

YOU, Shu-Han; CHANG, Yao-Lung; YEN, Chih-Feng. Rupture of the scarred and unscarred gravid uterus: outcomes and risk factors analysis. Taiwanese Journal of Obstetrics and Gynecology, v. 57, n. 2, p. 248-254, 2018 Disponível em: <https://pubmed.ncbi.nlm.nih.gov/29673669/>.

ZHAO, Baojing; WANG, Yanling; ZHANG, Ying. Uterine rupture in patients with a history of laparoscopy or hysteroscopy procedures: Three case reports. Medicine, v. 98, n. 20, 2019. Disponível em: <https://pubmed. ncbi.nlm.nih.gov/31096449/>. 


\section{SÍNDROME DE HERLYN-WERNER-WUNDERLICH: UMA ENTIDADE RARA A SER CONHECIDA}

NATHALIA BRAGA PEREIRA Discente do curso de Medicina da Universidade Estadual de Montes Claros

MARINA RODRIGUES CHAVES

Discente do curso de Medicina da Universidade Estadual de Montes Claros

ÁLLAN COSTA SOUZA

Discente do curso de Medicina da Universidad Privada Del Este; Cidade do Leste; Alto Paraná, Paraguai

MARIA FERNANDA DIAS BASÍLIO

Residente de Ginecologia e Obstetrícia do Hospital Universitário Clemente de Faria

LAÉRCIO FONSECA COSTA

Especialista em Ginecologia e Obstetrícia. Médico do Hospital Universitário Clemente de

Faria

\section{LUÇANDRA RAMOS ESPÍRITO SANTO}

Doutora em Ciências da Saúde. Departamento de Saúde Mental e Coletiva, Universidade Estadual de Montes Claros

RESUMO: A síndrome de Herlyn-Werner-Wunderlich é descrita pela tríade útero didelfo, hemivagina obstruída e agenesia renal, geralmente ipsilateral. Trata-se de uma rara anomalia dos ductos Müllerianos identificada pela primeira vez em 1922 pelo cirurgião inglês E. C. Purslow. Este relato apresenta o caso de uma paciente de 12 anos do sexo feminino, estudante, sem história prévia de comorbidades, que se dirigiu ao Hospital Universitário Clemente de Faria - Montes Claros/MG com quadro de dismenorreia. A ultrassonografia (US) pélvica evidenciou útero didelfo e achados compatíveis com hematometrocolpo. Em US de vias urinárias, observou-se agenesia renal direita. Foi solicitada ressonância magnética (RM), que apontou achados compatíveis com uma malformação Mulleriana, indicando o diagnóstico da síndrome. Por conseguinte, a paciente foi submetida à ressecção e marsupialização do septo vaginal, sendo drenada secreção mucosa de coloração hemossiderótica. $\mathrm{O}$ ato cirúrgico transcorreu sem intercorrências, e a paciente apresentou boa evolução no pós-operatório. A sintomatologia mais comumente relacionada à síndrome corresponde à dor pélvica cíclica, dismenorreia e massa abdominal, que surgem após a menarca. $\mathrm{O}$ diagnóstico geralmente ocorre por volta dos 14 anos, quando a paciente passa a referir os sintomas e é submetida à investigação do quadro através de exames de imagem como a ultrassonografia e, preferencialmente, a ressonância magnética. O tratamento padrão-ouro baseia-se na ressecção e marsupialização do septo vaginal da hemivagina obstruída. O prognóstico favorável está diretamente relacionado à propedêutica e à terapêutica precoces que, uma vez postergadas, podem acarretar complicações agudas, como piohematocolpo, piossalpingites ou pelviperitonites, e tardias, como endometriose, aderências pélvicas e risco de abortamento ou infertilidade, com potencial para interferir em etapas significativas do desenvolvimento biopsicossocial da paciente.

PALAVRAS-CHAVE: Adolescentes, Ductos Müllerianos, Anormalidades.

ABSTRACT: The Herlyn-Werner-Wunderlich syndrome is described by the triad uterus di- 
delphys, obstructed hemivagina and renal agenesis, usually ipsilateral. It is a rare anomaly of the Mullerian ducts first identified in 1922 by the english surgeon E. C. Purslow. This report presents the case of a 12-year-old female patient, a student, with no previous comorbidities, that attended to the Clemente de Faria University Hospital, in Montes Claros/MG displaying dysmenorrhea. The pelvic ultrasonography (USG) showed uterus didelphys and findings compatible with hematometrocolpos. Urinary tract USG demonstrated right-sided renal agenesis. Magnetic resonance imaging (MRI) was requested, in wich was found mullerian malformation, indicating the diagnosis of the syndrome. Thereafter, the patient was submited to resection and marsupialization of the vaginal septum, draining haemosiderotic mucous secretion. The surgical act elapsed without intercorrences, and the patient had good post-operative evolution. The symptomatology most commonly related to the syndrome is cyclic pelvic pain, dysmenorrhea and abdominal mass, starting after menarche. The diagnosis is usually around 14 years of age, when the patient starts to refer the symptoms and is submitted to imaging investigation with ultrasonography and, preferentially, magnetic resonance imaging. The gold standard treatment consists in resection and marsupialization of the obstructed hemivagina's vaginal septum. A favorable prognosis is directly related to early propaedeutics and therapeutics wich, if postponed, may result in acute complications, such as pyohematocolpos, pyosalpingitis or pelvic peritonitis, and late complications, such as endometriosis, pelvic adhesions and higher risk of abortion or infertility, potentially interfering significantly in the patient's biopsychosocial development. .

\section{INTRODUÇÃO}

A síndrome de Herlyn-Werner-Wunderlich (SHWW) foi inicialmente identificada em 1922 pelo cirurgião inglês E. C. Purslow. Posteriormente, Herlyn U., Werner H. e Wunderlich M. descreveram a tríade de útero didelfo, hemivagina obstruída e agenesia renal, geralmente ipsilateral, que caracteriza essa rara entidade (PASSOS, 2017). É reconhecida como uma anomalia dos ductos Müllerianos (canais paramesonéfricos), responsável por originar o útero, o colo do útero e os dois terços superiores da vagina (YILMAZ, 2017). O trato urogenital é também derivado dos ductos de Wolff (canais mesonéfricos), de modo que sua proximidade com os ductos paramesonéfricos explica a forte associação entre anomalias do trato genital e renais (PASSOS, 2017). A prevalência dessa síndrome é estimada entre 0,1 e 3,8\% (BORIA ALEGRE, 2019). Nesse contexto, ressalta-se a importância da difusão de relatos de casos dessa enfermidade, a fim de proporcionar diagnósticos precoces e prevenir complicações. Objetivo: Através deste relato de caso, objetiva-se proporcionar o debate científico acerca da SHWW, uma entidade rara e pouco conhecida entre o meio médico. Resultados e Discussão: Paciente de 12 anos, sexo feminino, estudante, previamente hígida, deu entrada no Hospital Universitário Clemente de Faria com quadro de dismenorreia intensa há um mês, posterior à menarca. Nega sexarca. Encontrava-se estável, bem orientada. Foi solicitada ultrassonografia (US) pélvica, que evidenciou útero didelfo, distensão da hemicavidade uterina direita preenchida por material levemente heterogêneo, com debris em suspensão, além de coleção heterogênea na projeção da cavidade vaginal, em contiguidade com o colo uterino direito, achados compatíveis com hematometrocolpo (Figura 1). Em US de vias urinárias, observou-se agenesia renal direita e rim esquerdo com suspeita de hidronefrose. Por fim, em ressonância magnética (RM) da pelve foi constatada uma malformação Mulleriana, que, associada aos achados da US, indicavam o diagnóstico da Síndrome de Herlyn-Werner-Wunderlich. Confirmado este diagnóstico, a paciente foi submetida a ressecção e marsupialização do septo vaginal (Figura 2). Na abordagem, foi identificado orifício fibrosado na pa- 
rede lateral direita da vagina. Procedeu-se a dilatação com drenagem de secreção mucosa de coloração hemossiderótica, sendo realizada posteriormente ampliação do orifício sagital e horizontalmente. Ato sem intercorrências. Paciente apresentou boa evolução no pós-operatório. A literatura aponta o caráter assintomático da síndrome até a menarca, quando as pacientes passam a apresentar quadro de dor pélvica cíclica, dismenorreia e massa abdominal (PERCOPE, 2008). A idade média do diagnóstico é de 14 anos (MONZÓN CASTILLO, 2019), sendo inferior nos casos de obstrução completa do septo, e superior nos casos de obstrução incompleta (TONG, 2013). Entretanto, na maioria dos casos, o diagnóstico geralmente é retardado em decorrência do fluxo menstrual regular da hemivagina não obstruída (YILMAZ, 2017). Em alguns casos coágulos sanguíneos podem ser fonte de infecção, o que pode desencadear doenças inflamatórias pélvicas e abscessos no tubo ovariano. Nesses casos, febre, calafrios, náusea e vômito são comumente relatados (MONZÓN CASTILLO, 2019). Na investigação do quadro, o primeiro exame de imagem a ser solicitado é a US pélvica, devido à sua ampla disponibilidade e baixo custo, entretanto, a RM é considerada padrão-ouro para o diagnóstico e o planejamento do tratamento cirúrgico, uma vez que garante melhor caracterização da anatomia pélvica (YILMAZ, 2017). O tratamento de escolha consiste na ressecção e marsupialização do septo vaginal da hemivagina obstruída (JINDAL, 2009). O prognóstico é favorável visto que $87 \%$ das mulheres com útero didelfo terão uma gravidez bem-sucedida (MONZÓN CASTILLO, 2019). Conclusão: Apesar de rara, a SHWW deve ser reconhecida pelos profissionais da área médica, sendo de extrema importância a cooperação entre pediatras, cirurgiões pediátricos, radiologistas e ginecologistas, pois a ausência de diagnóstico e tratamento precoces pode representar grande risco de complicações agudas, como piohematocolpo, piossalpingites ou pelviperitonites, e complicações tardias, como endometriose, aderências pélvicas e risco de abortamento ou infertilidade. Tais consequências apresentam potencial para desencadear sofrimento físico e psíquico, que interferem diretamente na qualidade de vida e no desenvolvimento integral do ser humano.

Figura 1. Imagem de Ultrassonografia da paciente evidenciando coleção heterogênea na projeção da cavidade vaginal, em contiguidade com o colo uterino direito.

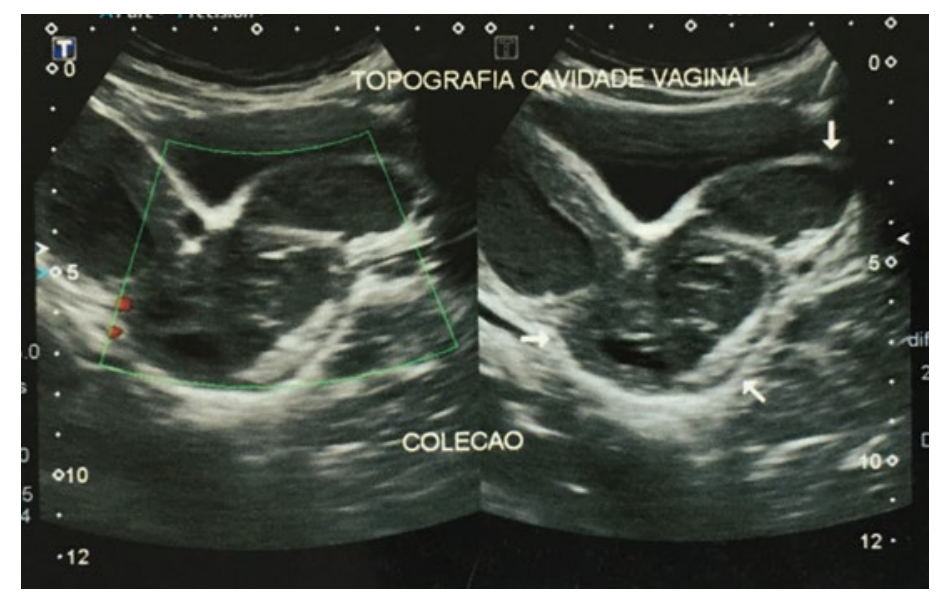


Figura 2. Imagem do procedimento cirúrgico após ressecção e marsupialização do septo vaginal previamente obstruído.

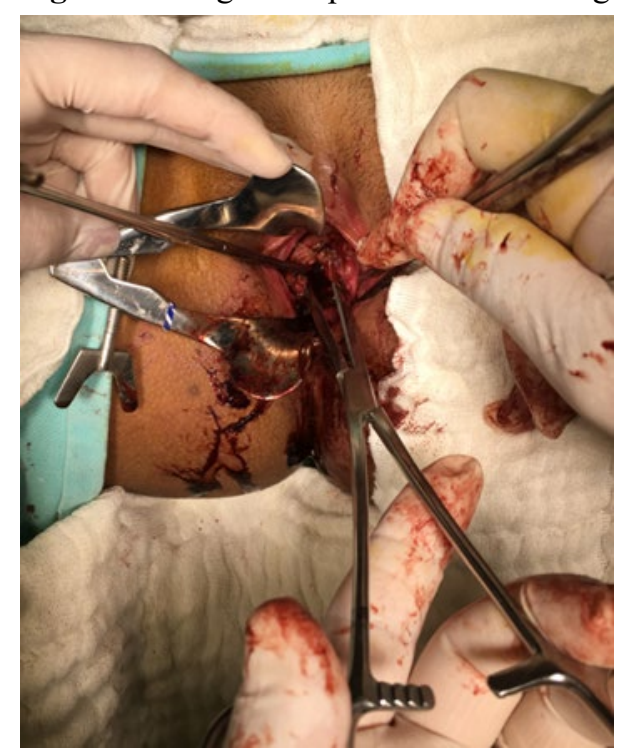

\section{REFERÊNCIAS}

BORIA ALEGRE, Félix et al. Síndrome de Herlyn-Werner-Wünderlich y diagnóstico tardío: a propósito de un caso. Revista Peruana de Ginecología y Obstetricia, v. 65, n. 3, p. 337-340, 2019.

JINDAL, Gaurav et al. Uterus didelphys with unilateral obstructed hemivagina with hematometrocolpos and hematosalpinx with ipsilateral renal agenesis. Journal of human reproductive sciences, v. 2, n. 2, p. 87, 2009.

MONZÓN CASTILLO, Eli Pedro; TEJADA MARTÍNEZ, Gabriel. Síndrome de Herlyn-WernerWunderlich: Reporte de un caso. Revista Peruana de Ginecología y Obstetricia, v. 65, n. 2, p. 213-218, 2019.

PASSOS, Itana et al. Síndrome de Herlyn-Werner-Wunderlich: patologia que todo ginecologista deve reconhecer. Adolescência e Saúde, v. 14, n. 1, p. 102-106, 2017.

PERCOPE, Fernanda Lopes; AQUINO, José Henrique Withers. Síndrome de Herlyn-Werner-Wunderlich: um diagnóstico que precisamos conhecer. Adolescência e Saúde, v. 5, n. 3, p. 23-26, 2008.

TONG, Jiali; ZHU, Lan; LANG, Jinghe. Clinical characteristics of 70 patients with Herlyn-Werner-Wunderlich syndrome. International Journal of Gynecology \& Obstetrics, v. 121, n. 2, p. 173-175, 2013.

YILMAZ, Sukriye; YILDIZ, Adalet Elcin; FITOZ, Suat. Herlyn-Werner-Wunderlich syndrome: sonographic and magnetic resonance (MR) imaging findings of this rare urogenital anomaly. Polish journal of radiology, v. 82 , p. $216,2017$. 


\section{TRAUMA HEPÁTICO: TRATAMENTO CIRÚRGICO VERSUS CONSERVADOR NO MANEJO DA AFECÇÃO}

LAIRANE BRIDI LOSS ${ }^{1}$

CAROLAINY FROHLICH LOSS ${ }^{1}$

LUCAS MELHADO VIEIRA ${ }^{1}$

ALLANA FREDERICH PINTO ${ }^{1}$

LUCIANO AZEVEDO DUARTE ${ }^{2}$

RESUMO: Introdução: O trauma hepático representa uma das principais causas de morte no trauma abdominal. As opções terapêuticas no trauma hepático são manejo não operatório (MNO), embolização e cirurgia aberta. A abordagem conservadora tem apresentado resultados satisfatórios, o que caracteriza o MNO no trauma hepático como o "padrão ouro" dentre as opções terapêuticas disponíveis. Objetivo: Analisar criteriosamente os principais aspectos descritos na literatura a respeito do manejo do trauma hepático. Metodologia: Trata-se de um estudo qualitativo exploratório apresentado na forma de revisão integrativa de literatura. Após a análise, 9 (nove) artigos foram selecionados. Os critérios de inclusão foram artigos publicados entre os anos 2012 e 2020, nos idiomas português, inglês e espanhol e indexados nas bases de dados PubMed, Scielo e na revista do Colégio Brasileiro de Cirurgiões (CBC). Resultados e discussão: Os principais fatores determinantes na escolha da abordagem terapêutica no contexto do trauma hepático são o estado hemodinâmico do paciente e as lesões associadas. Anteriormente, a estratégia terapêutica mais utilizada para o trauma hepático era $o$ tratamento cirúrgico. Entretanto, como consequência dos avanços na ressuscitação hídrica e na radiologia intervencionista, o MNO passou a ser o recurso terapêutico eleito para pacientes hemodinamicamente estáveis, proporcionando uma diminuição nas taxas de mortalidade, menor número de complicações e de tempo de internação hospitalar. Em pacientes instáveis, o tratamento cirúrgico permanece como a melhor opção. Conclusão: $O$ principal critério na determinação da abordagem terapêutica é o estado hemodinâmico do paciente e as lesões associadas. O MNO do trauma hepático é considerado a melhor opção dentre as terapêuticas disponíveis em pacientes hemodinamicamente estáveis.

PALAVRA-CHAVE: Traumatologia; Fígado; Cirurgia do sistema digestório; Saúde pública.

ABSTRACT: Introduction: Liver trauma represents one of the main causes of death in abdominal trauma. Therapeutic options in liver trauma are non-operative management (MNO), embolization and open surgery. The conservative approach has shown satisfactory results, which characterizes MNO in liver trauma as the "gold standard" among the therapeutic options available. Objective: Carefully analyze the main aspects described in the literature regarding the management of liver trauma. Methodology: This is a qualitative exploratory study presented in the form of an integrative literature review. After the

1 Acadêmico de Medicina do Centro Universitário do Espírito Santo - UNESC

2 Mestre em Ensino de Ciências da Saúde e do Ambiente; Professor do Centro Universitário do Espírito Santo UNESC. 
analysis, 9 (nine) articles were selected. The inclusion criteria were articles published between the years 2012 and 2020, in Portuguese, English and Spanish, and indexed in the PubMed, Scielo and the Brazilian College of Surgeons (CBC) databases. Results and discussion: The main determining factors in choosing the therapeutic approach in the context of liver trauma are the patient's hemodynamic status and associated injuries. Previously, the most used therapeutic strategy for liver trauma was surgical treatment. However, as a consequence of the advances in fluid resuscitation and in interventional radiology, MNO has become the therapeutic resource chosen for hemodynamically stable patients, providing a decrease in mortality rates, fewer complications and length of hospital stay. In unstable patients, surgical treatment remains the best option. Conclusion: The main criterion in determining the therapeutic approach is the patient's hemodynamic status and associated injuries. MNO of liver trauma is considered the best option among the therapies available in hemodynamically stable patients.

KEYWORDS: Traumatology; Liver; Digestive system surgery; Public health.

\section{INTRODUÇÃO}

O fígado é o maior órgão sólido da cavidade abdominal, bem como o mais frequentemente atingido em trauma fechado do abdome, feridas abdominais por armas branca e de fogo. Sua localização anatômica na região anterior, além da intensa vascularização e delicado parênquima, o tornam particularmente suscetível a lesões. Nas últimas três décadas, a incidência de lesão hepática aumentou devido ao aumento do número de acidentes automobilísticos e à identificação avançada de lesão devido a melhores modalidades diagnósticas. O trauma hepático está associado a uma taxa de mortalidade de $10 \%$ a $15 \%$ e é a principal causa de morte no trauma abdominal fechado (BUCI, S. et al., 2017; GARNER, C.S.J.P., 2012).

Antes de 1990, a abordagem cirúrgica era o "padrão ouro" para o tratamento do trauma hepático. Nas últimas décadas, os avanços em algumas ferramentas diagnósticas e terapêuticas, como tomografia computadorizada (TC), ultrassonografia em traumas, disponibilidade de angiografia, ressuscitação hídrica e monitoramento intensivo levaram a uma mudança consistente na estratégia de tratamento. Consequentemente, houve aumento no manejo conservador e no manejo não operatório (MNO). É amplamente aceito que o MNO é a terapia de excelência para as pequenas lesões hepáticas. Não obstante, há controvérsias no que diz respeito a sua eficácia em lesões de alto grau. Na prática, as duas abordagens podem ser realizadas, dependendo se a vítima necessita de laparotomia urgente ou não, sendo o estado hemodinâmico um dos principais fatores a ser considerado antes da escolha terapêutica (LETOUBLON, C. et al., 2016; SAQIB, Y., 2020; ZAGO, T.M. et al., 2013).

Atualmente, as opções para o manejo do trauma hepático em adultos e crianças são cirurgia aberta, angioembolização e MNO. Tradicionalmente, o MNO incluía um monitoramento cuidadoso do paciente hemodinamicamente estável, além de intervenções radiológicas, como embolização. Nas últimas duas décadas, o MNO tornou-se o padrão de atendimento em pacientes hemodinamicamente estáveis. O uso de escalas de trauma, como a classificação de gravidade de lesões proposta pela Associação Americana de Cirurgia do Trauma (AAST-OIS) é importante para avaliar o nível de acometimento hepático e de órgãos associados. Pesquisas em trauma hepático são essenciais para se 
obter uma adequada compreensão dos mecanismos de lesão hepática, a população sob maior risco e a morbimortalidade associada, os quais são fatores diretamente relacionados à escolha terapêutica para o paciente (GILYARD, S. et al., 2020; LETOUBLON, C. et al., 2016).

Apesar dos avanços no diagnóstico e tratamento, bem como a sistematização do atendimento proposta pelo Advanced Trauma Life Support (ATLS), as taxas de morbimortalidade nos traumas hepáticos permanecem altas. Dessa forma, o trauma do fígado representa um grave problema de saúde pública (KALIL, M.; AMARAL, I.M.A., 2016). Dessa forma, este estudo objetiva analisar os principais aspectos descritos na literatura a respeito do manejo do trauma hepático, especialmente em relação ao tratamento cirúrgico e conservador desse fenômeno clínico.

\section{METODOLOGIA}

Trata-se de um estudo realizado por meio de uma abordagem exploratória qualitativa do tipo revisão integrativa de literatura. Adotou-se a revisão integrativa da literatura dada sua contribuição para o processo de sistematização e análise dos resultados, visando à compreensão de determinado tema, a partir de outros estudos independentes. Por se tratar de uma revisão bibliográfica, não foi necessário realizar a submissão deste trabalho ao Comitê de Ética e Pesquisa.

Os critérios de inclusão foram artigos publicados entre os anos 2012 e 2020, nos idiomas português, inglês e espanhol e indexados nas bases de dados PubMed, Scientific Eletronic Library Online (SciELO) e na revista do Colégio Brasileiro de Cirurgiões (CBC). Os descritores utilizados para busca foram "liver trauma" boleano and "management" e seus respectivos correspondentes em português. Todas as categorias de artigo foram incluídas.

Os critérios de exclusão foram artigos publicados fora do período estabelecido previamente, repetição da base de dados, não estar relacionado diretamente à temática do estudo, estarem indisponíveis eletronicamente na íntegra e que não estiverem publicados nos idiomas português, inglês e espanhol.

De acordo com os critérios acima mencionados, foram encontradas 28 publicações, nas três bases de dados consultadas. A maioria delas (25 artigos) encontra-se indexada no PubMed. Após análise minuciosa mediante os critérios de inclusão e exclusão, 9 (nove) artigos foram selecionados para tabulação.

\section{RESULTADOS}

A análise dos resultados foi feita por meio da elaboração de uma tabela, a qual aborda os seguintes aspectos: autores, ano da publicação, título da pesquisa e suas principais conclusões. 
Tabela 1: Apresentação das principais conclusões dos artigos incluídos na revisão integrativa

\begin{tabular}{|c|c|c|c|}
\hline AUTOR & ANO & TÍTULO & CONCLUSÕES \\
\hline BARBIER, L. et al. & 2018 & $\begin{array}{l}\text { Can we refine the man- } \\
\text { agement of blunt liver } \\
\text { trauma? }\end{array}$ & $\begin{array}{l}\text { O MNO foi viável em } 69 \% \text { dos pacientes com } \\
\text { lesões hepáticas contusas, com uma taxa de su- } \\
\text { cesso de } 96 \% \text {. Lesões de órgãos associadas são } \\
\text { responsáveis pela maioria das cirurgias de emer- } \\
\text { gência. O trabalho recomenda TC de acompa- } \\
\text { nhamento a fim de detectar complicações hepá- } \\
\text { ticas e torácicas, em particular quando a lesão, } \\
\text { de acordo com a classificação da AAST é igual } \\
\text { ou superior a } 3 \text {. Lesões dos segmentos hepáti- } \\
\text { cos } 1,4 \text { e } 9 \text { foram associadas a complicações } \\
\text { biliares. }\end{array}$ \\
\hline $\begin{array}{l}\text { BRILLANTINO, A. } \\
\text { et al. }\end{array}$ & 2019 & $\begin{array}{l}\text { Non-Operative Man- } \\
\text { agement of Blunt Liver } \\
\text { Trauma: Safety, Effica- } \\
\text { cy and Complications } \\
\text { of a Standardized Treat- } \\
\text { ment Protocol }\end{array}$ & $\begin{array}{l}\text { Foram admitidos } 181 \text { pacientes com diagnósti- } \\
\text { co de lesão hepática foram incluídos no estudo. } \\
\text { Desses, de acordo com a escala de lesão de ór- } \\
\text { gão da AAST, } 63 \text { pacientes }(34,8 \%) \text { tinham grau } \\
\text { I, } 48 \text { pacientes }(26,5 \%) \text { grau II, } 39 \text { pacientes } \\
(21,5 \%) \text { grau III, } 21 \text { pacientes }(11,6 \%) \text { grau IV } \\
\text { e } 10 \text { pacientes }(5,5 \%) \text { grau V. A taxa de sucesso } \\
\text { geral do MNO foi de } 96,7 \% \text {. A taxa de mortali- } \\
\text { dade foi de } 7,4 \%(13) \text {. }\end{array}$ \\
\hline BUCI, S. et al. & 2017 & $\begin{array}{l}\text { The rate of success of } \\
\text { the conservative man- } \\
\text { agement of liver trauma } \\
\text { in a developing country }\end{array}$ & $\begin{array}{l}\text { A probabilidade de sucesso do MNO relaciona- } \\
\text {-se com o grau de lesão hepática e lesões intra- } \\
\text {-abdominais associadas. Os recursos hospitala- } \\
\text { res limitados e o baixo nível de consenso para } \\
\text { o MNO têm um impacto negativo no resultado. } \\
\text { As principais causas de falha são hemorragia se- } \\
\text { cundária e vazamento de bile. }\end{array}$ \\
\hline $\begin{array}{l}\text { FONSECA- NETO, } \\
\text { O.C.L.; EHRHA- } \\
\text { DT, R.; MIRANDO, } \\
\text { A.L. }\end{array}$ & 2013 & $\begin{array}{l}\text { Estudo da morbimor- } \\
\text { talidade em pacientes } \\
\text { com trauma hepático }\end{array}$ & $\begin{array}{l}\text { O estudo foi realizado pela análise retrospec- } \\
\text { tiva do prontuário de } 137 \text { pacientes. } 124 \text { eram } \\
\text { homens }(90,5 \%) \text {, sendo a maioria entre } 20-29 \\
\text { anos }(56,2 \%) \text {. Dentre os traumas, o abdominal } \\
\text { fechado foi prevalente }(67,9 \%) \text {. Dos penetran- } \\
\text { tes, foram preponderantes os traumas de arma } \\
\text { de fogo }(24,8 \%) .103 \text { tiveram apenas um seg- } \\
\text { mento acometido ( } 75 \%) \text { e } 34(24,8 \%) \text { dois. Le- } \\
\text { sões e grau II estiveram presentes em } 66,4 \% \text { dos } \\
\text { casos. Todos os } 137 \text { pacientes foram submeti- } \\
\text { dos à laparotomia, sendo } 89 \text { não-terapêutica e } \\
48 \text { necessárias para o reparo de lesões inerentes } \\
\text { ao trauma. As estruturas mais acometidas fo- } \\
\text { ram baço e diafragma. Dentre as complicações, } \\
\text { fístula biliar e abcesso hepático prevaleceram. } \\
\text { Houve } 7 \text { óbitos na análise. }\end{array}$ \\
\hline GILYARD, S. et al. & 2020 & $\begin{array}{l}\text { Contemporary Man- } \\
\text { agement of Hepat- } \\
\text { ic Trauma: What IRs } \\
\text { Need to Know }\end{array}$ & $\begin{array}{l}\text { Com o avanço das técnicas baseadas em cateter } \\
\text { de radiologia intervencionista, o papel da embo- } \\
\text { lização no tratamento de pacientes com trauma } \\
\text { hepático aumentou. Dada a melhora na mortali- } \\
\text { dade, a embolização será um pilar no tratamento } \\
\text { da lesão hepática em um futuro próximo. }\end{array}$ \\
\hline
\end{tabular}




\begin{tabular}{|c|c|c|c|}
\hline $\begin{array}{l}\text { KALIL, M.; AMA- } \\
\text { RAL, I.M.A. }\end{array}$ & 2016 & $\begin{array}{l}\text { Avaliação epidemioló- } \\
\text { gica de vítimas de trau- } \\
\text { ma hepático submetidas } \\
\text { a tratamento cirúrgico }\end{array}$ & $\begin{array}{l}392 \text { pacientes foram submetidos à laparotomia } \\
\text { e em } 107 \text { ocorreram lesões hepáticas. O trauma } \\
\text { mais frequente foi o penetrante, encontrado em } \\
84(78,5 \%) \text { pacientes, sendo } 72(85,7 \%) \text { deles } \\
\text { causados por arma de fogo e } 12(14,3 \%) \text { por } \\
\text { arma branca. O trauma contuso ocorreu em } 23 \\
\text { pacientes }(21,5 \%) \text {. O trauma hepático ocorreu } \\
\text { com maior frequência em pacientes do sexo } \\
\text { masculino }(83,2 \%) \text {, nas primeiras quatro déca- } \\
\text { das de vida }(83,2 \%) \text {. }\end{array}$ \\
\hline SAQIB, Y. & 2020 & $\begin{array}{l}\text { A systematic review } \\
\text { of the safety and effi- } \\
\text { cacy of non- operative } \\
\text { management in patients } \\
\text { with high grade liver } \\
\text { injury }\end{array}$ & $\begin{array}{l}\text { O MNO do trauma hepático é seguro e eficaz } \\
\text { em pacientes hemodinamicamente estáveis com } \\
\text { lesão hepática de alto grau. A mortalidade as- } \\
\text { sociada é menor em comparação com o mane- } \\
\text { jo cirúrgico. Mais estudos são necessários para } \\
\text { avaliar o impacto do MNO nas complicações } \\
\text { em lesões hepáticas de alto grau. }\end{array}$ \\
\hline $\begin{array}{l}\text { TARCHOULI, M. } \\
\text { et al. }\end{array}$ & 2018 & $\begin{array}{l}\text { Liver trauma: What } \\
\text { current management? }\end{array}$ & $\begin{array}{l}\text { Foram incluídos } 83 \text { pacientes no estudo, com } \\
\text { relevante dominância de homens }(85,5 \%) \text {. Os } \\
\text { indivíduos tinham em torno de } 33 \text { anos e apre- } \\
\text { sentavam, principalmente, o trauma abdominal } \\
\text { fechado. } 68 \text { lesões hepáticas }(81,9 \%) \text { foram } \\
\text { de baixa gravidade (graus I, II, III), frente a } 15 \\
(18,1 \%) \text { de alta gravidade (grau IV ou superior). } \\
\text { Houve tratamento cirúrgico em } 26(31,3 \%) \text { dos } \\
\text { pacientes e conduta não operatória em } 57 \text { casos } \\
(68,7 \%) \text {. Pacientes não expostos a cirurgia tive- } \\
\text { ram menor incidência de complicações e evolu- } \\
\text { ção ao óbito. }\end{array}$ \\
\hline ZAGO, T.M. et al. & 2013 & $\begin{array}{l}\text { Trauma hepático: uma } \\
\text { experiência de } 21 \text { anos }\end{array}$ & $\begin{array}{l}\text { O MNO, realizado em } 74 \text { dos } 287 \text { pacientes com } \\
\text { trauma hepático fechado neste estudo, se mos- } \\
\text { trou associado a menores complicações, menor } \\
\text { necessidade de transfusões sanguíneas e menor } \\
\text { mortalidade, mesmo em pacientes com trauma } \\
\text { hepático de maior grau. O apoio da radiologia } \\
\text { intervencionista pode se fazer necessário com } \\
\text { vantagens no prognóstico do paciente. }\end{array}$ \\
\hline
\end{tabular}

\section{DISCUSSÃO}

O trauma hepático está entre as principais causas de morte em lesões abdominais. Contudo, atualmente reconhece-se que entre $50 \%$ e $80 \%$ das lesões hepáticas cessam o sangramento espontaneamente. Melhores métodos diagnósticos e gerenciamento de terapia intensiva levaram progressivamente à aceitação do MNO na comunidade médica, resultando em redução das taxas de mortalidade (ALGHAMDI, H.M., 2017).

O sistema de pontuação de lesão hepática mais amplamente reconhecido é a Organ Injury Scale (Liver) publicada pela AAST, elaborada em 1987 e revisada em 1994. Os graus I e II são con- 
siderados lesões leves, enquanto os graus III-V representam lesão hepática grave; grau VI - avulsão hepática, raramente sobrevive. Quase dois terços das lesões grau IV ou V requerem laparotomia. O MNO bem-sucedido torna-se menos comum conforme o grau de lesão aumenta. A maioria dos pacientes admitidos por lesões hepáticas têm grau I, II ou III e são tratados com sucesso com MNO. No entanto, em muitos casos, não há correlação entre o grau de AAST e o estado fisiológico do paciente (COCCOLINI, F. et al., 2016; GARNER, C.S.J.P., 2012).

Segundo Zago et al. (2013), o MNO, realizado em 25\% dos pacientes com trauma hepático fechado no seu estudo, foi o tratamento de escolha para pacientes com trauma fechado, admitidos com estabilidade hemodinâmica. O referido procedimento tem sido realizado, pois a abordagem se mostrou associada a menores complicações, menor necessidade de transfusões sanguíneas, além de uma menor mortalidade, mesmo em pacientes com um trauma hepático de maior grau. Assim, o MNO em pacientes selecionados se mostrou seguro e efetivo, e frequentemente usado para doentes com este tipo de trauma naquele serviço.

De acordo com Kalil e Amaral (2016), até a década de 80 os cirurgiões ainda eram resistentes ao MNO, considerando que complicações infecciosas poderiam ocorrer, a hemorragia hepática poderia não cessar e a falta de drenagem da bile resultaria em fístulas biliares. Todavia, com a maior acessibilidade à ultrassonografia FAST (Focused Assement With Sonography for Trauma) e os avanços nos exames de imagem, o MNO passou a ser uma opção para pacientes hemodinamicamente estáveis e sem sinais de peritonite, diminuindo não só as taxas de mortalidade, como tempo de internação hospitalar, as taxas de complicações e a necessidade de transfusões de hemoderivados (KALIL, M. e AMARAL, I.M.A., 2016; ZAGO, T.M. et al. 2013).

Gilyard et al. (2020) coadunam com Zago et al. (2013), considerando em seu estudo que a abordagem do trauma hepático contuso no paciente adulto hemodinamicamente estável é o MNO. Vários estudos prospectivos demonstraram que o MNO é altamente eficaz, com taxas de falha de menos de 10\%. O MNO inclui monitoramento rigoroso, terapia de suporte e intervenções angiográficas. As diretrizes cirúrgicas internacionais mais recentes recomendam o MNO para lesões hepáticas, independentemente do grau, exigindo um papel significativo para o radiologista intervencionista na abordagem desses doentes. Não houve correlação relatada entre o grau de AAST e a falha do MNO. Devido ao sucesso no MNO, apenas $13 \%$ dos pacientes com trauma hepático são tratados cirurgicamente no mundo coevo.

De acordo com Saqib (2020), todos os oito estudos que foram revisadosproduziram resultados indicando que o MNO é seguro e eficaz em pacientes estáveis hemodinamicamente com trauma hepático de alto grau. Em contrapartida, evidências apontam que uma lesão hepática de alto grau também é um preditor independente para a necessidade de cirurgia de controle de danos. Baseando-se nas taxas de mortalidade e sucesso entre MNO e manejo operatório, o estudo sugeriu que o MNO pode ser usado com eficácia em pacientes com lesão hepática hemodinamicamente estáveis em todos os graus de lesão.

Assim como nos estudos acima mencionados, no trabalho de Buci et al. (2017), o estado hemodinâmico foi o principal critério para determinar a conduta terapêutica. Importante ressaltar 
que cerca de $85 \%$ dos pacientes com trauma hepático contuso são hemodinamicamente estáveis ou estabilizam após receber líquidos intravenosos (BUCI et al., 2017; KALIL, M. e AMARAL, I.M.A., 2013). O fracasso do tratamento conservador foi atribuído à deterioração dos parâmetros hemodinâmicos, vazamento de bile e à presença de complicações sépticas sobrepostas. A falha do tratamento conservador por hemorragia secundária ocorreu em 3\% dos casos, assim como bilemia e hemobilia.

Os pacientes com maior probabilidade de serem submetidos ao tratamento invasivo inicial apresentaram mais instabilidade hemodinâmica e maior grau de lesão. Lesões associadas, como trauma de baço e perfuração de órgãos ocos, foram responsáveis pela maioria das indicações de cirurgia de emergência. Outras lesões de órgãos abdominais estão associadas à falha do MNO. A falha do MNO é definida pela necessidade de cirurgia tardia e no estudo, representou $5 \%$ a $11 \%$ dos pacientes sem cirurgia precoce. Lesões dos segmentos hepáticos 1, 4 e 9 foram associadas a complicações biliares. A pressão arterial sistólica na admissão de $100 \mathrm{mmHg}$ ou menos e a presença de outra lesão de órgão abdominal foram identificados como fatores independentes de falha de MNO em AAST graus 4 e 5 (BARBIER, L. et al., 2018).

Torna-se relevante ressaltar que mesmo em pacientes com planos imediatos de cirurgia aberta, a TC do trauma pode ser útil no planejamento operatório. A rápida aquisição de imagens permitiu um atraso mínimo no tratamento definitivo. Embora historicamente a angiografia e a embolização fossem reservadas para pacientes que estavam hemodinamicamente estáveis, há um papel crescente para a angioembolização intraoperatória em pacientes instáveis. Antes da tomada de qualquer decisão, é de extrema importância avaliar quais as limitações hospitalares e quais métodos diagnósticos e terapêuticos estão disponíveis no serviço (BARBIER, L. et al., 2018; BUCI, S. et al., 2017; GILYARD, S. et al., 2020).

Após a falha do MNO, a embolização arterial é menos favorecida, principalmente em virtude do tempo necessário para configurar a sala de radiologia intervencionista, a complexidade do procedimento de embolização e a possível falha que irá atrasar uma intervenção cirúrgica definitiva (ALGHAMDI, H.M., 2017).

Assim como nos artigos acima descritos, no estudo de Brillantino et al. (2019) o MNO foi uma estratégia considerada segura e eficaz para terapêutica em pacientes hemodinamicamente estáveis com trauma abdominal fechado. No estudo, as principais complicações incluíram biloma, hematoma hepático e abcessos hepáticos, obtendo resultados satisfatórios com o tratamento por US ou drenagem guiada por TC, sem a necessidade de cirurgias. $\mathrm{O}$ tratamento cirúrgico, antes considerado obrigatório, permanece indicado em casos de falha no MNO ou em pacientes instáveis que não respondem à ressuscitação com fluidos. Além disso, os resultados sugerem que a embolização representa uma estratégia diagnóstica e terapêutica essencial em um número significativo de pacientes com lesões hepáticas contusas, embora seja necessária apenas em casos selecionados de lesões vasculares. Entretanto, o aparecimento de lesões vasculares foi mais frequente em pacientes com traumatismo esplênico fechado do que em pacientes com traumatismo hepático fechado.

Conforme menciona Tarchouli et al. (2018), como resultado dos avanços nas técnicas de imagem e o sucesso da experiência em crianças, a abordagem atual evoluiu para conduta não operativa 
em mais de $80 \%$ dos casos. Exames como a ultrassonografia abdominal e a TC têm importância adicional na investigação de pacientes com trauma abdominal, sendo procedimentos não invasivos e rápidos. Além disso, a TC é o exame padrão ouro para pacientes com trauma abdominal estável, servindo como auxílio ao cirurgião na decisão por uma abordagem terapêutica conversadora. A embolização angiografica é uma estratégia segura e eficaz que demonstrou reduzir o tempo de internação hospitalar e a necessidade de transfusões e intervenções cirúrgicas.

Os autores ainda ressaltam que os aspectos para a adoção do MNO progrediram e são criteriosos, sendo os mais importantes: a estabilidade hemodinâmica e a ausência de irritação peritoneal, disassociados do grau da lesão. Apesar do progresso, faz-se necessária observação intensa do paciente por meio de avaliações clínicas e laboratoriais, além da oferta de infraestrutura e suporte caso haja a necessidade de cirurgia imediata. Reitera-se que a conduta multidisciplinar é hoje a peça fundamental no tratamento de traumas hepáticos.

Fonseca-Neto, Ehrhadt e Mirando (2013) pontuam que o índice de trauma utilizado na triagem dos pacientes é eficaz na predição do prognóstico de sobrevida ou de morte, apesar de trazer limitações por não considerar a idade, mecanismo da lesão, multiplicidade de lesões locais e a importância da região do corpo que ocorreu a lesão. Além disso, os autores mencionam, contrariando a literatura, que houve maior indicação de laparotomia, fato esse que pode ser compreendido em função da ausência de métodos complementares de imagem como a ultrassonografia e a TC de abdome que amparam uma provável conduta não invasiva em vários pacientes.

\section{CONSIDERAÇÕES FINAIS}

Todos os nove estudos revisados produziram resultados que sugerem que o MNO é seguro e eficaz em pacientes hemodinamicamente estáveis com trauma hepático. A conduta do trauma hepático alterou-se de forma significante nas últimas décadas rumo ao $\mathrm{MNO}$, visto que a literatura cirúrgica confirma que $75-85 \%$ dos pacientes pararam de sangrar espontaneamente antes da laparotomia. $\mathrm{O}$ amparo da TC e da ultrassonografia são fundamentais para um enfoque terapêutico menos invasivo, atrelado ao uso de escalas de trauma que contribuem na estimativa do grau de acometimento hepático e de órgãos associados. Para a tomada de decisão em relação ao manejo do paciente, deve-se considerar, ainda, o nível de complexidade serviço hospitalar em que o doente e equipe se encontram, e quais recursos são disponíveis no local. 


\section{REFERÊNCIAS BIBLIOGRÁFICAS}

ALGHAMDI, H.M. Management of Liver Trauma. Saudi Journal of Medicine \& Medical Sciences, Al-Khobar, v. 5, n. 2, p. 104-109, 2017.

BARBIER, L. et al.. Can we refine the management of blunt liver trauma? Journal of Visceral Surgery, Paris, v. 156, n.1, p. 23-29, 2019.

BRILLANTINO, A. et al.. Non-Operative Management of Blunt Liver Trauma: Safety, Efficacy and Complications of a Standardized Treatment Protocol. Bulletin of Emergency and Trauma, Shiraz, v. 7, n. 1, p. 49-54, 2019.

BUCI, S. et al.. The rate of success of the conservative management of liver trauma in a developing country. World Journal of Emergency Surgery, Tirana,v. 12, n.24, 2017.

COCCOLINI, F. et al.. WSES classification and guidelines for liver trauma. World Journal of Emergency Surgery, Bergamo, v. 11, n.1, p. 1-8, 2016.

FONSECA-NETO O.C.L.; EHRHADT, R.; MIRANDO, A.L. Estudo da morbimortalidade em pacientes com trauma hepático. Arquivos Brasileiros de Cirurgia Digestiva, São Paulo, v. 26, n. 2, p. 129-132, 2013.

GARNER, C.S.J.P. Non-Operative Management of Liver Trauma. Journal of the Royal Army Medical Corps, South Yorkshire, v.158, n. 2, p. 85-95, 2012.

GILYARD, S. et al.. Contemporary Management of Hepatic Trauma: What IRs Need to Know. Seminars in Interventional Radiology, New York, v. 37, n.1, p. 35-43, 2020.

KALIL, M.; AMARAL, I.M.A. Avaliação epidemiológica de vítimas de trauma hepático submetidas a tratamento cirúrgico. Revista do Colégio Brasileiro de Cirurgiões, Rio de Janeiro, v. 43, n. 1, p. 022-027, 2016.

LETOUBLON, C. et al.. Management of blunt hepatic trauma. Journal of Visceral Surgery, Grenoble, v.153, n. 4 , p. 33-43,2016.

MAGAÑA-MAINERO, P.; GARAY-LECHUGA, D.; JIMÉNEZ-MARTINEZ, R.; VÁZQUEZ-MINERO, C.J. Quiste hepático gigante secundario a trauma abdominal severo. Hallazgo a 10 años y revisión de la literatura. Cirujano General, Ciudad de México, v. 42, n.1, p. 19-23, 2020.

NOYOLA-VILLALOBOS, H.F. et al..Tratamiento no operatorio de las lesiones hepáticaspor trauma no penetrante: artículo de revisión. Cirugía y Cirujanos, Ciudad de México, v. 84, n. 3, p. 263-266, 2016.

SAQIB, Y. A systematic review of the safety and efficacy of non-operative management in patients with high grade liver injury. Surgeon, Netherlands, v. 18, n. 3, p.165-177, 2020.

TARCHOULI, M. et al.. Liver trauma: What current management? Hepatobiliary \& Pancreatic Diseases International, Zhejiang, v. 17, n. 1, p. 39-44, 2018.

ZAGO, T.M. et al.. Trauma hepático: uma experiência de 21 anos. Revista do Colégio Brasileiro de Cirurgiões, Campinas, v. 40, n. 4, p. 318-322, 2013. 


\section{TROMBOEMBOLISMO VENOSO ASSOCIADO À INFECÇÃO POR SARS-COV-2}

BRUNO RODRIGUES PEREIRA ${ }^{1}$

GABRIEL PIRES CALZAVARA ${ }^{1}$

GUILHERME DE OLIVEIRA CINTRA FARIAS $^{1}$

JOÃO PEDRO BRANT ROCHA ${ }^{1}$

LUCAS NUNES BANDEIRA DE MELO ${ }^{1}$

LUIZ FRANCISCO DE MELLO ${ }^{1}$

PAULA MOREIRA SENA ${ }^{2}$

PEDRO HENRIQUE COELHO PINTO ${ }^{1}$

RESUMO: A COVID-19, infecção causada pelo vírus SARS-Cov-2, pode apresentar, nas formas mais graves, uma resposta inflamatória sistêmica acentuada e um risco aumentado de tromboembolismo venoso e arterial. A gênese do trombo é implicada por diversos fatores, e, diante da escassez de dados na literatura acerca desse tema, temos como objetivo, neste capítulo, por meio da revisão trabalhos científicos nas bases de dados PubMed e Scielo, sintetizar a relação entre tromboembolismo venoso (TEV) e a COVID-19, discutindo diagnóstico, possível subnotificação desses eventos e estratégias profiláticas utilizadas. Verificou-se, nas publicações, que a infecção pode ser um fator predisponente para formar trombos e consequente embolismo por meio de disfunção endotelial. Ademais, sugere-se a subnotificação de casos de tromboembolismo devido à redução de autópsias hospitalares pelo risco de contaminação dos patologistas, sobreposição de sintomas na doença e o foco dos profissionais de saúde no acometimento respiratório, principalmente em cenário de terapia intensiva. Assim, supõe-se que a incidência de tromboembolismo em pacientes com COVID-19 pode ser maior que a atualmente reportada. A COVID-19 intensifica processos inflamatórios, causando um estado de hipercoagulabilidade que, principalmente, promove o aumento da incidência de TEV em pacientes infectados. Em relação ao diagnóstico, verificou-se que o aumento do dímero $\mathrm{D}$ foi identificado como um indicador do desenvolvimento de TEV. Já em relação a profilaxia e tratamento, a OMS recomenda que a tromboprofilaxia deve ser implementada com uso de heparina de baixo peso molecular e, caso o paciente apresente disfunção renal, heparina não-fracionada. Além disso, devemos dar importância a estratificação individual do risco trombótico e hemorrágico. Diante do supracitado, torna-se necessária maior investigação acerca do diagnóstico desse quadro e o provável benefício da tromboprofilaxia, além de estudos de melhor qualidade sobre a real prevalência de TEV para que o manejo dos pacientes seja adequado em termos de prevenção e tratamento dessa complicação.

ABSTRACT: COVID-19, an infectious disease caused by the virus SARS-Cov-2 can in its most severe form present a systemic inflammatory response and an augmented risk of venous and arterial thromboembolism. The thrombogenesis process is increased due to a few factors, and, due to 
the lack of literature about this subject, the main objective of this review is to, through the revision of scientific articles, sintetize this possible relation between venous thromboembolism (VTE) and COVID-19 such as to see a possible sub notification of this cases and the prophylactic strategies used. Throughout the research it is possible to see a strong relation between infectious diseases and thrombogenesis due to endothelial dysfunction. Nevertheless, the lack of autopsies being made to avoid pathologists contamination, the symptoms superposition and the focus on the Respiratory syndrome are factors that lead to the sub notification of VTE death related cases. There's an intensification of the inflammatory process causing an hypercoagulability state which is the main factor that leads to the rise in VTE cases. In clinical diagnosis we can see augmented Dimer-d quantities, a blood marker directly related to VTE development. When it comes to treatment and prophylaxis, the use of unfractionated heparin is the gold standard, however, it's necessary to do the hemorrhagic and thrombotic risk stratification individually in each patient. To sum up, it's essential to do bigger investigations about COVID-19 diagnosis and the possible tromboprofilatic benefits such as the real prevalence of VTE in patients so the treatment and prevention of the illness can be more adequate.

KEY WORDS: COVID-19; thromboembolism; hemostasis; anticoagulation; venous thromboembolism;

\section{INTRODUÇÃO}

Coronavírus é o nome de uma família de vírus de RNA de fita simples, já conhecida pelos cientistas há décadas, mas sem relevância quando falava-se de epidemias até o início do século 21, quando houve um surto de Sars-CoV no Leste Asiático em 2002 e, 10 anos depois, surto de MERS (Síndrome Respiratória do Oriente Médio). A COVID-19, infecção causada pelo vírus Sars-CoV-2, o novo coronavírus, cursa atualmente em uma pandemia global. Apesar de sua taxa de mortalidade ser menor quando comparada às outras doenças causadas pelos vírus da mesma família, a COVID-19 é mais impactante devido à sua alta taxa de infecção. Até o dia 20 de outubro de 2020, mais de 40,8 milhões de pessoas foram infectadas e mais de 1,1 milhão morreram devido a suas complicações. Essa doença apresenta-se clinicamente nas formas graves com insuficiência respiratória e resposta inflamatória sistêmica acentuada, além de risco aumentado de tromboembolismo venoso e arterial. Vários fatores implicam na gênese do tromboembolismo, incluindo imobilização, inflamação excessiva e coagulação intravascular disseminada (CID). Diante da escassez de dados na literatura acerca dessa condição faz-se necessário buscas por diagnósticos acurados e estratégias de profilaxia e tratamento.

\section{OBJETIVO}

Sintetizar artigos relacionados ao tromboembolismo venoso (TEV) no contexto da COVID-19, discutindo a abordagem diagnóstica, destacando-se a possibilidade de subnotificação desses eventos e as estratégias profiláticas utilizadas. 


\section{METODOLOGIA}

Realizou-se uma busca de artigos científicos nas bases de dados, PubMed e Scielo, utilizando descritores como "COVID-19", "tromboembolismo" e "hemostasia", analisando e condensando as informações para elaboração do presente trabalho.

\section{RESULTADOS}

Os resultados dessa pesquisa serão divididos em dois questionamentos principais que serão a relação da COVID-19 com o aumento de fenômenos tromboembólicos e a subnotificação de casos de morte por tromboembolismo em pacientes de COVID.

A COVID-19 pode predispor eventos tromboembólicos venosos e arteriais devido ao estado inflamatório intenso, à hipóxia, à imobilização dos pacientes e à coagulação intravascular disseminada. Um estudo realizado em 2 hospitais universitários e em 1 hospital escola holandeses avaliou 184 pacientes admitidos na UTI com pneumonia por COVID-19 comprovada. A incidência cumulativa de complicações trombóticas foi de $31 \%$, com 25 casos de embolia pulmonar, 3 de acidente vascular encefálico isquêmico e 3 outros eventos trombóticos venosos (Figura 1). Esses pacientes apresentaram maior risco de morte por qualquer causa, com razão de risco de 5.4 (95\%CI 2.4-12) em relação aos pacientes sem eventos trombóticos diagnosticados. Outro estudo retrospectivo realizado em um hospital em Wuhan, na China, observou 88 pacientes críticos com COVID-19 sob terapia intensiva, dos quais $40(46 \%, 95 \%$ CI 35\%-56\%) desenvolveram TVP.

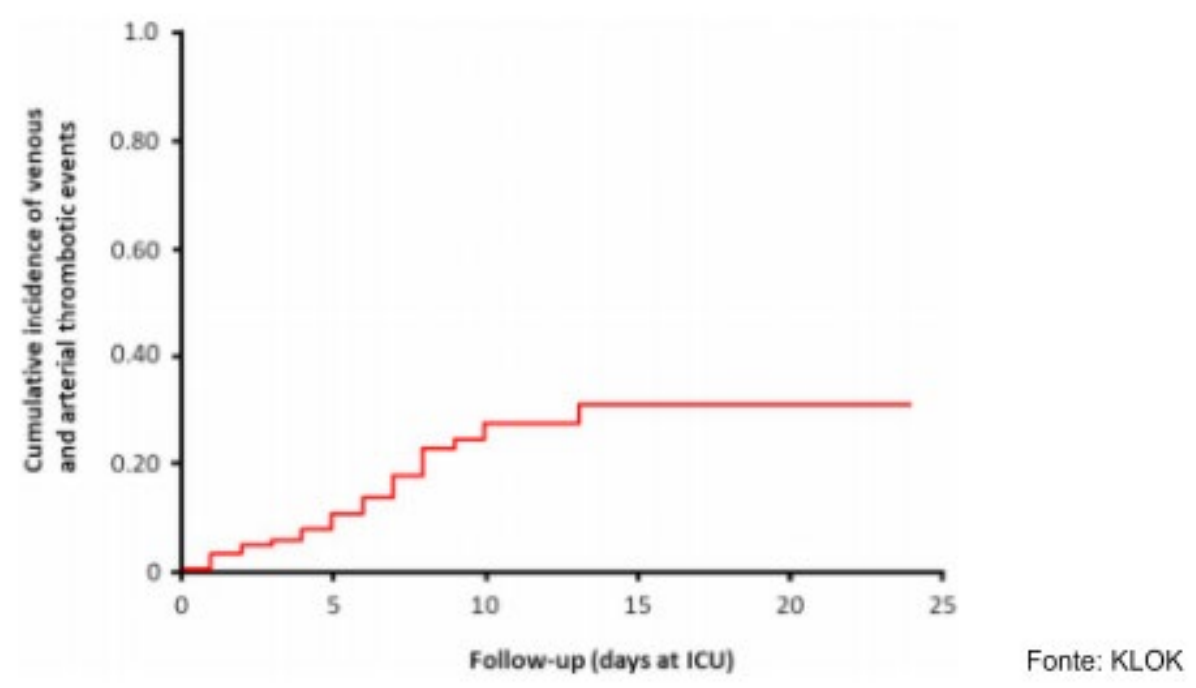

Figura 1: Incidência cumulativa de complicações trombóticas venosas e arteriais durante internação em UTI em pacientes com pneumonia por COVID-19 comprovada. 
Os artigos analisados abordaram a associação entre as diferentes formas de tromboprofilaxia associadas ao tratamento experimental para COVID-19. A infecção pode ser um fator predisponente para formar trombos e consequente embolismo, por meio de mecanismos patogênicos envolvidos na disfunção endotelial. Ademais, sugere-se uma subnotificação de casos de tromboembolismo, devido à redução de autópsias hospitalares, pelo risco de contaminação dos patologistas. Essa hipótese é sustentada por um estudo observacional retrospectivo com 388 pacientes em hospital acadêmico em Milão que encontrou uma prevalência baixa de TEV. Entretanto, apenas 11,3\% dos pacientes realizaram exames confirmatórios.

Um estudo de coorte prospectivo feito na universidade médica de Hamburg-Eppendorf realizou a autópsia de 12 pacientes que morreram em sequência devido à COVID-19. Entre esses pacientes, 7 dos 12 tiveram achados de tromboembolismo venoso profundo durante a autópsia, e esses não apresentaram sinais clínicos e não se desconfiava de TVP. Essa incidência é mais um indício da subnotificação dos casos de morte por fenômenos tromboembólicos em pacientes acometidos pelo SARS-CoV-2.

Outros estudos descreveram as coagulopatias (TEP e TVP) como uma das principais complicações da doença, analisando 191 pacientes. 50\% dos que morreram possuíam algum distúrbio da coagulação contra apenas $7 \%$ dos vivos. Esses dados nos mostram que há uma forte relação entre a morbidade da doença e a presença desses distúrbios, apontando mais uma vez a validade de se fazer uma tromboprofilaxia nos pacientes internados.

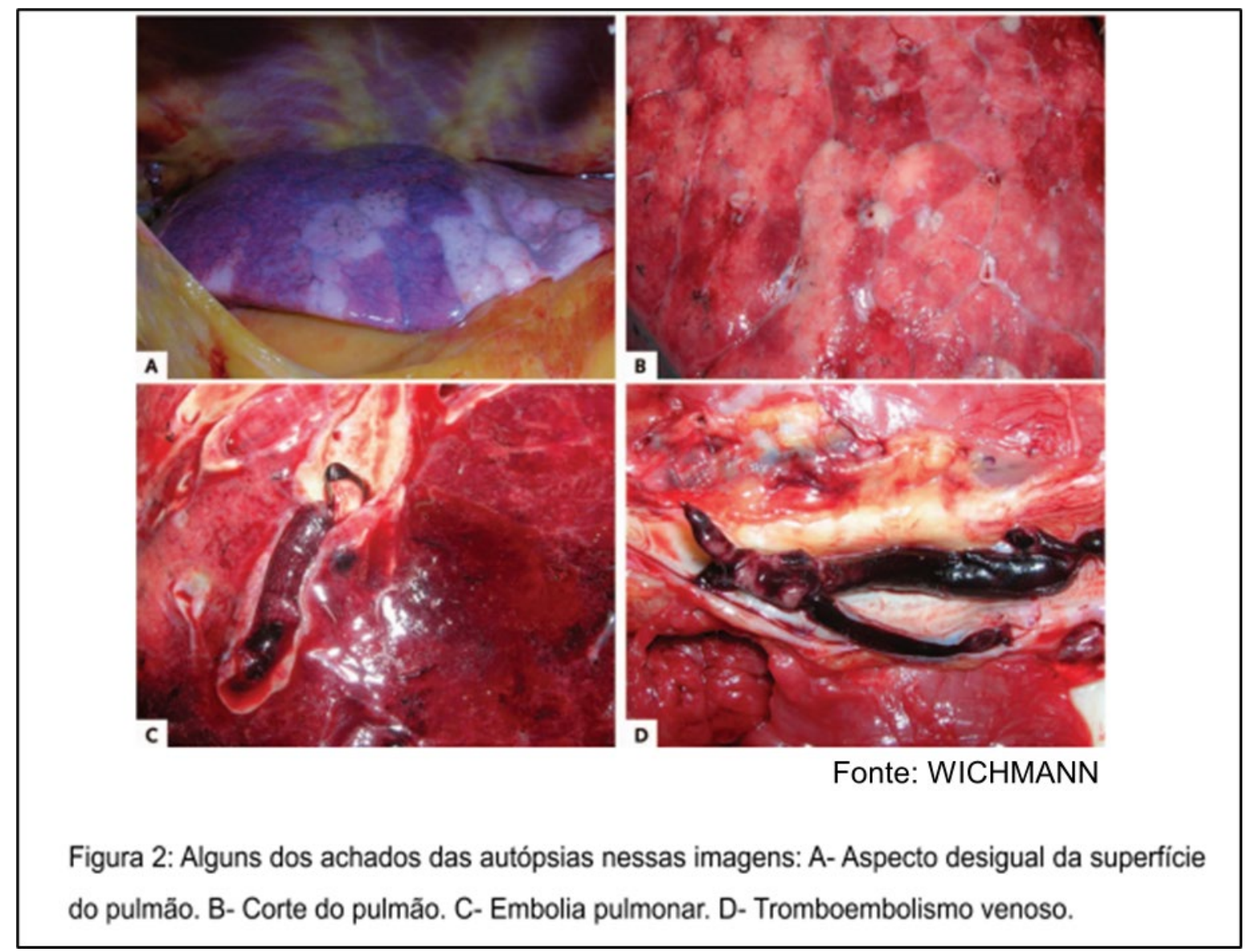


Esses achados foram em pacientes que tiveram sua causa de morte diagnosticada clinicamente como falência respiratória devido à pneumonia, todavia, os fenômenos tromboembólicos foram responsáveis pela morte súbita dos pacientes, algo que demonstra a necessidade de uma pesquisa mais intensiva nos pacientes da COVID-19.

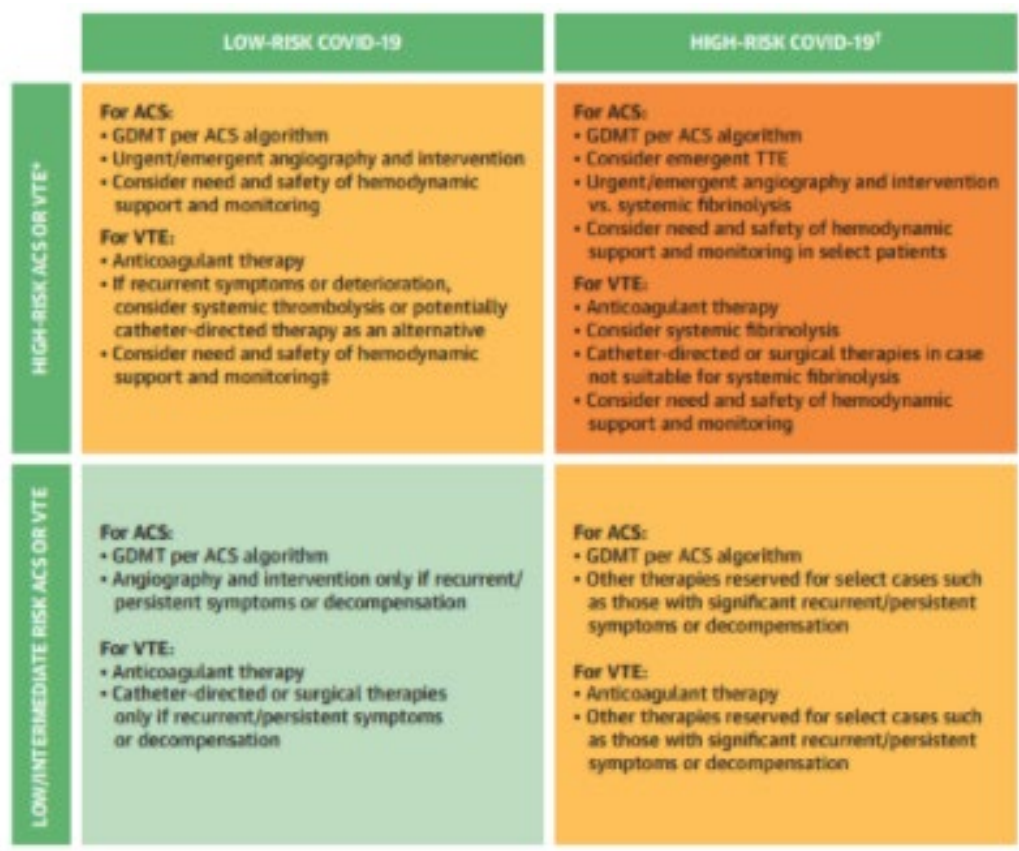

Fonte: BIKDELI

Figura 3: Esse quadro é um algoritmo de estratificação de risco para pacientes com COVID-19 feito pelo periódico do colégio americano de cardiologia. Ele propõe algumas diferenciações para adequar o tratamento profilático de tromboembolismo para diferentes pacientes.

Esse quadro é um algoritmo de estratificação de risco para pacientes com COVID-19 feito pelo periódico do colégio americano de cardiologia. Ele propõe algumas diferenciações para adequar o tratamento profilático de tromboembolismo para diferentes pacientes.

Pacientes com alto Risco de ACS (síndrome coronariana aguda) são pacientes com instabilidade hemodinâmica devido a disfunção ventricular esquerda. Pacientes com alto risco de VTE (Tromboembolismo Venoso) são pacientes com embolismo pulmonar que estão hemodinamicamente instáveis com evidência de disfunção, dilatação ventricular direita ou piora dos sintomas. Pacientes com COVID-19 de alto risco são pacientes confirmados ou com alta suspeita de confirmação de COVID-19 que necessitem de intubação. 


\section{DISCUSSÃO}

A fim de analisar o tromboembolismo venoso é necessário primeiramente recordar a tríade de Virchow: lesão endotelial, estado de hipercoagulabilidade e alteração de fluxo (estase). Esses são os três grandes grupos de fatores que promoverão a trombose intravascular, a qual, por sua vez, é a causadora direta de eventos tromboembólicos. Dessa forma, caso a infecção por SARS-CoV-2 cause prejuízo comprovado a algum desses fatores, viabilizando um estado de hipercoagulabilidade, a associação da COVID-19 com o tromboembolismo venoso tornar-se-á mais evidente.

O tromboembolismo venoso é composto por duas condições frequentes: a trombose venosa profunda (TVP) e o tromboembolismo pulmonar (TEP).

A TVP é um quadro caracterizado pela formação de trombos no lúmen de veias profundas, principalmente naquelas dos membros inferiores. Ela é comumente causada pela imobilização prolongada, em decorrência de viagens longas ou de permanência em leitos hospitalares por internações devido a cirurgias ou a doenças debilitantes. Contudo, frequentemente, durante a instalação do quadro, é percebido desequilíbrio entre os fatores pró e anticoagulantes no sangue e aspectos promotores de lesão endotelial. A TVP pode ser assintomática, mas geralmente se apresenta com edema, rubor e dor, além da possibilidade de desenvolver eczemas e até úlceras.

Quanto ao TEP, trata-se de um quadro caracterizado pela obstrução dos vasos arteriais pulmonares por tromboêmbolos oriundos de outras porções do sistema vascular, principalmente nos vasos profundos dos membros inferiores (MMII). Diante disso, o paciente pode apresentar sintomas como dor pleurítica, taquidispneia, taquicardia e edema de MMII.

O diagnóstico em ambos os casos é feito baseado na apresentação clínica do paciente, mas sua confirmação é dada por exame de imagem, principalmente o Eco-Doppler. Esse cenário deve receber uma atenção especial devido à prevalência ainda não elucidada desse quadro em pacientes com COVID-19.

Visto que o vírus SARS-Cov-2 promove as três fases da tríade de Virchow, ele pode ser fortemente associado ao maior desenvolvimento de TVP e TEP. A infecção, além de naturalmente promover um estado pró-inflamatório, também possui um mecanismo que intensifica esse processo, promovendo uma tempestade de citocinas que leva à Síndrome de Resposta Inflamatória Sistêmica (SRIS). Em pacientes mais gravemente afetados, o vírus, por meio da ligação com a enzima conversora de angiotensina 2 (ECA2), altamente presente nas células epiteliais pulmonares, nos cardiomiócitos e nos epitélios vasculares, consegue entrar nas células hospedeiras. $\mathrm{O}$ acometimento pulmonar promove agressão das células endoteliais, que, ao serem lesadas, induzem elevados níveis de citocinas pró-inflamatórias, como a IL-1 $\beta$, IL-6 e TNF- $\alpha$. Nesses pacientes a resposta imune se instala de forma excessiva e essa chamada "tempestade de citocinas" resulta em um quadro inflamatório sistêmico. É sabido que esse processo ocorre, ainda, com maior estresse das paredes vasculares, vasoconstrição e agressão direta da parede por citocinas pró-inflamatórias, aumentando a probabilidade de ocorrerem 
lesões endoteliais, o primeiro fator da tríade de Virchow. Essas lesões promoverão a liberação do fator de Von Willerbrand e ativação do fator tissular, dando início ao processo de coagulação.

Esse processo, por sua vez, será intensificado pelo estado de hipercoagulabilidade também originado na SRIS. Percebe-se, pois, a presença do segundo fator da tríade de Virchow. A Síndrome da Resposta Inflamatória Sistêmica provoca desbalanceamento entre os fatores pró-coagulantes, principalmente as trombinas e os anticoagulantes, como a antitrombina e a proteína $\mathrm{S}$, com redução da expressão destes e aumento daqueles.

As desordens hemostáticas apresentadas pelos pacientes com COVID-19 podem ser resultado da junção dos fatores anteriormente falados com a hipóxia característica da pneumonia originada na infecção viral. A hipóxia atua em duas vias, complicando o quadro: por um lado ela promove vasoconstrição e alteração do fluxo sanguíneo, representando o último fator da tríade de Virchow e contribuindo para a disfunção endotelial. Por outro, ela pode modificar a expressão fenotípica do endotélio vascular, provocando um estado pró-coagulante e pró-inflamatório, por meio da alteração de fatores de transcrição das células epiteliais. (Figura X)

Desse modo, a associação entre os casos mais graves de COVID-19 e a ocorrência de TVP e TEP é fortemente sugerida pela constatação de 3 fatores principais: a redução do fluxo sanguíneo, como resultado da vasoconstrição e agravado pela imobilização frequente dos pacientes; o desequilíbrio dos fatores pró e anticoagulantes, representando o estado de hipercoagulabilidade; e a lesão endotelial causada pelo estado inflamatório sistêmico. 


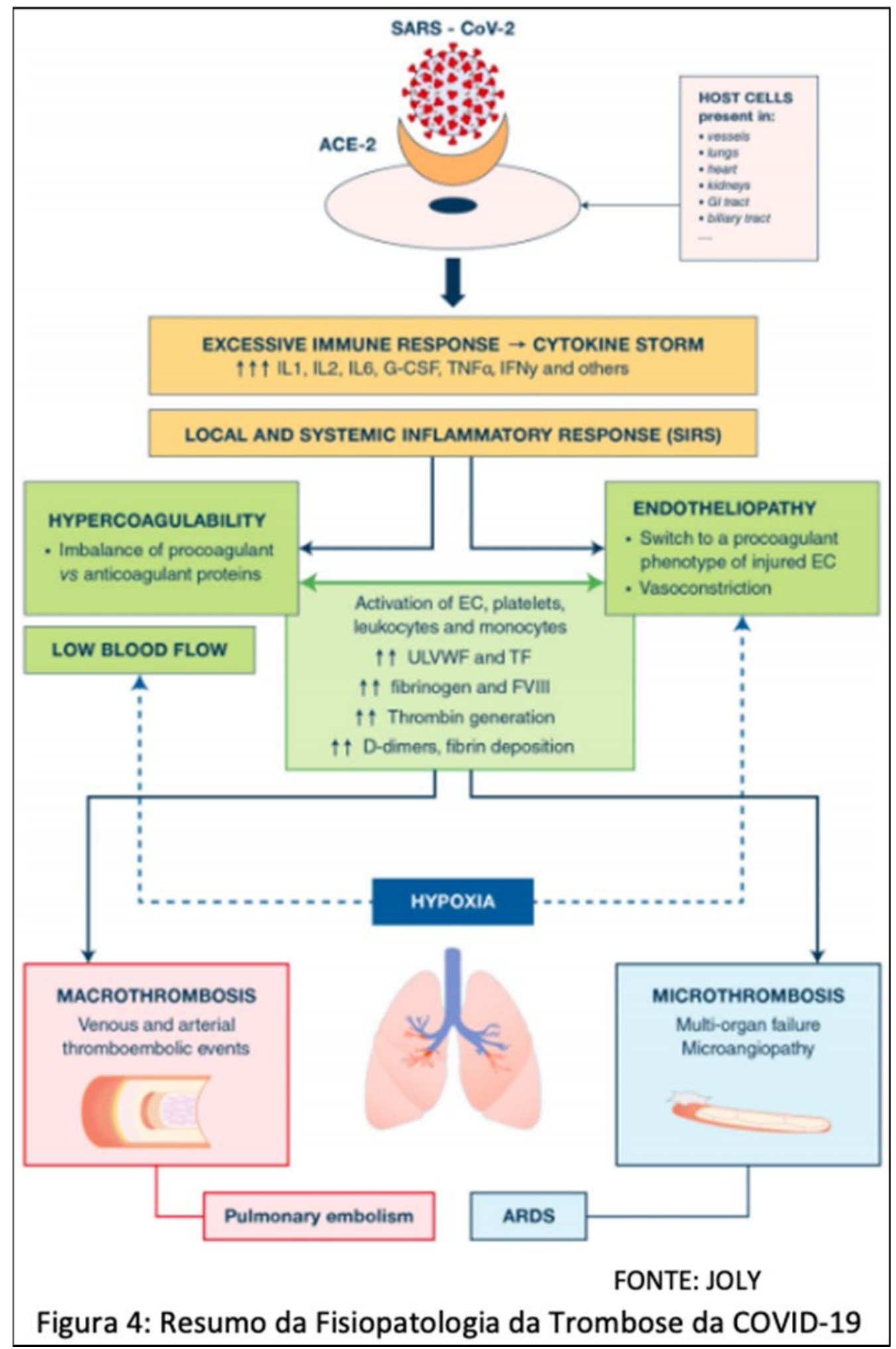

Os pacientes graves devem ser monitorados pelo acompanhamento do fibrinogênio, da contagem de plaquetas, do tempo de protrombina e do dímero-D. Elevações deste têm sido relacionadas a maior risco de desenvolvimento da Síndrome do Desconforto Respiratório Agudo (SDRA) e necessidade de internação em Unidades de Terapia Intensiva.

Frente a esse cenário, a utilização de tromboprofilaxia para pacientes internados com COVID-19 se torna uma pauta de discussão, principalmente no que diz respeito à dose utilizada ser a profilática padrão ou a terapêutica. 
A Organização Mundial da Saúde (OMS) recomenda a tromboprofilaxia com a dose profilática padrão em todos pacientes internados com COVID-19 com uso de heparina de baixo peso molecular (HBPM) e, caso o paciente apresente disfunção renal, heparina não-fracionada (HNF). A divergência em relação à dosagem a ser utilizada leva em consideração o fato de que o cenário de pandemia prejudica a eficácia diagnóstica de TVP e TEP em pacientes infectados, pois a realização dos métodos confirmatórios apresenta maior risco de contaminação para outros pacientes e para os profissionais da saúde.

A utilização da tromboprofilaxia necessita, ainda, de atenção para a estratificação do risco tromboembólico e hemorrágico individual. Pacientes com baixo risco hemorrágico devem receber a HBPM, sempre com monitoramento da função renal. Caso essa esteja prejudicada, a dose deve ser diminuída e a HNF torna-se uma boa alternativa. Já os pacientes com alto risco hemorrágico não podem receber a anticoagulação farmacológica. Deve-se, portanto, utilizar métodos mecânicos, como o uso de meias compressivas graduadas (MCG) dos membros inferiores e a compressão pneumática intermitente (CPI) até que os riscos hemorrágicos sejam diminuídos e então possa ser administrada a heparina.

Deve-se considerar, também, a continuidade da tromboprofilaxia com anticoagulantes orais para pacientes de risco tromboembólico mais elevado que recebam alta do hospital.

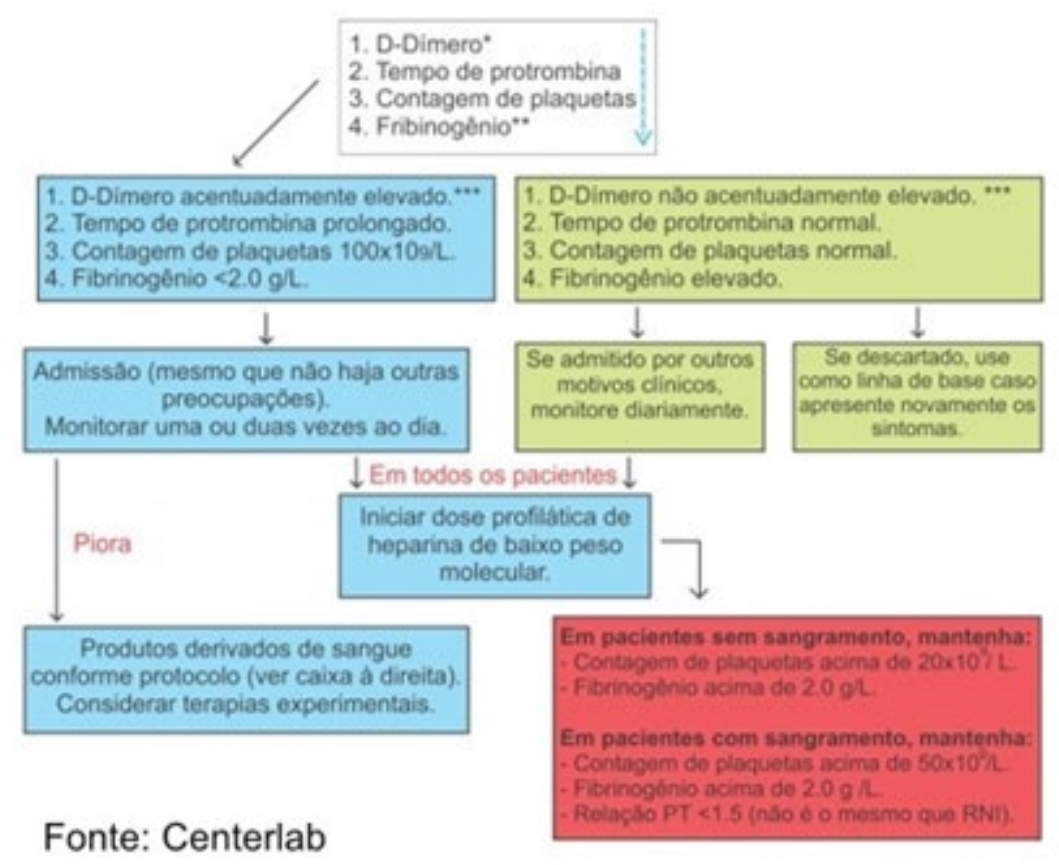

\section{Figura 5: Fluxograma para orientação de tromboprofilaxia em pacientes internados com COVID-19.}

Outra questão importante a ser debatida em relação à associação entre a COVID-19 e a ocorrência de TVP e TEP é a subnotificação dos casos. Como falado anteriormente, o diagnóstico confirmatório do tromboembolismo venoso (TEV) é feito por exames de imagem. Um desafio enfrentado 
é que os exames necessários apresentam risco para outros pacientes e para os profissionais da saúde, em razão do alto risco de transmissão do vírus. Além disso, a necessidade de pronação por muitos pacientes com síndrome respiratória aguda grave (SRAG) também representa um empecilho. Outro fator que influencia nesse caso é a sobreposição dos sintomas da TVP e do TEP com sintomas da COVID-19. Também, sinais e sintomas de TVP podem ser de difícil detecção especialmente em pacientes de UTI devido ao foco no tratamento do acometimento respiratório e o acesso infrequente aos MMII em busca de sinais de TVP.

Acredita-se, portanto, que o TEV possa estar subnotificado entre os pacientes com COVID-19, fato importante, uma vez que pacientes com SRAG têm maior predisposição à vasoconstrição pulmonar por hipóxia, hipertensão pulmonar e falência de ventrículo direito. Dessa forma, caso o TEV evolua com TEP, os danos podem ser irreparáveis.

\section{CONCLUSÃO}

À luz das análises realizadas, percebe-se que, devido ao contraste entre a atuação da COVID-19 no aumento dos processos inflamatórios e a baixa notificação de tromboembolismo venoso nos pacientes acometidos por essa doença, é possível haver uma maior incidência do TEV em pacientes com COVID-19 em relação à reportada. Diante disso, a detecção de taxas elevadas de dímero $\mathrm{D}$ e outros fatores coagulantes como tempo de protrombina, fibrinogênio e contagem de plaquetas torna necessária maior investigação acerca da instalação do quadro tromboembólico nos pacientes e o provável benefício da tromboprofilaxia. Por fim, a possibilidade de subnotificação de casos de TEV exige que mais estudos sobre a real prevalência sejam realizados, para que se possibilite uma melhor adequação no manejo dos pacientes em termos de prevenção e tratamento dessa complicação.

\section{REFERÊNCIAS BIBLIOGRÁFICAS}

BIKDELI, Behnood et al. COVID-19 and Thrombotic or Thromboembolic Disease: Implications for Prevention, Antithrombotic Therapy, and Follow-Up: JACC State-of-the-Art Review. Journal of the American College of Cardiology, v. 75, n. 23, p. 2950-2973, 2020. Disponível em: https://www.onlinejacc.org/ content/75/23/2950. Abstract. Acesso em: 20 out. 2020

CHEN, S. et al. DVT incidence and risk factors in critically ill patients with COVID19. Journal of Thrombosis and Thrombolysis , 2020. Disponível em: https://doi.org/10.1007/s11239-020-02181-w. Acesso em: 20 out. 2020 .

CONNORS, Jean et al. COVID-19 and its implications for thrombosis and anticoagulation. Blood, The Journal of the American Society of Hematology, Boston, 2020.

DOLHNIKOFF, Marisa et al. Pathological evidence of pulmonary thrombotic phenomena in severe COVID-19. Journal of Thrombosis and Haemostasis, São Paulo, 15 de abril de 2020. 
JOLY, Bérangère S; SIGURET, Virginie; VEYRADIER, Agnès. Understanding Pathophysiology of Hemostasis Disorders in Critically III Patients With COVID-19. Intensive care medicine, Paris, 15 de maio de 2020.

KLOK, F. A. et al. Incidence of thrombotic complications in critically ill ICU patients with COVID-19. Thrombosis Research, 2020. Disponível em: https://doi.org/10.1016/j.thromres.2020.04.013. Acesso em: 20 out. 2020.

LODIGIANI, C. et al. Venous and arterial thromboembolic complications in COVID-19 patients admitted to an academic hospital in Milan, Italy. Milão: Elsevier, 2020.

MARIETTA, M. et al. COVID-19 and haemostasis: a position paper from Italian Society on Thrombosis and Haemostasis (SISET). Blood Transfusion, 2020. Disponível em: https://www.ncbi.nlm.nih.gov/pmc/articles/PMC7250682/pdf/blt-18-167.pdf. Acesso em: 20 out. 2020

MIDDELDORP, Saskia et al. Incidence of Venous Thromboembolism in Hospitalized Patients With COVID-19. Journal of thrombosis and haemostasis, Amsterdam, 5 de maio de 2020.

MIESBACH W, MAKRIS M. COVID-19: Coagulopathy, Risk of Thrombosis, and the Rationale for Anticoagulation. Clinical and Applied Thrombosis/Hemostasis. January 2020.

POGGIALI, E. Deep Vein Thrombosis and Pulmonary Embolism: Two Complications of COVID-19 Pneumonia?. European Journal of Case Reports in Internal Medicine, 2020. Disponível em: https://www. ejcrim.com/index.php/EJCRIM/article/view/1646/2040. Acesso em: 20 out. 2020.

PORFIDIA, Angelo; POLA, Roberto. Venous thromboembolism in COVID-19 patients. Journal of Thrombosis and Haemostasis, Roma, 8 de abril de 2020.

WICHMANN, Dominic et al. Autopsy findings and venous thromboembolism in patients with COVID-19: a prospective cohort study. Annals of internal medicine, 2020. Disponível em: https://pubmed.ncbi.nlm.nih. gov/32374815/. Acesso em: 20 out. 2020

ZHAI, Z et al. Prevention and Treatment of Venous Thromboembolism Associated with Coronavirus Disease 2019 Infection: A Consensus Statement before Guidelines. Beijing: PMC, 2 


\title{
A INCIDÊNCIA DOS RISCOS CARDIOVASCULARES E SUA RELAÇÃO COM OS FATORES DE RISCOS
}

\author{
THE INCIDENCE OF CARDIOVASCULAR RISKS AND THEIR \\ RELATIONSHIP WITH RISK FACTORS
}

FERNANDO AUGUSTO DE CASTRO RIBEIRO

OSORINO RODRIGUES DOS SANTOS

NETO

CAROLINE BARROS FARIAS GOMES

QUEREN HAPUQUE ALMEIDA GONÇALVES MUNIZ

ÂNGELO RICARDO BALDUINO artigos encontrados foram selecionados quanto a originalidade e relevância. As buscas resultaram em um total de 15 artigos no site SCIELO BRAZIL, GOOGLE ACADÊMICO, BIBLIOTECA VIRTUAL DO MINISTÉRIO DA SAÚDE(BVSMS), REVISTA BRASILEIRA DE CARDIOLOGIA(CARDIOL), sendo excluídos 6 artigos inicialmente, através do filtro de ano de publicação e de leitura seletiva. RESULTADO: Foi possível identificar em todos os artigos selecionados que a incidência das DCV é altamente relacionada à exposição aos fatores de riscos e hábitos de vida dos indivíduos.

Palavras-chave: Doenças Cardiovasculares. Fatores de risco. Hábitos de vida

RESUMO: Introdução: As Doenças Cardiovasculares são consideradas como a maior causa de óbito no mundo na atualidade. Esse número elevado de óbitos se dá por conta da amplitude dos tipos e efeitos desencadeados pelas tais doenças que acometem o aparelho cardiovascular. $\mathrm{O}$ aparecimento das DCV está diretamente interligado aos fatores de risco que incluem o tabagismo, obesidade, etilismo, diabetes dentre outros fatores. Essas patologias além de levar muitos pacientes ao óbito, causa limitações a muitos indivíduos, de modo a interferir de forma negativa na qualidade de vida do enfermo. Objetivo: Esse trabalho teve por objetivo relacionar os fatores de riscos mais prevalentes para o desenvolvimento das Doenças Cardiovasculares, através de uma revisão de literatura. Metodologia: Este trabalho foi realizado através de uma revisão sistemática de literatura, usando as palavras chave "doenças cardiovasculares", "fatores de risco", "hábitos de vida". Para a seleção dos artigos foi usado como filtro de inclusão "ano de publicação", buscando apenas artigos publicados a partir de 2011. Os
ABSTRACT: Introduction: Cardiovascular Diseases are currently considered the leading cause of death in the world. This high number of deaths is due to the range of types and effects triggered by such diseases that affect the cardiovascular system. The onset of CVD is causally linked to risk factors that include smoking, obesity, alcoholism, diabetes, among other factors. These pathologies, in addition to leading many patients to death, cause limitations to many individuals, in order to negatively interfere with the patient's quality of life. Objective: To list the most prevalent risk factors for the development of Cardiovascular Diseases, through a literature review. Methodology: This work was carried out through a systematic literature review, using the keywords "cardiovascular diseases", "risk factors", "lifestyle". For the selection of articles, it was used as an inclusion filter "year of publication", seeking only articles published from 2011. The articles found were selected according to their originality and rele- 
vance. The searches resulted in a total of 15 articles on the website SCIELO BRAZIL, GOOGLE ACADÊMICO, VIRTUAL LIBRARY OF THE MINISTRY OF HEALTH (BVSMS), BRAZILIAN JOURNAL OF CARDIOLOGY (CARDIOL), with 6 articles initially excluded through the year of publication and selective reading. RESULT: It was possible to identify in all selected articles that the incidence of CVD is highly related to exposure to risk factors and lifestyle habits of individuals.

Keywords: Cardiovascular diseases. Risk factors. Life habits

\section{INTRODUÇÃO}

As Doenças Cardiovasculares (DCV) são um grupo de doenças que acometem o coração e os vasos sanguíneos, e se subdividem em sete tipos os quais são: Doenças Coronarianas, Doenças Cerebrovasculares, Doenças Arteriais Periféricas, Doenças Cardíaca Reumáticas, Cardiopatias Congênitas, Trombose Venosa Profunda e Embolia Pulmonar.

As doenças cardiovasculares (DCVs) são doenças que causam distúrbios no coração e vasos sanguíneos, responsáveis pela maior taxa de morbidade e mortalidade no mundo, sendo que requerem os mais elevados custos de assistência social e econômica (Garlucci, et al,2013).

O infarto agudo do miocárdio (IAM), é uma das doenças coronarianas mais prevalentes, que decorre da necrose e consequente morte dos cardiomiócitos causadas por um desequilíbrio entre a oferta e demanda de nutrientes ao tecido, ocorre obstrução do fluxo coronariano que pode ser transitório ou permanente (Siervuli, et al,2014).

Foi realizado um estudo em Florianópolis, Santa Catarina, de 2001 até 2011 que demonstrou que as doenças cerebrovasculares e a insuficiência cardíaca ocupam o $2^{\circ}$ e $3^{\circ}$ lugares no ranking de internações por condições sensíveis à atenção primária (Silva, et al,2019).

Segundo dados fornecidos pela Organização Mundial de Saúde estima-se que em 2015, 17,7 milhões de pessoas vieram a óbito por conta das DCV, considerado a maior causa de morte no mundo, que é representado por $31 \%$ das mortes em nível global.

Estudos epidemiológicos indicam que na ausência de fatores de risco, as doenças cardiovasculares raramente seriam causas de óbitos. Por conta disso, a investigação dos fatores de risco, para controla-los ou reduzi-los é a grande aposta para reduzir as complicações cardiovasculares (Varote, et al,2019).

As doenças cardiovasculares (DCV) são alterações no funcionamento do sistema cardíaco, sendo este responsável por transportar oxigênio e nutrientes necessários às células para essas executarem suas tarefas. Tais doenças são consideradas um grande problema de saúde pública. Esse conjunto de doenças está ligado a um conjunto de fatores de risco que são sedentarismo, tabagismo, stress, obesidade, hipertensão, diabetes e dislipidemia (Lima, et al,2014). 
A hipertensão arterial atinge aproximadamente um bilhão de indivíduos no mundo, segundo a OMS. Essa comorbidade é o principal fator de risco para doenças cardiovasculares, como infarto agudo do miocárdio e acidente vascular cerebral (G1.globo,2019).

Uma pesquisa realizada pela Federação Internacional de Diabetes indicou que mais de 400 milhões de casos de diabetes no mundo, 90\% apresenta pelo menos um fator de risco cardiovascular. Ainda nessa pesquisa foi detectada que $80 \%$ das mortes dos pacientes portadores de diabetes, tem relação direta com eventos cardiovasculares (Saúde IG,2019).

A obesidade é um dos fatores de risco para as doenças cardiovasculares. Dentre as seis principais causas de morte no brasil, quatro estão interligadas com o sobrepeso. Essas doenças são acidente vascular cerebral, infarto do miocárdio, diabetes e hipertensão (Revista Hcor saúde,2017).

A dislipidemia é considerada um dos principais fatores causadores da doença cardiovascular e cerebrovasculares, dentre essas estão aterosclerose, infarto agudo do miocárdio, doença isquêmica do coração, e o AVC (ANVISA,2011).

O AVC é uma patologia que representa um dos principais problemas de saúde na atualidade, constitui uma das patologias neurológicas de maior prevalência, e uma das principais causas de incapacidade ou limitação temporária ou definitiva e, ainda, uma das principais causas de incapacidade temporária ou definitiva. No Brasil, anualmente, são registradas 68 mil mortes por AVC (Goulart, et al,2016).

O risco de morte súbita é de aproximadamente 10 vezes mais em um indivíduo fumante que em um não fumante. Tabagistas passivo tem maior chance de desenvolver problemas coronarianos e infarto do miocárdio (Coloma,2014).

A interrupção do tabagismo, redução do sal na alimentação, consumo de alimentos saudáveis, prática de atividade física, e evitar etilismo exacerbado tem se mostrado como medidas eficazes para reduzir os riscos e complicações desencadeadas pelos eventos cardiovasculares (OPAS Brasil, 2017).

O consumo excessivo de sódio aumenta o risco de hipertensão e consequentemente das doenças cardiovasculares. Pesquisa aponta que dois terços do consumo de sal pelo brasileiro, advém do sal utilizado no ato da culinária. De acordo com a Pesquisa de Orçamentos Familiares do IBGE, o brasileiro consome mais que o dobro do sal recomendado pela Organização Mundial de Saúde (Ministério da Saúde,2019).

As doenças cardíacas limitam a qualidade de vida dos indivíduos, com relação à aspectos físicos, sociais, financeiros e de saúde. Essas doenças ainda incluem um impacto e custo na sociedade, devido a despesas do tratamento, afastamentos do trabalho e perda do bem-estar. Atualmente as doenças cardíacas representam o maior ônus para a saúde mundial, sendo responsável por 17 milhões de morte por ano (Stevens, et al,2018).

Para a realização do estudo, é necessário a utilização do Escore de Framimgham, que possibilita realizar associações entre os fatores de risco, que incluem tabagismo, dislipidemia, obesidade, 
sedentarismo, diabetes, etilismo exacerbado, e as características peculiares e imutáveis dos indivíduos, que são, a idade, o sexo e o histórico familiar. (H.T., et al, 2013).

A prevenção e o controle da hipertensão é uma das estratégias que promovem a saúde e previnem o indivíduo das situações de risco, ou seja, oferece benefícios não só para o indivíduo, mas também para a sociedade ( Radovanovic, et al,2014)

A implementação de políticas de saúde, como os estimulo para realização de atividade física e alimentação saudável, com acesso a prevenção primária e secundária de doença cardiovascular e a prática terapêutica em eventos agudos, e imprescindível para o controle das doenças cardiovasculares no mundo (Nascimento, et al,2018)

Intervenções rentáveis que são viáveis para a implementação até mesmo em locais com baixa renda foram identificadas pela Organização Mundial de Saúde(OMS) para prevenção e controle das doenças cardiovasculares. Essas intervenções são classificadas em individuais e coletivas. Tem se como exemplo a nível individual, o controle da pressão, já na medida em que diz respeito ao coletivo, construção de vias de caminhada e ciclismo (OPAS-Brasil,2017).

A população mundial está em um processo de envelhecimento populacional. Essa fase da idade implica no fator de risco não modificável, para o desenvolvimento das Doenças Cardiovasculares. Porém esse fator não modificável, quando associado com os fatores mofificáveis, como Hipertensão descontrolada, Diabetes descontrolada, Tabagismo, Deslipidemia, há uma potencialização para a ocorrência de um evento cardiovascular. Diante desse cenário, é necessário cessar e promover ações que tenham como objetivo cessar ou pelo menos atenuar os fatores de risco. Dentre essas ações incluem, prática de atividade física, alimentação saudável, cessar tabagismo e a realização de atividades peculiares que estimulam a satisfação do individuo deixadas de serem realizadas por conta de falta de tempo e disposição.

Portanto, esse estudo teve por objetivo analisar os fatores de riscos mais frequentes nas Doenças Cardiovasculares com o avanço da idade. E com isso diminuir as taxas de mortalidades oriundas das DCV.

\section{MATERIAL E MÉTODOS}

Esse estudo não foi submetido ao Comitê de Ética e Pesquisa por se tratar de uma revisão de literatura. Contudo, ressalta-se terem sido mantidas as ideias originais dos autores no processo de produção dos seus trabalhos.

O presente estudo refere-se a uma revisão sistemática de literatura abordando as principais vertentes: fatores de risco para o desenvolvimento das Doenças Cardiovasculares e as suas consequências para a população acometida. Nesse estudo, foi abordado primeiramente: a descrição dos eventos cardiovasculares e os fatores de risco, posteriormente: foi descrito a fisiopatologia, a epidemiologia, o prognóstico e os métodos diagnósticos. 
A procura pelos artigos utilizados na pesquisa, teve como base a plataforma da SCIELO Brazil, Organização Pan-Americana de Saúde (OPAS), Arquivo Brasileiro de Cardiologia, Arquivo Brasileiro de Cardiologia e International Jornal of Cardiovascular Sciens, Biblioteca Virtual em Saúde (BVSMS). O filtro de inclusão utilizado para a seleção dos artigos, foi o ano da pesquisa, sendo utilizados apenas os trabalhos realizados a partir do ano de 2010. Essa seleção teve como objetivo, desenvolver uma explicação abrangente do fenômeno temático, e a partir desses dados oriundos do estudo produzir um material teórico/intervencionista

A procura pelos artigos, totalizaram 21 pesquisas, mas 6 foram excluídas, com base no critério de inclusão. Então apenas 15 artigos foram pré-selecionados para a realização da pesquisa, por estarem enquadrados a todos os critérios desejados na pesquisa, tendo como principal intuito de revisão de literatura formular um perfil relacionado as Doenças Cardiovasculares

\section{RESULTADOS E DISCUSSÃO}

A análise dos resultados ocorreu com os seguintes aspectos: Artigo, ano e periódico; Objetivo; Resultado. A partir dos tópicos estabelecidos para revisão de literatura, foram pré-selecionados 15 artigos, sendo 08 Scielo Brazil, 05 Google Acadêmico, 01 Biblioteca Virtual do Ministério da Saúde e 01 Revista Brasileira de Cardiologia. Com a seleção de 09 artigos abordados na pesquisa.

Quadro 1: Artigos de inclusão e exclusão, 15 artigos selecionados para análise

\begin{tabular}{|c|c|c|}
\hline SCIELO BRAZIL & 8 resultados no total & $\begin{array}{c}5 \text { aplicando os critérios de } \\
\text { inclusão }\end{array}$ \\
\hline GOOGLE ACADEMICO & 5 resultados no total \\
BIBLIOTECA VIRTUAL \\
$\begin{array}{c}\text { DO MINISTÉRIO DA SAÚ- } \\
\text { DE(BVSMS) }\end{array}$
\end{tabular}

\begin{tabular}{|c|c|}
\hline Critérios de inclusão & 09 \\
\hline Critérios de exclusão & 06 \\
\hline
\end{tabular}

Fonte: Elaborada pelos autores 


\begin{tabular}{|c|c|c|}
\hline $\begin{array}{c}\text { Artigo, ano e } \\
\text { periódico }\end{array}$ & Objetivo & Resultado \\
\hline $\begin{array}{l}\text { A1( ), Garlucci, } \\
\text { et al,2013 }\end{array}$ & $\begin{array}{l}\text { Verificar a importância da obesidade e do } \\
\text { sedentarismo como risco no desenvolvi- } \\
\text { mento de doenças cardiovasculares }\end{array}$ & $\begin{array}{l}\text { Devido aos hábitos de vida irregulares da po- } \\
\text { pulação, a curva populacional de obesidade } \\
\text { está cada vez maior. Predispondo um maior } \\
\text { risco cardiovascular }\end{array}$ \\
\hline $\begin{array}{l}\text { A2( ), Siervuli, } \\
\text { et al, } 2014\end{array}$ & $\begin{array}{l}\text { Estudo das alterações morfológicas do } \\
\text { IAM e as variações morfológicas que fa- } \\
\text { vorecem o acometimento dessa doença }\end{array}$ & $\begin{array}{l}\text { São encontrados estudos que relatam a me- } \\
\text { lhora da função cardíaca, remodelamento } \\
\text { cardíaco e redução das placas de ateroma em } \\
\text { indivíduos submetidos à reabilitação cardíaca }\end{array}$ \\
\hline $\begin{array}{l}\text { A3( ), Silva, et } \\
\text { al, } 2019\end{array}$ & $\begin{array}{l}\text { Analisar a tendência das taxas de hospi- } \\
\text { talizações por condições cardiovascula- } \\
\text { res sensíveis a atenção primária a saúde } \\
\text { (CCSAP) }\end{array}$ & $\begin{array}{l}\text { Utilizados } 3.324 \text { internados; houve tendência } \\
\text { temporal decrescente para taxa de internações } \\
\text { (taxa de aumento anual: } 8,14 \text { IC:95\%, 11,78; } \\
\text { 4,35) e para IC:12,07- IC:95\%; 14,75; 9,30). } \\
\text { Tendência temporais nas taxas de hospitaliza- } \\
\text { ções por HAS, Angina e DC, foram estacio- } \\
\text { nárias }\end{array}$ \\
\hline $\begin{array}{l}\text { A4( ), Varote, et } \\
\text { al,2019 }\end{array}$ & $\begin{array}{l}\text { Avaliar o estado nutricional de idosos e re- } \\
\text { lacioná-lo com os fatores de risco cardio- } \\
\text { vascular (FRCV) na população idosa per- } \\
\text { tencente à Associação da Terceira Idade } \\
\text { no município de Monte Azul Paulista- SP }\end{array}$ & $\begin{array}{l}\text { De } 54 \text { idosos com média de idade } 73,72 \text { anos; } \\
\text { teve predomínio do sexo feminino }(90,7 \%) \text {. A } \\
\text { prevalência do FR para DCV: } 59,2 \% \text { obesida- } \\
\text { de total; } 25,9 \% \text { DM, } 62,9 \% \text { HAS; } 38,8 \% \text { Dis- } \\
\text { lipidemia; } 92,6 \% \text { obesidade central; } 75,9 \% \\
\text { CC; } 5,5 \% \text { tabagismo; } 75,9 \% \text { sedentarismo; } \\
1,85 \% \text { etilismo; e ingestão de alimentos con- } \\
\text { traindicados para DCV }\end{array}$ \\
\hline $\begin{array}{l}\text { A5( ), Maga- } \\
\text { lhães, et al,2014 }\end{array}$ & $\begin{array}{l}\text { Identificar os FR modificáveis e não mo- } \\
\text { dificáveis para DCV presentes nos pro- } \\
\text { fissionais de enfermagem, e descrever } \\
\text { estratégias de promoção da saúde para o } \\
\text { controle e prevenção desses fatores }\end{array}$ & $\begin{array}{l}\text { Perceberam-se fatores de risco como ante- } \\
\text { cedentes familiares com hipertensão arterial } \\
(72,9 \%) \text {, sedentários }(64,9 \%) \text {, peso elevado } \\
(56,4 \%) \text {, circunferência abdominal elevada } \\
(49,7 \%) \text {, dentre outros }\end{array}$ \\
\hline $\begin{array}{l}\text { A6( ), Goulart, } \\
\text { et al,2016 }\end{array}$ & $\begin{array}{l}\text { Caracterizar pacientes com acidente vas- } \\
\text { cular cerebral (AVC), verificar a preva- } \\
\text { lência de distúrbios de comunicação oral } \\
\text { relacionados e a frequência de encaminha- } \\
\text { mento para reabilitação fonoaudiológica }\end{array}$ & $\begin{array}{l}\text { Dos } 95 \text { pacientes, }(53,7 \%) \text { do sexo masculi- } \\
\text { no, com média de idade de 59,8 anos; }(59,3 \%) \\
\text { apresentavam histórico de HAS; (86,3\%) } \\
\text { apresentaram AVCi e }(55,8 \%) \text { distúrbios de } \\
\text { comunicação oral (DCO). Com média de in- } \\
\text { ternação de } 5 \text { dias. Não houve relação signifi- } \\
\text { cativa entre o tipo de AVC e DCO, tampouco } \\
\text { entre o local da lesão neurológica decorrente } \\
\text { do AVC e a ocorrência de DCO. Nenhum dos } \\
\text { sujeitos recebeu indicação de avaliação ou } \\
\text { tratamento fonoaudiológico durante a inter- } \\
\text { nação ou na alta }\end{array}$ \\
\hline
\end{tabular}




\begin{tabular}{|c|c|c|}
\hline $\begin{array}{l}\text { A7( ) Stevens, } \\
\text { et al,2018 }\end{array}$ & $\begin{array}{l}\text { Este estudo avaliou o custo de quatro im- } \\
\text { portantes doenças cardíacas no Brasil: } \\
\text { hipertensão, insuficiência cardíaca, infar- } \\
\text { to do miocárdio e fibrilação atrial. Além } \\
\text { disso, avaliou a relação de custo-efetivi- } \\
\text { dade de telemedicina e suporte telefônico } \\
\text { estruturado para o manejo de insuficiência } \\
\text { cardíaca }\end{array}$ & $\begin{array}{l}\text { Infarto do miocárdio acarretou o mais alto } \\
\text { custo financeiro (R } \$ 22,4 \text { bilhões/6,9 bilhões } \\
\text { de dólares), seguido de insuficiência cardía- } \\
\text { ca (R } \$ 22,1 \text { bilhões } / 6,8 \text { bilhões de dólares), } \\
\text { hipertensão (R } \$ 8 \text { bilhões/2,5 bilhões de dó- } \\
\text { lares) e, finalmente, fibrilação atrial (R } \$ 3,9 \\
\text { bilhões/1,2 bilhão de dólares). Telemedicina } \\
\text { e suporte telefônico estruturado são interven- } \\
\text { ções custo-efetivas para o aprimoramento do } \\
\text { manejo da insuficiência cardíaca }\end{array}$ \\
\hline $\begin{array}{l}\text { A8( ) H.T., et } \\
\text { al, } 2013\end{array}$ & $\begin{array}{l}\text { As recomendações desse documento ga- } \\
\text { nhem repercussão nacional, garantindo } \\
\text { tanto aos médicos como a seus pacientes, } \\
\text { o melhor tratamento e os benefícios da re- } \\
\text { dução do risco cardiovascular }\end{array}$ & $\begin{array}{l}\text { Desafios importantes se colocam como obstá- } \\
\text { culos ao tratamento otimizado do colesterol: } \\
\text { do diagnóstico correto das dislipidemias ao } \\
\text { custo do seu tratamento, envolvem, sobretu- } \\
\text { do, a relação médico-paciente, onde a inércia } \\
\text { terapêutica e a falta de adesão, dificultam que } \\
\text { a grande maioria dos pacientes sejam contem- } \\
\text { plados com os benefícios já comprovados. }\end{array}$ \\
\hline $\begin{array}{lr}\text { A9( ) } & \text { Nas- } \\
\text { cimento, } & \text { et } \\
\text { al,2018 } & \end{array}$ & $\begin{array}{l}\text { Descrever as tendências de morbidade e } \\
\text { mortalidade por doenças cardiovasculares } \\
\text { (DCV) nos PLP, entre } 1990 \text { e } 2016 \text {, estra- } \\
\text { tificadas por sexo, e sua associação com } \\
\text { os respectivos índices sociodemográficos } \\
\text { (SDI) }\end{array}$ & $\begin{array}{l}\text { Há diferenças na importância relativa da car- } \\
\text { ga de DCV nos PLP relacionadas às condi- } \\
\text { ções socioeconômicas. Entre as DCV, a doen- } \\
\text { ça isquêmica do coração foi a principal causa } \\
\text { de morte nos PLP em 2016, com exceção de } \\
\text { Moçambique e São Tomé e Príncipe, onde as } \\
\text { doenças cerebrovasculares a suplantaram. Os } \\
\text { fatores de risco atribuíveis mais relevantes } \\
\text { para as DCV entre os PLP foram a hiperten- } \\
\text { são arterial e os fatores dietéticos. Um valor } \\
\text { de p }<0,05 \text { foi considerado significativo. }\end{array}$ \\
\hline
\end{tabular}

O primeiro artigo utilizado na pesquisa foi desenvolvido por Garlucci, et al. (2013), teve como objetivo verificar a importância da obesidade e do sedentarismo como risco no desenvolvimento de doenças cardiovasculares. Para concluir esse objetivo, realizou-se uma revisão na literatura, buscando dados que apontam a influência da obesidade e do sedentarismo como forte predisponente ao desenvolvimento de cardiopatias, teve como base a análise de 50 artigos relacionados ao tema. $\mathrm{O}$ estudo teve como justificativa o aumento do consumo de alimentos inadequados, e diminuição nas práticas de atividade física. Segundo à OPAS esse cenário de hábitos de vida irregulares e inadequados propicia o desenvolvimento de doenças cardiovasculares, as quais são responsáveis pelas maiores taxas de morbidade e mortalidades no mundo. Esse estudo tem um resultado muito pertinente, pois comprova que os hábitos de vida influenciam de forma direta e negativa no organismo do indivíduo, podendo afetá-lo, de modo a desenvolver doenças de alta morbidade e mortalidade.

Outro estudo utilizado na pesquisa foi desenvolvido por Siervuli, et al. (2014), no qual foi realizada revisão da literatura em bancos de bases bibliográficas e acervos de livros, objetivando um estudo das alterações morfológicas do IAM e as variações morfológicas que favorecem o acometi- 
mento dessa doença. Segundo Berry e Cunha (2010), esse estudo evidenciou uma melhora da função cardíaca, remodelamento cardíaco e redução das placas de ateroma em indivíduos submetidos à reabilitação cardíaca. Essa melhora na funcionalidade cardíaca é um ótimo prognóstico para pacientes que sofreram algum evento cardiovascular, podendo interferir positivamente na qualidade de vida.

Também foi analisada a pesquisa produzida por Silva, et al. (2019), que teve como objetivo analisar a tendência das taxas de internação por CCSAP. As taxas de internação por CCSAP e IC diminuíram; entretanto as taxas por HAS, angina e doenças cerebrovasculares permaneceram constantes. Partindo dessa alteração nas taxas, fica explícito que a atenção primária tem uma função auto resolutiva no tratamento primário dos casos de CCSAP e IC, pois as taxas se reduziram em números consideráveis (Macinko, Dourado e Guanais,2011).

Segundo o estudo produzido por Varote, et al. (2019), o objetivo avaliar o estado nutricional de idosos e relacioná-lo com os FRCV na população idosa pertencente à Associação da $3^{\text {a }}$ Idade no município de Monte Azul Paulista- SP. Conclui- se que a maioria dos idosos entrevistados apresenta elevado risco para desenvolver complicações cardiovasculares. Segundo Freitas (2011) a população idosa, devido as alterações fisiológicas com o decorrer do envelhecimento populacional está mais susceptível a doenças de base e consequentemente a doenças cardiovasculares.

Outro estudo utilizado foi produzido por Magalhães, et al. (2014), que objetivou identificar os fatores de risco modificáveis e não modificáveis para doenças cardiovasculares presentes nos profissionais de enfermagem, e descrever estratégias de promoção da saúde para o controle e prevenção desses fatores. Teve como resultados que os fatores de risco como antecedentes familiares com HAS $(72,9 \%)$, sedentários $(64,9 \%)$, peso elevado $(56,4 \%)$, circunferência abdominal elevada $(49,7 \%)$ interferem de forma negativa, propiciando o desenvolvimento das DCV. Segundo Ribeiro, Cotta e Ribeiro (2012), fica evidente que é necessário diminuir a exposição aos fatores de riscos, através de medidas de educação em saúde e estimulação a hábitos de vida adequados.

O estudo realizado por Goulart, et al. (2016), teve objetivo de caracterizar pacientes com AVC, verificar a prevalência de distúrbios de comunicação oral relacionados e a frequência de encaminhamento para reabilitação fonoaudiológica. Mais de 50\% dos indivíduos acometidos por AVC apresentam distúrbios de comunicação oral durante o período de internação hospitalar onde não foram nem atendidos ou encaminhado a fonoaudiologia. Segundo Pena, Melleiro (2018), ocorre falha na comunicação entre os profissionais, que seria resolvido através de práticas que estimulem o aperfeiçoamento de equipes interdisciplinares, pois a comunicação é um instrumento determinante da qualidade e segurança das atividades profissionais.

\section{CONSIDERAÇÕES FINAIS}

O grupo de Doenças Cardiovasculares é composto por: Doenças Coronarianas, Doenças Cerebrovasculares, Doenças Arteriais Periféricas, Doenças Cardíaca Reumáticas, Cardiopatias Congênitas, Trombose Venosa Profunda e Embolia Pulmonar. 
Essas patologias representam um grave problema de saúde pública muito prevalente no mundo. Esse conjunto de doenças está relacionado a exposição à fatores de risco, tais como, tabagismo, etilismo, sedentarismo, alimentação inadequada, sobrepeso, dentre outros. Além disso, as DCV estão interligadas à patologias como DM, HAS e dislipidemia.

Contudo, percebe-se com os resultados do estudo, que quando o indivíduo evita a exposição aos FR, e realiza atividade física regularmente, a probabilidade de ocorrer um evento cardiovascular é diminuída de forma muito expressiva. Desse modo diminuindo a incidência das DCV.

\section{REFERÊNCIAS}

BERRY, John Richard Silveira; CUNHA Ademir Batista da, Avaliação dos Efeitos da Reabilitação Cardíaca em Pacientes Pós-Infarto do Miocárdio. Rev Bras Cardiol. Abril 2010.

FREITAS, Marco Polo Dias, Fatores de risco para doenças cardiovasculares em idosos- Coorte de idosos de Bambuí. Fundação Oswaldo Cruz. Fevereiro 2011.

GARLUCCI, Edilaine Monique de Souza et.al. Obesidade e sedentarismo: fatores de risco para doença cardiovascular. Com. Ciências Saúde. Abril 2014.

GOULART, Bárbara Niegia Garcia de et al . Caracterização de acidente vascular cerebral com enfoque em distúrbios da comunicação oral em pacientes de um hospital regional. Audiol., Commun. Res., São Paulo , v. 21, e1603, 2016 .

JORGE, Fernanda Magalhães et. al. Fatores de risco para doenças cardiovasculares em profissionais de enfermagem: estratégias de promoção da saúde. Revista Brasileira de Enfermagem. Vol. 67, núm. 3, mayo-junio, 2014, pp. 394-400.

MACINKO, James; DOURADO, Inês; GUANAIS, Frederico C., Doenças Crônicas, Atenção Primária e Desempenho dos Sistemas de Saúde Diagnósticos, instrumentos e intervenções. Banco Interamericano de Desenvolvimento. Novembro, 2011.

MAGALHAES, Fernanda Jorge et al . Fatores de risco para doenças cardiovasculares em profissionais de enfermagem: estratégias de promoção da saúde. Rev. bras. enferm., Brasília, v. 67, n. 3, p. 394-400, June 2014.

NASCIMENTO, Bruno Ramos et al . Epidemiologia das Doenças Cardiovasculares em Países de Língua Portuguesa: Dados do "Global Burden of Disease", 1990 a 2016. Arq. Bras. Cardiol., São Paulo, v. 110, n. 6, p. 500-511, June 2018.

PENA, M.; Melleiro, M. Eventos adversos decorrentes de falhas de comunicação: reflexões sobre um modelo para transição do cuidado. Revista de Enfermagem da UFSM. Set. 2018.

RADOVANOVIC, Cremilde Aparecida Trindade et al . Hipertensão arterial e outros fatores de risco associados às doenças cardiovasculares em adultos. Rev. Latino-Am. Enfermagem, Ribeirão Preto, v. 22, n. 4, p. 547-553, Aug. 2014 .

RIBEIRO, Amanda Gomes; COTTA, Rosângela Minardi Mitre; RIBEIRO, Sônia Machado Rocha. A promoção da saúde e a prevenção integrada dos fatores de risco para doenças cardiovasculares. Ciênc. saúde coletiva, Rio de Janeiro, v. 17, n. 1, p. 7-17, Jan. 2012.

SIERVULI, Marcos Tadeu Ferreira et. AL. Infarto do Miocárdio: Alterações Morfológicas e Breve Abordagem da Influência do Exercício Físico. Rev Bras Cardiol. Outubro 2014. 
SILVA, Marcus Vinicius Meneses da et al . Tendências das internações por condições cardiovasculares sensíveis à atenção primária à saúde no município de Senador Canedo, Goiás, 2001-2016. Epidemiol. Serv. Saúde, Brasília , v. 28, n. 1, e2018110, 2019.

STEVENS, Bryce et al. Os Custos das Doenças Cardíacas no Brasil. O Arq. Sutiãs. Cardiol., São Paulo, v. 111, n. 1, p. 29-36, julho de 2018.

VAROTE, Beatriz; AVI, Camilla Martins, Avaliação do estado nutricional e risco de desenvolvimento de doenças cardiovasculares em idosos da cidade de Monte Azul Paulista. Revista Ciências Nutricionais Online, v.3, n.1, p.46-51, 2019

XAVIER, H. T. et al . V Diretriz Brasileira de Dislipidemias e Prevenção da Aterosclerose. Arq. Bras. Cardiol., São Paulo, v. 101, n. 4, supl. 1, p. 1-20, Oct. 2013. 


\section{UMA REVISÃO INTEGRATIVA SOBRE TAMPONAMENTO CARDÍACO EM NEONATOS DEVIDO AO CATETERISMO VENOSO UMBILICAL}

JOSÉ RODRIGUES DOS SANTOS NETO

Universidade Federal de Campina Grande

MAYSA REGINA DE ASSIS LIMA

Universidade Federal de Campina Grande

VITOR HUGO LEOCADIO DE OLIVEIRA Universidade Federal do Acre

FRANCISCO JOSÉ DE ARAGÃO

Universidade Federal do Acre

EDIVANIO GONÇALVES DA SILVA SANTOS

Universidade Federal do Acre

GIOVANNI BADY CASSEB

Universidade Federal do Acre

RESUMO: O tamponamento cardíaco em neonatos devido ao cateterismo venoso umbilical é evento que pode ser fatal. Assim, preveni-lo e identificá-lo é fundamental. Objetivos: analisar a ocorrência do tamponamento cardíaco em neonatos com cateterismo venoso umbilical. Metodologia: trata-se de um estudo de revisão integrativa com abordagem qualitativa com objetivo descritivo. A busca foi realizada por meio do DeCS: "Cardiac Tamponade", "Infant, Newborn", "Umbilical Veins", "Catheterization". As bases de dados utilizadas foram: PubMeb, BVS e Web of Science. Os critérios de elegibilidade são: texto completo gratuito, obras que abordassem o no título e resumo o tema proposto. Os critérios de exclusão foram: estudos que abordassem tamponamento cardíaco em não neonatos e sem histó- rico de cateterismo, artigos duplicados, artigos pagos e não houve critério de idioma. No total foram utilizados para o estudo 6 artigos que se adequavam ao tema. Com a leitura dos estudos, concluiu-se que pacientes prematuros possuem alto risco de desenvolver tamponamento cardíaco pós utilização do cateter. As possíveis causas do tamponamento podem ser o contato da ponta do cateter com os átrios ou a passagem de solução hiperosmolar. As alterações clínicas foram súbitas e envolviam alterações cardiorrespiratórias e hemodinâmicas. $\mathrm{O}$ principal método diagnóstico e de acompanhamento foi a ecocardiografia.

PALAVRAS-CHAVE: Tamponamento cardíaco; Neonato; cateterismo venoso umbilical.

\section{ABSTRACT:}

Cardiac tamponade in neonates due to umbilical venous cateterism is an event that can be fatal. Thus, preventing and identifying it is fundamental. Objectives: to analyze the occurrence of cardiac tamponade in neonates with umbilical venous catheterization. Methodology: this is an integrative review study with a qualitative approach with a descriptive objective. The search was carried out through the DeCS: "Cardiac Tamponade", "Infant, Newborn", "Umbilical Veins", "Catheterization". The databases used were: PubMeb, BVS and Web of Science. The eligibility criteria are: free full text, works that addressed the title and abstract the proposed theme. The exclusion criteria were: studies that addressed cardiac tamponade in non-neonates and without a history of catheterization, duplicate articles, paid articles and there was no language criterion. In total, 6 articles were used for the study that suited 
the theme. Upon reading the studies, it was concluded that premature patients are at high risk of developing cardiac tamponade after using the catheter. Possible causes of tamponade may be the contact of the catheter tip with the atria or the passage of hyperosmolar solution. The clinical changes were sudden and involved cardiorespiratory and hemodynamic changes. The main diagnostic and follow-up method was echocardiography.

KEYWORDS: Cardiac Tamponade; Newborn; Umbilical venous cateterism.

\section{INTRODUÇÃO}

Cateterismo Venoso Umbilical em neonatos é uma via intravenosa bastante utilizada para reanimação e alimentação parenteral, em razão da facilidade do uso e baixo custo. O derrame pericárdico e o tamponamento, são eventos raros, porém, fatais; e foram relatados em 1 a $3 \%$ dos neonatos com cateteres, com mortalidade de 30 a 50\% (SEHGAL, COOK E DUNN, 2007). Portanto, compreender o mecanismo, as manifestações e como diagnosticar é imprescindível para uma intervenção rápida e preservação da vida do paciente. Dessa maneira, o objetivo do estudo é compreender a ocorrência do tamponamento cardíaco em neonatos.

\section{OBJETIVO}

Analisar a ocorrência do tamponamento cardíaco em função do cateterismo venoso umbilical em neonatos.

\section{METODOLOGIA}

O presente estudo foi conduzido seguindo o conceito de revisão integrativa estabelecido por Souza et al., (2015). Nesse contexto, trata-se de um estudo de revisão integrativa, com abordagem qualitativa, com objetivo descritivo. A pergunta norteadora foi: “Quais os achados clínicos, as causas possíveis, e o critério de diagnóstico tamponamento em pacientes neonatos com histórico de cateterismo venoso umbilical?"

A pesquisa foi ampla e realizada no dia 14/10/2020 por meio da plataforma CAPES nas bases de dados PubMed, Biblioteca Virtual em Saúde (BVS) e Web of Science. Os descritores utilizados foram baseados no Descritores em Ciências da Saúde (DeCS), a saber: "Cardiac Tamponade", "Infant, Newborn", "Umbilical Veins", “Catheterization”. Além disso, foram aplicados os operadores booleanos "AND". Outrossim, durante a busca utilizado o recurso de "advanced search" nas bases de dados. Os critérios de elegibilidade foram: texto completo gratuito, obras que abordassem o no título 
e resumo o tema proposto. Os critérios de exclusão foram: estudos que abordassem tamponamento cardíaco em não neonatos e sem histórico de cateterismo, artigos duplicados, artigos pagos e não houve critério de idioma.

A busca foi realizada por dois pesquisadores no mesmo dia, utilizando os mesmos descritores em computadores e conexões diferentes, no intuito de diminuir o risco de viés na seleção dos artigos. Além disso, em caso de discrepância entre os resultados obtidos pelos pesquisadores, um terceiro pesquisador auxiliará na elaboração da busca, minimizando assim a chance de erros. Portanto, utilizou-se os descritores na seguinte ordem: "Cardiac Tamponade", "Infant, Newborn”, "Umbilical Veins", "Catheterization", aplicou-se o operador booleano "AND" e os filtros para realização da busca. Nesse contexto, a ordem dos critérios aplicados foram: texto completo gratuito, artigos duplicados. Posteriormente, os trabalhos foram lidos integralmente e organizados em formato de tabela, empregando o software Microsoft Excel ${ }^{\circledR}$, contendo ano, título, autores, tipo do trabalho, principais achados, nível de evidência proposto por Melnyk e Fineout-Overholt (2005). Foi elaborado, também, um fluxograma com o roteiro da busca e os resultados.

Não foi necessário a submissão da pesquisa ao Comitê de Ética visto que a fonte de dados é de acesso público e primária. Também, é importante salientar que a revisão se embasa na Resolução $\mathrm{n}^{\circ}$ 466/12 e a Resolução n. 510/16, "toda pesquisa envolvendo seres humanos deve ser submetida à apreciação de um Comitê de Ética em Pesquisa (CEP)".

De acordo com o quadro 1, no total foram encontrados 47 artigos. Destes, 23 na PubMed, 21 na BVS e 3 na Web of Science. Após o critério texto completo gratuito foram excluídos 30 artigos. 4 Artigos foram descartados por serem pagos e 1 artigo foi excluído por não abordar pacientes com tamponamento cardíaco após o uso do cateter venoso umbilical. Além disso, 6 artigos estavam duplicados, portanto foram excluídos. Assim, restaram apenas 6 artigos.

Quadro 1

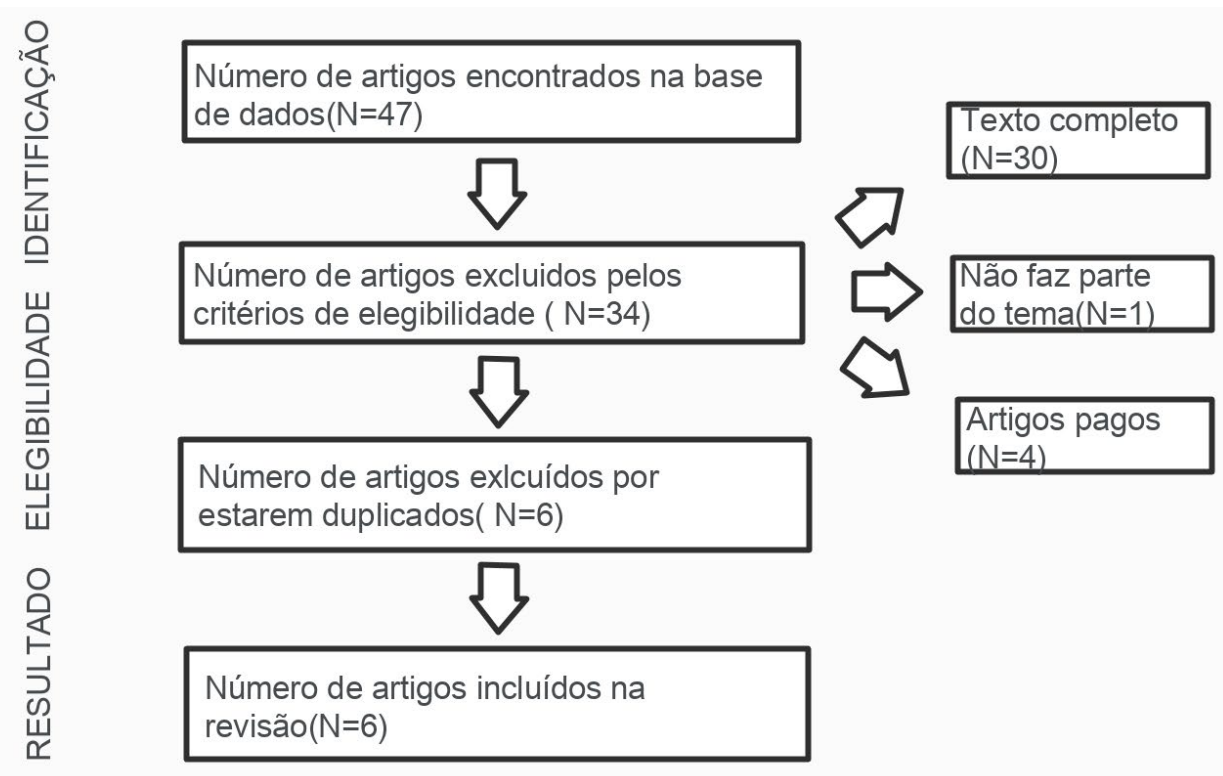




\begin{tabular}{|c|c|c|c|c|c|}
\hline Título & autor & Ano & $\begin{array}{l}\text { tipo de } \\
\text { estudo }\end{array}$ & $\begin{array}{c}\text { nível de } \\
\text { evidência }\end{array}$ & Resultados principais \\
\hline $\begin{array}{l}\text { Neonatal } \\
\text { Pericardial } \\
\text { Effusion and } \\
\text { Tamponade } \\
\text { After Umbilical } \\
\text { Venous Catheter } \\
\text { Insertion and the } \\
\text { Use of Saline } \\
\text { Contrast Echo } \\
\text { as a Diagnostic } \\
\text { Tool. }\end{array}$ & \begin{tabular}{|l} 
Mostafa \\
Elbatreek1, \\
Nabil Bassuoni \\
Shehata 2, \\
Amani Abu- \\
Shaheen 3, \\
Abdurahman \\
Almatary
\end{tabular} & 2019 & $\begin{array}{l}\text { Relato de } \\
\text { caso }\end{array}$ & VI & $\begin{array}{l}\text { Concluímos que derrame pericárdico e } \\
\text { tamponamento deve ser considerados } \\
\text { em neonatos com cateter central que } \\
\text { desenvolvem deterioração súbita e ine- } \\
\text { xplicada. A ecocardiografia com con- } \\
\text { traste salino pode confirmar a posição } \\
\text { ideal das linhas centrais e diagnosticar } \\
\text { derrame pericárdico relacionado à in- } \\
\text { serção de UVC. }\end{array}$ \\
\hline $\begin{array}{l}\text { Advantages of } \\
\text { being diligent: } \\
\text { lessons learnt } \\
\text { from umbilical } \\
\text { venous } \\
\text { catheterisation in } \\
\text { neonates }\end{array}$ & $\begin{array}{l}\text { Thangaraj } \\
\text { Abiramalatha } \\
1 \text {, Manish } \\
\text { Kumar 1, } \\
\text { Machilakath } \\
\text { Panangandi } \\
\text { Shabeer 1, } \\
\text { Niranjan } \\
\text { Thomas } 1\end{array}$ & 2016 & $\begin{array}{l}\text { Série de } \\
\text { casos }\end{array}$ & VI & $\begin{array}{l}\text { A inserção de UVC é um procedi- } \\
\text { mento cego, realizado, na maioria dos } \\
\text { centros, por residentes juniores. O } \\
\text { comprimento da inserção geralmente é } \\
\text { decidido com base no peso ao nascer } \\
\text { ou no comprimento umbilical do om- } \\
\text { bro. Frequentemente, essa estimativa } \\
\text { está incorreta, resultando em mau po- } \\
\text { sicionamento do cateter. A ecocardio- } \\
\text { grafia foi considerada superior à radio- } \\
\text { grafia abdominal na confirmação da } \\
\text { posição da ponta do UVC em todos os } \\
\text { estudos. A sensibilidade e especificida- } \\
\text { de da radiografia eram apenas cerca de } \\
60 \% \text {, enquanto as da ecocardiografia } \\
\text { eram mais de } 90 \% \text {. Em outro estudo, } \\
\text { a ecocardiografia mostrou que a ponta } \\
\text { do UVC estava localizada na posição } \\
\text { adequada em apenas } 23 \% \text { dos casos. } \\
\text { Portanto, o consenso recente é que a } \\
\text { ecocardiografia deve ser considera- } \\
\text { da para confirmar a colocação correta } \\
\text { dos UVCs. Os fatores que contribuem } \\
\text { para a trombose são trauma mecânico } \\
\text { na parede do vaso sanguíneo ou na câ- } \\
\text { mara cardíaca, danos causados pelos } \\
\text { fluidos hipertônicos infundidos, fluxo } \\
\text { sanguíneo interrompido e materiais do } \\
\text { cateter trombogênico. O risco de for- } \\
\text { mação de trombo aumenta significati- } \\
\text { vamente com a ponta de UVC dentro } \\
\text { do coração. Isso se deve ao aumento do } \\
\text { movimento da ponta do cateter secun- } \\
\text { dário às contrações cardíacas e distúr- } \\
\text { bios do fluxo ao redor da ponta dentro } \\
\text { das câmaras cardíacas, ao contrário do } \\
\text { fluxo sanguíneo laminar na veia cava } \\
\text { superior ou VCI. }\end{array}$ \\
\hline
\end{tabular}




\begin{tabular}{|c|c|c|c|c|c|}
\hline $\begin{array}{l}\text { Pericardial } \\
\text { effusion } \\
\text { with cardiac } \\
\text { tamponade } \\
\text { caused by a } \\
\text { central venous } \\
\text { catheter in a very } \\
\text { low birth weight } \\
\text { infant. }\end{array}$ & $\begin{array}{l}\text { Fatma-Zohra } \\
\text { Chioukh 1, } \\
\text { Karim Ben } \\
\text { Ameur 1, } \\
\text { Hayet Ben } \\
\text { Hmida 1, } \\
\text { Kamel } \\
\text { Monastiri } 1\end{array}$ & 2016 & $\begin{array}{l}\text { Relato de } \\
\text { caso }\end{array}$ & VI & $\begin{array}{l}\text { O tamponamento cardíaco como com- } \\
\text { plicação do cateterismo da veia umbi- } \\
\text { lical em recém-nascidos é raro, mas } \\
\text { grave e pode ocorrer mesmo nos casos } \\
\text { em que o cateter está devidamente po- } \\
\text { sicionado. O neonatologista deve estar } \\
\text { ciente da colocação da ponta do cateter } \\
\text { e considerar a PE / TC em um recém- } \\
\text {-nascido com descompensação cardía- } \\
\text { ca súbita. A pericardiocentese imediata } \\
\text { pode remover o PE e evitar morte sú- } \\
\text { bita. }\end{array}$ \\
\hline $\begin{array}{l}\text { Cardiac } \\
\text { tamponade } \\
\text { associated } \\
\text { with umbilical } \\
\text { venous catheter } \\
\text { (UVC) placed } \\
\text { in inappropriate } \\
\text { position }\end{array}$ & $\begin{array}{l}\text { Franco } \\
\text { Gálvez- } \\
\text { Cancino 1, } \\
\text { María de la } \\
\text { Luz Sánchez- } \\
\text { Tirado }\end{array}$ & 2015 & $\begin{array}{l}\text { Relato de } \\
\text { caso }\end{array}$ & VI & $\begin{array}{l}\text { O risco-benefício do uso de CVU deve } \\
\text { ser considerada e, após sua colocação, } \\
\text { recomenda-se a melhor posição para } \\
\text { sua ponta na inserção da veia cava } \\
\text { inferior (VCI) com o átrio direito ou } \\
\text { torácico. A radiografia de tórax é es- } \\
\text { sencial para determinar a profundida- } \\
\text { de de inserção e para corroborar uma } \\
\text { inserção satisfatória a fim de minimi- } \\
\text { zar complicações. Qualquer ponta de } \\
\text { cateter colocada no átrio direito ou } \\
\text { esquerdo é associado a maiores taxas } \\
\text { de complicações. Sua patogênese pode } \\
\text { estar associada com parede cardíaca ou } \\
\text { erosão vascular devido ao contato com } \\
\text { a ponta do cateter levando à perfura- } \\
\text { ção. Outro possível mecanismo de le- } \\
\text { são da parede miocárdica é dano osmó- } \\
\text { tico causado por soluções hipertônicas } \\
\text { infundidas através da linha venosa } \\
\text { central. Taquicardia às vezes pode ser } \\
\text { o único sintoma presente, e pode até } \\
\text { causar morte súbita sem sinais e sinto- } \\
\text { mas anteriores significativos presentes. } \\
\text { O diagnóstico se deve principalmente à } \\
\text { alta suspeita, quando há colocação pré- } \\
\text { via de CVC, com cardiopatia aumento } \\
\text { de forma, juntamente com taquicardia } \\
\text { persistente ou instabilidade cardiorres- } \\
\text { piratória súbita. }\end{array}$ \\
\hline
\end{tabular}




\begin{tabular}{|c|c|c|c|c|c|}
\hline $\begin{array}{l}\text { Pericardial } \\
\text { effusion } \\
\text { associated with } \\
\text { an appropriately } \\
\text { placed umbilical } \\
\text { venous catheter. }\end{array}$ & $\begin{array}{l}\text { A Sehgal 1, V } \\
\text { Cook, M Dunn }\end{array}$ & 2007 & $\begin{array}{l}\text { Relato de } \\
\text { caso }\end{array}$ & VI & $\begin{array}{l}\text { A maioria das complicações está rela- } \\
\text { cionada ao posicionamento, portanto, a } \\
\text { confirmação da posição é importante. } \\
\text { A posição recomendada para aponta } \\
\text { de um UVC é a junção de inferior veia } \\
\text { cava (IVC) e átrio direito. O tampona- } \\
\text { mento cardíaco é uma complicação in- } \\
\text { comum, mas com risco de vida, da co- } \\
\text { locação de UVC. Este caso documenta } \\
\text { a ocorrência de PCE e tamponamento } \\
\text { cardíaco na presença de posicionamen- } \\
\text { to ideal de UVC.A etiologia proposta } \\
\text { de PCE neste cenário é variada. Os } \\
\text { possíveis mecanismos são o alojamen- } \\
\text { to da ponta contra o coração batendo, } \\
\text { punção direta pela ponta do cateter ou } \\
\text { dano osmótico endotelial causado por } \\
\text { infusados hiperosmolares e subsequen- } \\
\text { te necrose transmural. A infusão de nu- } \\
\text { trição parenteral total hipertônica pode } \\
\text { ter desempenhado um papel neste caso. }\end{array}$ \\
\hline $\begin{array}{l}\text { tamponade } \\
\text { caused by central } \\
\text { venous catheter } \\
\text { in two newborns. }\end{array}$ & $\begin{array}{l}\text { Andrey Jose; } \\
\text { Canale, } \\
\text { Leonardo } \\
\text { Secchin; } \\
\text { Barbosa, } \\
\text { Rodrigo; et al., }\end{array}$ & 2008 & $\begin{array}{l}\text { Relato de } \\
\text { caso }\end{array}$ & V1 & $\begin{array}{l}\text { senvolve, normalmente ocorre entre o } \\
3^{\circ} \text { e o } 4^{\circ} \text { dia após a inserção do cateter. } \\
\text { Em nossos casos, o evento foi diagnos- } \\
\text { ticado nos dias } 5 \text { e } 2 \text { pós-implante do } \\
\text { cateter, respectivamente. Nos dois ca- } \\
\text { sos, a suspeita inicial era de sepse. A } \\
\text { radiografia de tórax no leito tem sido } \\
\text { o método mais utilizado para certifi- } \\
\text { car a localização do cateter umbilical } \\
\text { em todo o mundo e inclusive por nós. } \\
\text { Idealmente, a ponta do cateter umbili- } \\
\text { cal deve ficar localizada na junção da } \\
\text { veia cava inferior com o átrio direito. } \\
\text { Vários estudos têm demonstrado o po- } \\
\text { sicionamento incorreto em pacientes } \\
\text { que apresentavam localização ideal no } \\
\text { exame radiológico e que foram subme- } \\
\text { tidos ao exame ecográfico. Apenas um } \\
\text { dos nossos pacientes tinha a ponta do } \\
\text { cateter em localização adequada. No } \\
\text { outro, a ponta localizava-se em artéria } \\
\text { pulmonar e não foi mobilizada. Consi- } \\
\text { deramos inadequada tal conduta e um } \\
\text { reposicionamento deveria ter sido rea- } \\
\text { lizado. }\end{array}$ \\
\hline
\end{tabular}




\section{RESULTADOS:}

\section{Características clínicas}

A descompensação cardíaca que ocorre de forma súbita também é um sinal de tamponamento cardíaco. (CHIOUKH et al., 2016). O relato de caso escrito por Chioukh et al. (2016) mostrou uma paciente que nasceu de 27 semanas, por cesariana, com 970 gramas e teve piora cardiorrespiratória após 3 dias do implante do cateter. Foi realizada pericardiocentese com retirada total de $20 \mathrm{ml}$ e a paciente foi extubada no décimo dia após o procedimento.

Nos casos reportados por Monteiro et al. (2008), dois recém- nascidos de 37 e 38 semanas, com $3.450 \mathrm{~g}$ e $3.735 \mathrm{~g}$, evoluíram com piora cardiorrespiratória depois do quinto e do segundo dia de implantação do cateter venoso umbilical, o primeiro retirou $20 \mathrm{ml}$ e o segundo um total de $60 \mathrm{ml}$ através de pericardiocentese e foram extubados no quarto e no décimo dia após o procedimento.

No caso descrito por Sehgal, Cook e Dunn (2007) o recém-nascido de 28 semanas, de gestação gemelar, com $580 \mathrm{~g}$, evoluiu com aumento inexplicável nas necessidades de oxigênio, instabilidade hemodinâmica e crises apônicas recorrentes, a pericardiocentese retirou um total de $11 \mathrm{~cm}^{3}$. É válido informar que nesse caso o recém-nascido também apresentou persistência do canal arterial.

No caso descrito por Gálvez-Cancino; Sánchez-Tirado (2015) o recém-nascido de 35 semanas, parto cesária, com $2.180 \mathrm{~g}$, retirou-se $40 \mathrm{ml}$ através de pericardiocentese guiada por ecocardiograma.

Thangaraj et al. (2016) relatam o caso de um recém-nascido com 31 semanas de gestação, com $1.400 \mathrm{~g}$, no terceiro dia após a inserção de cateter venoso umbilical o paciente evoluiu com sinais de baixa perfusão e com acidose metabólica severa. A aspiração retirou ml e a extubação aconteceu depois de dois dias. Eles também relatam o caso de uma recém-nascida com 34 semanas de gestação, com $1.500 \mathrm{~g}$, depois de 3 dias de inserção do cateter venoso umbilical ela evoluiu com sinais de má perfusão e respiração agônica.

Elbatreek et al. (2019) relata o caso de uma recém-nascida de 3 semanas, pesando $1.300 \mathrm{~g}$, com 22 horas o paciente evoluiu com taquipneia e retração do gradil costal a pericardiocentese retirou $15 \mathrm{ml}$ e depois de 22 dias a paciente recebeu alta.

\section{Possíveis causas}

A fisiopatologia do tamponamento cardíaco em neonatos ainda não está bem elucidada, porém acredita-se que o mal posicionamento do cateter seja a principal causa (SEHGAL; COOK; DUNN, 2007; ABIRAMALATHA et al., 2016; GÁLVEZ-CANCINO; SÁNCHEZ-TIRADO, 2015; MONTEIRO et al., 2008; CHIOUKH et al., 2016) . Dessa forma, recomenda-se que inserção seja realizada entre a parte inferior da veia cava (IVC) e átrio direito (SEHGAL; COOK; DUNN, 2007; GÁLVEZ-CANCINO; SÁNCHEZ-TIRADO, 2015). Todavia, a inserção do cateter é um procedimento cego, realizado, na maioria dos centros, por residentes juniores. Além disso, o comprimento da inserção 
geralmente é decidido com base no peso ao nascer ou no comprimento umbilical do ombro. Frequentemente, essa estimativa está incorreta, resultando em mau posicionamento do cateter. (ABIRAMALATHA et al., 2016). Um levantamento retrospectivo dos registros dos últimos 18 anos mostrou que, de 2.186 cateteres em 1.862 bebês, $58,6 \%$ das pontas dos cateteres estavam no átrio direito. (CARTWRIGHT et al., 2004).

Nesse contexto, o tamponamento cardíaco se tornaria além de um problema grave, algo comum, uma vez que qualquer ponta de cateter colocada no átrio direito ou esquerdo é associado a maiores taxas de complicações devido a perfurações da ponta do cateter. Ademais, outro mecanismo de lesão pode ser devido ao dano osmótico causado por soluções hipertônicas infundidas através da linha venosa central. (GÁLVEZ-CANCINO; SÁNCHEZ-TIRANO, 2015). Dessa forma, a equipe em saúde deve ficar atenta ao posicionamento e a passagem de soluções e deve acompanhar de perto o residente ou o profissional que irá realizar o procedimento.

\section{Critérios diagnósticos}

A suspeita de tamponamento cardíaco, a disponibilidade do ecocardiógrafo e a habilidade ao usá-lo pode ajudar no manejo e salvar vidas. (SEHGAL; COOK; DUNN, 2007). Se o paciente tem histórico de colocação de cateter venoso umbilical, é observado o aumento da silhueta cardíaca, taquicardia, instabilidade cardiorrespiratória persistente ou repentina, há grande chance e deve haver grande suspeita de tamponamento cardíaco. (GÁLVEZ-CANCINO; SÁNCHEZ-TIRANO, 2015).

Portanto, uma boa forma de prevenir o acontecimento de tamponamento cardíaco é fazer ecocardiografias em intervalos regulares durante o tempo que o paciente continuar com o cateter venoso umbilical, garantindo que ele está na posição correta e diagnosticando precocemente complicações correlacionadas ao cateter. (THANGARAJ et al., 2016). Outro modo de diagnosticar precocemente e de modo eficaz para estabelecer rapidamente um tratamento é o uso de contraste salino na ecocardiografia. (ELBATREEK et al, 2019).

\section{CONCLUSÃO}

A possível explicação para o aparecimento do tamponamento cardíaco foi o contato direto da ponta do cateter no momento do acesso ou posteriormente por migração ou necrose da parede causada por infusão de solução hiperosmolar. Portanto, o cateter deve ser posicionado sem ter contato com os átrios e monitorado constantemente pela ecocardiografia. Além disso, em todo recém-nascido, principalmente prematuro, com acesso venoso que apresentar um quadro de alterações cardiorrespiratórias e hemodinâmicas súbitas inexplicáveis, deve ser investigado. Ademais, as alterações podem ocorrer a qualquer momento, contudo, foi mais relatado entre o primeiro e o quinto dia de posteriormente a colocação do cateter. 


\section{REFERÊNCIAS:}

ABIRAMALATHA, Thangaraj et al. Advantages of being diligent: lessons learnt from umbilical venous catheterisation in neonates. Case Reports, v. 2016, p. bcr2015214073, 2016.

CARTWRIGHT, DW Linhas venosas centrais em neonatos: um estudo de 2.186 cateteres. Archives of Disease in Childhood-Fetal and Neonatal Edition, v. 89, n. 6, pág. F504-F508, 2004.

CHIOUKH, Fatma-Zohra et al. Pericardial effusion with cardiac tamponade caused by a central venous catheter in a very low birth weight infant. Pan African Medical Journal, [S.L.], v. 25, p. 13-25, 2016. Pan African Medical Journal. http://dx.doi.org/10.11604/pamj.2016.25.13.8731.

ELBATREEK, Mostafa; SHEHATA, Nabil Bassuoni; ABU-SHAHEEN, Amani; ALMATARY, Abdurahman. Neonatal Pericardial Effusion and Tamponade After Umbilical Venous Catheter Insertion and the Use of Saline Contrast Echo as a Diagnostic Tool. American Journal Of Case Reports, [S.L.], v. 20, p. 1382-1386, 19 set. 2019. International Scientific Information, Inc. http://dx.doi.org/10.12659/ajcr.917723.

GÁLVEZ-CANCINO, F; Sánchez-Tirado, ML. Tamponamento cardíaco associado a cateter venoso umbilical (UVC) colocado em posição inadequada. Gac Med Mex, v. 3, n. 151, p. 396-398, 2015.

MELNYK BM, Fineout-Overholt E. Making the case for evidence-based practice.In: Melnyk BM, Fineout-Overholt E. Evidence-based practice in nursing \& healthcare. A guide to best practice. Philadelphia: Lippincot Williams \& Wilkins; 2005.p.3-24.

MONTEIRO, Andrey José et al. Tamponamento cardíaco em dois recém-nascidos causado por cateter umbilical. Rev Bras Cir Cardiovasc, São José do Rio Preto, v. 23, n. 3, p. 422-424, Sept. 2008 . Available from $<$ http://www.scielo.br/scielo.php?script=sci_arttext\&pid=S0102-76382008000300023\&lng=en\&nrm=iso $>$. access on 17 Oct. 2020. http://dx.doi.org/10.1590/S0102-76382008000300023.

SEHGAL, A; COOK, V; DUNN, M. Pericardial effusion associated with an appropriately placed umbilical venous catheter. Journal Of Perinatology, [S.L.], v. 27, n. 5, p. 317-319, 24 abr. 2007. Springer Science and Business Media LLC. http://dx.doi.org/10.1038/sj.jp.7211678.

SOUZA, Marcela Tavares de; SILVA, Michelly Dias da; CARVALHO, Rachel de. Revisão integrativa: o que é e como fazer. Einstein (São Paulo), São Paulo, v. 8, n. 1, p. 102-106, Mar. 2010. Available from <http:// www.scielo.br/scielo.php?script=sci_arttext\&pid=S1679-45082010000100102\&lng=en\&nrm=iso $>. \quad$ access on 14 Oct. 2020. https://doi.org/10.1590/s1679-45082010rw1134.

THANGARAJ, Abiramalatha; KUMAR, Manish; SHABEER, Machilakath Panangandi; THOMAS, Niranjan. Vantagens de ser diligente: lições aprendidas com o cateterismo venoso umbilical em neonatos. Bmj Case Reports, fev. 2016. Available from < https://www.researchgate.net/publication/298715246_Advantages_of_being_diligent_Lessons_learnt_from_umbilical_venous_catheterisation_in_neonates $>$. access on 17 Oct. 2020 . 


\section{CAPÍTULO 46}

\section{AVANÇOS NA ATENÇÃO BÁSICA ATRAVÉS DA IMPLEMENTAÇÃO DO E-SUS: UM RELATO DE EXPERIÊNCIA}

CAMILA BARBOSA CARVALHO DE AMORIM

Acadêmicas de Enfermagem da Faculdade de Ciências Aplicadas de Limoeiro- FACAL

ANA CAROLINA DA SILVA OLIVEIRA Acadêmicas de Enfermagem da Faculdade de Ciências Aplicadas de Limoeiro- FACAL

\section{RAFAELA ANDRADE DOS SANTOS}

PIMENTEL

Acadêmicas de Enfermagem da Faculdade de Ciências Aplicadas de Limoeiro- FACAL

EDVÂNIA JOSÉ DA SILVA Acadêmicas de Enfermagem da Faculdade de Ciências Aplicadas de Limoeiro- FACAL

\section{LEILA KARINA DE AMORIM PONTES}

Acadêmicas de Enfermagem da Faculdade de Ciências Aplicadas de Limoeiro- FACAL

RAIANA FERNANDA DA SILVA SANTOS Enfermeira, Mestre em Engenharia Biomédica pela Universidade Federal de Pernambuco (UFPE)

RESUMO: A tecnologia nos serviços de saúde traz consigo benefícios que visam a melhoria diária no processo de trabalho. $\mathrm{O}$ e- SUS é uma formação de ações do Ministério da Saúde para melhorar a gestão da informação na Atenção Básica (AB) por meio da informatização do Sistema Único de Saúde (SUS), essas informações são centralizadas ao paciente e mostram dados coletados dos mesmos. A estratégia do e- SUS AB estabelecida em 2013, tem como proposta apresentar um novo conceito do Sistema de In- formação em Saúde (SIS), com a finalidade de melhorar e possibilitar informações coletadas para prestar um atendimento de boa qualidade ao cidadão, proporcionando também obter uma análise sistemática dos dados para o planejamento estratégico de ações de acordo com a necessidade. No entanto, para implantação desse sistema é necessário estruturação nas Unidades Básicas de Saúde (UBS), principalmente com recursos tecnológicos como computadores e internet, além da adoção pelas equipes de saúde da família na migração de dados para o sistema, que antes acontecia de forma manual através do Sistema de Informação de Atenção Básica (SIAB). O trabalho trata-se de um relato de experiência sobre o processo de implementação do e- SUS numa Unidade de Saúde da Família (USF) no município de Limoeiro - PE, apontando os benefícios e as dificuldades do sistema encontrados pela equipe. Concluiu-se que a implementação do e-Sus contribuiu positivamente no processo de trabalho dos profissionais da atenção básica, principalmente no que se refere a facilidade de acesso às informações das famílias acompanhadas pela unidade, embora houvesse alguns desafios durante sua implantação.

PALAVRA-CHAVE: Tecnologia em Saúde. Atenção Básica. e- SUS.

ABSTRACT: The technology in the health services brings with it benefits that aim at the daily improvement in the work process. The e-SUS is a formation of actions by the Ministry of Health to improve the management of information in Primary Care (PC) through the computerization of the Unified Health System (SUS), this information is centralized to the patient and shows data collected from them. E-SUS AB's strategy should be in 2013, its proposal is to present a new concept of the Health Information System (HIS), 
with the improvement of improving and enabling information collected to provide good quality care to citizens, also providing obtain a systematic analysis of the data for strategic planning of actions according to the need. However, in order to implement this system, it is necessary to structure the Basic Health Units (BHU), mainly with technological resources such as computers and the internet, in addition to the adoption by family health teams in the migration of data to the system, which previously happened in a Manual through the Primary Care Information System (PCIS). The work is an experience report on the process of implementing e-SUS in a Family Health Unit (FHU) in the city of Limoeiro - PE, locating the benefits and difficulties of the system found by the team. It was concluded that the implementation of e-Sus contributed positively to the work process of primary care professionals, mainly the ease of access to information from families monitored by the unit was not mentioned, although there were some challenges during its implementation.

KEYWORDS: Health Technology. Primary Care. e- SUS.

\section{INTRODUÇÃO}

O uso da tecnologia nos serviços de saúde contribui significativamente no planejamento responsável de qualidade, resolubilidade e humanização no cuidado. No mundo globalizado, cenário atual em que vivemos, a informação e a comunicação são bases para as atividades de saúde objetivando a resolução de problemas e articulação entre os diferentes órgãos (SAMPAIO, 2017).

O Sistema de Informação em Saúde (SIS) é usado como ferramenta para o monitoramento e coleta de dados, tendo como base a Atenção Primária à Saúde a fim de fortalecer as informações para análise e compreensão de importantes problemas de saúde da população (BVS, 2008; SAMPAIO, 2017). Para isso, foi implantada a estratégia e-SUS AB, formada pelo Sistema de Informação em Saúde para Atenção Básica (SISAB) e pólo e-SUS AB. (BRASIL, 2017; SAMPAIO, 2017).

A proposta do e- SUS é usar a tecnologia para facilitar o trabalho das equipes nas Unidades Básicas de Saúde (UBS) e ofertar um atendimento qualificado ao cidadão. Seu sistema evita a necessidade de usar programas diferentes disponibilizando maior integração das informações. Destarte, os profissionais podem ter maior concentração no atendimento ao paciente aumentando sua produtividade (BRASIL, 2017).

Desta forma, o estudo tem como objetivo relatar a experiência vivida pelas autoras na implementação do e-SUS AB, abordando os avanços e dificuldades de sua implantação no desenvolvimento das atividades diárias numa USF.

\section{FUNDAMENTAÇÃO TEÓRICA}

A tecnologia quando usada no âmbito da saúde, por meio de uma abordagem psicossociológica, permite conhecer os modos de cuidar (ARONE \& CUNHA, 2006; SILVA E FERREIRA 2009). Esta ferramenta, quando usada em serviços de saúde faz parte dos programas de assistência 
e traz consigo benefícios que visam prevenção, tratamento e cuidado com a saúde (BRASIL 2010; SANTOS, 2016). O uso dessas tecnologias é amplo e proporciona melhoria na qualidade de vida dos usuários (SILVA \& FERREIRA, 2009).

Nos últimos anos a saúde pública tem avançando na área da tecnologia, para um melhor controle no atendimento e na qualidade do serviço (SILVA E FERREIRA 2009; TRINDADE, 2013). Recursos tecnológicos como a internet móvel ajudam na coleta e qualificações dos dados, diminuindo custos e proporcionando maior sustentabilidade aos processos do setor (LORENZETTI et al, 2012).

A portaria 1.412 de 10 de julho de 2013, do Ministério da Saúde, criou o Sistema de Informação em Saúde para Atenção Básica (SISAB), com o objetivo de melhorar a gestão da informação, a automação dos processos, a melhoria das condições de infraestrutura e a melhoria dos processos de trabalho. É considerado o sistema de informação da Atenção Básica para fins de financiamento e de adesão aos programas e estratégias da Política Nacional de Atenção Básica (BRASIL, 2013).

A operacionalização do SISAB é realizada por meio da estratégia do Departamento de Atenção Básica (DAB/SAS/MS) denominada e-SUS Atenção Básica (e-SUS AB). O e- SUS é um sistema composto por um software, onde facilita o processo de trabalho das Unidades de Saúde da Família da Atenção Básica (USF`s AB), contribuindo para o bom funcionamento da coleta de dados dos profissionais (CONASS, 2013; BRASIL, 2019).

\footnotetext{
"Com o uso do e- SUS AB torna-se possível o monitoramento contínuo da utilização do sistema, com base na análise sistemática dos dados estatísticos e numéricos consolidados mensalmente, o que traz subsídios para que se tenha dados que subsidiem análises situacionais fundamentais para o planejamento estratégico de ações pontuais". (CABRAL et al p. 1-4, 2015).
}

O e- SUS AB objetiva ampliar as informações com a modernização da sua plataforma, proporcionando ferramentas e aprimorando o acompanhamento da gestão. Para usa implantação, o Ministério da Saúde utiliza como recurso o programa Requalifica UBS a fim de adequar estrutura e equipamentos nas unidades, principalmente com computadores e internet. Vale ressaltar que o e-SUS AB se adequa a especificidade de cada região, mesmo com pouco recurso de informática (BRASIL, 2014).

No entanto, o grande desafio para implantação do e-SUS AB é a migração de dados do Sistema de Informação de Atenção Básica (SIAB), informações contidas de forma manual, para o SISAB. A transição das informações requer incialmente estruturação das UBS para receber essa tecnologia e a adoção do sistema pelas equipes de Saúde da Família (BRASIL, 2014).

\section{PROCESSOS METODOLÓGICOS}

Trata-se de um estudo descritivo na forma de relato de experiência. Para este fim, foram analisados e discutidos artigos e publicações de materiais relacionados ao tema a fim de auxiliar na descrição do processo de implantação do e- SUS numa USF do município de Limoeiro em Pernambuco. A 
USF possui uma equipe composta por 15 profissionais divididos nas categorias médica, enfermagem, saúde bucal e agentes comunitários de saúde. A implementação do sistema teve início em 2015, e aponta as qualidades, avanços e dificuldades na utilização do sistema.

\section{DESCRIÇÃO E DISCUSSÃO DA EXPERIÊNCIA}

Antes de ser implantado o e- SUS no município, os profissionais utilizavam o Sistema de Informação de Atenção Básica (SIAB) como ferramenta para registro dos procedimentos realizados. O SIAB era escrito num papel e mensalmente encaminhado à Secretaria Municipal de Saúde para digitação dos dados.

Em 2015 foi implantado no município de Limoeiro o Sistema de Informação em Saúde para Atenção Básica (SISAB), um software que contém duas versões do e- SUS AB: Prontuário Eletrônico do Cidadão (PEC) e a Coleta de Dados simplificados (CDS). Para isso, foram ofertadas capacitações e treinamentos durante uma semana para as equipes que compõem as USF como médicos, enfermeiros, tec. de enfermagem, agente comunitário de saúde (ACS), dentista, auxiliar de saúde bucal (ASB).

Posteriormente, a equipe recebeu treinamentos a fim de capacitar os envolvidos a utilizar o sistema do e-SUS no computador. Meses depois, uma nova capacitação foi realizada, dessa vez apenas para as ACS, com o intuito de transferirem as informações das fichas cadastrais das famílias cobertas pela USF para o sistema.

Quatro anos depois, a USF foi contemplada com tabletes, proporcionando facilidade e praticidade no trabalho dos profissionais, uma vez que o uso do papel foi posto em desuso e as informações compiladas diretamente no sistema.

A implementação do sistema também trouxe outros benefícios como a praticidade na coleta de informações do cliente, facilidade no levantamento de dados epidemiológicos, otimização do tempo do serviço prestado, facilidade na comunicação entre profissionais e gestores.

Com o uso do sistema, foi possível detectar o quantitativo de determinadas patologias (obesos, hipertensos, diabéticos, tuberculose, hanseníase, sintomáticos respiratórios, usuário de drogas, tabagista, usuário de álcool, acamados, domiciliados, deficientes, saúde mental), gestantes, crianças, recém-nascidos, idosos, números de pacientes, bolsa família, quantidade de famílias de cada ACS. 
Figura 1 - e-SUS AB Território

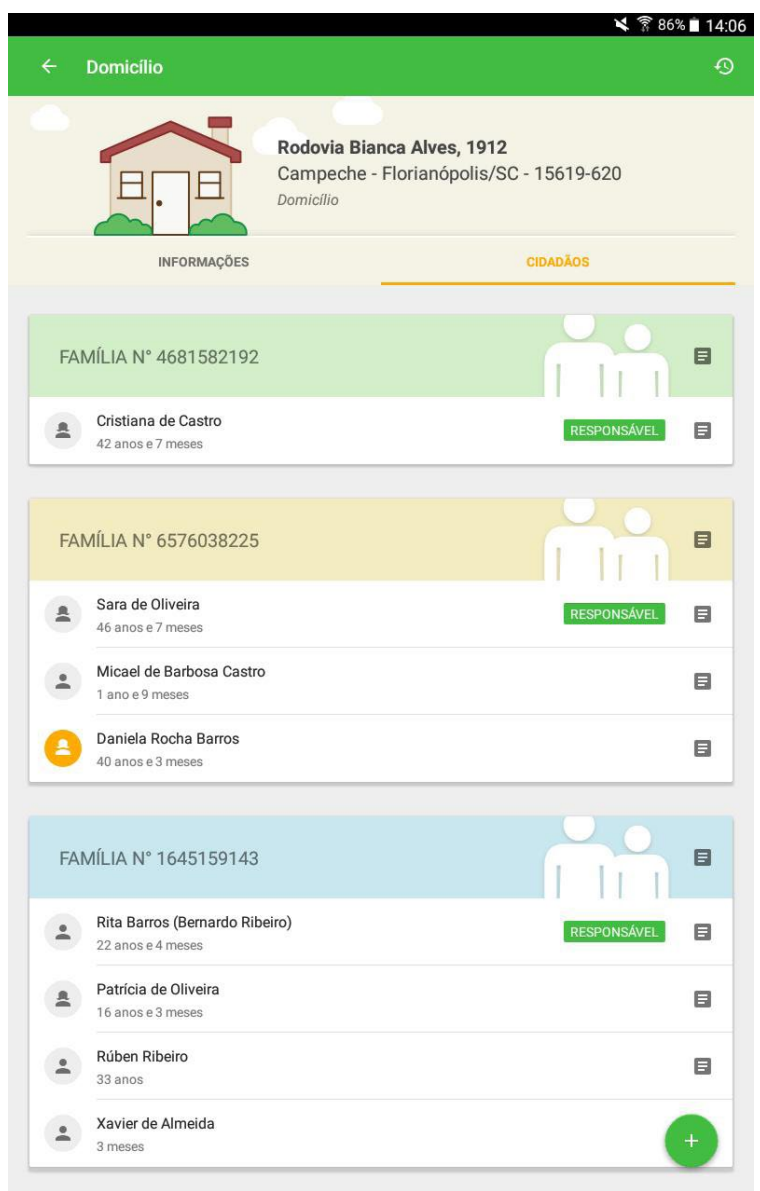

Fonte: DATASUS, 2016.

Figura 1 - e-SUS AB Território

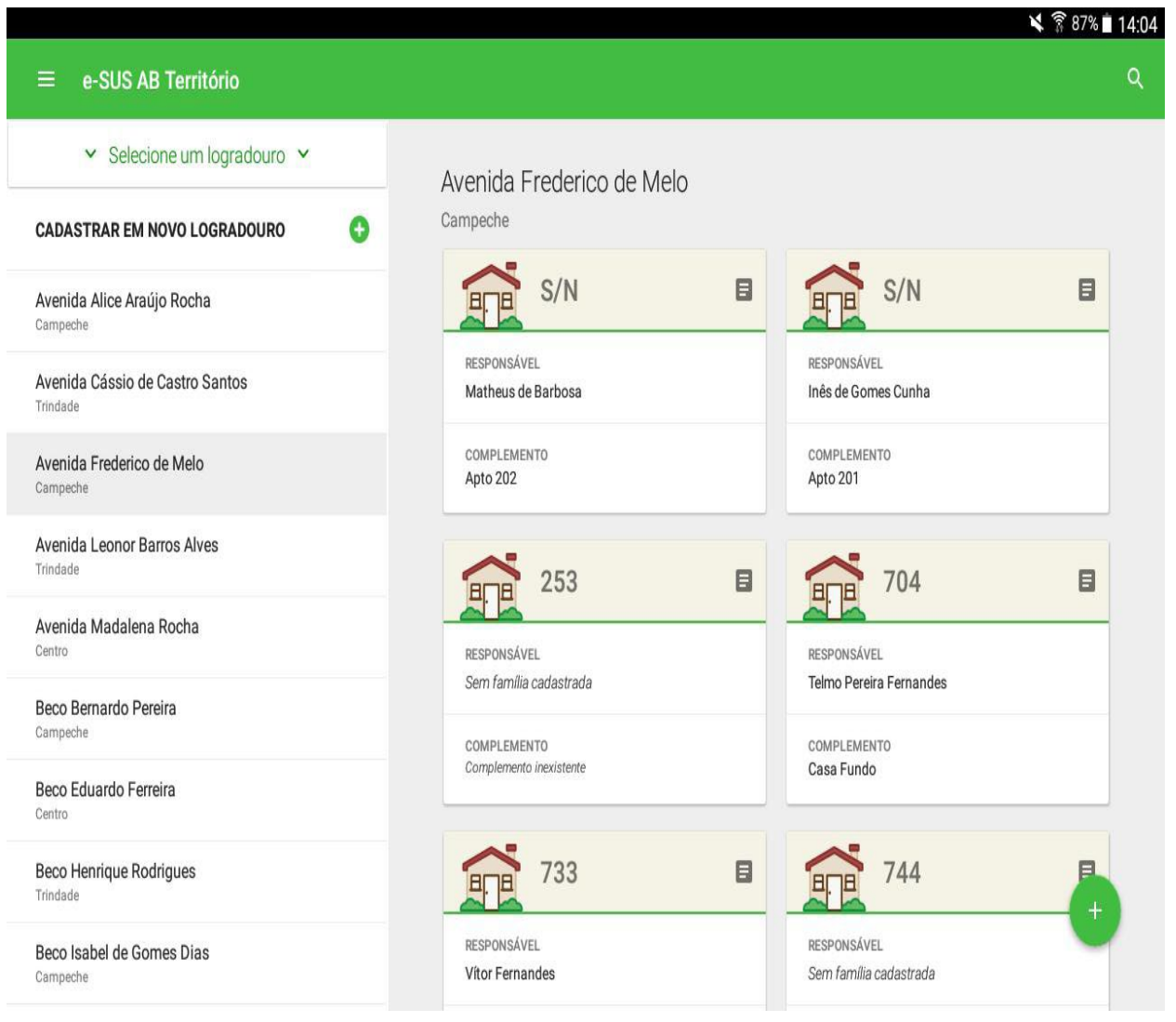

Fonte: DATASUS, 2016. 
No entanto, observou-se algumas dificuldades no uso e implementação desse sistema, como dificuldades de adaptação, falha do sistema, digitação, sobrecarga de trabalho para transcrição das fichas e dificuldade na compreensão e execução do sistema relacionados a falta de interação e limitações no uso de tecnologias.

\section{CONSIDERAÇÕES FINAIS}

O uso de tecnologias nos serviços de saúde torna-se cada vez mais necessário. Tais instrumentos colaboram na construção do conhecimento com a proposta de facilitar o processo de trabalho diário e viabilizar o entendimento e aplicação de uma ação de acordo com as necessidades encontradas.

A implementação do e-Sus viabiliza o trabalho dos profissionais da atenção básica por proporcionar simplicidade na coleta dos dados, obter controle no atendimento, fundamentar informações para tomadas de decisões estratégicas e individualização dos dados dos usuários além de poder integrar os sistemas de informações presentes na AB.

No entanto, alguns desafios são encontrados no que diz respeito a necessidade do aprimoramento do conhecimento sobre a implantação e- SUS AB para evitar erros que prejudiquem a atualização e manutenção do sistema. É fundamental que o profissional desenvolva competência necessária para viabilizar o uso do sistema e assim contribuir na atuação interdisciplinar que o ambiente proporciona.

\section{REFERÊNCIAS BIBLIOGRÁFICAS}

ARONE, E.M., CUNHA, I.C.K.O. Avaliação tecnológica como competência do enfermeiro: reflexões e pressupostos no cenário da ciência e tecnologia. Rev Bras Enferm. 2006 jul-ago; 59(4): 569-72.

BIBLIOTECA VIRTUAL EM SAÚDE. Informações Estratégicas. 2008. Disponível em: <http://bvsms.saude. gov.br/bvs/svs/inf_sist_informacao.php>. Acesso em: 15 de set. de 2019.

BRASIL. Ministério da Saúde. Secretaria de Ciência, Tecnologia e Insumos Estratégicos. Política Nacional de Gestão de Tecnologias em Saúde. Brasília: Ministério da Saúde, 2010.

BRASIL. Ministério da Saúde. Portaria n 1.412, de 10 de julho de 2013. Institui o Sistema de Informação em Saúde para a Atenção Básica (SISAB).Brasília, 2013.

BRASIL. Ministério da Saúde. Secretaria de Atenção à Saúde. Departamento de Atenção Básica. E-SUS Atenção Básica: manual de implantação. Ministério da Saúde, Secretaria de Atenção à Saúde, Departamento de Atenção Básica. - Brasília: Ministério da Saúde, 2014.

BRASIL. Ministério da Saúde. Secretaria de Atenção à Saúde. e-SUS Atenção Básica: Manual de Uso do Aplicativo e-SUS AB Território - Versão 2.2. Ministério da Saúde, Secretaria de Atenção à Saúde, Departamento de Atenção Básica. - Brasília: Ministério da Saúde, 2017. 
BRASIL. Departamento de Informática do SUS. e-SUS AB. Brasília, 2019. Disponível em: <http://datasus. saude.gov.br/projetos/50-e-sus>. Acesso em: 15 de set. de 2019

CABRAL, S.S.A. et al. A utilização do e-sus atenção básica (ab) no processo de fortalecimento da efetivação dos princípios doutrinários do SUS. INTENSA (Pombal - PB - Brasil) v.9, n. 1, p. 01-04, 2015.

CONASS. Estratégia e-SUS Atenção Básica Sistema de Informação em Saúde da Atenção Básica - SISAB. Brasília, 19 de abril de 2013. Disponível em: <https://www.conass.org.br/biblioteca/wp-content/uploads/2013/01/ NT-07-2013-e-SUS-e-SISAB.pdf $>$. Acesso em: 16 de set. de 2019

LORENZETTI, J. TRINDADE, L.L., PIRES, D.E.P., RAMOS, F.R.S. Tecnologia, inovação tecnológica e saúde: uma reflexão necessária. Texto Contexto Enferm, Florianópolis, 2012 Abr-Jun; 21(2): 432-9.

SAMPAIO, C.S.J.C. Otimização do e-SUS para profissionais da Atenção Primária à Saúde. Escola de Enfermagem de Ribeirão Preto - SP, 2017.

SANTOS, Z.M.S.A. Tecnologias em saúde: da abordagem teórica a construção e aplicação no cenário do cuidado [livro eletrônico] / Zélia Maria de Sousa Araújo Santos, Mirna Albuquerque Frota, Aline Barbosa Teixeira Martins. - Fortaleza: EdUECE, 2016.

SILVA, R.C., FERREIRA, M.A. A tecnologia em saúde: uma perspectiva psicossociológica aplicada ao cuidado de enfermagem. Esc Anna Nery Rev Enferm 2009 jan-mar; 13 (1): 169-173.

TRINDADE, E. A incorporação de novas tecnologias nos serviços de saúde: o desafio da análise dos fatores em jogo. Cad. Saúde Pública, Rio de Janeiro, 24(5):951-964, mai, 2008. 


\title{
O ESTADO NUTRICIONAL E OS PRINCIPAIS FATORES DE RISCO PARA O DESENVOLVIMENTO DE DOENÇAS CRÔNICAS NÃO TRANSMISSÍVEIS (DCNTs) ENTRE ESTUDANTES
}

\author{
THE NUTRITIONAL STATE AND THE MAIN RISK FACTORS FOR THE \\ DEVELOPMENT OF CHRONIC NON-TRANSMISSIBLE DISEASES (NCDS) \\ AMONG STUDENTS
}

LEIDIAN COELHO DE FREITAS

Instituto Federal de Ciência, Educação e Tecnologia do Pará - Campus Rural Marabá

(IFPA/CRMB)

BRUNO LIMA FREITAS

Instituto Federal de Ciência, Educação e Tecnologia do Pará - Campus Rural Marabá

(IFPA/CRMB)

CÉLIA DA SILVA NUNES

Instituto Federal de Ciência, Educação e Tecnologia do Pará - Campus Rural Marabá

(IFPA/CRMB)

DEUSANETE PINTO MACHADO

Instituto Federal de Ciência, Educação e Tecnologia do Pará - Campus Rural Marabá

(IFPA/CRMB)

MARIA DA PAZ DEMES GONÇALVES

Instituto Federal de Ciência, Educação e Tecnologia do Pará - Campus Rural Marabá

(IFPA/CRMB)

GRAZIELLA NUNES DE OLIVEIRA

Instituto Federal de Ciência, Educação e Tecnologia do Pará - Campus Rural Marabá

(IFPA/CRMB)

PAULA GRAZIELA PRATES COSTA

Instituto Federal de Ciência, Educação e Tecnologia do Pará - Campus Rural Marabá

(IFPA/CRMB)

DENISE SILVA OLIVEIRA

Instituto Federal de Ciência, Educação e Tecnologia do Pará - Campus Rural Marabá

(IFPA/CRMB)
RESUMO: A pesquisa objetivou avaliar o estado nutricional e fatores de risco para Doenças Crônicas Não Transmissíveis (DNCTs) entre alunos do IFPA/CRMB. Trata-se de um estudo descritivo com delineamento transversal. A amostra foi composta por 92 alunos. A pesquisa foi desenvolvida no período de Janeiro/2019 a Janeiro/2020. A coleta foi realizada por meio de um formulário semiestruturado com os alunos, contendo informações sócio demográficas, aspectos clínicos, medidas antropométricas, situação de saúde autorreferida, histórico familiar e pessoal, e estilo de vida. A faixa etária variou de 16 a 42 anos, sendo 68,48\% adolescentes. Deste público $68,5 \%$ são do sexo masculino. A maioria dos alunos estão com o estado nutricional adequado. Quanto ao estilo de vida, observou-se que a pratica de atividade física é de $59,3 \%$ e a atividade física mais praticadas são: corrida, voleibol, futebol e caminhada. Quanto ao consumo de álcool 31,5\% consumiam e $6,5 \%$ consumiam tabaco. Verificou-se que os principais fatores de risco que estiveram presentes na maioria da população do estudo foram: um consumo elevado de energia proveniente de alimentos gordurosos (carnes e leite), temperos industrializados e baixa ingestão de legumes, verduras e água, contribuindo para o desenvolvimento de DCNT. Deve-se promover educação em saúde, enfatizando uma melhor qualidade de vida, esperando contribuir com o conhecimento da comunidade e melhoria dos serviços prestados, na promoção de práticas alimentares saudáveis na prevenção ou minimização de DCNT, no sentido de fortalecer a importância de mudanças no comportamento alimentar e estilo de vida.

PALAVRA-CHAVE: Doenças crônicas. Fatores de risco. Estado nutricional. 


\begin{abstract}
The research aimed to assess the nutritional status and risk factors for Chronic Noncommunicable Diseases (DNCTs) among IFPA / CRMB students. This is a descriptive study with a cross-sectional design. The sample consisted of 92 students. The research was carried out from January / 2019 to January / 2020. Data collection was performed using a semi-structured form with students, containing socio-demographic information, clinical aspects, anthropometric measures, self-reported health status, family and personal history, and lifestyle. The age range ranged from 16 to 42 years, with $68.48 \%$ being adolescents. Of this audience, $68.5 \%$ are male. Most students are in adequate nutritional status. As for the lifestyle, it was observed that the practice of physical activity is $59.3 \%$ and the most practiced physical activity are: running, volleyball, football and walking. Regarding alcohol consumption, $31.5 \%$ consumed and $6.5 \%$ consumed tobacco. It was found that the main risk factors that were present in the majority of the study population were: a high consumption of energy from fatty foods (meat and milk), industrialized spices and low intake of vegetables, vegetables and water, contributing to the development of NCDs. Health education should be promoted, emphasizing a better quality of life, hoping to contribute to the knowledge of the community and improvement of the services provided, in the promotion of healthy eating practices in the prevention or minimization of NCDs, in order to strengthen the importance of changes in the eating behavior and lifestyle.
\end{abstract}

KEYWORDS: Chronic diseases. Risk factors. Nutritional status.

\title{
1. INTRODUÇÃO
}

O grupo das Doenças Crônicas Não Transmissíveis (DCNT) compreende majoritariamente doenças cardiovasculares, hipertensão arterial, diabetes, obesidade, dislipidemias, doenças respiratórias crônicas e câncer, a maioria dessas doenças têm fatores de risco comuns, e demandam por assistência continuada de serviços e ônus progressivo (BRASIL, 2019).

As DCNT configuram como as principais causas de mortalidade no Brasil, sendo responsáveis por $74 \%$ do total de óbitos no ano de 2016. Essas doenças são multifatorial e alta prevalência no Brasil (BRASIL, 2020).

A vida moderna alterou bastante os hábitos alimentares da população, levando a uma tendência denominada de transição nutricional, que se refere à substituição de uma dieta adequada por uma mais prática, porém, bem menos saudável. Esta última dieta destaca-se pela elevação no consumo de energia proveniente de carnes, leite e derivados (repletos de gorduras), bem como a diminuição do consumo de alimentos de origem vegetal. Além destas modificações bruscas nos hábitos alimentares, ocorreu ainda, uma expressiva diminuição na prática de atividades físicas, que juntos levam ao aumento da incidência das DCNT (ADRIAANSE et al, 2011).

Os hábitos alimentares apresentam-se como marcadores de risco para as DCNT, especificamente as doenças cardiovasculares, na medida em que o consumo elevado de colesterol, lipídios e ácidos graxos saturados somados ao baixo consumo de fibras, participam na etiologia das dislipidemias, obesidade, diabetes e hipertensão (CASTRO et al., 2004).

Objetivou-se avaliar o estado nutricional e identificar os principais fatores de risco para o desenvolvimento de DCNT em alunos do Instituto Federal de Ciência, Educação e Tecnologia do Pará - Campus Rural Marabá (IFPA/CRMB). 


\section{METODOLOGIA}

Trata-se de um estudo descritivo com delineamento transversal. A pesquisa foi desenvolvida no Departamento de Assistência e Saúde da Comunidade Acadêmica (DASCA), que presta atendimento ambulatorial à comunidade acadêmica do IFPA/CRMB. O atendimento nutricional ocorreu por encaminhamento ou demanda espontânea. Os dados da pesquisa foram coletados a partir do atendimento nutricional pela nutricionista do departamento.

O IFPA/CRMB é uma instituição de Educação Profissional e Tecnológica voltada para formação de profissionais do nível médio técnico e superior, especialmente para os Povos do Campo (agricultores, quilombolas e indígenas).

A população de estudo refere-se aos alunos do IFPA/CRMB. Esses alunos realizam o curso em ciclos, que é oferecido em regime de alternância pedagógica, composto por tempos e espaços formativos na escola (TE) e na comunidade (TC). O TE funciona em regime de internato, em que os estudantes permanecem por cerca de 30 dias na escola (estudando em período integral) e aproximadamente 30 dias nos lotes (comunidade). No TE os alunos são atendidos com cinco refeições regulares, fornecidas por um restaurante terceirizado. Adicionalmente, entre as refeições, os alunos consomem outros alimentos por conta própria.

Os alunos do IFPA/CRMB são na maioria adolescentes, agricultores familiares, agroextrativistas, pescadores artesanais e trabalhadores rurais assalariados sindicalizados. Os mesmos são provenientes da mesorregião sudeste paraense (BRASIL, 2010), apresentam diversificação de hábitos alimentares entre localidades, seja pelo processo cultural, pelas atividades econômicas ou pelo processo social e ambiental.

A amostra foi composta por 92 alunos. A pesquisa foi desenvolvida no período de Janeiro/2019 a Janeiro/2020. A coleta foi realizada por meio de formulário semiestruturado com os alunos, contendo informações sócio demográficas, aspectos clínicos, medidas antropométricas, situação de saúde autorreferida, histórico familiar e pessoal, e estilo de vida.

Inicialmente foi aplicado ao aluno um questionário contendo informações: sócio demográficas como: idade, sexo; aspectos clínicos como: situação de saúde autorreferida, antecedentes mórbidos pessoais e familiares.

Foram coletados dados antropométricos como: peso corporal e estatura. O estado nutricional foi avaliado utilizando-se o índice de massa corporal (IMC) isolado para adultos e associado a idade para adolescentes.

O IMC foi calculado por meio da razão do peso corporal e o quadrado da altura. Os pontos de cortes de IMC considerados para o diagnóstico nutricional foram preconizados pela Organização Mundial da Saúde, de acordo com a faixa etária (WHO, 1995; WHO, 2007).

Foram também recolhidas as informações sobre os aspectos sociais como: hábitos alimentares, atividade física, etilismo e tabagismo. 
Após a coleta de dados foi realizada a orientação alimentar e nutricional, com entrega de materiais educativos e agendado o retorno para acompanhamento do aluno.

\section{RESULTADOS}

Participaram da avaliação 92 alunos do IFPA/CRMB. A faixa etária da população variou de 16 a 42 anos, sendo a maioria 68,48\% adolescentes. Deste público 68,5\% do sexo masculino e 31,5\% do sexo feminino.

Quanto a situação de saúde autorreferida, antecedentes mórbidos pessoais e familiares a Tabela 1 , descreve a situação.

Tabela 1. Frequência do Estilo de Vida autorreferida dos alunos atendidos no setor de nutrição do DASCA do IFPA/CRMB segundo os antecedentes mórbidos pessoais e familiares, Marabá 2020.

\begin{tabular}{|l|l|l|}
\hline Doenças & Alunos & Familiares \\
\hline Hipertensão & $3 \%$ & $22 \%$ \\
\hline Diabetes & $3 \%$ & $24 \%$ \\
\hline Doença digestiva crônica & $3 \%$ & $4 \%$ \\
\hline Doenças do coração & $3 \%$ & $3 \%$ \\
\hline Dislipidemias & - & $3 \%$ \\
\hline Osteoporose & - & $2 \%$ \\
\hline Câncer & - & $2 \%$ \\
\hline Doença renal crônica & $1 \%$ & $1 \%$ \\
\hline Artrite, artrose e/ou reumatismo & - & $1 \%$ \\
\hline Doença crônica do pulmão & - & $1 \%$ \\
\hline
\end{tabular}

Fonte: Protocolo de Pesquisa do Setor de Nutrição do Campus Rural de Marabá, 2019/2020.

Quanto ao estado nutricional dos alunos adolescentes, segundo a estatura para idade: $74,6 \%$ estava adequada; $17,5 \%$ baixa e 7,9\% muito baixa. A classificação do estado nutricional segundo o IMC de acordo com a faixa etária 1,1\% desnutrição; $81,5 \%$ adequado; $16,3 \%$ sobrepeso e 1,1\% obesidade.

A frequência do estilo de vida quanto aos hábitos alimentares, verificou-se que 97,8\%, consumiam carnes com gordura, 85,6\% leite integral, 20,3\% legumes e verduras pelo menos uma vez na semana. A frequência usual do modo de preparo das refeições, observamos: 7,61\% não sabe, 42,39\% fritura, 1,09\% assado, 4,35\% grelhado e 44,56\% cozido. Os tipos de gorduras utilizados são: $88,04 \%$ óleo de soja, $6,52 \%$ banha, $5,44 \%$ outros vegetais. 
Os temperos utilizados pelos alunos são: vegetais, cebola, alho, tomate, pimentão, pimenta-de-cheiro, cheiro-verde, coentro, cebolinha, pimenta, pimenta-do-reino, cominho, colorau, açafrão, orégano, tempero completo, arisco, sazon, caldo de galinha, caldo de carne, extrato de tomate, molho inglês, azeite de oliva, óleo e sal.

Quando questionados sobre a ingestão de água somente 40,22\% ingere o recomendado.

A prevalência na pratica de atividade física é de 59,3\%. As atividades mais praticadas são: corrida, voleibol, futebol e caminhada.

A frequência do estilo de vida quanto ao consumo de bebidas alcoólicas: 31,5\% fazem uso de bebida alcoólica. Já quanto ao uso de tabagismo foi 6,5\% de fumantes e 27,2\% de fumantes passivo.

Com base nos itens analisados nesse estudo, verificou-se que os fatores de riscos que tiveram presentes na maioria da população do estudo foram: elevação no consumo de energia proveniente de alimentos gordurosos (carnes e leite), temperos industrializados e a baixa ingestão de alimentos de origem vegetal (legumes e verduras) e água, que contribuem para o desenvolvimento de DCNT.

Resultado semelhante ao estudo realizado com jovens e adolescentes nas escolas públicas do Rio Grande do Sul e Rio de Janeiro, o consumo alimentar constituído por alimentos de alta densidade energética e ricos em sódio, atribuído pelo consumo de alimentos industrializados (ANDRADE et al, 2003; AVOZANI et al, 2014).

Para o tratamento não medicamentoso e prevenção das DCNT é preconizado alterações no estilo de vida como: mudanças nos hábitos alimentares inadequados, consumo de sal em excesso, baixa ingestão de vegetais, obesidade, sedentarismo, tabagismo e consumo exagerado de álcool (BRASIL, 2013).

A Sociedade brasileira de cardiologia, sociedade brasileira de hipertensão, sociedade brasileira de nefrologia (2017) recomenda a ingestão de uma dieta DASH (Dietary Approaches to Stop Hypertension), sendo esta composta por frutas, principalmente as oleaginosas, além de verduras, grãos integrais, carnes brancas e derivados do leite desnatado. Entretanto, essa dieta contém quantidade reduzida de carne vermelha, gorduras saturadas, colesterol, alimentos ricos em sódio, doces e bebidas açucaradas. Vale ressaltar que essa dieta mostrou benefícios no controle da PA, inclusive em pacientes fazendo uso de anti-hipertensivos, isto porque contêm quantidades reduzidas de colesterol, gordura total e saturada, além de ser rica em potássio, fibras e magnésio.

Os fatores de riscos para o desenvolvimento de DCNT devem ser combatidos para que ocorra a redução na incidência ou retardamento de complicações decorrente dessas doenças, proporcionando desta forma uma melhoria na qualidade de vida (LIMA et al., 2016). 


\section{CONCLUSÕES}

De acordo com os dados levantados neste trabalho, evidencia-se a necessidade de desenvolver atividades práticas e teóricas sobre os temas que envolvem este trabalho, com vistas à educação em saúde, enfatizando uma melhor qualidade de vida, esperando contribuir com o conhecimento da comunidade e melhoria dos serviços prestados, na promoção de práticas alimentares saudáveis na prevenção ou minimização de DCNT, no sentido de fortalecer a importância de mudanças no comportamento alimentar e estilo de vida.

As ações que envolvem escolares podem garantir multiplicadores de educação em saúde. A partir dos dados foi criado o projeto de extensão Educação Nutricional: Promovendo Saúde e Prevenindo os Agravos das Doenças Crônicas Não Transmissíveis

\section{REFERÊNCIAS}

ADRIAANSE, M.A.; VINKERS, C.D.W.; RIDDER, D.T.D.; HOX, J.J.; WIT, J.B.F. Do implementation intentions help to eat a healthy diet? A systematic review and meta-analysis of the empirical evidence. Appetite, v.56, p.183-193, 2011.

ANDRADE, R.G.; PEREIRA, R.A.; SICHIERI, R. Consumo alimentar de adolescentes com e sem sobrepeso do Município do Rio de Janeiro. Caderno de Saúde Pública, Rio de Janeiro, v.19, n.5, p.1485-1495, set.- out. 2003.

AVOZANI, P.; SPINELLI, R.B.; ZEMOLIN, G.P; ZANARDO, V.P.S. Avaliação da ingestão de sódio e o risco de hipertensão arterial em Adolescentes das escolas públicas de Erechim-RS. Revista Perspectiva, Erechim, v.38, n.141, p.141-150, março/2014.

BRASIL. Ministério da Educação. Secretária de Educação Profissional e Tecnológica. Instituto Federal do Pará. Campus Rural de Marabá. Projeto Político Pedagógico do Campus Rural de Marabá. Marabá: 2010.

BRASIL. Ministério da Saúde. Secretaria de Atenção à Saúde. Departamento de Atenção Básica. Estratégias para o cuidado da pessoa com doença crônica: hipertensão arterial sistêmica. Cadernos de Atenção Básica, n. 37, 128 p., Brasília: 2013.

BRASIL. Ministério da Saúde. Secretaria de Vigilância em Saúde. Departamento de Vigilância de Doenças não Transmissíveis. Vigilância em Doenças Crônicas Não Transmissíveis. Brasília, DF. Disponível em: $<$ https://www.saude.gov.br/vigilancia-em-saude/vigilancia-de-doencas-cronicas-nao-transmissiveis-dent/fatores-de-risco>, Acesso em: 17 jul. 2020.

BRASIL. Ministério da Saúde. Secretaria de Vigilância em Saúde. Departamento de Análise em Saúde e Vigilância de Doenças não Transmissíveis. Vigitel Brasil 2018: vigilância de fatores de risco e proteção para doenças crônicas por inquérito telefônico: estimativas sobre frequência e distribuição sociodemográfica de fatores de risco e proteção para doenças crônicas nas capitais dos 26 estados brasileiros e no Distrito Federal em 2018. Brasília: 2019.

CASTRO, L.C.V; FRANCESCHINI, S.C.C; PRIORE, S.E.; PELUZIO, M.C.G. Nutrição e doenças cardiovasculares: os marcadores de risco em adultos. Revista de Nutrição, v 17, n.3, p. 369-377, 2004 
LIMA, D.B.S.; MOREIRA, T.M.M; BORGES, J.X.P; RODRIGUES, M.T.P. Associação entre adesão ao tratamento e diferentes tipos de complicações cardiovasculares em pacientes com Hipertensão Arterial. Revista Texto Contexto Enfermagem, Santa Catarina, v.25, n.3, p.1-9, 2016.

SOCIEDADE BRASILEIRA DE CARDIOLOGIA, SOCIEDADE BRASILEIRA DE HIPERTENSÃO, SOCIEDADE BRASILEIRA DE NEFROLOGIA. VII Diretrizes Brasileiras de Hipertensão Arterial. Revista de Arquivos Brasileiros de Cardiologia, Rio de Janeiro, v.24, n.1, p.87-91, 2017.

WHO - World Health Organization. Growht reference data for 5-19 years, 2007. Geneva, Switzerland: WHO, 2007. Disponível em: www.who.int/growthref/en/. Acessado em: 28 de julho de 2020. WHO - World Health Organization. Physical status: the use and interpretation of anthropometry. Geneva, Switzerland: WHO, 1995. 


\section{CAPÍTULO 48}

\section{ENCEFALOPATIA EM PACIENTES IDOSOS ACOMETIDOS PELA COVID-19: UMA REVISÃO INTEGRATIVA}

PAULO VICTOR MOREIRA BRITO' ${ }^{1}$

RENÊ LUIS MOURAANTUNES ${ }^{1}$

OÍGRES LEÃO SCHAUN DE ARAÚJO' ${ }^{1}$

GESSITANIA ROCHA PIRES PEREIRA ${ }^{1}$

GRASIELY FACCIN BORGES ${ }^{2}$

RONALDO DE TOLEDO ${ }^{2}$

RESUMO: O vírus SARS-CoV-2, é um agente altamente patogênico, responsável por causar a COVID-19. Os estudos têm destacado não apenas a sua alta capacidade de transmissão, mas também o seu elevado teor de comprometimento multissistêmico, incluindo o sistema nervoso. As encefalopatias podem estar associadas a agente infecciosos como o vírus da influenza e SARS-CoV-2. O objetivo do estudo foi descrever as características semiológicas, diagnósticas e terapêuticas da encefalopatia em pacientes idosos acometidos pela COVID-19. Trata-se de um estudo de revisão integrativa de literatura, relacionado a presença de encefalopatias em pacientes com COVID-19. A busca das bibliografias foi feita no mês de outubro de 2020, utilizando as bases de dados PubMed e do Portal Regional da Biblioteca Virtual em Saúde (BVS). Utilizou-se na estratégia de busca os seguintes Descritores em Ciências da Saúde (DeCS): "Encefalopatia"
AND “COVID-19”. As etapas deste estudo percorreram a sistematização, identificação e análise da produção bibliográfica disponível sobre a temática. Resultados e discussão: após a aplicação dos critérios de inclusão e exclusão, 16 artigos foram considerados aptos a integrar essa revisão. As manifestações mais frequentes incluem convulsão, distúrbios motores, distúrbios visuais e oculares, confusão mental e delírio. Os pacientes com sinais e sintomas preditivos de encefalopatia foram submetidos, sobretudo, a exames de imagem e de monitoramento eletrofisiológico. Os tratamentos empregados nos pacientes com encefalopatia objetivaram controlar a multiplicação viral, manter uma respiração adequada, conter a sintomatologia relacionada à afecção encefálica e de outras complicações. Destarte os desafios do desconhecido, o avanço tecnológico, a elevada produção científica e o compromisso com a ciência e a saúde da população, a produção de evidências científicas direcionadas à grupo populacional, amplamente atingido, possibilita direcionamento do pensamento clínico profissional e oportuniza a utilização de estratégias diversas, semiológicas, diagnósticas e terapêuticas no enfrentamento às infecções pelo SARS-CoV-2.

PALAVRA-CHAVE: Encefalopatias, Infecções por coronavírus, Infecções do Sistema Nervoso Central.

ABSTRACT: The SARS-CoV-2 virus, is a highly pathogenic agent, responsible for causing COVID-19. Studies have highlighted not only its high transmission capacity, but also its high content of multisystemic impairment, among them, 
the nervous system. Encephalopathies can be associated with infectious agents such as the influenza virus and SARS-CoV-2. The aimd was to describe the semiological, diagnostic and therapeutic characteristics of encephalopathy in elderly patients affected by COVID-19. This is an integrative literature review study, related to the presence of encephalopathies in patients with COVID-19. The search for bibliographies was carried out in October 2020, using the PubMed databases and the Regional Portal of the Virtual Health Library (VHL). In the search strategy, the following Health Sciences Descriptors (DeCS) were used: "Encephalopathy" AND "COVID-19". The stages of this study went through the systematization, identification and analysis of the available bibliographic production on the theme. After applying the inclusion and exclusion criteria, 16 articles were considered able to integrate this review. The most frequent manifestations include seizures, motor disorders, visual and eye disorders, mental confusion and delirium. Patients with signs and symptoms predictive of encephalopathy underwent, above all, imaging tests and electrophysiological monitoring. The treatments used in patients with encephalopathy aimed to control viral multiplication, maintain adequate breathing, contain symptoms related to brain disease and other complications. As well as the challenges of the unknown, technological advancement, high scientific production and commitment to science and the health of the population, the concatenation of scientific evidence aimed at the population group, widely affected, enables the direction of professional clinical thinking and provides opportunities for use of diverse, semiological, diagnostic and therapeutic strategies to deal with SARS-CoV-2 infections.

KEYWORDS: Brain Diseases, Coronavirus Infections, Central Nervous System Infections.

\section{INTRODUÇÃO}

$\mathrm{O}$ vírus SARS-CoV-2, da família Coronaviridae, é um agente altamente patogênico, responsável por causar a COVID-19, foi identificado pela primeira vez em 31 de dezembro de 2019 na cidade de Wuhan na China (CAROD-ARTAL, 2020). A partir daí iniciou-se sua rápida disseminação por vários países no mundo, levando a Organização Mundial da Saúde declarar emergência de saúde pública de interesse internacional em 30 de janeiro de 2020 e em 11 de março de 2020 pandemia por novo coronavírus (WHO, 2020).

A letalidade do vírus parece depender de vários fatores do hospedeiro o que implica em divergentes proporções de casos fatais entre países e até mesmo entre estados, de todo modo a alta e sustentada transmissibilidade do SARS-Cov-2 já causou um número bem maior de mortes do que as infecções pelos coronavírus anteriores (SARS-Cov, Mers-Cov) que combinados tiveram o número inferior a 2000 mortes (NALLEBALLE et al., 2020).

Acerca das manifestações clínicas apresentadas pelo indivíduo com a Covid-19, é válido ressaltar que muitos infectados irão cursar como assintomáticos, enquanto outros apresentarão sintomas mais comuns como tosse, febre, fadiga, falta de ar, mialgia, anosmia e produção de escarro (GHANNAM et al., 2020). Em alguns casos a doença pode cursar para um quadro mais grave de síndrome do desconforto respiratório agudo (BENAMEUR et al., 2020) necessitando, muitas vezes, de assistência respiratória, principalmente em caso de indivíduos que estão em grupo de risco - população idosa com diabetes ou comorbidades que acometem o sistema respiratório ou o cardiovascular (FILATOV et al., 2020). 
O SARS-CoV-2 afeta o sistema respiratório e cardiovascular e também o sistema nervoso, podendo levar as sintomatologias como tontura, hipogeusia, neuralgia e complicações como encefalopatia, doenças cerebrovasculares agudas, consciência prejudicada e lesão muscular esquelética (ESPINOSA et al., 2020). O mecanismo neuro invasivo que o SARS-Cov-2 utiliza para causar estes comprometimentos ainda é pouco descrito, mas já se sabe que o receptor ECA-2, o qual o vírus utiliza para entrada na célula, expressos em alta quantidade no epitélio respiratório, também se encontra em células da glia e neurônios do cérebro e da coluna vertebral o que poderia justificar como ele consegue se multiplicar e causar danos em estruturas nervosas (AHMAD; RATHORE, 2020).

A encefalopatia já é considerada uma condição importante quando se fala de infecção pelo SARS-CoV-2, podendo ser inclusive o único sintoma manifestado pelo paciente (BEACH et al., 2020). Para que um paciente seja diagnosticado com encefalopatia, é necessário que ele apresente alteração de seu estado mental, podendo manifestar confusão, desorientação alterações comportamentais ou até mesmo outras deficiências cognitivas (VENKATESAN et al., 2013). Quando a encefalopatia está associada ao SARS-Cov-2, ainda busca-se compreender se ela é primária - pela invasão do vírus no Sistema Nervoso Central - ou secundária - pela resposta inflamatória sistêmica ou outros fatores.

Os pacientes idosos da COVID-19 tendem a serem mais vulneráveis a desenvolver encefalopatia e que isto pode estar relacionado às comorbidades que são mais prevalentes nessa faixa etária e que predispõem algumas alterações hipóxicas ou metabólicas. Estes pacientes também possuem taxa de mortalidade aumentada em relação às outras faixas etárias, fato este relacionado com problemas pré-existentes (FIGUEIREDO et al., 2020). Estas, por sua vez, influenciam a produção de intensa resposta inflamatória, podendo resultar em um quadro de encefalopatia. Um estudo de revisão que analisou 42 prontuários constatou 56 casos de encefalopatia em pacientes com idades mais avançadas. Pacientes gravemente infectados pelo SARS-CoV-2, também estão expostos a este tipo de alteração, o que piora ainda mais o prognóstico do paciente da COVID-19 idoso e com comorbidades (GARG; PALIWAL; GUPTA, 2020).

Diante do exposto, este estudo buscou por meio de uma revisão integrativa descrever as características semiológicas, diagnósticas e terapêuticas da encefalopatia em pacientes idosos acometidos pela COVID-19.

\section{METODOLOGIA}

Trata-se de um estudo de revisão integrativa de literatura, relacionado a presença de encefalopatias em pacientes idosos com COVID-19. A questão norteadora da pesquisa foi: "Quais as características semiológicas, diagnóstica e terapêutica da encefalopatia em pacientes idosos acometidos pela COVID-19?".

A metodologia empregada obedeceu às seguintes fases: $1^{\text {a }}$ Fase: elaboração da pergunta norteadora; $2^{\mathrm{a}}$ Fase: busca ou amostragem na literatura; $3^{\mathrm{a}}$ Fase: coleta de dados; $4^{\mathrm{a}}$ Fase: análise crítica 
dos estudos incluídos; $5^{\text {a }}$ Fase: discussão dos resultados; e $6^{\text {a }}$ Fase: apresentação da revisão integrativa (SOUZA; SILVA; CARVALHO, 2010).

A busca das bibliografias foram realizadas no mês de outubro de 2020, utilizando as bases de dados PubMed e Portal Regional da Biblioteca Virtual em Saúde (BVS), que engloba as bibliotecas da SciELO, Cochrane, LILACS e outros acervos. Utilizou-se na estratégia de busca os seguintes Descritores em Ciências da Saúde (DeCS): “Encefalopatia” AND “COVID-19”.

Os trabalhos foram selecionados a partir dos seguintes critérios de inclusão: abordar a temática, ter cunho científico, os pacientes terem idade igual ou maior a 60 anos, e terem sido produzidos entre os anos de 2019 e 2020. Os critérios de exclusão foram aplicados quando: os documentos abordavam temas incapazes de responder à pergunta norteadora, quando se tratavam de livros completos, diretrizes, compilados de trabalhos, protocolos, cartas ao editor, preprints, dissertações, teses e trabalhos de revisão.

O levantamento foi realizado por meio do título, resumo, palavras-chave e escopo do trabalho. Na sequência, a partir da leitura do título, resumo e texto dos trabalhos, valendo-se dos critérios de inclusão e exclusão, foram selecionados os documentos aptos a compor esta revisão.

Os trabalhos selecionados foram organizados em forma de tabela, compreendendo os seguintes critérios para análise: autor, ano de publicação, idioma, idade e sexo dos pacientes, manifestações neurológicas, abordagem diagnóstica, terapêutica empregada e evolução. Posteriormente, realizou-se a análise crítica dos documentos, e com base nessa avaliação, foram extraídas as informações que tiveram a capacidade de responder o questionamento inicial dessa revisão e, desta forma, procede-se com uma síntese integrativa dos dados.

\section{RESULTADOS E DISCUSSÃO}

A busca inicial nas bases de dados, obteve como o resultado a identificação de 458 trabalhos, 301 na BVS, e 157 na PubMed. Dos quais, se repetirem entre as bases de busca, 202 restando então, 256 estudos. Na sequência, a partir da leitura dos resumos dos títulos trabalhos, 26 artigos foram excluídos; posteriormente, procedeu-se a leitura dos resumos, excluindo-se 06 estudos; por fim, procedeu-se a leitura por texto completo dos quais foram excluídos, quando aplicados os critérios, 162 trabalhos. Desta forma, 62 estudos foram elegíveis para análise dos dados e do rigor científico. Finalmente, os critérios de inclusão e exclusão orientaram novamente a seleção final dos trabalhos. Sendo assim, 16 artigos foram considerados aptos a integrar essa revisão (Figura 1). 
Figura 1: Fluxograma de identificação e seleção dos estudos com a aplicação dos critérios de inclusão e exclusão.

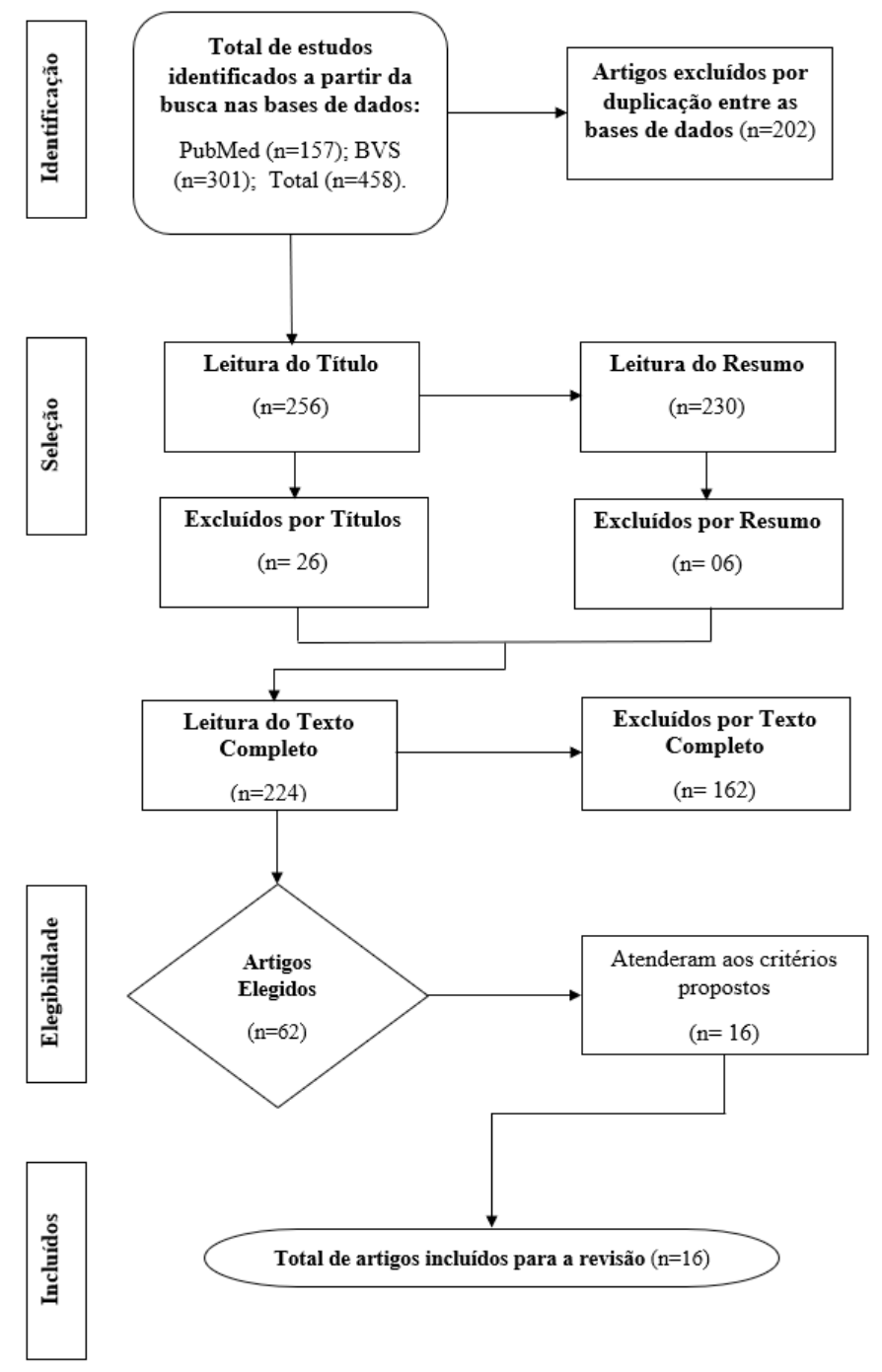

Trinta e dois $(n=32)$ pacientes com manifestações clínicas semelhantes a encefalopatias foram abarcados neste estudo. Desses, 19 (61,3\%) eram do sexo masculino. A idade mínima dos pacientes estudados corresponde à estratificação do grupo de idosos (60 anos), atingindo a idade máxima de 87 anos e idade média de 69,9 anos. Quase que na totalidade dos casos, o quadro clínico dos pacientes se agravou, desses, tiveram óbito como desfecho 5 pacientes (16\%); também, percebeu-se heterogêneo comportamento entre os desfechos, desde evolução grave extremamente rápida ao óbito em 5 dias, como alta clínica prolongada, após 61 dias de internação. A exceção de um paciente, afro-americano, não houve discriminação quanto à raça. Os estudos selecionados foram realizados nos Estados Unidos da América e na Europa.

Nos quadros 1 e 2, são apresentados os dezesseis trabalhos selecionados, os autores, ano e o idioma de publicação, idade e sexo dos pacientes, e uma síntese das manifestações neurológicas, condutas diagnósticas, terapêuticas empregadas e evolução dos casos. Para fins didáticos e organizacional, pautaremos a discussão dos resultados em quatro linhas de raciocínio: (1) Manifestações Clínicas; (2) Conduta Diagnóstica; (3) Terapêutica e; (4) Evolução e desfecho clínico. 
Quadro 1: Informações sobre os autores, idioma da publicação, ano, idioma, idade, sexo e manifestações neurológicas dos estudos selecionados.

\begin{tabular}{|c|c|c|c|}
\hline & $\begin{array}{l}\text { Autor, ano e } \\
\text { idioma }\end{array}$ & $\begin{array}{c}\text { Idade } \\
\text { (anos) e } \\
\text { Sexo }\end{array}$ & Manifestações Neurológicas \\
\hline 1 & $\begin{array}{l}\text { BEACH et al., } \\
\text { 2020, Inglês. }\end{array}$ & $\begin{array}{l}68 \mathrm{M} \\
70 \mathrm{M} \\
76 \mathrm{M} \mathrm{e} \\
87 \mathrm{~F}\end{array}$ & $\begin{array}{l}\text { Mioclonia multifocal nas extremidades superiores e inferiores bilaterais, } \\
\text { roda dentada nas extremidades superiores bilaterais, tom aumentado nas } \\
\text { extremidades inferiores bilaterais extremidades sem clônus do tornozelo } \\
\text { e uma preensão positiva e reflexo palmomenta; Incapacidade de obedecer } \\
\text { a comandos, fala incompreensível, movimentos agitados de braços e per- } \\
\text { nas, discinesia tardia oral leve. }\end{array}$ \\
\hline 2 & $\begin{array}{l}\text { BENAMEUR } \\
\text { et al., 2020, } \\
\text { Inglês. } \\
\end{array}$ & $64 \mathrm{M}$ & $\begin{array}{l}\text { Reflexo oculocefálico ausente, mioclonia multifocal afetando braços e } \\
\text { pernas bilaterais, ausência de dor e diminuição dos reflexos tendinosos } \\
\text { profundos. }\end{array}$ \\
\hline 3 & $\begin{array}{l}\text { CANHAM et } \\
\text { al., } 2020, \text { In- } \\
\text { glês. }\end{array}$ & $\begin{array}{l}62 \mathrm{~F}, 68 \mathrm{M} \\
69 \mathrm{M} \\
73 \mathrm{~F}, 74 \mathrm{M} \\
\text { e } 74 \mathrm{M}\end{array}$ & $\begin{array}{l}\text { Delírio com alucinações visuais e sonolência, convulsões focais, motor } \\
\text { e tônica; Sonolência e não responsividade a estímulos verbais e motores. }\end{array}$ \\
\hline 4 & $\begin{array}{l}\text { CHEN et al., } \\
\text { 2020, Inglês. }\end{array}$ & $60 \mathrm{~F}$ & - \\
\hline 5 & $\begin{array}{l}\text { CONTE et al., } \\
2020 \text {, Inglês. }\end{array}$ & $63 \mathrm{~F}$ & $\begin{array}{l}\text { Desvio esquerdo da cabeça e do olho; convulsões tônicas contínuas no } \\
\text { lado esquerdo do corpo. }\end{array}$ \\
\hline 6 & $\begin{array}{l}\text { DELORME et } \\
\text { al., } 2020, \text { In- } \\
\text { glês. } \\
\end{array}$ & $\begin{array}{c}60 \mathrm{~F}, 66 \mathrm{~F} \\
69 \mathrm{M} \mathrm{e} \\
72 \mathrm{M} \\
\end{array}$ & $\begin{array}{l}\text { Agitação psicomotora aguda, síndrome cognitiva e comportamental do } \\
\text { lobo frontal, mioclonia dos membros superiores e ataxia cerebelar; Ansie- } \\
\text { dade aguda, humor deprimido, acatisia e desequilíbrio da marcha. }\end{array}$ \\
\hline 7 & $\begin{array}{l}\text { ESPINOSA et } \\
\text { al., } 2020, \text { In- } \\
\text { glês. }\end{array}$ & $72 \mathrm{M}$ & $\begin{array}{l}\text { Não responsivo a comando verbal e a estímulos dolorosos nocivos; Refle- } \\
\text { xos do tronco cerebral preservados. }\end{array}$ \\
\hline 8 & $\begin{array}{l}\text { FILATOV et } \\
\text { al., } 2020, \text { In- } \\
\text { glês. }\end{array}$ & $74 \mathrm{M}$ & $\begin{array}{l}\text { Cefaleia, estado mental alterado, não verbal e incapaz de seguir quaisquer } \\
\text { comandos, capaz de mover todas as suas extremidades e reagir a estímulos } \\
\text { nocivos. }\end{array}$ \\
\hline 9 & $\begin{array}{l}\text { FRANCESCHI } \\
\text { et al., 2020, } \\
\text { Inglês. }\end{array}$ & $67 \mathrm{~F}$ & - \\
\hline 10 & $\begin{array}{l}\text { HEPBURN et } \\
\text { al., } 2020, \text { In- } \\
\text { glês. }\end{array}$ & $\begin{array}{l}76 \mathrm{M} \mathrm{e} \\
82 \mathrm{M}\end{array}$ & $\begin{array}{l}\text { Escala de coma de Glasgow de 14, reflexos tendinosos profundos exage- } \\
\text { rados, convulsões; espasmos faciais, estado epiléptico focal. }\end{array}$ \\
\hline 11 & $\begin{array}{l}\text { KIHIRA et al., } \\
\text { 2020, Inglês. }\end{array}$ & $60 \mathrm{M}$ & Desorientação e diminuição do estado de alerta. \\
\hline 12 & $\begin{array}{l}\text { KRETT et al., } \\
2020, \text { Inglês. }\end{array}$ & $69 \mathrm{M}$ & $\begin{array}{l}\text { Alerta e desorientado sem lateralização de déficits neurológicos, forte agi- } \\
\text { tação. }\end{array}$ \\
\hline 13 & $\begin{array}{l}\text { LLANSÓ; } \\
\text { URRA, 2020, } \\
\text { Inglês. } \\
\end{array}$ & $66 \mathrm{~F}$ & $\begin{array}{l}\text { Estado mental alterado, cefaleia prévia ou distúrbios visuais. Ao exame: } \\
\text { abre os olhos aos estímulos dolorosos, não teve resposta verbal e apresen- } \\
\text { tou resposta de retirada. }\end{array}$ \\
\hline 14 & $\begin{array}{l}\text { PARAUDA et } \\
\text { al., 2020, In- } \\
\text { glês. }\end{array}$ & $\begin{array}{c}64 \mathrm{M} \\
65 \mathrm{~F}, 73 \mathrm{M} \\
\text { e } 74 \mathrm{~F}\end{array}$ & $\begin{array}{l}\text { afasia global, obnubilação, movimentos espontâneos mínimos; desvio do } \\
\text { olhar à esquerda, crise tônico-clônica generalizada, estatus epiléptico fo- } \\
\text { cal; confusão persistente com agitação intermitente, obedecia a comandos } \\
\text { de forma inconsistente. }\end{array}$ \\
\hline 15 & $\begin{array}{l}\text { SPARR; BIE- } \\
\text { RI, 2020, In- } \\
\text { glês. }\end{array}$ & $62 \mathrm{~F}$ e $84 \mathrm{~F}$ & $\begin{array}{l}\text { Nível deprimido de excitação. Ao exame, abre os olhos para pedir, mas } \\
\text { não era interativa. }\end{array}$ \\
\hline 16 & $\begin{array}{l}\text { UMAPATHI } \\
\text { et al., } 2020 \text {, } \\
\text { Inglês. } \\
\end{array}$ & $73 \mathrm{M}$ & $\begin{array}{l}\text { Delírio hiperativo persistente, pontuado por episódios de fraqueza do lado } \\
\text { direito e esquerdo, quadriparesia espástica; sem movimentos volitivos dos } \\
\text { olhos e membros. }\end{array}$ \\
\hline
\end{tabular}

Legenda: F: Feminino, M: Masculino. 


\section{Manifestações Clínicas}

Os pacientes que necessitaram de internação, em sua maioria, buscaram os serviços de saúdes com queixas inespecíficas às encefalopatias e apresentaram como sinais e sintomas tosse, dispneia, febre e fadiga (BENAMEUR et al., 2020; ESPINOSA et al., 2020; FILATOV et al., 2020; PARAUDA et al., 2020; HEPBRUN et al., 2020; SPARR et al., 2020).

Em menor proporção, percebeu-se a presença de quadros encefalopáticos cujo à apresentação relatavam: confusão mental, estado mental alterado, fraqueza generalizada, anosmia e augesia (SPARR \& BIERI, 2020; HEPBURN et al., 2020; DELORME et al., 2020). Ademais, foram reveladas manifestações clínicas severas que direcionavam a acometimento sistêmico como insuficiência renal aguda, Síndrome do Desconforto Respiratório, choque séptico e taquipneia (SPARR \& BIERI, 2020; HEPBURN; LLANSO et al., 2020; PARAUDA et al., 2020; KRETT et al., 2020).

Dos relatos descritos foram observados $73 \%$ de pacientes com alteração do estado mental (CONTE et al., 2020; FRANCESCHI et al., 2020; KIHIRA et al., 2020; SPARR \& BIERI, 2020; FILATOV et al., 2020; FRANCESCHI et al., 2020; HEPBURN et al., 2020; LLANSÓ \& URRA, 2020; UMAPATHI et al., 2020; BEACH et al., 2020; DELORME et al., 2020; ESPINOSA et al., 2020; PARAUDA et al., 2020; CANHAM et al., 2020; KRETT et al., 2020), o que evidencia a agressividade e o grande potencial de virulência do SARS-CoV-2 ao tecido nervoso. As manifestações mais frequentes incluíram: convulsão que assumiu o percentual de 22,5\% (HEPBURN et al., 2020; PARAUDA et al., 2020; DELORME et al., 2020; BEACH et al., 2020; CANHAM et al., 2020; CONTE et al., 2020), distúrbios motores 30\% (KRETT et al., 2020; UMAPATHI et al., 2020; BENAMEUR et al., 2020; BEACH et al., 2020; DELORME et al., 2020; PARAUDA et al., 2020; ESPINOSA et al., 2020; HEPBURN et al., 2020), distúrbios visuais e oculares com 25\% (CONTE et al., 2020; KRETT et al., 2020; UMAPATHI et al., 2020; BENAMEUR et al., 2020; DELORME et al., 2020; PARAUDA et al., 2020; LLANSÓ \& URRA, 2020), confusão mental com 10\% (SPARR \& BIERI, 2020; FRANCESCHI et al., 2020; KRETT et al., 2020; PARAUDA et al., 2020) e delírio com 7,5\% dos casos (UMAPATHI et al., 2020; CANHAM et al., 2020).

De fato, as alterações do estado de consciência se fizeram presente ainda que não seja possível evidenciar se primária ou secundária à infecção viral. Embora essas manifestações não tenham sido claramente explicadas, no contexto atual há evidências crescentes de que a doença tem efeitos sob Sistema Nervoso Central. Estudos anteriores revelaram o potencial de virulência que predispõe o paciente a quadros de complicação multissistêmica devido aos níveis elevados de marcadores inflamatórios, maiores evidências de falência de múltiplos órgãos, sinais característicos de comprometimento neurológico e consequente desenvolvimento de encefalopatias, assim como sinais de alteração do trato corticoespinhal. Possivelmente as manifestações clínicas podem ser elucidadas por mecanismo multifatorial que pode envolver um possível neurotropismo de SARS-CoV-2, vale destacar que a quebra da barreira hematoencefálica precipitada por reações pró-inflamatórias de citocinas possibilita tais reações (HEPBURN et al., 2020). 
Um estudo, em particular, abordou as infecções pelo Sars-Cov-2 em pacientes psiquiátricos, com diagnósticos prévios de transtorno neurocognitivo grave com distúrbio comportamental, características psicóticas, demência por corpos de Lewy (DLB), lesão cerebral traumática, transtorno abuso de álcool, transtorno neurocognitivo maior, tipo não especificado e transtorno depressivo maior com características psicóticas (BEACH et al., 2020). A esses pacientes, a identificação de encefalopatia foi prejudicada ou sobreposta às condições prévias de saúde. Percebeu-se que o manejo desses pacientes exigia abordagens direcionadas que envolvessem terapêuticas com uso de antipsicóticos e neuroepilépticos, com frequente alteração de dose ou adição de novo medicamento para controle das manifestações clínicas.

Quadro 2: Informações sobre a conduta diagnóstica, terapêutica e evolução dos estudos selecionados.

\begin{tabular}{|c|c|c|c|}
\hline & $\begin{array}{c}\text { Conduta } \\
\text { Diagnostica }\end{array}$ & Terapêutica & Evolução \\
\hline 1 & $\begin{array}{l}\text { TC, EEG, PCR, } \\
\text { Creatinina, Só- } \\
\text { dio, Urocultura }\end{array}$ & $\begin{array}{c}\text { Atorvastatina, azitromicina, hidroxiclo- } \\
\text { roquina, olanzapina, haloperidol, clor- } \\
\text { promazina; Trazodona, ácido valpróico, } \\
\text { carbidopa-levodopa, lorazepam; Levetira- } \\
\text { cetam profilático; piperacilina / tazobactam. } \\
\text { clozapina e lítio; Metoprolol, furosemida, } \\
\text { ceftriaxona }\end{array}$ & $\begin{array}{l}\text { Paranóia, agressão, inquietação e golpes sem } \\
\text { propósito; Desorientação; FA com resposta } \\
\text { ventricular rápida e hipervolêmica, taquicardia, } \\
\text { agitação e agressividade com piora do estado } \\
\text { respiratório }\end{array}$ \\
\hline 2 & RM, LCR & Hidroxicloroquina, IOT & $\begin{array}{l}\text { Insuficiência respiratória hipóxica, mioclonia } \\
\text { multifocal após início do tratamento com hidro- } \\
\text { xicloroquina }\end{array}$ \\
\hline 3 & $\begin{array}{l}\text { TC, RM, EEG, } \\
\text { PCR }\end{array}$ & $\begin{array}{l}\text { Levetiracetam, phenytoin, carbamazepine, } \\
\text { primodone. lorazepam; Heparina, predniso- } \\
\text { lona, bisoprolol, citalopram; Remifentanil, } \\
\text { paliperidona; Azitromicina, hidrocortisona, } \\
\text { midazolam, hiocina, butilbrometo, co-amo- } \\
\text { xiclav, ciclizinamorfina, paracetamol, furo- } \\
\text { semida; Sinvastatina, gabapentina, omepra- } \\
\text { zol, amitriptilina, metiformina }\end{array}$ & - \\
\hline 4 & EEG & IOT; sedação (midazolam); levetiracetam & TVP, Pneumotórax \\
\hline 5 & $\begin{array}{l}\text { RM, EEG, Ve- } \\
\text { nografia }\end{array}$ & $\begin{array}{c}\text { IOT, inalação e óxido nítrico, lopinavir/ ri- } \\
\text { tonavir; piperacilina-tazobactam; sedativos } \\
\text { e opioides, anakinra, cefazolina, fenitoína, } \\
\text { diazepam }\end{array}$ & $\begin{array}{l}\text { UTI, lesão renal moderadamente aguda, melho- } \\
\text { ra gradual }\end{array}$ \\
\hline 6 & $\begin{array}{l}\text { TC-PET, RM, } \\
\text { EEG, LCR }\end{array}$ & $\begin{array}{l}\text { Imunoglobulinas polivalentes; corticoste- } \\
\text { roides; paroxetina, mirtazapina; levetirace- } \\
\text { tam, lacosamida }\end{array}$ & $\begin{array}{l}\text { Melhora gradual dos sintomas neurológicos; } \\
\text { Comprometimento cognitivo persistente; Inter- } \\
\text { nação na UTI e IOT a um quadro generalizado } \\
\text { do estado epiléptico convulsivo }\end{array}$ \\
\hline 7 & RM, LCR, EEG & $\begin{array}{l}\text { Hidroxicloroquina, ceftriaxona, azitromici- } \\
\text { na, vasopressores, IOT }\end{array}$ & $\begin{array}{l}\text { Insuficiência respiratória hipoxêmica aguda; } \\
\text { choque; hemodinamicamente instável; depen- } \\
\text { dente de ventilador; sedação descontinuada, ne- } \\
\text { nhuma melhora neurológica }\end{array}$ \\
\hline 8 & $\begin{array}{l}\text { TC, EEG, LCR, } \\
\text { PCR, D-Dimero }\end{array}$ & $\begin{array}{l}\text { Profilaxia antiepiléptica; TTO empírico: } \\
\text { vancomicina, meropenem e aciclovir; hi- } \\
\text { droxicloroquina e lopinavir/ ritonavir, IOT }\end{array}$ & Insuficiência respiratória, UTI \\
\hline 9 & $\mathrm{TC}, \mathrm{RM}$ & - & Melhora gradual dos sintomas neurológicos \\
\hline 10 & $\begin{array}{l}\text { TC, RM, EEG, } \\
\text { Fibrinogênio }\end{array}$ & $\begin{array}{l}\text { Vancomicina, Piperacilina-tazobactam, } \\
\text { Levetiracetam, Meropenem e Aciclovir; } \\
\text { Traqueostomia; Levetiracetam. }\end{array}$ & $\begin{array}{l}\text { Insuficiência respiratória hipoxêmica aguda; } \\
\text { UTI; Episódios de atividade clônica do membro } \\
\text { superior esquerdo; agravamento da encefalopa- } \\
\text { tia com declínio do nível de consciência; sono- } \\
\text { lência e incapacidade de seguir comandos }\end{array}$ \\
\hline
\end{tabular}




\begin{tabular}{|c|c|c|c|}
\hline 11 & $\begin{array}{l}\text { TC, RM, LCR, } \\
\text { EEG }\end{array}$ & IOT e Diálise & $\begin{array}{l}\text { IRH, choque cardiogênico, cardiomiopatia de } \\
\text { Takotsubo, IRA, estado mental alterado persis- } \\
\text { tente }\end{array}$ \\
\hline 12 & $\begin{array}{l}\text { TC, RM, LCR, } \\
\text { EEG, Ureia, } \\
\text { Creatinina, } \\
\text { Sódio, Coagulo- } \\
\text { grama }\end{array}$ & $\begin{array}{l}\text { Suporte vasopressor durante o tratamento } \\
\text { intensivo, hidroxicloroquina }\end{array}$ & $\begin{array}{l}\text { Lesão renal aguda, cetoacidose diabética, mo- } \\
\text { vimentos espontâneos, breves, de flexão e pro- } \\
\text { nação envolvendo os braços; tônus flácido nas } \\
\text { extremidades com arreflexia. Melhora do esta- } \\
\text { do neurológico }\end{array}$ \\
\hline 13 & TC, Sódio & $\begin{array}{l}\text { Lopinavir / ritonavir, hidroxicloroquina e } \\
\text { azitromicina; anti-IL-1 (anakinra diário) } \\
\text { e anti-IL-6 (dose única de tocilizumabe); } \\
\text { transfusão de hemácias, imunossupressores } \\
\text { e ventilação mecânica. }\end{array}$ & $\begin{array}{l}\text { Pneumonia bilateral; parada cardiorrespirató- } \\
\text { ria; superinfecção bacteriana; hiponatremia; he- } \\
\text { moptise maciça; embolização; IRA. infiltrados } \\
\text { radiológicos pioraram; aumento dos reagentes } \\
\text { de fase aguda }\end{array}$ \\
\hline 14 & $\begin{array}{l}\text { TC, RM, EEG, } \\
\text { Creatinina }\end{array}$ & $\begin{array}{l}\text { IOT; Bloqueador neuromuscular, hidroxi- } \\
\text { cloroquina; Tocilizumabe; Hemodiálise }\end{array}$ & $\begin{array}{l}\text { IRA, TVP, HAS persistente; Pneumonia bacte- } \\
\text { riana; Insuficiência respiratória persistente, pa- } \\
\text { ralisia e pronação, HAS aguda }\end{array}$ \\
\hline 15 & $\begin{array}{l}\text { RM, EEG, } \\
\text { Ureia, Creatini- } \\
\text { na, D-Dimero }\end{array}$ & $\begin{array}{l}\text { Hemodiálise; Oxigênio de alto fluxo, api- } \\
\text { xabana, hidroxicloroquina e esteróides }\end{array}$ & IRA; TVP \\
\hline 16 & $\begin{array}{l}\text { RM, LCR, } \\
\text { D-Dimero, } \\
\text { Fibrinogênio, } \\
\text { Antifolipídeo, } \\
\text { DsDNA }\end{array}$ & $\begin{array}{l}\text { Interferon beta } 1 \mathrm{~b} \text { e lopinavir/ ritonavir; } \\
\text { Ventilação por traqueostomia }\end{array}$ & $\begin{array}{l}\text { Mau estado neurológico, agitação e a inquie- } \\
\text { tação, sedação e contenção constantes, sem } \\
\text { resposta volitiva a estímulos externos. Ensaio } \\
\text { empírico de esteroides em altas doses, sem me- } \\
\text { lhora }\end{array}$ \\
\hline
\end{tabular}

Legenda: EEG: Eletroencefalografia, IRH: Hematúria renal idiopática, IOT: Intubação orotraqueal, IRA: Insuficiência renal aguda, LCR: Exame do líquido cefalorraquidiano, PET: Tomografia por emissão de pósitron, RM: Ressonância Magnética, TC: Tomografia Computadorizada, TVP: Trombose venosa profunda, UTI: Unidade de terapia intensiva.

\section{Conduta Diagnóstica}

Os pacientes com sinais e sintomas preditivos de encefalopatia foram submetidos, sobretudo, a exames de imagem e de monitoramento eletrofisiológico. Os principais exames empregados foram a Ressonância Magnética Nuclear (RMN), a Eletroencefalografia (EEG), ambos utilizados em 10 estudos (62,5\%), e a Tomografia Computadorizada (TC) aplicada em 9 estudos (56,25\%).

A RMN, o exame mais utilizado, revelou achados característicos de encefalopatia. Foram identificados infartos envolvendo ambos os hemisférios cerebrais e cerebelares, bem como, o esplênio do corpo caloso no seu lado direito, contendo, em alguns casos, evidências de hemorragia e necrose laminar cortical (UMAPATHI et al., 2020). Além disso, notou-se a presença de áreas de hiperintensidade na substância branca do sulco parieto-occipital (PARAUDA et al., 2020). Um estudo, no qual, relatou-se episódios de convulsões tônicas na evolução do paciente, o exame de RMN, mostrou edema cortical restrito à região posterior do hemisfério esquerdo, com a presença de tumefação sub e supratentorial (CONTE, et al., 2020).

O exame dos parâmetros eletrofisiológicos cerebrais, via EEG, demonstrou difuso desaceleramento de ondas teta, sem a presença de descargas epileptiformes nos casos em que não houve manifestações tônico-clônicas (KIHIRA et al., 2020). Padrões de lentidão bilateral e focal em região temporal com presença de contração ondulatória evidente, foram descritos em paciente com alterações neurológicas indicativas do quadro encefalopático (FILATOV et al., 2020). 
Os achados do exame de TC verificaram hipoatenuação bilateral com envolvimento da substância branca subcortical occiptal de maneira simétrica (PARAUDA et al., 2020). Em estudo que paciente comatoso que foi submetido ao exame para investigação de encefalopatia, além dos achados de hipodensidade da substância branca em região temporo-occipital, notou-se obliteração simétrica dos sulcos deste local (LLANSÓ; URRA, 2020). Em contexto que havia presença de encefalopatia hemorrágica reversível, foram evidenciados edema bilateralmente nas regiões parieto-occipitais provocando efeito de massa e apagamento de sulcos corticais (FRANCESCHI et al., 2020).

As análises laboratoriais de marcadores inflamatórios, hematológicos e proteicos, foram empregados no diagnóstico dos quadros de encefalopatia em alguns estudos. O exame do Líquido Cefalorraquidiano (LCR), teve como resultado na maioria dos casos padrões de normalidade, entretanto, encontrou-se ocorrência de hiperproteinorraquia (DELORME et al, 2020). A avaliação da Velocidade de Hemossedimentação (VHS) e dos níveis de Proteína C-Reativa (PCR), demonstram que a elevação da VHS e PCR pode manter correlação com piores prognósticos (BEACH et al., 2020).

\section{Terapêutica Empregada}

Os tratamentos empregados nos pacientes com encefalopatia objetivaram controlar a multiplicação viral do SARS-CoV-2, manter uma respiração adequada, conter a sintomatologia relacionada à afecção encefálica e de outras complicações.

A utilização empírica de antibióticos de amplo espectro e antivirais como vancomicina, meropenem e aciclovir, e o emprego off-label de hidroxicloroquina compuseram a abordagem farmacológica direcionada ao tratamento da COVID-19 (FILATOV et al., 2020); ainda neste contexto, a ceftriaxona e a azitromicina também fizeram parte de esquemas terapêuticos (ESPINOSA et al., 2020). Em decorrência da alta resposta pró-inflamatória, com consequente aumento na quantidade de citocinas, o tratamento com anticorpos monoclonais anti-interleucinas 1 e 6 , foram aplicados (LLANSÓ; URRA, 2020).

Nos pacientes que cursaram com desconforto respiratório, o suporte ventilatório com oxigênio de alto fluxo foi ofertado, naqueles que continuaram a descompensar, evoluindo para insuficiência respiratória hipoxêmica aguda, a intubação orotraqueal fez-se necessária (ESPINOSA et al., 2020). Os quadros que houveram lesão renal e encefalopatia urêmica, procedida de insuficiência renal aguda, o tratamento de escolha foi a diálise (KIHIRA et al., 2020).

Os estudos analisados não possuíam um protocolo específico para pacientes com COVID-19 que cursaram com encefalopatia, entretanto, houve emprego de medidas terapêuticas direcionadas, principalmente, para a prevenção e controle de convulsões, com uso de fenitoína e benzodiazepínicos (CONTE et al., 2020). Foram utilizados pulsos de corticoide com o objetivo de conter o processo inflamatório, subsidiando a tentativa de limitar o comprometimento encefálico (DELORME et al., 2020). 


\section{Evolução e Desfecho Clínico}

A evolução dos pacientes acometidos pelo COVID-19, que repercutiram em encefalopatias, foi em sua maioria, complicada, prolongada, com mau prognóstico e, por vezes, com desfecho desfavorável, falência múltipla de órgãos e óbitos (BEACH et al., 2020; CANHAM et al., 2020; CONTE et al., 2020; DELORME et al., 2020; FILATOV et al.,2020; HEPBURN et al., 2020; KRETT et al., 2020; LLANSÓ \& URRA, 2020; PARAUDA et al., 2020; SPARS \& BIERI, 2020; UMAPATHI et al., 2020).

Foram registrados com frequência a necessidade de intubação orotraqueal e de suporte ventilatório (KIHIRA et al., 2020; PARAUDA et al., 2020; CHEN et al., 2020). Ainda, foi relatado, em dois pacientes, a necessidade de traqueostomia (HEPBURN et al., 2020; UMAPATHI et al., 2020). Outro achado frequente, foi a evolução para insuficiência renal aguda, seguida da necessidade de diálise (CONTE et al., 2020; KIHIRA et al., 2020; KRETT et al., 2020; LLANSÓ \& URRA, 2020; PARAUDA et al., 2020; SPARS \& BIERI, 2020). Identificou-se que os pacientes que necessitaram de cuidados em terapia intensiva (UTI) atingiram períodos superiores a 61 dias (CONTE et al., 2020).

Dos critérios avaliados para a alta dos indivíduos, lista-se: análise de fluido cerebrospinal sem detecção de carga viral; estado de consciência, alerta e orientado; sem foco de déficits neurológicos ou com sintomatologias mínimas e transitórias (BEACH et al., 2020; DELORME et al., 2020; PARAUDA et al., 2020).

\section{CONCLUSÃO}

Para além das manifestações clínicas iniciais prevalentes na maioria dos estudos, que foram febre, tosse e dispneia, evidenciou-se que as complicações advindas da infecção por Sars-cov-2 no Sistema Nervoso Central se fizeram presente ainda na entrada ao serviço de saúde manifestando-se como estado mental alterado, confusão mental, cefaleia e declínio do nível de consciência. Como apresentado, a evolução à encefalopatia desenvolvida pelos pacientes foi em sua maioria, complicada, prolongada, com mau prognóstico e, por vezes, com desfecho desfavorável, falência múltipla de órgão e óbitos.

O diagnóstico base para as encefalopatias, para além da clínica, ancorou-se em recursos diversos e em realizações seriadas, conjuntas, ou isoladas, de Tomografia computadorizada, Ressonância Magnética e Eletroencefalograma que demonstraram significativo valor diagnóstico e características imagéticas das encefalopatias. Foi lançado mão de outros exames complementares que objetivaram a evolução da resposta inflamatória frente a terapêutica utilizada, com destaques aos marcadores inflamatórios PCR e VHS, bem como hemogramas, provas de avaliação renal, hepática, além de coagulogramas e dosagem do D-dímero. Da terapêutica, notou-se que a observação ao leito conduziu às escolhas adotadas. Medidas de suporte foram necessárias e incluíram: adoção da posição prona, suporte 
ventilatório, intubação orotraqueal, traqueostomia e diálise. Salienta-se, na terapêutica a conduta de antibioticoterapia empírica, os ensaios com antirretrovirais e a utilização off-label da hidroxicloroquina. A utilização do levetiracetam profilático às convulsões, foi outro achado frequente na conduta. O desfecho dos casos mostrou-se heterogêneo, contudo, a alta patogenicidade viral, bem como risco elevado à população idosa associado, entre outros fatores, a marcante presença de comorbidades, ficou evidenciado dado o número de óbitos, as internações complicadas e prolongadas, a necessidade de reabilitação e os déficits neurológicos apresentados. Por falta de dados, não foi possível identificar a persistência dos sintomas após a internação para a grande maioria dos estudos.

Destarte os desafios do desconhecido, o avanço tecnológico e dos estudos, a elevada produção científica e o compromisso com a ciência e a saúde da população, a produção de evidências científicas direcionadas à grupo populacional, de vera, atingido, possibilita direcionamento do pensamento clínico profissional e oportuniza a utilização de estratégias diversas no enfrentamento às infecções pelo Sars-cov-2. Afora as limitações deste estudo, mais estudos são necessários para que consigamos abarcar outros grupos etários e que obtenhamos eficácia no combate ao COVID-19.

\section{REFERÊNCIAS}

AHMAD, I.; RATHORE, F. A. Neurological manifestations and complications of COVID-19: A literature review. Journal of Clinical Neuroscience, 2020.

BEACH, S. R. et al. Delirium in COVID-19: A case series and exploration of potential mechanisms for central nervous system involvement. Gen Hosp Psychiatry, v. 65, p. 47-53, Jul-Aug 2020.

BENAMEUR, K. et al. Encephalopathy and Encephalitis Associated with Cerebrospinal Fluid Cytokine Alterations and Coronavirus Disease, Atlanta, Georgia, USA, 2020. Emerging Infectious Diseases, v. 26, n. 9, p. 2016-2021, Sep 2020.

CANHAM, L. J. W. et al. Electroencephalographic (EEG) features of encephalopathy in the setting of Covid-19: A case series. Clinical Neurophysiology Practice, v. 5, p. 199-205, 2020/01/01/ 2020.

CAROD-ARTAL, F. J. J. R. N. Complicaciones neurológicas por coronavirus y COVID-19. Rev Neurol., v. 70, p. 311-322, 2020.

CHEN, W. et al. Status epilepticus and other EEG findings in patients with COVID-19: A case series. Seizure, v. 81, p. $198-200$, Oct 2020.

CONTE, G. et al. COVID-19-Associated PRES-like Encephalopathy with Perivascular Gadolinium Enhancement. American Journal of Neuroradiology, 2020.

DELORME, C. et al. COVID-19-related encephalopathy: a case series with brain FDG-positron-emission tomography/computed tomography findings. European journal of neurology, 2020.

ESPINOSA, P. S. et al. Neurological Complications of Coronavirus Disease (COVID-19): Encephalopathy, MRI Brain and Cerebrospinal Fluid Findings: Case 2. Cureus, v. 12, n. 5, p. e7930, May 22020.

FIGUEIREDO, M. N. et al. Espectro clínico da covid-19 em idosos: revisão integrativa da literatura. Brazilian Journal of Development, v. 6, n. 9, p. 68173-68186, 2020.

FILATOV, A. et al. Neurological Complications of Coronavirus Disease (COVID-19): Encephalopathy. Cureus, v. 12, n. 3, p. e7352, Mar 212020. 
FRANCESCHI, A. M. et al. Hemorrhagic Posterior Reversible Encephalopathy Syndrome as a Manifestation of COVID-19 Infection. American Journal of Neuroradiology, v. 41, n. 7, p. 1173-1176, 2020.

GARG, R. K.; PALIWAL, V. K.; GUPTA, A. Encephalopathy in patients with COVID-19: A review. Journal of Medical Virology, 2020.

GHANNAM, M. et al. Neurological Involvement of Coronavirus Disease 2019: A Systematic Review. Journal of neurology, p.1-27, 2020.

HEPBURN, M. et al. Acute Symptomatic Seizures in Critically Ill Patients with COVID-19: Is There an Association? Neurocrit Care, p. 1-5, May 282020.

KIHIRA, S. et al. Imaging Features of Acute Encephalopathy in Patients with COVID-19: A Case Series. AJNR Am J Neuroradiol, v. 41, n. 10, p. 1804-1808, Oct 2020.

KRETT, J. D. et al. Hemorrhagic encephalopathy associated with COVID-19. J Neuroimmunol, v. 346, p. 577326, Jul 142020.

LLANSÓ, L.; URRA, X. Posterior Reversible Encephalopathy Syndrome in COVID-19 Disease: a Case-Report. SN Compr Clin Med, p. 1-3, Aug 262020.

NALLEBALLE, K. et al. Spectrum of neuropsychiatric manifestations in COVID-19. Brain, behavior, and immunity, v. 88, p. 71-74, 2020.

PARAUDA, S. C. et al. Posterior reversible encephalopathy syndrome in patients with COVID-19. J Neurol Sci, v. 416, p. 117019, Jul 92020.

SOUZA, Marcela Tavares de; SILVA, MICHELLY Dias da; CARVALHO, Rachel de. Revisão integrativa: o que é e como fazer. Einstein (São Paulo), v. 8, n. 1, p. 102-106, 2010.

SPARR, S. A.; BIERI, P. L. Infarction of the Splenium of the Corpus Callosum in the Age of COVID-19: A Snapshot in Time. Stroke, v. 51, n. 9, p. e223-e226, Sep 2020.

UMAPATHI, T. et al. Encephalopathy in COVID-19 patients; viral, parainfectious, or both? eNeurologicalSci, v. 21, p. 100275, Dec 2020.

VENKATESAN, A. et al. Case definitions, diagnostic algorithms, and priorities in encephalitis: consensus statement of the international encephalitis consortium. Clin Infect Dis, v. 57, n. 8, p. 1114-28, Oct 2013.

WHO. Rolling updates on coronavirus disease (COVID-19). Disponível em: $<$ https://www.who.int/emergencies/diseases/novel-coronavirus-2019/events-as-they-happen>. Acesso em: 7 nov. 2020. 
JOSEFA MARIA DAS GRAÇAS GOMES

DA SILVA

Unifacol

VITÓRIA MARIA FALCÃO DE LIMA

SALSA

Unifacol published between 2010 and 2018, reading abstracts and monographs, totaling 44 results with the selection 8 articles and 2 monographs.

Keywords: Nursing consultation; Obstetric nursing; Pregnancy; Deafness; Nurse-patient relations.
RESUMO: Diante os desafios encontrados pela equipe multidisciplinar de saúde e pelos usuários surdos, o estudo objetivou-se em identificar se a assistência a gestantes surdas está conforme a legislação vigente e garantindo a inclusão e humanização da mesma por parte dos profissionais de saúde. Trata-se de uma revisão integrativa da literatura, realizada nas bases de dados Scielo, Medline, BDENF, a partir dos critérios de inclusão: artigos publicados entre os anos de 2010 e 2018 , leitura de resumos e monografias, totalizando 44 resultados com a seleção de 8 artigos e 2 monografias.

Palavras-chave: Consulta de enfermagem; Enfermagem obstétrica; Gravidez; Surdez; Relações enfermeiro-paciente.

ABSTRACT: In view of the challenges encountered by the multidisciplinary health team and by deaf users, the study aimed to identify whether assistance to deaf pregnant women is in accordance with current legislation and ensuring the inclusion and humanization of it by health professionals. This is an integrative literature review, carried out in the Scielo, Medline, BDENF databases, based on the inclusion criteria: articles

\section{INTRODUÇÃO}

Segundo o Ministério da saúde, a surdez é o comprometimento total ou parcial da audição que pode ser dividida ligeira, média, severa, profunda e cofose, sua causa pode ser congênita ou adquirida (BRASIL, 2017). De acordo com o Ministério da Educação (2006), a linguagem possibilita ao homem compor seu pensamento, compreender seus sentimentos, registrar seus conhecimentos e se comunicar com outros homens. É em virtude dela que o homem tem seu ingresso na cultura, tornando-o capaz de transformações e mudanças inimagináveis.

A linguagem tem o valor fundamental de se fazer entender o próximo e a si mesmo. O Brasil reconhece sua Língua de Sinais (LS) de acordo com a Lei $N^{o} 10.436$, de 24 de abril de 2002, que dispõe sobre a Língua Brasileira de Sinais LIBRAS. 
Segundo o Decreto da Lei N ${ }^{0}$ 5.626, de dezembro de 2005 (Brasil, 2005), assegura o direito à saúde dos cidadãos com deficiência auditiva ou Surdos, a partir de 2006, o atendimento ás pessoas Surdas ou com deficiência auditiva na rede de serviços do Sistema Único de Saúde (SUS) e que este seja realizado por profissionais capacitados para utilização da LIBRAS ou para a sua tradução e interpretação.

A assistência à saúde necessita de comunicação, inteiramente centralizado no paciente, de modo responsável e cuidadoso, aonde se procura compreender e entender as necessidades apresentadas. Ao se buscar atendimento em qualquer unidade de saúde, o indivíduo surdo encontra dificuldade na comunicação com a equipe de saúde, por falta de capacitação dos profissionais, assim termina sendo gerada uma escassez na assistência integral e individual prestada.

O profissional de saúde deve humanizar a assistência em enfermagem, preocupar-se com a relação entre Enfermeiro/Paciente, e para isso necessita de um suporte técnico e científico que lhes habilite a entender este universo linguístico, social e cultural do surdo. (SILVA et al, 2020)

O Sistema Único de Saúde é um extenso projeto de inclusão social que se mostra em constante processo de e construção e aperfeiçoamento, embora ainda que haja dificuldade na maneira de comunicação entre profissionais de saúde e surdos (BRITO,2015).

A lei $17.029 \backslash 2020$, do deputado Gustavo Gouveia, dispõe sobre a atuação em hospitais, casas de parto, maternidades e estabelecimentos semelhantes da rede privada e pública de saúde de Pernambuco, que necessitam consentir a presença de intérprete e tradutor da Libras, sendo determinados livremente pelas parturientes e gestantes com deficiência auditiva, sendo estes permitidos adentrar em quaisquer locais de trabalho de parto, parto e pós-parto imediato, obedecendo a todo momento o regimento de segurança do ambiente hospitalar.

Nessa perspectiva, este estudo tem como foco central a atuação do enfermeiro obstetra na assistência às gestantes surdas na sala de parto e o qual grande é a necessidade de profissionais capacitados no acolhimento dessas gestantes, gerando um suporte e uma relação mais humanizada. Destaca-se a importância da comunicação entre a equipe de enfermagem e as pessoas com deficiência auditiva, com o intuito de promover a inclusão social dessas pessoas e aperfeiçoar a prática assistencial, por meio de criação de métodos de comunicação verbal e não verbal e a obtenção do entendimento da LIBRAS, uma vez que é por meio da comunicação que o profissional poderá entender as necessidades reais do paciente, compreendê-lo como ser holístico e perceber sua visão do mundo, entendendo seu modo de pensar, agir e sentir.

\section{METODOLOGIA}

Este estudo constituirá uma revisão bibliográfica de caráter qualitativo e descritivo a respeito da assistência à gestante surda na sala de parto. 
A coleta de dados ocorreu no período de Janeiro à Abril de 2020, e foram utilizadas para a pesquisa as bases de dados: Scientific Eletrônic Library Online (SCIELO), Revista Cogitare Enfermagem, Revista Cubana de Enfermagem, Revista Brasileira de Análises Clínicas, National Library of Medicine (MEDLINE) e base de dados bibliográficas especializada na área de Enfermagem (BDE$N F)$. Foi definido como critério de inclusão: artigos publicados entre os anos de 2010 e 2018, leitura de resumos e monografias, totalizando 44 resultados com a seleção de 8 artigos e 2 monografias. Utilizando as palavras chaves: Consulta de enfermagem; Enfermagem obstétrica; Gravidez; Surdez; Relações enfermeiro-paciente.

Assim, o estudo é indicado como revisão bibliográfica, já que é baseado em trabalhos executados por outros autores, a respeito do tema proposto. E é classificado como descritivo, pois se preocupa em descrever o fenômeno da dificuldade encontrada pelo enfermeiro obstetra em se comunicar com a gestante surda e, finalmente, qualitativa, pois não esta baseada em referencias numéricas, mas sim em dados da análise literária.

Para a análise, extração e síntese dos dados dos estudos selecionados, foi utilizado o formulário de extração de dados de ensaios clínicos. Foram extraídas as seguintes informações: ano de publicação, autor, desenho do estudo, referencial teórico utilizado, objetivo do estudo.

\section{RESULTADOS E DISCUSSÃO}

Diante do estudo realizado, pôde-se observar a dificuldade de comunicação por parte dos profissionais de saúde, pois a maioria não consegue realizar o dialogo na Língua Brasileira de Sinais (Libras) por falta de domínio e conhecimento. Nota-se também que há despreparo da equipe multiprofissional diante da situação em que uma parturiente surda é exposta a grande estresse por não ser capaz de se comunicar de modo que fosse compreendida. Nessa situação existe o apelo a mimicas e a linguagem escrita para que possa acontecer um dialogo onde ambas as partes consigam se comunicar, pondo em prática a sensibilidade e humanização por parte da equipe de saúde, tendo um novo olhar de parto humanizado.

Enfatizaram também a relevância da incorporação da aprendizagem dessa língua no desenvolvimento acadêmico dos profissionais de saúde. Sendo indispensável sensibilizar os profissionais de saúde para produzirem estratégias que estimulem os cuidados inclusivos às mulheres surdas.

O auxílio do intérprete de libras é uma pequena parcela para o processo de evolução de desenvolvimento de humanização do parto. Este profissional contribui para que a parturiente sinta-se segura, visto que a paciente sabe o que está sendo feito durante os procedimentos, e também pelo fato que a mesma muitas vezes não é capaz de conseguir se comunicar com toda a equipe de saúde A troca da LS por outro meio de comunicação com o surdo, é capaz de resultar em desconforto para eles. A assistência do intérprete é provável de melhorar o atendimento, contudo não é decisiva para que ele seja de qualidade. 
Mesmo com o auxilio de um interprete, a necessidade de um profissional capacitado é indispensável, além de estar conforme pede a legislação e garantir a inclusão. Ao chegar em um ambiente hospitalar e se deparar com um profissional capacitado, a gestante terá uma segurança maior do que com um interprete, uma vez que, conversando diretamente com o profissional a segurança passada será maior e isto levara a uma assistência de qualidade.

Nesta etapa do projeto pode - se resumir os seguintes aspectos relacionados a assistência: Politicas publicas: mesmo existindo uma legislação, ela não é vista na pratica do profissional de saúde; barreiras na comunicação: ainda existem barreiras na comunicação com os surdos, não há profissionais capacitados e nem interpretes; Queixas inespecíficas: má vontade do profissional, atendimento de baixa qualidade, dificuldades socioeconômicas.

Quadro 1- Características gerais dos artigos selecionados para análise.

\begin{tabular}{|l|l|l|}
\hline Artigo & Objetivo & Ano \\
\hline Chaveiro et al. & $\begin{array}{l}\text { Caracterizar a comunicação dos profissionais da saúde com a pessoa surda e } \\
\text { descrever recursos de relacionamento. }\end{array}$ & 2010 \\
\hline Nascimento et al. & $\begin{array}{l}\text { Apresentar a experiência vivenciada pelo profissional enfermeiro na consulta } \\
\text { à gestante surda numa Unidade de Saúde da Família - USF, no município de } \\
\text { Barrados Garças - MT. }\end{array}$ & 2011 \\
\hline Equy et al. & Avaliar a gestão desse paciente e propor algumas melhorias em potencial & 2012 \\
\hline Oliveira et al. & $\begin{array}{l}\text { Revelar como os surdos percebem a comunicação com os profissionais de } \\
\text { saúde, e compreender o significado da presença de um acompanhante orali- } \\
\text { zado como interlocutor, durante atendimento na rede pública de serviços } \\
\text { de saúde. }\end{array}$ & 2014 \\
\hline Brito et al. & $\begin{array}{l}\text { Apresentar panoramicamente alguns dispositivos legais que norteiam o en- } \\
\text { fermeiro e o cliente surdo em instituições de saúde. }\end{array}$ & 2015 \\
\hline Ferreira et al. & $\begin{array}{l}\text { Investigar a assistência de enfermagem ao trabalho de parto e parto, atra- } \\
\text { vés da percepção das parturientes, buscando desse modo, contribuir para o } \\
\text { aprimoramento do cuidado, uma vez que esse, para ser realizado, precisa da } \\
\text { contribuição direta tanto do profissional, quanto do cliente. }\end{array}$ & 2016 \\
\hline Silva et al. & $\begin{array}{l}\text { Determinar os principais desafios enfrentados pelos profissionais de enfer- } \\
\text { magem durante a assistência prestada aos usuários com DSA, em três hospi- } \\
\text { tais públicos do Distrito Federal (DF) }\end{array}$ & 2017 \\
\hline Nascimento et al. & Descrever as experiências de mulheres surdas durante a gravidez e parto. & 2017 \\
\hline
\end{tabular}

Elaborada pelas autoras.

Quadro 2- Características gerais das monografias selecionadas para análise.

\begin{tabular}{|l|l|l|}
\hline Monografia & Objetivo & Ano \\
\hline Costa et al. & $\begin{array}{l}\text { Identificar, através das percepções dos profissionais de enfermagem, como } \\
\text { o ambiente das praticas de saúde das unidades básicas tem possibilitado o } \\
\text { uso dos serviços pelo usuário surdo, considerando que este indivíduo, além } \\
\text { de sua necessidade especifica decorrente da condição de surdez, possui tam- } \\
\text { bém necessidades de saúde comuns a todos os cidadãos. }\end{array}$ & 2013 \\
\hline Miranda et al. & $\begin{array}{l}\text { Identificar as expectativas dos deficientes auditivos quanto as mais adequa- } \\
\text { das alternativas de comunicação não verbal a serem utilizadas pela equipe de } \\
\text { enfermagem para a assistência e cuidados de suas necessidades especificas. }\end{array}$ & 2014 \\
\hline
\end{tabular}

Elaborada pelas autoras. 


\section{CONCLUSÃO}

No decorrer desta pesquisa foi possível compreender a importância e necessidade da assistência a gestantes surdas de maneira integral e que possa suprir da e qualquer carência da assistência. A análise dos dados demonstrou os serviços de saúde ainda se encontram com uma assistência inadequada e com uma qualidade reduzida. Apesar de terem conhecimento sobre a legislação, os profissionais de saúde não estão preparados para a recepção das gestantes.

Existem muitas barreiras na assistência, é um desafio para toda a equipe de saúde se comunicar com os surdos. A capacitação de profissionais para a assistência as gestantes surdas é importante e essencial para a promoção de uma assistência humanizada e mais inclusa na sociedade. Além de ser um direito, é obrigação dos profissionais ofertar aos clientes uma atenção integral e mais humanizada o possível. Os profissionais devem buscam desenvolver capacitações, programas de educação continuada e treinamentos adequados para que possam auxiliar os clientes e assim quebrar todas as barreiras existentes na comunicação.

Seria de extrema importância que as leis fossem seguidas, como por exemplo, a Lei 17.029\2020 que dispõe sobre o acompanhamento de gestantes surdas por profissionais da sua escolha que possam traduzir e ser o intermediário da comunicação, desde que o acompanhante não esteja apto de se comunicar com ela e com a equipe de saúde.

\section{REFERÊNCIAS}

http://www.alepe.pe.gov.br/proposicao-texto-completo/?docid=4894\&tipoprop=p

https://bdm.unb.br/bitstream/10483/6916/1/2013_MarianaFerreiraMarquesCosta.pdf

http://blog.handtalk.me/historia-lingua-de-sinais/

BRASIL. Constituição (1988). Constituição da República Federativa do Brasil. Brasília, DF, Senado, 1998.

BRASIL. Decreto n. 3.298, de 20 de dezembro de 1999. Regulamenta a Lei no 7.853, de 24 de outubro de 1989, dispõe sobre a Política Nacional para a Integração da Pessoa Portadora de Deficiência, consolida as normas de proteção, e dá outras providências. Diário Oficial da República Federativa do Brasil, Brasília, DF, 21 dez. 1999.

BRASIL. Ministério da Saúde. Secretaria de Atenção à Saúde. Política Nacional de Saúde da Pessoa Portadora de Deficiência. Ministério da Saúde, Secretaria de Atenção à Saúde - Brasília: Editora do Ministério da Saúde, 2010.

http://bvsms.saude.gov.br/bvs/publicacoes/manual_acolhimento_classificacao_risco_obstetricia.pdf http://bvsms.saude.gov.br/bvs/publicacoes/politica_nacional_humanizacao_pnh_folheto.pdf

Chaveiro N, Barbosa MA, Porto CC, Munari DB, Medeiros M, Duarte SBR. Atendimento à pessoa surda que utiliza a língua de sinais, na perspectiva do profissional da saúde. Cogitare Enferm. 15(4): 639-45, 2010. 
Equy, V; Derore, A; Vassort, N; Mongourdin, B; Sergent, F.J Gynecol Obstet Biol Reprod (Paris); 41(6): 561-5, 2012 Oct.

FERREIRA, Luiza Mairla Soares et al. Assistência de enfermagem durante ou parto e parto: a percepção da mulher. Revista Cubana de Enfermagem, [Sl], v. 33, n. 2 de junho 2017. ISSN 1561-2961.

Ferro, C. C., dos Santos, C. M., \& de Campos, L. P. F. (2018). DESAFIOS DA EQUIPE DE ENFERMAGEM NO ATENDIMENTO HUMANIZADO AO PACIENTE SURDO. Perspectivas Online: Biológicas \& Saúde, 8(27).

https://g1.globo.com/pe/pernambuco/noticia/2020/08/19/1ei-determina-que-gravidas-surdas-podem-ter-tradutores-e-interpretes-de-libras-presentes-durante-parto.ghtml

LOPES, KARINA BARROS et al.. ASSISTÊNCIAAO PARTO DE UMA GESTANTE COM DEFICIÊNCIA AUDITIVA: RELATO DE EXPERIÊNCIA POR ACADÊMICOS DE ENFERMAGEM.. In: Anais do Congresso Brasileiro de Enfermagem Obstétrica e Neonatal. Anais...Campo Grande(MS) CCARGC, 2018.

Nascimento VF. Desafio do enfermeiro na consulta à gestante surda: relato de experiência. Nursing (São Paulo). 2011; 13(154):144-147.

https://www.ouviclin.com.br/surdez/direitos-dos-surdos

http://www.planalto.gov.br/ccivil_03/_Ato2004-2006/2005/Lei/L11108.htm

http://www.planalto.gov.br/ccivil_03/leis/2002/110436.htm

REILY, Lucia. O papel da Igreja nos primórdios da educação dos surdos. Rev. Bras. Educ., Rio de Janeiro , v. 12, n. 35, p. 308-326, Aug. 2007.

http://revista.faciplac.edu.br/index.php/RSF/article/view/101/57

SILVA, Elisabeth Soares Pereira da; PRADO, Rayssa Ferreira Sales de; PEREIRA, Sandyhelly Assunção; SILVA, Joerica da; MARTINS, Wanderson Alves. Elaboração de um instrumento educativo para atendimento de surdos nas unidades básicas de saúde: relato de experiência / elaboración de un instrumento educativo para atender a los sordos en las unidades básicas de salud: informe de experiência, Brazilian Journal of Development, v. 6, n. 7. 2020.

https://www.saude.gov.br/atencao-especializada-ehospitalar/especialidades/ otorrinolaringologia/prevenção

SOUSA, E.M.; ALMEIDA, M.A.P.T. Atendimento ao surdo na atenção básica: perspectiva da equipe multidisciplinar. Id onLine Revista Multidisciplinar e de Psicologia, Pernambuco, nº33, p. 72-82, 2017.

http://www.unirio.br/ppgenf/dissertacoes/dissertacoes-ppgenf-unirio-ano-2014/dissertacao-rodrigo-sousa-de-miranda

https://webcache.googleusercontent.com/search?q=cache:01BDrIonQ0IJ:https://www3.fmb.unesp.br/sete/ pluginfile.php/2645/mod_folder/content/0/apostila/032_Cochrane_Higgins_26APR2011.pdf\%3Fforcedownload $\% 3 \mathrm{D} 1+\& \mathrm{~cd}=1 \& \overline{\mathrm{h}} \mathrm{l}=\mathrm{pt}-\mathrm{BR} \& \mathrm{ct}=\mathrm{clnk} \& \mathrm{gl}=\mathrm{br}$ 


\section{PERFIL FUNCIONAL DA BEXIGA EM PACIENTES COM DOENÇA DE PARKINSON}

SÂNZIA DA SILVA VIRGINIO MELGÃO

Discente em fisioterapia na UFRN bexiga hiperativa durante o período pesquisado sendo uma questão que afeta o físico e o emocional. Necessitando de um olhar multidisciplinar, visto que essas disfunções apresentam impactos na participação social e qualidade de vida.

PALAVRA-CHAVE: Doença de Parkinson, bexiga urinária, qualidade de vida.

\section{(DP) é considerada a segunda doença neurode-}

RESUMO: Introdução: A Doença de Parkinson generativa mais comum, apresentando caráter progressivo e irreversível. Destaca-se como sintomas não motores a presença de disfunções urinárias. É uma patologia que afeta a qualidade de vida do paciente uma vez que compromete seu sistema motor, reduzindo suas atividades do cotidiano, limitando sua interação social e afetando o seu estado psicológico que poderá ser passível de outras patologias psíquicas como a depressão, ideia suicidas, isolamento social. Objetivo: Traçar o perfil funcional da bexiga dos pacientes com Doença de Parkinson Métodos: Trata-se de um estudo transversal, desenvolvido no Centro de Educação e Pesquisa em Saúde Anita Garibaldi e aprovado pelo comitê de Ética em Pesquisa (CAAE:09905119.7.0000.5537). A amostra foi composta por 12 pacientes. Os dados foram coletados mediante a realização de uma entrevista semi-estruturada, associada ao estudo urodinâmico e avaliação miccional. Resultados: A amostra foi composta por 9 homens e 3 mulheres, com idade média de 60,5 anos $( \pm 9,81)$. O estadiamento da doença foi pela escala Hoen e Yahr, apresentou variação entre os estágios 1 e 4 . Em relação ao perfil funcional da bexiga observou-se uma média de frequência urinária diária de $8,37( \pm 5,10)$ e presença de hiperatividade detrusora em 9 doas 12 participantes. Conclusão: Os dados corroboram com o que é descrito na literatura, caracterizando a bexiga hiperativa como principal alteração miccional. Os pacientes apresentaram a
ABSTRACT: ABSTRACT: Introduction: Parkinson's disease (PD) is considered the second most common neurodegenerative disease, presenting a progressive and irreversible character. The presence of urinary dysfunctions stands out as non-motor symptoms.E a pathology that affects the quality of life of the patient since it compromises his motor system, reducing his daily activities, limiting his social interaction and affecting his psychological state which may be susceptible to other psychic pathologies such as depression, suicidal ideas, social isolation. Objective: To trace the functional profile of the bladder of patients with Parkinson's Disease Methods: This is a cross-sectional study, developed at the Anita Garibaldi Health Education and Research Center and approved by the Research Ethics Committee (CAAE: 09905119.7.0000.5537) . The sample consisted of 12 patients. Data were collected through a semi-structured interview, associated with urodynamic study and voiding evaluation. Results: The sample consisted of 9 men and 3 women, with an average age of 60.5 years $( \pm$ 9.81). The disease was staged using the Hoen and Yahr scale, with variation between stages 1 and 4. Regarding the functional profile of the bladder, an average daily urinary frequency of 8.37 $( \pm 5.10)$ and the presence of hyperactivity were observed. detrusora in 9 of the 12 participants. 
Conclusion: The data corroborate what is described in the literature, characterizing the overactive bladder as the main voiding alteration. Patients had an overactive bladder during the survey period, which is an issue that affects the physical and emotional. Needing a multidisciplinary look, as these dysfunctions have an impact on social participation and quality of life.

KEYWORDS: Parkinson's disease, urinary bladder, quality of life. Três a cinco palavras.

\section{INTRODUÇÃO}

Nesse capitulo, vamos entender um pouco sobre a doença de Parkinson, entendendo alguns aspectos como ocorre a doença, principais sintomas, pontos importantes e controvertidos da patologia. Nesse estudo, houve o direcionamento a verificação da ocorrência da bexiga hiperativa que leva a alteração miccional afetando de maneira intensa a qualidade de vida do paciente. Assim, a doença de Parkinson deve ser vista como uma patologia que deve ser tratada de forma multidisciplinar, sendo tratada por fisioterapeuta, terapeuta ocupacional, nutrição, médico, assistente social, psicólogo, dentre outros profissionais que se fizerem necessário conforme o caso.

\section{DOENÇA DE PARKINSON E O ENVELHECIMENTO}

A doença de Parkinson se trata de uma doença degenerativa do sistema nervoso central, se apresenta de forma crônica com caráter progressivo, sendo mais comumente relatada em pessoas ido-

sas. É verdade que a medida que envelhecemos nossas células nervosas diminuem e com isso diminui a produção de dopamina. A dopamina é um neurotransmissor, ajudando na veiculação de mensagens entre as células nervosas. As células situadas na substancia negra se degeneram e são essas células que produzem a dopamina, substância que conduz as correntes nervosas pelo corpo humano.

Existem pacientes que perdem essa células produtoras de dopamina e manifestam os sintomas da doença de Parkinson, é uma doença que não em o caráter da hereditariedade.

O quadro clinico é composto por basicamente sintomas na parte motora como tremores, lentidão e diminuição dos movimentos planejados, músculos rígidos ao nível das articulações, dificuldades no equilíbrio. Com relação ao tremor ocorre quando o paciente está em repouso, se percebe ao segura uma folha de papel ou algo leve e piora quando o mesmo se encontra nervoso, ansioso, preocupado.

O paciente começa a realizar tarefas do cotidiano de forma lenta e muitas vezes os familiares e pessoas mais próximas não chegam a perceber o que ocorre no início da patologia, entretanto, os movimentos vão ficando mais lentos e então se percebe que a pessoa tem rigidez, lentidão de movimentos, aleém de outros sintomas como distúrbios da fala, dificuldade de engolir, dores, tontura, falta 
de equilíbrio, dificuldade em deambular, distúrbios do sono, respiratórios e distúrbio urinário ( bexiga hiperativa).

Muitos estudos apontam que a doença de Parkinson apresenta causa ambiental e genética, ou seja, pode ser inúmeros fatores. O problema urinário afeta muitos pacientes com Parkinson.

\section{DOENÇA DE PARKINSON E OS DIRTUBIOS URINÁRIOS}

Os pacientes que apresentam a doença de Parkinson tem muitas queixas de ordem urinária como, precisar ir muitas vezes realizar micções, sendo necessário em muitos casos interromper alguma atividade do cotidiano para urinar e as vezes não tem o tempo necessário para se deslocar para urinar ocorrendo a incontinência urinaria. É muito constrangedor para o paciente realizar atividades em locais sociais como clubes, parques, áreas comerciais em razão de apresentar a incontinência urinária. O esvaziamento vesical não ocorre de forma adequada o que pode ser em razão da hiperatividade da bexiga, comprometendo a qualidade de vida do paciente de forma acentuada.

Assim, por ser a bexiga hiperativa um traço frequente nos pacientes de Parkinson foi realizado um estudo com a finalidade de traçar o perfil desses pacientes. O estudo foi realizado no Centro de educação e Pesquisa em Saúde Anita Garibaldi localizado em Macaíba/RN, fundado em 2008, destinado a pesquisa e desenvolvimento e educação de profissionais de saúde, é um serviço de referência ambulatorial na suade materno-infantil, atende pacientes do SUS.

Então, o estudo foi aprovado pelo comitê de ética em pesquisa (CAAE:09905119.7.0000.5537), a amostra foi realizada em doze pacientes, sendo nove homens e três mulheres com a idade média de 60 sessenta anos na época da pesquisa. Os pacientes foram avaliados conforme a escala de Hoehn e Yahr que consiste numa escala que avalia a incapacidade dos indivíduos com doença de Parkinson, indicando estágios para a doença de Parkinson foram verificados pacientes entre os estágios de 1 ao estágio 04.

E o perfil do funcionamento da bexiga ficou verificado uma média de frequência urinária diária de 8,37 e em 09 dos 12 participantes ocorreu a presença de hiperatividade detrusora, ou seja mais de $50 \%$ dos pacientes observados apresentaram distúrbios urinários que comprometem a qualidade de vida deles. Em entrevista com os pacientes foi possível averiguar que a qualidade de vida dos mesmos é impactada, muitas vezes reduzindo ou impedindo o convívio social saudável, por este motivo pode os pacientes com estes distúrbios apresentar tendência ao isolamento social, depressão, frustações porque o convivo social com parentes e amigos fica prejudicado.

Nessa entrevista foi questionado aspectos urodinâmico e avaliação miccional, como quantas vezes ocorria a micção por dia, em que momentos, quais as dificuldades para realizar a micção em casa e fora de casa, se precisava de ajuda de terceiros para se deslocar para realizar a micção, resumindo foram feitas perguntas para coletar os dados a respeito da função miccional do paciente, sabendo como o mesmo se comporta e reage diante desse possível distúrbio. 


\section{CONCLUSÃO}

Diante dos dados coletados foi possível comprovar o que a literatura inerente a esse assunto afirma que a bexiga hiperativa consiste na principal alteração miccional do paciente com Parkinson, uma vez que a maioria dos pacientes analisados apresentaram alteração de ordem miccional, além disso, se conclui que disfunções urinárias comprometem a vida, o cotidiano, a sociabilidade de pacientes com doença de Parkinson, sendo necessário apoio familiar, bem como, um olhar multidisciplinar para auxiliar o paciente a se ajustar no seu dia- a dia e conseguir realizar suas tarefas diárias de forma mais segura e confortável.

\section{REFERENCIAS}

D’ANCONA, Carlos Arturo Levi. Avalição Urodinâmica e suas aplicações Clinicas. Editora Atheneu, 2015;

D’ANCONA, Carlos Arturo Levi. Aplicações Clinicas da Urodinâmica. Editora Atheneu. 2015;

MD NETTER, Frank H. Atlas de Anatomia Humana. $7^{\circ}$ Edição. Editora Elsevier. 


\section{AVALIAÇÃO ANATOMOPATOLÓGICA DE NÓDULOS DA TIREOIDE DIAGNOSTICADOS EM PACIENTES DA CIDADE DE MARINGÁ-PR}

VITOR ZANATA ADACHESKI

Universidade Estadual de Maringá - Paraná

JOÃO VITOR SCALON ESTÉRCIO RIZZO

Universidade Estadual de Maringá - Paraná

IORRAN NOCETI SILVESTRI

Universidade Estadual de Maringá - Paraná

MARIA CLARA ICERI

Universidade Estadual de Maringá - Paraná

EDILSON NOBUYOSHI KANESHIMA

Universidade Estadual de Maringá - Paraná

PAOLA DA COSTA SOUZA

Universidade Estadual de Maringá - Paraná

TÂNIA CRISTINA ALEXANDRINO

BECKER

Universidade Estadual de Maringá - Paraná

ALICE MARIA DE SOUZA KANESHIMA

Universidade Estadual de Maringá - Paraná analisados. O gênero feminino foi o mais afetado, apresentando a proporção de 4:1. A média de idade entre os pacientes foi de 49,4 anos e $40,2 \%$ dos nódulos estavam localizados no lobo direito, $33,2 \%$ no lobo esquerdo e 5,5\% em ambos lobos. $54,3 \%$ dos tumores apresentaram tamanho menor ou igual a $1 \mathrm{~cm}$. Além disso, de acordo com a descrição histopatológica, $84,1 \%$ dos tumores eram malignos, $2,6 \%$ benignos, $8,9 \%$ correspondiam a tireoidopatia não neoplásica e $4,4 \%$ foram encaminhados para análise imunohistoquímica. Dentre os tumores malignos, 96,3\% eram do tipo carcinoma papilífero. A classificação TNM é muito importante, mas neste estudo esta classificação não foi realizada adequadamente, pois o material de biópsia encaminhado para o laboratório não foi suficiente para realizar esta classificação de forma adequada. A obtenção das informações relacionadas com a malignidade, tamanho e localização da massa tumoral são relevantes por auxiliar na tomada de decisão em relação ao tratamento.

PALAVRA-CHAVE: Câncer da Tireoide; Nódulos da Tireoide;Carcinoma Papilífero, Classificação TNM.

ABSTRACT: The aim of this study was to collect anatomopathological information of thyroid nodules evaluated by the laboratory in the city of Maringá from January 2012 to December 2016. Informations were collected from the laboratory database. The anatomopathological reports of the thyroid nodules were selected to obtain informations such as: patient's gender and age; TNM classification, description and anatomical localization of tumor. In total, 542 reports were analysed. Female gender was the most affected, 
presenting a 4:1 ratio. The mean age among all patients was 49.4 years and $40.2 \%$ of the nodules were located in right thyroid lobe, $33.2 \%$ in left lobe and $5.5 \%$ in both lobes. $54.3 \%$ of the tumors had a size less than or equal to $1 \mathrm{~cm}$. Thyroid nodules were either malignant tumors $(84.1 \%)$ or benign tumors $(2.6 \%)$ and non-neoplasic thyroidopathy $(8.9 \%) .4 .4 \%$ were referred for immunohistochemical analysis. Among the malignous tumors, $96.3 \%$ were papillary carcinomas. The TNM classification is very important. TNM classification has not been performed properly. Biopsy material sent to the laboratory was not enough to perform proper classification. Obtaining information related to the malignancy, size and location of the tumor mass is relevant for assisting in decision making regarding treatment.

KEYWORDS: Thyroid Cancer; Thyroid Nodules; Papillary Carcinoma, TNM Classification.

\section{INTRODUÇÃO}

Os nódulos da tireóide apresentam grande variedade neoplásica, sendo desde adenomas foliculares até carcinomas (KUMAR, ABBAS, ASTER, 2020). O câncer da tireoide é a malignidade endócrina mais comum na atualidade (NETEA-MAIER et al., 2015), sendo que, para o Brasil, estima-se 1.830 novos casos no gênero masculino e 11.950 no feminino para cada ano do biênio 2020-2022, estimando-se um risco de 1,72 casos a cada 100 mil homens e 11,15 casos a cada 100 mil mulheres (BRASIL, 2019). A incidência do câncer da tireoide tem aumentado nos últimos anos, embora a mortalidade se mantenha constante. Esse processo é explicado pela introdução de novos métodos diagnóstico, dentre eles a ultrassonografia, causando sobrediagnóstico dessas patologias (KITAHARA, SCHNEIDER, BRENNER, 2018; VACCARELLA et al., 2016).

Os fatores de risco predisponentes para o desenvolvimento da doença são: exposição à radiação ionizante, principalmente na infância, história familiar de câncer de tireoide e dieta pobre em iodo (AMERICAN CANCER SOCIETY, 2019; STEWART, WILD, 2014). Além disso, também são fatores de risco:gênero feminino, tabagismo, obesidade, poluentes ambientais e exposições ambientais (THUN et al., 2017). A maior incidência do câncer da tireoide em mulheres em idade fértil está relacionada a influência do estrógeno sobre a proliferação neoplásicas por meio da ativação de seus receptores alfa e beta. Em um estudo foi observada maior presença de receptores beta em tecido neoplásico maligno, mas com característica de tecido diferenciado de tireoide e uma menor expressão do mesmo em tecido tireoidiano normal. A expressão desse receptor está associada ao maior risco de metástase linfonodal e à distância (CUNHA et al., 2017).

Os adenomas de tireoide são neoplasias benignas e encapsuladas derivadas do epitélio folicular, sendo firmes ou elásticos, homogêneos, redondos ou ovais e envoltos por uma cápsula fina e fibrosa. Os carcinomas foliculares apresentam características microscópicas similares aos adenomas, porém o carcinoma tende a ser mais celular, com cápsula grossa e irregular, frequentemente com regiões de necrose e maior presença de figuras de mitose (MCHENRY et al., 2011). Esse tipo de tumor comprime a tireoide adjacente não neoplásica. A maioria dos adenomas foliculares são não funcionais, no entanto, uma pequena parcela produz hormônios tireoidianos, sendo consideradosadenomas tóxicos que provocam a tireotoxicose. 
Clinicamente, a maioria dos pacientes com adenoma folicular ou carcinoma folicular se apresentam como um nódulo solitário em uma glândula tireoide normal. Porém, ambos podem ocorrer em associação com tireoidite e/ou hiperplasia nodular. Tumores muito grandes podem promover dispneia, crises de tosse ou sufocamento, rouquidão e disfagia como resultado de compressão da traqueia, nervo laríngeo recorrente ou esôfago pelo nódulo (MCHENRY et al., 2011).

O processo de diagnóstico se baseia na injeção de iodo radioativo: os adenomas captam menos iodo que o tecido tireoidiano normal e por isso aparecem como nódulos frios no mapeamento com iodo radiativo (KUMAR, ABBAS, ASTER, 2020). Dos nódulos frios, cerca de 10\% são carcinomas da tiroide (BOMELI et al., 2010). Por outro lado, é raro que nódulos hipercaptantes correspondam a neoplasias malignas. O diagnóstico de tireotoxicose é confirmado pela presença de nódulo quente. A grande maioria dos adenomas não sofrem malignização e apresentam um bom prognóstico (KUMAR, ABBAS, ASTER, 2020).

O câncer de tireoide pode ser classificado em carcinoma diferenciado da tireoide (CDT), carcinoma medular da tireoide (CMT) e carcinoma indiferenciado ou anaplásico da tireoide (CAT) (BRAY et al., 2018; HSU et al., 2014; HU et al., 2014).

O CDT representa cerca de $90 \%$ de todas as neoplasias tireoidianas e é dividido em carcinoma papilífero (CPT) e carcinoma folicular (CFT), sendo ambos derivados das células foliculares da tireoide. O primeiro é considerado a neoplasia tireoidiana mais comum (50-90\% de todos CDTs), apresentando-se firme, não encapsulado ou parcialmente encapsulado. É caracterizado histologicamente pela formação de papilas e por um conjunto de alterações nucleares (KUMAR, ABBAS, ASTER, 2020). Este carcinoma se apresenta clinicamente como nódulos tireoidianos simples e assintomáticos, mas podem exibir caráter de massa em linfonodo cervical. Disfagia, rouquidão, tosse e dispneia são indicativos de doença avançada, na qual metástases hematogênicas comumente estão presentes (THUN et al., 2017). O diagnóstico é baseado na distinção entre os nódulos benignos e malignos, por meio do mapeamento de radionuclídeo e Punção Aspirativa por Agulha Fina (PAAF). Os carcinomas papilares são massas frias na cintilografia e as análises citológicas tem feito a PAAF o método mais utilizado na distinção de tais nódulos. O CPT apresenta crescimento lento e, apesar de frequentemente se espalharem para os linfonodos do pescoço, são facilmente tratáveis e raramente fatais (MELMED et al., 2015).

O CFT constitui 5\% a 50\% dos CDTs e são mais comuns em áreas com deficiência de iodo. É caracterizado histologicamente por folículos bem formados, presença de invasão de cápsula, vasos sanguíneos e/ou invasão do tecido tireoidiano adjacente. Apresenta alguns subtipos histológicos, como o tumor classificado como de células de Hürthle ou células oxifílicas (MELMED et al., 2015). Apresenta-se clinicamente como nódulos indolores que crescem lentamente. Na cintilografia são nódulos frios, embora possam estar hiperfuncionantes se tornando quentes. O prognóstico depende da extensão da invasão e do estadiamento tumoral. Os CDT são tratados cirurgicamente através de tireoidectomia total e seguimento do paciente (KUMAR, ABBAS, ASTER, 2020; THUN et al., 2017). Apesar de o câncer da tireoide apresentar um bom prognóstico na maioria dos casos, quando o tumor não é diferenciado, esse prognóstico piora de forma significativa (NETEA-MAIER et al., 2015). 
O CMT representa 5-7\% dos cânceres tireoidianos (HU et al., 2014) e, diferentemente das outras neoplasias dessa glândula, o CMT pode apresentar uma predisposição familiar (KLOOS et al., 2009). Mutações germinativas no oncogeneRET estão presentes em 25\% a 35\% dos CMT. Além disso, até $65 \%$ dos pacientes com a forma esporádica do CMT apresentam tal mutação (DVORAKOVA, et al 2008; ELISEI et al., 2008). O CMT divide-se em CMT esporádico e CMT hereditário. O primeiro é a forma mais comum de CMT e não está associado a mutações no protooncogeneRET. Geralmente está presente em apenas um lobo da glândula ( $80 \%$ dos casos), ocorrendo em taxas equivalentes tanto em homens como em mulheres e na quarta década de vida (KLOSS et al., 2008). Pode sofrer metástase para regiões distantes da glândula tireoide, como para o fígado, pulmões, ossos, cérebro, pele e linfonodos(DURANTE et al., 2006). A forma hereditária do CMT está associada a mutações no protooncogene RET, pode ocorrer nos dois lobos da glândula tireoide e comumente ocorre em indivíduos com menos de 20 anos de idade, sendo que os pacientes frequentemente apresentam histórico familiar dessa forma de CMT. Assim como a forma esporádica, pode sofrer metástase para os pulmões, fígado e linfonodos, predispondo os pacientes a altas taxas de morbidade e mortalidade (KLOSS et al., 2008).

O CAT, diferentemente do CDT, é uma das neoplasias humanas mais agressivas. Apesar de representar apenas $2 \%$ das malignidades da tireoide, esses pacientes apresentam uma sobrevida média de 5 meses, sendo que apenas 20\% sobrevivem mais do que 1 ano (ARE et al., 2006; SMALLRIDGE et al., 2010). A apresentação clínica do CAT é frequentemente caracterizada por um crescimento rápido de uma massa na região do pescoço, associado a sintomas de compressão (NEFF et al., 2008). Além disso, essa forma apresenta um comportamento altamente invasivo, atingindo os linfonodos em $40 \%$ dos pacientes e regiões distantes da glândula tireoide em 60\% dos casos (CHEN et al., 2008). Outrossim, tratamentos que geralmente funcionam para o CDT, como ressecção cirúrgica e ablação por iodo radioativo são paliativas para o CAT devido à agressividade e capacidade de resistência dessa forma de câncer (SMALLRIDGE et al., 2010).

A classificação TNM corresponde a um sistema que avalia o acometimento e a extensão de tumores, sendo essencial para determinar o planejamento terapêutico e indicar o prognóstico e o acompanhamento do paciente. O sistema de estadiamento recomendado pela American ThyroidAssociation é a classificação TNM da American Joint CommitteeonCancer (AJCC, $7^{\text {a }}$ edição 2010). Tal sistema baseia-se no exame anátomo-patológico e na descrição cirúrgica, sendo utilizados três critérios para avaliar o estágio do câncer de tireoide: tamanho e extensão do tumor primário ( $\mathrm{T}$ ), presença ou ausência de metástases linfonodais regionais $(\mathrm{N})$ e a presença ou ausência de metástases à distância $(\mathrm{M})$.

Com o intuito de conhecer melhor as características dos nódulos da tireóide, neste trabalho foram coletadas informações anatomopatológicas de pacientes atendidos por um laboratório da cidade de Maringá referente ao período de janeiro de 2012 até dezembro de 2016. 


\section{MATERIAIS E MÉTODOS}

As informações foram coletadas junto ao banco de dados de um laboratório de Anatomia Patológica de Maringá-PR, e a seleção dos laudos anatomopatológicos de nódulos da tireoide, referente ao período de janeiro de 2012 até dezembro de 2016, foi realizada utilizando as palavras chave: câncer da tireoide; nódulo da tireoide; carcinoma papilíferoda tireoide; carcinoma folicularda tireoide; carcinoma medularda tireoide; carcinoma anaplásicoda tireoide; tireoide.

A partir dos laudos selecionados foram obtidas informações como:gênero e idade do paciente; descrição histopatológica, localização, anatômica e tamanho do tumor; produto da tireoidectomia, classificação TNM e análise imunohistoquímica. As informações coletadas foram anotadas em formulário próprio, seguindo as recomendações do protocolo do Collegeof American Pathologists (CAP) atualizado e publicado em junho de 2012. Para a análise das informações e elaboração de tabelas foi utilizado o software Microsoft Excel® versão 2016.

\section{RESULTADOS E DISCUSSÃO}

As informações contidas em 542 laudos anatomopatológicos de pacientes portadores de nódulos da tireoide, referente ao período de janeiro de 2012 a dezembro de 2016, foram analisadas e a distribuição dos processos patológicos, gênero, faixa etária, localização,tamanho e produto de tireoidectomia está apresentada na Tabela 1 . 
Tabela 1 - Distribuição dos processos patológicos, gênero, faixa etária, localização e tamanho do tumor, produto de tireoidectomiaobtidos a partir da análise de 542 laudos anatomopatológicos de pacientes portadores de nódulos da tireoide

\begin{tabular}{|c|c|c|c|c|c|c|c|c|c|c|c|c|c|c|c|c|c|c|c|c|}
\hline \multirow{4}{*}{ Variáveis } & \multirow{2}{*}{\multicolumn{4}{|c|}{$\begin{array}{l}\text { TIREOIDOPATIA } \\
\text { NÄO NEOPLȦSICA }\end{array}$}} & \multirow{2}{*}{\multicolumn{4}{|c|}{$\begin{array}{l}\text { NEOPLASIA } \\
\text { BENIGNA }\end{array}$}} & \multicolumn{8}{|c|}{ NEOPLASIA MALIGNA } & \multirow{2}{*}{\multicolumn{2}{|c|}{$\begin{array}{l}\text { COMPLEMENTAÇÄO } \\
\text { IMUNOHISTOQUIMICA }\end{array}$}} & \multirow{3}{*}{\multicolumn{2}{|c|}{ Total }} \\
\hline & & & & & & & & & & CD & & & & CMT & & CAT & & & & \\
\hline & \multicolumn{2}{|r|}{ BMC } & \multicolumn{2}{|c|}{ THN } & \multicolumn{2}{|r|}{$\mathrm{AF}$} & \multicolumn{2}{|r|}{ CLP } & \multicolumn{2}{|r|}{ CP } & \multicolumn{2}{|r|}{ CF } & \multirow[b]{2}{*}{$\mathbf{N}$} & \multirow[b]{2}{*}{$\%$} & \multirow[b]{2}{*}{$\mathbf{N}$} & \multirow[b]{2}{*}{$\%$} & \multirow[b]{2}{*}{$\mathbf{N}$} & & & \\
\hline & $\mathbf{N}$ & $\%$ & $\mathbf{N}$ & $\%$ & $\mathbf{N}$ & $\%$ & $\mathbf{N}$ & $\%$ & $\mathbf{N}$ & $\%$ & $\mathbf{N}$ & $\%$ & & & & & & $\%$ & $\mathbf{N}$ & $\%$ \\
\hline Gênero & & & & & & & & & & & & & & & & & & & & \\
\hline Feminino & 27 & $79,4 \%$ & 12 & $85,7 \%$ & 9 & $81,8 \%$ & 1 & $33,3 \%$ & 350 & $79,7 \%$ & 8 & $80,0 \%$ & 2 & $66,7 \%$ & 4 & $100 \%$ & 20 & $83,3 \%$ & 433 & $79,9 \%$ \\
\hline Masculino & 7 & $20,6 \%$ & 2 & $14,3 \%$ & 2 & $18,2 \%$ & 2 & $66,7 \%$ & 89 & $20,3 \%$ & 2 & $20,0 \%$ & 1 & $33,3 \%$ & 0 & $0,0 \%$ & 4 & $16,7 \%$ & 109 & $20,1 \%$ \\
\hline Total & 34 & $100 \%$ & 14 & $100 \%$ & 11 & $100 \%$ & 3 & $100 \%$ & 439 & $100 \%$ & 10 & $100 \%$ & 3 & $100 \%$ & 4 & $100 \%$ & 24 & $100 \%$ & 542 & $100 \%$ \\
\hline Faixa etária & & & & & & & & & & & & & & & & & & & & \\
\hline s19 anos & 1 & $2,9 \%$ & 1 & $7,1 \%$ & 0 & $0,0 \%$ & 0 & $0,0 \%$ & 5 & $1,1 \%$ & 1 & $10,0 \%$ & 0 & $0,0 \%$ & 0 & $0,0 \%$ & 0 & $0,0 \%$ & 8 & $1,5 \%$ \\
\hline 20-29 anos & 2 & $5,9 \%$ & 1 & $7,1 \%$ & 0 & $0,0 \%$ & 0 & $0,0 \%$ & 26 & $5,9 \%$ & 0 & $0,0 \%$ & 0 & $0,0 \%$ & 0 & $0,0 \%$ & 4 & $16,7 \%$ & 33 & $6,1 \%$ \\
\hline 30-39 anos & 4 & $11,8 \%$ & 1 & $7,1 \%$ & 0 & $0,0 \%$ & 0 & $0,0 \%$ & 90 & $20,5 \%$ & 1 & $10,0 \%$ & 1 & $33,3 \%$ & 0 & $0,0 \%$ & 3 & $12,5 \%$ & 100 & $18,5 \%$ \\
\hline $40-49$ anos & 4 & $11,8 \%$ & 5 & $35,7 \%$ & 1 & $9,1 \%$ & 1 & $33,3 \%$ & 100 & $22,8 \%$ & 3 & $30,0 \%$ & 1 & $33,3 \%$ & 0 & $0,0 \%$ & 4 & $16,7 \%$ & 119 & $22,0 \%$ \\
\hline $50-59$ anos & 6 & $17,6 \%$ & 1 & $7,1 \%$ & 4 & $36,4 \%$ & 0 & $0,0 \%$ & 104 & $23,7 \%$ & 2 & $20,0 \%$ & 0 & $0,0 \%$ & 0 & $0,0 \%$ & 5 & $20,8 \%$ & 122 & $22,5 \%$ \\
\hline $60-69$ anos & 7 & $20,6 \%$ & 2 & $14,3 \%$ & 2 & $18,2 \%$ & 2 & $66,7 \%$ & 70 & $15,9 \%$ & 3 & $30,0 \%$ & 1 & $33,3 \%$ & 2 & $50,0 \%$ & 4 & $16,7 \%$ & 93 & $17,2 \%$ \\
\hline$\geq 70$ anos & 10 & $29,4 \%$ & 2 & $14,3 \%$ & 4 & $36,4 \%$ & 0 & $0,0 \%$ & 39 & $8,9 \%$ & 0 & $0,0 \%$ & 0 & $0,0 \%$ & 2 & $50,0 \%$ & 4 & $16,7 \%$ & 61 & $11,3 \%$ \\
\hline NI & 0 & $0,0 \%$ & 1 & $7,1 \%$ & 0 & $0,0 \%$ & 0 & $0,0 \%$ & 5 & $1,1 \%$ & 0 & $0,0 \%$ & 0 & $0,0 \%$ & 0 & $0,0 \%$ & 0 & $0,0 \%$ & 6 & $1,1 \%$ \\
\hline Total & 34 & $100 \%$ & 14 & $100 \%$ & 11 & $100 \%$ & 3 & $100 \%$ & 439 & $100 \%$ & 10 & $100 \%$ & 3 & $100 \%$ & 4 & $100 \%$ & 24 & $100 \%$ & 542 & $100 \%$ \\
\hline Localização & & & & & & & & & & & & & & & & & & & & \\
\hline Lobo & & & & & & & & & & & & & & & & & & & & \\
\hline $\begin{array}{l}\text { Direito(D) } \\
\text { Lobo }\end{array}$ & 7 & $20,6 \%$ & 1 & $7,1 \%$ & 4 & $36,4 \%$ & 1 & $33,3 \%$ & 189 & $43,1 \%$ & 4 & $40,0 \%$ & 1 & $33,3 \%$ & 0 & $0,0 \%$ & 11 & $45,8 \%$ & 218 & $40,2 \%$ \\
\hline Esquerdo(E) & 6 & $17,6 \%$ & 2 & $14,3 \%$ & 4 & $36,4 \%$ & 0 & $0,0 \%$ & 156 & $35,5 \%$ & 3 & $30,0 \%$ & 2 & $66,7 \%$ & 1 & $25,0 \%$ & 6 & $25,0 \%$ & 180 & $33,2 \%$ \\
\hline Istmo & 0 & $0,0 \%$ & 0 & $0,0 \%$ & 1 & $9,1 \%$ & 0 & $0,0 \%$ & 17 & $3,9 \%$ & 0 & $0,0 \%$ & 0 & $0,0 \%$ & 0 & $0,0 \%$ & 1 & $4,2 \%$ & 19 & $3,5 \%$ \\
\hline $\begin{array}{l}\text { Lobo D e E } \\
\text { Lobo De }\end{array}$ & 3 & $8,8 \%$ & 0 & $0,0 \%$ & 0 & $0,0 \%$ & 0 & $0,0 \%$ & 26 & $5,9 \%$ & 0 & $0,0 \%$ & 0 & $0,0 \%$ & 1 & $25,0 \%$ & 0 & $0,0 \%$ & 30 & $5,5 \%$ \\
\hline $\begin{array}{l}\text { Istmo } \\
\text { Lobo E e }\end{array}$ & 0 & $0,0 \%$ & 1 & $7,1 \%$ & 0 & $0,0 \%$ & 0 & $0,0 \%$ & 4 & $0,9 \%$ & 0 & $0,0 \%$ & 0 & $0,0 \%$ & 0 & $0,0 \%$ & 0 & $0,0 \%$ & 5 & $0,9 \%$ \\
\hline $\begin{array}{l}\text { Istmo } \\
\text { Lobo D, E e }\end{array}$ & 0 & $0,0 \%$ & 0 & $0,0 \%$ & 0 & $0,0 \%$ & 0 & $0,0 \%$ & 10 & $2,3 \%$ & 0 & $0,0 \%$ & 0 & $0,0 \%$ & 0 & $0,0 \%$ & 1 & $4,2 \%$ & 11 & $2,0 \%$ \\
\hline Istmo & 3 & $8,8 \%$ & 0 & $0,0 \%$ & 1 & $9,1 \%$ & 0 & $0,0 \%$ & 2 & $0,5 \%$ & 0 & $0,0 \%$ & 0 & $0,0 \%$ & 2 & $50,0 \%$ & 5 & $20,8 \%$ & 13 & $2,4 \%$ \\
\hline NI & 15 & $44,1 \%$ & 10 & $71,4 \%$ & 1 & $9,1 \%$ & 1 & $33,3 \%$ & 35 & $8,0 \%$ & 3 & $30,0 \%$ & 0 & $0,0 \%$ & 0 & $0,0 \%$ & 0 & $0,0 \%$ & 65 & $12,0 \%$ \\
\hline Para & & & & & & & & & & & & & & & & & & & & \\
\hline Esquerda & 0 & $0,0 \%$ & 0 & $0,0 \%$ & 0 & $0,0 \%$ & 1 & $33,3 \%$ & 0 & $0,0 \%$ & 0 & $0,0 \%$ & 0 & $0,0 \%$ & 0 & $0,0 \%$ & 0 & $0,0 \%$ & 1 & $0,2 \%$ \\
\hline Total & 34 & $100 \%$ & 14 & $100 \%$ & 11 & $100 \%$ & 3 & $100 \%$ & 439 & $100 \%$ & 10 & $100 \%$ & 3 & $100 \%$ & 4 & $100 \%$ & 24 & $100 \%$ & 542 & $100 \%$ \\
\hline Tamanho & & & & & & & & & & & & & & & & & & & & \\
\hline $\mathrm{s} 1 \mathrm{~cm}$ & 7 & $20,0 \%$ & 1 & $7,1 \%$ & 2 & $18,2 \%$ & 0 & $0,0 \%$ & 302 & $62,3 \%$ & 2 & $18,2 \%$ & 0 & $0,0 \%$ & 0 & $0,0 \%$ & 5 & $20,8 \%$ & 319 & $54,1 \%$ \\
\hline $1-2 \mathrm{~cm}$ & 1 & $2,9 \%$ & 1 & $7,1 \%$ & 2 & $18,2 \%$ & 0 & $0,0 \%$ & 100 & $20,6 \%$ & 2 & $18,2 \%$ & 2 & $66,7 \%$ & 0 & $0,0 \%$ & 5 & $20,8 \%$ & 113 & $19,2 \%$ \\
\hline $2-3 \mathrm{~cm}$ & 0 & $0,0 \%$ & 0 & $0,0 \%$ & 1 & $9,1 \%$ & 0 & $0,0 \%$ & 29 & $6,0 \%$ & 1 & $9,1 \%$ & 0 & $0,0 \%$ & 0 & $0,0 \%$ & 3 & $12,5 \%$ & 34 & $5,8 \%$ \\
\hline $3-4 \mathrm{~cm}$ & 0 & $0,0 \%$ & 0 & $0,0 \%$ & 0 & $0,0 \%$ & 0 & $0,0 \%$ & 13 & $2,7 \%$ & 1 & $9,1 \%$ & 0 & $0,0 \%$ & 0 & $0,0 \%$ & 4 & $16,7 \%$ & 18 & $3,1 \%$ \\
\hline $24 \mathrm{~cm}$ & 0 & $0,0 \%$ & 0 & $0,0 \%$ & 4 & $36,4 \%$ & 0 & $0,0 \%$ & 17 & $3,5 \%$ & 3 & $27,3 \%$ & 0 & $0,0 \%$ & 3 & $75,0 \%$ & 4 & $16,7 \%$ & 31 & $5,3 \%$ \\
\hline NI & 27 & $77,1 \%$ & 12 & $85,7 \%$ & 2 & $18,2 \%$ & 3 & $100 \%$ & 24 & $4,9 \%$ & 2 & $18,2 \%$ & 1 & $33,3 \%$ & 1 & $25,0 \%$ & 3 & $12,5 \%$ & 75 & $12,7 \%$ \\
\hline Total & 35 & $100 \%$ & 14 & $100 \%$ & 11 & $100 \%$ & 3 & $100 \%$ & 485 & $100 \%$ & 11 & $100 \%$ & 3 & $100 \%$ & 4 & $100 \%$ & 24 & $100 \%$ & 590 & $100 \%$ \\
\hline Tireoid & & & & & & & & & & & & & & & & & & & & \\
\hline Total & 27 & $79,4 \%$ & 8 & $57,1 \%$ & 6 & $54,5 \%$ & 0 & $0,0 \%$ & 393 & $89,5 \%$ & 10 & $100 \%$ & 3 & $100 \%$ & 4 & $100 \%$ & 23 & $95,8 \%$ & 474 & $87,5 \%$ \\
\hline Parcial & 7 & $20,6 \%$ & 6 & $42,9 \%$ & 5 & $45,5 \%$ & 3 & $100 \%$ & 46 & $10,5 \%$ & 0 & $0,0 \%$ & 0 & $0,0 \%$ & 0 & $0,0 \%$ & 1 & $4,2 \%$ & 68 & $12,5 \%$ \\
\hline Total & 34 & $100 \%$ & 14 & $100 \%$ & 11 & $100 \%$ & 3 & $100 \%$ & 439 & $100 \%$ & 10 & $100 \%$ & 3 & $100 \%$ & 4 & $100 \%$ & 24 & $100 \%$ & 542 & $100 \%$ \\
\hline
\end{tabular}

Legenda: AF: Adenoma Folicular; BMC: Bócio Multinodular Coloide; CAT: Carcinoma Anaplásico da Tireoide; CDT: Carcinoma Diferenciado da Tireoide; CF: Carcinoma Folicular; CLP: CistadenomaLinfomatosoPapilífero; CMT: Carcinoma Medular da Tireoide; CP: Carcinoma Papilífero; THN: Tireoidite de Hashimoto Nodular.

Fonte: Laudos anatomopatológicos, 2012/2016. Elaborado pelos autores,2020.

Na Tabela 1, pode-se constatar que 79,9\% $(\mathrm{n}=433)$ dos nódulos da tireóide ocorreram no gênero feminino e 20,1\% (n=109) no gênero masculino, havendo uma proporção deaproximadamente 4:1, sendo condizente com o descrito na literatura (BRAY et al., 2018; CAMBOIM et al., 2009; FERLAY et al., 2018; ROCHA et al., 2018).

A média da idade foi de 49,4 anos, com desvio-padrão de $\pm 15,6$, a paciente mais jovem tinha 5 anos enquanto que a mais idosa apresentava tinha 94 anos. A faixa etária mais prevalente foi dos 50-59 anos correspondendo a 22,5\% dos casos $(n=122)$. O valor da média de idade foi superior em relação ao descrito por alguns autores, cuja média de idade variou entre 38,9 a 47,5 anos (CAMBOIM et al., 2009; EL-FOLL, et al., 2015; FAMA et al., 2015; NEMETZ et al., 2011). 
Em relação à localização dos nódulos da tireoide, verificou-se que 40,2\% $(\mathrm{n}=218)$ estavam localizados no lobo direito, 33,2\% $(n=180)$ no lobo esquerdo e 5,5\% $(n=30)$ em ambos lobos. Os demais casos não tiveram a localização determinada ou estavam localizados em outras regiões da tireoide.Cerca de 54,1\% $(\mathrm{n}=319)$ dos nódulos analisados apresentaram tamanho inferior a $1 \mathrm{~cm}$. Este percentual é maior em relação ao descrito na literatura que varia de 24,2\% a 46,2\% (EL-FOLL et al., 2015; ROCHA et al., 2018). No entanto, normalmente a maior ocorrência são de nódulos com tamanho de até $2 \mathrm{~cm}$ (CAMBOIM et al., 2009; NEMETZ et al., 2011). A utilização da ultrassonografia (USG) tem contribuído para a detecção de nódulos de forma precoce, e por isso, acredita-se que nódulos de tamanhos menores estão sendo detectados e encaminhados como material de biópsia para a confirmação do diagnóstico (DAVIES et al., 2006; ITO et al., 2007).

Na Tabela 1 é possível verificar que 84,1\% $(\mathrm{n}=456)$ dos nódulos da tireoide apresentaram características de neoplasias malignas, enquanto que 2,6\% $(\mathrm{n}=14)$ eram neoplasias benignas e 8,9\% $(\mathrm{n}=48)$ eram processos patológicos não neoplásicos. Em 24 casos, não foi possível a determinação do diagnóstico por meio da análise histopatológica, sendo necessário encaminhamento para a análise imunohistoquímica.

As tireoidopatias não neoplásicas representaram 8,9\% $(\mathrm{n}=48)$ dos nódulos, dentro desta categoria $72,9 \%(n=35)$ foram produtos de tireoidectomia total. Este dado evidencia o descompasso entre o diagnóstico e a estratégia terapêutica, na qual o efeito do sobrediagnóstico tem acarretado em morbidades e prejuízo no seguimento do paciente (KITAHARA, SCHNEIDER, BRENNER, 2018; VACCARELLA et al., 2016). Tais processos não neoplásicos poderiam ser acompanhados clinicamente e com o auxílio de métodos de imagem, como a USG, evitando assim uma intervenção cirúrgica desnecessária.

As neoplasias malignas representaram 84,1\% $(n=456)$ dos casos, o tipo histológico de maior ocorrência foi o Carcinoma Papilífero, com $81,0 \%$ dos casos, sendo um valor percentual inferior ao descrito por ROCHA et al (2018) que foi de 91,6\%. No entanto, quando é considerada somente a ocorrência deste carcinoma entre as demais neoplasias malignas, verifica-se que o valor percentual passa a ser de 96,3\%. O Carcinoma Folicular apresentou 2,2\% $(n=10)$ da amostra, sendo este valor inferior ao descrito na literatura (CAMBOIM et al., 2009; ROCHA et al., 2018). Os CDT representaram mais de $90 \%$ dos casos dentre as neoplasias malignas, acometendo majoritamenteo sexo feminino, mantendo a proporção 4:1, corroborando com a literatura (CAMBOIM et al., 2009; ROCHA et al., 2018).

O carcinoma medular correspondeu $0,6 \%(n=3)$ dos casos, sendo 2 mulheres e um homem acometido. Pelo fato do estudo não ter realizado a complementação imunohistoquímica, não é possível identificar o padrão genético e a distinção de CMT esporádico e hereditário. A forma esporádica é a mais comum, presente apenas em um lobo da glândula, acometendo proporcionalmente homens e mulheres na quarta década de vida (KLOSS et al., 2008). A forma hereditária está associada a mutações no protooncogene RET, os dois lobos são acometidos e a incidência ocorre antes dos 20 anos de idade (DVORAKOVA et al., 2008; ELISEI et al., 2008). O carcinoma indiferenciado representou $0,9 \%(n=4)$ dos casos, todos do gênero feminino com extensão extratireoidea e invasão angiolinfática 
significativa. Associa-se este tipo de carcinoma a um pior prognóstico pela sua característica invasiva e metastática (CHEN et al., 2008; SMALLRIDGE et al., 2012).

Em relação às lesões associadas, o Bócio Multinodular Coloide e a Tireoidite de Hashimoto Nodular foram detectadas, correspondendo em $44,8 \%$ e $39,2 \%$ dos casos respectivamente. No presente estudo $66,7 \%(\mathrm{n}=362)$ dos pacientes apresentaram lesões associadas, valor este que se encontra superior a literatura, na qual variou de 15,8\% à 32,7\% (CAMBOIM et al., 2009; NEMETZ et al., 2011).

O tamanho do tumor primário (T); a disseminação para os linfonodos regionais $(\mathrm{N})$ e a presença de metástase em outras partes do corpo (M) são componentes utilizados na classificação TNM da American Joint CommitteeonCancer(AJCC) e os valores percentuais dos componentes T e Nestãoapresentados na Tabela 2. Deve ser ressaltado que não foi possível avaliar o componente $\mathrm{M}$ que trata da ocorrência de metástase à distância, pois todas as amostras apresentaram resultado Mx.Em 22,9\% do total de pacientes que foram submetidos à biópsia de conteúdo tireoidiano não foi possível avaliar o tamanho do tumor primário, metástase linfonodal e metástase à distância.

Tabela 2 - Distribuição percentual, do número de casos de pacientes portadores de nódulos da tireóide e a relação entre os componentes T e $\mathrm{N}$ da classificação TNM

\begin{tabular}{|c|c|c|c|c|c|c|c|c|c|c|}
\hline \multirow{2}{*}{$\begin{array}{c}\text { Estadiamento } \\
\mathbf{T}\end{array}$} & \multicolumn{2}{|c|}{ N0 } & \multicolumn{2}{|c|}{ N1a } & \multicolumn{2}{|c|}{ N1b } & \multicolumn{2}{|c|}{$\mathbf{N x}$} & \multicolumn{2}{|c|}{ Total } \\
\hline & $\mathbf{N}$ & $\%$ & $\mathbf{N}$ & $\%$ & $\mathbf{N}$ & $\%$ & $\mathbf{N}$ & $\%$ & $\mathrm{~N}$ & $\%$ \\
\hline T1a & 134 & $24,7 \%$ & 16 & $3,0 \%$ & 4 & $0,7 \%$ & 105 & $19,4 \%$ & 259 & $47,8 \%$ \\
\hline $\mathrm{T} 1 \mathrm{~b}$ & 34 & $6,3 \%$ & 14 & $2,6 \%$ & 7 & $1,3 \%$ & 19 & $3,5 \%$ & 74 & $13,7 \%$ \\
\hline $\mathrm{T} 2$ & 10 & $1,8 \%$ & 10 & $1,8 \%$ & 0 & $0,0 \%$ & 5 & $0,9 \%$ & 25 & $4,5 \%$ \\
\hline $\mathrm{T} 3$ & 18 & $3,3 \%$ & 20 & $3,7 \%$ & 6 & $1,1 \%$ & 14 & $2,6 \%$ & 58 & $10,7 \%$ \\
\hline $\mathrm{T} 4 \mathrm{a}$ & 0 & $0,0 \%$ & 1 & $0,2 \%$ & 0 & $0,0 \%$ & 0 & $0,0 \%$ & 1 & $0,2 \%$ \\
\hline $\mathrm{T} 4 \mathrm{~b}$ & 1 & $0,2 \%$ & 0 & $0,0 \%$ & 0 & $0,0 \%$ & 0 & $0,0 \%$ & 1 & $0,2 \%$ \\
\hline $\mathrm{Tx}$ & 0 & $0,0 \%$ & 0 & $0,0 \%$ & 0 & $0,0 \%$ & 124 & $22,9 \%$ & 124 & $22,9 \%$ \\
\hline Total & 197 & $36,3 \%$ & 61 & $11,3 \%$ & 17 & $3,1 \%$ & 267 & $49,3 \%$ & 542 & $100 \%$ \\
\hline
\end{tabular}

Fonte: Laudos anatomopatológicos, 2012/2016. Elaborado pelos autores, 2020.

O componente T1a (tumor menor que $1 \mathrm{~cm}$, sem invasão extratireoidiana) foi detectado em $47,8 \%$ do grupo de pacientes avaliados, devendo ser ressaltado que esse valor encontra-se superior em relação ao estudo desenvolvido por ROCHA et al (2018) ao qual apresentou um percentual de 25,7\%. Em relação aos componentes T1b (tumor entre 1 e $2 \mathrm{~cm}$, sem invasão extratireoidiana), T2 (tumor entre 2 e $4 \mathrm{~cm}$, sem invasão extratireoidiana), T3 (tumor maior que $4 \mathrm{~cm}$ limitado à tireoide) e T4a,b (tumor invade estruturas adjacentes) todos valores percentuais foram inferiores ao descrito por ROCHA et al (2018) e apenas o estadiamento T2 apresentou um nível de detecção superior ao descrito por CHOI et al (2009). Em 22,9\% dos casos, não foi possível avaliar o componente T, sendo então classificado como Tx. Este valor percentual é maior em relação ao descrito por CHOI et al (2009).

O componente N0 indica não acometimento de linfonodos regionais, sendo detectado em $36,3 \%$ dos casos, este valor é inferior ao descrito por ROCHA et al (2018) e CHOI et al (2009), nos quais os valores percentuais são de 78,9\% e 60,2\%, respectivamente. Já em relação ao componente N1a, em que há comprometimento dos linfonodos do grupo pré-traqueal, paratraqueal, pré-laringeal 
e mediastino superior, verificou-se que o valor percentual é superior ao descrito por ROCHA et al (2018) e inferior ao de CHOI et al (2009). O componente N1bindica metástases unilaterais, bilaterais ou contralaterais (linfonodos do nível I, II, III, IV ou V), retrofaringianos e os valores percentuais são menores quando comparados com os estudos desenvolvidos por ROCHA et al (2018) e CHOI et al (2009). Em quase a metade dos casos analisados (49,3\%) não houve a avaliação dos linfonodos (Nx).

\section{CONCLUSÃO}

Neste trabalho pode ser constatado que a maior ocorrência de nódulos da tireoide foi no gênero feminino, a faixa etária dos 50-59 anos de idade foi a mais acometida, a maior parte dos nódulos analisados apresentaram tamanho inferior a $1 \mathrm{~cm}$, o Carcinoma Papilífero da Tireoide foi a neoplasia maligna com maior ocorrência. Todas estas informações são condizentes com a literatura científica, sendo relevantes por auxiliar na tomada de decisão em relação ao tratamento, além de abrir perspectivas para estudos relacionados com a identificação de fatores de risco presentes na população.

O estudo realizado apontou que, embora a classificação TNM tenha sido solicitada, nem sempre foi possível de ser realizada, pois em alguns casos o material de biópsia encaminhado para o laboratório não foi suficiente para avaliar os componentes do sistema TNM dos pacientes. Recomenda-se sempre que possível, o envio de material suficiente para avaliação pelo sistema TNM que contribui com importantes informações relacionadas com o acompanhamento e o estabelecimento do prognóstico para os pacientes e da estratégia terapêutica.

\section{REFERÊNCIAS}

AMERICAN CANCER SOCIETY. Cancerfacts\& figures 2019. Atlanta: American CancerSociety, 2019a.Disponívelem: https://www.cancer.org/content/dam/cancer-org/research/cancer-facts-and-statistics/annual-cancer-facts-and-figures/2019/cancer-facts-and-figures-2019.pdf. Acessoem: 22 nov. 2020.

ARE, C.; SHAHA, A. R. Anaplasticthyroid carcinoma: biology, pathogenesis, prognosticfactors, andtreatment approaches. AnnalsofSurgicalOncology, v. 13, n. 4, p. 453-464, 2006.Disponívelem: https://pubmed.ncbi. nlm.nih.gov/16474910/. Acessoem: 22 nov. 2020.

BOMELI, S. R.; LEBEAU, S. O.; FERRIS, R. L. Evaluationof a thyroidnodule. OtolaryngologicClinicsof North America, v. 43, n. 2, p. 229-238, 2010. Disponível em: https://www.ncbi.nlm.nih.gov/pmc/articles/ PMC2879398/pdf/nihms-177041.pdf/?tool=EBI. Acesso em: 22 nov. 2020.

BRASIL. Ministério da Saúde. "Instituto Nacional de Câncer José Alencar Gomes da Silva (INCA). Estimativa 2020: Incidência de Câncer no Brasil. Rio de Janeiro." (2019). Disponível em: https://www.inca.gov. br/sites/ufu.sti.inca.local/files//media/document/estimativa-2020-incidencia-de-cancer-no-brasil.pdf. Acesso em: 22 nov. 2020.

BRAY, F. et al. Global câncer statistics 2018: GLOBOCAN estimatesofincidenceandmortalityworldwide for 36 cancers in 185 countries. CA Cancer J Clin, Hoboken, v. 68, n. 6, p. 394-424, Nov. 2018.Disponívelem: https://pubmed.ncbi.nlm.nih.gov/30207593/. Acessoem: 21 nov. 2020. 
BYRD, D. R. et al. AJCC cancerstaging manual.SeventhEdition. New York: Springer, 2010.

CAMBOIM, D. C.et al. Carcinoma papilífero da tireoide associado à tireoidite de Hashimoto: frequência e aspectos histopatológicos. J BrasPatolMedLab, v. 45, n. 1, p. 75-82, 2009.Disponívelem: https://www.redalyc. org/pdf/3935/393541946012.pdf. Acessoem: 20 nov. 2020.

CHEN, J. et al. Surgeryandradiotherapy improves survival in patientswithanaplasticthyroid carcinoma: analysisofthesurveillance, epidemiology, andendresults 1983-2002. American JournalofClinicalOncology, v. 31, n. 5, p. 460-464, 2008.Disponívelem: https://journals.lww.com/amjclinicaloncology/Abstract/2008/10000/ Surgery_and_Radiotherapy_Improves_Survival_in.9.aspx. Acessoem: 23 nov. 2020.

CHOI, J. S. et al. Preoperative Staging of Papillary Thyroid Carcinoma: Comparison of Ultrasound Imagingand CT. American JournalofRoentgenology, Virgínia, v. 193, n. 3, p. 871-878, Sept, 2009. Disponívelem: https://www.ajronline.org/doi/full/10.2214/AJR.09.2386. Acesso: 20 nov. 2020.

CUNHA, T. O. V. Avaliação imuno-histoquímica da expressão de receptor de estrógeno $\beta$ no carcinoma diferenciado de tireoide. 2017. Dissertação (Mestrado em Patologia) -Faculdade de Medicina,Universidade Federal do Ceará, Fortaleza, 2018. Disponível em: http://www.repositorio.ufc.br/bitstream/riufc/29850/1/2017_ dis_tovcunha.pdf. Acesso em: 19 nov. 2020.

DAVIES, L.et al. Increasingincidenceofthyroidcancer in the United States, 1973-2002. JAMA, v. 295, n.18, p. 2164-2167, 2006.Disponívelem: https:/jamanetwork.com/journals/jama/fullarticle/10.1001/ jama.295.18.2164. Acessoem: 20 nov. 2020.

DURANTE, C. et al. Long-termoutcomeof 444 patientswithdistantmetastasesfrompapillaryandfollicularthyroid carcinoma: benefitsandlimitsofradioiodinetherapy. The JournalofClinicalEndocrinology\&Metabolism, v. 91, n. 8, p. 2892-2899, 2006.Disponívelem: https://academic.oup.com/jcem/article/91/8/2892/2656354. Acessoem: 20 nov. 2020.

DVORAKOVA, S. et al. Somaticmutations in the RET proto-oncogene in sporadicmedullarythyroid carcinomas. Molecular andcellularendocrinology, v. 284, n. 1-2, p. 21-27, 2008.Disponívelem: https://www.sciencedirect.com/science/article/abs/pii/S0303720708000038?via\%3Dihub. Acessoem: 18 nov. 2020.

EL-FOLL, H. A.et al. Patternanddistributionoflymph node metastases in papillarythyroidcancer. J ClinExpPathol, v. 5, n. 204, 2015.Disponívelem: https://www.omicsonline.org/open-access/pattern-and-distribution-of-lymph-node-metastases-in-papillary-thyroid-cancer-2161-0681.1000204.php?aid=37339. Acessoem: 20 nov. 2020.

ELISEI, R. et al. Prognosticsignificanceofsomatic RET oncogenemutations in sporadicmedullarythyroidcancer: a 10-year follow-up study. The JournalofClinicalEndocrinology\&Metabolism, v. 93, n. 3, p. 682-687, 2008.Disponívelem: https://pubmed.ncbi.nlm.nih.gov/18073307/. Acessoem: 21 nov. 2020.

FAMA, F.et al. Patternof nodal involvement in papillarythyroidcancer: a challengeofquantitativeanalysis. International jornal ofclinicaland experimental pathology, v. 8, n. 9, p. 11629-11634, 2015. Disponível em: https://www.ncbi.nlm.nih.gov/pmc/articles/PMC4637717/. Acesso em: 22 nov. 2020.

FERLAY, J. et al. (ed.). Cancertoday. Lyon, France: InternationalAgency for ResearchonCancer, 2018. (IARC CancerBase, n. 15). Disponívelem: https://publications.iarc.fr/Databases/ Iarc-Cancerbases/Cancer-Today-Powered-By-GLOBOCAN-2018--2018. Acessoem: 20 nov. 2020.

HSU, K. T. et al. Novel approaches in anaplasticthyroid câncer therapy. The oncologist, v. 19, n. 11, p. 11481155, 2014.Disponívelem: https:/www.ncbi.nlm.nih.gov/pmc/articles/PMC4221369/. Acessoem: 19 nov. 2020.

HU, M. I.; YING, A. K.; JIMENEZ, C.. Update onmedullarythyroidcancer. EndocrinologyandMetabolismClinics, v. 43, n. 2, p. 423-442, 2014.Disponívelem: https://www.sciencedirect.com/science/article/abs/pii/ S088985291400005X?via\%3Dihub. Acessoem: 21 nov. 2020. 
ITO, Y. et al. A therapeuticstrategy for incidentallydetectedpapillarymicrocarcinomaofthethyroid. Nat ClinPractEndocrinolMetab v. 3, n. 3, p.240-248, 2007.Disponívelem: https://pubmed.ncbi.nlm.nih. gov/17315032/. Acessoem: 22 nov. 2020.

KITAHARA, C.M.;SCHNEIDER, A.B.; BRENNER,A.V. Thyroidcancer. In: Thun MJ, Linet MS, Cerhan JR, Haiman CA, Schottenfeld D, eds. CancerEpidemiologyandPrevention. 4th ed. New York: Oxford University Press; 2018:839-860.

KLOOS, R.T. et al. Medullarythyroidcancer: management guidelinesofthe American ThyroidAssociation. Thyroid, v. 19, n. 6, p. 565-612, 2009.Disponívelem: https://www.researchgate.net/publication/26241175_ Medullary_Thyroid_Cancer_Management_Guidelines_of_the_American_Thyroid_Association. Acessoem: 20 nov. 2020.

KUMAR, V; ABBAS, A. K.; ASTER J. C. Robbins \&CotranPathologic Basic ofDisease. TenthEdition e-book. Elsevierhealthsciences, 2020.

MCHENRY, C. R.; PHITAYAKORN, R. Follicular adenoma and carcinoma ofthethyroidgland. The Oncologist, v. 16, n. 5, p. 585, 2011.Disponívelem: https://www.ncbi.nlm.nih.gov/pmc/articles/PMC3228182/. Acessoem 21 nov. 2020.

MELMED, S. et al. Williams text book ofendocrinology. Elsevier Health Sciences, 2015. 14 ed., 8.272 p.

NEFF, R. L. et al. Anaplasticthyroidcancer. EndocrinologyandMetabolismClinicsof North America, v. 37, n. 2, p. 525-538, 2008.Disponívelem: https://pubmed.ncbi.nlm.nih.gov/18502341/. Acessoem: 22 nov. 2020.

NEMETZ, M. A. et al. A presença de Tireoidite Linfocitária Crônica influencia o estadiamento tumoral do Carcinoma Diferenciado da Tireoide? BrazilianJournalofOtorhinolaryngology, v. 77, n. 1, p. 77-83, 2011. Disponívelem: https://www.scielo.br/scielo.php?pid=S1808-86942011000100013\&script=sci_abstract\&tlng=pt. Acessoem: 20 nov. 2020.

NETEA-MAIER, R. T. et al. Autophagy in thyroidcancer: presentknowledgeand future perspectives. Frontiers in endocrinology, v. 6, p. 22, 2015.Disponívelem: https://www.frontiersin.org/articles/10.3389/fendo.2015.00022/full. Acessoem: 19 nov. 2020.

ROCHA, R. M.et al. Carcinoma bem diferenciado de tireoide: perfil epidemiológico, resultados cirúrgicos e resposta oncológica. Revista do Colégio Brasileiro de Cirurgiões, v. 45, n. 5, 2018. Disponível em: https:// www.scielo.br/scielo.php?pid=S0100-69912018000500152\&script=sci_arttext. Acesso em: 22 nov. 2020.

ROSÁRIO, P. W. et al. Nódulo tireoidiano e câncer diferenciado de tireoide: atualização do consenso brasileiro. Arquivos Brasileiros de Endocrinologia \& Metabologia. São Paulo. Vol. 57, n. 4, p.240-264, 2013. Disponível em: https://www.scielo.br/pdf/abem/v57n4/pt_02.pdf. Acesso em: 21 nov. 2020.

SMALLRIDGE, R. C.; COPLAND, J. A. Anaplasticthyroid carcinoma: pathogenesisandemergingtherapies. ClinicalOncology, v. 22, n. 6, p. 486-497, 2010.

STEWART, B. W.; WILD, C. P. (ed.). World cancerreport 2014. Lyon: IARC Press, 2014. 1010 p.

THUN, M. et al.(ed.). Cancer Epidemiology and Prevention. Oxford University Press, 2017. 4 ed. 1328 p.

VACCARELLA, S. et al. Worldwidethyroid-cancerepidemic? The increasingimpactofoverdiagnosis. The New Englandjournalof medicine, Boston, v. 375, n. 7, p. 614-617, Aug. 2016.Disponívelem: https://www. nejm.org/doi/full/10.1056/NEJMp1604412. Acessoem: 22 nov. 2020. 


\section{DO DEFUNTO VELADO À PEÇA ANATÔMICA DISSECADA: EMBALSAMAMENTO, TANATOPRAXIA E RITOS FÚNEBRES NA ERA MODERNA}

EDUARDO MANGOLIM BRANDANI DA SILVA

\section{CHRISTIAN FAUSTO MORAES DOS}

SANTOS

Universidade estadual de Maringá

RESUMO O embalsamamento para cadáveres humanos esteve presente em todos os períodos históricos. Essa pesquisa busca dar um panorama dessa metodologia durante a Era moderna europeia, passando pelos séculos XVI, XVII e XVIII. A primeira etapa é verificar o que foi herdado da Idade Média. Num segundo momento a medicina e tanatologia dos séculos da Era moderna serão explanadas, ao lado da associação com as questões medievais herdadas. Pensando nos métodos, cada século tem um enfoque: No XVI o método de Ambroise Paré; No XVII os acadêmicos de Leiden; No XVIII a metodologia da família Hunter. $\mathrm{O}$ centro do debate é compreender as intenções por trás desse método na Era Moderna e como, no fim desse período, houve uma guinada em sentido de questões de saúde pública que se difundiu no decorrer do século XIX.

PALAVRA-CHAVE: Embalsamamento, Tanatopraxia, Medicina, Idade moderna.

ABSTRACT: The embalming for corpses has been present in all historic periods. This text looks to give a panorama of this methodology during the Modern Age, passing through the XVI, XVII and XVIII centuries. The first step is to verify what had been inherited from The Middle Ages. In a second step, the medicine and thanatology from the Modern Age centuries will be explained along the association with the inherited medieval matters. Thinking about the methods each has focus: In the XVI the method of Ambroise Paré; In XVII the academics of Leiden; In the XVIII the Hunter's family methodology. The debate center is to comprehend the intentions of embalming during the Modern Age and how in the end of this period the embalming reason turned to public health matters, reason that had diffused during the XIX century.

KEYWORDS: Embalming, Thanatopractice, Medicine, Modern Age.

\section{INTRODUÇÃO.}

Quando nos deparamos com grupos humanos uma das questões que mais suscita curiosidade acaba sendo a morte. Esse acontecimento gera uma série de ritos e processos que estão intimamente ligados com o imaginário desses grupos, indo de dimensões de entendimento religioso até o lidar técnico com o cadáver. O embalsamamento aparece como um processo técnico que esteve presente em todos os períodos da humanidade, vindo desde civilizações do mundo antigo e se fazendo contínuo no tempo imediato em que vivemos (BRENNER, pp.316, 2014). 
As motivações por trás do embalsamar também se alteram no decorrer do tempo. No entanto existem alguns padrões que se dão por meio de temporalidade comum, como nas culturas antigas por motivos religiosos (JOHNSON et all A., pp.983, 2012). No caso Europeu motivos mais padronizados passaram à se dar na Idade Média com a intenção de preservar a imagem do rei, enquanto que na Idade Moderna a finalidade principal se deu em sentido de estudar o corpo anatômico assim como produzir peças anatômicas para estudos e demonstrações (JOHNSON et all A., pp.983, 2012).

O embalsamamento por ter ampla longevidade possui periodizações próprias. No entanto o período que nos importa aqui é o segundo, este conhecido como período dos anatomistas (650 D.C. - 1861 D.C.) (BRENNER, pp.316, 2014). Nesse período as intenções tanatopráticas foram variadas. No entanto citam-se três enfoques das preparações cadavéricas: Transportes cadavéricos para viagens; Preparação de reis e nobres para funerais; O estudo anatômico por meio de peças anatômicas (JOHNSON et all A., pp.983, 2012).

\section{O corpo e a fé: Medicina, tanatologia e embalsamamento na Idade Média.}

O embalsamamento depende das concepções de cada época, o mesmo valendo para a medicina no decorrer do tempo (TROMPETE \& LEMONNIER, pp.10-11, 2009). Frente à tal questão importa elucidar alguns conceitos da medicina na Idade Moderna e as formas de embalsamamento que se desenvolveram nesse período. No entanto perpassar tal discussão exige um breve olhar sobre as questões da Idade Média.

O corpo, no decorrer da maior parte da Idade Média, acabou sendo pensado como receptáculo da alma. Nessa lógica a medicina passava pelo crivo da igreja (GÉLIS, pp.20-21, 2012). Os princípios da medicina nesse período se centravam no cuidar da alma. Portanto o corpo não teria relevância em cuidados. Como ele seria projeção dessa alma, puni-lo por meio de martírios era uma opção para o arrependimento do pecado, como um processo de negar as tentações da carne (GÉLIS, pp.20-21, 2012).

Essa condição dura durou por quase toda a Idade Média europeia. No entanto esse paradigma deu sinais de contestação ainda neste período, por meio de fontes Greco-árabes do século IX que foram adquiridas nos eventos das cruzadas e traduzidas na cidade de Toledo no século XI (MARINOZZI, pp.311, 2012) (MANDRESSI, pp.415-416, 2012). O que torna tais fontes relevantes é que elas suscitaram dois processos. O primeiro deles foi o interesse pelo estudo anatômico que surgiu no decorrer do século XIII (MANDRESSI, pp.417-418, 2012). O segundo processo foi uma alteração profunda no paradigma médico, que dependia do ensino de tipo escolástico e da fé, conteúdo inédito esse, conhecido como paradigma hipocrático-galênico e que teve projeção no século XII, tendo forte presença e desdobramentos até o século XIX (LINDEMANN, pp.68-69, 2002).

Tendo em vista esse novo paradigma, que também é conhecido como modelo humoral, é interessante explicar qual era sua lógica de funcionamento do corpo. A anatomia humana seria constituída de um invólucro de pele que conteria em seu interior os quatro fluídos essenciais para a vida (PORTER \& VIGARELLO, pp.443-444, 2012). Cada fluido estaria associado à um elemento da na- 
tureza assim como teriam propriedades especificas, com isso em mente é preciso citar cada um deles: Fleuma seria fria e úmida, associada à água e produzida no cérebro e pulmão; Sangue seria quente e úmido, associado ao ar e produzido no fígado; Bílis amarela seria quente e seca, associada ao fogo e produzida na vesícula biliar; Bílis negra, fria e seca, associada à terra e produzida no baço (LINDEMANN, pp.68-69, 2002) (PORTER \& VIGARELLO, pp.443-444, 2012).

O funcionamento desse corpo dependia de um contínuo equilíbrio de existência desses fluídos que seriam os humores, portanto a ideia seria de que uma doença existiria graças a um desequilíbrio humoral, o que quer dizer excesso ou falta de qualquer um dos quatro humores (PORTER \& VIGARELLO, pp.444-445, 2012). A análise médica de um indivíduo dependia da verificação das condições individuais dele, pois, com esse paradigma, a lógica seria de que a doença partia de quadros bem individuais de desequilíbrio e não uma questão contagiosa como temos no tempo presente (CARVALHO, pp.42, 2002).

Apesar de não haver uma concepção de contágio, os princípios hipocrático-galênicos pressupunham a ideia de salubridade, ou seja, os ares e lugares poderiam causar algum desequilíbrio humoral, levando à doença, sendo assim o que esse paradigma deixa evidente é que questões externas ao indivíduo influenciavam sua saúde. O quadro do enfermo sugeria o possível motivo externo que poderia ter lhe afetado, enquanto que o tratamento era concebido por meio da alopatia (TEIXEIRA, pp.111, 2002). A alopatia foi a principal ferramenta construída pelo modelo humoral, pois sua lógica terapêutica consistia no combate ao desequilíbrio por meio de recursos que tivessem propriedades contrárias à da enfermidade (CARVALHO, pp.42-44, 2002) (TEIXEIRA, pp.111, 2002). As maneiras de tratar poderiam consistir em dietas, exercícios, preparações médicas e sangrias (CARVALHO, pp.42-44, 2002) PORTER \& VIGARELLO, pp.447-448, 2012).

As descrições desse paradigma, ao lado das explicações anatômicas sobre o corpo, suscitaram numa profunda mudança de visão de mundo para o campo médico, que começou à florescer no fim da idade média mas que teve profusão ampla à partir do século XVI (MANDRESSI, pp422-425, 2012). Com a ideia do corpo depender de humores para se manter vivo, surgiu a dimensão da alopatia. Os cirurgiões e anatomistas que lidavam com o embalsamar de defuntos passaram à compreender que, para se combater o processo da corrupção, sinônimo de putrefação nesse caso, o ideal seria ter recursos alopáticos à tal condição (JOHNSON et all A., pp.1003, pp.2012) (TEIXEIRA, pp.111, 2002).

Muito do método medieval prosperaria até meados do século XVII, pois uma série de técnicas e recursos deste período passou por inovações no decorrer do século XVI (BRENNER, pp.318, 2014). O embalsamamento medieval não se manteve estático. No entanto, a metodologia mais usual pode ser resumida num processo que consistia em evisceração, imersão do corpo em álcool e utilização de ervas e aromatizantes nas incisões. O processo era finalizado com o enfaixamento do corpo para evitar a exposição desse (TROMPETE \& LEMONNIER, pp.11, 2009) (BRENNER, pp.318, 2014). As inovações tanatopráticas da Era Moderna tiveram esses procedimentos de embalsamamento como base.

O interesse anatômico e o modelo humoral estavam consolidados no século XIII. A maioria das dissecções, no decorrer do período medieval se deram entre os séculos XIII e XIV. Em geral, tal 
prática visava visualizar as partes anatômicas para comparar com o que era encontrado nos tratados. Ao mesmo tempo, o ato de dissecar, começava a ser adotado para de verificar as estruturas e, assim, aprimorar as metodologias sobre o cadáver (JOHNSON et all A., pp.1003-1004, 2012) (MANDRESSI, pp.416-417, 2012).

Ao afirmarmos que a maioria das dissecções se deram nesses dois séculos, cabe elucidar que isso não significa que tal prática havia se tornado corriqueira e comum. De fato o processo que freava tais procedimentos surgiu por via de um mal entendido (MANDRESSI, pp.411-412, 2012). A bula papal Detestande Feritatis de 1299, decretada pelo papa Bonifácio VIII, levou muitos à crer que o trabalho de abrir corpos estava proibido. No entanto, essa bula proibia o desmembramento cadavérico para transporte, feito muito comum durante as cruzadas (WEISS-KREJCI, pp.162-165, 2005).

A intenção desse decreto partia de uma questão importante para o imaginário cristão popular. Acreditava-se que o corpo desmembrado não poderia ter uma ressurreição e, consequentemente, adentrar no reino dos céus. Mesmo não havendo nenhuma passagem ou texto bíblico que condenasse tal prática, a pena de excomunhão era algo agravante num tempo em que a fé era hegemônica em uma sociedade como a medieval (JOHNSON et all A., pp.1005, 2012). Apesar dos revezes, a prática da dissecção não se interrompeu. Afinal, nesses séculos, uma série de anatomistas providenciaram corpos para estudos. A conclusão mais óbvia é que havia mais uma falta de interesse/necessidade em explorar os corpos, do que um temor pela excomunhão. Os conhecimentos da escolástica e do modelo humoral eram consolidados de tal maneira, que muitos achavam não ser necessário realizar novas experimentações em um campo de saber que era, até então, dado como definitivo (MANDRESSI, pp.419-421, 2012).

Esse decreto papal veio à ser abolido em 1537. Período em que os cirurgiões e anatomistas já haviam se ampliado em número e experimentações envolvendo cadáveres. No entanto antes da abolição do Detestande Feritatis, uma série de profissionais e curiosos se colocaram na condição de explorar os tecidos, fluídos e estruturas que compunham os cadáveres (WEISS-KREJCI, pp.167, 2005) (KELLY A, pp.4, 2010). Dentre alguns nomes podemos citar Alessandra Giliani (1307-1326), Leonardo da Vinci (1452-1519), Jacopo Berengario de Carpi (1460-1530), Bartolomeo Eustachi (1500/1514-1574) (JOHNSON et al A., pp.1005, 2012). Tais estudiosos, por meio de aplicações de ceras ou água quente em vasos sanguíneos, além de ampla observação dos órgãos e das partes internas, acabaram influenciando em muito os estudos e experimentos do século XVI. O que rapidamente se refletiu nos processos tanatopráticos (BRENNER, pp.318, 2014) (JOHNSON et al A., pp.1005, 2012).

\section{A peça anatômica: Medicina e tanatopraxia europeia no século XVI.}

Com todos esses aperfeiçoamentos, que vinham se desenvolvendo desde a Idade Média, coube aos indivíduos do século XVI colocar em prática tais ideias por meio da verificação, observação e experimentação. O grande nome da anatomia, nesse período, fora o físico de origem Belga Andreas 
Vesalius (1512-1564) (KICHOFEL, pp.389, 2003). A formação de Vesálio se deu entre 1533 e 1537, sendo que seus dois principais tutores foram Dubois e Guinther, indivíduos que estavam bem ligados ao modelo hipocrático-galênico (KUSUKAWA, pp.184-185, 2012). Vesálio acreditava que havia muitas vantagens em estudar os corpos pela prática, condição essa que, desde estudante, era bem requerida pelo físico. Posto isso, o belga, quando professor em Pádua, decidiu realizar uma série de dissecções em 1539, num tempo difícil de adquirir corpos, para relacionar os escritos de Galeno com a experimentação (KUSUKAWA, pp.191-194, 2012). Muito do que Vesálio observou na prática não tinha correlação com o escrito por Galeno, condição essa que suscitou em Vesálio o pensamento de que talvez Galeno nunca tivesse dissecado corpos humanos, mas sim animais similares como primatas (KUSUKAWA, pp.191-194, 2012) (KELLY A, pp.23-24, 2010).

Esse processo levou Vesálio à duas epifanias de grande relevância para a área médica, incluindo a tanatopraxia. A primeira delas de que a prática era relevante para o aprendizado, assim como para a formulação de novas teorias. Ele concluiu também que o corpo humano do observador tinha muitas ferramentas uteis para a compreensão do mundo natural, de maneira que considerava a visão a ferramenta mais útil (KUSUKAWA, pp.199-204, 2012) (KICHOFEL, pp.390, 2003). Tais condições levaram Vesálio à produzir a obra De humani Corporis fabrica de 1543, conquista essa fruto de seu longo histórico de dissecções, e que dava uma nova dimensão anatômica do corpo, contendo uma série de desenhos por privilegiar a cultura visual assim como incitar a experimentação (KUSUKAWA, pp.199-204, 2012) (MANDRESSI, pp.419-421, 2012).

Vesálio não negava os preceitos do modelo humoral, assim como não estava propondo uma afronta à igreja que defendia esses conhecimentos. Ele apenas propunha uma nova significação aos conhecimentos hipocrático-galênicos. Os saberes institucionalizados em seu tempo, como as propostas de Mondino de Liuzzi (1270-1326) sobre o humoralismo, eram ultrapassados por Vesálio (KICHOFEL, pp.391-396, 2003).

O modelo vigente em seu tempo era da escolástica, portanto a prática e as ilustrações seriam como uma fuga aos textos que eram afirmados como verdadeiros pela fé, portanto as inovações não tinham muito espaço no século XVI (KICHOFEL, pp.397-400, 2003).

Vesálio temia que aqueles ligados à área da saúde tivessem uma formação deficitária, uma vez que não houvesse o intento de buscar inovações ou o interesse em verificar os corpos. O estudo médico se dava num período de quatro anos, os alunos acabavam atrelados firmemente ao modelo escolástico, se pautando nos clássicos antigos. No entanto, indivíduos como Vesálio foram consideravelmente relevantes para esse campo, suas descobertas e inovações levaram os cursos de medicina à incluírem estudos como de anatomia e botânica (LINDEMANN, pp.93-95, 2002). O anfiteatro anatômico para exposição cadavérica, ao lado do horto botânico para o estudo de propriedades das plantas, foram instituições universitárias que revolucionaram a formação médica, assim como a do profissional cirurgião (REBOLLO, pp.307-317, 2010).

É importante ressaltar que os campos da cirurgia e da medicina eram distintos até o fim do século XVIII, quando por fim se uniram. Isso significa afirmar que o físico tinha um status superior e, geralmente, não tinha experiência prática. O que levava estes profissionais a se especializarem em 
problemas oriundos do desequilíbrio humoral, não realizando intervenções (LINDEMANN, pp.99110, 2002). O cirurgião seria um indivíduo de arte mecânica. Dentro de uma cultura que privilegiava o pensamento, acabavam inferiorizados. No entanto, eles tinham uma importância igual senão maior que a dos físicos, afinal cirurgiões realizavam procedimentos práticos e tinham continuidade ao lidar com corpos (LINDEMANN, pp.103-104, 2002). Pensando nas artes tanatopráticas, ambos tinham contato com esse processo. No entanto, os cirurgiões se destacaram mais neste campo, pois tinham muito contato com cadáveres em seus estudos, condição essa que favorecia o trabalho envolvendo defuntos.

Além dos impactos das descobertas de Vesálio, dois outros processos permitiram um aprimoramento na arte tanatoprática, dentre eles podemos listar imprensa de Johannes Gutenberg (1400 - 1468) de 1450 e a chegada do europeu ao Novo Mundo (KELLY A, pp.4, 2010). A prensa de Gutenberg permitiu que mais alunos pudessem estar no campo médico, isso porque os materiais antes eram manuscritos, o que levou à um consequente barateamento do preço de materiais. Além de que as imagens poderiam ser padronizadas em meio à prensa (LINDEMANN, pp.96-97, 2002) (KUSUKAWA, pp.201-204, 2012). Em relação às invasões europeias na América, se deduz que o contato com novos indivíduos e recursos pela primeira vez contatados, o imaginário europeu teve de se ampliar para compreender como tais realidades poderiam existir. Um processo que suscitou curiosidade e interesse por parte dos europeus. Não somente graças a possibilidade de enriquecimento financeiro mas, também, por conta de todo um universo de novos saberes que poderiam ser encontrados no contato com cada civilização, animal, planta e mineral daquele Novo Mundo (KELLY A, pp.106-122, 2010).

O embalsamamento no século XVI herdava muito do citado resumo do método medieval. Procedimentos como evisceração, utilização de álcool, recursos aromáticos e ervas consideradas preservativas ainda era bem presente. No entanto, novos recursos passaram à ser utilizados em concomitância com alguns aprimoramentos (JOHNSON et al A., pp.1007, 2012). Muitos indivíduos foram atuantes nesse século, no campo da tanatopraxia como Peter Forestus (1521-1597) e Marco Aurélio Severino (1580-1656), no entanto, o indivíduo que deu ao embalsamamento um novo patamar fora Ambroise Paré (1510-1590) (JOHNSON et al A., pp.1007, 2012) (MARINOZZI, pp.314, 2012).

O método desenvolvido por Paré teve larga influência na segunda metade do século XVI e na primeira do século XVII. O procedimento era longo e detalhado, mas trazia similaridades com o método medieval de tanatopraxia (JOHNSON et al A., pp.1008, 2012). As descrições do cirurgião francês se centravam em relatos de tanatopraxia feita em cadáveres de indivíduos nobiliários. É provável que ele tenha realizado testes em outros corpos antes de se sentir seguro para tal realização, lembrando que um método como esse visava proteger a imagem do nobre até o dia do funeral (JOHNSON et al A., pp.1008, 2012).

A metodologia de Paré utilizava processos que remontam à baixa Idade Média. Ele adotava a técnica de evisceração, aplicava uma série de ervas nas cavidades realizadas, assim como fazia aplicações de álcool e diluições alcoólicas (JOHNSON et al A., pp.1008, 2012). A inovação central de seu processo foram as incisões que seguiam os vasos sanguíneos do defunto. Com tais vias expostas Paré expelia o sangue por meio de expressão dessas vias (JOHNSON et al A., pp.1008, 2012). 
Aparentemente Paré não teve contato com a teoria da circulação sanguínea de William Harvey (1578-1657). No entanto, já haviam sido realizadas amplas observações sobre como a umidade tem alto potencial de corrupção, o que este cirurgião francês demonstrava saber, pois recomendava a necessidade de extrair o máximo de sangue possível e gerar uma limpeza com álcool dos vasos, o que ampliava o tempo de durabilidade do cadáver embalsamado (GORE, pp.199, 2005). A intenção de produzir peças anatômicas era algo presente entre profissionais da saúde desde o século XIII. No entanto uma possibilidade mais concreta só fora possível na segunda metade do século XVII, metodologia essa que dependeu dos feitos de Paré (JOHNSON et al A., pp.1009, 2012).

Com Paré, as recomendações de extrair o sangue se fizeram cada vez mais presentes. No entanto, a possibilidade de uma nova metodologia tanatoprática esteve dependente de conceitos médicos que se deram no século XVI e XVII. Nessa linha de raciocínio as questões propostas por Paracelso sobre utilização de químicos, a circulação sanguínea de William Harvey e as iatromedicinas do século XVII formaram a base para que, em fins do século XVII, tal metodologia fosse possível. Essa metodologia fora concebida por meio de um grupo de médicos holandeses em Leiden, metodologia essa que seria a injeção de químicos que não utilizava a evisceração (JOHNSON et al A., pp.1009, 2012).

\section{A circulação e os químicos: Medicina e embalsamamento europeu no século XVII.}

Harvey era um indivíduo bem ligado ao pensamento aristotélico, de forma que tinha crença no modelo galênico. Contudo, influenciado pela ideia de observação e experimentação do século XVI, o médico inglês decidira observar certas questões clássicas em meio à prática (REBOLLO, pp.506, 2002). Frente às testagens ele entendeu que a ideia do sangue ter um fim no próprio corpo era inconcebível, pois o sistema dos vasos do corpo era circular, inclusive, por conta de suas observações sobre o pulmão, ele concebia o fenômeno da circulação sanguínea como duplo (REBOLLO, pp.506, 2002).

Harvey preenche a lacuna técnica sobre a utilização de injeções. Por meio da circulação as substâncias aplicadas poderiam chegar à todo o corpo. No entanto, fora outro indivíduo que permitiu um ampliar de horizontes para as substâncias de possível utilização, sendo ele o físico Suíço Paracelso (1493-1541) (LINDEMANN, pp.76-77, 2002). Paracelso estudou nos maiores centros europeus do século XVI, período que o modelo humoral tinha forte presença. Apesar disso, Paracelso repudiou essa teoria veementemente (TEIXEIRA, pp.114, 2002). Aliado à questões da quiromancia, astrologia e alquimia Paracelso acreditava que o corpo era constituído de três elementos como o sal, o enxofre e o mercúrio (KELLY A, pp. 11-12, 2010). Os prenúncios da química seria o modelo de guia de Paracelso para o entendimento do corpo e de suas doenças. Posto isso, a ciência natural e seus recursos seriam o melhor tratamento, portanto compostos químicos extraídos de plantas, animais e minerais seriam a base da terapêutica (LINDEMANN, pp.77, 2002) (TEIXEIRA, pp.115, 2002).

As questões e paradigmas suscitados por Harvey e Paracelso ampliaram o horizonte de possibilidade dentro da medicina na era moderna, o que permitiu o florescimento das iatromedicinas. 
Estas ganham força na medida em que a teoria hipocrático-galênica vai perdendo sua validade frente às novas descobertas no campo da anatomia e fisiologia. A iatroquímica aparece no começo do século XVII e prospera até o fim desse período, enquanto a iatromecânica surge no fim do século XVII e ganha maior espaço no século XVIII (LINDEMANN, pp.78-79, 2002) (TEIXEIRA, pp.117, 2002). Essas medicinas possuíam diferenças entre si assim como com o modelo humoral. No entanto, muito da percepção hipocrático-galênica se manteve, principalmente a questão do equilíbrio e de alopatia, mesmo que nesses novos campos tais conceitos se aplicassem de outra maneira (TEIXEIRA, pp.117, 2002).

A iatroquímica foi uma teoria desenvolvida pelo físico belga Van Helmont (1580-1644). Esta preconizava que o corpo se mantinha por reações químicas internas como a efervescência, a fermentação e a putrefação. Dessa forma, a saúde dependia do equilíbrio de tais reações (LINDEMANN, pp.79-80, 2002). O tratamento se dava por meio de recursos químicos. Tal princípio também era aplicado à cadáveres. Tal teoria acabou por influenciar a tanatopraxia na busca de novos recursos que poderiam combater a putrefação (TEIXEIRA, pp.117, 2002). (TEIXEIRA, pp.117, 2002).

A iatromecânica ou iatrofísica, fora desenvolvida pelo físico holandês Herman Boerhaave (1668-1738), suas teorias também partiam de um princípio de equilíbrio. No entanto, o entendimento era de que o corpo seria como uma máquina ou fábrica. $\mathrm{O}$ corpo funcionaria por meio de movimentos internos como a circulação (LINDEMANN, pp.82-83, 2002). O traço comum ao galenismo era de que a doença seria proveniente de um desequilíbrio interno, como se algo estivesse interrompendo a circularidade dos fluidos internos ou não estivesse permitindo que algum movimento se desse (TEIXEIRA, pp.118, 2002).

A maioria das múmias europeias datam do período entre os séculos XVII e XIX. Isso porque as técnicas que se consolidaram, possibilitaram à tanatopraxia maior durabilidade aos corpos embalsamados (FORNACIARI \& CAPASSO, pp.193, 1996). Quando é dito que um conhecimento tanatoprático como o de Ambroise Paré acabou influenciando modelos posteriores é preciso ter a ressalva em mente de que esses conhecimentos geralmente eram secretos, portanto eles nem sempre estavam em tratados ou apareciam em postulados no momento em que a carreira profissional já estava consolidada (TROMPETE \& LEMONNIER, pp.11, 2009). Esses conhecimentos eram apresentados de maneira aprofundada apenas aos aprendizes mais próximos ou por meio de demonstrações anatômicas em aulas. Nesse caso, geralmente, a apreensão do conteúdo só se dava pelo observar sem um roteiro escrito (TROMPETE \& LEMONNIER, pp.11, 2009).

Com essas inovações concretizadas no século XVII, outro profissional, que já auxiliava no embalsamamento, acabou ganhando destaque. O boticário garantia os recursos básicos para o embalsamamento, assim como preparava recursos mais complexos, caso o cirurgião que viria à realizar o embalsamamento assim necessitasse, principalmente num momento em que recursos químicos estavam tão em voga (CORBINEAU, pp.152, 2017).

Porém houve um grupo que teve primazia na produção de uma metodologia tanatoprática que congregou todos os avanços médicos do século XVII. Foram os holandeses sediados na cidade de Leiden (BRENNER, pp.318, 2014). Tal processo se consolidou graças, em grande parte às inovações 
concebidas pelo físico holandês Regnier de Graaf (1641-1673) que desenvolveu uma seringa para injeção de mercúrio nas artérias humanas (BRENNER, pp.318, 2014). Os indivíduos que revolucionaram a conservação de corpos com essa técnica, e propuseram a utilização dela para o embalsamamento, foram Jan Swammerdam (1637-1680), que produziu a metodologia, Frederik Ruysch (1638-1731), que por meio da prática a refinou e Stephen Blanchard (1650-1720) que a publicou abertamente disseminando-a (JOHNSON et al A., pp.1009, 2012).

Swammerdam, incialmente, testou seu modelo apenas em insetos. Ele conectava uma cânula numa seringa de forma que inseria uma composição à base de álcool e terebintina nos pequenos invertebrados (JOHNSON et al A., pp.1009, 2012). Ruysch adotou essa técnica e se colocou na posição de aplica-la em cadáveres humanos. Posto isso batizou a substância de Liquor Balsamicum, esta composta de sangue de porco, óxido de mercúrio e azul da Prússia, sendo esse último um pigmento, o que denota provavelmente a construção de uma peça anatômica que possibilitaria a verificação dos vasos (JOHNSON et all A., pp.1009, 2012) (BRENNER, pp.318, 2014). Blanchard publicou um livro em 1688 no qual descrevia a técnica de Ruysch, processo esse que foi um grande passo, pois deu um salto na preservação. Além disso sua técnica de embalsamamento consistia numa ampla lavagem intestinal, tendo, em seguida, a aplicação de uma mistura de espirito de vinho (álcool forte) com a terebintina. Tal modelo influenciou largamente os procedimentos do século XVIII e XIX (JOHNSON et al A., pp.1010).

Houve duas linhas metodológicas que foram desenvolvidas e disseminadas no fim do século XVII e primeira metade do século XVIII. Ambas foram empregadas por holandeses. A primeira produzida por Stephen Blanchard, que ficou conhecida como Sicca Balsamatio e a segunda do físico holandês Gabriel Clauderus tendo sido produzida em 1695 e conhecida como Humida Balsamatio (JOHNSON et al A., pp.1010, 2012) (MARINOZZI, pp.315, 2012). O Sicca Balsamatio consistia numa lavagem intestinal, sem evisceração, com uma série de incisões para injeção arterial, geralmente associado com o uso de um sifão. O Humida Balsamatio consistia em deixar o corpo em meio à uma solução dessecante e antisséptica, de forma que esse corpo sofresse várias incisões. Além disso, o corpo seria injetado com o mesmo líquido que este ficara submerso. Por fim se pode pensar que esse corpo seria desidratado (JOHNSON et al A., pp.1010, 2012) (MARINOZZI, pp.315, 2012).

Esses corpos no caso holandês, quando não eram destinados à exposição enquanto peças anatômicas, acabavam tendo suas partes interiores retiradas de maneira que a cera era utilizada para preenchimento. Neste caso, a finalidade era fúnebre. Os trabalhos de restauração sobre o corpo cadavérico se davam para que a imagem do indivíduo da realeza ou nobiliário pudesse ser mantida com maior vivacidade (JOHNSON et all B., pp.1225, 2012) (MARINOZZI, pp.316, 2012).

A medicina, entre os séculos XVI e XVIII, é pensada muitas vezes como uma série de caminhos e medidas que foram tomadas sob um crivo racional. No entanto, esses indivíduos atuantes estavam permeados pelo fantástico, pelo religioso e pelo fabuloso. Campos como a química e a física dependeram de processos como a alquimia e a astrologia, sendo ambas filosofias cotidianas naquele tempo. Logo, os percursos da medicina não podem ser entendidos como uma série de medidas racionais (DEBUS, pp.66-70, 1996). A medicina também não era um campo isolado. Havendo, em seu desenvolvimento, uma série de relações e dependências com outras áreas como a química e a física 
(CARDOSO, pp.26-27, 2010). As iatromedicinas são a prova mais latente disso. Os inventos e teorias que possibilitaram o surgimento de tais áreas dependeram de pesquisas de outros campos de saber. Um sinal da influência e diálogo entre os campos (DEBUS, pp.81, 1996) (CARDOSO, pp.26-27, 2010).

Antes do século XVIII, existiu um método de embalsamamento bem destacado no século XVII. Este entretanto, tinha outras finalidades. Tal método foi muito difundido durante a Idade Média, se popularizou no século XVII e ainda era presente no século XVIII (COLLETER et al., pp.1718, 2016). Este consistia no embalsamamento de algum órgão especifico que seria enterrado em local sacro ou em local simbólico da linhagem da família. Tal rito geralmente se restringia à realeza e nobres. No entanto, no século XVII, surgiu o interesse de ter essas partes individuais para centros universitários assim como hospitais, com objetivo do estudo anatômico do órgão ou parte do corpo (COLLETER et al., pp.17-18, 2016) (JOHNSON et al A., pp.1011, 2012).

\section{Medicina Ilustrada: Medicina e tanatologia europeia no século XVIII.}

As luzes também se fizeram presentes no campo da medicina no século XVIII. Na área da saúde esse período teve, como destaque, uma série de homens de letras que deram continuidade à investigações no campo da iatromecânica, assim como se assistiu a inúmeros desdobramentos da iatroquímica em novas vertentes médicas (LINDEMANN, pp.84, 2002). Dentre as novas correntes da iatroquímica é importante ressaltar o animismo de Ernst Stahl (1659-1734) e as múltiplas concepções acerca do vitalismo.

Stahl não negava os processos da iatroquímica, ele os entendia como verdadeiros. No entanto, em meio à sua forte crença, havia dimensão de que a vida não viria do equilíbrio entre diferentes elementos, mas sim da Anima (alma), que seria uma espécie de quintessência que, inclusive seria responsável por coordenar os processos internos (TEIXEIRA, pp.117, 2002) (PORTER \& VIGARELLO, pp.466-467, 2012). Nas obras de Boissier de Sauvages (1706-1767), apesar de encontrarmos a afirmação de que a alma era responsável pela vida, este médico e botânico francês denota uma tendência vitalista, ao acreditar que as partes individuais do corpo possuiriam, cada uma, sua força vital (PORTER \& VIGARELLO, pp.470-471, 2012).

A fundação do modelo vitalista, de maneira plena, se deu com o físico francês Paul-Joseph Barthez (1735-1806). Barthez acreditava que havia, de fato, uma substância superior e imaterial. Para ele tal substância estaria em todas as partes do corpo, ao lado dos processos materiais. Ela seria, segundo o físico francês, uma força vital (TEIXEIRA, pp.117, 2002) (WAISSE et al., pp.631-632, 2011). Para Barthez a alma existia também ao lado das funções materiais e da força vital. Mas ela, a alma, não mantinha a vida, apenas garantia o pensamento (WAISSE et al., pp.632-634, 2011). Barthez concebia que a força vital gerava o organismo. No entanto, outro físico francês cujas investigações ganharam notoriedade no período, tinha uma explicação diferente para o fenômeno força vital. Theóphile de Bordel (1722-1726) acreditava que o organismo gerava a força vital e não o contrário. 
Portanto, o material seria responsável pelo imaterial (WAISSE et al., pp.636, 2011). O vitalismo tinha como base a ideia de força vital, mas sua função e origem variavam de acordo com os autores, situação que denota a ideia de pluralismo (WAISSE et al., pp.638, 2011).

A corrente do vitalismo foi bem importante para a tanatopraxia, pois o entendimento dessa escola é de que o corpo sobrevivia por meio de uma série de processos internos. No entanto, a morte não traria a interrupção dos processos, pois com ela a putrefação teria espaço. Portanto a tanatopraxia poderia gerar um processo de adiamento da corrupção do corpo (WAISSE et al., pp.636, 2011).

O século XVIII foi bem importante para inventos cirúrgicos, situação essa que influenciou diretamente as técnicas de embalsamar. Dentre tais inovações tecnológicas a primeira delas fora a seringa de sucção, modelo esse criado por Dominique Anel (1679-1730) que, ao contrário do modelo de injeção, serviria para retirar fluídos das partes internas, ideal para serem utilizadas em vasos e cavidades cadavéricas (BISHOP, pp.116-117, 2010). A segunda invenção foram os antissépticos que se relacionavam com salubridade, sendo eles pensados para a utilização em casos cirúrgicos algo também útil para lidar com cadáveres, pois a putrefação se dá em detrimento de bactérias e fungos (RANDOLPH, pp.139-143, 2000). No caso inglês os antissépticos eram à base de minerais ácidos, enquanto que na França eles tinham como base álcoois, terebintina e aloés (RANDOLPH, pp.140, 2000). A existência dos dois tipos de seringas ao lado de recursos antissépticos fora fundamental para a construção de um modelo de embalsamamento mais eficiente (JOHNSON et al A., pp.1011, 2012).

O procedimento de embalsamamento inovador do século XVIII fora desenvolvido na Inglaterra. Tal método esteve atrelado à uma questão utilitária, pois o que se nota é a combinação de técnicas mais antigas, como a evisceração, ao lado da aplicação de recursos químicos nos vasos e cavidades, por meio de injeções (JOHNSON et all A., pp.1011, 2012). Essa metodologia fora desenvolvida por William Hunter (1718-1783). Esse anatomista escocês deixou enorme legado no campo da medicina por meio de tratados e pesquisas, bem como diversas dissecções, além de que teve um papel importante enquanto professor, situação essa que favorece a ideia de transmissão do conhecimento tanatoprático (KELLY B, pp.28, 2010) (TROMPETE \& LEMONNIER, pp.11, 2009).

Sua metodologia consistia numa aplicação de uma substância à base de terebintinas e óleos aromáticos como o de camomila, sendo assim essa aplicação era feita até que o corpo atingisse uma coloração avermelhada (JOHNSON et al A., pp.1011, 2012). A próxima etapa consistia em um procedimento de evisceração torácica e abdominal. Dessa forma, as cavidades eram lavadas com água e espirito de vinho, enquanto isso as partes retiradas teriam seus fluidos expelidos, eram lavadas com água e álcool e ainda recebiam injeções do mesmo fluido embalsamador utilizado nas injeções arteriais na primeira etapa desse processo (JOHNSON et al A., pp.1012, 2012). A intenção era de que tais partes retornassem ao corpo ao invés do descarte. Esse método se mostrava funcional quando a finalidade era a produção de uma peça anatômica, ou em um caso fúnebre. No entanto, em situações fúnebres, era mais arriscado manter os órgãos, pois o cadáver não ficava submerso em composição preservativa tal qual uma peça anatômica (JOHNSON et al A., pp.1012, 2012). Todas as incisões, assim como poros naturais do corpo, recebiam uma mistura em pó de canfora e nitro (JOHNSON et al A., pp.1012, 2012). 
Na preparação citada acima, o enfoque geralmente se dava em torno de uma peça anatômica. Portanto, William Hunter propunha depositar o cadáver numa caixa de gesso cheia de espirito de vinho e de tempos em tempos esse corpo deveria sofrer restaurações (JOHNSON et al A., pp.1012$1013,2012)$. William deixava claro que o corpo deveria ser trabalhado oito horas depois da morte no verão e cerca de vinte e quatro horas no inverno, preocupação essa que provavelmente perpassava a percepção de outros cirurgiões anteriores ao seu período (JOHNSON et al A., pp.1013, 2012).

O irmão de William, John Hunter (1728-1793) também teve interesse nesses procedimentos, tendo ele sido um indivíduo de amplo destaque, devido à múltiplas dissecções e ensinamentos que ele realizou, principalmente no período da guerra dos sete anos (RANDOLPH, pp.142, 2000). John tinha muito interesse pelo estudo anatômico, posto isso ele necessitava adquirir diversos corpos para seus estudos (KELLY B, pp.32-35, 2010). O estado era um provedor de corpos desde o século XVI em muitos centros urbanos, sendo esses advindos de indivíduos criminosos que foram executados ou que tivessem morrido de morte natural e não fossem reclamados. No entanto, o século XVIII teve uma diminuição de penas capitais o que tornou o acesso por via institucional mais limitado (KELLY B, pp.32-35, 2010). Tal revés fora contornado pelo florescimento de um comércio clandestino que fornecia esses corpos. A nova dinâmica para aquisição se dava por meio de notificadores que informavam os interessados que disputavam a compra desses corpos (KELLY B, pp.32-35, 2010). Outro ato comum nesse tempo foram as profanações de covas de indivíduos recém inumados feitas pelos ressurreicionistas, nome dado aos ladrões de cadáveres recém-sepultados. Atos esses que levaram à um aumento na vigilância em cemitérios e mesmo à instalação de jaulas em volta da sepultura (KELLY B, pp.32-35, 2010) (JOHNSON et all A., pp.1014, 2012).

O indivíduo que refinou a técnica da família Hunter fora outro membro dessa família. O físico Mathew Baillie (1761-1823) a princípio empregava a mesma solução de embalsamamento de seu tio William Hunter (JOHNSON et all A., pp. 1015, 2012). Sua metodologia num primeiro momento, seria similar à de seu tio, com a aplicação do preservativo por via da artéria femoral. Contudo, sua forma de embalsamar tinha uma diferença essencial: o método desenvolvido por Baillie dispensava a necessidade de evisceração (JOHNSON et all A., pp. 1015, 2012). A inovação introduzida pelo sobrinho de William Hunter consistia em realizar incisões e, em seguida, introduzir um cano por onde seria inserida água. Essa deveria ser retirada em seguida (JOHNSON et all A., pp. 1015, 2012). Nos órgãos seria inserido espirito de vinho canforado, enquanto que na bexiga, olhos, narinas, boca e ouvidos seria aplicada uma mistura de pó de canfora, pó de nitro e alguma resina, isso depois de todos os líquidos terem sido expelidos (JOHNSON et all A., pp. 1015, 2012).

O modelo inglês com a utilização de terebintina, óleos aromáticos, injeções e a possibilidade da evisceração deu condições para que, caso o corpo fosse bem preparado, houvesse a possibilidade de se ter uma peça anatômica para estudos e para o ensino. Afinal, em meio à substâncias preservativas e com os devidos reparos, um corpo poderia durar alguns anos (BRENNER, pp.319, 2014) (THOMAS, pp.196, 1989). Essas metodologias também definiram uma nova etapa para o corpo embalsamado cuja finalidade era o transporte e ritos fúnebres. Isso porque tal corpo, uma vez preparado poderia durar alguns dias sem ter de sofrer reparos. Aos poucos, aqueles que poderiam pagar por um procedimento como este, puderam se dar ao luxo de realizar velórios que durassem alguns dias, ou 
transportar o corpo por curtas distâncias (BRENNER, pp.319, 2014) (THOMAS, pp.196, 1989). A ideia no caso dos velórios era o de presentificar o indivíduo defunto de forma à afastar sinais da morte do ente querido (THOMAS, pp.196-197, 1989).

\section{Novos horizontes: Caminhos do embalsamamento do fim do século XVIII ao começo do século XX.}

Em meados do século XVIII uma cultura mais racional fora se estabelecendo. Os caminhos da medicina, apesar de serem permeados pelo humorismo, tendia à uma dimensão de fuga dos tradicionalismos (LINDEMANN, pp.89-91, 2002). Um desses modelos fora a anatomia patológica que passou à procurar certos padrões de doenças sobre o corpo (PORTER \& VIGARELLO, pp.474-476, 2012). O vitalismo, ainda presente nesse período, tinha a concepção de que a putrefação se dava pela perda da força vital. Porém, a novidade seria de que a putrefação, processo observado na morte, gerava a liberação de uma série de gases tóxicos e contagiosos, os miasmas. Frente à possibilidade de um cenário epidemiológico essa teoria influenciou os governos ilustrados que saíram em busca de reformas e medidas públicas, tema esse que se relaciona com o embalsamamento por lidar com corpos de cadáveres que poderiam se putrefazer (MARINOZZI, pp.317, 2012).

O campo da ciência médica, entre o fim do século XVIII e começo do XIX, passou por um processo revolucionário. Nesse período, os campos da cirurgia e da medicina se uniram em prol de uma única profissão que congregou ambos conhecimentos. Condição essa que permitiu um novo horizonte de pensamento e pesquisa na saúde (LINDEMANN, pp.97-100, 2002), (PORTER \& VIGARELLO, pp.478-479, 2012). O aprendizado agora podia se dar por meio de trabalhos de campo, de maneira que o hospital, que já era lugar de estudo de cirurgiões, se tornara o centro das investigações (LINDEMANN, pp.88-91, 2002).

Para o embalsamamento, a união desses dois campos significava uma nova significação para sua realização. Um dos processos derivados do iluminismo fora a ideia de secularização do corpo, portanto o corpo humano foi cada vez mais sendo visto como um objeto de intervenções que não dependiam apenas de crença e imagem, mas que também acabava associado à demandas de saúde pública, devido à preocupação miasmática (LINDEMANN, pp.97-100, 2002), (MARINOZZI, pp.318, 2009).

O corpo embalsamado no decorrer da Era Moderna europeia esteve atrelado à estudos (peças anatômicas), transportes e ritos fúnebres de classes altas. No entanto, o fim do século XVIII direcionou à ideia de higiene pública como nova categoria de embalsamamento, que se tornou possível para pessoas de menor poder aquisitivo (MARINOZZI, pp.318, 2009) (TROMPETE \& LEMONNIER, pp.15-16, 2009). O processo de embalsamar passaria das mãos de médicos e cirurgiões para a prática do profissional embalsamador. No entanto essa mudança de paradigma só se sedimentou com a guerra civil estadunidense (1861-1865) onde indústrias funerárias surgiram com intentos de embalsamar 
dentro de uma categoria de saúde pública (MARINOZZI, pp.318, 2009) (TROMPETE \& LEMONNIER, pp.15-16, 2009).

O desenvolvimento da metodologia de embalsamamento contemporânea dependeu de todos os avanços que se deram na era moderna. O que fica evidente nas metodologias que foram sendo elaboradas. O mais interessante é que não foram os profissionais da medicina que desenvolveram uma metodologia de longa preservação ao cadáver mas sim químicos como Jean-Nicolas Gannal (17911852) (JOHNSON et al A., pp.1016-1018, 2012). Os químicos entram em cena devido à condição de que a metodologia em si, com Mathew Baillie já, tinha alcançado um grau elevado. No entanto os recursos químicos, em si, especialmente no século XIX, propiciavam novas possibilidades e um consequente novo patamar (JOHNSON et al A., pp.1016-1018, 2012).

Químicos como Gannal, frente às metodologias do século XVIII e em meio à seus estudos de agentes químicos sobre matéria orgânica, percebera que soluções de base metálica poderiam surtir grande efeito na preservação. Portanto sua sugestão fora da aplicação de uma injeção com solução de acetato de alumínio na carótida (JOHNSON et al A., pp.1016-1018, 2012). Ele não fora o único que testou recursos químicos, o médico italiano Giusepe Tranchina (1797-1837) utilizou uma solução com arsênico, enquanto que o anatomista francês J. P. Sucquet (1840-1870) propunha a utilização de uma solução de cloreto de zinco (JOHNSON et al A., pp.1016-1018, 2012). O modelo de Tranchina não teve muito sucesso pois em 1822 o arsênico fora considerado cancerígeno. Além do mais o arsênico tinha um longo histórico de uso como veneno. Se houvesse uma investigação sobre o defunto que tivesse sido trabalhado com arsênico poderia haver o risco de surgir a dúvida sobre o envenenamento (GONTIJO \& BITTENCOURT, pp.81-82, 2005).

Os métodos de embalsamamento desenvolvidos por estes químicos, anatomistas e médicos entre fins do século XVIII e início do XIX, foram essenciais para que houvesse a popularização desta técnica de conservação para classes menos abastadas. À partir de tais inovações houve a possibilidade de que o físico estadunidense Thomas Holmes (1817-1900) desenvolvesse sua forma de embalsamar, muito similar à de Gannal. Isso porque, durante a guerra, ele tratou muitos defuntos para famílias enlutadas que buscavam um último momento com os soldados falecidos (JOHNSON et al A., pp. 10271029, 2012) (TROMPETE \& LEMONNIER, pp.14-20, 2009). Tal cenário atraiu empresas químicas que vinham crescendo, pois elas poderiam produzir recursos químicos com base naqueles utilizados por embalsamadores, além de que poderiam aprender a técnica em si. De fato muitas empresas químicas, buscando expansão, acabaram sendo atraídas pela ideia de expandir, por meio do embalsamamento fúnebre. À partir daí surge a indústria funerária durante esse período de guerra (JOHNSON et al A., pp. 1027-1029, 2012) (TROMPETE \& LEMONNIER, pp.14-20, 2009).

O embalsamamento fora, por longo tempo, um procedimento de elevado custo. As classes populares não tinham acesso à tais modelos, portanto essas indústrias tendo noção desse fato, entenderam que a ideia de vender o embalsamamento como um produto poderia gerar um amplo capital, isso por meio de preços que fossem possíveis às classes médias e parcelas das classes populares (TROMPETE \& LEMONNIER, pp.14-20, 2009). A ideia dessas empresas agradava também o Estado pois lidar com os cadáveres por meio da preservação ia ao encontro do novo ideal de salubridade, portanto era um auxílio em relação à saúde pública (TROMPETE \& LEMONNIER, pp.14-20, 2009). 
A possibilidade de ter acesso ao embalsamamento de seu falecido ente querido, agradava a população por meio do afastamento da morte. Agradava o estado por resolver questões de saúde pública e contemplava os interesses financeiros dessa nova indústria derivada do capital industrial químico (TROMPETE \& LEMONNIER, pp.14-20, 2009). No fim do século XIX, se ampliou a parcela da população que tinha possibilidade de realizar esse procedimento, enquanto na primeira metade do século XX, houve o processo de universalização, situando aqui que algumas nações optaram por ser um processo estatal e não privado (JOHNSON et al A., pp. 1027-1029, 2012) (TROMPETE \& LEMONNIER, pp.14-20, 2009).

\section{CONCLUSÃO.}

O embalsamamento, amplamente empregado durante a Era Moderna teve muito de suas técnicas e fórmulas herdadas da Idade Média. Como por exemplo o emprego da evisceração. No entanto, enquanto tempo de intensas transformações em que o imaginário dos indivíduos foram se ampliando em relação à compreensão do mundo, o impacto sobre a metodologia de embalsamar se fez de maneira contundente (JOHNSON et all A., pp.983, 2012) (LINDEMANN, pp.84, 2002). Apesar das intensas transformações colocadas entre os séculos XVI e XVIII, as intenções por trás do embalsamar se mantiveram as mesmas das herdadas da Idade Média (BRENNER, pp.316, 2014). A intenção de transportes se manteve, porém, o avanço se deu no sentido de que, com maior tempo de durabilidade, foram possíveis maiores distâncias (BRENNER, pp.319, 2014). Em relação à questão fúnebre, nota-se que essa metodologia não esteve restrita à apenas indivíduos da realeza, pois a nobreza fora em busca de se beneficiar desse procedimento (JOHNSON et al A., pp.1005, 2012).

Um dos grandes avanços se deu em relação à produção de peças anatômicas que vinham sendo buscadas desde o século XIII, pois se na metodologia de Paré um corpo tinha baixa durabilidade, dois séculos depois, no XVIII, por meio de imersão em soluções preservativas e aplicações arteriais dos mesmos preservativos uma peça anatômica, com a devida manutenção, poderia durar até quatro anos (BRENNER, pp.319, 2014) (THOMAS, pp.196, 1989). A inovação, em sentido de intenção por trás da tanatopraxia e não de metodologia, fora a importante questão da saúde pública. O corpo cadavérico, dentro da óptica das correntes médicas da segunda metade do século XVIII, era um produtor de miasmas e gases pútridos, isso devido à putrefação. Portanto o embalsamamento veio à calhar para garantir a higiene e salubrificação (MARINOZZI, pp.317, 2012)

\section{REFERÊNCIAS.}

BISHOP, W.J. Knife, Fire and Boiling oil - The Early of surgery. 1 ed. Londres: Robert Hale, 2010

BRENNER, E. Human body preservation - Old and new techniques. Journal of Anatomy, V.224, pp.316244, 2014. 
CARDOSO, A. O lugar da medicina na revolução científica. Revista Portuguesa de Filosofia. V.66, N.1, pp.25-40, 2010.

CARVALHO, M.M. A medicina em história: A medicina Hipocrática. Leituras, V.4, N.1, pp.41-44, 2002.

COLLETER R., DEDOUIT, F., DUCHESNE, S., MOKRANE, F.Z., GENDROT, V., GÉRARD, P., DABERNAT, H., CRUBÉZY, E. e TELMON, N. Procedures and Frequencies of Embalming and Heart Extractions in Modern Period in Brittany. Contribution to the Evolution of Ritual Funerary in Europe. Plos One, pp.1-21, 2016.

CORBINEAU, R., RUAS, M.P., PAIN, D.B., FORNACIARI, G., DUPONT, H. e COLLETER, R. Plants and aromatics for embalming in Late Middle Ages and modern period: a synthesis of written sources and archaeobotanical data (France, Italy). Vegetation, History and Archaeobotany, V.27, pp.151-164, 2017

DEBUS, A.G. Chemists, Physicians, and Changing Perspectives on the Scientific Revolution. Isis, V.89, N.1, pp.66-81, 1998

FORNACIARI G. e CAPASSO, L. Natural and artificial 13th-19th century mummies in Italy. In: Human Mummies. 1 ed. New York: Springer, 1996, pp.195-203

GELIS, J. O corpo, a igreja e o sagrado. In: História do corpo - volume 1: Da renascença às luzes. 5 ed. São Paulo: Vozes, 2012, pp.19-130.

GONTIJO, B. e BITTENCOURT, F. Arsênico - uma revisão histórica. An Bras Dermatol, V.80, N.1, pp.8185,2005

GORE, P.S. EMBALMING AND THE SOCIAL CONSTRUCTION OF THE CORPSE IN CONTEMPORARY ENGLAND. Tese, Department of sociology, Brunel University, 2005

JOHNSON A, E.C., JOHNSON, G.R. e JOHNSON, M. The origin and history of embalming. In: Embalming history, Theory and practice. 5 ed. New York: Mcgraw hill, 2012, pp.981-1078.

JOHNSONS B, E.C., JOHNSON, G.R. e WILLIAM, M.J. History of modern restorative arte. In: Embalming history, Theory and practice. 5 ed. New York: Mcgraw hill, 2012, pp.1225-1257.

KELLY A, K. The history of medicine: The scientific revolution and medicine (1450-1700). 1 ed. New York: Facts of file, 2010.

KELLY B, K. The history of medicine: Old world and new - Early medical care (1700-1840). 1 ed. New York: Facts of file, 2010.

KICHOFEL, E.H.P. A lição de anatomia de Andreas Vesalius e a ciência moderna. Scientiae Studia, V.1, N.3, pp.389-404, 2003.

KREJCI, E.W. Excarnation, evisceration, and exhumation in medieval and post-medieval Europe. In: Interacting with the dead: Perspectives on Mortuary Archaelogy for the new millenium. 1 ed. Gainesville: University press of Florida, 2005, pp.155-172.

KUSUKAWA, S. Picturing the book of nature - Image, text, and Argument in sixteenth-century human anatomy and medical botany. 1 ed. Chicago: University of Chicago Press, 2012.

LINDEMANN, M. Medicina e sociedade no início da Europa moderna: Novas abordagens da historia europeia. 1 ed. Lisboa: Replicação, 2002.

MANDRESSI, R. Dissecações e anatomia. In: História do corpo - volume 1: Da renascença às luzes. 5 ed. São Paulo: Vozes, 2012, pp.411-440.

MARINOZZI, S. The Embalming Art in the Modern Age: The Mummies of Caroline, Letizia and Joachim- Napoleon Agar as Examples of Funerary Rites in the Napoleonic Empire. Nuncius, V.27, pp.309329, 2012. 
PORTER, R. e VIGARELLO, G. Corpo, saúde e Doenças. In: História do corpo - Volume 1: Da renascença às luzes. 5 ed. São Paulo: Vozes, 2012, pp.441-486.

RANDOLPH, F. Surgery in the 1700s. In: Science and Its times: understanding the social significance of scientific Discovery, Volume 1. 1 ed. Farmington Hills: Gale Research Inc., 2000, pp.139-144

REBOLLO, R.A. A difusão da doutrina da circulação do sangue: a correspondência entre William Harvey e Caspar Hofmann em maio de 1636. História, Ciências, Saúde, V.9, N.3, pp.479-513, 2002.

REBOLLO, R.A. A escola médica de Pádua: Medicina e filosofia no período moderno. História, Ciências ,Saúde, V.17, N.2, pp.307-331, 2010

TEIXEIRA, M.Z. O vitalismo homeopático ao longo da história da medicina. Homeopatia Brasileira, V.8, N.2, pp.109-123, 2002.

THOMAS, L.V. El cadaver. 1 ed. Cidade do México: Colección popular, 1989.

TROMPETTE, P. e LEMONNIER, M. Funeral embalming: The transformation of a medical innovation. Science Studies, V.2, N.2, pp.9-30, 2009.

WAISSE, S., AMARAL, M.T.C.G., GOLDFARB, A. e ANA. M. Raízes do vitalismo francês: Bordeu e Barthez, entre Paris e Montpellier. História, Ciências, Saúde, V.18, N.3, pp.625-640, 2011. 


\section{CARACTERIZAÇÃO E DIAGNÓSTICO DE TUMORES RELACIONADOS AO CÂNCER COLORRETAL (CCR) NA CIDADE DE MARINGÁ-PR}

IORRAN NOCETI SILVESTRI

Universidade Estadual de Maringá - Paraná

MARIA CLARA ICERI

Universidade Estadual de Maringá - Paraná

VITOR ZANATA ADACHESKI

Universidade Estadual de Maringá - Paraná

JOÃO VITOR SCALON ESTÉRCIO RIZZO

Universidade Estadual de Maringá - Paraná

EDILSON NOBUYOSHIKANESHIMA Universidade Estadual de Maringá - Paraná

PAOLA DA COSTA SOUZA

Universidade Estadual de Maringá - Paraná

TÂNIA CRISTINA ALEXANDRINO

BECKER

Universidade Estadual de Maringá - Paraná

ALICE MARIA DE SOUZA KANESHIMA

Universidade Estadual de Maringá - Paraná

RESUMO: Neste estudo foi realizado um estudo retrospectivo da ocorrência do câncer colorretal (CCR) na cidade de Maringá para caracterizar estes tumores que são o terceiro tipo de câncer mais comum no gênero masculino e o segundo no feminino. A coleta de dados foi realizada em formulário próprio, sendo coletadas informações gerais dos pacientes e da massa tumoral, sendo selecionados 416 laudos anátomo-patológicos onde $51,5 \%$ eram de pacientes do gênero feminino e $48,5 \%$ masculino. Aproximadamente
$70 \%$ dos pacientes acometidos pelo CCR apresentavam idade entre 50-79 anos. Os tumores localizados na região retossigmoide foram diagnosticados em $25,7 \%$ dos casos analisados e os tumores retais foram diagnosticados em 14,9\% dos pacientes avaliados neste grupo, havendo ocorrência de 8,6\% no gênero masculino. Os tumores no cólon ascendente apresentaram ocorrência de 5,8\% no gênero feminino. Na classificação quanto ao grau histológico, a maioria dos tumores $(68,1 \%)$ foi classificada como grau 2 . A histopatologia também avaliou a característica de invasividade tumoral, a extensão a outras estruturas, o número de linfonodos comprometidos, a presença de metástases a distância, as margens cirúrgicas, a invasão linfovascular, a invasão perineural e a classificação TNM. Os componentes T3 e N0 foram classificados em 39,4\% do total de pacientes portadores de CCR e o componente M0 foi classificado em $70,2 \%$ dos pacientes. Todas estas informações demonstram a complexidade do diagnóstico, e a dificuldade para o estabelecimento do prognóstico e de um tratamento adequado. No entanto, estas informações são importantes para auxiliar a conduta terapêutica.

PALAVRAS-CHAVE: câncer colorretal; classificação TNM; adenocarcinoma colorretal.

ABSTRACT: In this study was realized a retrospective study of the occurrence of colorectal cancer (CRC). It was carried out in Maringá-PR to characterize these tumors, which are the third most common cancer in males and second in females. Data collection was carried out in specific form. General information of patients and tumor mass has been collected. 416 anatomical-pathological reports were selected, and $51.5 \%$ were 
female and $48.5 \%$ male. Approximately $70 \%$ of the patients affected by CRC were aged between $50-79$ years old. Tumors located in the rectosigmoid region were diagnosed in $25.7 \%$ of the cases and rectum tumors in $14.9 \%$ of the patients evaluated in this study, with $8.6 \%$ occurring in males. Tumors located in ascending colon had an occurrence of $5.8 \%$ in females. The classification according to histological grade, most tumors $(68.1 \%)$ were classified as grade 2 . The histopathology also evaluated invasive characteristic of tumor, extension to other structures, compromised lymph nodes, distant metastasis, surgical margin, lymphovascular invasion, perineural invasion and TNM classification. Components T3 and N0 were classified in $39.4 \%$ of the total patients with CRC and component M0 was classified in $70.2 \%$ of patients. All of this information demonstrates the complexity of the diagnosis and the difficulty in establishing the prognosis and an appropriate treatment. However, this information is important to help the therapeutic conduct.

KEYWORDS: colorectal cancer; TNM classification; colorectal adenocarcinoma.

\section{INTRODUÇÃO}

O câncer colorretal (CCR) acomete todo intestino grosso, inclusive a linha pectínea na junção do reto com o canal anal (INCA, 2020). O intestino grosso possui alto índice de replicação celular, sendo exposto a carcinógenos físicos, químicos e biológicos, e aumentando a possibilidade de alterações genéticas e moleculares que estão relacionadas ao desenvolvimento de processos neoplásicos (ARVELO; SOJO \& COTTE, 2015).

O processo da carcinogênese colorretal pode envolver duas vias genéticas que sofrem mutações sucessivas. A via APC/ $\beta$-catenina envolve mutações ou eventos epigenéticos que silenciam as cópias do gene $A P C$ pertencente à classe do gene supressor de tumor, cujo produto é a proteína APC, que degrada a proteína $\beta$-catenina (estimuladora de proliferação celular). A outra via genética é aquela relacionada com a instabilidade de microssatélites, na qual ocorre a inativação de genes reparadores de DNA, favorecendo o crescimento celular descontrolado e o desenvolvimento do câncer (KUMAR, ABBAS, ASTER, 2013; BRASILEIRO FILHO, 2013).

A patogênese molecular do CCR do tipo esporádico é a mais comum e está relacionada com aproximadamente $85 \%$ dos casos de CCR, apresentando caráter heterogêneo podendo afetar diversos genes que sofrem mutações, acarretando na formação do adenoma, que por sua vez, pode ser transformado em adenocarcinoma. Normalmente, neste modelo, a primeira mutação ocorre no gene $A P C$ (Adenomatous Polyposis Coli) que é um gene supressor tumoral, levando a formação de pólipos ou adenomas, tendo característica de benignidade. Ao longo de um período de aproximadamente 10 anos, o genoma de cerca de $15 \%$ desses pólipos acumulam mutações no oncogene $K R A S$ (V-Ki-ras2 Kirsten rat sarcoma viral oncogene homolog), no gene supressor tumoral TP53 (tumor protein 53), nos genes que codificam elementos da via de sinalização da via do $T G F-\beta$ (transforming growth factor), como o gene TGFBR2 (transforming growth factor beta receptor 2), SMAD4 (SMAD family member 4) e no gene $D C C$ (deleted in colorectal carcinoma), que contribuem para a transformação em um adenocarcinoma (BENSON \& HAMILTON, 2011; FEARON, 2011). 
Os sinais e sintomas dessa patologia não são patognomônicos, dificultando o diagnóstico, mas pessoas com mais de 50 anos apresentando anemias, mudanças no hábito intestinal (diarreia ou constipação intestinal), sangramento nas fezes, tenesmo, cólicas, fezes pastosas de coloração escura, cansaço, náuseas e vômitos podem apresentar a suspeita de CCR, e o diagnóstico pode ser realizado por meio de exames como colonoscopia ou retossigmoidoscopia juntamente com a biópsia do tecido lesado (INCA, 2020).

O Sistema TNM da American Joint Committee on Cancer (AJCC) é o método mais utilizado para avaliar o estágio em que se encontra o CCR, neste sistema são avaliados 3 componentes representados pela letra $\mathrm{T}$, que representa o tamanho do tumor primário; a letra N, metástases em linfonodos regionais; e a letra $\mathrm{M}$ avalia metástases para outros órgãos. A classificação dos tumores pode ser: TX, Tis, T0, T1, T2, T3, T4a e T4b; NX, N0, N1, N1a, N1b, N1c, N2, N2a e N2b; M0, M1a e M1b. A letra $\mathrm{X}$ simboliza que o quesito não pode ser avaliado, 0 simboliza ausência do quesito, Tis significa que o tumor está em estágio inicial (in situ) e os números 1-4 e letras a-c representam a evolução ou intensidade do quesito (American Cancer Society, 2020).

O CCR é o terceiro tipo de câncer mais comum no gênero masculino e o segundo no gênero feminino. No ano de 2018 foram estimados, a nível global, 1.006.019 novos casos em homens correspondendo a 10,9\% de todos os casos de câncer que incidem no gênero masculino e 794.958 novos casos em mulheres $(9,5 \%$ de todos os casos de câncer incidentes no gênero feminino). Aproximadamente $55 \%$ desses casos de incidência ocorreram em países desenvolvidos e provavelmente está relacionado com as melhores condições de acesso ao sistema de saúde. Normalmente a mortalidade é inferior à incidência, e no ano de 2018 ocorreram 881.000 mortes por CCR correspondendo a 9\% de todas as mortes relacionadas ao câncer nesse ano. As taxas de incidência do CCR são cerca de três vezes maiores nos países desenvolvidos em relação aos países em desenvolvimento, mas não há variância nas taxas de mortalidade. A diminuição da taxa de mortalidade nos países desenvolvidos é o reflexo da adoção de boas práticas relacionadas ao tratamento e ao manejo do câncer e consequentemente aumentando a taxa de sobrevida (ARNOLD et al., 2017).

A incidência do CCR está aumentando no Brasil, assim como nos demais países subdesenvolvidos, tendo a estimativa de 40.990 novos casos para 2020 (INCA, 2019). O CCR é o $3^{\circ}$ tipo de câncer com maior mortalidade tanto no gênero masculino como no feminino, no entanto, quando a taxa de mortalidade de ambos os gêneros é somada, então passa a ocupar o $2^{\circ}$ lugar. Deve ser ressaltado que o número de óbitos entre 2008 e 2016 apresentou um aumento de 45\%, havendo uma elevação dos casos de 11.953 para 17.284 , respectivamente.

Em relação às taxas de mortalidade na região Sul foi observado um aumento principalmente no gênero masculino, entre os anos de 1990 a 2014. Este aumento pode estar relacionado com o maior consumo de alimentos processados, de carne vermelha rica em gordura e consumo de álcool e tabaco (BARROS et al., 2017; VINEIS \& WILD, 2014). Além disso, o consumo de verduras e frutas é baixo nas regiões Sul e Sudeste (BARROS et al., 2017).

A região Sul do Brasil é a segunda em casos de internações por câncer de cólon e estima-se que para 2020 o Paraná seja o quinto estado brasileiro com maior número de casos, mas este número 
vem crescendo nos últimos anos (DATASUS, 2020). No entanto, a taxa de mortalidade no estado do Paraná está em declínio indicando eficiência nos protocolos de tratamento aplicados (INCA, 2020; CORRÊA et al, 2016; DATASUS, 2020).

Diante do exposto, torna-se necessário realizar um estudo retrospectivo da ocorrência de CCR diagnosticados por um laboratório de Anatomia Patológica da cidade de Maringá, referente ao período de 2016 a 2019 com o intuito de caracterizar estes tumores presentes na população de Maringá-PR.

\section{MATERIAIS E MÉTODOS}

A coleta de dados referente à análise retrospectiva de laudos anatomopatológicos obtidos entre os anos de 2016 e 2019, provenientes do banco de dados de um laboratório da cidade de Maringá-PR foi realizada em formulário próprio.

Este formulário foi elaborado com a finalidade de obter informações gerais dos pacientes portadores de Câncer Colorretal (CCR) tais como idade e gênero, e também da massa tumoral como a localização anatômica do tumor, classificação de acordo com o grau histológico ou de diferenciação do tumor; o grau de invasividade tumoral; a extensão em outras estruturas, o número de linfonodos comprometidos, a presença de metástases a distância, as margens cirúrgicas, a invasão linfovascular; a invasão perineural; a classificação pelo Sistema TNM.

A seleção dos laudos anátomo patológicos foi realizada por meio de acesso ao sistema de informações contido no banco de dados de um laboratório da cidade de Maringá-PR, utilizando as seguintes palavras chaves: câncer colorretal; adenocarcinoma colorretal; carcinoma colorretal; cólon e reto. Os laudos com dados incompletos do paciente ou que não apresentavam o achado morfológico de câncer colorretal (CCR) não foram incluídos neste estudo.

O software Microsoft Excel ${ }^{\circledR}$ versão 2016 foi utilizado para a análise das informações e elaboração de gráficos e tabelas.

\section{RESULTADOS E DISCUSSÃO}

Entre os anos de 2016 a 2019 foram selecionados 416 laudos anátomo-patológicos de pacientes portadores de câncer colorretal (CCR) que foram diagnosticados em um Laboratório de Anatomia Patológica do município de Maringá-PR. Verificou-se que 51,5\% dos laudos eram provenientes de pacientes do gênero feminino e 48,5\% do gênero masculino. Esta discreta prevalência no gênero feminino pode estar relacionada com maior exposição ao estrógeno e ao fato da mutação no gene $p 16$ ser nove vezes mais frequente em mulheres (OUAKRIM et al., 2015). 
Nos últimos anos foi registrado um aumento do número de casos de CCR no gênero masculino, sendo o $2^{\circ}$ tipo de câncer mais frequente nesta população (INCA, 2020; DATASUS, 2020). Este aumento pode estar relacionado com o maior consumo de alimentos processados e de carne vermelha rica em gordura, baixa ingestão de frutas e hortaliças, além do etilismo e tabagismo (BARROS et al., 2017).

A Figura 1 mostra que aproximadamente $70 \%$ dos pacientes acometidos pelo CCR apresentavam idade entre 50-79 anos, sendo condizente com as informações divulgadas pelo INCA (2020) em que a prevalência de CCR ocorre a partir dos 50 anos. Deve ser observado que a faixa etária com idade entre 70-79 anos foi a mais acometida, correspondendo a 25\% do total de pacientes avaliados que pode estar relacionado com o acúmulo de alterações genéticas decorrentes da atuação de carcinógenos presentes no meio ambiente ou em alimentos e pela diminuição efetiva da resposta imunitária em decorrência da idade avançada (VAN EEGHEN et al., 2015).

O CCR é raro antes dos 50 anos de idade e quando ocorre pode ter etiologia hereditária (LEVIN \& CORLEY, 2013). Os tumores hereditários correspondem a cerca de 5\% dos casos de CCR, e têm como origem mutações pontuais em alelos que podem ser transmitidos hereditariamente, aumentando a predisposição para o desenvolvimento de CCR (HALF \& BRESALIER, 2004). Nenhum paciente na faixa etária entre 0-29 anos foi diagnosticado como portador de CCR, no entanto, pacientes com idade entre 30-49 anos apresentaram massa tumoral e corresponderam a 16,4\% do total de pacientes avaliados neste estudo. A realização de estudos adicionais, utilizando técnicas genético-moleculares, torna-se necessária para confirmar a influência hereditária nestes pacientes (LEVIN \& CORLEY, 2013).

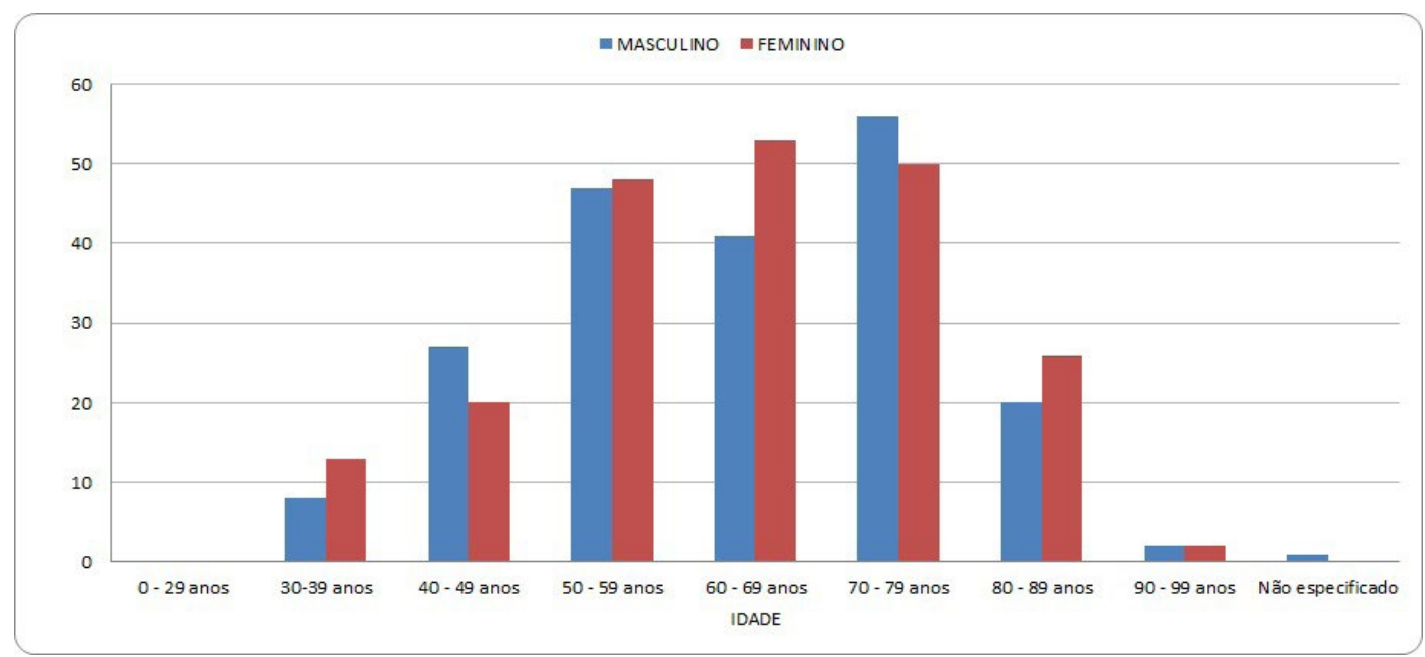

Figura 1: Distribuição percentual dos pacientes acometidos pelo câncer colorretal de acordo com a faixa etária.

Na Tabela 1 é possível verificar que 13,7\% dos tumores diagnosticados são metastáticos, ou seja, estes tumores foram diagnosticados em outros órgãos, mas apresentavam características histopatológicas de adenocarcinoma colorretal. Em relação aos tumores diagnosticados ao longo do trato intestinal, alguns apresentaram maior ocorrência, como é o caso dos tumores localizados na região 
retossigmoide que correspondem a 25,7\% dos tumores diagnosticados, estando presentes em ambos os gêneros. As informações divulgadas pelo INCA (2020) também descrevem a região retossigmoide como a mais acometida por massa tumoral na população brasileira. Os tumores retais foram diagnosticados em 14,9\% dos pacientes avaliados neste grupo, havendo uma ocorrência de 8,6\% no gênero masculino, enquanto que os tumores localizados no cólon ascendente apresentaram ocorrência de $5,8 \%$ no gênero feminino. Segundo LAPORTE et al (2018), as mulheres prevalentemente apresentam mais tumores de cólon ascendente devido à instabilidade em microssatélites e os homens uma maior incidência de tumores retais.

Tabela 1: Localização anatômica da massa tumoral e distribuição percentual dos casos de câncer colorretal na população feminina e masculina

\begin{tabular}{ccc}
\hline Localização anatômica (\%) & População feminina (\%) & População masculina (\%) \\
\hline Metástase $(13,7)$ & 8,2 & 5,5 \\
Retossigmóide $(25,7)$ & 13,7 & 12,0 \\
Reto $(14,9)$ & 6,3 & 8,6 \\
Cólon ascendente $(10,6)$ & 5,8 & 4,8 \\
Cólon transverso $(4,1)$ & 2,4 & 1,7 \\
Cólon descendente $(4,3)$ & 1,2 & 3,1 \\
Cólon sigmóide $(8,2)$ & 6,0 & 2,2 \\
Cólon - região não especificada $(9,4)$ & 4,1 & 5,3 \\
Ceco (6,0) & 3,1 & 2,9 \\
Canal anal (0,5) & 0 & 0,5 \\
Outras regiões do trato intestinal $(2,6)$ & 0,7 & 1,9 \\
\hline
\end{tabular}

Total de casos: $416(100 \%)$

$214 \operatorname{casos}(51,5 \%)$

$202 \operatorname{casos}(48,5 \%)$

Os tumores de CCR podem ser classificados de acordo com o grau histológico e $6,8 \%$ dos tumores foram classificados como grau 1 (característica histológica bem diferenciada), a maioria dos tumores $(68,1 \%)$ foi classificada como grau 2 (moderadamente diferenciado) e 3,1\% como grau 3 (pouco diferenciado). Em 22\% dos tumores não foi possível especificar o grau histológico.

Como a maioria dos tumores foi classificada como grau 2, isto pode ser um indicativo de que o diagnóstico do CCR não ocorreu de forma precoce. Esta dificuldade para realizar o diagnóstico precoce pode ter relação com o pequeno número de redes de atenção à saúde e também com a deficiência da infra-estrutura necessária para um melhor rastreamento e diagnóstico precoce deste tipo de câncer (BARROS et al., 2017; VINEIS \& WILD, 2014).

A correlação entre o grau histológico com a idade e o gênero dos pacientes forneceu informações relevantes, sendo observado que os tumores classificados como grau 1 e 2 acometem mais o gênero masculino com idade entre 70-79 anos e o gênero feminino entre 60-69 anos. De acordo com OUAKRIM et al. (2015) a frequência de mutação do gene pl6 é nove vezes mais frequente em mulheres, o que aumenta a predisposição das mulheres ao desenvolvimento de CCR. Esta maior predisposição pode estar relacionada com diagnóstico de CCR grau 1 e 2 em mulheres na faixa etária entre 60-69 anos. No entanto, deve ser ressaltado que as mulheres são mais conscientes e atentas 
aos possíveis sinais e sintomas relacionados com possíveis neoplasias, por isso buscam atendimento junto ao sistema de saúde, possibilitando o diagnóstico precoce em relação ao gênero masculino,que nem sempre percebe ou até ignora estes sinais e sintomas, e dificilmente procura assistência médica, retardando o diagnóstico.

A avaliação histopatológica determina o grau de diferenciação tumoral, mas também avalia o grau da invasividade tumoral, a extensão a outras estruturas, o número de linfonodos comprometidos, a presença de metástases a distância, as margens cirúrgicas, a invasão linfovascular e a invasão perineural (JASS, 2007; UENO et al., 2007; LIEBIG et al., 2009).

Com relação ao grau de invasividade tumoral, verificou-se que neste grupo de pacientes, a mucosa e lâmina própria sofreram invasão em 1,7\% dos casos; a camada submucosa encontrava-se invadida em 4,1\%; 14,7\% tiveram a camada muscular própria invadida; 37,9\% apresentaram invasão na subserosa; $17,4 \%$ na camada serosa; $0,5 \%$ no tecido adiposo e omento e em $23,7 \%$ dos casos não foi possível especificar o local da invasão. Estes resultados apresentados demonstram que mais da metade dos casos sofreram invasão tumoral na camada subserosa, serosa, tecido adiposo e omento. O padrão de infiltração predominante foi do tipo úlcero-infiltrativo ( $70 \%$ dos casos), enquanto que os padrões polipoide e vegetante e suas variações estavam presentes em $7 \%$ dos casos e no restante ( $23 \%$ dos casos) não foi possível a especificação. A resposta linfocítica intratumoral e peritumoral foi ausente na grande maioria dos tumores (74\% e 91\%, respectivamente). Apenas cerca de $11 \%$ dos tumores foram referidos com margens cirúrgicas comprometidas; $21,7 \%$ apresentou invasão angiolinfática e 9\% apresentou invasão perineural. Além disso, em 30,4\% dos casos também foram encontrados linfonodos comprometidos. Todas estas informações são importantes e auxiliam na conduta terapêutica (WASHINGTON et al., 2009; BENSON III et al, 2018).

O estadiamento TNM da AJCC (American Joint Committee on Cancer) leva em consideração: a invasão mural do tumor $(\mathrm{T})$; o comprometimento de linfonodos $(\mathrm{N})$ e a presença de metástases a distância (M) (AMIN et al., 2017; BENSON III et al, 2018). Na Tabela 2, verifica-se que os componentes T3 e N0 foram classificados em 39,4\% do total de pacientes portadores de CCR. Os tumores T3 apresentam características infiltrativas na camada da muscular própria, podendo também atingir a camada subserosa. E no caso destes pacientes, os tumores também foram classificados como N0 demonstrando em termos de fator prognóstico, uma menor taxa de sobrevida em relação aos tumores T1-2 e N1 conforme descrito por CHU et al. (2016). O componente M0 foi classificado em 70,2\% dos pacientes, sendo demonstrado que a doença metastática não estava presente na maioria dos pacientes, ou seja, células do CCR não encontravam-se disseminadas em outros órgãos. 
Tabela 2: Distribuição percentual dos casos de pacientes portadores de CCR em relação à cada componente TNM

\begin{tabular}{cccccc}
\hline \multicolumn{3}{c}{ Sistema TNM (American Joint Committee on Cancer - AJCC) } \\
\hline \multicolumn{2}{c}{ Componente T } & \multicolumn{2}{c}{ Componente N } & \multicolumn{2}{c}{ Componente M } \\
\hline $\mathrm{T}_{\text {is }}$ & $1,4 \%$ & $\mathrm{~N}_{\mathrm{X}}$ & $0,8 \%$ & $\mathrm{M} 0$ & $70,2 \%$ \\
$\mathrm{~T} 1$ & $3,9 \%$ & $\mathrm{~N} 0$ & $39,4 \%$ & $\mathrm{M} 1$ & $5,0 \%$ \\
$\mathrm{~T} 2$ & $18,4 \%$ & $\mathrm{~N} 1$ & $22,2 \%$ & Não especificado & $24,8 \%$ \\
$\mathrm{~T} 3$ & $39,4 \%$ & $\mathrm{~N} 2$ & $12,8 \%$ & \\
$\mathrm{~T} 4$ & $12,1 \%$ & Não especificado & $24,8 \%$ & & \\
Não especificado & $24,8 \%$ & & & & \\
\hline
\end{tabular}

A classificação do sistema TNM também pode contribuir para o estabelecimento do fator prognóstico e para a definição do tratamento em pacientes com CCR uma vez que os critérios da escala TNM são amplos e avaliam fatores de invasão mural tumoral, comprometimento linfonodal e presença de metástase a distância (O’CONNELL et al., 2008).

Todas essas considerações demonstram a complexidade do diagnóstico do CCR, do estabelecimento do prognóstico e de um tratamento adequado. Diante disso, e também pelo fato de que o CCR é um tipo de câncer que pode ser prevenido desde que a população seja capaz de identificar os fatores de risco e promova mudanças nos hábitos alimentares e de vida, evidencia-se a necessidade de se atentar para os sinais e sintomas precoces e métodos de rastreio, para que assim possa ocorrer a diminuição da incidência do CCR na população em geral.

\section{CONCLUSÃO}

O câncer colorretal (CCR) apresenta maior incidência em pacientes com mais de 50 anos de idade, apresentando maior ocorrência na região retossigmoide afetando ambos os gêneros. A maioria dos tumores de CCR foram classificados como grau 2 (moderadamente diferenciado), de acordo com o grau histológico. A avaliação histopatológica foi capaz de determinar o grau de diferenciação tumoral, e também avaliou o grau de invasividade tumoral, a extensão a outras estruturas, o número de linfonodos comprometidos, a presença de metástases a distância, as margens cirúrgicas, a invasão linfovascular e a invasão perineural e a classificação TNM. Todas estas informações são importantes e auxiliam na conduta terapêutica. Inclusive o estadiamento pelo sistema TNM também pode contribuir para o estabelecimento do fator prognóstico e para a definição do tratamento em pacientes com CCR, uma vez que os critérios da escala TNM são amplos e avaliam fatores de invasão mural tumoral, comprometimento linfonodal e presença de metástase à distância. 


\section{REFERÊNCIAS}

1. American Cancer Society. Colorectal cancer stages, 2020. Disponível em: https://www.cancer.org/cancer/ colon-rectal-cancer/detection-diagnosis-staging/staged.html. Acesso em: 21 nov. de 2020.

2. AMIN, Mahul B. et al. The eighth edition AJCC cancer staging manual: continuing to build a bridge from a population-based to a more "personalized" approach to cancer staging. CA: a cancer journal for clinicians, v. 67, n. 2, p. 93-99, 2017.

3. ARNOLD, Melina et al. Global patterns and trends in colorectal cancer incidence and mortality. Gut, v. 66, n. 4, p. 683-691, 2017.

4. ARVELO, Francisco; SOJO, Felipe; COTTE, Carlos. Biology of colorectal cancer. Ecancermedicalscience, v. 9, 2015.

5. BARROS, Mariana Castro et al. EVOLUÇÃO DA MORTALIDADE POR CÂNCER DE FÍGADO E COLORRETAL SEGUNDO SEXO E REGIÕES DO BRASIL DE 1990 A 2014. Revista Ceuma Perspectivas, v. 29, n. 1, p. 88-97, 2017.

6. BENSON, Al B. et al. NCCN Guidelines Insights Colon Cancer, Version 2.2018 Featured Updates to the NCCN Guidelines. J Natl Compr Canc Netw, v. 16, n. 4, p. 359-369, 2018.

7. BENSON 3RD, Al B.; HAMILTON, Stanley R. Path toward prognostication and prediction: an evolving matrix. Journal of clinical oncology: official journal of the American Society of Clinical Oncology, v. 29, n. 35, p. 4599-4601, 2011.

8. BRASILEIRO FILHO, Geraldo. Bogliolo Patologia Geral. 8. ed. Rio de Janeiro: Guanabara Koogan, 2013.

9. CHU, Quyen D. et al. Positive surgical margins contribute to the survival paradox between patients with stage IIB/C (T4N0) and stage IIIA (T1-2N1, T1N2a) colon cancer. Surgery, v. 160, n. 5, p. 1333-1343, 2016.

10.CORRÊA, Romualdo da Silva et al. Sobrevivência de câncer colorretal em uma Unidade de Referência do Câncer. Journal Of Coloproctology. Rio de Janeiro, p. 203-207. dez. 2016.

11. FEARON, Eric R. Molecular genetics of colorectal cancer. Annual Review of Pathology: Mechanisms of Disease, v. 6, p. 479-507, 2011.

12.HALF, Elizabeth E.; BRESALIER, Robert S. Clinical management of hereditary colorectal cancer syndromes. Current opinion in gastroenterology, v. 20, n. 1, p. 32-42, 2004.

13.Instituto Nacional de Câncer (INCA). Câncer de intestino. 2020. Disponível em: https://www.inca.gov.br/ tipos-de-cancer/cancer-de-intestino. Acesso em: 21 nov. 2020.

14. Instituto Nacional de Câncer (INCA). Estimativa 2020: incidência de câncer no Brasil. Rio de Janeiro, 2019. Disponível em: https://www.inca.gov.br/sites/ufu.sti.inca.local/files//media/document//estimativa-2020-incidencia-de-cancer-no-brasil.pdf. Acesso em: 21 nov. 2020.

15.JASS, J. R. Classification of colorectal cancer based on correlation of clinical, morphological and molecular features. Histopathology, v. 50, n. 1, p. 113-130, 2007.

16.KUMAR, Vinay; ABBAS, Abul K.; ASTER, Jon C.. Robbins Patologia Básica. 9. ed. Rio de Janeiro: Elsevier, 2013.

17.LAPORTE, Gustavo A. et al. Clinical importance of DNA repair in sporadic colorectal cancer. Critical reviews in oncology/hematology, v. 126, p. 168-185, 2018.

18. LIEBIG, Catherine et al. Perineural invasion is an independent predictor of outcome in colorectal cancer. Journal of clinical oncology, v. 27, n. 31, p. 5131, 2009. 
19.Ministério da Saúde (Brasil). DATASUS. 2020. Disponível em: http://tabnet.datasus.gov.br/cgi/tabcgi. exe?sih/cnv/niPR.def. Acesso em: 21 nov. 2020.

20.O'CONNELL, Michael J. et al. Survival following recurrence in stage II and III colon cancer: findings from the ACCENT data set. Journal of Clinical Oncology, v. 26, n. 14, p. 2336-2341, 2008.

21.OUAKRIM, Driss Ait et al. Trends in colorectal cancer mortality in Europe: retrospective analysis of the WHO mortality database. Bmj, v. 351, p. h4970, 2015.

22.UENO, Hideki et al. Extramural cancer deposits without nodal structure in colorectal cancer: optimal categorization for prognostic staging. American journal of clinical pathology, v. 127, n. 2, p. 287-294, 2007.

23.VAN EEGHEN, Elmer E. et al. Impact of age and comorbidity on survival in colorectal cancer. Journal of gastrointestinal oncology, v. 6, n. 6, p. 605, 2015. VILAR, Eduardo; GRUBER, Stephen B. Microsatellite instability in colorectal cancer - the stable evidence. Nature reviews Clinical oncology, v. 7, n. 3, p. 153, fev. 2010. Disponível em: https://www.nature.com/articles/nrclinonc.2009.237\#citeas.Acesso em: 22 nov. 2020.

24.VINEIS, PAOLO; WILD, CHRISTOPHER P. Global cancer patterns: Causes and prevention. The Lancet, v. 383, n. 9916, p. 549-557, 2014.

25.WASHINGTON, Mary Kay et al. Protocol for the examination of specimens from patients with primary carcinoma of the colon and rectum. Archives of pathology \& laboratory medicine, v. 133, n. 10, p. 1539$1551,2009$. 


\section{EFEITOS DA ELETROESTIMULAÇÃO NERVOSA TRANSCUTÂNEA NA REDUÇÃO DO QUADRO ÁLGICO EM UNIVERSITÁRIAS PORTADORAS DE DISMENORREIA}

ELIZABETH BEZERRA GOMES DA SILVA

Estudante do Curso de Fisioterapia do Centro de Ciências Biológicas e Saúde, Unicap;

MARIANNE COTRIM PEREIRA

Graduada em Fisioterapia pela Universidade Católica de Pernambuco;

SILVANA MARIA MACÊDO UCHÔA Professora do Curso de Fisioterapia do Centro de Ciências Biológicas e Saúde

MARINA DE LIMA NEVES BARROS

Professora do Curso de Fisioterapia do Centro de Ciências Biológicas e Saúde

ÉRICA PATRÍCIA BORBA LIRA UCHÔA Professora do Curso de Fisioterapia do Centro de Ciências Biológicas e Saúde

VALÉRIA CONCEIÇÃO PASSOS DE CARVALHO

Professora do Curso de Fisioterapia do Centro de Ciências Biológicas e Saúde

RESUMO: Dismenorreia é o termo usado para denominar as cólicas menstruais dolorosas que podem ocorrer horas antes, durante e dias após a menstruação. Pode ser causada por fator psíquico, endócrino, como também, pela produção excessiva de prostaglandina uterina. Tem elevada prevalência, afetando aproximadamente 50\% das mulheres em idade reprodutiva, e, em 10\% destas, a intensidade da dor interfere no convívio social. Objetivo: Avaliar a redução do quadro álgico através da aplicação da Estimulação Elétrica Nervosa Transcutânea (TENS) entre universitárias portadoras de dismenorreia. Mé- todos: Estudo do tipo experimental (antes e depois), com 22 acadêmicas, entre outubro/2018 a abri1/2019. Os dados foram coletados através do Questionário dos Sintomas Menstruais (MSQ) e da Escala Visual Analógica (EVA), foram realizadas 12 sessões de eletroanalgesia no modo Burst, e ao final foram reavaliadas com o MSQ e a EVA. A amostra foi dividida em dois grupos de forma aleatória (sorteio), um Grupo Controle ( $\mathrm{GC}, \mathrm{n}=11)$ que receberam apenas uma cartilha contendo orientações e exercícios para serem feitos em casa e o Grupo Intervenção (GI, n=11) que foi submetido ao protocolo de atendimento estabelecido para a pesquisa. A análise foi descritiva e analítica na qual todas as conclusões foram tomadas com nível de significância de 5\%. Resultados: A maioria das acadêmicas tinham entre 18 a 26 anos, eram solteiras, naturais da Região Metropolitana de Recife, apenas estudavam, eram brancas e de religião católica. A prevalência de Dismenorreia foi de $62,5 \%$ na amostra pesquisada. Na comparação da EVA (antes e depois) no GI pode ser observada uma houve uma redução significante em todas as variáveis pesquisadas depois do tratamento ( $\mathrm{p}$-valor $=0,008$ ), passando de uma dor moderada para uma mínima. Conclusão: $O$ presente estudo sugere ser efetiva a utilização da TENS na redução do quadro álgico das estudantes portadoras de Dismenorreia.

PALAVRA-CHAVE: ELETROANALGESIA, ASSOALHO PÉLVICO, DISMENORREIA.

ABSTRACT: Dysmenorrhea is the term used to describe painful menstrual cramps that can occur hours before, during and days after menstruation. It can be caused by psychic, endocrine factor, as well as by the excessive production of uterine 
prostaglandin. It has a high prevalence, affecting approximately $50 \%$ of women of reproductive age, and in $10 \%$ of these, the intensity of pain interferes with social life. Objective: To evaluate the reduction of pain through the application of Transcutaneous Electrical Nerve Stimulation (TENS) among university students with dysmenorrhea. Methods: Experimental study (before and after), with 22 students, between October / 2018 to April / 2019. Data were collected through the Menstrual Symptoms Questionnaire (MSQ) and the Visual Analog Scale (EVA), 12 sessions of electroanalgesia were performed in Burst mode, and at the end they were reevaluated with the MSQ and EVA. The sample was divided into two groups at random (draw), a Control Group $(\mathrm{CG}, \mathrm{n}=11)$ that received only a booklet containing guidelines and exercises to be done at home and the Intervention Group (IG, $\mathrm{n}=11)$ that was submitted to the service protocol established for the research. The analysis was descriptive and analytical in which all conclusions were taken with a significance level of 5\%. Results: Most of the students were between 18 and 26 years old, were single, born in the Metropolitan Region of Recife, just studied, were white and Catholic. The prevalence of dysmenorrhea was $62.5 \%$ in the surveyed sample. When comparing VAS (before and after) in GI, a significant reduction was observed in all variables surveyed after treatment ( $\mathrm{p}$-value $=0.008$ ), going from moderate to minimal pain. Conclusion: The present study suggests that the use of TENS is effective in reducing pain in students with dysmenorrhea.

KEYWORDS:TRANSCUTANEUS ELETRIC NERVE STIMULATION, PELVIC FLOOR, DYSMENORRHEA.

\section{INTRODUÇÃO}

O termo "dismenorreia" é usado para denominar as cólicas menstruais dolorosas na região inferior do abdome que ocorre horas antes, durante e dias após a menstruação, apresentando náuseas, diarreia, dor lombar e cefaleia. Pode ser causada por fator psíquico, endócrino, como também, pela produção excessiva de prostaglandina uterina. A dismenorreia é uma afecção de elevada prevalência, afetando aproximadamente 50\% das mulheres em idade reprodutiva, e, em 10\% destas, a intensidade da dor interfere no convívio social (ACQUA, BENDLIN, 2015; MIELI, 2013).

A dismenorreia pode ser dividida como primária quando sua causa fundamenta-se unicamente em alterações hormonais, com ausência de patologias pélvicas enquanto a secundária está correlacionada a patologias pré-existentes podendo provocar vários disfunções como aderências uterina, ciclos irregulares, doença inflamatória pélvica e endometriose (OLIVEIRA; CIRQUEIRA, 2019).

Grande parcela da população feminina que sofre de dismenorreia primária, manifesta quadros de sinais e sintomas que podem levar a incapacitação em suas tarefas habituais, podendo ocasionar distúrbios psicológicos como depressão e ansiedade, impactando em $66,8 \%$ da sua produtividade das horas trabalhadas, acarretando em resultados como demissão, modificação dos horários e férias, impossibilitando também suas atividades de vida diária e lazer (AMARO,2016).

A fisioterapia oferece diversos recursos que visam diminuir o desconforto, promover relaxamento muscular ou até mesmo eliminar as dores provocadas pela dismenorreia, dentro desses recursos, a Estimulação Elétrica Nervosa Transcutânea (TENS) é um dos recursos terapêuticos mais recomendados e utilizados sendo de simples manuseio e fácil aplicação ( OLIVEIRA; CIRQUEIRA, 2019). 
A TENS, fundamenta-se na teoria das comportas da dor, desta forma irá ocorrer uma hiperestimulação das fibras tipo A, para, assim, bloquear a transmissão das fibras tipo C nas comportas do corno posterior da medula, levando a inibição da dor. Considerada uma técnica de aplicação simples e indolor na qual os eletrodos são colocados sobre a pele íntegra com a finalidade de estimular as fibras nervosas de grande diâmetro, perfeitamente mielinizadas possibilitando a condução elétrica rápida, ativando a nível central, os sistemas analgésicos descendentes de caráter inibitório sobre a transmissão nociceptiva conduzida pelas fibras não mielinizadas de pequeno calibre, estabelecendo desta forma a redução ou até mesmo a inibição da dor (AGNE, 2015).

Atualmente a fisioterapia vem se solidificando como uma ciência da saúde que estuda e promove a reabilitação de órgãos e sistemas que sofreram alterações, podendo oferecer através de recursos terapêuticos prevenção, eliminação ou melhora das condições patológicas. (MEDEIROS, 2003; FERREIRA, 2017), além de ser uma prática clínica totalmente alicerçada em evidências e pesquisas (MOREIRA, 2017).

O objetivo principal desta pesquisa foi avaliar a redução do quadro álgico através da aplicação da TENS entre universitárias portadoras de dismenorreia. Contribuindo desta forma para a implementação de forma eficaz e científica no tratamento da dismenorreia da população em estudo e favorecer uma melhor qualidade de vida.

\section{MATERIAL E MÉTODOS}

Estudo do tipo experimental (antes e depois), com 50 acadêmicas (amostra de conveniência) que se adequaram aos seguintes critérios de inclusão: faixa etária entre 18 a 30 anos; ser portadora de dismenorreia; está devidamente matriculada na instituição de ensino superior pesquisada. Entre os critérios de exclusão temos: Pacientes com deficiência cognitiva que impossibilite o entendimento entre pesquisada e pesquisador; não aceitar participar da pesquisa; ser portadora apenas de Tensão pré-menstrual (TPM).

É parte integrante do projeto de pesquisa intitulado "ABORDAGENS FISIOTERAPÊUTICAS NAS DISFUNÇÕES DO ASSOALHO PÉLVICO” sob a coordenação da Profa. Dra. VALÉRIA CONCEIÇÃO PASSOS DE CARVALHO, cadastrado sob o n ${ }^{\circ}$ 442930-BIO-059-2015/1-6 e aprovado pelo comitê de ética de pesquisa com seres humanos da UNICAP n ${ }^{\circ} \mathrm{CAAE} \mathrm{N}^{\circ}$ 56355116.7.0000.5206, obedecendo às orientações da Resolução 466/12 da Comissão Nacional de Ética em pesquisa, órgão do Ministério da Saúde. Este projeto está vinculado ao grupo de pesquisa FISIOTERAPIA BASEADA EM EVIDÊNCIAS.

Após assinatura do Termo de Consentimento Livre Esclarecido (TCLE), foi aplicado um questionário composto por perguntas para obtenção do perfil sócio-demográfico e reprodutivo das mulheres, ou seja: idade, raça, religião, escolaridade, profissão, renda mensal familiar, número de pessoas no domicilio, histórico reprodutivo, desenvolvido pelas próprias pesquisadoras para atingir o objetivo da presente pesquisa. 
Posteriormente, foi aplicado o MSQ (Questionário de autoavaliação dos sintomas menstruais). Tal escala contém 23 questões, na qual cada uma delas teve seis opções de resposta, a opção marcada irá depender do grau em que a os sintomas afetam as atividades contidas nas determinadas perguntas (CARVALHO et al, 2009). Para classificar as acadêmicas como portadoras de dismenorreia, as mesmas teriam que apresentar escore 3 ou mais nas questões: Peso abdominal, desconforto ou dor; dores ou cólicas no abdome; sensação inchaço e sensação de fadiga.

Foi realizada também a aplicação da Escala Analógica Visual da Dor (EVA) que é uma escala de fácil compreensão à paciente. É provida de instruções claras e conceitos simples, permitindo aplicação rápida com intervenção mínima. Consiste em uma régua de dez centímetros de comprimento que contém as palavras "sem dor", "dor média" e "dor máxima". A paciente indica a intensidade de sua dor marcando exatamente no local em que considera estar à intensidade de sua dor (SOUZA et al, 2005).

Após a seleção a amostra foi dividida em dois grupos de forma aleatória (sorteio), um Grupo Controle (GC) que receberam apenas uma cartilha contendo orientações e exercícios para serem feitos em casa e o Grupo Intervenção (GI), no qual as voluntárias foram submetidas a 12 sessões de eletroanalgesia, as sessões tem duração de 30 minutos, os eletrodos superficiais foram colocados na região lombosacra, com as mesmas em decúbito dorsal. O protocolo de aplicação da TENS foi na modalidade BURST com frequência de base de $100 \mathrm{~Hz}$ por um tempo de 30 minutos (AGNE, 2015). Tal modalidade foi escolhida embasada em estudos já realizados comparando o uso do TENS convencional com o TENS burst em mulheres dismenorréicas, obtendo melhores resultados com a utilização do TENS supracitado. Ao final do tratamento foram reavaliadas através da aplicação da EVA e do MSQ para comparar o antes e o depois nos dois grupos.

Para verificar a existência de diferenças na intensidade de dor aferida pela Escala Visual Analógica (EVA) antes e depois da intervenção, inicialmente consideramos a possibilidade da aplicação de testes paramétricos, avaliando a distribuição dos dados. Uma vez que a distribuição dos dados da Escala Visual Analógica (EVA) revelou não ser normal, utilizamos o teste de Wilcoxon pareado.

Para os avaliar a frequência de fatores de risco entre pacientes com dismenorréia, foram realizados testes de Qui-quadrado de aderência de forma a verificar se existam diferenças nas proporções entre as categorias de cada um desses fatores. Ainda, para verificar se a escala do questionário dos sintomas menstruais (MSQ) estão relacionadas com tratamento (antes e depois) no grupo de controle e no grupo de intervenção foram utilizados testes Qui-quadrado de independência. Todas as análises formam realizadas em ambiente de desenvolvimento $\mathrm{R}$ ( $\mathrm{R}$ Core Team, 2018) e para todos os testes assumimos valores de $\mathrm{p}<0,05$ como significativos.

\section{RESULTADOS}

A coleta da presente pesquisa foi realizada durante o período de outubro de 2018 e abril de 2019, sendo aplicados aplicados 253 (duzentos e cinquenta e três) questionários sobre o perfil 
sócio-demográfico e reprodutivo das mulheres. As participantes tinha idades entre 18 e 26 anos (98\%), com relação ao estado civil, a maioria relatou ser solteira (82\%), 83\% das entrevistadas são da Região Metropolitana de Recife. Ainda, a maioria dos participantes da amostra são apenas estudantes (75\%) e as outras $25 \%$ desenvolve algum tipo de atividade profissional. A maior parte das entrevistadas se autodeclaram brancas (57\%), seguido de pardas (32\%). Por fim, 57\% da amostra diz ser católica, 17\% evangélica e 7\% informou pertencer à religião espírita.

Quando questionadas sobre o intervalo entre as menstruações, 44\% afirmou ter um intervalo entre 28 a 30 dias enquanto $47 \%$ relatou que o seu intervalo entre os ciclos menstruais era sempre maior ou menor que 30 dias. Com relação à intensidade do fluxo, $66 \%$ das entrevistadas diz ter um fluxo moderado, seguido por um fluxo que consideram grande (25\%). Além disso, quando perguntado se tinham problemas ginecológicos $77 \%$ respondeu que não, no entanto, ao se perguntar sobre problemas ginecológicos com familiares, $44 \%$ respondeu afirmativamente.

Do total de entrevistadas, $53 \%$ relataram já terem iniciado sua vida sexual enquanto $45 \%$ disse que não e $2 \%$ optou por não responder. Entre as participantes que iniciaram sua atividade sexual, a maioria (62\%) informou ter tido sua primeira relação sexual com idades compreendidas entre 13 e 17 anos e 33\% entre 18 e 22 anos de idade. Quase a totalidade da amostra (90\%), afirmou usar algum tipo de método contraceptivo. Desses métodos os mais relatados foram a camisinha $(30 \%)$ e a pílula (25\%). Além disso, 30\% das participantes afirmar preferir usar um conjunto de 2 ou mais métodos contraceptivos durante a relação sexual. $97 \%$ das participantes não possuí filhos e não tem hábito de fumar. Por outro lado, quando questionadas sobre o consumo de bebidas alcoólicas 53\% afirmou beber.

Os resultados referentes ao MSQ (Questionário de autoavaliação dos sintomas menstruais). Após os critérios de classificação podemos observar que 85 acadêmicas $(33,6 \%)$ tinham Tensão Pré-menstrual (TPM), 1 (0,4\%) dismenorreia e 158 (62,45\%) da amostra tinham TPM associada a Dismenorréia, $9(3,56 \%)$ das acadêmicas relataram não ter nenhum incomodo relacionada a menstruação.

\section{Resultados MSQ}

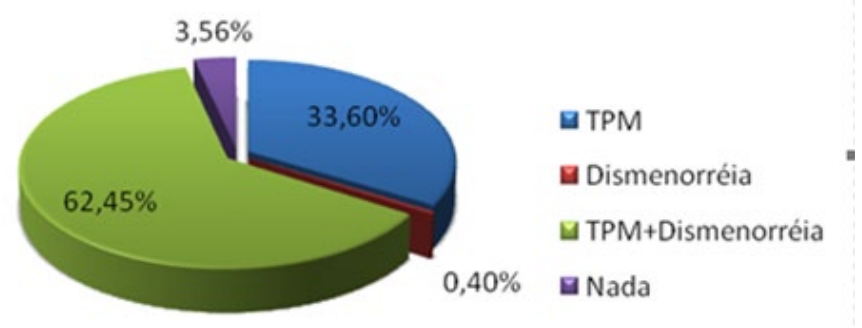

Entre as acadêmicas aptas a participar da intervenção e que aceitaram participar da pesquisa, o tamanho da amostra ficou em 22 sendo as mesmas alocadas de forma aleatória (sorteio) em dois grupos: GC contendo 11 (onze) voluntárias e GE também com 11 (onze) voluntárias como já descrito em materiais e métodos. 
Ao quantificar a redução do quadro álgico das voluntárias, pode-se observar diferenças significativas na escala de dor (EVA) entre o antes (média \pm desvio padrão: 7,5 $\pm 1,17$ ) e depois (média \pm desvio padrão: $3,4 \pm 2,83$ ) da administração do tratamento no GE (p-valor $=0,008$ ). Os resultados indicam que as participantes do GE tiveram uma diminuição na escala de dor após o tratamento administrado. Já quando comparamos essas mesmas variáveis no GC, verificamos que também houve diferenças significativas entre antes (média \pm desvio padrão: 7,5 $\pm 2,06$ ) e depois (média \pm desvio padrão: $6,7 \pm 1,95$ ) do tratamento, no entanto essa diminuição foi bem menos acentuada ( $\mathrm{p}$-valor= 0,03) (Tabela 3).

Tabela 3 - Resultados das análises das diferenças observadas na Escala Visual Analógica antes e após a intervenção.

\begin{tabular}{lcccc}
\hline \multirow{2}{*}{ Grupo } & $\begin{array}{c}\text { Análise } \\
\text { realizada }\end{array}$ & $\begin{array}{c}\text { ANTES } \\
\text { Média (desvio padrão) }\end{array}$ & $\begin{array}{c}\text { DEPOIS } \\
\text { Média (desvio padrão) }\end{array}$ & Valor de "p" \\
\hline Intervenção & $\begin{array}{c}\text { Wilcoxon } \\
\text { pareado }\end{array}$ & $\mathbf{7 , 5 ( 1 , 1 7 )}$ & $\mathbf{3 , 4}(\mathbf{2 , 8 3})$ & $\mathbf{0 , 0 0 8}$ \\
Controle & $\begin{array}{c}\text { Wilcoxon } \\
\text { pareado }\end{array}$ & $\mathbf{7 , 5 ( 2 , 0 6 )}$ & $\mathbf{6 , 7}(\mathbf{1 , 9 5})$ & $\mathbf{0 , 0 3}$ \\
\hline
\end{tabular}

Na tabela 4 podemos observar a associação de alguns fatores relacionados a presença de TPM e Dismenorréia são eles: Problemas emocionais; ciclo menstrual irregular; fluxo de intensidade grande; problemas ginecológicos. Problemas ginecológicos na família; ser tabagista(p-valor $=<0,0001)$.

Tabela 4 - Sumarização dos fatores de risco associados à presença de dismenorreia, porcentagens, valor da estatística e o valor de $\mathrm{p}$. Os valores em negrito sinalizam valores de $\mathrm{p}$ significativos.

\begin{tabular}{|c|c|c|c|}
\hline Fator de risco & Porcentagens & $\begin{array}{l}\text { Valor da } \\
\text { estatística }\end{array}$ & Valor de $p$ \\
\hline Problemas emocionais & $\begin{array}{l}\text { Sim }(26 \%) \\
\text { Não }(74 \%)\end{array}$ & 44,65 & $<0,0001$ \\
\hline Ciclo menstrual & $\begin{array}{l}\text { Regular }(80 \%) \\
\text { Irregular }(20 \%)\end{array}$ & 89,28 & $<0,0001$ \\
\hline Intervalo entre menstruações & $\begin{array}{c}{[28-30](42 \%)} \\
{[<28 \text { ou }>30](49 \%)}\end{array}$ & 42,26 & $>0,92$ \\
\hline Intensidade do fluxo & $\begin{array}{c}\text { Pequeno }(6 \%) \\
\text { Moderado }(64 \%) \\
\text { Grande }(28 \%)\end{array}$ & 152,03 & $<0,0001$ \\
\hline Problemas ginecológicos & $\begin{array}{l}\text { Sim }(25 \%) \\
\text { Não }(75 \%)\end{array}$ & 40,51 & $<0,0001$ \\
\hline Problemas ginecológicos na família & $\begin{array}{l}\text { Sim }(49 \%) \\
\text { Não }(51 \%)\end{array}$ & 0,006 & 0,94 \\
\hline $\begin{array}{c}\text { Grau de parentesco dos familiares que possuem } \\
\text { problemas ginecológicos }\end{array}$ & $\begin{array}{c}\text { Primeiro }(81 \%) \\
\text { Segundo }(15 \%) \\
\text { Terceiro }(4 \%)\end{array}$ & 77,21 & $<0,0001$ \\
\hline Tabagista & $\begin{array}{c}\text { Sim }(3 \%) \\
\text { Não }(97 \%)\end{array}$ & 138,63 & $<0,0001$ \\
\hline Etilista & $\begin{array}{l}\operatorname{Sim}(53 \%) \\
\text { Não }(47 \%) \\
\end{array}$ & 0,41 & 0,52 \\
\hline
\end{tabular}


Não verificamos qualquer diferença significativa na escala dos sintomas menstruais baseado no MSQ entre o antes e depois do tratamento no grupo intervenção (X2 =4,8889; $\mathrm{gl}=2 ; \mathrm{p}=0,08)$. Esse resultado foi também observado para o grupo controle $(\mathrm{X} 2=2,2 ; \mathrm{gl}=2 ; \mathrm{p}=0,33)$.

Figura 1 - Gráfico de pizza da escala dos sintomas menstruais baseado no MSQ em relação a antes e depois da administração do tratamento no grupo intervenção.

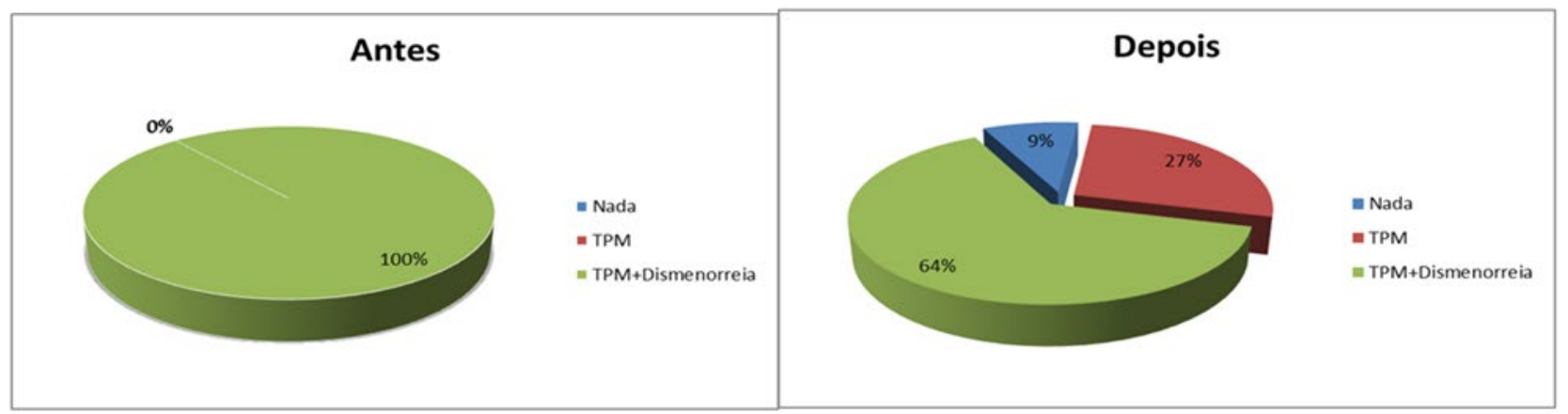

Figura 2 - Gráfico de pizza da escala dos sintomas menstruais baseado no MSQ em relação a antes e depois da administração do tratamento no grupo controle.

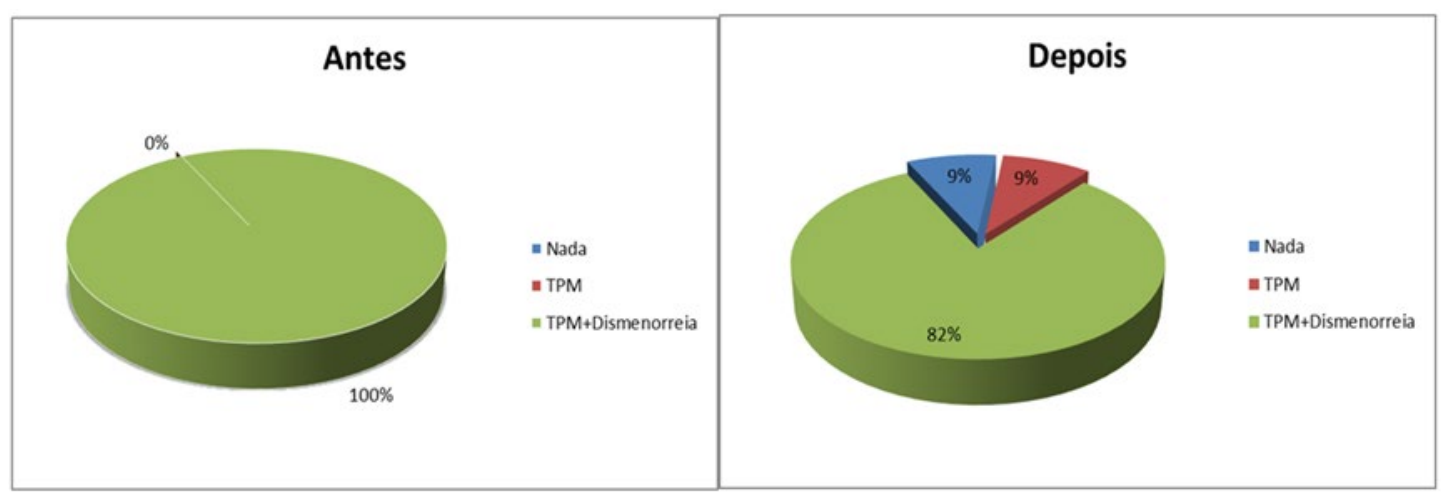

\section{DISCUSSÃO}

$\mathrm{Na}$ presente pesquisa pode ser observada uma alta prevalência de Dismenorreia associada a TPM, sendo as pesquisadas adultas jovens, solteiras, provenientes da Região Metropolitana do Recife. Em relação ao perfil reprodutivo pode ser constatado que a grande maioria das estudantes relataram um fluxo moderado, afirmaram já ter vida sexual ativa, utilizam algum tipo de método contraceptivo e também não apresentavam filhos, perfil condizente com pesquisas conduzidas entre universitárias brasileiras (ALVES et al. 2019; SILVA et al. 2016).

A alta prevalência da dismenorreia em jovens pode ser justificada pela razão de quanto menor for o volume do útero maior será a produção e liberação de prostaglandina, consequentemente uma frequência e intensidade maior de contração uterina, promovendo a exacerbação da dor. Desta forma 
temos a presença de dismenorreia primária mais prevalente em adultas jovens, nulíparas, como descritos no perfil da amostra pesquisada (AMARO,2016).

Na classificação das disfunções menstruais referentes aos resultados do MSQ, pode ser observado um predomínio de $62,45 \%$ de estudantes que se enquadraram nos critérios de portadoras de dismenorreia associada com a TPM. Condizentes com outras pesquisas que também encontraram alta prevalência dessa síndrome entre estudantes (NUNES, J. M. D. O. et al.2013; SEZEREMETA,2013; GRANDI, G. et al.2012).

A aplicação do protocolo de analgesia utilizado neste estudo se mostrou eficaz no sentido de que houve redução significante entre o antes e o depois ( $p$-valor =0,008). Dado esse também encontrado outros estudos para alívio da dor, utilizando a eletroanalgesia, sendo os mesmos justificados devido a diminuição da condução nervosa do estímulo nociceptivo decorrente da contração uterina para a expulsão do endométrio, o que corrobora com a teoria da comporta da dor, com a redução da velocidade deste estímulo, sugerindo-se que a TENS é um método não farmacológico eficaz e seguro para o tratamento da dismenorreia (LAURETTI et al. 2015; PATEL et al. 2016; SILVA, et al. 2016).

De acordo com os resultados, problemas emocionais têm impactos significativos no desfecho pesquisado, esse fato se dá pois as alterações emocionais negativas relacionadas ao período menstrual podem provocar um efeito de superestimação da dor e com isso sentimentos de ansiedade, depressão entre outras emoções negativas (MOU et al. 2019; LUZ et al. 2015).

No presente estudo, os ciclos menstruais regulares não foram considerados um fator de risco para dismenorreia. No entanto, a maioria das estudantes (80\%) apresentou ciclos menstruais regulares ( $\mathrm{p}$-valor $=0,0001)$, em concordância com a literatura. Considera-se que a causa da dismenorreia seja a demasiada quantidade de prostaglandinas liberadas durante o ciclo regular de ovulação, o que provoca contrações e dor no tecido uterino. Também foi observado na amostra que $81 \%$ (p-valor=< $0,0001)$ relataram haver parente de primeiro grau com problemas ginecológicos. Resultados semelhantes foram obtidos na literatura no quais estudantes com dismenorreia relataram ter um familiar em primeiro grau sem especificar a relação, com dor e desconforto durante a menstruação. $\mathrm{O}$ que sugere, de acordo com determinados estudos que mulheres com história familiar de dismenorréia podem sentir dor menstrual devido ao comportamento aprendido de suas mães e irmãs. Entretanto, outros estudos também sugeriram uma suscetibilidade genética à dismenorréia. (GIRAY, \&. et al. 2009; TAVALLAEE et al. 2011; Fernández-Martínez E, Onieva-Zafra MD, Parra-Fernández ML, 2018)

E por fim a intensidade do fluxo menstrual se mostrou associada a presença da dismenorreia(p-valor $=<0,0001)$. O que favorece a teoria de espasmos da musculatura uterina, e consequente aumento de prostaglandinas na tentativa de empurrar o conteúdo do endométrio para fora do útero, ou seja, quanto maior o fluxo uterino, maior a intensidade de contração uterina e dor (FARAMARZI, M; SALMALIAN, H., 2014; SILVA, F. B. P. et al. 2019). 


\section{CONCLUSÃO}

Os resultados da presente pesquisa sugerem que a TENS foi eficaz para a redução do quadro álgico das estudantes portadoras de Dismenorréia e TPM. Ressalta-se que as variáveis relacionadas ao perfil bio-social e reprodutivo estiveram associadas a presença de Dismenorréia e TPM. Partindo destas evidências sugere-se a implantação de medidas de promoção e prevenção junto a esta população, bem como, a inclusão da aplicação da TENS na rotina dos serviços de fisioterapia que tratam da saúde da mulher e suas queixas relacionadas ao período menstrual.

\section{REFERENCIAS}

ACQUA, R. D; BENDLIN, T. Dismenorreia, Revista Femina, Maringá, v. 43, n. 6, nov-mar, 2015.

AGNE, Jones Eduardo. Eletrotermofototerapia. 3 ed. Rio Grande do Sul: Santa maria, 2015, 448p.

ALVES, M. H. F. et al. Prevalência da tensão pré-menstrual entre universitárias. Fisioterapia Brasil, v. 20, n. 3, p. 392-399, mai./2019.

AMARO, F. R. A. Atuação Da Fisioterapia No Tratamento Da Dismenorreia Primaria Em Mulheres: Uma Revisão de Literatura. 2016. 39 f. Monografia (Especialização) - Curso de Fisioterapia, Faculdade de Educação e Meio Ambiente, Ariquemes, 2016.

CARVALHO, V. P de et al. Repercussões do transtorno disfórico pré-menstrual entre universitárias, Revista de psiquiatria Rio Grande do Sul, Porto Alegre, v. 31, n.2, 2009.

FARAMARZI, M.; SALMALIAN, H. Association of Psychologic and Nonpsychologic Factors With Primary Dysmenorrhea. Iran Red Crescent Med J, v.16, n.8, p. 159-167. 2014.Fernández-Martínez E, Onieva-Zafra MD, Parra-Fernández ML. Lifestyle and prevalence of dysmenorrhea among Spanish female university students. PloS ONE, v.13, n.8, jul./ago.2018.

FERREIRA, E. J et al. Atuação da fisioterapia na dismenorreia primária. Vita et Sanitas, v. 4, n. 1, p. 57-72, 2017.

GIRAY, \&. et al. Prevalence and predictors of dysmenorrhea among students at a university in Turkey. International Journal of Gynecology \& Obstetrics, v. 107, n. 1, p. 39-43, 2009.

GRANDI, G. et al. Prevalence of menstrual pain in young women: what is dysmenorrhea? Journal of Pain Research, v. 5, p. 169-174, jun./2012.

LAURETTI, G. R. et al. The New Portable Transcutaneous Electrical Nerve Stimulation Device Was Efficacious in the Control of Primary Dysmenorrhea Cramp Pain. Neuromodulation: Technology at the Neural Interface, [s.1.], v. 18, n. 6, p.522-527, 5 fev. 2015.

LUZ, J. M et al. Consequências da Síndrome Pré-Menstrual em Acadêmicas de Enfermagem, RETEP, Fortaleza/CE, v.7, n. 2, 1537-1541, 2015

MEDEIROS, M. W. Efeitos da fisioterapia no aprimoramento da vida sexual feminina. Tubarão, UNISUL, 2003. Monografia.

MIELI, M. A. P. Dismenorreia primária: tratamento, Revista associação médica brasileira, São Paulo, p. 413-419. 2013. 
MOREIRA, D. O. Fisioterapia: uma ciência baseada em evidências, Revista fisioterapia em movimento, Curitiba, v. 30, n.1, jan-mar, 2017.

MOU et al. Mediating effect of interpersonal relations on negative emotions and dysmenorrhea in female adolescents.General Psychiatry. v. 32, n. 1, fev./2019.

NUNES, J. M. D. O. et al. PREVALÊNCIA DE DISMENORREIA EM UNIVERSITÁRIAS E SUA RELAÇÃO COM ABSENTEÍSMO ESCOLAR, EXERCÍCIO FÍSICO E USO DE MEDICAMENTOS. Rev Bras Promoc Saude, Fortaleza, v. 26, n. 3, p. 381-386, fev./2013.

OLIVEIRA, Melina Muniz; CIRQUEIRA, Rosana Porto. Eficácia da Eletroterapia na Dismenorreia: Revisão de Literatura. Id On Line Revista Multidisciplinar e de Psicologia. v.13, n. 43, p. 448-454, 2019

PATEL, Vrunda; , Megha Sheth; VYAS, Neeta. Effect of transcutaneous electrical nerve stimulation on pain in subjects with primary dysmenorrhea. International Archives of Integrated Medicine, v. 3, n. 6, p. 1-5, mai./ jun. 2016.

SEZEREMETA, D. C. et al. Dismenorreia: Ocorrência na Vida de Acadêmicas da Área de Saúde. Ciências Biológicas e da Saúde, vol.15, nº 2, p. 123-126, 2013

SILVA, B. C. P. D. et al. Estimulação elétrica nervosa transcutânea no tratamento da dor pélvica causada pela dismenorréia primária. ConScientiae Saúde, Barra Mansa - RJ Brasil, v. 15, n. 4, p. 650-656, dez./2016.

SILVA, F. B. P. et al. Prevalência Da Dismenorreia E Sua Influência Na Vida De Trabalhadoras Brasileiras. Revista Saúde e Desenvolvimento, v. 13, n. 14, p. 64-82, 2019.

SOUZA, Luciana Silva de. Avaliação dos Efeitos da estimulação Elétrica Nervosa Transcutânea durante o trabalho de parto. 2005. 69 f. Trabalho de Conclusão de Curso (Bacharelado em Fisioterapia) - Universidade do Sul de Santa Catarina, Tubarão, 2005.

TAVALLAEE et al. The prevalence of menstrual pain and associated risk factors among Iranian women. Journal of Obstetrics and Gynaecology Research, v. 37, n. 5, p. 442-451,2011 


\section{CONTROLE DE QUALIDADE DE MEDICAMENTOS QUE CONTÊM O PRINCÍPIO ATIVO NAPROXENO}

BÁRBARA ALEXSSANDRA SCARABELOT RODRIGUEZ

Acadêmica do Curso de Farmácia do Centro Universitário União das Américas (Uniamérica), Foz do Iguaçu, PR. E-mail: barbara_scars@hotmail.com

FERNANDO AUGUSTO DE FREITAS Professor do curso de Farmácia do Centro de Ensino Superior de Foz do Iguaçu (Cesufoz), Foz do Iguaçu, PR. E-mail: fernandoaugustodefreitas.faf@gmail.com

RESUMO: O fármaco Naproxeno é um anti-inflamatório não esteroidal (AINE) e atua como inibidor competitivo e reversível das enzimas cicloxigenases (COXs). Por sua ação analgésica e antipirética, é utilizado no tratamento de doenças reumáticas e processos inflamatórios agudos. Os AINEs estão entre as classes de medicamentos mais prescritos no mundo em função dos seus efeitos analgésicos e anti-inflamatórios, sendo frequentemente utilizados devido à capacidade de serem adquiridos sem receita médica. A atual legislação determina a necessidade de intercambialidade entre os medicamentos genéricos e similares com os medicamentos de referência, mediante testes de equivalência e bioequivalência. Sendo assim, este trabalho tem como objetivo efetuar o controle de qualidade e equivalência farmacêutica de medicamentos que possuem o princípio ativo naproxeno. Os medicamentos utilizados neste estudo foram identificados como NxT (referência), NSN (similar) e NeT (genérico) e todos se tratam de comprimidos não revestidos com $500 \mathrm{mg}$. As análises realizadas neste trabalho (peso médio, dureza e friabilidade) fazem parte do conjunto das técnicas determinadas pela Farmacopeia Brasileira $6^{\mathrm{a}} \mathrm{Ed}$. para a avaliação da intercambialidade entre os medicamentos de referência, genéricos e similares. Os resultados mostraram que os medicamentos examinados possuem uma boa uniformidade no peso, com os valores de coeficiente de variação $(\mathrm{CV})$ e desvio-padrão (DP) iguais a NxT $(0,90 \% \mathrm{e} \pm 0,005423)$, NeT $(1,11 \%$ e $\pm 0,006757)$, NSN $(1,53 \%$ e $\pm 0,009986)$. Da mesma forma, no teste de friabilidade todas as perdas de peso estavam abaixo do limite máximo. Este trabalho demonstrou que os medicamentos tiveram resultados satisfatórios nos testes parciais a que foram submetidos, o que demonstrou boa conformidade, de modo que os medicamentos NSN (similar) e NeT (genérico) apresentaram-se equivalentes ao medicamento de NxT (referência).

PALAVRAS-CHAVES: Equivalência Farmacêutica. Controle de qualidade. Naproxeno.

ABSTRACT: The drug Naproxen is a non-steroidal anti-inflammatory drug (NSAID) and acts as a competitive and reversible inhibitor of cyclooxygenase (COXs) enzymes. Due to its analgesic and antipyretic action, it is used in the treatment of rheumatic diseases and acute inflammatory processes. NSAIDs are among the most commonly prescribed classes of medication in the world due to their analgesic and anti-inflammatory effects, and are regularly used due to their possibility to be purchased without a prescription. The current legislation determines the need for interchangeability between reference, generic and similar drugs, through equivalence and bioequivalence tests. Therefore, this article aims to carry out the quality control and pharmaceutical equivalence of medicines that have the active ingredient naproxen. The products used in this study were 
identified as NxT (reference), NSN (similar) and NeT (generic) and all are $500 \mathrm{mg}$ uncoated tablets. The analyses described in this article (determination of average weight, mechanical strength through the tests of hardness and friability) were performed according to the Brazilian pharmacopoeia 6th edition (2019) for the assessment of interchangeability between reference, generic and similar drugs. The results showed that the examined products have good weight uniformity, with the coefficient of variation $(\mathrm{CV})$ and standard deviation $(\mathrm{SD})$ values equal to NxT $(0.90 \%$ and \pm 0.005423$), \mathrm{NeT}(1,11$ $\%$ and \pm 0.006757$)$, NSN (1.53 \% and \pm 0.009986$)$. Finally, in the friability test, all weight losses were below the maximum limit, being NxT $(0.2354 \%)$, NeT $(0.2437 \%)$ and NSN $(0.2049 \%)$. This study demonstrated that the products had satisfactory results in the partial tests they were submitted to, which demonstrated good compliance, so that the product NSN (similar) and NeT (generic) were equivalent to the product of NxT (reference).

KEYWORDS: Pharmaceutical equivalence. Quality control. Naproxen.

\section{INTRODUÇÃO}

Os anti-inflamatórios não esteroidais (AINEs) estão entre as classes de medicamentos mais prescritos no mundo em função dos seus efeitos analgésicos e anti-inflamatórios (MELGAÇO et al., 2010), sendo frequentemente utilizados devido à capacidade de serem adquiridos sem receita médica (NIGRO; FORTES, 2005). Os anti-inflamatórios não esteroidais são fármacos capazes de inibir de forma seletiva ou não, a enzima cicloxigenase (COX), a qual é responsável pela formação de prostaglandinas (PGs) (KUMMER; COELHO, 2002).

A enzima cicloxigenase se divide em dois grupos de isoformas que recebem a denominação COX-1 e COX-2, com diferentes funções fisiológicas. A isoforma COX1 tem uma expressão constitutiva e está envolvida com a manutenção do estado fisiológico normal do organismo, agindo como citoprotetora da mucosa gástrica, homeostase renal e plaquetária, entre outras. Por outro lado, a isoforma COX-2 é induzida por situações de trauma tissular, inflamação, estímulos químicos, citocinas, endotoxinas e fatores de crescimento (KUMMER; COELHO, 2002).

As isoformas da cicloxigenase COX-1 e COX-2 estão envolvidas na produção de prostaglandinas, que formam um grupo de moléculas relacionadas com processos de inflamação, fluxo sanguíneo, formação de coágulos, termorregulação, diurese, contração da musculatura lisa, broncoconstrição, entre outros (MONTEIRO et al., 2008). Para que ocorra a síntese das prostaglandinas, no entanto, diversas moléculas se ligam a receptores específicos da membrana celular, que por sua vez, levam à ativação da enzima fosfolipase A2 pela ação de uma cascata enzimática. Uma vez ativada, a enzima fosfolipase A2 converte os fosfolipídeos de membrana em ácido araquidônico, o qual é liberado no citoplasma e pode ser metabolizado por duas vias independentes.

A via da lipoxigenase leva à produção de leucotrienos, lipoxinas e outros compostos, enquanto a via das cicloxigenases está relacionada com a biossíntese de prostaglandinas, prostaciclinas e tromboxanos (CARVALHO; CARVALHO; RIOS-SANTOS, 2004). Cabe ressaltar que os glicocorticoides possuem ação inibitória na expressão do gene da COX-2, motivo pelo qual estes compostos possuem 
ação anti-inflamatória seletiva para a COX-2. Por outro lado, a ação anti-inflamatória dos AINEs ocorre nas duas isoformas das enzimas COX (BATLOUNI, 2010).

Diferentes medicamentos com ação anti-inflamatória, como por exemplo o naproxeno e o cetoprofeno, estão na lista dos MIP (Medicamentos Isentos de Prescrição) apesar dos diferentes potenciais de toxicidade. Com a capacidade de inibir as enzimas COX-1 e COX2, a ação farmacológica dos AINEs é utilizada para o tratamento de artrite reumatoide, lúpus eritematoso, polimiosite entre outros (LUZ et al., 2006). Além disso, são administrados por via oral, endovenosa, retal e transdérmica (SANDOVAL et al., 2017).

O fármaco Naproxeno é um anti-inflamatório não esteroidal derivado do ácido propiônico e atua como inibidor competitivo e reversível das cicloxigenases. Por sua ação analgésica e antipirética, é utilizado no tratamento de doenças reumáticas e processos inflamatórios agudos. Sua inibição das cicloxigenases bloqueia a conversão do ácido araquidônico em prostaglandinas pró-inflamatórias, de tal forma que esse mecanismo inibe a síntese de prostaglandinas relacionadas com a dor, inflamação e febre (TODD; CLISSOLD, 1990). Sua fórmula estrutural está mostrada na Figura 1.

O naproxeno está disponível na via de administração oral em forma de comprimido e suspensão, drágeas na via de administração retal e géis como ação tópica. Na forma de comprimido e supositório está presente na concentração de $250 \mathrm{mg}$ e $500 \mathrm{mg}$ em sua forma livre e $550 \mathrm{mg}$ para a sua forma sódica. A apresentação da suspensão oral, predominantemente usado na pediatria, está disponível na concentração de $25 \mathrm{mg} / \mathrm{mL}$ e na forma de gel na concentração $10 \%$. Além de ser utilizado como anti-inflamatório, o naproxeno é associado com opioides ou anestésicos locais para aliviar a dor de processos pós-operatórios (BALI et al., 2016).

Figura 1 - Fórmula estrutural do Naproxeno.

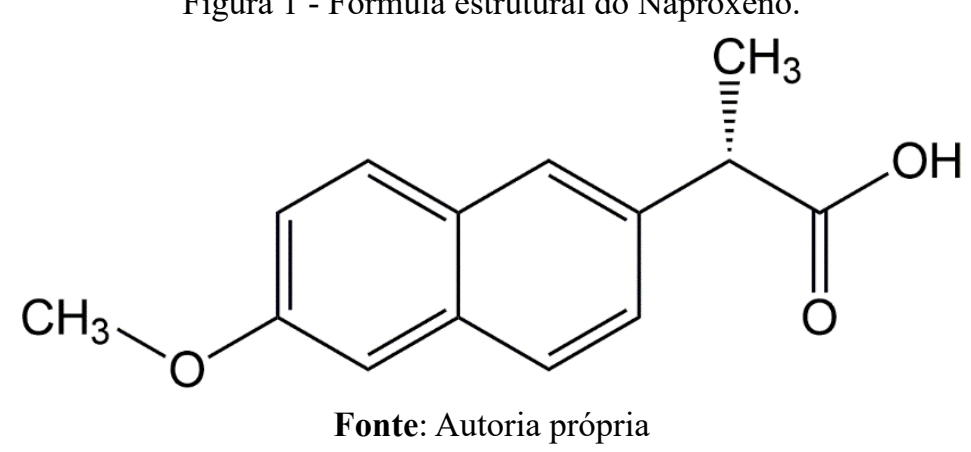

A Lei $\mathrm{n}^{\circ} 9.787$ de 10 de fevereiro de 1999 estabeleceu as bases legais para o registro dos medicamentos genéricos no Brasil e permitiu a sua comercialização como sendo intercambiável com o medicamento de referência, mediante testes de equivalência e bioequivalência. Para isso, a Agência Nacional de Vigilância Sanitária (ANVISA) dispõe de bases legais a serem cumpridas por parte de indústrias farmacêuticas para garantir a qualidade dos medicamentos (ARAÚJO et al., 2010). Dentre elas, destaca-se a RDC $n^{\circ}$ 16, de 2 de março de 2007 (ANVISA, 2007), que possui procedimentos técnicos a serem cumpridos para certificar a segurança e a eficácia dos medicamentos genéricos. 
Os medicamentos similares eram produzidos no início sem a necessidade de possuir testes de equivalência farmacêutica e biodisponibilidade relativa para obterem o registro da ANVISA (MORAIS et al., 2015). Isso mudou em 2003, quando a ANVISA tornou obrigatório que os medicamentos similares fossem submetidos a estudos comparativos com o medicamento inovador para serem aprovados e registrados. Neste sentido, a regulamentação dos medicamentos similares foi efetuada inicialmente pela RDC 133/2003, com respaldo para o registro de novas solicitações de fármacos similares e pela RDC 134/2003, para os similares já existentes. No entanto, a RDC 133/2003 foi revogada e os critérios para a concessão e renovação do registro de medicamentos com princípios ativos sintéticos e semissintéticos, classificados como novos, genéricos e similares, atualmente são regulamentados pela RDC no 200, de 26 de dezembro de 2017 e suas atualizações (ANVISA, 2017). A RDC 134/2003 sofreu diversas atualizações, mas continua em vigor (ANVISA, 2003).

Em 2014, por meio da RDC No 58/2014 (ANVISA, 2014), a ANVISA determinou que os similares podem ser intercambiáveis com o seu respectivo medicamento de referência mediante a aprovação dos resultados dos testes de bioequivalência e equivalência farmacêutica. Dessa forma, dois medicamentos são considerados equivalentes quando ambos possuem a mesma dose, forma farmacêutica e a mesma substância ativa (ANVISA, 2010), devendo estar de acordo com as especificações da Farmacopeia Brasileira para ter um indicativo de controle de qualidade.

As diferenças nos processos de fabricação são aceitáveis devido à particularidade de cada fabricante com os seus equipamentos e fornecedores de matérias-primas. Isso acaba gerando debate quanto à eficácia dos medicamentos, visto que há vários processos de produção que não são exatamente iguais aos utilizados pelos fabricantes dos medicamentos de referência (MEDEIROS; MOTA; ALVIM, 2019). A variabilidade nas tecnologias empregadas, bem como nas características físicas e físico-químicas dos medicamentos e na singularidade dos componentes utilizados, pode comprometer o desempenho do fármaco no organismo. Além disso, as formas farmacêuticas sólidas são as que apresentam maiores possibilidades de problemas na biodisponibilidade (STORPIRTIS et al., 2004).

Para DAMASCENO et al., (2019) os medicamentos fabricados de forma irregular podem diminuir ou ausentar a presença dos efeitos desejados, interferindo, consequentemente, na ação terapêutica esperada. Por isso, é imprescindível que as indústrias farmacêuticas assegurem a efetividade de seus produtos. Em um estudo feito para avaliar a qualidade de medicamentos que possuem o princípio ativo atenolol, foi demonstrado que todas as sete amostras estudadas se encontravam dentro das especificações esperadas, correspondendo a um índice de reprovação nulo (BUZZI et al., 2006). O mesmo comportamento foi observado em outro trabalho realizado para avaliar a equivalência farmacêutica de três apresentações de furosemida, onde foi constatado que todas as amostras apresentaram resultados satisfatórios (DAMASCENO et al., 2019).

No entanto, no estudo realizado para analisar o perfil de dissolução de três apresentações de comprimidos de propranolol, uma apresentação de genérico mostrou-se intercambiável com o medicamento de referência, mas outro medicamento genérico e um similar foram reprovados, concluindo desvio de qualidade entre esses produtos (RODRIGUES et al., 2006), o que destaca a importância de estudos que visam examinar a qualidade dos medicamentos disponíveis para o consumo da população. 
Segundo a RDC n 31 de 11 de agosto de 2010 (ANVISA, 2010), equivalentes farmacêuticos são medicamentos que possuem a mesma forma farmacêutica, via de administração e quantidade da substância ativa (mesmo sal ou éster) da molécula terapêutica, podendo ou não conter excipientes iguais. Os medicamentos de referência são considerados inovadores por serem os primeiros lançados no mercado e após a expiração da patente, medicamentos genéricos e similares podem ser fabricados como sendo um análogo ao seu produto inovador. Diante da necessidade de garantir a qualidade destes medicamentos, este trabalho tem por finalidade realizar os testes de equivalência farmacêutica para avaliar a efetividade de diferentes apresentações de naproxeno disponíveis no mercado.

\section{MATERIAIS E MÉTODOS}

Para a realização deste estudo foram utilizados 50 comprimidos não revestidos de naproxeno de diferentes marcas presentes no mercado, de um mesmo lote e data de fabricação para cada produto, os quais foram adquiridos em uma farmácia comercial na cidade de Foz do Iguaçu/PR. Os medicamentos escolhidos foram identificados como NxT (referência), NSN (similar) e NeT (genérico), todos com $500 \mathrm{mg}$ do princípio ativo. Os testes de peso médio, dureza e friabilidade seguiram as especificações da Farmacopeia Brasileira $6^{\text {a }}$ Ed. (BRASIL, 2019).

\section{Peso Médio}

Para se obter o peso médio foi realizada a pesagem individual de 20 comprimidos de cada lote utilizando-se uma balança analítica da marca SHIMADZU, modelo AUY220 (precisão de 0,0001 g), de modo que o peso médio foi obtido pela razão entre o peso total obtido e o número de comprimidos utilizados.

\section{Dureza}

Para realizar o teste de dureza foi utilizado o aparelho durômetro da marca Ethik, modelo 298/ DGP (precisão de $0,1 \mathrm{~N}$ ) e os resultados foram expressos em newtons (N). Conforme a orientação da Farmacopeia Brasileira $6^{\mathrm{a}}$ Ed., foram utilizados 10 comprimidos de cada lote, os quais foram colocados no equipamento sempre seguindo a mesma orientação.

\section{Friabilidade}

Foram pesados 20 comprimidos de cada lote e colocados no friabilômetro da marca Ethik Technology, modelo 300-2 (versão II) a uma velocidade de 25 rotações por minuto (rpm) durante 4 minutos. Posteriormente, os comprimidos foram pesados novamente após a remoção de qualquer resíduo de pó da superfície. A diferença observada entre o peso inicial e o peso final, permitiu o cálculo 
da friabilidade, a qual foi expressa em função da porcentagem de pó perdida durante o procedimento. De acordo com as especificações da Farmacopeia Brasileira $6^{\mathrm{a}}$ Ed., o teste de friabilidade deve ser empregado somente nos comprimidos não revestidos.

\section{RESULTADOS E DISCUSSÃO}

A homogeneidade dos comprimidos de um mesmo lote é avaliada pelo teste de peso médio, sendo que aqueles que possuem pesos distintos podem apresentar quantidades diferentes do princípio ativo (BUZZI et al., 2006). Segundo a Farmacopeia $6^{\mathrm{a}}$ Ed., o Coeficiente de Variação (CV) para os comprimidos não revestidos e com peso médio superior a $250 \mathrm{mg}$ é de $\pm 5 \%$. Além disso, a farmacopeia orienta que se pode tolerar não mais que duas unidades fora dos limites de $\pm 5 \%$, ou seja, limite de $\pm 1 \mathrm{CV}$, bem como nenhuma unidade pode estar acima ou abaixo do dobro das porcentagens indicadas com limite de $\pm 2 \mathrm{CV}$.

Todos os medicamentos testados foram aprovados nos critérios estabelecidos pela Farmacopeia $6^{\text {a }}$ Ed. para a avaliação de peso, mostrando boa uniformidade. Os resultados mostrados na Tabela 2 demonstram que os valores obtidos nos respectivos CV estão significativamente abaixo do limite máximo de $\pm 5 \%$, sendo que o medicamento similar NSN foi o que apresentou o maior Desvio Padrão (DP), com um valor igual $\pm 0,009986$ e o respectivo $(\mathrm{CV})$ igual a $1,53 \%$.

Tabela 1 - Avaliação de peso médio nos comprimidos de naproxeno.

\begin{tabular}{|c|c|c|c|c|c|c|}
\hline Amostra & $\begin{array}{c}\text { Peso médio } \\
\text { (mg) }\end{array}$ & DP & $\begin{array}{l}\text { CV } \\
(\%)\end{array}$ & $\begin{array}{r}\mathbf{N}^{\mathbf{o}} \\
\text { compri } \\
\text { fora dos } \\
\pm 1 \mathrm{CV}\end{array}$ & $\begin{array}{l}\text { los } \\
\text { ites } \\
\pm \\
2 \\
\mathrm{C} \\
\mathrm{V} \\
\end{array}$ & Conclusão \\
\hline $\mathrm{NxT}$ & 600,45 & $\pm 0,005423$ & 0,90 & 0 & 0 & Aprovado \\
\hline $\mathrm{NeT}$ & 604,93 & $\pm 0,006757$ & 1,11 & 0 & 0 & Aprovado \\
\hline $\mathrm{NSN}$ & 652,23 & $\pm 0,009986$ & 1,53 & 0 & 0 & Aprovado \\
\hline
\end{tabular}

Fonte: Autoria própria

O medicamento deve apresentar resistência adequada, visto que pode sofrer desgaste por fricção e choques mecânicos em qualquer etapa do seu processo de produção até o transporte e manuseio do paciente (MEDEIROS; MOTA; ALVIM, 2019), de modo que a resistência do comprimido ao esmagamento é avaliada no teste de dureza. Conforme consta na Farmacopeia $6^{\text {a }}$ Ed., os testes de dureza são informativos e os resultados são expressos em Newtons $(\mathrm{N})$, sendo que os valores médios observados de 10 comprimidos utilizados para cada medicamento foram NxT (149,6 N), NeT (117,8 N) e NSN $(255,6 \mathrm{~N})$. 
No teste de friabilidade todas as apresentações estavam de acordo com a Farmacopeia $6^{\mathrm{a}}$ Ed., onde o limite máximo aceitável é uma perda de $1,5 \%$. O resultado é mostrado na Tabela 3, onde se observa que o maior valor obtido no teste de friabilidade foi para o medicamento $\mathrm{NeT}$, com uma perda igual a $0,2433 \%$ e que ainda é muito inferior ao limite máximo estabelecido pela Farmacopeia.

Tabela 2 - Resultados obtidos no teste de friabilidade nos comprimidos de naproxeno.

\begin{tabular}{|c|c|c|c|c|}
\hline Amostra & Massa Inicial $(\mathrm{g})$ & Massa Final $(\mathrm{g})$ & Perda (\%) & Conclusão \\
\hline NxT & 12,0223 & 11,9940 & 0,2354 & Aprovado \\
NeT & 12,1068 & 12,0773 & 0,2437 & Aprovado \\
NSN & 12,9792 & 12,9526 & 0,2049 & Aprovado \\
\hline
\end{tabular}

Fonte: Autoria própria

\section{CONCLUSÕES}

Este trabalho demonstrou que todos os medicamentos tiveram resultados satisfatórios nos testes parciais a que foram submetidos (peso médio, dureza e friabilidade), mostrando boa conformidade com o que se espera pela Farmacopeia $6^{\text {a }}$ Ed. Sendo assim, os resultados obtidos até a presente etapa deste trabalho mostraram que os medicamentos genéricos e similares examinados são equivalentes ao medicamento de referência. Em um momento posterior, serão feitos os ensaios complementares de quantificação, dissolução e desintegração para garantir que medicamentos avaliados neste trabalho são considerados equivalentes e, consequentemente, intercambiáveis.

\section{AGRADECIMENTOS}

Os autores agradecem ao Centro de Ensino Superior de Foz do Iguaçu (Cesufoz) pelo apoio logístico institucional.

\section{REFERÊNCIAS}

ANVISA. Ministério da Saúde. Agência Nacional de Vigilância Sanitária. Resolução-RDC no 134, de 29 de maio de 2003. Disponível em: $<$ http://portal.anvisa.gov.br/legislacao/?inheritRedirect=true\#/visualizar/27186>. Acesso em: 27 maio. 2020.

ANVISA. Ministério da Saúde. Agência Nacional de Vigilância Sanitária. Resolução-RDC no 16, de 2 de março de 2007. Disponível em: $<$ http://bvsms.saude.gov.br/bvs/saudelegis/anvisa/2007/rdc0016_02_03_2007. html>. Acesso em: 19 abr. 2020. 
ANVISA. Ministério da Saúde. Agência Nacional de Vigilância Sanitária. Resolução-RDC n ${ }^{0}$, de 11 de agosto de 2010. Disponível em: $<$ http://bvsms.saude.gov.br/bvs/saudelegis/anvisa/2010/res0031_11_08_2010. html>. Acesso em: 10 dez. 2020.

ANVISA. Ministério da Saúde. Agência Nacional de Vigilância Sanitária. Resolução-RDC $\mathbf{n}^{0}$ 58, de 10 de outubro de 2014. Disponível em: $<$ http://portal.anvisa.gov.br/legislacao/?inheritRedirect=true\#/visualizar/29262>. Acesso em: 19 abr. 2020.

ANVISA. Ministério da Saúde. Agência Nacional de Vigilância Sanitária. Resolução-RDC no 200, de 26 de dezembro de 2017. Disponível em: $<$ http://portal.anvisa.gov.br/legislacao/?inheritRedirect=true\#/visualizar/364436>. Acesso em: 27 mar. 2020.

ARAÚJO, L. U. et al. Medicamentos genéricos no Brasil: panorama histórico e legislação. Rev Panam Salud Publica, v. 28, n. 5, p. 480-492, 2010.

BALI, C. et al. Comparação dos efeitos analgésicos pós-operatórios de naproxeno sódico e naproxeno sódicofosfato de codeína em artroscopia de menisco. Brazilian Journal of Anesthesiology, v. 66, n. 2, p. 151-156, 2016.

BATLOUNI, M. Anti-Inflamatórios Não Esteroides: Efeitos Cardiovasculares, Cérebro-Vasculares e Renais. Arq Bras Cardiol, v. 94, n. 4, p. 556-563, 2010.

BRASIL. Farmacopeia Brasileira. Farmacopeia Brasileira 6 ${ }^{\mathbf{a}}$ Ed., v. 1, p. 1-873, 2019.

BUZZI, V. et al. Avaliação da qualidade de comprimidos de Atenolol: Estudo comparativo entre medicamentos de referência, genérico e similar. Arq. Ciênc. Saúde Unipar, Umuarama, v. 10, n. 3, p. 119-122, 2006.

CARVALHO, W. A.; CARVALHO, R. D. S.; RIOS-SANTOS, F. Analgésicos inibidores específicos da ciclooxigenase-2: Avanços terapêuticos. Revista Brasileira de Anestesiologia, v. 54, n. 3, p. 448-464, 2004.

DAMASCENO, E. M. A. et al. Valiação da qualidade físicoquímica de comprimidos de furosemida. Revista Saúde Viva Multidisciplinar da AJES, v. 2, n. 2, p. 1-12, 2019.

KUMMER, C. L.; COELHO, T. C. R. B. Antiinflamatórios não esteróides inibidores da ciclooxigenase-2 (COX-2): Aspectos atuais. Revista Brasileira de Anestesiologia, v. 52, n. 4, p. 498-512, 2002.

LUZ, T. C. B. et al. Fatores associados ao uso de antiinflamatórios não esteróides em população de funcionários de uma universidade no Rio de Janeiro: Estudo Pró-Saúde. Revista Brasileira de Epidemiologia, v. 9, n. 4, p. 514-526, 2006.

MEDEIROS, E. F. C.; MOTA, L. V.; ALVIM, H. G. O. Medicamentos de referência, genérico e similar: avaliação da qualidade dos comprimidos de captopril e enalapril. Rev. Cient. Sena Aires, v. 8, n. 1, p. 49-61, 2019.

MELGAÇO, S. S. C. et al. Nefrotoxicidade dos anti-inflamatórios não esteroidais. Medicina, v. 43, n. 4, p. 382-390, 2010.

MONTEIRO, E. C. A. et al. Os antiinflamatórios não esteroidais (AINEs). Temas de Reumatologia Clínica, v. 9, n. 2, p. 53-63, 2008.

MORAIS, F. E. et al. Caracterização e avaliação do comportamento térmico dos medicamentos de referência, genérico e similar contendo o ácido acetilsalicílico como princípio ativo. Brazilian Journal of Thermal Analysis, v. 4, n. 1-2, p. 1, 2015.

NIGRO, D.; FORTES, Z. B. Efeitos farmacológicos dos diuréticos e dos bloqueadores dos canais de cálcio. Revista Brasileira de Hipertensão, v. 12, p. 103-107, 2005.

RODRIGUES, P. O. et al. Equivalência farmacêutica entre comprimidos de propranolol comercializados no mercado nacional. Infarma, v. 18, n. 3/4, p. 16-21, 2006. 
SANDOVAL, A. C. et al. O uso indiscriminado dos Anti-Inflamatórios Não Esteroidais (AINES). Revista Científica FAEMA, v. 8, n. 2, p. 165, 2017.

STORPIRTIS, S. et al. a Equivalência farmacêutica no contexto da intercambialidade entre medicamentos genéricos e de referência: bases técnicas e científicas. Infarma, v. 16, n. 9/10, p. 51-56, 2004.

TODD, P. A.; CLISSOLD, S. P. Naproxen: a reappraisal of its pharmacology and therapeutic use in rheumatic diseases and pain states. Drugs, v. 40, n. 1, p. 91-137, 1990. 


\section{DIFICULDADES NA COLETA DE GASOMETRIA ARTERIAL DE PACIENTES OBESOS EM UMA UNIDADE DE PRONTO ATENDIMENTO: RELATO DE EXPERIÊNCIA}

TATIANA FABÍOLA DA SILVA LIMA Centro Universitário Metropolitano da Amazônia (UNIFAMAZ)

WEBER MARCOS

Centro Universitário Metropolitano da Amazônia (UNIFAMAZ)

VIRGÍNIA MERCÊS LARA PESSOA OLIVEIRA

Centro Universitário Metropolitano da Amazônia (UNIFAMAZ)

MARCOS MIRANDA RODRIGUES

Centro Universitário Metropolitano da Amazônia

(UNIFAMAZ)

INÁCIO LIMA DO NASCIMENTO

Centro Universitário Metropolitano da Amazônia

(UNIFAMAZ)

RENATA FORO LIMA CARDOSO

Centro Universitário Metropolitano da Amazônia

(UNIFAMAZ)

IRANY ALMEIDA SILVA DOS SANTOS

Centro Universitário Metropolitano da Amazônia

(UNIFAMAZ)

GESSICA DA SILVA FARIAS VIANA

Centro Universitário Metropolitano da Amazônia

(UNIFAMAZ)

RESUMO: Objetivo: Relatar as dificuldades vivenciadas por acadêmicos de enfermagem na punção arterial para análise de gasometria arterial em pacientes obesos. Materiais e Métodos: Trata-se de um estudo descritivo, do tipo relato de experiencia desenvolvidas durante aula prática externa, por acadêmicos do oitavo semestre do curso de enfermagem, na disciplina de urgência e emergência, de uma Instituição Privada de Ensino Superior, realizado em uma Unidade de Pronto Atendimento. Os principais fatores encontrados como barreiras para realização das punções foram a dificuldade em sentir a pulsação das artérias e dificuldades em puncionar sozinho, ambas causadas pelo acúmulo de gordura no local principalmente pelo abdome que se sobrepunha a região pélvica. Conclusão: Pôde-se evidenciar a relação das dificuldades de punção e a falta de recursos humanos com a necessidade de a temática ser abordada com maior frequência, para que esta resulte em um cuidado integral equitativo.

PALAVRAS-CHAVE: Enfermagem, Gasometria arterial, Obesidade.

ABSTRACT: Objective: To report the difficulties experienced by nursing students in arterial puncture for analysis of arterial blood gases in obese patients. Materials and methods: It is a descriptive study, of the type of experience developed during an external practical class, by students of the eighth semester of the nursing course, in the discipline of urgency and emergency, from a Private Higher Education Institution, held from in an Emergency Care Unit. The main factors found as barriers to perform the punctures were the difficulty in feeling the pulsation of the arteries and difficulties in puncturing alone, both caused by the accumulation of fat in the site mainly by the abdomen that overlapped the pelvic region. Conclusion: It was possible to highlight the relationship between the puncture difficulties 
and the lack of human resources with the need for the theme to be addressed more frequently, so that it results in equitable comprehensive care.

KEY WORDS: Nursing, Blood gas analysis, Obesity.

\section{INTRODUÇÃO}

A gasometria, ou análise de gases no sangue arterial, é um exame invasivo realizado através de punção arterial, que tem por objetivo verificar se as trocas gasosas estão ocorrendo da maneira correta através de valores de potencial de Hidrogênio $(\mathrm{pH})$ sanguíneo, da pressão parcial de gás carbônico e oxigênio, íon Bicarbonato e saturação da Oxi-hemoglobina, avaliando principalmente o equilíbrio acidobásico orgânico. Assim, pode-se avaliar a adequação de ventilação, equilíbrio ácido-base, e oxigenação; avaliar a resposta do paciente à terapia ou avaliação diagnóstica, e por fim monitorar a gravidade e progressão de um processo de doença (PINTO et al. 2017).

A equipe de enfermagem que atua na atenção às urgências e emergências como as Unidades de Terapia Intensiva (UTI) ou Unidade de Pronto Atendimento (UPA) devem estar aptas a responder por suas ações no que se refere à esfera das funções e deveres no trabalho, além de estar constantemente motivada a melhorar sua qualificação profissional através de um programa de educação continuada (ROLIM et al. 2013).

O trabalho da enfermagem nas urgências e emergências está regulamentado pelo Conselho Federal de Enfermagem (COFEN), que assegura ao enfermeiro com especialização o direito de registrar o seu certificado no Conselho Regional de Enfermagem de sua jurisdição, conferindo legalidade para atuação na área especifica do exercício profissional (FILHO et al. 2016). Assim, a lei do exercício profissional de enfermagem 7.498 de 25 de junho de 1986, regulamentada pelo Decreto $\mathrm{n}^{\circ} 94.406$ de 08 de junho de 1987 e, assim, a Resolução COFEN nº 390/2011, refere que:

\footnotetext{
No âmbito da equipe de Enfermagem, a punção arterial tanto para fins de gasometria como para monitorização da pressão arterial invasiva é um procedimento privativo do Enfermeiro, observadas as disposições legais da profissão. O Enfermeiro deverá estar dotado dos conhecimentos, competências e habilidades que garantam rigor técnico-científico ao procedimento, atentando para a capacitação contínua necessária à sua realização COFEN, 2011).
}

Marques et al. (2014) ao considerar que cuidar de pacientes em estado de obesidade é questão estrutural, afirmam ser relevante a existência de condições mínimas para este cuidar. Isto requer materiais adaptados ao seu porte físico, assim como maior número de pessoas para exercer algumas atividades de maior força física. Destacam o fato de que cuidar destes gera um desgaste físico grande e consideram que estes pacientes exigem cuidados de enfermagem diferenciados.

A Organização Mundial da Saúde (OMS) define a obesidade como uma condição crônica que traz grandes repercussões à saúde, e é caracterizada pelo acúmulo excessivo de gordura. No Brasil, diferentes documentos do governo partilham da mesma a definição da OMS e a concebe simultane- 
amente como doença e fator de risco para outras doenças, como condição crônica multifatorial complexa e, ainda, como manifestação da insegurança alimentar e nutricional (DIAS et al. 2017).

A OMS recomenda iniciar o monitoramento o mais cedo possível. Vários parâmetros antropométricos foram propostos e estudados, no intuito de avaliar melhor a obesidade central como circunferência da cintura (CC), circunferência do pescoço (NC), índice de conicidade (IC), e relação cintura / altura (RCQ), utilizando-se dos seguintes valores: peso normal IMC $>18,5$ e $<25 \mathrm{~kg} / \mathrm{m}^{2}$; sobrepeso IMC $\geq 25 \mathrm{~kg} / \mathrm{m}^{2}$ e $<30 \mathrm{~kg} / \mathrm{m}^{2}$ e obesidade para IMC $\geq 30 \mathrm{~kg} / \mathrm{m}^{2}$ (BARROSO et al. 2017).

O índice corporal mais usado para estimar excesso de peso e obesidade é o IMC. Embora seja um dos índices mais amplamente utilizados para o diagnóstico da obesidade, ele não avalia a composição corporal. Portanto, é de fundamental importância o uso de métodos com maior capacidade de diagnosticar a gordura corporal, a fim de selecionar parâmetros para um diagnóstico mais preciso da obesidade (MIALICH et al. 2018).

No intuito de compartilhar o estudo com a comunidade acadêmica e demais interessados na temática, espera-se estar contribuindo de forma direta e/ou indireta para futuros planejamentos de ações e medidas relacionadas às formas de se manejar este paciente

Assim, o presente estudo busca relatar a experiência sobre as dificuldades vivenciadas por acadêmicos de enfermagem na realização de punção arterial para análise de gasometria arterial em pacientes obesos, durante aula prática externa da disciplina de Urgência e Emergência, e sobre as implicações e contribuições destas para o aprendizado teórico-prático.

\section{MATERIAIS E MÉTODOS}

Trata-se de um estudo descritivo, do tipo relato de experiência, onde se buscou relatar as dificuldades vivenciadas por acadêmicos de enfermagem na punção arterial para análise de gasometria arterial em pacientes obesos, desenvolvidas durante aula prática externa, por acadêmicos do oitavo semestre do curso de enfermagem, na disciplina de urgência e emergência, de uma Instituição Privada de Ensino Superior, realizado no cenário de prática Unidade de Pronto Atendimento.

Participaram do grupo de prática cinco discentes e um enfermeiro preceptor com expertise em urgência e emergência. O perfil dos usuários era heterogêneo, sendo composto, naquele momento, em sua maioria por mulheres com idade entre 54 e 68 anos; todos se encontravam em uso de sedativos e intubados; quanto aos quadros clínicos, todos possuíam alguma patologia respiratória cujo tratamento ou diagnóstico exigia a gasometria.

Os encontros foram divididos pelos discentes e o docente em quatro momentos, portanto, no momento inicial, foram realizados o aprofundamento teórico e discussões sobre a temática entre o preceptor e os discentes, no qual foram relembrados conteúdos de anatomia e fisiologia neurológica, respiratória e circulatória, exame físico geral, escalas de sedação (Richmond Agitation Sedation Scale - RASS e Escala de Ramsey) normas e rotinas da instituição, classificação de risco, fluxo, funciona- 
lidade e continuidade da RUE e o conceito teórico de gasometria arterial, visto que este é um procedimento de extrema importância na monitorização e manutenção dos parâmetros vitais do paciente e que é realizado com grande frequência.

No segundo momento, foram realizadas as instruções sobre a punção arterial para a gasometria arterial, abordando os principais elementos como materiais para a punção e Equipamentos de Proteção Individual (EPIs), escolha da seringa/agulha, antissepsia, critérios para escolha da artéria a ser puncionada, manipulação correta da amostra e leitura/interpretação dos resultados obtidos através do equipamento analisador de $\mathrm{pH}$ e gases sanguíneos. No terceiro momento, após as devidas considerações, instruções e esclarecimentos foram realizados as punções arteriais pelos discentes, sob a supervisão do preceptor, momento este em que foi identificado os problemas e dificuldades de se realizar punção arterial em pacientes obesos.

O ultimo momento correspondeu a uma nova discussão sobre as dificuldades em localizar e sentir a punção arterial, dificuldade de puncionar a artéria femoral sem ajuda de terceiros, devido ao fato do abdome se sobrepor a região e dificuldades também de puncionar outros locais devido ao excesso de tecido adiposo no sítio de punção.

\section{RESULTADOS E DISCUSSÕES}

Dos oito pacientes presentes nos diferentes dias em que os discentes estavam no campo de prática e em que fora coletado o sangue através da punção arterial - quatro encontravam-se em situação de obesidade. No decorrer da coleta, as dificuldades de punção começaram a se fazer presentes. Dentre os quatro pacientes citados anteriormente, três deles não tiveram sua punção realizada pelos discentes e sim pelo preceptor e apenas um teve coleta realizada por um discente, porém sem sucesso nas primeiras tentativas.

Outros fatores foram encontrados como barreiras para realização das punções, entre eles, a dificuldade em sentir a pulsação das artérias e dificuldades em puncionar sozinho, ambas causadas pelo acúmulo de gordura no local e principalmente pelo abdome que se sobrepunha a região pélvica dificultando a coleta na artéria femoral. Neste caso a punção só era possível se outro discente elevasse o abdome da paciente, pois este recobria a região inguinal. Sendo necessário que um aluno ficasse responsável por esta elevação da gordura abdominal. Também se sentia desgastado devido ao grande peso abdominal.

Apenas uma punção foi realizada por uma das discentes com supervisão do preceptor, porém sem sucesso nas primeiras tentativas na artéria femoral direita e esquerda pelo igual motivo de não sentir com qualidade a pulsação e pela sobreposição do abdome nesta região. Tentou-se realiza-la na artéria pedial, também sem sucesso. O resultado esperado só foi atingido quando se puncionou a artéria carótida, sítio de punção que não é comum e que se tem um grau de dificuldade maior, pois há necessidade de afastar o músculo esternocleidomastóideo e há o risco de se lesionar a traqueia. 
Outro contratempo encontrado foi a dificuldade de puncionar com agulhas dos calibres $25 \mathrm{x} 07$ mm e 30x08 mm, que são valores médios ideais aplicados a adultos com maior massa muscular ou considerados obesos, porém encontrou-se dificuldades em utilizar-se destes calibres que nas primeiras tentativas de uso não se teve o desfecho esperado, o que aumentou a sensação de insegurança dos acadêmicos. Apesar dos contratempos, o resultado pressentido foi obtido com êxito.

Na rotina de trabalho da sala de estabilização a gasometria arterial é de competência exclusivamente do enfermeiro, é coletada em pacientes em ventilação mecânica, sedados e com diagnóstico de alguma doença respiratória ou qualquer outra patologia onde o diagnóstico ou tratamento requeira a coleta de sangue para gasometria e, segundo Araújo et al. (2015), o procedimento é de fundamental importância nas unidades de terapia intensiva, permitindo assim, a avaliação do risco de comprometimento dos órgãos, que podem levar o paciente a óbito.

A coleta era realizada nas primeiras horas após internação. Nos pacientes sob suporte ventilatório a coleta de gasometria segundo Barbas et al. (2014) deve ser realizada cerca de 20 minutos após o ajuste inicial dos parâmetros do ventilador e diariamente, enquanto durar a fase aguda do quadro do paciente. Isso se justifica pelo fato de que assim, pode-se ter uma avaliação mais fidedigna sobre o estado geral do paciente e, também, possibilitando que novas intervenções possam ser implementadas de acordo com o quadro clínico do paciente, visando sua melhora.

As punções foram realizadas nas artérias femorais, pois não era possível puncionar as artérias ulnar e radial. Para Pinto et al. (2017) recomenda-se como local preferível a artéria radial ao nível do túnel do carpo, por não apresentem veias próximas importantes e, assim, reduzir a probabilidade de punção venosa acidental. E, como última opção, a artéria femoral, que só deverá ser utilizada em casos insólitos, uma vez que abaixo do ligamento inguinal não existe circulação colateral propícia.

Três, das quatro punções realizadas foram conduzidas pelo preceptor, pois os discentes sentiram extremas dificuldades quanto a sentir a pulsação, visto que a camada adiposa sobre o local dava uma maior profundidade a artéria, gerando receio de realizar o procedimento. Salviano et al. (2017) infere que o enfermeiro deve estar preparado para compreender e legitimar as bases epistemológicas da enfermagem direcionadas para o cuidado ético e humanizado, dotado da destreza e expertise do pensamento crítico e científico e, capaz de governar-se e de tomar decisões assistenciais mantendo a dignidade e a singularidade do ser cuidado.

Outra dificuldade sentida pelos discentes foi em realizar a punção devido a grande quantidade de adiposidade abdominal. Um discente ficou responsável por puncionar e o outro por elevar o abdome da paciente, o que culminou para este último forte cansaço físico. Fato que ocorreu apenas por um determinado momento, mas para o profissional que lida diariamente com este procedimento, nesta condição, com falta de recursos humanos, pode resultar em danos maiores a saúde, como o risco ergonômico.

Costa et al. (2013) concordam e reforçam que a falta de material apropriado; sobrecargas de atividades relacionada à pequena quantidade de funcionários para as demandas exigidas, estresse, pouco conhecimento sobre ergonomia, não utilização das normas de biossegurança, o ritmo de trabalho, pressão temporal, ficar em pé por longos períodos de tempo, o levantamento ou transferência de 
pacientes são fatores que podem contribuir para a ocorrência de Doenças Osteomusculares Relacionadas ao Trabalho (DORT).

As aulas práticas em ambientes externos à faculdade têm como objetivo principal promover oportunidades de experienciar (para além da teoria), os conteúdos acadêmicos estudados em sala de aula, proporcionando conhecimentos e atitudes relacionadas com a profissão escolhida pelo aluno, principalmente na área da saúde e, como ressalta Pimentel et al. (2015) estas aulas permitem, de maneira especial, uma reflexão sobre as atividades da futura profissão, possibilitando um processo de ensino-aprendizagem exercido por meio da prática. Ainda proporciona aos discentes a vivência e o relacionamento com a equipe multi e Interprofissional.

\section{CONCLUSÃO}

Através da experiência relatada, foi possível observar fatores positivos e negativos na coleta de sangue arterial em pacientes obesos, tais quais: dificuldade em puncionar, dificuldade em sentir as artérias pulsando e no manuseio do paciente.

Como ponto positivo, a possibilidade em poder vivenciar a experiência nova de cuidar de um paciente em estado de obesidade, visto este estar presente no cotidiano da profissão. Percebe-se que as dificuldades supracitadas não estão relacionadas apenas com a falta de experiência dos acadêmicos, uma vez que até mesmo o enfermeiro e professor do grupo, com anos de experiência também sentiu certa dificuldade inicial. Esta também tem relação com a falta de recursos humanos, uma vez que eram necessárias duas pessoas na realização do procedimento: uma para elevar o abdome do paciente e outra para puncionar, não acontecendo desta forma, havia cansaço físico de quem realizava o procedimento sozinho.

Tais aspectos suscitam a necessidade de a temática também ser abordada em sala de aula, pois na teoria do âmbito acadêmico aprende-se a realizar o procedimento na perspectiva de um paciente anatômico e fisiologicamente normotípico e quando o aluno adentra ao âmbito da prática, se vê despreparado ou inseguro para lidar com tal situação, e desta forma resulta no comprometimento do verdadeiro significado de cuidado integral equitativo.

\section{REFERÊNCIAS}

ARAÚJO, G. M. et al. Procedimento de gasometria arterial em unidade de terapia intensiva: relato de experiência. Revista de Enfermagem, 2015; 11 (11): 72-79.

BARBAS, C. S. V. et al. Recomendações brasileiras de ventilação mecânica 2013. Parte I. Rev Bras Ter Intensiva, 2014; 26 (2): 89-121.

BARROSO, T. A. et al. Associação Entre a Obesidade Central e a Incidência de Doenças e Fatores de Risco Cardiovascular. International Journal of Cardiovascular Sciences, 2017; 30(5)416-424. 
BRASIL. Ministério da saúde. Portaria 342. Disponível em: https://bvsms.saude.gov.br/bvs/saudelegis/ $\mathrm{gm} / 2017$.

CONSELHO FEDERAL DE ENFERMAGEM. Resolução COFEN Nº 390/2011. 20 de outubro de 2011, pág. 146 - Seção 1.

COSTA, I. K. F. et al. Sintomas Musculoesqueléticos em Profissionais de Enfermagem. Prática Hospitalar, 2013; Ano XV (88): 31-36.

DIAS, P. C. et al. Obesidade e políticas públicas: concepções e estratégias adotadas pelo governo brasileiro. Cad. Saúde Pública 2017, 2016; 33(7): 1-12.

FILHO, L. A. M. et al. Competência legal do enfermeiro na urgência/ emergência. Enferm. Foco, 2016; 7(1): $18-23$.

MARQUES, E. S. et al. O significado de cuidar do paciente obeso para um grupo de enfermeiras. Rev. Eletr. Enf., 2014; 16(1):151-160.

MIALICH, M. S. Application of adiposity indices to a sample of physically active individuals living in the city of Ribeirão Preto, São Paulo, Brazil. Medical Express (São Paulo, online), 2018; 5: 1-6.

PIMENTEL, E. C. et al. Ensino e aprendizagem em estágio supervisionado: Estágio integrado em saúde. Revista Brasileira de Educação Médica, 2015; 39 (3): 352-358.

PINTO, J. M. A. et al. Gasometria arterial: aplicações e implicações para a enfermagem. Revista Amazônia Science \& Health, 2017; 5(2): 33-39.

ROLIM, L. R. et al. Conhecimento do enfermeiro de unidade de terapia intensiva sobre gasometria arterial. Rev. Enferm. UFPE on line, 2013; 7(1):713-721.

SALVIANO, M. E. M. et al. Epistemologia do cuidado de enfermagem: uma reflexão sobre suas bases. Rev. Bras. Enferm. [Internet], 2017; 69(6): 1240-1245. 


\section{FATORES QUE AFETAM A SAÚDE MENTAL DE ESTUDANTES UNIVERSITÁRIOS INDIGENAS: REVISÃO INTEGRATIVA DA LITERATURA}

TATIANA FABÍOLA DA SILVA LIMA Centro Universitário Metropolitano da Amazônia (UNIFAMAZ)

MÁRCIO EVERTON MENDES FERNANDES

Centro Universitário Metropolitano da Amazônia (UNIFAMAZ)

SHIRLEY AVIZ DE MIRANDA

Centro Universitário Metropolitano da Amazônia (UNIFAMAZ)

ANA GRACINDA IGNÁCIO DA SILVA

Centro Universitário Metropolitano da Amazônia (UNIFAMAZ)

MARCELO VALENTE DE SOUZA Faculdade da Amazônia (FAAM)

MARIA RUTE DE SOUZA ARAUJO Centro Universitário Metropolitano da Amazônia (UNIFAMAZ)

CINTHYA LORENA BEZERRA SARMANHO

Centro Universitário Metropolitano da Amazônia (UNIFAMAZ)

SUSIANE MARTINS SILVA

Centro Universitário Metropolitano da Amazônia (UNIFAMAZ) é anterior à política diferenciada implementada pelo governo. Considera-se que o choque entre novas ideias, culturas, linguagens são fatores que afetam a saúde mental. Este estudo teve como objetivo identificar as evidências na literatura sobre os principais fatores que afetam a saúde mental de universitários indígenas. Trata-se uma Revisão Integrativa da Literatura, o período delimitado foi de 2015 a 2020. Para o levantamento dos estudos realizou-se uma busca nas bases de dados: Scientific Eletronic Library Online (SciELO), Literatura Latino-Americana e do Caribe em Ciências da Saúde (LILACS), Biblioteca Digital Brasileira de Teses e Dissertações (BDTD) e Scielo Livros com os descritores "Saúde Mental; "Indígenas"; "Universitários". Foram encontrados 8 estudos, que após analise de Bardin, definiu-se três categorias: Políticas afirmativas e a luta pela permanência na universidade; Processo de ensino-aprendizagem x saúde mental; Atuação do enfermeiro no contexto intercultural. Os resultados demonstram uma correlação negativa entre o déficit de políticas afirmativas e de permanência, preconceitos, saúde mental de acadêmicos afetada. Dada a relação entre os estressores e fatores acadêmicos, é necessário aprimorar ações de permanência nas instituições de ensino superior, tanto materiais quanto pedagógicas e nas produções científicas, ainda carentes de uma reflexão profunda sobre o tema.

Palavras-chave: Saúde Mental; Indígenas; Universitários.

ABSTRACT: The literature states that the search by the indigenous people for higher education in Brazil predates the differentiated policy implemented by the government. The clash between
RESUMO: A literatura refere que a busca por parte dos indígenas pelo ensino superior no Brasil 
new ideas, cultures, languages is considered to be factors that affect mental health. This study aimed to identify the evidence in the literature about the main factors that affect the mental health of indigenous university students. This is an Integrative Literature Review, the delimited period was from 2015 to 2020. To survey the studies, a search was carried out in the databases: Scientific Eletronic Library Online (SciELO), Latin American and Caribbean Literature in Sciences da Saúde (LILACS), Brazilian Digital Library of Theses and Dissertations (BDTD) and Scielo Books with the descriptors "Mental Health; "Indigenous"; "College students". Eight studies were found, that after Bardin's analysis, three categories were defined: Affirmative policies and the struggle to stay at the university; Teaching-learning process x mental health; Nurses' performance in the intercultural context. The results demonstrate a negative correlation between the deficit of affirmative and permanence policies, prejudices, the affected students' mental health. Given the relationship between stressors and academic factors, it is necessary to improve permanence actions in higher education institutions, both material and pedagogical and in scientific productions, which still lack a deep reflection on the theme. The results demonstrate a negative correlation between the deficit of affirmative and permanence policies, prejudices, the affected students' mental health. Given the relationship between stressors and academic factors, it is necessary to improve permanence actions in higher education institutions, both material and pedagogical and in scientific productions, which still lack a deep reflection on the theme. The results demonstrate a negative correlation between the deficit of affirmative and permanence policies, prejudices, the affected students' mental health. Given the relationship between stressors and academic factors, it is necessary to improve permanence actions in higher education institutions, both material and pedagogical and in scientific productions, which still lack a deep reflection on the theme.

Key words: Mental health; Indigenous; University students.

\section{INTRODUÇÃO}

A busca por parte dos indígenas pelo ensino superior no Brasil é anterior à política diferenciada implementada pelos governos estadual e federal, mas com as políticas de acesso ao ensino superior público, a presença indígena nas Instituições de Ensino Superior (IES) se amplia significativamente (ARROYO, 2015).

Entende-se que é necessário mais que apenas políticas de ações sociais afirmativas voltadas para ingresso ou acesso ao ensino superior, é necessário que haja a articulação do conhecimento acadêmico com os saberes dos povos tradicionais indígenas e dos mais diversos grupos étnicos, para se garantir uma maior pluricidade das Universidades, pois o aumento significativo do sofrimento mental em discentes universitários aponta um crescente e acelerado processo de adoecimento desses indivíduos (LIMA, 2018).

A modificação no formato social das universidades brasileiras está expressa nos relatórios do último Censo da Educação Superior, divulgado pelo Ministério da Educação em 2017. O estudo demonstrou que o número de indígenas matriculados em instituições públicas e privadas aumentou $52,5 \%$ de 2015 para 2016, passando de 32.147 para 49.026, com a região norte apresentando 4.383 estudantes indígenas na rede pública e 8.364 na rede particular (BRASIL, 2018).

Considerando-se que o choque entre novas ideias, culturas, linguagens, também são fatores que afetam a saúde mental, o ingresso na universidade favorece o surgimento de questões emocio- 
nais e, em alguns casos, a experiência universitária contribui para rupturas/transições através das interações estabelecidas com o saber acadêmico. Nesse espaço, é possível observar as contradições: as desigualdades sociais, o diálogo intercultural, crenças, pertencimentos e práticas culturais. (RESSURREIÇÃO; SAMPAIO, 2017).

Pontua-se que há um número muito pequeno de estudos, principalmente na área da enfermagem, que tematizam a etnicidade e questões psicossociais envolvidas no acesso e na permanência de estudantes indígenas no ensino superior. A escolha do tema prende-se ao fato de estar em linha direta com a área da saúde em geral e mais especificamente com a enfermagem o que contribuirá com o enriquecimento e expansão dos conhecimentos e se tornará um diferencial no desempenho profissional da comunidade acadêmica.

É neste ponto que se insere o papel da enfermagem na saúde mental, tendo como foco o contexto histórico, o cuidado em seu contexto cultural e específico a cada povo, pois os indivíduos se comportam de maneira diferenciada dependendo do contexto cultural no qual estão inseridos. Historicamente e até culturalmente, a saúde mental é uma área de atuação ainda pouco explorada pelos enfermeiros e, quando ocorre há uma persistente inclinação para a ênfase clínica, numa perspectiva individualizada e fracionada do indivíduo.

E se tratando da saúde mental de populações tradicionais, mais especificamente de povos originários no ensino superior a produção é ainda menor, por outro lado, nos últimos anos verificam-se propostas de atuação numa perspectiva, preventiva e institucional no apoio aos discentes: acolhimento, formação acadêmica, relações interpessoais, estratégias de aprendizagem e desenvolvimento de competências.

Ainda considera-se que os problemas de violência e preconceito na questão do sistema social, no qual os indígenas estão incluídos, exige uma análise muito profunda de todas as variáveis envolvidas, mas que não serão aprofundados aqui. Compreende-se assim, que a saúde mental não está relacionada apenas a ausência de psicopatologias, mas envolve todo o contexto biopsicossocioespiritual, como afirmaram Silva e colaboradores (2016), na definição de saúde consagrada pela Organização Mundial de Saúde que é bastante ampla e contempla três esferas relacionadas ao ser humano, quais sejam: corpo, psique e ambiente social.

Estas reflexões estão voltadas para a compreensão da singularidade dos sujeitos e a principal importância para a enfermagem é possibilitar o resgate da subjetividade do indivíduo, ou seja, é a mudança do olhar biologicista para um olhar mais compreensivo, singular, aprofundando. A enfermagem deve respeitar os princípios da dignidade, interação com o outro, se isentar de preconceitos, crenças pessoais e valores (CARRARA et al., 2015).

Dentro desse contexto, o presente trabalho se justifica por resumir os principais pontos, podendo servir como base para outros trabalhos e contribuindo como fonte de informações para toda a comunidade acadêmica e demais interessados na área que foi abrangida. Assim, questiona-se: Quais as evidências na literatura no período de 2015 a 2020 sobre os principais fatores que afetam a saúde mental estudantes universitários indígenas? 
O objetivo geral deste estudo é identificar as evidências na literatura no período de 2015 a 2020 sobre os principais fatores que afetam a saúde mental estudantes universitários indígenas.

\section{MATERIAIS E MÉTODOS}

Trata-se de um estudo bibliográfico baseado em artigos acadêmicos dos anos de 2015 a 2020, do tipo Revisão Integrativa da Literatura (RIL). A revisão integrativa da literatura tem como metodologia de pesquisa a utilização dados secundários advindos de uma associação de pesquisas que tratam de um tópico específico. Essa categoria admite a inclusão concomitante de estudos experimentais e não experimentais, quantitativos e qualitativos, com o intuito de fornecer uma compreensão abrangente do fenômeno sob investigação (SIQUEIRA; SANTOS; LEONIDAS, 2020).

Segundo Souza, Silva, Carvalho (2010), a RIL possui seis fases em seu processo de elaboração: a primeira fase pauta-se na elaboração da pergunta norteadora, a segunda é a busca ou amostragem na literatura, a terceira é a coleta de dados, a quarta é a fase de análise crítica dos dados incluídos, na quinta encontra-se a discussão e os resultados e a última fase consiste na apresentação da revisão integrativa.

Para o levantamento dos artigos na literatura, realizou-se buscas nas bases de dados: Scientific Eletronic Library Online (SciELO), Literatura Latino-Americana e do Caribe em Ciências da Saúde (LILACS) e Biblioteca Digital Brasileira de Teses e Dissertações (BDTD) e Scielo Livros. Foram utilizados, para busca dos artigos os seguintes descritores e suas combinações na língua portuguesa: "Saúde Mental”; "Indígenas"; "Universitários".

A partir deste conjunto de descritores e para a busca dos artigos, através dos filtros das próprias bases de dados, estabeleceram-se os seguintes critérios de inclusão: dissertações, teses e artigos disponíveis na integra, em língua portuguesa no período de 2015 a 2020 com acesso gratuito e que tivessem afinidade com a temática. Foram definidos como critérios de exclusão: livros digitais, artigos em língua estrangeira, resumos, artigos duplicados e fora do período definido para o estudo e que não se adequassem aos objetivos da pesquisa.

As referências foram transferidas, para análise das repetições entre as bases de dados, ao Software Mendeley, onde foram excluídas as repetições. Após isto, as referências foram importadas para o Programa Excel-Windows 10, verificando novamente as duplicações.

A coleta dos dados pautou-se no instrumento do formulário validado por Ursi e Galvão (2015) adaptado. Neste instrumento, após leitura minuciosa, os dados extraídos foram transcritos, possibilitando o detalhamento de cada estudo, que podem ser organizados por planilhas em ordem numérica crescente, por exemplo, de acordo com o ano de publicação e o título da pesquisa (SOUZA; SILVA; CARVALHO, 2010; TEIXEIRA et al. 2013).

Para análise dos dados, foi utilizada a Análise de Conteúdo Temático de Bardin (ACTB). As distintas etapas da análise de conteúdo organizam-se em torno de três núcleos cronológicos: A pré- 
-análise, exploração do material e o tratamento dos resultados (BARDIN, 2016). A primeira etapa da avaliação das referências incluídas constou da leitura dos títulos dos artigos, a segunda, da leitura dos resumos, e a terceira, da leitura critica e avaliação na íntegra dos estudos selecionados anteriormente.

Nas duas primeiras etapas excluíram-se os estudos cuja população alvo não eram de universitários indígenas, com desfecho que não houvesse fatores que afetam a saúde mental e não estavam disponíveis para acesso. Na terceira etapa, os artigos foram lidos na íntegra e, para se verificar a pertinência de sua inclusão, utilizou-se as informações: língua (português), resultados e discussões, país da pesquisa, relação com os fatores ou estressores do sofrimento psíquico e associações significativas entre as variáveis independentes e desfecho.

\section{RESULTADOS}

Identificaram-se no total 249 publicações, sendo 203 no LILACS, 23 na SciELO, 03 produções na Biblioteca Digital Brasileira de Teses e Dissertações, 20 produções no Scielo livros. Destes, foram encontrados 41 estudos duplicados, permanecendo 208 estudos. Após aplicação dos critérios de inclusão, a amostra inicial foi de 57 produções. Após leitura na íntegra, análise crítica dos artigos e sua relação com os objetivos dos estudos, a amostra final foi de 8 produções, sendo 04 Scielo; 02 lilacs e 02 estudos da Biblioteca Digital Brasileira de Teses e Dissertações (BDTD). Os resultado dos estudos selecionados foram adicionados ao fluxograma PRISMA (MOHER et al., 2009). 
Figura 1: Fluxograma PRISMA referente às etapas da seleção dos estudos e inclusão dos artigos na revisão.

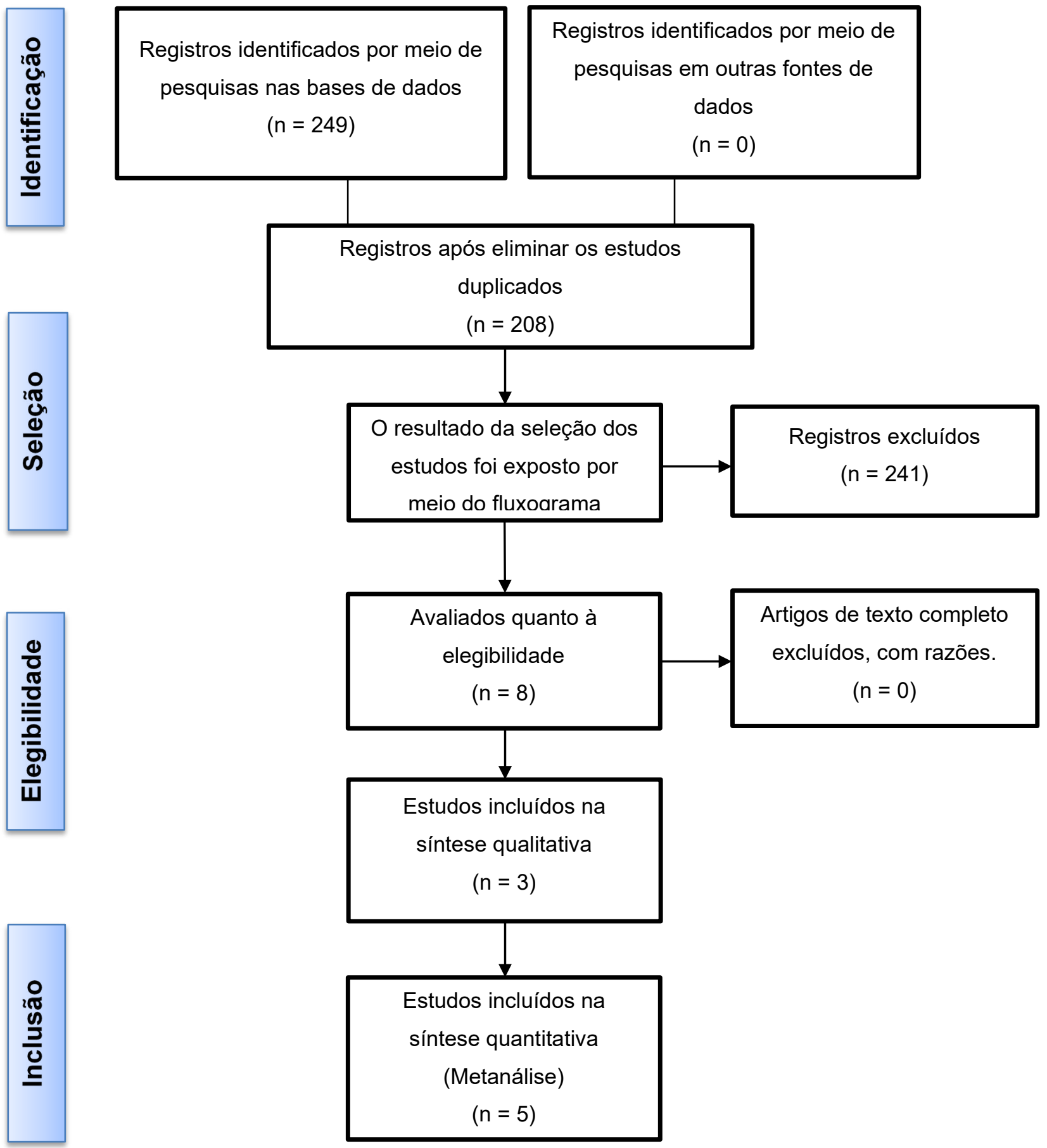

Fonte: (MOHER et al., 2009, adaptado); n=número de artigos

Após a análise critica dos estudos, e identificação da amostra de 8 produções, os artigos foram agrupados, onde foi utilizado o instrumento adaptado de Ursi e Galvão (2015). Optou-se por selecionar os itens: Autor/Periódico/ano; Título; Objetivo; Resultado (Quadro 1). 


\begin{tabular}{|c|c|c|c|}
\hline $\begin{array}{c}\text { AUTOR; } \\
\text { PERIÓDICO; } \\
\text { ANO }\end{array}$ & TÍTULO & OBJETIVO & RESULTADO \\
\hline $\begin{array}{l}\text { OLIVEIRA, A. DA } \\
\text { C.; BELTRÃO, J. F.; } \\
\text { DOMINGUES, W. } \\
\text { C. L. } \\
\text { Rev. História e Di- } \\
\text { versidade. UEMG } \\
\text { - Unemat, Editora; } \\
\text { ISSN: 2237-6569, } \\
2015 .\end{array}$ & $\begin{array}{l}\text { Povos indígenas, } \\
\text { ações afirmativas e } \\
\text { universidade: Con- } \\
\text { quistas e dilemas na } \\
\text { reserva de vagas na } \\
\text { Universidade Fede- } \\
\text { ral do Pará. }\end{array}$ & $\begin{array}{l}\text { Analisar como se materializa o } \\
\text { preceito normativo que regula- } \\
\text { menta as ações afirmativas de } \\
\text { ingresso universitário e exer- } \\
\text { cício do direito à diversidade } \\
\text { cultural na Universidade. }\end{array}$ & $\begin{array}{l}\text { Construção de uma política indigenista } \\
\text { na universidade que reconheça a partici- } \\
\text { pação indígena como um fator positivo } \\
\text { e não medida aleatória, com base em } \\
\text { compromissos e responsabilidade. In- } \\
\text { ternalização dos direitos indígenas nas } \\
\text { políticas universitárias, de modo a des- } \\
\text { locar os debates e decisões institucio- } \\
\text { nais os valores-direitos da autonomia, } \\
\text { participação e cidadania diferenciada } \\
\text { dos povos indígenas; }\end{array}$ \\
\hline $\begin{array}{l}\text { BATISTA, M. } \\
\text { Q.; ZANELLO, V. } \\
\\
\text { Estud. psicol. (Na- } \\
\text { tal) [online], vol.21, } \\
\text { n.4, pp.403-414. } \\
\text { ISSN 1678-4669, } \\
\text { dez., 2016. }\end{array}$ & $\begin{array}{l}\text { Saúde mental em } \\
\text { contextos indíge- } \\
\text { nas: Escassez de } \\
\text { pesquisas brasilei- } \\
\text { ras, invisibilidade } \\
\text { das diferenças. }\end{array}$ & $\begin{array}{l}\text { Realizar um levantamento de } \\
\text { artigos produzidos sobre o } \\
\text { tema saúde mental em contex- } \\
\text { tos indígenas entre os anos de } \\
1999 \text { e } 2012 \text { nas principais pla- } \\
\text { taformas científicas brasileiras. }\end{array}$ & $\begin{array}{l}\text { É possível observar que a publicação } \\
\text { de artigos relativos à saúde mental } \\
\text { em contextos indígenas começou a } \\
\text { aparecer somente em } 2006 \text {. Observa-se } \\
\text { que a etnia mais pesquisada é a Guarani. } \\
\text { As pesquisas ainda são tão incipientes } \\
\text { que não permitem um recorte desse } \\
\text { tipo, ficando restritos a discussões ge- } \\
\text { neralistas. }\end{array}$ \\
\hline $\begin{array}{l}\text { VIANA, I; MAHEI- } \\
\text { RIE, K. } \\
\text { Rev. Polis Psi- } \\
\text { que [online]. 2017, } \\
\text { vol.7, n.3, pp. 224- } \\
\text { 249. ISSN 2238- } \\
\text { 152X, 2017. }\end{array}$ & $\begin{array}{l}\text { Identidades em } \\
\text { Reinvenção: O For- } \\
\text { talecimento Cole- } \\
\text { tivo de Estudantes } \\
\text { Indígenas no Meio } \\
\text { Universitário. }\end{array}$ & $\begin{array}{l}\text { Abordar aspectos gerais da } \\
\text { presença indígena nas univer- } \\
\text { sidades brasileiras, a reinven- } \\
\text { ção identitária e o fortaleci- } \\
\text { mento de coletivos, marcando } \\
\text { a universidade como um novo } \\
\text { território de fronteira e de luta. }\end{array}$ & $\begin{array}{l}\text { A construção de raça indigena que ope- } \\
\text { ra no imaginário social e produz o ra- } \\
\text { cismo; a ausência de relações que po- } \\
\text { tencializam a humanidade dos Povos } \\
\text { Indígenas tem promovido sofrimentos } \\
\text { ético-políticos e que revela a negação } \\
\text { imposta socialmente, vendo sua potên- } \\
\text { cia enquanto humano ser diminuída. }\end{array}$ \\
\hline $\begin{array}{l}\text { FERNANDES, R. } \\
\text { M. C.; AMES, V.; } \\
\text { DOMINGOS, A. } \\
\text { Rev. O Social em } \\
\text { Questão. ISSN: } \\
\text { 1415-1804 (Press) / } \\
\text { 2238-9091 (Online), } \\
\text { abr., } 2017 .\end{array}$ & $\begin{array}{l}\text { Encontros e desen- } \\
\text { contros das ações } \\
\text { afirmativas no en- } \\
\text { sino superior: as } \\
\text { resistências dos es- } \\
\text { tudantes indígenas. }\end{array}$ & $\begin{array}{l}\text { Refletir acerca da presença in- } \\
\text { dígena nas universidades, seus } \\
\text { desafios, dificuldades os pro- } \\
\text { cessos de resistência instaura- } \\
\text { dos pelos estudantes indígenas, } \\
\text { repensar das práticas e con- } \\
\text { cepções acerca dos processos } \\
\text { de ensino-aprendizagens e das } \\
\text { relações interculturais. }\end{array}$ & $\begin{array}{l}\text { É preciso avançar com relação a } \\
\text { diferentes aspectos, tais como: } \\
\text { implementação de processos didáticos } \\
\text { e pedagógicos diferenciados de } \\
\text { avaliação e ensino-aprendizagem, } \\
\text { ruptura da tutela e do assistencialismo } \\
\text { no acompanhamento dos estudantes } \\
\text { indígenas no âmbito das universidades, } \\
\text { reconhecimento desses estudantes como } \\
\text { sujeitos de direitos. }\end{array}$ \\
\hline $\begin{array}{l}\text { MARTINS, J. C. L. } \\
\text { 2017. } 174 \text { f., il. Teses } \\
\text { USP - Dissertação } \\
\text { (Mestrado em Saúde } \\
\text { Pública) - Universi- } \\
\text { dade de São Paulo, } \\
\text { São Paulo, 2017. }\end{array}$ & $\begin{array}{l}\text { O trabalho do en- } \\
\text { fermeiro na saúde } \\
\text { indígena: desenvol- } \\
\text { vendo competên- } \\
\text { cias para atuação } \\
\text { no contexto inter- } \\
\text { cultural. }\end{array}$ & $\begin{array}{l}\text { Analisar a vivência do trabalho } \\
\text { de saúde dentro do território } \\
\text { indígena como um espaço po- } \\
\text { tencial de aprendizagem para } \\
\text { que o enfermeiro qualifique } \\
\text { sua prática profissional voltada } \\
\text { para atuação neste contexto in- } \\
\text { tercultural. }\end{array}$ & $\begin{array}{l}\text { A partir da inserção no serviço, os enfer- } \\
\text { meiros iniciam um processo de aprendi- } \\
\text { zado que segue impulsionado cotidia- } \\
\text { namente pelas situações vivenciadas no } \\
\text { trabalho e que tem os indígenas como } \\
\text { principais mediadores. A interculturali- } \\
\text { dade se mostra como fator inerente que } \\
\text { caracteriza o contexto e as demandas } \\
\text { que são colocadas aos profissionais que } \\
\text { nele atuam. }\end{array}$ \\
\hline $\begin{array}{l}\text { SANTOS, M.S.F. } \\
\text { DOS. } \\
\text { 2018. } 169 \text { f., il. } \\
\text { Tese (Doutorado em } \\
\text { Educação) - Univer- } \\
\text { sidade de Brasília, } \\
\text { Brasília, } 2018 .\end{array}$ & $\begin{array}{l}\text { Da aldeia à univer- } \\
\text { sidade - Os estu- } \\
\text { dantes indígenas no } \\
\text { diálogo de saberes } \\
\text { tradicional e cientí- } \\
\text { fico na UFT. }\end{array}$ & $\begin{array}{l}\text { Compreender a natureza dos } \\
\text { diálogos entre os saberes aca- } \\
\text { dêmicos produzidos e os sabe- } \\
\text { res tradicionais, dos estudantes } \\
\text { indígenas; capacitação dos do- } \\
\text { centes e adaptações do seu am- } \\
\text { biente para melhor o acolher no } \\
\text { intuito de realizar a inclusão. }\end{array}$ & $\begin{array}{l}\text { não existe articulação entre os saberes } \\
\text { indígenas e os da universidade. Com re- } \\
\text { lação aos estudantes indígenas que não } \\
\text { conseguem se integrar às regras atuais } \\
\text { da universidade, e com os que não se } \\
\text { sentem parte da universidade, consta- } \\
\text { tou-se despreparo dos professores, pre- } \\
\text { conceitos sofridos, estigmas e exclusão } \\
\text { social da comunidade acadêmica. }\end{array}$ \\
\hline
\end{tabular}




\begin{tabular}{|c|c|c|c|}
\hline $\begin{array}{l}\text { ARINO, D. O; BAR- } \\
\text { DAGI, M. P. } \\
\text { Psicol. } \\
\text { pesq. [online]., } \\
\text { vol.12, n.3, pp. 44- } \\
\text { 52. ISSN 1982-1247. } \\
\text { dez., 2018. }\end{array}$ & $\begin{array}{l}\text { Relação entre Fa- } \\
\text { tores Acadêmicos e } \\
\text { a Saúde Mental de } \\
\text { Estudantes Univer- } \\
\text { sitários. }\end{array}$ & $\begin{array}{l}\text { Analisar as relações entre an- } \\
\text { siedade, depressão e stress com } \\
\text { a qualidade das vivências aca- } \\
\text { dêmicas e a autoeficácia. }\end{array}$ & $\begin{array}{l}\text { Os resultados demonstram uma correla- } \\
\text { ção negativa, estatisticamente significa- } \\
\text { tiva, entre ansiedade, stress e depressão } \\
\text { e as vivências acadêmicas e, também, } \\
\text { com a autoeficácia. }\end{array}$ \\
\hline $\begin{array}{l}\text { BERGAMASCHI, } \\
\text { M. A.; DOEBBER, } \\
\text { M. B.; BRITO, P. O. } \\
\text { Rev. Bras. Estud. } \\
\text { Pedagog. [online]. } \\
\text { vol.99, n.251, pp.37- } \\
\text { 53. ISSN 2176-6681. } \\
\text { abr., 2018. }\end{array}$ & $\begin{array}{l}\text { Estudantes indíge- } \\
\text { nas em universida- } \\
\text { des brasileiras: um } \\
\text { estudo das políticas } \\
\text { de acesso e perma- } \\
\text { nência. }\end{array}$ & $\begin{array}{l}\text { Abordar a presença indígena } \\
\text { no ensino superior brasileiro } \\
\text { em universidades que execu- } \\
\text { tam políticas afirmativas para } \\
\text { ingresso e permanência des- } \\
\text { ses estudantes; Analisar teses } \\
\text { e dissertações, que tematizam } \\
\text { o ingresso de estudantes indí- } \\
\text { genas e questões relacionadas } \\
\text { à sua permanência na univer- } \\
\text { sidade. }\end{array}$ & $\begin{array}{l}\text { Os resultados mostraram que a presen- } \\
\text { ça indígena no ensino superior oferece } \\
\text { possibilidades de autorreflexão sobre as } \\
\text { práticas pedagógicas da instituição de } \\
\text { ensino superior e seu papel social. Tam- } \\
\text { bém apontam que a permanência dos } \\
\text { estudantes indígenas é um grande de- } \\
\text { safio para universidades e que diálogo } \\
\text { e postura receptiva aos conhecimentos } \\
\text { originários podem ser o primeiro passo } \\
\text { para efetivar processos de intercultura- } \\
\text { lidade. }\end{array}$ \\
\hline
\end{tabular}

Fonte: adaptado de Ursi e Galvão (2015)

Os artigos selecionados foram investigados e distribuídos de acordo com seus conteúdos em três categorias, sendo elas: Políticas afirmativas e a luta pela permanência na universidade; Processo de ensino-aprendizagem x saúde mental; Atuação do enfermeiro no contexto intercultural.

$\mathrm{Na}$ primeira categoria, foram adicionados os 04 artigos que perpassam pela temática, compreendendo os títulos: (1) "Povos indígenas, ações afirmativas e universidade: Conquistas e dilemas na reserva de vagas na Universidade Federal do Pará"; (2) "Identidades em Reinvenção: O Fortalecimento Coletivo de Estudantes Indígenas no Meio Universitário"; (3) "Estudantes indígenas em universidades brasileiras: um estudo das políticas de acesso e permanência"; (4) "Encontros e desencontros das ações afirmativas no ensino superior: as resistências dos estudantes indígenas.”.

Ainda na primeira categoria, 02 artigos possuem enfoque nas questões que dificultam a permanência dos estudantes indígenas na universidade atrelado a afirmação identitária e a pouca visibilidade política, são eles: "Identidades em Reinvenção: O Fortalecimento Coletivo de Estudantes Indígenas no Meio Universitário.” ; "Estudantes indígenas em universidades brasileiras: um estudo das políticas de acesso e permanência”.

Mais 02 estudos enquadram-se na primeira categoria e vêm abordando a regulamentação das ações afirmativas de ingresso universitário e a proposta de qualificação do corpo docente e técnico para saber lidar com a diversidade cultural, tornando o ambiente mais acolhedor a estes estudantes, estes são: "Povos indígenas, ações afirmativas e universidade: Conquistas e dilemas na reserva de vagas na Universidade Federal do Pará" e "Encontros e desencontros das ações afirmativas no ensino superior: as resistências dos estudantes indígenas".

Destaca-se o título: "Povos indígenas, ações afirmativas e universidade: Conquistas e dilemas na reserva de vagas na Universidade Federal do Pará", onde se observa que a vinda destes estudantes à universidade trouxe grandes desafios, pois muitos advêm de comunidades que vivem em considerá- 
vel grau de isolamento e ainda não dominam os códigos e tecnologias da universidade. Os indígenas estudantes logo descobrem que a política afirmativa de inclusão é rasa e que a partir dali terão que se virar como qualquer outro discente que, diferentemente deles, falam e entendem a língua da universidade.

Destaca-se também outro título: "Identidades em Reinvenção: O Fortalecimento Coletivo de Estudantes Indígenas no Meio Universitário" que mostra que a universidade atravessada pelas ações afirmativas tornou-se um novo território e uma fronteira que tem efetuado embate entre distintos sistemas, modos de viver e culturas. Ao mesmo tempo, a universidade ocupada por indígenas, tem sido palco para a expressão de problemáticas que são de toda a sociedade: desigualdades sociais e preconceitos com relação aos povos originários e a identidade coletiva de indígenas.

Na segunda categoria, 03 estudos foram encontrados, compreendendo os títulos: (1) "Saúde mental em contextos indígenas: Escassez de pesquisas brasileiras, invisibilidade das diferenças.”; (2) "Da aldeia à universidade - Os estudantes indígenas no diálogo de saberes tradicional e científico na UFT."; (3) "Relação entre Fatores Acadêmicos e a Saúde Mental de Estudantes Universitários.".

Com foco nas relações entre ansiedade, depressão, estresse e a vivência acadêmica, 01 artigo a contempla: "Relação entre Fatores Acadêmicos e a Saúde Mental de Estudantes Universitários". Aborda e investiga a relação entre sintomas sugestivos de depressão, ansiedade e stress com as vivências acadêmicas, que se define como a qualidade da experiência acadêmica percebida e a autoeficácia para formação superior, consideradas crenças acerca da própria capacidade de desempenhar ações demandadas para sua formação.

Ainda na segunda categoria tem-se 01 estudo que retrata a relação dos estigmas envolvidos entre os sabes acadêmicos e os saberes tradicionais indígenas atrelados a falha no processo de ensino-aprendizagem, alertando para uma nova reflexão sobre as práticas pedagógicas, tem-se o artigo: "Da aldeia à universidade - Os estudantes indígenas no diálogo de saberes tradicional e científico na UFT".

O último atrelado a segunda categoria revela a saúde mental no contexto indígena fadada a restrição de discussões generalistas: "Relação entre Fatores Acadêmicos e a Saúde Mental de Estudantes Universitários”. Este mostra como a abordagem da saúde mental pode ser problemática, já que aspectos que facilmente seriam remetidos a está área em nossa sociedade, como dependência de drogas, suicídio e uso de psicofármacos, não são tão evidentes em populações indígenas, exigindo cuidados éticos e culturais. Mesmo que o estudo tente mostrar uma problematização de forma universal, ele parte de pressupostos ancorados em visões ocidentais para mapear o contexto da saúde mental indígena brasileira.

Na terceira categoria, há 01 estudo que aborda a atuação do enfermeiro no contexto intercultural: "O trabalho do enfermeiro na saúde indígena: desenvolvendo competências para atuação no contexto intercultural". O estudo aponta que é a partir das dimensões do processo de trabalho efetivo em sua atuação no serviço, no trabalho vivo, que o enfermeiro vivencia uma interação marcada pela interculturalidade e potencialmente conflituosa. 


\section{DISCUSSÃO}

\subsection{Políticas afirmativas e a luta pela permanência na universidade}

Para Oliveira, Beltrão e Domingues (2015) existem inúmeras dificuldades no processo de inclusão dos indígenas e pouca qualificação do corpo docente e técnico pra lidar com as especificidades de cada estudante. Apontam que as propostas jurídicas tornam legítima a oferta de reserva de vagas, enquanto direito da autonomia universitária para a melhoria das possibilidades de inclusão, cuja inserção a partir do mecanismo das cotas étnicas - dentro da modalidade de ações afirmativas de cotas - não garante o respeito e a valorização da diversidade cultural e das vulnerabilizações sociais a que estão sujeitos os indígenas.

Nas pesquisas de Vianna e Maheire (2017) a presença indígena nos espaços universitários tem provocado estranhamentos e questionamentos e tem desafiado as instituições a se reverem em diferentes pontos. Seus estudos concluem que os estudantes indígenas experenciam resultados de um imaginário social que os estereotipa e que os aponta como indivíduos genéricos e traz com isso a reprodução de discursos que os colocam como figuras folclóricas: as vezes selvagem, as vezes impassível.

Os estudos de Bergamaschi, Doebber e Brito (2018) apontam dados escassos sobre as possibilidades oferecidas aos estudantes indígenas para a permanência nas universidades, mostram que a ênfase dos programas de ações afirmativas para indígenas, tem sido apenas no ingresso, tornando-se secundária a questão da permanência. Apresentam uma série de argumentos que justificam a preocupação com o momento inicial do percurso, onde há grandes índices de desistência. No entanto, apontam a necessidade de apoio concomitante ao ingresso e à continuidade dos estudos e finalizam que, se o acesso se dá de forma diferenciada, as condições de permanência têm que ser adequadas para os que ingressarem.

Fernandes, Ames e Domingos (2017) afirmam que a universidade é um território agora marcado por indivíduos historicamente negligenciadas e vozes antes caladas. Neste estudo reflexivo, os autores apresentam, a partir da visão do estudante indígena, as suas dificuldades de permanência: dificuldades de domínio do português, dos conteúdos ensinados, da dinâmica das salas de aula e a socialização do conhecimento em detrimento das tradições de suas comunidades; preconceitos; incompreensão dos processos administrativo-burocráticos.

O resumo das pesquisas referentes a esta categoria inferem que as dificuldades de adaptação aliadas a pouca visibilidade política junto à comunidade acadêmica indígena, são alguns dos fatores motivadores de desistência da graduação. Ao considerar-se estes estudos, constatou-se que o processo de inclusão neste espaço, atém-se apenas ao acesso por meio das cotas e políticas afirmativas. Ou seja, gera-se uma consequência errônea de que estes programas estão tornando a sociedade mais igualitária, quando na verdade o que se tem é somente a aceitação e conformismo para com as diversas e sutis formas de injustiça. 


\subsection{Processo de ensino-aprendizagem $x$ saúde mental}

Os estudos de Batista e Zanello (2016) apontam que não apenas as pesquisas sobre saúde mental entre os povos indígenas no Brasil são escassas, mas os poucos artigos encontrados demonstraram, em sua maioria, pouca reflexão teórica e epistemológica sobre o uso das categorias saúde mental e indígena. Isto influencia diretamente em uma redução de conhecimento por parte dos não indígenas sobre a saúde destes. Com isto tem-se o resultado apresentado por de Bergamaschi, Doebber e Brito (2018), que aponta o não saber lidar e não entender das especificidades desta população.

A partir da amostra obtida, observou-se que a falta de articulação entre os saberes indígenas e os saberes ocidentais da universidade se consolidam como potencial causa do despreparo dos educadores, que incide diretamente nos educandos, gerando preconceito, discriminações, estigmas e a exclusão social por parte da comunidade acadêmica. A estas causas, soma-se aos fatores que levam ao estresse/sofrimento psicológico dos discentes por não conseguirem se integrar às regras atuais da universidade, por não compreenderem de forma efetiva o conteúdo estudado, fazendo com que não se sintam parte dela.

Na tese de doutorado de Santos (2018) abordou-se o repensar das práticas de ensino-aprendizagem, com adequação do curso à realidade do acadêmico indígena, visto que as aulas ministradas são pautadas no padrão ocidental, desta forma o aluno não consegue adequar o que aprendeu à sua realidade na aldeia, o que segundo os autores leva a uma frustração e sensação de insuficiência. Santos concorda com Fernandes, Ames e Domingos (2017) que, para haver uma melhora neste quadro devem haver reflexões, sobre os desafios e dificuldades enfrentadas por esta população, levando a rediscussão do direito à diversidade cultural.

A pesquisa correlacional, de caráter descritivo e com corte transversal de Ariño e Bardagi (2018) demonstra que a sensação de pertencimento e a formação de vínculos faz parte da consolidação de identidade profissional. Entretanto, ao ingressar no Ensino Superior o graduando começa a experienciar um novo conjunto de atividades e demandas complexas, como as de domínio social, que envolve novos padrões de relacionamento com a família, professores e colegas, que poderá impactar na percepção da própria capacidade de se relacionar com os demais, reduzindo sua autoeficácia e mais ainda na aprendizagem.

Ariño e Bardagi (2018) ainda afirmam que obter conhecimento sobre o processo de saúde-doença dos estudantes permitirá repensar uma formação adequada e de qualidade. Considerando a importância dessa etapa para o desenvolvimento psicossocial e profissional, Santos (2018) refere ser necessário conhecer e intervir sobre essa realidade, pensar em novas práticas pedagógicas do ensinar, para que os universitários possam vivenciar o período de formação superior sem adoecer em decorrência de fatores acadêmicos associados. 


\subsection{Atuação da enfermagem no contexto intercultural}

A produção científica da enfermagem em saúde mental indígena é extremamente escassa e se sustenta em quase toda a sua totalidade na saúde mental de idosos e gestantes. Se tratando do contexto de saúde mental do indígena universitário, esta é quase nula.

Na dissertação de mestrado de Martins (2017) a presença da enfermagem na saúde indígena, que apesar de não abordar a saúde mental no contexto citado anteriormente, se faz de extrema importância pois trás o papel do/a enfermeiro/a dentro da transculturalidade, a importância do trabalhar com o conhecimento tradicional que também pode contribuir para a eficácia das ações, estreitar a relação com os indígenas que devem ser valorizados na prática de atenção à saúde, fortalecer a cultura dessas populações e resgatar o saber acumulado.

Silva et al., (2018) em seus estudos que tem como objetivo a disseminação destes conhecimentos transculturais na comunidade acadêmica, concorda com Martins (2017) destacando que a cultura amazônica é formada por diversos povos, onde os mesmos possuem conhecimentos próprios e a enfermagem deve saber e aprender como lidar e respeitar suas experiências.

Araújo et al., (2020) avalia que a teoria transcultural proposta por Madeleine Leininger como sendo o ramo da enfermagem que enfoca o estudo comparativo e a análise de culturas com respeito à enfermagem e as práticas de cuidados de saúde-doença, às crenças e aos valores (conceito ocidental) e o modo de viver (conceito dos povos tradicionais), com a meta de proporcionar um serviço de atendimento de enfermagem significativo e eficaz para as pessoas, de acordo com os seus valores culturais e seu contexto de saúde-doença.

Ainda segundo Martins (2017) a formação profissional para atuação voltada à saúde indígena constitui ainda um desafio e a prática profissional tem sido reveladora das lacunas do processo formativo. Rohrbach (2015) complementa afirmando que as culturas são únicas e devem ser estudadas e avaliadas de acordo com seus valores. Castro et al., (2020) conclui que para alcançar os patamares da integralidade no contexto das populações tradicionais, é necessário que isso ocorra desde a formação desses profissionais pois permite incorporar de modo integral as habilidades profissionais necessárias.

\section{CONCLUSÃO}

O fato de existir um quantitativo pequeno de pesquisas científicas acerca da saúde mental de indígenas universitários e menos ainda por parte da enfermagem abre-se um leque de indagações e busca pela compreensão e intervenções sobre a temática. Os estudos que subsidiaram esta pesquisa afirmam que a presença indígena no ensino superior promove a oportunidade de uma autorreflexão sobre o fazer da universidade, seu papel social e suas práticas pedagógicas. Ainda apresenta o protagonismo da enfermagem na saúde mental, tendo como foco o cuidado em seu contexto histórico, cultural entendendo que os indivíduos se comportam de maneira diferenciada dependendo do contexto no qual inserem-se. 
Observa-se um esforço duplo: dos estudantes indígenas, que tentam, apesar de todos os percalços socioeconômicos, políticos e culturais permanecer na universidade a fim de deter de dos seus direitos e transformar de alguma forma a sua realidade e a da sua comunidade, bem como para potencializar suas lutas; e da universidade, que tenta se adequar as necessidades e especificidades de cada um destes estudantes. Nesse movimento, geram-se muitas incompreensões. Tudo isto gera os fatores estressores e que se levam para o caminho do sofrimento mental, direta ou indiretamente.

Se o número de universitários indígenas aumentou consideravelmente no Brasil, é imprescindível dispensar esforços no aprimoramento das ações de permanência nas instituições de ensino superior, tanto materiais quanto pedagógicas, nas produções científicas ainda carentes de uma reflexão profunda sobre o tema para que o alcance das informações seja acessível principalmente aquelas produzidas por profissionais da saúde, que podem ser construídas com os estudantes, e das que precisam ser implementadas com técnicos e docentes das universidades que recebem estes acadêmicos.

Há fortes motivos para dizer que há tímidas discussões, mas ainda muito generalistas sobre o tema, em especial as que debatem sobre as dificuldades de permanência e o preconceito vivenciado

pelos indígenas. Contudo, os desafios não se restringem aos espaços das IES. É preciso estender a discussão a toda comunidade acadêmica, incluí-las nas disciplinas de formação, debatê-las em sala de aula e ampliar estes estudos para que esta se dissemine e assim minimize os danos causados a saúde mental de acadêmicos indígenas.

\section{REFERÊNCIAS}

ARAUJO, M. R. A. de et al. Saúde sexual e reprodutiva na etnia Xukuru do Ororubá: diga às mulheres que avancem. Saúde debate, Rio de Janeiro, v. 44, n. 124, p. 193-204, Mar. 2020.

ARINO, D. O.; BARDAGI, M. P. Relação entre Fatores Acadêmicos e a Saúde Mental de Estudantes Universitários. Psicol. pesq., Juiz de Fora, v. 12, n. 3, p. 44-52, dez. 2018.

ARROYO, M. G. O Direito a Educação e a Nova Segregação Social e Racial - Tempos Insatisfatórios? Educação em Revista, v. 31, n. 3, p. 15-47, 2015.

BARDIN L. Análise de Conteúdo. Lisboa (POR): Edições 70; 2016.

BATISTA, M. Q.; ZANELLO, V. Saúde mental em contextos indígenas: escassez de pesquisas brasileiras, invisibilidade das diferenças. Estud. psicol. (Natal). Natal, v. 21, n. 4, p. 403-414, dez. De 2016.

BERGAMASCHI, M. A.; DOEBBER, M. B.; BRITO, P. O. Estudantes indígenas em universidades brasileiras: um estudo das políticas de acesso e permanência. Rev. Bras. Estud. Pedagog., Brasília, v. 99, n. 251, p. 37-53, Jan. 2018 .

BRASIL. Ministério da justiça. Justiça e segurança pública. Assessoria de comunicação social: Portal do governo Brasileiro. Brasília, 2018. Disponível em: $<$ https://www.justica.gov.br/news/estudantes-indigenas-ganham-as-universidades>. Acesso em 18 mai. 2020.

CARRARA, G. L. R., et al., Assistência de enfermagem humanizada em saúde mental: uma revisão da literatura. Revista Fafibe On-Line, v. 8, n.1, p. 86-107, 2015. 
CASTRO, N. J. C. de et al. Ensino da Saúde das Populações tradicionais em cursos de graduação em Enfermagem. Enfermagem em Foco, [S.1.], v. 10, n. 6, maio 2020.

FERNANDES, R. M. C.; AMES, V.; DOMINGOS, A. Encontros e desencontros das ações afirmativas no ensino superior: as resistências dos estudantes indígenas. O Social em Questão, v. 20, n. 37, p. 71-90, 2017.

LIMA, A. C. DE S. Ações afirmativas no ensino superior e povos indígenas no Brasil: uma trajetória de trabalho. Horiz antropol Porto Alegre, v. 24, n. 50, p. 377-448, 2018.

MARTINS, J. C. L. O trabalho do enfermeiro na saúde indígena: desenvolvendo competências para atuação no contexto intercultural. Dissertação de Mestrado em Saúde Pública, Universidade de São Paulo, São Paulo, 174 f., il. 2017.

MOHER, D. et al. Preferred reporting items for systematic reviews and meta-analyses: The PRISMA statement. PLoS Medicine, v. 6, n. 7, 2009.

OLIVEIRA, A. DA C.; BELTRÃO, J. F.; DOMINGUES, W. C. L. Povos indígenas, ações afirmativas e universidade: Conquistas e dilemas na reserva de vagas na Universidade Federal do Pará. Revistra História e Diversidade. v. 6, n.1, p. 232, 2015.

RESSURREICAO, S. B. DA; SAMPAIO, S. M. da R. Transições e reconfigurações do self de jovens indígenas na experiência universitária. Psicol. Esc. Educ., Maringá, v. 21, n. 3, p. 495-504, dez. 2017.

ROHRBACH, V. C. Perspectivas históricas da antropologia. Reflexões propostas à Enfermagem Transcultural. Investir. educ. enferm. Medellín, v. 33, n. 2, p. 365-373, ago. 2015.

SANTOS, M.S.F. DOS. Da aldeia à universidade - Os estudantes indígenas no diálogo de saberes tradicional e científico na UFT. Tese de Doutorado em Educação - Programa de pós-graduação, Universidade de Brasília, 169 f., il. Universidade de Brasília, Brasília, 2018.

SILVA, L. G. DA. Povos Indígenas no contexto do ensino superior: os desafios do acesso e da permanência na UFPR. Campos-Revista de Antropologia, v. 17, n. 2, p. 101-1012, 2016.

SILVA, A. G. I. DA. et al. Enfermagem e a Diversidade Transcultural Amazônica: Um Relato de Experiência. Revista Eletrônica Acervo Saúde, n. 19, p. 212, 30 dez. 2018.

SIQUEIRA, A. B. R.; SANTOS, M. A. DOS; LEONIDAS, C. Confluências das relações familiares e transtornos alimentares: revisão integrativa da literatura. Psicol. clin., Rio de Janeiro, v. 32, n. 1, p. 123-149, abr. 2020 .

SOUZA, M. T. DE; SILVA, M. D. DA; CARVALHO, Rachel de. Revisão integrativa: o que é e como fazer. Einstein (São Paulo), São Paulo, v. 8, n. 1, p. 102-106, Mar. 2010.

TEIXEIRA, E. Revisão Integrativa da Literatura passo-a-passo \& covergências com outros métodos de revisão, REUFPI, 2013.

URSI, E.S; GALVÃO, C.M. Avaliação das escalas de risco para úlcera por pressão em pacientes críticos: uma coorte prospectiva. Acta Paul Enferm. 2015; 23(1):28-35.

VIANA, Iclicia; MAHEIRIE, Kátia. Identidades em Reinvenção: O Fortalecimento Coletivo de Estudantes Indígenas no Meio Universitário. Rev. Polis Psique, Porto Alegre, v. 7, n. 3, p. 224-249, dez. 2017. 


\section{INFLUÊNCIA DA TÉCNICA DE IMPOSTAÇÃO DE MÃOS (REIKI) SOBRE O PROCESSO DE CICATRIZAÇÃO DE CAMUNDONGOS COM ÚLCERA CUTÂNEA}

GLORIA EDELMA MEGA Universidade do Vale do Itajaí (UNIVALI)

MARINA CORRÊA ANDREOLLA Universidade do Vale do Itajaí (UNIVALI)

MARIA VERONICA DAVILA PASTOR Universidade do Vale do Itajaí (UNIVALI)

MARLUCE CORREA Instituto Reikiano

MÁRCIA MARIA DE SOUZA Universidade do Vale do Itajaí (UNIVALI)

RESUMO: Entre as terapias complementares aprovadas pela Organização Mundial da Saúde (OMS) encontra-se a técnica de cura através da impostação de mãos, o Reiki. Tal modalidade terapêutica é um potencial humano natural conhecido desde épocas remotas, sendo atualmente utilizada em diversas situações clínicas como a dor musculoesquelética, oncológica, a ansiedade, e a depressão, dentre outras. Embora, se tenha na literatura diversos trabalhos em humanos, avaliando os efeitos terapêuticos do Reiki, muitos duvidam de sua eficácia e atribuem a autossugestão ou efeito placebo como responsável pelos efeitos benéficos da técnica. No presente trabalho comparou-se os efeitos cicatrizantes do Reiki ao fármaco convencional utilizando camundongos Swiss Webster divididos em: Grupo 1 (naive); Grupo 2 (creme Novacort ${ }^{\circledR}$ ); Grupo 3 (Novacort $\AA$ + Reiki por 30 min.); Grupo 4, 5 e 6 (Reiki por 10, 15 e $30 \mathrm{~min}$.). Os tratamentos foram feitos de forma duplo-cega até a cicatri- zação das ulcerações em um dos grupos experimentais. Para avaliar o processo de cicatrização, as feridas foram fotografadas e analisadas através do software EARP®. Ao final dos experimentos, os animais foram eutanasiados e uma porção da pele foi coletada para análises histológicas. Nos resultados obtidos os animais que receberam Reiki apresentaram fechamento das feridas em tempo menor, quando comparados aos que foram tratados com o fármaco padrão. Houve também superior migração de fibroblastos nos animais tratados somente com Reiki e Reiki em conjunto com o fármaco padrão, quando comparados com o grupo Controle. Analisando os resultados em conjunto, evidencia-se os efeitos terapêuticos do Reiki, e os discrimina do efeito placebo, dado que animais de laboratório não exibem a capacidade de autossugestão.

PALAVRA-CHAVE: Terapia complementar, Reiki, cicatrização, úlcera cutânea.

ABSTRACT: Among the complementary therapies approved by the World Health Organization (WHO), there is the technique of healing through the laying of hands, known as Reiki. This therapeutic modality is a natural human potential known since ancient times, being currently used in several clinical situations such as musculoskeletal pain, cancer, anxiety, and depression, among others. Although there are several works with humans in the literature, evaluating the therapeutic effects of Reiki, many doubt its effectiveness and attribute the self-suggestion or placebo effect as responsible for the beneficial effects of the technique. In the present study the healing effects of Reiki were compared to the conventional drug, using Swiss Webster mice divided into: Group 1 
(naive); Group 2 (Novacort ${ }^{\circledR}$ cream); Group 3 (Novacort ${ }^{\circledR}+$ Reiki for 30 min.); Group 4, 5 and 6 (Reiki for 10, 15 and $30 \mathrm{~min}$.). The treatments were performed in a double-blind manner until the ulcerations healed in one of the experimental groups. To assess the healing process, the wounds were photographed and analyzed using the EARP ${ }^{\circledR}$ software. At the end of the experiments, the animals were euthanized and a portion of the skin was collected for histological analysis. The results obtained demonstrate that animals treated with Reiki had faster wound closure compared to those that were treated with the standard drug, and a higher migration of fibroblasts in animals treated only with Reiki and Reiki in conjunction with the standard drug. Analyzing the results together, evinces the therapeutic effects of Reiki, and discriminates against the placebo effect, given that laboratory animals do not exhibit the ability to self-suggest.

KEYWORDS: Complementary therapy, Reiki, healing, skin ulcer.

\section{INTRODUÇÃO}

O processo de cicatrização inicia-se quando a integridade da pele é afetada, em uma tentativa do organismo recuperar a sua função. Tal processo é resultante de uma cascata biológica de eventos comprometidos em reparar, reestruturar e fechar de forma rápida a lesão (SZWED e SANTOS, 2016). Embora não haja dados precisos no Brasil, alguns trabalhos demonstram que a úlcera crônica causa dano e destruição ao tecido de forma lenta que pode interferir na qualidade de vida de seus portadores, tanto nas atividades de vida diária, quanto nas relações sociais, causando afastamento do trabalho, um impacto psíquico e econômico da cronificação da lesão (NOVAK et al., 2019). Isso demonstra que, estudos sobre terapias alternativas, menos invasivas e onerosas se fazem necessárias e a técnica de impostação de mãos - Reiki - pode ser uma alternativa, já que preenche os critérios acima estabelecidos. Soma-se também ao fato de que o Reiki foi oficializado no ano de 2006 como uma Prática Integrativa e Complementar por meio da Portaria 971 de 03 de maio, obedecendo à diretriz preconizada pela OMS, sendo ofertada a partir de então pelo Sistema Único de Saúde, tornando-se parte da Política Nacional de Práticas Integrativas e Complementares, presente em todas as capitais do Brasil e sendo encontrada em maior parte na Atenção Básica (SPEZZIA e SPEZZIA, 2018). Além disso, é uma terapia complementar que pode ser acessível a um maior número de pessoas, e que para ser administrado o profissional deve ter passado por todos os níveis de aprendizado que são: nível I, nível II e nível Mestre/Professor, os quais envolvem diferentes princípios, habilidades e técnicas (MICK, 2016).

Reiki é uma técnica japonesa que ajuda a diminuir o estresse e facilita o relaxamento, além de auxiliar a restabelecer as habilidades inatas do corpo de manter a harmonia e o equilíbrio, tratando o indivíduo como um todo - mente, corpo e espírito. Essa prática que vem ganhando notoriedade em um âmbito geral, é considerada complementar e integrativa, ou seja, tem o intuito de fomentar a medicina convencional, promovendo a cura através da canalização e transmissão pelas mãos da energia dos centros cognitivos superiores (MICK, 2016; KUREBAYASHI et al., 2016). A palavra é derivada dos kanji "rei" que significa energia universal e "ki", energia vital. 
Acredita-se então, que Reiki é a energia vital guiada, porém não relacionada a doutrinas religiosas, sendo que é aceita e praticada por indivíduos das mais diversas religiões e credos (VIEIRA, 2017). Contudo, ainda há muitas dúvidas sobre a efetividade desse tipo de tratamento, devido a existência da correlação entre a técnica e o efeito placebo, apesar de já existirem relatos na literatura com resultados positivos. A linha de pesquisa contrária a técnicas integrativas acredita que o efeito do Reiki seja devido a autossugestão (MCMANUS, 2017), embora haja evidências de que a energia canalizada pelo Reiki irá influenciar o campo energético que o corpo produz, atingindo das camadas mais profundas as mais superficiais e vice-versa. Ou seja, a pele como o maior órgão do corpo, e desempenhando um papel vital - por ser uma barreira contra infecções e outros agentes agressores externos -, poderá também ser afetada pelo Reiki mesmo em animais, demonstrando que não há tal correlação.

De acordo com Wong et al. (2016), a pele é formada por duas camadas distintas: epiderme, porção mais externa da pele e derme, localizada abaixo dessa. A hipoderme apesar de estar intimamente ligada às funções da pele e ter um papel essencial em conjunto das demais camadas, não é considerada parte da pele, ela se encontra abaixo da derme e é responsável por fazer a união entre essa camada e os órgãos subjacentes. As úlceras ou também conhecidas por feridas, acometem geralmente a camada da epiderme e derme, porém em casos mais graves podem atingir a hipoderme. Sendo assim, quando a barreira natural da pele é desestruturada, pelo acometimento de uma úlcera, sua função protetora fica comprometida, tornando-se sensível a influências externas e consequentemente, mais suscetível a infecções (WONG et al., 2016).

A dificuldade de tratar algumas feridas, principalmente, úlceras abertas em pacientes como os diabéticos, ou pacientes acamados portadores de escaras, gerou a necessidade de introduzir novas técnicas para melhorar o processo de cicatrização. Desse modo, processos terapêuticos que auxiliem nas várias etapas do mecanismo de cicatrização (fase inflamatória, proliferativa, remodelagem) são importantes. Portanto, no presente estudo foi proposto a avaliação dos efeitos do Reiki em úlceras de pele induzidas em camundongos, no sentido de não só demonstrar sua efetividade terapêutica, como também desvencilhar da técnica do Reiki o processo de autossugestão.

\section{METODOLOGIA}

A presente pesquisa qualitativa de cunho experimental na área farmacêutica, foi realizada na Universidade do Vale do Itajaí, em Itajaí, Santa Catarina, durante o período de fevereiro de 2018 a junho de 2019 e teve por objetivo contrapor a correlação entre Reiki e autossugestão e comprovar a sua eficácia sobre o processo de cicatrização de camundongos com úlcera cutânea. 


\section{Ensaios farmacológicos}

Para os experimentos foram utilizados camundongos Swiss Webster fêmeas (25 a 30g), obtidos do biotério da UNIVALI, mantidos em ciclo claro/escuro de 12 horas aclimatados a temperatura de $22 \pm 2^{\circ} \mathrm{C}$ e tratados com água e ração ad libitum, exceto durante os experimentos. Nos ensaios farmacológicos o $\mathrm{N}$ por grupo foi em média de 8 animais. Os protocolos experimentais foram submetidos à Comissão de Ética no Uso de Animais (CEUA), sendo aprovado com o parecer CEUA 056/18p. Os animais foram divididos em grupos diferentes G1 (animais sem tratamento Reiki), G2 (animais tratados com creme cicatrizante Novacort ${ }^{\circledR}$ ) G3 (animais tratados com Reiki 30 minutos antes do creme), G4, G5 e G6 (animais tratados somente com Reiki aplicado por 10, 15 e 30 minutos). Os tratamentos com o creme foram feitos diariamente, enquanto o Reiki foi aplicado em dias alternados, ambos de forma duplo-cega e se prolongaram até ocorrer o fechamento (cicatrização) de um dos grupos experimentais.

\section{Ensaio de cicatrização in vivo}

Com a finalidade de avaliar a atividade cicatrizante do Reiki sobre a regeneração tecidual, foi realizado o modelo de cicatrização de úlcera cutânea em camundongos, segundo metodologia descrita por Iba e colaboradores (2004) e padronizada em nossos laboratórios por Trivelatto Grassi et al. (2013). Passado o período de aclimatação dos animais, esses foram anestesiados por via intraperitoneal com solução $1: 1$ de quetamina $(100 \mathrm{mg} / \mathrm{kg})$ e xilazina $(10 \mathrm{mg} / \mathrm{kg})$. Após a constatação da anestesia pela perda dos reflexos, foi realizada em todos os animais a tricotomia do dorso e demarcação da área de produção das úlceras. Em seguida, foi feita a assepsia dessa área com álcool $70 \%$ e realizada a excisão cirúrgica com auxílio de um punch cirúrgico de $1,5 \mathrm{~cm}$ de diâmetro, sendo retiradas pele e gordura subcutânea com auxílio de tesoura e pinça anatômica (Figura 01). Posteriormente ao procedimento cirúrgico, os animais foram transferidos para uma caixa e submetidos ao aquecimento sob luz amarela, com o objetivo de inibir a hipotermia. Após 72 horas da cirurgia, foi administrado nos animais pela via intraperitoneal dipirona sódica $(100 \mathrm{mg} / \mathrm{kg})$, para alívio do processo doloroso antes do início dos tratamentos.

Figura 01 - Procedimento de indução das úlceras cutâneas

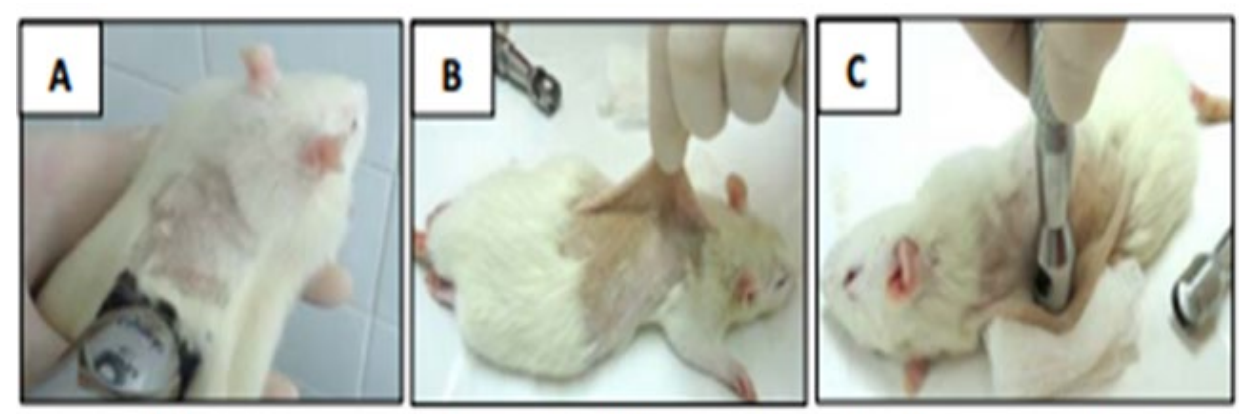

A- Tricotomia do dorso e assepsia; B- Determinação do local para confecção da úlcera; C- Confecção da úlcera com o punch cirúrgico. 
Decorrido o tempo de recuperação, as úlceras foram fotografadas diariamente e de forma individual, com auxílio de uma régua de $30 \mathrm{~cm}$ perpendicular a úlcera, para a padronização da unidade de área das lesões em milímetros. Transcorrido o período de tratamento, o qual foi encerrado com a completa cicatrização de um dos grupos, realizou-se a eutanásia dos animais em câmara de gás (conforme procedimentos da UNIVALI) para análises morfométricas finais das feridas. A partir das fotografias, as áreas das úlceras foram calculadas pelo software EARP® em mm2.

\section{Procedimento de Impostação de Mãos - Reiki}

Passado 24 horas da indução das ulcerações, a técnica de impostação de mãos foi realizada por um mesmo profissional (Mestre em Reiki) nos grupos G3 (Reiki + Novacort ${ }^{\circledR)}$ ); G4 (Reiki aplicado por 10 min.); G5 (Reiki aplicado por $15 \mathrm{~min}$.) e G6 (Reiki aplicado por $30 \mathrm{~min}$.) por todo o período de experimentação, em dias alternados, sem que ocorresse o contato físico direto entre o indutor e a ferida de cada animal, enquanto que o creme foi aplicado diariamente. O Reiki foi aplicado por grupo de animais os quais eram mantidos em caixas - moradias posicionadas sobre uma mesa no laboratório de farmacologia para melhor aplicação - sinalizadas por símbolos (G3 - círculo, G4 - quadrado, G5 sorriso e G6 - coração) impedindo que os pesquisadores soubessem quais os tratamentos que estavam sendo realizados. Os grupos G1 e G2, também identificados com símbolos, eram formados respectivamente por: animais controle (sem tratamento Reiki) e animais tratados somente com Novacort ${ }$. Todos os grupos tiveram as suas úlceras medidas e documentadas com fotos até o encerramento do experimento. O procedimento foi feito em sala silenciosa, com controle de luminosidade (40 LUX) e temperatura $\left(22 \pm 1^{\circ} \mathrm{C}\right)$.

\section{Análise histológica}

Os tecidos representados pelas cicatrizes no dorso de cada animal foram retirados cirurgicamente após a eutanásia dos mesmos. As peças foram fixadas primeiramente em álcool 70\% por 48 horas e posteriormente trocado por solução de formol 10\%. As peças foram acondicionadas e enviadas ao laboratório HISTOCELL para realização do corte histológico, em seguida foi feita a análise em coloração Hematoxilina-Eosina e Picrosirius em aumento de 400x, para observação de elementos cicatriciais. Para essa análise, foram identificados as regiões de cicatrização sem folículos pilosos e demais estruturas da pele nos cortes histológicos, três fotos de cada grupo foram tiradas em campos consecutivos nessas regiões, posteriormente retículos com o mesmo tamanho foram sobrepostos a essas imagens e os fibroblastos foram contados nas interseções, no final resultando em uma média de fibroblastos por grupo.

\section{Análise estatística}

Os dados obtidos foram apresentados com médias seguidas pelos respectivos erros padrão médios (EMP), e submetidos a análises de variância, e quando necessário, seguidos de teste de múlti- 
pla comparação a partir dos modelos Post Hoc de Dunnett e Newman, utilizando o software GraphPad INSTAT ${ }^{\circledR}$. Foram considerados estatisticamente significantes os valores de $p<0,05$.

\section{RESULTADOS E DISCUSSÃO}

A técnica de impostação de mãos, o Reiki, é uma das modalidades de terapias complementares hoje em dia utilizadas no mundo inteiro (BILLOT et al., 2019). Já são conhecidos os efeitos benéficos do Reiki sobre a dor (DOĞAN, 2018), sobre a depressão e ansiedade (JOYCE e HERBISON, 2015; TOPDEMIR e SARITAS, 2020), bem como sobre os efeitos colaterais oriundos de procedimentos oncológicos como a radioterapia (IACOROSSI et al., 2017). Porém, não constam na literatura resultados relacionados aos efeitos do Reiki sobre o processo de cicatrização, nem com ensaios clínicos ou pré-clínicos. No presente estudo, foi demonstrado que o Reiki pode ser usado como alternativa na terapêutica de feridas cutâneas induzidas, e ainda evidenciado que a eficácia obtida pelo tratamento com Reiki não tem relação com o efeito placebo, um dos argumentos utilizados por pesquisadores contrários às terapias complementares.

De acordo com o estudo de Sanchéz-Cruz et al. (2016), as úlceras cutâneas se tornaram uma epidemia silenciosa na região Latino-americana, principalmente no Brasil, com repercussões econômicas e sociais. Isso também é relatado no estudo de Trivellato e colaboradores (2018), realizado a partir da análise documental de registros e prontuários de pessoas com úlceras cutâneas, onde observou-se uma perda na qualidade de vida diária de seus portadores, uma vez que, as dores causam limitação no trabalho, no lazer e na convivência familiar. A combinação dos fatores etiológicos das úlceras cutâneas muitas vezes acarretam em uma cicatrização prolongada e mesmo que gerada por diferentes causas, todas apresentam inflamação crônica, tornando o indivíduo suscetível a complicações graves como infecção, dor, redução ou perda da mobilidade articular, dificuldade na marcha, linfangite, erisipela, amputação do membro, entre outras (DE SOUZA GRICIO et al., 2017).

Os estudos de cicatrização de feridas são intrincados, principalmente, devido à natureza multifacetada do ambiente da ferida e à complexidade do processo de cicatrização, que ocorre fundamentalmente em três fases: inflamação, formação de tecido de granulação, deposição de matriz extracelular e remodelação (ZOMER e TRENTIN, 2018). Há uma variedade de modelos pré-clínicos possíveis, como em camundongos, coelhos e porcos, que podem ser usados para imitar feridas agudas ou comprometidas, por exemplo, feridas diabéticas. Essas podem ser induzidas por muitas técnicas diferentes, sendo a excisão ou incisão a mais comum. Posteriormente, os pesquisadores precisam selecionar métodos apropriados e reproduzíveis que permitam monitorar a progressão da ferida ao longo do tempo. A avaliação pode ser realizada por protocolos não invasivos, documentação fotográfica (incluindo análise de imagens), técnicas biofísicas e/ou protocolos invasivos que exigirão biópsias de feridas (MASSON-MEYERS et al., 2020)

No presente estudo foi utilizado o modelo de feridas cutâneas em camundongos. Apesar das inúmeras diferenças morfofuncionais, imunológicas e genéticas, os camundongos têm contribuído 
bastante para o conhecimento do processo de cicatrização de feridas (ZOMER e TRENTIN, 2018). Normalmente o modelo é utilizado para avaliar a eficácia de substâncias cicatrizantes incorporadas ou não a cremes sejam elas de origem sintética ou natural. Neste estudo o modelo foi utilizado para avaliar a eficácia do Reiki como terapia complementar para o processo de cicatrização. Os resultados demonstrados foram obtidos com base nas fotos analisadas através do software EARP ${ }^{\circledR}$, sendo possível construir um gráfico de pontos (Figura 02B) com as áreas das ulcerações, e a partir desse, um gráfico de barras com a média das áreas seguidas pelos respectivos erros padrão médios, ao decorrer dos 35 dias de experimento (Figura 02A). Como demonstrado na figura 02, o tratamento dos animais com Reiki (G4-10min) , (G5 -15min) e (G6 $30 \mathrm{~min}$ ) promoveu uma redução de forma significativa $(\mathrm{p}<0.01, \mathrm{p}<0.001)$ do tempo requerido para o fechamento das feridas comparados com animais do grupo G1 (Naive- animais sem tratamento) e G2 (animais somente tratados com o creme). Os resultados também demonstram que o efeito do Reiki sobre o fechamento das feridas cutâneas independe do tempo de aplicação uma vez que, em num período de aproximadamente 15 dias após a indução das feridas, as mesmas se encontram praticamente fechadas e, que nos grupos não tratados com Reiki esse período se prolongou por cerca de 35 dias.

Figura 02. Avaliação do tempo de fechamento das feridas cutâneas

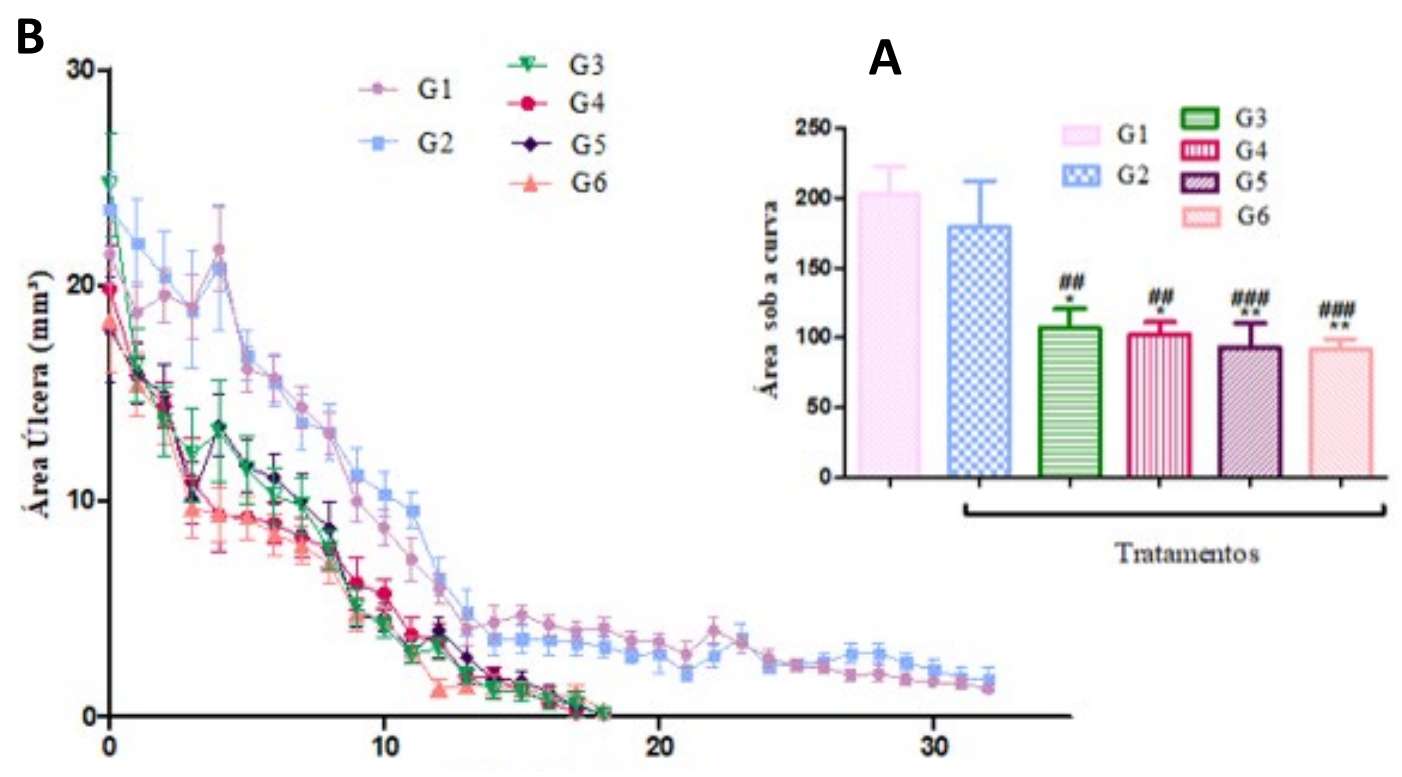

Grupo 1. Naive (animais sem tratamento); Grupo 2. Animais tratados com creme cicatrizante Novacort ${ }^{\circledR ;}$;rupo 3. Animais tratados com creme cicatrizante + Reiki por 30 min.; Grupo 4. Animais tratados com Reiki por 10 min.; Grupo 5. Animais tratados com Reiki por 15 min.; Grupo 6. Animais tratados com Reiki por 30 min. Asteriscos denotam significâncias estatísticas quando comparados ao grupo controle positivo (G2) * $\mathbf{p}<0.05, * * \mathbf{p}<0.01$ e \# denotam significância estatística quando comparado com o controle negativo (G1) \#\#p $<0.01, \# \# \#$ p $<0.001$.

Pela análise macroscópica (Figura 03) também é possível verificar que o fechamento das feridas nos grupos G4, G5 e sobretudo G6 ocorre ocorreu de forma muito efetiva, sendo observado inclusive no grupo G6 não só fechamento da ferida em si, como também o restabelecimento da pelagem dos animais. Nos grupos G1, G2 e G3, sobretudo G2 (animais tratados somente com o creme) ao final do $15^{\circ}$ dia de tratamento as feridas ainda se encontravam abertas, com bordas necrosantes e com indício de processo inflamatório. $\mathrm{O}$ creme usado como controle positivo (Novocort ${ }^{\circledR}$ ) tem como ativos o 
Cetoconazol (20mg), Dipropionato de Betametasona (0,64mg) e Sulfato de Neomicina (2,5mg). Tais ativos em sinergia previnem a contaminação microbiana, porém o fato de ter a Betametasona, um agente glicocorticóide, promove retardo do processo cicatricial, característica comum a essa classe de fármacos quando usada cronicamente (SEVILLA e PÉREZ, 2018), o que explica o retardo do fechamento da ferida da mesma forma que ocorreu nos animais controle - que não tiveram tratamento algum. Evidenciou-se também que ocorreu fechamento parcial das feridas nos animais que receberam a administração do Reiki com o creme (G3), sugerindo que o Reiki estaria promovendo a cicatrização em detrimento do efeito do corticoide.

Figura 03. Análise macroscópica das feridas cutâneas

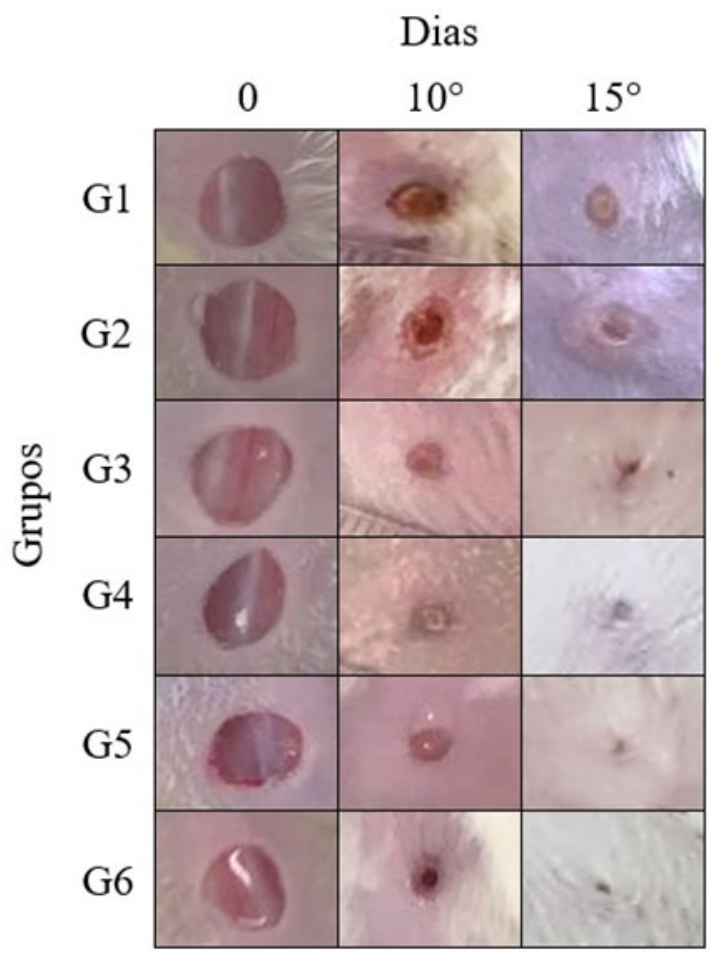

Grupo 1. Naive (animais sem tratamento); Grupo 2. Animais tratados com creme cicatrizante Novacort ${ }^{\circledR}$; Grupo 3. Animais tratados com creme cicatrizante + Reiki por 30 min.; Grupo 4. Animais tratados com Reiki por 10 min.; Grupo 5. Animais tratados com Reiki por 15 min.; Grupo 6. Animais tratados com Reiki por 30 min.

O próximo passo do presente estudo foi a análise histológica do processo de cicatrização. Muitas vezes ocorre o fechamento de uma ferida somente de forma superficial, sem que haja a reorganização das camadas da pele (ZOMER e TRENTIN, 2018). Como já citado, a pele apresenta duas camadas distintas: a epiderme e a derme; a primeira, formada por epitélio estratificado pavimentoso queratinizado e células como os queratinócitos; e a segunda, formada por tecido conjuntivo frouxo e tecido conjuntivo denso não modelado que servem de conexão, sustentação e preenchimento (DE SOUZA et al., 2017). A matriz extracelular da derme possui fibras colágenas e nela são encontradas células como fibroblastos e macrófagos. Essa matriz tem a finalidade de absorver impactos, resistir à tração e oferecer elasticidade durante o processo de cicatrização (DE SOUZA, 2017; NGUYEN e SOULIKA, 2019). Os fibroblastos do tecido conjuntivo são as células responsáveis pela fibroplasia (produção de colágeno) e contribuem para a deposição de matriz extracelular, angiogênese, cicatrização e reepitelização da região da ferida (DE SOUZA, 2017; NGUYEN e SOULIKA, 2019). Após à 
síntese de novos componentes da matriz extracelular, migração e proliferação de fibroblastos, durante a fibroplasia, se inicia o desenvolvimento do tecido de granulação, um tecido especializado indicador do processo de cicatrização. A cicatrização de uma ferida ocorre, portanto, quando a pele possibilita a atividade tensora normal do tecido (GARBUIO et al., 2018).

$\mathrm{Na}$ análise histológica das amostras coradas com Hematoxilina-Eosina (HE), foi observado maior quantidade de fibroblastos no tratamento dos grupos G3 (Reiki por 30 minutos + creme cicatrizante) e G6 (Reiki por 30 minutos), havendo uma diferença estatística de $p<0,001$ quando comparados ao grupo G1 (sem tratamento), ou seja, nesses grupos que foram tratados com a terapia de impostação de mãos a fibroplasia foi mais nítida, bem como os efeitos desse processo, que resultaram em uma pele íntegra e bem estruturada como a figura 4 demonstra. Já o grupo G3, quando comparado ao grupo Controle, obteve diferença estatística de p $<0,05$ e G6 p $<0,01$. No entanto, os grupos G4 e G5 (Reiki por 10 e 15 minutos), não obtiveram diferença estatística quando comparados ao Controle, situação que pode ser justificada por algumas variáveis, como diferença nos campos das fotos, corte histológico irregular e por ter sido a contagem de fibroblastos feita de forma manual.

Figura 04. Quantidade de fibroblastos em cada corte histológico representados em médias seguidas pelos respectivos erros padrão médios
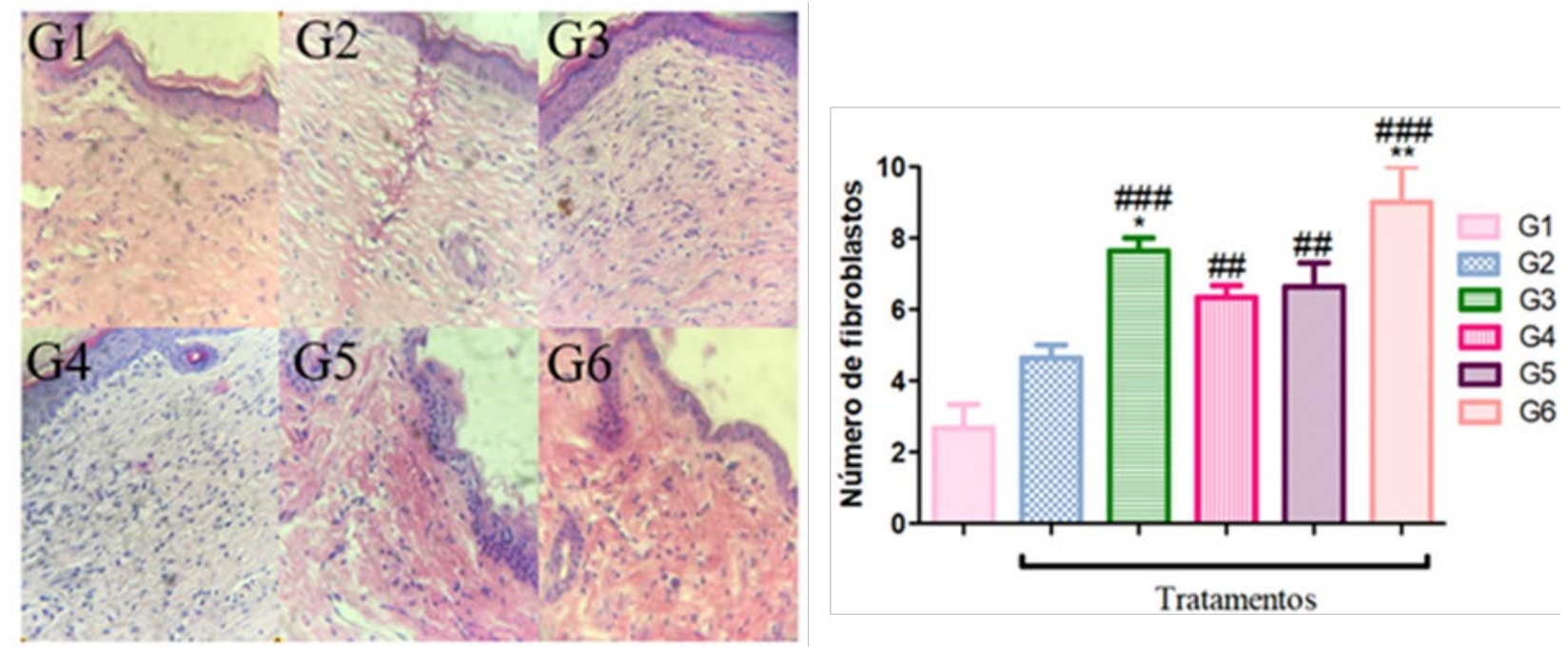

Cortes histológicos dos respectivos grupos experimentais em aumento de 400x - HE, observa-se fibroblastos em coloração basófila. Asteriscos denotam significâncias estatísticas quando comparados ao grupo controle positivo (G2) * $\mathbf{p}<0.05, * * \mathbf{p}<0.01$ e \# denotam significância estatística quando comparado com o controle negativo (G1) $\# \# \mathbf{p}<\mathbf{0 . 0 1}$, \#\#\# $\mathbf{p}<\mathbf{0 . 0 0 1}$.

A análise qualitativa dos fragmentos corados com Picrosirius (figura 05), mostrou uma diferença expressiva na distribuição das fibras colágenas nos grupos G4, G5 e G6, quando comparados ao grupo controle G1, o que também evidencia que ocorreu o processo de fibroplasia de forma expressiva nos grupos que receberam o tratamento de Reiki. No grupo G2 observou-se uma diminuição na distribuição das fibras colágenas, o que possivelmente está relacionado ao tratamento com o creme contendo corticoide na sua composição, que sabidamente inibe a produção de colágeno pelos fibroblastos (SEVILLA e PÉREZ, 2018). 
Figura 05. Cortes histológicos dos respectivos grupos experimentais, na coloração Picrosirius

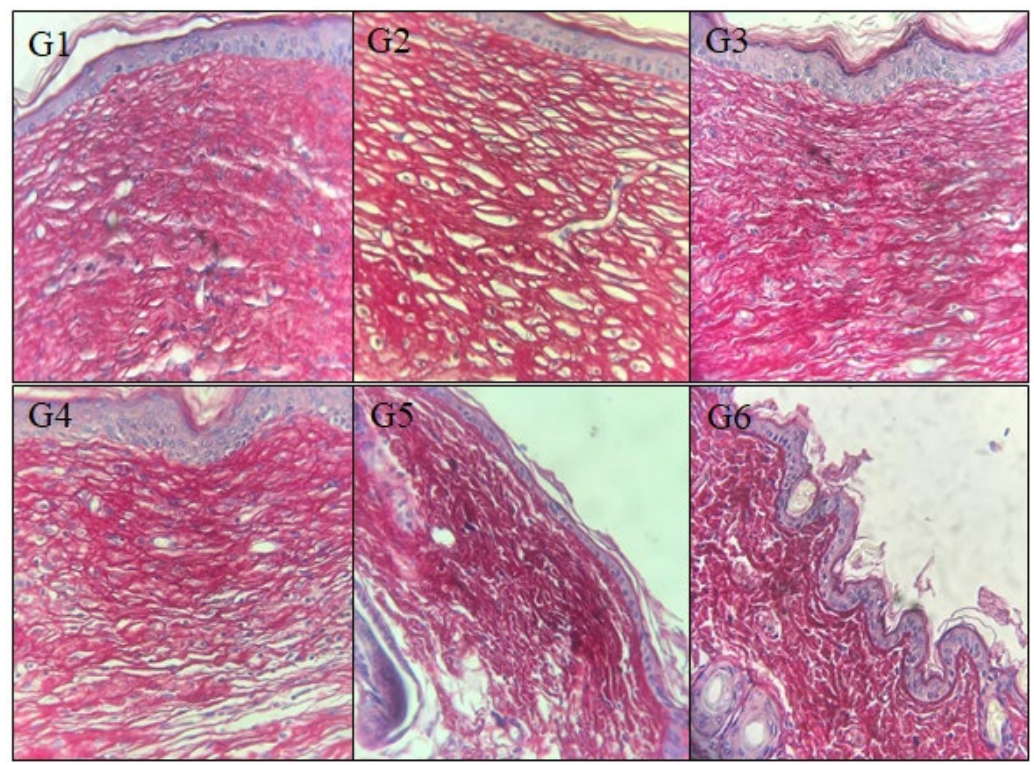

Grupo 1. Naive (animais sem tratamento); Grupo 2. Animais tratados com creme cicatrizante Novacort ${ }^{\circledR}$; Grupo 3. Animais tratados com creme cicatrizante + Reiki por 30 min.; Grupo 4. Animais tratados com Reiki por 10 min.; Grupo 5. Animais tratados com Reiki por 15 min.; Grupo 6. Animais tratados com Reiki por 30 min. G2, G3, G4, G5 e G6 possuem coloração mais intensa que G1. Aumento de 400x.

Os resultados em conjunto evidenciaram que o Reiki exibe a propriedade cicatrizante e poderia ser uma opção a mais de tratamento. Segundo Say et al. (2019), é crescente o interesse em se descobrir e desenvolver meios de tratamento para as úlceras crônicas uma vez que, são responsáveis por um alto índice de morbidade e mortalidade, além de gerarem altos custos econômicos decorrentes dos cuidados com curativos, internações e situações de difícil manejo, tanto para os indivíduos acometidos quanto para seus familiares. O uso da técnica do Reiki se mostrou vantajoso, dado que é uma ferramenta de fácil acesso ao público e de baixo custo (PARRAGA, 2016). No entanto, os efeitos terapêuticos dessa prática ainda não são compreendidos completamente, e somente evidências científicas mínimas na literatura demonstram a sua eficácia e sua contribuição ao cuidado pessoal, bem-estar e qualidade de vida (VIEIRA, 2017). Além de haver poucas pesquisas na literatura confirmando os benefícios do Reiki a saúde, as existentes são mais voltadas para dor, diminuição da ansiedade e estresse, deixando uma lacuna para questões cicatriciais, mostrando a importância dos resultados obtidos no presente estudo.

Os benefícios do Reiki como terapia complementar, foram demonstrados por Freitag, De Andrade \& Badke (2015), analisando cerca de 398 artigos científicos. Os autores revelam que o Reiki provoca mudanças significativas no indivíduo, principalmente em relação à ansiedade, dores, estresse, aumento das células de defesa e diminuição dos níveis pressóricos, seja a técnica usada isoladamente ou junto com o tratamento farmacológico. Um dos efeitos do Reiki pode ser atribuído ao Placebo. Entretanto, McManus (2017) deixa claro que o Reiki é melhor que o placebo e possui vasto potencial como terapia complementar, bem como os resultados demonstrados no presente estudo. Outras pesquisas também corroboram com os resultados obtidos nesse trabalho por exemplo, De Souza et al. (2017), tiveram como objetivo investigar o efeito do toque terapêutico na contração da área das feridas dorsais e na proliferação de fibroblastos na pele de 24 ratos Wistar machos, concluindo que o 
toque terapêutico pode acelerar o reparo da ferida, possivelmente aumentando a atividade dos fibroblastos. Dessa forma, a técnica de impostação das mãos Reiki pode ser outra ferramenta para auxiliar na cicatrização de úlceras cutâneas, pois os efeitos terapêuticos mostram muitos benefícios por se tratar de uma terapia integrativa menos invasiva e não possuir efeitos colaterais, além de ser acessível a maior número de pessoas. Diante disso, o presente trabalho confirmou os dados da literatura sobre a influência do Reiki sobre o processo cicatricial, evidenciando que não houve efeito placebo e que ocorreu a recuperação da integridade e funcionalidade da pele dos camundongos.

\section{CONCLUSÃO}

Os resultados do presente estudo permitem concluir que a técnica do Reiki apresentou um efeito significativo na cicatrização das úlceras cutâneas de camundongos, tanto no aspecto macroscópico quanto histologicamente. Observou-se o fechamento macroscópico das feridas de forma mais rápida nos grupos de animais tratados com Reiki, comparado ao grupo que foi tratado somente com o fármaco padrão e Naive. Além disso, através das análises histológicas, foi visualizada uma superior migração de fibroblastos nos animais tratados com Reiki.

\section{AGRADECIMENTOS}

As autoras agradecem aos professores e colegas que ajudaram a tornar esse trabalho uma realidade. Um agradecimento especial a Enfermeira Cleonice Correa (Mestre em Reiki) pela disponibilidade de participar da pesquisa através da aplicação do Reiki nos animais.

\section{REFERÊNCIAS}

BILLOT, M.; DAYCARD, M.; WOOD, C.; TCHALLA, A.B.M.J. Reiki therapy for pain, anxiety and quality of life. BMJ Supportive \& Palliative Care, v. 9, n. 4, p. 434-438, 2019.

DE SOUZA, A.L.T.; ROSA, D.P.C.; BLANCO, B.A.; PASSAGLIA, P.; STABILE, A.M.; Effects of Therapeutic Touch on Healing of the Skin in Rats. Explore, v. 13, n. 5, p. 333-338, 2017.

DE SOUZA, G.G; ZAGO, N.N.; PINHEIRO, N.M.; MENDONÇA, A.C. Impacto da utilização de recursos fisioterapêuticos no tratamento de úlceras cutâneas de diferentes etiologias. ConScientiae Saúde, v. 16, n. 1, p. 17-25, 2017.

DOĞAN, M.T. The effect of reiki on pain: A meta-analysis. Complementary therapies in clinical practice, v. 31, p. 384-387, 2018.

FREITAG, V.L; DE ANDRADE, A.; BADKE, M.R. O Reiki como forma terapêutica no cuidado à saúde: uma revisão narrativa da literatura. Enfermería Global, v. 14, n. 2, p. 335-356, 2015. 
GARBUIO, D.C; ZAMARIOLI, C.M.; DA SILVA, N.C.M; DE SOUZA OLIVEIRA-KUMAKURA, A.R.; CARVALHO, E.C. Instrumentos para avaliação da cicatrização de lesões de pele: revisão integrativa. Revista Eletrônica de Enfermagem, v. 20, 2018.

JOYCE, J.L.; HERBISON, G.P. Reiki for depression and anxiety. Cochrane Database of Systematic Reviews, n. 4, 2015.

IBA, Y.; SHIBATA, A.; KATO, M.; MASUKAWA, T. Possible involvement of mast cells in collagen remodeling in the late phase of cutaneous wound healing in mice. International immunopharmacology, v. 4, n. 14, p. 1873-1880, 2004.

KUREBAYASHI, L.F.S; TURRINI, R.N.T; SOUZA, T.P.B.D.; TAKIGUCHI, R.S.; KUBA, G.; NAGUMO, M.T. Massagem e Reiki para redução de estresse e ansiedade: Ensaio Clínico Randomizado. Revista Latino-Americana de Enfermagem, v. 24, p. 1-8, 2016.

IACOROSSI, L.; DI RIDOLFI, P.; BIGIARINI, L.; GIANNARELLI, D.; SANGUINETI, G. The impact of Reiki on side effects in patients with head-neck neoplasia undergoing radiotherapy: a pilot study. Professioni infermieristiche, v. 70, n. 3, p. 214-221, 2017.

MASSON-MEYERS, D.S; ANDRADE, T.A.M.; CAETANO, G.F.; GUIMARAES, F.R.; LEITE, M.N.; LEITE, S.N.; FRADE, M.A.C. Experimental models and methods for cutaneous wound healing assessment. International Journal of Experimental Pathology, 2020.

MCMANUS, D.E. Reiki is better than placebo and has broad potential as a complementary health therapy. Journal of evidence-based complementary \& alternative medicine, v. 22, n. 4, p. 1051-1057, 2017.

MICK, W.H. Gendai Reiki Sem Mitos: origens, o que é o que não é Reiki. Curitiba: Copygraf, Gráfica e Editora Ltda, 2016, cap.1, 112p.

NGUYEN, A.V; SOULIKA, A.M. The Dynamics of the Skin's Immune System. International journal of molecular sciences, v. 20, n. 8, p. 1811, 2019.

NOVAK, V.C; CAMARGO, D.S.; QUARTIERO, C.R.B.; CARRASCO, A.C. Perfil epidemiológico e qualidade de vida de indivíduos com úlceras crônicas. In: Anais do Congresso Brasileiro da Associação Brasileira de Fisioterapia Traumato-Ortopédica-ABRAFITO. 2019.

PARRAGA, J.M. Análise dos efeitos do Reiki como intervenção na atenção à saúde do idoso: uma revisão sistemática. Porto Alegre, 2017. 45 p. Monografia (Bacharelado em Enfermagem), Universidade Federal do Rio Grande do Sul.

SÁNCHEZ-CRUZ, L.; MARTÍNEZ-VILLARREAL, A.; LOZANO-PLATONOFF, A.; CÁRDENAS-SÁNCHEZ, A.; CONTRERAS-RUIZ, J. Epidemiología de las úlceras cutáneas en Latinoamérica. Med. Cutan. Iber. Lat. Am., v. 44, n. 3, p. 183-97, 2016.

SAY, K.G. O tratamento fisioterapêutico de úlceras cutâneas venosas crônicas através da laserterapia com dois comprimentos de onda. Fisioterapia Brasil, v. 4, n. 1, p. 40-49, 2009.

SEVILLA, L.M.; PÉREZ, P. Roles of the Glucocorticoid and Mineralocorticoid Receptors in Skin Pathophysiology. International journal of molecular sciences, v. 19, n. 7, p. 1906, 2018.

SPEZZIA, S.; SPEZZIA, S. O uso do Reiki na assistência à saúde e no Sistema Único de Saúde. Revista de Saúde Pública do Paraná, v. 1, n. 1, p. 108-115, 2018.

SZWED, D.N.; DOS SANTOS, V.L.P. Fatores de crescimento envolvidos na cicatrização de pele. Cadernos da Escola de Saúde, v. 1, n. 15, 2016.

TOPDEMIR, E.A; SARITAS, S. The effect of preoperative Reiki application on patient anxiety levels. Explore, n. 20, p. 40-9, 2020. 
TRIVELLATO-GRASSI, L.; MALHEIROS, A.; MEYRE-SILVA, C.; BUSS, Z.D.A.S.; MONGUILHOTT, E.D.; FRODE, T.S.; DA SILVA, K.A.; DE SOUZA, M.M. From popular use to pharmacological validation: a study of the anti-inflammatory, anti-nociceptive and healing effects of Chenopodium ambrosioides extract. Journal of Ethnopharmacology, v. 145, n. 1, p. 127-138, 2013.

TRIVELLATO, M.L.D.M.; KOLCHRAIBER. F.C.; FREDERICO, G.A.; MORALES, D.C.A.M.; SILVA, A. C.M.; GAMBA, M.A. Práticas avançadas no cuidado integral de enfermagem a pessoas com úlceras cutâneas. Acta Paulista de Enfermagem, v. 31, n. 6, p. 600-608, 2018.

VIEIRA, T.C. O Reiki nas práticas de cuidado de profissionais do Sistema Único de Saúde. Florianópolis, 2017. 119p. Dissertação (Mestrado em Saúde Coletiva), Universidade Federal de Santa Catarina.

WONG, R.; GEYER, S.; WENINGER, W.; GUIMBERTEAU, J.C.; WONG, J.K. The dynamic anatomy and patterning of skin. Experimental dermatology, v. 25, n. 2, p. 92-98, 2016.

ZOMER, H.D; TRENTIN, A.G. Skin wound healing in humans and mice: Challenges in translational research. Journal of dermatological science, v. 90, n. 1, p. 3-12, 2018. 
PAULO DE ALVARENGA CORDEIRO

TERRA

Universidade Federal Fluminense

KEREN VIEIRA DE ALCÂNTARA

Universidade Federal Fluminense

DOUGLAS GUEDES FERREIRA

Universidade Federal Fluminense

NATÁLIA ARRUDA COSTA CAMACHO

REBELLO

Universidade Federal Fluminense

CLÁUDIA REZENDE VIEIRA DE

MENDONÇA-SOUZA

Universidade Federal Fluminense

THIAGO PAVONI GOMES CHAGAS

Universidade Federal Fluminense

RESUMO: Enterobacterales resistentes aos carbapenemas são importantes causas de infecções relacionadas à assistência à saúde. Tais microrganismos foram considerados patógenos prioritários pela OMS para a pesquisa e o desenvolvimento de novos antimicrobianos. O objetivo do estudo foi investigar a produção de carbapenemases entre isolados de Enterobacterales resistentes aos carbapenemas oriundos de pacientes internados em um hospital universitário. Um total de 22 isolados clínicos de Enterobacterales resistentes aos carbapenemas foram incluídos no trabalho. A identificação bacteriana e a suscetibilidade aos antimicrobianos foram determinadas pelo sistema automatizado Phoenix BD ${ }^{\mathrm{TM}}$ (BD Diagnostic Systems, Sparks, MD). MALDI-TOF
MS (do inglês, Matrix-Assisted Laser Desorption/ Ionization-Time of Flight Mass Spectrometry) foi aplicado para a confirmação da identificação bacteriana. A determinação da CIM (Concentração Inibitória Mínima) frente à poli-

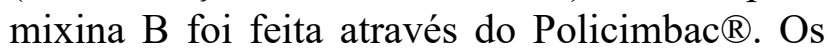
isolados foram submetidos a métodos fenotípicos para detecção da produção de carbapenemase. A reação em cadeia da polimerase foi usada para detectar os genes $b l a_{\mathrm{KPC}}, b l a_{\mathrm{NDM}}$ e $b l a_{\mathrm{OXA}-48-\mathrm{like}}$. A espécie bacteriana mais frequente foi Klebsiella pneumoniae $(63,7 \%)$. A produção fenotípica de carbapenemases foi observada em 63,6\% (14/22) dos isolados. Foi observado que $92,9 \%$ dos isolados produtores de carbapenemase tinham o gene $b l a_{\mathrm{KPC}}$. Nenhum dos isolados apresentou o gene bla ${ }_{\text {OXA-48-like }}$ O único isolado de $K$. pneumoniae produtor de NDM apresentou resistência à polimixina $\mathrm{B}(\mathrm{MIC}=16 \mu \mathrm{g} / \mathrm{mL})$. O reconhecimento imediato desses isolados resistentes aos carbapenemas é importante para o estabelecimento de medidas terapêuticas e medidas de controle de infecção adequadas para reduzir a disseminação destes microrganismos no ambiente hospitalar.

Palavras-chave: resistência aos antimicrobianos, beta-lactâmicos, Enterobacterales, carbapenemases.

ABSTRACT: Carbapenem-resistant Enterobacterales remain important causes of hospital-acquired infections and are prioritized for research and development of new antibiotics by the WHO.This study aimed to detect carbapenemase-producing Enterobacterales clinical isolates recovered from patients admitted to a teaching hospital. A total of 22 carbapenem-resistant Enterobacterales clinical isolates were included. 
Bacterial identification and the antimicrobial susceptibility were determined by automated system Phoenix BD TM (BD Diagnostic Systems, Sparks, MD). MALDI-TOF MS (Matrix-Assisted Laser Desorption/Ionization-Time of Flight Mass Spectrometry) was applied for the final species identification. MIC (Minimum Inhibitory Concentration) values for polymyxin B were determined by the commercial Policimbac ${ }^{\circledR}$ system. The isolates were submitted to phenotypic methods for the detection of carbapenemase production. Polymerase chain reaction (PCR) was used to detect genes encoding carbapenemases $\left(b l a_{\mathrm{KPC}}, b l a_{\mathrm{NDM}}\right.$ and $\left.b l a_{\mathrm{OXA}-48 \text {-like }}\right)$. Klebsiella pneumoniae was the most frequent bacterial species isolated $(63,7 \%)$. The production of carbapenemases was observed in $63,6 \%$ $(14 / 22)$ of the isolates. It was found that $92,9 \%$ of the carbapenemase-producing isolates had the $b l a_{\mathrm{K}-}$ PC gene None of the isolates presented the $b l a_{\text {OXA-48-like }}$ gene. By MIC results, a NDM-producing $K$. pneumoniae isolate displayed resistance to polymyxin $\mathrm{B}(\mathrm{MIC}=16 \mu \mathrm{g} / \mathrm{mL})$. The early recognition of these carbapenem-resistant isolates is important for establishment of therapeutic and infection control measures to reduce the bacterial spread within hospital environments.

Keywords: antimicrobial resistance, beta-lactams, Enterobacterales, carbapenemases.

\section{INTRODUÇÃO}

Em 2019, a resistência antimicrobiana passou a ser considerada uma das dez principais ameaças à saúde global de acordo com a Organização Mundial da Saúde (ORGANIZAÇÃO MUNDIAL DA SAÚDE, 2019). Entre os patógenos multirresistentes prioritários para a pesquisa e o desenvolvimento de novos antimicrobianos, encontram-se as Enterobacterales resistentes aos carbapenemas e/ ou as produtoras de beta-lactamases de espectro estendido (do inglês, Extended-Spectrum Beta-Lactamase, ESBL) (WILLYARD, 2017).

A ordem Enterobacterales é formada por sete famílias, incluindo a família Enterobacteriace$a e$, (ADEOLU et al, 2016) constituída por bacilos Gram-negativos fermentadores de glicose, anaeróbios facultativos, oxidase-negativa, catalase- positiva, com capacidade de reduzir nitrato a nitrito e imóveis ou móveis. Quanto à distribuição, são encontrados amplamente na natureza e muitas espécies fazem parte da microbiota dos seres humanos e demais animais, onde podem permanecer como microrganismos comensais ou causar doenças (OCTAVIA et al., 2014). São consideráveis patógenos oportunistas, e além das infecções comunitárias, podem estar associados às infecções relacionadas à assistência à saúde (IRAS). Entre os principais gêneros e espécies de importância médica, estão Klebsiella spp., Escherichia coli, Enterobacter spp., Serratia marcescens, entre outras (EXNER et al., 2017).

Para o tratamento dessas infecções causadas por Enterobacterales, antibióticos beta-lactâmicos, que incluem as cefalosporinas e os carbapenemas, são considerados as opções de primeira linha (DE OLIVEIRA et al., 2020). Os carbapenemas, entre os beta-lactâmicos, apresentam um amplo espectro de atividade antibacteriana; e como são altamente eficazes contra muitas espécies bacterianas e apresentam poucos eventos adversos são considerados o último recurso de tratamento para infecções bacterianas graves (MELETIS, 2016). No entanto, a eficácia desse tratamento vem sendo comprometida pelo aumento e pela disseminação da resistência aos beta-lactâmicos, especialmente aos carbapenemas (DE OLIVEIRA et al., 2020). Uma vez que a resistência aos carbapenemas está, 
muitas vezes, associada à multirresistência, restam poucas opções terapêuticas viáveis (MARRA et al., 2011). Assim, as infecções causadas por Enterobacterales resistentes aos carbapenemas têm sido associadas a altas taxas de mortalidade (KAYE, POGUE, 2015; PORRECA et al., 2018; TAMMA, SIMNER, 2018).

A resistência aos carbapenemas ocorre, principalmente, devido à produção de enzimas beta-lactamases do tipo carbapenemases (CODJOE, DONKOR, 2018; LASKO, NICOLAU, 2020). A resistência mediada por essas carbapenemases é considerada clinicamente muito importante, porque essas enzimas hidrolisam todos ou quase todos os beta-lactâmicos, conferem altos níveis de concentrações inibitórias mínimas frente aos carbapenemas e são codificadas por genes que estão, muitas vezes, associados a elementos genéticos móveis (tais como plasmídeos e/ou transposons) (MELETIS, 2016).

As carbapenemases estão distribuídas nas classes moleculares A (serino-carbapenemases), B (Metalo-beta-lactamase - MBL) e D (oxacilinases) (WALSH, 2010; NORDMANN, POIREL, 2014). As carbapenemases de classe A (como, por exemplo, a Klebsiella pneumoniae carbapenemase - KPC, e Guiana beta-lactamase de espectro estendido - GES), têm como características: a presença de um resíduo de serina em seus sítios ativos e são inibidas pelo ácido clavulânico ou ácido borônico. As carbapenemases de classe B, também conhecidas como metalo-beta-lactamases (como, por exemplo, Metalo-beta-lactamase de Nova Deli - NDM, Verona Integron metalo-beta-lactamase - VIM e Imipenemase metalo-beta-lactamase- IMP) requererem íons de zinco para sua atividade enzimática, hidrolisam todos os beta-lactâmicos (exceto aztreonam) e são inibidas por agentes quelantes, tais como o ácido etilenodiaminotetracético (EDTA). No caso das carbapenemases de classe D, as oxacilinases, incluem enzimas semelhantes a OXA-48-like, que hidrolisam beta-lactâmicos de espectro estreito e carbapenemas fracamente e não são inibidas pelos inibidores clássicos (NORDMANN, DORTET, POIREL, 2012; BONOMO et al, 2018; TOUATI,MAIRI, 2019). Entre as várias carbapenemases descritas, as que têm sido mais associadas às Enterobacterales resistentes aos carbapenemas são as do tipo KPC, NDM e OXA-48-like.

Com isso, o objetivo deste trabalho foi detectar fenotipicamente e genotipicamente a produção de carbapenemases entre amostras de Enterobacterales resistentes aos carbapenemas oriundas de pacientes atendidos em um hospital universitário da região metropolitana do Rio de Janeiro.

\section{METODOLOGIA}

\section{Coleta e identificação das amostras bacterianas}

Foram incluídas 22 amostras bacterianas com perfil de resistência aos carbapenemas, coletadas entre agosto de 2018 e abril de 2019, provenientes da rotina de um Laboratório de Microbiologia do Serviço de Patologia Clínica de um hospital universitário no Rio de Janeiro. As amostras, isoladas a partir 21 pacientes atendidos, foram obtidas a partir dos seguintes materiais clínicos: urina $(\mathrm{n}=10)$, 
sangue $(n=5)$, secreção de ferida $(n=3)$, liquor $(n=2)$ lavado broncoalveolar $(n=1)$ e aspirado traqueal $(\mathrm{n}=1)$.

A identificação prévia das amostras bacterianas e o perfil de sensibilidade aos antimicrobianos foram obtidos através do sistema automatizado Phoenix BD ${ }^{\mathrm{TM}}$ (BD Diagnostic Systems, Sparks, MD). As amostras bacterianas foram submetidas à Espectrometria de Massa com Ionização por Dessorção a Laser Assistida por Matriz e analisador de Tempo de Voo (do inglês, Matrix-Assisted Laser Desorption/Ionization-Time of Flight Mass Spectrometry - MALDI-TOF MS), utilizando a plataforma MALDI Biotyper (Bruker Daltonics, Alemanha), para confirmação da identificação das espécies.

\section{Deteç̧ão fenotípica da resistência à polimixina}

A determinação da CIM (Concentração Inibitória Mínima) da polimixina B foi feita através do sistema Policimbac ${ }^{\circledR}$ (Probac do Brasil, São Paulo, SP), de acordo com as recomendações do fabricante.

\section{Testes Fenotípicos para detecção da produção de carbapenemases}

As amostras foram submetidas ao Método de Inativação do Carbapenema Modificado (MICm) para detecção fenotípica da produção de carbapenemase. Adicionalmente, também foram submetidas ao Método de Inativação do Carbapenema com EDTA (MICe), para classificação da carbapenemase em serino-beta-lactamase ou metalo-beta-lactamase (MBL). Os procedimentos dos testes, bem como a leitura e interpretação dos mesmos foram realizados de acordo com as recomendações do Clinical and Laboratory Standards Institute (CLSI, 2018).

\section{Detecção dos determinantes genéticos de resistência}

Para essa detecção, a extração do DNA bacteriano foi realizada através de lise mecânica. As amostras foram plaqueadas em ágar Triptona de Soja (TSA) e incubadas a $35^{\circ} \mathrm{C}$ por $18-24 \mathrm{~h}$. Destas, foi retirada uma colônia com uma alça bacteriológica e transferida para tubos contendo $500 \mu \mathrm{L}$ de água ultrapurificada. As suspensões foram homogeneizadas e submetidas à sonicação, em cuba de ultrassom, três vezes por 30 segundos com um intervalo de 10 segundos entre cada ciclo de tempo. Cada suspensão foi, então, submetida à centrifugação (13000 x g por 1 minuto) e armazenada a $-20^{\circ} \mathrm{C}$ até sua utilização.

Todas as amostras foram submetidas a reações de PCR multiplex para a detecção dos genes codificadores de carbapenemases $b l a_{\mathrm{KPC}}, b l a_{\mathrm{NDM}}$ e bla $a_{\mathrm{OXA}-48 \text {-like }}$ (MONTEIRO et al., 2012). Cada reação foi preparada contendo $2 \mu \mathrm{L}$ de DNA bacteriano extraído, 7,5 $\mu \mathrm{L}$ de água água ultrapurificada, $0,5 \mu \mathrm{L}$ (20 pmoles) de cada primer para os genes-alvo e 12,5 $\mu$ de PCR MasterMix (contendo Tris e KCl,

pH 8,4, 1,7 mM de $\mathrm{MgCl} 2,0,2 \mathrm{mM}$ dNTP mix e 2,5 Ude $\mathrm{MgCl}$ 2, 0,2 mM dNTP mix e 2,5 U de Taq Polimerase), totalizando um volume final de $25 \mu \mathrm{L}$. As condições de amplificação foram: (i) um ciclo 
de desnaturação inicial a $94^{\circ} \mathrm{C}$ por 5 minutos; (ii) 30 ciclos de desnaturação $\left(94^{\circ} \mathrm{C}\right.$ por 1 minuto), anelamento $\left(50^{\circ} \mathrm{C}\right.$ por 1 minuto) e extensão $\left(72^{\circ} \mathrm{C}\right.$ por 1 minuto); (iii) e um ciclo de extensão final a $72^{\circ} \mathrm{C}$ por 5 minutos. A amplificação do DNA foi visualizada através de eletroforese em gel de agarose a 1,5\% em TBE 0,4X. Após a corrida eletroforética, o gel foi corado com brometo de etídio $(0,5 \mathrm{~g} / \mathrm{L})$.

\section{Considerações Éticas}

O presente trabalho foi aprovado pelo Comitê de Ética em Pesquisa, da Faculdade de Medicina, da Universidade Federal Fluminense, sob o parecer número 2.920.186, CAAE 95984018.6.0000.5243.

\section{RESULTADOS}

Do total de amostras investigadas, K. pneumoniae foi a espécie mais frequente $(63,7 \% ; \mathrm{n}=14)$, seguida por $E$. coli $(13,6 \% \mathrm{n}=3)$ e $S$. marcescens $(13,6 \%, \mathrm{n}=3)$. Amostras do Complexo Enterobacter cloacae também foram identificadas (Tabela 1). Cabe ressaltar que a distribuição de acordo com o espécime clínico, das 14 amostras de K. pneumoniae foi a seguinte: urina ( $\mathrm{n}=6)$, sangue $(\mathrm{n}=3)$, secreção de ferida $(n=2)$, liquor $(n=2)$ e aspirado traqueal $(n=1)$.

Com relação ao perfil de sensibilidade aos antimicrobianos, as taxas de resistência aos carbapenemas testados imipenem, ertapenem e meropenem foram 95,5\%, 90,9\% e 86,4\% respectivamente (Tabela 2). Todas as amostras foram sensíveis à polimixina $\mathrm{B}$ exceto uma, identificada como K. pneumoniae, que apresentou resistência, com a $\mathrm{CIM}=16 \mu \mathrm{g} / \mathrm{mL}$.

Tabela 1 - Identificação e espécime clínico das 22 amostras.

\begin{tabular}{lcc}
\hline & $\mathrm{n}$ & $\%$ \\
\hline Identificação bacteriana & & \\
Klebsiella pneumoniae & 14 & 63,7 \\
Escherichia coli & 3 & 13,6 \\
Serratia marcescens & 3 & 13,6 \\
Complexo Enterobacter cloacae & 2 & 9,1 \\
Espécime clínico & & \\
Urina & 10 & 45,5 \\
Sangue & 5 & 22,7 \\
Secreção de ferida & 3 & 13,6 \\
Líquor & 2 & 9,1 \\
Lavado broncoalveolar & 1 & 4,5 \\
Aspirado traqueal & 1 & 4,5 \\
\hline
\end{tabular}


Tabela 2 - Perfis de suscetibilidade aos antimicrobianos das 22 amostras.

Perfis de Suscetibilidade

Antimicrobiano

Sensível n (\%) Intermediário n (\%) Resistente n (\%)

Imipenem $0(0 \%)$

$1(4,5 \%)$

$21(95,5 \%)$

Ertapenem

$2(9,1 \%)$

$0(0 \%)$

$20(90,9 \%)$

Meropenem

$3(13,6 \%)$

$0(0 \%)$

$19(86,4 \%)$

Ceftazidima

$4(18,2 \%)$

$0(0 \%)$

$18(81,8 \%)$

Ceftriaxona

$4(18,2 \%)$

$0(0 \%)$

$18(81,8 \%)$

Cefepima

$5(22,7 \%)$

$0(0 \%)$

$17(77,3 \%)$

Piperacilina/Tazobactam

$5(22,7 \%)$

$0(0 \%)$

$17(77,3 \%)$

Ciprofloxacina

$5(22,7 \%)$

$0(0 \%)$

$17(77,3 \%)$

Sulfametoxazol-trimetoprima

$6(27,3 \%)$

$0(0 \%)$

$16(72,7 \%)$

Gentamicina

$18(81,8 \%)$

$0(0 \%)$

$4(18,2 \%)$

Amicacina

$20(90,9 \%)$

$0(0 \%)$

$2(9,1 \%)$

Entre as 22 amostras bacterianas submetidas aos testes fenotípicos $\mathrm{MICm} / \mathrm{MICe}, 63,6 \%$ $(14 / 22)$ apresentaram resultado positivo, das quais, 13 (92,9\%) foram caracterizadas como produtoras de serino-carbapenemases e uma $(7,1 \%)$, como produtora de metalo-carbapenemase.

Com relação aos testes moleculares, entre os determinantes genéticos investigados, o gene bla $_{\mathrm{KPC}}$ foi o mais frequente $(13 / 14 ; 92,9 \%)$. Enquanto o gene bla $a_{\mathrm{NDM}}$ foi encontrado em uma única amostra de $K$. pneumoniae, que fenotipicamente também foi caracterizada como produtora de metalo-beta-lactamase. O gene bla ${ }_{\text {OXA-48-like }}$ e a co-associação dos genes não foram encontrados em nenhuma amostra estudada. Comparando-se os resultados dos testes moleculares com os dos testes fenotípicos, verificou-se a concordância de $100 \%$ dos resultados (Tabela 3).

Tabela 3 - Resultado dos testes fenotípicos e moleculares das 22 amostras de Enterobacterales resistentes aos carbapenemas.

\begin{tabular}{lcccc}
\hline Resultado dos Testes & \multicolumn{3}{c}{ Resultado dos testes moleculares } \\
\cline { 2 - 4 } fenotípicos & $b l a_{\mathrm{KPC}} \mathrm{n}(\%)$ & $b l a_{\mathrm{NDM}} \mathrm{n}(\%)$ & $b l a_{\text {OXA-48-like }} \mathrm{n}(\%)$ & Negativo \\
CIMm/CIMe & $13(100 \%)$ & $0(0 \%)$ & $0(0 \%)$ & $0(0 \%)$ \\
Positivo Serino, $\mathrm{n}=13$ & $0(0 \%)$ & $1(100 \%)$ & $(0 \%)$ & $0(0 \%)$ \\
Positivo Metalo, $\mathrm{n}=1$ & $0(0 \%)$ & $0(\%)$ & $0(0 \%)$ & $8(100 \%)$ \\
Negativo, $\mathrm{n}=8$ & &
\end{tabular}


Com relação à distribuição das espécies e os resultados da detecção de carbapenemases, apenas as amostras de K. pneumoniae (14/26) foram identificadas como produtoras de carbapenemases. No caso dos isolados das demais espécies, apesar de resistentes aos carbapenemas, não foi detectada a produção das enzimas do tipo carbapenemases.

\section{DISCUSSÃO}

Enterobacterales resistentes aos carbapenemas se estabelecem como um grande desafio para o tratamento, controle e prevenção das IRAS. Neste trabalho, avaliamos 22 amostras bacterianas, com perfil de resistência a pelo menos um carbapenema, quanto à produção de carbapenemases, a partir de amostras clínicas de pacientes atendidos em um hospital universitário. Com relação à identificação das espécies bacterianas, K. pneumoniae foi a mais frequente (14/22), isolada principalmente a partir da urina, seguida de sangue, secreção de ferida e líquor. No estudo de, K. pneumoniae também foi a espécie mais frequente, principalmente, nas infecções de corrente sanguínea e infecção do trato urinário (ALVIM, COUTO, GAZZINELLI, 2019). Essa espécie bacteriana já foi descrita como uma das principais causas de IRAS nos Estados Unidos, sendo a segunda principal causa de infecções da corrente sanguínea. Nesse caso das infecções sanguíneas, a taxa de mortalidade pode ultrapassar 20\% (PODSCHUN E ULLMANN, 1998; MEATHERALL et al., 2009, MARTIN, BACHMAN, 2018). De acordo com Podschun e Ullmann (1998), o trato urinário é o local mais comum de infecção por K. pneumoniae. No estudo de Rodrigues e Barroso (2011), K. pneumoniae foi a segunda espécie mais prevalente nas infecções do trato urinário, tendo constituído $11 \%$ das infecções identificadas em uma unidade de saúde de Portugal. K. pneumoniae também é responsável por infecções de feridas e/ ou sítios cirúrgicos, representando em torno de $13 \%$ de todas as infecções causadas por Klebsiella (PODSCHUN, ULLMANN, 1998; MAGILL et al., 2014, MARTIN, BACHMAN, 2018).

No Brasil, segundo dados do Boletim Segurança do Paciente e Qualidade em Serviços de Saúde $\mathrm{n}^{\mathrm{o}} 21$ da ANVISA, K. pneumoniae resistentes aos carbepenemas e cefalosprinas de $3^{\circ}$ e $4^{\circ}$ geração foram responsáveis por $44,1 \%$ das infecções primárias de corrente sanguínea em UTI adultos no país. No caso das infecções do trato urinário associados ao cateter vesical de demora, a taxa foi de 42\% (AGÊNCIA NACIONAL DE VIGILÂNCIA SANITÁRIA, 2020). No presente trabalho, esse fenótipo de resistência aos carbepenemas e às cefalosprinas de $3^{\circ}$ e $4^{\circ}$ geração foi observado entre as amostras de K. pneumoniae. Como todas as amostras foram caracterizadas como produtoras de carbapenamases, isso já era esperado, uma vez que as carbapenemases, com algumas exceções, tornam aos beta-lactâmicos, incluindo as cefalosporinas e carbapenemas, inativos (DOI, PATERSON, 2015).

Como apresentado, 63,6\% das amostras resistentes aos carbapenemas foram caracterizadas como produtoras de carbapenemases. Dados da literatura já apontam que a resistência aos carbapenemas em bacilos Gram-negativos, geralmente, é resultante da produção de carbapenemases ou produção de cefalosporinases combinadas com alterações na permeabilidade da parede celular bacteriana (QUEENAN, BUSH, 2007; BONOMO et al., 2018). Para aquelas amostras caracterizadas como não produtoras de carbapenemases, outros mecanismos, que merecem ser investigados em trabalhos 
futuros, podem estar relacionados, tais como perda de expressão de genes que codificam porinas, mutações nos genes cromossomais das porinas e/ou hiperexpressão dos sistemas de efluxo (NORDMANN, POIREL, 2019).

A presença do gene $b l a_{\mathrm{KPC}}$ foi detectada em 92,9\% das amostras produtoras de carbapenemases. Considerada a carbapenemase de classe A de maior importância devido a sua hidrólise mais eficiente dos antibióticos beta-lactâmicos (QUEENAN, BUSH, 2007), a carbapenemase codificada pelo gene $b l a_{\mathrm{KPC}}$ foi descrita pela primeira vez em 2000, a partir de uma amostra de K. pneumoniae datada de 1996, na Carolina do Norte, Estados Unidos (YIGIT et al., 2001). Desde então, essas enzimas se espalharam por diferentes países dos diferentes continentes (MUNOZ-PRICE et al., 2013), incluindo o Brasil (PEREIRA et al., 2013; TAVARES et al., 2015). Embora, neste trabalho, o gene bla $a_{\mathrm{KPC}}$ tenha sido detectado apenas nas amostras de $K$. pneumoniae, o mesmo tem sido detectado em outras espécies de Enterobacterales (TAVARES et al., 2015).

Amostras bacterianas produtoras de KPC tornaram-se endêmicas no território nacional, com descrições de casos nas diferentes regiões brasileiras (ROSSI, 2011, PEREIRA et al., 2013; TAVARES et al., 2015). Essa capacidade de disseminação se deve a muitos fatores, especialmente, a sua associação aos elementos genéticos móveis como plasmídeos. Plasmídeos com o gene bla $_{\mathrm{KPC}}$ sofrem transferência horizontal, através da conjugação entre as células bacterianas, tornando esse movimento de célula para célula um grande facilitador para a sua propagação (PORRECA et al., 2018).

Uma única amostra de $K$. pneumoniae foi caracterizada como produtora de metalo-beta-lactamase, positiva para o gene $b l a_{\mathrm{NDM}}$. Bactérias produtoras de NDM são globalmente distribuídas (WU et al., 2019). A primeira identificação de NDM, no Brasil foi, em 2013, em Providencia rettgeri isolada de um paciente do Rio Grande do Sul (CARVALHO-ASSEF et al., 2013). Um programa de vigilância global (The Study for Monitoring Antimicrobial Resistance Trends - SMART) avaliou 103.960 isolados de Enterobacteriaceae de 55 países do período de 2008 a 2014 . E, neste trabalho, bla ${ }_{\mathrm{NDM}}$ foi o terceiro gene mais comum $(19,4 \%)$, ficando atrás de bla $_{\mathrm{KPC}}(53,2 \%)$ e bla $a_{\text {OXA-48-like }}(20,1 \%)$. Adicionalmente, estes genes foram identificados com mais frequência em Klebsiella $(\mathrm{n}=1.127)$, E. coli $(\mathrm{n}$ $=149)$ e E. cloacae $(\mathrm{n}=110)($ KARLOWSKY et al., 2017).

A única amostra produtora de NDM, descrita neste trabalho, também apresentou resistência à polimixina $\mathrm{B}(\mathrm{CIM}=16 \mu \mathrm{g} / \mathrm{mL})$. $\mathrm{O}$ aumento de infecções causadas por bactérias Gram-negativas multirresistentes, especialmente com resistência a carbapenemas, levou a reintrodução das polimixinas (colistina e polimixina B) como uma opção de tratamento (OLAITAN et al., 2014). No entanto, uma incidência crescente de infecções bacterianas resistentes às polimixinas vem sendo relatada no ambiente hospitalar (SRINIVAS, RIVARD, 2017; NANG; LI; VELKOV, 2019).

\section{CONCLUSÃO}

Os resultados aqui descritos, embora locais, reforçam o atual desafio imposto pelas Enterobacterales resistentes aos carbapenemas. Estes microrganismos se disseminaram pelos ambientes 
hospitalares em todo o mundo na última década. Neste trabalho, detectamos um percentual elevado (59\%) de K. pneumoniae produtoras de carbapenemases do tipo KPC entre as amostras investigadas. A detecção rápida e precoce de microrganismos resistentes e seus respectivos determinantes de resistência torna-se fundamental para o monitoramento, controle e prevenção no ambiente hospitalar. A presença de uma amostra produtora de MBL do tipo NDM e resistente à polimixina, no hospital investigado, também reforça a importância do monitoramento através de métodos fenotípicos e genotípicos de amostras com esse fenótipo de resistência.

\section{AGRADECIMENTOS}

Agradecemos ao Programa Institucional de Bolsas de Iniciação Científica - PIBIC (UFF/ CNPq). Este trabalho também teve o apoio do Programa de Fomento à Pesquisa FOPESQ/UFF -2020.

\section{REFERÊNCIAS BIBLIOGRÁFICAS}

ADEOLU, Mobolaji; ALNAJAR, Seema; NAUSHAD Sohail; GUPTA, Radhey S. Genome based phylogeny and taxonomy of the Enterobacteriales': ord. nov. divided into the families Enterobacteriaceae, Erwiniaceae fam. nov., Pectobacteriaceae fam. nov., Yersiniaceae fam. nov., Hafniaceae fam. nov., Morganellaceae fam. nov., and Budviciaceae fam. nov. Int J Syst Evol Microbiol, v. 66, n.12, p. 5575-5599, 2016.

AGÊNCIA NACIONAL DE VIGILÂNCIA SANITÁRIA. Boletim Segurança do Paciente e Qualidade em Serviços de Saúde $n^{\circ}$ 20: Avaliação dos indicadores nacionais das IRAS e RM 2018. Disponível em: https://www20.anvisa.gov.br/ segurancadopaciente/index.php/publicacoes/item/boletim-seguranca-do-paciente-e-qualidade-em-servicos-de-saude-n-20-incidentes-relacionados-a-assistencia-a-saude-2018. Acesso em 11 dez. 2020.

ALVIM, Andre Luis Silva; COUTO, Braulio; GAZZINELLI, Andrea. Perfil epidemiológico das infecções relacionadas à assistência à saúde causadas por Enterobactérias produtoras de Carbapenemase. Rev esc enferm USP, v. 53, 2019.

BONOMO, Robert A et al. Carbapenemase-Producing Organisms: A Global Scourge. Clinical Infect Dis, v. 66, n. 8, p.1290-1297, 2018.

CARVALHO-ASSEF, Ana Paula et al. Isolation of NDM-producing Providencia rettgeri in Brazil. J Antimicrob Chemother, v. 68, n. 12, p. 2956-2957, 2013.

CLINICAL AND LABORATORY STANDARDS INSTITUTE. Performance Standards for Antimicrobial Susceptibility Testing. 28th ed. Clinical and Laboratory Standards Institute, Wayne, PA: 2018.

CODJOE, Francis S; DONKOR, Eric S. Carbapenem Resistance: A Review. Med Sci (Basel), v. 6, n. 1, p. 1, 2017.

DE OLIVEIRA, David et al. Antimicrobial Resistance in ESKAPE Pathogens. Clin Microbiol Rev, v. 33, n. $3,2020$.

DOI, Yohei; PATERSON, David L. Carbapenemase-Producing Enterobacteriaceae. Semin Respir Crit Care Med, v. 36, n. 1, p. 74-84, 2015. 
EXNER, Martin et al. Antibiotic resistance: What is so special about multidrug-resistant Gram-negative bacteria? GMS Hyg Infect Control, v. 12, 2017.

KARLOWSKY, James A et al. In vitro activity of imipenem against carbapenemase-positive Enterobacteriaceae isolates collected by the SMART global surveillance program from 2008 to 2014. J Clin Microbiol, v.55, n.6, p.1638-1649, 2017.

KAYE, Keith S; POGUE Jason M. Infections Caused by Resistant Gram-Negative Bacteria: Epidemiology and Management. Pharmacotherapy, v. 35, n. 10, p. 949-962, 2015.

LASKO, Maxwell J; NICOLAU, David P. Carbapenem-Resistant Enterobacterales: Considerations for Treatment in the Era of New Antimicrobials and Evolving Enzymology. Curr Infect Dis Rep, v. 22, n. 3, 2020.

MAGILL, Shelley S et al. Multistate point-prevalence survey of healthcare-associated infections. N Engl J Med, v. 370, n. 13, p. 1198-208, 2014.

MARRA Alexandre R, et al. Nosocomial bloodstream infections in Brazilian hospitals: analysis of 2,563 cases from a prospective nationwide surveillance study. J Clin Microbiol. v. 49, n. 5, p. 1866-1871, 2011.

MARTIN, Rebekah M; BACHMAN, MIchael A. Colonization, Infection, and the Accessory Genome of Klebsiella pneumoniae. Front Cell Infect Microbiol, v. 8, 2018.

MEATHERALL Bonnie L, et al. Incidence risk factors, and outcomes of Klebsiella pneumoniae bacteremia. Am J Med, v. 122, n. 9, p. 866-873, 2009.

MELETIS, Georgios. Carbapenem resistance: overview of the problem and future perspectives. Ther Adv Infect Dis, v. 3, n. 1, p. 15-21, 2016.

MONTEIRO, Jussimara et al. Rapid detection of carbapenemase genes by multiplex real-time PCR. J Antimicrob Chemother, v. 67, n.4, p. 906-909, 2012.

MUNOZ-PRICE, LS et al. Clinical epidemiology of the global expansion of Klebsiella pneumoniae carbapenemases. Lancet Infect Dis, v. 13, n. 9, p. 785-796, 2013.

NANG, Sue C; LI Jian, VELKOV Tony. The rise and spread of mcr plasmid-mediated polymyxin resistance. Crit Rev Microbiol, v. 45, n. 2, p. 131-161, 2019.

NORDMANN, Patrice; DORTET Laurent; POIREL, Laurent. Carbapenem resistance in Enterobacteriaceae: here is the storm! Trends Mol Med, v. 18, n. 5, p. 263-272, 2012.

NORDMANN, Patrice; POIREL, Laurent. The difficult-to-control spread of carbapenemase producers among Enterobacteriaceae worldwide. Clin Microbiol Infect, v. 20, n. 9, p. 821-830, 2014.

NORDMANN, Patrice; POIREL, Laurent. Epidemiology and Diagnostics of Carbapenem Resistance in Gram-negative Bacteria. Clin Infect Dis, v. 13, S521-S528, 2019.

OCTAVIA, Sophie; LANG, Ruth The family Enterobacteriacea. In: ROSEMBERG, Eugene; DELONG, Edward F; LORY, Stephen; STACKEBRANDT, Erko; THOMPSON, Fabiano. (eds). The Prokaryotes, 4th edition. Berlin: Springer, 2014.

OLAITAN, Abiola et al. Mechanisms of polymyxin resistance: acquired and intrinsic resistance in bacteria. Front Microbiol, v. 5, 2014.

ORGANIZAÇÃO MUNDIAL DA SAÚDE. Ten threats to global health in 2019. 2019. Disponível em: https:// www.who.int/news-room/spotlight/ten-threats-to-global-health- in-2019. Acesso em 11 dez. 2020.

PEREIRA, Polyana Silva et al. Update of the molecular epidemiology of KPC-2-producing Klebsiella pneumoniae in Brazil: spread of clonal complex 11 (ST11, ST437 and ST340). J Antimicrob Chemother, v. 68, n. 2, p. 312-316, 2013. 
PODSCHUN R; ULLMANN U. Klebsiella spp. as nosocomial pathogens: epidemiology, taxonomy, typing methods, and pathogenicity factors. Clin Microbiol Rev, v.11, n. 4, p. 589-603, 1998.

PORRECA, Ann Marie; SULLIVAN, Kaede V; GALLAGHER, JASON C. The Epidemiology, Evolution, and Treatment of KPC-Producing Organisms. Curr Infect Dis Rep, v. 20, n. 6, p.13, 2018.

QUEENAN, Anne Marie; BUSH, Karen. Carbapenemases: the versatile beta-lactamases. Clin Microbiol Rev, v. 20, n. 3, p. 440-58, 2007.

RODRIGUES, Francisco; BARROSO, Ana Paula. Etiologia e sensibilidade bacteriana em infecções do tracto urinário. Rev Port Sau Pub, v. 29, n. 2, 2011.

ROSSI, Flávia. The challenges of antimicrobial resistance in Brazil. Clin Infect Dis, v. 52, n. 9, p. 1138-1143, 2011.

SRINIVAS, Pavithra; RIVARD Kaitlyn. Polymyxin resistance in Gram-negative pathogens. Curr Infect Dis Rep, v. 19, n. 11, p. 38, 2017.

TAMMA, Pranita; SIMNER, Patricia. Phenotypic Detection of Carbapenemase-Producing Organisms from Clinical Isolates. J Clin Microbiol, v. 56, n. 11, 2018.

TAVARES, Carolina Padilha et al. Molecular epidemiology of KPC-2-producing Enterobacteriaceae (nonKlebsiella pneumoniae) isolated from Brazil. Diagn Microbiol Infect Dis, v. 82, n. 4, p.326-30, 2015.

TOUATI, Abdelaziz; MAIRI, Assia. Carbapenemase-Producing Enterobacterales in Algeria: A Systematic Review. Microb Drug Resist, v. 26, n. 5, p. 475-482, 2020.

WALSH, Timothy R. Emerging carbapenemases: a global perspective. Int J Antimicrob Agents, v. 36, p. S8-S14, 2010.

WILLYARD, Cassandra. The drug-resistant bacteria that pose the greatest health threats. Nature, v. 543, $\mathrm{n}$. 7643, p. 15, 2017.

WU, Wenjing et al. NDM Metallo-beta-Lactamases and Their Bacterial Producers in Health Care Settings. Clin Microbiol Rev, v. 32, n. 2, 2019.

YIGIT, Hesna et al. Novel carbapenem-hydrolyzing ßlactamase, KPC-1, from a carbapenem-resistant strain of Klebsiella pneumoniae. Antimicrob Agents Chemother, v. 45, n. 4, p. 1151-1161, 2001. 


\section{EDUCAÇÃO EM SAÚDE BUCAL PARA GESTANTES PARTICIPANTES DE FISIOTERAPIA AQUÁTICA NO CENTRO DE REABILITAÇÃO DA UNIOESTE}

ANA LUÍZA GARCIA PROCÓPIO

Universidade Estadual do Oeste do Paraná-

UNIOESTE

ANDRÉ LUIZ MARÇAL TERRERI

Universidade Estadual do Oeste do ParanáUNIOESTE

DHIENARA SGARBOSA TOMIN

Universidade Estadual do Oeste do ParanáUNIOESTE

\section{HELENARA SALVATI BERTOLOSSI} MOREIRA

Universidade Estadual do Oeste do ParanáUNIOESTE

LUANA ASSUNÇÃO DELGADO

Universidade Estadual do Oeste do ParanáUNIOESTE

\section{MARIA GORETI WEIAND BERTOLDO}

Universidade Estadual do Oeste do ParanáUNIOESTE

RESUMO: O período gestacional tem diversas peculiaridades e os cuidados demandados devem proporcionar a integralidade da saúde da mulher grávida. Dessa forma, a "Ação interdisciplinar em promoção de saúde bucal" realizou orientações de saúde à gestantes, durante atividades de fisioterapia aquática, desenvolvidas pelo curso de Fisioterapia no Centro de Reabilitação Física (CRF) da Universidade Estadual do Oeste do Paraná UNIOESTE. Apresentamos os resultados obtidos com palestras e orientações voltadas para a promoção e educação em saúde bucal, desenvolvidas pelos alunos da graduação do curso de Odontologia, à pacientes gestantes durante atividades hidroterapêuticas. Utilizou-se a piscina de fisioterapia aquática do CRF como um espaço alternativo e dinâmico para o repasse de orientações acerca da saúde bucal da gestante e do bebê. A promoção de saúde se deu através de palestras, demonstrações de higienização oral, em macromodelos, e distribuição de folders expositivos, sobre os temas abordados ao fim de cada atividade, assim como abertura de um campo de debate e troca de experiência, onde dúvidas foram sanadas. Durante o desenvolvimento do projeto de extensão, até o ano de 2019, foram abordadas 30 gestantes que realizam acompanhamento no CRF com idade gestacional de 3 a 8 meses. Foi possível analisar o interesse intenso por parte destas, levando ao aprendizado sobre técnica de escovação e mudanças de hábitos benéficos a saúde bucal. Ademais, verificou-se o aprendizado pelos próprios participantes da equipe como, o desenvolvimento da apresentação oral, a interação com esses pacientes e a aquisição de um perfil comportamental para os futuros atendimentos com gestantes. O projeto "Ação Interdisciplinar Em Promoção De Saúde Bucal" teve grande importância para as mulheres grávidas que frequentam CRF, bem como para os graduandos participantes, os quais adquiriram conhecimentos por meio da interdisciplinaridade entre os cursos de Odontologia e Fisioterapia.

Palavras Chave: Gestantes, Saúde Bucal, Interdisciplinar.

ABSTRACT: The gestational period has several peculiarities and the care demanded must provide comprehensive health for the pregnant women. In this way, the "Interdisciplinary action to promote oral health" provided health guidelines for pregnant women, during activities at the Physical Rehabilitation Center (CRF) of UNIOESTE. We 
present the results obtained with lectures and guidelines aimed at promotion and education in oral health, developed by undergraduate students of the dentistry course to pregnant patients during hydrotherapeutic activities. The CRF hydrotherapy pool was used as an alternative and dynamic space for passing on guidance on the oral health of the pregnant woman and the baby. Health promotion took place through lectures demonstration of oral hygiene, in macromodels, and distribution of exhibition folders, on the topics covered, ate the end of each activity, as well as opening a field of debate and exchange of experiences where doubts have been resolved. During the development of the extension project, until 2019, 30 pregnant women who were followed up at the CRF with a gestational age of 3 to 8 months were approached. It was possible to analyze their intense interest, leading to learning about brushing techniques and changes in habits beneficial to oral health. In addition there was learning by the team members themselves, the interaction with these patients and the acquisition of a behavioral profile for future care with pregnant .The project "Interdisciplinary action in oral health promotion" was of great importance for pregnant women attending the CRF, as well as for participating undergraduates, who acquired knowledge through interdisciplinary between Dentistry and Physiotherapy.

Keyword: Pregnant women, Oral health, Interdisciplinary.

\section{INTRODUÇÃO}

A atenção ao parto e ao pré-natal tem sido priorizada como uma das principais políticas de saúde nas sociedades contemporâneas, promovendo um benefício diferenciado ao grupo de gestantes e crianças.

Conforme FERREIRA (2015) o período gestacional tem diversas peculiaridades e os cuidados demandados pelo mesmo e o conjunto de alterações que este imprime sobre a mulher, com possíveis implicações sobre o bebê, é imperativo abordar a gestante sob o ponto de vista da integralidade. Portanto, é necessária a oferta de um conjunto de ações, numa perspectiva de atenção integral, na qual o cuidado vai além do acompanhamento realizado com o médico e enfermeiro, o que requer cuidados com outros profissionais, como o cirurgião dentista, a partir do pré-natal odontológico.

Dessa maneira, as orientações sobre à saúde tanto da mãe quanto do bebê durante o período gestacional são de extrema importância, pois é uma época que ocorrem intensas mudanças na vida da gestante, , elas fisiológicas relacionadas a saúde bucal. É importante destacar que,durante a gravidez, as mulheres estão aptas a receberem novos conhecimentos e também mais receptivas à mudança, fatores que podem ocasionar atitudes mais saudáveis sobre a sua saúde e do futuro bebê. (MOIMAZ, 2011)

O conhecimento produzido por intervenções educativas, que devem possibilitar a articulação das vivências cotidianas com as informações advindas do campo científico, cria um vínculo entre a ação assistencial e o pensar-fazer cotidiano, que converge para elevação do estado de saúde. Além do cuidado ao bebê, o cuidado da gestante para consigo mesma, também depende de informações e motivações para que os tabus, medos e ansiedades que envolvem o tratamento odontológico sejam quebrados. (OLIVEIRA, 2014) 
Diante disso, o projeto de extensão: Ação Interdisciplinar na Promoção de Saúde Bucal em parceria com o Centro de Reabilitação Física (CRF) e o Curso de Fisioterapia da Universidade Estadual do Oeste do Paraná (Unioeste), campus Cascavel, abrangeu um grupo de gestantes participantes do projeto de extensão: "Hidroterapia na prevenção e tratamento de desconfortos musculoesqueléticos gestacionais" já vigentes no curso de Fisioterapia.

Dessa forma os acadêmicos de Odontologia e Fisioterapia, pertencentes ao projeto de extensão interdisciplinar, promoveram palestras por meio de ações educativas, entrega de folders e demonstrações em macromodelos, abordando os temas de saúde bucal e higienização oral da mãe e da criança. Otimizando o tempo e complementando o efeito promovido pela realização de exercícios aquáticos, e o momento de relaxamento, ampliando e diversificando os efeitos fisiológicos, elegendo a piscina térmica como espaço para promover saúde. Sendo assim, a união das duas áreas de saúde, associando os projetos de extensão, buscou a atenção plena da saúde da gestante e a visão abrangente de relação mãe-bebê, evidenciando a relação da saúde bucal com o pré e pós natal.

\section{DESENVOLVIMENTO}

O Projeto Ação Interdisciplinar na Promoção de Saúde Bucal, teve início no ano de 2018, ao total foi realizado orientações a um grupo de 30 gestantes, que se encontravam na piscina térmica do Centro de Reabilitação Física (CRF). A sequência de palestras foi realizada semanalmente e durava um mês, três encontros destinados à exposição de conteúdos e resolução e dúvidas e o último, para debate, troca de experiências, retorno e considerações das gestantes. No ano de 2018 foram abertas duas turmas e em 2019 mais duas, sendo que continham número variado de gestantes, devido as diferentes idades gestacionais, assim como as que participavam de mais de uma sequência de palestra. Todas as mães estavam inscritas nas atividades hidroterapêuticas, promovidas pelo Projeto de Extensão "Hidroterapia na prevenção e tratamento de desconfortos musculoesqueléticos gestacionais" do curso de Fisioterapia e faziam pré-natal na rede pública e particular.

Durante essas atividades, houve a formação de um espaço alternativo e propício para a promoção de saúde, visto que ao mesmo tempo as gestantes tinham atenção plena à própria saúde e a saúde do bebê, aumentando consideravelmente, o interesse e a compreensão aos assuntos abordados. 


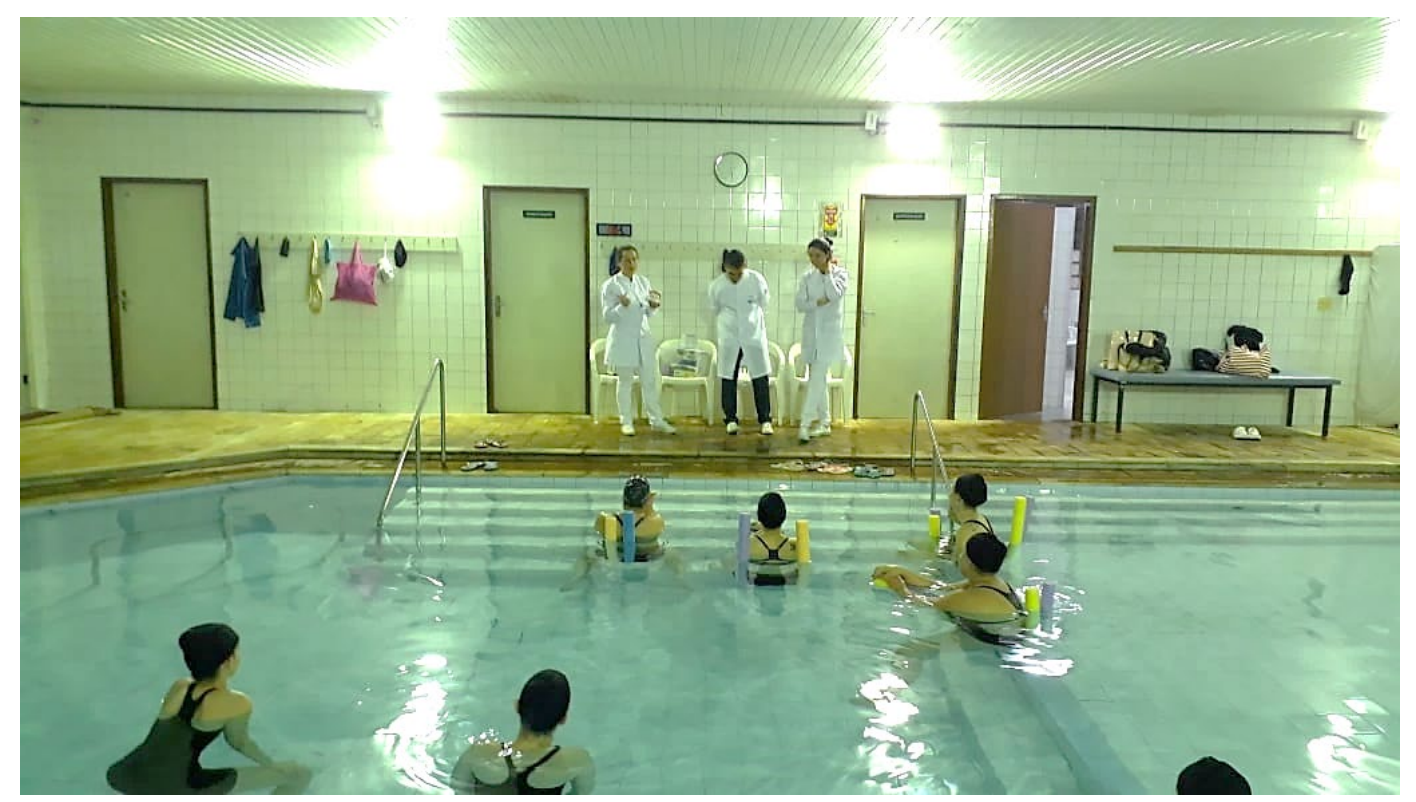

IMAGEM I- Gestantes recebendo informações de Saúde Bucal na Piscina

De acordo com REIS et al (2010), a educação em saúde, tanto individual quanto coletiva é, notoriamente, o ponto chave para a promoção de saúde bucal na gestante, tratando-se como fator motivacional e indutivo à mudança de comportamentos e hábitos para a prevenção de doenças. Não obstante, SOUZA, ROECKER e MARCON (2011), descrevem a importância de se realizar um atendimento humanizado para com a mulher gestante, sendo o pré-natal, a janela ideal para o desenvolvimento de práticas educativas com o intuito de prepará-la para viver uma gestação de forma positiva, ou seja, sem intercorrências dolorosas e traumáticas. Ainda assim, é importante salientarmos que o atendimento odontológico deve sim ser feito em conjunto com o pré-natal, e que o mesmo não causa malefício alguma a saúde da mãe e do bebê.

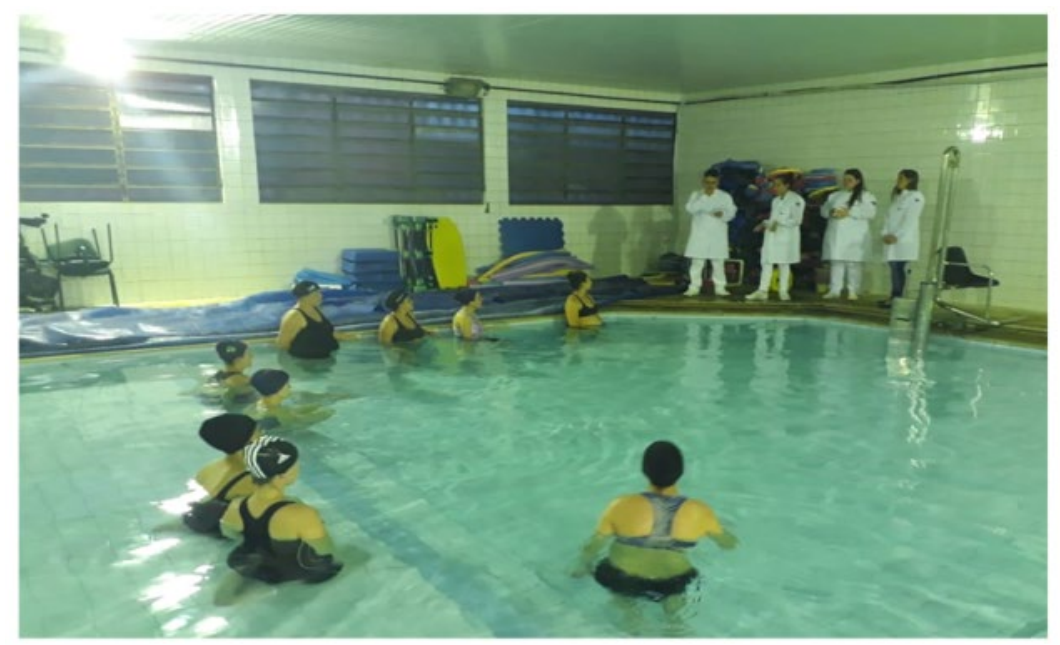

IMAGEM II- Gestantes recebendo informações de Saúde Bucal na Piscina

Dentro do período gestacional o organismo da mulher sofre uma série de alterações, que têm como objetivo desenvolver o feto e preparar o corpo da gestante para o parto e amamentação. As mu- 
danças fisiológicas que ocorrem durante a gravidez incluem transformações que vão atuar sobre todo o organismo, inclusive sobre a cavidade bucal e na fisiologia oral. (ALEIXO, 2016)

Ainda, segundo Aleixo (2016) as mais comuns são: aumento da salivação, náuseas e enjoos, alterações sobre o periodonto, ganho de peso exagerado, hipotensão postural, aumento da urina, restrição da função respiratória, potencial de hipoglicemia, diminuição ou aumento dos batimentos cardíacos e desmaios.

Essas alterações têm influência direta na cavidade bucal, portanto a busca ao atendimento odontológico é essencial. Além disso, durante a gravidez, algumas dificuldades são observadas, como a intolerância ao creme dental devido as náuseas, o que leva a uma menor frequência de higiene oral e, associada à uma dieta mais açucarada torna o ambiente bucal mais cariogênico. $\mathrm{O}$ atendimento nessa fase envolve desde remoção de irritações locais que possam estar agredindo a gengiva, até o aconselhamento preventivo para a saúde bucal da mãe e do bebê. (RIGO, 2016)

A gengivite observada durante a gravidez é causada pelo biofilme que se localiza próximo ou dentro do sulco gengival e está associada a fatores sistêmicos como alterações hormonais exacerbada pela intensa produção de hormônios sexuais femininos. Normalmente recebe a denominação de gengivite gravídica e apresenta como fator associado, a alteração do metabolismo tecidual (o aumento da permeabilidade vascular, aumento do fluxo de fluido gengival e síntese de prostaglandinas), aumentando o processo inflamatório. (ALEIXO,2016)

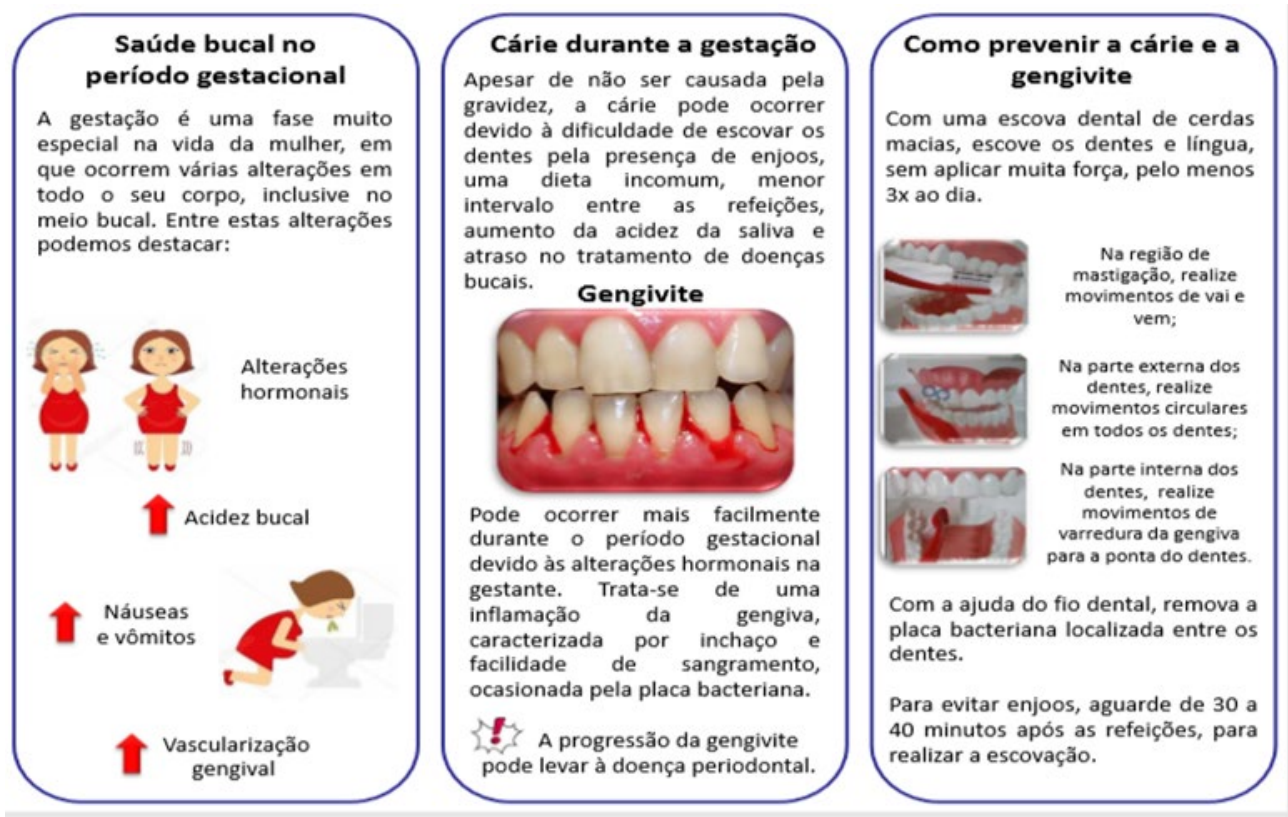

IMAGEM III- Folder de Saúde Bucal da Gestante

A técnica de higienização bucal para gestantes, demonstrada em macromodelos, durante a exposição oral, baseava-se na realização de movimentos de escovação e uso de fio dental, aconselhando sempre a mesmas para que façam a higienização 30 minutos após a refeição para evitar náuseas e vômitos, e em casos de enjoos por conta do sabor do dentifrício realizar a escovação sem o mesmo, visto que a remoção de placa acontece pelas cerdas da escova dental. 


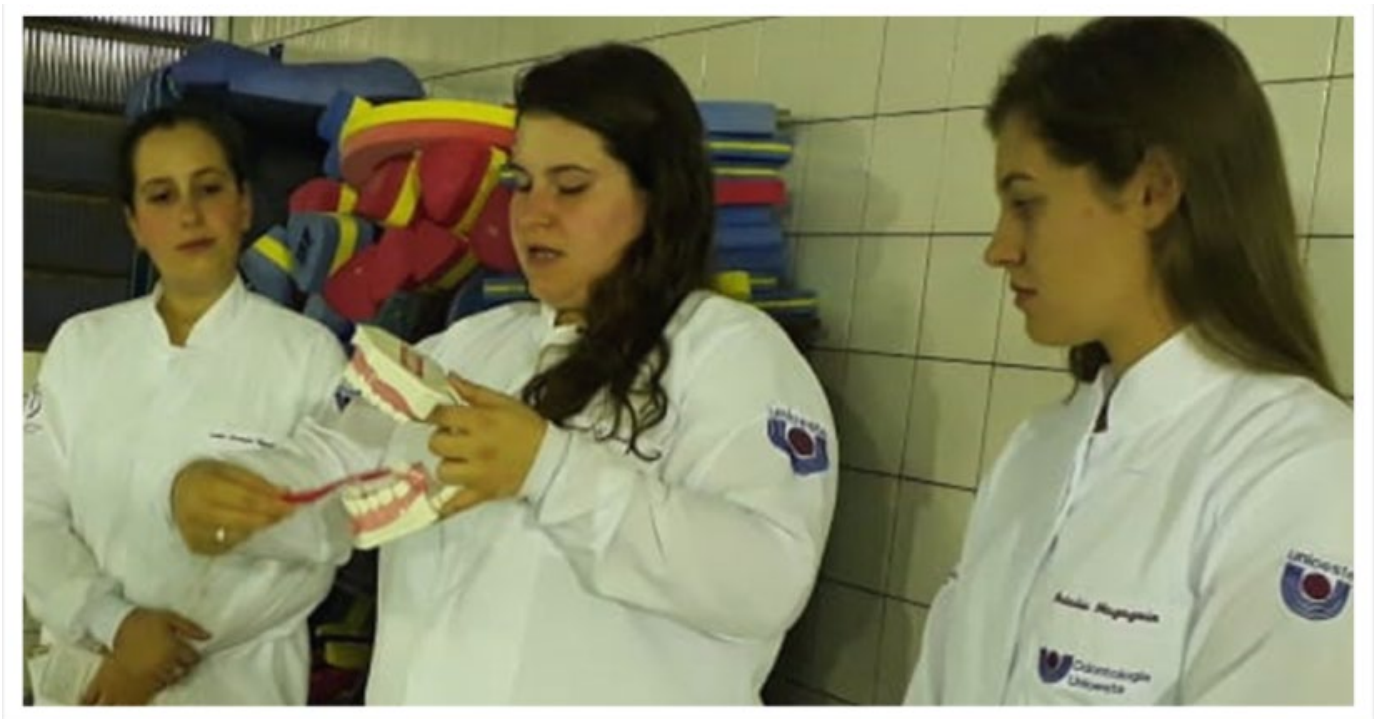

IMAGEM IV e V- - Gestantes recebendo demonstrações de higiene bucal em macromodelos.

Todas as orientações foram amplamente reforçadas pois a higienização incorreta além de desenvolver problemas dentários também acarretam problemas periodontais que podem induzir o parto prematuro. (VIEIRA, 2010). As duas doenças periodontais mais prevalentes e extensivamente investigadas são a gengivite induzida por placa e a periodontite crônica, um processo inflamatório que se estende às estruturas periodontais de suporte. Enquanto a gengivite é uma condição reversível, a periodontite crônica provoca perda de tecido conjuntivo e reabsorção irreversível da crista óssea alveolar.

Dessa forma, conforme ZANATTA (2007) a doença periodontal (DP), pode estar associada à ocorrência de parto prematuro e ao nascimento de recém-nascidos de baixo peso (RNBP) através dos mesmos mecanismos que outras infecções maternas. Os estímulos inflamatórios podem induzir uma hiperirritabilidade da musculatura lisa uterina, provocando a contração do útero e dilatação cervical, atuando como gatilho para o parto prematuro.

A infecção e o processo inflamatórios resultantes podem causar danos à placenta, restringindo, dessa forma, o crescimento fetal. (VIEIRA, 2010). Tanto a periodontite quanto a gengivite envolvem a agressão direta por microrganismos do biofilme bacteriano e mecanismos de defesa do hospedeiro afetando diretamente o organismo como um todo.

Para a higienização oral do bebê, que ainda não possui dentes recomenda-se utilizar uma gaze umedecida que enrolada no dedo da mãe percorre toda a cavidade oral da criança. Já com a erupção do primeiro dente, o que acontece por volta dos 6 meses de vida, inicia-se a higienização com escova e a quantidade de dentifrício de um grão de arroz até dois anos de idade e dentifrício na quantidade de um grão de ervilha até os 4 anos.(ALEIXO 2016) 


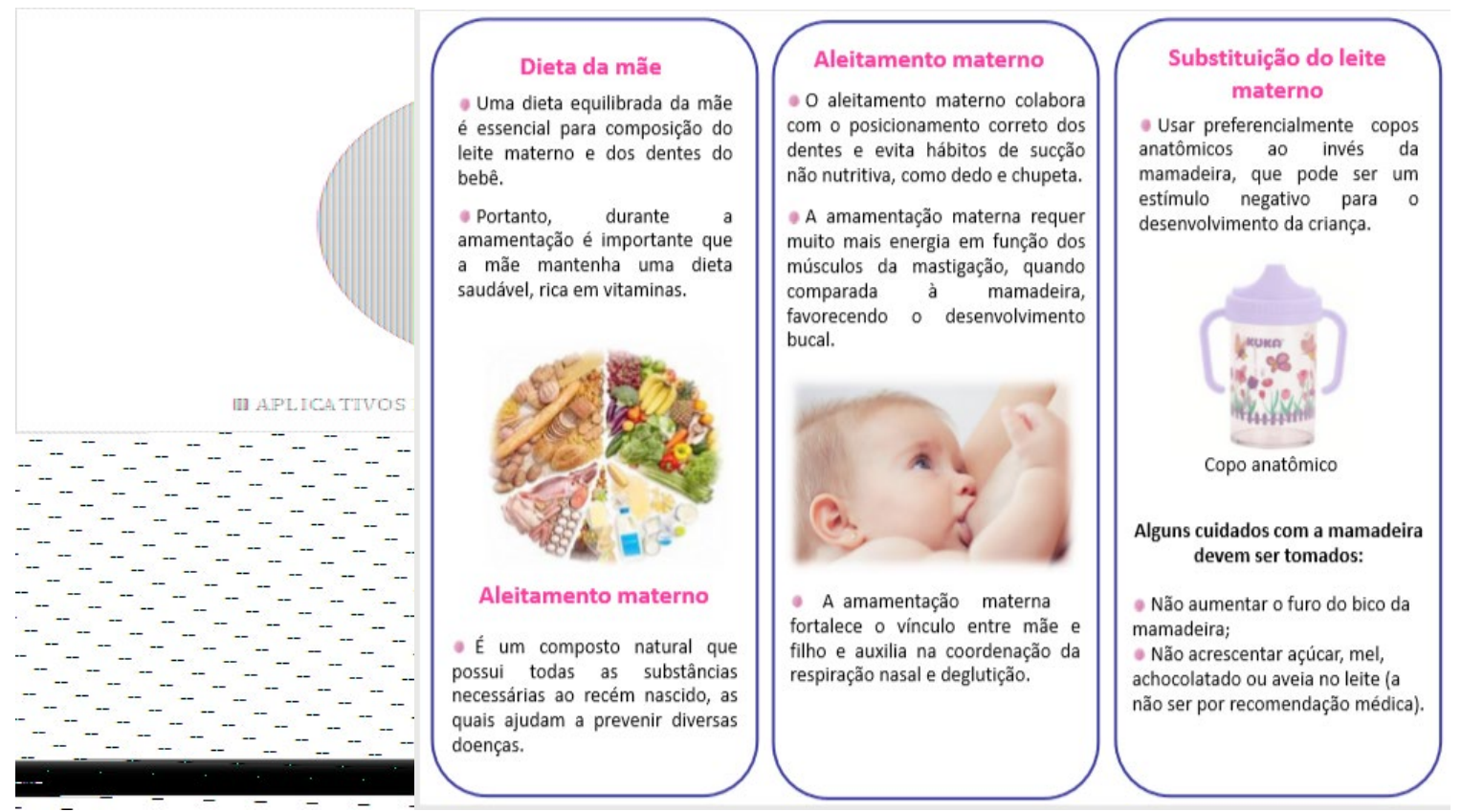

IMAGEM VI- Folder de Saúde Bucal do Bebê.

Nessas exposições orais também foi ressaltada a importância de os pais serem os exemplos dos filhos em relação a hábitos de higiene, a criança que tem sua higienização oral iniciada nos primeiros meses de vida associada a assistir os hábitos de higiene oral dos pais são mais receptivas a esses hábitos.

Segundo RIGO, DALAZEN, GARBIN (2016) mães que recebem orientação odontológica durante a gestação tem uma maior percepção sobre a saúde bucal dos seus filhos. Tais orientações, recebidas na gestação influenciam as mães nos procedimentos adotados com os seus filhos, principalmente com relação ao início da higienização oral, primeira consulta ao Cirurgião Dentista, tempo de amamentação e o conhecimento sobre os fatores que levam ao aparecimento da doença cárie.

FARIAS (2012) fez um estudo, com a amostra composta por 112 mães, em que os filhos tinham idade 0 e 6 anos, de ambos os gêneros. Após a análise dos dados, pode-se constatar que parcela significativa das mães, aproximadamente 75,9\%, afirmou já ter recebido orientação de algum dentista sobre a saúde bucal de crianças. Dentre a maioria destas $(81,3 \%)$ foi verificado que a própria realiza a higiene bucal de seus filhos. Um pouco mais a metade das mães (52,7\%) relatou que os dentes dos filhos são higienizados duas vezes ao dia. Assim constata-se que mães que receberam orientações de cirurgiões dentistas, durante o período gestacional ou durante a infância dos filhos, apresentam maior conhecimento sobre a saúde bucal e métodos de higienização bucal na infância e gestação. (FARIAS, 2012)

Folders com os conteúdos abordados foram entregues as futuras mães na saída da atividade. Neles os conteúdos expostos estavam detalhados e serviriam de referência caso houvesse alguma dúvida e também para que essas gestantes cientes do conteúdo que estavam recebendo poderiam repassa-los para outras futuras mães, principalmente aquelas que fazem parte de seus círculos sociais, gerando uma corrente de promoção de Saúde. 
Ressaltou-se, às gestantes, ao fim de cada palestra, a oferta de tratamento odontológico gratuito e especializado ofertado pela clínica de Odontologia da Universidade, assim como recomendações para que pós-parto procurassem o Banco de Leite Humano do Hospital Universitário (HU) da cidade, visto a importância da amamentação. Em tempo, tivemos o retorno das duas instituições relatando que as gestantes, atendidas pelo projeto, procuraram as mesmas e receberam tratamento odontológico e auxílio na amamentação, sendo que algumas se tornaram também doadoras de leite humano.

Ao fim de cada explanação sobre os temas abordados, abriu-se um espaço para a interatividade das gestantes. As futuras mães tiveram vários questionamentos e dúvidas, essas foram todas sanadas baseadas no conhecimento prévio adquirido pelos alunos sobre os temas. Nesses momentos também houve uma troca de aprendizado e experiências, algumas das gestantes já estavam em sua segunda ou terceira experiencia gestacional e relataram as experiencias odontológicas que tiveram durante as outras gestações, algumas com perda dentária, recusa de tratamento de seus cirurgiões dentistas e dificuldades em relação a amamentação por falta de orientação.

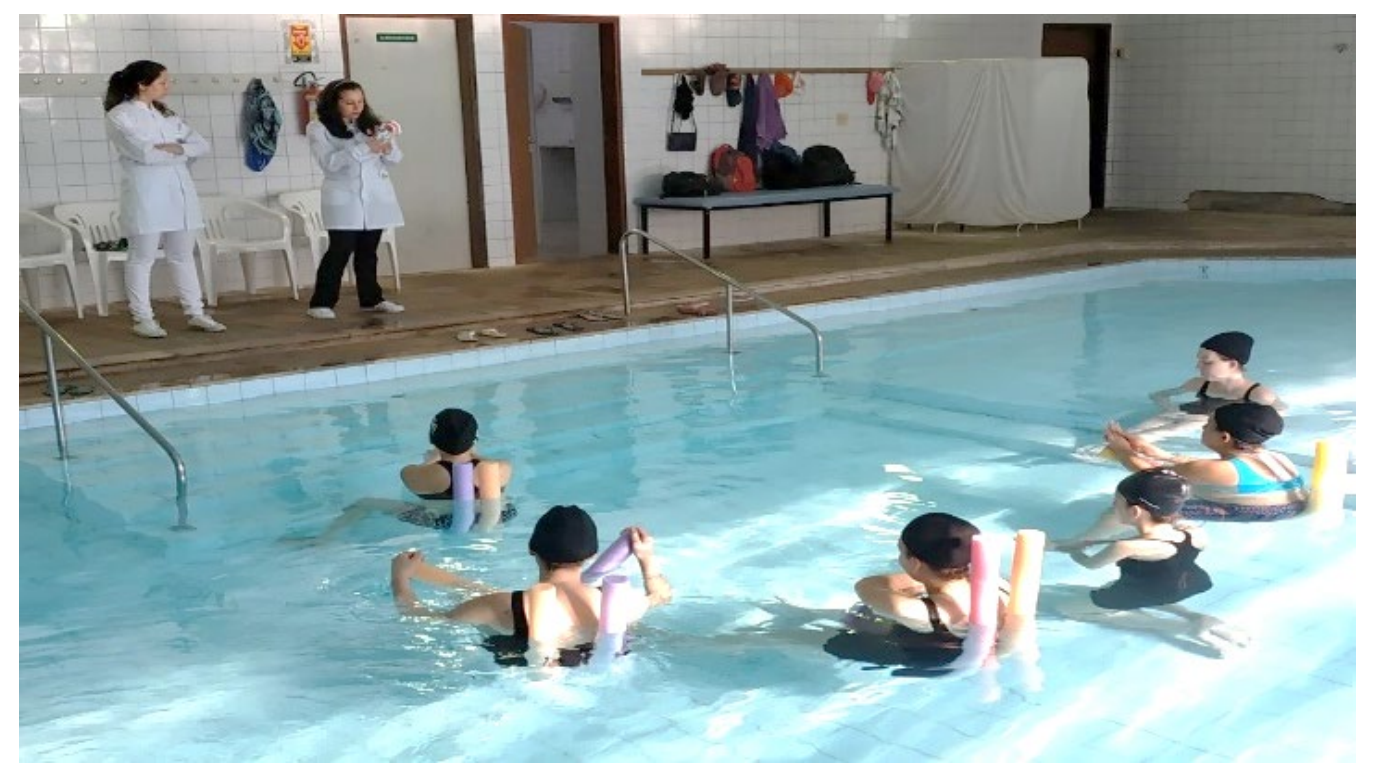

IMAGEM VIII - Debate entre Gestantes e Acadêmicos sobre saúde bucal do bebê.

\section{CONCLUSÃO}

Participaram do projeto num total de 30 gestantes que já estavam realizando o acompanhamento pré-natal no centro de reabilitação física da Unioeste (CRF). Participantes do Projeto "Hidroterapia na Prevenção e Tratamento de Desconfortos Musculoesqueléticos Gestacionais" do curso de Fisioterapia. Dessa forma, obteve-se uma interdisciplinaridade entre os cursos de Odontologia e Fisioterapia demonstrando uma série de resultados benéficos. 


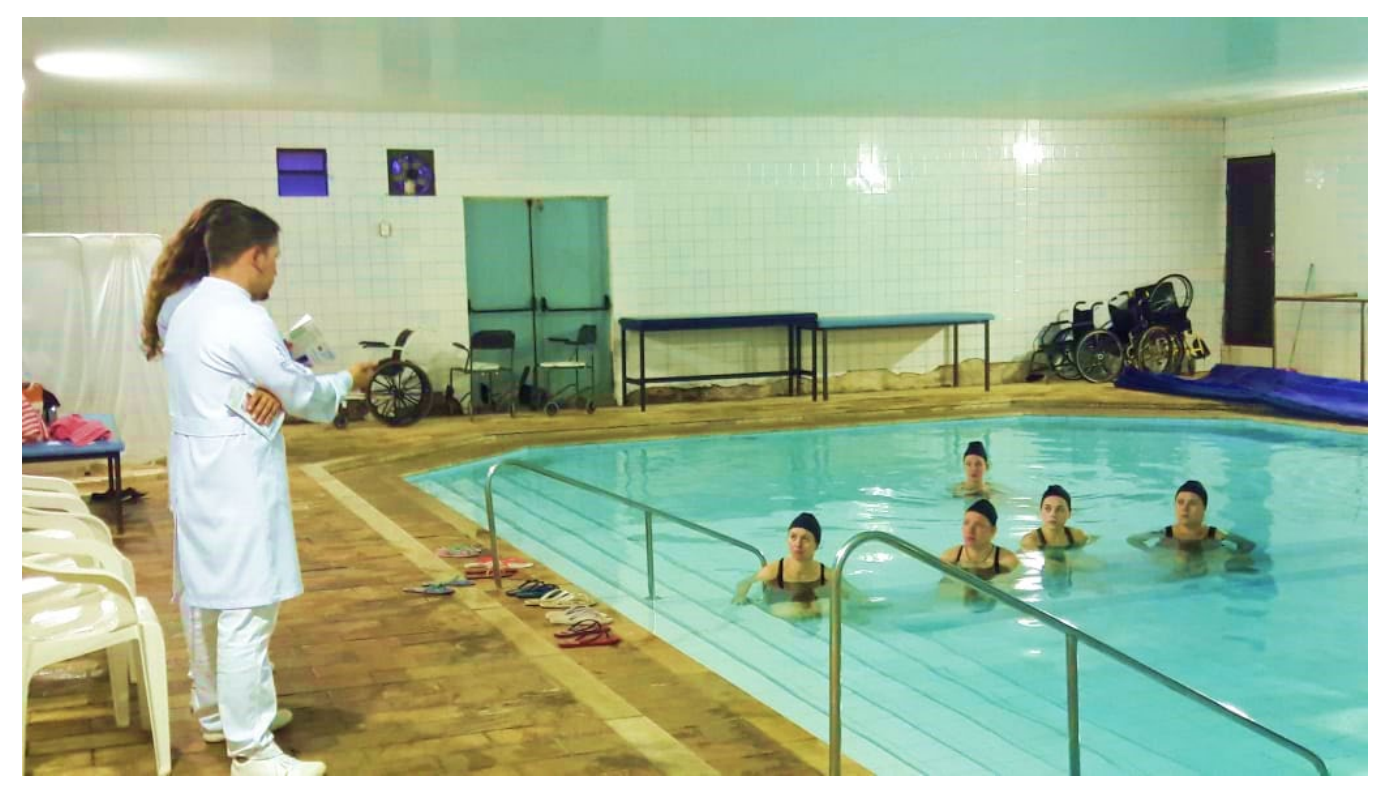

IMAGEM IX- Atividades sendo exercidas na piscina do CRF

Assim, houve a percepção da nossa equipe sobre o desconhecimento das gestantes em relação a incidência cárie na gravidez, sangramento gengival, gengivite e periodontite e higienização oral do bebê visto que houveram questionamentos feitos pelas mesmas sobre esses assuntos. Dessa forma, analisou um interesse intenso das mesmas sobre os temas abordados, levando a um aprendizado acerca das técnicas de escovação e mudanças de hábitos benéficos a saúde bucal, visto que a maioria delas após essas orientações as mesmas buscaram atendimento gratuito e especializado na Clínica Odontológica da UNIOESTE e no Banco de Leite Humano do Hospital Universitário (HU).

Portanto, esse resultado prova que elas estavam receptivas e dispostas para cuidar da sua saúde como um todo e o interesse de realizar o pré-natal odontológico, visto que aprenderam a importância e a relação da saúde bucal da mãe com a da criança, sanando as dúvidas sobre o comportamento das futuras mães quanto aos seus próprios hábitos de higiene bucal, podendo ser considerado o principal fator influenciador na aquisição de hábitos por parte das crianças, independentemente do nível socioeconômico das mães ou suas crenças a respeito da saúde bucal.

Ademais, os resultados se refletem na nossa equipe, pois houve um aprendizado muito grande pelos participantes do projeto. Por parte dos graduandos foi desenvolvida a exposição oral e a postura e em apresentações frente a um certo número de pessoas, a interação com as gestantes participantes do projeto e a aquisição de um perfil comportamental para os futuros atendimentos em clinicas com as mesmas. Além disso, foi adquirida também a satisfação pessoal e profissional por meio de nossa equipe, em poder observar interesse por parte das gestantes sobre o assunto abordado e o retorno que recebemos ao ter ciência que as mesmas procuraram os atendimentos por nós indicados. 


\section{REFERÊNCIAS BIBLIOGRÁFICAS}

ALEIXO, Rodrigo Queiroz et al. Alterações Bucais em Gestantes-Revisão da Literatura. Revista Saber Científico, v. 1, n. 1, p. 68-80, 2016.

FARIAS, Aline Queiroz de et al. Análise de conhecimentos e prática das mães sobre a saúde bucal de seus filhos na faixa etária de 0 a 6 anos do município de Casinhas, Estado de Pernambuco. Odontologia Clínico-Científica (Online), v. 11, n. 3, p. 243-245, 2012.

FERREIRA, Suélem Maria Santana Pinheiro et al. Conhecimento em saúde bucal do bebê e expectativa relativa ao pré-natal odontológico: retrato de um município baiano de grande porte. Revista da Faculdade de Odontologia de Lins, v. 25, n. 2, p. 19-30, 2015.

MOIMAZ, Suzely Adas Saliba et al. Resultados de dez anos do Programa de Atenção Odontológica à Gestante. Revista Ciência em Extensão, v. 7, n. 1, p. 42-56, 2011.

OLIVEIRA, Eliana Cristina et al. Atendimento odontológico a gestantes: a importância do conhecimento da saúde bucal. Revista de Iniciação Científica da Universidade Vale do Rio Verde, v. 4, n. 1, 2014.

REIS, Deise Moreira et al. Educação em saúde como estratégia de promoção de saúde bucal em gestantes. Ciência \& Saúde Coletiva, v. 15, p. 269-276, 2010.

RIGO, Lilian; DALAZEN, Jaqueline; GARBIN, Raíssa Rigo. Impacto da orientação odontológica para mães durante a gestação em relação à saúde bucal dos filhos. Einstein (Sao Paulo), v. 14, n. 2, p. 219-225, 2016.

SOUZA, Viviane Barbosa; ROECKER, Simone; MARCON, Sonia Silva. Ações educativas durante a assistência pré-natal: percepção de gestantes atendidas na rede básica de Maringá-PR. Revista Eletrônica de Enfermagem, v. 13, n. 2, p. 199-210, 2011.

VIEIRA, Denise Regina Pontes et al. Associação entre doença periodontal na gravidez e parto pré-termo baixo peso ao nascer. Odontologia Clínico-Científica (Online), v. 9, n. 4, p. 311-314, 2010.

ZANATTA, Fabrício Batistin et al. Doença periodontal materna e nascimento prematuro e de baixo peso: uma revisão crítica das evidências atuais. Arquivos Catarinenses de Medicina, v. 36, n. 1, p. 96-102, 2007. 


\section{TABAGISMO E CIGARROS ELETRÔNICOS: SAÚDE BUCAL E SISTÊMICA}

JULIANA THEBERGE DOS SANTO DE OLIVEIRA UNIVERSIDADE FEDERAL DO RIO DE JANEIRO

TAMMY MARTINS DE OLIVEIRA UNIVERSIDADE FEDERAL DO RIO DE JANEIRO

MARIA CYNÉSIA MEDEIROS DE BARROS UNIVERSIDADE FEDERAL DO RIO DE JANEIRO

RESUMO: Os Dispositivos Eletrônicos de Liberação de Nicotina (ENDS) são produtos que não realizam a combustão da folha de tabaco, sendo sua ativação por meio do aquecimento e volatilização da nicotina, para ser inalada sem as demais substâncias nocivas do cigarro convencional. Atualmente, há um aumento pelo emprego de ENDS em terapias de cessação do tabagismo, contrapondo ao seu crescente uso recreativo em populações de jovens e adultos. Esse capítulo aborda a literatura científica sobre o uso de produtos tradicionais derivados do tabaco e as novas modalidades de uso do tabaco. Uma breve perspectiva histórica sobre o tabaco e reflexões sobre políticas públicas importantes também são apresentadas, enfatizando a relevância da Convenção-Quadro da OMS para o Controle do Tabaco no Brasil e no mundo. $\mathrm{O}$ texto também menciona que apesar da proibição da comercialização dos ENDS, infelizmente, trata-se de um mercado ilegal em expansão. $O$ surgimento relativamente recente de diferentes dispositivos, os ENDS, ainda carece de informações a respeito de sua segurança de uso e possíveis consequências patológicas. Por fim, este capítulo enfatiza o importante papel do cirurgião-dentista na prevenção e cessação do uso de tabaco tradicional e de suas novas formas.

PALAVRA-CHAVE: Cigarros Eletrônicos, Tabagismo, Saúde Pública.

ABSTRACT: Electronic Nicotine Release Devices (ENDS) are products that do not carry out the combustion of the tobacco leaf, being its activation through heating and volatilization of nicotine, to be inhaled without the other harmful substances of conventional cigarettes. Currently, there is an increase through the use of ENDS in smoking cessation therapies, in contrast to its growing recreational use in youth and adult populations. This chapter discusses the scientific literature on the use of traditional tobacco products and the new modalities of tobacco use. A brief historical perspective on tobacco and reflections on important public policies are also presented, emphasizing the relevance of the WHO Framework Convention on Tobacco Control in Brazil and worldwide. The text also mentions that despite the ban on the marketing of ENDS, unfortunately, it is a growing illegal market. The relatively recent emergence of different devices, ENDS, still lacks information regarding their safety of use and possible pathological consequences. Finally, this chapter emphasizes the important role of the dental surgeon in preventing and ceasing the use of traditional tobacco and its new forms.

KEYWORDS: Electronic Cigarettes, Tobacco Use Cessation, Public Health. 


\section{TABACO: BREVE HISTÓRICO}

As folhas de tabaco são originárias da América, seu cultivo remonta há ao menos oito mil anos e o tabagismo há pelo menos dois mil. A chegada de Colombo iniciou o processo de exportação para a Europa com consequente disseminação do tabaco pelo mundo, tornando-se uma grande moeda de troca (DROPE et al., 2018).

Em 1828, Posselt e Reiman foram os responsáveis pelo isolamento da nicotina proveniente das folhas de tabaco. Orfila, em 1843, foi o pioneiro na realização dos primeiros estudos farmacológicos desse vegetal (GILMAN \& GOODMAN, 2005).

Na década de 1880, a invenção da máquina de fabricar cigarros por James Bonsack, promoveu aumento da produção e oferta de cigarros para a população, crescendo seu consumo pelo mundo e expandindo este mercado (SOCIEDADE BRASILEIRA DE PNEUMONOLOGIA E TISIOLOGIA, 2012; DROPE et al.,2018).

Outros dois grandes momentos de aumento do consumo de tabaco se deram na $1^{\mathrm{a}}$ e $2^{\mathrm{a}}$ Guerra Mundial (DELUCIA et al., 2007). E agora, 140 anos depois da invenção da máquina de processar cigarros, é provável que a hegemonia do consumo de cigarros convencionais comece a sofrer substituição pelos Dispositivos Eletrônicos de Liberação de Nicotina (SILVA, 2016).

\section{O PANORAMA ATUAL DO TABAGISMO}

Em face do cenário epidemiológico atual do tabagismo, esta patologia é definida como uma doença crônica causada pela dependência à nicotina, substância capaz de aumentar a liberação neurotransmissores como a dopamina e serotonina (OMS/OPAS,1997; MARQUES et al., 2001; ROSE et al., 2003).

Ademais, por ter o seu início de uso geralmente ainda durante a menor idade, é categorizada como patologia pediátrica e uma das maiores causas de mortes evitáveis na atualidade, concentrando números mais expressivos nos países em desenvolvimento e dentro da população de baixa e média renda (BRASIL-OPAS, 2019).

Existem mais de um bilhão de fumantes no mundo e o tabaco mata mais da metade daqueles que fumam regularmente, sendo o tabagismo um dos principais fatores de risco para o desenvolvimento de outras doenças crônicas não transmissíveis (WHO 2008, 2011, 2013; LIM, 2012).

Desde 2003, a Convenção-Quadro da OMS para o Controle do Tabaco (CQCT da OMS) sedimentou um importante tratado internacional para redução da epidemia de tabagismo pelo mundo. Em 2007, a OMS inaugurou a articulação de uma metodologia para a implementação das medidas propostas na CQCT da OMS, baseada em uma estratégia denominada MPOWER, com o intuito de 
facilitar não somente a efetuação pelos países membros, como também seu monitoramento (BRASIL-OPAS, 2019).

A estratégia MPOWER se concentra na monitorização do uso do tabaco, com foco em políticas de prevenção e proteção dos indivíduos frente ao tabagismo, oferta de ajuda para cessação tabágica pelos usuários, disseminação dos perigos ocasionados pelo consumo desta droga, redução de publicidade relacionada, promoção ou patrocínio do tabaco através de proibições legais, bem como o aumento da taxação sobre o tabaco e seus produtos derivados (BRASIL-OPAS, 2019).

No Brasil, cerca de 156 mil vidas poderiam ser preservadas anualmente e 12,6\% de todas as mortes podem ser atribuídas ao tabagismo. Os gastos decorrentes de custos médicos e custos por perda de produtividade devido à essa doença no país somam 56,9 bilhões de reais, que correspondem à 1\% do Produto Interno Bruto (PIB) brasileiro; no entanto, a arrecadação de impostos com a venda de cigarros cobre apenas $23 \%$ deste montante (PINTO, 2017).

Apesar disso, o Brasil, desde 2019, destaca-se como a segunda nação a implementar na totalidade a estratégia MPOWER, em um esforço estatal a nível de políticas públicas multisetoriais no combate à adicção de nicotina. As estratégias embrionárias de combate ao tabagismo existem desde 1981, as quais somadas e aprimoradas, fortaleceram a queda progressiva das taxas ao longo da linha temporal até os dias atuais, onde estas estratégias culminam em uma efetiva redução do tabagismo no país e de suas complicações (BRASIL-OPAS, 2019).

$\mathrm{Na}$ América Latina, os reflexos decorrentes do fumo recaem em estatísticas desafiadoras frente ao câncer de pulmão, o maior causador de morte e o terceiro tipo de neoplasia mais comum, pois $65 \%$ dos casos é em consequência do uso de tabaco. E mesmo o fumo passivo é detentor de dados alarmantes: 93 mil mortes. Apesar da queda mundial, novos esforços são necessários para a manutenção do declínio do tabagismo nas novas gerações (BRASIL-OPAS, 2019).

Nesse cenário, surgido em versão comercial em 2003 na China e patenteado em 2004, o cigarro eletrônico (e-Cig) foi idealizado para auxiliar na terapia de cessação tabágica, através da proposta de manutenção do aporte de nicotina para o usuário, sem o contato com as demais substâncias deletérias fruto da combustão do cigarro convencional, o que ocasionou sua intensa popularização global desde o seu invento (TRTCHOUNIAN; TALBOT, 2011).

Todavia, sua segurança de uso e mesmo sua eficácia terapêutica frente ao vício em nicotina sofre divergências dentro da comunidade científica, em decorrência da incipiência de estudos clínicos randomizados controlados longitudinais, amostras contundentes, metodologias adequadas e isenção de conflitos de interesses que não ameacem a credibilidade dos resultados obtidos e que se apresentem como uma carta branca para o uso destes dispositivos (FRANCK et al., 2014).

Atualmente o termo difundido cigarro eletrônico denomina popularmente toda a gama de gadgets que possuem o funcionamento baseado na volatilização de substâncias para serem inaladas (CAPONNETO et al, 2012). Os Sistemas de Liberação de Nicotina ou também conhecidos como Dispositivos Eletrônicos de Liberação de Nicotina, por sua vez, compreendem os dispositivos com o fornecimento dessa substância para o utilizador (WALLEY; JENSSEN, 2015). 
Os e-Cigs também podem ser denominados Dispositivos Eletrônicos para Fumar (DEFs) (SILVA; MOREIRA, 2019). Ainda em situações onde a composição seja livre de nicotina, é possível encontrar diversas substâncias no líquido de seus cartuchos, incluindo o canabidiol e o tetrahidrocanabinol (THC), substâncias presentes na Cannabis sativa, além de flavorizantes (SINGH; LIPPMANN, 2018).

\section{DO TABAGISMO AO VAPING, O QUE MUDOU?}

Os produtos tradicionais à base de tabaco podem ser fumados ou não fumados (MINISTÉRIO DA SAÚDE, 2010). Entre os produtos fumados temos:

- Cigarro convencional: Tabaco enrolado em qualquer material, exceto folha de tabaco, de forma industrializada e que pode ou não ter filtro; (MINISTÉRIO DA SAÚDE, 2010);

- Cigarro de palha: Tabaco enrolado artesanalmente em palha de milho; (MINISTÉRIO DA SAÚDE, 2010);

- Charuto: Tabaco curado enrolado em folhas de tabaco. Por ser curado e apresentar pH alcalino, é melhor absorvido através da cavidade bucal, por isso, não é tragado para os pulmões. Apesar disso, o fumante de charuto é exposto a uma maior quantidade de fumaça quando comparado ao fumante de cigarros (IRIBARREN, 1999; BALBANI \& MONTOVANI, 2005; VIEGAS, 2008; MINISTÉRIO DA SAÚDE, 2010);

- Cigarrilha: Charuto pequeno (MINISTÉRIO DA SAÚDE, 2010);

- Cachimbo: Instrumento, normalmente feito em madeira, utilizado para fumar: o fumo é depositado em uma das pontas e aspirado na outra após a queima (OLIVEIRA \& BARROS, 2020);

- Narguile: Dispositivo que permite o aquecimento do tabaco e a fumaça passa por um reservatório de água antes de ser aspirada através de uma mangueira. Muitos acreditam que a água do reservatório seja capaz de filtrar as substâncias tóxicas, mas isto não acontece: seu uso é prejudicial à saúde e pode causar dependência (NEERGAARD et al., 2007; MAZIAK W, 2008; MINISTÉRIO DA SAÚDE, 2010; INCA, 2019);

- Fumo de Rolo: Feito a partir de folhas de tabaco que são entrelaçadas e enroladas para curarem ao sol (MINISTÉRIO DA SAÚDE, 2010).

Outra categoria de formas de tabaco são as denominadas sem fumaça: na forma seca - podendo ser inalada ou inspirada - conhecida como rapé, ou úmida, conhecida como Sachê de Betel (normalmente alojado entre a gengiva e bochecha). São divulgadas pela indústria como uma forma discreta de utilizar o tabaco, possibilitando o uso inclusive em ambientes onde é proibido fumar (VIEGAS, 2008; NEVILLE, 2009). 
Partindo para os e-Cigs, estes gadgets dispõem de uma vasta variabilidade de designs, e funções. Entretanto, alguns componentes são encontrados de forma comum na maioria das marcas e modelos, sendo eles a bateria, o atomizador, o reservatório e o bocal. Boa parte dos dispositivos também dispõe de uma luz indicadora de nível de bateria e utilização do dispositivo (TRTCHOUNIAN; TALBOT, 2011).

Figura 1 - Componentes básicos de um Dispositivo Eletrônico Para Fumar

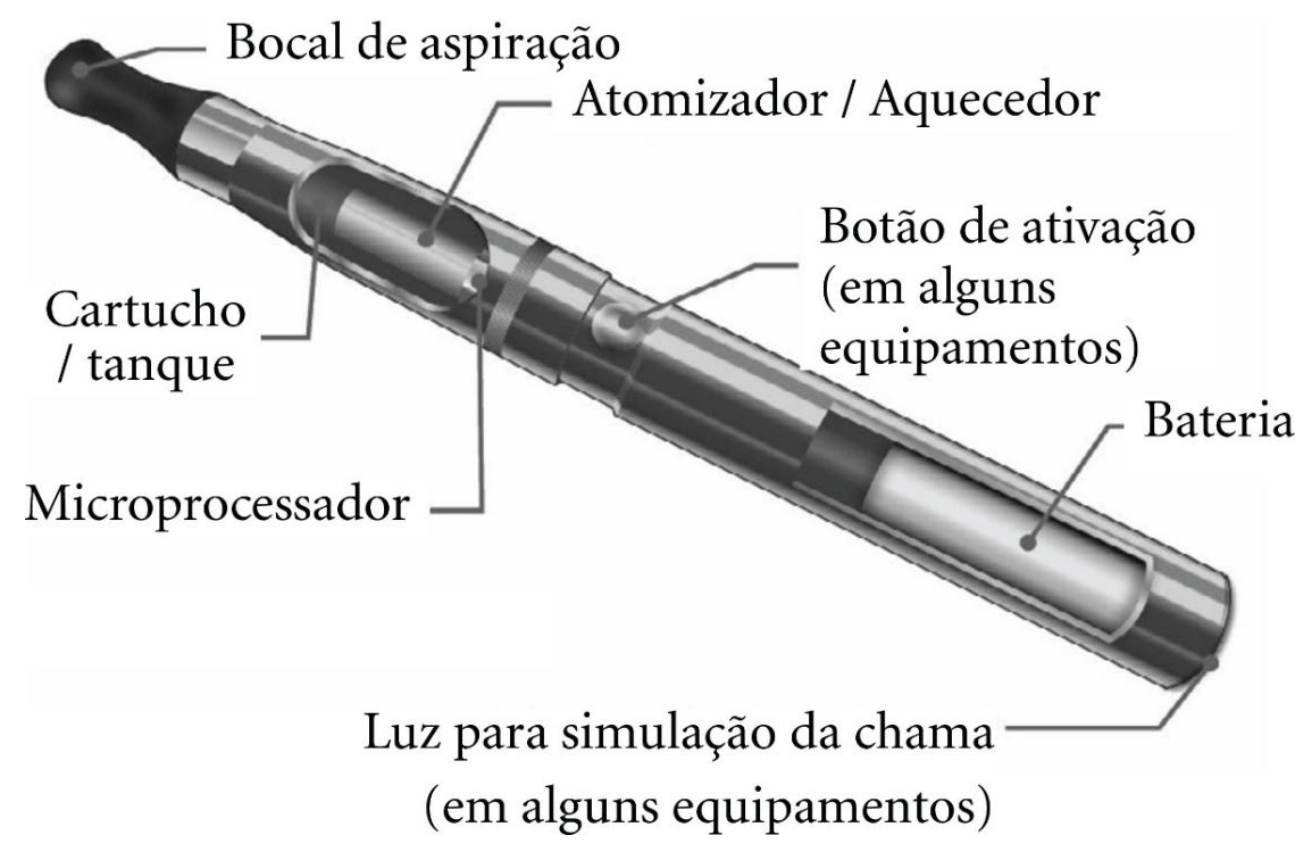

Fonte: (SILVA; MOREIRA, 2019 apud U. S. Fire Departament, 2014)

A bateria será responsável pela geração de calor a partir da energia, para o atomizador, um componente intermediário atuante na etapa de transferência do calor gerado de forma constante para o reservatório. No reservatório é abrigado o líquido - também chamado de e-liquid ou e-juice, contendo propileno glicol ou glicerina vegetal, podendo ou não apresentar nicotina e flavorizantes, que serão volatizados para que vapores gerados sejam inalados através do bocal pelo consumidor (CDC, 2020; CAPONNETO et al., 2012).

Apesar da não convenção formal de termos, a aspiração do aerossol gerado de um Dispositivo Eletrônico para Fumar é, geralmente, denominada vaping, ao passo que a aspiração da fumaça gerada na combustão do cigarro convencional, fumo. A prática de volatilizar óleos essenciais concentrados de ervas, incluindo de Cannabis sativa é informalmente denominada dab ou dabbing. Há também a modalidade mista, onde inala-se uma mistura de tabaco com derivados da maconha, que recebe o nome de mooking (URBAN DICIONARY, 2020).

Uma das problemáticas de funcionamento da primeira geração de Sistemas Eletrônicos de Liberação de Nicotina vem do processo de aquecimento dessa substância, com reduzida disponibilidade sanguínea para o praticante de vaping em relação ao tabagista convencional (YINGST et al.,2019). Isso se dá pela natureza de base fraca da molécula de nicotina. Isto é, em pH ácido na fumaça por 
combustão do cigarro convencional, sua liberação ocorre na forma protonada, com baixa absorção pela mucosa oral, mas rápida absorção pulmonar, promovida pela extensa área de superfície de contato dos alvéolos e ágil incremento na corrente sanguínea e chegando ao cérebro rapidamente (ROSEMBERG, 1985; BENOWITZ, HUKKANEN; JACOB, 2009).

Entretanto, em produtos derivados do tabaco que possuem fumaça alcalina, como é o caso do cachimbo e do charuto, a maior fase de absorção se dá na mucosa oral, pela natureza não protonada da molécula, uma vez que o processo de difusão ocorre com maior facilidade nas barreiras biológicas com a nicotina não carregada (em base livre). A absorção oral, além de mais lenta, é mais atingida pelo efeito de primeira passagem no fígado, que reduz a chegada a nicotina ao cérebro. (BENOWITZ, HUKKANEN; JACOB, 2009). Além disso, a absorção oral está associada às maiores taxas de câncer de boca e orofaringe desse segmento de consumidores (ROSEMBERG, 1985). Vale ressaltar que o aerossol gerado pelo cigarro eletrônico possui $\mathrm{pH}$ maior que a fumaça do cigarro convencional (NATIONAL ACADEMIES OF SCIENCES, ENGINEERING, AND MEDICINE, 2018).

$\mathrm{O}$ aumento da concentração de nicotina em base livre nas fórmulas de e-liquid, no entanto, oferecem sensações desconfortáveis na garganta dos usuários. Para aumentar o $\mathrm{pH}$ e, consequentemente, a maior disponibilidade da nicotina, a indústria de e-Cigs formulou os sais de nicotina, a partir da incorporação de um ácido (GHOLAP et al., 2020), podendo ser esse o benzoico, lático, levulínico, salicílico, málico ou tartárico (HARVANKO et al., 2020).

A criação de um sal que liberasse quantidades maiores de nicotina permitiu a reprodução do aporte encontrado no cigarro tradicional, promovendo também diferentes sensações, com alterações organolépticas associadas aos flavorizantes - aditivos comuns no reservatório, em que as consequências do uso recorrente ainda não foram amplamente estudadas, além de representarem um maior fator viciante (DUELL; PANKOW; PEYTON, 2020).

Figura 2 - Formação química do sal de nicotina com emprego do ácido benzoico empregado nos no líquido dos DELN:

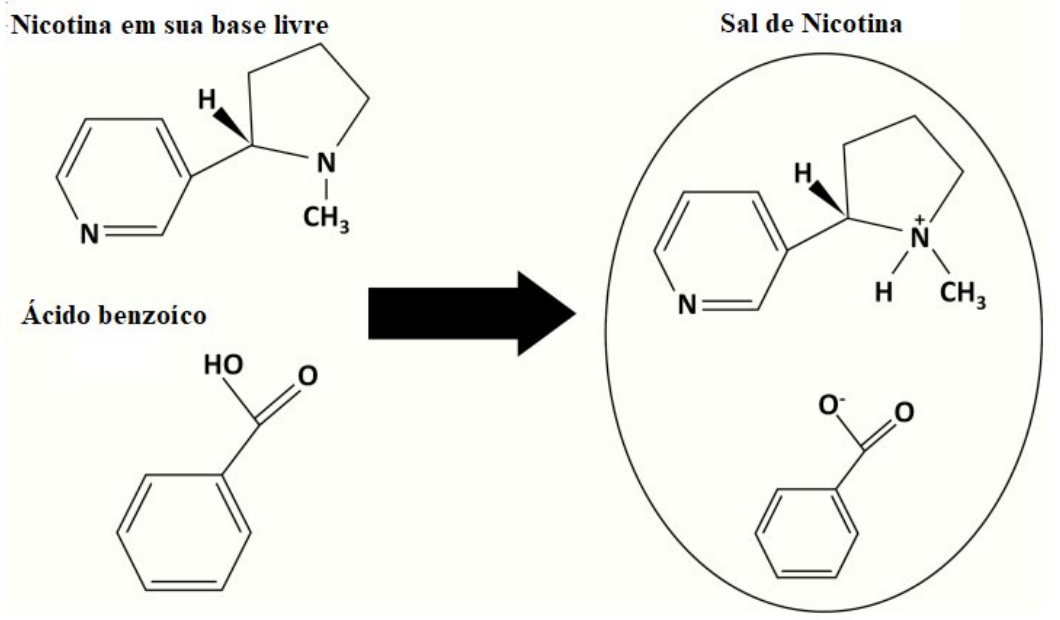

Fonte: HARVANKO et al., 2020. (Traduzido) 
Além disso, apesar da prática de vaping não consistir no contato com produtos da combustão do tabaco, seus aerossóis gerados já comprovaram serem dotados de expressivas quantidades de metais pesados, sabidamente reconhecidos como causadores de doenças respiratórias, tais como o alumínio, estanho, ferro, níquel, prata, silicato e cromo. Em geral, a maioria dos componentes metálicos estão presentes em maior ou igual quantidade no aerossol do $e$-Cig em relação à fumaça do cigarro tradicional (WILLIAMS et al., 2013).

\subsection{TIPOS OS TIPOS DE DISPOSITIVOS ELETRÔNICOS PARA FUMAR}

Em 2014, O número estimado de marcas de DEFs girava em 466, enquanto a quantidade de sabores, 7764, representando um desafio para a pesquisa científica e mesmo para a regulamentação sobre o design, uso, propaganda, embalagens e fabricação desses dispositivos. As concentrações de nicotina também não são padronizadas entre os fabricantes (ZHU et al., 2014).

A variabilidade de marcas e modelos pode ser descrita separando-se quatro gerações do produto pelos seus graus de funcionalidade. Entretanto, o design e a finalidade ou forma de uso também são caracterizantes dos produtos. (TRTCHOUNIAN; TALBOT, 2011).

Os Dispositivos Eletrônicos para Fumar podem ser denominados cig-a-likes, e-cigs, e-cigarettes, electronic hookah, e-hookah, hookah sticks, personal vaporizers ou vaporizadores, vapes, vaping devices, vape pens, mechanical MODs, e-pipes, e-cigars, dab pens, dab rigs, oil pens, tanks, MODs, POD-MODs, entre outros. Para aqueles que dispõe de nicotina em seu reservatório, cabe a nomenclatura generalista Dispositivo Eletrônico de Liberação de Nicotina, do inglês, ENDS.

A primeira geração de e-Cigs, conhecida popularmente como cig-a-likes, surgiu com a utilização limitada a uma ou poucas vezes, mimetizando o design e sensações do cigarro convencional, sendo estes dispositivos descartados ao término da bateria ou do líquido e de construção de uma peça única. Duas linhas de dispositivos marcaram o histórico de início dos cigarros eletrônicos: os completamente descartáveis e os com bateria recarregável (CDC, 2020; SILVA; MOREIRA, 2019).

A principal evolução da primeira para a segunda geração se deu pela possibilidade de utilização do dispositivo por múltiplas vezes, podendo ocorrer o reaproveitamento dos cartuchos com refil e a introdução de flavorizantes dos mais variados sabores, solventes ou mesmo óleos de extratos vegetais, incluindo as espécies de maconha. Nesse tipo de design, a bateria passa a ser destacável do reservatório (CDC, 2020). Nessa categoria encontram-se a maioria dos e-cigs, vapes, vape pens, dab pens e dab rigs.

$\mathrm{Na}$ terceira geração, encontram-se os dispositivos do tipo modificáveis (MODs), de preço mais elevado e os quais possuem não somente uma maior capacidade de armazenamento de líquido, como também a inserção de funcionalidades, tais como a inserção de bobinas personalizáveis, o controle de temperatura e de mistura das substâncias pelo usuário, com a opção de adição de um componente denominado Sub-Ohm Tank, utilizado para a realização de nuvem maior de aerossol para os entusiastas de vaping e usuários mais experientes (SILVA; MOREIRA, 2019, CDC, 2020). 
Voltado para usuários iniciantes, a quarta e mais recente geração de dispositivos, do tipo PODs, possui design arrojado e discreto, composto de dois dispositivos em separado, sendo um reservatório descartável e o dispositivo que efetivamente faz a volatilização. O preço acessível, somada à facilidade de uso e ao grande aporte de nicotina pelo emprego de sais dessa substância atrai ex-fumantes e o público jovem. Ademais, os gadgets do tipo POD-MODs, aliam as características específicas dos dispositivos da terceira geração, com a proposição de facilidade de uso e controle pelo usuário da quarta geração. (CDC, 2020)

\section{IMPACTOS PATOLÓGICOS DO TABAGISMO E DO USO DE DISPOSITIVOS PARA FUMAR}

\subsection{A SAÚDE SISTÊMICA E O TABAGISMO}

Existem 21 doenças estabelecidas como tabaco-relacionadas e provavelmente são elas que explicam a maior mortalidade entre fumantes quando comparada aos não fumantes; apesar de novos estudos apontarem para a possibilidade de tabagistas estarem morrendo por doenças que até então não eram relacionadas ao fumo, como o câncer de mama e próstata. Dentre as doenças já estabelecidas, estão:

- 12 tipos de câncer: câncer de lábio e da cavidade oral, câncer de esôfago, câncer de estômago, câncer colorretal, câncer de fígado, câncer de pâncreas, câncer de laringe, câncer de pulmão, câncer de bexiga, câncer de rim e pelve renal, leucemia mielóide aguda e câncer cervical;

- Doenças cardiovasculares, como doença cardíaca isquêmica, aterosclerose, aneurisma da aorta e derrame;

- Diabetes mellitus tipo II;

- Doenças respiratórias, como a doença pulmonar obstrutiva crônica e pneumonia, incluindo influenza (UNITED STATES DEPARTMENT OF HEALTH AND HUMAN SERVICES, 2014; THUN et al., 2013; CARTER et al., 2015).

Outrossim, o uso dos Dispositivos Eletrônicos de Liberação de Nicotina tem sido associado à grave doença pulmonar, denominada Injúria Pulmonar Relacionada ao Uso de Cigarro Eletrônico, do inglês, EVALI, e países como o Estados Unidos estão enfrentando um surto sem precedentes (CDC, 2019).

Os sintomas mais comuns da EVALI são a dispneia e tosse; os pacientes costumam apresentar hipoxemia e opacidades bilaterais pulmonares nas imagens do tórax. Muitos indivíduos necessitam de tratamento em unidade de terapia intensiva e uso de esteroides (KALININSKIY A, et al., 2019). A recomendação é não utilizar cigarros eletrônicos, vaporizadores e outros tipos de dispositivos seme- 
lhantes, pois as substâncias causadoras da lesão pulmonar desta patologia ainda não são conhecidas (CDC, 2019).

\subsection{A SAÚDE BUCAL E O USO DE TABACO}

Além de carcinomas orais, onde os tabagistas possuem de 2 a 3 vezes mais chances de desenvolverem esta patologia, o uso de tabaco está associado com o acometimento de diversas outras implicações orais, tais como melanoses na mucosa e lábios, pigmentação extrínseca do esmalte, halitose (NEVILLE, 2009), estomatite nicotínica, queratose (TAYBOS, 2003), leucoplasias (BÁNÓCZY; GINTNER; DOMBI, 2001), eritoplasias (ESTRADA PEREIRA et al., 2010), língua negra (YAN; MISTRY, 2010), doença periodontal (GAETTI-JARDIM JUNIOR; ZANOLI, 1998) e perimplantite (LINDHE; MEYLE, 2008).

Os cigarros eletrônicos não estão isentos de promover susceptibilidade a problemas bucais. As alterações teciduais causadas pela nicotina tanto pelo fumante convencional, quanto pelo de cigarros eletrônicos possuem similar perfil histopatológico, embora não somente a nicotina seja responsável pelos efeitos deletérios destes dispositivos, sendo os flavorizantes e aditivos químicos também atores importantes no processo de desbalanço tecidual na boca (CHEN; TODD; FAIRCLOUGH, 2019).

Entre as implicações a níveis teciduais promovidas pelo uso de cigarros eletrônicos e pelo cigarro tradicional há a diminuição da proliferação de osteoblastos, fibroblastos gengivais e células do ligamento periodontal, reduzida capacidade de migração celular, aumento de secreção de citocinas pró inflamatórias e produção de espécies reativas de oxigênio, além de modificações em citoesqueleto e matriz extracelular de células do epitélio gengival, aumento da expressão de BAX, um gene pró-apoptótico, bem como o aumento da atividade de Caspase-3, enzima também pró-apoptótica (CHEN; TODD; FAIRCLOUGH, 2019).

\section{A LEGISLAÇÃO DOS DISPOSITIVOS ELETRÔNICOS PARA FUMAR NO BRASIL}

A Agência Nacional de Vigilância Sanitária - ANVISA é o órgão deliberativo que possui em uma de suas atribuições a regulamentação, controle e fiscalização de produtos e serviços que incubem risco à saúde pública, dentre eles os produtos e serviços fumígenos, sejam aqueles que contenham ou não tabaco, de acordo com a Art. $8^{\circ}, \S 1^{\circ}$, inciso X da Lei no 9.782, de 26 de janeiro de 1999 (BRASIL, 1999).

Dentro deste cenário, a crescente popularidade de cigarros eletrônicos impulsionou a ANVISA em 2019 a vetar a comercialização, a propaganda e mesmo a importação de cigarros eletrônicos e de refis para utilização nestes produtos, bem como o fornecimento gratuito às crianças e adolescentes, através da Resolução de Diretoria Colegiada da Anvisa: RDC no 46, de 28 de agosto de 2009 - RDC 46/2009 (BRASIL, 2009), tendo como prerrogativa: 
Considerando a Convenção Quadro para Controle do Tabaco, promulgada através do Decreto 5.658 de 02 de janeiro de 2006; considerando a inexistência de dados científicos que comprovem a eficiência, a eficácia e a segurança no uso e manuseio de quaisquer dispositivos eletrônicos para fumar, conhecidos como cigarro eletrônico, em face da incidência do Princípio da Precaução, adota a seguinte Resolução e eu, Diretor Presidente Substituto, determino sua publicação:

Art. $1^{\circ}$ Fica proibida a comercialização, a importação e a propaganda de quaisquer dispositivos eletrônicos para fumar, conhecidos como cigarros eletrônicos, e-cigaretes, e-ciggy, ecigar, entre outros, especialmente os que aleguem substituição de cigarro, cigarrilha, charuto, cachimbo e similares no hábito de fumar ou objetivem alternativa no tratamento do tabagismo.

Parágrafo único. Estão incluídos na proibição que trata o caput deste artigo quaisquer acessórios e refis destinados ao uso em qualquer dispositivo eletrônico para fumar. [...] (BRASIL, 2009)

Além do supracitado, é estabelecida na RDC 46/2009 que a admissibilidade de DEFs pela ANVISA dependerá de registro, prevendo a mostra de dados científicos toxicológicos que venham a comprovar a intercambialidade do cigarro convencional por esses produtos. Ademais, os estudos conduzidos têm de estar em conformidade com metodologia internacionalmente reconhecida e aceita, para a avaliação de potencial risco à saúde do utilizador e contaminação ambiental com os compostos oriundos desses dispositivos (BRASIL, 2009).

Embora o veto de comercialização exista, o uso de cigarros eletrônicos não é considerado crime e a rigorosidade de fiscalização mostra-se reduzida se comparada aos cigarros tradicionais. A venda segue de forma ilegal (ALMEIDA et al.,2017), sendo possível encontrar esse produto em sites especializados e ou mesmo em lojas varejistas virtuais populares.

\section{LIDANDO COM O TABAGISMO: O INCENTIVO À CESSAÇÃO DO USO DE TABACO PELO CIRURGIÃO-DENTISTA}

O Conselho Regional de Odontologia do Rio de Janeiro publicou em 2020 o "Manual Para Controle E Prevenção Do Tabagismo Por Cirurgiões-Dentistas" onde enfatiza o papel que o cirurgião-dentista, como profissional da saúde, tem na prevenção e controle do tabagismo, destacando que as consultas de rotina/revisão são uma ótima oportunidade para orientação dos pacientes. O consultório odontológico deve ser um ambiente livre de tabaco, com materiais alertando sobre os malefícios causados pelo tabaco e os benefícios da cessação deixados a mostra na recepção (OLIVEIRA \& BARROS, 2020).

Pacientes que não fumam devem ser orientados a nunca iniciar e fumantes devem ser sempre encorajados a pararem de fumar. Para os tabagistas, a consulta pode incluir informações a respeito das lesões e doenças que o tabaco pode causar na cavidade bucal e no corpo e imagens comparando bocas de fumantes e não fumantes podem ser exibidas. Aos pacientes que já apresentam lesões e/ou doenças na cavidade oral, é possível mostrar no espelho, com a finalidade do indivíduo identificar o problema e buscar a solução (OLIVEIRA \& BARROS, 2020). 
O diálogo com o paciente e uma boa avaliação inicial são essenciais para o planejamento do tratamento de cessação. O cirurgião-dentista deve limitar seu trabalho, neste ponto, ao aconselhamento, instrução, orientação e encaminhamento do paciente. Alguns fumantes podem precisar de acompanhamento com médicos e/ou psicólogos. Em casos onde há necessidade de terapia farmacológica, o acompanhamento médico é fundamental e estes são os únicos habilitados a prescreverem medicações com a finalidade de cessação do tabagismo (OLIVEIRA \& BARROS, 2020).

Entre as abordagens existentes para cessação do tabagismo, destacam-se as intervenções motivacionais, com ou sem o acompanhamento de terapia comportamental cognitiva; a farmacoterapia quando a abordagem comportamental se mostra insuficiente frente à dependência química da nicotina e as terapias de reposição de nicotina (TRNs), composta por diferentes apresentações que variam em tempo de liberação rápido ou lento dessa substância para o paciente. Há também a possibilidade do emprego de terapias combinadas, onde a reposição de nicotina é associada com medidas farmacológicas (REICHERT et al.,2008).

Entre os fatores elencados passíveis de dificultar cessação, encontram-se a baixa motivação, a síndrome de abstinência, o grau de dependência, a personalidade do paciente, o acometimento por doenças psiquiátricas e alterações para o peso corporal. Entretanto, mesmo para pacientes que não consigam efetuar a cessação, é preconizada a redução de danos através da diminuição do consumo de tabaco ao dia (REICHERT et al.,2008).

O uso de cigarros eletrônicos como constituinte das TRNs, entretanto, carece de consenso na comunidade científica, reforçando assim a necessidade de condução de mais estudos para esclarecimentos técnicos em relação a eficácia e segurança desse dispositivo, que constatem o risco reduzido para os usuários de cigarros convencionais, mas que não recaiam em expansão de tabagismo em outros nichos populacionais, especialmente adolescentes e jovens adultos.

Por fim, é possível inferir que antes da inserção de e-Cigs na terapia de cessação tabágica, é necessária também uma padronização e regulamentação dos processos produtivos, do uso e do descarte destes dispositivos, a fim de se prevenir consequências deletérias para a saúde dos indivíduos e o meio ambiente.

A dimensão do cuidado que o cirurgião-dentista pode abranger através da difusão do conhecimento e das orientações para a cessação do tabagismo devem fazer parte de sua formação e de sua atuação profissional. Desta forma, o cirurgião-dentista é capaz de proporcionar aos seus pacientes e à população uma atuação como um profissional da saúde dedicado a contribuir para que o tabagismo e suas novas formas de uso não prejudiquem a saúde humana. 


\section{REFERÊNCIAS}

ALMEIDA, Liz Maria de et al. Névoas, vapores e outras volatilidades ilusórias dos cigarros eletrônicos. Cadernos de Saúde Pública, v. 33, p. e00139615, 2017.

ANVISA. Resolução RDC n 62, de 22 de dezembro 2010. Dispõe sobre as embalagens e os materiais de propaganda e os pontos de venda dos produtos fumígenos derivados do tabaco. Brasília.

BALBANI, Aracy Pereira Silveira; MONTOVANI, Jair Cortez. Métodos para abandono do tabagismo e tratamento da dependência da nicotina. Revista Brasileira de Otorrinolaringologia, v. 71, n. 6, p. 820-827, 2005.

BÁNÓCZY, Jolán; GINTNER, Zeno; DOMBI, Csaba. Tobacco use and oral leukoplakia. Journal of Dental Education, v. 65, n. 4, p. 322-327, 2001.

BENOWITZ, N. L.; HUKKANEN, J.; JACOB, P. Nicotine, chemistry, 21ublicações, kinetics and biomarkers. Handb. Exp. Pharmacol., v. 192, p. 29 - 60, 2009.

BRASIL, 1999. Lei no 9.782, de 26 de janeiro de 1999. Define o Sistema Nacional de Vigilância Sanitária, cria a Agência Nacional de Vigilância Sanitária, e dá outras providências. Disponivel em: < http://www. planalto.gov.br/ccivil_03/Leis/L9782.htm>. Acesso em: 13 dez. 2020.

BRASIL. MINISTÉRIO DA SAÚDE. AGÊNCIA NACIONAL DE VIGILÂNCIA SANITÁRIA, 2009. Resolução da Diretoria Colegiada - RDC n ${ }^{\circ}$ 46, de 28 de agosto de 2009. Proíbe a comercialização, a importação e a propaganda de quaisquer dispositivos eletrônicos para fumar, conhecidos como cigarro eletrônico. Disponível em: <http://bvsms.saude.gov.br/bvs/saudelegis/anvisa/2009/res0046_28_08_2009.html>. Acesso em: 13 dez. 2020

BRASIL. Organização Pan-Americana de Saúde. Organização Mundial da Saúde. Folha Informativa - Tabaco, OPAS/OMS. Brasil, 2019. Página inicial. Disponível em: https://www.paho.org/bra/index.php?option=com_content\&view=article\&id=5641:folha-informativa-tabaco\&Itemid=1097. Acesso em: $12 \mathrm{dez} .2020$.

BRASIL. Organização Pan-Americana de Saúde. Organização Mundial da Saúde. TABAGISMO, OPAS/ OMS. Brasil, 2018. Página inicial. Disponível em: https://www.paho.org/bra/index.php?option=com_content\&view=article\&id=5641:folha-informativa-tabaco\&Itemid=1097. Acesso em: $12 \mathrm{dez} .2020$

CAPONNETTO, Pasquale et al. The emerging phenomenon of electronic cigarettes. Expert Review of Respiratory Medicine, v. 6, n. 1, p. 63-74, 2012.

CARTER, Brian D. et al. Smoking and mortality—beyond established causes. New England journal of medicine, v. 372, n. 7, p. 631-640, 2015.

CDC - Centers for Disease Control and Prevention. (2020b) E-cigarette, or vaping, products visual dictionary. Disponível em: https://www.cdc.gov/tobacco/basic_information/e-cigarettes/pdfs/ecigarette-or-vaping-products-visual-dictionary508.pdf. Acesso em: 12 dez. 2020.

CDC. Outbreak of lung injury associated with e-cigarette use, or vaping. Atlanta, GA: US Department of Health and Human Services, Centers for Disease Control and Prevention-CDC; 2019.

CHEN, I.-Ling; TODD, Ian; FAIRCLOUGH, Lucy C. Immunological and pathological effects of electronic cigarettes. Basic \& Clinical Pharmacology \& Toxicology, v. 125, n. 3, p. 237-252, 2019.

DA SILVA, Luiz Carlos Corrêa et al. Controle do tabagismo: desafios e conquistas. Jornal Brasileiro de Pneumologia, v. 42, n. 4, p. 290-298, 2016. 
DELUCIA R, Planeta CS, GALLACI M, Avellar MCW, Oliveira Filho RM. Farmacologia Integrada. 3. ed. Rio de Janeiro: Editora Revinter, 2007

DROPE, Jeffrey et al. The Tobacco Atlas. Atlanta, GA: American Cancer Society. Inc. and Vital Strategies, 2018.

DUELL, Anna K.; PANKOW, James F.; PEYTON, David H. Nicotine in tobacco product aerosols: 'It's déjà vu all over again'. Tobacco Control, v. 29, n. 6, p. 656-662, 2020.

ESTRADA PEREIRA, Gladys Aída et al. Diagnóstico clínico e histopatológico de la eritroplasia bucal. Medisan, v. 14, n. 4, p. 0-0, 2010.

FRANCK, Caroline et al. Electronic cigarettes in North America: history, use, and implications for smoking cessation. Circulation, v. 129, n. 19, p. 1945-1952, 2014.

GAETTI-JARDIM JUNIOR, E; ZANOLI, T; PEDRINI, D. O tabagismo como fator de risco para as doenças periodontais: aspectos microbiológicos. Rev Odontol Univ São Paulo, São Paulo, v. 12, n. 4, p. 315-321, Oct. 1998.

GOODMAN, L. S.; GILMAN. As Bases Farmacológicas da Terapêutica. 12 ed. Rio de Janeiro: McGraw-Hill. 2012. 2112p.

HARVANKO, Arit M. et al. Characterization of Nicotine Salts in 23 Electronic Cigarette Refill Liquids. Nicotine and Tobacco Research, v. 22, n. 7, p. 1239-1243, 2020.

INCA. Instituto Nacional de Câncer José Alencar Gomes da Silva. Atitudes e crenças, In: Narguilé: o que sabemos? Martins S. (org.). Instituto Nacional de Câncer José Alencar Gomes da Silva. - Rio de Janeiro: INCA, 2019, p. 30. https://www.inca.gov.br/publicacoes

IRIBARREN, Carlos et al. Effect of cigar smoking on the risk of cardiovascular disease, chronic obstructive pulmonary disease, and cancer in men. New England Journal of Medicine, v. 340, n. 23, p. 1773-1780, 1999.

KALININSKIY, Aleksandr et al. E-cigarette, or vaping, product use associated lung injury (EVALI): case series and diagnostic approach. The Lancet Respiratory Medicine, v. 7, n. 12, p. 1017-1026, 2019.

LIM, Stephen S. et al. A comparative risk assessment of burden of disease and injury attributable to 67 risk factors and risk factor clusters in 21 regions, 1990-2010: a systematic analysis for the Global Burden of Disease Study 2010. The Lancet, v. 380, n. 9859, p. 2224-2260, 2012.

LINDHE, Jan; MEYLE, Joerg; GROUP D OF THE EUROPEAN WORKSHOP ON PERIODONTOLOGY. Peri-implant diseases: consensus report of the sixth European workshop on periodontology. Journal of clinical periodontology, v. 35, p. 282-285, 2008.

MARQUES, Ana Cecilia et al. Consenso sobre o tratamento da dependência de nicotina. Revista Brasileira Psiquiatria, São Paulo, v. 23, n. 4, p. 200-214, Dec. 2001.

MAZIAK W. The waterpipe: time for action. Addict Abingdon Engl. 2008 Nov;103(11):1763-7.

NATIONAL ACADEMIES OF SCIENCES, ENGINEERING, AND MEDICINE et al. Public health consequences of e-cigarettes. National Academies Press, 2018.

NEERGAARD, James et al. Waterpipe smoking and nicotine exposure: a review of the current evidence. Nicotine \& tobacco research, v. 9, n. 10, p. 987-994, 2007.

NEVILLE, B. Patologia Oral e Maxilo Facial. 3. ed. São Paulo: Elsevier, 2009. 
OLIVEIRA, Tammy Martins \& BARROS, Maria Cynésia Medeiros de. Manual para Controle e Prevenção do Tabagismo por Cirurgiões-Dentistas. Conselho Regional de Odontologia. Rio de Janeiro, 2020. Disponível em: https://www.cro-rj.org.br/noticia-38-manual-sobre-prevencao-do-tabagismo-para-cirurgioes-dentistas. Acesso em: 13 dez. 2020

OMS/OPAS- Décima Revisão de Classificação Estatística Internacional de Doenças e Problemas Relacionados à Saúde (CID-10-1997), EDUSP, vol. 1, 1997.

PINTO, Marcia et al. Carga de doença atribuível ao uso do tabaco no Brasil e potencial impacto do aumento de preços por meio de impostos. Instituto de Efectividad Clinica y Sanitaria, Buenos Aires, Argentina. Maio, 2017.

REICHERT, Jonatas et al. Diretrizes para cessação do tabagismo-2008. Jornal Brasileiro de Pneumologia, v. 34, n. 10 , p. 845-880, 2008.

ROSE, Jed E. et al. PET studies of the influences of nicotine on neural systems in cigarette smokers. American Journal of Psychiatry, v. 160, n. 2, p. 323-333, 2003.

ROSEMBERG, José. Nicotina: droga universal. 1985. p. 240-240. Disponível em: <https://sbpt.org.br/portal/wp-content/uploads/2019/01/LIVRO-NICOTINA-PROF-ROSEMBERG-2003.pdf > Acesso em: 13 dez. 2020

SILVA, André Luiz Oliveira da; MOREIRA, Josino Costa. A proibição dos cigarros eletrônicos no Brasil: sucesso ou fracasso?. Ciência \& Saúde Coletiva, v. 24, p. 3013-3024, 2019.

SINGH, Devina; LIPPMANN, Steven. Vaping medical marijuana, Postgraduate Medicine, v.130. n.2 p. 183$185,2018$.

SOCIEDADE BRASILEIRA DE PNEUMOLOGIA E TISIOLOGIA et al. Manual de condutas e práticas em tabagismo. São Paulo: AC Farmacêutica, 2012.

TAYBOS, George. Oral changes associated with tobacco use. The American journal of the medical sciences, v. 326, n. 4, p. 179-182, 2003.

THUN, M et al. 50-Year Trends in Smoking-Related Mortality in the United States. New England Journal of Medicine, [s.1.], v. 368, n. 4, p.351-364, 24 jan. 2013.

TRTCHOUNIAN, Anna; TALBOT, Prue. Electronic nicotine delivery systems: is there a need for regulation?. Tobacco Control, v. 20, n. 1, p. 47-52, 2011.

U.S. DEPARTMENT OF HEALTH AND HUMAN SERVICES. The Health Consequences of Smoking: 50 Years of Progress. A Report of the Surgeon General. Atlanta, GA: U.S. Department of Health and Human Services, Centers for Disease Control and Prevention, National Center for Chronic Disease Prevention and Health Promotion, Office on Smoking and Health, 2014. Printed with corrections, January 2014.

URBAN DICIONARY. Disponível em: <https://www.urbandictionary.com/> Acesso em: 13 dez. 2020

VIEGAS, Carlos Alberto de Assis. Formas não habituais de uso do tabaco. Jornal Brasileiro de Pneumologia, v. 34, n. 12, p. 1069-1073, 2008..

WALLEY, Susan C; JENSSEN, Brian P. Electronic nicotine delivery systems. Pediatrics, v. 136, n. 5, p. 10181026, 2015.

WHO. WORLD HEALTH ORGANIZATION. Global status report no communicable diseases 2010. Description of the global burden of NCDs, their risk factors and determinants. Genebra: Who Library, 2011.

WHO. WORLD HEALTH ORGANIZATION. Report on the Global Tobacco Epidemic 2008: The MPOWER Package. Genebra: Who Library, 2008. 
WHO. WORLD HEALTH ORGANIZATION. WHO report on the global tobacco epidemic 2013. Genebra: Who Library, 2013.

WILLIAMS, Monique et al. Metal and silicate particles including nanoparticles are present in electronic cigarette cartomizer fluid and aerosol. PloS one, v. 8, n. 3, p. e57987, 2013.

YAN, P; MISTRY N; AU S. Dermacase: can you identify this condition? Black hairy tongue. CanFam Phys. 2010 May; 56 (5): 439-41

YINGST, Jessica M. et al. Nicotine absorption during electronic cigarette use among regular users. PloS one, v. 14, n. 7, p. e0220300, 2019.

ZHU, Shu-Hong et al. Four hundred and sixty brands of e-cigarettes and counting: implications for product regulation. Tobacco control, v. 23, n. suppl 3, p. iii3-iii9, 2014. 


\section{CÂNCER DE MAMA ACESSÓRIA: REVISÃO DE LITERATURA}

EDUARDO FRANCO CORREIA CRUZ FILHO

Centro Universitário de João Pessoa

ANNA JULIE MEDEIROS CABRAL

Centro Universitário de João Pessoa

CAMILA ARAÚJO NOVAIS LIMA

Centro Universitário de João Pessoa

FRANÇUELDA PEREIRA DA NÓBREGA

MARQUES

Centro Universitário de João Pessoa

GABRIEL LUCENA DE CARVALHO

SOARES

Centro Universitário de João Pessoa

SAMUEL ESTRELA DE ABRANTES

Centro Universitário de João Pessoa

ANA SUZY DE GOIS MELO CRUZ

Médica formada pela Universidade Federal do Rio

Grande do Norte

BRUNO ARAÚJO NOVAIS LIMA

Médico formado pela Faculdade de Medicina Nova

Esperança

RESUMO: O câncer de mama acessória tem incidência de $0,3 \%$ considerando todos os carcinomas mamários e trata-se de um problema raro e pouco estudado, portanto de difícil diagnóstico que está associado com a polismatia que afeta aproximadamente $6 \%$ da população, principalmente mulheres. A partir disso, este estudo teve como prioridade trazer uma abordagem ao câncer de mama acessória de uma maneira epidemiológica e fisiopatológica. Para atingir esse objetivo foi utilizado uma pesquisa narrativa de literatura do tipo descritiva, com uma abordagem qualitativa. A pesquisa foi realizada em dezembro de 2020, utilizando a base de dados eletrônica da Biblioteca Virtual em Saúde (BVS). Além disso, nos casos abordados foi comprovada a presença de câncer, todos apresentavam, também, manifestações da presença da mama acessória, seja na autoestima, seja com repercussões fisiopatológicas, ainda sobre esse tema, a baixa incidência não é justificativa para a ausência de vigilância dos casos de mama acessória. Pelo contrário, a tendência analisada no presente estudo demonstra agressividade desses tumores que, além de difícil e tardio diagnóstico, apresentam malignidade em aproximadamente $81 \%$ dentre os 13 casos estudados. Ademais, sobre os tumores de mama acessória, cabe ponderar seus tipos mais comuns e confrontá-los com os achados dos artigos. Os tipos mais recorrentes de tumor encontrados no presente estudo foram tumores malignos, dos quais o carcinoma ductal invasivo sobressai-se, representando 56,25\% dos casos. Apareceram também carcinomas lobulares invasivos $(18,75 \%)$, fibroadenomas $(18,75 \%)$ e apenas um tumor triplo negativo $(6,75 \%)$. Portanto, observa-se a relevância do tema, bem como maior necessidade de divulgação de informações acerta dessa comorbidades.

PALAVRA-CHAVE: Carcinoma Mamário Humano; Neoplasias Da Mama; Mama.

ABSTRACT: Accessory breast cancer has an incidence of $0.3 \%$ considering all breast carcinomas and it is a rare and poorly studied problem, therefore difficult to diagnose, which is associated with the polysmatia that affects approximately $6 \%$ of the population, mainly women. From this, this study had as a priority to bring an approach to accessory breast cancer in an epidemiological 
and pathophysiological way. To achieve this goal, a descriptive literature narrative research with a qualitative approach was used. The research was carried out in December 2020, using the electronic database of the Virtual Health Library (VHL). In addition, in the cases addressed, the presence of cancer was proven, all also showed manifestations of the presence of the accessory breast, either in self-esteem or with pathophysiological repercussions, even on this topic, the low incidence is not a reason for the lack of surveillance of accessory breast cases. On the contrary, the trend analyzed in the present study demonstrates the aggressiveness of these tumors, which, in addition to being difficult and late diagnosis, present malignancy in approximately $81 \%$ among the 13 cases studied. Furthermore, regarding accessory breast tumors, it is worth considering their most common types and comparing them with the findings of the articles. The most recurrent types of tumor found in the present study were malignant tumors, of which invasive ductal carcinoma stands out, representing $56.25 \%$ of cases. Invasive lobular carcinomas (18.75\%), fibroadenomas $(18.75 \%)$ and only one triple negative tumor $(6.75 \%)$ also appeared. Therefore, the relevance of the theme is observed, as well as a greater need to disseminate information about this comorbidities.

KEYWORDS: Human Breast Carcinoma; Breast Neoplasms; Breast.

\section{INTRODUÇÃO}

A mama é um órgão par localizado na parte ânterosuperior do tórax, delimitada posteriormente pelo músculo peitoral maior, sendo constituída por ductos, lobos e estroma. A glândula mamária é uma espécie de glândula sudorípara apócrina modificada, que possui grau elevado de especialização. O desenvolvimento tem início entre a quarta e a sexta semana gestacional, sendo formada principalmente por dois folhetos embrionários, o ectoderma e a mesoderma. O tecido epitelial é composto pelas células ectodérmicas, e os vasos sanguíneos e linfáticos, tecido adiposo, entre outros componentes da mama, são compostos pelas células mesodérmicas (ORSINE, 2016).

O ectoderma emite faixas espessas desde as regiões axilares até as inguinais, formando as cristas mamárias, que transformam-se em botões, passando por um processo de transição, que permite a mudança do fenótipo celular, transfigurando-se de uma célula epitelial para mesenquimal. Os botões ramificam-se em brotos primários e estes em brotos secundários, que são canalizados em aproximadamente 15 a 20 ductos lactíferos ao fim do período gestacional, induzidos pelos hormônios sexuais femininos. Nessa etapa, a epiderme forma uma fosseta mamária rasa, que gera o mamilo, que estará em contínuo desenvolvimento, sendo completamente constituído na puberdade (ORSINE, 2016).

O desenvolvimento das mamas ocorre semelhantemente no sexo masculino e feminino. Contudo, as mamas femininas sofrem algumas mudanças, como o aumento da glândula e o amadurecimento dos ductos lactíferos, mediante alterações hormonais. Sendo assim, as cristas mamárias formam ao longo do processo dois pontos focais, caso um persista ou involua 1 de forma incompleta, restando vestígios, há possibilidade de gerar a mamá acessória com ou sem a presença da estrutura mamilo-areolar (ORSINE, 2016).

Portanto, quando há a formação do tecido mamário supranumerário, o indivíduo possui a polimastia - presença de uma mama acessória completa ou incompleta. Esse quadro atinge cerca de 1 a $5 \%$ da população, ocorrendo geralmente nas regiões axilares - mais prevalentes - e abdominais, sendo predominante no sexo feminino. Outrossim, é classificada em aberrante, caso esteja presente a 
glândula sem o mamilo e/ou a aréola, ou ectópica, que possui todas as estruturas tradicionais. A mama acessória pode sofrer alterações e mutações, sendo suscetível, assim como a mama normoimplantada à neoplasias benignas e malignas (SANTOS JUNIOR, 2016).

A politelia é um termo que se refere a presença de um mamilo extranumerário, sendo considerado pela literatura como uma anomalia congênita benigna, que é frequente no sexo masculino. Embora seja congênito, geralmente só é diagnosticado após períodos como a puberdade, gravidez e lactação, quando o mamilo apresenta manifestações clínicas como edema, dor e eliminação de secreções. Ademais, a politelia permanece despercebida, frequentemente, devido aos seus aspectos macroscópicos, semelhantes aos nevos, verrugas, lipomas e fibromas (SANTOS JUNIOR, 2016).

O quadro da polimastia ou politelia é encarado diversas vezes como um imbróglio associado apenas a aspectos relacionados à estética, interferindo na autoestima do paciente. Por conseguinte, os pacientes procuram os especialistas para exérese dessa variação anatômica, que precisa de acompanhamento contínuo e progressivo, com rastreamento, e em todos os casos, deve ser encaminhado para uma análise histopatológica. As células mutadas cancerígenas, geralmente se difundem através da rede linfática, gerando depósitos metastáticos de forma sistêmica. No câncer de mama, usualmente, o linfonodo axilar é o primeiro a receber as células cancerígenas, sendo denominado de linfonodo sentinela, sendo necessário a análise imediata pela patologia.

O Instituto Nacional do Câncer (INCA) estima que o Brasil, em 2020, 2021 e 2022, terá cerca de 625 mil novos casos de câncer a cada ano desse triênio. Desses dados, os novos casos de câncer de mama são aproximadamente 66.280 a cada ano, sendo o tipo carcinogênico que mais acomete as mulheres, em todas as regiões do país. Além de que, é previsto que as populações mais predominantes sejam da Região Sudeste (81,06 novos casos a cada 100.000 mulheres) e da Região Sul (71,6 a cada 100.000), seguidas da Região Centro-Oeste, Nordeste e Norte (INCA, 2019).

Todavia, a incidência do carcinoma de mama acessória corresponde a cerca de $0,3 \%$ de todos os casos de câncer de mama. Sendo assim, por apresentar baixa incidência, informações relevantes sobre esse quadro clínico são pouco disseminadas, tornando o diagnóstico mais complexo. Logo, por ser uma alteração com alta probabilidade de mutações e com elevado poder de propagação, é necessário que haja um estudo maior sobre o tema, e que a sua fisiopatologia seja abordada abrangentemente pela comunidade médica, tendo em vista um diagnóstico precoce e um melhor prognóstico (SANTOS JUNIOR, 2016).

\section{METODOLOGIA}

Trata-se de uma revisão narrativa de literatura, do tipo descritivo, com análise qualitativa. As buscas foram realizadas em dezembro de 2020, utilizando a base de dados eletrônica da Biblioteca Virtual em Saúde (BVS). Os Descritores em Ciências da Saúde (DeCs) utilizados nas buscas foram: "Carcinoma Mamário Humano", "Neoplasias da Mama", "Mama”, interligados aos operadores booleanos "AND" e "OR" para a conexão entre os termos supracitados. 
Foram estabelecidos os seguintes critérios de inclusão ou exclusão de um estudo: A) Inclusão: Estudos que abordassem o tema: polimastia ou câncer de mama, estudos publicados entre janeiro de 2015 e dezembro de 2020, sem restrições de idiomas. B) Exclusão: Anterior à 2015, resumo não se refere ao tema, estudo duplicado e texto de acesso restrito.

A triagem inicial dos estudos foi realizada na própria base de dados, primeiramente por meio da leitura dos títulos e resumos. Em seguida, os estudos elegíveis foram submetidos a uma leitura na íntegra. Ademais, diante da dificuldade em localizar estudos por se tratar de um tema relativamente raro, optou-se por consultar também as referências utilizadas pelos estudos já selecionados, com o objetivo de aumentar o embasamento do presente estudo.

Inicialmente foram localizados 46 resultados, que após passarem pelo processo de triagem resultaram em 15 estudos. A maior parte dos estudos foi publicada em 2020, com 4 artigos, o ano que obteve o menor índice de publicação foi 2015, com apenas 1 estudo selecionado. O quadro 1 mostra a caracterização dos estudos selecionados nessa revisão.

Quadro 1: Caracterização dos estudos selecionados

\begin{tabular}{|c|c|c|c|}
\hline $\mathbf{N}$ & ANO & TÍTULO & AUTOR \\
\hline 1 & 2015 & $\begin{array}{l}\text { Diagnosis and treatment of accessory breast cancer in } 11 \\
\text { patients }\end{array}$ & ZHANG, Shuo et al. \\
\hline 2 & 2016 & $\begin{array}{l}\text { Anatomy of the lymphatic drainage of the upper limb and } \\
\text { breast and its role in lymphedema prevention after breast } \\
\text { cancer treatment }\end{array}$ & CUADRADO, G. A. et al. \\
\hline 3 & 2016 & $\begin{array}{l}\text { Elaboração de via de desenvolvimento da glândula mamá- } \\
\text { ria e estimativa da origem dos seus genes e do sistema }\end{array}$ & ORSINE, Lissur Azevedo \\
\hline 4 & 2016 & Polimastia e politelia: imagem & $\begin{array}{l}\text { SANTOS JUNIOR, Luiz Ayrton; } \\
\text { EULÁLIO FILHO, Walberto } \\
\text { Monteiro Neiva; MEDEIROS } \\
\text { NETO, Antônio Marques de. }\end{array}$ \\
\hline 5 & 2017 & $\begin{array}{l}\text { Multiple bilateral fibroadenoma of the breast and axillary } \\
\text { accessory breast: case report }\end{array}$ & CONDE, Délio Marques et al. \\
\hline 6 & 2017 & $\begin{array}{l}\text { Conhecimento de mulheres sobre medidas de detecção pre- } \\
\text { coce do câncer de mama }\end{array}$ & SOARES, Lidia Santos et al. \\
\hline 7 & 2017 & $\begin{array}{l}\text { Câncer de mama axilar: Revisão da literatura sobre o tema } \\
\text { de um caso }\end{array}$ & $\begin{array}{l}\text { URIBE, Alonso; BERRIOS, Carla; } \\
\text { LI, Yang Yi. }\end{array}$ \\
\hline 8 & 2018 & $\begin{array}{c}\text { Diretrizes para detecção precoce do câncer de mama no } \\
\text { Brasil. II-Novas recomendações nacionais, principais evi- } \\
\text { dências e controvérsias }\end{array}$ & MIGOWSKI, Arn et al. \\
\hline 9 & 2018 & $\begin{array}{c}\text { Mama supernumeraria axilar. Presentación de un caso y } \\
\text { revisión de la literatura. }\end{array}$ & $\begin{array}{l}\text { TORRES AJA, Lidia; RAMÍREZ } \\
\text { RODRÍGUEZ, Tamara; PUERTO } \\
\text { LORENZO, José }\end{array}$ \\
\hline 10 & 2019 & Tratamento fisioterápico em pacientes pós mastectomia & LINHARES. A. E. M. S. \\
\hline 11 & 2019 & Seio supranumerário. Apresentação do caso & $\begin{array}{c}\text { MENÉNDEZ DÍAZ, Carlos } \\
\text { Antonio; SILVA BARRERA, Sheilly }\end{array}$ \\
\hline 12 & 2020 & Linfedema & CATALDO, J. L. \\
\hline 13 & 2020 & Câncer de mama ectópico axilar. Caso clínico & $\begin{array}{l}\text { COSSA, Juan; PRADERI, Luis; } \\
\text { MOURE, Luis }\end{array}$ \\
\hline 14 & 2020 & $\begin{array}{c}\text { Brasil terá } 625 \text { mil novos casos de câncer a cada ano do } \\
\text { triênio } 2020-2022\end{array}$ & $\begin{array}{l}\text { INSTITUTO NACIONAL DE } \\
\text { CÂNCER JOSÉ ALENCAR } \\
\text { GOMES DA SILVA }\end{array}$ \\
\hline 15 & 2020 & Fibroadenoma em mama acessória axilar: relato de caso & $\begin{array}{c}\text { LAPORTE, Bruno Eduardo Pereira } \\
\text { et al. }\end{array}$ \\
\hline
\end{tabular}

Fonte: Desenvolvido pelo autor 
Dentre os artigos selecionados para a confecção do presente artigo, destacam-se 05 (cinco) por relatarem casos de pacientes portadores de câncer de mama acessória, seja ele benigno ou maligno. Destes artigos, apenas dois (dois) trabalhos analisam o caso de mais de um paciente, sendo 02 (dois) casos e 11 (onze) casos, respectivamente. Então, a presente literatura selecionada será apresentada e confrontada à luz dos estudos mais recentes sobre o tema.

Primeiramente, trataremos dos casos benignos de câncer de mama acessória. Laporte et al. (2020) relata a história de uma jovem mulher de 23 anos que queixa-se de um nódulo palpável na axila. Fez-se, inicialmente, um ultrassom em seus seios e axila, que mostraram um nódulo irregular e sólido, com vascularização central ao doppler. Suas dimensões tornavam-o compatível com um BIRADS 4. A paciente foi submetida a um exame de biópsia por aspiração com pequena agulha. $\mathrm{O}$ resultado foi inconclusivo, porém, o médico e a paciente optaram pela excisão do nódulo. O exame anatomopatológico evidenciou uma neoplasia benigna, um fibroadenoma de mama axilar.

Também, é reportado no artigo de Tiwary, Kumar e Khanna (2015) dois casos distintos de cânceres igualmente benignos. Nesse sentido, trata-se de duas mulheres jovens (de 18 e 21 anos) portadoras de tumorações assintomáticas na região axilar. Para uma delas, é relatado que ao exame físico foi detectado que aquela tumoração possuía margens bem definidas, consistência firme e certa mobilidade. Ambas fizeram o exame de Citologia Aspirativa por Agulha Fina (CAAF) e biópsia de excisão, o que resultou em ambos os casos no diagnóstico de fibroadenoma de mama ectópica. Em ambos os casos, apesar de tratar-se de um tipo benigno de neoplasia, optou-se pela retirada cirúrgica do tumor.

Ademais, outro grande estudo, proposto por Zhang et al. (2015) analisou 11 (onze) pacientes acometidos pelo câncer de mama acessória. Segundo ele, todos os pacientes envolvidos na pesquisa são mulheres e tiveram seu diagnóstico confirmado histologicamente por meio de biópsia. Desses onze, 5 (cinco) notaram de início nódulos na área axilar direita, enquanto 6 (seis) na esquerda. $\mathrm{O}$ tamanho do tumor foi determinado por ultrassom, tomografia computadorizada (TC) ou ressonância magnética (RM). Todos os tumores eram imóveis, sólidos e de bordas irregulares. Desses, apenas 1 (um) apresentou aumento dos linfonodos ipsilaterais e 7 (sete) queixavam-se de dor axilar na região da tumoração. Os sintomas sistêmicos apresentados foram perda de peso, febre, suor noturno intenso, fraqueza hepatoesplenomegalia e edema de membros inferiores.

Ainda sobre os mesmos casos, a imunohistoquímica apontava sinais de neoplasia maligna. Isso porque, 8 (oito) foram identificados como carcinoma ductal invasivo e 3 (três) como carcinoma lobular invasivo. Foi feito o estadiamento patológico, que revelou 2 (dois) pacientes no estágio I da doença, 4 (quatro) no estágio II, 4 (quatro) no estágio III e 1 (um) no estágio IV. Metástases em linfonodos axilares foram encontradas em 5 pacientes. Nove desses tecidos eram receptores de estrogênio-positivo e sete progesterona-positivo. Apenas 4 (quatro) dos tumores não expressaram o receptor HER2. 
Descobertos os algozes, a cirurgia foi feita por um grupo de cirurgiões e os tumores retirados. Mastectomias radicais modificadas foram realizadas em 2 (dois) pacientes, enquanto ressecções de de mama e axila. Em 3 (três) casos, o tumor axilar foi considerado localmente avançado, tornando difícil a sua ressecção completa, o que requereu uma terapia quimioterápica neoadjuvante. Apesar disso, todos os pacientes fizeram de 2 a 8 ciclos de quimioterapia adjuvante (pós-cirúrgica). Ao final, apenas dois pacientes sucumbiram à doença e vieram a óbito.

Cossa, Praderi e Moure (2020) discorre sobre o caso de uma paciente de 39 anos que apresenta tecido ectópico bilateralmente na região axilar, com mama ectópica à direita, que secreta leite durante a amamentação de seus filhos, e nódulo à esquerda. à consulta, foi detectado tumor tinha em média $1 \mathrm{~cm}$ e foi requerido inicialmente mamografia e ecografia, que mostrou tumor de $10 \mathrm{~mm}$, sólido à eco, irregular e de aspecto suspeito para câncer (BIRADS 4). A punção mostrou carcinoma ductal invasivo grau 2, luminal B. A ressonância mamária, não informou alterações a nível mamário nem axilar, foi feita mastectomia axilar esquerda e ressecção do linfonodo sentinela. À biópsia, é identificado tumor com margens livres e biópsia do linfonodo sentinela mostra micrometástase de $3 \mathrm{~mm}$, o que leva à linfadenectomia axilar esquerda. Após isso tudo, ao estudo anatomopatológico foi detectado carcinoma ductal invasor luminal B (HER 2 negativo) e um segundo tumor infiltrante de características tubuloalveolares. Por fim, não é mencionado tratamento quimioterápico ou radioterápico adjuvante para o caso, apesar de considerar que esse tipo de tratamento segue a mesma lógica de cânceres de mama anatômicos.

Por último, Uribe, Berrios e Li (2017) relatam o caso de uma paciente de 41 anos que foi encaminhada ao médico especialista de mama devido à ecografia com presença nódulo axilar direito BIRADS 4 de $28 \mathrm{~mm}$. A biópsia informa neoplasia epitelial sólida pobremente diferenciada. Imunohistoquímica sugestiva de neoplasia primária de mama, subtipo molecular triplo negativo. Opta-se por ressecção axilar associado a um estudo de disseminação tumoral com tomografia axial computadorizada e cintilografia óssea, que dão negativo para metástases. A dissecção axilar mostrou 0/21 linfonodos comprometidos. Opta-se por quimioterapia e radioterapia ( $4 \mathrm{AC}+12$ Taxanos). A paciente tem boa evolução e encontra-se sem evidência de doença.

\section{RESULTADOS E DISCUSSÃO}

De início, cabe discorrer um pouco acerca da mama acessória e a sua repercussão na vida do portador. Isso porque mesmo nos casos abordados dos quais foi comprovada a presença de câncer, todos apresentavam, antes de tudo, manifestações da presença da mama acessória, seja na autoestima, seja com repercussões fisiopatológicas. Cossa, Praderi e Moure (2020) trazem em seu trabalho o caso de uma paciente que durante suas duas gestações era comum a ejeção de leite pelas suas mamas ectópicas na região axilar. Fora implicações estéticas, Uribe, Berrios e Li (2017) mostram que as alterações hormonais típicas da gestação, agem sobre as mamas ectópicas gerando crescimento e preparação para secretar leite, mas para além disso, outros sintomas podem ser descritos à parte, como inflamação, alterações pré menstruais, dor e dificuldade de mobilidade, dependendo do caso. 
Nesse sentido, cabe agora focar no principal problema envolvendo a mama acessória, a chance do desenvolvimento de câncer, maligno ou não, nessas estruturas. Como foi dito anteriormente, apenas $0,3 \%$ de todos os carcinomas mamários acometem mamas acessórias e, além disso, apenas $1 \%$ a $6 \%$ da população possuem polimastia. Esses dados de baixa incidência tornam, muitas vezes, o diagnóstico difícil, pois a baixa divulgação do tema e a dificuldade de autoconhecimento da mama acessória (quando assintomática), podem ser possíveis justificativas para o diagnóstico tardio em todos os casos analisados.

Ainda sobre esse tema, a baixa incidência não é justificativa para a ausência de vigilância dos casos de mama acessória. Pelo contrário, a tendência analisada no presente estudo demonstra agressividade desses tumores que, além de difícil e tardio diagnóstico, apresentam malignidade em aproximadamente $81 \%$ dos casos (13 pacientes). Apesar de a literatura reportar que os fibroadenomas são os principais tipos de neoplasias, segundo Zhang et al (2020), dentre outros autores, essa tendência não se repetiu no presente estudo, muito provavelmente devido ao pequeno espaço amostral. Foi encontrado, então, que os casos malignos apresentaram cada um tipos histológicos específicos, contudo, todos necessitaram de tratamento contundente, químico e cirúrgico, havendo, inclusive, desfecho negativo em uma minoria dos casos, representados por 02 óbitos pela doença.

Outro ponto passível de discussão é a localização anatômica da mama acessória, que em todos os casos estudados restringiu-se à região axilar. Isso corrobora com os estudos de Zhang et al (2015), que mostram $60 \%$ a $70 \%$ de incidência dos cânceres de mama acessória sobre a região axilar. Sendo assim, vale lembrar que a drenagem linfática, em especial da axila, ainda é pouco relatada na literatura, como sugere Cuadrado et al. (2016), ainda mais quando uma estrutura aberrante está presente. Quaisquer intervenções cirúrgicas na região da mama, seja a dissecção de um linfonodo sentinela, seja a mastectomia de mama acessória, ou não, podem estar relacionadas à ocorrência de linfedema, como sugere o mesmo autor.

Ademais, o rastreio do câncer de mama acessória é crucial para o diagnóstico precoce dessa doença. Então, são vários os exames que podem ser feitos para detectar sua presença, mas destaque-se aqui a importância do autoexame. Apesar das mais recentes contraindicações das literaturas especializadas a esse método, os resultados do presente trabalho mostram que em todos os casos o primeiro sinal de tumor nas mamas axilares foi pela palpação, posto que as pacientes não eram sintomáticas. Além disso, muitos dos pacientes nem reconhecem que possuem mamas acessórias e não sabem da necessidade de cuidados com elas, daí a importância do autoconhecimento.

Reconhecido o tumor, são requeridos outros exames para que seja possível propor uma melhor abordagem ao problema. Os exames de imagem foram de extrema importância para o estadiamento do tumor, nos casos abordados, enquanto as biópsias e imunohistoquímica foram pontos chave para a compreensão do tipo histológico e outros parâmetros do tumor. Segundo Zhang et al. (2015), Tomografia Computadorizada (CT), Ressonância Magnética (RM), exames de ultrassom e Positron Emiting Tomography (PET/CT) podem ser cruciais no diagnóstico diferencial do câncer de mama acessória. Já a mamografia, segundo o mesmo autor, pode contribuir com informações adicionais no sentido de avaliar melhor aquela axila e mama, em busca micro-calcificações, por exemplo. 
Sobre os tumores de mama acessória, cabe ponderar seus tipos mais comuns e confrontá-los com os achados dos artigos. Os tipos mais recorrentes de tumor encontrados no presente estudo foram tumores malignos, dos quais o carcinoma ductal invasivo sobressai-se, representando 56,25\% dos casos. Apareceram também carcinomas lobulares invasivos (18,75\%), fibroadenomas (18,75\%) e apenas um tumor triplo negativo (6,75\%). De cara, percebe-se uma discordância com a literatura vigente, pois, como foi citado anteriormente, o principal tipo de câncer de mama acessória é o fibroadenoma, que é benigno. Dentre os tipos malignos, de fato houve convergência com os relatos encontrados na literatura, que têm na figura do carcinoma ductal invasivo o mais comum dos cânceres malignos, segundo Zhang et al (2015), dentre outros autores.

Identificado o tipo de tumor, é de extrema importância a proposição de uma linha de tratamento. Primeiramente cabe destacar que a excisão cirúrgica dos tumores foi realizada em todos os casos, inclusive os benignos. Em apenas um caso, em que o tumor encontrava-se localmente avançado, foi necessária uma intervenção quimioterápica neoadjuvante. Os tumores benignos não se beneficiaram de tratamentos quimioterápicos posteriores (quimioterapia adjuvante), enquanto todos os malignos beneficiaram-se. Quanto ao esquema quimioterápico, todos os tumores de mama acessória foram individualizados posto o estadiamento do tumor, não sendo empregada radioterapia ou hormonioterapia nos casos estudados, apesar de ser possível a associação, segundo Uribe, Berrios e Li Z (2017), caso necessário.

\section{CONCLUSÃO}

Em vista dos argumentos apresentados, a mama acessória, que é um sinal de falha no desenvolvimento embrionário, é bastante preditiva de complicações que levam a um possível câncer e, por esse motivo, fica evidente a importância de sua remoção até mesmo em casos de benignidade, devido à possibilidade de malignidade. Além disso, por ser uma condição clínica de baixa incidência, e por apresentar escasso material sobre o assunto, a desinformação torna os pacientes sujeitos às possíveis complicações dessa condição clínica.

O controle do câncer de mama é uma das prioridades no plano dos estados e municípios através das políticas públicas, no desenvolvimento de ações que vão da promoção da saúde, numa consulta, nas campanhas educativas até os cuidados paliativos daqueles pacientes que estão enfrentando o tratamento e o sofrimento com a doença. Sendo assim é de suma importância a sequência de futuros trabalhos que possibilitem, na atenção básica, a instrução do auto exame como critério de indicação de busca por profissional na área médica, no intuito de levar o conhecimento sobre essa condição clínica e de concomitantemente diminuir os casos de óbito por causa dessa falha embrionária. 


\section{REFERÊNCIAS}

CATALDO, J. L. Linfedema. São Paulo, Sociedade Brasileira de Angiologia e Cirurgia Vascular, 2016. Disponível em: https://www.sbacv.org.br/artigos/medicos/linfedema. Acesso em: 19 Dez. 2020.

CONDE, Délio Marques et al. Multiple bilateral fibroadenoma of the breast and axillary accessory breast: case report. Rev Bras Mastologia, v. 27, n. 1, p. 69-73, 2017.

COSSA, Juan; PRADERI, Luis; MOURE, Luis. Câncer de mama ectópico axilar. Caso clínico. Revista Surgery, v. 72, n. 2 P. 160-163, 2020.

CUADRADO, G. A. et al. Anatomy of the lymphatic drainage of the upper limb and breast and its role in lymphedema prevention after breast cancer treatment. International Journal of Morphology, 2016.

INSTITUTO NACIONAL DE CÂNCER JOSÉ ALENCAR GOMES DA SILVA. Brasil terá $\mathbf{6 2 5}$ mil novos casos de câncer a cada ano do triênio 2020-2022. Rio de Janeiro: INCA, 2020. Disponível em: https://www. inca.gov.br/noticias/brasil-tera-625-mil-novos-casos-de-cancer-cada-ano-do-trienio-2020-2022. Acesso em: 19 Dez. 2020.

LAPORTE, Bruno Eduardo Pereira et al. Fibroadenoma em mama acessória axilar: relato de caso. Mastologia (online), p. 1-4, 2020.

LINHARES. A. E. M. S. Tratamento fisioterápico em pacientes pós mastectomia. 2019. 119 f. Dissertação (Mestrado em Ciências Médico-Cirúrgicas) - Faculdade de Medicina, Programa de Pós-Graduação em Ciências Médico-Cirúrgicas, Universidade Federal do Ceará, Fortaleza, 2019.

MENÉNDEZ DÍAZ, Carlos Antonio; SILVA BARRERA, Sheilly. Seio supranumerário. Apresentação do caso. Medical Scientific Mail, v. 23, n. 2 P. 666-671, 2019.

MIGOWSKI, Arn et al. Diretrizes para detecção precoce do câncer de mama no Brasil. II-Novas recomendações nacionais, principais evidências e controvérsias. Cadernos de Saúde Pública, v. 34, p. e00074817, 2018.

ORSINE, Lissur Azevedo. Elaboração de via de desenvolvimento da glândula mamária e estimativa da origem dos seus genes e do sistema. 2016. $144 \mathrm{f}$. Dissertação (Mestrado em Bioinformática) - Programa de Pós-graduação em bioinformática, Universidade Federal de Minas Gerais, Belo Horizonte, 2016.

SANTOS JUNIOR, Luiz Ayrton; EULÁLIO FILHO, Walberto Monteiro Neiva; MEDEIROS NETO, Antônio Marques de. Polimastia e politelia: imagem. Revista Brasileira de Mastologia, v. 26, n. 1, p. 24-25, 2016.

SOARES, Lidia Santos et al. Conhecimento de mulheres sobre medidas de detecção precoce do câncer de mama. HU Revista, v. 43, n. 2, p. 127-132, 2017.

TORRES AJA, Lidia; RAMÍREZ RODRÍGUEZ, Tamara; PUERTO LORENZO, José. Mama supernumeraria axilar. Presentación de un caso y revisión de la literatura. Revista Finlay, v. 8, n. 1, p. 75-79, 2018.

URIBE, Alonso; BERRIOS, Carla; LI, Yang Yi. Câncer de mama axilar: Revisão da literatura sobre o tema de um caso. Revista chilena de obstetrícia e ginecologia, v. 82, n. 4, pág. 416-423, 2017.

ZHANG, Shuo et al. Diagnosis and treatment of accessory breast cancer in 11 patients. Oncology letters, v. 10, n. 3, p. 1783-1788, 2015. 


\section{TRATAMENTO ODONTOLÓGICO DE PACIENTES COM COAGULOPATIA HEREDITÁRIA: HEMOFILIA E DOENÇA DE VON WILLEBRAND}

RAFAEL BEZERRA DOS SANTOS

Centro Universitário Santo Agostinho

JADNA SILVA FRANCO

Centro Universitário Santo Agostinho

JEFFERSON ALVES FREITAS

UNINASSAU Redenção

\section{DAIANE PORTELA DE CARVALHO} FERREIRA

Centro Universitário Santo Agostinho

FABÍOLA SANTOS LIMA DE OLIVEIRA Universidade CEUMA

MARIA DO AMPARO VELOSO

MAGALHÃES

Docente Centro Universitário Santo Agostinho

RESUMO: Disfunções sanguíneas podem causar prejuízos em qualquer área do corpo, dentre elas destaca-se as coagulopatias hereditárias que compreendem doenças hemorrágicas decorrentes da carência de proteína plasmática, ou seja, fatores de coagulação. As coagulopatias hereditárias mais frequentes são a hemofilia e a doença Von Willebrand. O objetivo deste trabalho consiste em escrever sobre o tratamento odontológico de pacientes com coagulopatias hereditárias mais comuns bem como a hemofilia e a doença de Von Willebrand. Tratou-se de uma revisão da literatura com abordagem qualitativa, realizada por meio da busca de artigos científicos, nas bases de dados: BVS, SCIELO, LILACS e PUBMED utilizando os descritores: Hematologia; Coagu- lopatia; Tratamento Odontológico com o uso do operador booleano AND. Foram selecionados 16 artigos que evidenciaram que a hemofilia e a doença de Von Willebrand são as coagulopatias hereditárias mais comuns, indivíduos que às manifestam apresentam complicações de difícil solução na hora da abordagem odontológica, diante disso, o cirurgião dentista deve realizar uma boa anamnese, caso desconfie de algo, deve solicitar exame hematológico antes de iniciar o tratamento, visto que esses pacientes apresentam índice de sangramento elevado. O tratamento para estas coagulopatias irá depender de seu grau de severidade da patologia bem como do procedimento que irá ser realizado no paciente. Indivíduos que apresentam hemofilia e doença de Von Willebrand estão suscetíveis a terem complicações durante a abordagem odontológica em consultório ou centro cirúrgico, diante disso, é de suma importância que cirurgiões dentistas tenham conhecimentos destas patologias a fim de evitar consequências sendo crucial o trabalho em equipe com o hematologista, pois irá refletir no sucesso do tratamento odontológico e no prognóstico do paciente.

PALAVRA-CHAVE: Coagulopatia; Hematologia; Tratamento Odontológico.

ABSTRACT: Blood dysfunctions can cause damages in any area of the body, among them the hereditary coagulopathies that include hemorrhagic diseases due to the lack of plasmatic protein, that is, coagulation factors. The most frequent hereditary coagulopathies are hemophilia and Von Willebrand disease. The aim of this work is to write about the dental treatment of patients with the most common hereditary coagulopathies as well as hemophilia and Von Willebrand dis- 
ease. It was a literature review with qualitative approach, carried out through the search of scientific articles in the databases: BVS, SCIELO, LILACS and PUBMED using the descriptors: Hematology; Coagulopathy; Dental Treatment with the use of the Boolean operator AND. 16 articles were selected which showed that hemophilia and Von Willebrand's disease are the most common hereditary coagulopathies, individuals who manifest them present complications of difficult solution at the time of the dental approach, in front of that, the dentist surgeon should perform a good anamnesis, in case he suspects something, he should request hematological examination before starting the treatment, since these patients present high bleeding rate. The treatment for these coagulopathies will depend on their degree of severity of the pathology as well as the procedure that will be performed on the patient. Individuals with hemophilia and Von Willebrand's disease are likely to have complications during the dental approach in the office or surgical center, therefore, it is of utmost importance that dentists have knowledge of these pathologies in order to avoid consequences being crucial the team work with the hematologist, because it will reflect on the success of dental treatment and prognosis of the patient.

KEYWORDS: Coagulopathy; Hematology; Dental Treatment.

\section{INTRODUÇÃO}

Disfunções sanguíneas podem causar sérios prejuízos em qualquer área do corpo humano, dentre elas destaca-se as coagulopatias hereditárias que compreendem doenças hemorrágicas decorrentes da carência quantitativa e qualitativa de proteína plasmática, ou seja, fatores de coagulação. As coagulopatias mais comuns são: hemofilia e doença de Von Willerand que devem ser identificadas antes de qualquer procedimento odontológico mais invasivo. A literatura aponta que quando diagnosticada e tratada precocemente, o indivíduo com coagulopatia hereditária tem a mesma expectativa de vida similar à média da população. (MARQUES, 2010; BRAVO, 2016).

As discrasias sanguíneas são um grupo de condições o qual existem problemas no processo de coagulação sanguínea, estas discrasias podem levar a um intenso sangramento por um tempo prolongado após uma lesão, pode ocorrer também sangramento espontâneo afetando os tecidos e órgãos internos (CANO-FRANCO, 2017).

As principais características clínicas das coagulopatias hereditárias, são os sangramentos, que podem acontecer de forma espontânea ou induzida por algum trauma e/ou cirurgia, desta forma, procedimentos invasivos ainda que mínimos podem resultar em sangramentos prolongados que pode acabar prejudicamento a conclusão do procedimento (PINHEIRO, 2017).

A hemofilia se caracteriza pela deficiência dos fatores VIII(A) e IX(B) da coagulação, trata-se de uma doença hereditária ligada ao cromossomo $X$, sendo marcada por um prolongado sangramento por conta da diminuição ou ausência dos fatores de coagulação necessário para o coágulo sanguíneo, classificada em grave, moderado e leve. Von Willebrand é um distúrbio hemorrágico bem comum causado pela anormalidade no fator Von Willebrand, possui como manifestação comum: fácil aumento de hematomas, frequentes epistaxe e menorragia em mulheres (MARQUES, 2010; RESENDE, 2019). 
Os distúrbios hemorrágicos são raros, todavia, seu tratamento deve ser especializado. Pacientes que possuem essas coagulopatias podem negligenciar sua saúde bucal em razão do sangramento durante a escovação dos dentes e uso do fio dental, essa negligência pode trazer sérios danos à mucosa bucal do indivíduo que futuramente deverá consultar um dentista para tratamento odontológico. (PINHEIRO, 2017).

O cirurgião dentista deve estar a par do impacto da doença de Von Willebrand e hemofilia no tratamento odontológico de pacientes que possuem estas disfunções sanguíneas visto que os profissionais que possuem o conhecimento destas, realizam um melhor tratamento clínico, em virtude de estes apresentarem um alto risco de sangramento na cavidade oral, sobretudo, durante um procedimento cirúrgico ou trauma. Diante disso, o melhor maneja da hemorragia pré-operatória é a prevenção (MALMQUIST, 2011).

A participação de dentistas em equipes multidisciplinares no atendimento a pacientes portadores de coagulopatias hereditárias tem propiciado que o tratamento odontológico seja ambulatorial, diminuindo significativamente reposição de fator (SILVA, 2012).

O objetivo deste trabalho consiste em escrever sobre o tratamento odontológico de pacientes com coagulopatias hereditárias mais comuns bem como a hemofilia e a doença de Von Willebrand.

\section{METODOLOGIA}

O presente estudo tem como base uma revisão da literatura, com abordagem qualitativa. $\mathrm{O}$ levantamento bibliográfico foi realizado no mês de dezembro de 2020, por meio da consulta direta em livros e artigos pela internet, no endereço eletrônico da plataforma da Biblioteca Virtual de Saúde (BVS), nas seguintes bases de dados: Scielo, Lilacs, Pubmed/Medline. Foram utilizados os descritores: Hematologia (Hematology), Coagulopatia (Coagulopathy) e Tratamento Odontológico (Dental Treatment), associados ao operador booleano AND.

Os critérios de inclusão foram textos nos idiomas português e inglês, conteúdo relevante ao tema, capítulos de livro, trabalhos na íntegra e publicados entre 2007 e 2020 em português, inglês e espanhol. Como critérios de exclusão produções irrelevantes ao tema e trabalhos que não estivessem na íntegra, anais de congressos, teses, dissertações, tendo em vista o que há de mais recente a respeito do tema proposto e outros idiomas que não o português e o inglês. Durante as buscas de artigos científicos foi evidenciada uma escassez de trabalhos quanto ao tema proposto, diante disso, foram encontrados 67 trabalhos o qual foram feitas leituras dos títulos e resumos, dentre estes foram escolhidos 16 artigos para realização deste trabalho. 
Figura 1 - Fluxograma com resultados das buscas nas bases de dados.

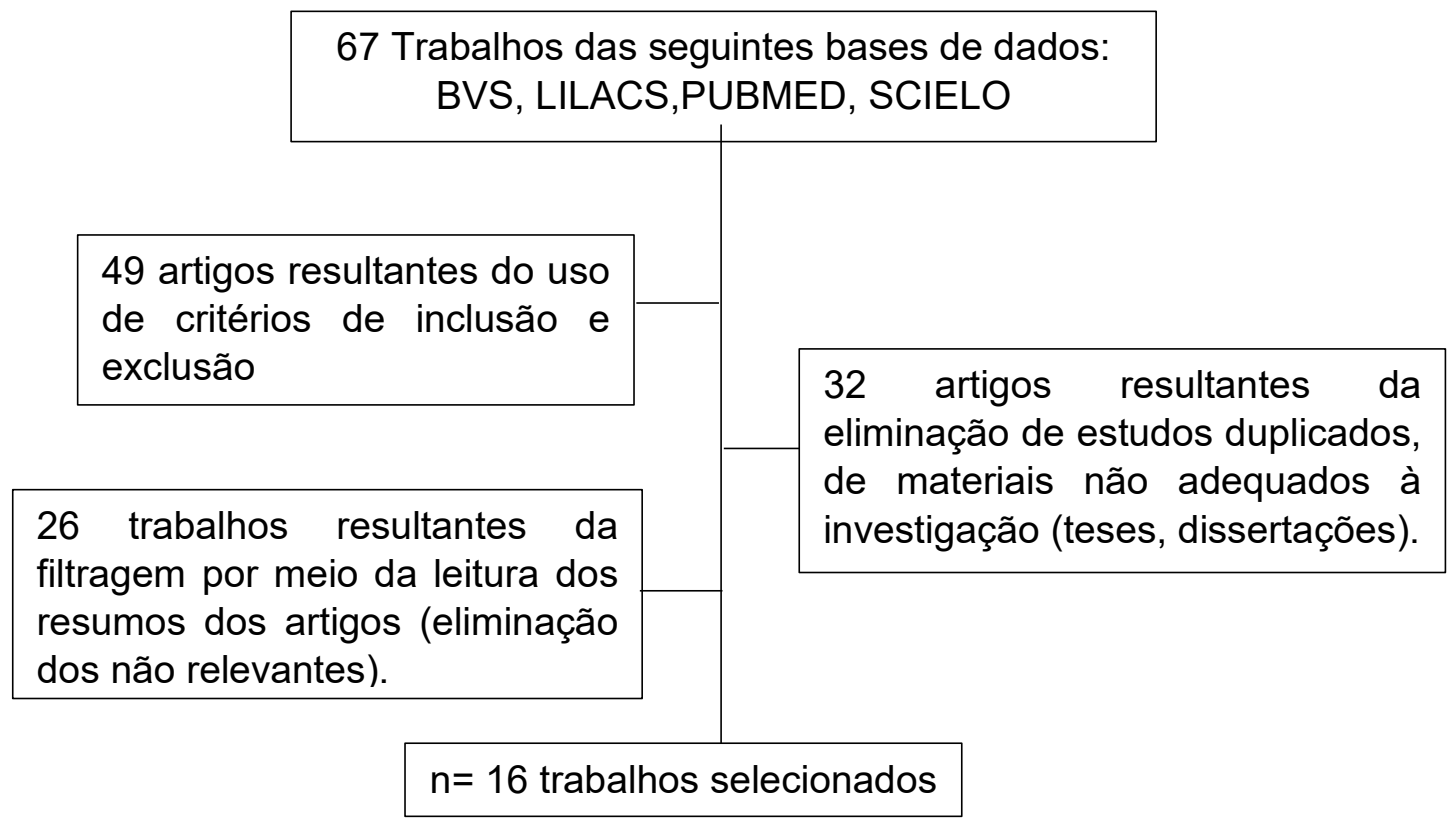

Fonte: Autoria própria.

\section{RESULTADOS}

Tabela 1: Informações sobre os trabalhos coletados nas bases de dados

\begin{tabular}{|c|c|c|c|}
\hline AUTORES & TÍTULO DO TRABALHO & $\begin{array}{c}\text { ANO DE } \\
\text { PUBLICAÇÃO }\end{array}$ & BASE DE DADOS \\
\hline BARBOSA et al & $\begin{array}{l}\text { Doença de von Willebrand e Aneste- } \\
\text { sia }\end{array}$ & 2007 & SCIELO \\
\hline $\begin{array}{l}\text { JOVER CERVERÓ } \\
\text { et al }\end{array}$ & $\begin{array}{l}\text { Dental treatment of patients with co- } \\
\text { agulation factor alterations: An up- } \\
\text { date }\end{array}$ & 2007 & PUBMED \\
\hline MARQUES et al & $\begin{array}{l}\text { Atendimento odontológico em pa- } \\
\text { cientes com Hemofilia e Doença de } \\
\text { von Willebrand }\end{array}$ & 2010 & LILACS \\
\hline KUMAR et al & $\begin{array}{l}\text { Robbins e Cotran - Patologia - Ba- } \\
\text { ses Patológicas das Doenças }\end{array}$ & 2010 & LIVRO \\
\hline BERNTORP et al & $\begin{array}{l}\text { Treatment of haemophilia } A \text { and } B \\
\text { and von Willebrands disease: sum- } \\
\text { mary and conclusions of a system- } \\
\text { atic review as part of a Swedish } \\
\text { health-technology assessment }\end{array}$ & 2012 & PUBMED \\
\hline SILVA et al & $\begin{array}{l}\text { Tratamento Periodontal de Paciente } \\
\text { Hemofílico }\end{array}$ & 2012 & BVS \\
\hline ATARA et al & $\begin{array}{l}\text { Endodontic Management of Patient } \\
\text { with Hemophilia }\end{array}$ & 2013 & PUBMED \\
\hline ZALIUNIENE et al & Hemophilia and oral health & 2014 & PUBMED \\
\hline LÓPEZ et al & $\begin{array}{l}\text { Hemophilia A. Considerations for } \\
\text { dental management of pediatric pa- } \\
\text { tients }\end{array}$ & 2014 & PUBMED \\
\hline
\end{tabular}




\begin{tabular}{llll} 
Ministério da Saúde & $\begin{array}{l}\text { Manual de Atendimento odontoló- } \\
\text { gico a pacientes com coagulopatias } \\
\text { hereditárias }\end{array}$ & 2015 & Ministério da Saúde \\
BRAVO et al & $\begin{array}{l}\text { Reabilitação odontológica multidis- } \\
\text { ciplinar em paciente pediátrico com } \\
\text { hemofilia. Relato de caso }\end{array}$ & 2016 & SCIELO \\
\hline CHAPIN et al & $\begin{array}{l}\text { Outcomes in Patients With Hemo- } \\
\text { philia and von Willebrand Disease } \\
\text { Undergoing Invasive or Surgical } \\
\text { Procedures }\end{array}$ & 2016 & PUBMED \\
\hline $\begin{array}{l}\text { CANO-FRANCO } \\
\text { et al }\end{array}$ & $\begin{array}{l}\text { Cuidado odontológico de pacientes } \\
\text { con trastornos hereditarios de la coa- } \\
\text { gulación }\end{array}$ & 2017 & LILACS \\
\hline PINHEIRO et al & $\begin{array}{l}\text { Hemofilias e Doença de von Wille- } \\
\text { brand: uma revisão de literatura }\end{array}$ & 2017 & SCIELO \\
\hline FON et al & $\begin{array}{l}\text { Atendimento odontológico em pa- } \\
\text { ciente portador de coagulopatia con- } \\
\text { gênita: Relato de caso }\end{array}$ & 2018 & BVS \\
\hline RESENDE et al & $\begin{array}{l}\text { Atendimento Odontológico Ao Pa- } \\
\text { ciente Portador De Hemofilia C: } \\
\text { Quais São Cuidados Necessários } \\
\text { Para Um Correto Atendimento? - } \\
\text { Revisão De Literatura }\end{array}$ & & \\
\hline
\end{tabular}

\section{DISCUSSÃO}

De acordo com a literatura as discrasias sanguíneas são patologias comuns, nestas se destacam a Hemofilia e doença de Von Willebrand. A Hemofilia é um distúrbio congênito autossômico recessivo ligada ao cromossomo $\mathrm{X}$, caracterizada por sangramento prolongado cuja causa é a diminuição ou ausência dos fatores de coagulação necessários para a formação do coágulo sanguíneo. Seu diagnóstico é realizado através de uma anamnese minuciosa com história médica do paciente e familiares (MARQUES, 2010; BRAVO, 2016).

A hemofilia é classifica em A e B, todavia, ambas têm o mesmo aspecto clínico com incidências diferentes. A hemofilia A é um distúrbio relacionado a deficiência do fator VIII de coagulação, tendo maior incidências no sexo masculino, já a hemofilia B caracteriza-se pela deficiência do fator de coagulação IX, assim, ambas são subdivididas conforme seus níveis de atividades do fator no sangue, sendo ela: suave, moderada ou severa (ZANIULIENE, 2014; BRASIL, 2015).

A doença de Von Willebrand é um distúrbio hemorrágico hereditário mias prevalente, de herança autossômica dominante, sendo capaz de apresentar expressão fenotípica variável. Esta patologia é caracterizada pela deficiência no fator de Von Willebrand (fator vW), sendo classificada em tipo I ao tipo IV e indivíduos que a possuem apresentam diferentes manifestações clinicas como sangramento espontâneo de membranas mucosas, sangramento excessivo de lesões, com tendencias à hematomas fáceis, epistaxes frequentes e menorragia (MARQUES, 2010; BRASIL, 2015; KUMAR, 2010). 
O diagnóstico pode ser realizado clinicamente, o qual alguns sinais e sinais direcionam para o tipo de distúrbios, por exemplo, quando o indivíduo apresenta hematomas musculares ou hemorragias intra-articulares, são indicativos de hemofilia, já quando apresenta hemorragias na pele e mucosas causadas possivelmente por alterações de hemostasia primária com envolvimento da cascata de coagulação, pode indicar doença de Von Willebrand (PINHEIRO, 2017).

FON (2017) e Marques (2010) relatam que pacientes com coagulopatias hereditárias representam um desafio para o atendimento odontológico, uma vez que além de apresentarem tal discrasia sanguínea com alto risco de sangramento na cavidade bucal, tendem a apresentar também doenças periodontais e incidências de cáries. Diante disso, existem abordagens odontológicas diferentes para estes pacientes, pois o seu tratamento irá depender não só da gravidade da doença mas também do procedimento que irá ser realizado, cujo objetivo de tais procedimentos é minimizar os riscos ao paciente sempre mantendo hemostasia através de métodos adjuvantes e locais. Diante disso, os cuidados de pacientes com hemofilia e doença de Von Willebrand deve ser cautelosa com o apoio do hematologista responsável pelo paciente.

Para tratar de tais pacientes, alguns cuidados devem ser tomados. Na escolha da medicação destes pacientes, principalmente para controle da dor de leve a moderada, o cirurgião dentista deve prescrever medicamentos derivados do paracetamol ou dipirona. Por apresentarem funções de suas atividades inibitórias de agregação plaquetária a aspirina bem como seus derivados são contraindicados à estes pacientes. Quanto a prescrição de anti-inflamatórios, é restringida devido a sua atividade anti-agregantes, devendo o hematologista ser consultado (MARQUES, 2010; JOVER CERVERÓ, 2007; BARBOSA, 2007).

Quanto a utilização de soluções anestésicas, de acordo com o Ministério da saúde, recomenda-se anestésicos contendo vasoconstrictores em sua solução, contudo, não se deve utilizar em pacientes que apresentem comorbidades. A infusão da solução anestésica deve ser feita de forma lenta e progressiva objetivando a redução de aparecimento de hematomas, pois de acordo com Marques (2010) a formação de hematomas durante técnicas anestésicas infiltrativa é rara, mas caso ocorra tal situação, o dentista pode usar gelo macerado e manter no local por aproximadamente 20 minutos. A técnica anestésica troncular deve ser evitada nestes pacientes devido a formação de hematomas e sangramento na região pterigoideana ou áreas ao redor da faringe. Estes pacientes também podem ser submetidos a sedação consciente com o uso do oxido nitroso, porém, devem estar acompanhados de médicos anestesistas e do hematologista (BRASIL, 2015).

No tratamento periodontal, pacientes que apresentam estas discrasias geralmente possuem tecidos gengivais inflamados e hiperêmicos, gerando então um índice elevado de sangramento durante o tratamento periodontal, com isso, pacientes que possuem doença periodontal grave ou moderada devem ser atendidos individualmente. A sondagem periodontal, raspagem e o alisamento supragengival pode ser realizado normalmente pelo dentista sem risco de sangramento considerável. Para medida profilática de sangramento, pode-se utilizar bochechos com soluções antifibrinolíticos antes e após o tratamento periodontal. Em casos em que é necessária realizar a cirurgia periodontal devido a saúde bucal do paciente estar precária, a terapêutica cirúrgica é considerada de alto risco devido a sangramentos durante a cirurgia, diante disso, deve-se haver o preparo prévio do paciente, com re- 
posição dos fatores de coagulação e reserva de plaquetas buscando a hemostasia local. Em casos de cirurgia periodontal em que o procedimento envolve o alisamento radicular, se faz necessário elevar o fator em até 50\% (SILVA, 2012; BRASIL, 2015; CANO-FRANCO, 2017).

Figura 1. Paciente antes da intervenção cirúrgica periodontal.

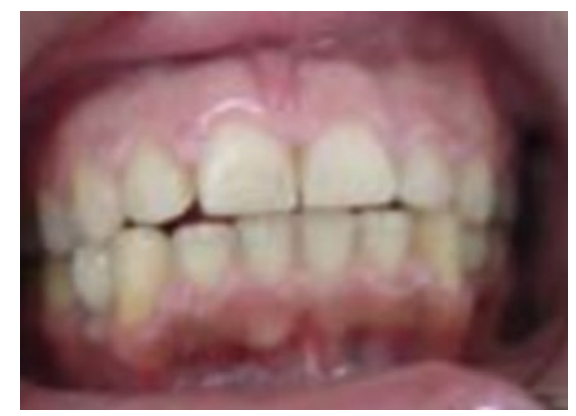

Fonte: SILVA, 2012

Figura 2A e 2B. Paciente durante a intervenção cirúrgica periodontal.
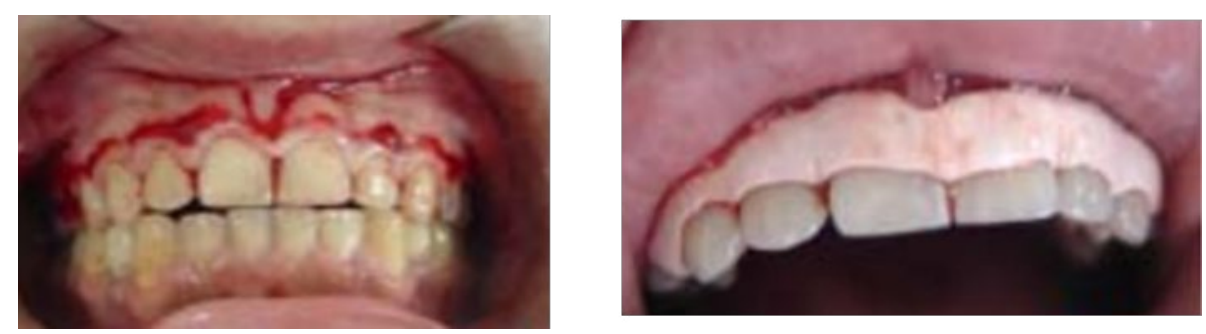

Fonte: SILVA, 2012.

Quanto ao tratamento restaurador, os procedimentos podem ser realizados normalmente, uma vez que não há risco de sangramento durantes o procedimento restaurador, contudo devem ser realizados com cuidados buscando preservação da integridade da mucosa. Recomenda-se o uso de isolamento absoluto do campo operatório para proteger a mucosa caso o cirurgião dentista não se sinta seguro, colocando com cuidado os grampos, lençol de borracha, matrizes e cunhas (BRASIL, 2015; BRAVO, 2016).

O tratamento endodôntico destes pacientes não chega a ocorrer riscos de sangramentos podendo ser realizada normalmente, contudo, é preferível a extração dentária sempre que possível, não havendo também a necessidade de reposição de fatores de coagulação a menos que seja necessária realização da técnica de bloqueio do nervo alveolar inferior. Em casos de pulpectomia é comum o sangramento intrarradicular, diante disso, deve-se usar hipoclorito de sódio a $0,5 \%$ em todos os casos e o ácido etilenodiamino tetracético(EDTA) a 17\% acompanhado de medicação intracanal, por exemplo o dexametasona, que ajuda na diminuição do processo inflamatório na região apical do dente. Quanto a pulpotomia nestes pacientes, não há na literatura sucesso deste procedimento no sentido de atingir a hemostasia local (MARQUES, 2010; BRASIL, 2015). 
Cano-Franco (2017) afirma que para realizar o tratamento endodôntico de pacientes com hemofilia, o cirurgião-dentista deve ter uma boa previsibilidade, não devendo obturar de forma a deixar o canal muito preenchido na região apical, ou seja, o enchimento nunca deve ser feito além da região apical de um dente vital.

Quanto ao uso da instrumentação, o uso de instrumentos endométricos eletrônicos reduz a necessidade de realização de radiografias intraoperatórias e, consequentemente, o risco de lesões nos tecidos moles (ATARA, 2013).

Figura 3. Visão pré-operatória do tratamento endodôntico em paciente hemofílico.

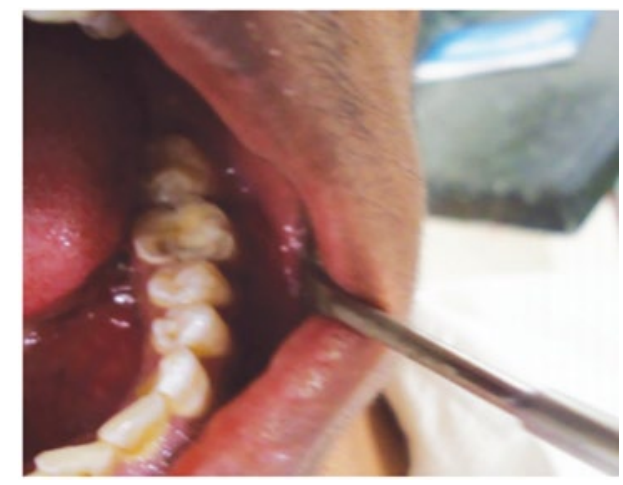

Fonte: ATARA, 2013.

Figura $4^{\text {a }}$ e 4B. Visão após conclusão do tratamento de canal radicular e radiografia pós tratamento.
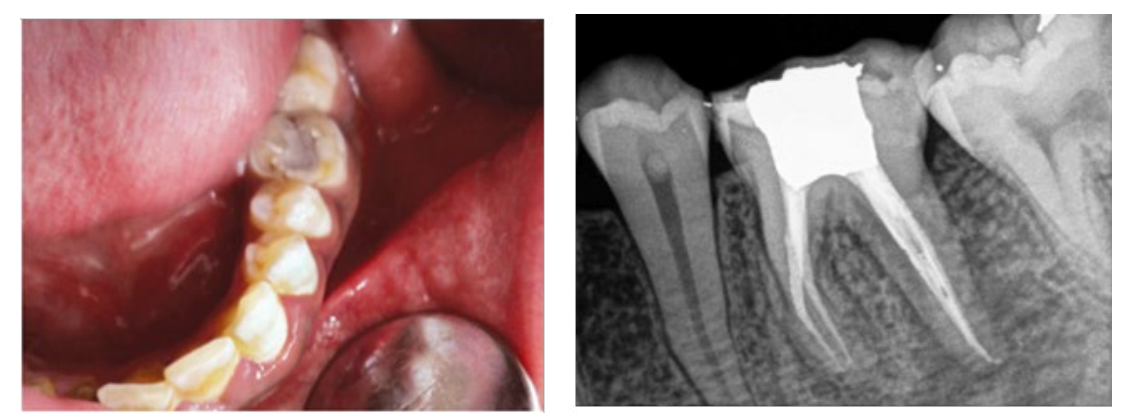

Fonte: ATARA, 2013.

Quanto a reabilitação protética, a mesma não oferece nenhum risco de sangramento durante seu processo de confecção, contudo, o dentista deve manejar o tecido oral delicadamente durante a confecção da prótese para reduzir o risco de equimose no paciente cuidados na escolha e manipulação das moldeiras. O tratamento ortodôntico também não oferece riscos nem contraindicações, o ortodontista deve somente ter cuidado ao colocar os braquetes nos dentes e evitar lesões na mucosa bucal durante este processo, devendo sempre orientar sobre os cuidados com a higiene oral para redução do risco de cárie e evitar o estabelecimento de inflamações, infecções gengivais e doenças periodontais(MARQUES, 2010). 
A cirurgia oral é um dos procedimentos que oferecem maior risco de sangramento, diante disso, o hematologista deve ser consultado para planejar o tratamento cirúrgico precedido de avalição clínica e com imagens adequadas, avaliar riscos e benefícios. É de suma importância que o procedimento cirúrgico seja realizado por um profissional capacitado que tenha conhecimento destes distúrbios, para que na hora do transoperatório caso ocorra intercorrências, ele seja capaz de proceder o mais rápido possível. Uma das cirurgias comuns é a exodontia de terceiros molares que deve ser considerada como uma cirúrgica de elevado risco de sangramento, nesta é recomendada antifibrinolíticos via oral 24 horas antes do inicio do procedimento, e sua manutenção deve perdurar por pelo menos 7 dias, a indicação de medicamentos sistêmicos deve ser realizada juntamente com o médico hematologista. Realizada a extração, coloca-se o SF dentro do alvéolo de forma a preenche-lo completamente, e realizada a sutura com fios reabsorvíveis de maneira a aproximar ao máximo as bordas da ferida cirúrgica, visando cicatrização por primeira intenção. Em exodontias de dentes decíduos o tecido de granulação associado à reabsorção irregular de raiz deve ser removido, devido a sua permanência estar associada a sangramentos frequentes. No pós-operatório, sempre orientar o paciente a não fazer uso do fumo, evitar comidas quentes, repouso nas primeiras 24 horas.(MARQUES, 2010; BRASIL,2015).

\section{CONCLUSÃO}

Indivíduos que apresentam hemofilia e doença de Von Willebrand estão suscetíveis a terem complicações durante a abordagem odontológica em consultório ou centro cirúrgico, o qual o planejamento deve ser realizado em conjunto com a equipe médica responsável pelo paciente, diante disso, é de suma importância que cirurgiões dentistas tenham conhecimentos destas patologias hereditárias a fim de evitar consequências durantes procedimentos odontológicos sendo crucial o trabalho em equipe com o hematologista, pois irá refletir no sucesso do tratamento odontológico e no prognóstico do paciente.

\section{REFERÊNCIAS}

ATARA, Rahul Ramesh et al. Endodontic management of patient with hemophilia. International Journal of Prosthodontics \& Restorative Dentistry, v. 3, n. 3, p. 101, 2013.

BARbOSA, F. T. CUNHA, R. M. BARBOSA, L. T. Doença de von Willebrand e Anestesia. Revista Brasileira de Anestesiologia, v. 57, n. 3, p. 315-323, 2007.

BERNTORP, Erik et al. Treatment of haemophilia A and B and von Willebrand's disease: summary and conclusions of a systematic review as part of a Swedish health-technology assessment. Haemophilia, v. 18, n. 2, p. 158-165, 2012.

Brasil. Ministério da Saúde. Secretaria de Atenção a Saúde. Departamento de Atenção Especializada e Temática. Manual de atendimento odontológico a pacientes com coagulopatias hereditárias. Brasília : Ministério da Saúde, 2015. 
BRAVO, Maria de Lourdes Ortiz et al. Reabilitação odontológica multidisciplinar em paciente pediátrico com hemofilia. Relato de caso. Revista da Associacao Paulista de Cirurgioes Dentistas, v. 70, n. 2, p. 210-214, 2016.

CANO-FRANCO, MA; ORTIZ-ORREGO, GE; GONZÁLEZ-ARIZA, SE. Cuidado odontológico de pacientes con trastornos hereditarios de la coagulación. CES Odontología, v. 30, n. 1, p. 30-40, 2017.

CHAPIN, John et al. Outcomes in patients with hemophilia and von Willebrand disease undergoing invasive or surgical procedures. Clinical and Applied Thrombosis/Hemostasis, v. 23, n. 2, p. 148-154, 2017.

FON, Bárbara Lessa et al. ATENDIMENTO ODONTOLÓGICO EM PACIENTE PORTADOR DE COAGULOPATIA CONGÊNITA: Relato de caso. Revista da AcBO-ISSN 2316-7262, v. 7, n. 1, 2017.

JOVER CERVERÓ, Alba et al. Dental treatment of patients with coagulation factor alterations: An update. Medicina Oral, Patología Oral y Cirugía Bucal (Internet), v. 12, n. 5, p. 380-387, 2007.

KUMAR, V.; ABBAS, A.; FAUSTO N. Robbins e Cotran - Patologia - Bases Patológicas das Doenças. 8. ed. Rio de Janeiro: Elsevier, 2010;

LÓPEZ, S; LUIS OR; FIERRO NC. Hemophilia A. Considerations in the dental management of pediatric patients. A case report. Journal of Oral Research, v. 3, n. 3, p. 173-177, 2014.

MARQUES, RVCF et al. Atendimento odontológico em pacientes com Hemofilia e Doença de von Willebrand. Arquivos em Odontologia, v. 46, n. 3, 2010.

PINHEIRO, YT; SILVA ECL; MACIEL MA; SOUSA ET. Hemofilias e Doença de von Willebrand: uma revisão de literatura. ARCHIVES OF HEALTH INVESTIGATION, v. 6, n. 5, 2017.

RESENDE, AFB; PEREIRA IV; ANDRADE MV; SARTORETTO SC; RESENDE RFB. Atendimento Odontológico Ao Paciente Portador De Hemofilia C: Quais São Cuidados Necessários Para Um Correto Atendimento?-Revisão De Literatura. Revista Fluminense de Odontologia, v. 1, n. 51, 2019.

SILVA SC; SILVA ESC; MENEZES KT; JUNIOR RL; BRITO RL. Tratamento periodontal de paciente hemofílico. Rev. bras. ciênc. saúde, p. 243-248, 2012.

ZALIUNIENE, Ruta et al. Hemophilia and oral health. Stomatologija, v. 16, n. 4, p. 127-31, 2014. 


\section{LASERTERAPIA NO TRATAMENTO DA HIPERSENSIBILIDADE DENTINÁRIA: REVISÃO DE LITERATURA}

ANA ROBERTA NEGROMONTE DA SILVA Discente Faculdade de Odontologia, Universidade de Pernambuco

MARIA EDUARDA DE MORAIS CAVALCANTI

Discente Faculdade de Odontologia, Universidade de Pernambuco

MARINA MARIA FERREIRA FALCÃO Discente Faculdade de Odontologia, Universidade de Pernambuco

\section{MÁRCIA DE ALMEIDA DURÃO}

Pós-Doutoranda em Dentística, Universidade de Pernambuco

RESUMO: Introdução: A hipersensibilidade dentinária (HD) tem etiologia multifatorial e é um processo patológico, cujos mecanismos de tensão, fricção e degradação química estão presentes. São dependentes de estímulos físico-químicos, nos túbulos dentinários expostos ou em falhas estruturais, como trincas e fissuras em esmalte podendo desencadear sensibilidade aguda e de curta duração. Objetivo: analisar estudos sobre o uso da laserterapia no tratamento da hipersensibilidade dentinária. Metodologia: Foram realizadas buscas nas bases de dados: Biblioteca Virtual da Saúde (BVS) e Scielo, de artigos publicados nos últimos 21 anos, com os descritores "Hipersensibilidade dentinária", "Dessensibilizante" e "Laserterapia" em português e inglês, sendo analisados 30 artigos. Desenvolvimento: Para diagnosticar HD deve-se ter como auxílio uma sonda ou seringa tríplice, sendo a última mais sensível. A teoria mais aceita para a HD é a teoria hidrodinâmica de Brännström. Normalmente a exposição dentinária é proveniente de lesões cervicais não cariosas, devendo-se realizar o diagnóstico diferencial criteriosamente. $\mathrm{O}$ tratamento básico da HD visa alterar o fluxo dos fluidos nos túbulos dentinários, pela oclusão tubular ou modificação química do nervo pulpar. A laserterapia é utilizada no alívio da HD, por seu efeito coagulante das proteínas dos fluidos dentinários, que reduzem a permeabilidade dos túbulos por derretimento parcial da superfície. O laser de alta potência, Nd:YAG é o padrão-ouro na literatura, por apresentar maior efeito analgésico em casos de HD, quando comparado a outros lasers. Isso ocorre devido a sua capacidade de obliterar os túbulos dentinários, amolecendo e resolidificando a dentina, sem lesionar a polpa ou fissurar a dentina irradiada. Os lasers de baixa potência não promovem aquecimento e estimulam as células proporcionando efeito analgésico, anti-inflamatório e de biomodulação. Conclusão: A laserterapia é um tratamento efetivo para HD, que destaca-se na Odontologia, por ser definitivo, indolor, de fácil e rápida aplicação e não ser agressivo ao organismo.

PALAVRAS-CHAVE: Hipersensibilidade dentinária; Laserterapia; Dessensibilizante.

ABSTRACT: Introduction: Dentin hypersensitivity (DH) has multifactorial etiology and is a pathological process, whose mechanisms of tension, friction and chemical degradation are present. They are dependent on physicochemical stimuli, exposed dentinal tubules or structural flaws, such as cracks and enamel cracks and can trigger acute and short-term sensitivity. Objective: to analyze studies on the use of laser therapy 
in the treatment of dentinhypersensitivity. Methodology: Searches were performed in the databases: Virtual Health Library (VHL), Google Academic and Scielo, of articles published in the last 21 years, with the descriptors "Dentin hypersensitivity", "desensitizing" and "laser therapy" in Portuguese and English, being analyzed 30 articles. Development: To diagnose DH should be aided by a triple tube or syringe, the latter being more sensitive. The most accepted theory for DH is Brännström's hydrodynamic theory. Usually dentin exposure comes from non-carious cervical lesions, and differential diagnosis should be carefully performed. The basic treatment of $\mathrm{DH}$ aims to alter the flow of fluids in the dentinal tubules, by tubular occlusion or chemical modification of the pulp nerve. Laser therapy is used to relieve $\mathrm{DH}$, because of its coagulating effect of dentin fluid proteins, which reduce the permeability of tubules by partial surface melting. The high-power laser, Nd:YAG is the gold standard in the literature, because it has a higher analgesic effect in hd cases when compared to other lasers. This is due to its ability to obliterate the dentinal tubules, softening and resolidifying the dentin, without injuring the pulp or cracking the irradiated dentin. Low-power lasers do not promote heating and stimulate cells providing analgesic, anti-inflammatory and biomodulation effect. Conclusion: Laser therapy is an effective treatment for DH, which stands out in dentistry, because it is definitive, painless, easy and fast to apply and not aggressive to the body.

KEYWORDS: Dentin hypersensitivity; Laser therapy; Desensitizing.

\section{INTRODUÇÃO}

Hipersensibilidade dentinária (HD) é considerada como uma dor de curta duração, aguda e súbita em resposta a estímulos térmicos, evaporativos, táteis, osmóticos ou químicos, os quais não são atribuídos a outras patologias dentárias (CORONA et al., 2003) O mecanismo da HD tem sido explicado por muitas teorias. A mais aceita atualmente é a teoria hidrodinâmica, a qual explica que quando um estímulo é aplicado na dentina, ocorre o deslocamento de fluido dentro dos túbulos em direção à polpa ou em sentido contrário, promovendo uma deformação mecânica das fibras nervosas que estão dentro dos túbulos ou na interface polpa/dentina, sendo transmitida como dor (BRÄNNSTRÖM, 1984). A HD afeta em média $35 \%$ da população mundial, com maior ocorrência na faixa etária de 30 anos e atingindo igualmente ambos os sexos. Os jovens possuem maior incidência de HD devido a camada de dentina ser mais fina em comparação aos idosos e, consequentemente, um vedamento menos eficaz dos túbulos dentinários (CAVALCANTE et al., 2015). Os dentes mais acometidos pela HD são os caninos e os pré-molares, seguidos pelos incisivos e molares. Em geral, a HD acomete as superfícies vestibulares, principalmente a região cervical, em cerca de 90\% (SGOLASTRA, 2013). Vários são os fatores que levam a exposição da superfície dentinária, dentre eles: uma escovação forçada, erosão, ablação causada pelo bruxismo, hábitos parafuncionais ou estresse oclusal, por problemas periodontais, por selamento incompleto da dentina após preparos de dentística, por deficiência fisiológica na junção esmalte-cemento, após preparos protéticos de dentes com vitalidade pulpar, após condicionamento do esmalte ou dentina por ácido não devidamente controlado, etc (PÉCORA, 1999). A HD é um caso complexo, o qual envolve alterações fisiológicas e psicológicas (CARTWRIGHT, 2014). A exposição dos túbulos dentinários na região cervical dos dentes, pode ocorrer devido aos processos de erosão, abfração ou abrasão, os quais ocasionam na perda de estrutura dentária (PASHLEY et al, 2008). Embora a hipersensibilidade seja o primeiro indício clínico de uma lesão cervical não cariosa, a perda de estrutura dentária e a exposição da dentina não precisa necessariamente 
estar presente para que haja a HD. Vários relatos possuíam apenas a camada do esmalte cervical vulnerável, mais fina ou com trincas em sua estrutura, possibilitando a entrada de estímulos ao longo da dentina, iniciando assim, a sensação dolorosa (SOARES; GRIPPO, 2017). A HD pode ser diagnosticada clinicamente através de teste mecânico com a sonda exploradora ou por desidratação com o jato de ar (SHINTOME et al., 2007). O teste com a seringa tríplice é mais sensível para avaliar a dor que o teste mecânico. Isso é explicado pelo fato do estímulo com o ar causar três efeitos diferentes: evaporação, térmico e compressão do ar no fluido dentinário, ao mesmo tempo que o teste mecânico provoca apenas o efeito de compressão (LOPES, 2015). Os sintomas da hipersensibilidade dentinária podem regredir espontaneamente, bem como a permeabilidade dentinária pode ser minimizada naturalmente. Processos naturais também levam a dessensibilização, como: remineralização pela saliva, dentina reparativa, dentina esclerótica e formação de cálculo dentário sobre a superfície dentinária. (DANTAS, 2013). Quando esses processos ocorrerem deve-se optar por um tratamento que leve a diminuição do fluxo de líquidos nos túbulos dentinários (GARONE, 1996). Os requisitos para que o tratamento da HD seja o ideal foram citados por Grossmann, em 1935, e são válidos até hoje, são eles: biocompatibilidade, não ocasionar dor, de rápida e fácil aplicação, ação rápida, não manchar os dentes e ser efeito a longo prazo. O desafio atual para a odontologia é eleger um tratamento eficaz que anule a sensação dolorosa da HD e previna a recidiva (SHINTOME et al., 2007). Várias terapias vêm sendo descritas, tais como: ajuste oclusal, mudança de hábitos alimentares e de higiene bucal, utilização de dentifrícios dessensibilizantes, aplicação de sistemas adesivos e/ou restauração e aplicação de produtos profissionais e aplicação de produtos profissionais dessensibilizantes de ação neural e/ ou obliteradora. Entretanto, os estudos mostram que nenhuma dessas terapias é totalmente eficiente de forma isolada no controle da dor a longo prazo. Assim, hoje em dia, o laser se tornou uma opção confiável e reproduzível, com taxas de sucesso maiores do que 90\% (WILDER-SMITH et al, 2000).

Como marcador de referência do tratamento da hipersensibilidade dentinária, existente na literatura, data 400 a.C. e refere-se ao uso do ópio (GARONE, 1996). Existem inúmeras modalidades e produtos para o tratamento da $\mathrm{HD}$, mas inicialmente deve-se eliminar qualquer outra patologia envolvida (ZEQUI; GARCIA, 2005). Uma dessas modalidades é o uso do laser, os primeiros relatos de seu uso datam em 1917, quando Albert Einstein formulou a teoria da emissão estimulada da radiação. Já na odontologia sua aplicação foi usada a partir da década de 60 e se popularizou na década de 80 . A palavra Laser é uma abreviação do termo em inglês Light Amplification by Stimulated emission of Radiation, que no português significa Amplificação da Luz por Emissão Estimulada de Radiação, que nada mais é que uma radiação eletromagnética não ionizante, essa fonte luminosa tem como característica própria monocromaticidade, coerência e unidirecionalidade o que a difere de outras fontes luminosas (KARU, 2003). O laser gera diferentes reações teciduais ao interagir com o tecido, a partir do seu meio ativo, densidade de potência, comprimento de onda e propriedades ópticas do tecido alvo, (LADALARDO, 2004). Em consonância com a literatura, tanto os lasers de comprimento de onda vermelho, quanto os de infravermelho são eficazes no tratamento da HD (LADALARDO, 2004). São métodos físicos que levam o complexo dentino-polpa a responder à irradiação com obliteração dos túbulos dentinários. o laser interage com a polpa dentária causando desse modo um efeito fotobiomodulador, que gera um aumento a atividade metabólica celular dos odontoblastos e consequente obliteração dos túbulos dentinários com a intensificação da produção de dentina terciária, no entanto ele não tem um efeito diretamente curativo (LADALARDO, 2004). Os lasers de alta 
intensidade, como o Nd:YAG, provocam aumento da temperatura e produção de calor, apresentando propriedades de corte, vaporização e hemostasia, além de que exemplificam um tipo de obliteração dos túbulos dentinários por meio da fusão da dentina e consequentemente representa uma modalidade de tratamento para a hipersensibilidade (BARROS FC et al., 2008; LAN LIU, 1995; MIDDA; PEREIRA, 1995; RENTON-HARPER, 1991; WHITE et al., 1993;). Os lasers usados na odontologia para o tratamento de hipersensibilidade podem ser separados em dois grupos: os de baixa intensidade e os de alta intensidade. No que se refere aos de baixa, têm-se o de Hélio-Neônio (He-Ne) e Arseneto de Gálio e Alumínio (AsGaAl). Já os de alta intensidade são os de Neodímio Ytrio Alumínio Granado (Nd:YAG) e o de dióxido de carbono (CO2). Os "soft lasers", também conhecido como lasers de baixa intensidade, possuem uma ação rápida, elevam a temperatura da área irradiada em menos de $0,1^{\circ} \mathrm{C}$ e por apresentarem um comprimento de onda pequeno, isso permite que haja estimulação da circulação e da atividade celular e aumento na produção de ATP com subsequente bioestimulação. Seu efeito analgésico se dá pela elevação do limiar de excitabilidade das terminações nervosas livres, redução dos transmissores nociceptivos, como a bradicinina e a serotonina, limitando a liberação do ácido araquidônico pelas células danificadas ou ainda pelo aumento na produção de $\beta$ endorfina, um mediador fisiológico secretado para minimizar a sensação dolorosa, no líquido cefalorraquidiano. Os demais efeitos proporcionados pelo laser de baixa potência são anti-inflamatórios, miorrelaxantes, cicatrizantes e vasculares (SHINTOME et al., 2007). Devido a vasta aplicação clínica do laser de baixa intensidade, ele tem sido mais aceito pelos cirurgiões-dentistas (PEIXOTO, 2010). Os mais usados atualmente são os lasers de diodo. Autores têm explicado que os dentes que não respondem por duas sessões de terapia podem ser indicados à endodontia, entretanto, as respostas dos tratamento diferem de acordo com a faixa etária, sendo, para os idosos, uma média de quatro sessões de terapia (QUERIDO, 2O1O).

\section{OBJETIVO:}

Analisar estudos sobre o uso da laserterapia no tratamento da hipersensibilidade dentinária.

\section{METODOLOGIA:}

Esta revisão de literatura selecionou artigos publicados entre 1999 e 2020, nas bases de dados, Biblioteca Virtual de Saúde (BVS) e SciELO. Os descritores utilizados na estratégia de busca foram: Hipersensibilidade dentinária; Laserterapia e Dessensibilizante. Como critérios de inclusão foram selecionados artigos científicos que apresentavam a relação entre o laser como modalidade de tratamento da hipersensibilidade dentinária, nos idiomas inglês e português. Como critério de exclusão foram estudos em duplicatas. Sendo analisados o total de 30 artigos. 


\section{DESENVOLVIMENTO:}

A literatura está de acordo com o fato de que mesmo havendo diversas opções de tratamento, nenhuma reduz a dor da HD a nível suficientemente eficaz (PINHEIRO, 2004). Embora não exista um dessensibilizante ideal, qualquer método deve ser efetivo desde o primeiro uso, além de seguir alguns critérios como ser indolor, de baixo custo, não irritar tecidos moles ou ligamento periodontal, fácil aplicação, ser permanente e não descolorir nem manchar os dentes (NOYA, 2004). Os lasers terapêuticos têm sua aplicação voltada para a bioestimulação há mais de 20 anos, iniciando na dermatologia e logo em seguida, passou a ter ação voltada para cicatrização de lesões na boca, trismo, pós operatório e hipersensibilidade dentinária. Seu efeito analgésico tem sido estudado desde os primórdios, principalmente nas dores crônicas vindas tanto dos receptores periféricos quanto do estímulo do sistema nervoso central. Existem várias técnicas de aplicação do laser no tratamento da hipersensibilidade dentinária cervical, porém em todas elas há a necessidade de calibrar devidamente o aparelho antes, para que seja emitida a quantidade certa de energia e assim, a terapia seja realizada de forma certa e efetiva (PAIVA; SENNA et al., 2017).

Ao analisar resultados após a primeira sessão de laserterapia pela estimulação pelo ar não houve redução da hipersensibilidade dentinária, já a partir da segunda sessão bons resultados são encontrados (NOYA, 2004). Indica-se duas ou três sessões em 4 dias intervalos para um procedimento bem sucedido (NOYA, 2004). Em relação à estimulação por sonda, há uma redução significativa já na primeira sessão. A redução na primeira sessão permite que o paciente melhore sua qualidade de higiene oral (NOYA, 2004). A dessensibilização por estimulação térmica deve ser considerada primeiramente pelo profissional, já que representa uma das principais queixas dos pacientes e com a melhora estabelecesse uma relação de confiança entre o profissional e o paciente desde a primeira sessão (NOYA, 2004). Comparando resultados com os grupos placebo, tanto no teste táctil quanto no térmico evaporativo, o grupo laser obteve diminuição significativa na sensação dolorosa (SARTORI, 2018).

Através de um estudo experimental com o laser de diodo 810nm (baixa potência) foi possível verificar que o tempo de irradiação influência no resultado obtido, já que, aquele que recebeu aplicação por um tempo maior teve sua dor encerrada após 15 minutos, por outro lado, aquele que recebeu aplicação por menos tempo, só conseguiu o mesmo resultado na segunda sessão, 7 dias após a primeira (HASHIM et al., 2014). Demais estudos realizados com o laser de diodo foram realizados, e obtiveram como resultado que ele de fato, reduz a sensibilidade até em quadros que a resposta inicial ao estímulo tátil era elevada (FEMIANO et al., 2017). Além disso, sua aplicação antes das restaurações por resina composta em dentes que não respondem bem ao tratamento com produtos dessensibilizantes, reduz mais ainda o desconforto gerado pela sintomatologia dolorosa (FEMIANO et al., 2017). Embora, mais testes clínicos randomizados e controlados sejam indispensáveis, até então os estudos apontam para um bom resultado quanto a diminuição da sensação dolorosa e HD, tanto no uso dos lasers de baixa $\left(700 \mathrm{~nm}, 3 \mathrm{~J} / \mathrm{cm}^{2}\right)$ quanto nos de alta potência (800 nm, $8 \mathrm{~J} / \mathrm{cm} 2$ ) (ROCHA, 2020). 
Entre os lasers para o tratamento da hipersensibilidade mais se estuda os seguintes: Nd:YAG, lasers de érbio, de diodo e CO2 (COSTA et al., 2016). A irradiação a laser Nd:YAG na dentina provoca o derretimento da superfície da dentina o que leva a um fechamento dos orifícios de túbulos expostos sem criar rachaduras superficiais (LAN et al, 2004). Entretanto, os resultados ainda não se mostram totalmente eficazes e requerem associações químicas, como com flúor e oxalatos, e o custo alto trás dificuldades (NOYA, 2004). No tratamento da HD com o laser GaAlAs, somente uma sessão de aplicação é suficiente para eliminar estímulos térmicos. Para diminuição da sensibilidade ao estímulo evaporativo, é preciso duas sessões. O laser Nd:YAG, quando comparado ao laser de AsGaAl, possui resultados semelhantes (SHINTOME et al., 2007). O trabalho que fez uso do laser de alta potência em associação com o de baixa potência obteve resultados satisfatórios quanto à redução da hipersensibilidade, entretanto, não houve diferença significativa para o grupo em que foi utilizado apenas o laser de baixa potência (DANTAS, 2013).

Os lasers não cirúrgicos que operam em baixa potência pode ao ser aplicado por meios ativos de diodo nos comprimentos de onda vermelhos $(632,660 \mathrm{~nm})$ atinge camadas mais superficiais e infravermelhos $(820,940 \mathrm{~nm}$ ) atinge camadas mais profundas (CARROL et al, 2014). O grau de absorção depende das características ópticas do tecido alvo (MOUZINHO et al., 2010). Quando é usada uma dosagem menor do que a recomendada, os efeitos esperados podem não ser alcançados, dado que uma dosagem superior resultará em um processo de reparação retardado (DE SOUZA ASSIS, 2019). Os riscos aumentam significativamente para os lasers de alta potência, são exemplos: o superaquecimento, danos à polpa, formação de trincas, carbonização do tecido duro e aquecimentos exagerados da raiz e do periodonto (DE SOUZA ASSIS, 2019). Como desvantagem dos lasers no consultório odontológico, tem-se o alto custo dos aparelhos (SOUSA, 2015). Pacientes afetados por periodontite têm maior prevalência HD comparado a não afetados, além disso tende a aumentar o número de adultos portadores de HD nos próximos anos por conta da manutenção mais prolongada dos dentes (UMBERTO, 2012).

A comparação individual entre o laser e os fluoretos no tratamento da HD não demonstram diferenças significativas. Entretanto, o uso concomitante resultou na oclusão de mais de $90 \%$ dos túbulos dentinários, permanecendo estável a longo prazo (DONATO, 2017). O laser atua ao nível neuronal da polpa e a dessensibilização é mais rápida, com analgesia imediata, podendo estimular funções fisiológicas das células (CORONA et al., 2003). O laser contribui na diminuição do calibre dos túbulos, tornando a aplicação dos vernizes de flúor mais estável e duradoura (LAN et al, 2004). Além dos estudos com o fluoreto,houve uma comparação entre os lasers de baixa potência em diferentes doses, os de alta potência (Nd:YAG) e o dessensibilizante glutaraldeído (Gluma), chegando a conclusão de que nenhum deles apresentou diferenças significativas nos resultados entre si (LOPES et al., 2017). 


\section{CONSIDERAÇÕES FINAIS:}

A aplicação do laser de baixa e alta potência no alívio da dor têm demonstrado resultados positivos. O uso da laserterapia com comprimento de onda adequado estimula a circulação e a atividade celular, atuando na biomodulação, devido ao aumento da produção de ATP mitocondrial. Além disso, promove um aumento do limiar de excitabilidade das terminações nervosas livres, que resulta em ação analgésica. Na literatura destacam-se os lasers de Nd: YAG e o de AsGaAl por serem eficazes no tratamento da $\mathrm{HD}$, não havendo diferenças significativas nos resultados entre os dois. O nível de aceitação pelo paciente é satisfatório devido a ausência de efeitos colaterais, fácil aplicação e a possibilidade de associação com outros métodos terapêuticos.

\section{REFERÊNCIAS:}

BASTING, Roberta Tarkany; SILVEIRA, Aliciana Pereira; DE OLIVEIRA BATISTA, Iara. Tratamento da hipersensibilidade dentinária com laser de baixa intensidade. Arquivos em Odontologia, v. 44, n. 2, 2008.

BRANNSTROM M. The hydrodynamic theory of dentinal pain: sensation in preparations, caries and the dentinal crack. J Endod 1984; 42(6):331-333.

CARROL, J. D. et al. Developments in low level light therapy (LLLT) for dentistry. Dental Materials, v. 30, n.5, p. $465-475,2014$

CARTWRIGHT RB. Hipersensibilidade dentinária: uma revisão narrativa. Community Dent Health 2014; 31: $15-20$

CAVALCANTE, Samuel Pereira; DE SOUZA JÚNIOR, Valteir Garcia; DIAS, Pâmella Coelho. Efetividade de diferentes tipos de tratamento no controle da hipersensibilidade dentinária cervical. Revista Uningá, v. 56, n. S7, p. 68-79, 2019.

CORONA, Silmara Aparecida Milori et al. Clinical evaluation of low-level laser therapy and fluoride varnish for treating cervical dentinal hypersensitivity. Journal of Oral Rehabilitation, v. 30, n. 12, p. 1183-1189, 2003.

CUNHA, Sandra Ribeiro et al. The association between Nd: YAG laser and desensitizing dentifrices for the treatment of dentin hypersensitivity. Lasers in medical science, v. 32, n. 4, p. 873-880, 2017.

DANTAS, Euler Maciel et al. Tratamento da hipersensibilidade dentinária cervical com laser de baixa potência: revisão de literatura. Odontologia Clínico-Científica (Online), v. 12, n. 1, p. 07-11, 2013.

DE GEUS, Juliana Larocca et al. Effectiveness Of Andtoothsensitivitywithat-home bleaching in smokers: a multicenter clinical trial. The Journal Of The American Dental Association, v. 146, n. 4, p. 233-240, 2015.

DE OLIVEIRA ROCHA, Aurélio et al. A utilização da laserterapia para o controle da hipersensibilidade dentinária: uma revisão sistematizada da literatura. Revista Eletrônica Acervo Odontológico, v. 2, p. e3907-e3907, 2020.

DE SOUZAASSIS, Victória Kelly; CARDOSO, Franscielle Lopes; SILVA, Brunno Pereira. Aplicabilidade da laserterapia no cenário odontológico: uma terapêutica em ascensão-revisão de literatura. Anais do Seminário Científico do UNIFACIG, n. 5, 2019. 
DONATO, Matteo. Tecnologia laser em medicina dentária: opções de tratamento em tecidos duros dentários. 2017. Tese de Doutorado.

FEMIANO, F. et al. Effectiveness on oral pain of 808-nm diode laser used prior to composite restoration for symptomatic non-carious cervical lesions unresponsive to desensitizing agents. Lasers in medical science, v. 32, n. 1, p. 67-71, 2017.

GARONE FILHO, W. Lesões Cervicais e Hipersensibilidade Dentinária. In: Kriger, L. Atualização na Clínica Odontológica: A Prática da Clínica Geral. São Paulo: Ed. Artes Médicas, 1996, Capítulo 3, p.35-75.

GROSSMAN, L. I. A systematic method for the treatment of hypersensitivity dentin. JADA, v.22, n. 4, p.592602, Apr., 1935.

HASHIM NT, et al. Efeito da aplicação clínica do laser de diodo $(810 \mathrm{~nm})$ no tratamento da hipersensibilidade dentinária. BMC Res Notes. 2014; 13; 7: 31.

KARU, T. I. et al. Molecular mechanism of the therapeutic effect of low-intensity laser radiation. Lasers Life Sci, v. 2, n. 1, p. 53-74, 1988.

KIELBASSA, Andrej M. et al. Tooth Sensitivity During And After vital tooth bleaching: A systematic review on an unsolved problem. Quintessence International, v. 46, n. 10, 2015.

LADALARDO, Thereza Christinna Cellos Gonçalves Pinheiro et al. Laser therapy in the treatment of dentine hypersensitivity. Brazilian dental journal, v. 15, n. 2, p. 144-150, 2004.

LOPES, Anely Oliveira; ARANHA, Ana Cecília Correa. ComparativeevaluationoftheeffectsofNd: YAG laser and a desensitizer agent the treatment of dentin hypersensitivity: a clinical study. Photomedicine And laser surgery, v. 31, n. 3, p. 132-138, 2013.

LOPES, Anely Oliveira; DE PAULA EDUARDO, Carlos; ARANHA, Ana Cecília Correa. Clinical Evaluation Of Low-power laser and a desensitizing agent dentin hypersensitivity. Lasers in medical science, v. 30, n. 2, p. 823-829, 2015.

LOPES, Anely Oliveira; DE PAULA EDUARDO, Carlos; ARANHA, Ana Cecília Correa. Evaluation Of Different Treatment Protocols for dentin hypersensitivity: an 18-month randomized clinical trial. Lasers in medical science, v. 32, n. 5, p. 1023-1030, 2017.

LUONG, Minh N. et al. In Vitro StudyontheEffectof a New BioactiveDesensitizeronDentinTubuleSealingandBonding. Journal of Functional materials, v. 11, n. 2, p. 38, 2020.

MACHADO, Alana Cristina et al. Effect of in-office desensitizers containing calciumandphosphateondentin permeability and tubule occlusion. Journal Of Dentistry, v. 86, p. 53-59, 2019.

MORASCHINI, Vittorio; DA COSTA, Larissa Salina; DOS SANTOS, Gustavo Oliveira. Effectiveness for dentin hypersensitivity treatment of non-carious cervical lesions: a meta-analysis. Clinical Oral Investigations, v. 22, n. 2, p. 617-631, 2018.

NOYA, Márcia Sepúlveda et al. ClinicalevaluationoftheimmediateeffectivenessofGaAIAs laser onthetherapyofdentinhypersensitivity. Journal of Applied Oral Science, v. 12, n. 4, p. 363-366, 2004.

PAIVA, Marcelo de Lima; MORAES, Marcus Vinicius. Laser de baixa potência no tratamento da hipersensibilidade dentinária cervical-proposta de um guia ilustrado. Trabalho de Conclusão de Curso, Curso de Odontologia do Instituto Tocantinense Presidente Antônio Carlos Porto - ITPAC PORTO NACIONAL, 2017.

SENNA, A.M.; MACHADO-DE-SENA, R.M. ; FACUNDES, A. L. ; NEPOMUCENO, P. B. ; FERREIRA, R. E. Low-level laser therapy equipment needs calibration before clinical use. Lasers in Medical Science. v. 32. p. 1669-1710, 2017.

PASHLEY, D. H. T. F. Consensus-based recommendations for the diagnosis and management of dentin hypersensitivity. Comp Contin Educ Dent, v. 29, n. 8, p. 1S-35S, 2008. 
PÉCORA, Jesus Djalma Brugnera Júnior et al. Laser na Odontologia: O uso do laser no tratamento da hipersensibilidade dentária. LIS - Localizador de Informação em Saúde, 1999. https://pesquisa.bvsalud.org/ portal/resource/pt/lis-LISBR1.1-729.

PEIXOTO, Letícia Monteiro et al. dentinária cervical. Revista Brasileira de Pesquisa em Saúde, v. 12, n. 2, p. 69-74, 2010.

PORTO, Isabel CCM; ANDRADE, Ana KM; MONTES, Marcos AJR. Diagnosis And Treatment Of Dentinal Hypersensitivity. Journal Of Oral science, v. 51, n. 3, p. 323-332, 2009.

QUERIDO, Maria Teresa Aiello; RASLAN, Suzane A.; SCHERMA, Alexandre Prado. Hipersensibilidade dentinária: revisão da literatura. Revista de Periodontia, v. 20, n. 02, p. 39-46, 2010.

RIBEIRO, Pedro José Targino et al. Mecanismos de ação dos recursos terapêuticos disponíveis para o tratamento da hipersensibilidade dentinária cervical. Odontologia Clínico-Científica (Online), v. 15, n. 2, p. 83-90, 2016.

SARTORI, Ricardo; SOARES, Priscila Portella. Laserterapia de baixa potência no tratamento da hipersensibilidade dentinária. Revista da Faculdade de Odontologia-RFO, v. 23, n. 1, 2018.

SHINTOME, Luciana Keiko et al. Avaliação clínica da laserterapia no tratamento da hipersensibilidade dentinária. Brazilian Dental Science, v. 10, n. 1, 2007.

SOARES PV, GRIPPO JO. Lesões cervicais não-cariosas e Hipersensibilidade dentinária cervical: Etiologia,Diagnóstico e Tratamento.1 Ed,São Paulo: Quintessence, 2017;17-22p.

SOARES, Priscila Portella. Laserterapia de baixa frequência no tratamento da hipersensibilidade dentinária. 2017.

SGOLASTRA, F. et al. Lasers para o tratamento da hipersensibilidade dentinária: uma meta-análise. Journal of Dental Research , v. 92, n. 6, pág. 492-499, 2013.

UMBERTO, Romeo et al., Tratamento da hipersensibilidade dentinária por laser de diodo: um estudo clínico. Int J Dent 2012; 1-8.

WEST, Nicola; SEONG, Joon; DAVIES, Maria. Dentine Hypersensitivity. In: Erosive Tooth Wear. KargerPublishers, p. 108-122, 2014.

WILDER-SMITH, P. E. et al. Treatment of Dentine Hypersensitivity By Lasers: A Review. J. Clin. Periodont, v. $27,2000$.

BARROS FC et al., 2008; LAN; LIU, 1995; MIDDA; PEREIRA, 1995; RENTON-HARPER, 1991; WHITE et al., 1993.

ZANIN, Fatima et al. Clareamento de dentes vitais com a utilização da luz. Rev. Assoc. Paul. Cir. Dent, p. 338-345, 2010.

Zequi SC, Garcia T M B. Hipersensibilidade dentinária cervical - Definição etiologia e tratamento. Só Técnicas Estéticas 2005; 2: 69-75. 
JADNA SILVA FRANCO Centro Universitário Santo Agostinho

RAFAEL BEZERRA DOS SANTOS

Centro Universitário Santo Agostinho

DAIANE PORTELA DE CARVALHO FERREIRA

Centro Universitário Santo Agostinho

CAIO CARVALHO MOURA FÉ UNINASSAU Redenção

MAURA PIMENTEL COSTA CRONEMBERGER UNINASSAU Redenção

LARA BEATRIZ DA PAZ COSTA Centro Universitário UNIFTC

CELBE PATRÍCIA PORFÍRIO FRANCO Docente do Centro Universitário Santo Agostinho

RESUMO: É uma séria infecção, potencialmente fatal e de rápida evolução, uma celulite que apresenta quadro clínico agudo de rápida progressão proveniente da disseminação de infecção dos dentes molares inferiores com envolvimento dos espaços submandibular, sublingual e submentoniano, caracterizado como uma complicação infecciosa da região de cabeça e pescoço. $\mathrm{O}$ objetivo deste trabalho é investigar e analisar as evidências científicas acerca da Angina de Ludwig como uma complicação infecciosa da região de cabeça e pescoço. Trata-se de uma revisão sistemática, realizada em dezembro de 2020 com busca nas bases de dados: BVS, SCIELO, LILACS e PUBMED, usando a estratégia PICO com a utilização dos descritores: Angina de Ludwig, Infecções da Cabeça e Pescoço, Infecções Odontogênicas associados ao operador booleano AND e OR. Inclusão de estudos entre 2010 a 2020 com textos na íntegra, relevantes e disponível em português, inglês ou espanhol. Exclusão de textos incompletos, repetidos e sem relevância para temática. Os 17 estudos selecionados evidenciaram que a Angina de Ludwig, atualmente é abordada junto às infecções cervicais profundas, denominadas como infecções supurativas que se disseminam, desenvolvem ao longo dos espaços dos planos faciais da cabeça e do pescoço, apresentando grande número de bactérias que contribuem para infecção, sendo iniciada por estreptococos e perpetuada por microrganismos anaeróbios. É essencial o diagnóstico preciso, recursos de imagens, agentes antimicrobianos de amplo espectro, oxigenoterapia hiperbárica, intervenção cirúrgica radical com remoção do agente etiológico, controle metabólico e reposição de fluidos, tendo grande relevância na reabilitação do paciente. Indicado tratamento imediato e multidisciplinar, a fim de minimizar as possibilidades de sequelas ou óbito. A AL é uma complicação grave das infecções de cabeça e pescoço que pode levar o paciente ao óbito, devido a obstrução das vias respiratórias ou comprometimento do estado geral. São fundamentais o diagnóstico precoce e o tratamento imediato para um prognóstico favorável.

PALAVRA-CHAVE: Angina de Ludwig; Infecções da Cabeça e Pescoço; Infecções Odontogênicas. 
ABSTRACT: It is a serious infection, potentially fatal and of rapid evolution, a cellulite that presents an acute clinical picture of rapid progression from the dissemination of infection of the lower molar teeth with involvement of the submandibular, sublingual and submentonian spaces, characterized as an infectious complication of the head and neck region. The objective of this study is to investigate and analyze the scientific evidence on Ludwig's Angina as an infectious complication of the head and neck region. It is a systematic review, conducted in December 2020 with search in the databases: VHL, SCIELO, LILACS and PUBMED, using the PICO strategy with the use of the descriptors: Ludwig's Angina, Head and Neck Infections, Dental Infections associated with the Boolean operator AND and OR. Inclusion of studies between 2010 and 2020 with full texts, relevant and available in Portuguese, English or Spanish. Exclusion of incomplete, repeated and not relevant texts. The 17 studies selected showed that Angina de Ludwig is currently approached along with deep cervical infections, called suppurative infections that spread, develop along the spaces of the facial planes of the head and neck, presenting a large number of bacteria that contribute to infection, being initiated by streptococcus and perpetuated by anaerobic microorganisms. It is essential the accurate diagnosis, imaging resources, antimicrobial agents of broad spectrum, hyperbaric oxygen therapy, radical surgical intervention with removal of the etiological agent, metabolic control and fluid replacement, having great relevance in the patient's rehabilitation. Immediate and multidisciplinary treatment is indicated, in order to minimize the possibilities of sequelae or death. AL is a serious complication of head and neck infections that can lead the patient to death, due to obstruction of the airways or compromise of the general state. Early diagnosis and immediate treatment are fundamental for a favorable prognosis

KEYWORDS: Ludwig's Angina, Head \& Neck Infections, Odontogenic Infections

\section{INTRODUÇÃO}

A Angina de Ludwig é uma séria celulite infecciosa aguda, que provoca o enrijecimento de estruturas como o assoalho bucal, causando dificuldade na deglutição, elevação da língua, e risco de obstrução das vidas aéreas, isto acontece devido ao envolvimento bilateral dos espaços submandibulares, sublingual (FILHO, 2019).

Esta patologia foi descrita inicialmente em cinco pacientes por Wilhelm Frederick Von Ludwig em 1836, o pesquisador a descreveu como uma celulite de rápida evolução, com aumento de volume em tecidos moles na região do pescoço e assoalho bucal, podendo evoluir para necrose dos tecidos, requerendo emergência médica e tratamento imediato, caso não tratada corretamente pode ser fatal (PACHECO, 2018).

De acordo com Fellini (2017) e Moura (2010), etiologicamente a doença é caracterizada de origem odontogênica associadas a infecções de segundo e terceiro molar, ocorrendo na faixa de $53,8 \%$ a 99\% dos casos, com prevalência no sexo masculino. Outras causas também podem ser atribuídas a AL como a imunodepressão, traumas na cavidade bucal, presença de lesões de cárie, como drogas e álcool, fatores estes que se tornam predisponentes para o surgimento da infecção. Filho (2019) destaca também que outras causas também estão relacionadas com as doenças locais tal como a Síndrome da Imunodeficiência adquirida(SIDA), otites médias, o uso de piercing na língua, além de drogas injetáveis. 
As características clínicas da doença incluem o edema e eritema submandibular, assoalho da boca, pacientes também apresentam febre, trismo, disfagia, linfadenopatia, dor. Alguns achados clínicos como dispneia, taquipneia, estrido e cianose pode estar relacionado a obstrução das vias aéreas levando à um alerta quanto a saúde do paciente (PACHECO, 2018; FILHO, 2019). São encontrados vários microrganismos, tanto gram positivos quanto gram negativos, aeróbios e anaeróbios como: Streptococcus alfahemolitico, Staphylococcus aureus, S. epidermidis e H. influenza (MOURA, 2010).

A disseminação dos microrganismos e de seus produtos, ocorrem pela penetração direta nos tecidos mais profundos por entre os planos faciais, osso e vasos sanguíneos, vasos linfáticos, nervos, ou pelas glândulas salivares(FILHO, 2019).

O diagnóstico da AL é realizado através de achados clínicos da doença, e complementas com exames radiográficos como a tomografia computadorizada, ultrassom e ressonância magnética, usados para detectar a dimensão da infecção. A importância da avaliação precoce por imagem decorre da enorme gama de complicações da AL, várias delas potencialmente fatais (PACHECO, 2018).

Os achados clínicos observados pelo pesquisador Grodznky no ano de 1836 ainda são citados e utilizados para o diagnóstico da Angina de Ludwi nos dias de hoje. Grodznky apresentou uma sugestão o qual mencionava haver uma celulite perimandibular bilateral com envolvimento de mais de um espaço facial, além de infiltração serosanguinolenta com presença ou ausência de pus, uma infiltração que atinge o tecido conjuntivo, fáscias e músculos, sem envolver glândulas, e que se espalha por continuidades dos planos teciduais e não por via linfática (SANTOS, 2019).

De acordo com Fernandes (2020) esta infecção é totalmente falta pois uma de suas complicações envolve a obstrução das vias aéreas, risco de trombose a veia jugular interna, pericardite, empiema pleural, desconforto respiratório, mediastinite, trombose do seio cavernoso, além do risco de disseminação para órgãos distantes.

O tratamento da AL consiste na manutenção das vias aéreas, que pode ser realizada através de intubação endotraqueal, ou traqueostomia, visto que esta infeção pode levar a obstrução das vias aéreas rapidamente, intensa e prolongada antibiocoterapia, drenagem cirúrgica e a remoção do fator causal da infeção. Além disso, mesmo sendo conhecida, a literatura aponta que devido ao seu alto potencial de letalidade, esta infecção merece atenção redobrada (FILHO, 2019).

Assim, a AL é uma grave infecção que oferece risco à vida do paciente, exigindo preparo do cirurgião dentista para diagnosticar precocemente e realizar o tratamento correto. Diante disso, este trabalho tem por objetivo investigar e analisar as evidências científicas acerca da Angina de Ludwig como uma complicação infecciosa da região de cabeça e pescoço.

\section{METODOLOGIA}

Trata-se de uma revisão sistemática com abordagem qualitativa, realizada em dezembro de 2020 com busca nas bases de dados: Biblioteca Virtual em Saúde (BVS), SCIELO, LILACS e ME- 
DLINE, usando a estratégia PICO. Foram utilizados os descritores a partir do DeCS: Angina de Ludwig (Ludwig's Angina), Infecções da Cabeça e Pescoço (Head \& Neck Infections), Infecções Odontogênicas (Odontogenic Infections) associados ao operador booleano And e Or.

Como critério de inclusão, estudos entre 2010 a 2020 com textos na íntegra, livros, relevantes ao tema abordado e disponível nos idiomas português, inglês ou espanhol. Como critério de exclusão de textos que não estivessem na íntegra, repetidos e sem relevância tendo em vista o que há de mais recente a respeito do tema proposto. Encontrados 134 trabalhos em que foram analisados através das leituras dos títulos e resumos, dentre estes foram obtidos 17 artigos que passaram pela leitura completa de seus conteúdos e extração de pontos relevantes para realização da pesquisa.

Figura 1 - Fluxograma com resultados das buscas nas bases de dados.

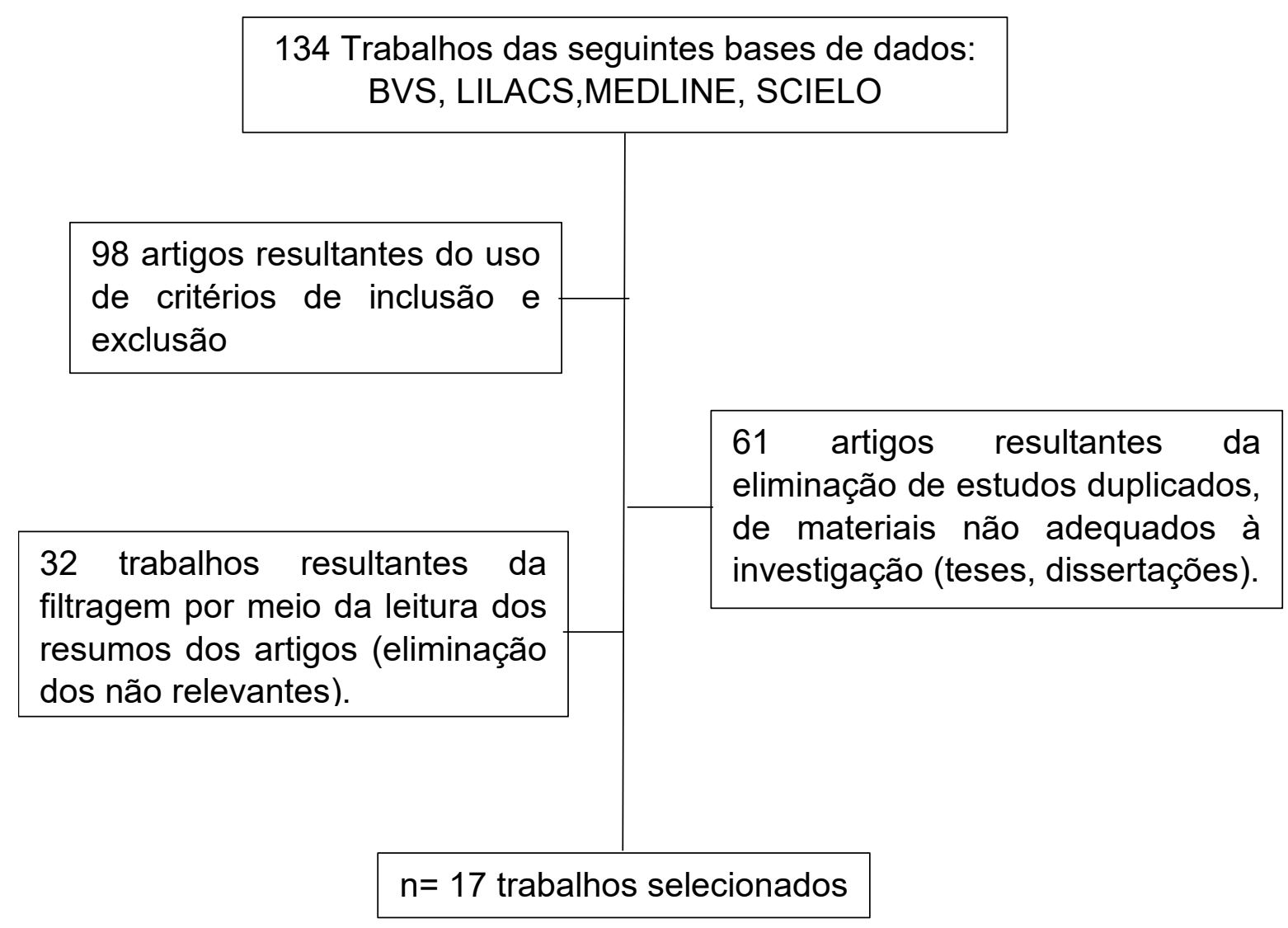

Fonte: Autoria própria. 


\section{RESULTADOS}

Tabela 1: Informações sobre os trabalhos coletados nas bases de dados

\begin{tabular}{|c|c|c|c|}
\hline AUTORES & TÍTULO DO TRABALHO & $\begin{array}{c}\text { ANO DE } \\
\text { PUBLICAÇÃO }\end{array}$ & BASE DE DADOS \\
\hline MOURA et al & $\begin{array}{l}\text { Complicação Sistêmica de angina de } \\
\text { Ludwig; relato de caso }\end{array}$ & 2010 & SCIELO \\
\hline $\mathrm{RICH}$ et al & $\begin{array}{l}\text { Head and neck infection and inflam- } \\
\text { mation }\end{array}$ & 2011 & MEDLINE \\
\hline WOLFE et al & $\begin{array}{l}\text { Is surgical airway necessary for air- } \\
\text { way management in deep neck infec- } \\
\text { tions and Ludwig angina? }\end{array}$ & 2011 & MEDLINE \\
\hline BAKSHI et al & Ludwig's angina & 2016 & MEDLINE \\
\hline NEVILLE et al & Patologia Oral e MaxiloFacial & 2016 & LIVRO \\
\hline FELLINI et al & $\begin{array}{l}\text { Manejo da via aérea na angina de } \\
\text { Ludwig-um desafio: relato de caso. }\end{array}$ & 2017 & BVS \\
\hline FREITAS et al & $\begin{array}{l}\text { Estudo imaginológico de um caso de } \\
\text { angina de Ludwig. }\end{array}$ & 2017 & LILACS \\
\hline PAK et al & Ludwig's angina & 2017 & MEDLINE \\
\hline CUSTÓDIO et al & $\begin{array}{l}\text { Angina De Ludwig: Importância Da } \\
\text { Prevenção Diagnóstica Na Prática } \\
\text { Clínica }\end{array}$ & 2018 & SCIELO \\
\hline EDETANLEN et al & $\begin{array}{l}\text { Comparison of outcomes in conser- } \\
\text { vative versus surgical treatments for } \\
\text { Ludwig's angina }\end{array}$ & 2018 & MEDLINE \\
\hline PACHECO et al & $\begin{array}{l}\text { Angina De Ludwig Com Mediastini- } \\
\text { te: Relato De Caso }\end{array}$ & 2018 & BVS \\
\hline FILHO et al & $\begin{array}{l}\text { Angina de Ludwig - Aspectos Rele- } \\
\text { vantes para o Cirurgião Dentista }\end{array}$ & 2019 & BVS \\
\hline LEITE et al & $\begin{array}{l}\text { Paciente acometido por Angina de } \\
\text { Ludwig com grave progressão reabi- } \\
\text { litado com próteses dentárias: relato } \\
\text { de caso }\end{array}$ & 2019 & SCIELO \\
\hline PARKER et al & $\begin{array}{l}\text { Ludwig's angina: a multidisciplinary } \\
\text { concern }\end{array}$ & 2019 & MEDLINE \\
\hline SANTOS et al & $\begin{array}{l}\text { Angina de Ludwig em paciente por- } \\
\text { tador de esquizofrenia: relato de caso }\end{array}$ & 2019 & SCIELO \\
\hline FERNANDES et al & $\begin{array}{l}\text { Complicações relativas às infecções } \\
\text { odontogênicas: Angina de Ludwig }\end{array}$ & 2020 & SCIELO \\
\hline DUARTE et al & $\begin{array}{l}\text { Angina de Ludwig, a propósito de } \\
\text { um caso clínico }\end{array}$ & 2020 & LILACS \\
\hline VALLÉE et al & $\begin{array}{l}\text { Ludwig's angina: A diagnostic and } \\
\text { surgical priority }\end{array}$ & 2020 & MEDLINE \\
\hline
\end{tabular}

Fonte: Autoria própria. 


\section{DISCUSSÃO}

A Angina de Ludwig recebeu esse nome em homenagem ao médico e pesquisador alemão Frederick Von Ludwig em 1836, que realizou as primeiras evidencias clínicas da infecção. O nome Angina vem do latim angere, que significa estrangular, termo considerado adequado para a patologia em referência as suas características clínicas. Em 70\% dos casos, a AL desenvolve-se através da disseminação de uma infecção aguda dos molares inferiores (NEVILLE, 2016).

A AL é considerada uma doença fatal, sendo uma necrose progressiva, promovendo edema nos tecidos moles, ocasionando na elevação e deslocamento posterior da língua (FERNANDES, 2020). O pico de incidência da doença ocorre entre os 20 e 40 anos de idade, com maior prevalência em indivíduos do sexo masculino (PARKER, 2019).

De acordo com Duarte (2020), a Angina de Ludwig é uma infecção difusa, considerada grave, potencialmente fatal e de rápida evolução, que tem início no pavimento da cavidade bucal, evoluindo para o espaço sublingual(superiormente), e submandibular(inferiormente).

Em meados dos anos 40, desde a introdução dos antibióticos, com os avanços nas abordagens clínico-cirúrgicas bem como as melhorias da higiene bucal, a taxa de mortalidade por esta infecção chegou a atingir mais de 50\%, contudo, diminuiu significativamente (PARKER, 2019).

Figura 1. Apresentação clínica inicial. A: vista frontal; B: vista lateral.

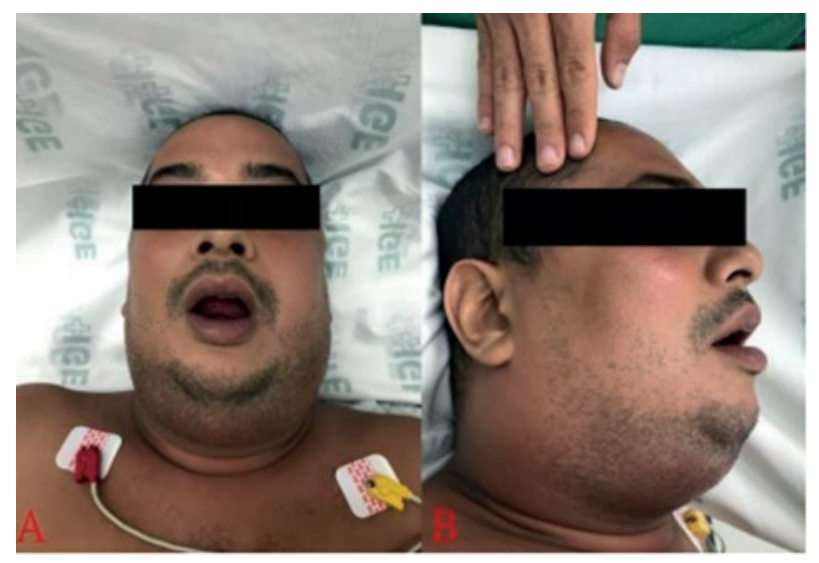

Fonte: SANTOS, 2019.

Figura 2. Criança com edema difuso na região de pescoço e assoalho bucal, elevação da língua.

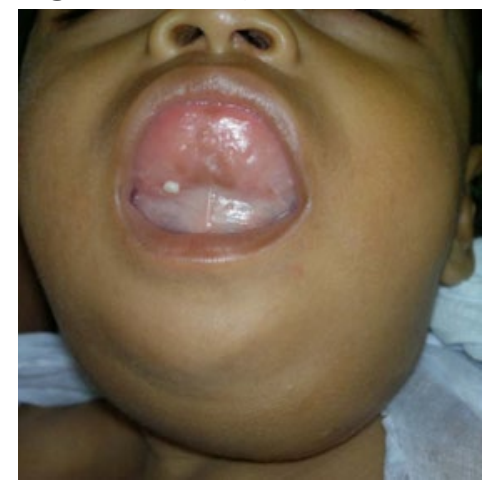

Fonte: BAKSHI, 2016. 


\section{DIAGNÓSTICO E ASPECTOS CLÍNICOS}

O diagnóstico da Angina de Ludwig é realizado através de suas características clinicas, na avaliação dos sinais e sintomas apresentados pelos pacientes associados a exames de imagem (PACHECO, 2018).

O diagnóstico desta infecção se dá através de exames clínicos acompanhados de exames radiográficos como a tomografia computadorizada, ultrassom e ressonância magnética que podem ser utilizados para detectar a extensão cervical da celulite (SANTOS, 2019).

De acordo com Filho(2019), a etiologia da infecção está frequentemente ligada a afecções dentárias, apresentando-se de 53\% a 99\% dos casos, decorrente principalmente de infecções periapicais, problemas periodontais, fraturas ósseas, pós-operatório, injeções anestésicas, lacerações, resultando na disseminação da infecção para regiões de cabeça e pescoço.

Pacheco (2018) em seu trabalho descreve os principais fatores etiológicos da Angina de Ludwig, sendo eles: infecções odontogênicas correspondendo na faixa de $40 \%$ e $60 \%$ dos casos, frequentemente a partir de um dos molares inferiores infectados. A disseminação da infecção ocorre de forma direta na faringe, outros fatores etiológicos mencionados pelo autor incluem linfadenite supurativa, osteomielite cervical, trauma penetrante, injeção intravenosa na veia jugular interna.

Santos (2019) aponta que a etiologia desta infecção é polimicrobiana, visto que infecções odontogênicas são as principais causas da AL, logo, essa infecção se oriunda da microbiota oral e, desta forma, os organismos aeróbios e anaeróbios são facilmente encontrados.

Quanto as características clínicas da Angina de Ludwig, Pacheco (2018) descreve que os principais achados clínicos mais evidenciados nesta infecção incluem edema e eritema na região superior do pescoço, ocorre com frequência no assoalho bucal, e o sintomas que o paciente apresenta são dor, febre, disfagia e odinofagia.

O estudo realizado por Filho (2019) destaca a sintomatologia em: presença de edema na região submandibular, trismo (dificuldade na abertura da boca), elevação da língua, febre, linfadenopatia. O autor menciona ainda que os pacientes relatam história recente de exodontia, sintomas respiratórios como dispneia, taquipneia, estridor.

De acordo com Neville (2016) a AL cria uma tumefação maciça na região do pescoço com capacidade de se estender para próximo às clavículas. Quando se tem o envolvimento do espaço sublingual, cria-se uma elevação, dilatação posterior e protrusão da língua ocorrendo o comprometimento das vias aéreas dificultando a respiração do paciente. Quando a infecção adentra o espaço submandibular, ocasiona então a dilatação e sensibilidade do pescoço acima do osso hioide, logo, quando ocorre o envolvimento da região faríngea lateral, pode ocasionar na obstrução secundário ao edema laringiano.

Moura (2010) e Neville (2016) descrevem também em seus trabalhos sintomatologia da infecção como taquipneia, dispneia, taquicardia, estridor, inquietação e a necessidade do paciente em 
manter uma posição ereta sugerem obstrução das vias aéreas. Febre, calafrios, leucocitose e sedimentação elevada podem ser observadas no paciente.

Figura 3. Angina de Ludwig. Tumefação de tecido mole da região submandibular direita.

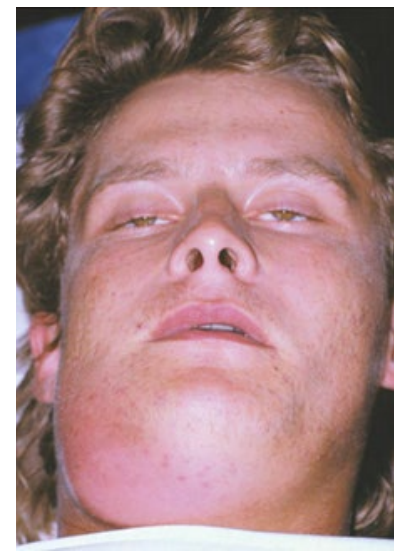

Fonte: NEVILLE, 2016.

\section{CARACTERISTICAS RADIOGRÁFICAS}

Os exames de imagem da região de pescoço e tórax são capazes de revelar várias características que aparecem no decorrer da infecção, todavia, procedimentos realizados anteriormente as radiografias como traqueostomia, acesso venoso central e/ou drenagem cervical, podem tornar difícil a interpretação das radiografias do tórax. A ultrassonografia pode demonstrar a presença de coleções purulentas. Os exames de imagens planas convencionais são de grande valia na abordagem inicial, para se observar o possível foco dentário infeccioso (FREITAS, 2017)

A tomografia computadorizada e a ressonância magnética podem apontar a extensão da lesão o comprometimento das vias aéreas e a presença de gases entremeados nos tecidos musculares (RANA, 2011).

Figura 4. Ultrassom, no eixo longitudinal da glândula submandibular esquerda, com infiltrado inflamatório com líquido e gás.

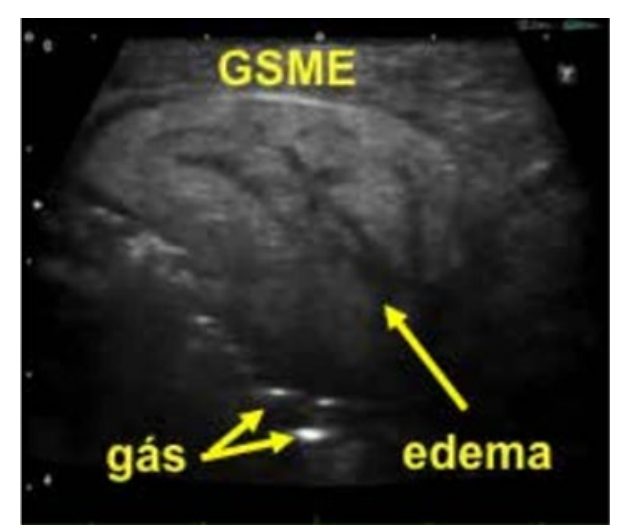

Fonte: FREITAS, 2017. 
Figura 5: Corte axial de TC de cabeça e pescoço mostrando aumento de volume na região submandibular e desvio da via área.

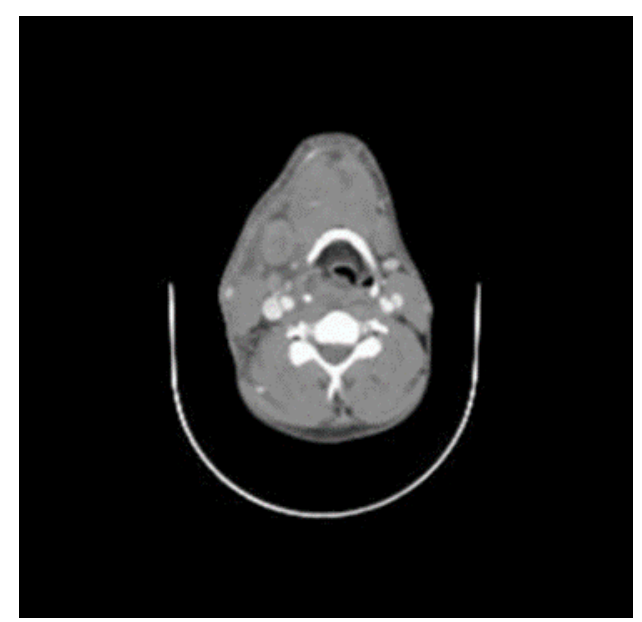

Fonte: LEITE, 2019.

\section{TRATAMENTO E PROGNÓSTICO}

O tratamento da infecção consiste na manutenção das vias aéreas, que pode ser realizado através da intubação endotraqueal ou traqueostomia, antibiocoterapia e hidratação, remoção do fator etiológico, incisão e drenagem da infecção (SANTOS, 2019).

Neville (2016) afirma que o tratamento da Angina de Ludwig consiste da remoção do processo infeccioso e terapia antibiótica intravenosa, o autor descreve ainda as medicações utilizadas que são: penicilina, com ou sem clindamicina ou metronidazol, geralmente sendo estes as medicações de primeira escolha, junto à cultura e o teste de sensibilidade utilizados para guiar a terapia final. $\mathrm{O}$ uso de corticosteroides é prescrito por alguns clínicos para reduzir o inchaço na área da infecção e aumentar a penetração dos antibióticos.

Figura 6. Aspecto logo após acessos cirúrgicos bilaterais e colocação de drenos.

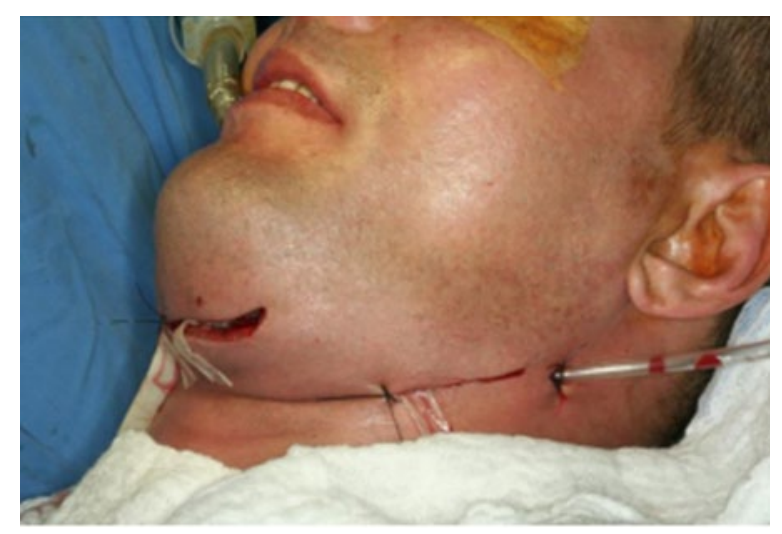

Fonte: LEITE, 2019. 
Se o paciente não receber o tratamento de forma adequada, pode ocasionar em sequelas como comprometimento estético, paralisia do nervo recorrente, osteomielite da mandíbula, pode ocorrer ainda a obstrução aguda das vias aéreas, infecção e ruptura da artéria carótida dentre outras. Quando mais precocemente for diagnosticada, melhor será o prognóstico para pacientes que possuírem a infecção (MOURA, 2019).

\section{CONCLUSÃO}

Atualmente a Angina de Ludwig continua sendo uma complicação grave das infecções de cabeça e pescoço, se não diagnosticada e tratada corretamente pode levar o paciente ao óbito, devido a obstrução das vias respiratórias ou comprometimento do estado geral. Todavia, são fundamentais o diagnóstico precoce e o tratamento imediato para um prognóstico favorável sem maiores complicações.

\section{REFERÊNCIAS}

BAKSHI, Satvinder Singh. Ludwig's angina. Archives of Disease in Childhood, v. 101, n. 6, p. 545-545, 2016.

CUSTÓDIO, FC, PEREIRA, FP. ANGINA DE LUDWIG: IMPORTÂNCIA DA PREVENÇÃO DIAGNÓSTICA NA PRÁTICA CLÍNICA. ANAIS DO FÓRUM DE INICIAÇÃO CIENTÍFICA DO UNIFUNEC, v. 9, n. 9, 2018.

DUARTE AP. SOUSA G. COSTA, J. LOURENÇO, C. MOTTA, S. COSTA, H. Angina de Ludwig, a propósito de um caso clínico. Revista Portuguesa de Estomatologia, Medicina Dentária e Cirurgia Maxilofacial, 61(1):29-32, 2020.

EDETANLEN BE; SAHEEB BD. Comparison of outcomes in conservative versus surgical treatments for Ludwig's angina. Medical Principles and Practice, v. 27, n. 4, p. 362-366, 2018.

FELLINI RT. VOLQUIND D. SCHNOR OH. ANGELETTI MG. SOUZA OE. Manejo da via aérea na angina de Ludwig-um desafio: relato de caso. Brazilian Journal of Anesthesiology, v. 67, n. 6, p. 637-640, 2017.

FERNANDES SL, FERREIRA LPS, OLIVEIRA MA, FERNANDES GC, TIEGHI NETO V, SANTANA TM, MORETTO MJ. Complicações relativas às infecções odontogênicas: Angina de Ludwig. Journal of Multidisciplinary Dentistry, v. 10, n. 1, p. 46-51, 2020.

FILHO, DBS; SOUZA FGM. Angina de Ludwig - Aspectos Relevantes para o Cirurgião Dentista. Rev. FavenorteInterd. [on-line], v. 01, n. 01, p. 14-19, jan./dez., 2019.

FREITAS, Claudio Froes et al. Estudo imaginológico de um caso de angina de Ludwig. Revista de Odontologia da Universidade Cidade de São Paulo, [S.1.], v. 25, n. 2, p. 164 - 169, dez. 2017.

LEITE, Adriana Caroline et al. Paciente acometido por Angina de Ludwig com grave progressão reabilitado com próteses dentárias: relato de caso. Arch. Health Invest, p. 119-124, 2019. 
MOURA OS, ALVARES LD, TUJI FM, NOGUEIRA JSE. Complicação Sistêmica de angina de Ludwig; relato de caso. Revista Paraense de Medicina, v. 24, n. 2, p. 71, 2010.

NEVILLE, Brad W. et al. Patologia oral e maxilofacial. 4. ed. Rio de Janeiro: Elsevier, 2016.

PACHECO, Regis Pereira; KHOURI, Daniel Goulart. ANGINA DE LUDWIG COM MEDIASTINITE: RELATO DE CASO. REVISTA UNINGÁ, v. 55, n. S1, p. 73-76, 2018.

PAK, Stella et al. Ludwig's angina. Cureus, v. 9, n. 8, 2017.

PARKER, Emma; MORTIMORE, Gerri. Ludwig's angina: a multidisciplinary concern. British Journal of Nursing, v. 28, n. 9, p. 547-551, 2019.

RICH SR; MOONIS Gul. Head and neck infection and inflammation. Radiologic Clinics, v. 49, n. 1, p. 165-182, 2011.

SANTOS EA, BARBOSA AD, COSTA CFB, QUINTAS PH, DULTRA FKAA. Angina de Ludwig em paciente portador de esquizofrenia: relato de caso. Revista de Ciências Médicas e Biológicas, v. 18, n. 2, p. 270-274, 2019.

VALLÉE, Maxime et al. Ludwig's angina: A diagnostic and surgical priority. International Journal of Infectious Diseases, 93:160-162, 2020.

WOLFE, Mary M.; DAVIS, James W.; PARKS, Steven N. Is surgical airway necessary for airway management in deep neck infections and Ludwig angina?. Journal of critical care, v. 26, n. 1, p. 11-14, 2011. 
